Historic, Archive Document

Do not assume content reflects current

scientific knowledge, policies, or practices. 



\section{Central Prince of Wales}

Forest Service

Tongass

National

Forest

R10-MB-229b

\section{Final Environmental}

Impact Statement

July 1993

UAs

\section{Ketchikan Pulp Company}

Long-Term Timber Sale Contract:

\section{Volume II: Unit Cards (Appx. F)}

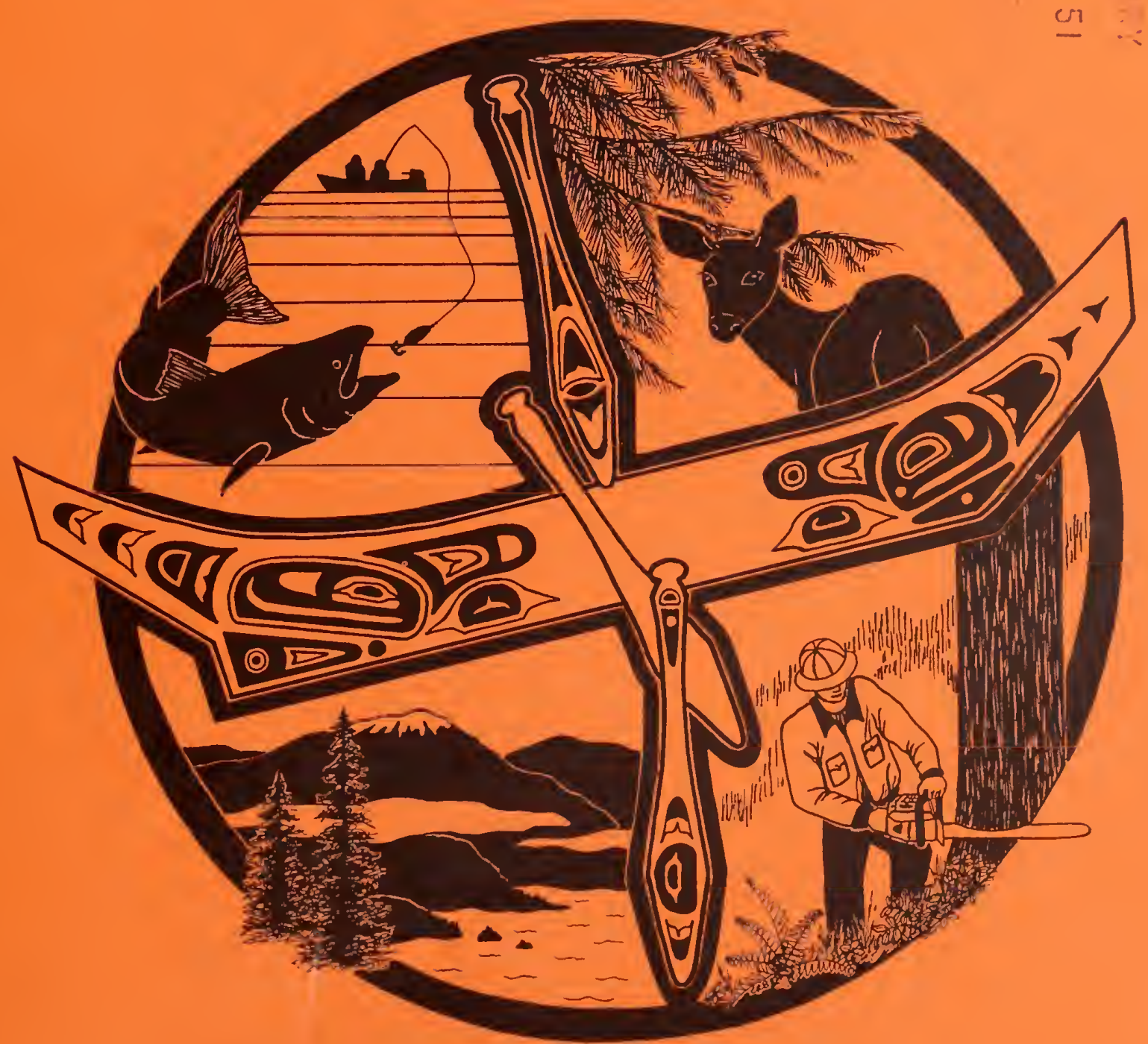



APPENDIX G

\section{Unit Cards and Road Cards}

Central Prince of Wales Final Environmental Impact Statement 



\section{UNIT CARDS}

Unit cards have been developed for each harvest unit and associated road proposed for the Central Prince of Wales (CPOW) Environmental Impact statement (EIS). These cards are intended to display site-specific information, enabling the public to more fully understand harvest implications. They also serve as a mechanism to consolidate information gathered during office/field

reconnaissance of the proposed harvest units to Forest Service field personnel, and were used by the Interdisciplinary Team (IDT) for consideration in preparation of the Final EIS.

The Unit Cards consist of two parts: (1) a schematic map, and (2) a detailed description of the unit. The map displays the proposed unit and associated roads in the center of the page. Other features shown include: streamcourses, existing roads, previously harvested areas, contour lines, lakes, saltwater, and eagle nests.

The reverse side of the card provides a physical description of the unit, as well as identification of resource concerns which must be considered during implementation of harvest. The physical description includes the location, planned acreage, estimated sawlog plus utility volume, silvicultural system, predominant forest type, aspect, and a breakdown by volume class, elevation range, and soil mass movement index. Resource considerations are identified for soils, timber, engineering, fisheries/watersheds, wildlife, recreation, visuals, lands, cultural resources, and geology. 

Unit $549.2-201$

Planned acres 23

Estimated volume (mbf) 300

Logging system skyl ine

silvicultural system Riparian

Forest type Hemlock
Alternat ives considered

Quad PBGA4SWS

Mgmt Area $\mathrm{K} 03$

WAA 1527

Photo 1990108

Aspect West

PHYSICAL DESCRIPTION

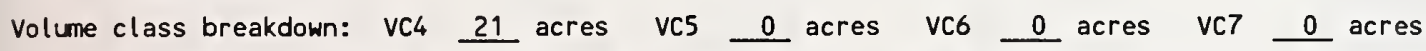

Elevation breakdown: $0-800 \mathrm{ft} . \underline{22}$ acres $800-1200 \mathrm{ft} . \underline{0}$ acres $1200-1500 \mathrm{ft}$. $\underline{0}$ acres over $1500 \mathrm{ft}$. 0 acres Mass movement index: Low 13 acres Medium 0 acres High 6 acres Very High 0 acres

\section{SOILS}

This unit has high mass movement index soils. Partial log suspension required over these areas.(BMP13.9)

This unit has > 40\% MCGilvery soils. Partial suspension required (BMP13.9)

to ensure reforestation (BMP13.19).

This unit contains 12 acres of forested wetlands. Site specific BMPs will be designed for selected approved

logging system and road construction practices. (BMPs 12.5, 13.9, 13.15).

This unit contains 10 acres of slopes > $75 \%$.

\section{TIMBER}

Uneven-aged harvest for riparian management on an estimated 11 acres.

\section{ENGINEER ING}

High mass movement index soils. Road construction must minimize landslide potential (BMP14).

The road into this unit crosses a $\underline{B} 4$ channel. Meet stream and lake protection prescription requirements in TLMP Draft Revision (1991a) for this process group.

slopes greater than $75 \%$ may require full bench construction and endhaul of waste (BMP14.7).

\section{FISH/WATERSHED}

There are no fishery mitigation measures anticipated for this unit.

\section{WILDLIFE}

There are no wildlife mitigation measures anticipated for this unit.

\section{RECREATION / VISUALS}

This unit has a proposed Voo of MM and is not seen from any viewpoint identified by this project.

\section{LANDS}

There are no lands mitigation measures anticipated for this unit.

\section{CULTURAL RESOURCES}

There are no cultural resource mitigation measures anticipated for this unit.

\section{GEOLOGY}

There are no karst mitigation measures anticipated for this unit. 


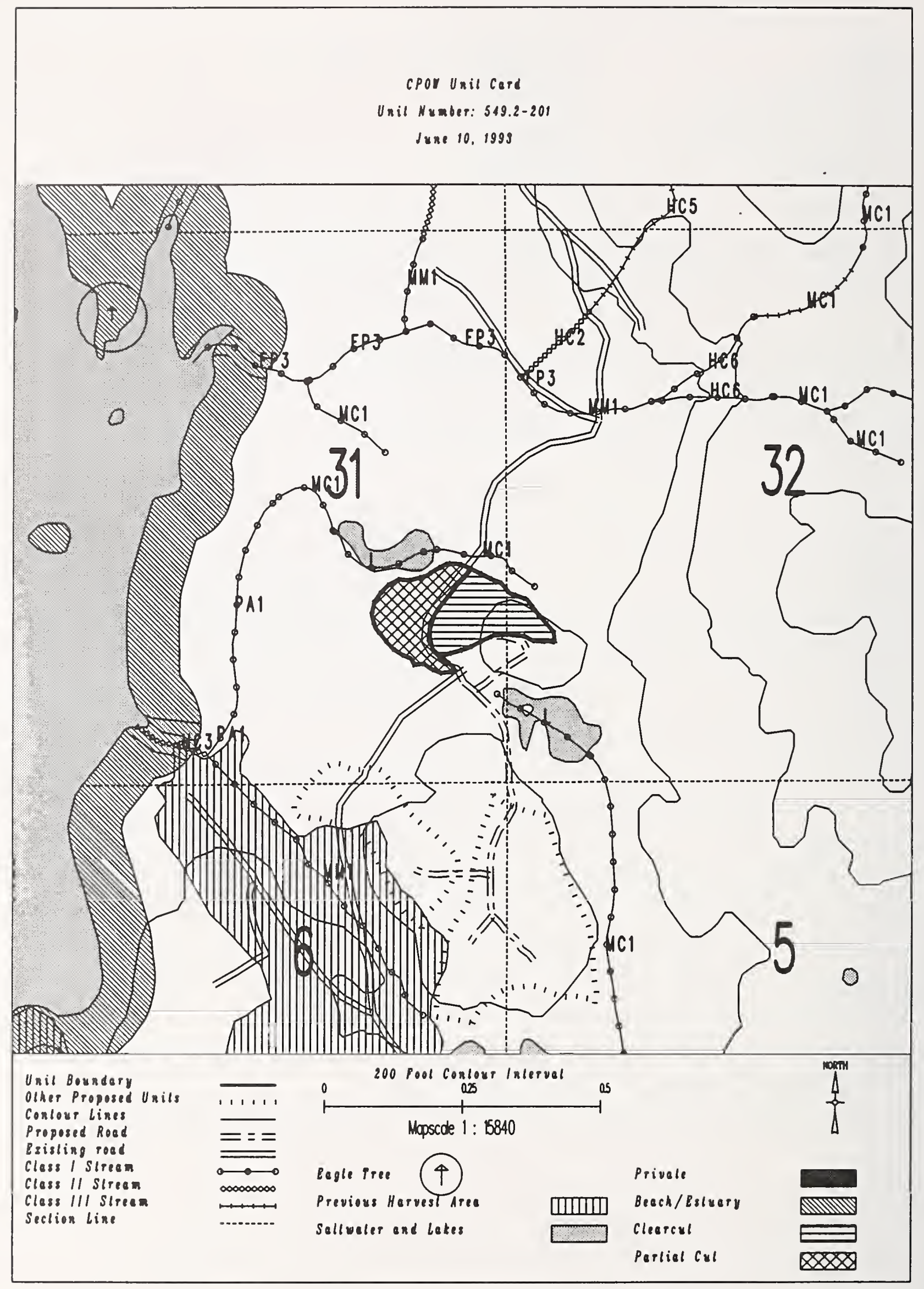


Unit 549.2-201

Planned acres 23

Estimated volume (mbf)

Logging system skyline

silvicultural system selective

Forest type Hemlock
Alternatives considered

Quad PBGA4SWS

Mgmt Area $\mathrm{KO3}$

WAA 1527

Photo 1990108

Aspect West

PHYSICAL DESCRIPTION

Volume class breakdown: VC4 21 acres VC5 0 acres vC6 $\quad 0$ acres vC7 0 acres

Elevation breakdown: $0-800 \mathrm{ft} . \underline{22}$ acres $800-1200 \mathrm{ft} . \underline{0}$ acres $1200-1500 \mathrm{ft} . \overline{0}$ acres over $1500 \mathrm{ft}$. 0 Mass movement index: Low 13 acres Medium $\_$acres High 6 acres Very High 0 acres

\section{SOILS}

This unit has high mass movement index soils. Partial log suspension required over these areas.(BMP13.9)

This unit has > 40\% MCGilvery soils. Partial suspension required (BMP13.9)

to ensure reforestation (BMP13.19).

This unit contains 12 acres of forested wetlands. Site specific BMPs will be designed for selected approved

logging system and road construction practices. (BMPs 12.5, 13.9, 13.15).

This unit contains 10 acres of slopes > $75 \%$.

TIMBER

Selective, uneven-aged harvest designed to meet specific resource concern.

ENGINEER ING

High mass movement index soils. Road construction must minimize landslide potential (BMP14).

The road into this unit crosses a $\underline{B} 4$ channel. Meet stream and lake protection prescription requirements in TLMP

Draft Revision (1991a) for this process group.

slopes > $75 \%$ may require full bench construction and endhaul of waste (BMP14.7).

FISH/WATERSHED

This unit is presecribed for selective harvest to protect soils/riparian habitat.

\section{WILDLIFE}

There are no wildlife mitigation measures anticipated for this unit.

RECREATION / VISUALS

This unit has a proposed VoO of MM and is not seen from any viewpoint identified by this project.

\section{LANDS}

There are no lands mitigation measures anticipated for this unit.

CULTURAL RESOURCES

There are no cultural resource mitigation measures anticipated for this unit.

GEOLOGY

There are no karst mitigation measures anticipated for this unit. 


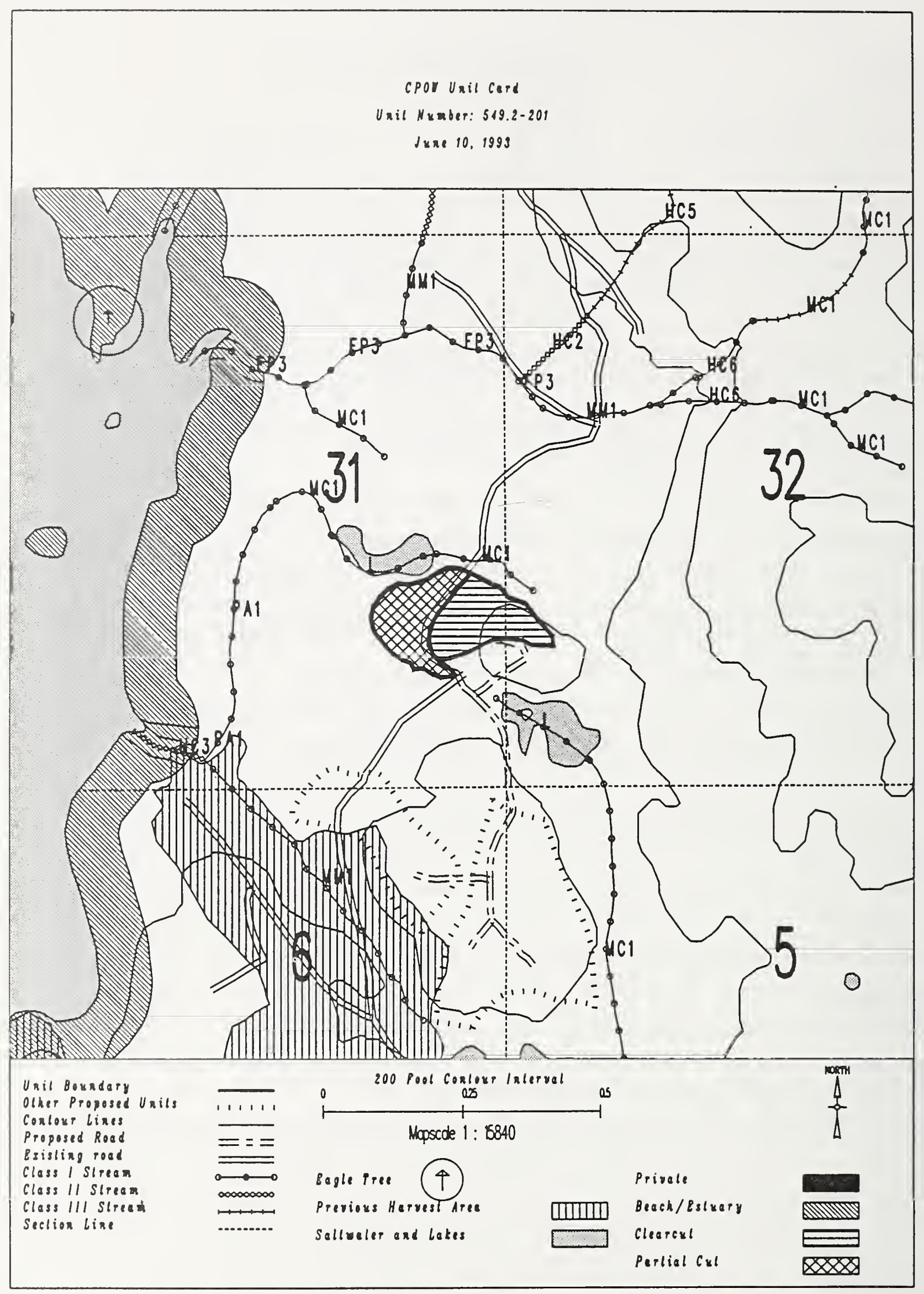


Unit $\quad$ 549.2-205

Planned acres 16

Estimated volume (mbf) 252

Logging system skyline

Silvicultural system seed Tree

Forest type Hemlock
Alternatives considered

F3 F4

Mgmt Area $\mathrm{KO3}$

WAA 1527

Photo 1990109

Aspect West

PHYSICAL DESCRIPTION

Volume class breakdown: VC4 14 acres VC5 0 acres VC6 $\quad 0$ acres VC7 $\quad 0$ acres

Elevation breakdown: $0-800 \mathrm{ft} .15$ acres $800-1200 \mathrm{ft} . \underline{0}$ acres 1200-1500 ft. 0 acres over $1500 \mathrm{ft}$. 0 acres Mass movement index: Low $\underline{0}$ acres Medium 0 acres High 7 acres Very High 0 acres

SOILS

This unit has high mass movement index soils. Partial log suspension required over these areas. (BMP13.9)

This unit has > 40\% McGilvery soils. Partial suspension required (BMP13.9)

to ensure reforestation (BMP13.19).

This unit contains 10 acres of slopes $>75 \%$.

TIMBER

Seed tree harvest.

ENGINEER ING

High mass movement index soils. Road construction must minimize landslide potential (BMP14).

slopes greater than $75 \%$ may require full bench construction and endhaul of waste (BMP14.7).

FISH/WATERSHED

This unit contains streams which have recently been classified/channel typed but require field verification.

WILDLIFE

There are no wildlife mitigation measures anticipated for this unit.

RECREATION / VISUALS

The unit has a proposed Voo of $M$ within the viewshed of Sarheen Creek

as viewed from $1 / 2$ mile from west coast of Prince of Wales.

\section{LANDS}

There are no lands mitigation measures anticipated for this unit.

\section{CULTURAL RESOURCES}

There are no cultural resource mitigation measures anticipated for this unit.

\section{GEOLOGY}

There are no karst mitigation measures anticipated for this unit. 
CPOY Unil Card

Unil Number: 519.2-205

June 10, 1999

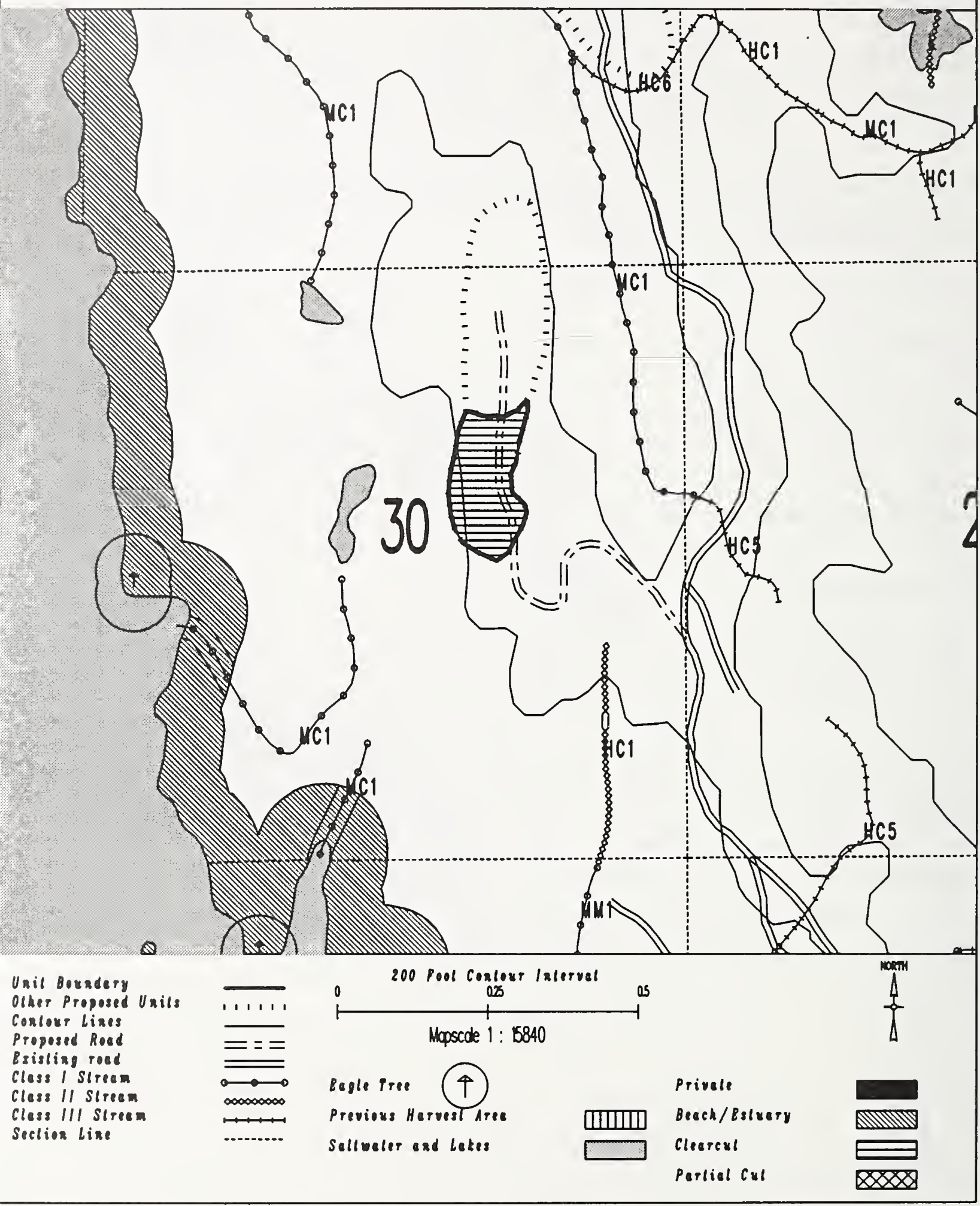


Unit $\quad 549.2-205$

Planned acres 16

Estimated volume (mbf)

Logging system skyline

silvicultural system selective

Forest type Hemlock
Alternatives considered F5

WAA 1527

Photo 1990109

Aspect West

PHYSICAL DESCRIPTION

Volume class breakdown: VC4 14 acres VC5 $\quad 0$ acres VC6 $\quad 0$ acres VC7 $\quad 0$ acres

Elevation breakdown: $0-800 \mathrm{ft} . \underline{15}$ acres $800-1200 \mathrm{ft} . \quad 0$ acres $1200-1500 \mathrm{ft}$. 0 acres over $1500 \mathrm{ft}$. 0 acres Mass movement index: Low 0 acres Medium 0 acres High 7 acres Very High 0

SOILS

This unit has high mass movement index soils. Partial log suspension required over these areas.(BMP13.9)

This unit has > 40\% McGilvery soils. Partial suspension required (BMP13.9)

to ensure reforestation (BMP13.19).

This unit contains 10 acres of slopes $>75 \%$.

TIMBER

Selective, uneven-aged harvest designed to meet specific resource concern.

ENG INEER I NG

High mass movement index soils. Road construction must minimize landslide potential (BMP14).

slopes > $75 \%$ may require full bench construction and endhaul of waste (BMP14.7).

\section{FI SH/WATER SHED}

This unit contains streams which have recently been classified/channel typed but require field verification.

\section{WILDLIFE}

Selective harvest prescribed to integrate wildlife habitat with timber production.

\section{RECREATION / VISUALS}

The unit has a proposed VQO of $M$ within the viewshed of Sarheen Creek

as viewed from $1 / 2$ mile from west coast of Prince of Wales.

\section{LANDS}

There are no lands mitigation measures anticipated for this unit.

\section{CULTURAL RESOURCES}

There are no cultural resource mitigation measures anticipated for this unit.

There are no karst mitigation measures anticipated for this unit. 
cpor Uail cerd

Unil Number: 519.2-205

June 10, 1993

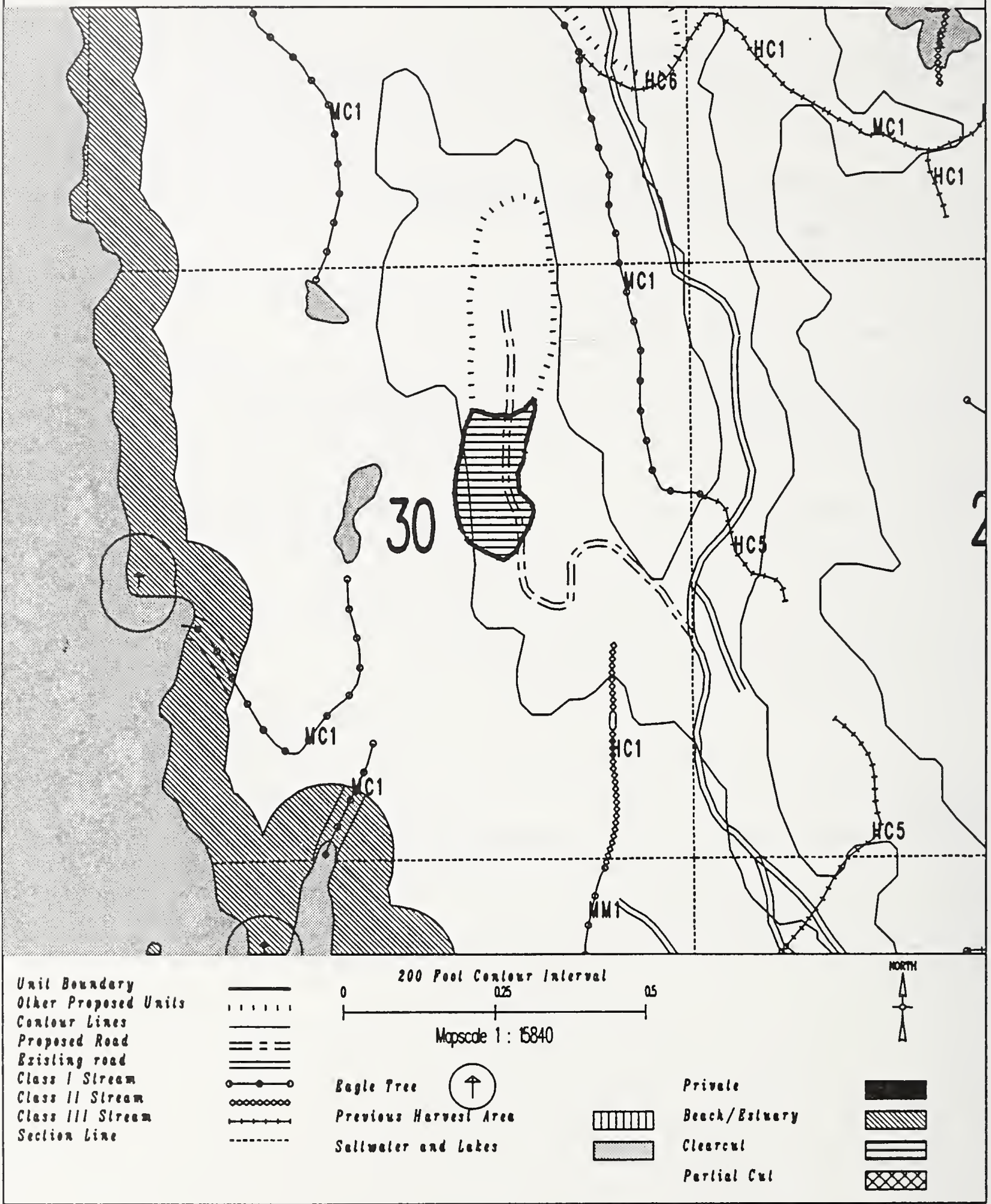


UNIT PLAN/LAYOUT/SALE ADMINISTRATION CARD FOR CPOW FEIS

Unit 549.2-206

Planned acres 27

Estimated volume (mbf) 521

Logging system skyline

Silvicultural system clearcut

Forest type cedar
Alternatives considered

Quad PBGA4SWS

Mgmt Area $\mathrm{KO3}$

WAA 1527

Photo 1990109

Aspect East

PHYSICAL DESCRIPTION

Volume class breakdown: VC4 26 acres vC5 0 acres vc6 $\quad 0$ acres vc7 $\quad 0$ acres

Elevation breakdown: $0-800 \mathrm{ft} . \underline{26}$ acres $800-1200 \mathrm{ft} . \underline{0}$ acres $1200-1500 \mathrm{ft} . \underline{0}$ acres over $1500 \mathrm{ft}$. 0 acres Mass movement index: Low 11 acres Medium $\_$acres High 8 acres Very High 0 acres

\section{SOILS}

This unit has high mass movement index soils. Partial log suspension required over these areas. (BMP13.9)

This unit has > 40\% McGilvery soils. Partial suspension required (BMP13.9)

to ensure reforestation (BMP13.19).

This unit contains 10 acres of forested wetlands. Site specific BMPs will be designed for selected approved

logging system and road construction practices. (BMPs 12.5, 13.9, 13.15).

This unit contains 15 acres of slopes $>75 \%$.

\section{TIMBER}

There are no timber mitigation measures anticipated for this unit.

\section{ENGINEERING}

High mass movement index soils. Road construction must minimize landslide potential (BMP14).

Slopes greater than $75 \%$ may require full bench construction and endhaul of waste (BMP 14.7).

\section{FISH/WATERSHED}

This unit contains streams which have recently been classified/channel typed but require field verification.

\section{WILDLIFE}

There are no wildlife mitigation measures anticipated for this unit.

\section{RECREATION / VISUALS}

The unit has a proposed voo of $M$ within the viewshed of Sarheen Creek

as viewed from $1 / 2$ mile from west coast of Prince of Wales.

\section{LANDS}

There are no lands mitigation measures anticipated for this unit.

CULTURAL RESOURCES

There are no cultural resource mitigation measures anticipated for this unit.

GEOLOGY

There are no karst mitigation measures anticipated for this unit. 


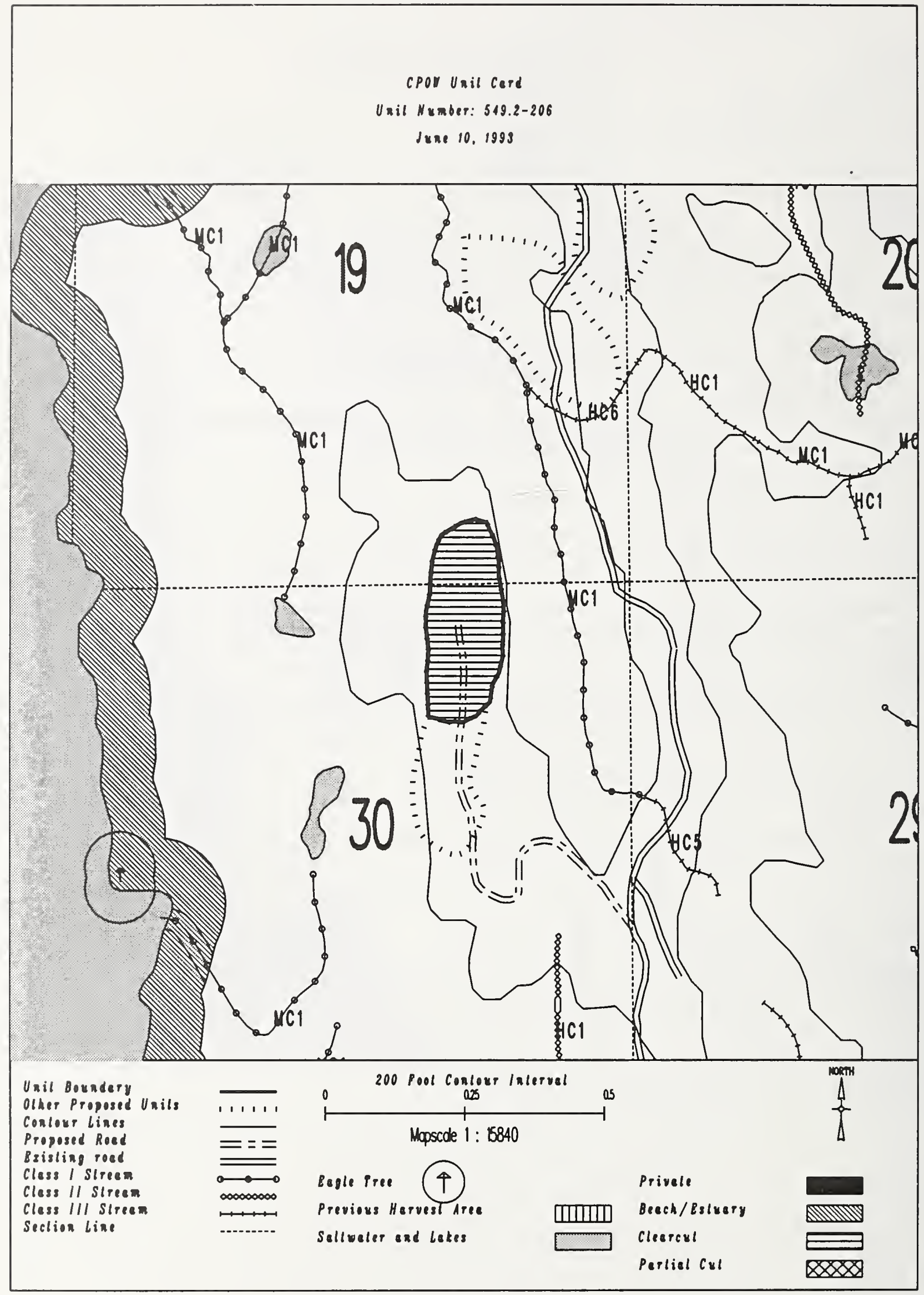


UNIT PLAN/LAYOUT/SALE ADMINISTRATION CARD FOR CPOW FEIS

Unit $\underline{549.2-206}$

Planned acres 27

Estimated volume (mbf) 521

Logging system skyline

silvicultural system Selective

forest type Cedar
Alternatives considered

F5
PBGA4SWS

Mgmt Area $\mathrm{KO3}$

WAA 1527

Photo 1990109

Aspect East

PHYSICAL DESCRIPIION

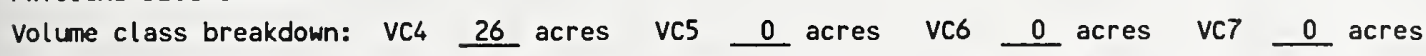

Elevation breakdown: $0-800 \mathrm{ft} . \underline{26}$ acres $800-1200 \mathrm{ft} . \underline{0}$ acres $1200-1500 \mathrm{ft} . \underline{0}$ acres over $1500 \mathrm{ft} . \underline{0}$ acres Mass movement index: Low 11 acres Medium 0 acres High 8 acres Very High 0 acres

SOILS

This unit has high mass movement index soils. Partial log suspension required over these areas.(BMP13.9)

This unit has > 40\% McGilvery soils. Partial suspension required (BMP13.9)

to ensure reforestation (BMP13.19).

This unit contains 10 acres of forested wetlands. Site specific BMPs will be designed for selected approved

logging system and road construction practices. (BMPS 12.5, 13.9, 13.15).

This unit contains 15 acres of slopes $>75 \%$.

TIMBER

Selective, uneven-aged harvest designed to meet specific resource concern.

ENGINEERING

High mass movement index soils. Road construction must minimize landslide potential (BMP14).

slopes > 75\% may require full bench construction and endhaul of waste (BMP14.7).

FISH/WATERSHED

This unit contains streams which have recently been classified/channel typed but require field verification.

WILDL IFE

Selective harvest prescribed to preserve goshawk foraging habitat/other objectives identified by District IDT.

RECREATION / VISUALS

The unit has a proposed voo of $M$ within the viewshed of Sarheen Creek

as viewed from $1 / 2$ mile from west coast of Prince of Wales.

\section{LANDS}

There are no lands mitigation measures anticipated for this unit.

CULTURAL RESOURCES

There are no cultural resource mitigation measures anticipated for this unit.

GEOLOGY

There are no karst mitigation measures anticipated for this unit. 
CPOY Unil Cerd

Unit Namber: 519.2-206

June 10. 1993

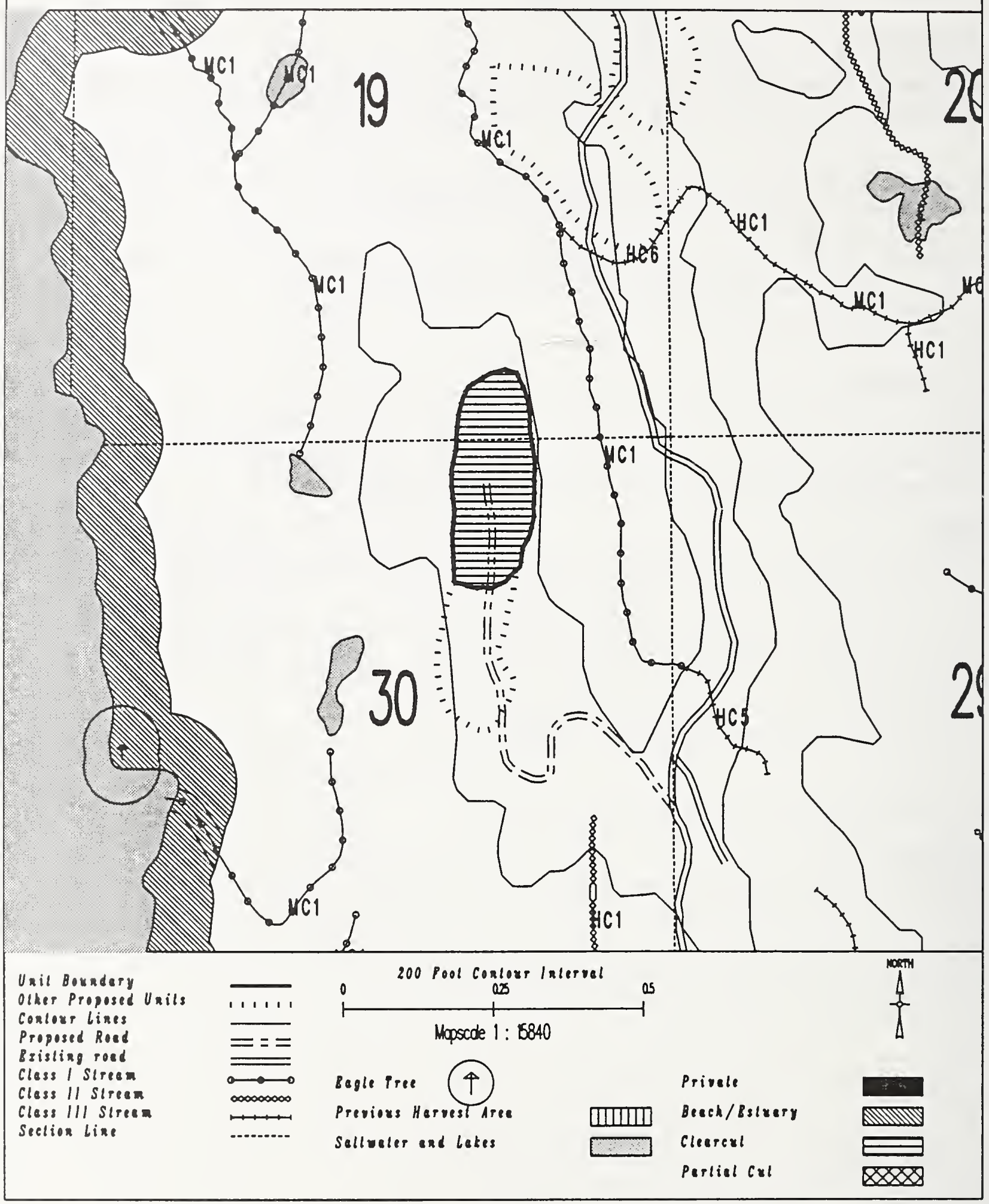


Unit 549.2-207

Planned acres 20

Estimated volume (mbf)

Logging system skyline

silvicultural system clearcut

Forest type Hemlock
Alternatives considered F3 F4 F5 F6

Quad PBGA4SWS

Mgmt Area $\mathrm{KO3}$

WAA 1527

Photo 1990110

Aspect West

\section{PHYSICAL DESCRIPTION}

Volume class breakdown: vC4 19 acres VC5 1 acres vC6 $\quad 0$ acres vc7 $\quad 0$ acres

Elevation breakdown: $0-800 \mathrm{ft} .18$ acres $800-1200 \mathrm{ft} . \underline{0}$ acres $1200-1500 \mathrm{ft}$. 0 acres over $1500 \mathrm{ft}$. 0 acres Mass movement index: Low 9 acres Medium 0 acres High 3 acres Very High 0 acres

\section{SOILS}

This unit has high mass movement index soils. Partial log suspension required over these areas.(BMP13.9)

This unit has > 40\% McGilvery soils. Partial suspension required (BMP13.9)

to ensure reforestation (BMP13.19).

This unit contains $\_$acres of forested wetlands. Site specific BMPs will be designed for selected approved

logging system and road construction practices. (BMPs 12.5, 13.9, 13.15).

This unit contains 6 acres of slopes $>75 \%$.

\section{TIMBER}

There are no timber mitigation measures anticipated for this unit.

\section{ENGINEER ING}

Slopes greater than $75 \%$ may require full bench construction and endhaul of waste (BMP 14.7).

\section{FISH/WATERSHED}

There are no fishery mitigation measures anticipated for this unit.

\section{WILDLIFE}

There are no wildlife mitigation measures anticipated for this unit.

\section{RECREATION / VISUALS}

This unit has a proposed vao of MM and is not seen from any viewpoint identified by this project.

\section{LANDS}

There are no lands mitigation measures anticipated for this unit.

CULTURAL RESOURCES

There are no cultural resource mitigation measures anticipated for this unit.

GEOLOGY

Planned unit boundary/road location/logging system are designed to avoid damage to significant karst features.

Mitigation measures may apply. Unit layout/changes must be coordinated with Cave Resource Specialists. 
cpor Unil Cerd

Unil Number: 519.2-207

Juke 10, 1993

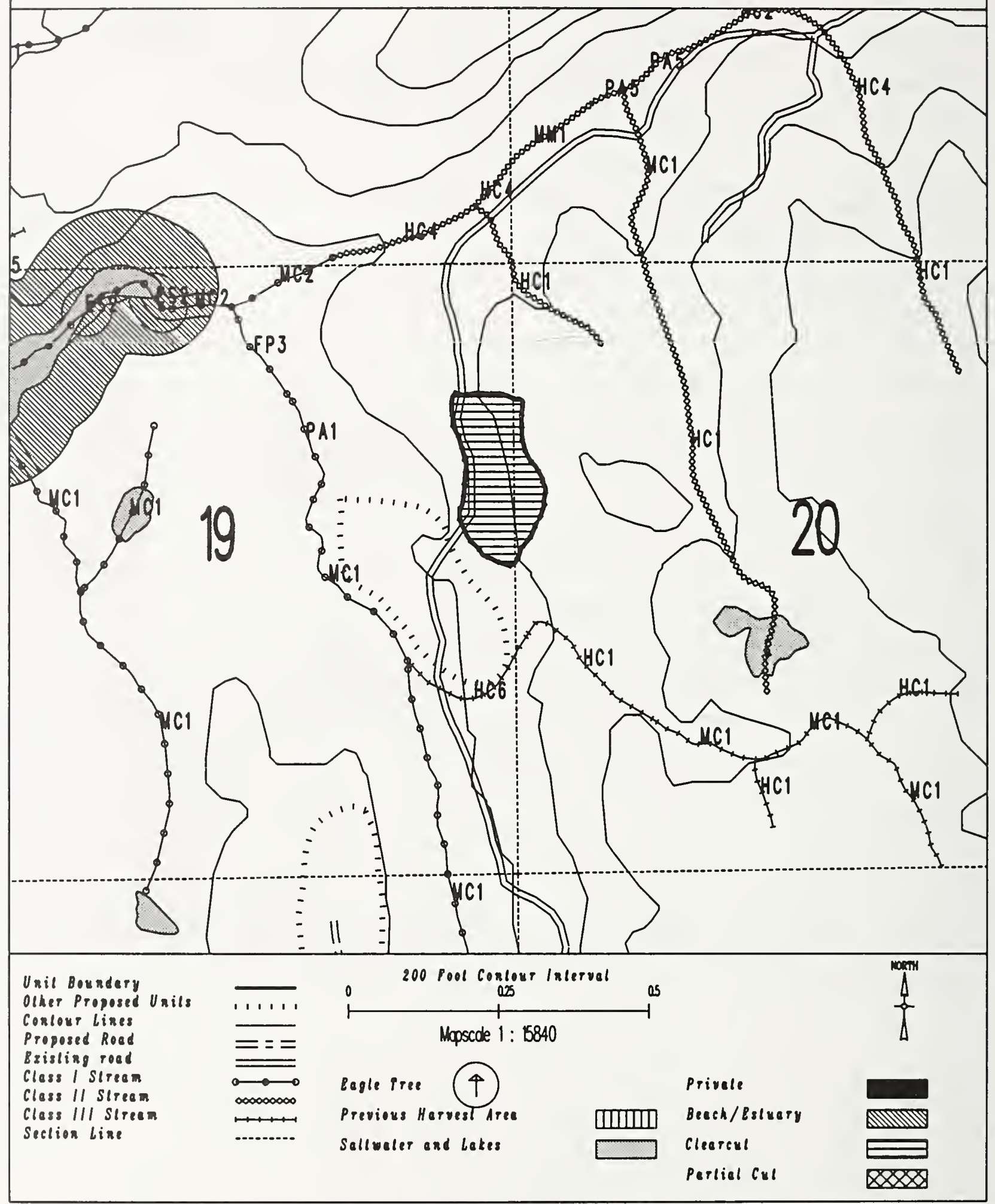


Unit $549.2-230$

Planned acres 31

Estimated volume (mbf)

Logging system skyline

silvicultural system clearcut

Forest type Hemlock
Alternatives considered

Quad PBGA4SWS

Mgmt Area $\mathrm{KO3}$

WAA 1527

Photo 1990111

Aspect West

\section{PHYSICAL DESCRIPTION}

Volume class breakdown: VC4 23 acres VC5 $\quad 8$ acres vC6 $\quad 0$ acres vc7 0 acres

Elevation breakdown: $0-800 \mathrm{ft} . \underline{29}$ acres $800-1200 \mathrm{ft} . \underline{0}$ acres $1200-1500 \mathrm{ft}$. 0 acres over $1500 \mathrm{ft}$. 0 Mass movement index: Low 15 acres Medium $\underline{0}$ acres High 9 acres Very High 0

SOILS

This unit has high mass movement index soils. Partial log suspension required over these areas. (8MP13.9) This unit contains 16 acres of forested wetlands. Site specific BMPs will be designed for selected approved

logging system and road construction practices. (BMPs 12.5, 13.9, 13.15).

\section{TIMBER}

There are no timber mitigation measures anticipated for this unit.

\section{ENGINEERING}

High mass movement index soils. Road construction must minimize landslide potential (8MP14).

\section{FISH/WATERSHED}

Potential impact on significant fishery habitat. May be necessary to expand planned buffer in accordance with AHMU Handbook.

\section{WILDLIFE}

There are no wildlife mitigation measures anticipated for this unit.

\section{RECREATION / VISUALS}

This unit has a proposed Voo of MM and is not seen from any viewpoint identified by this project.

\section{LANDS}

There are no lands mitigation measures anticipated for this unit.

\section{CULTURAL RESOURCES}

There are no cultural resource mitigation measures anticipated for this unit.

GEOLOGY

There are no karst mitigation measures anticipated for this unit. 


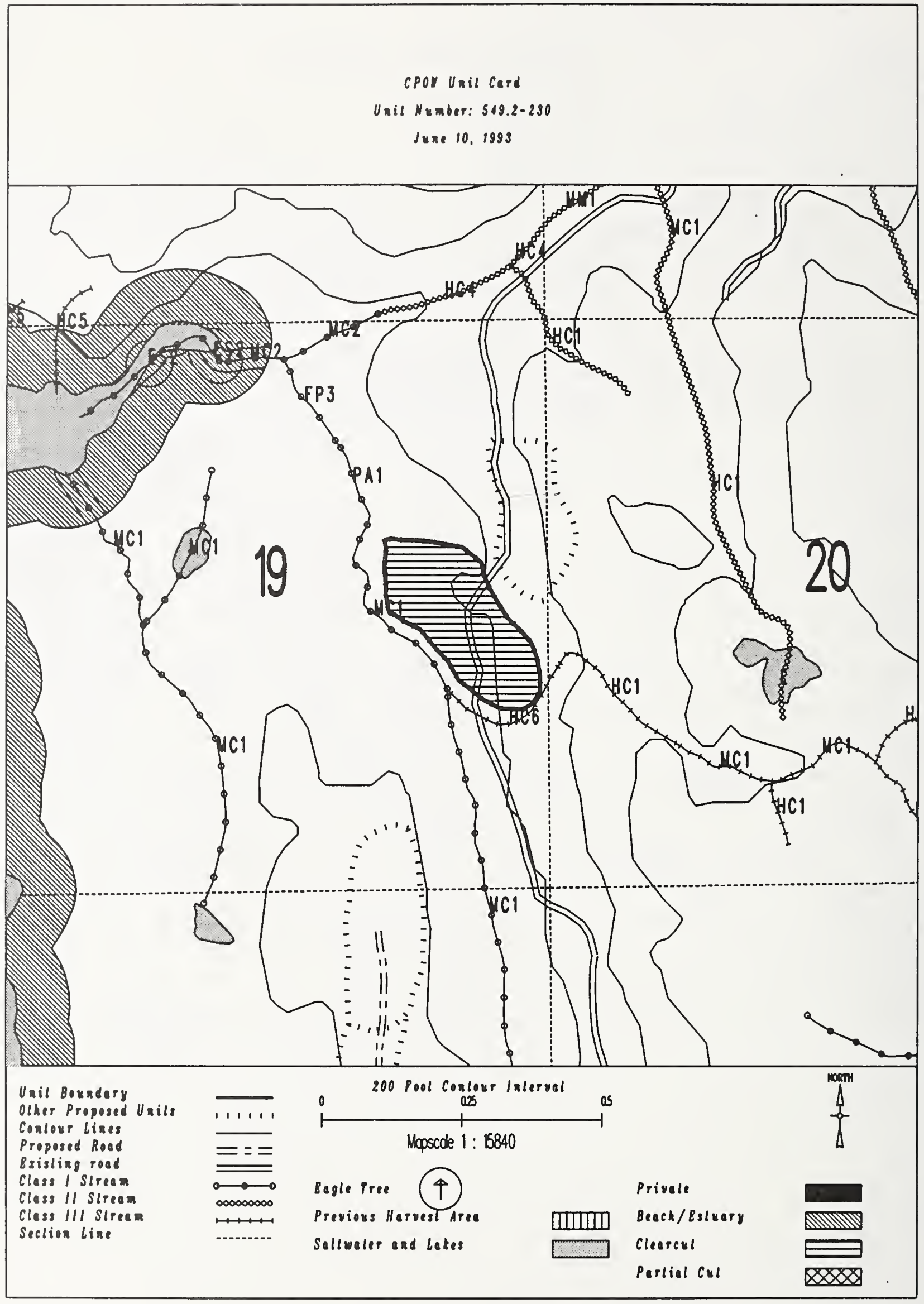




\section{Unit $\quad$ 549.2-230}

Planned acres 31

Estimated volume (mbf)

Logging system skyline

Silvicultural system Selective

Forest type Hemlock
Alternat ives considered

Quad PBGA4SWS

Mgmt Area $\mathrm{KO3}$

WAA 1527

Photo 1990111

Aspect West

\section{PHYSICAL DESCRIPIION}

Volume class breakdown: VC4 23 acres VC5 $\quad 8$ acres VC6 $\quad 0$ acres VC7 $\quad 0$ acres

Elevation breakdown: $0-800 \mathrm{ft} . \underline{29}$ acres $800-1200 \mathrm{ft} . \underline{0}$ acres $1200-1500 \mathrm{ft} . \underline{0}$ acres over $1500 \mathrm{ft}$. 0 Mass movement index: Low 15 acres Medium 0 acres High 9 acres Very High 0 acres

\section{SOILS}

This unit has high mass movement index soils. Partial log suspension required over these areas. (BMP13.9) This unit contains 16 acres of forested wetlands. Site specific BMPs will be designed for selected approved logging system and road construction practices. (BMPs 12.5, 13.9, 13.15).

\section{TIMBER}

Selective, uneven-aged harvest designed to meet specific resource concern.

\section{ENGINEER ING}

High mass movement index soils. Road construction must minimize landslide potential (BMP14).

\section{FISH/WATERSHED}

Potential impact on significant fishery habitat. May be necessary to expand planned buffer in accordance with AHMU Handbook.

\section{WILDLIFE}

Selective harvest prescribed to preserve goshawk foraging habitat/other objectives identified by 0 istrict IDT.

RECREATION / VISUALS

This unit has a proposed VQO of MM and is not seen from any viewpoint identified by this project.

\section{LANOS}

There are no lands mitigation measures anticipated for this unit.

\section{CULTURAL RESOURCES}

There are no cultural resource mitigation measures anticipated for this unit.

GEOLOGY

There are no karst mitigation measures anticipated for this unit. 
cpor Unil cerd

Unil Number: 519.2-230

Juse 10, 1993

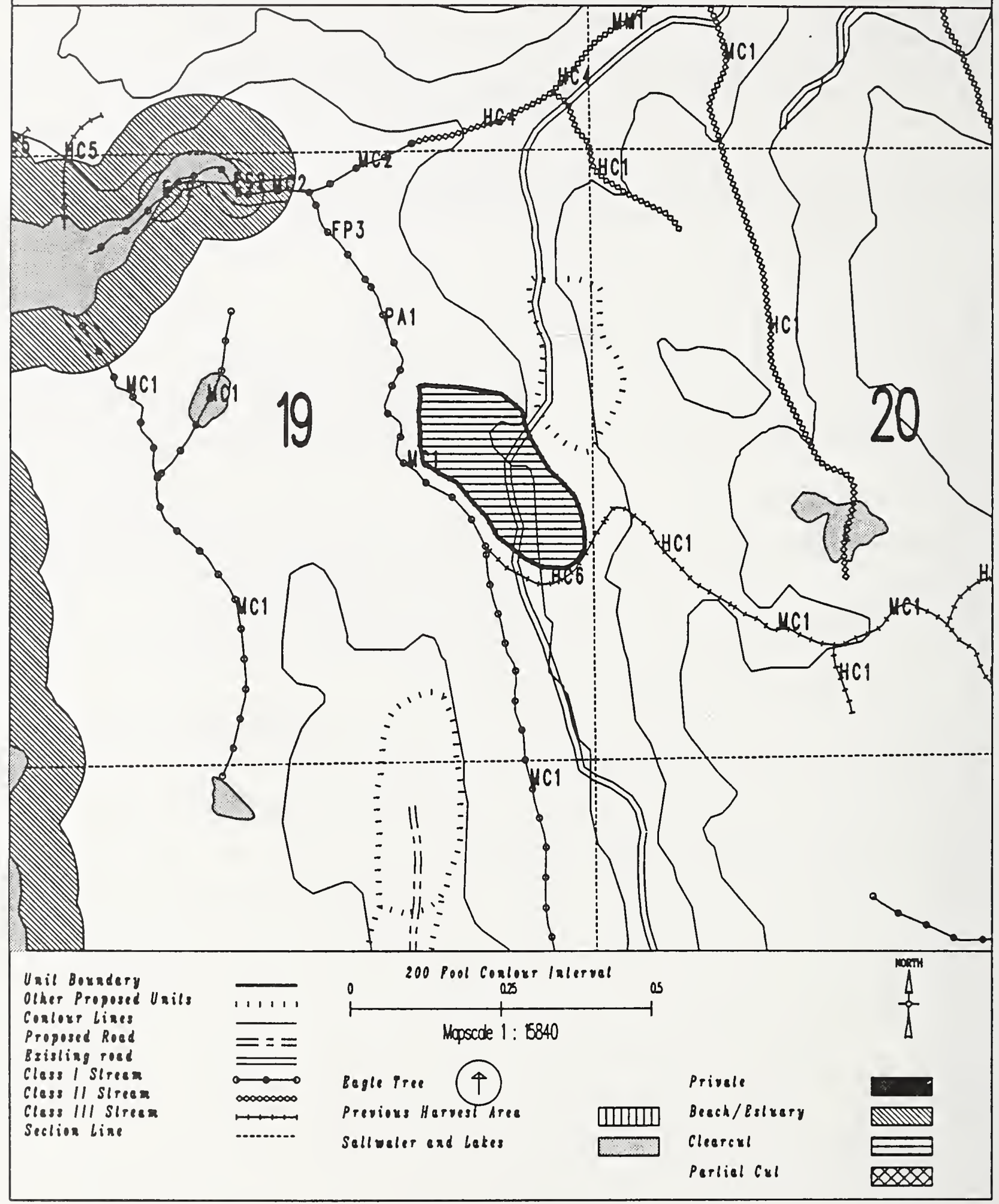


Unit $550-208$

Planned acres 18

Estimated volume (mbf) 438

Logging system Highlead

silvicultural system clearcut

Forest type Hemlock
Alternatives considered

Quad PBGA4SWN

Mgmt Area $\mathrm{KO3}$

WAA 1530

Photo 1990024

Aspect South

\section{PHYSICAL DESCRIPTION}

Volume class breakdown: VC4 $\quad 10$ acres VC5 $\quad 8$ acres VC6 $\quad 0$ acres VC7 $\quad 0$ acres

Elevation breakdown: $0-800 \mathrm{ft} .{ }_{0}^{0}$ acres $800-1200 \mathrm{ft} . \underline{16}$ acres $1200-1500 \mathrm{ft}$. 0 acres over $1500 \mathrm{ft}$. 0 acres Mass movement index: Low 16 acres Medium 0 acres High 0 acres Very High 0 acres

SOILS

There are no soils mitigation measures anticipated for this unit.

\section{TIMBER}

There are no timber mitigation measures anticipated for this unit.

\section{ENGINEER ING}

There are no engineering mitigation measures anticipated for this unit.

\section{FISH/WATERSHED}

There are no fishery mitigation measures anticipated for this unit.

\section{WILDLIFE}

There are no wildlife mitigation measures anticipated for this unit.

\section{RECREATION / VISUALS}

This unit has a proposed VoO of MM and is not seen from any viewpoint identified by this project.

\section{LANDS}

There are no lands mitigation measures anticipated for this unit.

CULTURAL RESOURCES

There are no cultural resource mitigation measures anticipated for this unit.

GEOLOGY

Planned unit boundary/road location/logging system are designed to avoid damage to significant karst features.

Mitigation measures may apply. Unit layout/changes must be coordinated with Cave Resource Specialists. 


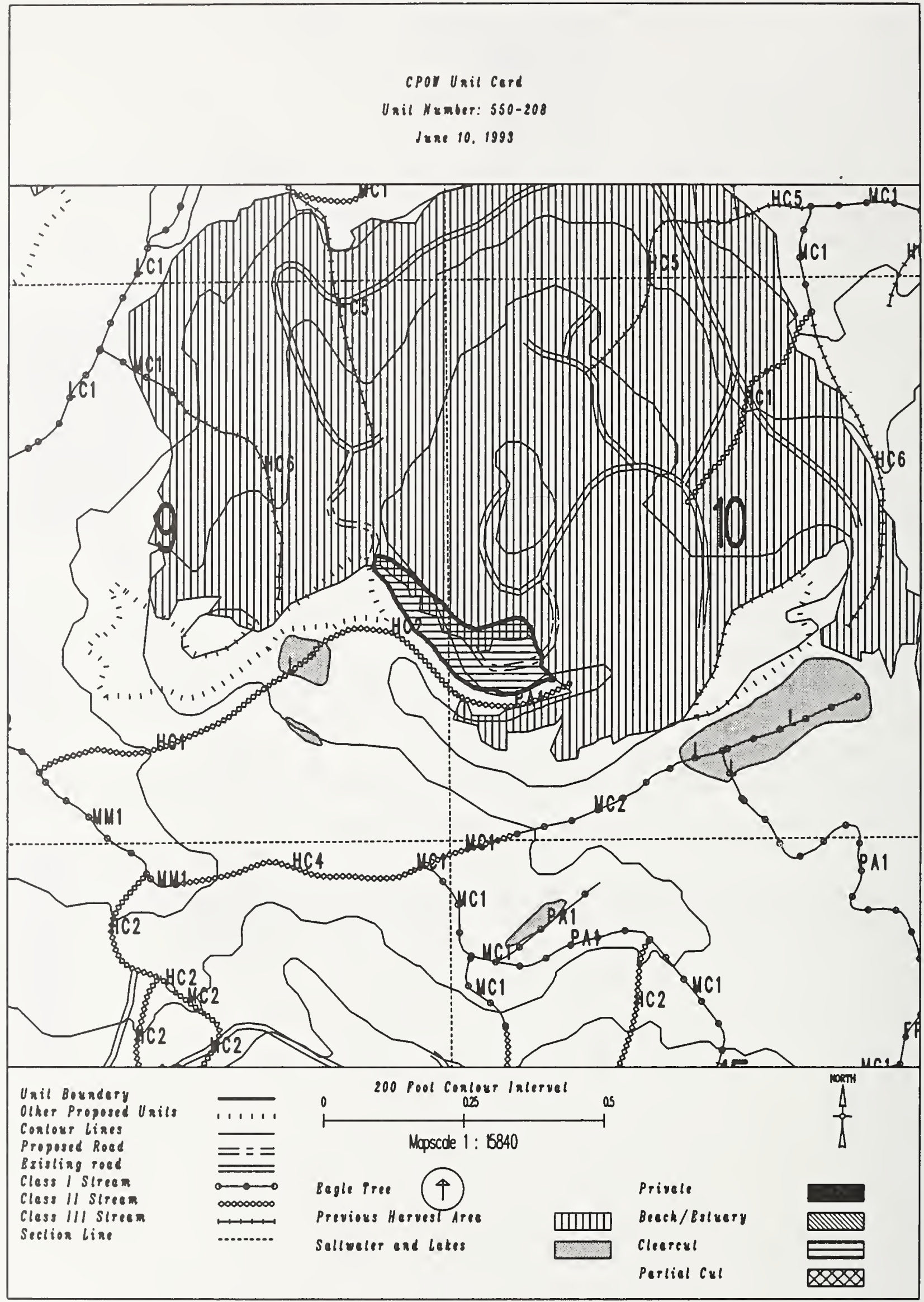


Unit 550-211

Planned acres 44

Estimated volume (mbf) 976

Logging system skyline

silvicultural system clearcut

Forest type Hemlock
Alternatives considered

Quad PBGA4SWN

Mgmt Area $\mathrm{KO3}$

WAA 1530

Photo 1990023

Aspect West

\section{PHYSICAL DESCRIPTION}

Volume class breakdown: VC4 28 acres vc5 14 acres $\quad$ VC6 $\quad 0$ acres vc7 $\quad 0 \quad$ acres

Elevation breakdown: $0-800 \mathrm{ft} . \underline{43}$ acres $800-1200 \mathrm{ft} . \underline{0}$ acres $1200-1500 \mathrm{ft}$. 0 acres over $1500 \mathrm{ft}$. 0 acres Mass movement index: Low 27 acres Medium 0 acres High 6 acres Very High 0 acres

\section{SOILS}

This unit has high mass movement index soils. Partial log suspension required over these areas.(BMP13.9)

This unit contains 20 acres of forested wetlands. Site specific BMPs will be designed for selected approved

logging system and road construction practices. (BMPs 12.5, 13.9, 13.15).

\section{TIMBER}

There are no timber mitigation measures anticipated for this unit.

\section{ENGINEERING}

High mass movement index soils. Road construction must minimize landslide potential (BMP14).

\section{FISH/WATERSHED}

There are no fishery mitigation measures anticipated for this unit.

\section{WILDLIFE}

There are no wildlife mitigation measures anticipated for this unit.

\section{RECREATION / VISUALS}

This unit has a proposed VQO of MM and is not seen from any viewpoint identified by this project.

\section{LANDS}

There are no lands mitigation measures anticipated for this unit.

\section{CULTURAL RESOURCES}

There are no cultural resource mitigation measures anticipated for this unit.

This unit is underlain with karst, although no significant features have yet been identified. 


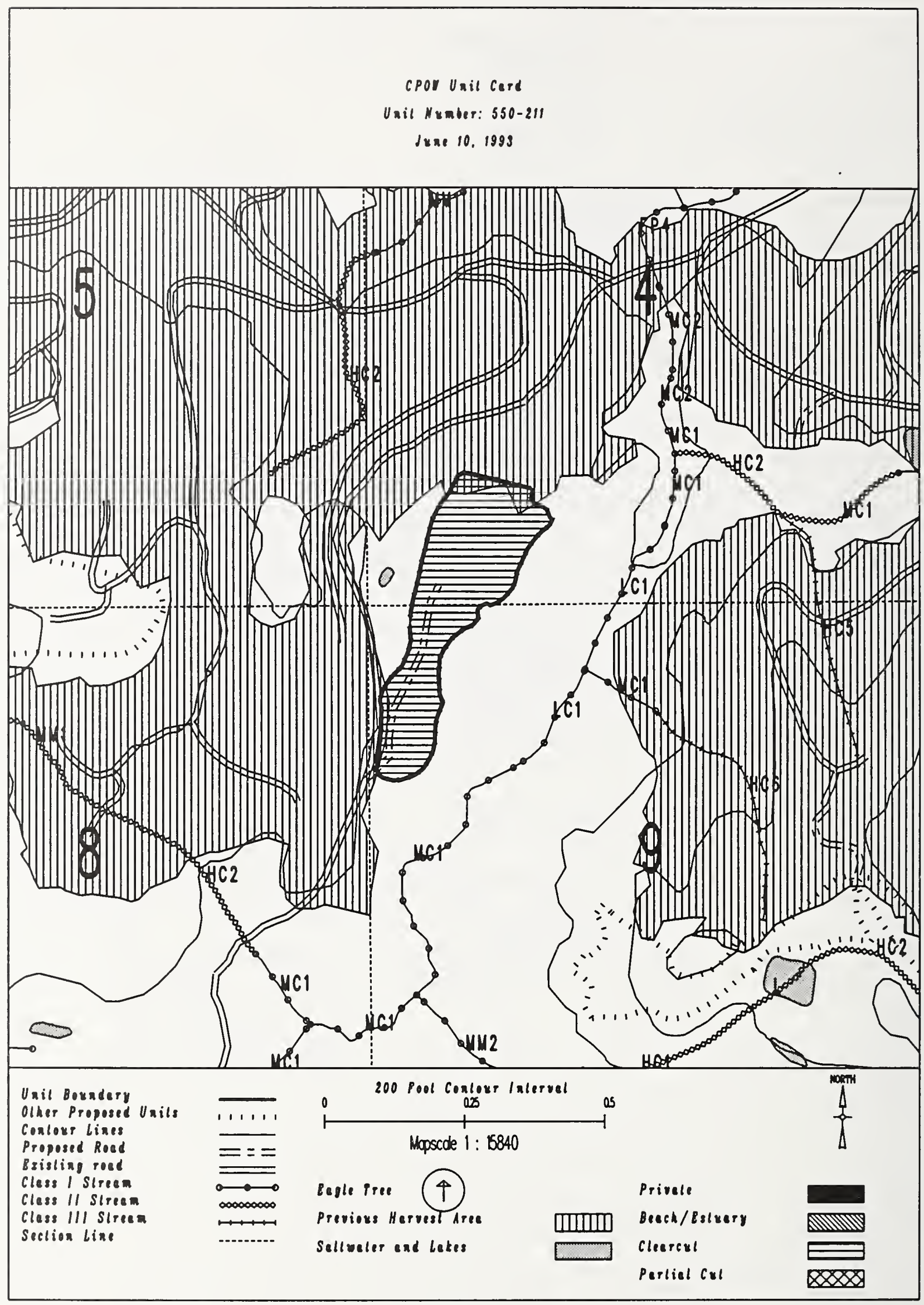


Unit $550-213$

Planned acres 37

Estimated volume (mbf) $\mathbf{7 8 8}$

Logging system slackline

silvicultural system clearcut

Forest type Hemlock

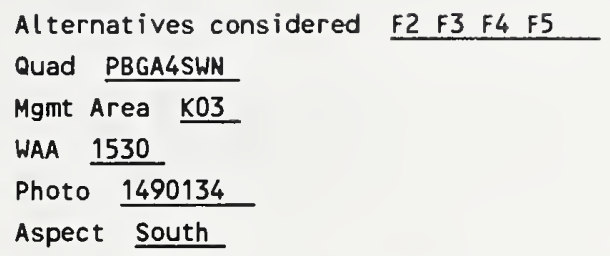

\section{PHYSICAL DESCRIPTION}

Volume class breakdown: VC4 $\underline{26}$ acres VC5 $\quad 9$ acres VC6 $\quad 0$ acres VC7 $\quad 0$ acres

Elevation breakdown: $0-800 \mathrm{ft} . \underline{26}$ acres $800-1200 \mathrm{ft} . \underline{6}$ acres $1200-1500 \mathrm{ft} . \underline{0}$ acres over $1500 \mathrm{ft}$. 0 acres Mass movement index: Low 12 acres Medium $\underline{0}$ acres High 24 acres Very High $\underline{0}$ acres

\section{SOILS}

This unit has high mass movement index soils. Partial log suspension required over these areas.(BMP13.9)

This unit contains 19 acres of forested wetlands. Site specific BMPs will be designed for selected approved

logging system and road construction practices. (BMPs 12.5, 13.9, 13.15).

This unit contains 11 acres of slopes > $75 \%$.

\section{TIMBER}

There are no timber mitigation measures anticipated for this unit.

\section{ENG INEER ING}

High mass movement index soils. Road construction must minimize landslide potential (BMP14).

slopes greater than $75 \%$ may require full bench construction and endhaul of waste (BMP14.7).

\section{FISH/WATERSHED}

This unit contains a $\underline{A 6}$ class $\underline{3}$ stream. No specific buffer or suspension requirement.

\section{HILDLIFE}

There are no wildlife mitigation measures anticipated for this unit.

\section{RECREATION / VISUALS}

This unit has a proposed Voo of MM and is not seen from any viewpoint identified by this project.

\section{LANDS}

There are no lands mitigation measures anticipated for this unit.

CULTURAL RESOURCES

There are no cultural resource mitigation measures anticipated for this unit.

GEOLOGY

Planned unit boundary/road location/logging system are designed to avoid damage to significant karst features. Mitigation measures may apply. Unit layout/changes must be coordinated with Cave Resource Specialists. 


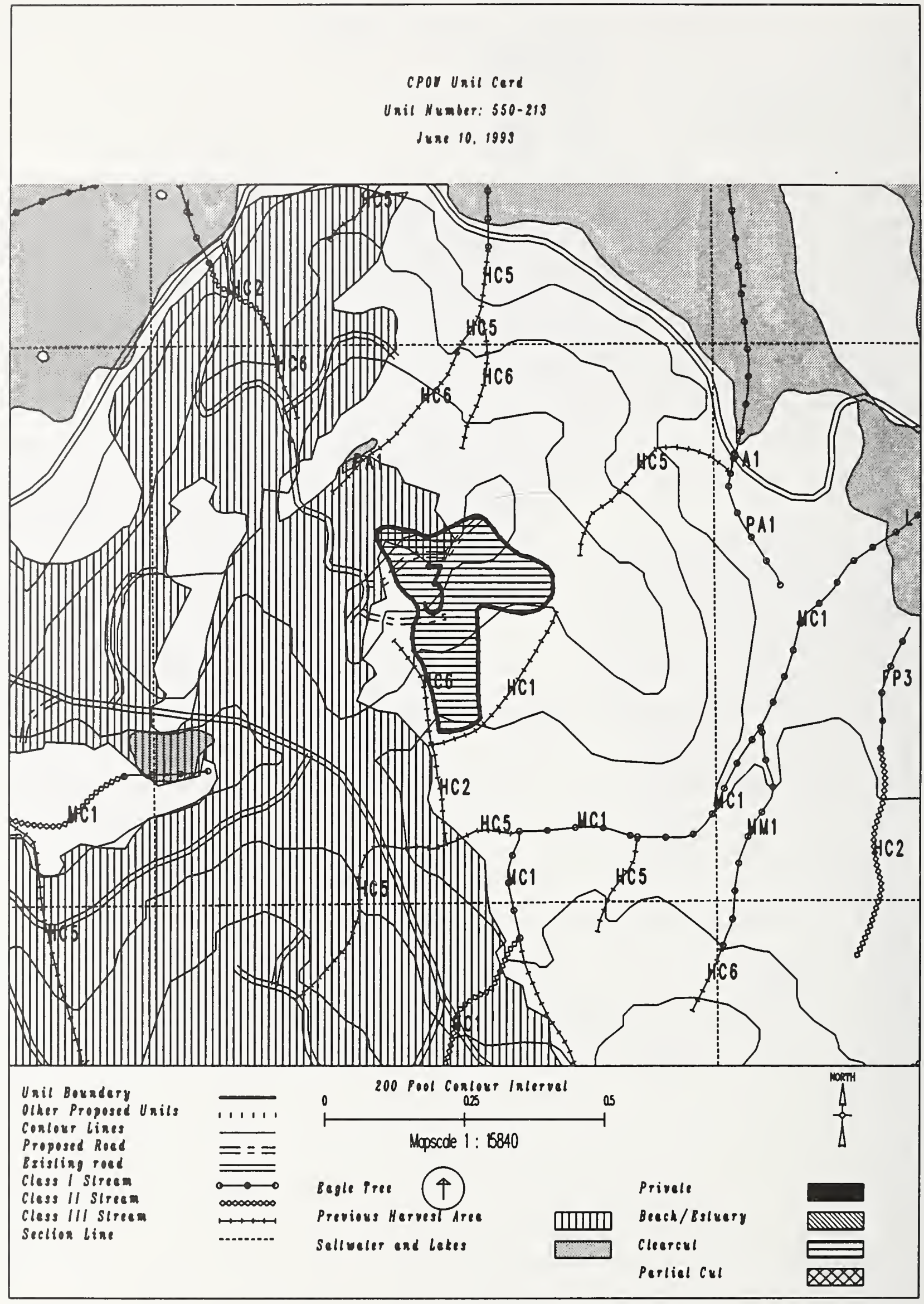


Unit $550-215$

Planned acres 37

Est imated volume (mbf) 1279

Logging system skyline

silvicultural system clearcut

Forest type Hemlock
Alternatives considered F2 F3 F4

Quad PBGA4NHS

Mgmt Area $\mathrm{K} 03$

WAA 1530

Photo 1990116

Aspect West

PHYSICAL DESCRIPTION

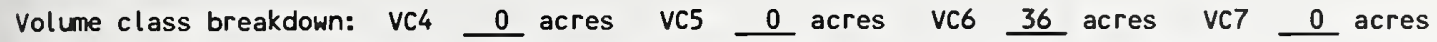

Elevation breakdown: $0-800 \mathrm{ft} . \underline{0}$ acres $800-1200 \mathrm{ft} . \underline{36}$ acres $1200-1500 \mathrm{ft} . \underline{0}$ acres over $1500 \mathrm{ft}$. 0 Mass movement index: Low $\_$acres Medium 36 acres High 0 acres Very High 0

SOILS

There are no soils mitigation measures anticipated for this unit.

TIMBER

There are no timber mitigation measures anticipated for this unit.

ENGINEER ING

There are no engineering mitigation measures anticipated for this unit.

FISH/WATERSHED

There are no fishery mitigation measures anticipated for this unit.

WILDLIFE

There are no wildlife mitigation measures anticipated for this unit.

RECREATION / VISUALS

This unit has a proposed voo of MM and is not seen from any viewpoint identified by this project.

LANDS

There are no lands mitigation measures anticipated for this unit.

CULTURAL RESOURCES

There are no cultural resource mitigation measures anticipated for this unit.

GEOLOGY

Planned unit boundary/road location/logging system are designed to avoid damage to significant karst features. Mitigation measures may apply. Unit layout/changes must be coordinated with Cave Resource Specialists. 


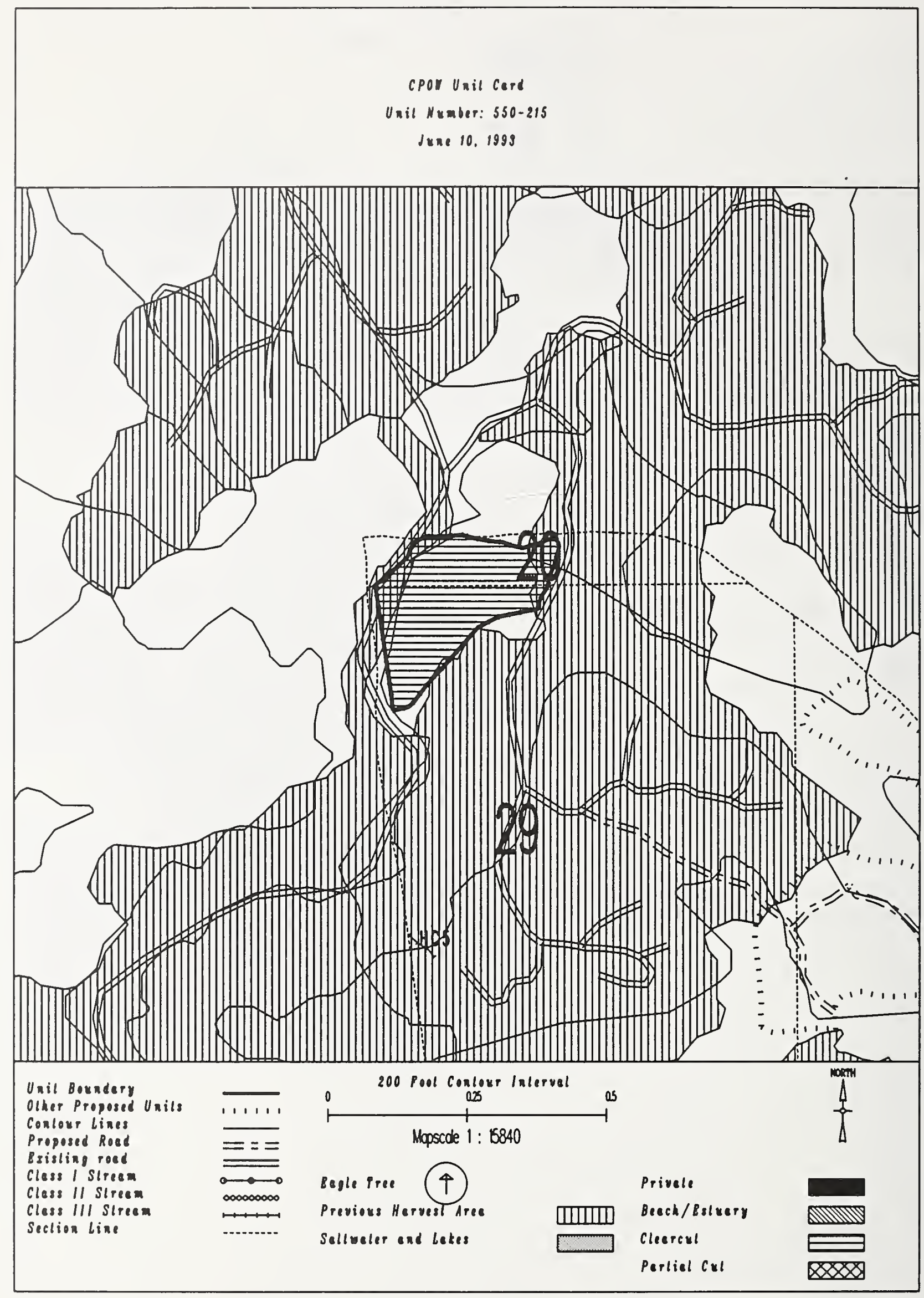


Unit $\quad 550-218$

Planned acres 67

Est imated volume (mbf) 1006

Logging system skyl ine

silvicultural system clearcut

Forest type Hemlock
Alternatives considered F2 F3 F4 F5

Quad PBGA4SEN

Mgmt Area $\mathrm{KO3}$

WAA 1530

Photo 1490133

Aspect West

PHYSICAL DESCRIPTION

Volume class breakdown: VC4 28 acres VC5 15 acres vC6 $\quad 0$ acres vc7 $\quad 0$ acres

Elevation breakdown: $0-800 \mathrm{ft} . \underline{64}$ acres $800-1200 \mathrm{ft} . \underline{0}$ acres $1200-1500 \mathrm{ft} . \underline{0}$ acres over $1500 \mathrm{ft}$. 0 acres Mass movement index: Low 54 acres Medium 0 acres High 13 acres Very High 0 acres

\section{Solls}

This unit has high mass movement index soils. Partial log suspension required over these areas. (BMP13.9)

This unit has a slight possibility to be reclassified as MMI $=4$.

This unit has > 40\% MCGilvery soils. Partial suspension required (BMP13.9)

to ensure reforestation (BMP13.19).

This unit contains 40 acres of forested wetlands. Site specific BMPs will be designed for selected approved logging system and road construction practices. (BMPs 12.5, 13.9, 13.15).

\section{TIMBER}

There are no timber mitigation measures anticipated for this unit.

\section{ENGINEER ING}

High mass movement index soils. Road construction must minimize landslide potential (BMP14).

\section{FISH/WATERSHED}

Potential for additional Class $1 / 11$ streams within unit. May be necessary to place additional buffers within unit in accordance with AHMU Handbook.

This unit contains streams which have recently been classified/channel typed but require field verification.

\section{WILDLIFE}

There are no wildlife mitigation measures anticipated for this unit.

RECREATION / VISUALS

This unit has a proposed voo of MM and is not seen from any viewpoint identified by this project.

\section{LANDS}

This unit adjacent to other ownership. Boundary establishment required prior to layout.

CULTURAL RESOURCES

There are no cultural resource mitigation measures anticipated for this unit. 
cpor Unil Cerd

Unil Number: $550-218$

June 10, 1993

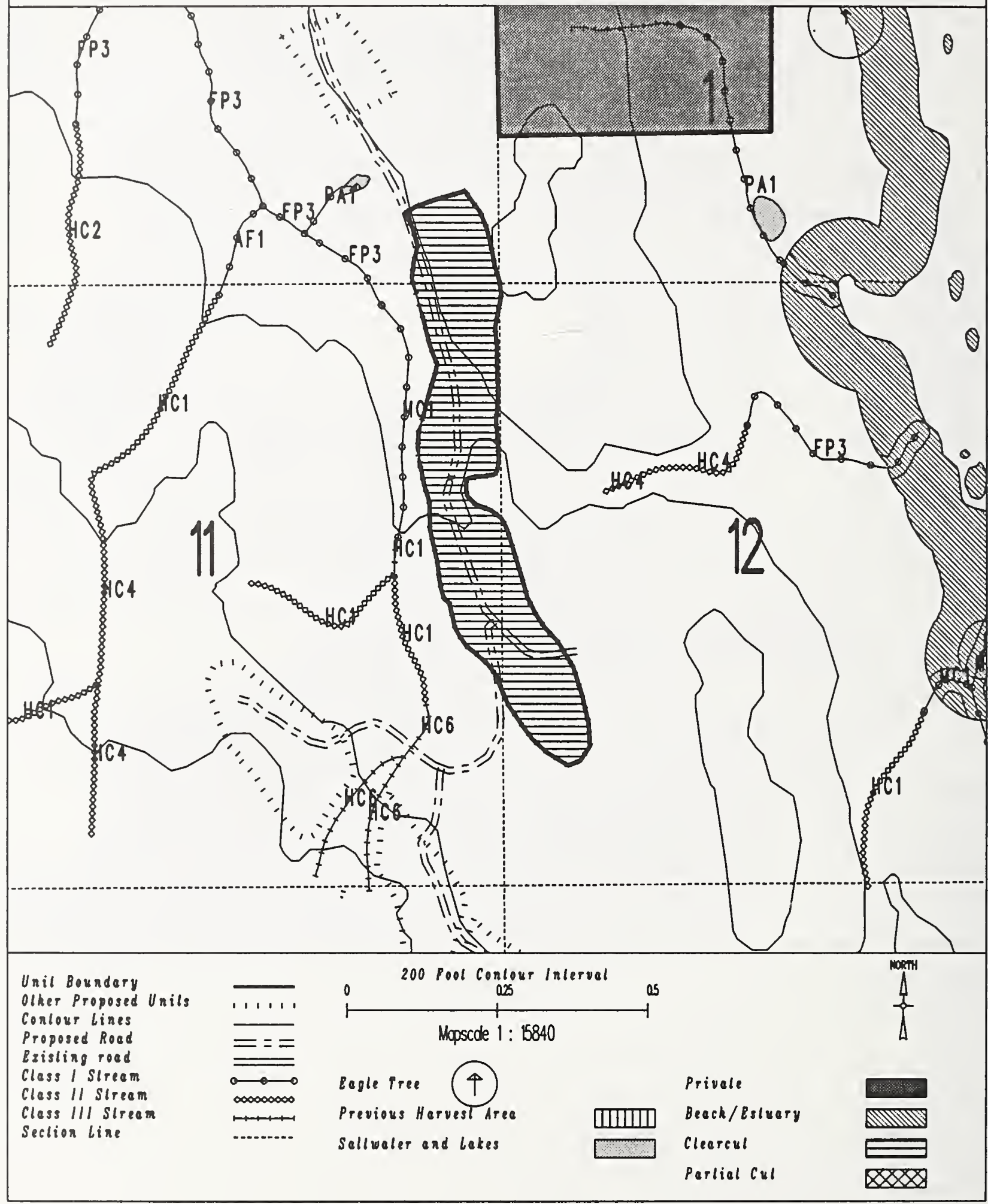


Unit $550-220$

Planned acres 40

Estimated volume (mbf) 914

Logging system skyline

silvicultural system clearcut

forest type Mixed conifer
Al ternatives considered $\quad$ 2 F3 $\quad F 4 \quad F 5$

Quad PBGA4SEN

Mgmt Area $\mathrm{KO3}$

WAA 1530

Photo 1490132

Aspect North

PHYSICAL DESCRIPTION

Volume class breakdown: VC4 16 acres VC5 $\underline{20}$ acres VC6 $\quad 0$ acres VC7 $\quad 0$ acres

Elevation breakdown: $0-800 \mathrm{ft} . \underline{36}$ acres $800-1200 \mathrm{ft} . \underline{0}$ acres $1200-1500 \mathrm{ft}$. 0 acres over $1500 \mathrm{ft}$. 0 acres Mass movement index: Low $\underline{12}$ acres Medium $\underline{0}$ acres High $\underline{27}$ acres Very High $\underline{0}$ acres

SOILS

This unit has high mass movement index soils. Partial log suspension required over these areas.(BMP13.9)

This unit has > 40\% McGilvery soils. Partial suspension required (BMP13.9)

to ensure reforestation (BMP13.19).

This unit contains 33 acres of forested wetlands. Site specific BMPs will be designed for selected approved logging system and road construction practices. (BMPs 12.5, 13.9, 13.15).

\section{TIMBER}

Water quality streams may be present, where it is impractical to split yard. Full suspension required over all streamcourses (BMPs13.9, 13.16).

\section{ENGINEERING}

High mass movement index soils. Road construction must minimize landslide potential (BMP14).

\section{FISH/WATERSHED}

This unit contains a $\underline{A} 1$ class $\underline{3}$ stream. No specific buffer required, but full suspension, if yarding across.

\section{WILDLIFE}

There are no wildlife mitigation measures anticipated for this unit.

RECREATION / VISUALS

The unit has a proposed $v 00$ of $M$ within the viewshed of whale Pass

as viewed from $1 / 2$ mile from shore.

\section{LANDS}

There are no lands mitigation measures anticipated for this unit.

CULTURAL RESOURCES

There are no cultural resource mitigation measures anticipated for this unit.

GEOLOGY

There are no karst mitigation measures anticipated for this unit. 
CPOI Unil Cerd

Unil Number: $550-220$

June 10, 1993

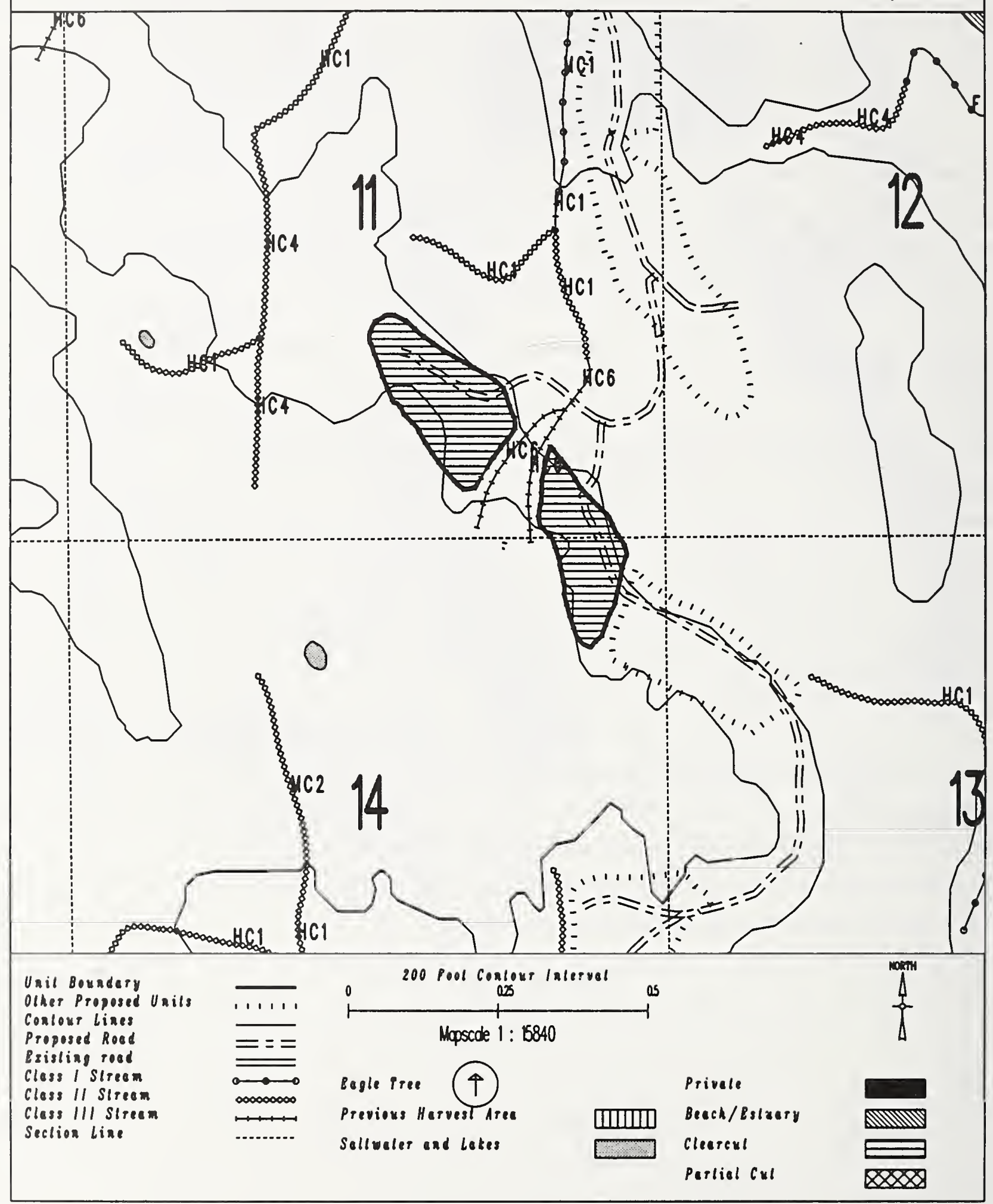




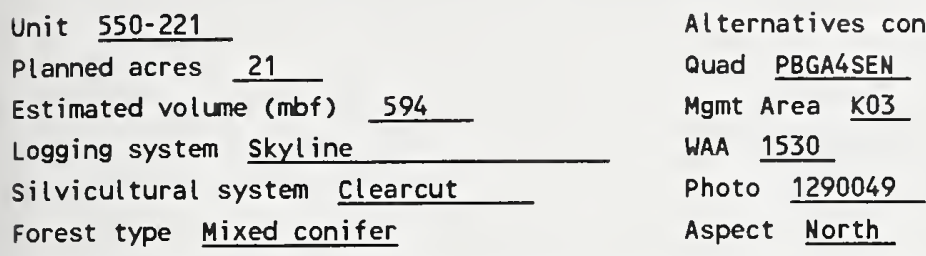

This unit has high mass movement index soils. Partial log suspension required over these areas.(BMP13.9) This unit contains 18 acres of forested wetlands. Site specific BMPs will be designed for selected approved logging system and road construction practices. (BMPs 12.5, 13.9, 13.15).

TIMBER

There are no timber mitigation measures anticipated for this unit.

ENGINEER ING

High mass movement index soils. Road construction must minimize landslide potential (BMP14).

FISH/WATERSHED

This unit contains streams which have recently been classified/channel typed but require field verification.

\section{WILDLIFE}

There are no wildlife mitigation measures anticipated for this unit.

RECREATION / VISUALS

The unit has a proposed voo of $M$ within the viewshed of whale Pass

as viewed from $1 / 2$ mile from shore.

\section{LANDS}

There are no lands mitigation measures anticipated for this unit.

CULTURAL RESOURCES

There are no cultural resource mitigation measures anticipated for this unit.

GEOLOGY

There are no karst mitigation measures anticipated for this unit. 


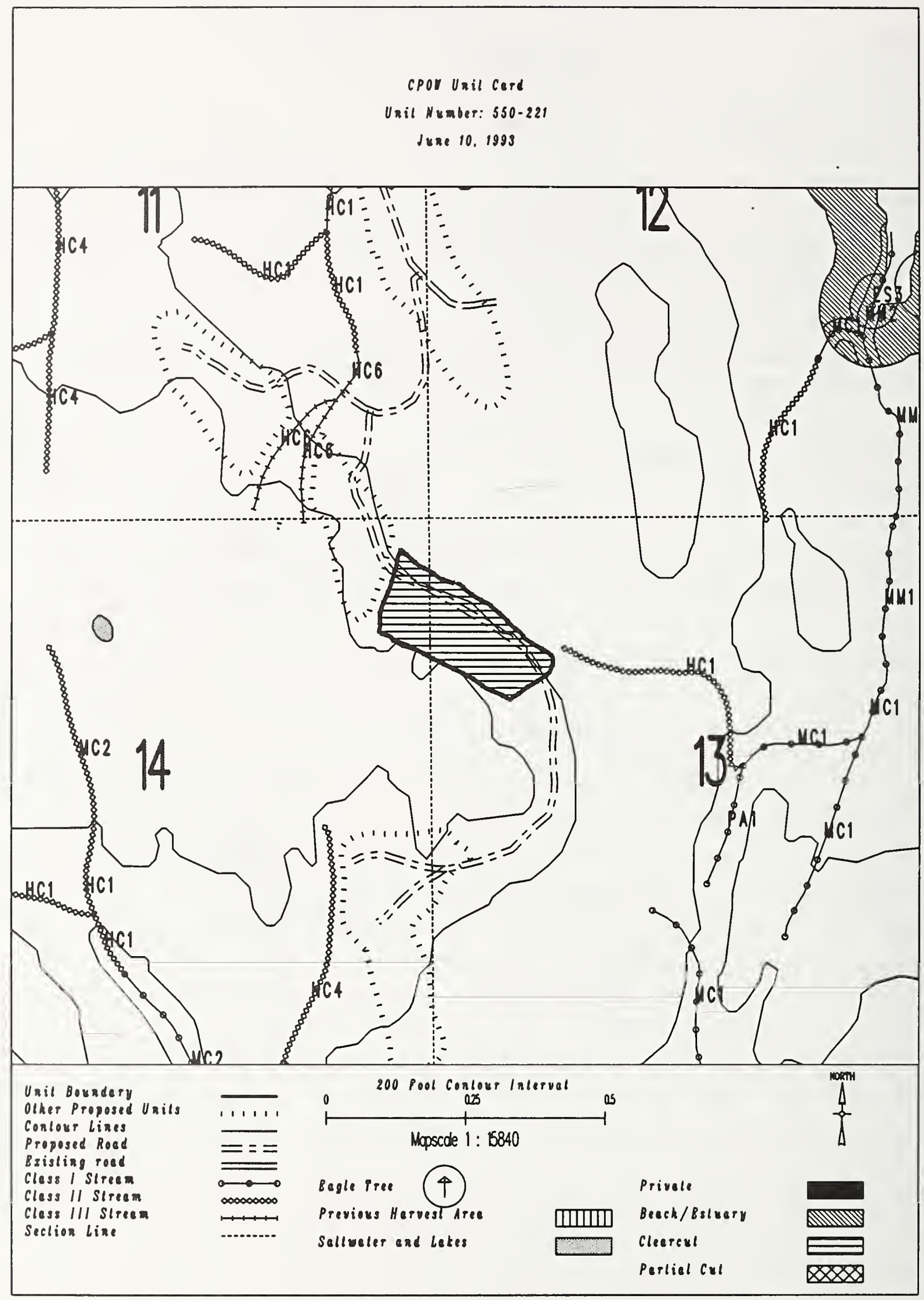


Unit 550-222

Planned acres 11

Estimated volume (mbf)

Logging system skyline

silvicultural system clearcut

Forest type Hemlock
Alternatives considered $\quad$ F2 F3 F4 F5

Quad PBGA4SEN

Mgmt Area $\mathrm{KO3}$

WAA 1530

Photo 1490134

Aspect West

PHYSICAL DESCRIPTION

Volume class breakdown: VC4 0 acres VC5 10 acres VC6 $\quad 0$ acres VC7 0 acres

Elevation breakdown: $0-800 \mathrm{ft} .11$ acres $800-1200 \mathrm{ft} . \quad 0$ acres $1200-1500 \mathrm{ft} .0$

Mass movement index: Low 1 acres Medium 0 acres High 9 acres Very High 0 acres

SOILS

This unit has high mass movement index soils. Partial log suspension required over these areas.(BMP13.9)

This unit contains 10 acres of forested wetlands. Site specific BMPs will be designed for selected approved

logging system and road construction practices. (BMPs 12.5, 13.9, 13.15).

\section{TIMBER}

There are no timber mitigation measures anticipated for this unit.

ENGINEERING

High mass movement index soils. Road construction must minimize landslide potential (BMP14).

FISH/WATERSHED

There are no fishery mitigation measures anticipated for this unit.

WILDLIFE

There are no wildlife mitigation measures anticipated for this unit.

RECREATION / VISUALS

This unit has a proposed VQO of MM and is not seen from any viewpoint identified by this project.

LANDS

There are no lands mitigation measures anticipated for this unit.

CULTURAL RESOURCES

There are no cultural resource mitigation measures anticipated for this unit.

There are no karst mitigation measures anticipated for this unit. 
cPor Unil Cerd

Unil Number: 550-222

June 10. 1999

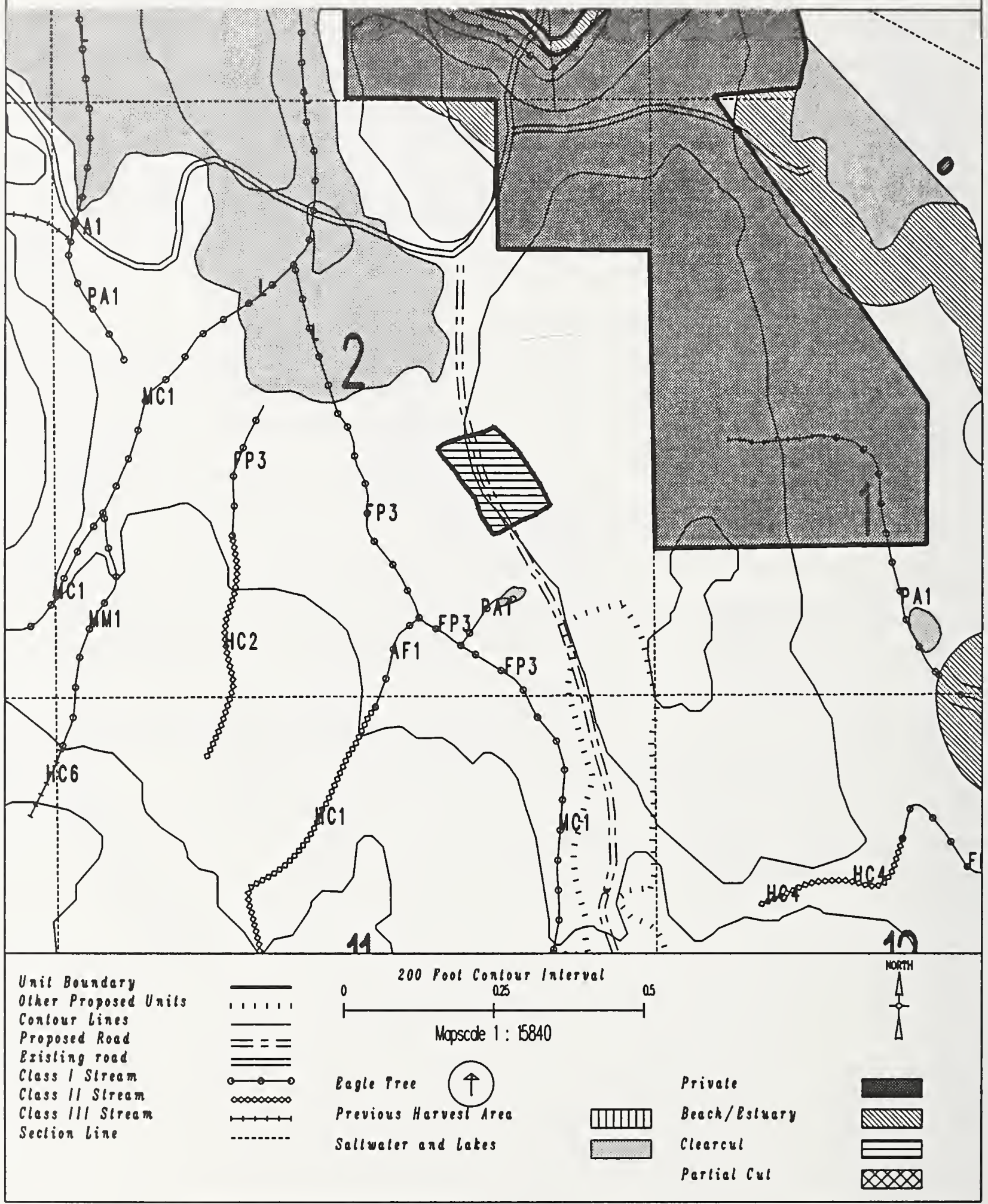


Unit $\quad 550-227$

Planned acres 71

Estimated volume (mbf) 2329

Logging system skyline

silvicultural system clearcut

Forest type Hemlock
Alternatives considered

F3

Quad PBGA4SWN

Mgmt Area $\mathrm{KO3}$

WAA 1530

Photo 1990113

Aspect North

PHYSICAL DESCRIPIION

Volume class breakdown: VC4 $\quad 0$ acres VC5 15 acres VC6 53 acres VC7 $\quad 0$ acres

Elevation breakdown: $0-800 \mathrm{ft} .70$ acres $800-1200 \mathrm{ft} . \quad 0$ acres $1200-1500 \mathrm{ft}$. 0 acres over $1500 \mathrm{ft}$. 0 acres Mass movement index: Low 0 acres Medium 3 acres High 27 acres Very High 0

SOILS

This unit has high mass movement index soils. Partial log suspension required over these areas. (BMP13.9)

This unit contains 27 acres of forested wetlands. Site specific BMPs will be designed for selected approved logging system and road construction practices. (BMPs 12.5, 13.9, 13.15).

\section{TIMBER}

There are no timber mitigation measures anticipated for this unit.

\section{ENGINEER ING}

High mass movenent index soils. Road construction must minimize landslide potential (BMP14).

\section{FISH/WATERSHED}

There are no fishery mitigation measures anticipated for this unit.

WILDLIFE

There are no wildlife mitigation measures anticipated for this unit.

RECREATION / VISUALS

This unit has a proposed VQO of MM and is not seen from any viewpoint identified by this project.

LANDS

There are no lands mitigation measures anticipated for this unit.

CULTURAL RESOURCES

There are no cultural resource mitigation measures anticipated for this unit.

\section{GEOLOGY}

Planned unit boundary/road location/logging system are designed to avoid damage to significant karst features. Mitigation measures may apply. Unit layout/changes must be coordinated with Cave Resource Specialists. 


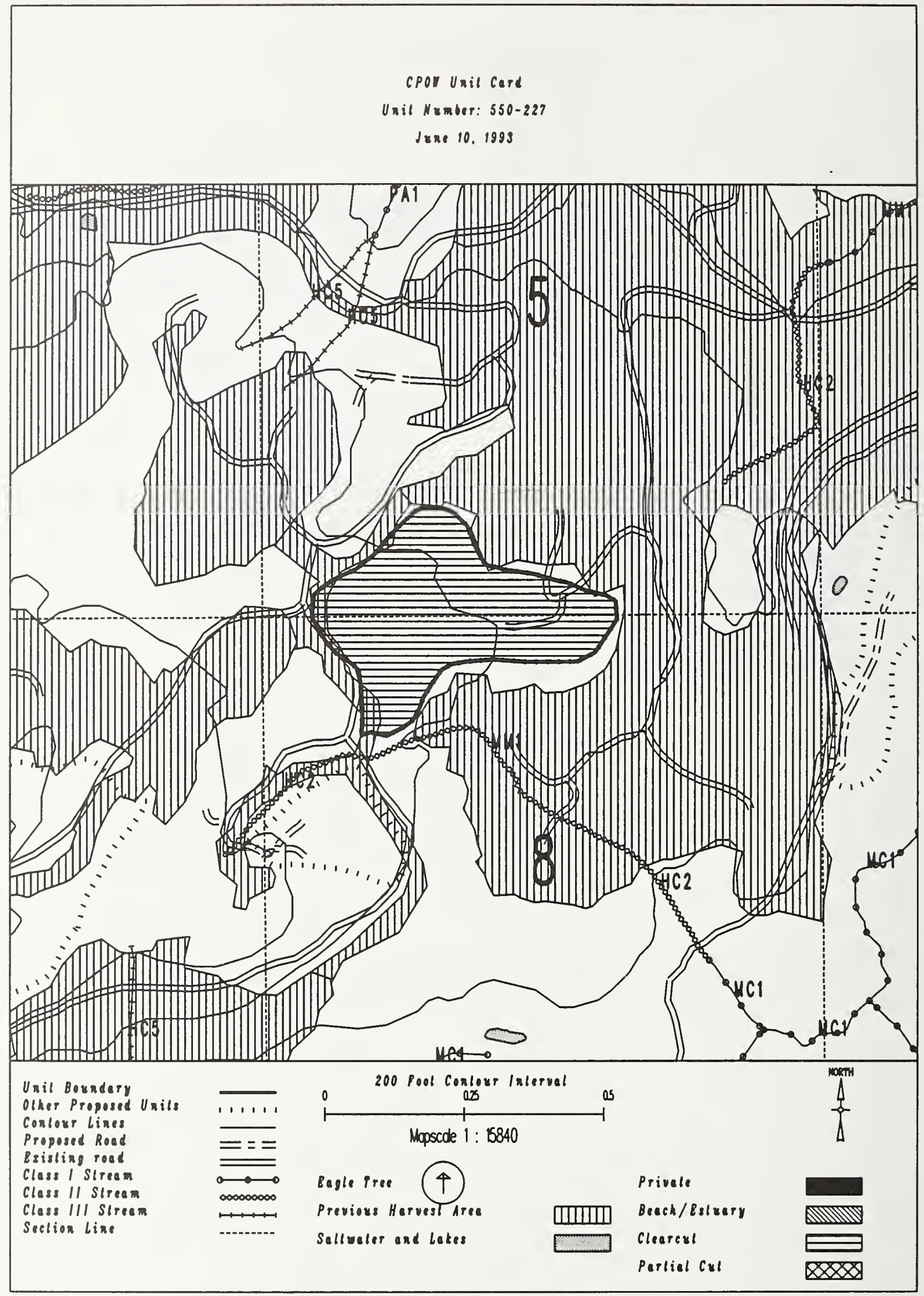


Unit $\quad 550-228$

Planned acres $\underline{22}$

Estimated volume (mbf) 782

Logging system skyline

silvicultural system clearcut

forest type Hemlock
Al ternatives considered

Quad PBGA4SWN

Mgmt Area $\mathrm{KO3}$

WAA 1530

Photo 1990113

Aspect East

\section{PHYSICAL DESCRIPTION}

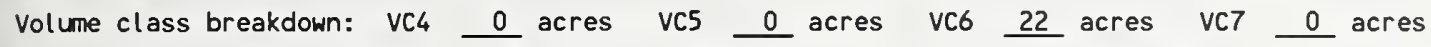

Elevation breakdown: $0-800 \mathrm{ft} . \underline{21}$ acres $800-1200 \mathrm{ft} . \underline{0}$ acres 1200-1500 ft. 0 acres over $1500 \mathrm{ft}$. 0 acres Mass movement index: Low $\_$acres Medium 15 acres High 2 acres Very High 0

\section{SOILS}

There are no soils mitigation measures anticipated for this unit.

\section{TIMBER}

There are no timber mitigation measures anticipated for this unit.

\section{ENGINEER ING}

There are no engineering mitigation measures anticipated for this unit.

\section{FISH/WATERSHED}

There are no fishery mitigation measures anticipated for this unit.

HILDLIFE

There are no wildlife mitigation measures anticipated for this unit.

RECREATION / VISUALS

This unit has a proposed Voo of MM and is not seen from any viewpoint identified by this project.

\section{LANDS}

There are no lands mitigation measures anticipated for this unit.

CULTURAL RESOURCES

There are no cultural resource mitigation measures anticipated for this unit.

\section{GEOLOGY}

Planned unit boundary/road location/logging system are designed to avoid damage to significant karst features. Mitigation measures may apply. Unit layout/changes must be coordinated with Cave Resource Specialists. 


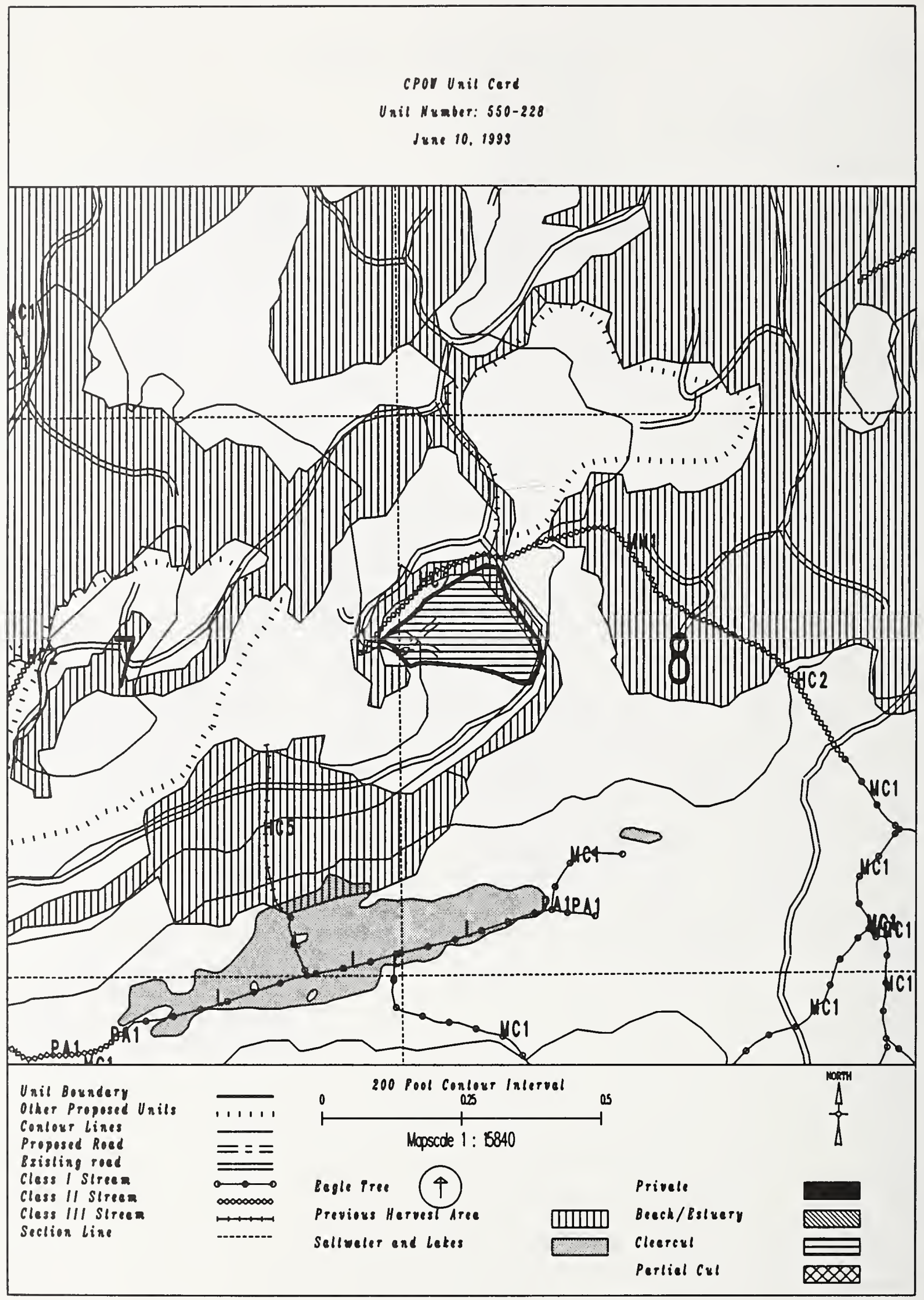


Unit $\quad 550-237$

Planned acres 27

Estimated volume (mbf)

Logging system skyl ine

silvicultural system Clearcut

Forest type Mixed conifer
Alternatives considered

Quad PBGA4SWN

Mgmt Area $\mathrm{KO3}$

WAA 1530

Photo 1990115

Aspect South

\section{PHYSICAL DESCRIPTION}

Volume class breakdown: VC4 11 acres VC5 11 acres VC6 0 acres VC7 $\quad 0$ acres

Elevation breakdown: $0-800 \mathrm{ft} . \underline{21}$ acres $800-1200 \mathrm{ft} . \underline{0}$ acres $1200-1500 \mathrm{ft} . \underline{0}$ acres over $1500 \mathrm{ft}$. 0 Mass movement index: Low 16 acres Medium 0 acres High 4 acres Very High 0

\section{SOILS}

This unit has high mass movement index soils. Partial log suspension required over these areas.(BMP13.9)

This unit contains 12 acres of forested wetlands. Site specific BMPs will be designed for selected approved

logging system and road construction practices. (BMPs 12.5, 13.9, 13.15).

\section{TIMBER}

There are no timber mitigation measures anticipated for this unit.

\section{ENGINEERING}

There are no engineering mitigation measures anticipated for this unit.

\section{FISH/WATERSHED}

Potential for additional Class I/II streams within unit. May be necessary to place additional buffers within unit in accordance with AHMU Handbook.

\section{WILDLIFE}

There are no wildlife mitigation measures anticipated for this unit.

RECREATION / VISUALS

This unit has a proposed Voo of MM and is not seen from any viewpoint identified by this project.

\section{LANDS}

There are no lands mitigation measures anticipated for this unit.

\section{CULTURAL RESOURCES}

There are no cultural resource mitigation measures anticipated for this unit.

\section{GEOLOGY}

This unit is underlain with karst, although no significant features have yet been identified. 


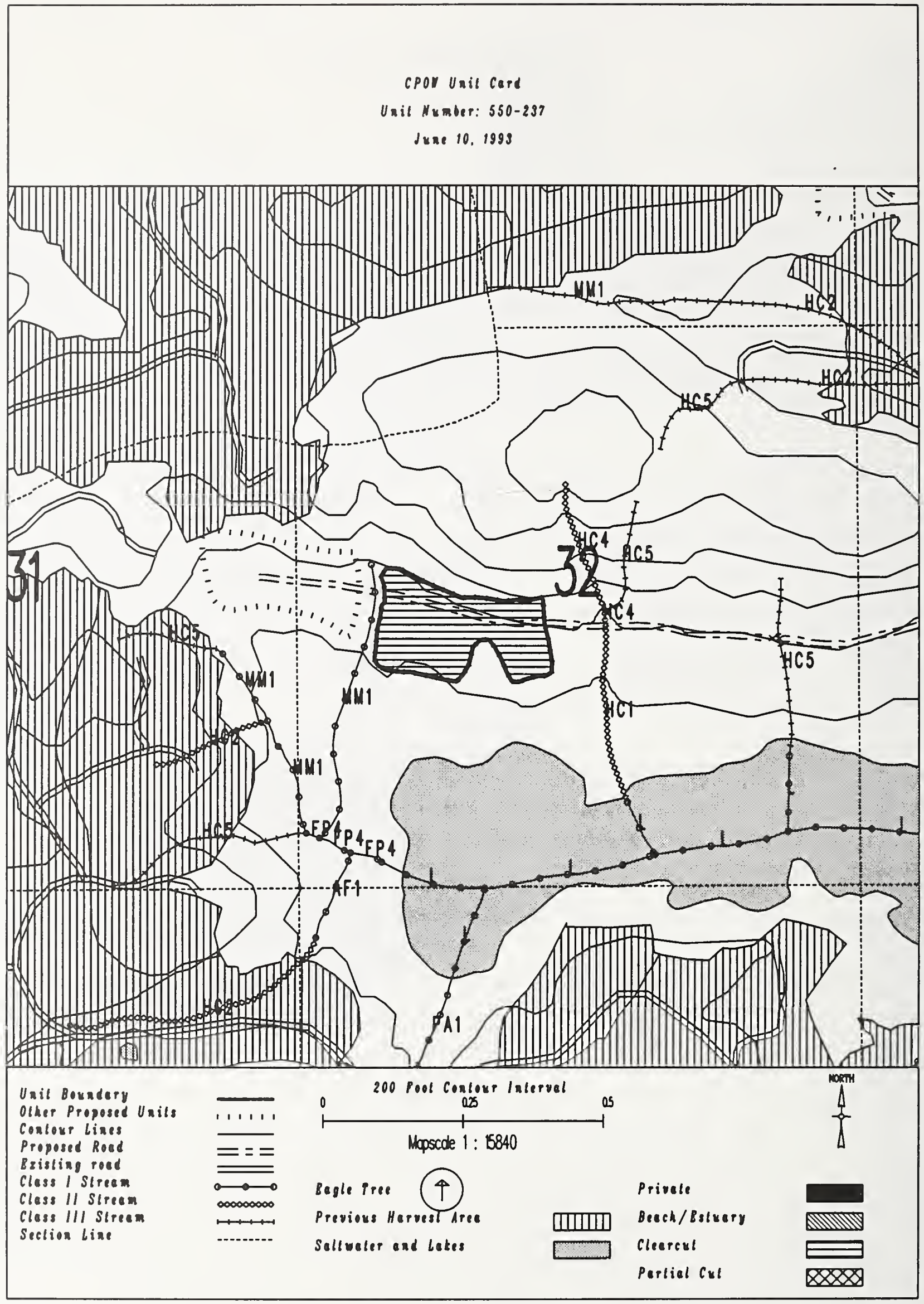


UNIT PLAN/LAYOUT/SALE ADMINISTRATION CARD FOR CPOW FEIS

Unit $\mathbf{5 5 0 - 2 3 8}$

Planned acres 22

Estimated volume (mbf)

Logging system skyline

silvicultural system clearcut

Forest type Hemlock
Alternatives considered F2 F3

Quad PBGA4SWN

Mgmt Area $\underline{\mathrm{KO3}}$

WAA 1530

Photo 1990115

Aspect $\underline{\text { South }}$

\section{PHYSICAL DESCRIPTION}

Volume class breakdown: VC4 9 acres VC5 13 acres VC6 $\quad 0$ acres VC7 0 acres

Elevation breakdown: $0-800 \mathrm{ft} . \underline{21}$ acres $800-1200 \mathrm{ft} . \underline{0}$ acres 1200-1500 ft. 0 acres over $1500 \mathrm{ft}$. 0 acres Mass movement index: Low 20 acres Medium 1 acres High 0 acres Very High 0

SOILS

This unit contains 10 -acres of forested wetlands. Site specific BMPs will be designed for selected approved logging system and road construction practices. (BMPs 12.5, 13.9, 13.15).

\section{TIMBER}

There are no timber mitigation measures anticipated for this unit.

\section{ENGINEER ING}

The road into this unit crosses a B2 channel. Meet stream and lake protection prescription requirements in TLMP Oraft Revision (1991a) for this process group.

\section{FISH/WATERSHED}

This unit contains streams which have recently been classified/channel typed but require field verification.

\section{WILOLIFE}

There are no wildlife mitigation measures anticipated for this unit.

\section{RECREATION / VISUALS}

This unit has a proposed VQO of MM and is not seen from any viewpoint identified by this project.

\section{LANDS}

There are no lands mitigation measures anticipated for this unit.

CULTURAL RESOURCES

There are no cultural resource mitigation measures anticipated for this unit.

GEOLOGY

This unit is underlain with karst, although no significant features have yet been identified. 


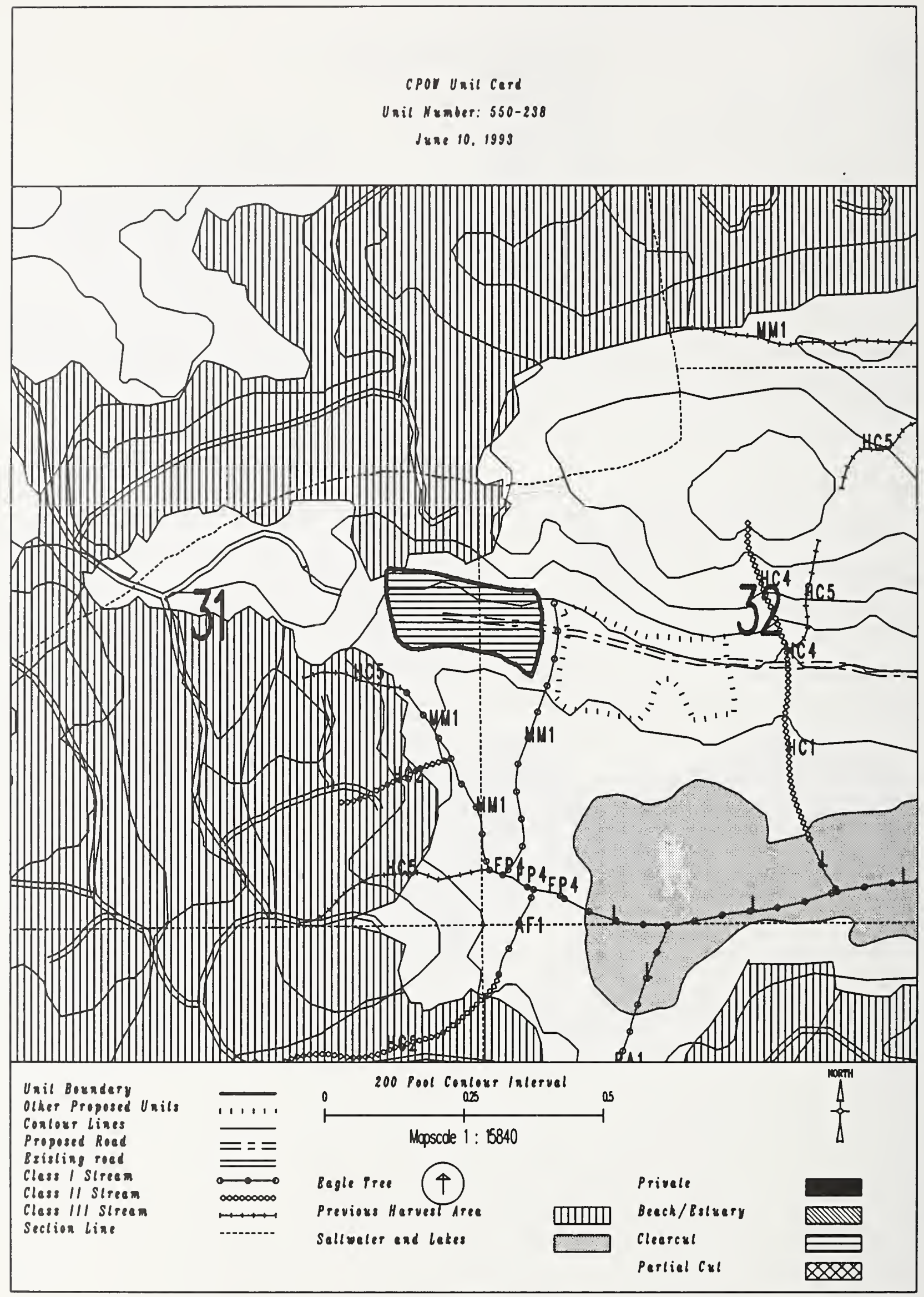


Unit 550-239

Planned acres $\underline{58}$

Est imated volume (mbf) 1987

Logging system slackline

silvicultural system clearcut

Forest type Hemlock
Alternatives considered $\mathrm{F2} F 3 \quad F 4$

Quad PBGA4SWN

Mgmt Area $\mathrm{KO3}$

WAA 1530

Photo 1990020

Aspect South

\section{PHYSICAL DESCRIPTION}

Volume class breakdown: VC4 $\quad 0$ acres VC5 31 acres VC6 30 acres VC7 $\quad 0$ acres

Elevation breakdown: $0-800 \mathrm{ft} . \underline{2}$ acres $800-1200 \mathrm{ft} . \underline{57}$ acres $1200-1500 \mathrm{ft} . \underline{0}$ acres over $1500 \mathrm{ft}$. 0 acres Mass movement index: Low 0 acres Medium 60 acres High 0 acres Very High 0 acres

SOILS

There are no soils mitigation measures anticipated for this unit.

\section{TIMBER}

There are no timber mitigation measures anticipated for this unit.

\section{ENGINEERING}

There are no engineering mitigation measures anticipated for this unit.

\section{FISH/WATERSHED}

There are no fishery mitigation measures anticipated for this unit.

\section{WILDLIFE}

There are no wildlife mitigation measures anticipated for this unit.

RECREATION / VISUALS

This unit has a proposed VQO of MM and is not seen from any viewpoint identified by this project.

\section{LANDS}

There are no lands mitigation measures anticipated for this unit.

CULTURAL RESOURCES

There are no cultural resource mitigation measures anticipated for this unit.

\section{GEOLOGY}

Planned unit boundary/road location/logging system are designed to avoid damage to significant karst features. Mitigation measures may apply. Unit layout/changes must be coordinated with Cave Resource Specialists. 
cPor Unil cerd

Unit Hember: $550-299$

June 10. 1993

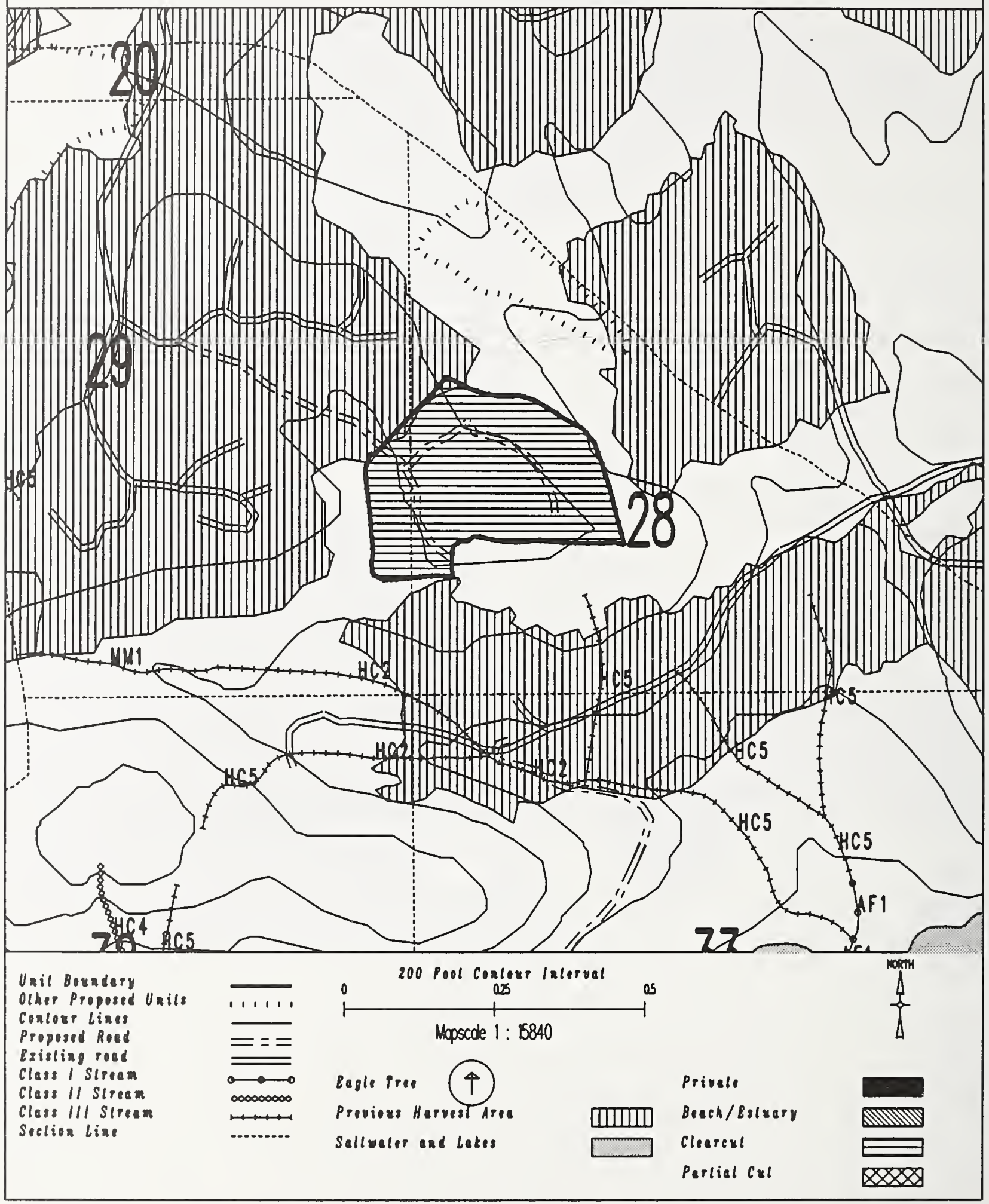


Unit $551-238$

Planned acres 33

Est imated volume (mbf)

Logging system skyline

silvicultural system clearcut

Furest type Cedar

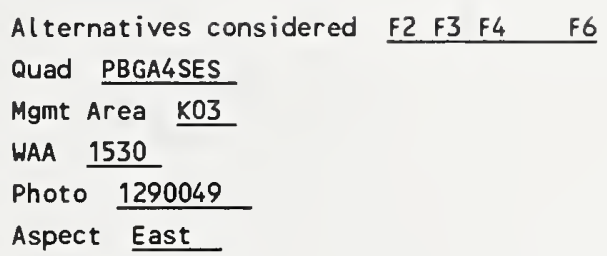

PHYSICAL DESCRIPTION

Volume class breakdown: VC4 22 acres VC5 $\quad \underline{0}$ acres vC6 $\quad 0$ acres vC7 $\quad 0$ acres

Elevation breakdown: $0-800 \mathrm{ft} . \underline{29}$ acres $800-1200 \mathrm{ft} . \underline{0}$ acres $1200-1500 \mathrm{ft} . \underline{0}$ acres over $1500 \mathrm{ft}$. 0 acres Mass movement index: Low 32 acres Medium $\_$acres High 0 acres Very High 0 acres

\section{SOILS}

This unit contains 16 acres of forested wetlands. Site specific BMPs will be designed for selected approved logging system and road construction practices. (BMPs 12.5, 13.9, 13.15).

\section{TIMBER}

There are no timber mitigation measures anticipated for this unit.

\section{ENGINEER ING}

There are no engineering mitigation measures anticipated for this unit.

\section{FISH/WATERSHED}

There are no fishery mitigation measures anticipated for this unit.

\section{WILDLIFE}

There are no wildlife mitigation measures anticipated for this unit.

\section{RECREATION / VISUALS}

The unit has a proposed VQO of $M$ within the viewshed of whale Pass

as viewed from $1 / 2 \mathrm{mile}$ from shore.

\section{LANDS}

There are no lands mitigation measures anticipated for this unit.

CULTURAL RESOURCES

There are no cultural resource mitigation measures anticipated for this unit. 


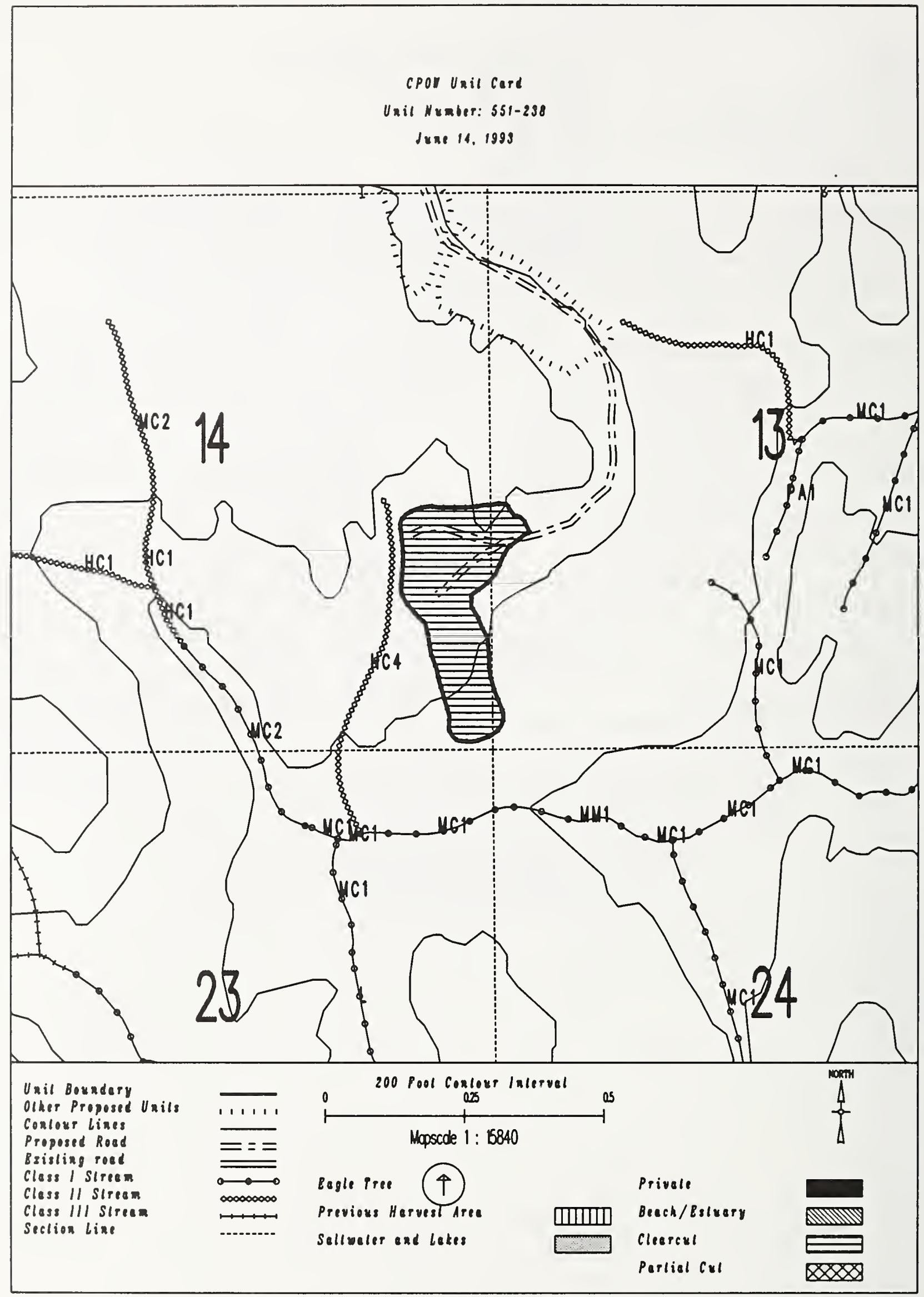


Unit $551-249$

Planned acres 69

Estimated volume (mbf) 1714

Logging system slackline

silvicultural system Clearcut

Forest type Hemlock
Alternatives considered

Quad PBGA4SES

Mgmt Area $\mathrm{KO3}$

WAA 1530

Photo 1190018

Aspect West

PHYSICAL DESCRIPTION

Volume class breakdown: VC4 $\quad 50$ acres VC5 $\quad 24$ acres $v C 6 \quad 0$ acres $\quad$ vC7 $\quad 0$ acres

Elevation breakdown: $0-800 \mathrm{ft} . \underline{71}$ acres $800-1200 \mathrm{ft} . \underline{0}$ acres $1200-1500 \mathrm{ft} . \underline{0}$ acres over $1500 \mathrm{ft}$. 0 acres Mass movement index: Low 56 acres Medium 0 acres High 15 acres Very High 0 acres

SOILS

This unit has high mass movement index soils. Partial log suspension required over these areas. (BMP13.9)

This unit contains $\underline{42}$ acres of forested wetlands. Site specific BMPs will be designed for selected approved

logging system and road construction practices. (BMPs 12.5, 13.9, 13.15).

This unit contains 2 acres of slopes $>75 \%$.

TIMBER

There are no timber mitigation measures anticipated for this unit.

ENGINEER ING

High mass movement index soils. Road construction must minimize landslide potential (BMP14).

FISH/WATERSHED

There are no fishery mitigation measures anticipated for this unit.

\section{WILDLIFE}

Maintain diversity within unit by leaving 1-5 acre-sized islands of green trees at a rate of 1 acre of island for every 20 acres harvested. Leave islands must be compatible with logging system and safe working conditions.

\section{RECREATION / VISUALS}

The unit has a proposed VQO of PR within the viewshed of whale Pass

as viewed from $1 / 2 \mathrm{mile}$ from shore.

\section{LANDS}

There are no lands mitigation measures anticipated for this unit.

CULTURAL RESOURCES

There are no cultural resource mitigation measures anticipated for this unit.

There are no karst mitigation measures anticipated for this unit. 
cpor Unil cerd

Unil Number: $551-219$

Juxe 10. 1993

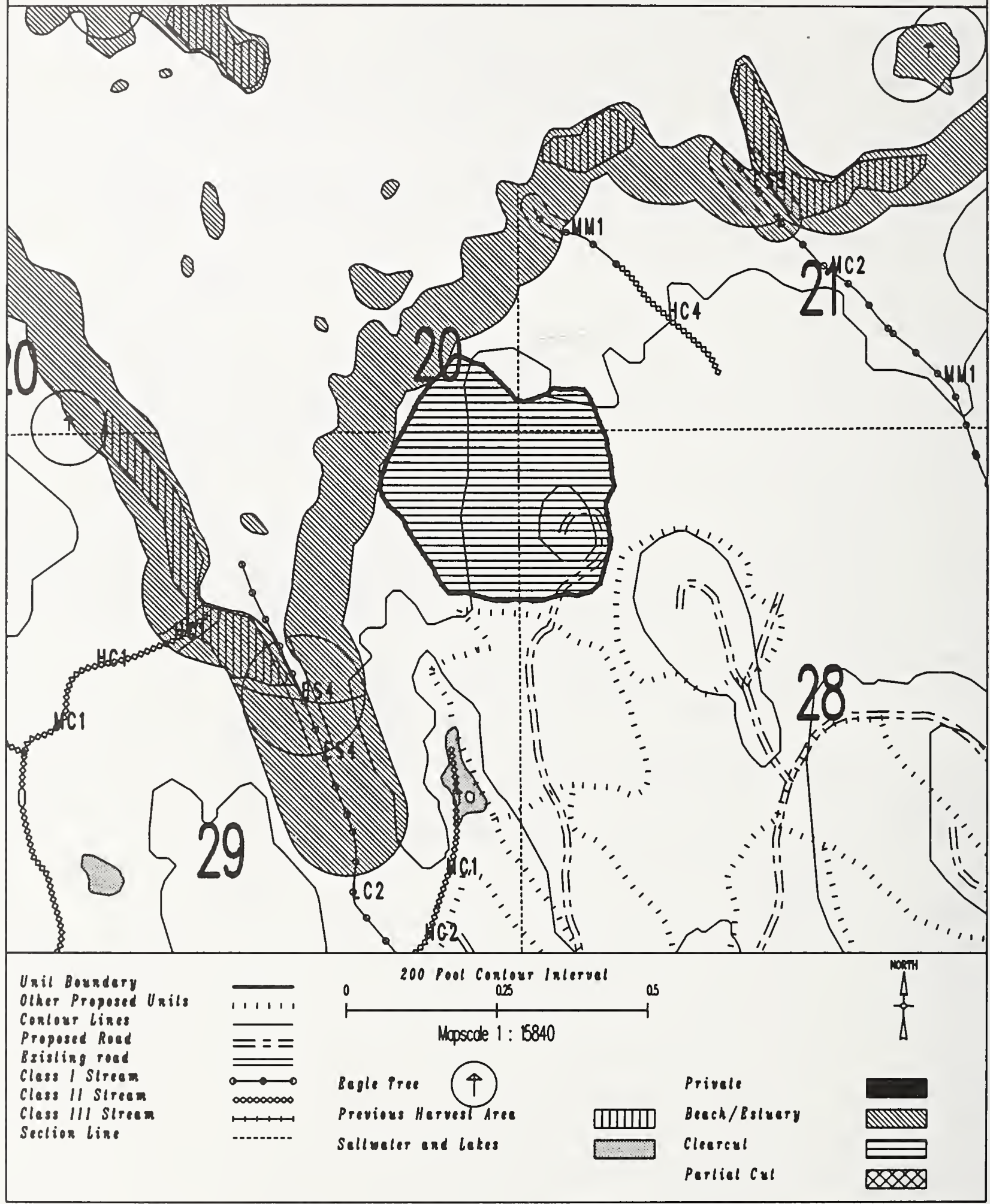


Unit $551-250$

Planned acres 33

Estimated volume (mbf) 681

Logging system Highlead

silvicultural system clearcut

Forest type Hemlock
Al ternatives considered

Quad PBGA4SES

Mgmt Area $\mathrm{KO3}$

WAA 1530

Photo 1190018

Aspect North

PHYSICAL DESCRIPTION

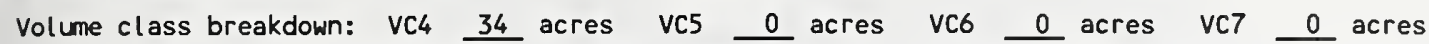

Elevation breakdown: $0-800 \mathrm{ft} .34$ acres $800-1200 \mathrm{ft} . \underline{0}$ acres 1200-1500 ft. 0 acres over $1500 \mathrm{ft}$. 0 acres Mass movement index: Low 4 acres Medium 0 acres High 18 acres Very High 0 acres

\section{SOILS}

This unit has high mass movement index soils. Partial log suspension required over these areas.(BMP13.9)

This unit contains $\underline{24}$ acres of forested wetlands. Site specific BMPs will be designed for selected approved

logging system and road construction practices. (BMPs 12.5, 13.9, 13.15).

This unit contains 21 acres of slopes > $75 \%$.

\section{TIMBER}

Water quality streams may be present, where it is impractical to split yard. Full suspension required over all streancourses (BMPs13.9, 13.16).

\section{ENG I NEER ING}

High mass movement index soils. Road construction must minimize landslide potential (BMP14).

slopes greater than $75 \%$ may require full bench construction and endhaul of waste (BMP14.7).

\section{FISH/WATERSHED}

There are no fishery mitigation measures anticipated for this unit.

\section{WILDLIFE}

Maintain diversity within unit by leaving 1-5 acre-sized islands of green trees at a rate of 1 acre of island for every 20 acres harvested. Leave islands must be compatible with logging system and safe working conditions.

\section{RECREATION / VISUALS}

This unit has a proposed voo of MM and is not seen from any viewpoint identified by this project.

\section{LANDS}

There are no lands mitigation measures anticipated for this unit.

\section{CULTURAL RESOURCES}

There are no cultural resource mitigation measures anticipated for this unit.

\section{GEOLOGY}

There are no karst mitigation measures anticipated for this unit. 
CPOI Unil Cerd

Unil Number: $551-250$

June 10, 1993

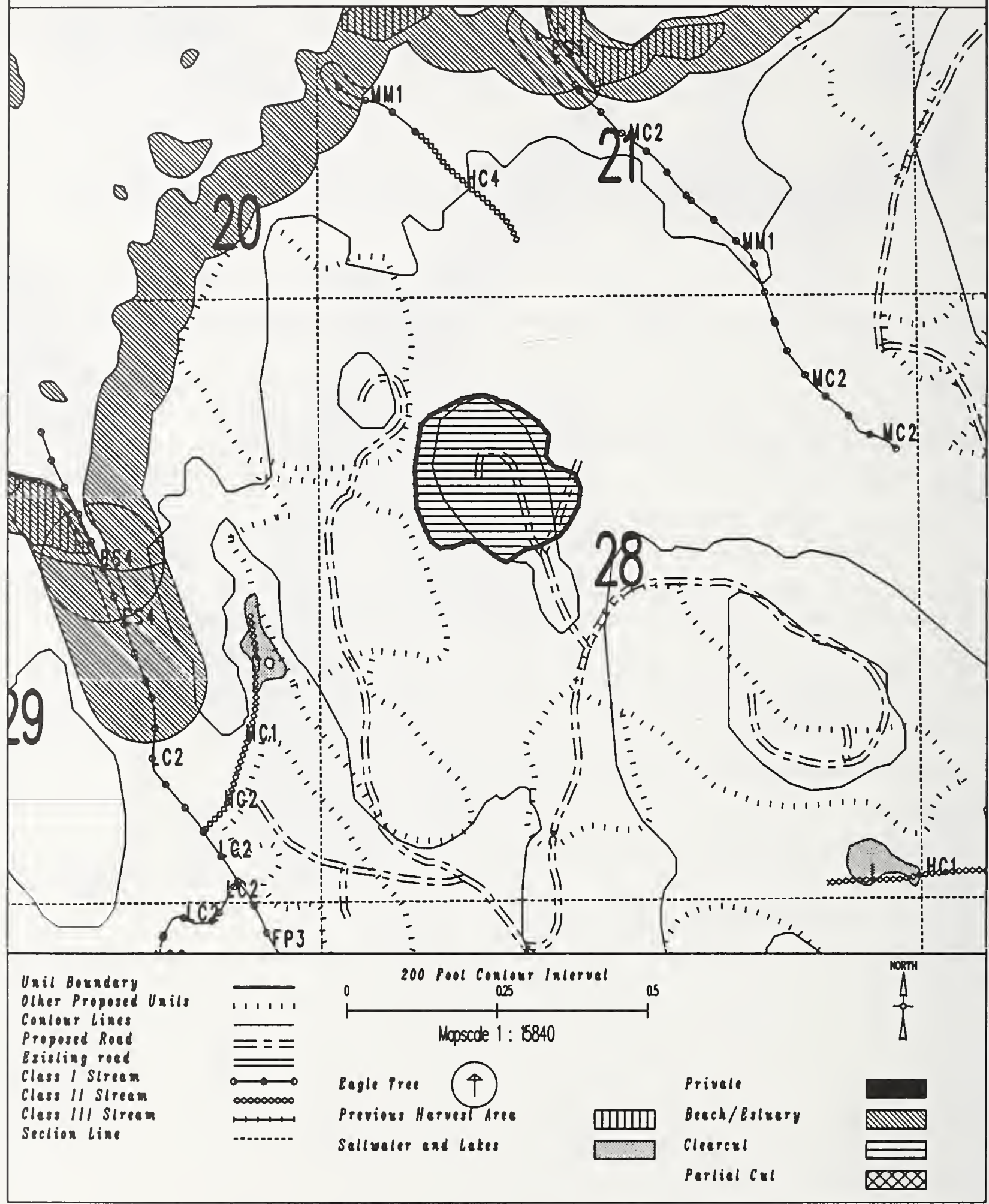


Unit $\underline{551-254}$

Planned acres $\underline{25}$

Estimated volume (mbf)

Logging system skyline

Silvicultural system clearcut

Forest type Mixed conifer
Al ternatives considered

F3

Quad PBGA4SES

Mgmt Area $\mathrm{KO3}$

WAA 1530

Photo 1190018

Aspect West

PHYSICAL DESCRIPTION

Volume class breakdown: VC4 12 acres VC5 12 acres VC6 $\quad 0$ acres VC7 $\quad 0$ acres

Elevation breakdown: $0-800 \mathrm{ft} .23$ acres $800-1200 \mathrm{ft} . \underline{0}$ acres $1200-1500 \mathrm{ft} . \underline{0}$ acres over $1500 \mathrm{ft}$. 0 acres Mass movement index: Low 5 acres Medium 0 acres High 3 acres Very High 0

SOILS

This unit has high mass movement index soils. Partial log suspension required over these areas. (BMP13.9)

This unit contains 14 acres of forested wetlands. Site specific BMPs will be designed for selected approved

logging system and road construction practices. (BMPs 12.5, 13.9, 13.15).

This unit contains 7 acres of slopes $>75 \%$.

\section{TIMBER}

There are no timber mitigation measures anticipated for this unit.

ENGINEER ING

Slopes greater than $75 \%$ may require full bench construction and endhaul of waste (BMP14.7).

\section{FISH/WATER SHED}

There are no fishery mitigation measures anticipated for this unit.

WI LDL I FE

There are no wildlife mitigation measures anticipated for this unit.

RECREATION / VISUALS

The unit has a proposed VQO of PR with in the viewshed of whale Pass

as viewed from $1 / 2$ mile from shore.

\section{LANDS}

There are no lands mitigation measures anticipated for this unit.

CULTURAL RESOURCES

There are no cultural resource mitigation measures anticipated for this unit.

There are no karst mitigation measures anticipated for this unit. 


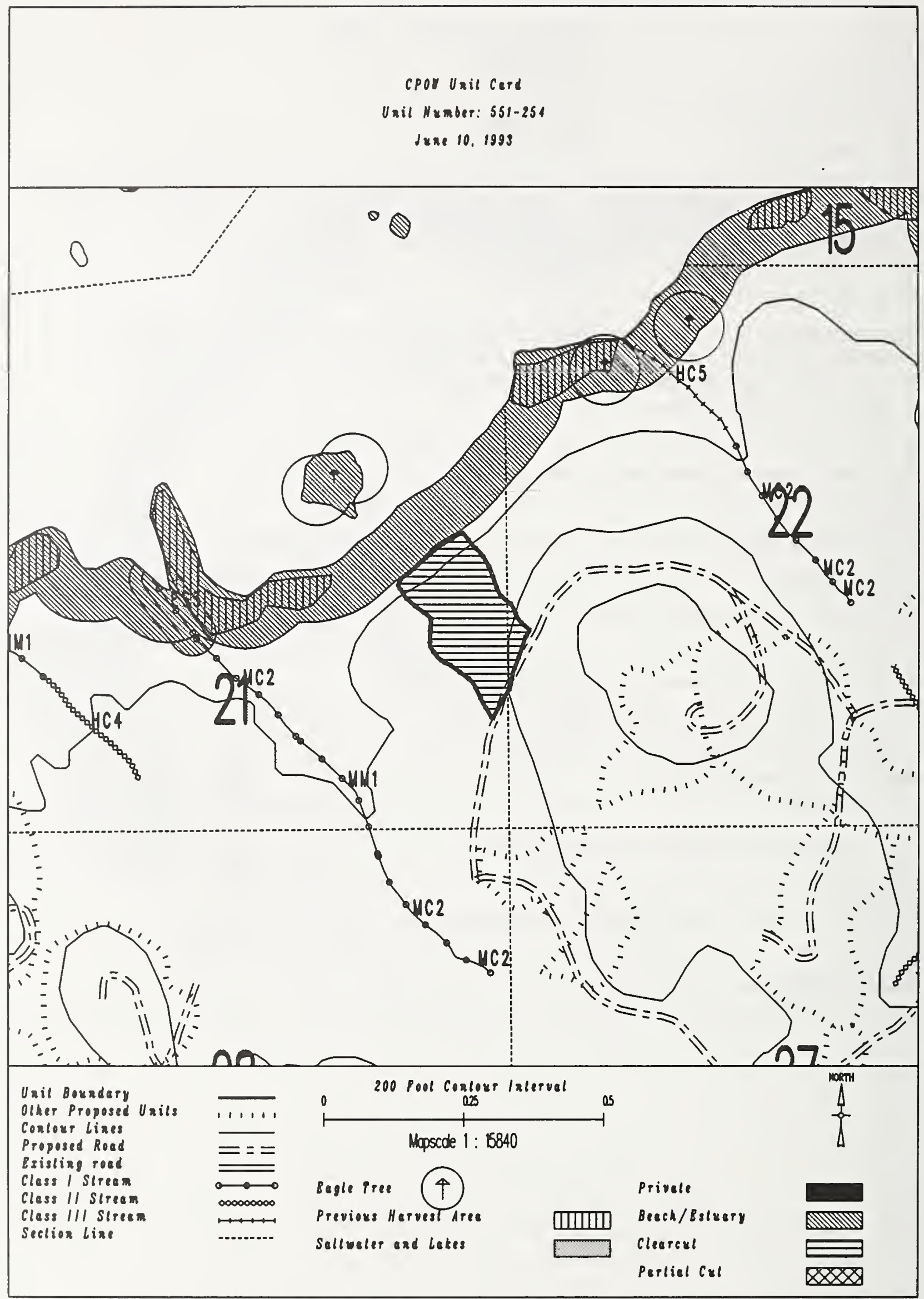


Unit $\quad 552-201$

Planned acres 53

Estimated volume (mbf) 1150

Logging system slackline

silvicultural system clearcut

Forest type Hemlock
Alternatives considered

F3

Quad PBGA4SES

Mgmt Area $\mathrm{K08}$

WAA 1421

Photo 1190074

Aspect East

PHYSICAL DESCRIPTION

Volume class breakdown: VC4 53 acres vC5 $\quad 3$ acres vc6 $\quad 0$ acres vc7 $\quad 0$ acres

Elevation breakdown: $0-800 \mathrm{ft} . \underline{53}$ acres $800-1200 \mathrm{ft} . \quad 0$ acres $1200-1500 \mathrm{ft} .{ }_{0}^{0}$ acres over $1500 \mathrm{ft}$. 0 acres Mass movement index: Low 7 acres Medium 21 acres High 2 acres Very High 0 acres

SOILS

This unit contains $\underline{\mathbf{5 0}}$ acres of forested wetlands. Site specific BMPs will be designed for selected approved logging system and road construction practices. (BMPs 12.5, 13.9, 13.15).

This unit contains 3 acres of slopes > $75 \%$.

TIMBER

There are no timber mitigation measures anticipated for this unit.

ENGINEER I NG

There are no engineering mitigation measures anticipated for this unit.

\section{FISH/WATERSHED}

There are no fishery mitigation measures anticipated for this unit.

\section{WILDLIFE}

Maintain diversity within unit by leaving 1-5 acre-sized islands of green trees at a rate of 1 acre of island for every 20 acres harvested. Leave islands must be compatible with logging system and safe working conditions.

\section{RECREATION / VISUALS}

The unit has a proposed VQO of PR within the viewshed of whale Pass

as viewed from $1 / 2 \mathrm{mile}$ from shore.

\section{LANDS}

There are no lands mitigation measures anticipated for this unit.

CULTURAL RESOURCES

The planned unit boundary and road location is immediately adjacent to significant cultural resources. Any changes must be coordinated with cultural resource personnel.

There are no karst mitigation measures anticipated for this unit. 


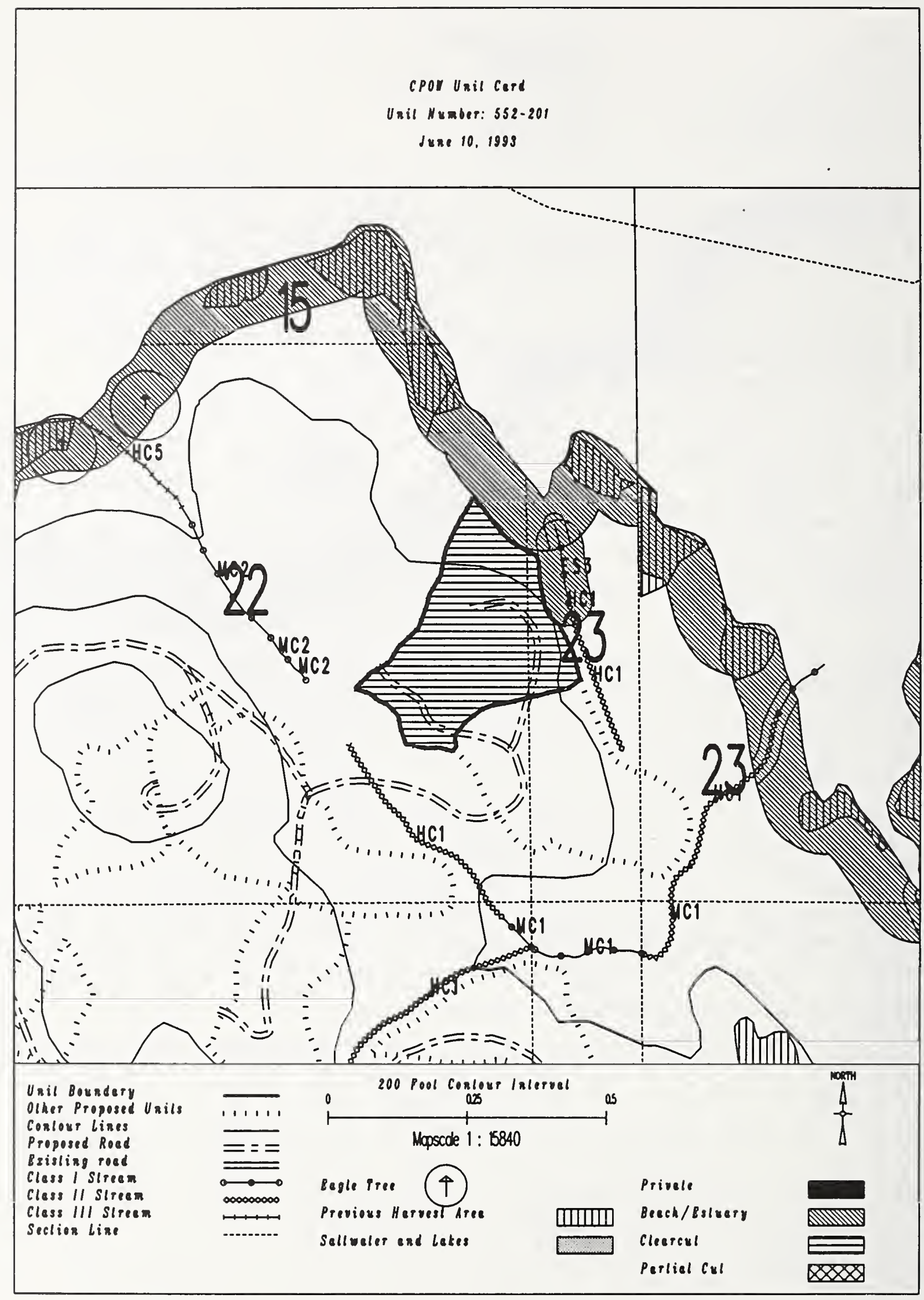


Unit $552-202$

Planned acres 51

Estimated volume (mbf) 1477

Logging system Skyline

silvicultural system clearcut

Forest type Hemlock
Al ternatives considered

Quad PBGA4SES

Mgmt Area $\mathrm{K08}$

WAA 1421

Photo 1190074

Aspect East

PHYSICAL DESCRIPTION

Volume class breakdown: VC4 $\quad 10$ acres VC5 $\quad 43$ acres VC6 $\quad 0$ acres vc7 $\quad 0$ acres

Elevation breakdown: $0-800 \mathrm{ft} .51$ acres $800-1200 \mathrm{ft} . \quad 0$ acres 1200-1500 ft. 0 acres over $1500 \mathrm{ft}$. 0 acres Mass movement index: Low 13 acres Medium $\underline{27}$ acres High $\underline{2}$ acres Very High 0 acres

\section{SOILS}

This unit contains 42 acres of forested wetlands. Site specific BMPs will be designed for selected approved logging system and road construction practices. (8MPS 12.5, 13.9, 13.15).

This unit contains 2 acres of slopes $>75 \%$.

\section{TIMBER}

There are no timber mitigation measures anticipated for this unit.

\section{ENGINEER ING}

There are no engineering mitigation measures anticipated for this unit.

\section{FISH/WATERSHED}

There are no fishery mitigation measures anticipated for this unit.

\section{WILDLIFE}

Maintain diversity within unit by leaving 1-5 acre-sized islands of green trees at a rate of 1 acre of island for every 20 acres harvested. Leave islands must be compatible with logging system and safe working conditions.

RECREATION / VISUALS

This unit has a proposed Voo of MM and is not seen from any viewpoint identified by this project.

LANDS

There are no lands mitigation measures anticipated for this unit.

CULTURAL RESOURCES

There are no cultural resource mitigation measures anticipated for this unit.

There are no karst mitigation measures anticipated for this unit. 


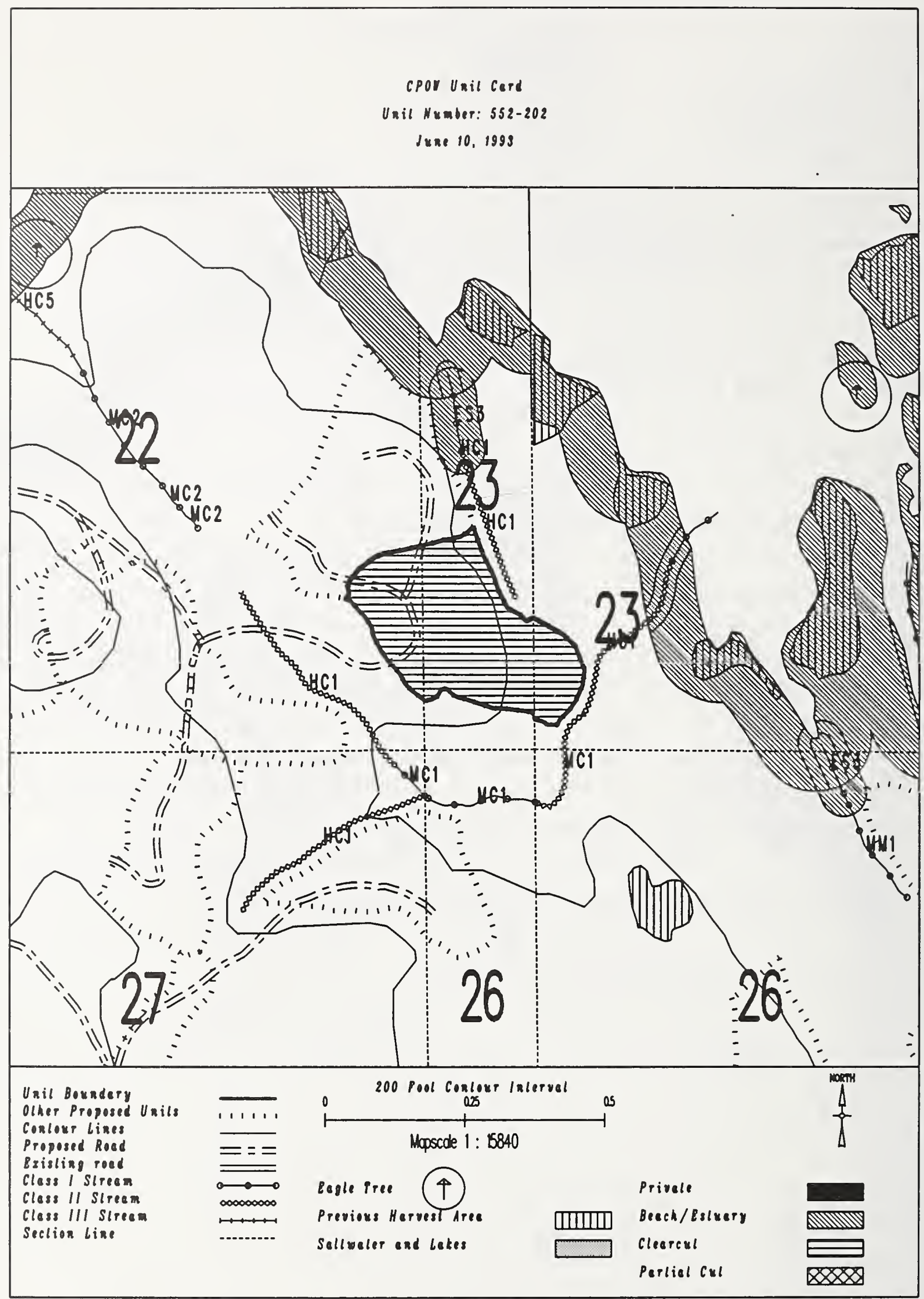


Unit $\quad 552-203$

Planned acres 33

Estimated volume (mbf)

Logging system skyline

silvicultural system clearcut

Forest type Hemlock
Alternatives considered

Quad PBGA4SES

Mgmt Area $\mathrm{K08}$

WAA 1421

Photo 1190073

Aspect East

PHYSICAL DESCRIPTION

Volume class breakdown: VC4 34 acres VC5 $\quad \begin{array}{llllllll}0 & \text { acres } & \text { VC6 } & 0 & 0 & \text { acres } & \text { VC7 } & 0\end{array}$

Elevation breakdown: $0-800 \mathrm{ft} . \underline{33}$ acres $800-1200 \mathrm{ft} . \underline{0}$ acres $1200-1500 \mathrm{ft}$. 0 acres over $1500 \mathrm{ft}$. 0 acres

Mass movement index: Low 15 acres Medium 0 acres High 11 acres Very High 0 acres

SOILS

This unit has high mass movement index soils. Partial log suspension required over these areas.(BMP13.9)

This unit contains 22 acres of forested wetlands. Site specific BMPs will be designed for selected approved

logging system and road construction practices. (BMPs 12.5, 13.9, 13.15).

TIMBER

There are no timber mitigation measures anticipated for this unit.

ENGINEERING

High mass movement index soils. Road construction must minimize landslide potential (BMP14).

FISH/WATERSHED

There are no fishery mitigation measures anticipated for this unit.

HILDLIFE

There are no wildlife mitigation measures anticipated for this unit.

RECREATION / VISUALS

This unit has a proposed Voo of MM and is not seen from any viewpoint identified by this project.

LANDS

There are no lands mitigation measures anticipated for this unit.

CULTURAL RESOURCES

There are no cultural resource mitigation measures anticipated for this unit.

GEOLOGY

There are no karst mitigation measures anticipated for this unit. 


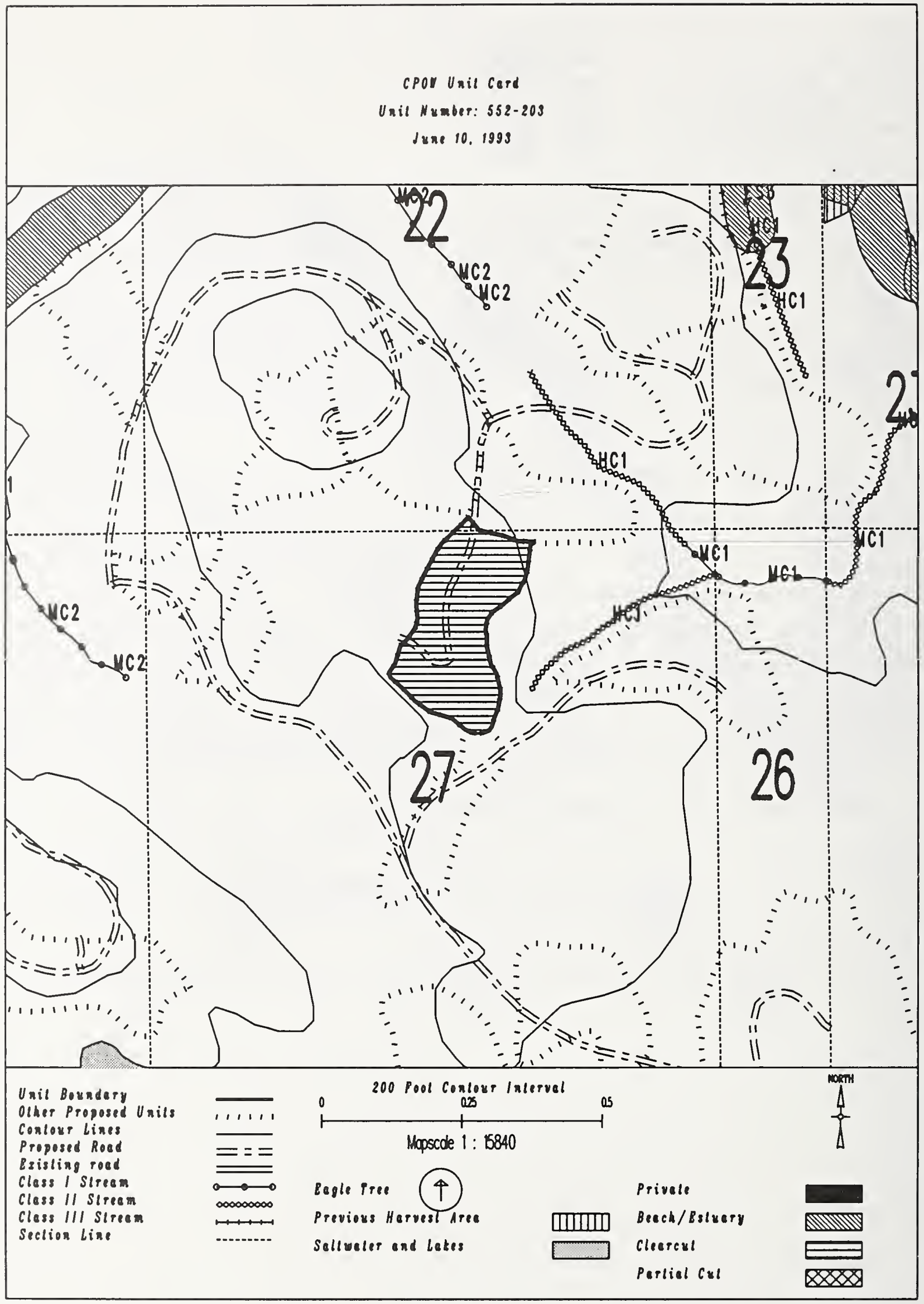


Unit $552-206$

Planned acres 42

Estimated volume (mbf) 1026

Logging system Highlead

silvicultural system clearcut

Forest type Cedar
Alternatives considered

F3

Quad PBGA4SES

Mgmt Area $\mathrm{K} 08$

HAA 1421

Photo 1190073

Aspect East

PHYSICAL DESCRIPTION

Volume class breakdown: VC4 29 acres VC5 15 acres VC6 $\quad 0$ acres VC7 $\quad 0$ acres

Elevation breakdown: $0-800 \mathrm{ft} . \underline{42}$ acres $800-1200 \mathrm{ft} . \underline{0}$ acres 1200-1500 ft. 0 acres over $1500 \mathrm{ft}$. 0 acres Mass movement index: Low $\underline{31}$ acres Medium $\_$acres High 11 acres Very High 0

\section{SOILS}

This unit has high mass movement index soils. Partial log suspension required over these areas.(BMP13.9)

This unit contains 27 acres of forested wetlands. Site specific BMPs will be designed for selected approved

logging system and road construction practices. (BMPs 12.5, 13.9, 13.15).

This unit contains 1 acres of slopes $>75 \%$.

\section{TIMBER}

There are no timber mitigation measures anticipated for this unit.

\section{ENGINEER ING}

High mass movement index soils. Road construction must minimize landslide potential (BMP14).

\section{FISH/WATERSHED}

There are no fishery mitigation measures anticipated for this unit.

\section{WI LDL IFE}

There are no wildlife mitigation measures anticipated for this unit.

RECREATION / VISUALS

This unit has a proposed Voo of MM and is not-seen from any viewpoint identified by this project.

\section{LANDS}

There are no lands mitigation measures anticipated for this unit.

\section{CULTURAL RESOURCES}

There are no cultural resource mitigation measures anticipated for this unit.

\section{GEOLOGY}

There are no karst mitigation measures anticipated for this unit. 


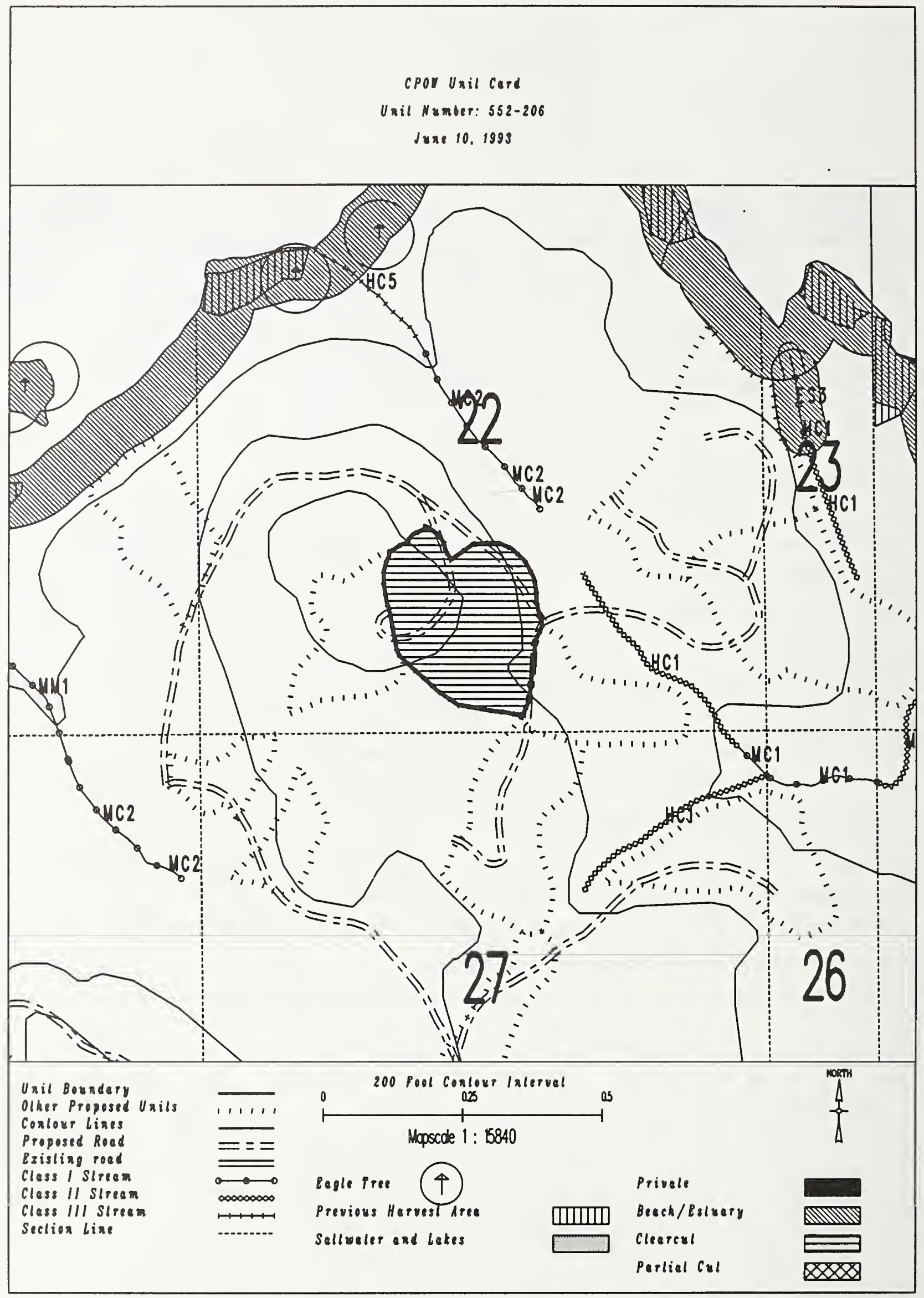


Unit $552-207$

Planned acres 21

Estimated volume (mbf)

Logging system Highlead

silvicultural system Clearcut

Forest type Hemlock

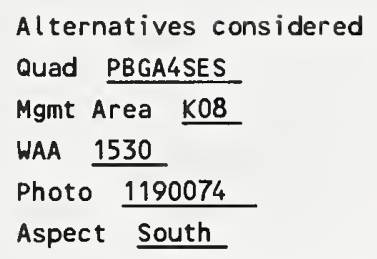

F3

\section{PHYSICAL DESCRIPTION}

Volume class breakdown: VC4 16 acres VC5 4 acres VC6 $\quad 0$ acres VC7 $\quad 0$ acres

Elevation breakdown: $0-800 \mathrm{ft} .19$ acres $800-1200 \mathrm{ft} . \quad 0$ acres $1200-1500 \mathrm{ft} . \underline{0}$ acres over $1500 \mathrm{ft}$. 0 acres Mass movement index: Low 17 acres Medium 0 acres High 0 acres Very High 0

\section{SOILS}

This unit contains 11 acres of forested wetlands. Site specific BMPs will be designed for selected approved logging system and road construction practices. (BMPs 12.5, 13.9, 13.15).

\section{TIMBER}

There are no timber mitigation measures anticipated for this unit.

\section{ENGINEERING}

There are no engineering mitigation measures anticipated for this unit.

\section{FISH/WATERSHED}

There are no fishery mitigation measures anticipated for this unit.

\section{WILDLIFE}

There are no wildlife mitigation measures anticipated for this unit.

\section{RECREATION / VISUALS}

This unit has a proposed Voo of MM and is not seen from any viewpoint identified by this project.

\section{LANDS}

There are no lands mitigation measures anticipated for this unit.

CULTURAL RESOURCES

There are no cultural resource mitigation measures anticipated for this unit.

GEOLOGY

There are no karst mitigation measures anticipated for this unit. 


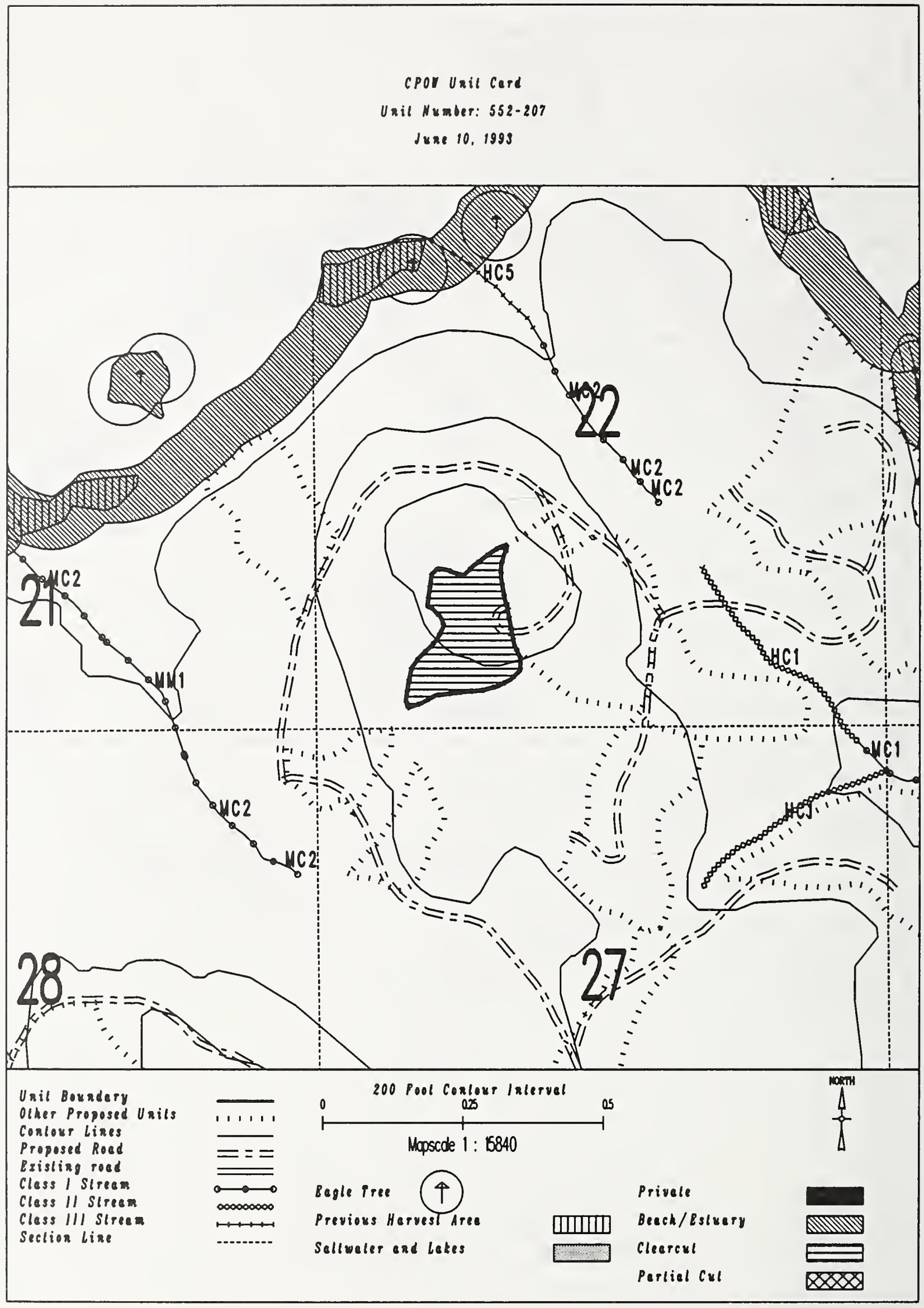


Unit $552-211$

Planned acres 53

Estimated volume (mbf) 1535

Logging system Skyline

silvicultural system clearcut

Forest type Mixed conifer
Alternat ives considered

Quad PBGA4SES

Mgmt Area $\mathrm{K08}$

WAA 1421

Photo 1190072

Aspect East

\section{PHYSICAL DESCRIPTION}

Volume class breakdown: VC4 1 acres VC5 51 acres VC6 $\quad 0$ acres VC7 0 acres

Elevation breakdown: $0-800 \mathrm{ft} .50$ acres $800-1200 \mathrm{ft} . \underline{0}$ acres 1200-1500 ft. 0 acres over $1500 \mathrm{ft}$. 0 Mass movement index: Low $\underline{20}$ acres Medium $\underline{23}$ acres High $\underline{3}$ acres Very High $\underline{0}$ acres

\section{SOILS}

This unit contains 42 acres of forested wetlands. Site specific BMPs will be designed for selected approved logging system and road construction practices. (BMPs 12.5, 13.9, 13.15).

\section{TIMBER}

There are no timber mitigation measures anticipated for this unit.

\section{ENG I NEER I NG}

There are no engineering mitigation measures anticipated for this unit.

\section{FISH/WATERSHED}

There are no fishery mitigation measures anticipated for this unit.

\section{WILDLIFE}

There are no wildlife mitigation measures anticipated for this unit.

RECREATION / VISUALS

This unit has a proposed VQO of MM and is not seen from any viewpoint identified by this project.

\section{LANDS}

There are no lands mitigation measures anticipated for this unit.

\section{CULTURAL RESOURCES}

There are no cultural resource mitigation measures anticipated for this unit. 
cPor Unil cerd

Unit Number: 552-211

June 10, 1999

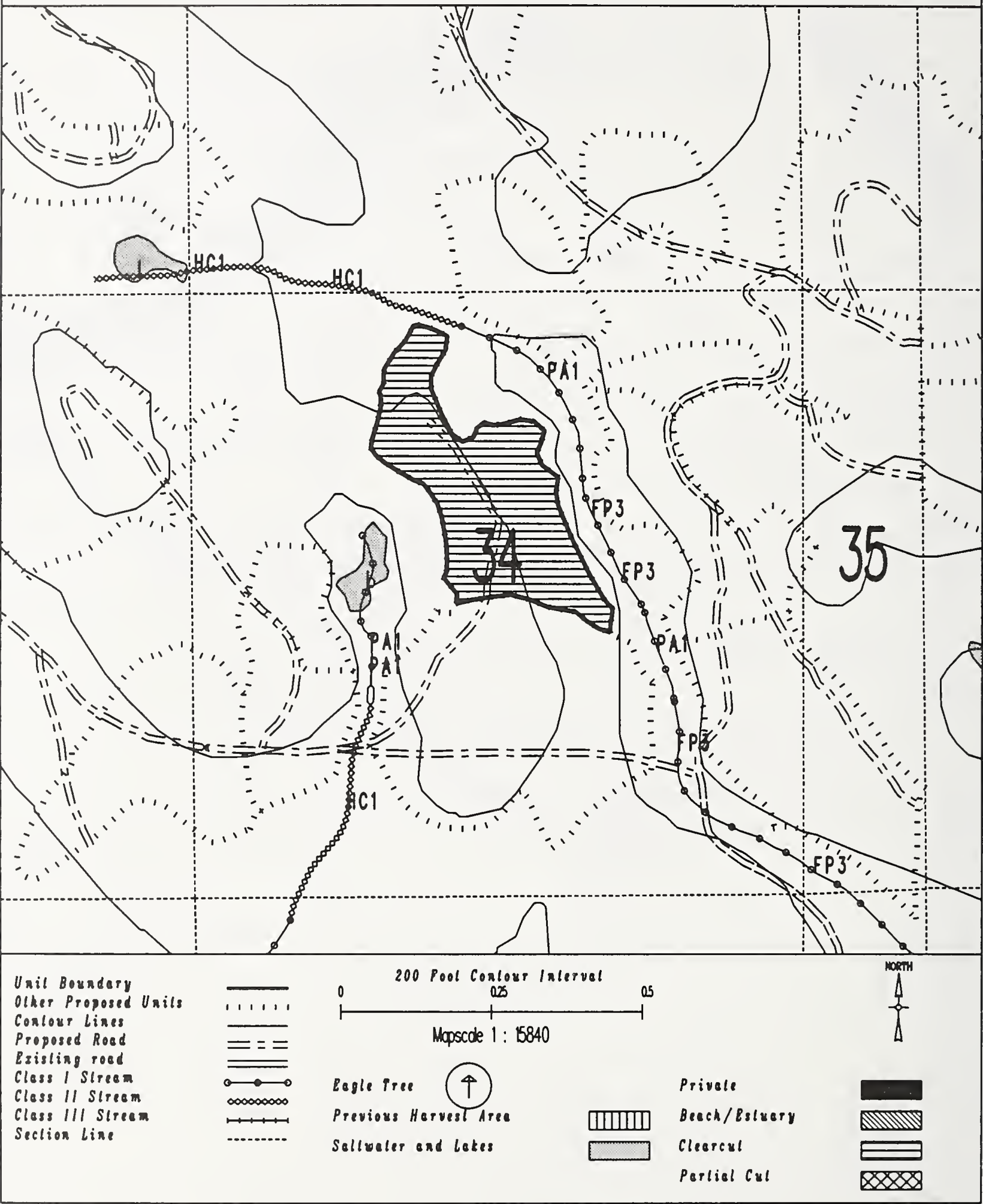


Unit 552-215

Planned acres 17

Estimated volume (mbf) 340

Logging system Highlead

silvicultural system Clearcut

Forest type Hemlock
Alternatives considered

Quad PBGA4SES

Mgmt Area $\mathrm{K08}$

WAA 1421

Photo 1190072

Aspect West

PHYSICAL DESCRIPTION

Volume class breakdown: VC4 17 acres VC5 $\quad 0$ acres VC6 $\quad 0$ acres vc7 $\quad 0$ acres

Elevation breakdown: $0-800 \mathrm{ft}$. 17 acres $800-1200 \mathrm{ft} . \quad 0$ acres $1200-1500 \mathrm{ft} . \underline{0}$ acres over $1500 \mathrm{ft}$. 0 acres Mass movement index: Low 15 acres Medium 0 acres High 1 acres Very High 0 acres

\section{SOILS}

This unit contains 10 acres of forested wetlands. Site specific BMPs will be designed for selected approved logging system and road construction practices. (BMPs 12.5, 13.9, 13.15).

\section{TIMBER}

Potential regeneration problem. Monitor regeneration to determine if hand planting is required to meet BMP13.19.

\section{ENGINEERING}

There are no engineering mitigation measures anticipated for this unit.

\section{FISH/WATERSHED}

There are no fishery mitigation measures anticipated for this unit.

\section{WILDLIFE}

There are no wildlife mitigation measures anticipated for this unit.

\section{RECREATION / VISUALS}

This unit has a proposed Voo of MM and is not seen from any viewpoint identified by this project.

\section{LANDS}

There are no lands mitigation measures anticipated for this unit.

\section{CULTURAL RESOURCES}

There are no cultural resource mitigation measures anticipated for this unit.

There are no karst mitigation measures anticipated for this unit. 
CPOV Unil cerd

Unil Humber: 552-215

Juse 10, 1999

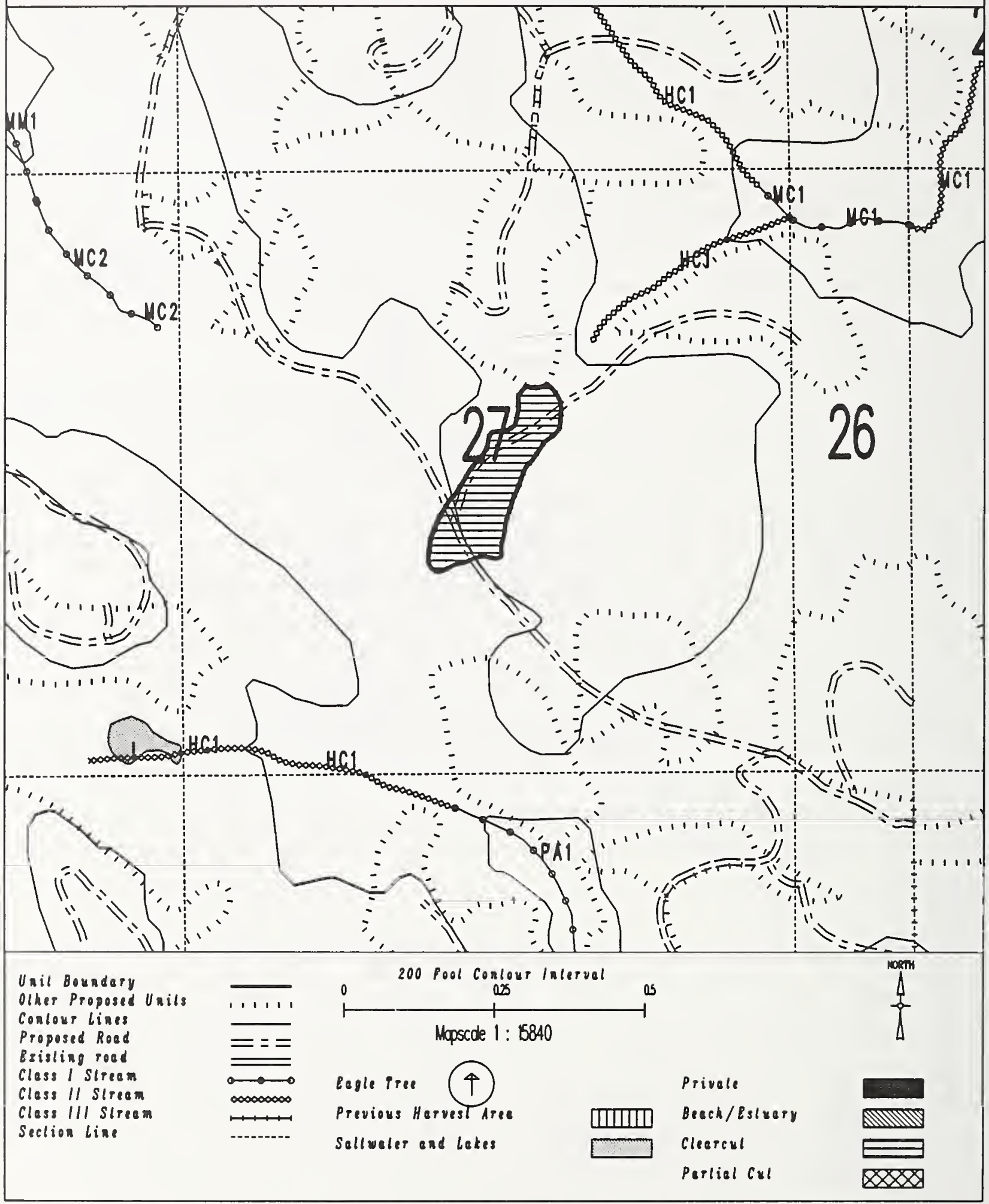


Unit $552-216$

Planned acres 33

Estimated volume (mbf) 980

Logging system skyline

silvicultural system clearcut

Forest type Hemlock
Alternatives considered

F3

Quad PBGA4SES

Mgmt Area K08

WAA 1421

Photo 1190073

Aspect North

PHYSICAL OESCRIPTION

Volume class breakdown: VC4 $\quad 0$ acres vC5 33 acres vC6 $\quad 0$ acres VC7 $\quad 0$ acres

Elevation breakdown: $0-800 \mathrm{ft} . \underline{31}$ acres $800-1200 \mathrm{ft} . \quad 0$ acres $1200-1500 \mathrm{ft} . \underline{0}$ acres over $1500 \mathrm{ft}$. 0 acres Mass movement index: Low 12 acres Medium 0 acres High 0 acres Very High 0 acres

SOILS

This unit contains 27 acres of forested wetlands. Site specific BMPs will be designed for selected approved logging system and road construction practices. (BMPs 12.5, 13.9, 13.15).

TIMBER

There are no timber mitigation measures anticipated for this unit.

\section{ENGINEER ING}

There are no engineering mitigation measures anticipated for this unit.

\section{FISH/WATERSHEO}

There are no fishery mitigation measures anticipated for this unit.

WILOL IFE

There are no wildlife mitigation measures anticipated for this unit.

RECREATION / VISUALS

This unit has a proposed voo of MM and is not seen from any viewpoint identified by this project.

\section{LANDS}

There are no lands mitigation measures anticipated for this unit.

CULTURAL RESOURCES

There are no cultural resource mitigation measures anticipated for this unit.

There are no karst mitigation measures anticipated for this unit. 


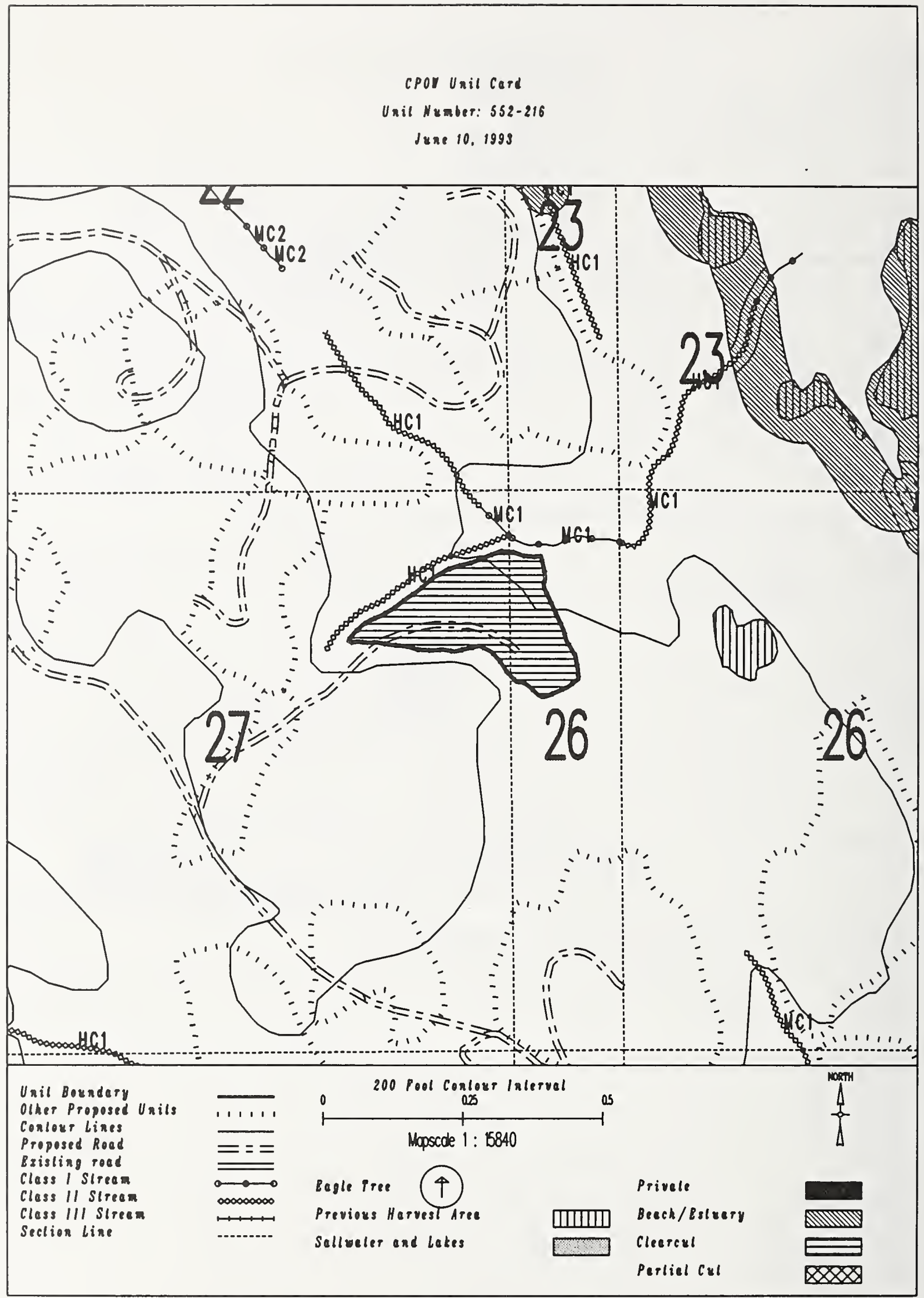


Unit

Planned acres 79

Estimated volume (mbf) 1522

Logging system Highlead

silvicultural system clearcut

Forest type Hemlock
Alternatives considered

Quad PBGA3SWS

Mgmt Area $\mathrm{K08}$

WAA 1421

Photo 1190072

Aspect East

\section{PHYSICAL DESCRIPTION}

Volume class breakdown: VC4 76 acres VC5 0 acres vC6 $\quad 0$ acres VC7 $\quad 0$ acres

Elevation breakdown: $0-800 \mathrm{ft} . \underline{76}$ acres $800-1200 \mathrm{ft} . \quad 0$ acres $1200-1500 \mathrm{ft} . \quad 0$ acres over $1500 \mathrm{ft}$. 0 acres Mass movement index: Low 32 acres Medium 0 acres High 25 acres Very High 0

\section{SOILS}

This unit has high mass movement index soils. Partial log suspension required over these areas. (BMP13.9)

This unit contains 62 acres of forested wetlands. Site specific BMPs will be designed for selected approved

logging system and road construction practices. (BMPS 12.5, 13.9, 13.15).

\section{TIMBER}

There are no timber mitigation measures anticipated for this unit.

\section{ENGINEER ING}

Very difficult road construction due to unstable, slope $>75 \%$ or extended steep grades.

May need to revise logging system to helicopter.

High mass movement index soils. Road construction must minimize landslide potential (BMP14).

\section{FISH/WATERSHED}

This unit contains streams which have recently been classified/channel typed but require field verification.

\section{WILDLIFE}

There are no wildlife mitigation measures anticipated for this unit.

\section{RECREATION / VISUALS}

This unit has a proposed VQO of MM and is not seen from any viewpoint identified by this project.

\section{LANDS}

There are no lands mitigation measures anticipated for this unit.

CULTURAL RESOURCES

There are no cultural resource mitigation measures anticipated for this unit. 
CPOI Unil Cerd

Uail Number: $552-217$

June 10. 1993

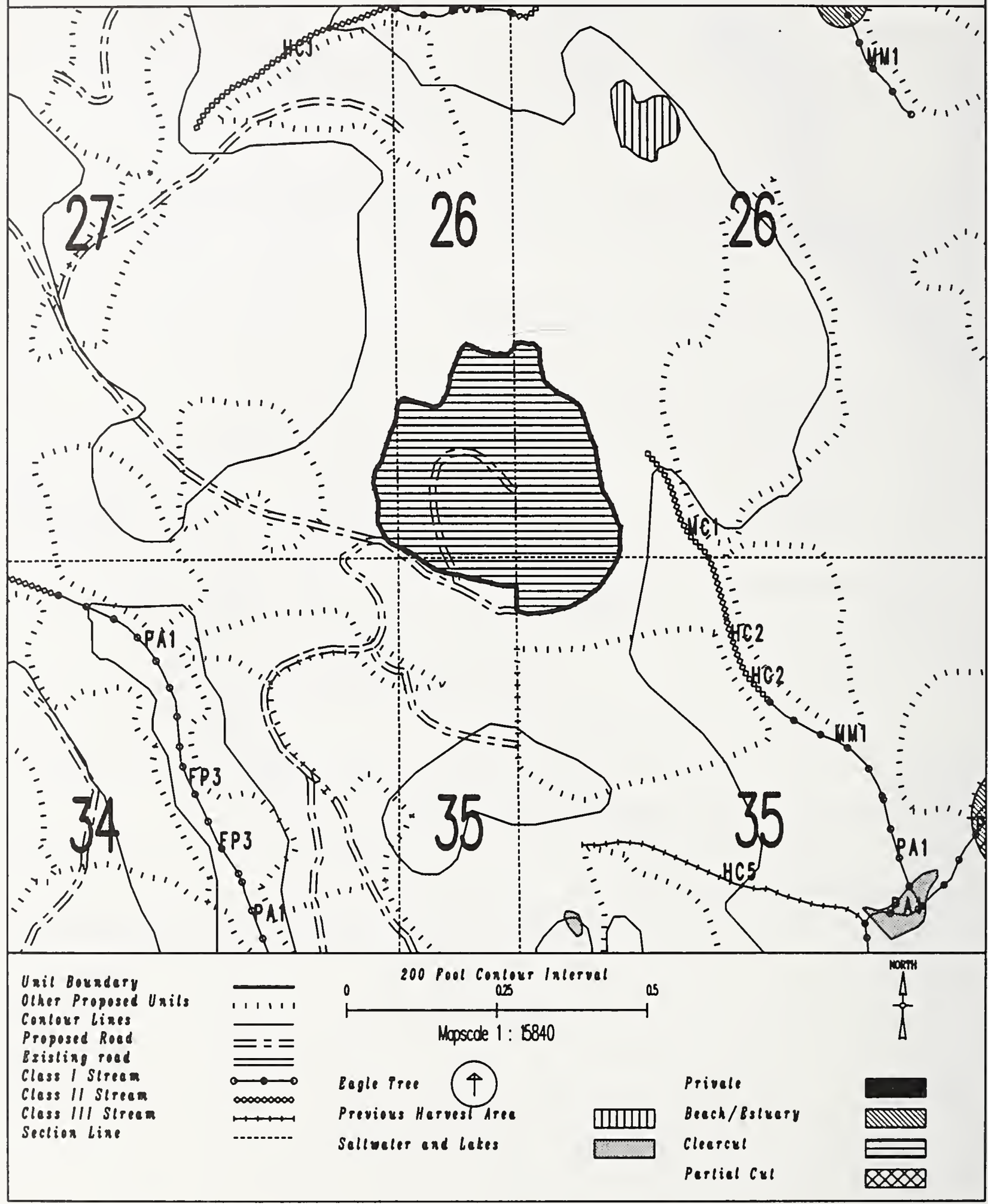


Unit $552-218$

Planned acres 16

Estimated volume (mbf) 398

Logging system Highlead

silvicultural system clearcut

Forest type Cedar
Alternatives considered F3

Mgmt Area $\underline{\mathrm{K} 08}$

WAA 1421

Photo 1190072

Aspect North

PHYSICAL DESCRIPTION

Volume class breakdown: VC4 $\quad \begin{array}{lllllllllllll}8 & \text { acres } & \text { VC5 } & 8 & 8 & \text { acres } & \text { VC6 } & 0 & 0 & \text { acres }\end{array}$

Elevation breakdown: $0-800 \mathrm{ft} .15$ acres $800-1200 \mathrm{ft} . \underline{0}$ acres $1200-1500 \mathrm{ft}$. 0 acres over $1500 \mathrm{ft}$. 0 acres Mass movement index: Low 7 acres Medium 0 acres High 4 acres Very High 0 acres

SOILS

This unit has high mass movement index soils. Partial log suspension required over these areas.(BMP13.9)

This unit contains 10 acres of forested wetlands. Site specific BMPs will be designed for selected approved

logging system and road construction practices. (BMPs 12.5, 13.9, 13.15).

TIMBER

Potential for shovel logging on 2 _ acres, if soil and water quality protected (BMP13.7)

\section{ENGINEER ING}

There are no engineering mitigation measures anticipated for this unit.

\section{FISH/WATERSHED}

Potential for additional Class I/II streams within unit. May be necessary to place additional buffers within unit

in accordance with AHMU Handbook.

\section{WILDLIFE}

There are no wildlife mitigation measures anticipated for this unit.

RECREATION / VISUALS

This unit has a proposed VQO of MM and is not seen from any viewpoint identified by this project.

\section{LANDS}

There are no lands mitigation measures anticipated for this unit.

CULTURAL RESOURCES

There are no cultural resource mitigation measures anticipated for this unit.

GEOLOGY

There are no karst mitigation measures anticipated for this unit. 


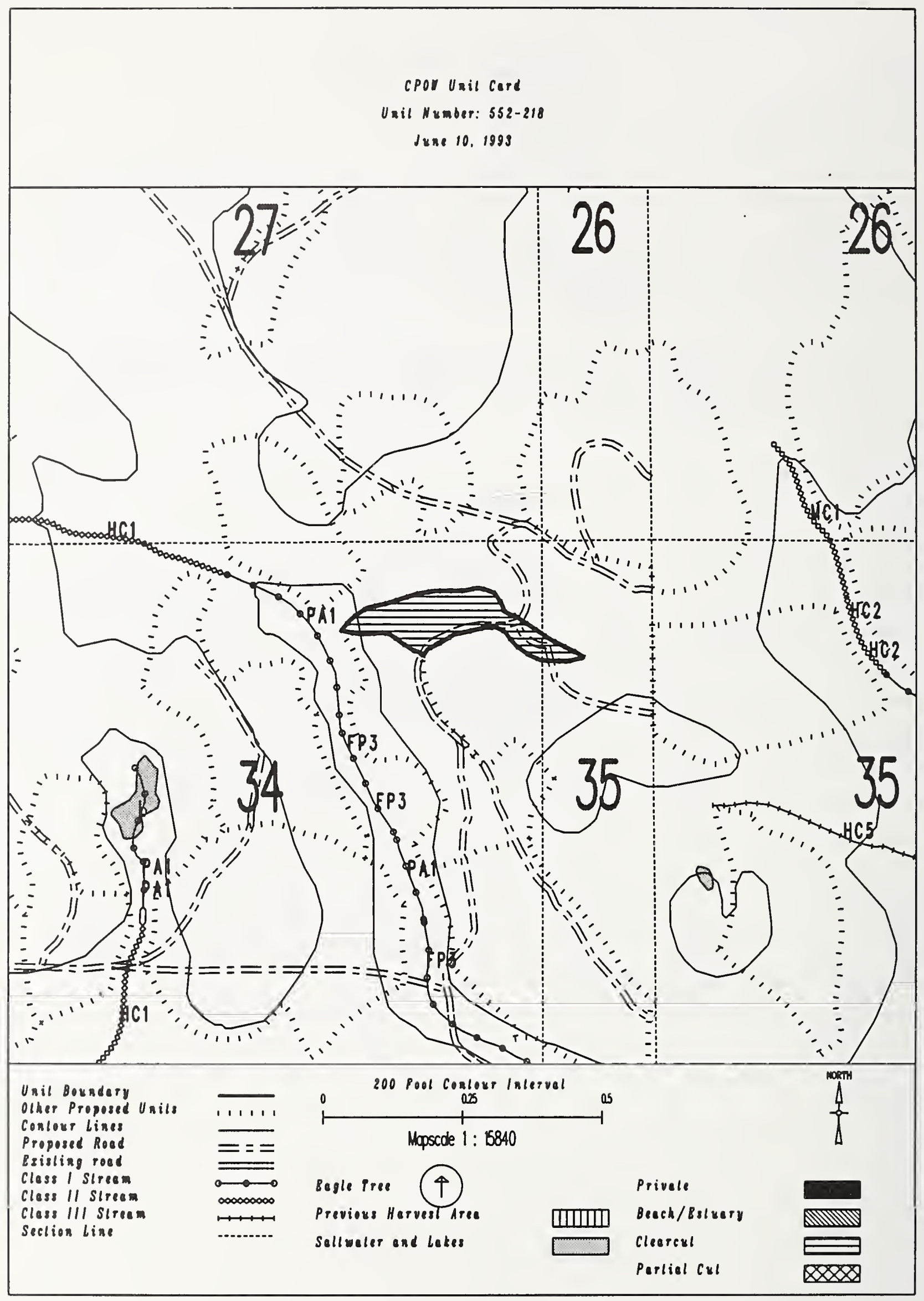




\section{Unit $\quad 552-220$}

Planned acres 62

Estimated volume (mbf) 1127

Logging system skyline

silvicultural system clearcut

Forest type Hemlock
Alternatives considered

Quad PBGA4SES

Mgmt Area $\mathrm{KO8}$

WAA 1421

Photo 1190071

Aspect North

PHYSICAL DESCRIPTION

Volume class breakdown: VC4 $\quad 40$ acres VC5 11 acres vC6 $\quad 0$ acres vc7 $\quad 0$ acres

Elevation breakdown: $0-800 \mathrm{ft} . \underline{60}$ acres $800-1200 \mathrm{ft} . \underline{0}$ acres $1200-1500 \mathrm{ft}$. 0 acres over $1500 \mathrm{ft}$. 0 acres Mass movement index: Low 21 acres Medium 8 acres High 14 acres Very High 0 acres

\section{SOILS}

This unit has high mass movement index soils. Partial log suspension required over these areas.(BMP13.9)

This unit contains 34 acres of forested wetlands. Site specific BMPs will be designed for selected approved

logging system and road construction practices. (BMPs 12.5, 13.9, 13.15).

\section{TIMBER}

There are no timber mitigation measures anticipated for this unit.

\section{ENGINEERING}

High mass movement index soils. Road construction must minimize landslide potential (BMP14).

\section{FISH/WATERSHED}

There are no fishery mitigation measures anticipated for this unit.

\section{WILDLIFE}

There are no wildlife mitigation measures anticipated for this unit.

\section{RECREATION / VISUALS}

This unit has a proposed voo of MM and is not seen from any viewpoint identified by this project.

\section{LANDS}

There are no lands mitigation measures anticipated for this unit.

CULTURAL RESOURCES

There are no cultural resource mitigation measures anticipated for this unit.

GEOLOGY

There are no karst mitigation measures anticipated for this unit. 


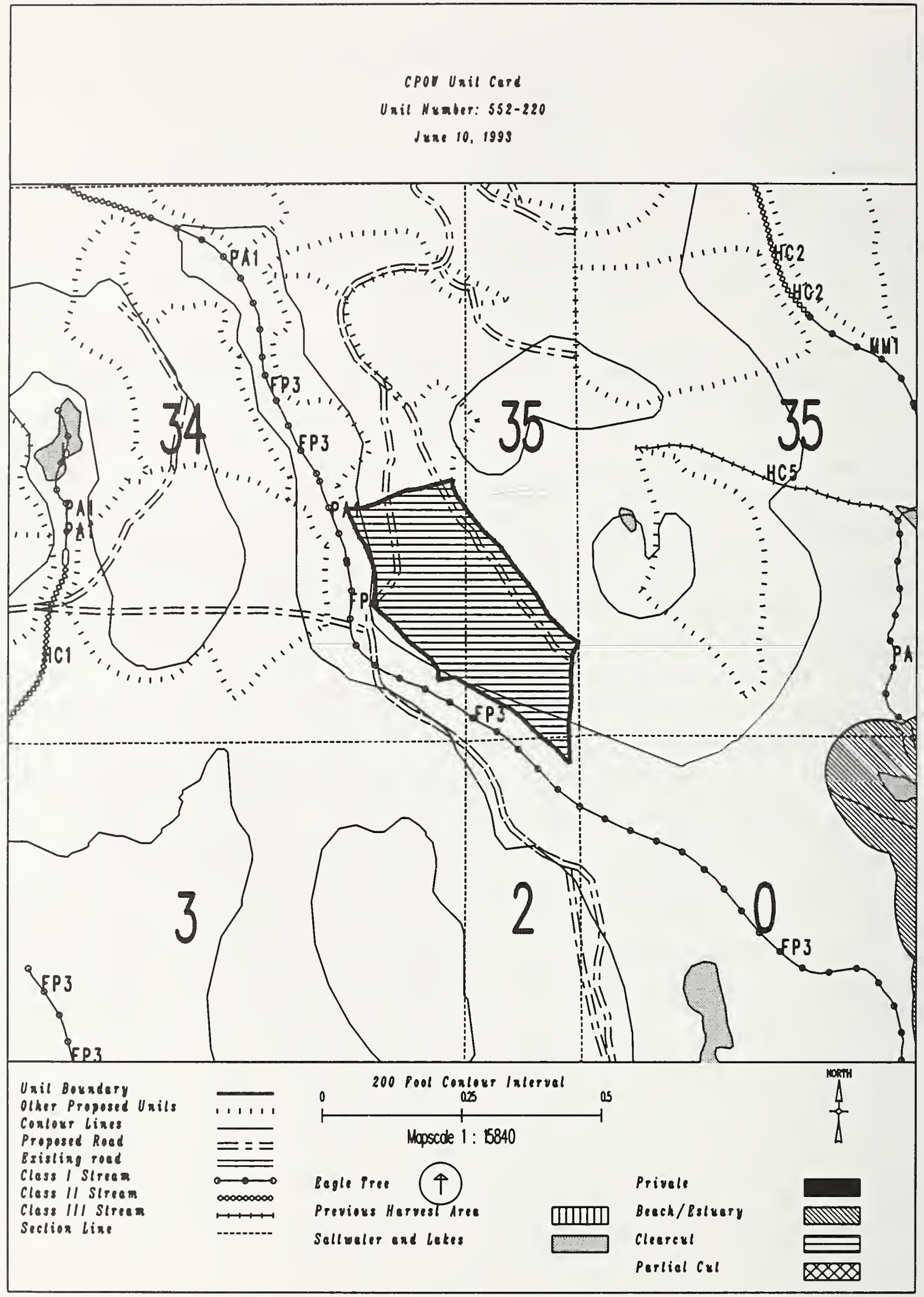




\section{Unit 552-221}

Planned acres 55

Estimated volume (mbf) 1633

Logging system skyline

silvicultural system clearcut

forest type Hemlock

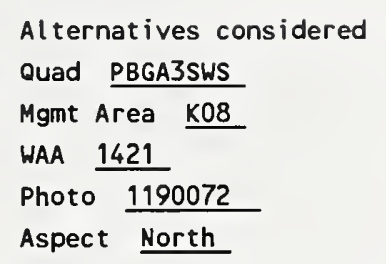

\section{PHYSICAL DESCRIPTION}

Volume class breakdown: VC4 $\quad 0$ acres VC5 55 acres VC6 $\quad 0$ acres VC7 $\quad 0$ acres

Elevation breakdown: $0-800 \mathrm{ft} . \underline{52}$ acres $800-1200 \mathrm{ft} . \underline{0}$ acres $1200-1500 \mathrm{ft} . \underline{0}$ acres over $1500 \mathrm{ft}$. 0 acres Mass movement index: Low 14 acres Medium $\underline{0}$ acres High $\underline{21}$ acres Very High $\underline{0}$ acres

\section{SOILS}

This unit has high mass movement index soils. Partial log suspension required over these areas.(BMP13.9)

This unit contains 38 acres of forested wetlands. Site specific BMPs will be designed for selected approved

logging system and road construction practices. (BMPS 12.5, 13.9, 13.15).

\section{TIMBER}

There are no timber mitigation measures anticipated for this unit.

\section{ENGINEER ING}

High mass movement index soils. Road construction must minimize landslide potential (BMP14).

\section{FISH/WATERSHED}

There are no fishery mitigation measures anticipated for this unit.

\section{WILDLIFE}

There are no wildlife mitigation measures anticipated for this unit.

\section{RECREATION / VISUALS}

This unit has a proposed VQO of MM and is not seen from any viewpoint identified by this project.

\section{LANDS}

There are no lands mitigation measures anticipated for this unit.

CULTURAL RESOURCES

There are no cultural resource mitigation measures anticipated for this unit.

GEOLOGY

There are no karst mitigation measures anticipated for this unit. 
cpor Unil cerd

Unil Number: 552-221

June 14, 1993

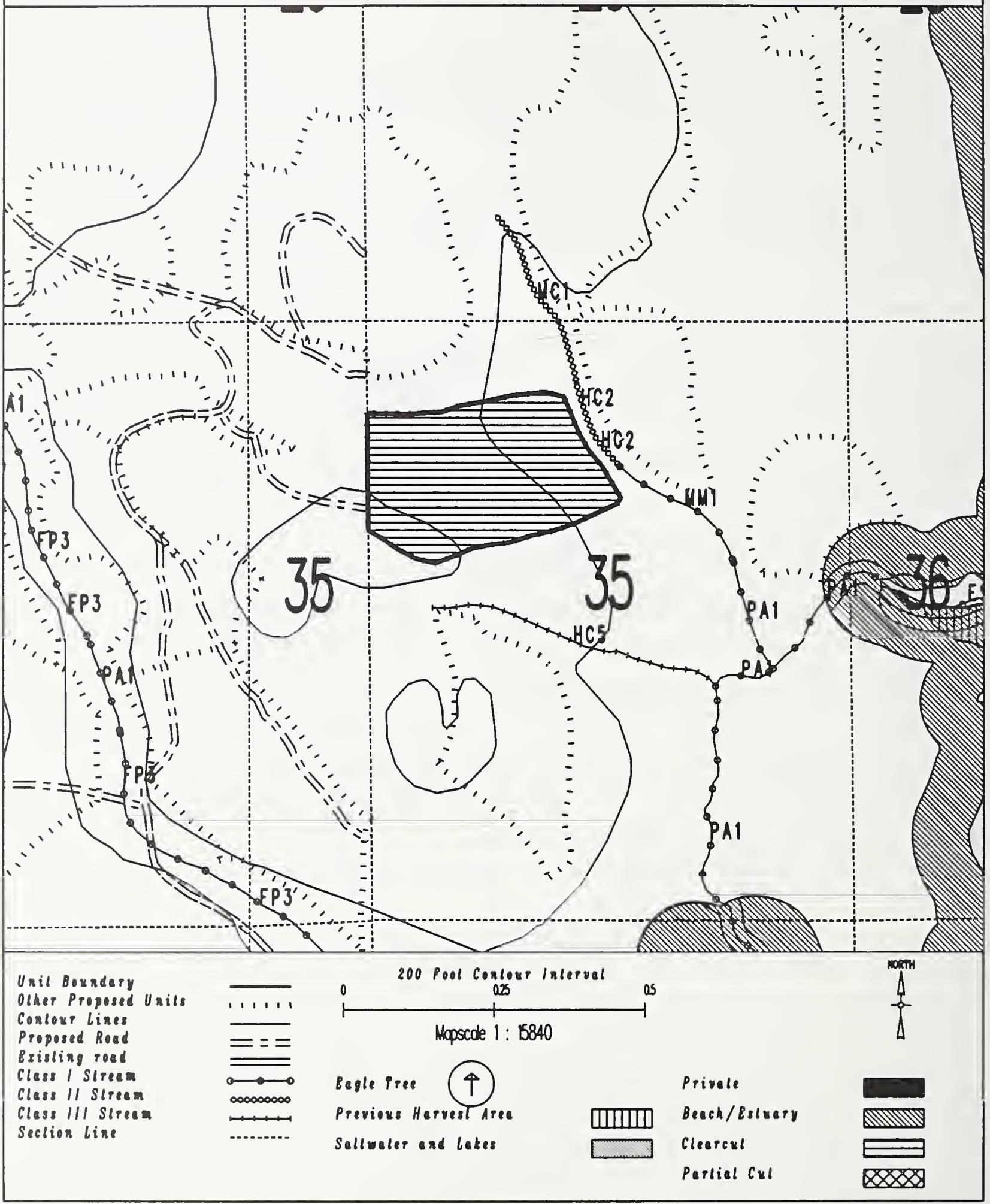


Unit 552-224

Planned acres 68

Est imated volume (mbf) 1399

Logging system skyline

silvicultural system clearcut

Forest type Hemlock

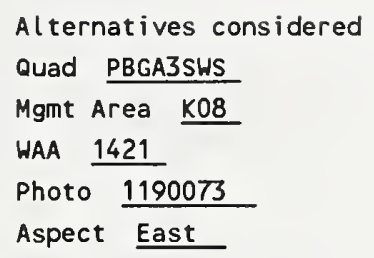

PHYSICAL DESCRIPTION

Volume class breakdown: VC4 58 acres VC5 $\quad 8$ acres VC6 $\quad 0$ acres VC7 $\quad 0$ acres

Elevation breakdown: $0-800 \mathrm{ft} . \underline{67}$ acres $800-1200 \mathrm{ft} . \underline{0}$ acres $1200-1500 \mathrm{ft}$. 0 acres over $1500 \mathrm{ft}$. 0 Mass movement index: Low $\underline{24}$ acres Medium $\underline{0}$ acres High 26 acres Very High 0

SOILS

This unit has high mass movement index soils. Partial log suspension required over these areas. (BMP13.9)

This unit contains 36 acres of forested wetlands. Site specific BMPs will be designed for selected approved

logging system and road construction practices. (BMPs 12.5, 13.9, 13.15).

This unit contains 9 acres of slopes $>75 \%$.

TIMBER

There are no timber mitigation measures anticipated for this unit.

ENG INEER ING

High mass movement index soils. Road construction must minimize landslide potential (BMP14).

slopes greater than $75 \%$ may require full bench construction and endhaul of waste (BMP14.7).

FISH/WATERSHED

There are no fishery mitigation measures anticipated for this unit.

\section{HILOL IFE}

There are no wildlife mitigation measures anticipated for this unit.

\section{RECREATION / VISUALS}

This unit has a proposed VQO of MM and is not seen from any viewpoint identified by this project.

\section{LANDS}

There are no lands mitigation measures anticipated for this unit.

CULTURAL RESOURCES

There are no cultural resource mitigation measures anticipated for this unit.

There are no karst mitigation measures anticipated for this unit. 


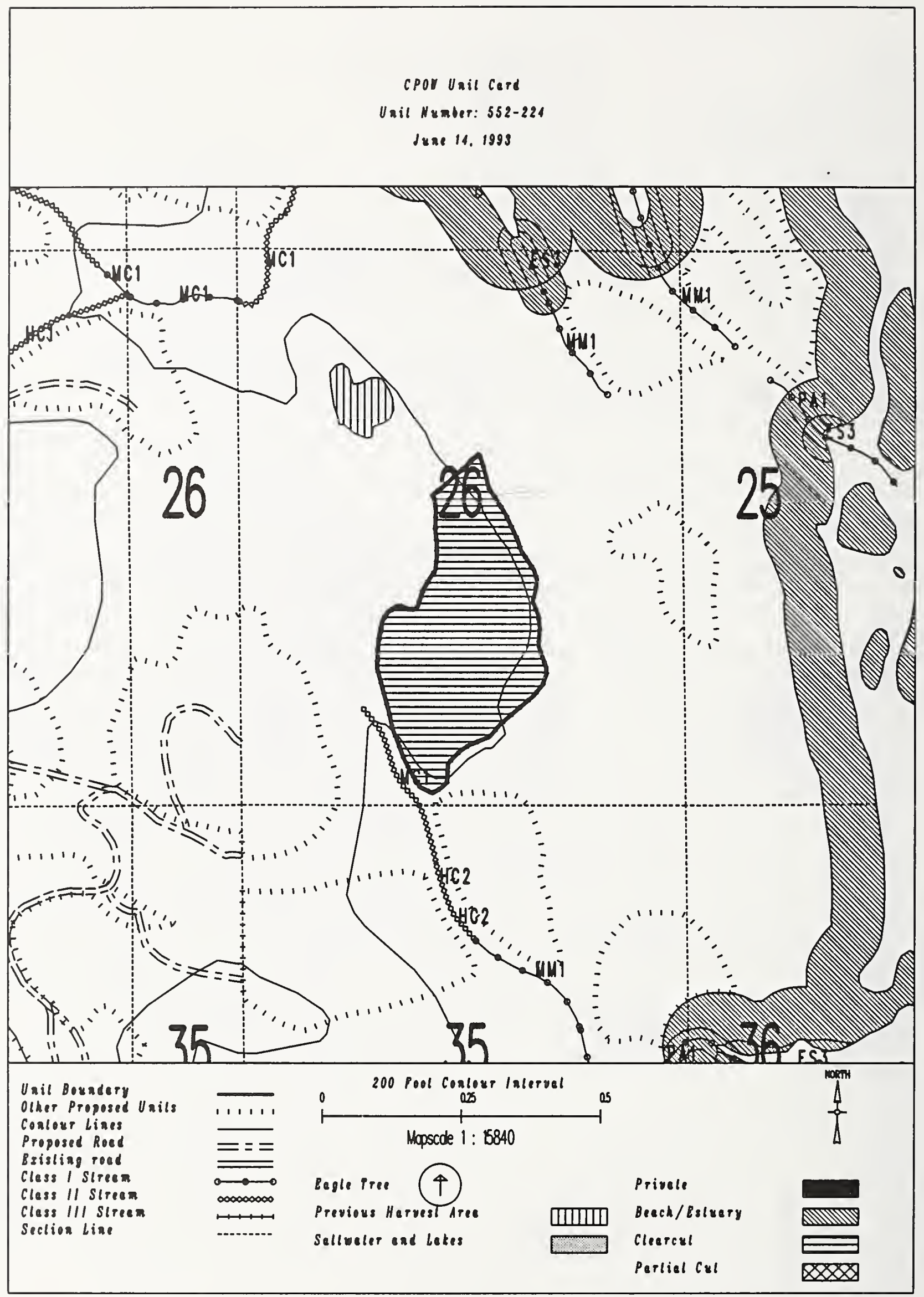


Unit $\quad 552-227$

Planned acres 39

Est imated volume (mbf) 780

Logging system skyline

silvicultural system clearcut

Forest type Hemlock
Alternatives considered F3
Mgmt Area $\mathrm{KO8}$

WAA 1421

Photo 1190071

Aspect East

\section{PHYSICAL DESCRIPTION}

Volume class breakdown: VC4 36 acres VC5 $\quad 2$ acres vC6 $\quad 0$ acres vc7 $\quad 0$ acres

Elevation breakdown: $0-800 \mathrm{ft} . \underline{37}$ acres $800-1200 \mathrm{ft} . \underline{0}$ acres $1200-1500 \mathrm{ft} . \underline{0}$ acres over $1500 \mathrm{ft}$. 0 Mass movement index: Low 23 acres Medium 0 acres High 6 acres Very High 0 acres

SOILS

This unit has high mass movement index soils. Partial log suspension required over these areas. (BMP13.9)

This unit contains 18 acres of forested wetlands. Site specific BMPs will be designed for selected approved logging system and road construction practices. (BMPS 12.5, 13.9, 13.15).

\section{TIMBER}

There are no timber mitigation measures anticipated for this unit.

\section{ENGINEER ING}

High mass movement index soils. Road construction must minimize landslide potential (BMP14).

\section{FISH/WATERSHED}

There are no fishery mitigation measures anticipated for this unit.

WILDLIFE

There are no wildlife mitigation measures anticipated for this unit.

RECREATION / VISUALS

This unit has a proposed Voo of MM and is not seen from any viewpoint identified by this project.

\section{LANDS}

There are no lands mitigation measures anticipated for this unit.

\section{CULTURAL RESOURCES}

There are no cultural resource mitigation measures anticipated for this unit.

\section{GEOLOGY}

There are no karst mitigation measures anticipated for this unit. 


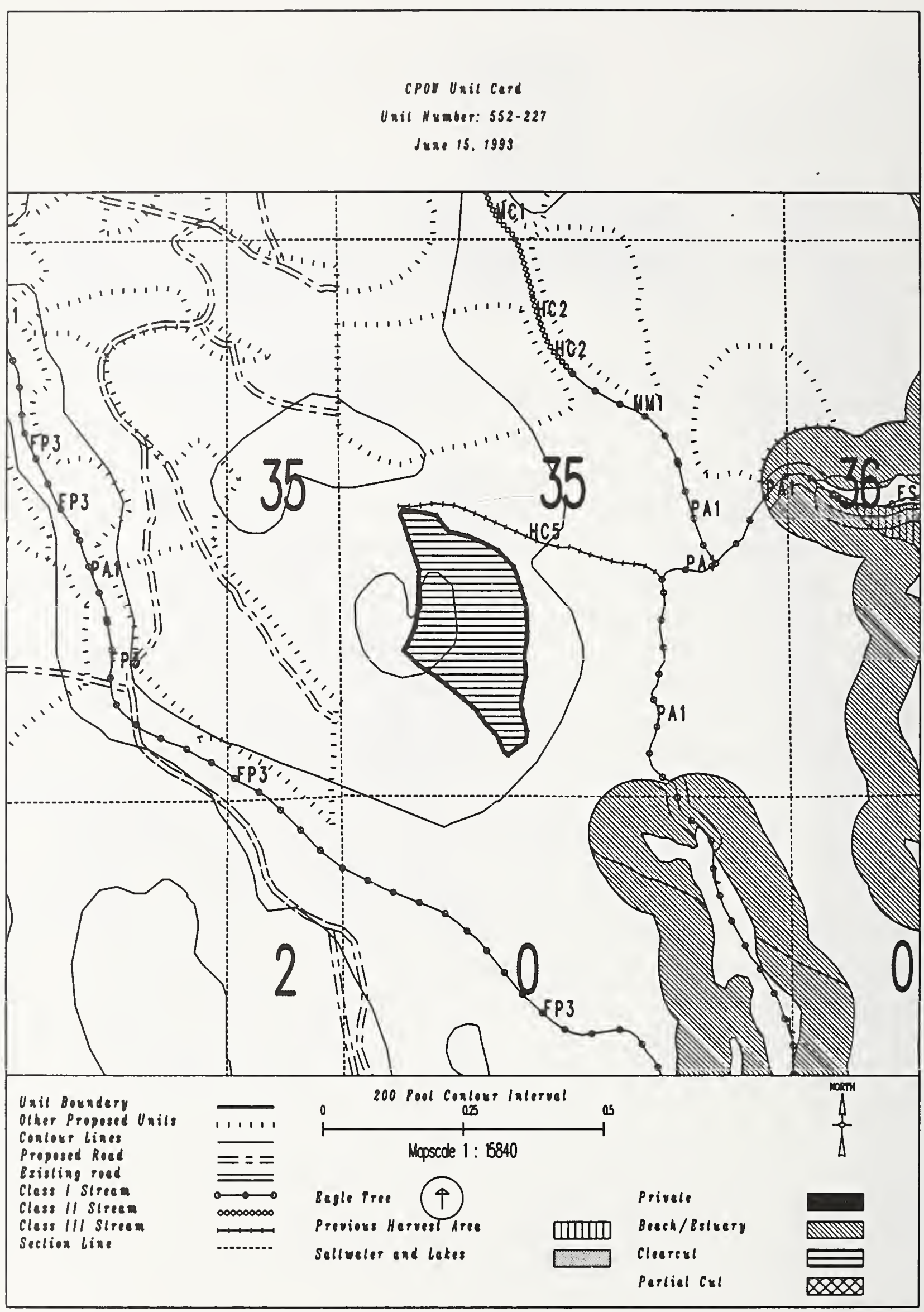


Unit 552-262

Planned acres 28

Estimated volume (mbf) 849

Logging system Highlead

silvicultural system clearcut

Forest type Hemlock
Alternatives considered

F3

Quad PBGA3SWS

Mgmt Area K08

WAA 1421

Photo 990072

Aspect East

PHYSICAL DESCRIPTION

Volume class breakdown: VC4 $\quad 0$ acres VC5 25 acres VC6 $\quad 3$ acres VC7 $\quad 0$ acres

Elevation breakdown: $0-800 \mathrm{ft} . \underline{25}$ acres $800-1200 \mathrm{ft} . \underline{0}$ acres 1200-1500 ft. 0 acres over $1500 \mathrm{ft}$. 0 acres Mass movement index: Low $\_$acres Medium $\_$acres High 12 acres Very High 0

\section{SOILS}

This unit has high mass movement index soils. Partial log suspension required over these areas.(BMP13.9)

This unit contains 24 acres of forested wetlands. Site specific BMPs will be designed for selected approved

logging system and road construction practices. (BMPs 12.5, 13.9, 13.15).

\section{TIMBER}

There are no timber mitigation measures anticipated for this unit.

\section{ENGINEERING}

High mass movement index soils. Road construction must minimize landslide potential (BMP14).

\section{FISH/WATERSHED}

There are no fishery mitigation measures anticipated for this unit.

\section{HILDLI FE}

There are no wildlife mitigation measures anticipated for this unit.

RECREATION / VISUALS

This unit has a proposed VQO of MM and is not seen from any viewpoint identified by this project.

\section{LANDS}

There are no lands mitigation measures anticipated for this unit.

CULTURAL RESOURCES

There are no cultural resource mitigation measures anticipated for this unit.

GEOLOGY

There are no karst mitigation measures anticipated for this unit. 


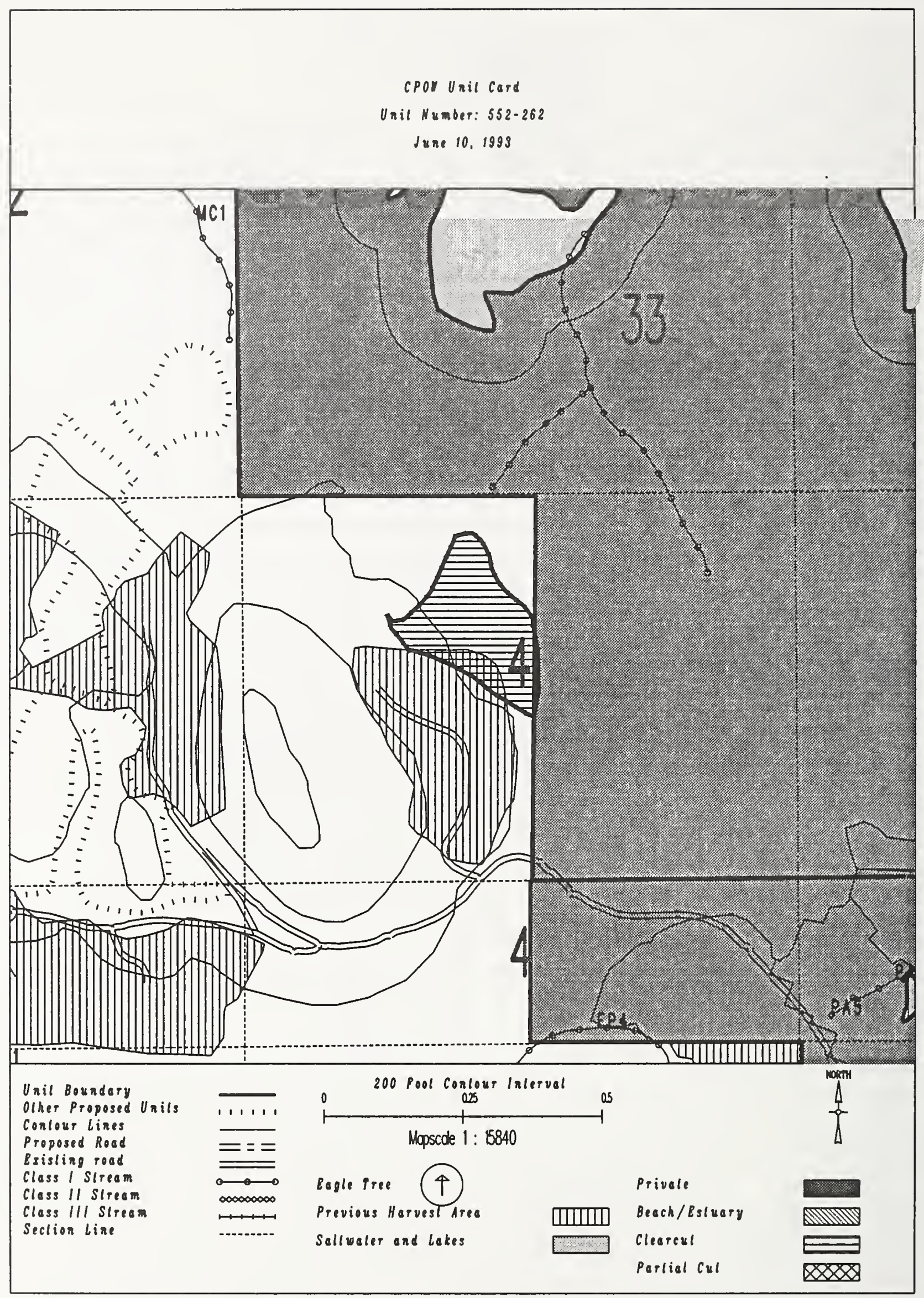


Unit $552-273$

Planned acres 12

Estimated volume (mbf)

Logging system skyline

silvicultural system Clearcut

Forest type Mixed conifer
Alternatives considered

F3

Mgmt Area $\mathrm{KOB}$

WAA 1421

Photo 990062

Aspect North

\section{PHYSICAL DESCRIPTION}

Volume class breakdown: VC4 0 acres VC5 0 acres vC6 11 acres vc7 0 acres

Elevation breakdown: $0-800 \mathrm{ft} .10$ acres $800-1200 \mathrm{ft} . \quad 0$ acres $1200-1500 \mathrm{ft}$. 0 acres over $1500 \mathrm{ft}$. 0 acres Mass movement index: Low 0 acres Medium 6 acres High 0 acres Very High 0 acres

SOILS

This unit contains 11 acres of forested wetlands. Site specific BMPs will be designed for selected approved logging system and road construction practices. (BMPs 12.5, 13.9, 13.15).

\section{TIMBER}

There are no timber mitigation measures anticipated for this unit.

\section{ENGINEERINC}

There are no engineering mitigation measures anticipated for this unit.

\section{FISH/WATERSHED}

Potential for additional Class I/II streams within unit. May be necessary to place additional buffers within unit in accordance with AHMU Handbook.

WILDLIFE

Harvest operations restricted to April 1 to October 31 to protect trumpeter swans on Barnes, Sweetwater Lakes.

\section{RECREATION / VISUALS}

The unit has a proposed voo of $M$ within the viewshed of Barnes Lake as viewed from from the forest recreation cabin.

\section{LANDS}

There are no lands mitigation measures anticipated for this unit.

CULTURAL RESOURCES

There are no cultural resource mitigation measures anticipated for this unit. 


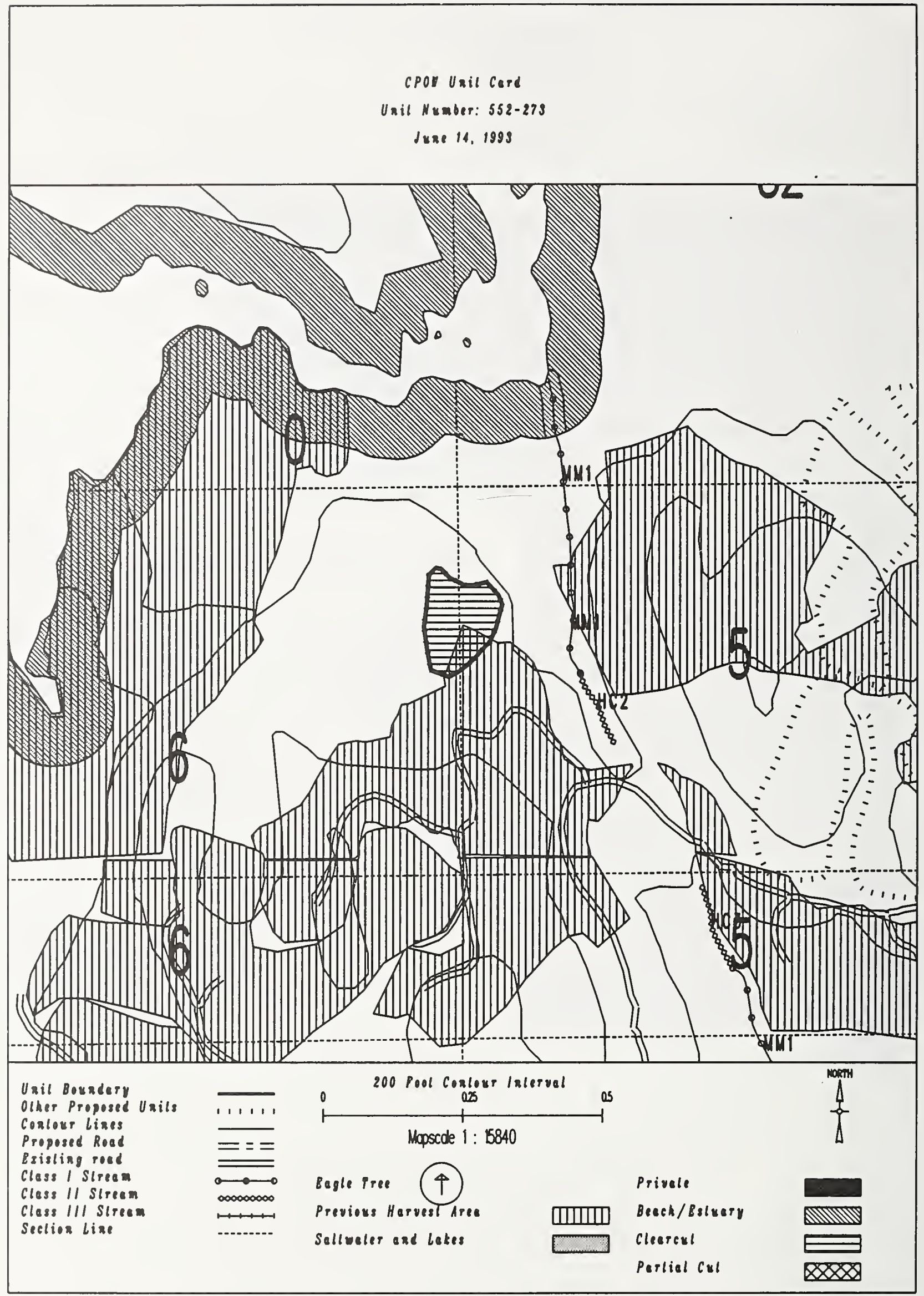


Unit 553-201

Planned acres 27

Est imated volume (mbf) 591

Logging system Highlead

silvicultural system Clearcut

Forest type Hemlock
Alternatives considered

Quad PBGA4SES

Mgmt Area $\mathrm{K08}$

WAA 1530

Photo 1190019

Aspect South

\section{PHYSICAL DESCRIPTION}

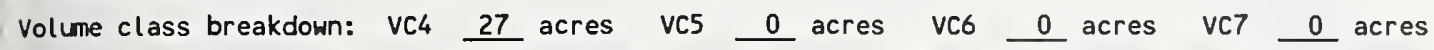

Elevation breakdown: $0-800 \mathrm{ft} . \underline{22}$ acres $800-1200 \mathrm{ft} . \underline{0}$ acres $1200-1500 \mathrm{ft} . \underline{0}$ acres over $1500 \mathrm{ft}$. 0 acres Mass movement index: Low 12 acres Medium 14 acres High 0 acres Very High 0 acres

\section{SOILS}

This unit contains 20 acres of forested wetlands. Site specific BMPs will be designed for selected approved logging system and road construction practices. (BMPs 12.5, 13.9, 13.15).

\section{TIMBER}

There are no timber mitigation measures anticipated for this unit.

\section{ENGINEER ING}

There are no engineering mitigation measures anticipated for this unit.

\section{FISH/WATERSHED}

There are no fishery mitigation measures anticipated for this unit.

\section{WILDLIFE}

There are no wildlife mitigation measures anticipated for this unit.

\section{RECREATION / VISUALS}

This unit has a proposed Vao of MM and is not seen from any viewpoint identified by this project.

\section{LANDS}

There are no lands mitigation measures anticipated for this unit.

CULTURAL RESOURCES

There are no cultural resource mitigation measures anticipated for this unit. 


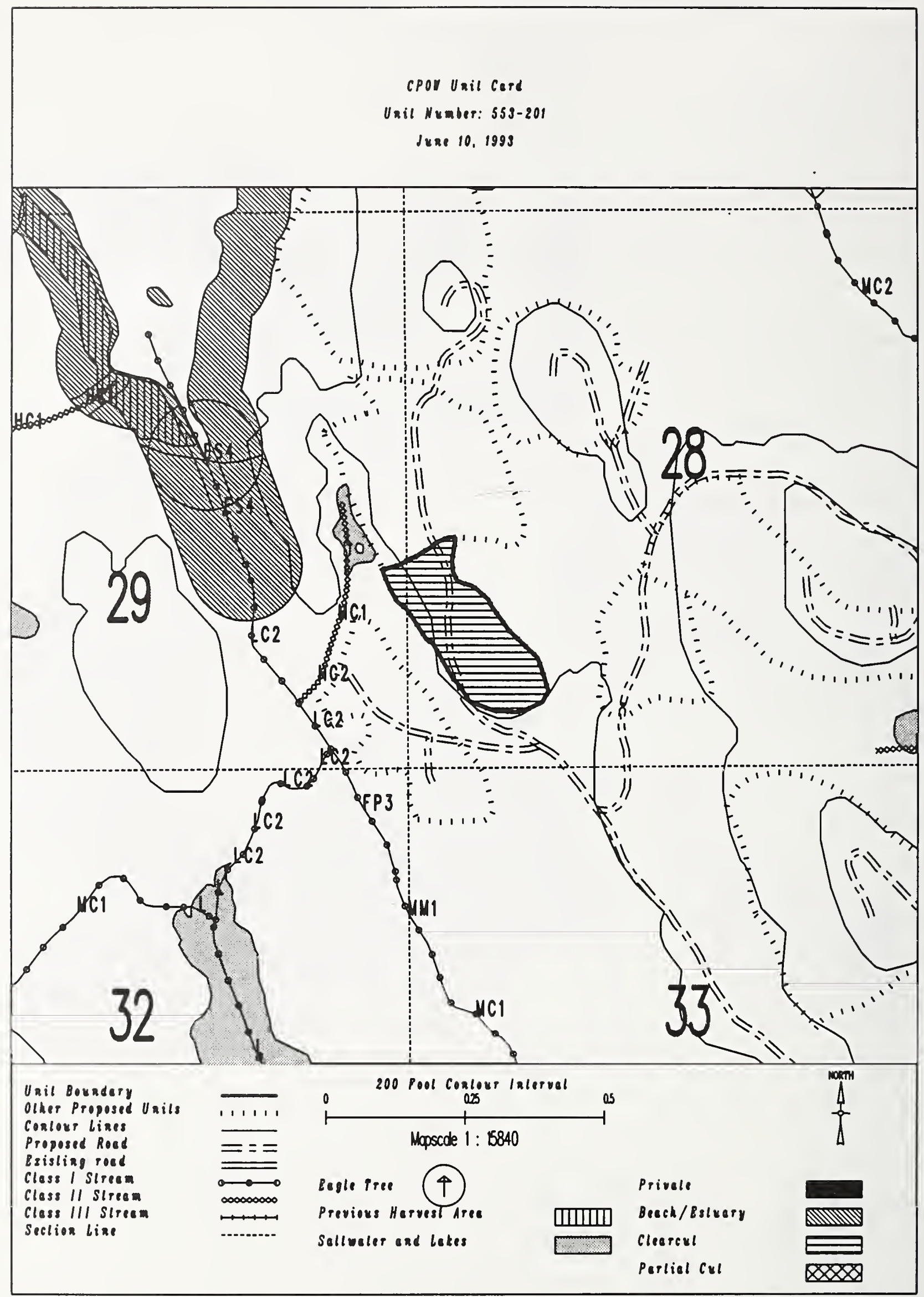


Unit 553-202

Planned acres 67

Estimated volume (mbf) 1488

Logging system Highlead

silvicultural system clearcut

Forest type Hemlock
Alternatives considered F3

Quad PBGA4SES

Mgmt Area $\mathrm{K} 08$

WAA 1530

Photo 1190019

Aspect South

PHYSICAL DESCRIPIION

Volume class breakdown: VC4 $\quad 62$ acres VC5 $\quad 4$ acres VC6 $\quad 0$ acres VC7 $\quad 0$ acres

Elevation breakdown: $0-800 \mathrm{ft} .64$ acres $800-1200 \mathrm{ft} . \quad 0$ acres $1200-1500 \mathrm{ft}$. 0 acres over $1500 \mathrm{ft}$. 0 acres Mass movement index: Low 16 acres Medium $\_$acres High 36 acres Very High 0

SOILS

This unit has high mass movement index soils. Partial log suspension required over these areas. (BMP13.9)

This unit contains 56 acres of forested wetlands. Site specific BMPs will be designed for selected approved

logging system and road construction practices. (BMPs 12.5, 13.9, 13.15).

TIMBER

There are no timber mitigation measures anticipated for this unit.

ENGINEER ING

High mass movement index soils. Road construction must minimize landslide potential (BMP14).

FISH/WATERSHED

There are no fishery mitigation measures anticipated for this unit.

WILDLIFE

There are no wildlife mitigation measures anticipated for this unit.

RECREATION / VISUALS

The unit has a proposed VQO of $M$ within the viewshed of whale Pass

as viewed from $1 / 2$ mile from shore.

\section{LANDS}

There are no lands mitigation measures anticipated for this unit.

CULTURAL RESOURCES

There are no cultural resource mitigation measures anticipated for this unit.

GEOLOGY

There are no karst mitigation measures anticipated for this unit. 


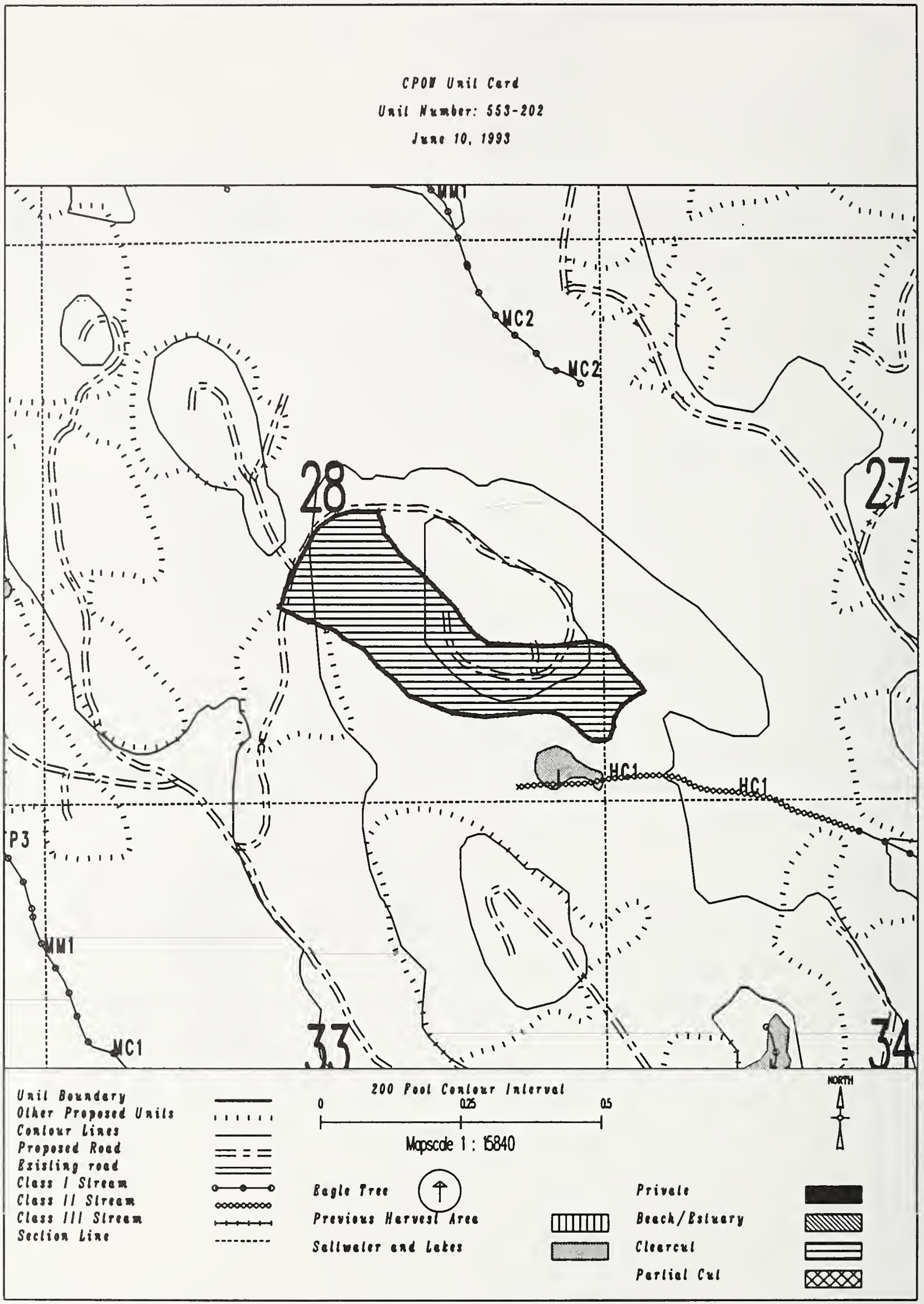


Unit 553-203

Planned acres 24

Est imated volume (mbf) 525

Logging system Highlead

silvicultural system clearcut

Forest type Hemlock
Alternatives considered

Quad PBGA4SES

Mgmt Area $\mathrm{K08}$

WAA 1530

Photo 1190020

Aspect West

PHYSICAL DESCRIPTION

Volume class breakdown: VC4 24 acres VC5 $\quad 0$ acres VC6 $\quad 0$ acres VC7 $\quad 0$ acres

Elevation breakdown: $0-800 \mathrm{ft} . \underline{23}$ acres $800-1200 \mathrm{ft} . \underline{0}$ acres 1200-1500 ft. 0 acres over $1500 \mathrm{ft}$. 0 acres Mass movement index: Low 10 acres Medium 20 acres High 2 acres Very High 0

SOILS

This unit contains 18 acres of forested wetlands. Site specific BMPs will be designed for selected approved logging system and road construction practices. (BMPs 12.5, 13.9, 13.15).

TIMBER

There are no timber mitigation measures anticipated for this unit.

ENGINEERING

There are no engineering mitigation measures anticipated for this unit.

\section{FISH/WATERSHED}

There are no fishery mitigation measures anticipated for this unit.

WILDLIFE

There are no wildlife mitigation measures anticipated for this unit.

RECREATION / VISUALS

This unit has a proposed Voo of MM and is not seen from any viewpoint identified by this project.

\section{LANDS}

There are no lands mitigation measures anticipated for this unit.

\section{CULTURAL RESOURCES}

There are no cultural resource mitigation measures anticipated for this unit.

There are no karst mitigation measures anticipated for this unit. 


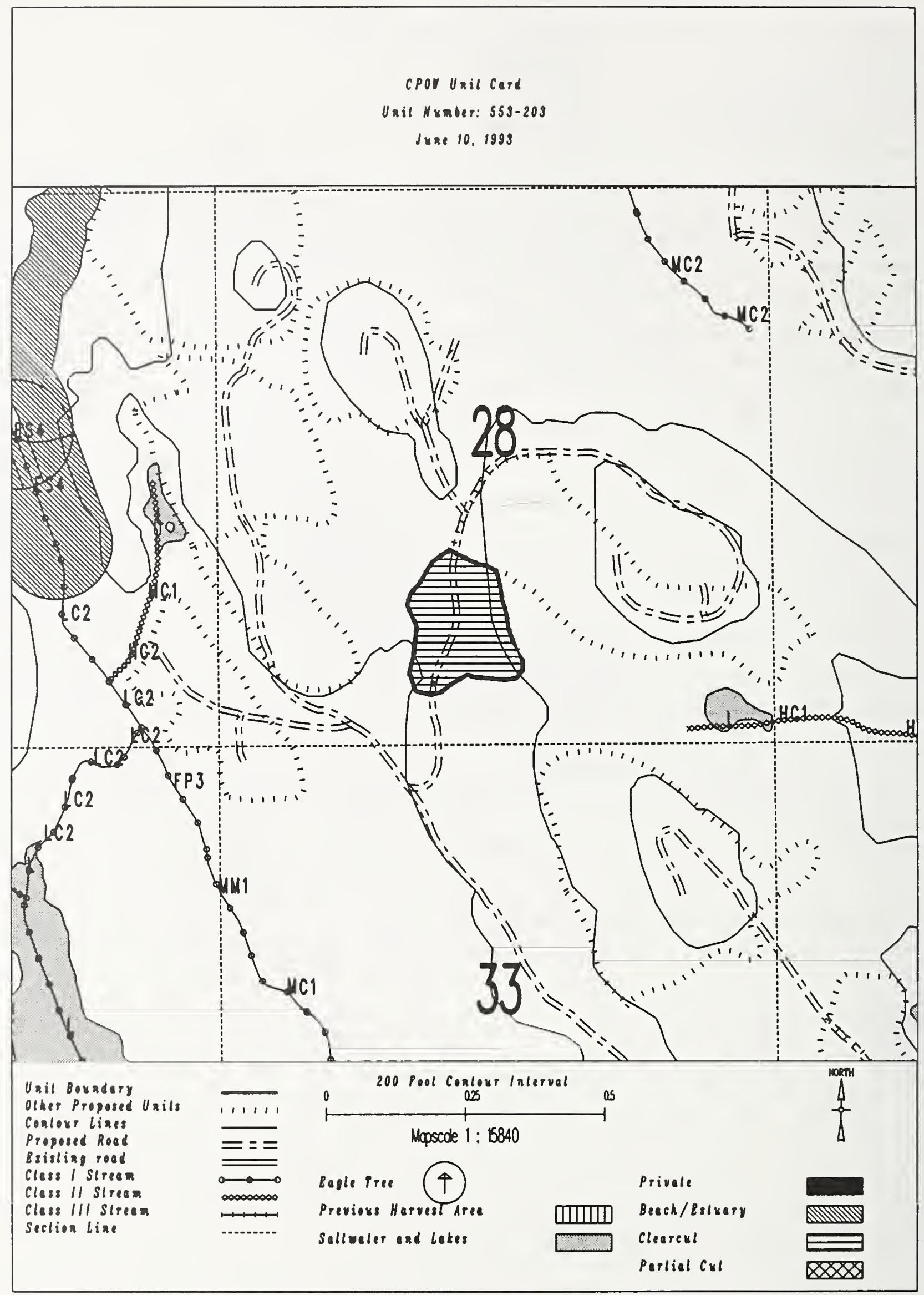




\section{Unit 553-205}

Planned acres 78

Estimated volume (mbf) 1664

Logging system skyline

silvicultural system clearcut

Forest type Hemlock

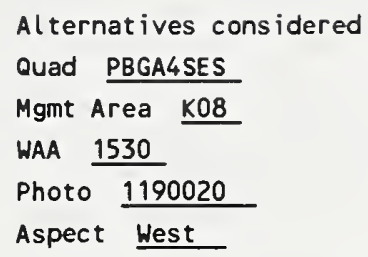

PHYSICAL DESCRIPTION

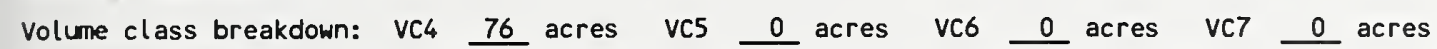

Elevation breakdown: $0-800 \mathrm{ft} . \underline{75}$ acres $800-1200 \mathrm{ft} . \underline{0}$ acres $1200-1500 \mathrm{ft} . \underline{0}$ acres over $1500 \mathrm{ft}$. 0 acres Mass movement index: Low 18 acres Medium 0 acres High 48 acres Very High 0 acres

\section{SOILS}

This unit has high mass movement index soils. Partial log suspension required over these areas. (BMP13.9)

This unit contains 69 acres of forested wetlands. Site specific BMPs will be designed for selected approved logging system and road construction practices. (BMPs 12.5, 13.9, 13.15).

\section{TIMBER}

There are no timber mitigation measures anticipated for this unit.

\section{ENGINEER ING}

High mass movement index soils. Road construction must minimize landslide potential (BMP14).

\section{FISH/WATERSHED}

There are no fishery mitigation measures anticipated for this unit.

\section{WI LDL IFE}

There are no wildlife mitigation measures anticipated for this unit.

RECREATION / VISUALS

This unit has a proposed VoO of MM and is not seen from any viewpoint identified by this project.

\section{LANDS}

There are no lands mitigation measures anticipated for this unit.

\section{CULTURAL RESOURCES}

There are no cultural resource mitigation measures anticipated for this unit.

\section{GEOLOGY}

There are no karst mitigation measures anticipated for this unit. 


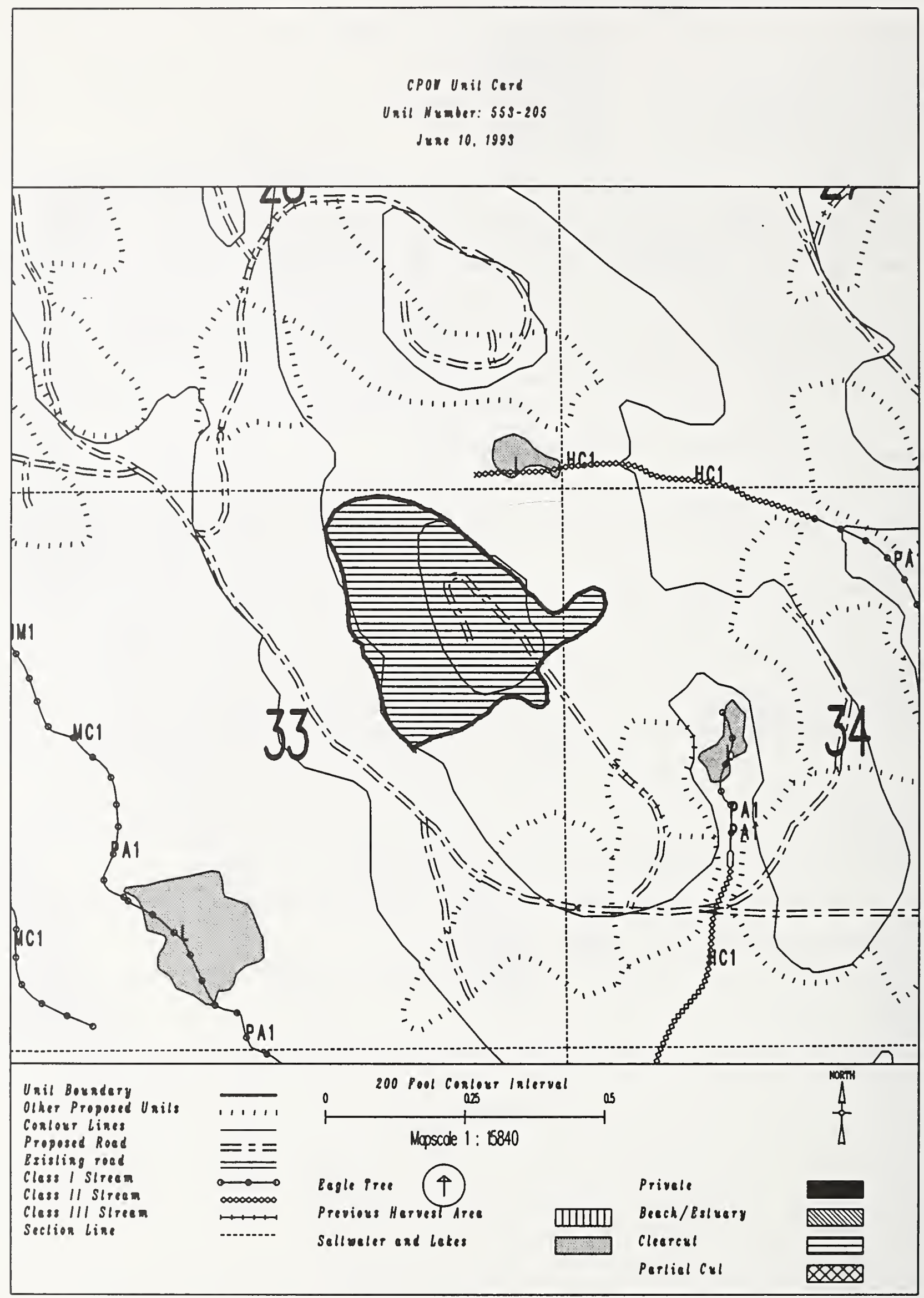


Unit 553-207

Planned acres 51

Est imated volume (mbf) 1094

Logging system skyline

silvicultural system Clearcut

Forest type Hemlock
Al ternatives considered

Quad PBGA4SES

Mgmt Area $\mathrm{K} 08$

WAA 1530

Photo 1190020

Aspect South

\section{PHYSICAL DESCRIPTION}

Volume class breakdown: VC4 50 acres vc5 $\quad 0$ acres vc6 $\quad 0$ acres vc7 $\quad 0$ acres

Elevation breakdown: $0-800 \mathrm{ft} . \underline{48}$ acres $800-1200 \mathrm{ft} . \underline{0}$ acres $1200-1500 \mathrm{ft} . \underline{0}$ acres over $1500 \mathrm{ft}$. 0 Mass movement index: Low 5 acres Medium 0 acres High 0 acres Very High 0 acres

SOILS

This unit contains 48 acres of forested wetlands. Site specific BMPs will be designed for selected approved logging system and road construction practices. (BMPs 12.5, 13.9, 13.15).

\section{TIMBER}

There are no timber mitigation measures anticipated for this unit.

\section{ENGINEER ING}

There are no engineering mitigation measures anticipated for this unit.

\section{FISH/WATERSHED}

There are no fishery mitigation measures anticipated for this unit.

WILDLIFE

There are no wildlife mitigation measures anticipated for this unit.

RECREATION / VISUALS

This unit has a proposed VQO of MM and is not seen from any viewpoint identified by this project.

\section{LANDS}

There are no lands mitigation measures anticipated for this unit.

There are no cultural resource mitigation measures anticipated for this unit. 


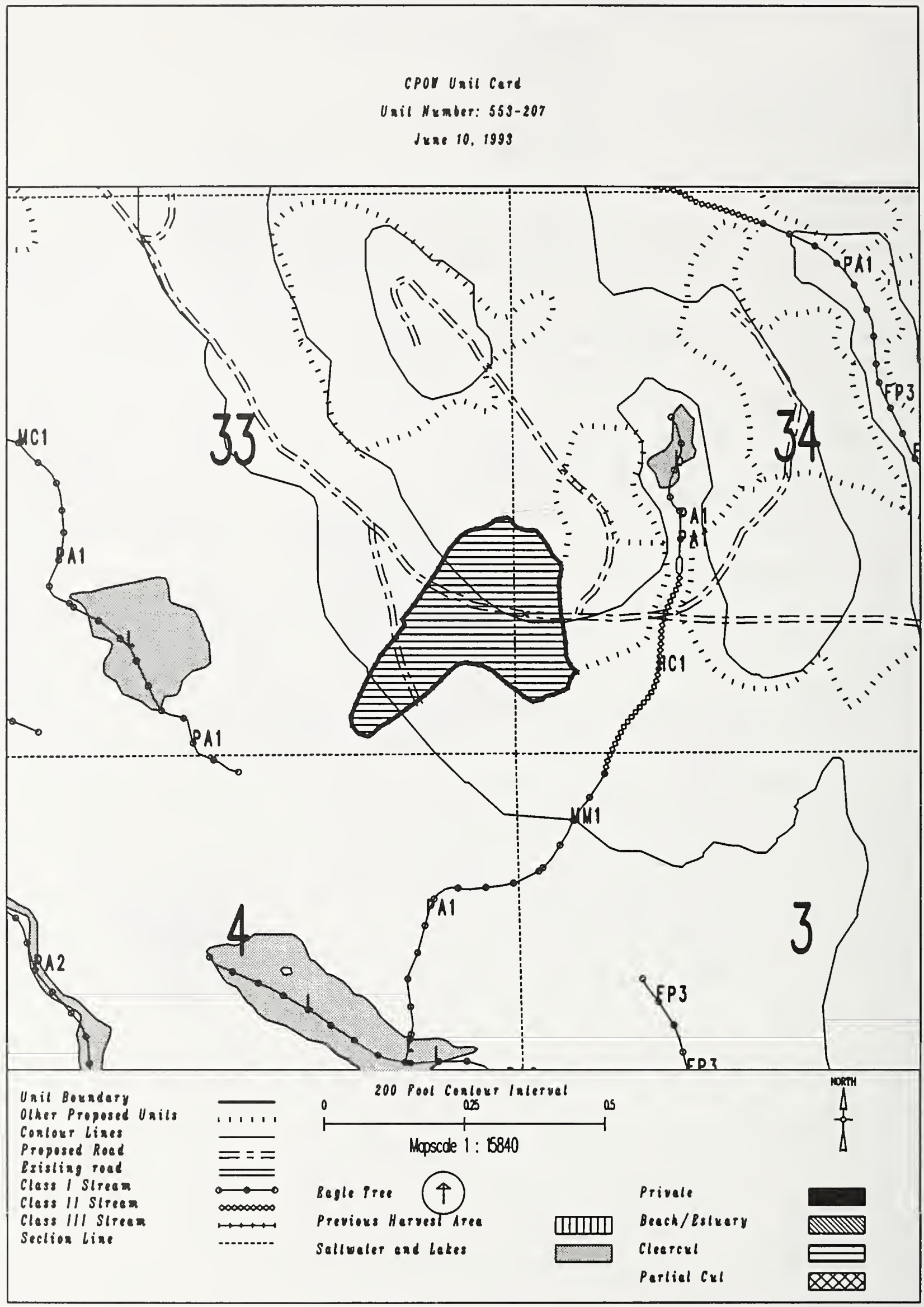


Unit $553-219$

Planned acres 40

Estimated volume (mbf) 705

Logging system Highlead

silvicultural system Riparian

Forest type Hemlock
Alternatives considered

F3

Quad PBGA4SES

Mgmt Area $\mathrm{KOB}$

WAA 1530

Photo 1190020

Aspect East

\section{PHYSICAL DESCRIPTION}

Volume class breakdown: VC4 40 acres VC5 0 acres VC6 0 acres VC7 0

Elevation breakdown: $0-800 \mathrm{ft} . \underline{37}$ acres $800-1200 \mathrm{ft} . \quad 0$ acres 1200-1500 ft. 0 acres over $1500 \mathrm{ft}$. 0 acres Mass movement index: Low 11 acres Medium 0 acres High 0 acres Very High 0 acres

SOILS

This unit contains 34 acres of forested wetlands. Site specific BMPs will be designed for selected approved logging system and road construction practices. (BMPs 12.5, 13.9, 13.15).

\section{TIMBER}

Uneven-aged harvest for riparian management on an estimated 13 acres.

Potential for shovel logging on 5 acres, if soil and water quality protected (BMP13.7)

\section{ENGINEER ING}

There are no engineering mitigation measures anticipated for this unit.

\section{FISH/WATERSHED}

There are no fishery mitigation measures anticipated for this unit.

\section{WILDLI FE}

There are no wildlife mitigation measures anticipated for this unit.

\section{RECREATION / VISUALS}

This unit has a proposed VQO of MM and is not seen from any viewpoint identified by this project.

\section{LANDS}

There are no lands mitigation measures anticipated for this unit.

\section{CULTURAL RESOURCES}

There are no cultural resource mitigation measures anticipated for this unit. 
cpor Unil Cerd

Unil Number: 55s-219

June 10, 1993

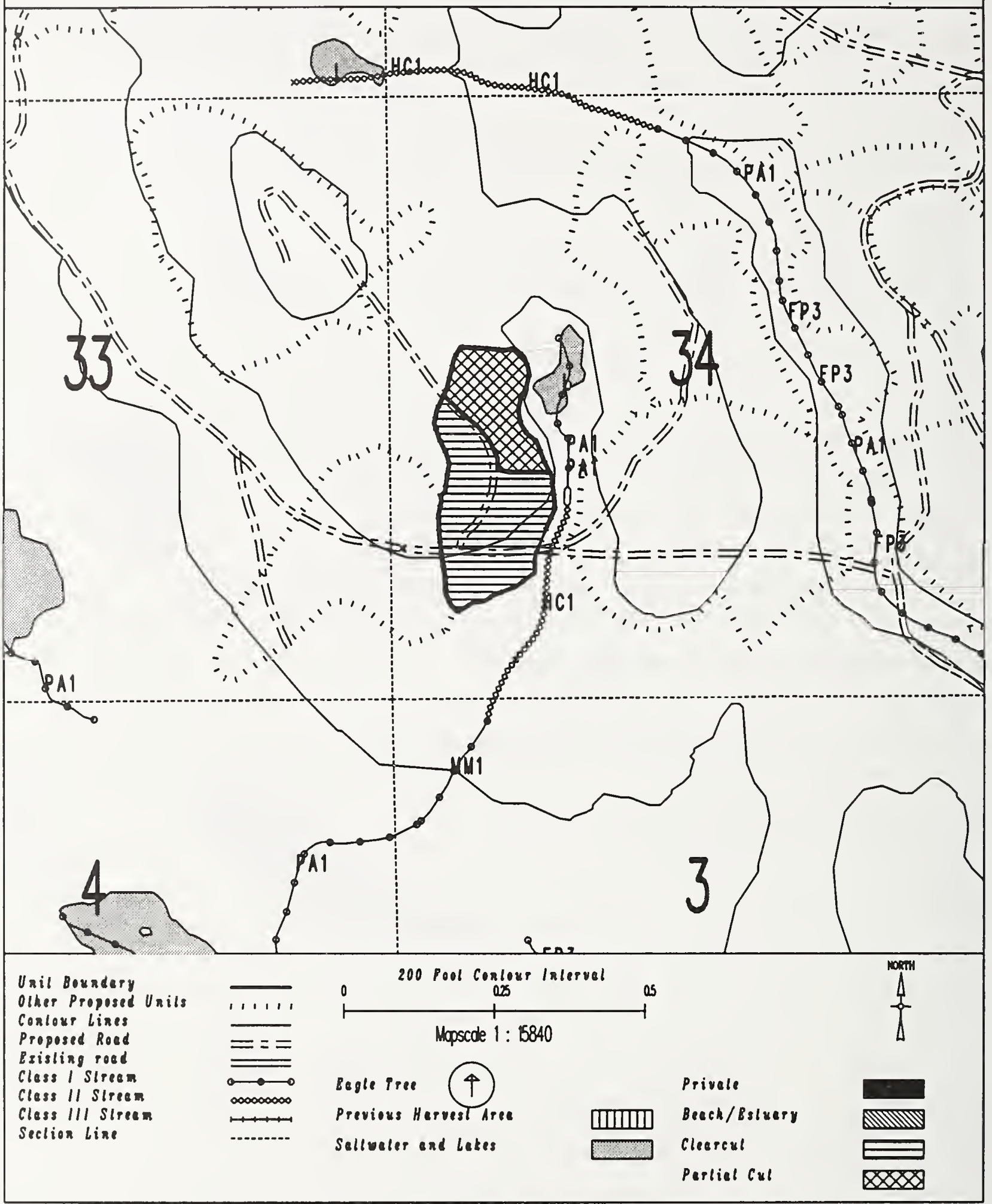


Unit 553-221

Planned acres 34

Estimated volume (mbf) 1082

Logging system skyline

silvicultural system Clearcut

Forest type Hemlock
Alternatives considered $\mathbf{F 2}$

Quad CRGD4NEN

Mgmt Area $\mathrm{KO8}$

WAA 1530

Photo

Aspect South

PHYSICAL DESCRIPTION

Volume class breakdown: VC4 $\quad 0$ acres VC5 33 acres vC6 $\quad 0$ acres vC7 $\quad 0$ acres

Elevation breakdown: $0-800 \mathrm{ft} . \underline{32}$ acres $800-1200 \mathrm{ft} . \underline{0}$ acres $1200-1500 \mathrm{ft} . \underline{0}$ acres over $1500 \mathrm{ft} . \underline{0}$ acres Mass movement index: Low 9 acres Medium 0 acres High 14 acres Very High 0 acres

\section{SOILS}

This unit has high mass movement index soils. Partial log suspension required over these areas.(BMP13.9)

This unit has < 40\% MCGilvery soils. Partial suspension required (BMP13.9) to ensure reforestation (BMP13.19).

This unit contains 18 acres of forested wetlands. Site specific BMPs will be designed for selected approved

logging system and road construction practices. (BMPs 12.5, 13.9, 13.15).

This unit contains 24 acres of slopes $>75 \%$.

\section{TIMBER}

There are no timber mitigation measures anticipated for this unit.

\section{ENGINEERING}

High mass movement index soils. Road construction must minimize landslide potential (BMP14).

The road into this unit crosses a $\underline{L 3}$ channel. Meet stream and lake protection prescription requirements in TLMP Draft Revision (1991a) for this process group.

slopes greater than $75 \%$ may require full bench construction and endhaul of waste (BMP14.7).

\section{FISH/WATERSHED}

Potential for additional Class I/II streams within unit. May be necessary to place additional buffers within unit in accordance with AHMU Handbook.

\section{WILDLIFE}

There are no wildlife mitigation measures anticipated for this unit.

\section{RECREATION / VISUALS}

This unit has a proposed voo of MM and is not seen from any viewpoint identified by this project.

\section{LANDS}

There are no lands mitigation measures anticipated for this unit.

CULTURAL RESOURCES

There are no cultural resource mitigation measures anticipated for this unit.

There are no karst mitigation measures anticipated for this unit. 
CPOY Unil Cerd

Unil Nuaber: 553-221

June 10, 1993

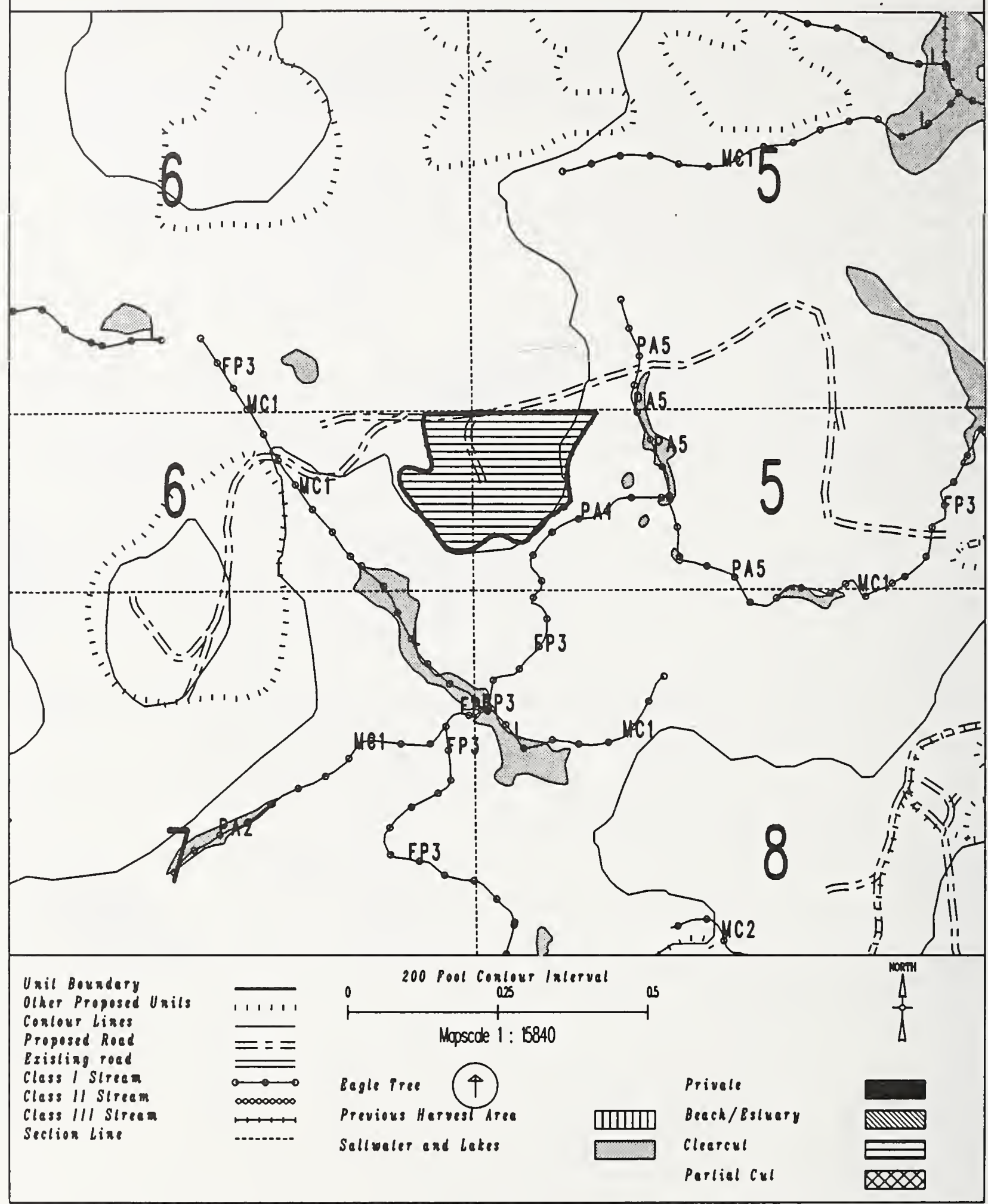


Unit 553-222

Planned acres 65

Estimated volume (mbf) 1423

Logging system skyline

silvicultural system clearcut

Forest type Hemlock
Alternatives considered $F$

Quad CRGD4NEN

Mgmt Area $\mathrm{K08}$

WAA 1530

Photo 1190105

Aspect East

\section{PHYSICAL DESCRIPTION}

Volume class breakdown: VC4 65 acres VC5 $\quad 0$ acres VC6 $\quad 0$ acres VC7 $\quad 0$ acres

Elevation breakdown: $0-800 \mathrm{ft} . \underline{63}$ acres $800-1200 \mathrm{ft} . \underline{0}$ acres $1200-1500 \mathrm{ft}$. 0 acres over $1500 \mathrm{ft}$. 0 acres Mass movement index: Low 13 acres Medium 0 acres High 30 acres Very High 0 acres

\section{SOILS}

This unit has high mass movement index soils. Partial log suspension required over these areas.(BMP13.9)

This unit contains 37 acres of forested wetlands. Site specific BMPs will be designed for selected approved logging system and road construction practices. (BMPs 12.5, 13.9, 13.15).

This unit contains 50 acres of slopes $>75 \%$.

TIMBER

Potential for shovel logging on 13 acres, if soil and water quality protected (BMP13.7)

\section{ENGINEER ING}

High mass movement index soils. Road construction must minimize landslide potential (BMP14).

The road into this unit crosses a $\underline{B 4}$ channel. Meet stream and lake protection prescription requirements in TLMP Draft Revision (1991a) for this process group.

slopes greater than $75 \%$ may require full bench construction and endhaul of waste (BMP14.7).

\section{FISH/WATERSHED}

There are no fishery mitigation measures anticipated for this unit.

\section{WILDLIFE}

There are no wildlife mitigation measures anticipated for this unit.

\section{RECREATION / VISUALS}

This unit has a proposed VQO of MM and is not seen from any viewpoint identified by this project.

\section{LANDS}

This unit adjacent to Sarkar Management Area. Boundary establishment required prior to Layout.

\section{CULTURAL RESOURCES}

There are no cultural resource mitigation measures anticipated for this unit. 


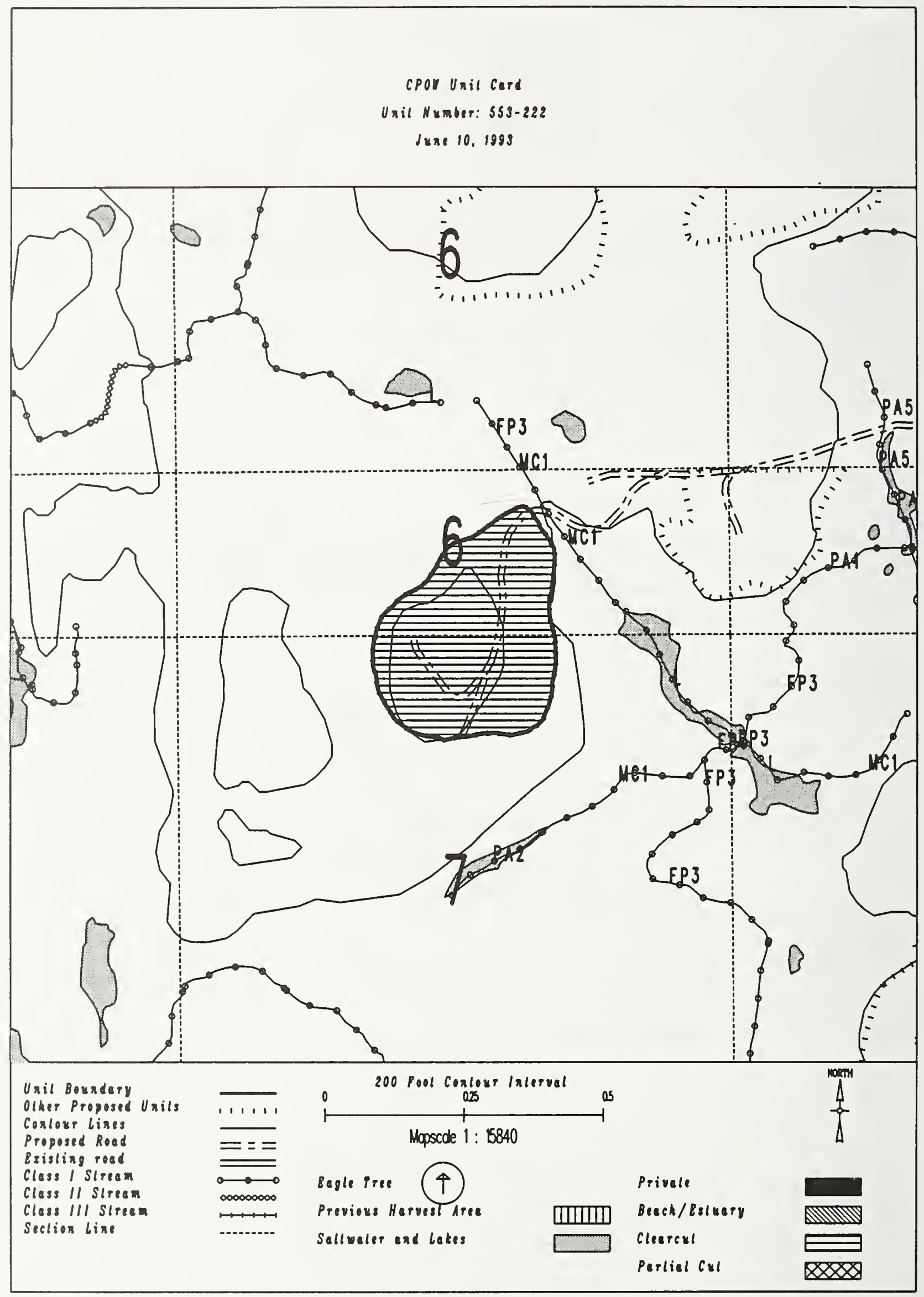


Unit $553-228$

Planned acres 34

Estimated volume (mbf)

Logging system skyline

silvicultural system Riparian

Forest type Mixed conifer
Alternatives considered F2

Quad CRGD4NEN

Mgmt Area $\mathrm{KO8}$

WAA 1530

Photo

Aspect North

PHYSICAL DESCRIPTION

Volume class breakdown: VC4 $\quad 10$ acres VC5 23 acres VC6 $\quad 0$ acres vC7 $\quad 0$ acres

Elevation breakdown: $0-800 \mathrm{ft} . \underline{29}$ acres $800-1200 \mathrm{ft} . \underline{0}$ acres $1200-1500 \mathrm{ft} . \underline{0}$ acres over $1500 \mathrm{ft}$. 0 Mass movement index: Low 5 acres Medium 26 acres High 1 acres Very High 0 acres

SOILS

This unit contains 31 acres of forested wetlands. Site specific BMPs will be designed for selected approved logging system and road construction practices. (BMPs 12.5, 13.9, 13.15).

TIMBER

Uneven-aged harvest for riparian management on an estimated 6 acres.

Potential for shovel logging on 11 acres, if soil and water quality protected (BMP 13.7)

\section{ENGINEER ING}

There are no engineering mitigation measures anticipated for this unit.

\section{FISH/WATERSHED}

There are no fishery mitigation measures anticipated for this unit.

WILDLIFE

There are no wildlife mitigation measures anticipated for this unit.

RECREATION / VISUALS

This unit has a proposed Voo of MM and is not seen from any viewpoint identified by this project.

\section{LANDS}

There are no lands mitigation measures anticipated for this unit.

CULTURAL RESOURCES

There are no cultural resource mitigation measures anticipated for this unit.

There are no karst mitigation measures anticipated for this unit. 


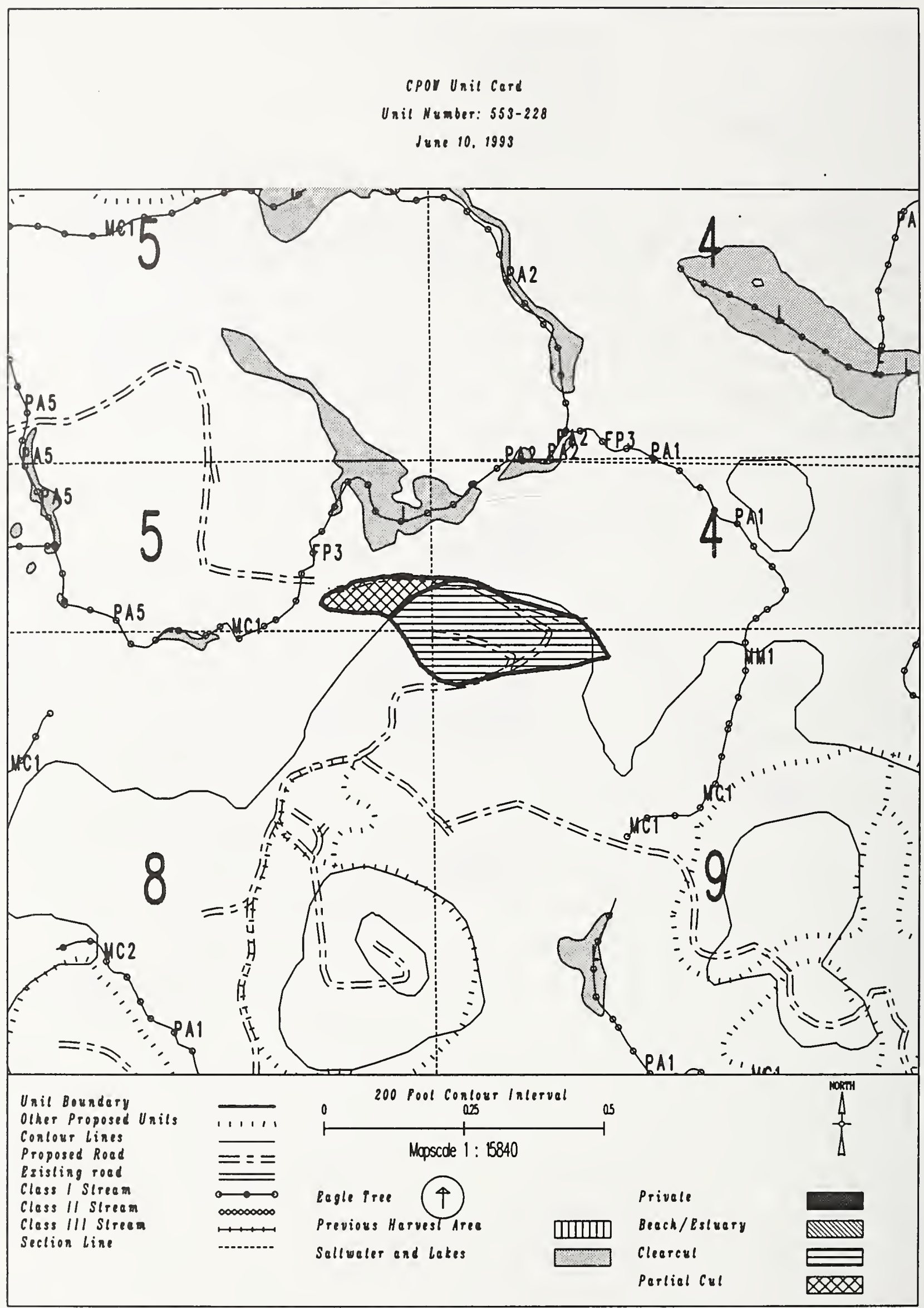


Unit 553-232

Planned acres 81

Estimated volume (mbf) 2088

Logging system skyline

silvicultural system Clearcut

Forest type Cedar
Alternatives considered F2

Quad CRGD4NEN

Mgmt Area K08

WAA 1530

Photo 1190106

Aspect East

PHYSICAL DESCRIPTION

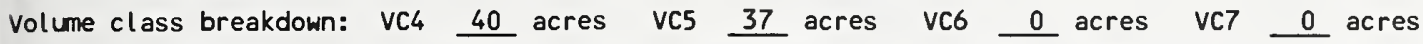

Elevation breakdown: $0-800 \mathrm{ft} . \underline{77}$ acres $800-1200 \mathrm{ft} . \underline{0}$ acres $1200-1500 \mathrm{ft} . \underline{0}$ acres over $1500 \mathrm{ft}$. 0 acres Mass movement index: Low 23 acres Medium $\underline{0}$ acres High 31 acres Very High 0 acres

SOILS

This unit has high mass movement index soils. Partial log suspension required over these areas. (BMP13.9)

This unit contains 26 acres of forested wetlands. Site specific BMPs will be designed for selected approved

logging system and road construction practices. (BMPs 12.5, 13.9, 13.15).

This unit contains 58 acres of slopes $>75 \%$.

TIMBER

There are no timber mitigation measures anticipated for this unit.

ENG INEER ING

High mass movement index soils. Road construction must minimize landslide potential (BMP14).

slopes greater than $75 \%$ may require full bench construction and endhaul of waste (BMP14.7).

\section{FISH/WA TERSHED}

There are no fishery mitigation measures anticipated for this unit.

\section{WILDL IFE}

There are no wildlife mitigation measures anticipated for this unit.

\section{RECREATION / VISUALS}

This unit has a proposed VoO of MM and is not seen from any viewpoint identified by this project.

\section{LANDS}

There are no lands mitigation measures anticipated for this unit.

CULTURAL RESOURCES

There are no cultural resource mitigation measures anticipated for this unit.

GEOLOGY

There are no karst mitigation measures anticipated for this unit. 


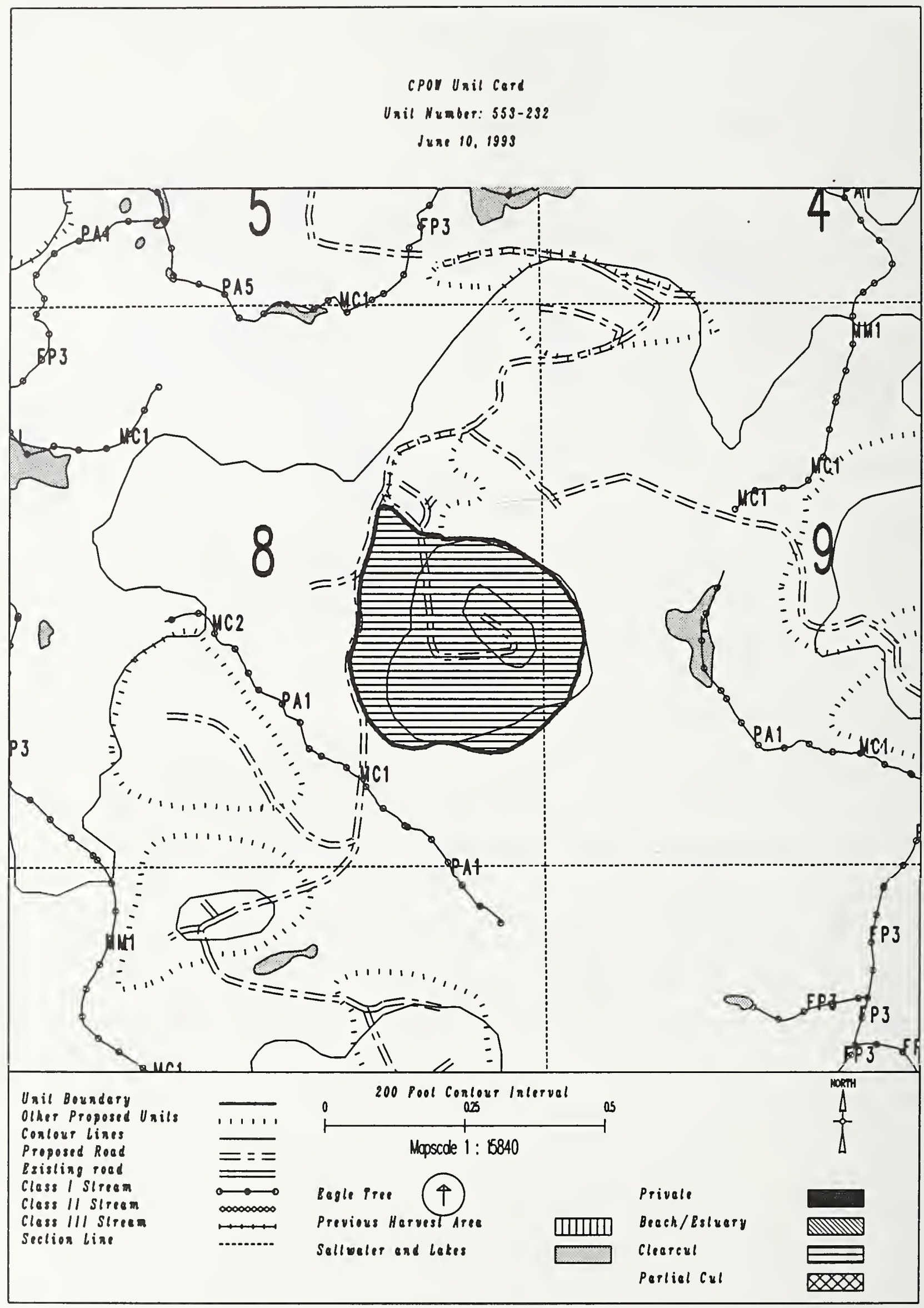




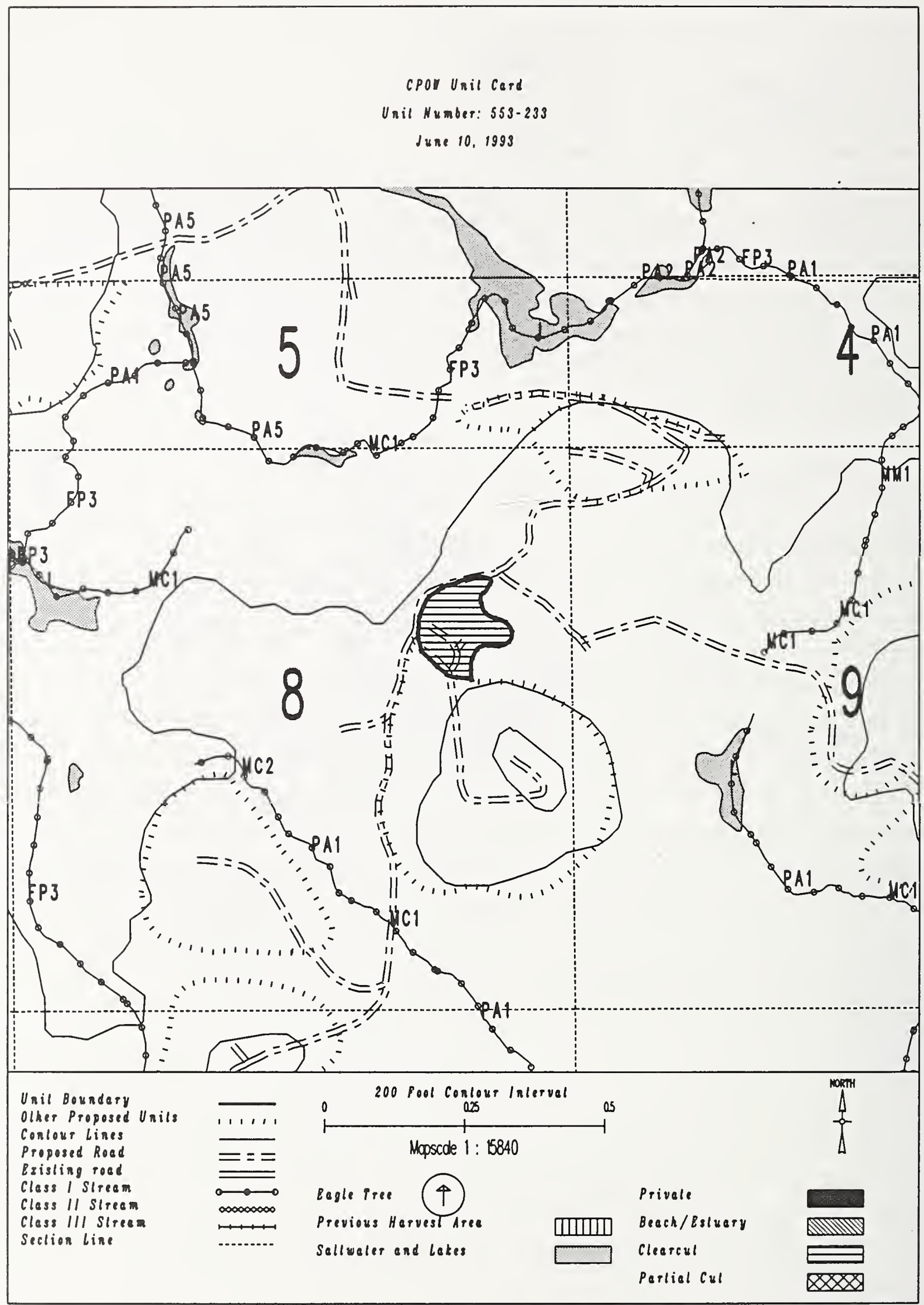




\section{Unit 553-235}

Planned acres 47

Estimated volume (mbf)

Logging system skyline

silvicultural system clearcut

Forest type Hemlock
Alternatives considered $F$

Quad CRGD4NEN

Mgmt Area $\mathrm{KO8}$

WAA 1530

Photo

Aspect North

PHYSICAL DESCRIPTION

Volume class breakdown: VC4 29 acres VC5 $\quad 3$ acres VC6 $\quad 0$ acres VC7 $\quad 0$ acres

Elevation breakdown: $0-800 \mathrm{ft} . \underline{44}$ acres $800-1200 \mathrm{ft} . \underline{0}$ acres $1200-1500 \mathrm{ft} . \underline{0}$ acres over $1500 \mathrm{ft}$. 0 Mass movement index: Low 21 acres Medium $\underline{0}$ acres High 15 acres Very High 0 acres

SOILS

This unit has high mass movement index soils. Partial log suspension required over these areas.(BMP13.9)

This unit has > 40\% MCGilvery soils. Partial suspension required (BMP13.9).

to ensure reforestation (BMP13.19).

This unit contains 24 acres of forested wetlands. Site specific BMPs will be designed for selected approved

logging system and road construction practices. (BMPs 12.5, 13.9, 13.15).

This unit contains 25 acres of slopes $>75 \%$.

TIMBER

Water quality streams may be present, where it is impractical to split yard. Full suspension required over all streamcourses (BMPs13.9, 13.16).

\section{ENGINEERING}

High mass movement index soils. Road construction must minimize landslide potential (BMP14).

The road into this unit crosses a $\underline{B} 4$ channel. Meet stream and lake protection prescription requirements in TLMP Draft Revision (1991a) for this process group.

slopes greater than $75 \%$ may require full bench construction and endhaul of waste (BMP14.7).

\section{FISH/WATERSHED}

There are no fishery mitigation measures anticipated for this unit.

\section{WILDLIFE}

There are no wildlife mitigation measures anticipated for this unit.

RECREATION / VISUALS

This unit has a proposed voo of MM and is not seen from any viewpoint identified by this project.

\section{LANDS}

There are no lands mitigation measures anticipated for this unit.

CULTURAL RESOURCES

There are no cultural resource mitigation measures anticipated for this unit.

GEOLOGY

There are no karst mitigation measures anticipated for this unit. 


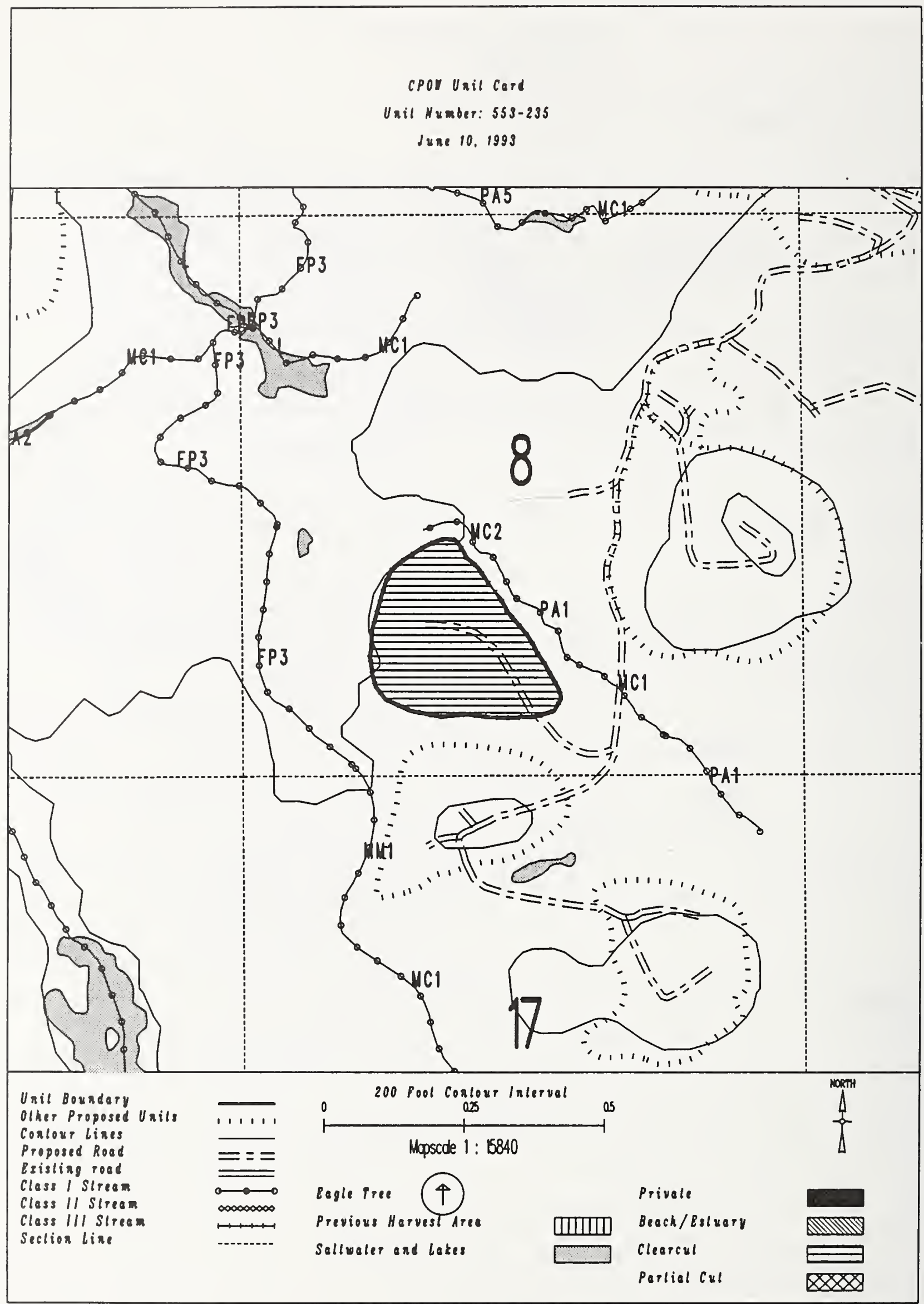


Unit $553-236$

Planned acres 37

Estimated volume (mbf)

Logging system skyl ine

silvicultural system clearcut

Forest type Cedar
Alternatives considered F2

Quad CRGD4NEN

Mgmt Area $\mathrm{K} 08$

WAA 1530

Photo 1190106

Aspect North

PHYSICAL DESCRIPTION

Volume class breakdown: VC4 $\quad 22$ acres VC5 $\quad 14$ acres vc6 $\quad 0$ acres $v c 7 \quad 0$ acres

Elevation breakdown: $0-800 \mathrm{ft} . \underline{36}$ acres $800-1200 \mathrm{ft} . \underline{0}$ acres $1200-1500 \mathrm{ft} . \underline{0}$ acres over $1500 \mathrm{ft}$. 0 Mass movement index: Low 3 acres Medium 0 acres High 18 acres Very High 0 acres

\section{SOILS}

This unit has high mass movement index soils. Partial log suspension required over these areas. (BMP13.9)

This unit contains 14 acres of forested wetlands. Site specific BMPs will be designed for selected approved

logging system and road construction practices. (BMPs 12.5, 13.9, 13.15).

This unit contains 33 acres of slopes $>75 \%$.

\section{TIMBER}

There are no timber mitigation measures anticipated for this unit.

\section{ENGINEER ING}

High mass movement index soils. Road construction must minimize landslide potential (BMP14).

slopes greater than $75 \%$ may require full bench construction and endhaul of waste (BMP14.7).

\section{FISH/WATERSHED}

There are no fishery mitigation measures anticipated for this unit.

\section{WILDL I FE}

There are no wildlife mitigation measures anticipated for this unit.

\section{RECREATION / VISUALS}

This unit has a proposed Voo of MM and is not seen from any viewpoint identified by this project.

\section{LANDS}

There are no lands mitigation measures anticipated for this unit.

\section{CULTURAL RESOURCES}

There are no cultural resource mitigation measures anticipated for this unit.

\section{GEOLOGY}

There are no karst mitigation measures anticipated for this unit. 
Unil Number: $559-296$

Jyne 10. 1993

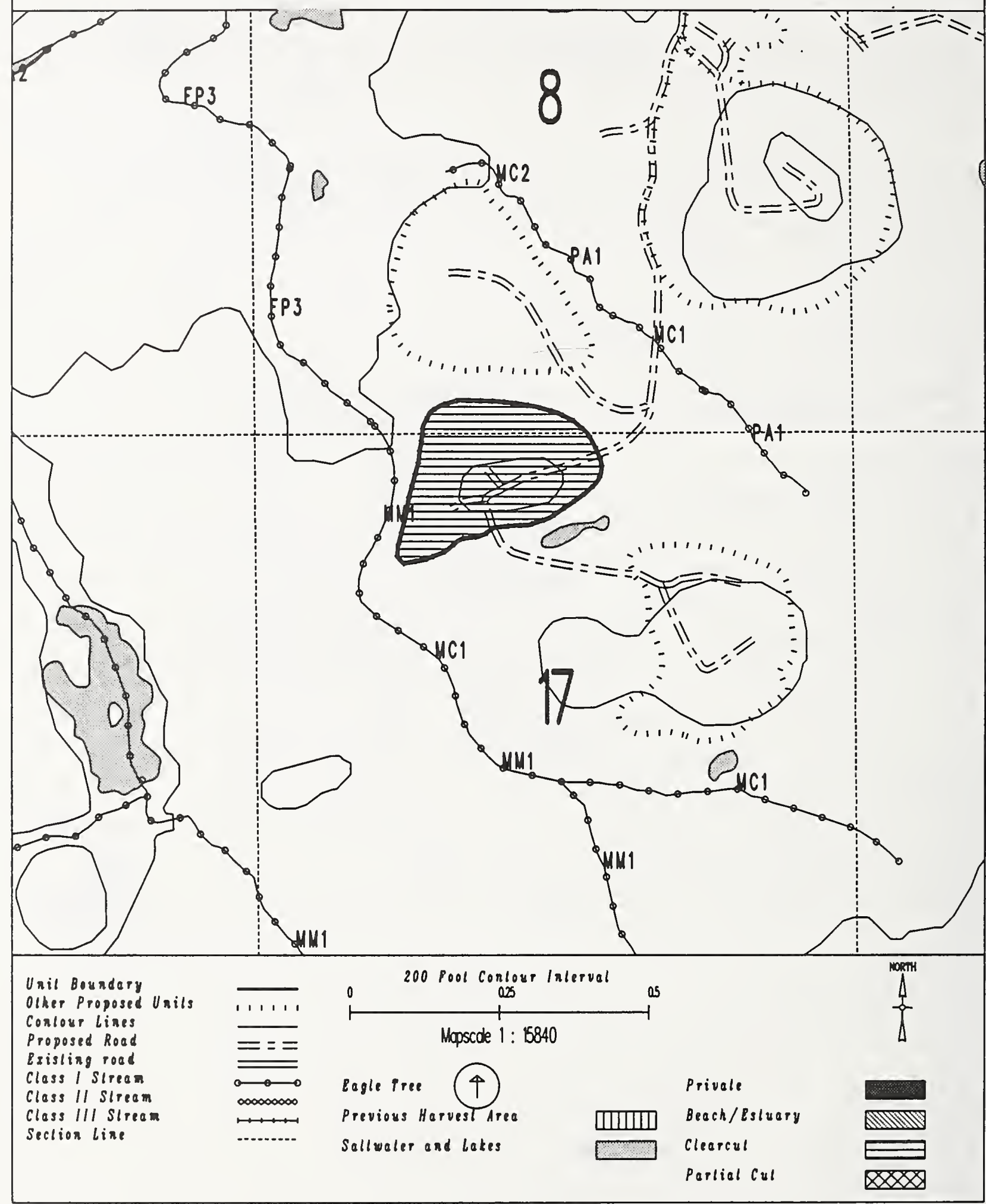


Unit $\quad$ 553-237

Planned acres 45

Estimated volume (mbf) 941

Logging system skyline

silvicultural system clearcut

forest type Hemlock
Alternatives considered $\mathbf{F 2}$

Quad CRGD4NEN

Mgmt Area $\mathrm{KO8}$

WAA 1530

Photo 1190237

Aspect West

PHYSICAL DESCRIPTION

Volume class breakdown: VC4 43 acres VC5 $\quad 0$ acres vC6 $\quad 0$ acres VC7 $\quad 0$ acres

Elevation breakdown: $0-800 \mathrm{ft} . \underline{43}$ acres $800-1200 \mathrm{ft} . \underline{0}$ acres 1200-1500 ft. 0 acres over $1500 \mathrm{ft}$. 0 acres Mass movement index: Low 15 acres Medium 0 acres High 17 acres Very High

SOILS

This unit has high mass movement index soils. Partial log suspension required over these areas.(BMP13.9)

This unit contains 22 acres of forested wetlands. Site specific BMPs will be designed for selected approved

logging system and road construction practices. (BMPs 12.5, 13.9, 13.15).

This unit contains 28 acres of slopes $>75 \%$.

TIMBER

There are no timber mitigation measures anticipated for this unit.

\section{ENG INEER ING}

High mass movement index soils. Road construction must minimize landslide potential (BMP14).

The road into this unit crosses a B4 channel. Meet stream and lake protection prescription requirements in TLMP

Draft Revision (1991a) for this process group.

Slopes greater than $75 \%$ may require full bench construction and endhaul of waste (BMP14.7).

FISH/WATERSHED

There are no fishery mitigation measures anticipated for this unit.

WILDLIFE

There are no wildlife mitigation measures anticipated for this unit.

RECREATION / VISUALS

This unit has a proposed VQO of MM and is not seen from any viewpoint identified by this project.

LANDS

There are no lands mitigation measures anticipated for this unit.

CULTURAL RESOURCES

There are no cultural resource mitigation measures anticipated for this unit.

There are no karst mitigation measures anticipated for this unit. 


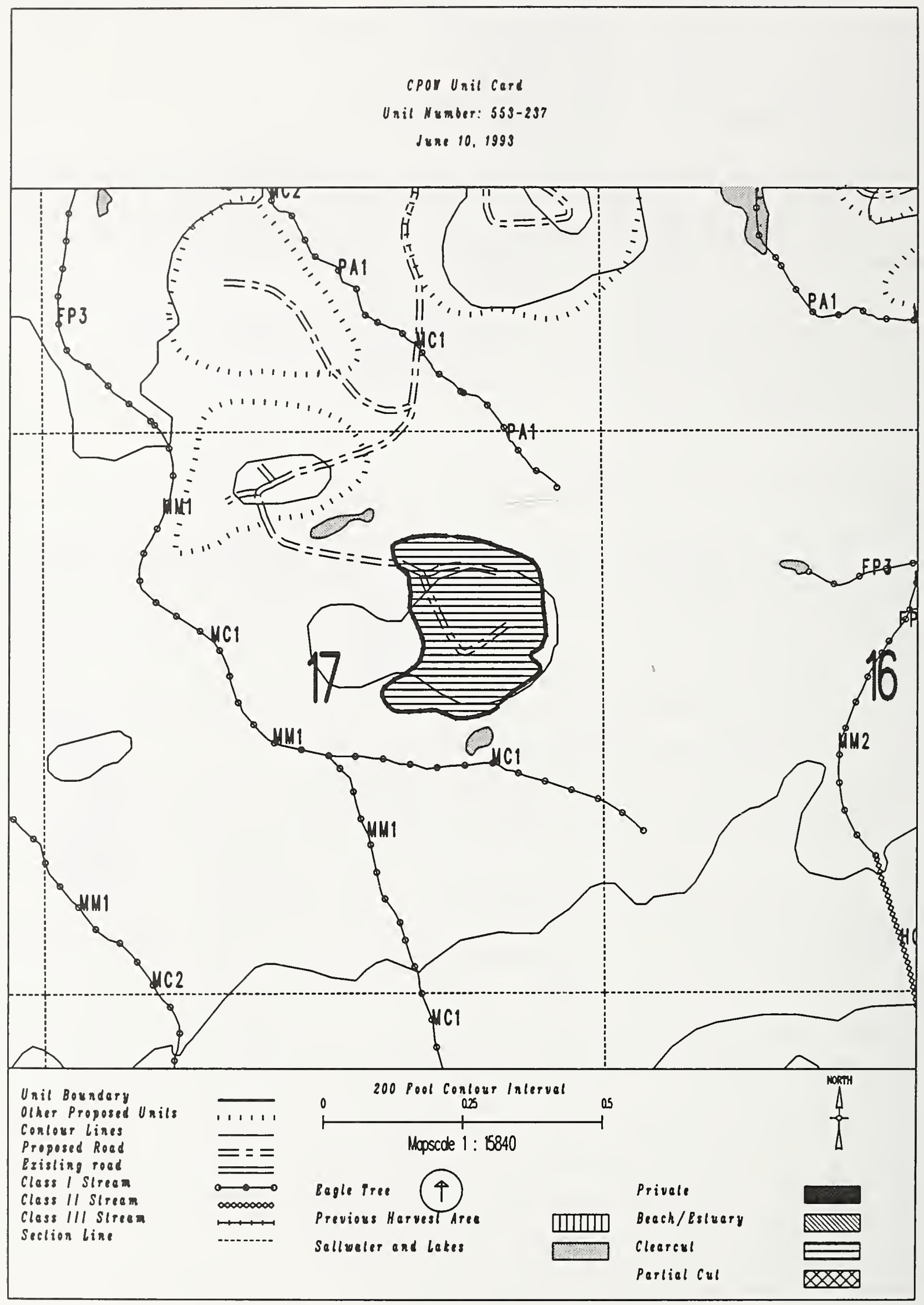


Unit 553-245

Planned acres 33

Est imated volume (mbf) 895

Logging system skyline

silvicultural system clearcut

Forest type Mixed conifer
Alternatives considered

Quad PBGA4SES

Mgmt Area $\mathrm{K08}$

WAA 1422

Photo 1190019

Aspect West

PHYSICAL DESCRIPTION

Volume class breakdown: VC4 $\quad 0$ acres VC5 18 acres VC6 $\quad 8$ acres VC7 0

Elevation breakdown: $0-800 \mathrm{ft} . \underline{32}$ acres $800-1200 \mathrm{ft} . \underline{0}$ acres $1200-1500 \mathrm{ft}$. 0 acres over $1500 \mathrm{ft}$. 0 acres Mass movement index: Low 4 acres Medium 0 acres High 19 acres Very High 0 acres

SOILS

This unit has high mass movement index soils. Partial log suspension required over these areas.(BMP13.9)

This unit contains 23 acres of forested wetlands. Site specific BMPs will be designed for selected approved

logging system and road construction practices. (BMPs 12.5, 13.9, 13.15).

\section{TIMBER}

There are no timber mitigation measures anticipated for this unit.

\section{ENGINEER ING}

High mass movement index soils. Road construction must minimize landslide potential (BMP14).

\section{FISH/WATERSHED}

Potential for additional Class I/II streams within unit. May be necessary to place additional buffers within unit in accordance with AHMU Handbook.

\section{WILDLIFE}

There are no wildlife mitigation measures anticipated for this unit.

\section{RECREATION / VISUALS}

This unit has a proposed Voo of MM and is not seen from any viewpoint identified by this project.

LANDS

There are no lands mitigation measures anticipated for this unit.

\section{CULTURAL RESOURCES}

The planned unit boundary and road location is immediately adjacent to significant cultural resources. Any changes must be coordinated with cultural resource personnel.

\section{GEOLOGY}

There are no karst mitigation measures anticipated for this unit. 


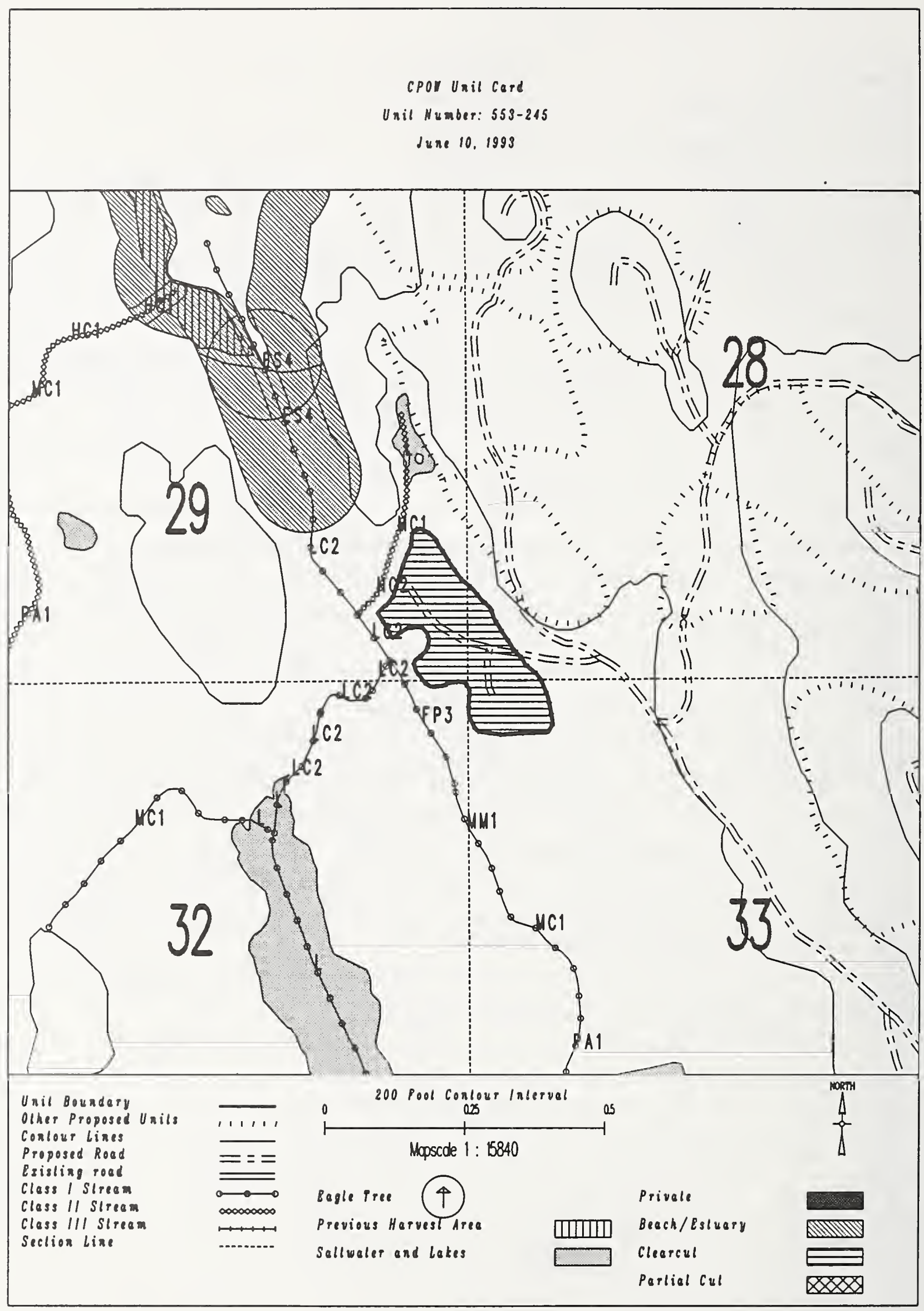


Unit $554.2-200$

Planned acres 45

Estimated volume (mbf) 876

Logging system skyline

silvicultural system Clearcut

Forest type Hemlock
Alternatives considered

F3 F4

Mgmt Area $\mathrm{K} 07$

WAA 1422

Photo 1990107

Aspect South

PHYSICAL DESCRIPTION

Volume class breakdown: VC4 40 acres VC5 $\quad 0$ acres vC6 $\quad 0$ acres vc7 $\quad 0$ acres

Elevation breakdown: $0-800 \mathrm{ft} . \underline{44}$ acres $800-1200 \mathrm{ft} . \underline{0}$ acres $1200-1500 \mathrm{ft} . \underline{0}$ acres over $1500 \mathrm{ft}$. 0 Mass movement index: Low 13 acres Medium 1 acres High 12 acres Very High 0 acres

\section{SOILS}

This unit has high mass movement index soils. Partial log suspension required over these areas.(BMP13.9)

This unit contains 29 acres of forested wetlands. Site specific BMPs will be designed for selected approved

logging system and road construction practices. (BMPs 12.5, 13.9, 13.15).

This unit contains 20 acres of slopes $>75 \%$.

\section{TIMBER}

Potential for shovel logging on 5 acres, if soil and water quality protected (BMP13.7)

\section{ENG INEER ING}

High mass movement index soils. Road construction must minimize landslide potential (BMP14). Slopes greater than $75 \%$ may require full bench construction and endhaul of waste (BMP14.7).

\section{FISH/WATERSHED}

There are no fishery mitigation measures anticipated for this unit.

\section{WILOLIFE}

There are no wildlife mitigation measures anticipated for this unit.

\section{RECREATION / VISUALS}

This unit has a proposed VQO of MM and is not seen from any viewpoint identified by this project.

\section{LANDS}

There are no lands mitigation measures anticipated for this unit.

CULTURAL RESOURCES

There are no cultural resource mitigation measures anticipated for this unit.

There are no karst mitigation measures anticipated for this unit. 


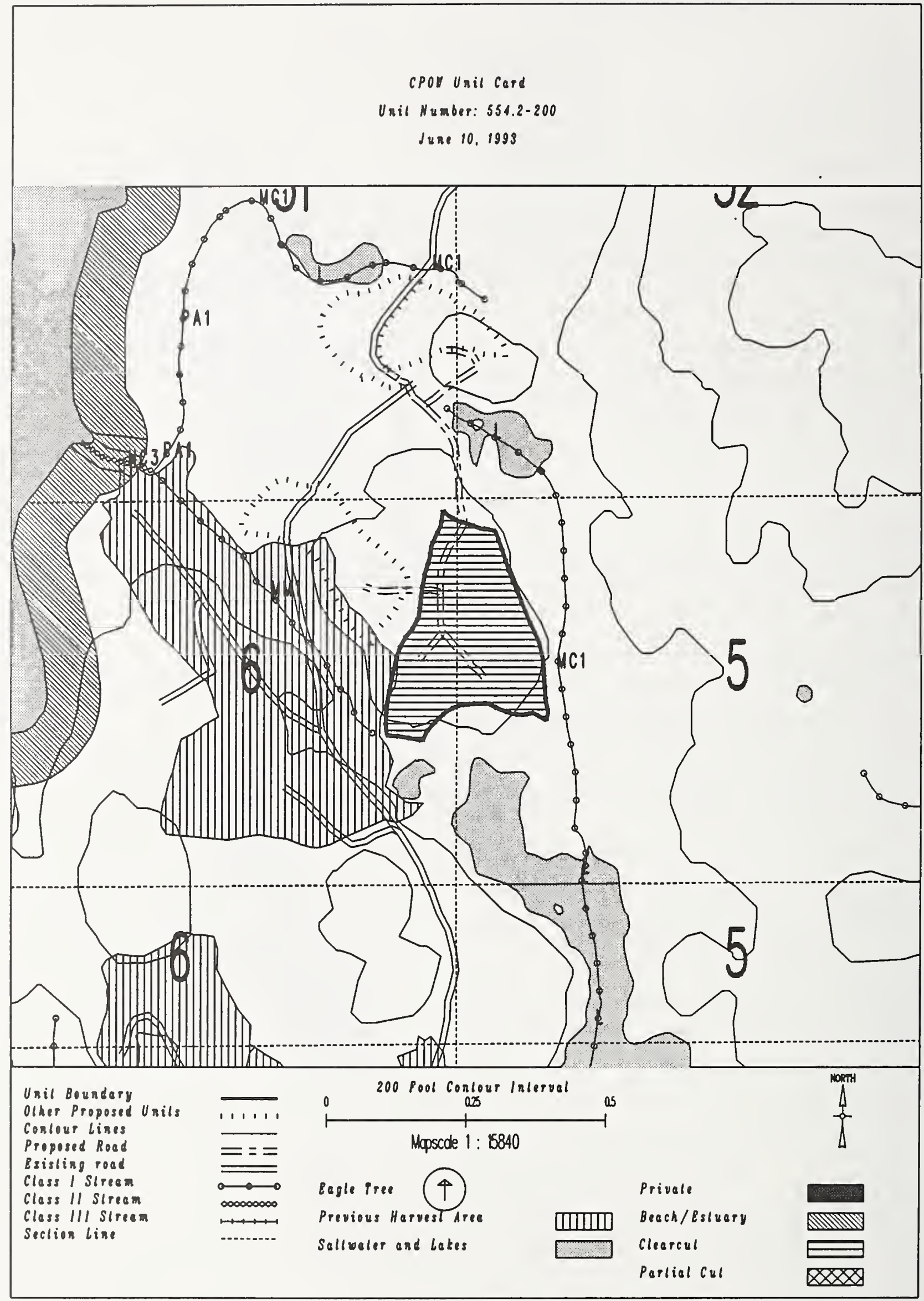


Unit 554.2-200

Planned acres 45

Estimated volume (mbf) $\mathbf{8 7 6}$

Logging system skyline

Silvicultural system Selective

Forest type Hemlock
Alternatives considered

Quad PBGA4SWS

Mgmt Area $\mathrm{KOT}$

WAA 1422

Photo 1990107

Aspect South

PHYSICAL DESCRIPTION

Volume class breakdown: VC4 $\quad 40$ acres VC5 $\quad 0$ acres VC6 $\quad 0$ acres VC7 $\quad 0$ acres

Elevation breakdown: $0-800 \mathrm{ft} . \quad 444$ acres $800-1200 \mathrm{ft} . \quad 0$ acres $1200-1500 \mathrm{ft} . \quad 0$ acres over $1500 \mathrm{ft}$. 0 Mass movement index: Low 13 acres Medium 1 acres High 12 acres Very High 0 acres

\section{SOILS}

This unit has high mass movement index soils. Partial log suspension required over these areas. (BMP13.9)

This unit contains 29 acres of forested wetlands. Site specific BMPs will be designed for selected approved

logging system and road construction practices. (BMPs 12.5, 13.9, 13.15).

This unit contains 20 acres of slopes > $75 \%$.

\section{TIMBER}

Selective; uneven-aged harvest designed to meet specific resource concern.

potential for shovel logging on 5 acres, if soil and water quality protected (BMP13.7)

\section{ENGINEER ING}

High mass movement index soils. Road construction must minimize landslide potential (BMP14).

slopes > 75\% may require full bench construction and endhaul of waste (BMP14.7).

\section{FISH/WATERSHED}

There are no fishery mitigation measures anticipated for this unit.

\section{WILDLIFE}

There are no wildlife mitigation measures anticipated for this unit.

\section{RECREATION / VISUALS}

This unit has a proposed VoO of MM and is not seen from any viewpoint identified by this project.

\section{LANDS}

There are no lands mitigation measures anticipated for this unit.

\section{CULTURAL RESOURCES}

There are no cultural resource mitigation measures anticipated for this unit.

\section{GEOLOGY}

Selective harvest prescribed to protect significant karst resources. 


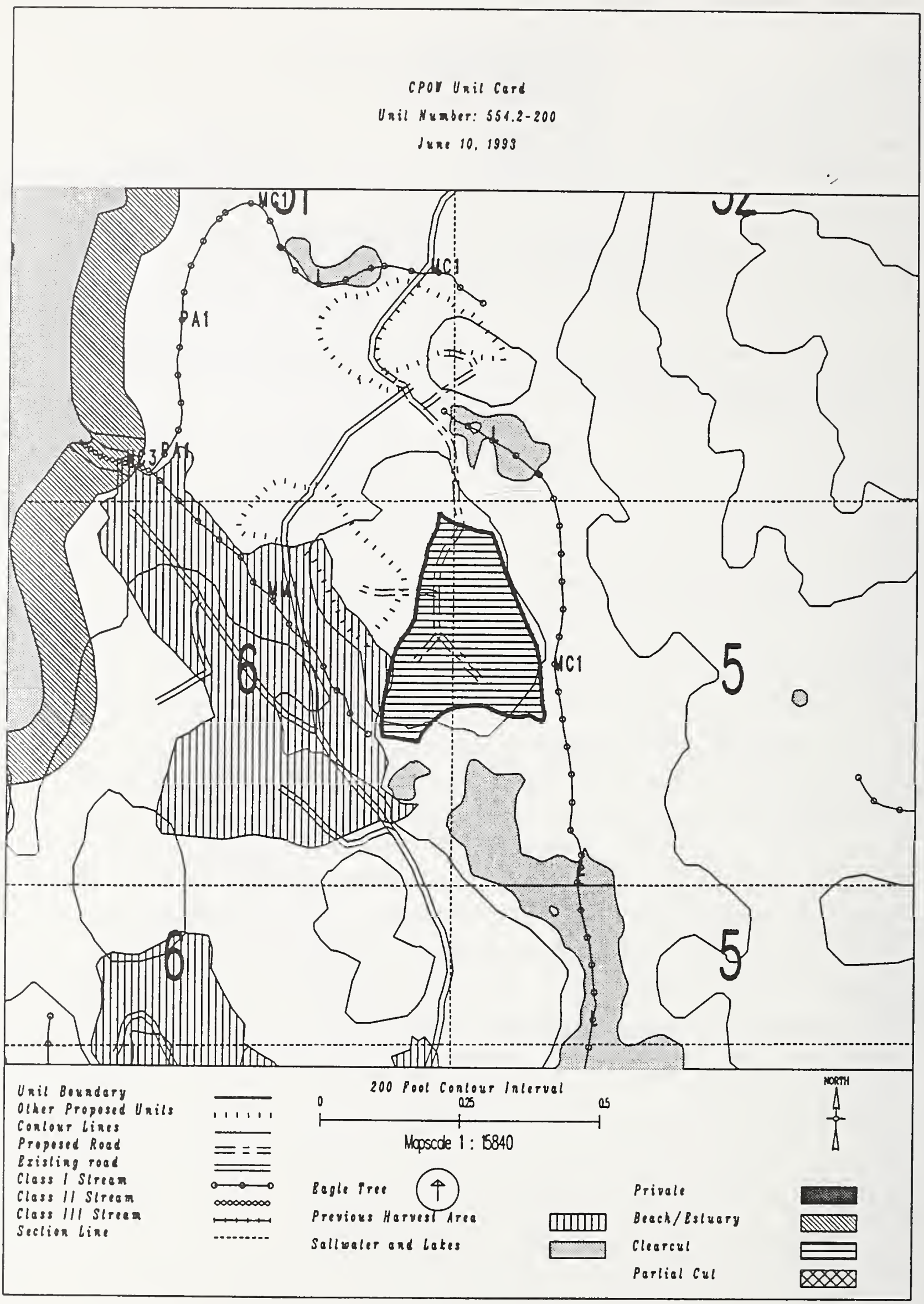


Unit $554.2-201$

Planned acres $\underline{23}$

Estimated volume (mbf) 372

Logging system Highlead

silvicultural system clearcut

Forest type Hemlock
Alternatives considered \begin{tabular}{lllll} 
F2 & $\mathrm{F} 3$ & $\mathrm{~F} 4$ & $\mathrm{~F} 6$ \\
\hline
\end{tabular}

Quad PBGA4SWS

Mgmt Area $\mathrm{K} 07$

WAA 1422

Photo 1990107

Aspect West

\section{PHYSICAL DESCRIPTION}

Volume class breakdown: VC4 17 acres VC5 $\quad 0$ acres VC6 $\quad 0$ acres VC7 $\quad 0$ acres

Elevation breakdown: $0-800 \mathrm{ft} . \underline{22}$ acres 800-1200 ft. 0 acres 1200-1500 ft. 0 acres over $1500 \mathrm{ft}$. 0 acres Mass movement index: Low 15 acres Medium 7 acres High 0 acres Very High 0 acres

\section{SOILS}

This unit contains 15 acres of forested wetlands. Site specific BMPs will be designed for selected approved logging system and road construction practices. (BMPs 12.5, 13.9, 13.15).

\section{TIMBER}

Potential regeneration problem. Monitor regeneration to determine if hand planting is required to meet BMP13.19.

Potential for shovel logging on 4 acres, if soil and water quality protected (BMP13.7)

\section{ENGINEERING}

There are no engineering mitigation measures anticipated for this unit.

\section{FISH/WATERSHED}

There are no fishery mitigation measures anticipated for this unit.

\section{WILDLIFE}

There are no wildlife mitigation measures anticipated for this unit.

RECREATION / VISUALS

This unit has a proposed VQO of MM and is not seen from any viewpoint identified by this project.

\section{LANDS}

There are no lands mitigation measures anticipated for this unit.

CULTURAL RESOURCES

There are no cultural resource mitigation measures anticipated for this unit. 


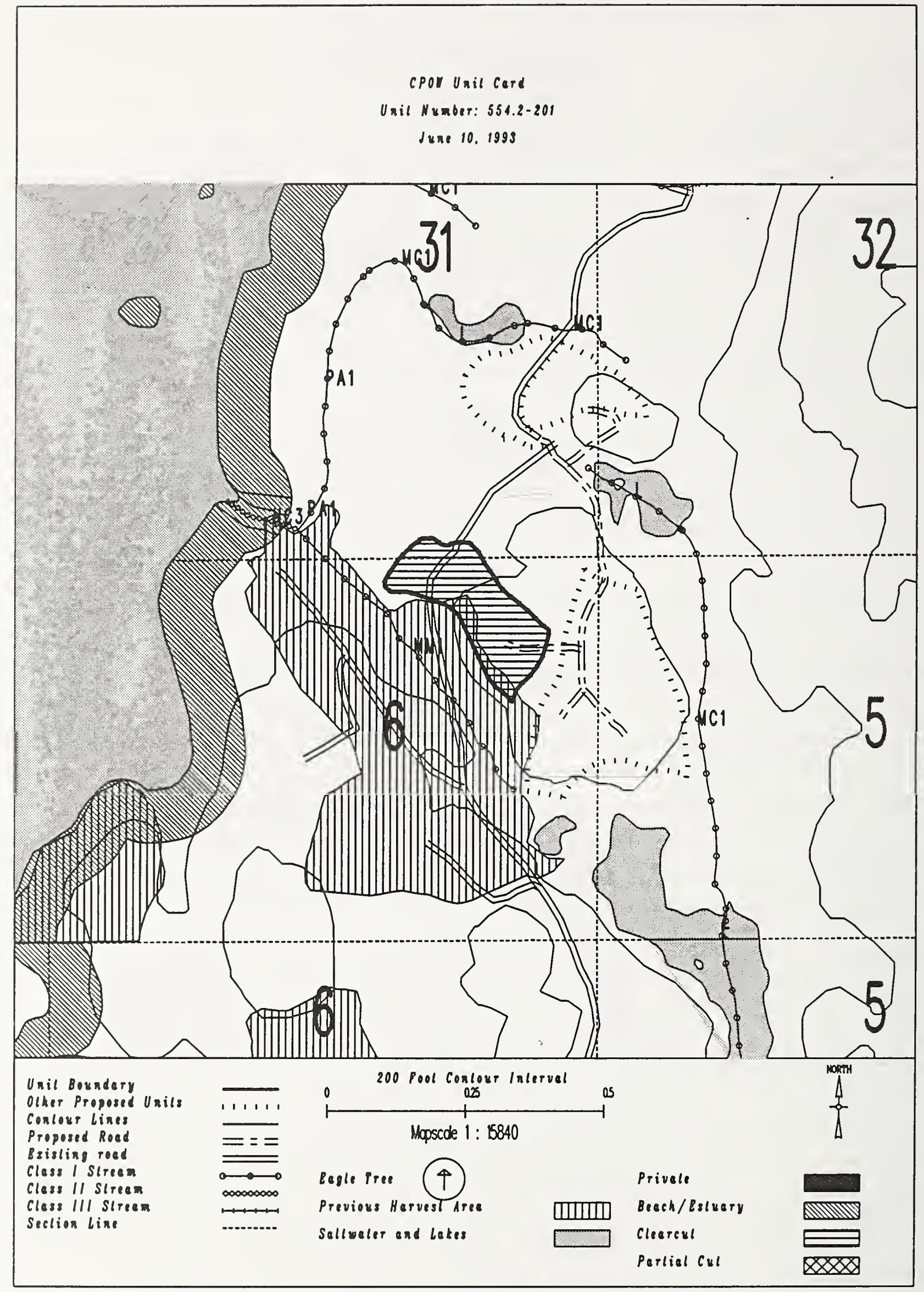


Unit $554.2: 201$

Planned acres 23

Estimated volume (mbf) 372

Logging system Highlead

silvicultural system Selective

Forest type Hemlock
Alternatives considered F5

Quad PBGA4SWS

Mgmt Area $\mathrm{KO7}$

WAA 1422

Photo 1990107

Aspect Hest

\section{PHYSICAL DESCRIPTION}

Volume class breakdown: VC4 17 acres VC5 $\quad 0$ acres VC6 $\quad 0$ acres vC7 $\quad 0$ acres

Elevation breakdown: $0-800 \mathrm{ft} . \underline{22}$ acres $800-1200 \mathrm{ft} . \underline{0}$ acres 1200-1500 ft. 0 acres over $1500 \mathrm{ft} . \underline{0}$ acres Mass movement index: Low 15 acres Medium 7 acres High 0 acres Very High 0

SOILS

This unit contains 15 acres of forested wetlands. Site specific BMPs will be designed for selected approved

logging system and road construction practices. (BMPs 12.5, 13.9, 13.15).

\section{TIMBER}

Potential regeneration problem. Monitor regeneration to determine if hand planting is required to meet BMP13.19. Selective, uneven-aged harvest designed to meet specific resource concern.

Potential for shovel logging on 4 acres, if soil and water quality protected (BMP13.7)

\section{ENGINEERING}

There are no engineering mitigation measures anticipated for this unit.

\section{FISH/WATERSHED}

There are no fishery mitigation measures anticipated for this unit.

WILDLIFE

Selective harvest prescribed to preserve goshawk foraging habitat/other objectives identified by District IDT.

RECREATION / VISUALS

This unit has a proposed VQO of MM and is not seen from any viewpoint identified by this project.

\section{LANDS}

There are no lands mitigation measures anticipated for this unit.

\section{CULTURAL RESOURCES}

There are no cultural resource mitigation measures anticipated for this unit.

\section{GEOLOGY}

There are no karst mitigation measures anticipated for this unit. 


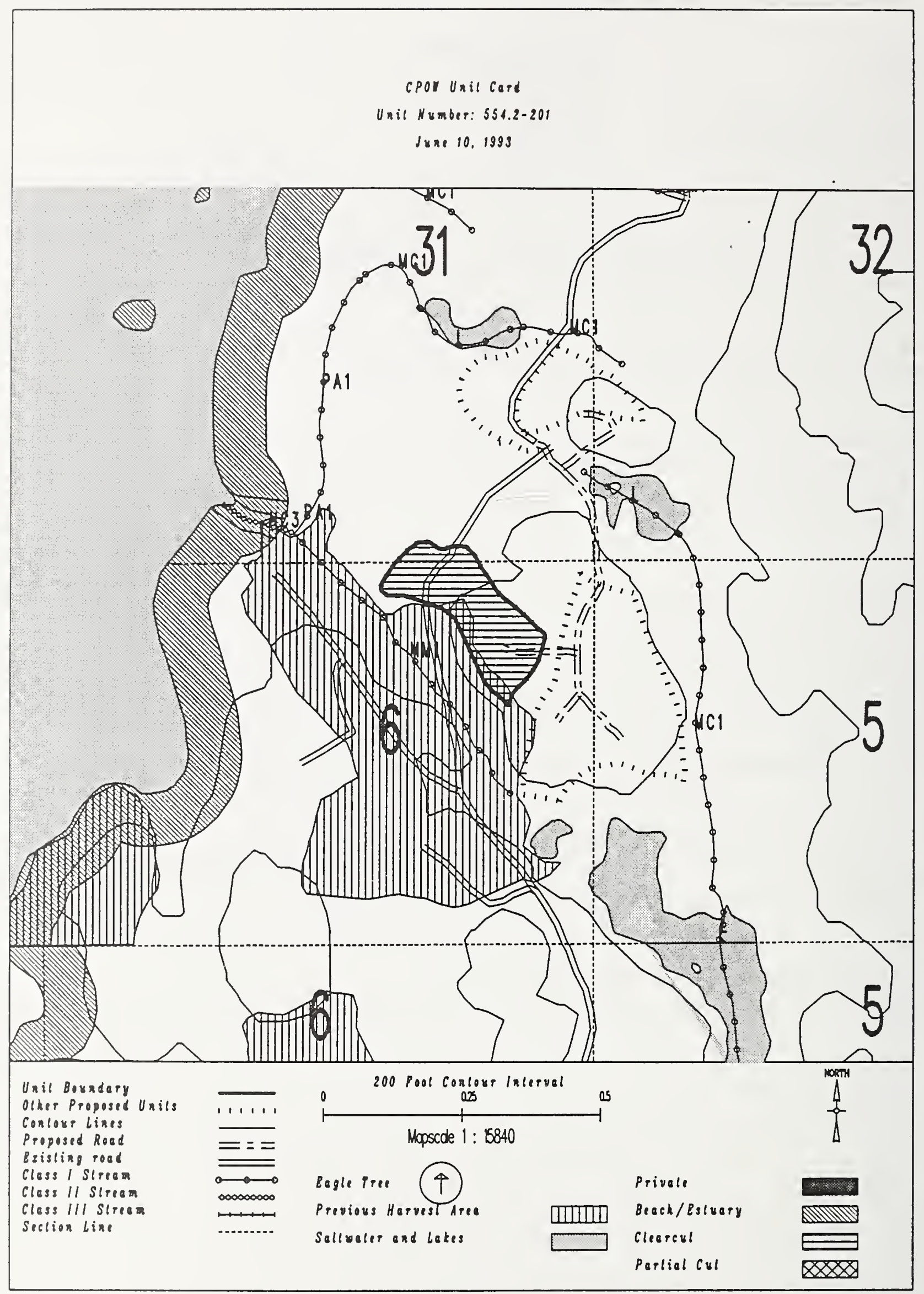


Unit $\quad 554.2-210$

Planned acres 23

Estimated volume (mbf) 622

Logging system Highlead

silvicultural system Clearcut

Forest type Hemlock
Alternatives considered F2 F3 F4

Quad CRGD4NWN

Mgmt Area K07

WAA 1422

Photo 1990102

Aspect South

PHYSICAL DESCRIPTION

Volume class breakdown: VC4 $\quad 0$ acres vc5 0 acres vc6 7 acres vc7 7 acres

Elevation breakdown: $0-800 \mathrm{ft} . \underline{22}$ acres $800-1200 \mathrm{ft} . \underline{0}$ acres $1200-1500 \mathrm{ft} . \underline{0}$ acres over $1500 \mathrm{ft}$. 0 acres Mass movement index: Low $\_$acres Medium 22 acres High 0 acres Very High 0 acres

SOILS

There are no soils mitigation measures anticipated for this unit.

TIMBER

There are no timber mitigation measures anticipated for this unit.

ENGINEERING

There are no engineering mitigation measures anticipated for this unit.

\section{FISH/WATERSHED}

There are no fishery mitigation measures anticipated for this unit.

\section{WILDLIFE}

There are no wildlife mitigation measures anticipated for this unit.

RECREATICN / VISUALS

This unit has a proposed VQO of MM and is not seen from any viewpoint identified by this project.

\section{LANDS}

There are no lands mitigation measures anticipated for this unit.

CULTURAL RESOURCES

There are no cultural resource mitigation measures anticipated for this unit.

GEOLOGY

This unit is underlain with karst, although no significant features have yet been identified. 


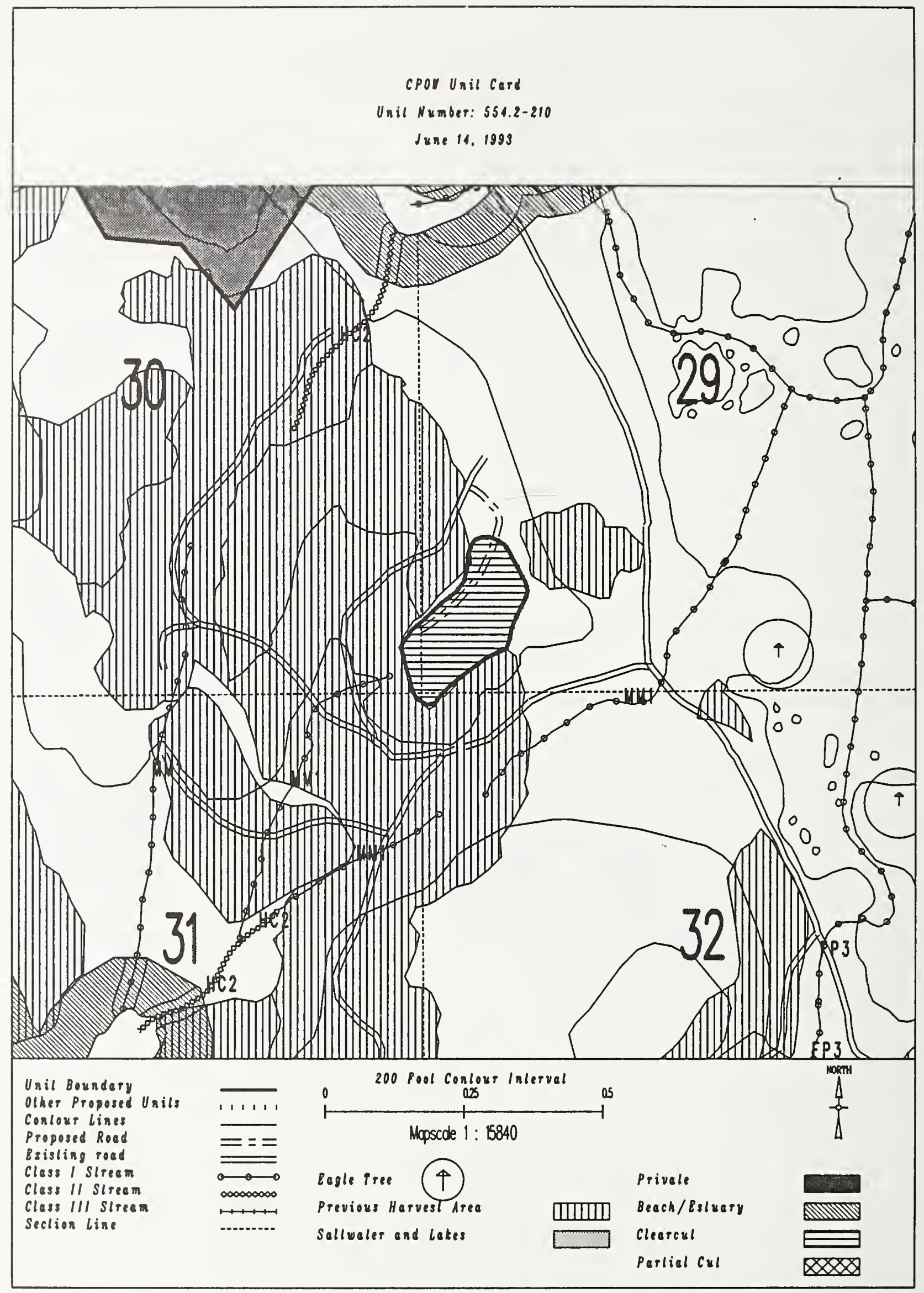


Unit $554.2-210$

Planned acres 23

Estimated volume (mbf)

Logging system Highlead

Silvicultural system Selective

Forest type Hemlock
Alternatives considered

Quad CRGD4NWN

Mgmt Area K07

WAA 1422

Photo 1990102

Aspect South

PHYSICAL DESCRIPTION

Volume class breakdown: VC4 $\quad \begin{array}{llllllllllllll}0 & \text { acres } & \text { VC5 } & 0 & \text { acres } & \text { VC6 } & 7 & \text { acres } & \text { VC7 } & 7 & \end{array}$

Elevation breakdown: $0-800 \mathrm{ft} . \underline{22}$ acres 800-1200 ft. $\ldots$ acres 1200-1500 ft. 0 acres over $1500 \mathrm{ft}$. 0 acres Mass movement index: Low 0 acres Medium $\underline{22}$ acres High 0 acres Very High $\underline{0}$ acres

SOILS

There are no soils mitigation measures anticipated for this unit.

TIMBER

Selective, uneven-aged harvest designed to meet specific resource concern.

ENG I NEER I NG

There are no engineering mitigation measures anticipated for this unit.

FISH/WATERSHED

There are no fishery mitigation measures anticipated for this unit.

WILDLIFE

Selective harvest prescribed to preserve goshawk foraging habitat/other objectives identified by $D i s t r i c t$ IDT.

RECREATION / VISUALS

This unit has a proposed VQO of MM and is not seen from any viewpoint identified by this project.

LANDS

There are no lands mitigation measures anticipated for this unit.

CULTURAL RESOURCES

There are no cultural resource mitigation measures anticipated for this unit.

GEOLOGY

This unit is underlain with karst, although no significant features have yet been identified. 


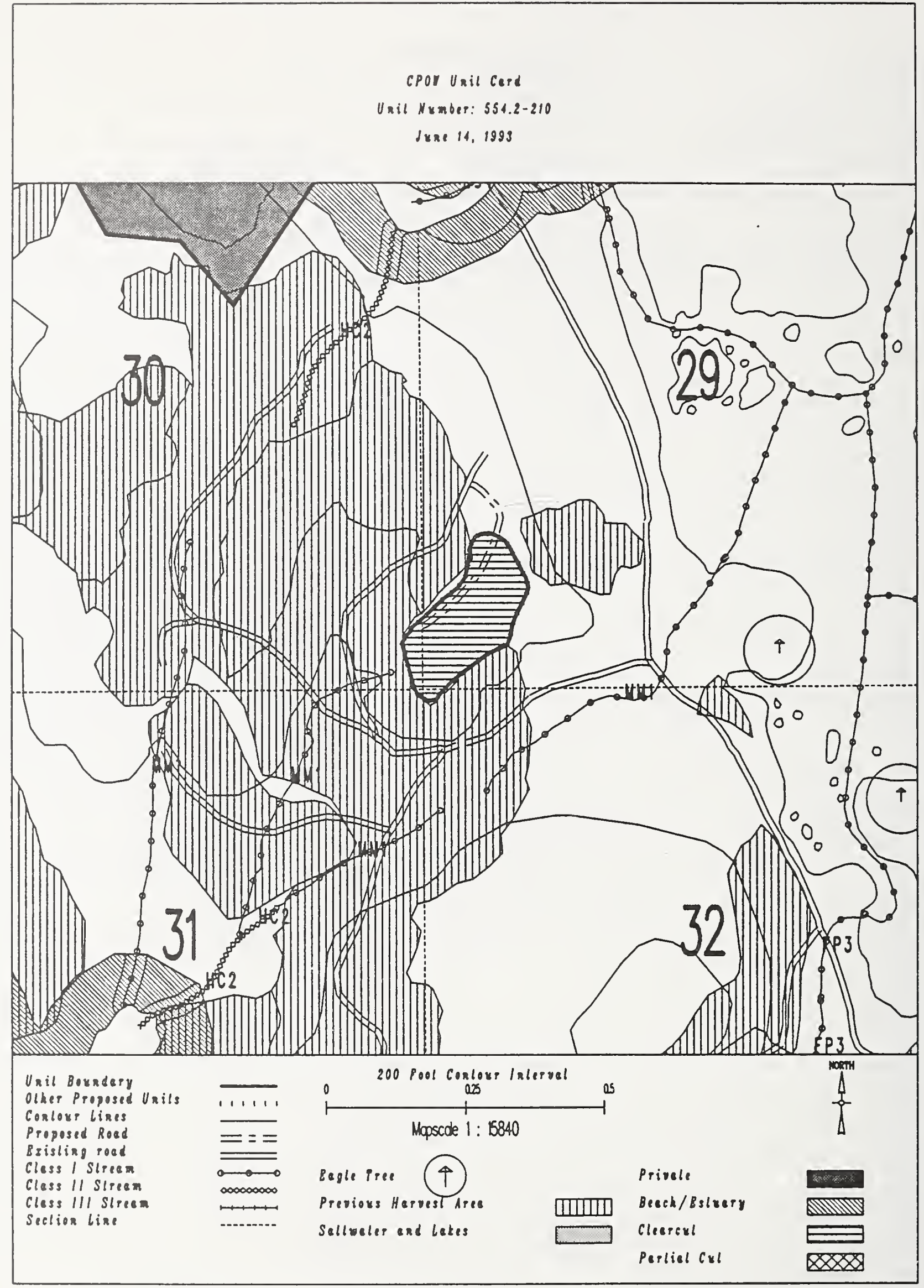


Unit 554.2-213

Planned acres 17

Estimated volume (mbf) 388

Logging system Highlead

silvicultural system Clearcut

Forest type Hemlock

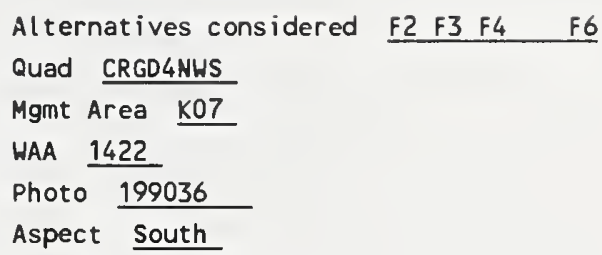

PHYSICAL DESCRIPTION

Volume class breakdown: VC4 13 acres VC5 $\quad 2$ acres vC6 $\quad 1$ acres VC7 $\quad \begin{array}{lllllll}0 & \text { acres }\end{array}$ Elevation breakdown: $0-800 \mathrm{ft} . \underline{16}$ acres $800-1200 \mathrm{ft} . \underline{0}$ acres $1200-1500 \mathrm{ft} . \underline{0}$ acres over $1500 \mathrm{ft}$. 0 acres Mass movement index: Low 7 acres Medium 0 acres High 5 acres Very High 0 acres

SOILS

This unit has high mass movement index soils. Partial log suspension required over these areas. (BMP13.9) This unit contains 13 acres of forested wetlands. Site specific BMPs will be designed for selected approved logging system and road construction practices. (BMPs 12.5, 13.9, 13.15).

TIMBER

Potential.for shovel logging on 10 acres, if soil and water quality protected (BMP13.7)

\section{ENG I NEER ING}

There are no engineering mitigation measures anticipated for this unit.

\section{FISH/WATERSHED}

There are no fishery mitigation measures anticipated for this unit.

HILDL I FE

There are no wildlife mitigation measures anticipated for this unit.

RECREATION / VISUALS

This unit has a proposed VQO of MM and is not seen from any viewpoint identified by this project.

There are no lands mitigation measures anticipated for this unit.

There are no cultural resource mitigation measures anticipated for this unit.

There are no karst mitigation measures anticipated for this unit. 


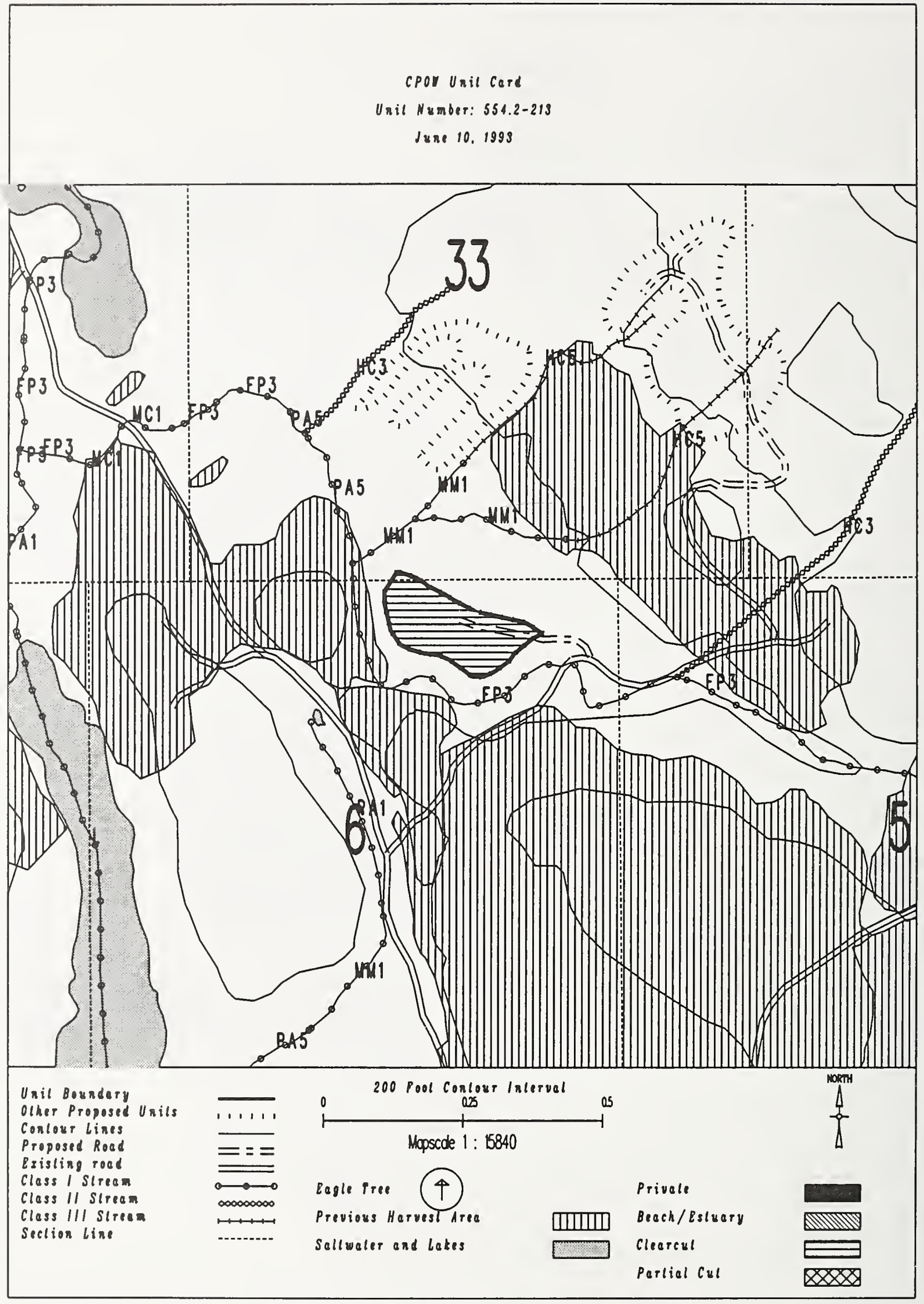


Unit $\quad \underline{554.2-213}$

Planned acres 17

Est imated volume (mbf)

Logging system Highlead

silvicultural system Selective

Forest type Hemlock
Alternatives considered F5

Mgmt Area $\mathrm{Ko7}$

WAA 1422

Photo 199036

Aspect South

PHYSICAL DESCRIPTION

Volume class breakdown: VC4 13 acres VC5 $\quad 2$ acres VC6 1 acres VC7 $\quad 0$ acres

Elevation breakdown: $0-800 \mathrm{ft} .16$ acres $800-1200 \mathrm{ft} . \underline{0}$ acres $1200-1500 \mathrm{ft} . \underline{0}$ acres over $1500 \mathrm{ft}$. 0 Mass movement index: Low 7 acres Medium 0 acres High 5 acres Very High 0 acres

SOILS

This unit has high mass movement index soils. Partial log suspension required over these areas.(BMP13.9)

This unit contains 13 acres of forested wetlands. Site specific BMPs will be designed for selected approved

logging system and road construction practices. (BMPs 12.5, 13.9, 13.15).

TIMBER

Selective, uneven-aged harvest designed to meet specific resource concern.

Potential for shovel logging on 10 acres, if soil and water quality protected (BMP13.7)

\section{ENGINEER INC}

There are no engineering mitigation measures anticipated for this unit.

\section{FISH/WATERSHED}

There are no fishery mitigation measures anticipated for this unit.

\section{WILDLIFE}

Selective harvest prescribed to preserve goshawk foraging habitat/other objectives identified by District IDT.

\section{RECREATION / VISUALS}

This unit has a proposed VQO of MM and is not seen from any viewpoint identified by this project.

\section{LANDS}

There are no lands mitigation measures anticipated for this unit.

CULTURAL RESOURCES

There are no cultural resource mitigation measures anticipated for this unit.

There are no karst mitigation measures anticipated for this unit. 


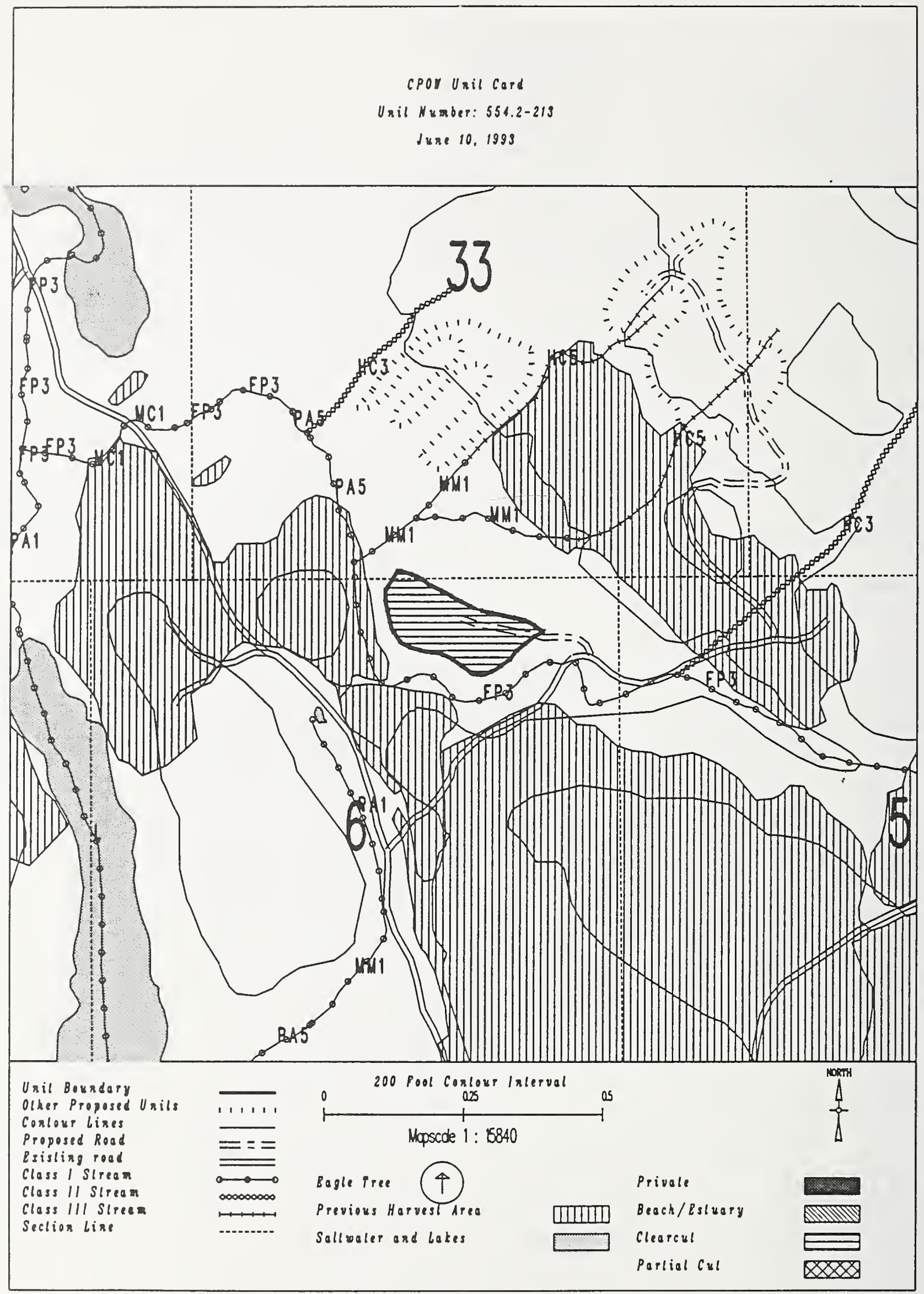


Unit $554.2 \cdot 215$

Planned acres 40

Est imated volume (mbf) $\quad 874$

Logging system skyline

silvicultural system clearcut

Forest type Hemlock
Alternatives considered $\quad$ F2 $F 3 \quad F 4 \quad$ F6

Quad CRGD4NWS

Mgmt Area $\mathrm{KO7}$

WAA 1422

Photo 1990035

Aspect South

\section{PHYSICAL DESCRIPTION}

Volume class breakdown: VC4 1 acres VC5 26 acres VC6 $\quad 0$ acres VC7 $\quad 0$ acres

Elevation breakdown: $0-800 \mathrm{ft} . \underline{38}$ acres $800-1200 \mathrm{ft} . \underline{0}$ acres $1200-1500 \mathrm{ft} . \underline{0}$ acres over $1500 \mathrm{ft}$. 0 acres Mass movement index: Low 13 acres Medium 24 acres High 0 acres Very High 0 acres

\section{SOILS}

This unit contains 30 acres of forested wetlands. Site specific BMPs will be designed for selected approved logging system and road construction practices. (BMPS 12.5, 13.9, 13.15).

\section{TIMBER}

There are no timber mitigation measures anticipated for this unit.

\section{ENG INEER I NG}

There are no engineering mitigation measures anticipated for this unit.

\section{FISH/WATERSHED}

This unit contains a $\underline{A} 4$ class $\underline{3}$ stream. No specific buffer required, but full suspension, if yarding across.

\section{HILDLIFE}

There are no wildlife mitigation measures anticipated for this unit.

\section{RECREAT ION / VISUALS}

This unit has a proposed Voo of MM and is not seen from any viewpoint identified by this project.

There are no lands mitigation measures anticipated for this unit.

\section{CULTURAL RESOURCES}

There are no cultural resource mitigation measures anticipated for this unit. 


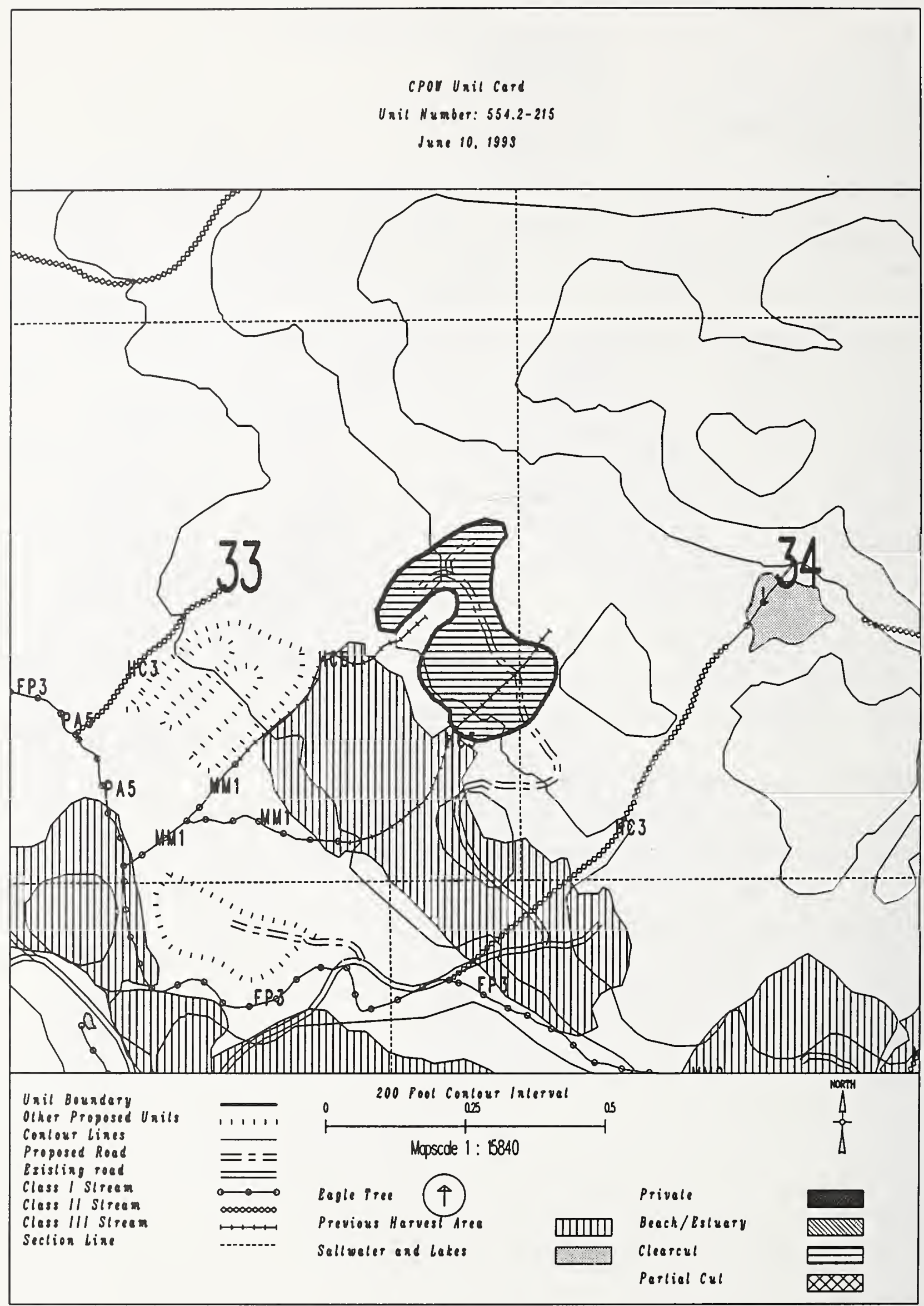


Unit 554.2-215

Planned acres 40

Estimated volume (mbf) $\quad 874$

Logging system skyline

silvicultural system selective

Forest type Hemlock
Alternatives considered

Quad CRGD4NWS

Mgmt Area $\mathrm{KO7}$

WAA 1422

Photo 1990035

Aspect South

\section{PHYSICAL DESCRIPTION}

volume class breakdown: VC4 1 acres VC5 26 acres VC6 $\quad 0$ acres vC7 0 acres

Elevation breakdown: $0-800 \mathrm{ft} . \underline{38}$ acres $800-1200 \mathrm{ft} . \underline{0}$ acres $1200-1500 \mathrm{ft} . \underline{0}$ acres over $1500 \mathrm{ft}$. 0 Mass movement index: Low 13 acres Medium 24 acres High 0 acres Very High 0

\section{SOILS}

This unit contains $\underline{30}$ acres of forested wetlands. Site specific BMPs will be designed for selected approved

logging system and road construction practices. (BMPs 12.5, 13.9, 13.15).

\section{TIMBER}

Selective, uneven-aged harvest designed to meet specific resource concern.

\section{ENGINEER ING}

There are no engineering mitigation measures anticipated for this unit.

\section{FISH/WATERSHED}

This unit contains a $\underline{A 4}$ class $\underline{3}$ stream. No specific buffer required, but full suspension, if yarding across.

\section{WILOLIFE}

Selective harvest prescribed to preserve goshawk foraging habitat/other objectives identified by District IDT.

\section{RECREATION / VISUALS}

This unit has a proposed VQO of MM and is not seen from any viewpoint identified by this project.

\section{LANDS}

There are no lands mitigation measures anticipated for this unit.

CULTURAL RESOURCES

There are no cultural resource mitigation measures anticipated for this unit.

\section{GEOLOGY}

There are no karst mitigation measures anticipated for this unit. 


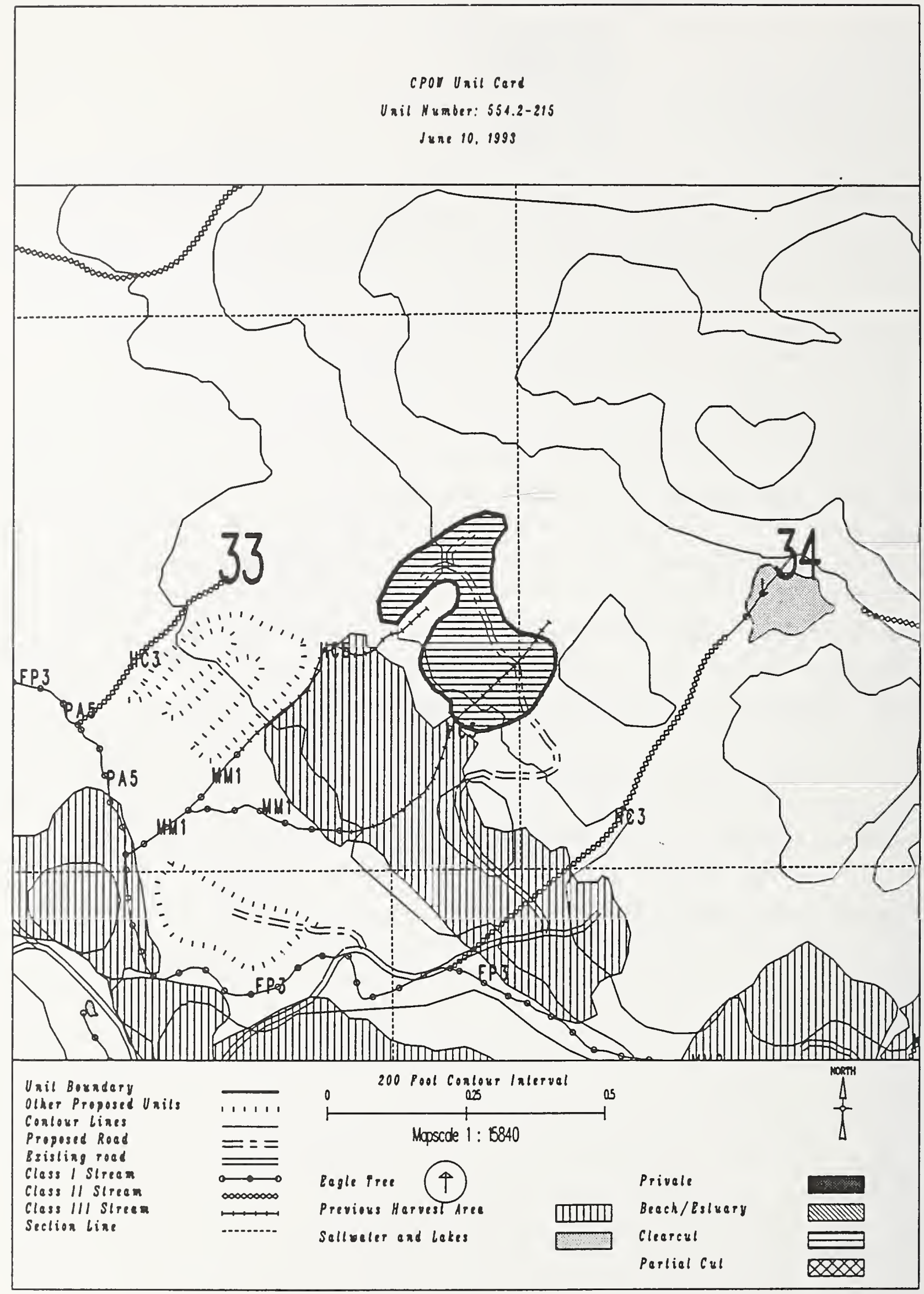


Unit $554.2-220$

Planned acres 31

Estimated volume (mbf) 1218

Logging system Highlead

silvicultural system Clearcut

Forest type Hemlock
Alternatives considered

F3 F4
Mgmt Area $\mathrm{KOT}$

WAA 1422

Photo 1990106

Aspect West

PHYSICAL DESCRIPTION

Volume class breakdown: VC4 4 acres VC5 $\quad 0$ acres VC6 11 acres vC7 14 acres

Elevation breakdown: $0-800 \mathrm{ft} . \underline{30}$ acres $800-1200 \mathrm{ft} . \underline{0}$ acres 1200-1500 ft. 0 acres over $1500 \mathrm{ft}$. 0 acres Mass movement index: Low 1 acres Medium 30 acres High 0 acres Very High 0 acres

\section{SOILS}

This unit contains 13 acres of forested wetlands. Site specific BMPs will be designed for selected approved logging system and road construction practices. (BMPs 12.5, 13.9, 13.15).

\section{TIMBER}

There are no timber mitigation measures anticipated for this unit.

\section{ENGINEER ING}

There are no engineering mitigation measures anticipated for this unit.

\section{FISH/WATERSHED}

Potential for additional Class I/II streams within unit. May be necessary to place additional buffers within unit in accordance with AHMU Handbook.

Potential impact on significant fishery habitat. May be necessary to expand planned buffer in accordance with AHMU Handbook.

HILDLI FE

There are no wildlife mitigation measures anticipated for this unit.

RECREATION / VISUALS

This unit has a proposed VQO of MM and is not seen from any viewpoint identified by this project.

\section{LANDS}

There are no lands mitigation measures anticipated for this unit.

CULTURAL RESOURCES

There are no cultural resource mitigation measures anticipated for this unit. 
cPor Uail Card

Unil Number: $554.2-220$

June 10, 1999

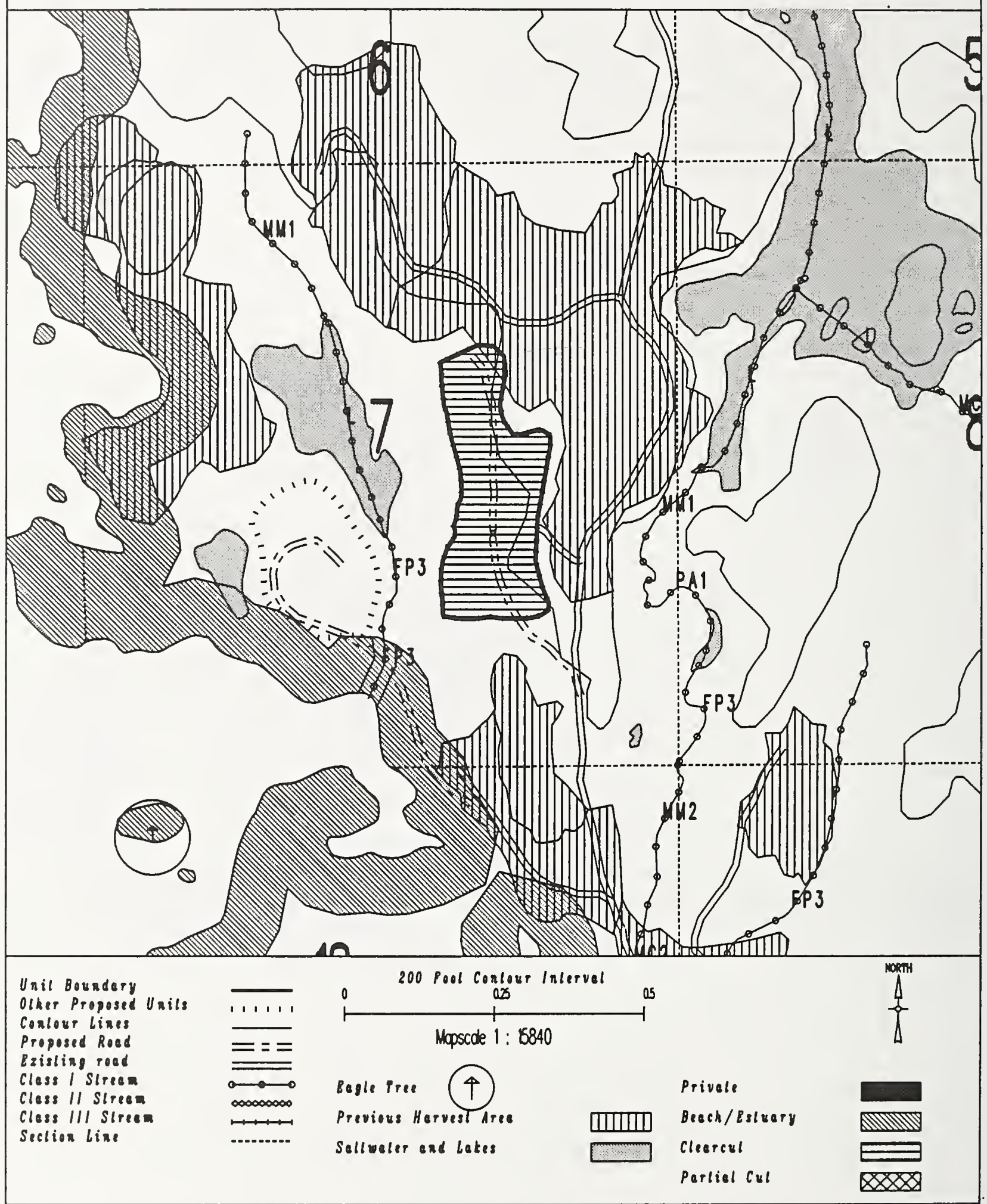


Unit $554.2-220$

Planned acres 31

Estimated volume (mbf) 1218

Logging system Highlead

silvicultural system Selective

Forest type Hemlock
Alternatives considered

Quad CRGO4NWN

Mgmt Area $\mathrm{KOT}$

WAA 1422

Photo 1990106

Aspect West

PHYSICAL DESCRIPTION

Volume class breakdown: VC4 4 acres VC5 $\quad 0$ acres VC6 11 acres VC7 14 acres

Elevation breakdown: $0-800 \mathrm{ft} . \underline{30}$ acres $800-1200 \mathrm{ft} . \quad \ldots$ acres $1200-1500 \mathrm{ft} . \underline{0}$ acres over $1500 \mathrm{ft}$. 0 Mass movement index: Low 1 acres Medium 30 acres High 0 acres Very High 0 acres

SOILS

This unit contains 13 acres of forested wetlands. Site specific BMPs will be designed for selected approved logging system and road construction practices. (BMPs 12.5, 13.9, 13.15).

TIMBER

Selective, uneven-aged harvest designed to meet specific resource concern.

ENGINEERING

There are no engineering mitigation measures anticipated for this unit.

\section{FISH/WATERSHED}

Potential for additional Class $1 / 11$ streams within unit. May be necessary to place additional buffers within unit in accordance with AHMU Handbook.

Potential impact on significant fishery habitat. May be necessary to expand planned buffer in accordance with AHMU Handbook.

\section{WILDLIFE}

Selective harvest prescribed to preserve goshawk foraging habitat/other objectives identified by District IDT.

\section{RECREATION / VISUALS}

This unit has a proposed VQo of MM and is not seen from any viewpoint identified by this project.

\section{LANDS}

There are no lands mitigation measures anticipated for this unit.

CULTURAL RESOURCES

There are no cultural resource mitigation measures anticipated for this unit.

GEOLOGY

Planned unit boundary/road location/logging system are designed to avoid damage to significant karst features. Mitigation measures may apply. Unit layout/changes must be coordinated with Cave Resource Specialists. 


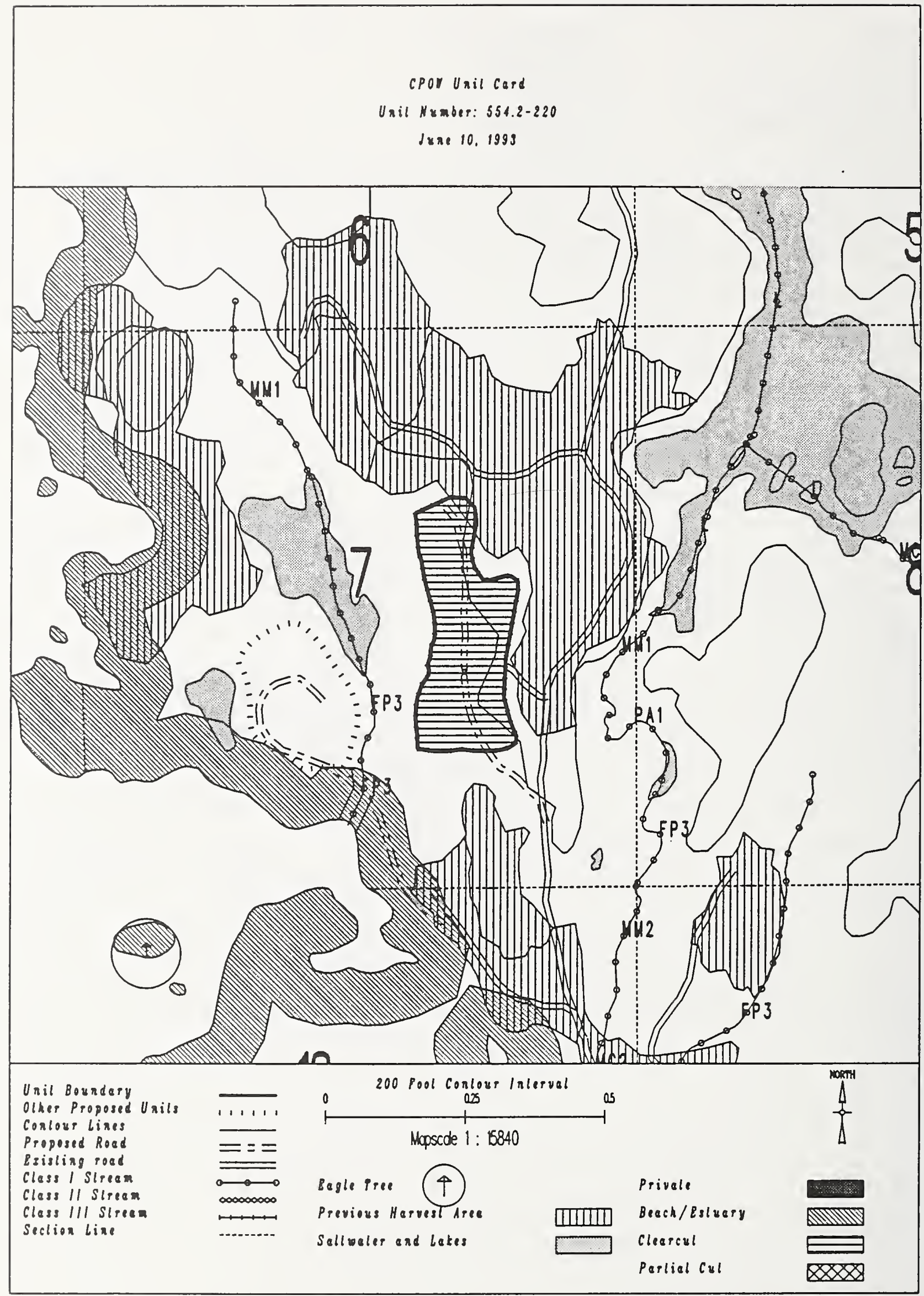


Unit $554.2-225$

Planned acres 25

Estimated volume (mbf)

Logging system skyline

silvicultural system Riparian

Forest type Cedar
Alternatives considered F3 F4

Quad CRGD4NWN

Mgmt Area $\mathrm{KOT}$

WAA 1422

Photo 1990106

Aspect South

PHYSICAL DESCRIPIION

Volume class breakdown: VC4 23 acres VC5 $\quad 2$ acres vc6 $\quad 0$ acres vc7 $\quad 0$ acres

Elevation breakdown: $0-800 \mathrm{ft} . \underline{24}$ acres $800-1200 \mathrm{ft} . \underline{0}$ acres $1200-1500 \mathrm{ft} . \underline{0}$ acres over $1500 \mathrm{ft}$. 0 acres Mass movement index: Low $\_$acres Medium 1 acres High 0 acres Very High 0 acres

SOILS

This unit contains 24 acres of forested wetlands. Site specific BMPs will be designed for selected approved logging system and road construction practices. (BMPs 12.5, 13.9, 13.15).

TIMBER

Uneven-aged harvest for riparian management on an estimated 25 acres.

potential for shovel logging on 2 acres, if soil and water quality protected (BMP13.7)

\section{ENGINEER ING}

The road into this unit crosses a B1 channel. Meet stream and lake protection prescription requirements in TLMP Draft Revision (1991a) for this process group.

\section{FISH/WATERSHED}

Potential for additional Class I/II streams within unit. May be necessary to place additional buffers within unit in accordance with AHMU Handbook.

\section{WILDLIFE}

There are no wildlife mitigation measures anticipated for this unit.

\section{RECREATION / VISUALS}

The unit has a proposed VQO of $M$ within the viewshed of Sarkar Cove as viewed from $1 / 8 \mathrm{mile}$ from west coast of Prince of Wales.

\section{LANDS}

There are no lands mitigation measures anticipated for this unit.

\section{CULTURAL RESOURCES}

There are no cultural resource mitigation measures anticipated for this unit.

\section{GEOLOGY}

This unit is underlain with karst, although no significant features have yet been identified. 


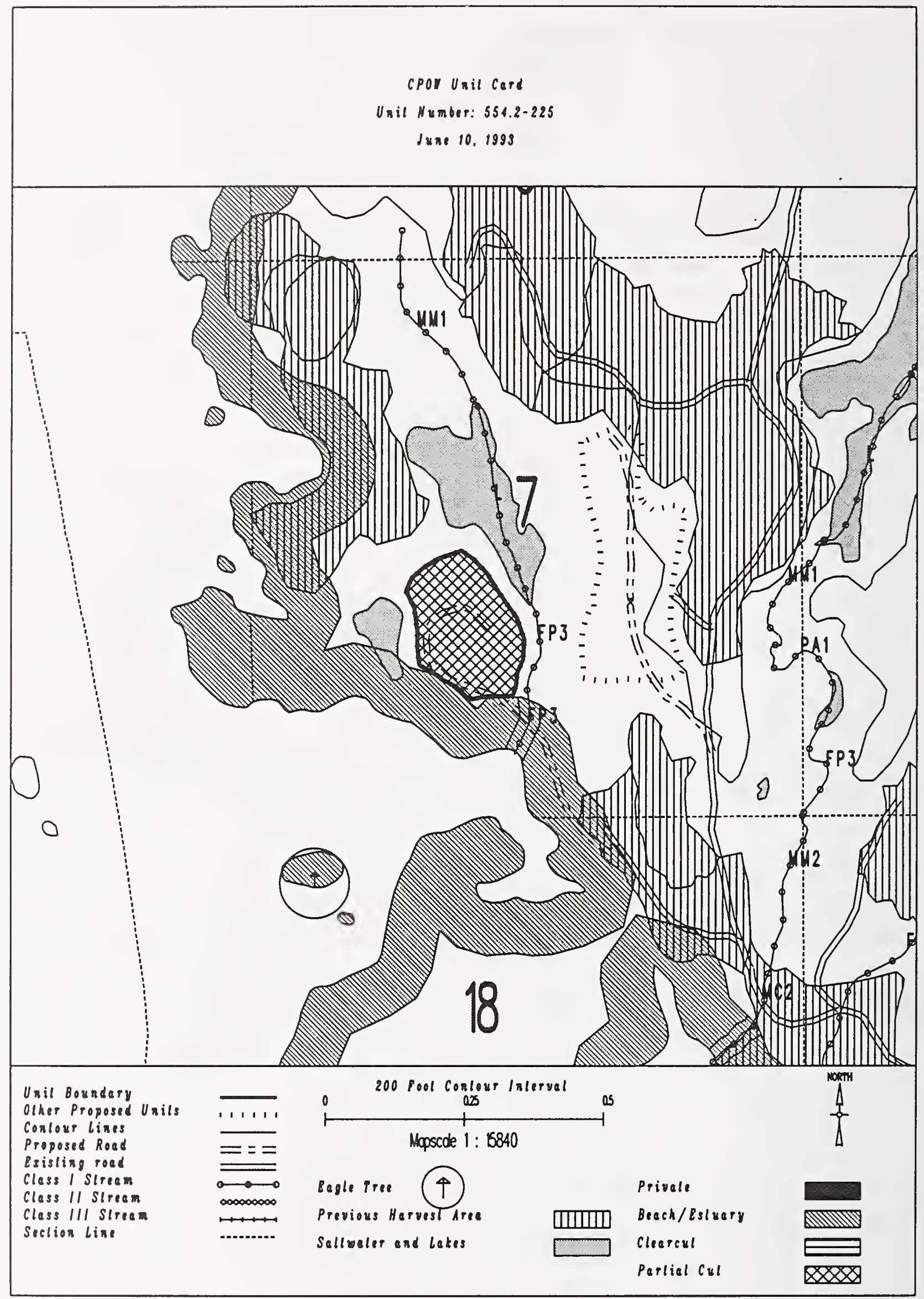


Unit 554.2-225

Planned acres 25

Estimated volume (mbf) 228

Logging system skyline

Silvicultural system Selective

Forest type Cedar
Alternatives considered

Quad CRGD4NWN

Mgmt Area K07

WAA 1422

Photo 1990106

Aspect South

PHYSICAL DESCRIPTION

Volume class breakdown: VC4 23 acres VC5 $\quad 2$ acres vc6 $\quad 0$ acres vc7 $\quad 0$ acres

Elevation breakdown: $0-800 \mathrm{ft} . \underline{24}$ acres $800-1200 \mathrm{ft} . \underline{0}$ acres $1200-1500 \mathrm{ft} . \underline{0}$ acres over $1500 \mathrm{ft}$. 0 acres

Mass movement index: Low 0 acres Medium 1 acres $\mathrm{High} \quad 0$ acres Very $\mathrm{High \quad} 0$ acres

SOILS

This unit contains 24 acres of forested wetlands. Site specific BMPs will be designed for selected approved

logging system and road construction practices. (BMPs 12.5, 13.9, 13.15).

TIMBER

Selective, uneven-aged harvest designed to meet specific resource concern.

Potential for shovel logging on 2 acres, if soil and water quality protected (BMP13.7)

\section{ENGINEER ING}

The road into this unit crosses a B1 channel. Meet stream and lake protection prescription requirements in TLMP Draft Revision (1991a) for this process group.

\section{FISH/WATERSHED}

This unit is presecribed for selective harvest to protect soils/riparian habitat.

Potential for additional Class I/II streams within unit. May be necessary to place additional buffers within unit in accordance with AHMU Handbook.

\section{WILDLIFE}

There are no wildlife mitigation measures anticipated for this unit.

\section{RECREATION / VISUALS}

The unit has a proposed VQO of $M$ within the viewshed of Sarkar Cove as viewed from $1 / 8$ mile from west coast of Prince of Wales.

LANDS

There are no lands mitigation measures anticipated for this unit.

\section{CULTURAL RESOURCES}

There are no cultural resource mitigation measures anticipated for this unit.

\section{GEOLOGY}

This unit is underlain with karst, al though no significant features have yet been identified. 
cpor Unil Cerd

Unil Number: 554.2-225

June 10, 1993

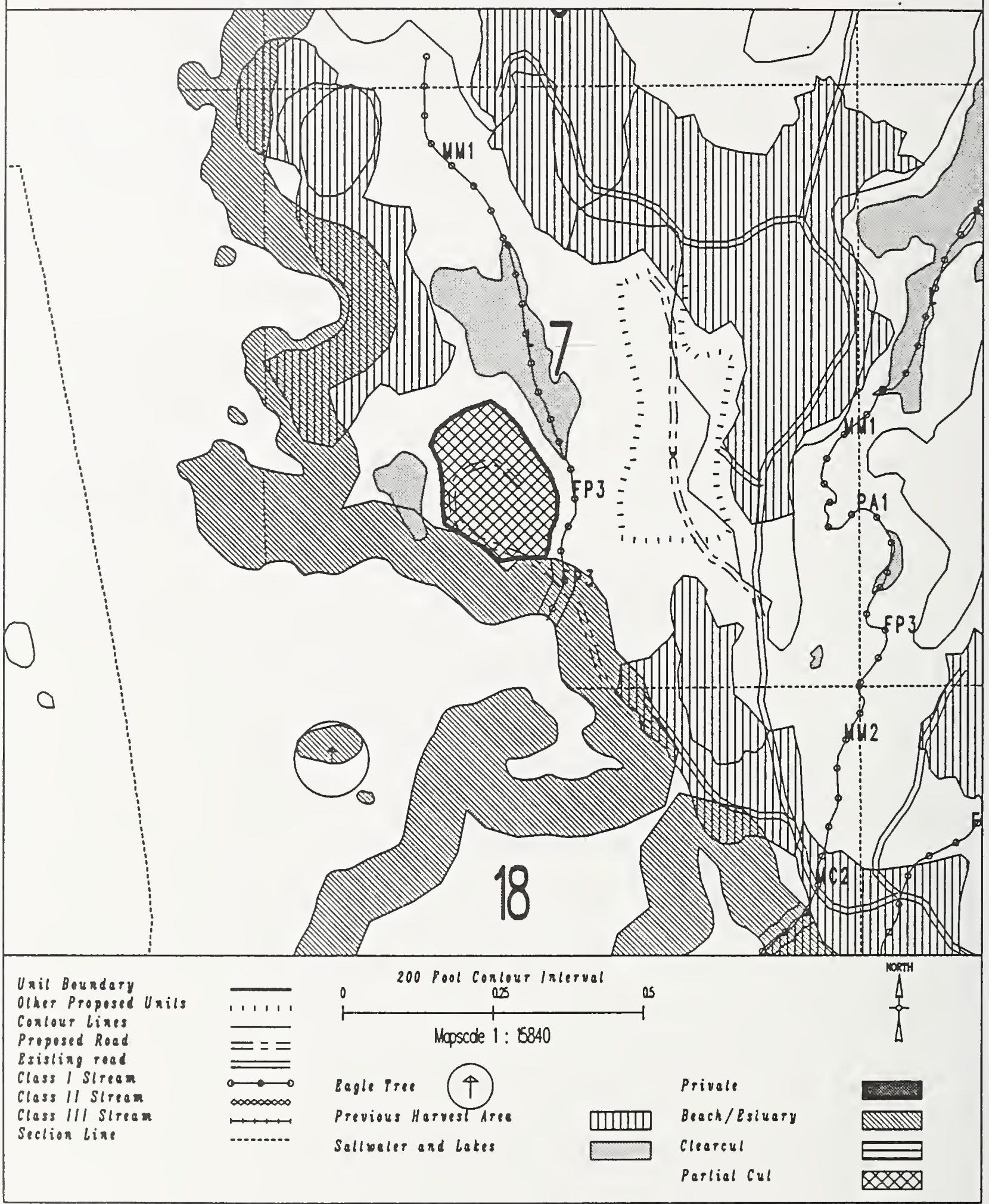


Unit 557-200 B

Planned acres 46

Estimated volume (mbf) 1620

Logging system skyline

silvicultural system clearcut

Forest type Hemlock
Alternatives considered F2 F3 F4

Quad CRGD4NWS

Mgmt Area $\mathrm{KO7}$

WAA 1531

Photo 1990101

Aspect South

PHYSICAL DESCRIPTION

Volume class breakdown: VC4 $\quad 0$ acres VC5 32 acres vC6 15 acres vc7 $\quad 0$ acres

Elevation breakdown: $0-800 \mathrm{ft} . \underline{42}$ acres 800-1200 ft. _ 0 acres 1200-1500 ft. 0 acres over $1500 \mathrm{ft}$. 0 acres Mass movement index: Low $\_$acres Medium 46 acres High $\_$acres Very High 0 acres

SOILS

There are no soils mitigation measures anticipated for this unit.

TIMBER

There are no timber mitigation measures anticipated for this unit.

\section{ENGINEER ING}

There are no engineering mitigation measures anticipated for this unit.

\section{FISH/WATERSHED}

Potential for additional Class $1 / 11$ streams within unit. May be necessary to place additional buffers within unit in accordance with AHMU Handbook.

Potential impact on significant fishery habitat. May be necessary to expand planned buffer in accordance with AHMU Handbook.

This unit contains streams which have recently been classified/channel typed but require field verification.

WILDLI FE

There are no wildlife mitigation measures anticipated for this unit.

RECREATION / VISUALS

The unit has a proposed VQO of MM within the viewshed of Sarkar Cove as viewed from $1 / 8$ mile from west coast of Prince of Wales.

LANDS

There are no lands mitigation measures anticipated for this unit.

\section{CULTURAL RESOURCES}

The planned unit boundary and road location is immediately adjacent to significant cultural resources. Any changes must be coordinated with cultural resource personnel.

\section{GEOLOGY}

Planned unit boundary/road location/logging system are designed to avoid damage to significant karst features. Mitigation measures may apply. Unit layout/changes must be coordinated with Cave Resource Specialists. 


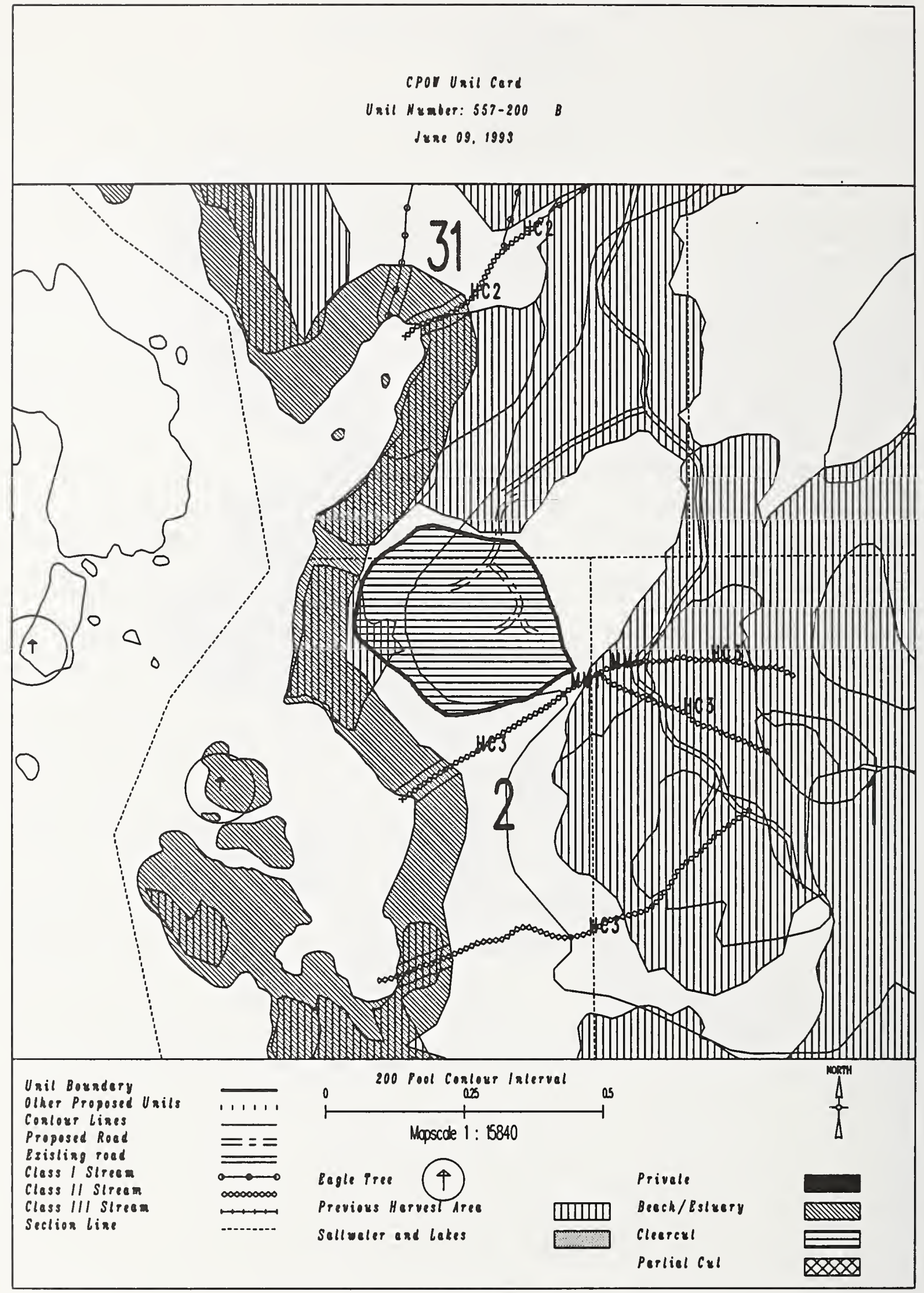


Unit $\quad 557-200 \quad B$

Planned acres 46

Estimated volume (mbf) 1620

Logging system skyline

silvicultural system selective

Forest type Hemlock
Alternat ives considered

Quad CRGO4NWS

Mgmt Area $\mathrm{KO7}$

WAA 1531

Photo 1990101

Aspect South

PHYSICAL DESCRIPTION

Volume class breakdown: VC4 $\quad 0$ acres VC5 32 acres VC6 15 acres VC7 $\quad 0$ acres

Elevation breakdown: $0-800 \mathrm{ft} . \underline{42}$ acres 800-1200 ft. 0 acres $1200-1500 \mathrm{ft}$. 0 acres over $1500 \mathrm{ft}$. 0 acres Mass movement index: Low $\underline{0}$ acres Medium 46 acres High 0 acres Very High 0

\section{SOILS}

There are no soils mitigation measures anticipated for this unit.

\section{TIMBER}

Selective, uneven-aged harvest designed to meet specific resource concern.

\section{ENGINEER ING}

There are no engineering mitigation measures anticipated for this unit.

\section{FISH/WATERSHED}

Potential for additional Class I/II streams within unit. May be necessary to place additional buffers within unit in accordance with AHMU Handbook.

Potential impact on significant fishery habitat. May be necessary to expand planned buffer in accordance with AHMU Handbook.

This unit contains streams which have recently been classified/channel typed but require field verification.

\section{WILDLIFE}

There are no wildlife mitigation measures anticipated for this unit.

\section{RECREATION / VISUALS}

The unit has a proposed VQO of MM within the viewshed of Sarkar Cove

as viewed from $1 / 8$ mile from west coast of Prince of Wales.

Selective harvest prescribed to preserve visual quality.

\section{LANDS}

There are no lands mitigation measures anticipated for this unit.

\section{CULTURAL RESOURCES}

The planned unit boundary and road location is immediately adjacent to significant cultural resources. Any changes must be coordinated with cultural resource personnel.

Selective harvest prescribed to protect adjacent significant cultural resources.

\section{GEOLOGY}

Planned unit boundary/road location/logging system are designed to avoid damage to significant karst features.

Mitigation measures may apply. Unit layout/changes must be coordinated with Cave Resource Specialists. Selective harvest prescribed to protect significant karst resources. 


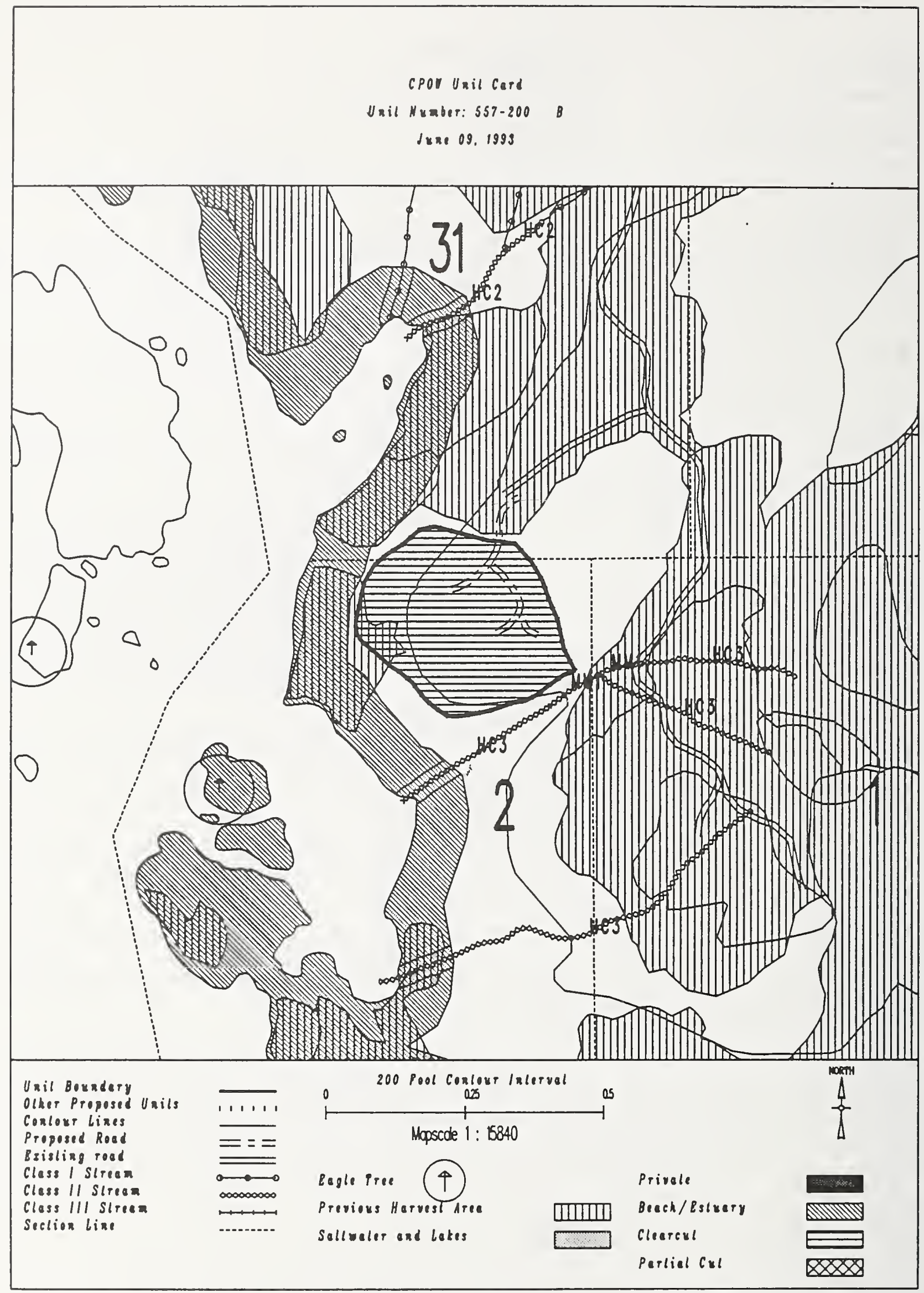


Unit 571-201

Planned acres 22

Est imated volume (mbf) 710

Logging system skyline

silvicultural system clearcut

Forest type Hemlock
Alternatives considered F2 F3 F4 F5 F6

Quad CRGD4NEN

Mgmt Area $\mathrm{KO7}$

WAA 1422

Photo 1190027

Aspect West

\section{PHYSICAL DESCRIPTION}

Volime class breakdown: VC4 1 acres VC5 21 acres VC6 $\quad 0$ acres VC7 $\quad 0$ acres

Elevation breakdown: $0-800 \mathrm{ft} . \quad 0$ acres $800-1200 \mathrm{ft} . \underline{15}$ acres $1200-1500 \mathrm{ft} . \underline{5}$ acres over $1500 \mathrm{ft}$. 0 acres Mass movement index: Low 21 acres Medium 0 acres High 0 acres Very High 0 acres

SOILS

This unit contains 10 acres of forested wetlands. Site specific BMPs will be designed for selected approved

logging system and road construction practices. (BMPs 12.5, 13.9, 13.15).

\section{TIMBER}

There are no timber mitigation measures anticipated for this unit.

\section{ENGINEER ING}

There are no engineering mitigation measures anticipated for this unit.

\section{FISH/WATERSHED}

There are no fishery mitigation measures anticipated for this unit.

\section{WI LDLIFE}

There are no wildlife mitigation measures anticipated for this unit.

\section{RECREATION / VISUALS}

This unit has a proposed vao of MM and is not seen from any viewpoint identified by this project.

\section{LANDS}

There are no lands mitigation measures anticipated for this unit.

CULTURAL RESOURCES

There are no cultural resource mitigation measures anticipated for this unit. 


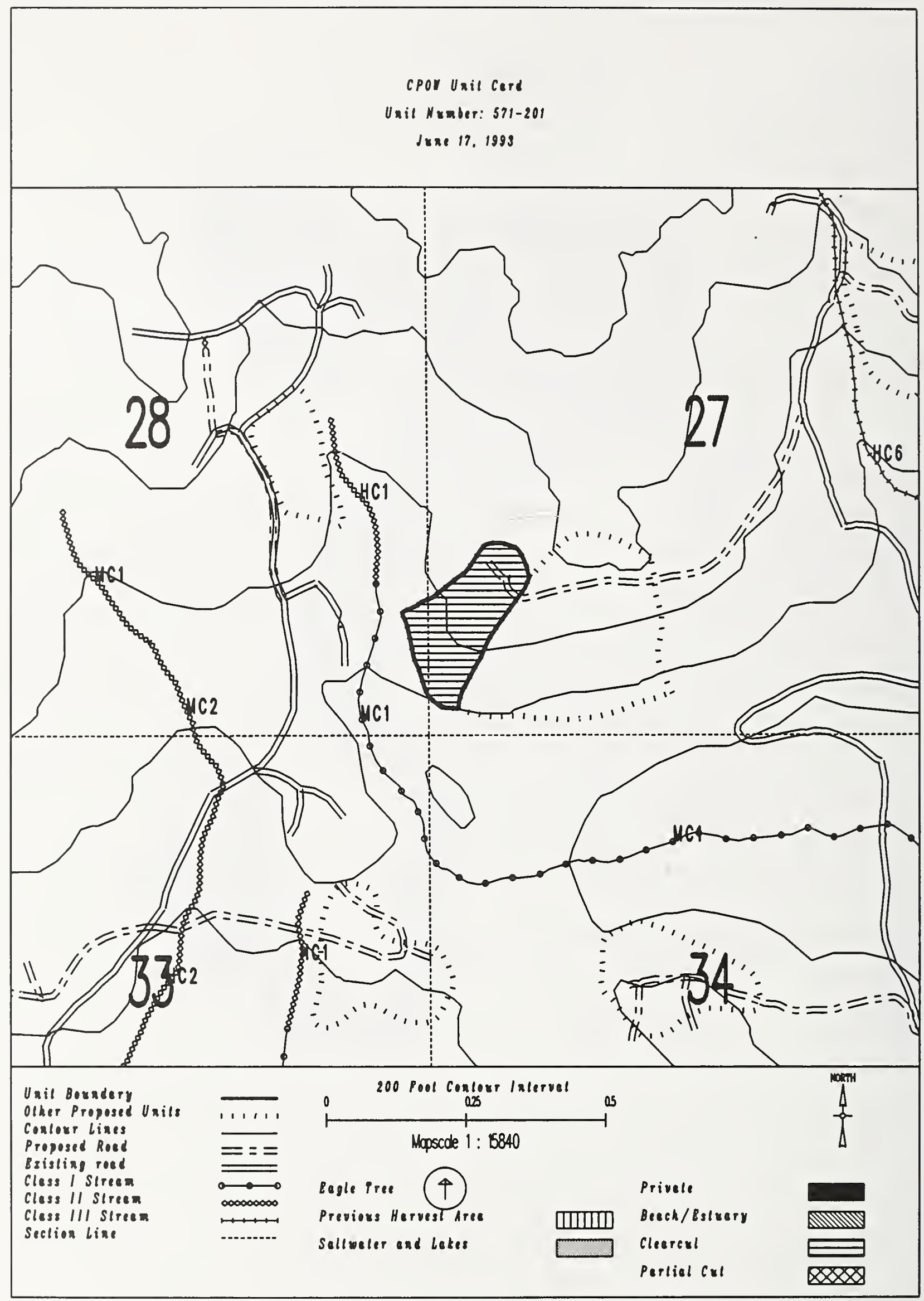


Unit $571-203$

Planned acres 15

Est imated volume (mbf) 306

Logging system Highlead

silvicultural system Clearcut

Forest type Hemlock
Al ternatives considered F2 F3

Quad CRGD4NEN

Mgmt Area $\mathrm{KOT}$

HAA 1422

Photo

Aspect South

PHYSICAL DESCRIPTION

Volume class breakdown: VC4 14 acres VC5 $\quad 0$ acres VC6 $\quad 0$ acres VC7 $\quad 0$ acres

El evation breakdown: $0-800 \mathrm{ft} . \quad 0$ acres $800-1200 \mathrm{ft} . \underline{13}$ acres 1200-1500 ft. 0 acres over $1500 \mathrm{ft}$. 0 Mass movement index: Low 14 acres Medium 0 acres High 0 acres Very High 0

\section{SOILS}

This unit contains 6 acres of forested wetlands. Site specific BMPs will be designed for selected approved logging system and road construction practices. (BMPs 12.5, 13.9, 13.15).

\section{TIMBER}

There are no timber mitigation measures anticipated for this unit.

\section{ENGINEER ING}

There are no engineering mitigation measures anticipated for this unit.

\section{FISH/WATERSHED}

There are no fishery mitigation measures anticipated for this unit.

\section{WILDLIFE}

There are no wildlife mitigation measures anticipated for this unit.

\section{RECREATION / VISUALS}

This unit has a proposed VQO of MM and is not seen from any viewpoint identified by this project.

\section{LANDS}

There are no lands mitigation measures anticipated for this unit.

\section{CULTURAL RESOURCES}

There are no cultural resource mitigation measures anticipated for this unit.

There are no karst mitigation measures anticipated for this unit. 


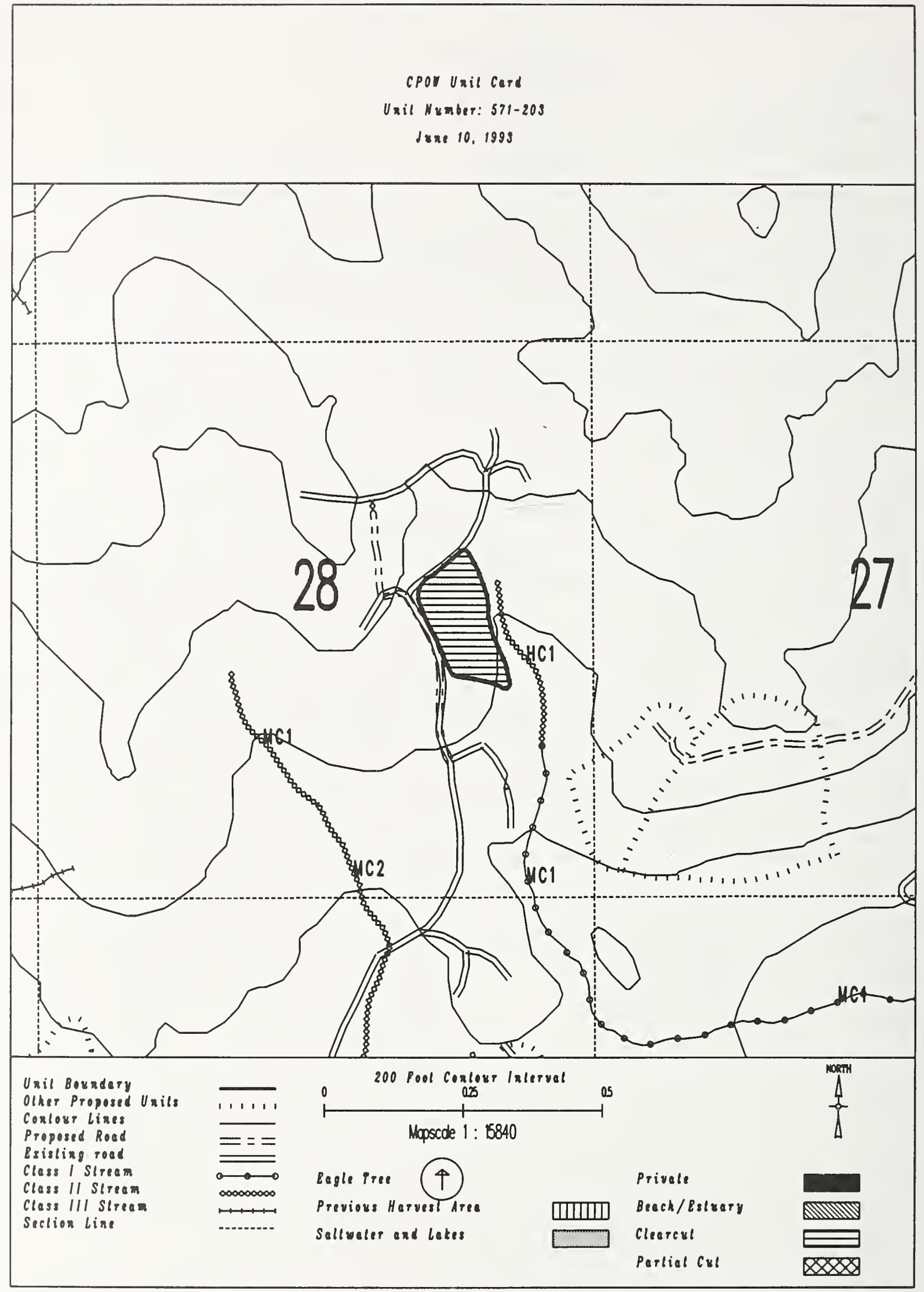




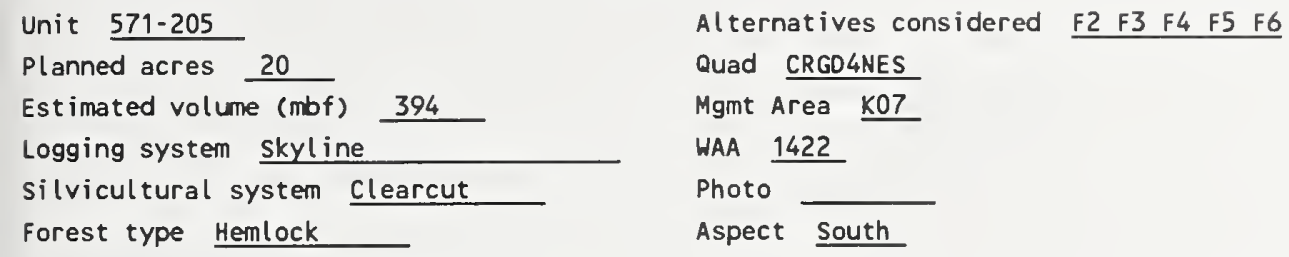

\section{SOILS}

This unit has high mass movement index soils. Partial log suspension required over these areas. (BMP13.9)

This unit contains 12 acres of forested wetlands. Site specific BMPs will be designed for selected approved logging system and road construction practices. (BMPs 12.5, 13.9, 13.15).

\section{TIMBER}

There are no timber mitigation measures anticipated for this unit.

\section{ENGINEER ING}

There are no engineering mitigation measures anticipated for this unit.

\section{FISH/WATERSHED}

Potential for additional Class $1 / 11$ streams within unit. May be necessary to place additional buffers within unit in accordance with AHMU Handbook.

This unit contains streams which have recently been classified/channel typed but require field verification.

\section{WILOLIFE}

There are no wildlife mitigation measures anticipated for this unit.

\section{RECREATION / VISUALS}

This unit has a proposed Voo of $M M$ and is not seen from any viewpoint identified by this project.

\section{LANOS}

There are no lands mitigation measures anticipated for this unit.

\section{CULTURAL RESOURCES}

There are no cultural resource mitigation measures anticipated for this unit.

\section{GEOLOGY}

There are no karst mitigation measures anticipated for this unit. 


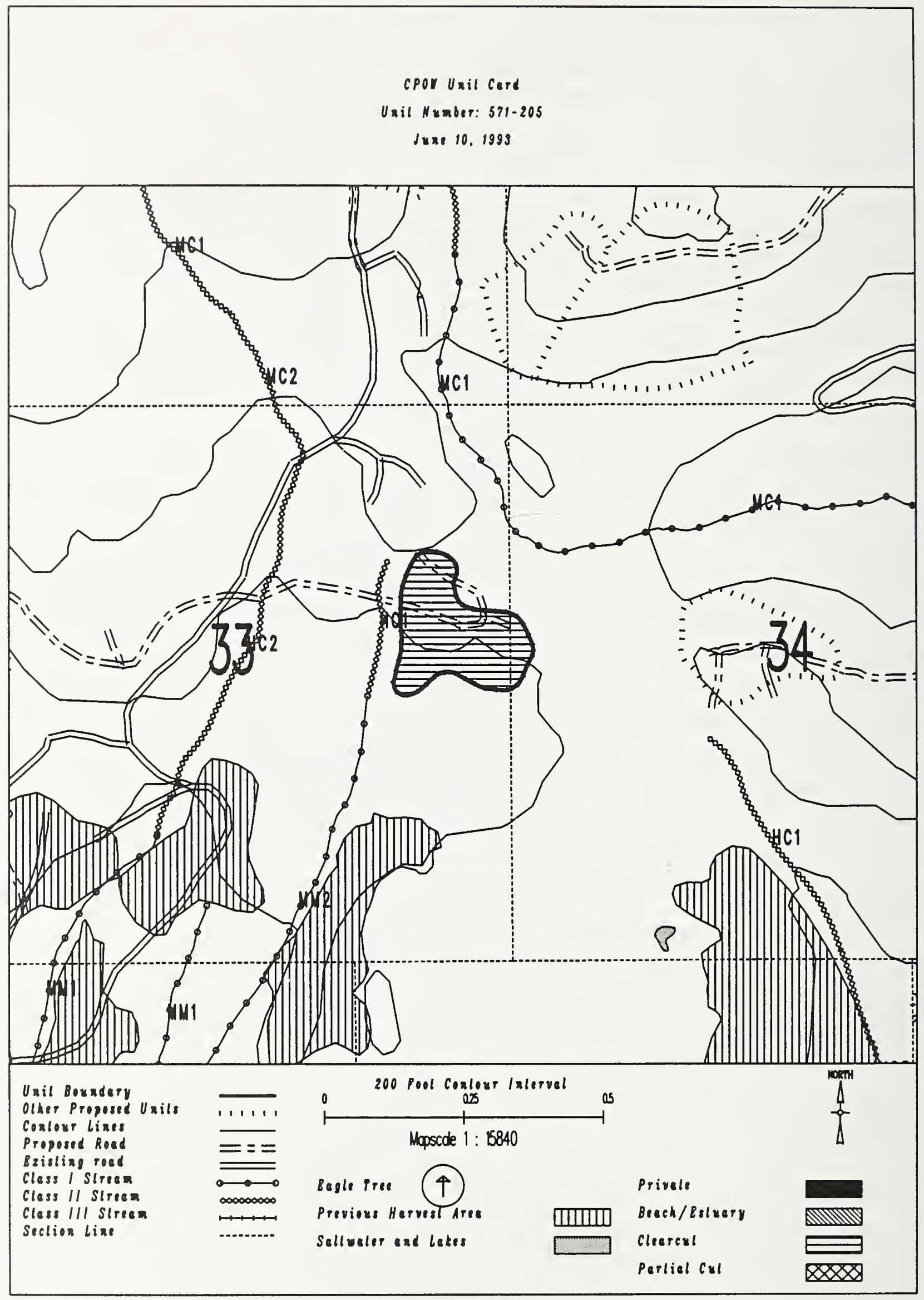


Unit 571-209

Planned acres 10

Est imated volume (mbf) 219

Logging system Highlead

silvicultural system clearcut

Forest type cedar

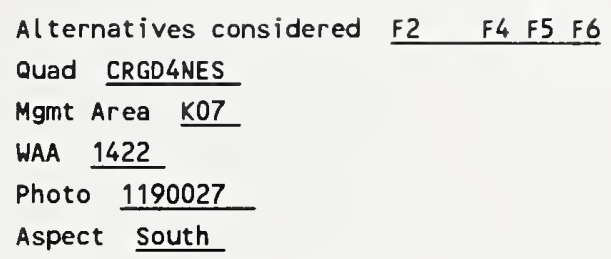

\section{PHYSICAL DESCRIPTION}

Volume class breakdown: VC4 10 acres VC5 $\quad 0$ acres VC6 $\quad 0$ acres VC7 $\quad 0$ acres

Elevation breakdown: $0-800 \mathrm{ft} . \underline{7}$ acres $800-1200 \mathrm{ft} . \underline{0}$ acres $1200-1500 \mathrm{ft} . \overline{0}$ acres over $1500 \mathrm{ft}$. 0 Mass movement index: Low 0 acres Medium 0 acres High 5 acres Very High 0 acres

\section{SOILS}

This unit has high mass movement index soils. Partial log suspension required over these areas. (BMP13.9)

This unit has < $40 \%$ MCGilvery soils. Partial suspension required (BMP13.9) to ensure reforestation (BMP13.19). This unit contains 17 acres of forested wetlands. Site specific BMPs will be designed for selected approved logging system and road construction practices. (BMPs 12.5, 13.9, 13.15). This unit contains 4 acres of slopes $>75 \%$.

\section{TIMBER}

There are no timber mitigation measures anticipated for this unit.

\section{ENGINEER ING}

There are no engineering mitigation measures anticipated for this unit.

\section{FI SH/HATERSHED}

Leave all deciduous and conifer trees ( $<12^{\prime \prime} \mathrm{dbh}$ ) in $35 \mathrm{ft}$ buffer adjacent to Class III streams to provide shade. This unit contains streams which have recently been classified/channel typed but require field verification.

\section{WILDLIFE}

Maintain diversity within unit by leaving $1-5$ acre-sized islands of green trees at a rate of 1 acre of island for every 20 acres harvested. Leave islands must be compatible with logging system and safe working conditions.

\section{RECREATION / VISUALS}

This unit has a proposed VQO of MM and is not seen from any viewpoint identified by this project.

\section{LANDS}

This unit adjacent to Sarkar Management Area. Boundary establishment required prior to layout.

\section{CULTURAL RESOURCES}

There are no cultural resource mitigation measures anticipated for this unit. 


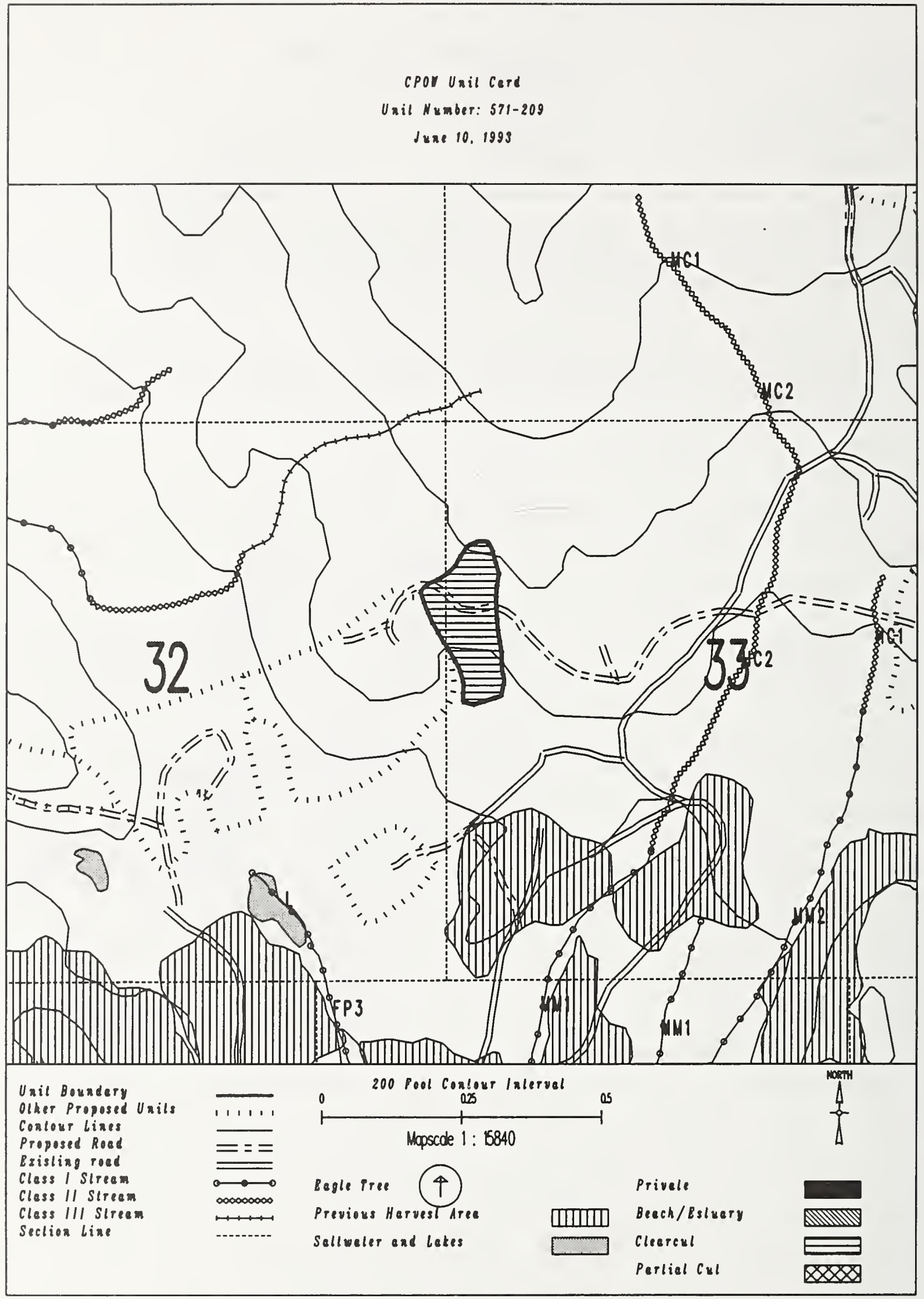


Unit $\quad 571-210$

Planned acres 49

Estimated volume (mbf) 1345

Logging system slackline

silvicultural system Clearcut

Forest type Mixed conifer
Al ternatives considered F4 F5 F6

PHYSICAL DESCRIPTION

Volume class breakdown: VC4 $\quad 30$ acres VC5 21 acres VC6 $\quad 0$ acres VC7 $\quad 0$ acres

Elevation breakdown: $0-800 \mathrm{ft} . \underline{47}$ acres $800-1200 \mathrm{ft} . \underline{0}$ acres $1200-1500 \mathrm{ft} . \underline{0}$ acres over $1500 \mathrm{ft}$. 0 acres Mass movement index: Low $\underline{0}$ acres Medium 0 acres High 25 acres Very High 0

SOILS

This unit has high mass movement index soils. Partial log suspension required over these areas.(8MP13.9)

This unit contains 35 acres of forested wetlands. Site specific BMPs will be designed for selected approved

logging system and road construction practices. (8MPs 12.5, 13.9, 13.15).

This unit contains 5 acres of slopes $>75 \%$.

\section{TIMBER}

There are no timber mitigation measures anticipated for this unit.

\section{ENGINEERING}

High mass movement index soils. Road construction must minimize landslide potential (BMP14).

\section{FISH/WATERSHED}

Leave all deciduous and conifer trees (< $12^{\prime \prime \prime} \mathrm{dbh}$ ) in $35 \mathrm{ft}$ buffer adjacent to Class III streams to provide shade. This unit contains streams which have recently been classified/channel typed but require field verification.

\section{WILDLIFE}

Maintain diversity within unit by leaving 1-5 acre-sized islands of green trees at a rate of 1 acre of island for every 20 acres harvested. Leave islands must be compatible with logging system and safe working conditions.

\section{RECREATION / VISUALS}

This unit has a proposed VQO of MM and is not seen from any viewpoint identified by this project.

\section{LANDS}

This unit adjacent to Sarkar Management Area. Boundary establishment required prior to Layout.

CULTURAL RESOURCES

There are no cultural resource mitigation measures anticipated for this unit.

GEOLOGY

There are no karst mitigation measures anticipated for this unit. 


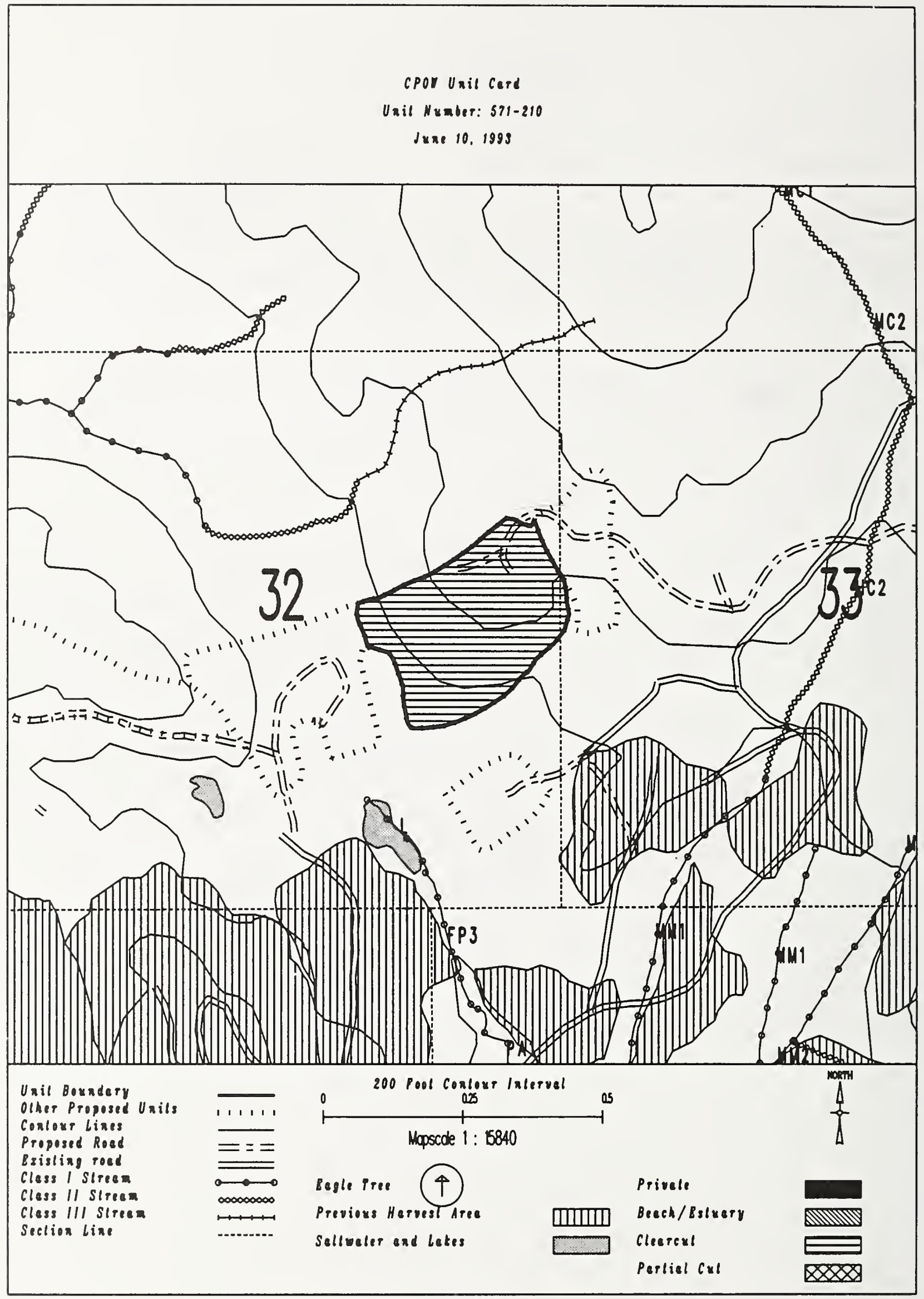




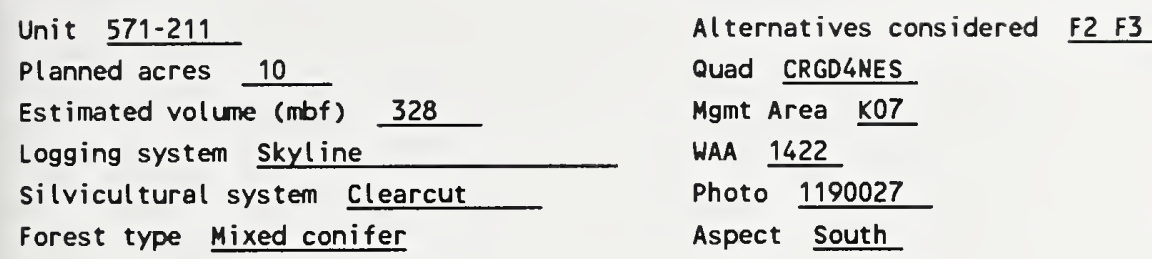

Planned unit boundary/road location/logging system are designed to avoid damage to significant karst features. Mitigation measures may apply. Unit layout/changes must be coordinated with Cave Resource Specialists. 


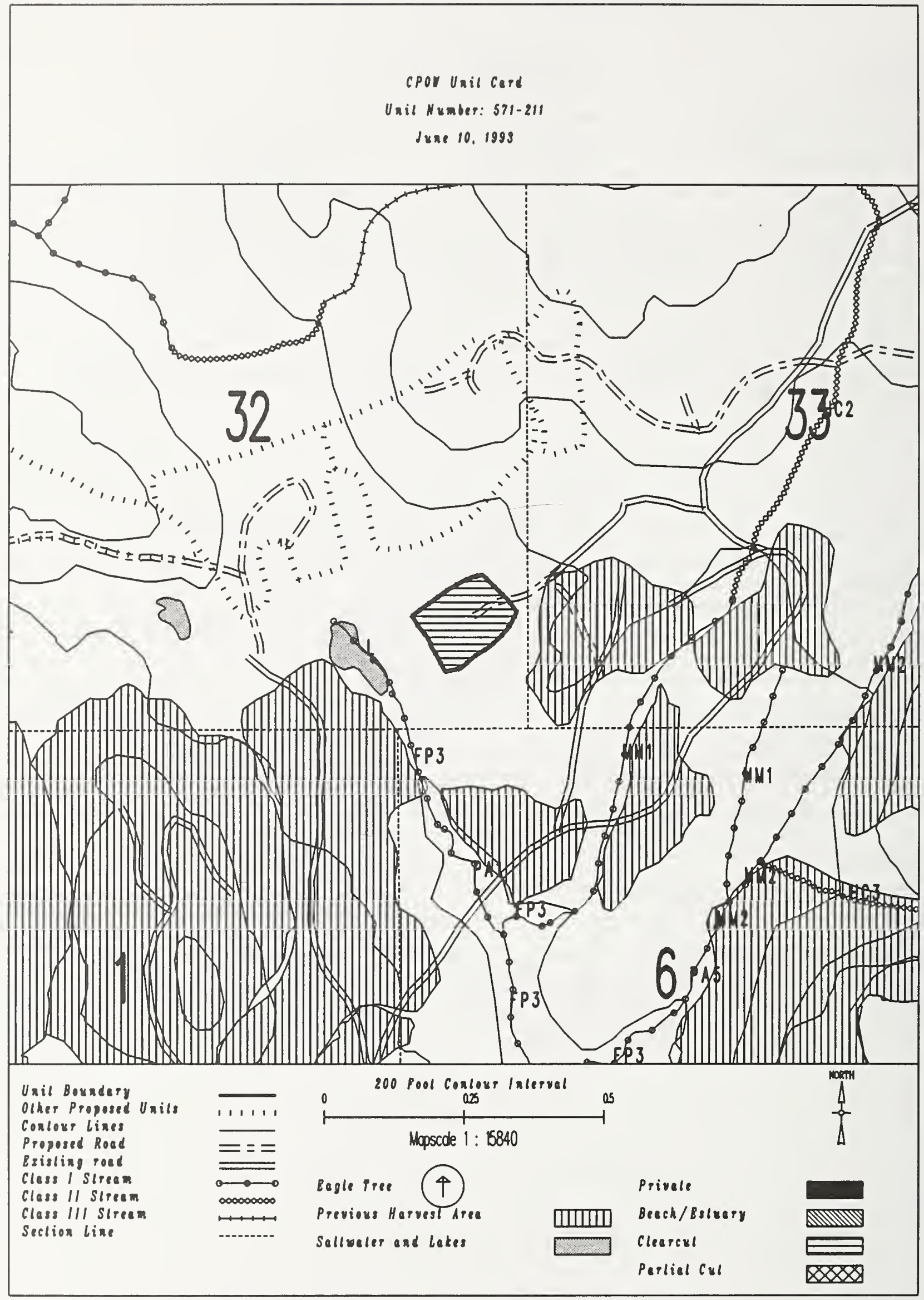


Unit $571-213$

Planned acres 37

Estimated volume (mbf) 1017

Logging system Highlead

silvicultural system Clearcut

Forest type Mixed conifer
Alternatives considered F2 F3 F6

Quad CRGD4NES

Mgmt Area $\mathrm{KOT}$

WAA 1422

Photo 1190027

Aspect South

\section{PHYSICAL DESCRIPTION}

Volume class breakdown: VC4 21 acres VC5 17 acres vc6 $\quad 0$ acres vc7 $\quad 0$ acres

Elevation breakdown: $0-800 \mathrm{ft} . \underline{36}$ acres $800-1200 \mathrm{ft} . \quad 0$ acres $1200-1500 \mathrm{ft}$. $\frac{0}{0}$ acres over $1500 \mathrm{ft}$. 0 Mass movement index: Low 2 acres Medium 10 acres High 15 acres Very High 0 acres

\section{SOILS}

This unit has high mass movement index soils. Partial log suspension required over these areas. (BMP13.9)

This unit contains 25 acres of forested wetlands. Site specific BMPs will be designed for selected approved

logging system and road construction practices. (BMPs 12.5, 13.9, 13.15).

\section{TIMBER}

There are no timber mitigation measures anticipated for this unit.

\section{ENGINEER ING}

High mass movement index soils. Road construction must minimize landslide potential (BMP14).

\section{FISH/WATERSHED}

Potential for additional Class I/II streams within unit. May be necessary to place additional buffers within unit in accordance with AHMU Handbook.

Leave all deciduous and conifer trees ( $<12^{\prime \prime} \mathrm{dbh}$ ) in $35 \mathrm{ft}$ buffer adjacent to class 111 streams to provide shade. This unit contains streams which have recently been classified/channel typed but require field verification.

\section{WILDLIFE}

Maintain diversity within unit by leaving 1-5 acre-sized islands of green trees at a rate of 1 acre of island for every 20 acres harvested. Leave islands must be compatible with logging system and safe working conditions.

\section{RECREATION / VISUALS}

This unit has a proposed voo of MM and is not seen from any viewpoint identified by this project.

\section{LANDS}

This unit adjacent to Sarkar Management Area. Boundary establishment required prior to layout.

\section{CULTURAL RESOURCES}

There are no cultural resource mitigation measures anticipated for this unit.

This unit is underlain with karst, although no significant features have yet been identified. 


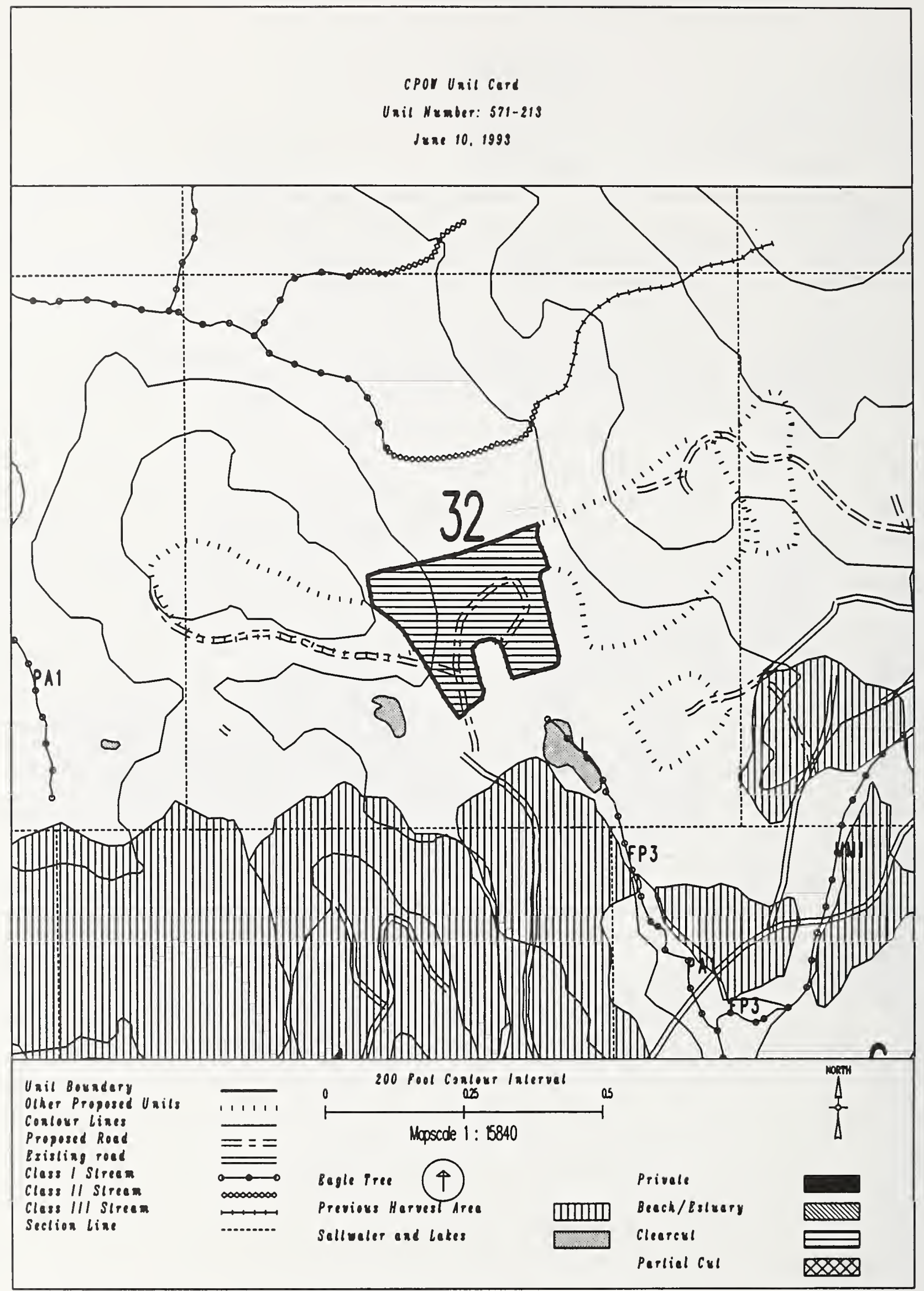


Unit $\quad \mathbf{5 7 1 - 2 1 4}$

Planned acres 34

Est imated volume (mbf) 1199

Logging system Highlead

Silvicultural system Clearcut

Forest type Mixed conifer
Alternatives considered $\begin{array}{lllll}\text { F2 } & \text { F3 } & \text { F4 } & \text { F5 } & \text { F6 }\end{array}$

Quad CRGD4NES

Mgmt Area $\mathrm{KOT}$

WAA 1422

Photo 1190110

Aspect South

\section{PHYSICAL DESCRIPTION}

Volume class breakdown: VC4 $\quad 0$ acres VC5 18 acres vC6 16 acres vc7 $\quad 0$ acres

Elevation breakdown: $0-800 \mathrm{ft} .31$ acres $800-1200 \mathrm{ft} . \quad 0$ acres $1200-1500 \mathrm{ft}$. 0 acres over $1500 \mathrm{ft}$. 0 acres Mass movement index: Low 1 acres Medium 25 acres High 3 acres Very High 0

SOILS

This unit has < $40 \%$ McGilvery soils. Partial suspension required (BMP13.9) to ensure reforestation (BMP13.19).

This unit contains 6 acres of forested wetlands. Site specific BMPs will be designed for selected approved

logging system and road construction practices. (BMPs 12.5, 13.9, 13.15).

\section{TIMBER}

There are no timber mitigation measures anticipated for this unit.

\section{ENGINEERING}

There are no engineering mitigation measures anticipated for this unit.

\section{FISH/WATERSHED}

Leave all deciduous and conifer trees (< $12^{\prime \prime} \mathrm{dbh}$ ) in $35 \mathrm{ft}$ buffer adjacent to Class IIl streams to provide shade. This unit contains streams which have recently been classified/channel typed but require field verification.

\section{WILDLIFE}

Maintain diversity within unit by leaving 1-5 acre-sized islands of green trees at a rate of 1 acre of island for every 20 acres harvested. Leave islands must be compatible with logging system and safe working conditions.

\section{RECREATION / VISUALS}

This unit has a proposed Voo of MM and is not seen from any viewpoint identified by this project.

\section{LANDS}

This unit adjacent to Sarkar Management Area. Boundary establishment required prior to layout.

There are no cultural resource mitigation measures anticipated for this unit. 


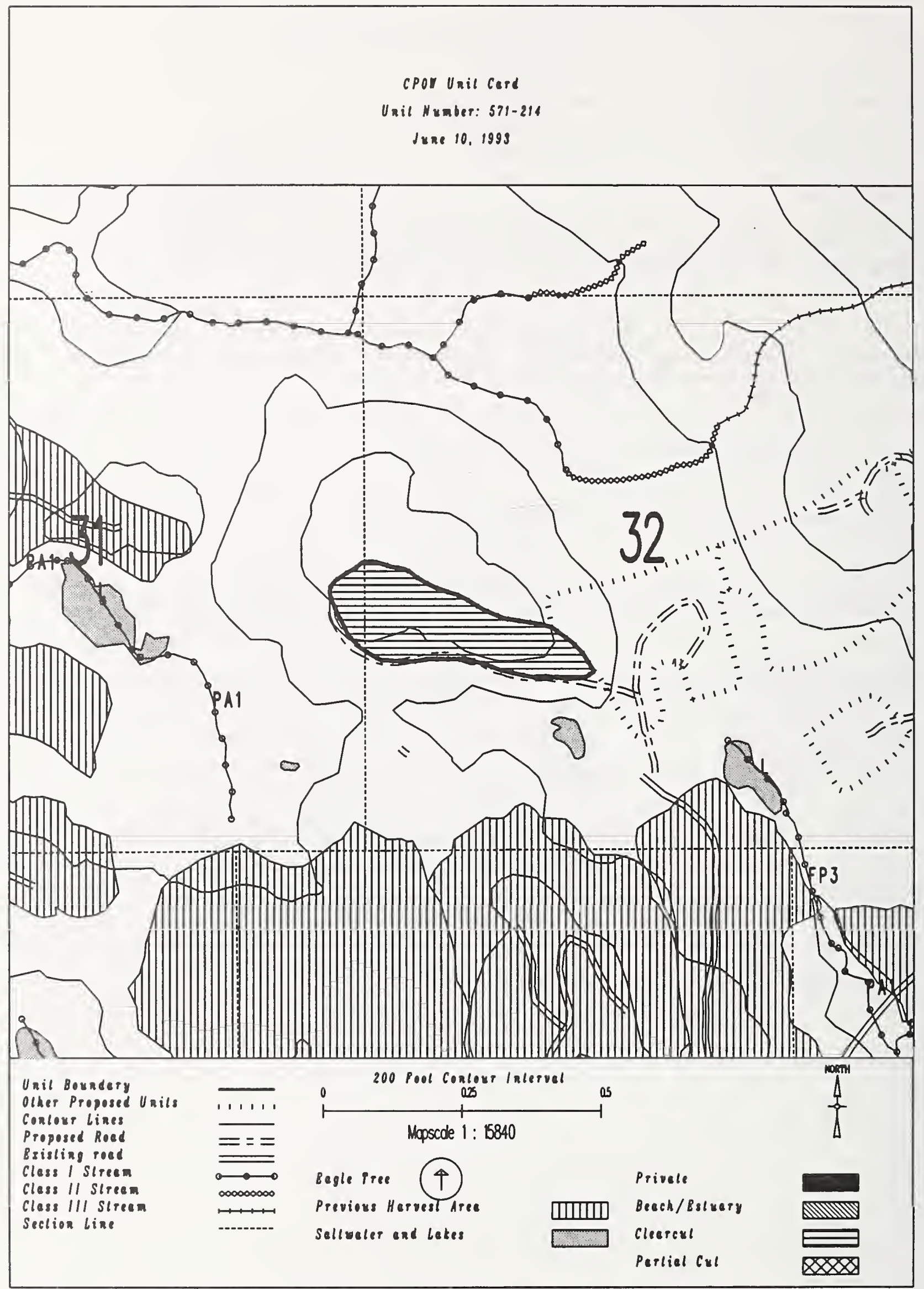


Unit $571-225$

Planned acres 11

Estimated volume (mbf)

Logging system Highlead

silvicultural system Clearcut

Forest type Mixed conifer
Alternatives considered \begin{tabular}{lllll}
$\mathrm{F} 2$ & $\mathrm{~F} 3$ & $\mathrm{~F} 4$ & $\mathrm{~F} 5$ & $\mathrm{~F} 6$ \\
\hline
\end{tabular}

Quad CRGD4NES

Mgmt Area $\mathrm{KOT}$

HAA 1422

Photo 1190112

Aspect Hest

\section{PHYSICAL DESCRIPTION}

Volume class breakdown: VC4 9 acres VC5 $\quad 0$ acres VC6 2 acres VC7 0 acres

Elevation breakdown: $0-800 \mathrm{ft} . \underline{10}$ acres $800-1200 \mathrm{ft} . \underline{0}$ acres 1200-1500 ft. 0 acres over $1500 \mathrm{ft}$. 0 acres Mass movement index: Low 2 acres Medium 0 acres High 4 acres Very High 0 acres

\section{SOILS}

This unit has high mass movement index soils. Partial log suspension required over these areas.(BMP13.9)

This unit contains 1 acres of slopes $>75 \%$.

\section{TIMBER}

There are no timber mitigation measures anticipated for this unit.

\section{ENGINEER ING}

There are no engineering mitigation measures anticipated for this unit.

\section{FISH/WATERSHED}

There are no fishery mitigation measures anticipated for this unit.

\section{WILDLIFE}

Maintain diversity within unit by leaving 1-5 acre-sized islands of green trees at a rate of 1 acre of island for every 20 acres harvested. Leave islands must be compatible with logging system and safe working conditions.

RECREATION / VISUALS

This unit has a proposed vQO of MM and is not seen from any viewpoint identified by this project.

\section{LANDS}

There are no lands mitigation measures anticipated for this unit.

CULTURAL RESOURCES

There are no cultural resource mitigation measures anticipated for this unit.

GEOLOGY

There are no karst mitigation measures anticipated for this unit. 


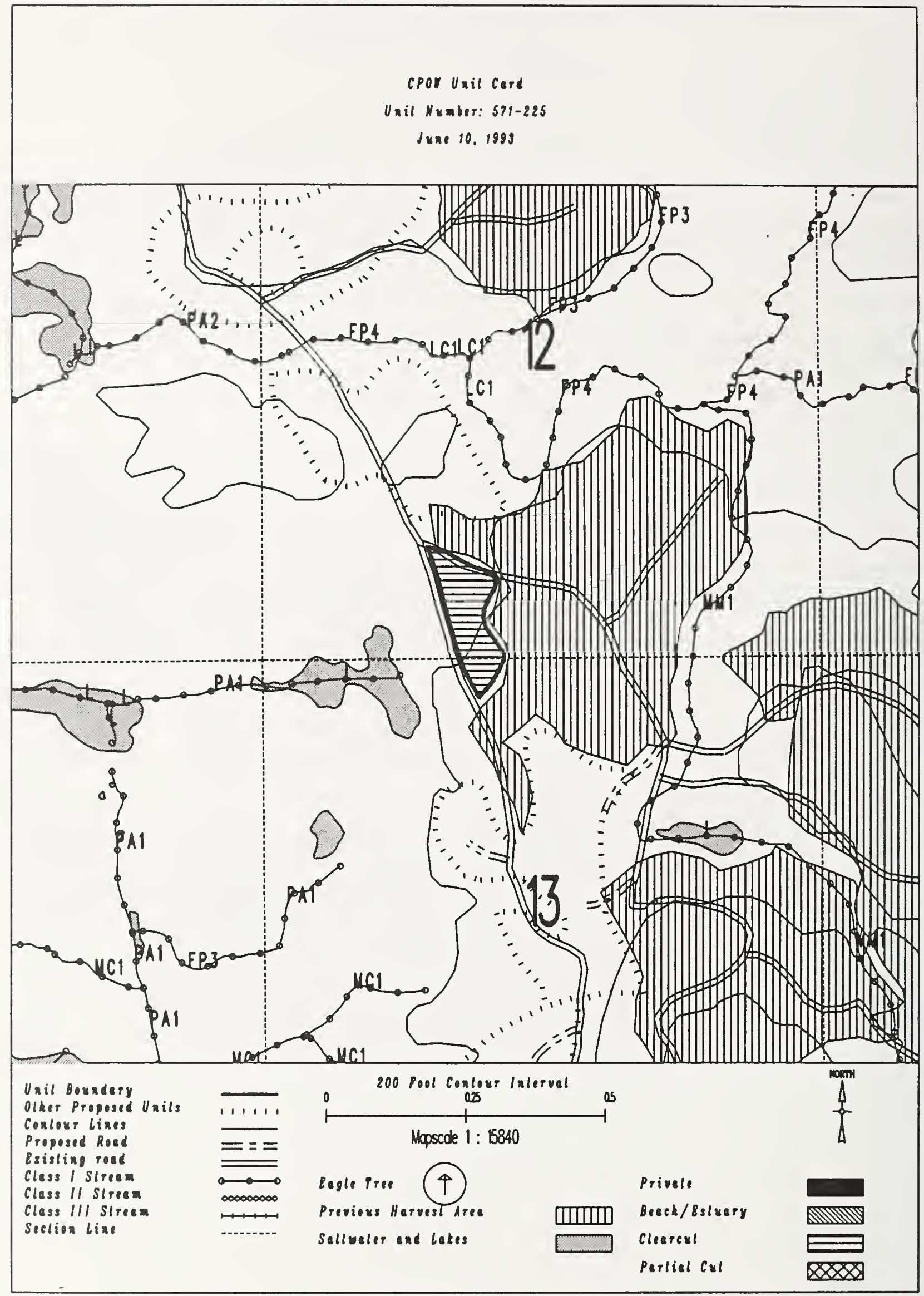


Unit $\quad 571-226$

Planned acres 48

Est imated volume (mbf) 1392

Logging system Highlead

silvicultural system Clearcut

Forest type Cedar
Alternatives considered

Quad CRGD4NES

Mgmt Area $\mathrm{KO7}$

WAA 1422

Photo 1190113

Aspect West

PHYSICAL DESCRIPTION

Volume class breakdown: VC4 34 acres VC5 12 acres VC6 $\quad 0$ acres VC7 5 acres

Elevation breakdown: $0-800 \mathrm{ft} . \underline{49}$ acres $800-1200 \mathrm{ft} . \underline{0}$ acres $1200-1500 \mathrm{ft} . \underline{0}$ acres over $1500 \mathrm{ft}$. 0 acres Mass movement index: Low 3 acres Medium 0 acres High 5 acres Very High 0 acres

SOILS

This unit has high mass movement index soils. Partial log suspension required over these areas.(BMP13.9)

This unit contains 40 acres of forested wetlands. Site specific BMPs will be designed for selected approved

logging system and road construction practices. (BMPs 12.5, 13.9, 13.15).

\section{TIMBER}

There are no timber mitigation measures anticipated for this unit.

\section{ENGINEERING}

There are no engineering mitigation measures anticipated for this unit.

\section{FISH/WATERSHED}

There are no fishery mitigation measures anticipated for this unit.

HILDLIFE

There are no wildlife mitigation measures anticipated for this unit.

RECREATION / VISUALS

This unit has a proposed VQO of MM and is not seen from any viewpoint identified by this project.

\section{LANDS}

There are no lands mitigation measures anticipated for this unit.

CULTURAL RESOURCES

There are no cultural resource mitigation measures anticipated for this unit.

There are no karst mitigation measures anticipated for this unit. 


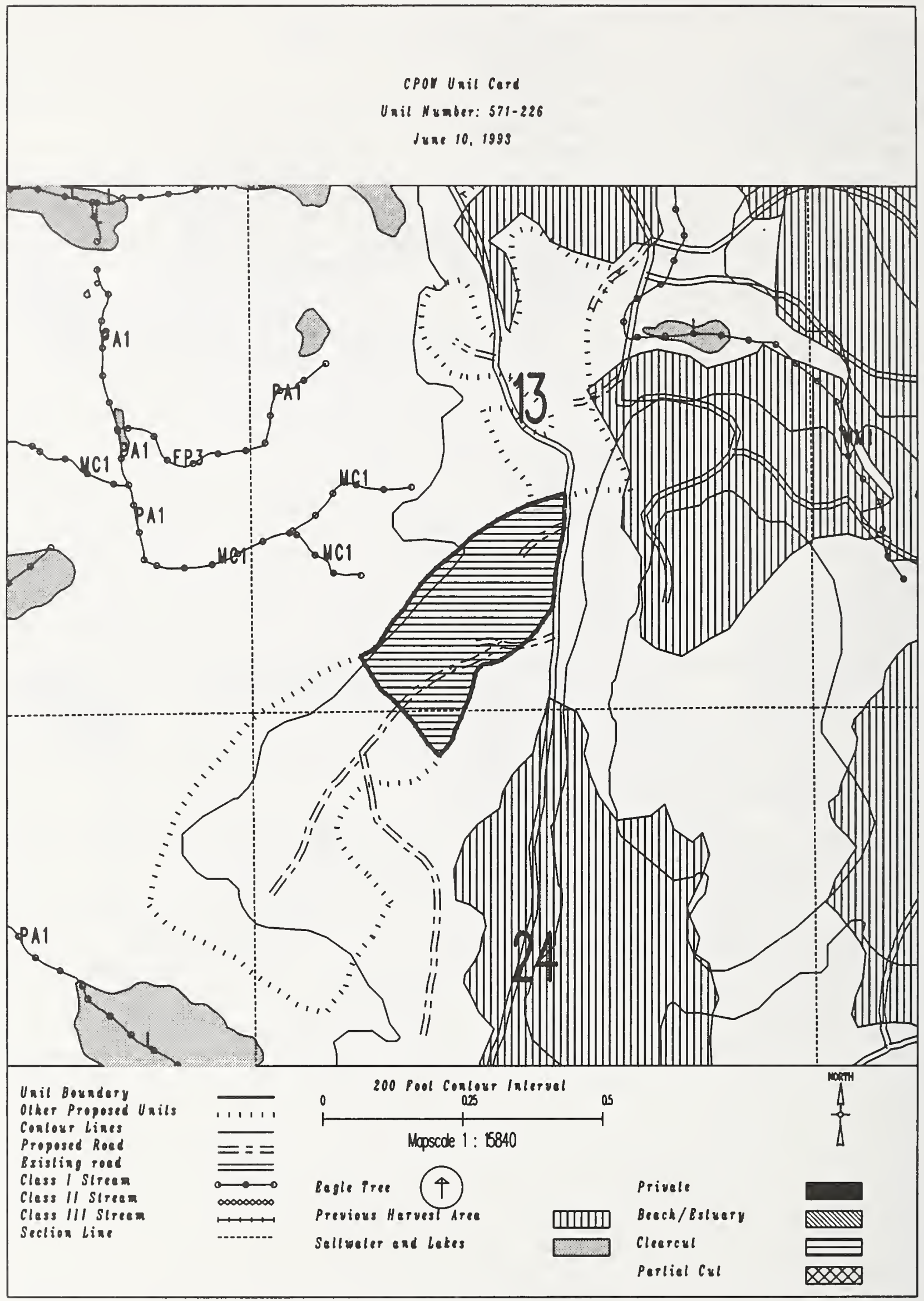


Unit $\quad 571-227$

Planned acres 111

Estimated volume (mbf) 2397

Logging system slackline

silvicultural system clearcut

Forest type Hemlock
Alternatives considered F2 F3 F5 F6

Quad CRGD4NES

Mgmt Area $\mathrm{KOT}$

WAA 1422

Photo 1190114

Aspect West

\section{PHYSICAL DESCRIPTION}

Volume class breakdown: VC4 108 acres VC5 10 acres vC6 $\quad 0$ acres VC7 $\quad 0$ acres

Elevation breakdown: $0-800 \mathrm{ft} . \underline{109}$ acres $800-1200 \mathrm{ft} . \underline{0}$ acres 1200-1500 ft. 0 acres over $1500 \mathrm{ft}$. 0 acres Mass movement index: Low 66 acres Medium 3 acres High 0 acres Very High 0 acres

\section{SOILS}

This unit contains 72 acres of forested wetlands. Site specific BMPs will be designed for selected approved

logging system and road construction practices. (BMPs 12.5, 13.9, 13.15).

\section{TIMBER}

Potential for shovel logging on 96 acres, if soil and water quality protected (BMP13.7)

\section{ENGINEERING}

There are no engineering mitigation measures anticipated for this unit.

\section{FISH/WATERSHED}

There are no fishery mitigation measures anticipated for this unit.

\section{WILDLIFE}

Maintain diversity within unit by leaving 1-5 acre-sized islands of green trees at a rate of 1 acre of island for every 20 acres harvested. Leave islands must be compatible with logging system and safe working conditions.

\section{RECREATION / VISUALS}

This unit has a proposed Voo of MM and is not seen from any viewpoint identified by this project.

\section{LANDS}

There are no lands mitigation measures anticipated for this unit.

CULTURAL RESOURCES

There are no cultural resource mitigation measures anticipated for this unit. 


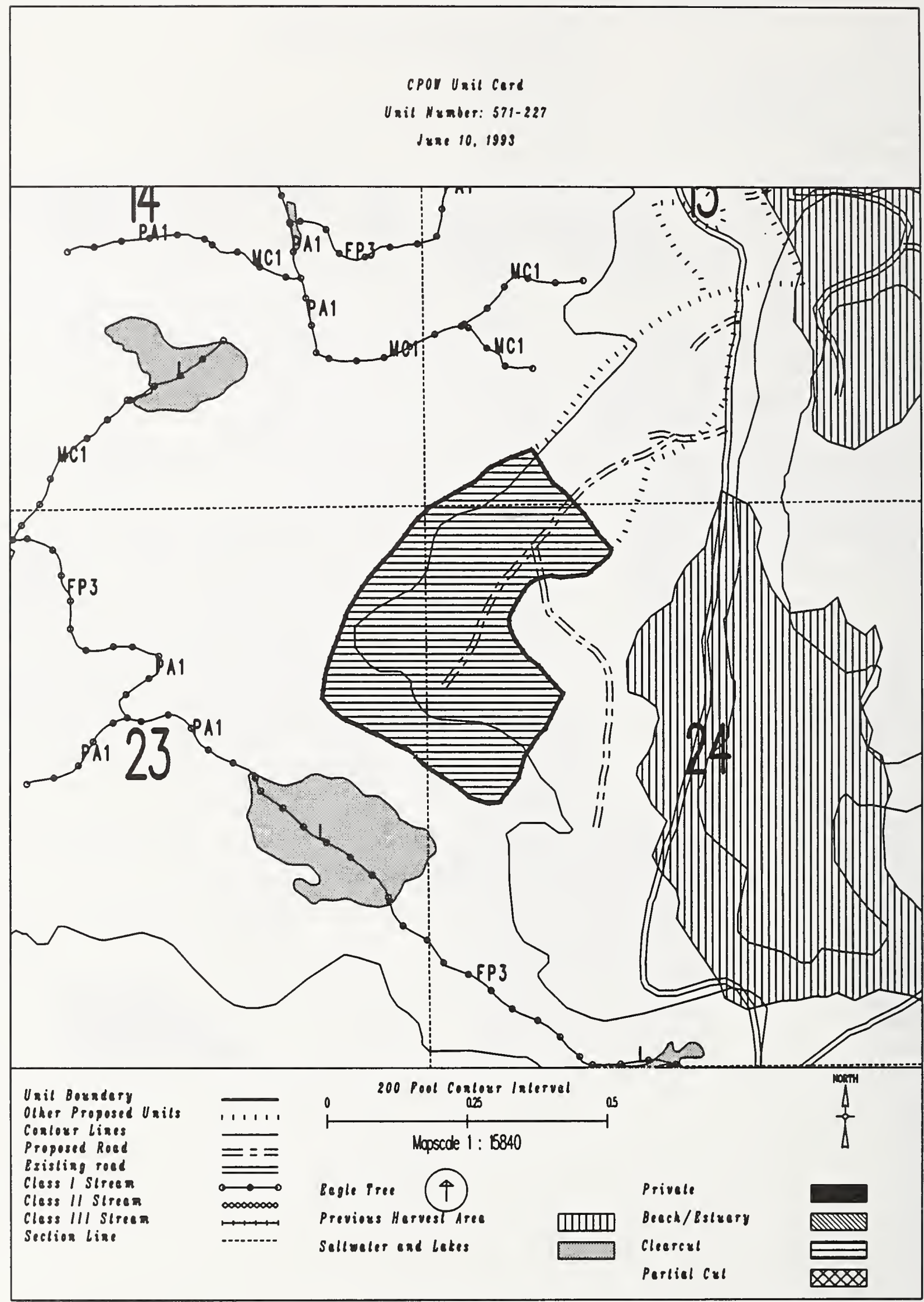


Unit $\mathbf{5 7 1 - 2 3 5}$

Planned acres 23

Estimated volume (mbf)

Logging system skyline

silvicultural system clearcut

Forest type Hemlock
Alternatives considered

Quad CRGD4NES

Mgmt Area $\mathrm{KOT}$

WAA 1422

Photo

Aspect East

\section{PHYSICAL DESCRIPTION}

Volume class breakdown: VC4 1 acres VC5 23 acres VC6 $\quad 0$ acres VC7 0 acres

Elevation breakdown: $0-800 \mathrm{ft} .18$ acres $800-1200 \mathrm{ft} . \underline{0}$ acres $1200-1500 \mathrm{ft} .0$ acres over $1500 \mathrm{ft}$. 0 Mass movement index: Low 0 acres Medium 0 acres High 15 acres Very High 0

\section{SOILS}

This unit has high mass movement index soils. Partial log suspension required over these areas.(BMP13.9)

This unit contains 15 acres of forested wetlands. Site specific BMPs will be designed for selected approved

logging system and road construction practices. (BMPs 12.5, 13.9, 13.15).

\section{TIMBER}

Water quality streams may be present, where it is impractical to split yard. Full suspension required over all streamcourses (BMPs13.9, 13.16).

\section{ENGINEER ING}

High mass movement index soils. Road construction must minimize landslide potential (BMP14).

\section{FISH/WATERSHED}

There are no fishery mitigation measures anticipated for this unit.

\section{WILDLIFE}

There are no wildlife mitigation measures anticipated for this unit.

RECREATION / VISUALS

This unit has a proposed VQO of MM and is not seen from any viewpoint identified by this project.

\section{LANDS}

There are no lands mitigation measures anticipated for this unit.

CULTURAL RESOURCES

There are no cultural resource mitigation measures anticipated for this unit.

GEOLOGY

Planned unit boundary/road location/logging system are designed to avoid damage to significant karst features. Mitigation measures may apply. Unit layout/changes must be coordinated with Cave Resource Specialists. 


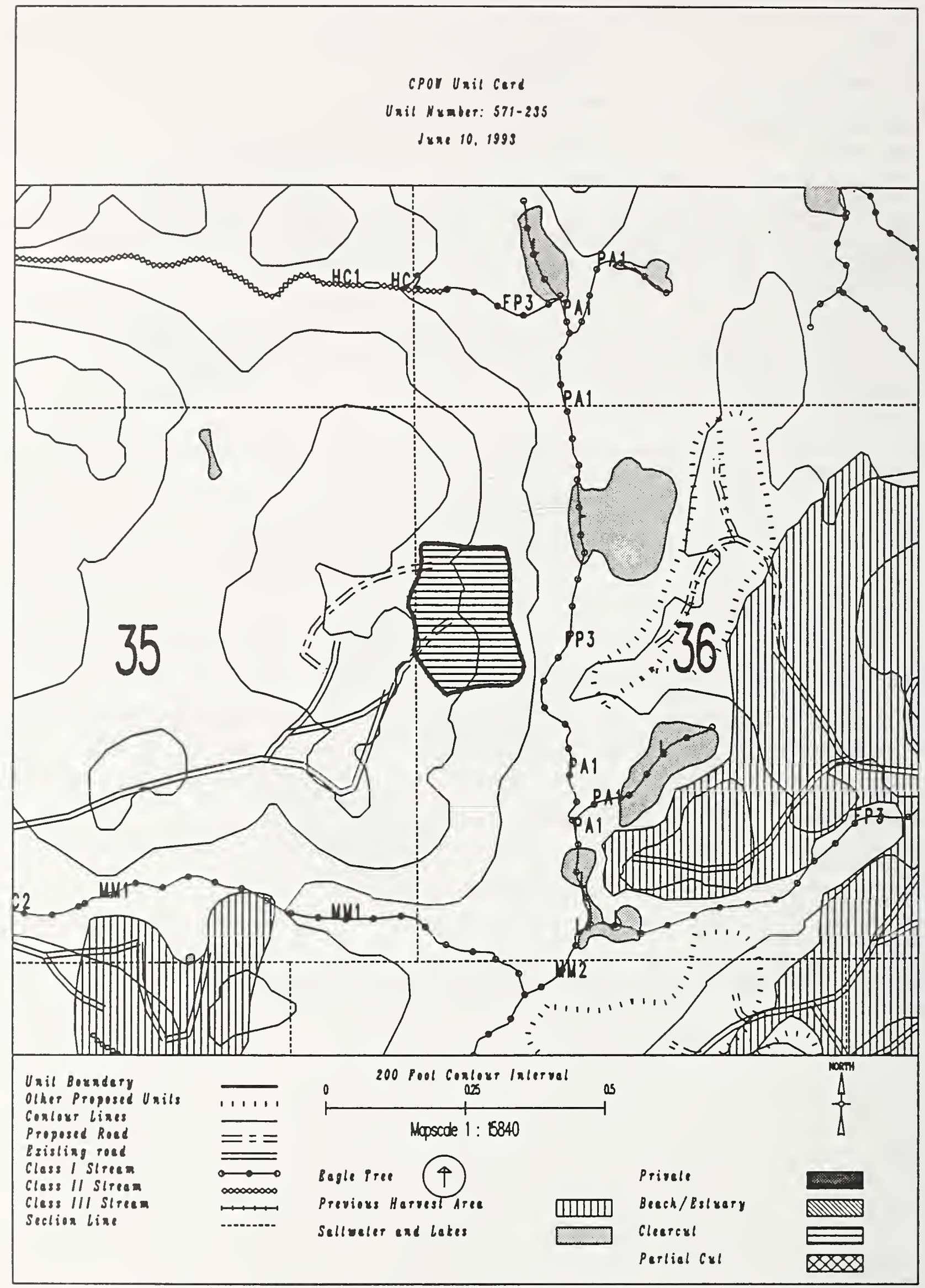


Unit 571-235

Planned acres 2

Estimated volume (mbf)

Logging system skyline

Silvicultural system Selective

Forest type Hemlock
Al ternatives considered

Quad CRGD4NES

Mgmt Area $\mathrm{KOT}$

WAA 1422

Photo

Aspect East

\section{PHYSICAL DESCRIPTION}

Volume class breakdown: VC4 1 acres VC5 23 acres VC6 $\quad 0$ acres vC7 $\quad 0$ acres

Elevation breakdown: $0-800 \mathrm{ft} .18$ acres $800-1200 \mathrm{ft}$. _ 0 acres 1200-1500 ft. 0 acres over $1500 \mathrm{ft}$. 0 acres

Mass movement index: Low 0 acres Medium 0 acres High 15 acres Very High 0 acres

\section{SOILS}

This unit has high mass movement index soils. Partial log suspension required over these areas. (BMP13.9)

This unit contains 15 acres of forested wetlands. Site specific BMPs will be designed for selected approved

logging system and road construction practices. (BMPs 12.5, 13.9, 13.15).

\section{TIMBER}

Selective, uneven-aged harvest designed to meet specific resource concern.

Water quality streams may be present, where it is impractical to split yard. Full suspension required over all streamcourses (BMPs13.9, 13.16).

\section{ENGINEERING}

High mass movement index soils. Road construction must minimize landslide potential (BMP14).

\section{FISH/HATERSHED}

There are no fishery mitigation measures anticipated for this unit.

\section{WILDLIFE}

There are no wildlife mitigation measures anticipated for this unit.

\section{RECREATION / VISUALS}

This unit has a proposed Voo of MM and is not seen from any viewpoint identified by this project.

\section{LANDS}

There are no lands mitigation measures anticipated for this unit.

\section{CULTURAL RESOURCES}

There are no cultural resource mitigation measures anticipated for this unit.

GEOLOGY

Planned unit boundary/road location/logging system are designed to avoid damage to significant karst features.

Mitigation measures may apply. Unit layout/changes must be coordinated with Cave Resource Specialists. Selective harvest prescribed to protect significant karst resources. 


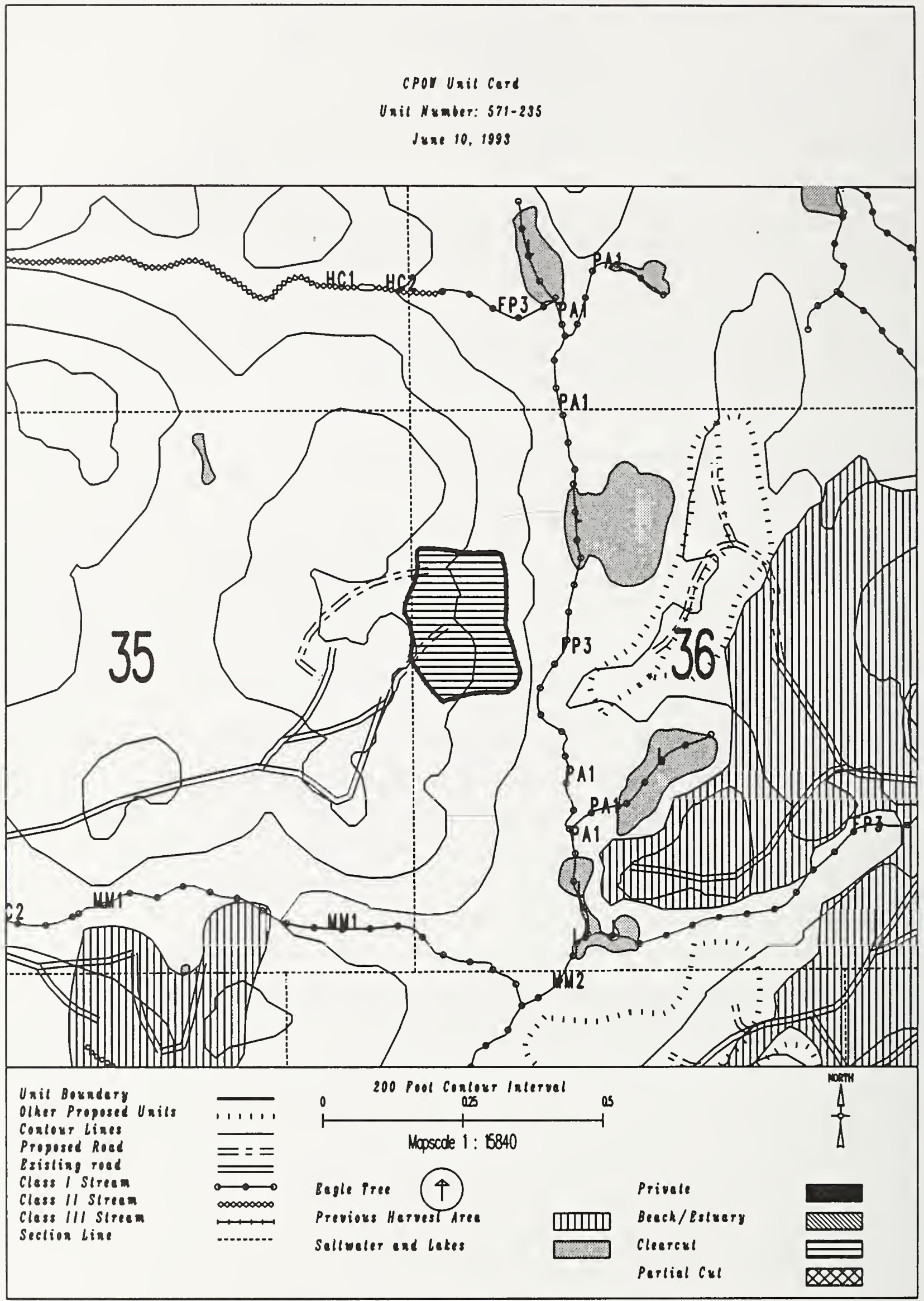


Unit $571-252$

Planned acres 43

Est imated volume (mbf) 1555

Logging system Highlead

silvicultural system Riparian

Forest type Mixed conifer
Alternatives considered F2 F3 F4

Quad CRGD4NES

Mgmt Area $\mathrm{KO7}$

WAA 1422

Photo 1290040

Aspect West

PHYSICAL OESCRIPTION

Volume class breakdown: VC4 $\quad 0$ acres vC5 $\quad 0$ acres vC6 $\quad 0$ acres vc7 42 acres

Elevation breakdown: $0-800 \mathrm{ft} . \angle 40$ acres $800-1200 \mathrm{ft} . \ldots$

Mass movement index: Low $\underline{0}$ acres Medium $\underline{22}$ acres High 20 acres Very High 0

\section{SOILS}

This unit has high mass movement index soils. Partial log suspension required over these areas.(BMP13.9)

This unit contains 20 acres of slopes $>75 \%$.

\section{TIMBER}

Uneven-aged harvest for riparian management on an estimated 19 acres.

\section{ENGINEERING}

High mass movement index soils. Road construction must minimize (andslide potential (BMP14).

slopes greater than $75 \%$ may require full bench construction and endhaul of waste (BMP14.7).

\section{FISH/WATERSHED}

Potential for additional Class $1 / I I$ streams within unit. May be necessary to place additional buffers within unit in accordance with AHMU Handbook.

Potential impact on significant fishery habitat. May be necessary to expand planned buffer in accordance with AHMU Handbook.

\section{WILOLIFE}

There are no wildlife mitigation measures anticipated for this unit.

\section{RECREATION / VISUALS}

This unit has a proposed Voo of MM and is not seen from any viewpoint identified by this project.

\section{LANOS}

This unit adjacent to Sarkar Management Area. Boundary establishment required prior to layout.

\section{CULTURAL RESOURCES}

The planned unit boundary and road location is immediately adjacent to significant cultural resources. Any changes must be coordinated with cultural resource personnel.

\section{GEOLOGY}

This unit is underlain with karst, although no significant features have yet been identified. 


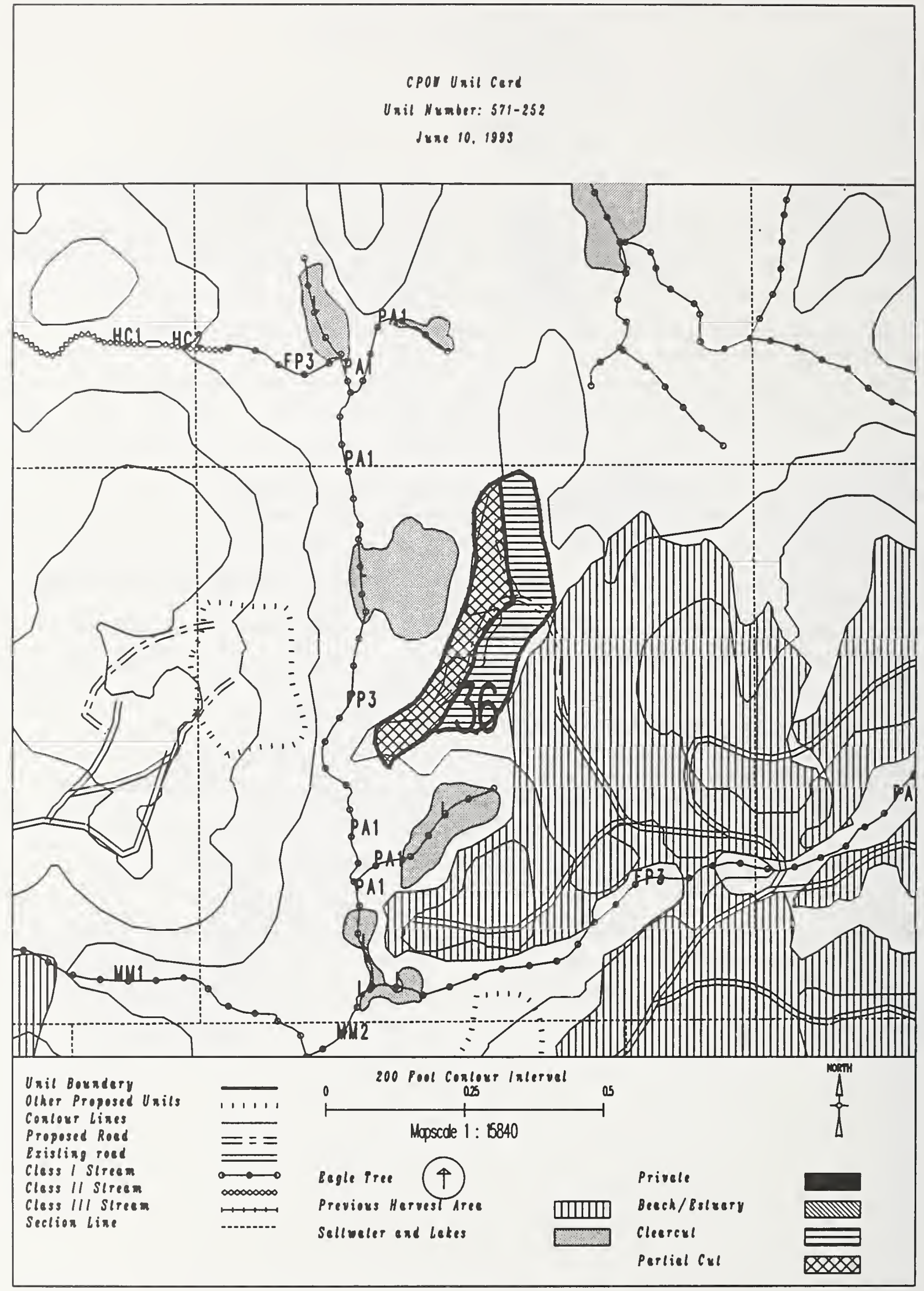


Unit 571-252

Planned acres 43

Estimated volume (mbf) 1555

Logging system Highlead

silvicultural system Selective

Forest type Mixed conifer
Alternatives considered

Quad CRGD4NES

Mgmt Area $\mathrm{KO7}$

WAA 1422

Photo 1290040

Aspect West

\section{PHYSICAL DESCRIPTION}

Volume class breakdown: vC4 $\quad 0$ acres vC5 $\quad 0$ acres vc6 $\quad 0$ acres vc7 42 acres

Elevation breakdown: $0-800 \mathrm{ft} . \underline{40}$ acres $800-1200 \mathrm{ft} . \ldots$

Mass movement index: Low $\underline{0}$ acres Medium 22 acres High 20 acres Very High 0

\section{SOILS}

This unit has high mass movement index soils. Partial log suspension required over these areas.(BMP13.9)

This unit contains 20 acres of slopes $>75 \%$.

\section{TIMBER}

Selective, uneven-aged harvest designed to meet specific resource concern.

\section{ENGINEERING}

High mass movement index soils. Road construction must minimize landslide potential (BMP14).

slopes > 75\% may require full bench construction and endhaul of waste (BMP14.7).

\section{FISH/WATERSHED}

This unit is presecribed for selective harvest to protect soils/riparian habitat.

potential for additional Class $1 / 11$ streams within unit. May be necessary to place additional buffers within unit

in accordance with AHMU Handbook.

Potential impact on significant fishery habitat. May be necessary to expand planned buffer in accordance with AHMU Handbook.

\section{WILDLIFE}

There are no wildlife mitigation measures anticipated for this unit.

\section{RECREATION / VISUALS}

This unit has a proposed VQO of MM and is not seen from any viewpoint identified by this project.

\section{LANDS}

This unit adjacent to Sarkar Management Area. Boundary establishment required prior to layout.

\section{CULTURAL RESOURCES}

The planned unit boundary and road location is immediately adjacent to significant cultural resources. Any changes must be coordinated with cultural resource personnel.

This unit is underlain with karst, although no significant features have yet been identified. 


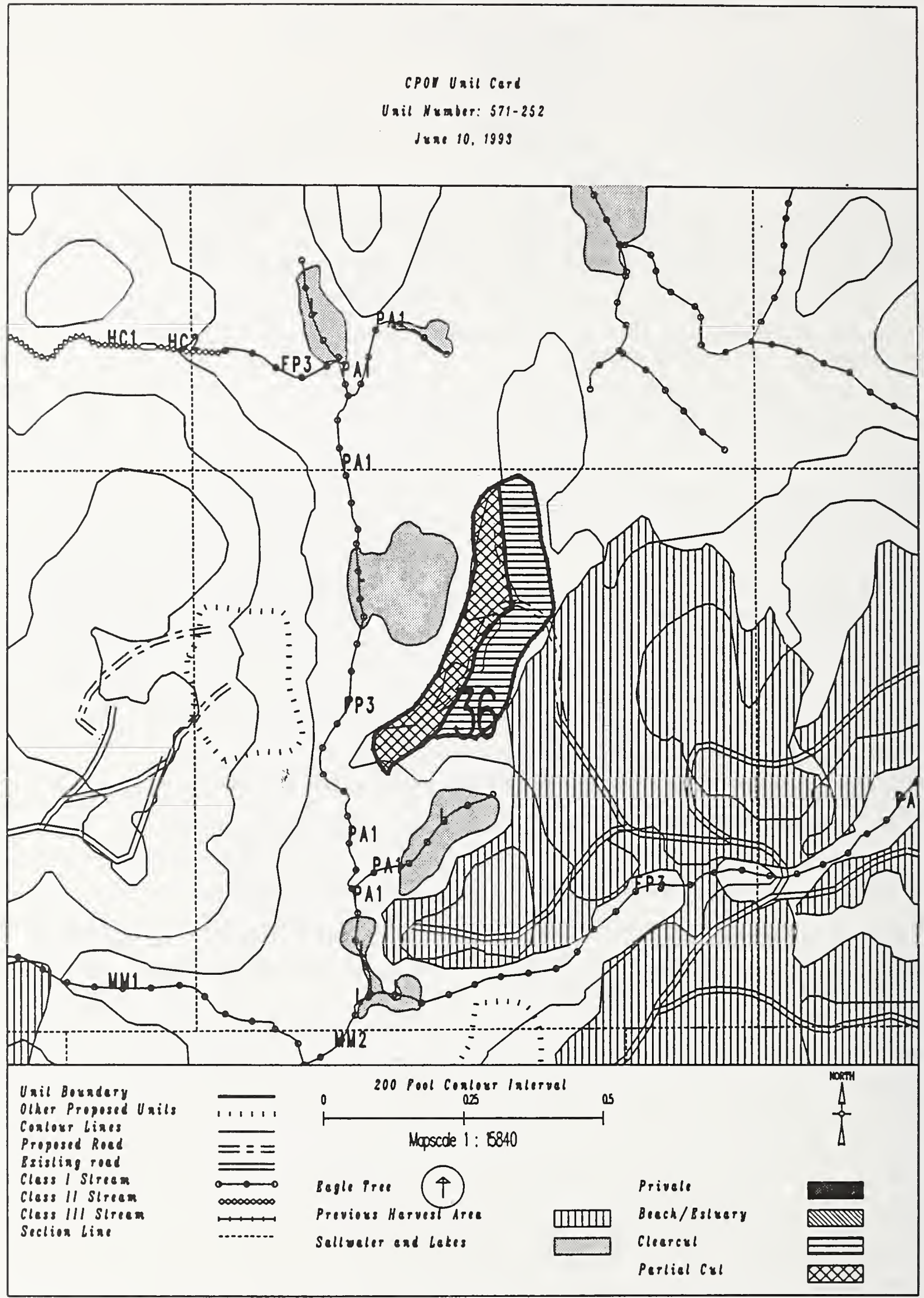


Unit $\mathbf{5 7 1 - 2 5 3}$

Planned acres 72

Estimated volume (mbf) 3395

Logging system skyline

Silvicultural system clearcut

Forest type Mixed conifer
Alternatives considered F2 F3 F4

Quad CRGD4NES

Mgmt Area $\mathrm{KO7}$

WAA 1422

Photo 1290038

Aspect West

\section{PHYSICAL DESCRIPIION}

Volume class breakdown: VC4 0 acres VC5 9 acres VC6 0 acres VC7 61 acres

Elevation breakdown: $0-800 \mathrm{ft} .69$ acres $800-1200 \mathrm{ft} . \underline{0}$ acres $1200-1500 \mathrm{ft}$. 0 acres over $1500 \mathrm{ft}$. 0 acres Mass movement index: Low $\underline{9}$ acres Medium 26 acres High $\underline{36}$ acres Very High 0

\section{SOILS}

This unit has high mass movement index soils. Partial log suspension required over these areas. (BMP13.9)

This unit contains 35 acres of slopes > $75 \%$.

\section{TIMBER}

There are no timber mitigation measures anticipated for this unit.

\section{ENGINEERING}

Very difficult road construction due to unstable, slope $>75 \%$ or extended steep grades.

May need to revise logging system to helicopter.

High mass movement index soils. Road construction must minimize landslide potential (BMP14).

slopes greater than $75 \%$ may require full bench construction and endhaul of waste (BMP14.7).

\section{FISH/WATERSHED}

Potential for additional Class I/II streams within unit. May be necessary to place additional buffers within unit in accordance with AHMU Handbook.

Potential impact on significant fishery habitat. May be necessary to expand planned buffer in accordance with AMMU Handbook.

\section{WILDLIFE}

There are no wildlife mitigation measures anticipated for this unit.

\section{RECREATION / VISUALS}

This unit has a proposed VQO of MM and is not seen from any viewpoint identified by this project.

\section{LANDS}

There are no lands mitigation measures anticipated for this unit.

\section{CULTURAL RESOURCES}

There are no cultural resource mitigation measures anticipated for this unit.

\section{GEOLOGY}

This unit is underlain with karst, although no significant features have yet been identified. 


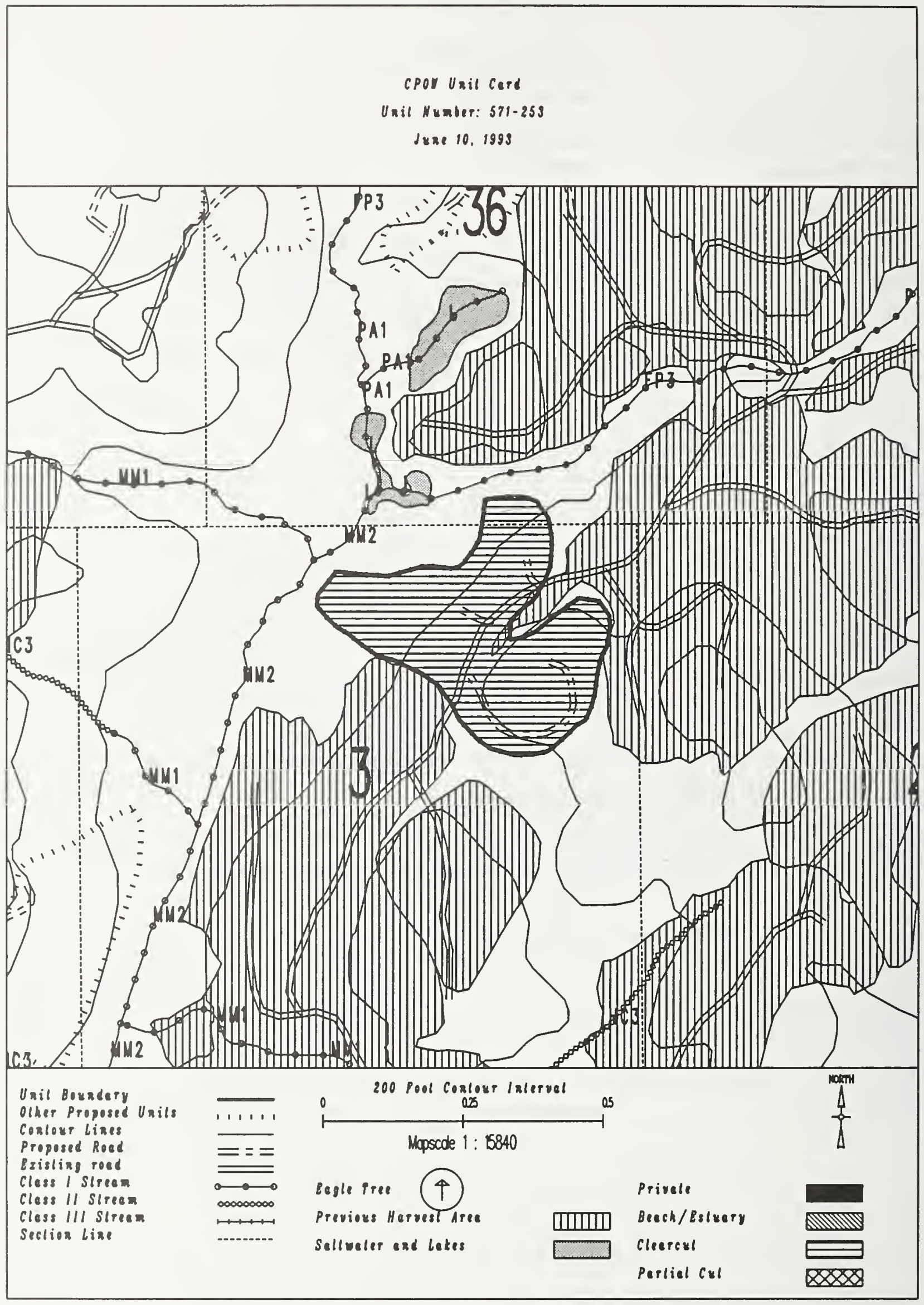


Unit $571-253$

Planned acres 72

Estimated volume (mbf) 3395

Logging system skyline

silvicultural system Selective

Forest type Mixed conifer
Alternatives considered F5
Mgmt

WAA 1422

Photo 1290038

Aspect West

PHYSICAL DESCRIPTION

Volume class breakdown: VC4 0 acres vC5 9 acres vC6 0 acres vC7 61 acres

Elevation breakdown: $0-800 \mathrm{ft} . \underline{69}$ acres $800-1200 \mathrm{ft} . \underline{0}$ acres $1200-1500 \mathrm{ft} . \underline{0}$ acres over $1500 \mathrm{ft}$. 0 acres Mass movement index: Low 9 acres Medium 26 acres High 36 acres Very High 0 acres

\section{SOILS}

This unit has high mass movement index soils. Partial $\log$ suspension required over these areas.(BMP13.9)

This unit contains 35 acres of slopes $>75 \%$.

\section{TIMBER}

Selective, uneven-aged harvest designed to meet specific resource concern.

\section{ENGINEERING}

Very difficult road construction due to unstable, slopes over $75 \%$ or extended steep grades.

May need to revise logging system to helicopter.

High mass movement index soils. Road construction must minimize landslide potential (BMP14).

Slopes > $75 \%$ may require full bench construction and endhaul of waste (BMP14.7).

\section{FISH/WATERSHED}

Potential for additional Class $1 / 11$ streams within unit. May be necessary to place additional buffers within unit in accordance with AHMU Handbook.

Potential impact on significant fishery habitat. May be necessary to expand planned buffer in accordance with AHMU Handbook.

\section{WILDLIFE}

Selective harvest prescribed to preserve goshawk foraging habitat/other objectives identified by District IDT.

RECREATION / VISUALS

This unit has a proposed VQO of MM and is not seen from any viewpoint identified by this project.

\section{LANDS}

There are no lands mitigation measures anticipated for this unit.

\section{CULTURAL RESOURCES}

There are no cultural resource mitigation measures anticipated for this unit.

\section{GEOLOGY}

This unit is underlain with karst, although no significant features have yet been identified. 


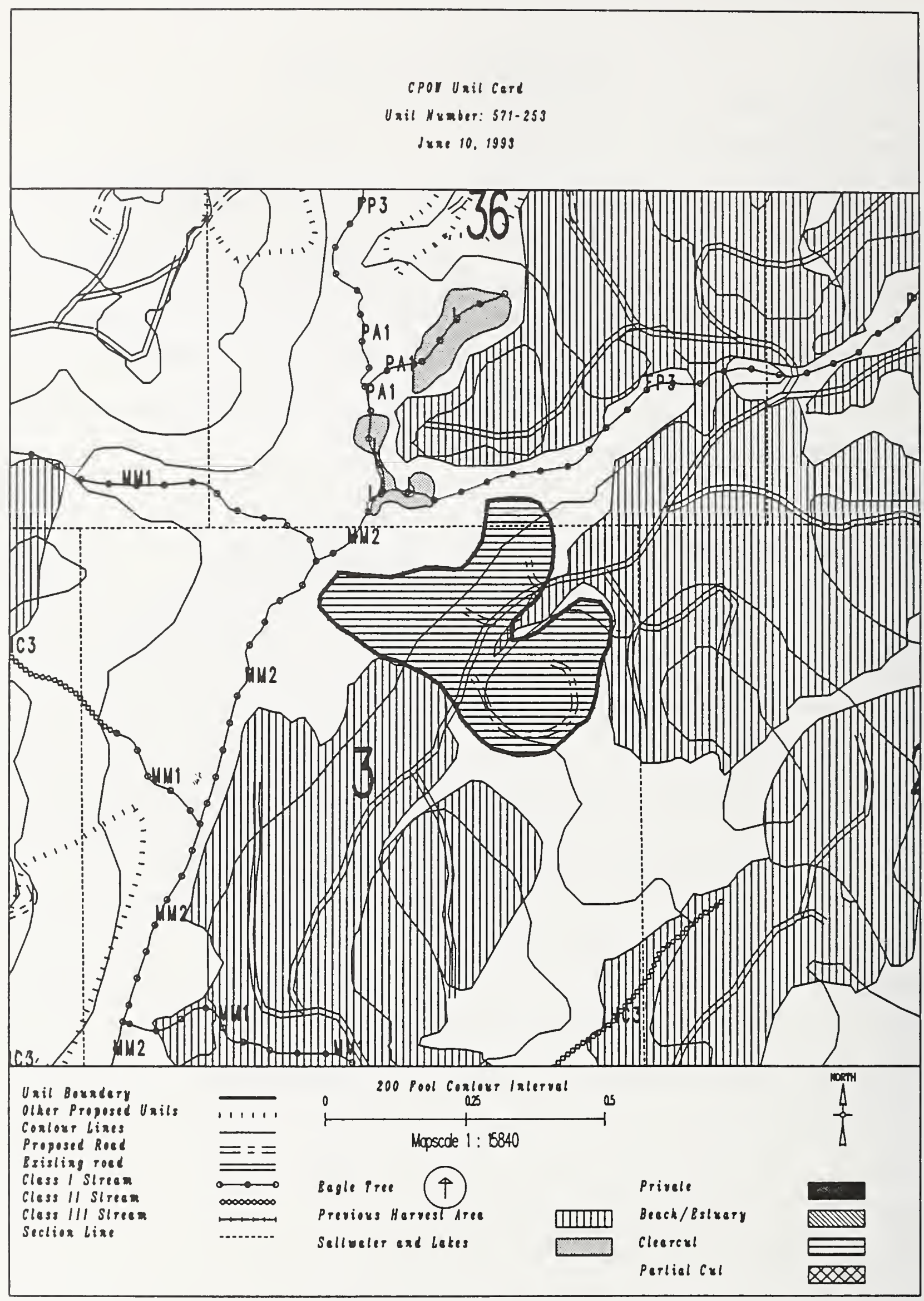




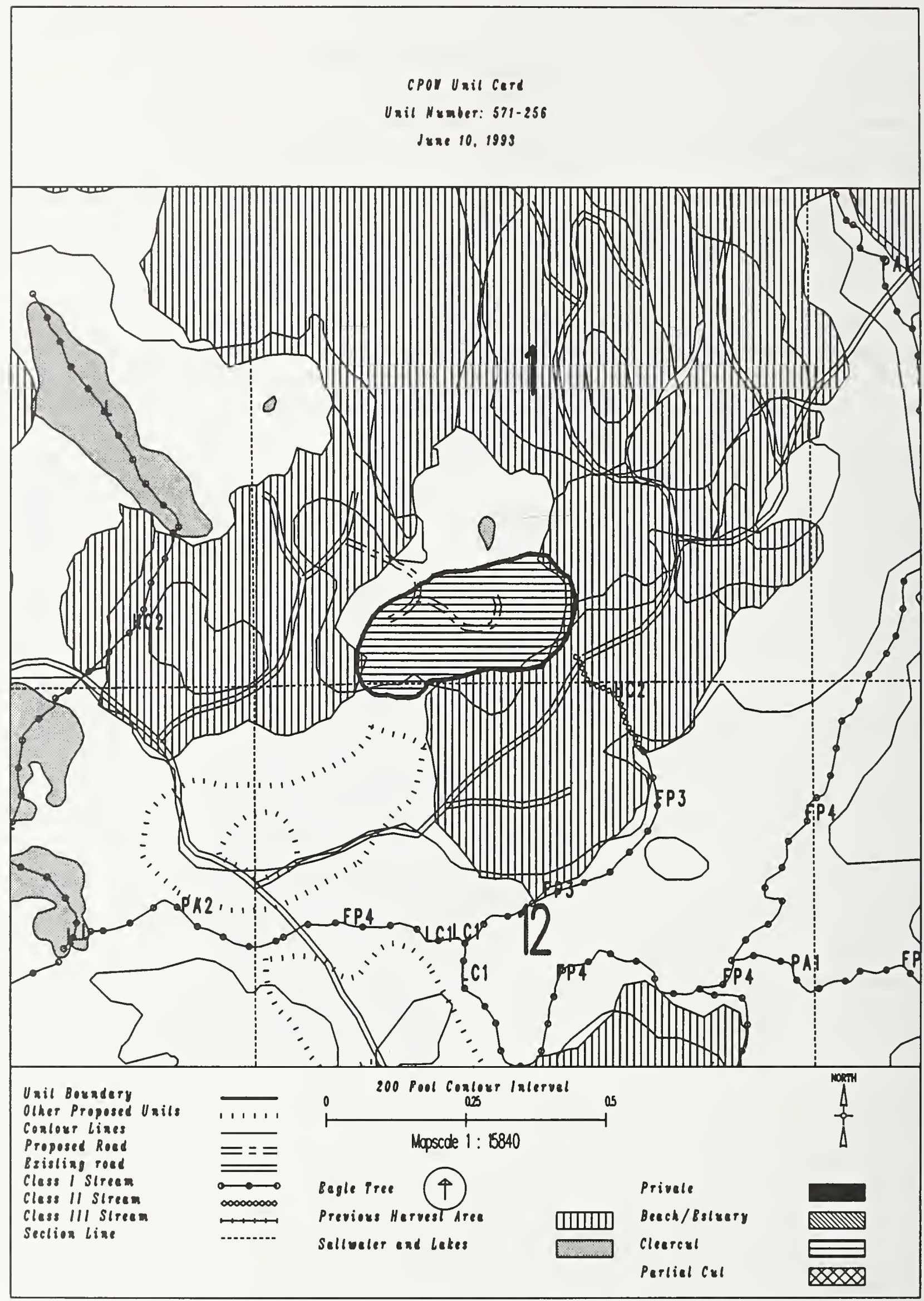




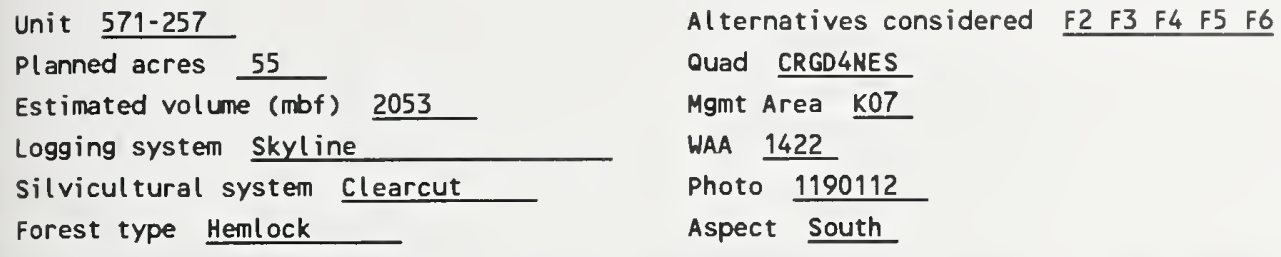




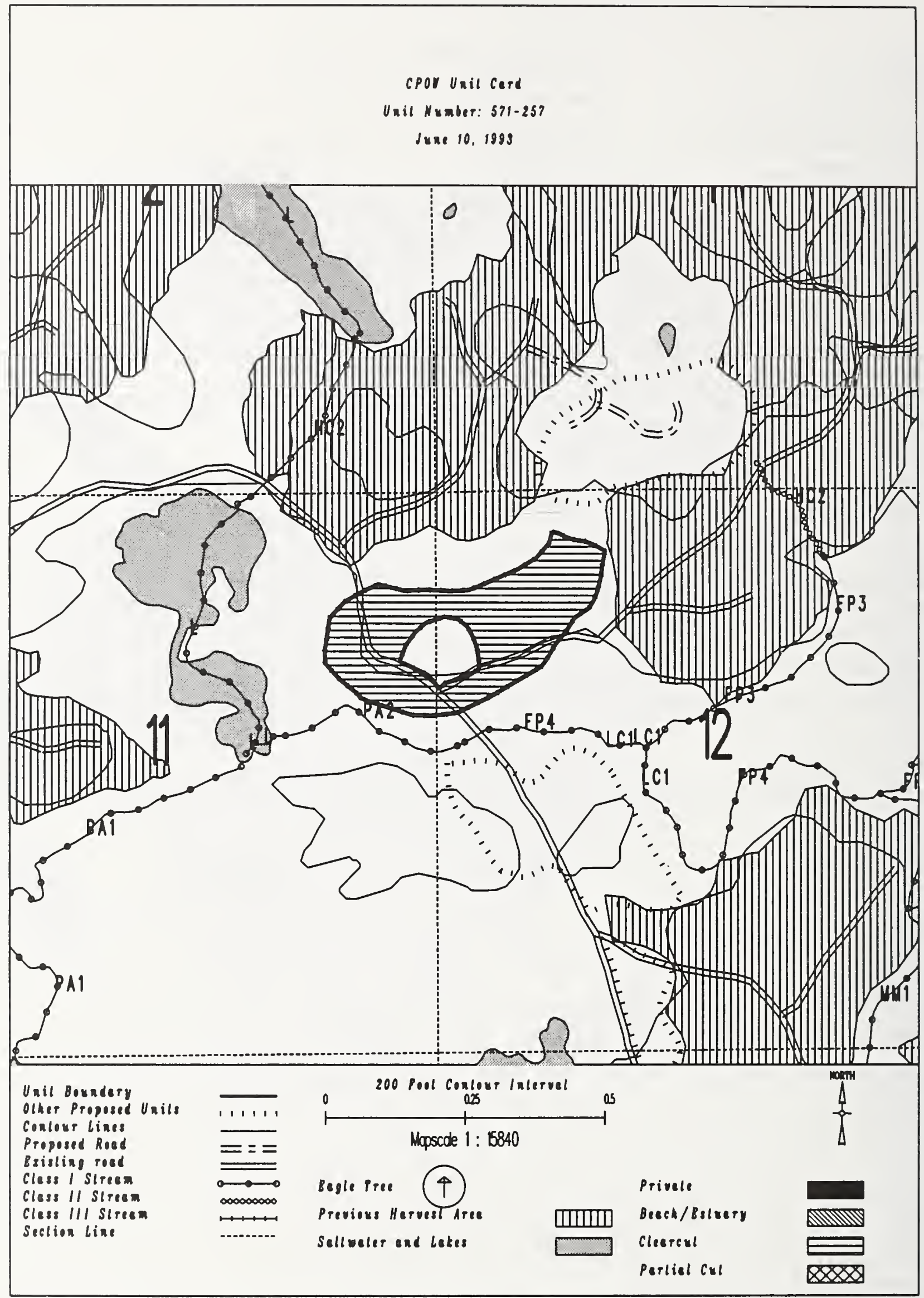


Unit $571-258$

Planned acres 45

Estimated volume (mbf) 1308

Logging system Highlead

Silvicultural system clearcut

Forest type Hemlock
Alternatives considered $\quad$ F2 $F 3$ F4 F5 $\quad$ F6

Quad CRGD4NES

Mgmt Area $\mathrm{KOT}$

WAA 1422

Photo 1190112

Aspect North

PHYSICAL DESCRIPTION

Volume class breakdown: VC4 22 acres VC5 22 acres vC6 20 acres VC7 $\quad 0$ acres

Elevation breakdown: $0-800 \mathrm{ft} . \underline{43}$ acres 800-1200 ft. 0 acres 1200-1500 ft. 0 acres over $1500 \mathrm{ft}$. 0 acres Mass movement index: Low 9 acres Medium 0 acres High 19 acres Very High 0

SOILS

This unit has high mass movenent index soils. Partial log suspension required over these areas.(BMP13.9)

This unit contains 27 acres of forested wetlands. Site specific BMPs will be designed for selected approved

logging system and road construction practices. (BMPs 12.5, 13.9, 13.15).

\section{TIMBER}

There are no timber mitigation measures anticipated for this unit.

\section{ENGINEERING}

High mass movement index soils. Road construction must minimize landslide potential (BMP14).

The road into this unit crosses a C1 channel. Meet stream and lake protection prescription requirements in TLMP Draft Revision (1991a) for this process group.

\section{FISH/WATERSHED}

Potential for additional Class 1/II streams within unit. May be necessary to place additional buffers within unit in accordance with AHMU Handbook.

Potential impact on significant fishery habitat. May be necessary to expand planned buffer in accordance with AHMU Handbook.

\section{WILDLIFE}

Maintain diversity within unit by leaving 1-5 acre-sized islands of green trees at a rate of 1 acre of island for every 20 acres harvested. Leave islands must be compatible with logging system and safe working conditions.

\section{RECREATION / VISUALS}

This unit has a proposed VDO of MM and is not seen from any viewpoint identified by this project.

\section{LANDS}

There are no lands mitigation measures anticipated for this unit.

\section{CULTURAL RESOURCES}

There are no cultural resource mitigation measures anticipated for this unit.

GEOLOGY

There are no karst mitigation measures anticipated for this unit. 


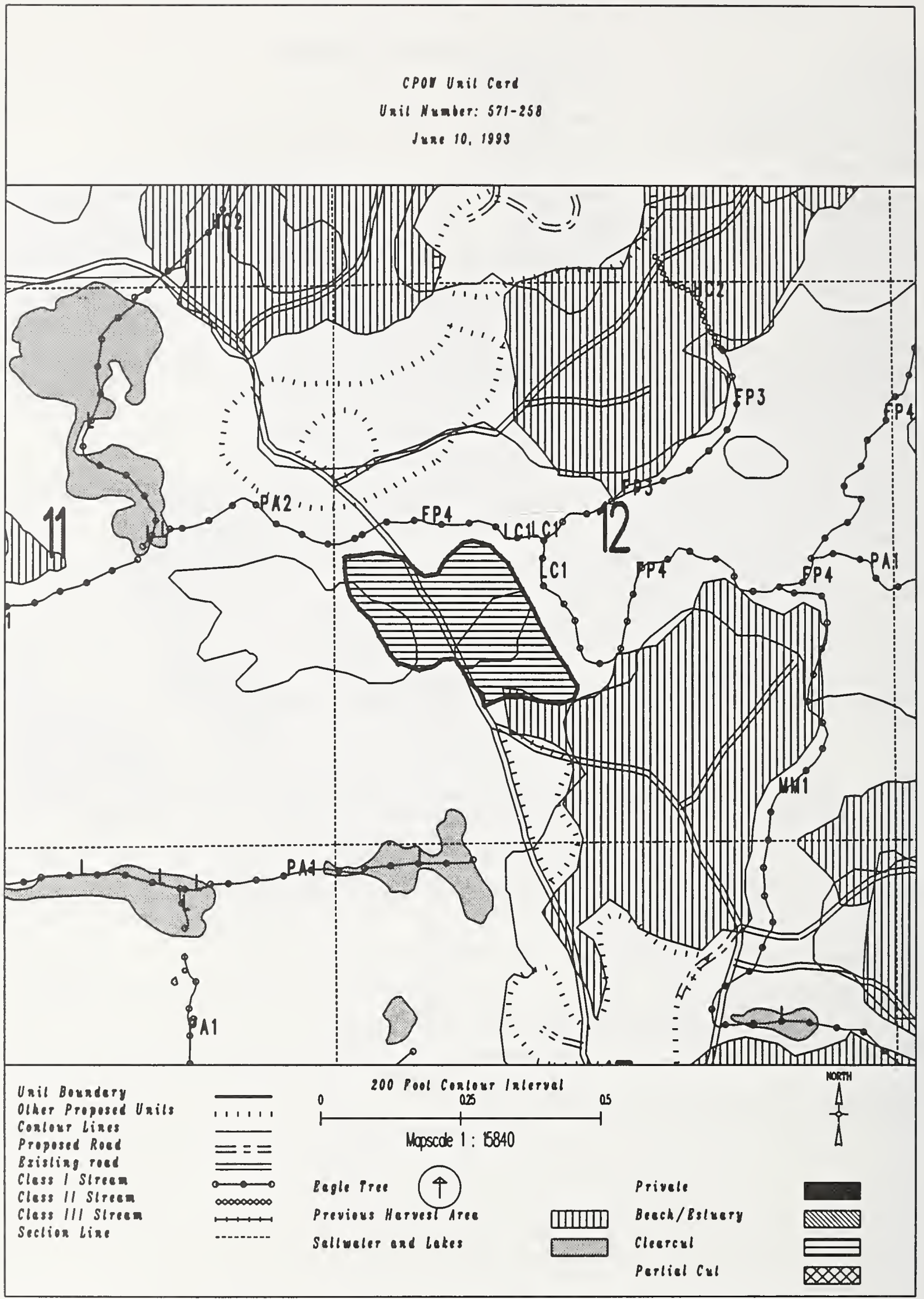


Unit $\quad 571-260$

Planned acres 51

Est imated volume (mbf) 2078

Logging system skyline

silvicultural system clearcut

Forest type Hemlock
Alternatives considered $\underline{F}$

Quad CRGD4NES

Mgmt Area $\mathrm{KO7}$

WAA 1422

Photo 1190113

Aspect West

PHYSICAL DESCRIPTION

Volume class breakdown: VC4 4 acres VC5 8 acres VC6 0 acres VC7 34 acres

Elevation breakdown: $0-800 \mathrm{ft} .49$ acres $800-1200 \mathrm{ft} . \quad 0$ acres 1200-1500 ft. 0 acres over $1500 \mathrm{ft}$. 0 Mass movement index: Low 8 acres Medium 1 acres High 26 acres Very High 0 acres

SOILS

This unit has high mass movement index soils. Partial log suspension required over these areas.(BMP13.9)

This unit contains 14 acres of forested wetlands. Site specific BMPs will be designed for selected approved

logging system and road construction practices. (BMPs 12.5, 13.9, 13.15).

This unit contains 15 acres of slopes $>75 \%$.

\section{TIMBER}

Potential for shovel logging on 45 acres, if soil and water quality protected (BMP13.7)

\section{ENGINEERING}

High mass movement index soils. Road construction must minimize landslide potential (BMP14).

Slopes greater than $75 \%$ may require full bench construction and endhaul of waste (BMP14.7).

\section{FISH/WATERSHED}

Potential for additional Class I/II streams within unit. May be necessary to place additional buffers within unit in accordance with AHMU Handbook.

Potential impact on significant fishery habitat. May be necessary to expand planned buffer in accordance with AHMU Handbook.

\section{WI LDL IFE}

There are no wildlife mitigation measures anticipated for this unit.

\section{RECREATION / VISUALS}

This unit has a proposed VQO of MM and is not seen from any viewpoint identified by this project.

\section{LANDS}

There are no lands mitigation measures anticipated for this unit.

\section{CULTURAL RESOURCES}

There are no cultural resource mitigation measures anticipated for this unit.

\section{GEOLOGY}

There are no karst mitigation measures anticipated for this unit. 


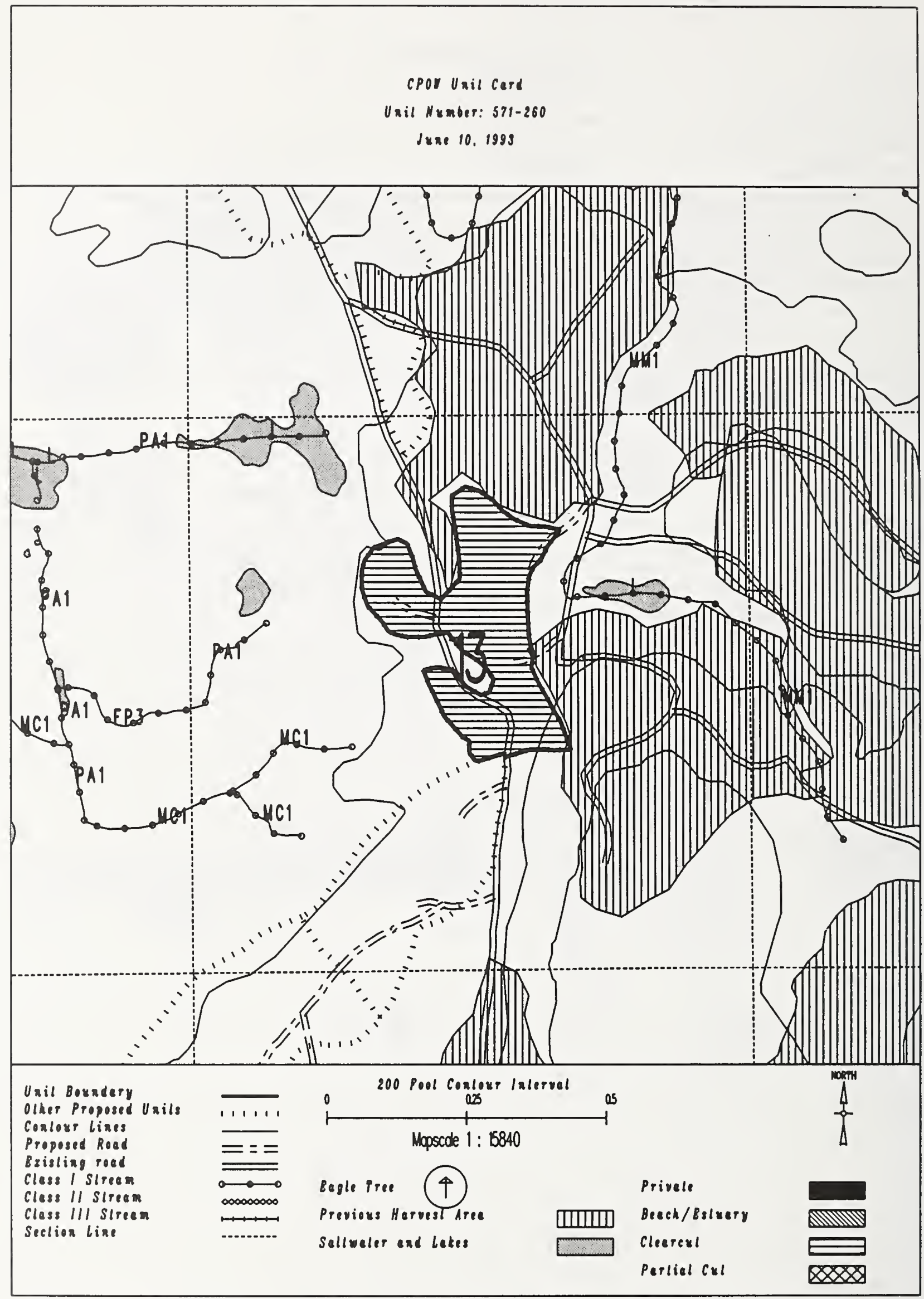


Unit $571-266$

Planned acres 56

Estimated volume (mbf) 2795

Logging system slackline

silvicultural system clearcut

Forest type Mixed conifer
Alternatives considered F2 F3 F4

Quad CRGD4NES

Mgmt Area $\mathrm{K} 07$

WAA 1422

Photo 1290037

Aspect East

PHYSICAL DESCRIPTION

Volume class breakdown: VC4 $\quad 0$ acres VC5 $\quad 0$ acres VC6 $\quad 0$ acres VC7 55 acres

Elevation breakdown: $0-800 \mathrm{ft} .54$ acres $800-1200 \mathrm{ft} . \underline{0}$ acres $1200-1500 \mathrm{ft}$. 0 acres over $1500 \mathrm{ft}$. 0 acres Mass movement index: Low 0 acres Medium 13 acres High $\underline{41}$ acres Very High $\underline{0}$ acres

SOILS

This unit has high mass movement index soils. Partial log suspension required over these areas.(BMP13.9)

This unit contains 41 acres of slopes $>75 \%$.

TIMBER

There are no timber mitigation measures anticipated for this unit.

ENGINEERING

Very difficult road construction due to unstable, slope > $75 \%$ or extended steep grades.

May need to revise logging system to helicopter.

High mass movement index soils. Road construction must minimize landslide potential (BMP14).

The road into this unit crosses a $B 2$ channel. Meet stream and lake protection prescription requirements in TLMP

Draft Revision (1991a) for this process group.

slopes greater than $75 \%$ may require full bench construction and endhaul of waste (BMP14.7).

FISH/WATERSHED

Potential for additional $\mathrm{Class} 1 / 11$ streams within unit. May be necessary to place additional buffers within unit

in accordance with AHMU Handbook.

\section{HILDLIFE}

There are no wildlife mitigation measures anticipated for this unit.

\section{RECREATION / VISUALS}

This unit has a proposed VQO of MM and is not seen from any viewpoint identified by this project.

\section{LANDS}

There are no lands mitigation measures anticipated for this unit.

CULTURAL RESOURCES

There are no cultural resource mitigation measures anticipated for this unit.

GEOLOGY

Planned unit boundary/road location/logging system are designed to avoid damage to significant karst features.

Mitigation measures may apply. Unit layout/changes must be coordinated with Cave Resource Specialists. 


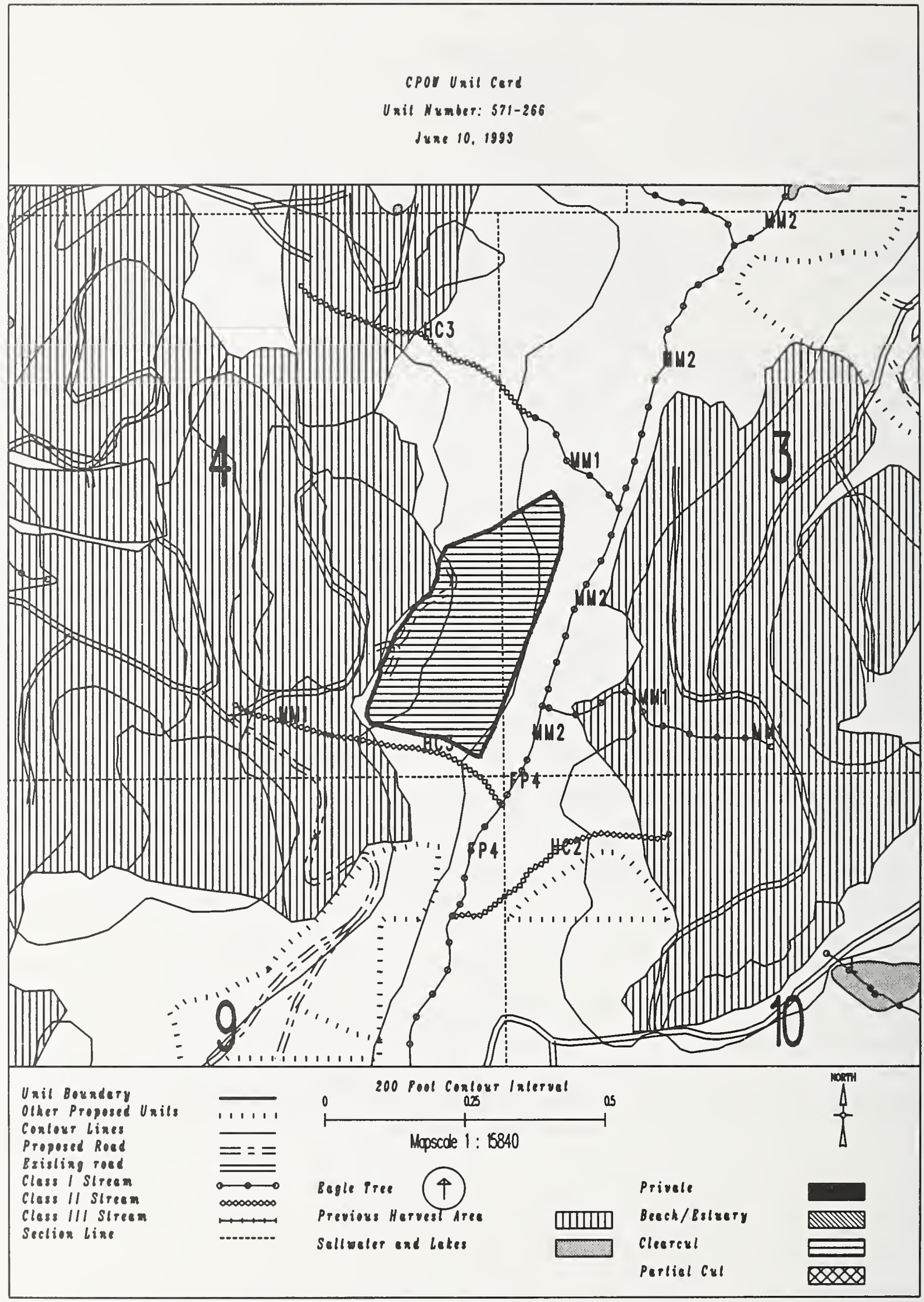


Unit $\quad 571-266$

Planned acres 56

Estimated volume (mbf) 2795

Logging system slackline

Silvicultural system Selective

Forest type Mixed conifer
Alternatives considered

Quad CRGD4NES

Mgmt Area $\mathrm{KO7}$

WAA 1422

Photo 1290037

Aspect East

PHYSICAL DESCRIPTION

Volume class breakdown: VC4 $\quad 0$ acres VC5 $\quad 0$ acres VC6 $\quad 0$ acres vC7 55 acres

Elevation breakdown: $0-800 \mathrm{ft} .54$ acres $800-1200 \mathrm{ft} . \quad 0$ acres $1200-1500 \mathrm{ft}$. 0 acres over $1500 \mathrm{ft}$. 0 acres

Mass movement index: Low $\_$acres Medium 13 acres High 41 acres Very High 0 acres

SOILS

This unit has high mass movement index soils. Partial log suspension required over these areas.(BMP13.9)

This unit contains 41 acres of slopes $>75 \%$.

TIMBER

Selective, uneven-aged harvest designed to meet specific resource concern.

\section{ENGINEER ING}

Very difficult road construction due to unstable, slopes over $75 \%$ or extended steep grades.

May need to revise logging system to helicopter.

High mass movement index soils. Road construction must minimize landslide potential (BMP14).

The road into this unit crosses a 12 channel. Meet stream and lake protection prescription requirements in TLMP

Draft Revision (1991a) for this process group.

slopes > 75\% may require full bench construction and endhaul of waste (BMP14.7).

FISH/WATERSHED

Potential for additional Class I/II streams within unit. May be necessary to place additional buffers within unit

in accordance with AHMU Handbook.

\section{WILDLIFE}

There are no wildlife mitigation measures anticipated for this unit.

RECREATION / VISUALS

This unit has a proposed vaO of MM and is not seen from any viewpoint identified by this project.

LANDS

There are no lands mitigation measures anticipated for this unit.

CULTURAL RESOURCES

There are no cultural resource mitigation measures anticipated for this unit.

GEOLOGY

Planned unit boundary/road location/logging system are designed to avoid damage to significant karst features.

Mitigation measures may apply. Unit layout/changes must be coordinated with Cave Resource Specialists. selective harvest prescribed to protect significant karst resources. 


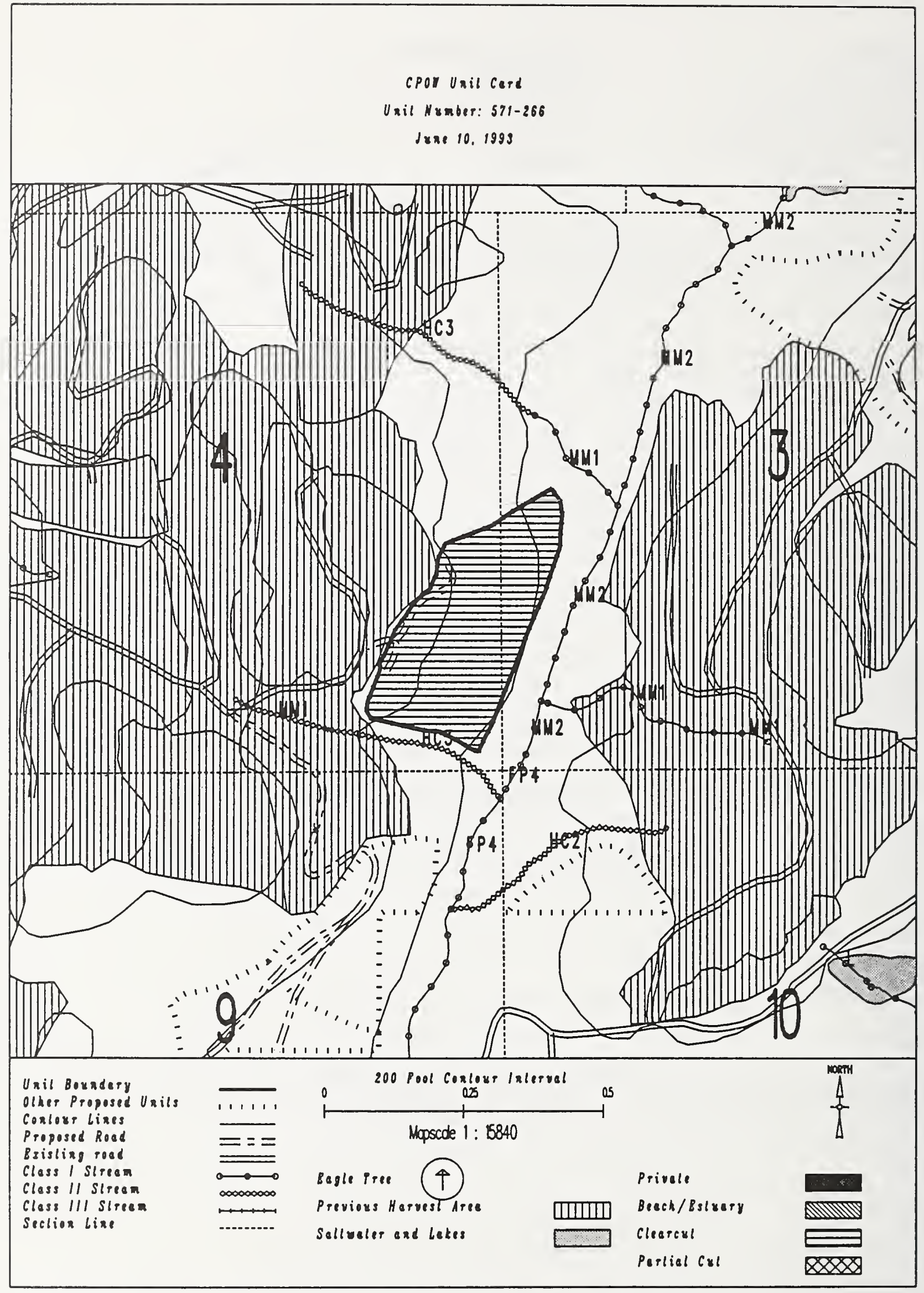


Unit $\quad \mathbf{5 7 1 - 2 6 7}$

Planned acres 25

Est imated volume (mbf) 1169

Logging system skyline

Silvicultural system Clearcut

Forest type Mixed conifer
Alternatives considered F2 F3 F4

Quad CRGD4NES

Mgmt Area $\mathrm{KOT}$

WAA 1422

Photo 1290168

Aspect East

\section{PHYSICAL DESCRIPTION}

Volume class breakdown: VC4 0 acres VC5 0 acres VC6 0 acres vc7 23 acres

Elevation breakdown: $0-800 \mathrm{ft} . \underline{20}$ acres $800-1200 \mathrm{ft} . \underline{0}$ acres $1200-1500 \mathrm{ft} . \underline{0}$ acres over $1500 \mathrm{ft}$. 0 Mass movement index: Low $\underline{0}$ acres Medium 23 acres High 1 acres Very High 0

\section{SOILS}

This unit contains 1 acres of slopes $>75 \%$.

\section{TIMBER}

Water quality streams may be present, where it is impractical to split yard. Full suspension required over all

streamcourses (BMPs13.9, 13.16).

\section{ENGINEERING}

There are no engineering mitigation measures anticipated for this unit.

\section{FISH/WATERSHED}

Potential impact on significant fishery habitat. May be necessary to expand planned buffer in accordance with AHMU Handbook.

This unit contains streams which have recently been classified/channel typed but require field verification.

\section{WILDLIFE}

There are no wildlife mitigation measures anticipated for this unit.

RECREATION / VISUALS

This unit has a proposed $V 0 O$ of $M M$ and is not seen from any viewpoint identified by this project.

\section{LANDS}

This unit adjacent to other ownership. Boundary establishment required prior to layout.

CULTURAL RESOURCES

There are no cultural resource mitigation measures anticipated for this unit.

GEOLOGY

Planned unit boundary/road location/logging system are designed to avoid damage to significant karst features. Mitigation measures may apply. Unit layout/changes must be coordinated with Cave Resource Specialists. 


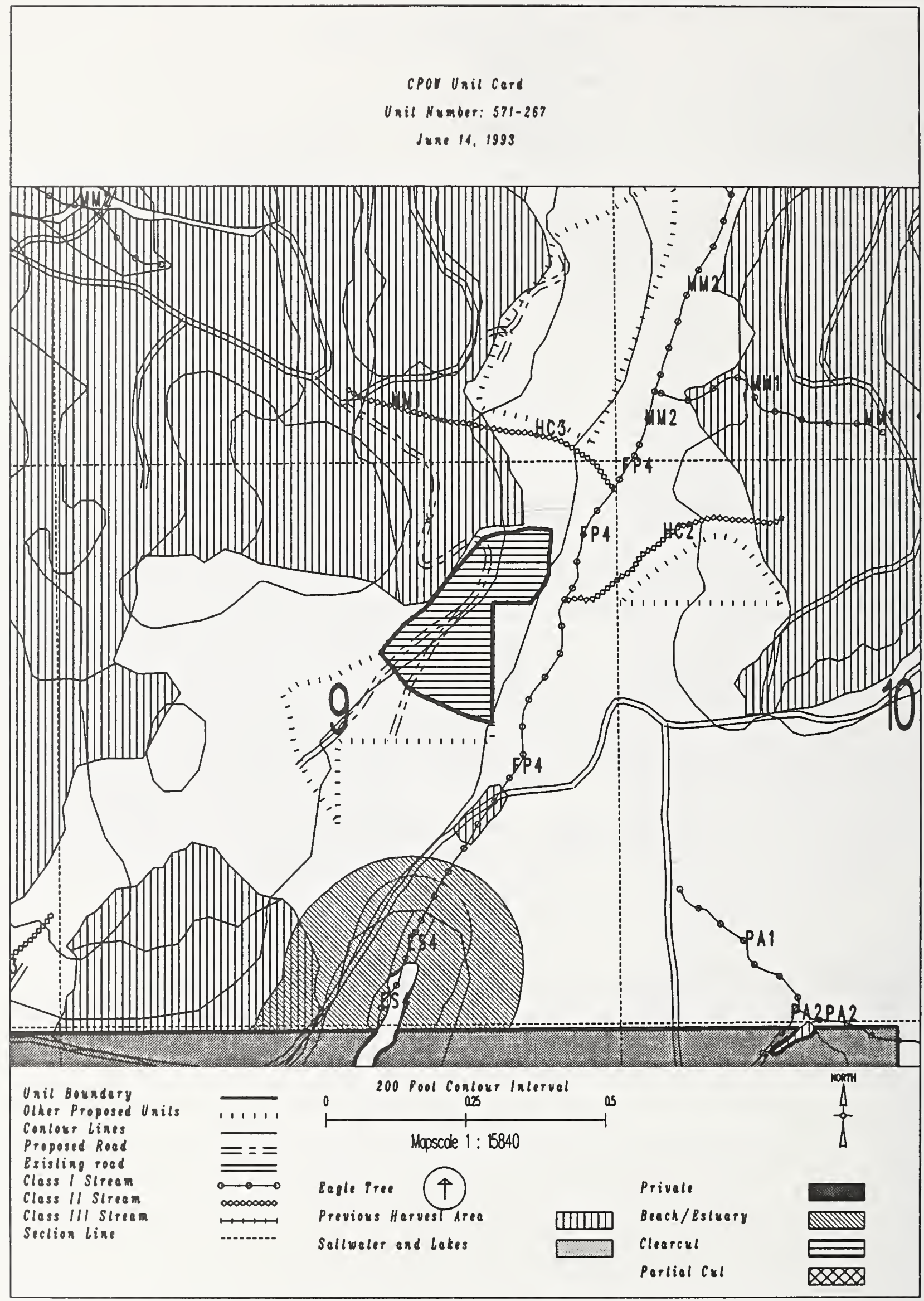


Unit 571-267

Planned acres $\underline{25}$

Est imated volume (mbf) 1169

Logging system skyline

Silvicultural system Selective

Forest type Mixed conifer
Alternatives considered F5

PHYSICAL DESCRIPTION

Volume class breakdown: VC4 0 acres VC5 $\quad 0$ acres vc6 $\quad 0$ acres vc7 23 acres

Elevation breakdown: $0-800 \mathrm{ft} . \underline{20}$ acres $800-1200 \mathrm{ft} . \underline{0}$ acres $1200-1500 \mathrm{ft} . \underline{0}$ acres over $1500 \mathrm{ft}$. 0 Mass movement index: Low 0 acres Medium 23 acres High 1 acres Very High 0 acres

SOILS

This unit contains 1 acres of slopes > $75 \%$.

TIMBER

Selective, uneven-aged harvest designed to meet specific resource concern.

Water quality streams may be present, where it is impractical to split yard. Full suspension required over all

streamcourses (BMPs13.9, 13.16).

\section{ENGINEERING}

There are no engineering mitigation measures anticipated for this unit.

\section{FISH/WATERSHED}

Potential impact on significant fishery habitat. May be necessary to expand planned buffer in accordance with AHMU Handbook.

This unit contains streams which have recently been classified/channel typed but require field verification.

WILDLIFE

There are no wildlife mitigation measures anticipated for this unit.

RECREATION / VISUALS

This unit has a proposed voo of MM and is not seen from any viewpoint identified by this project.

LANDS

This unit adjacent to other ownership. Boundary establishment required prior to layout.

CULTURAL RESOURCES

There are no cultural resource mitigation measures anticipated for this unit.

GEOLOGY

Planned unit boundary/road location/logging system are designed to avoid damage to significant karst features.

Mitigation measures may apply. Unit layout/changes must be coordinated with Cave Resource Specialists.

Selective harvest prescribed to protect significant karst resources. 


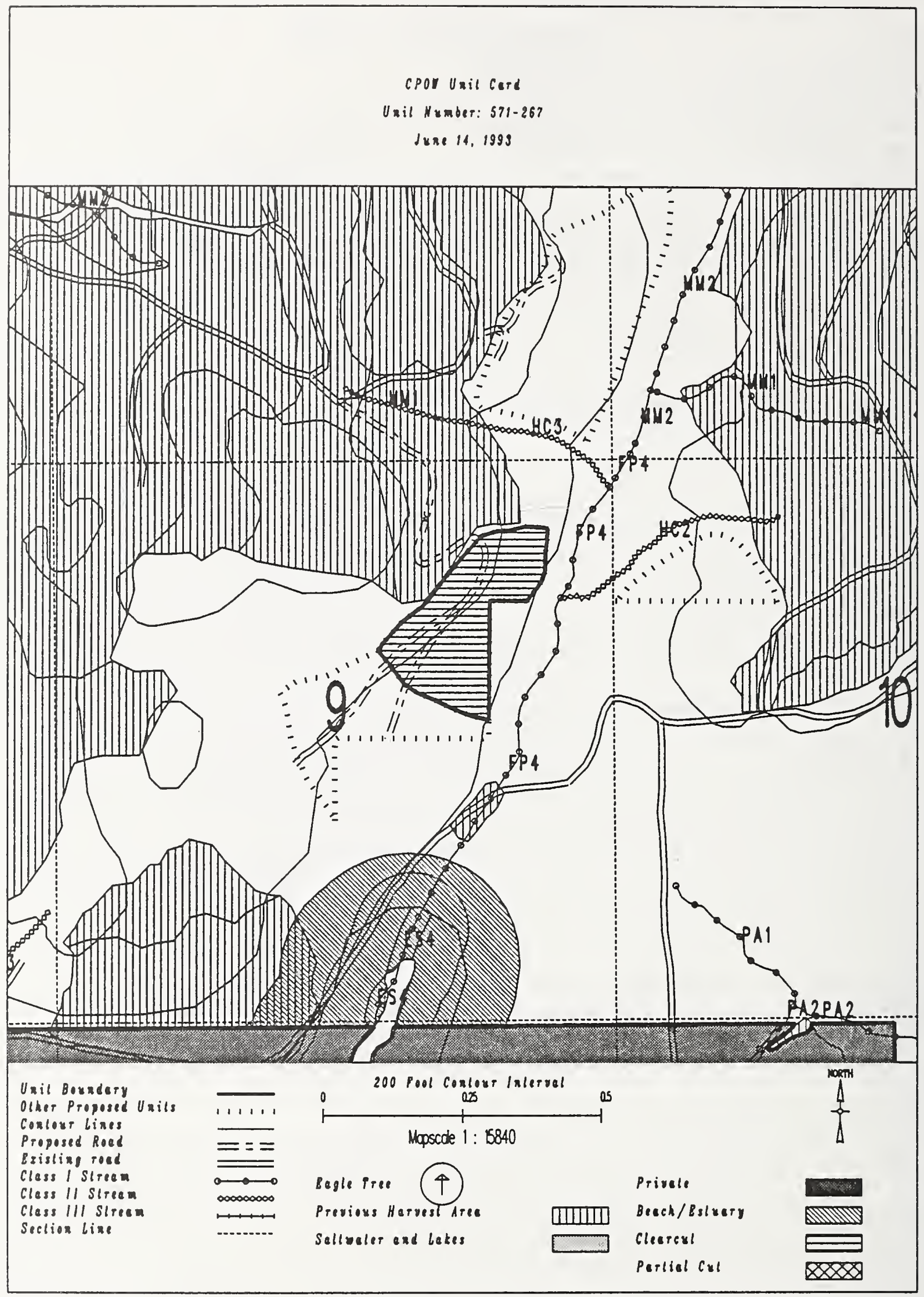


Unit $571-268$

Planned acres 19

Est imated volume (mbf) 1067

Logging system skyline

silvicultural system clearcut

Forest type spruce
Al ternatives considered F2 F3 F4

Quad CRGD4NES

Mgmt Area $\mathrm{KOT}$

WAA 1422

Photo 1290168

Aspect East

PHYSICAL DESCRIPTION

Volume class breakdown: VC4 $\quad 0$ acres VC5 $\quad 0$ acres VC6 $\quad 0$ acres vc7 21 acres

Elevation breakdown: $0-800 \mathrm{ft} .18$ acres $800-1200 \mathrm{ft} . \quad 0$ acres $1200-1500 \mathrm{ft}$. 0 acres over $1500 \mathrm{ft}$. 0 acres Mass movement index: Low 0 acres Medium 19 acres High 0 acres Very High 0

SOILS

There are no soils mitigation measures anticipated for this unit.

TIMBER

Water quality streams may be present, where it is impractical to split yard. Full suspension required over all streamcourses (BMPs13.9, 13.16).

ENGINEER ING

There are no engineering mitigation measures anticipated for this unit.

FISH/WATERSHED

Potential impact on significant fishery habitat. May be necessary to expand planned buffer in accordance with AHMU Handbook.

Proposed stream buffers may need to be modified to meet AHMU Handbook standards.

This unit contains streams which have recently been classified/channel typed but require field verification.

WILDLIFE

There are no wildlife mitigation measures anticipated for this unit.

RECREATION / VISUALS

This unit has a proposed vQo of MM and is not seen from any viewpoint identified by this project.

LANDS

This unit adjacent to other ownership. Boundary establishment required prior to layout.

CULTURAL RESOURCES

There are no cultural resource mitigation measures anticipated for this unit.

GEOLOGY

This unit is underlain with karst, although no significant features have yet been identified. 


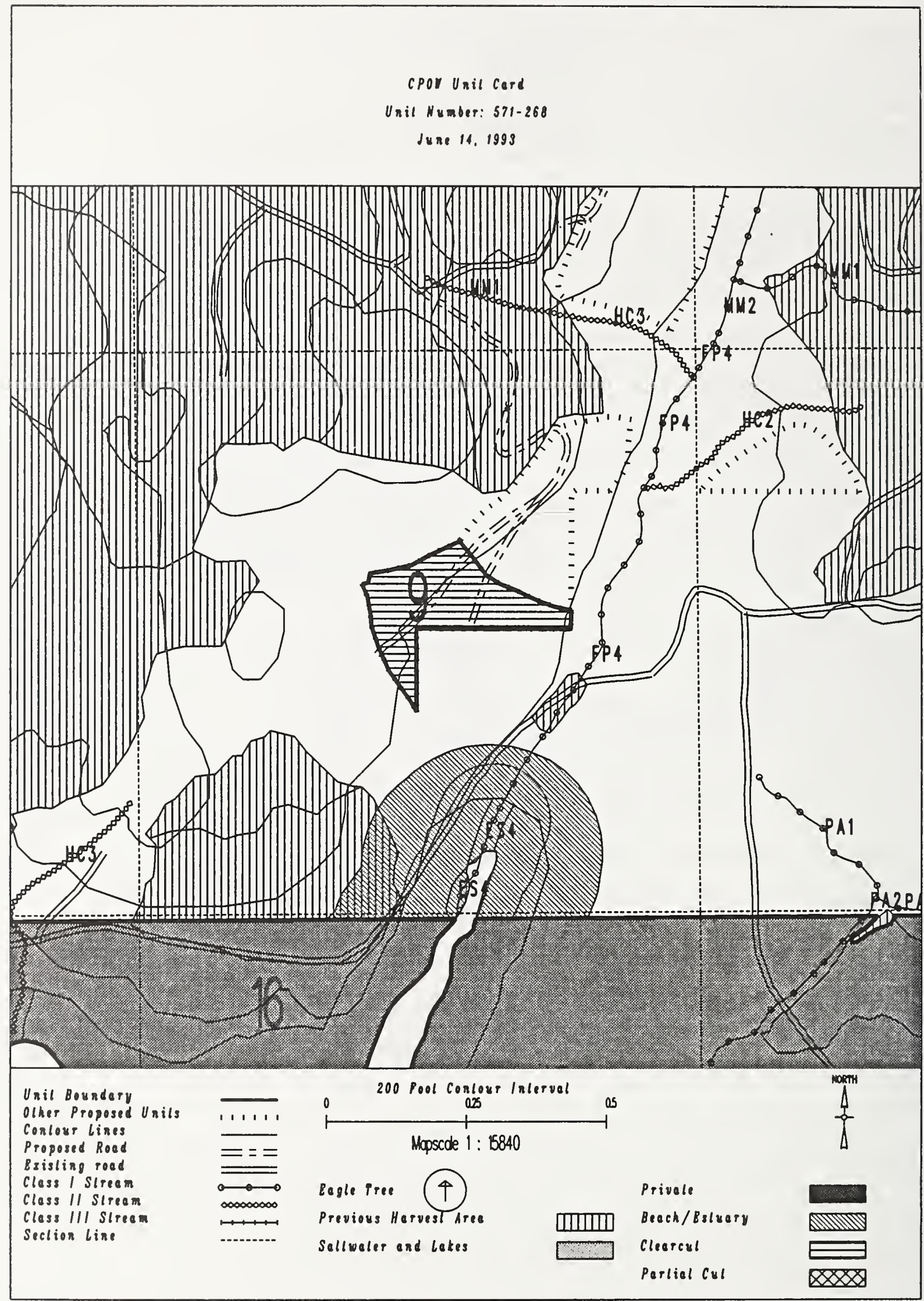


Unit $\quad \mathbf{5 7 1 - 2 6 8}$

Planned acres 19

Est imated volume (mbf) 1067

Logging system skyline

silvicultural system selective

Forest type spruce
Alternatives considered F5

Quad CRGD4NES

Mgmt Area $\mathrm{KO7}$

WAA 1422

Photo 1290168

Aspect East

PHYSICAL DESCRIPTION

Volume class breakdown: VC4 $\quad 0$ acres VC5 $\quad 0$ acres VC6 $\quad 0$ acres VC7 21 acres

Elevation breakdown: $0-800 \mathrm{ft} . \underline{18}$ acres $800-1200 \mathrm{ft} . \underline{0}_{0}$ acres $1200-1500 \mathrm{ft} . \underline{0}$ acres over $1500 \mathrm{ft} . \underline{0}$ acres Mass movement index: Low $\_$acres Medium 19 acres High $\underline{0}$ acres Very High 0

SOILS

There are no soils mitigation measures anticipated for this unit.

TIMBER

Selective, uneven-aged harvest designed to meet specific resource concern.

Water quality streams may be present, where it is impractical to split yard. Full suspension required over all streamcourses (BMPs13.9, 13.16).

\section{ENGINEERING}

There are no engineering mitigation measures anticipated for this unit.

FISH/WATERSHED

Potential impact on significant fishery habitat. May be necessary to expand planned buffer in accordance with AHMU Handbook.

Proposed stream buffers may need to be modified to meet AHMU Handbook standards.

This unit contains streams which have recently been classified/channel typed but require field verification.

WILDLIFE

Selective harvest prescribed to preserve goshawk foraging habitat/other objectives identified by District IDT.

RECREATION / VISUALS

This unit has a proposed vQO of MM and is not seen from any viewpoint identified by this project.

\section{LANDS}

This unit adjacent to other ownership. Boundary establishment required prior to layout.

\section{CULTURAL RESOURCES}

There are no cultural resource mitigation measures anticipated for this unit.

GEOLOGY

This unit is underlain with karst, although no significant features have yet been identified. 


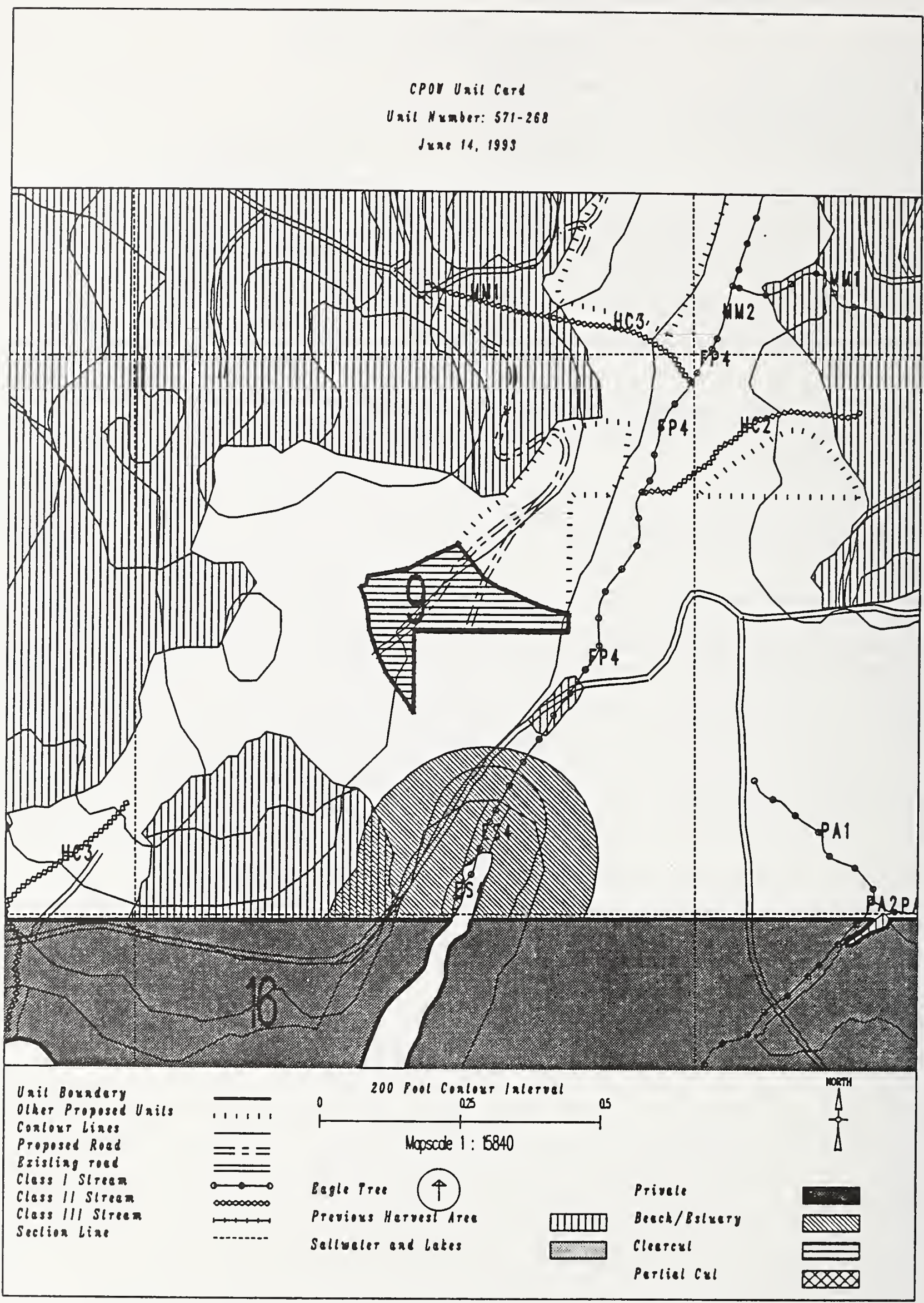


Unit $\quad 571-274$

Planned acres 29

Estimated volume (mbf) 1270

Logging system Highlead

silvicultural system clearcut

Forest type Mixed conifer

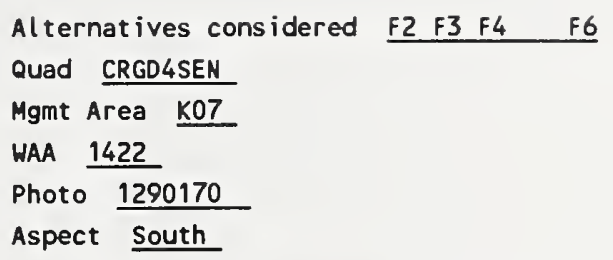

PHYSICAL DESCRIPTION

Volume class breakdown: vC4 0 acres VC5 0 acres vc6 $\quad 0$ acres vc7 25 acres

Elevation breakdown: $0-800 \mathrm{ft} . \underline{26}$ acres $800-1200 \mathrm{ft} . \underline{0}$ acres $1200-1500 \mathrm{ft} . \underline{0}$ acres over $1500 \mathrm{ft}$. 0 Mass movement index: Low 0 acres Medium 28 acres High 0 acres Very High 0 acres

SOILS

There are no soils mitigation measures anticipated for this unit.

TIMBER

There are no timber mitigation measures anticipated for this unit.

ENGINEERING

There are no engineering mitigation measures anticipated for this unit.

FISH/WATERSHED

This unit contains streams which have recently been classified/channel typed but require field verification.

WILDLIFE

There are no wildlife mitigation measures anticipated for this unit.

RECREATION / VISUALS

The unit has a proposed vaO of MM within the viewshed of Kussan Point

as viewed from 1 mile from west coast of Prince of Wales.

\section{LANDS}

There are no lands mitigation measures anticipated for this unit.

CULTURAL RESOURCES

There are no cultural resource mitigation measures anticipated for this unit.

GEOLOGY

There are no karst mitigation measures anticipated for this unit. 


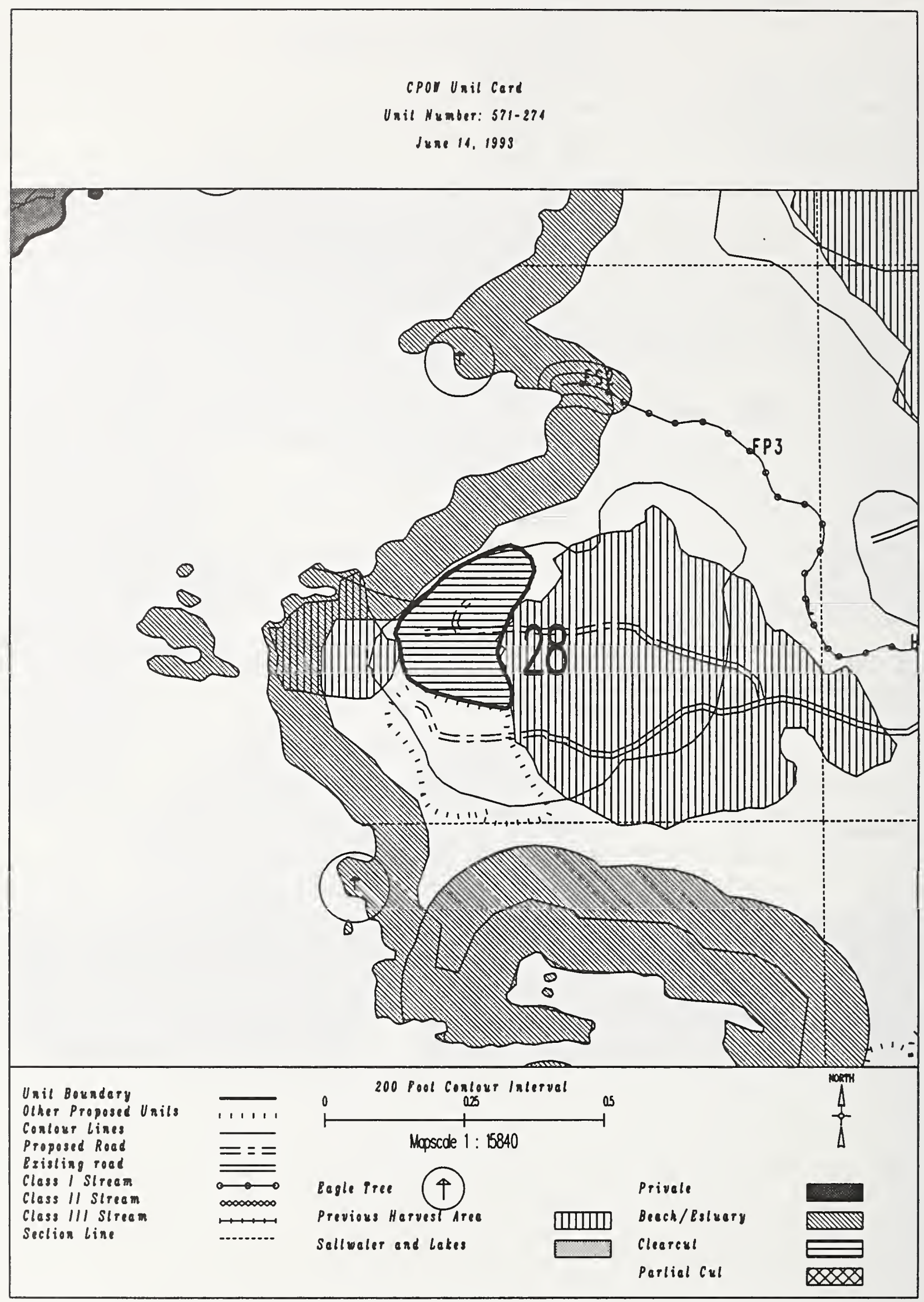


Unit $572-211$

Planned acres 89

Estimated volume (mbf) 1761

Logging system skyline

silvicultural system clearcut

Forest type Hemlock
Alternatives considered F2 F3 F4 F5 F6

Quad CRGD3NWN

Mgmt Area K09

HAA 1420

Photo 690156

Aspect West

\section{PHYSICAL DESCR IPTION}

Volume class breakdown: VC4 55 acres vC5 17 acres vC6 $\quad 0$ acres VC7 $\quad 0$ acres

Elevation breakdown: $0-800 \mathrm{ft} . \underline{88}$ acres $800-1200 \mathrm{ft} . \underline{0}$ acres $1200-1500 \mathrm{ft}$. 0 acres over $1500 \mathrm{ft}$. 0 acres Mass movement index: Low 37 acres Medium 0 acres High 31 acres Very High 0 acres

\section{SOILS}

This unit has high mass movement index soils. Partial log suspension required over these areas.(BMP13.9)

This unit contains 63 acres of forested wetlands. Site specific BMPs will be designed for selected approved

logging system and road construction practices. (BMPs 12.5, 13.9, 13.15).

\section{TIMBER}

There are no timber mitigation measures anticipated for this unit.

\section{ENGINEER ING}

High mass movement index soils. Road construction must minimize landslide potential (BMP14).

\section{FISH/HATERSHED}

There are no fishery mitigation measures anticipated for this unit.

\section{WILDLIFE}

Maintain diversity within unit by leaving 1-5 acre-sized islands of green trees at a rate of 1 acre of island for every 20 acres harvested. Leave islands must be compatible with logging system and safe working conditions.

RECREATION / VISUALS

This unit has a proposed VQO of MM and is not seen from any viewpoint identified by this project.

\section{LANDS}

This unit adjacent to other ownership. Boundary establishment required prior to layout.

CULTURAL RESOURCES

There are no cultural resource mitigation measures anticipated for this unit. 


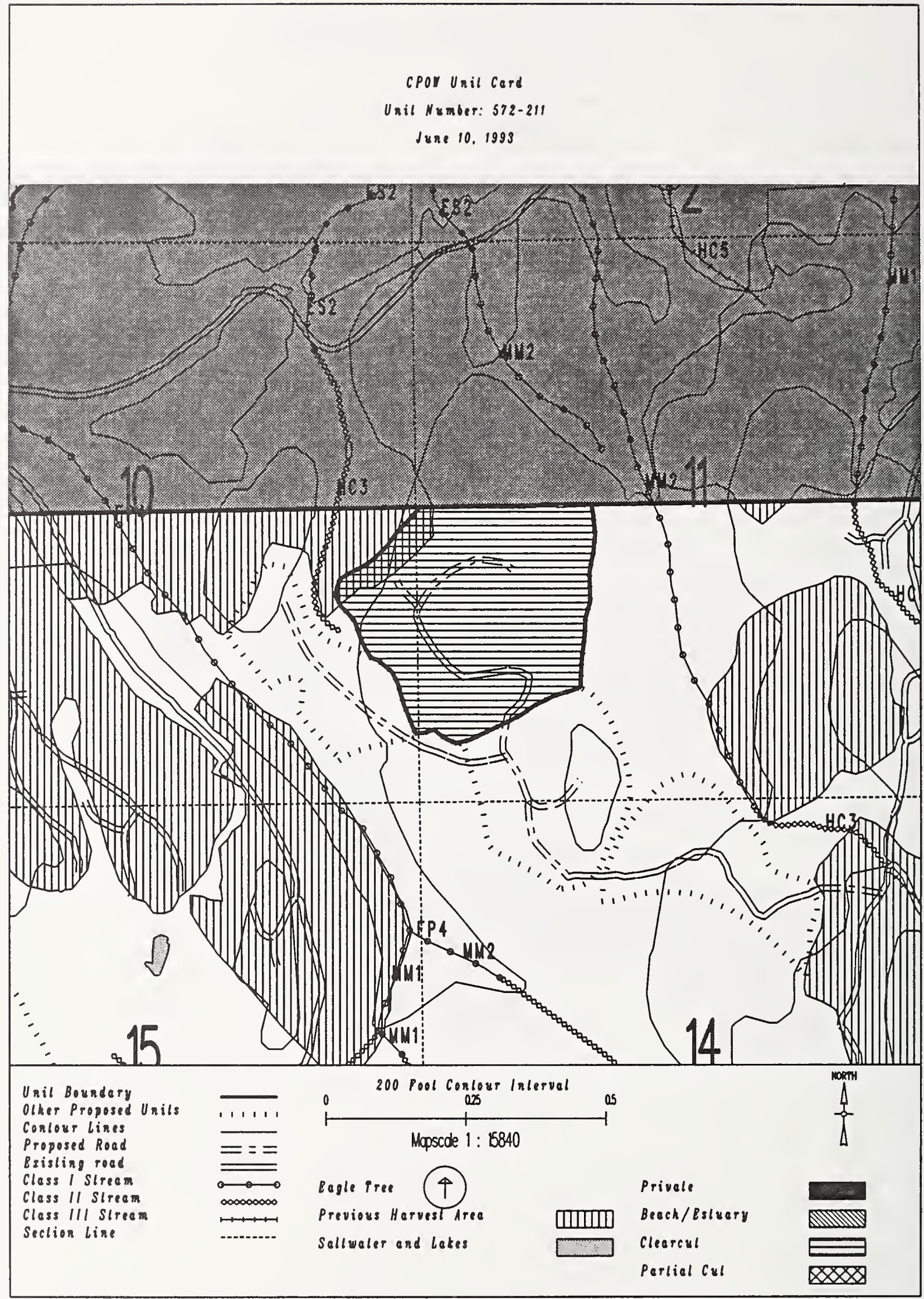


Unit $\underline{572-212}$

Planned acres 47

Estimated volume (mbf)

logging system skyline

silvicultural system clearcut

Forest type Hemlock
Alternatives considered

Quad CRGD3NUN

Mgmt Area $\underline{\mathrm{KO9}}$

WAA 1420

Photo 690156

Aspect West

PHYSICAL DESCRIPTION

Volume class breakdown: VC4 41 acres vC5 $\quad 0$ acres vC6 $\quad 0$ acres vC7 0 acres

Elevation breakdown: $0-800 \mathrm{ft} . \underline{46}$ acres $800-1200 \mathrm{ft} . \underline{0}$ acres $1200-1500 \mathrm{ft} . \underline{0}$ acres over $1500 \mathrm{ft}$. 0 Mass movement index:. Low 20 acres Medium $\underline{0}$ acres High 22 acres Very High 0 acres

SOILS

This unit has high mass movement index soils. Partial log suspension required over these areas. (BMP13.9)

This unit contains 36 acres of forested wetlands. Site specific BMPs will be designed for selected approved

logging system and road construction practices. (BMPs 12.5, 13.9, 13.15).

TIMBER

Potential for shovel logging on 28 acres, if soil and water quality protected (BMP13.7)

ENG INEER ING

High mass movement index soils. Road construction must minimize landslide potential (BMP14).

\section{FISH/HATERSHED}

There are no fishery mitigation measures anticipated for this unit.

HILDL IFE

There are no wildlife mitigation measures anticipated for this unit.

RECREATION / VISUALS

This unit has a proposed VQO of MM and is not seen from any viewpoint identified by this project.

\section{LANDS}

There are no lands mitigation measures anticipated for this unit.

CULTURAL RESOURCES

There are no cultural resource mitigation measures anticipated for this unit.

GEOLOGY

There are no karst mitigation measures anticipated for this unit. 


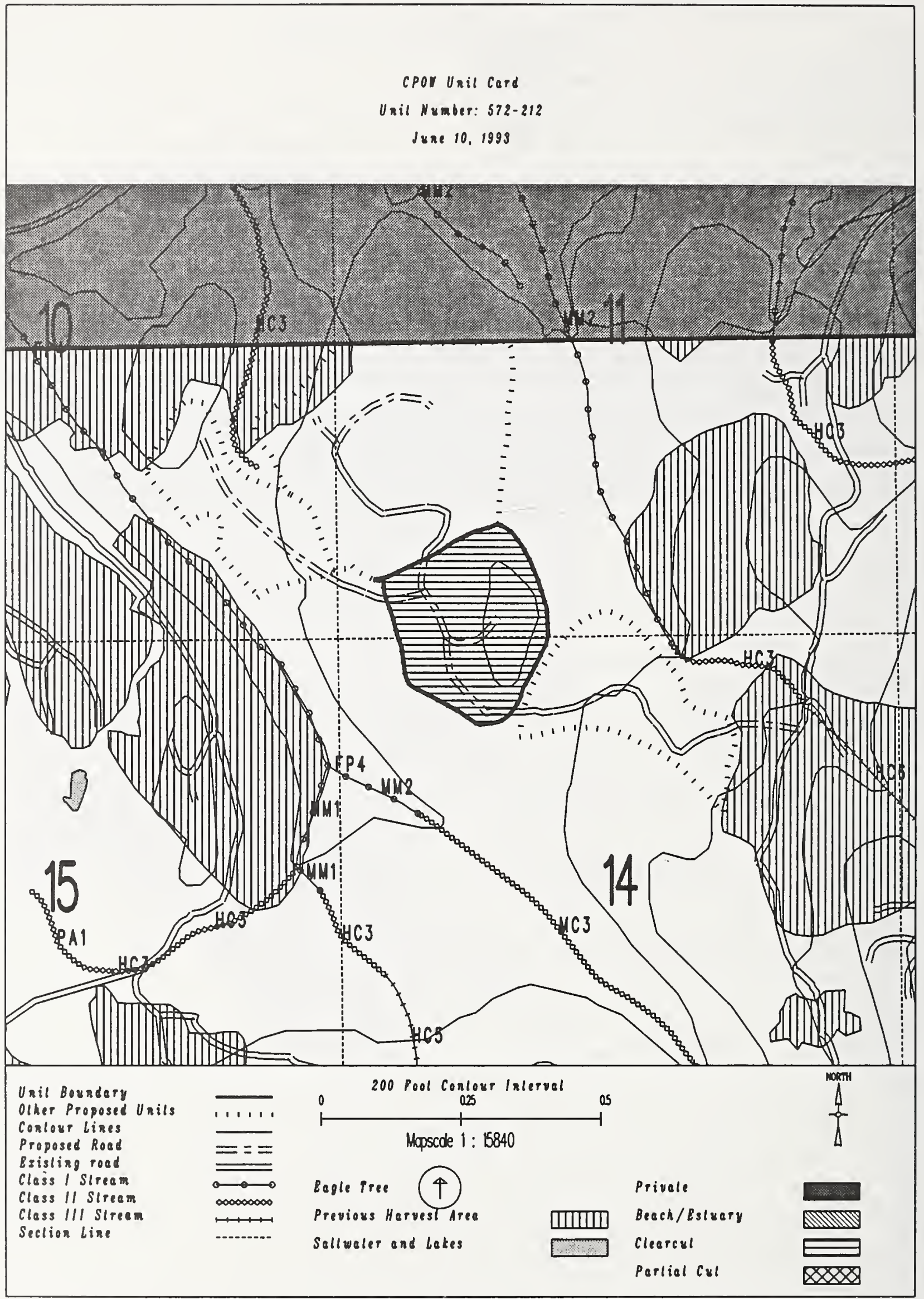


Unit 572-221

Planned acres 39

Estimated volume (mbf) 315

Logging system skyline

silvicultural system seed Tree

Forest type Hemlock

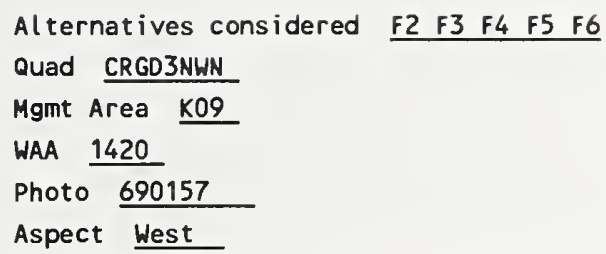

PHYSICAL DESCRIPTION

Volume class breakdown: VC4 16 acres vC5 $\quad 0$ acres vc6 $\quad 0$ acres vc7 $\quad 0$ acres

Elevation breakdown: $0-800 \mathrm{ft} . \underline{37}$ acres $800-1200 \mathrm{ft} . \underline{0}$ acres $1200-1500 \mathrm{ft} . \underline{0}$ acres over $1500 \mathrm{ft}$. 0 Mass movement index: Low 27 acres Medium 4 acres High 5 acres Very High 0 acres

\section{SOILS}

This unit has high mass movement index soils. Partial log suspension required over these areas.(BMP13.9) This unit contains 25 acres of forested wetlands. Site specific BMPs will be designed for selected approved logging system and road construction practices. (BMPS 12.5, 13.9, 13.15).

TIMBER

Seed tree harvest.

\section{ENGINEER ING}

There are no engineering mitigation measures anticipated for this unit.

\section{FISH/WATERSHED}

Potential for additional Class I/II streams within unit. May be necessary to place additional buffers within unit in accordance with AHMU Handbook.

\section{WILDLI FE}

There are no wildlife mitigation measures anticipated for this unit.

\section{RECREATION / VISUALS}

This unit has a proposed VQO of MM and is not seen from any viewpoint identified by this project.

\section{LANDS}

There are no lands mitigation measures anticipated for this unit.

\section{CULTURAL RESOURCES}

There are no cultural resource mitigation measures anticipated for this unit.

There are no karst mitigation measures anticipated for this unit. 
cpor Unil Cerd

Unil Number: 572-221

June 10, 1998

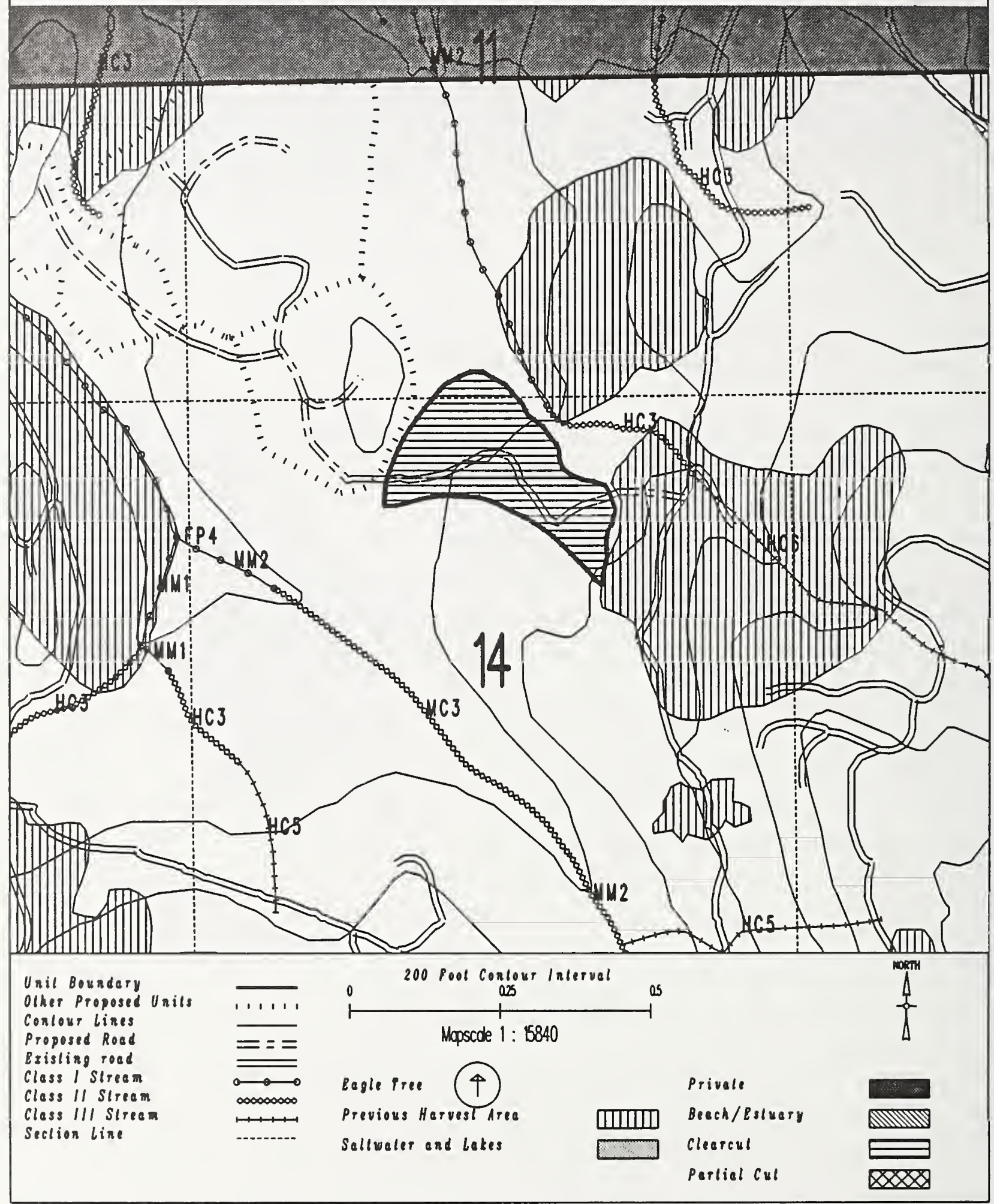




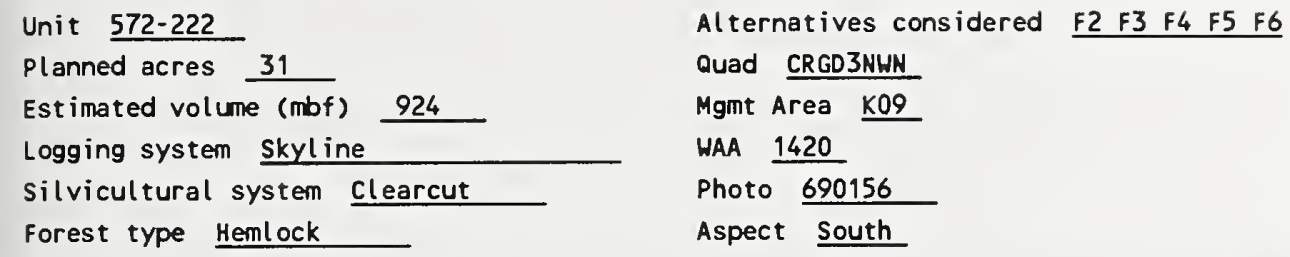

\section{WILDLIFE}

Maintain diversity within unit by leaving 1-5 acre-sized islands of green trees at a rate of 1 acre of island for every 20 acres harvested. Leave islands must be compatible with logging system and safe working conditions.

\section{RECREATION / VISUALS}

This unit has a proposed vao of MM and is not seen from any viewpoint identified by this project.

\section{LANDS}

There are no lands mitigation measures anticipated for this unit.

\section{CULTURAL RESOURCES}

There are no cultural resource mitigation measures anticipated for this unit. 


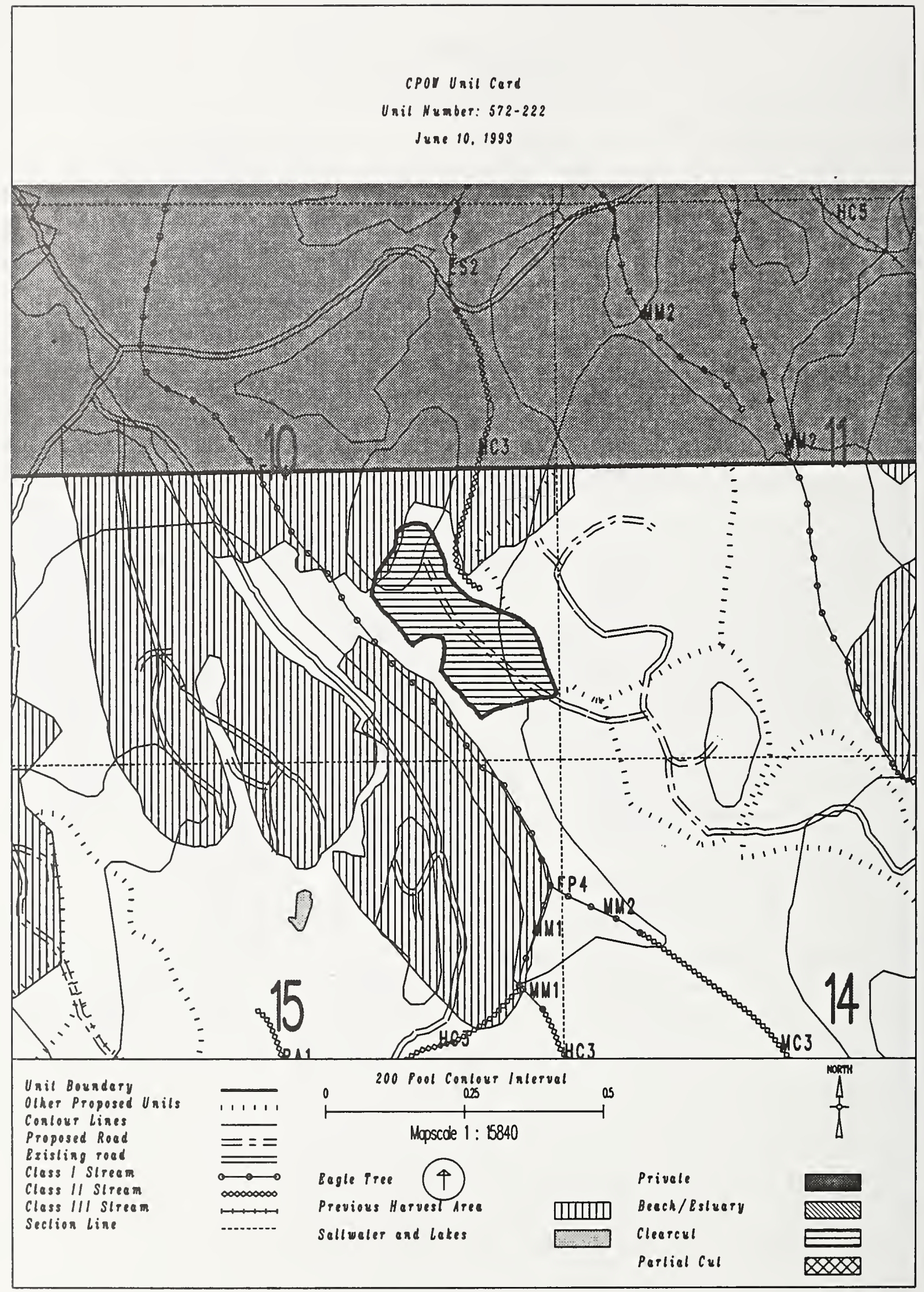


Unit $572-226$

Planned acres 26

Estimated volume (mbf)

Logging system skyline

silvicultural system clearcut

forest type Hemlock
Alternatives considered \begin{tabular}{lllll}
$\mathrm{F} 2$ & $\mathrm{~F} 3$ & $\mathrm{~F} 4$ & $\mathrm{~F} 6$ \\
\hline
\end{tabular}

Quad CRGD3NEN

Mgmt Area KO9

WAA 1420

Photo 1090101

Aspect North

\section{PHYSICAL DESCRIPTION}

Volume class breakdown: VC4 15 acres VC5 $\quad 3$ acres VC6 $\quad 8$ acres VC7 $\quad 0$ acres

Elevation breakdown: $0-800 \mathrm{ft} . \underline{23}$ acres $800-1200 \mathrm{ft} . \underline{0}$ acres $1200-1500 \mathrm{ft} . \underline{0}$ acres over $1500 \mathrm{ft}$. 0 acres Mass movement index: Low 0 acres Medium 7 acres High 5 acres Very High 0

\section{SOILS}

This unit has high mass movement index soils. Partial log suspension required over these areas.(BMP13.9)

This unit contains 16 acres of forested wetlands. Site specific BMPs will be designed for selected approved

logging system and road construction practices. (BMPs 12.5, 13.9, 13.15).

\section{TIMBER}

There are no timber mitigation measures anticipated for this unit.

\section{ENGINEERING}

The road into this unit crosses a $\underline{B 2}$ channel. Meet stream and lake protection prescription requirements in TLMP Draft Revision (1991a) for this process group.

\section{FISH/WATERSHED}

There are no fishery mitigation measures anticipated for this unit.

\section{WILDLIFE}

There are no wildlife mitigation measures anticipated for this unit.

\section{RECREATION / VISUALS}

The unit has a proposed vQO of $M$ within the viewshed of Baird Peak as viewed from ferry/cruise ship route (2-4 miles off shore).

\section{LANDS}

This unit adjacent to other ownership. Boundary establishment required prior to layout.

CULTURAL RESOURCES

There are no cultural resource mitigation measures anticipated for this unit.

GEOLOGY

There are no karst mitigation measures anticipated for this unit. 


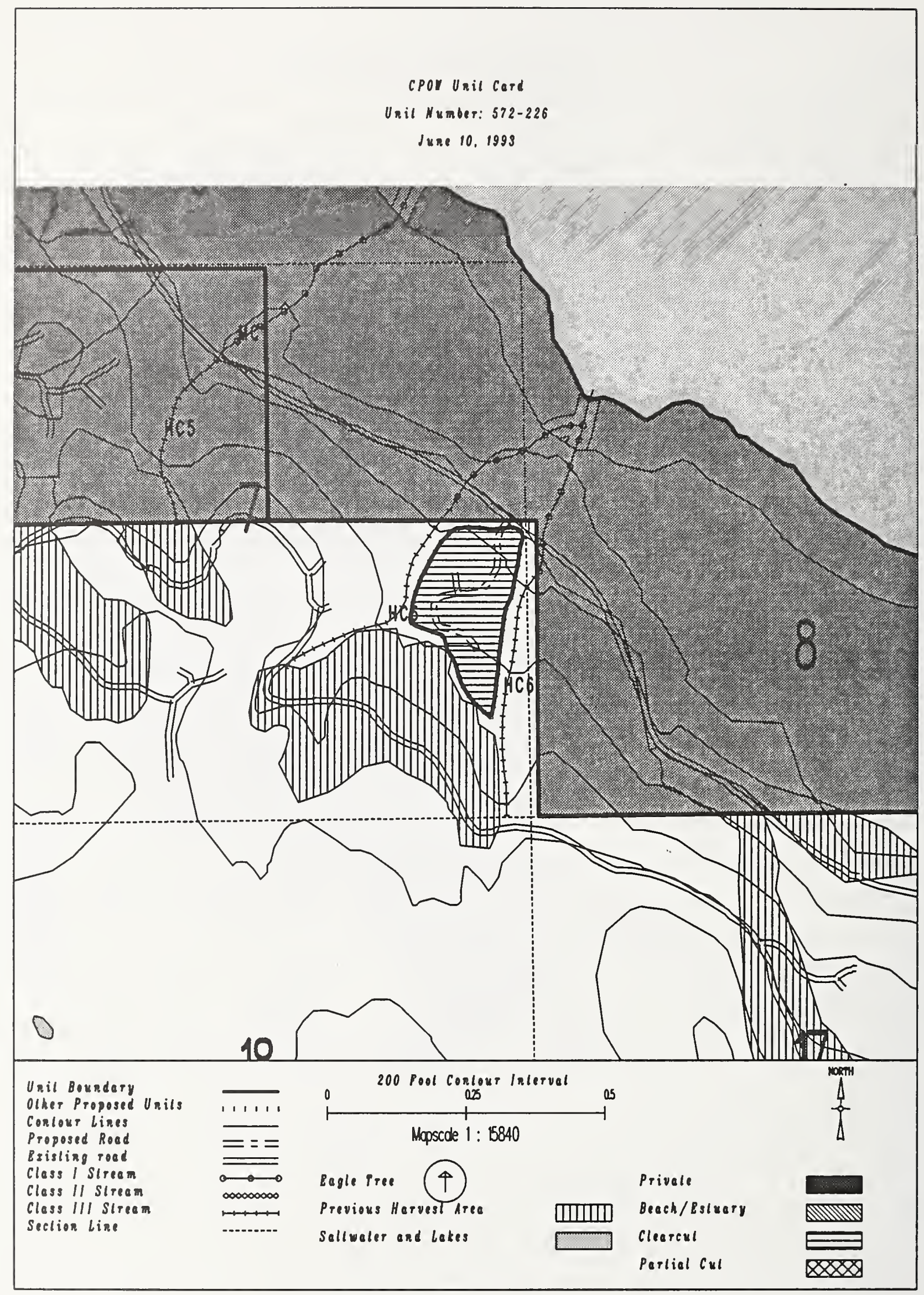


Unit 573-203

Planned acres 37

Estimated volume (mbf) 788

Logging system Highlead

silvicultural system clearcut

Forest type Hemlock
Alternatives considered F2 F3 F4 F5 F6

Quad CRGO3NWN

Mgmt Area $\mathrm{K} 08$

WAA 1421

Photo 990074

Aspect South

\section{PHYSICAL DESCRIPTION}

Volume class breakdown: VC4 33 acres vC5 $\quad 2$ acres vc6 $\quad 0$ acres vc7 $\quad 0$ acres

Elevation breakdown: $0-800 \mathrm{ft} . \underline{36}$ acres $800-1200 \mathrm{ft} . \underline{0}$ acres $1200-1500 \mathrm{ft} . \underline{0}$ acres over $1500 \mathrm{ft}$. 0 Mass movement index: Low 37 acres Medium 0 acres High 0 acres Very High 0 acres

\section{SOILS}

There are no soils mitigation measures anticipated for this unit.

\section{TIMBER}

There are no timber mitigation measures anticipated for this unit.

\section{ENGINEERING}

There are no engineering mitigation measures anticipated for this unit.

\section{FISH/WATERSHED}

This unit contains streams which have recently been classified/channel typed but require field verification.

\section{HILDLIFE}

Maintain diversity within unit by leaving 1-5 acre-sized islands of green trees at a rate of 1 acre of island for every 20 acres harvested. Leave islands must be compatible with logging system and safe working conditions.

RECREATION / VISUALS

This unit has a proposed VQO of MM and is not seen from any viewpoint identified by this project.

\section{LANDS}

There are no lands mitigation measures anticipated for this unit.

CULTURAL RESOURCES

There are no cultural resource mitigation measures anticipated for this unit. 


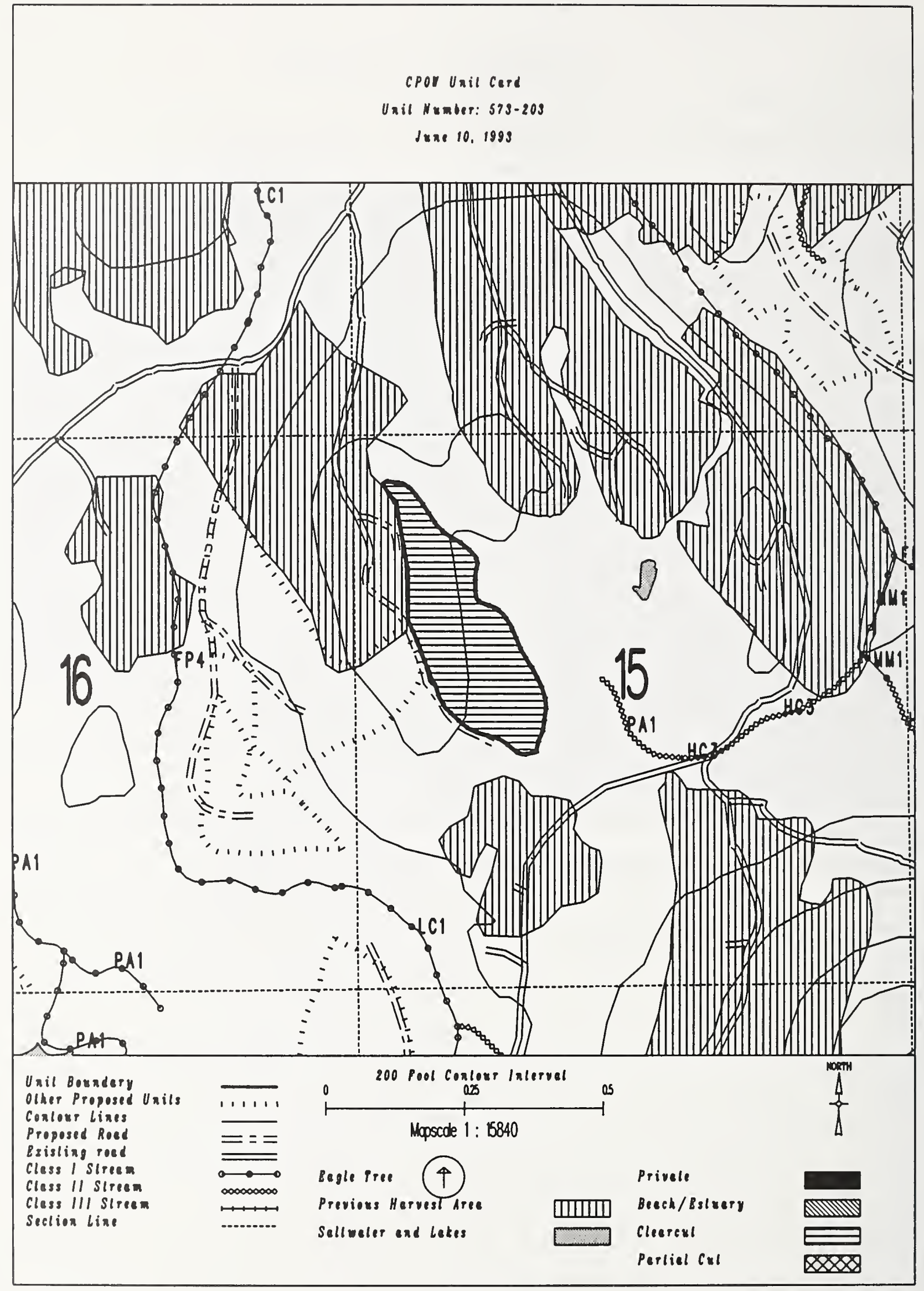


Unit 573-206

Planned acres 53

Estimated volume (mbf) 1334

Logging system Highlead

silvicultural system clearcut

Forest type Hemlock

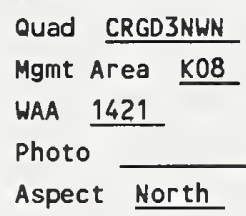

PHYSICAL DESCRIPTION

Volume class breakdown: VC4 22 acres VC5 26 acres VC6 $\quad 0$ acres vc7 $\quad 0$ acres

Elevation breakdown: $0-800 \mathrm{ft} . \underline{53}$ acres $800-1200 \mathrm{ft} . \quad 0$ acres $1200-1500 \mathrm{ft} . \underline{0}$ acres over $1500 \mathrm{ft}$. Mass movement index: Low 2 acres Medium 17 acres High 0 acres Very High 0 acres

SOILS

This unit contains 50 acres of forested wetlands. Site specific BMPs will be designed for selected approved logging system and road construction practices. (BMPs 12.5, 13.9, 13.15).

TIMBER

There are no timber mitigation measures anticipated for this unit.

ENGINEERING

There are no engineering mitigation measures anticipated for this unit.

FISH/WATERSHED

Proposed stream buffers may need to be modified to meet AHMU Handbook standards.

WILDLIFE

There are no wildlife mitigation measures anticipated for this unit.

RECREATION / VISUALS

This unit has a propesed VQO of MM and is not seen from any viewpoint identified by this project.

There are no lands mitigation measures anticipated for this unit.

There are no cultural resource mitigation measures anticipated for this unit. 


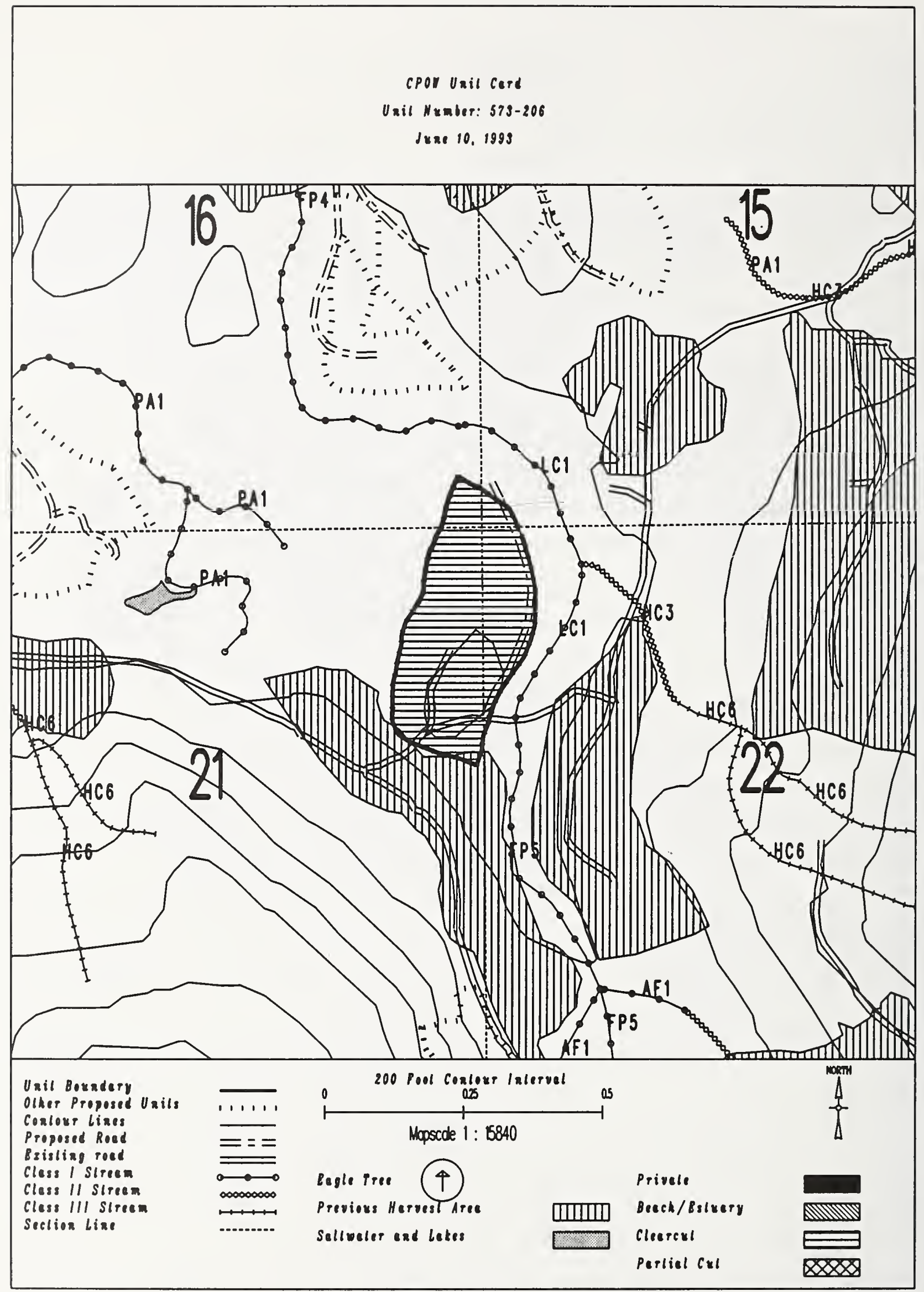


Unit $573-210$

Planned acres 21

Est imated volume (mbf) 595

Logging system Highlead

silvicultural system Clearcut

Forest type Mixed conifer
Alternatives considered

Quad CRGD3NHN

Mgmt Area $\mathrm{KO8}$

WAA 1421

Photo 990058

Aspect East

PHYSICAL DESCRIPTION

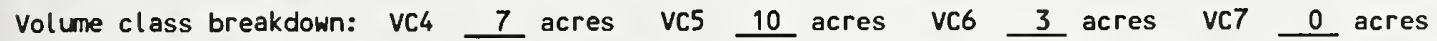

Elevation breakdown: $0-800 \mathrm{ft} . \underline{20}$ acres 800-1200 ft. 0 acres 1200-1500 ft. 0 acres over $1500 \mathrm{ft}$. 0 acres

Mass movement index: Low 9 acres Medium 2 acres High 0 acres Very High 0

SOILS

This unit contains 16 acres of forested wetlands. Site specific BMPs will be designed for selected approved

logging system and road construction practices. (BMPs 12.5, 13.9, 13.15).

TIMBER

Potential for shovel logging on 21 acres, if soil and water quality protected (BMP13.7)

\section{ENGINEER ING}

There are no engineering mitigation measures anticipated for this unit.

FISH/WATERSHED

Potential for additional Class $1 / 11$ streams within unit. May be necessary to place additional buffers within unit

in accordance with AHMU Handbook.

HILDLIFE

Harvest operations restricted to April 1 to October 31 to protect trumpeter swans on Barnes, Sweetwater Lakes.

\section{RECREATION / VISUALS}

This unit has a proposed voo of MM and is not seen from any viewpoint identified by this project.

LANDS

There are no lands mitigation measures anticipated for this unit.

CULTURAL RESOURCES

There are no cultural resource mitigation measures anticipated for this unit.

There are no karst mitigation measures anticipated for this unit. 


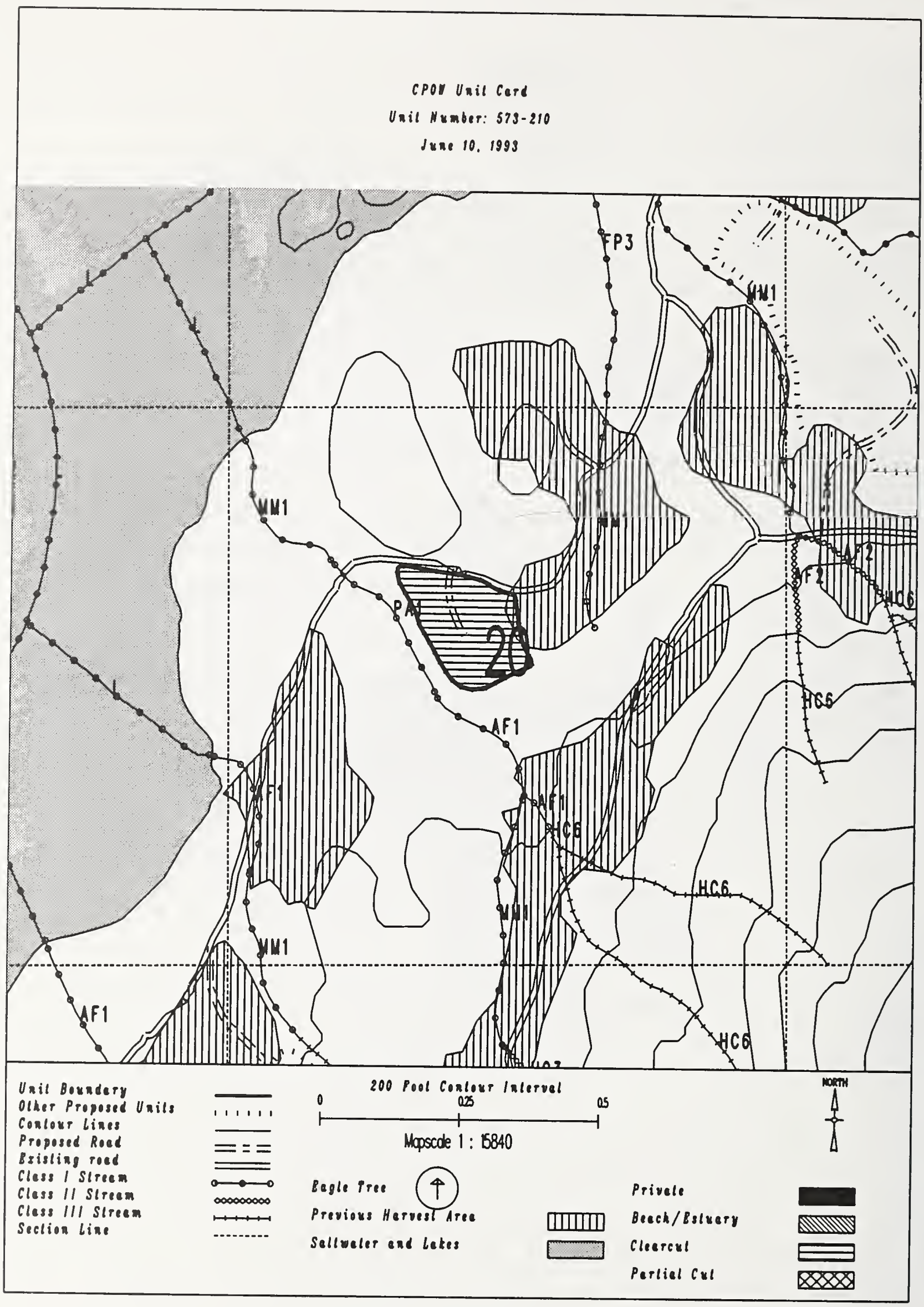


Unit 573-225

Planned acres 33

Estimated volume (mbf) 879

Logging system skyline

silvicultural system clearcut

Forest type Hemlock
Alternatives considered

Quad CRGD3NWN

Mgmt Area K08

WAA 1421

Photo 890106

Aspect South

PHYSICAL DESCRIPTION

Volume class breakdown: VC4 23 acres VC5 $\quad 1$ acres VC6 $\quad 9$ acres VC7 $\quad 0$ acres

Elevation breakdown: $0-800 \mathrm{ft} . \underline{33}$ acres $800-1200 \mathrm{ft} . \quad 0$ acres $1200-1500 \mathrm{ft}$. 0 acres over $1500 \mathrm{ft}$. 0 acres

Mass movement index: Low $\underline{0}$ acres Medium 2 acres High 16 acres Very High 0 acres

\section{SOILS}

This unit has high mass movement index soils. Partial log suspension required over these areas.(BMP13.9)

This unit contains 32 acres of forested wetlands. Site specific BMPs will be designed for selected approved

logging system and road construction practices. (BMPs 12.5, 13.9, 13.15).

This unit contains 1 acres of slopes > $75 \%$.

\section{TIMBER}

Potential for shovel logging on 20 acres, if soil and water quality protected (BMP13.7)

\section{ENGINEERING}

High mass movement index soils. Road construction must minimize landslide potential (BMP14).

\section{FISH/WATERSHED}

There are no fishery mitigation measures anticipated for this unit.

\section{WILDLIFE}

Harvest operations restricted to April 1 to October 31 to protect trumpeter swans on Barnes, Sweetwater Lakes.

RECREATION / VISUALS

This unit has a proposed Voo of $M M$ and is not seen from any viewpoint identified by this project.

\section{LANDS}

There are no lands mitigation measures anticipated for this unit.

\section{CULTURAL RESOURCES}

There are no cultural resource mitigation measures anticipated for this unit.

There are no karst mitigation measures anticipated for this unit. 


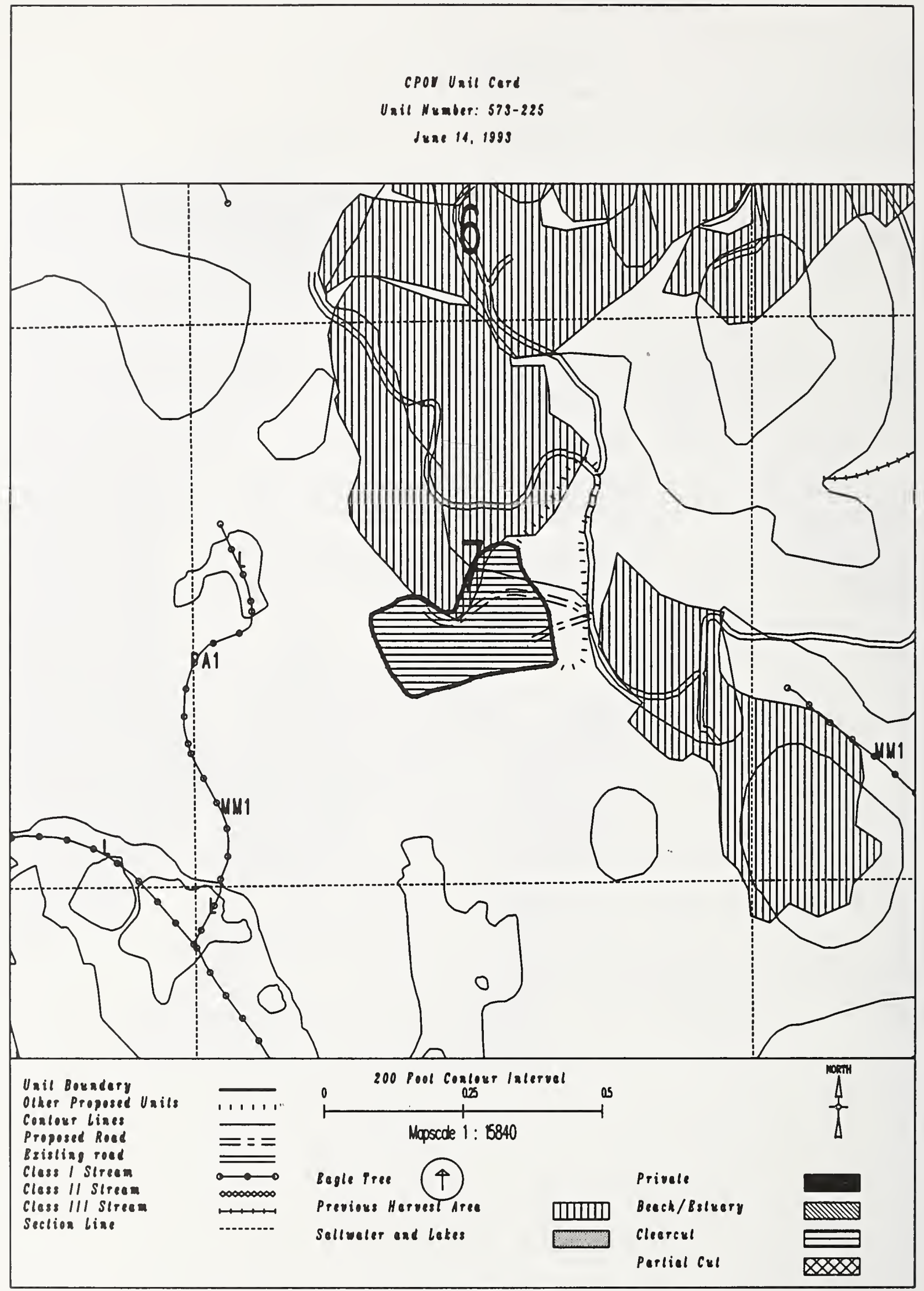


Unit 573-227

Planned acres 44

Estimated volume (mbf) 1159

Logging system skyline

silvicultural system clearcut

Forest type Hemlock
Alternat ives considered

F3

Mgmt Area $\mathrm{K08}$

WAA 1421

Photo

Aspect South

PHYSICAL DESCRIPTION

Volume class breakdown: VC4 $\underline{23}$ acres vc5 20 acres vc6 $\quad 0$ acres vc7 $\quad 0$ acres

Elevation breakdown: $0-800 \mathrm{ft} . \underline{42}$ acres $800-1200 \mathrm{ft} .{ }_{0}^{0}$ acres $1200-1500 \mathrm{ft} . \underline{0}$ acres over $1500 \mathrm{ft}$. 0 acres Mass movement index: Low 0 acres Medium $\_$acres High 26 acres Very High 0 acres

\section{SOILS}

This unit has high mass movement index soils. Partial log suspension required over these areas.(BMP13.9)

This unit contains 43 acres of forested wetlands. Site specific BMPs will be designed for selected approved logging system and road construction practices. (BMPs 12.5, 13.9, 13.15).

\section{TIMBER}

There are no timber mitigation measures anticipated for this unit.

\section{ENGINEER ING}

High mass movement index soils. Road construction must minimize landslide potential (BMP14).

The road into this unit crosses a $\underline{11}$ channel. Meet stream and lake protection prescription requirements in TLMP Draft Revision (1991a) for this process group.

\section{FISH/HATERSHED}

Potential for additional Class I/II streams within unit. May be necessary to place additional buffers within unit in accordance with AHMU Handbook.

\section{WILDLIFE}

There are no wildlife mitigation measures anticipated for this unit.

\section{RECREATION / VISUALS}

This unit has a proposed Voo of MM and is not seen from any viewpoint identified by this project.

\section{LANDS}

There are no lands mitigation measures anticipated for this unit.

CULTURAL RESOURCES

There are no cultural resource mitigation measures anticipated for this unit.

There are no karst mitigation measures anticipated for this unit. 


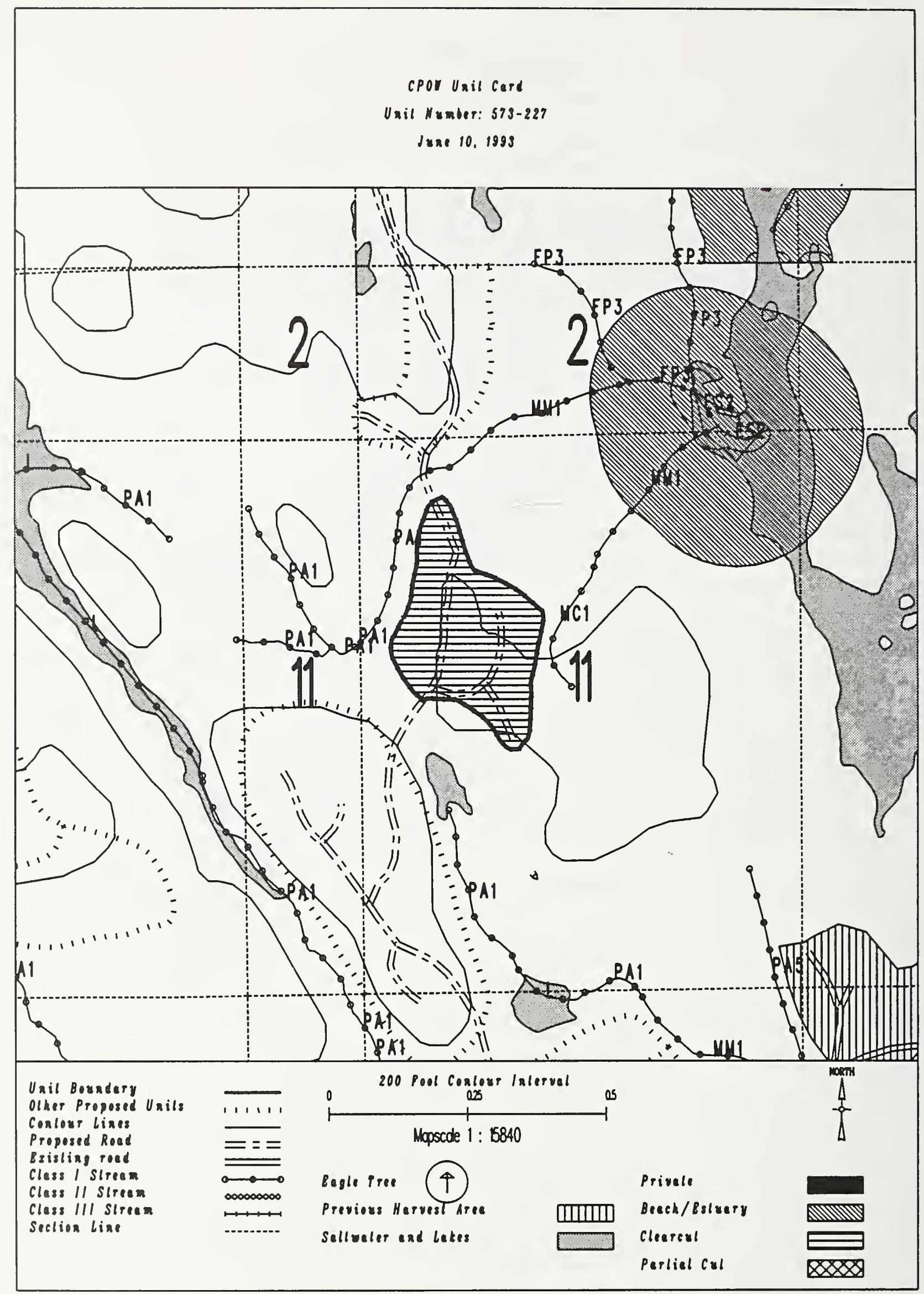


Unit $\quad$ 573-228

Planned acres 34

Estimated volume (mbf)

Logging system skyline

silvicultural system clearcut

Forest type Hemlock
Al ternat ives considered

Quad CRGD3NHN

Mgmt Area $\mathrm{KO8}$

WAA 1421

Photo 1190070

Aspect South

\section{PHYSICAL DESCRIPTION}

Volume class breakdown: VC4 11 acres VC5 23 acres vC6 $\quad 0$ acres vC7 $\quad 0$ acres

Elevation breakdown: $0-800 \mathrm{ft} . \underline{31}$ acres $800-1200 \mathrm{ft} . \underline{0}$ acres $1200-1500 \mathrm{ft}$. 0 acres over $1500 \mathrm{ft}$. 0 acres Mass movement index: Low 1 acres Medium 0 acres High 19 acres Very High 0 acres

\section{SOILS}

This unit has high mass movement index soils. Partial log suspension required over these areas.(BMP13.9)

This unit contains 32 acres of forested wetlands. Site specific BMPs will be designed for selected approved

logging system and road construction practices. (BMPs 12.5, 13.9, 13.15).

\section{TIMBER}

There are no timber mitigation measures anticipated for this unit.

\section{ENGINEER ING}

High mass movement index soils. Road construction must minimize landslide potential (BMP14).

\section{FISH/HATER SHED}

There are no fishery mitigation measures anticipated for this unit.

\section{WILDLIFE}

Harvest operations restricted to April 1 to October 31 to protect trumpeter swans on Barnes, Sweetwater Lakes.

\section{RECREATION / VISUALS}

This unit has a proposed VQO of MM and is not seen from any viewpoint identified by this project.

\section{LANDS}

There are no lands mitigation measures anticipated for this unit.

\section{CULTURAL RESOURCES}

There are no cultural resource mitigation measures anticipated for this unit.

There are no karst mitigation measures anticipated for this unit. 
CPOY Unil Cerd

Unil Number: 573-228

Juxe 10, 1993

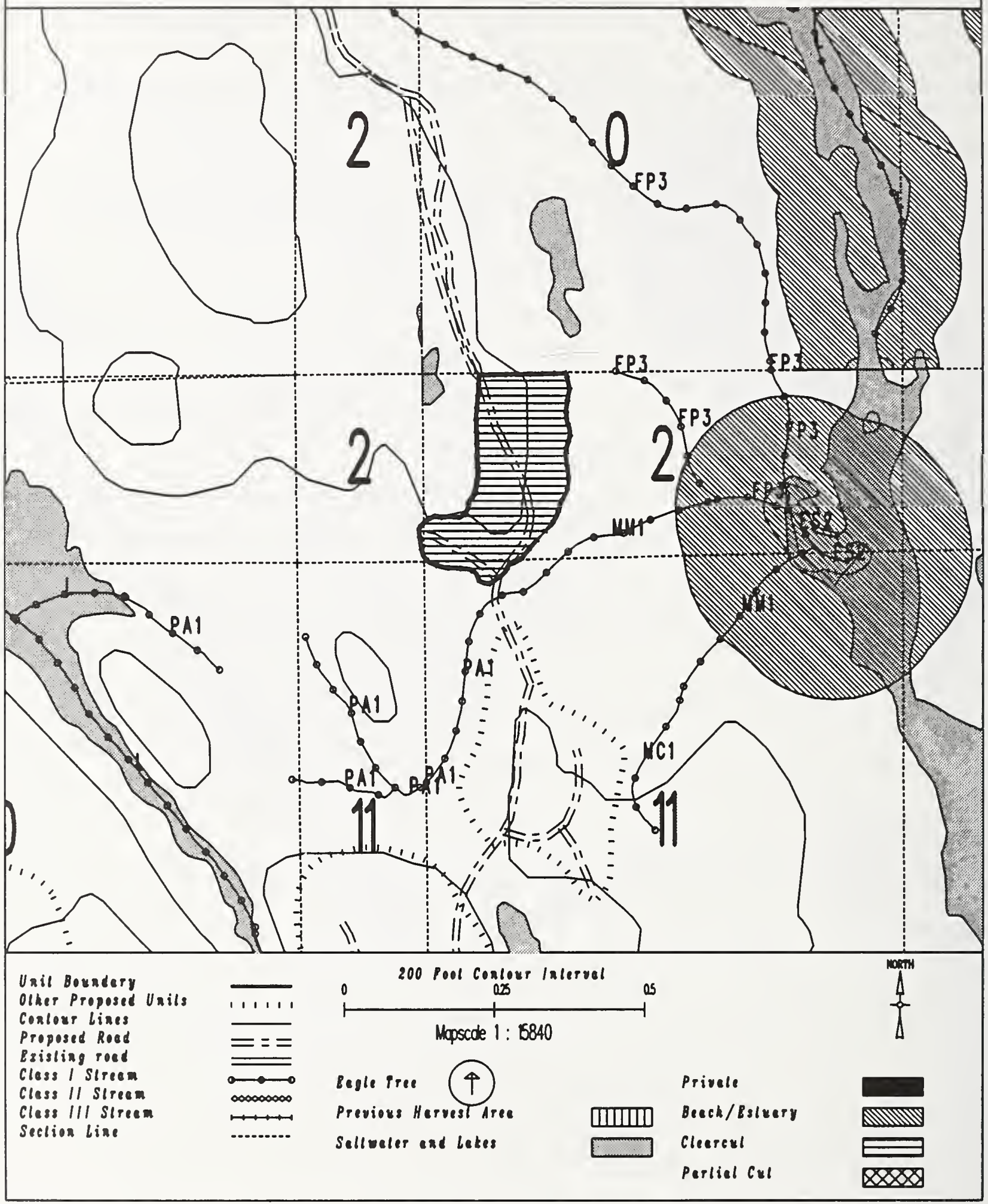


Unit $\quad 573-231$

Planned acres 40

Estimated volume (mbf) 1006

Logging system Highlead

silvicultural system clearcut

Forest type Mixed conifer
Alternatives considered

Quad CRGD3NWN

Mgmt Area $\mathrm{KO8}$

WAA 1421

Photo

Aspect East

PHYSICAL DESCRIPTION

Volume class breakdown: VC4 19 acres VC5 18 acres vC6 0 acres VC7 0

Elevation breakdown: $0-800 \mathrm{ft} . \quad 39$ acres $800-1200 \mathrm{ft} . \quad 0$ acres $1200-1500 \mathrm{ft}$. 0 acres over $1500 \mathrm{ft}$. 0 acres Mass movement index: Low 25 acres Medium 0 acres High 14 acres Very High 0

SOILS

This unit has high mass movement index soils. Partial log suspension required over these areas.(BMP13.9)

This unit contains 12 acres of forested wetlands. Site specific BMPs will be designed for selected approved logging system and road construction practices. (BMPs 12.5, 13.9, 13.15).

\section{TIMBER}

Potential for shovel logging on 12 acres, if soil and water quality protected (BMP13.7)

\section{ENGINEER ING}

High mass movement index soils. Road construction must minimize landslide potential (BMP14).

\section{FISH/WATERSHED}

There are no fishery mitigation measures anticipated for this unit.

\section{WI LDL IFE}

There are no wildlife mitigation measures anticipated for this unit.

RECREATION / VISUALS

The unit has a proposed VoO of PR within the viewshed of Sweetwater Lake as viewed from from centerline of lake.

\section{LANDS}

There are no lands mitigation measures anticipated for this unit.

CULTURAL RESOURCES

There are no cultural resource mitigation measures anticipated for this unit. 


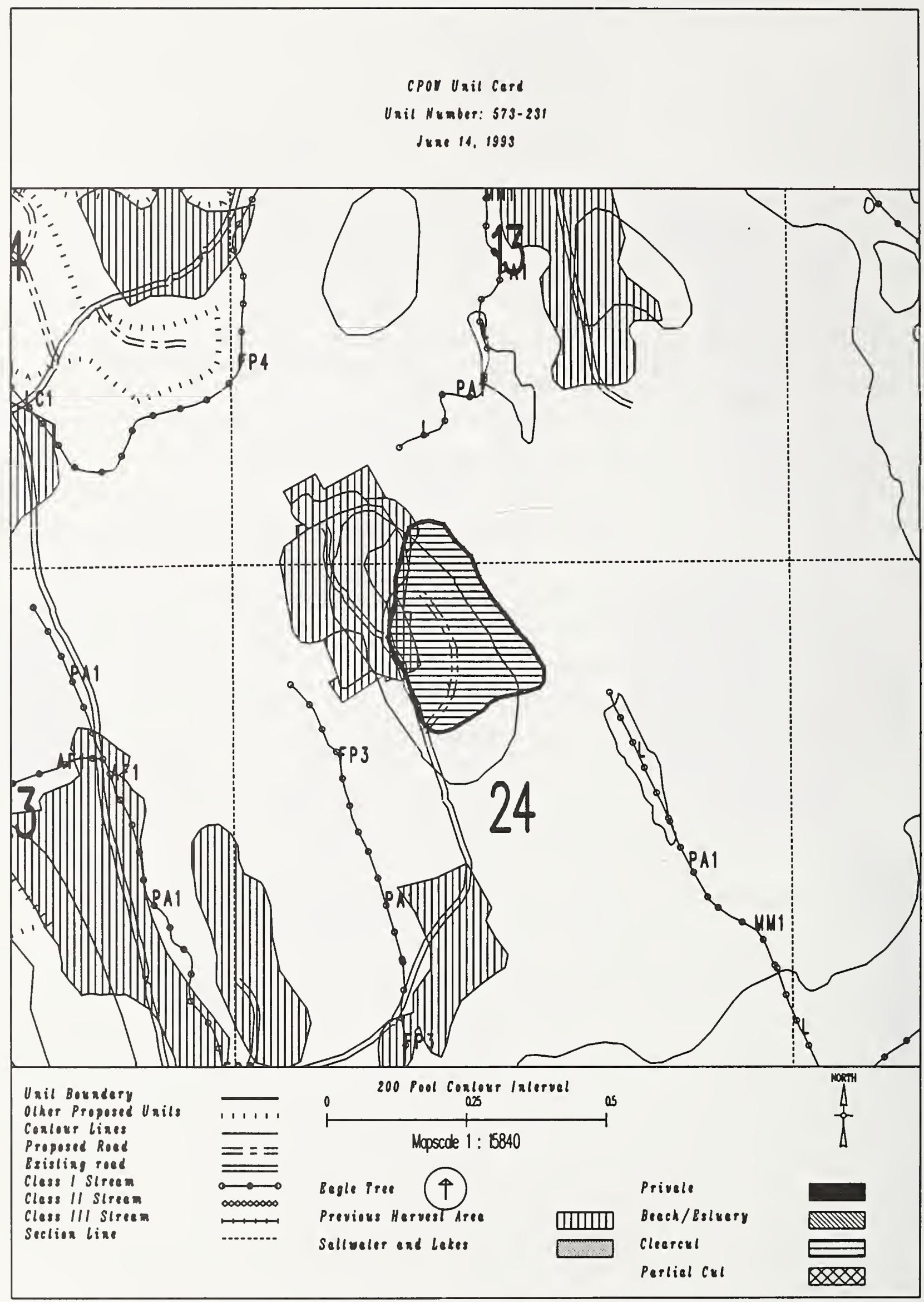


Unit $\underline{573-237 \quad A}$

Planned acres 53

Estimated volume (mbf) 1116

Logging system skyline

silvicultural system Clearcut

Forest type Hemlock
Alternatives considered $F$

Quad CRGD3NHS

Mgmt Area K08

WAA 1421

Photo

Aspect South

\section{PHYSICAL DESCRIPTION}

Volume class breakdown: VC4 $\quad \begin{array}{lllllllllll}45 & \text { acres } & \text { VC5 } & 4 & \text { acres } & \text { VC6 } & 0 & 0 & \text { acres } & \text { VC7 } & 0\end{array}$

Elevation breakdown: $0-800 \mathrm{ft} . \underline{3}$ acres $800-1200 \mathrm{ft} . \underline{29}$ acres $1200-1500 \mathrm{ft} . \underline{6}$ acres over $1500 \mathrm{ft} . \underline{0}$ acres Mass movement index: Low 0 acres Medium 0 acres High 52 acres Very High 0

\section{SOILS}

This unit has high mass movement index soils. Partial log suspension required over these areas.(BMP13.9)

This unit contains 35 acres of forested wetlands. Site specific BMPs will be designed for selected approved

logging system and road construction practices. (BMPs 12.5, 13.9, 13.15).

This unit contains 31 acres of slopes > $75 \%$.

\section{TIMBER}

There are no timber mitigation measures anticipated for this unit.

\section{ENGINEER ING}

High mass movement index soils. Road construction must minimize landslide potential (BMP14).

slopes greater than $75 \%$ may require full bench construction and endhaul of waste (BMP14.7).

\section{FISH/WATERSHED}

This unit contains a 11 class $\underline{2}$ stream. Allow no harvest within 100 feet and full suspension, if yarding across. This unit contains a $\underline{A} 7$ class $\underline{3}$ stream. No specific buffer or suspension requirement.

\section{WILDLIFE}

There are no wildlife mitigation measures anticipated for this unit.

RECREATION / VISUALS

This unit has a proposed VQO of MM and is not seen from any viewpoint identified by this project.

\section{LANDS}

There are no lands mitigation measures anticipated for this unit.

CULTURAL RESOURCES

There are no cultural resource mitigation measures anticipated for this unit.

GEOLOGY

There are no karst mitigation measures anticipated for this unit. 


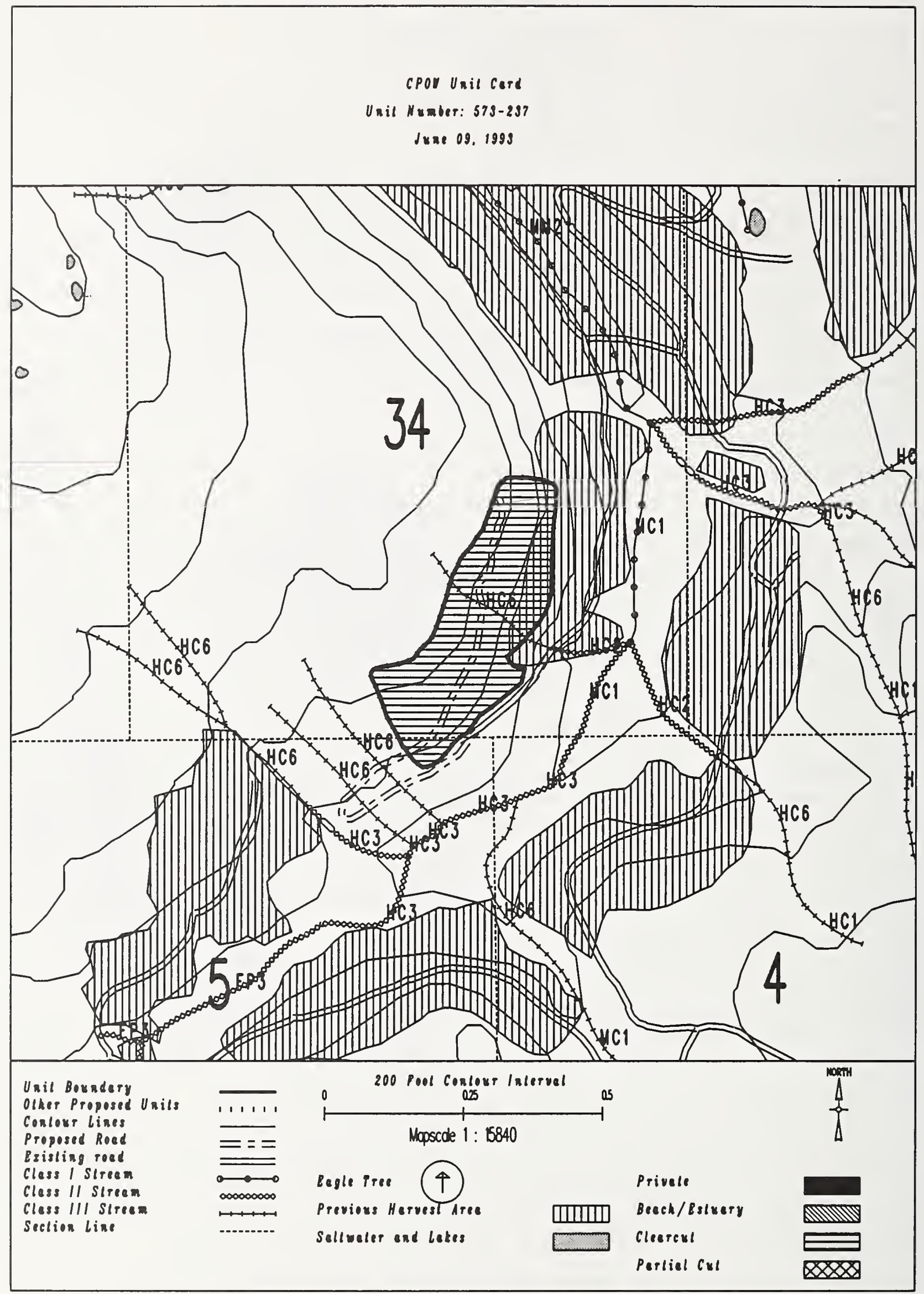


Unit $\quad 573-237$

Planned acres 14

Estimated volume (mbf) 479

Logging system skyline

silvicultural system clearcut

Forest type Mixed conifer
Al ternatives considered

Quad CRGD3NWS

Mgmt Area K08

WAA 1421

Photo

Aspect West

\section{PHYSICAL DESCR IPTION}

Volume class breakdown: VC4 1 acres VC5 0 acres vC6 12 acres vc7 0 acres

Elevation breakdown: $0.800 \mathrm{ft} . \underline{0}$ acres $800-1200 \mathrm{ft} . \underline{0}$ acres 1200-1500 ft. 4 acres over $1500 \mathrm{ft}$. 0 Mass movement index: Low 0 acres Mediun 0 acres High 5 acres Very High 0 acres

SOILS

This unit has high mass movement index soils. Partial log suspension required over these areas.(BMP13.9)

This unit contains 8 acres of forested wetlands. Site specific BMPs will be designed for selected approved

logging system and road construction practices. (BMPs 12.5, 13.9, 13.15).

\section{TIMBER}

There are no timber mitigation measures anticipated for this unit.

ENGINEERING

Very difficult road construction due to unstable, slope $>75 \%$ or extended steep grades.

May need to revise logging system to helicopter.

\section{FISH/WATERSHED}

There are no fishery mitigation measures anticipated for this unit.

WILDLIFE

There are no wildlife mitigation measures anticipated for this unit.

RECREATION / VISUALS

This unit has a proposed Voo of MM and is not seen from any viewpoint identified by this project.

\section{LANDS}

There are no lands mitigation measures anticipated for this unit.

\section{CULTURAL RESOURCES}

There are no cultural resource mitigation measures anticipated for this unit.

\section{GEOLOGY}

There are no karst mitigation measures anticipated for this unit. 


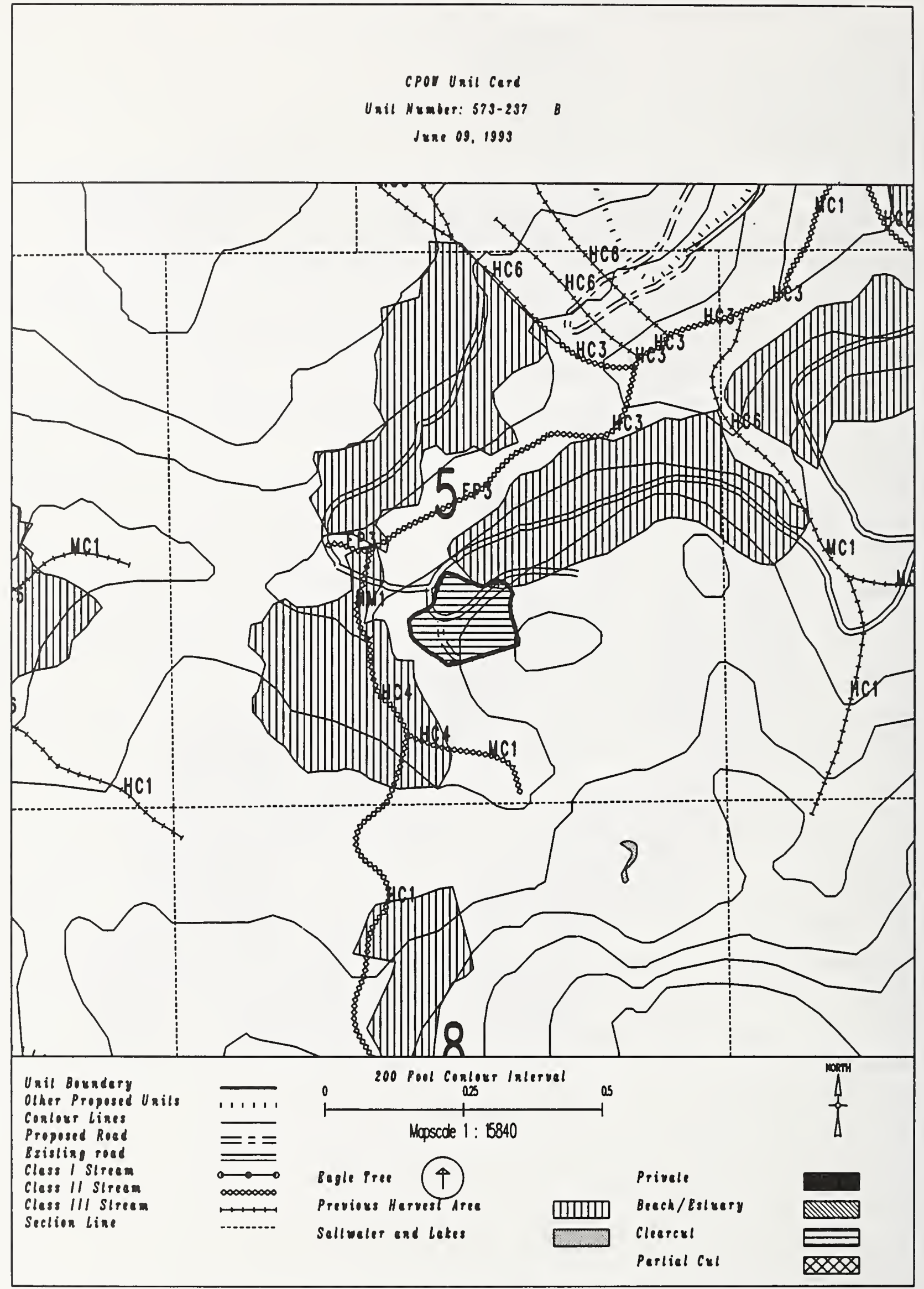




\section{Unit $\quad \mathbf{5 7 3 - 2 3 8}$}

Planned acres 28

Estimated volume (mbf)

logging system skyline

silvicultural system clearcut

Forest type Hemlock
Alternatives considered

Quad CRGD4NEN

Mgmt Area $\mathrm{KO8}$

WAA 1421

Photo 1190022

Aspect South

\section{PHYSICAL DESCRIPTION}

Volume class breakdown: VC4 26 acres VC5 $\quad 0$ acres VC6 $\quad 0$ acres VC7 $\quad 0$ acres

Elevation breakdown: $0-800 \mathrm{ft} . \underline{26}$ acres $800-1200 \mathrm{ft} . \underline{0}$ acres $1200-1500 \mathrm{ft} . \underline{0}$ acres over $1500 \mathrm{ft} . \underline{0}$ acres Mass movement index: Low 18 acres Medium 0 acres High 5 acres Very High 0 acres

\section{SOILS}

This unit has high mass movement index soils. Partial $\log$ suspension required over these areas. (BMP13.9) This unit contains 14 acres of forested wetlands. Site specific BMPs will be designed for selected approved logging system and road construction practices. (BMPS 12.5, 13.9, 13.15). This unit contains 9 acres of slopes > $75 \%$.

TIMBER

There are no timber mitigation measures anticipated for this unit.

\section{ENGINEER ING}

Slopes greater than $75 \%$ may require full bench construction and endhaul of waste (BMP14.7).

\section{FISH/WATERSHED}

There are no fishery mitigation measures anticipated for this unit.

\section{WILDLIFE}

There are no wildlife mitigation measures anticipated for this unit.

\section{RECREATION / VISUALS}

This unit has a proposed Vao of MM and is not seen from any viewpoint identified by this project.

\section{LANDS}

There are no lands mitigation measures anticipated for this unit.

\section{CULTURAL RESOURCES}

There are no cultural resource mitigation measures anticipated for this unit.

\section{GEOLOGY}

There are no karst mitigation measures anticipated for this unit. 


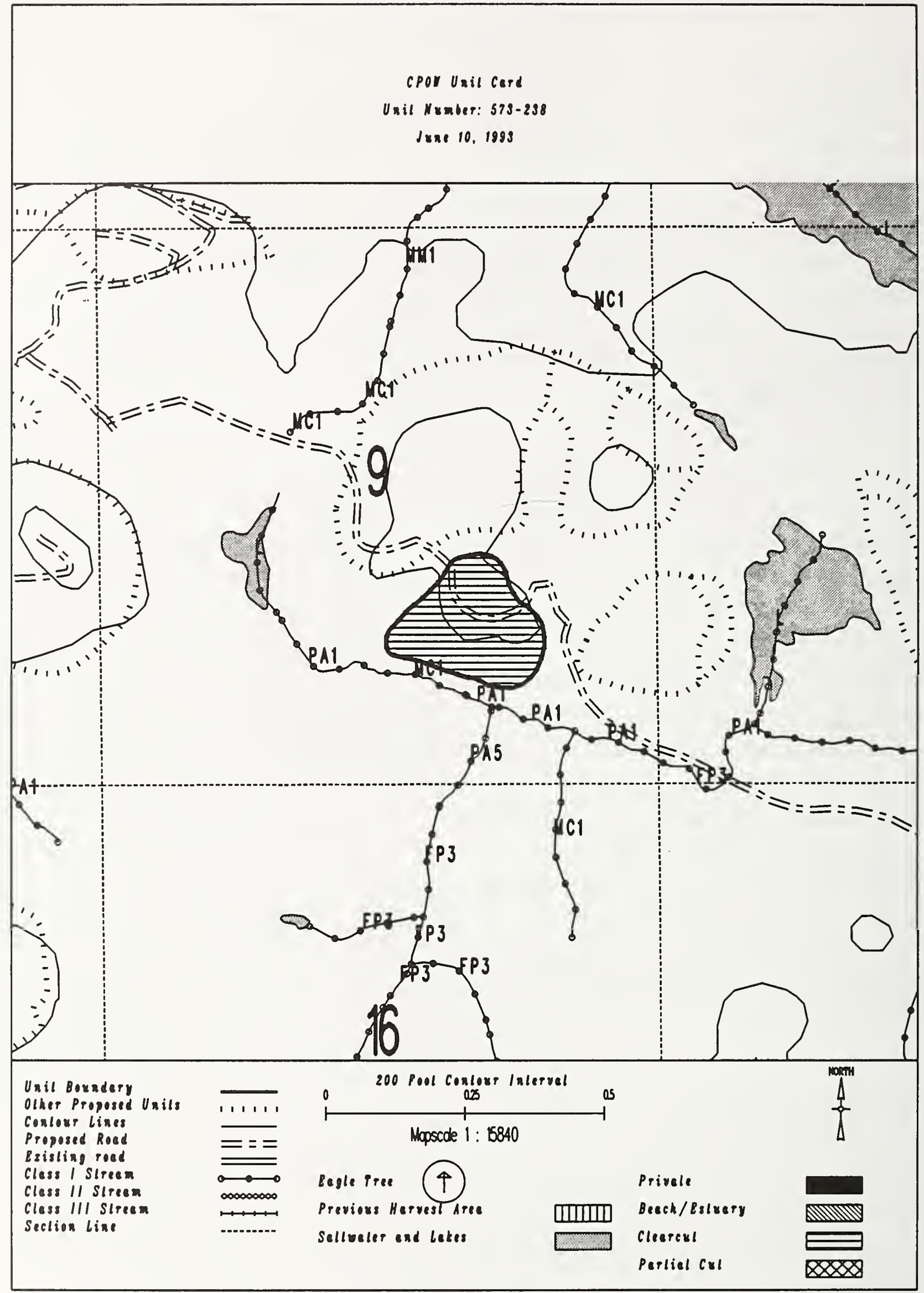




\section{Unit 573-242}

Planned acres 42

Estimated volume (mbf) 1115

Logging system skyline

silvicultural system clearcut

Forest type Hemlock

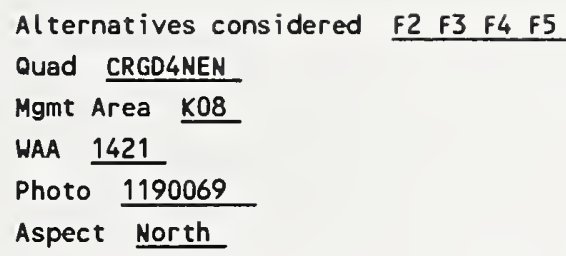

\section{PHYSICAL DESCRIPTION}

Volume class breakdown: VC4 18 acres VC5 22 acres VC6 $\quad 0$ acres VC7 $\quad 0$ acres

Elevation breakdown: $0-800 \mathrm{ft} . \underline{37}$ acres $800-1200 \mathrm{ft} . \quad 0$ acres $1200-1500 \mathrm{ft} . \quad 0$ acres over $1500 \mathrm{ft}$. 0 acres Mass movement index: Low 24 acres Medium $\_$acres High 17 acres Very High 0 acres

\section{SOILS}

This unit has high mass movement index soils. Partial log suspension required over these areas. (BMP13.9) This unit contains 19 acres of forested wetlands. Site specific BMPs will be designed for selected approved logging system and road construction practices. (BMPs 12.5, 13.9, 13.15).

\section{TIMBER}

There are no timber mitigation measures anticipated for this unit.

\section{ENG I NEER I NG}

High mass movement index soils. Road construction must minimize landslide potential (BMP14).

\section{FISH/WATERSHEO}

Potential for additional Class I/II streams within unit. May be necessary to place additional buffers within unit in accordance with AHMU Handbook.

\section{HILOLIFE}

Maintain diversity within unit by leaving 1-5 acre-sized islands of green trees at a rate of 1 acre of island for every 20 acres harvested. Leave islands must be compatible with logging system and safe working conditions.

\section{RECREATION / VISUALS}

This unit has a proposed VoO of MM and is not seen from any viewpoint identified by this project.

\section{LANDS}

There are no lands mitigation measures anticipated for this unit.

\section{CULTURAL RESOURCES}

There are no cultural resource mitigation measures anticipated for this unit.

\section{GEOLOGY}

There are no karst mitigation measures anticipated for this unit. 


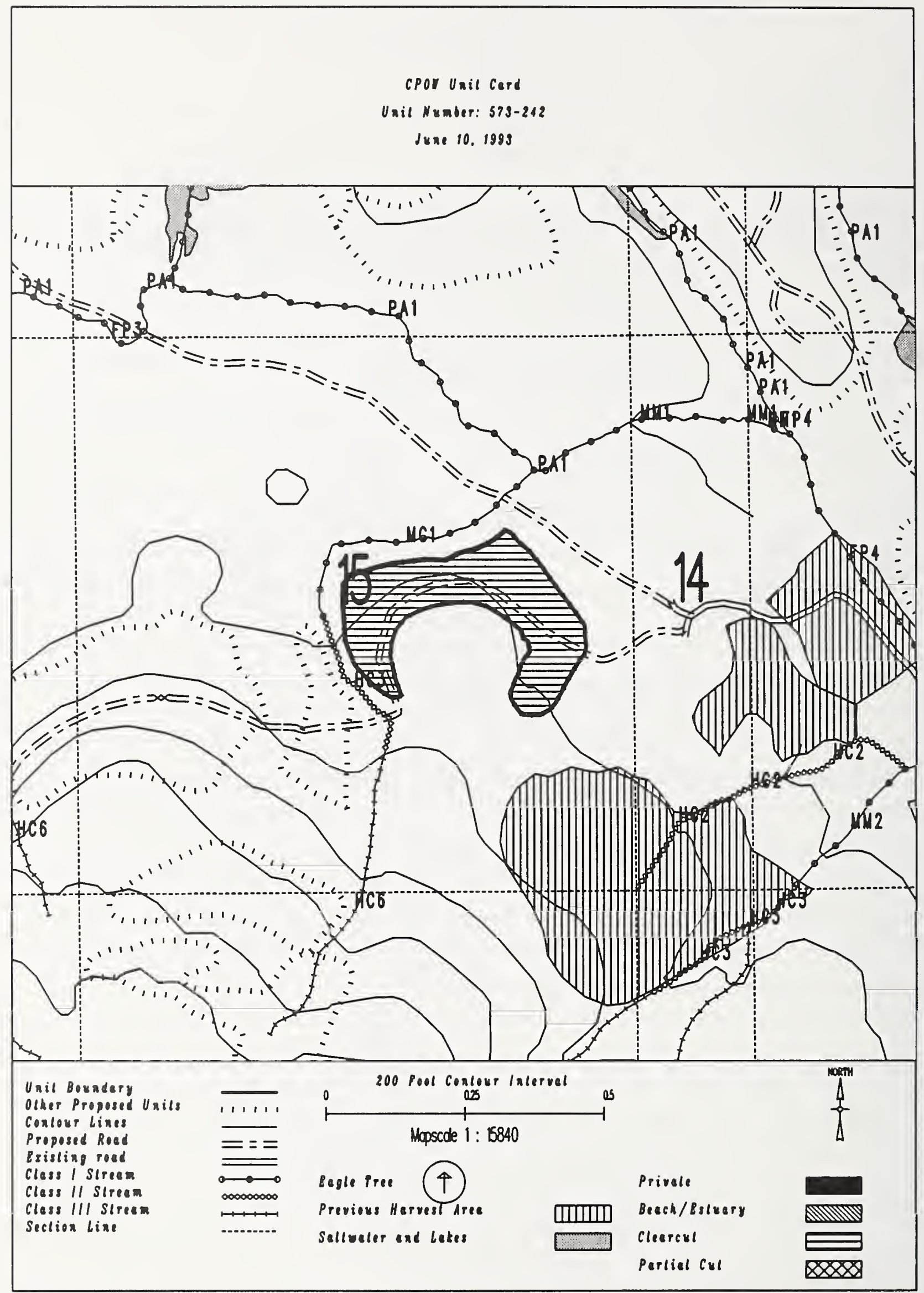


Unit 573-243

Planned acres 14

Est imated volume (mbf) 459

Logging system Highlead

silvicultural system clearcut

Forest type Mixed conifer
Alternatives considered $F 2$

Quad CRGD4NEN

Mgmt Area K08

WAA 1421

Photo 1190024

Aspect North

PHYSICAL DESCRIPTION

Volume class breakdown: VC4 $\quad \begin{array}{lllllllllll}0 & \text { acres VC5 } & 14 & \text { acres } & \text { VC6 } & 0 & 0 & \text { acres } & \text { VC7 } & 0 & 0\end{array}$

Elevation breakdown: $0-800 \mathrm{ft} . \underline{11}$ acres $800-1200 \mathrm{ft} . \quad 0$ acres $1200-1500 \mathrm{ft} . \underline{0}$ acres over $1500 \mathrm{ft}$. 0 Mass movement index: Low 11 acres Medium 0 acres High 2 acres Very High 0 acres

SOILS

This unit has high mass movement index soils. Partial log suspension required over these areas.(BMP13.9)

TIMBER

There are no timber mitigation measures anticipated for this unit.

ENGINEER ING

There are no engineering mitigation measures anticipated for this unit.

\section{FISH/WATERSHED}

There are no fishery mitigation measures anticipated for this unit.

\section{WILDLIFE}

Maintain diversity within unit by leaving 1-5 acre-sized islands of green trees at a rate of 1 acre of island for every 20 acres harvested. Leave islands must be compatible with logging system and safe working conditions.

RECREATION / VISUALS

The unit has a proposed voo of $M$ within the viewshed of whale Pass

as viewed from $1 / 2$ mile from shore.

\section{LANDS}

There are no lands mitigation measures anticipated for this unit.

CULTURAL RESOURCES

There are no cultural resource mitigation measures anticipated for this unit.

GEOLOGY

There are no karst mitigation measures anticipated for this unit. 
cPor Unil Cerd

Unil Namber: 573-243

Juae 10, 1993

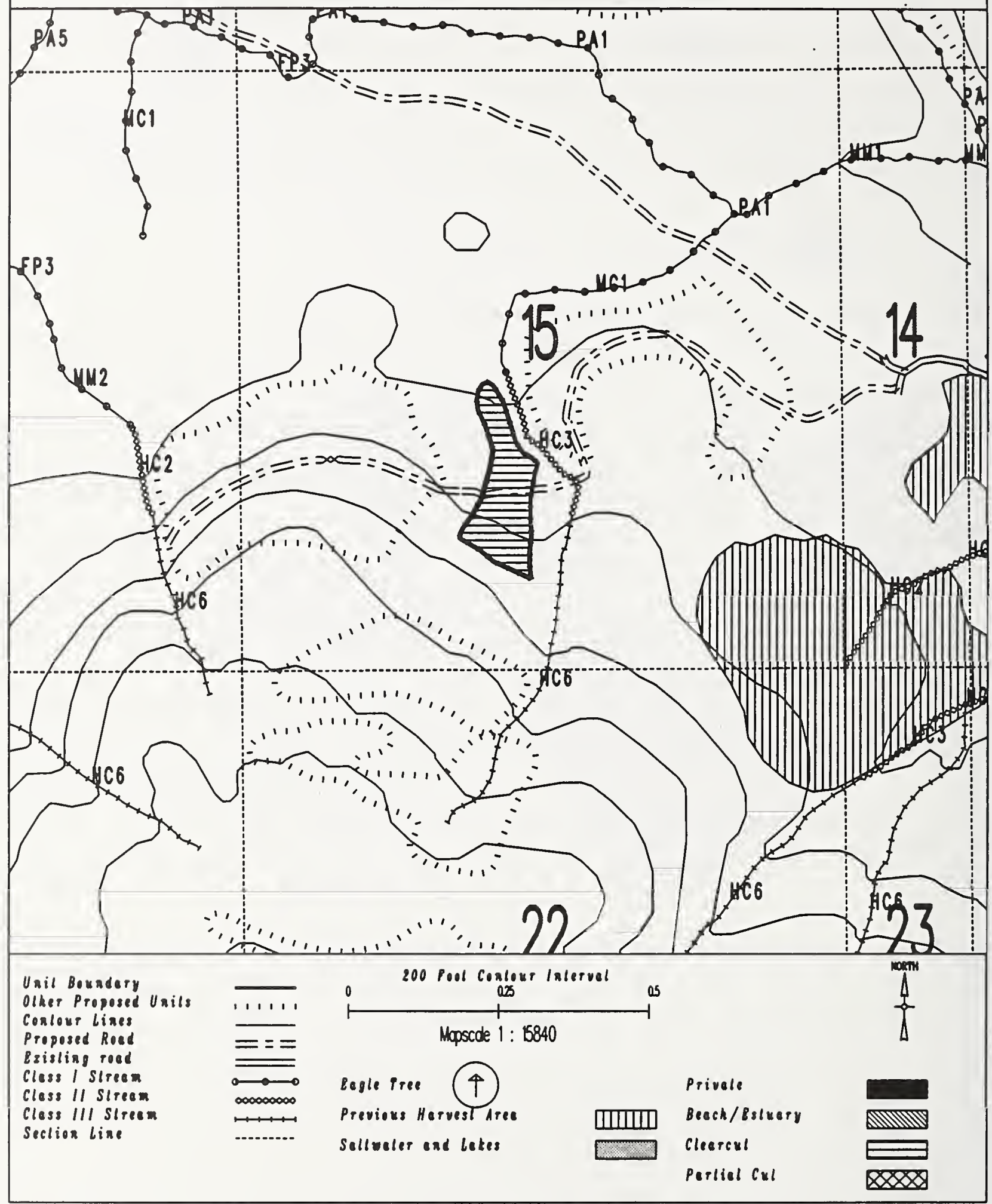


Unit 573-244

Planned acres 71

Estimated volume (mbf) 2342

Logging system slackline

silvicultural system clearcut

Forest type Mixed conifer
Alternatives considered $\mathrm{F2} F 3$ F4 F5

Quad CRGD4NEN

Mgmt Area $\mathrm{K08}$

WAA 1421

Photo 1190024

Aspect North

PHYSICAL DESCRIPTION

Volume class breakdown: VC4 12 acres VC5 17 acres VC6 40 acres vC7 $\quad 0$ acres

Elevation breakdown: $0-800 \mathrm{ft} . \underline{46}$ acres $800-1200 \mathrm{ft} . \underline{12}$ acres $1200-1500 \mathrm{ft} . \underline{0}$ acres over $1500 \mathrm{ft}$. 0 acres Mass movement index: Low 24 acres Medium 0 acres High 46 acres Very High 0 acres

SOILS

This unit has high mass movement index soils. Partial log suspension required over these areas.(BMP13.9)

This unit contains 12 acres of forested wetlands. Site specific BMPs will be designed for selected approved

logging system and road construction practices. (BMPS 12.5, 13.9, 13.15).

\section{TIMBER}

There are no timber mitigation measures anticipated for this unit.

ENGINEERING

High mass movement index soils. Road construction must minimize landslide potential (BMP14).

\section{FISH/WATERSHED}

There are no fishery mitigation measures anticipated for this unit.

\section{WILDLIFE}

Maintain diversity within unit by leaving 1-5 acre-sized islands of green trees at a rate of 1 acre of island for every 20 acres harvested. Leave islands must be compatible with logging system and safe working conditions.

\section{RECREATION / VISUALS}

The unit has a proposed veo of $M$ within the viewshed of Whale Pass

as viewed from $1 / 2$ mile from shore.

\section{LANDS}

There are no lands mitigation measures anticipated for this unit.

CULTURAL RESOURCES

There are no cultural resource mitigation measures anticipated for this unit.

There are no karst mitigation measures anticipated for this unit. 


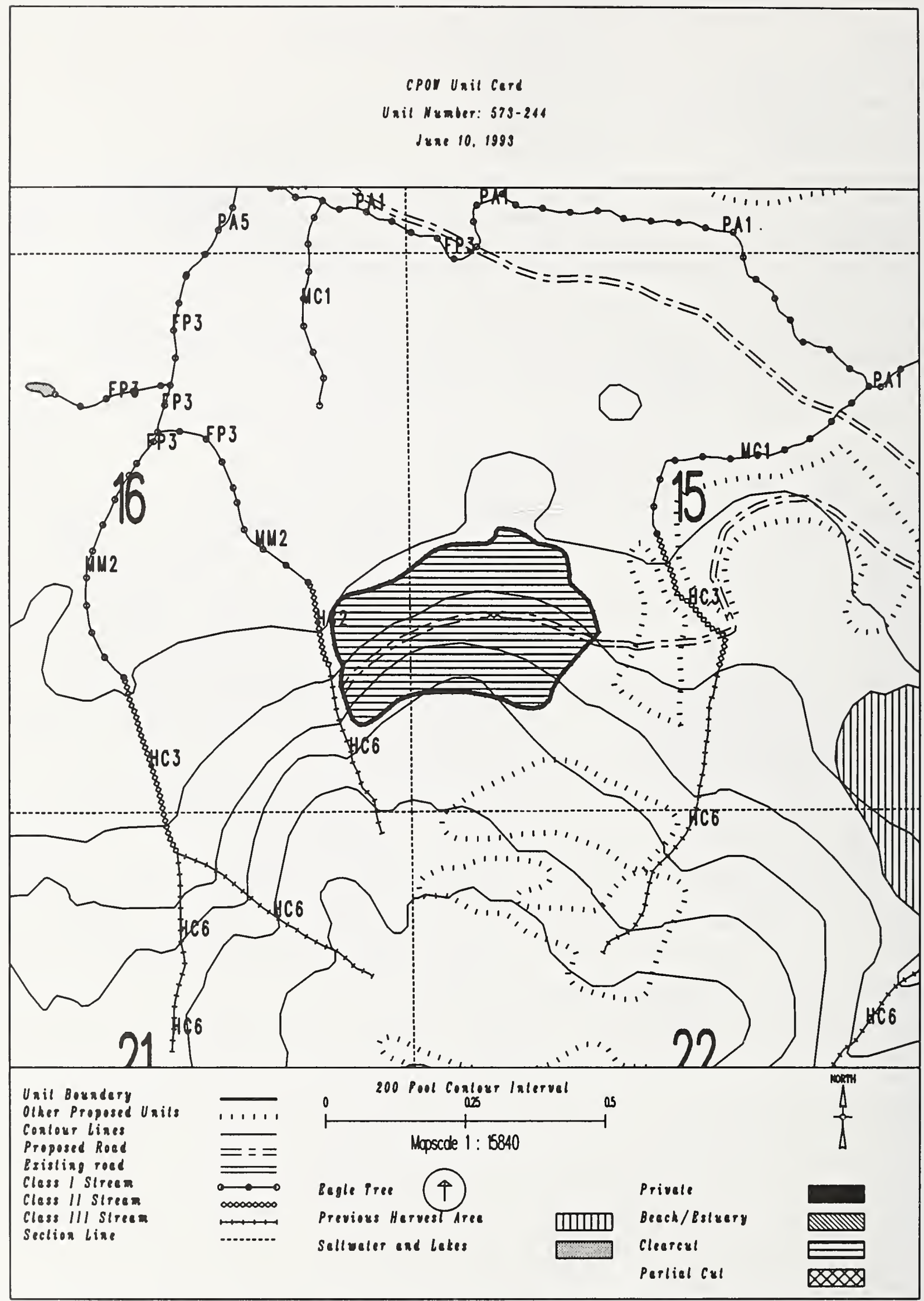


Unit 573-248

Planned acres 29

Estimated volume (mbf) 918

Logging system Helicopter

silvicultural system Clearcut

Forest type Mixed conifer
Alternatives considered

Quad CRGD4NEN

Mgmt Area $\mathrm{K08}$

WAA 1421

Photo 1190024

Aspect North

PHYSICAL DESCRIPTION

Volume class breakdown: VC4 $\quad 0$ acres VC5 28 acres VC6 $\quad 0$ acres vC7 $\quad 0$ acres

Elevation breakdown: $0-800 \mathrm{ft} . \underline{0}$ acres $800-1200 \mathrm{ft} . \underline{16}$ acres $1200-1500 \mathrm{ft}$. 8 acres over $1500 \mathrm{ft}$. 0 Mass movement index: Low 28 acres Medium $\_$acres High 0 acres Very High 0 acres

SOILS

This unit has > 40\% McGilvery soils. Partial suspension required (BMP13.9)

to ensure reforestation (BMP13.19).

TIMBER

There are no timber mitigation measures anticipated for this unit.

\section{ENG INEER ING}

There are no engineering mitigation measures anticipated for this unit.

\section{FISH/HATERSHED}

There are no fishery mitigation measures anticipated for this unit.

WILDLIFE

There are no wildlife mitigation measures anticipated for this unit.

\section{RECREATION / VISUALS}

The unit has a proposed voo of $M$ within the viewshed of Whale Pass as viewed from $1 / 2 \mathrm{mile}$ from shore.

\section{LANDS}

There are no lands mitigation measures anticipated for this unit.

CULTURAL RESOURCES

There are no cultural resource mitigation measures anticipated for this unit.

There are no karst mitigation measures anticipated for this unit. 


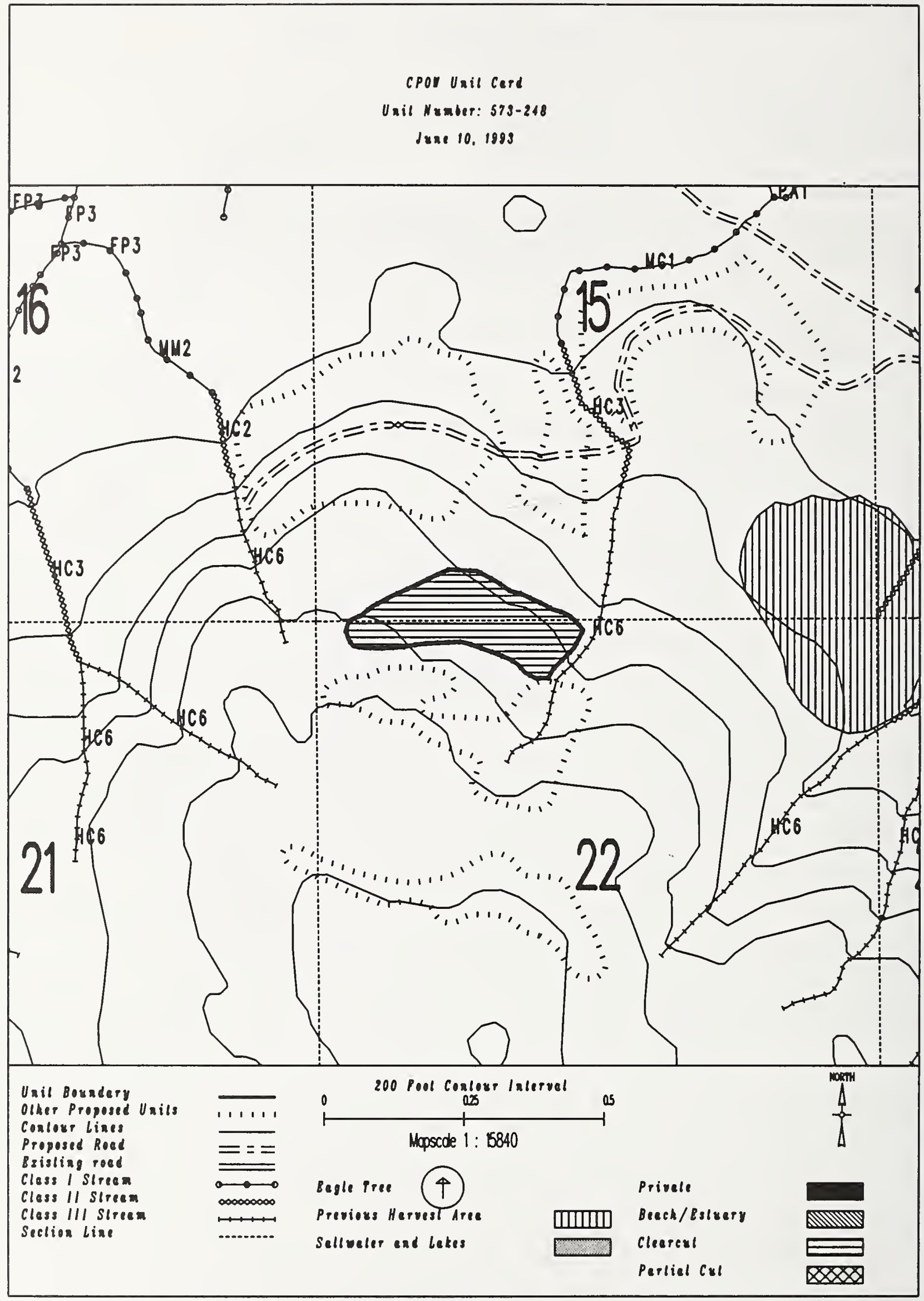


Unit 573-249

Planned acres 34

Estimated volume (mbf) 643

Logging system Helicopter

silvicultural system shelterwood

Forest type Mixed conifer
Alternatives considered F2 $\quad$ F4 F5 F6

Quad CRGD4NEN

Mgmt Area $\mathrm{KOB}$

WAA 1421

Photo 1190024

Aspect North

PHYSICAL DESCRIPTION

Volume class breakdown: VC4 15 acres VC5 18 acres VC6 $\quad 0$ acres VC7 $\quad 0$ acres

Elevation breakdown: $0-800 \mathrm{ft} . \underline{0}$ acres $800-1200 \mathrm{ft} . \underline{0}$ acres $1200-1500 \mathrm{ft} . \underline{3}$ acres over $1500 \mathrm{ft}$. 0 Mass movement index: Low 33 acres Medium 0 acres High 0 acres Very High 0 acres

\section{SOILS}

This unit has > 40\% McGilvery soils. Partial suspension required (BMP13.9)

to ensure reforestation (BMP13.19).'

\section{TIMBER}

Shelterwood harvest. Cedar will not be harvested.

\section{ENGINEER ING}

There are no engineering mitigation measures anticipated for this unit.

\section{FISH/WATERSHED}

This unit contains a $\underline{A} 1$ class $\underline{3}$ stream. No specific buffer required, but full suspension, if yarding across.

\section{WILDLIFE}

There are no wildlife mitigation measures anticipated for this unit.

\section{RECREATION / VISUALS}

The unit has a proposed voo of $M$ within the viewshed of whale Pass

as viewed from $1 / 2$ mile from shore.

\section{LANDS}

There are no lands mitigation measures anticipated for this unit.

\section{CULTURAL RESOURCES}

There are no cultural resource mitigation measures anticipated for this unit.

There are no karst mitigation measures anticipated for this unit. 


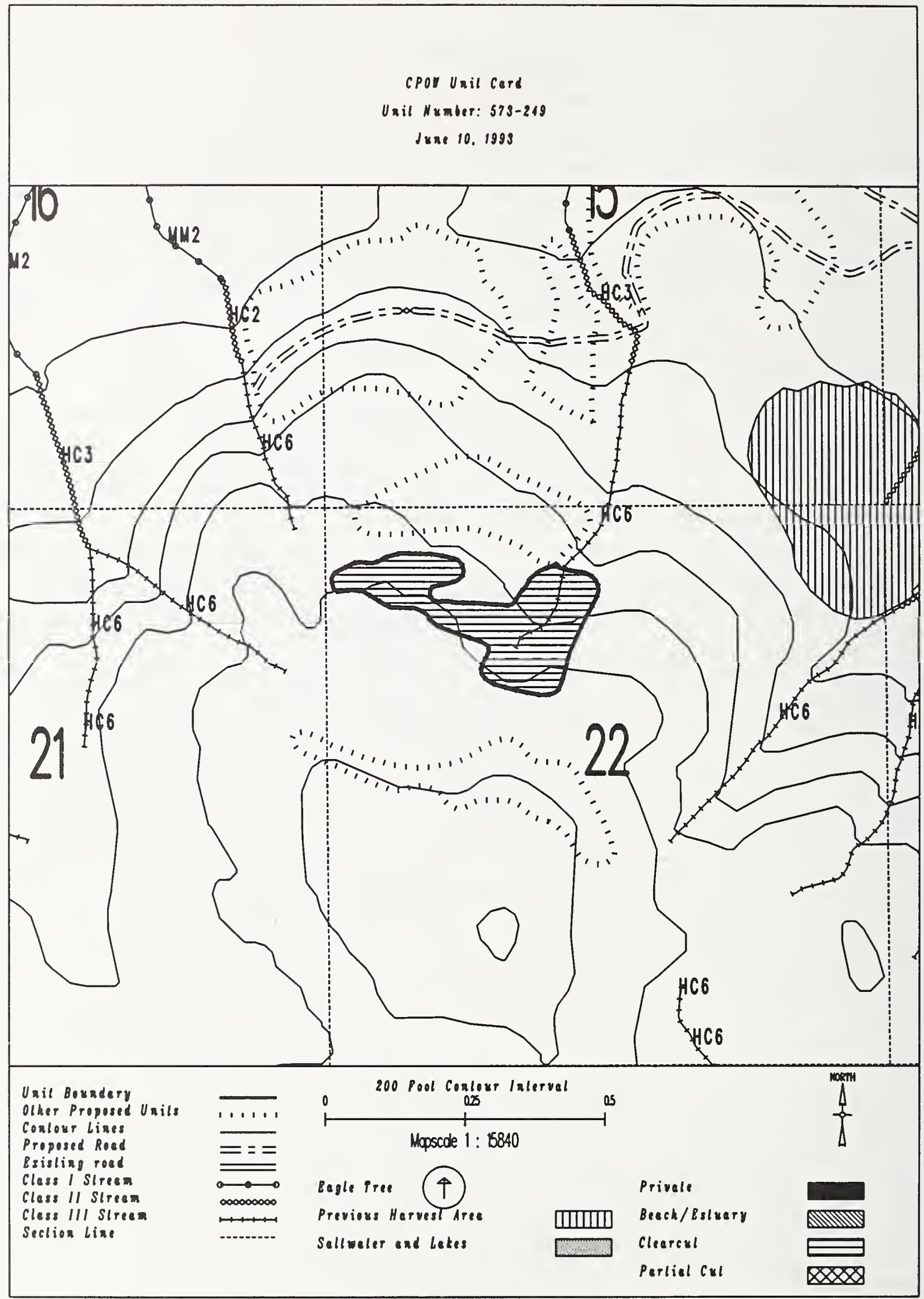


Unit $573-250$

Planned acres $\underline{25}$

Estimated volume (mbf)

Logging system skyline

silvicultural system clearcut

Forest type Hemlock

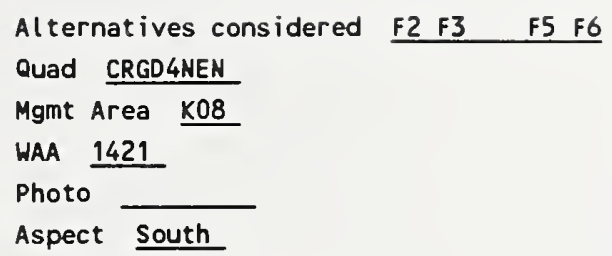

\section{PHYSICAL DESCRIPTION}

Volume class breakdown: vC4 6 acres vc5 18 acres vc6 $\quad 0$ acres vc7 $\quad 0$ acres

Elevation breakdown: $0.800 \mathrm{ft} . \underline{0}$ acres $800-1200 \mathrm{ft} . \underline{9}$ acres $1200-1500 \mathrm{ft}$. 11 acres over $1500 \mathrm{ft}$. 0 Mass movement index: Low 17 acres Medium 0 acres High 7 acres Very High 0 acres

\section{SOILS}

This unit has high mass movement index soils. Partial log suspension required over these areas.(BMP13.9) This unit contains 15 acres of forested wetlands. Site specific BMPs will be designed for selected approved logging system and road construction practices. (BMPs 12.5, 13.9, 13.15). This unit contains 7 acres of slopes $>75 \%$.

\section{TIMBER}

There are no timber mitigation measures anticipated for this unit.

\section{ENGINEERING}

High mass movement index soils. Road construction must minimize landslide potential (BMP14). slopes greater than $75 \%$ may require full bench construction and endhaul of waste (BMP14.7).

\section{FISH/WATERSHED}

There are no fishery mitigation measures anticipated for this unit.

\section{HILDLIFE}

There are no wildlife mitigation measures anticipated for this unit.

RECREATION / VISUALS

This unit has a proposed Voo of MM and is not seen from any viewpoint identified by this project.

\section{LANDS}

There are no lands mitigation measures anticipated for this unit.

CULTURAL RESOURCES

There are no cultural resource mitigation measures anticipated for this unit. 


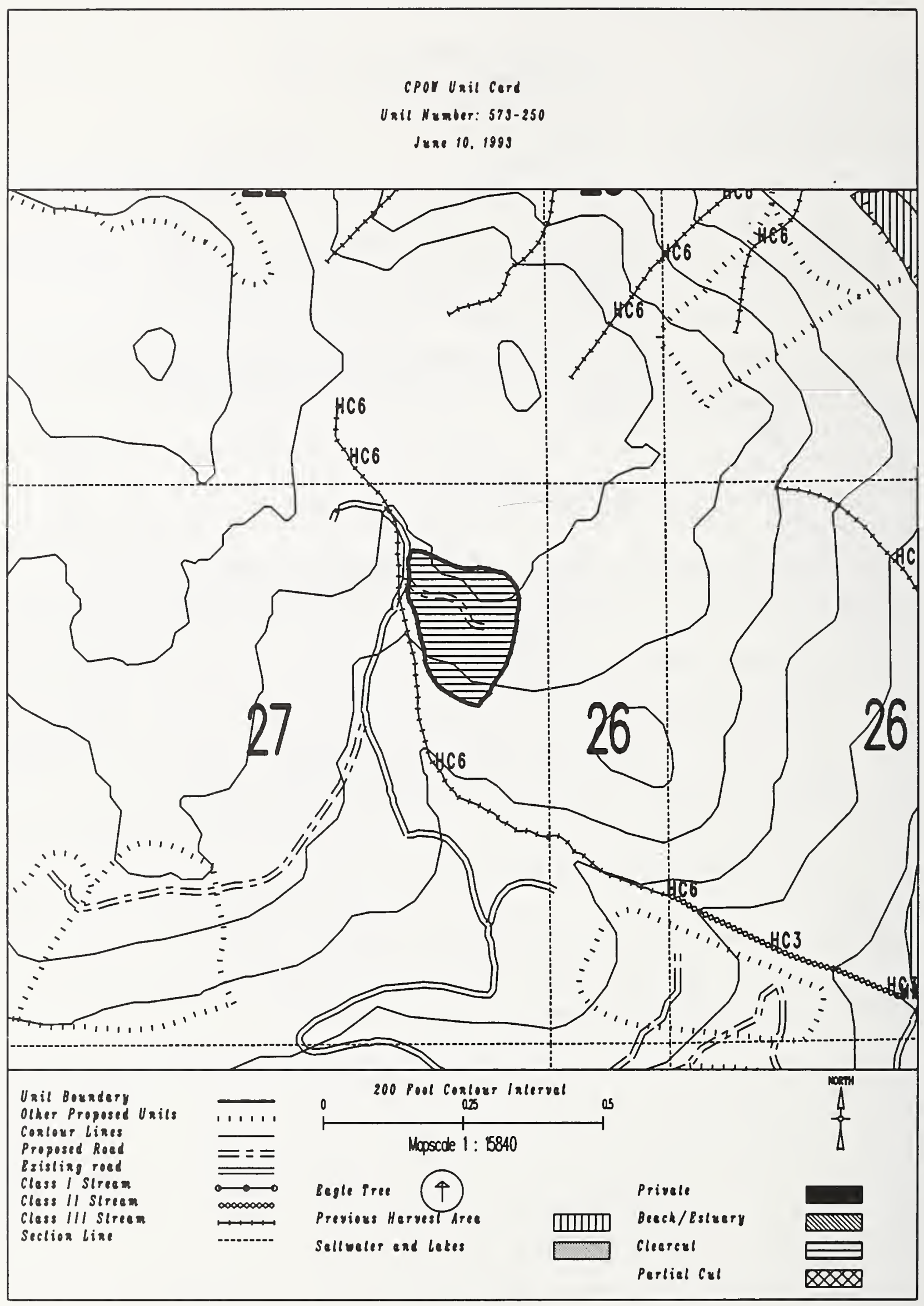




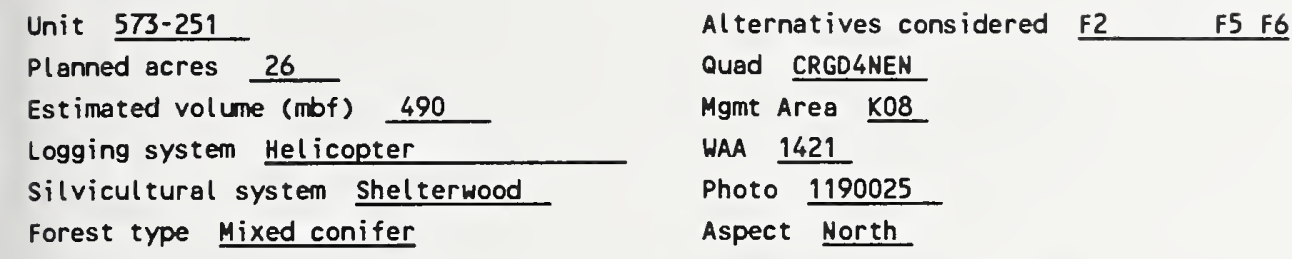


cpol Unil Cerd

Unil Number: 57s-2st

June 10, 1995

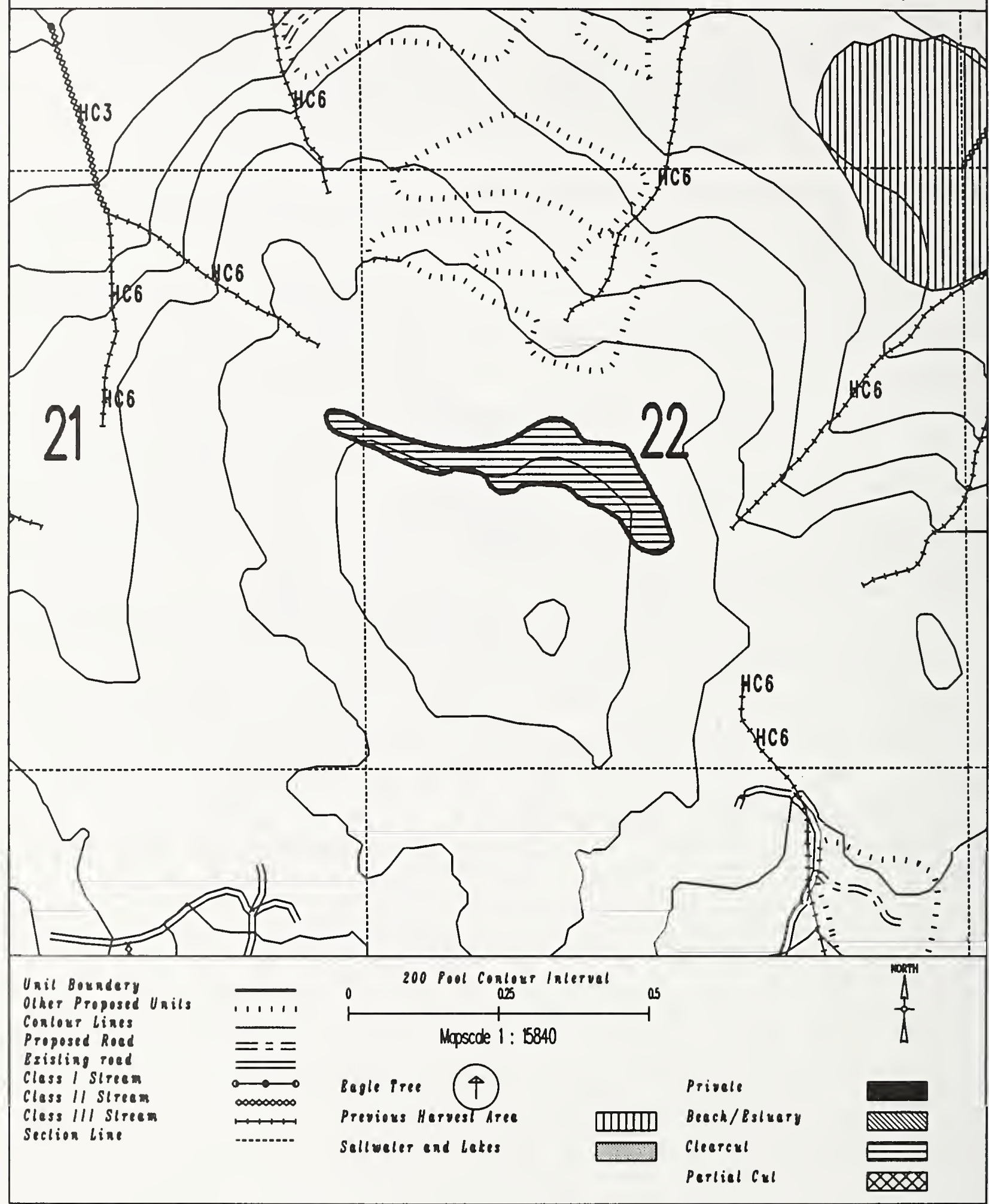


Unit $\quad 573-260$

Planned acres 17

Estimated volume (mbf)

Logging system skyline

silvicultural system Clearcut

Forest type Mixed conifer
Alternatives considered F2 $F 3$ F4

Quad CRGD3NWN

Mgmt Area $\mathrm{K08}$

WAA 1421

Photo 990075

Aspect East

\section{PHYSICAL DESCRIPTION}

Volume class breakdown: VC4 $\quad 0$ acres VC5 1 acres vC6 17 acres vC7 $\quad 0$ acres

Elevation breakdown: $0-800 \mathrm{ft} . \underline{14}$ acres $800-1200 \mathrm{ft} . \underline{0}$ acres $1200-1500 \mathrm{ft} . \underline{0}$ acres over $1500 \mathrm{ft}$. 0 acres Mass movement index: Low 0 acres Medium 0 acres High 16 acres Very High 0

\section{SOILS}

This unit has high mass movement index soils. Partial log suspension required over these areas. (BMP13.9)

This unit has a slight possibility to be reclassified as MMI $=4$.

\section{TIMBER}

There are no timber mitigation measures anticipated for this unit.

\section{ENGINEER ING}

High mass movement index soils. Road construction must minimize landslide potential (BMP14).

\section{FISH/WATERSHED}

There are no fishery mitigation measures anticipated for this unit.

\section{WILDLIFE}

There are no wildlife mitigation measures anticipated for this unit.

RECREATION / VISUALS

This unit has a proposed VQO of MM and is not seen from any viewpoint identified by this project.

\section{LANDS}

There are no lands mitigation measures anticipated for this unit.

CULTURAL RESOURCES

There are no cultural resource mitigation measures anticipated for this unit.

GEOLOGY

There are no karst mitigation measures anticipated for this unit. 
cPor Uail cerd

Unil Namber: $573-260$

June 10, 1993

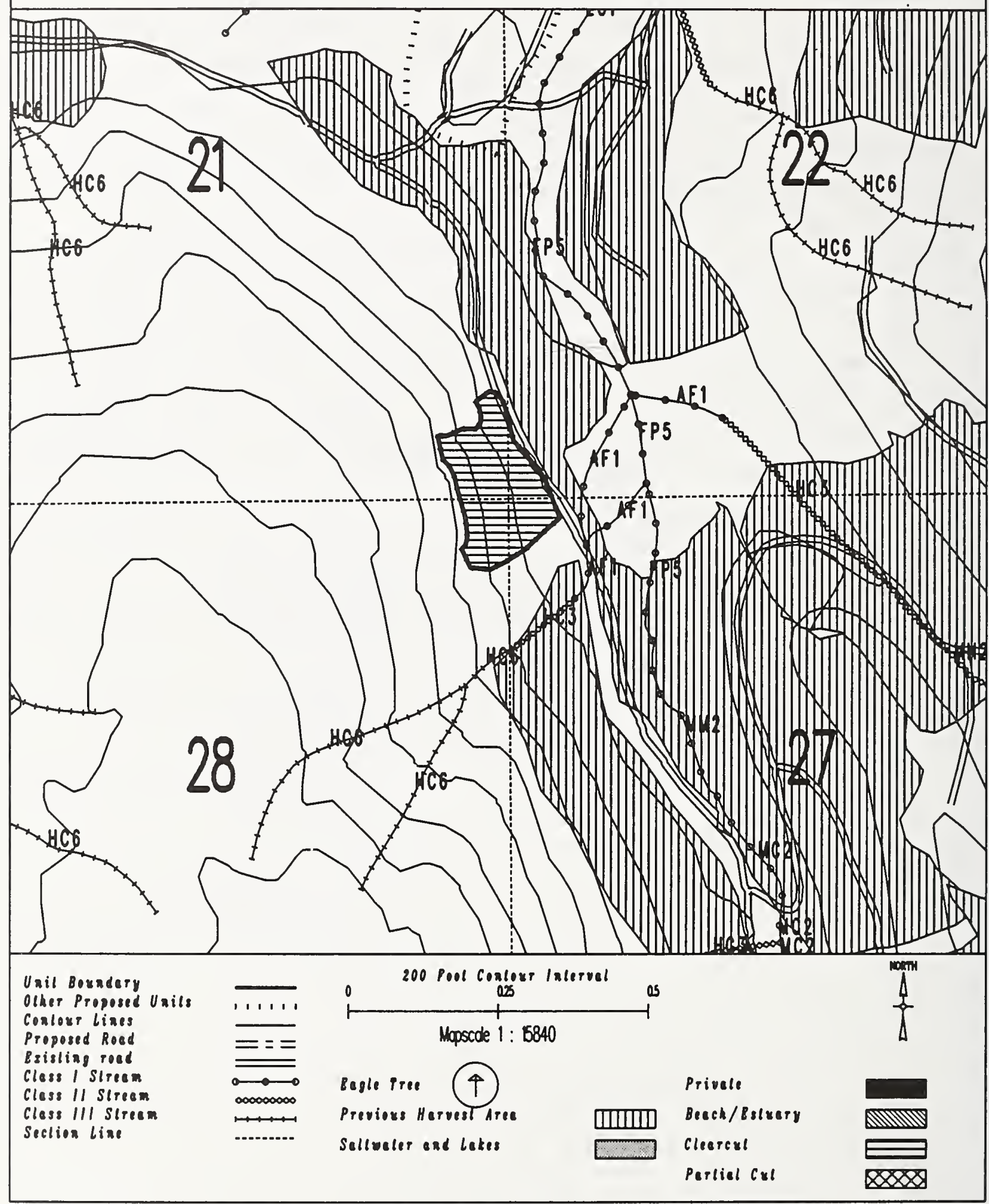


Unit $\quad$ 573-264

Planned acres 51

Estimated volume (mbf) 1788

Logging system skyline

Silvicultural system clearcut

Forest type Mixed conifer
Al ternatives considered

Quad CRGD3NWN

Mgmt Area $\mathrm{KOB}$

WAA 1421

Photo 990058

Aspect West

PHYSICAL DESCRIPTION

Volume class breakdown: VC4 $\quad 0$ acres VC5 29 acres vC6 22 acres vc7 0 acres

Elevation breakdown: $0-800 \mathrm{ft} . \underline{48}$ acres $800-1200 \mathrm{ft} . \underline{0}$ acres 1200-1500 ft. 0 acres over $1500 \mathrm{ft}$. 0 acres Mass movement index: Low 1 acres Medium $\underline{31}$ acres High 0 acres Very High 0

SOILS

This unit has a slight possibility to be reclassified as MMI $=4$.

This unit contains 50 acres of forested wetlands. Site specific BMPs will be designed for selected approved logging system and road construction practices. (BMPs 12.5, 13.9, 13.15).

\section{TIMBER}

Potential for shovel logging on 30 acres, if soil and water quality protected (BMP13.7)

ENGINEERING

High mass movement index soils. Road construction must minimize landslide potential (BMP14).

FISH/WATERSHED

Potential for additional Class I/II streams within unit. May be necessary to place additional buffers within unit in accordance with AHMU Handbook.

Potential impact on significant fishery habitat. May be necessary to expand planned buffer in accordance with AHMU Handbook.

WILDLIFE

Harvest operations restricted to April 1 to October 31 to protect trumpeter swans on Barnes, Sweetwater Lakes.

RECREATION / VISUALS

The unit has a proposed voo of $M$ within the viewshed of Sweetwater Lake as viewed from from centerline of lake.

LANDS

There are no lands mitigation measures anticipated for this unit.

CULTURAL RESOURCES

There are no cultural resource mitigation measures anticipated for this unit.

There are no karst mitigation measures anticipated for this unit. 


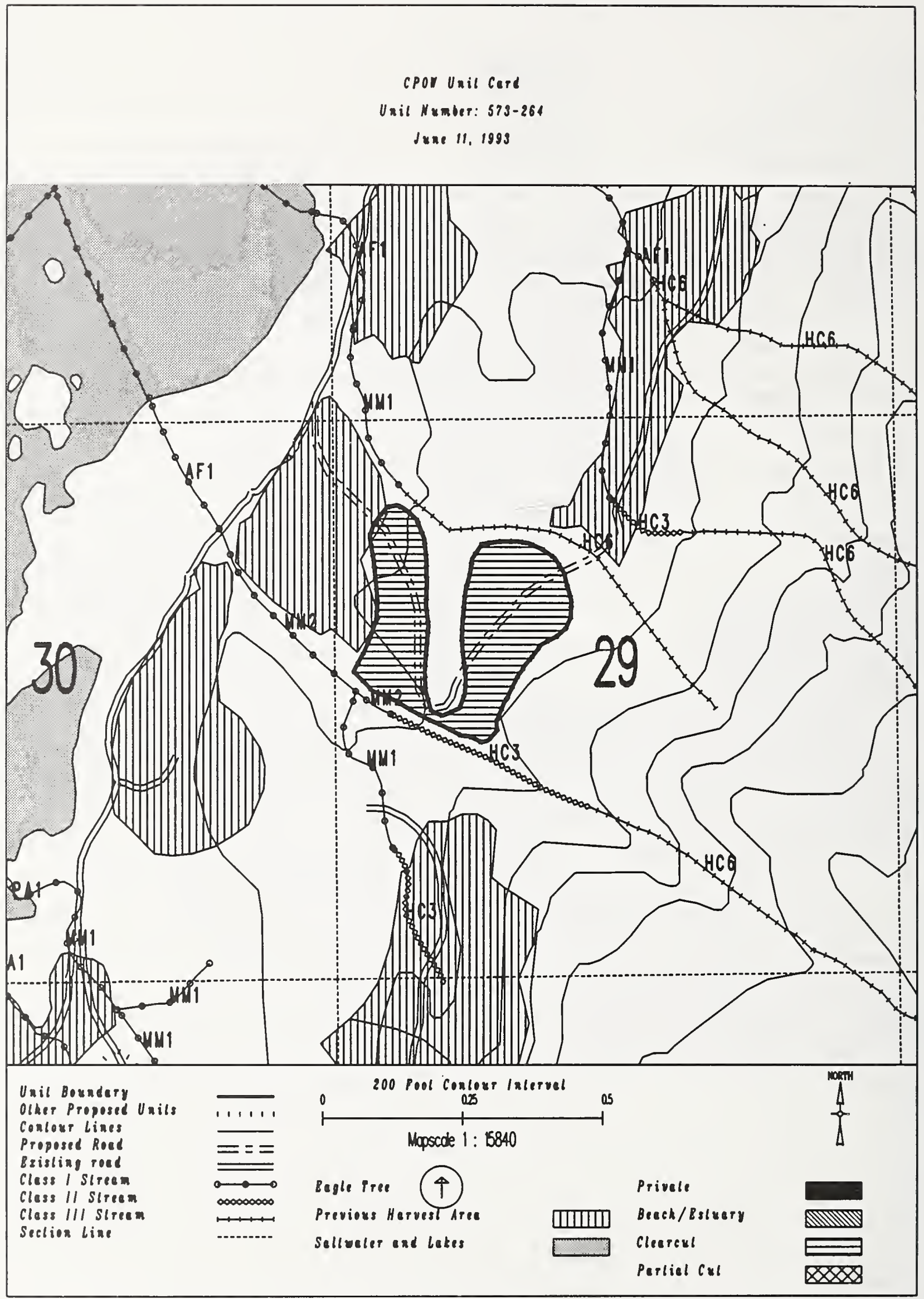


Unit $\underline{573-268}$

Planned acres 77

Estimated volume (mbf) $\underline{2457}$

Logging system skyline

Silvicultural system clearcut

Forest type Hemlock
Alternatives considered

Quad CRGD3NWN

Mgmt Area K08

WAA 1421

Photo 990074

Aspect South

\section{PHYSICAL DESCRIPTION}

Volume class breakdown: VC4 11 acres VC5 20 acres VC6 41 acres vc7 0 acres

Elevation breakdown: $0-800 \mathrm{ft} . \underline{74}$ acres $800-1200 \mathrm{ft} . \quad 0$ acres $1200-1500 \mathrm{ft} .{ }_{0} 0$ acres over $1500 \mathrm{ft}$. 0 acres Mass movement index: Low 4 acres Medium 19 acres High 16 acres Very High 0 acres

\section{SOILS}

This unit has high mass movement index soils. Partial log suspension required over these areas.(BMP13.9)

This unit contains 49 acres of forested wetlands. Site specific BMPs will be designed for selected approved

logging system and road construction practices. (BMPs 12.5, 13.9, 13.15).

\section{TIMBER}

There are no timber mitigation measures anticipated for this unit.

\section{ENGINEERING}

High mass movement index soils. Road construction must minimize landslide potential (BMP14).

\section{FISH/WATERSHED}

Potential for additional Class $1 / 11$ streams within unit. May be necessary to place additional buffers within unit in accordance with AHMU Handbook.

Potential impact on significant fishery habitat. May be necessary to expand planned buffer in accordance with AHMU Handbook.

\section{WILDLIFE}

Harvest operations restricted to April 1 to October 31 to protect trumpeter swans on Barnes, Sweetwater Lakes.

\section{RECREATION / VISUALS}

This unit has a proposed $V Q O$ of $M M$ and is not seen from any viewpoint identified by this project.

\section{LANDS}

There are no lands mitigation measures anticipated for this unit.

CULTURAL RESOURCES

There are no cultural resource mitigation measures anticipated for this unit. 


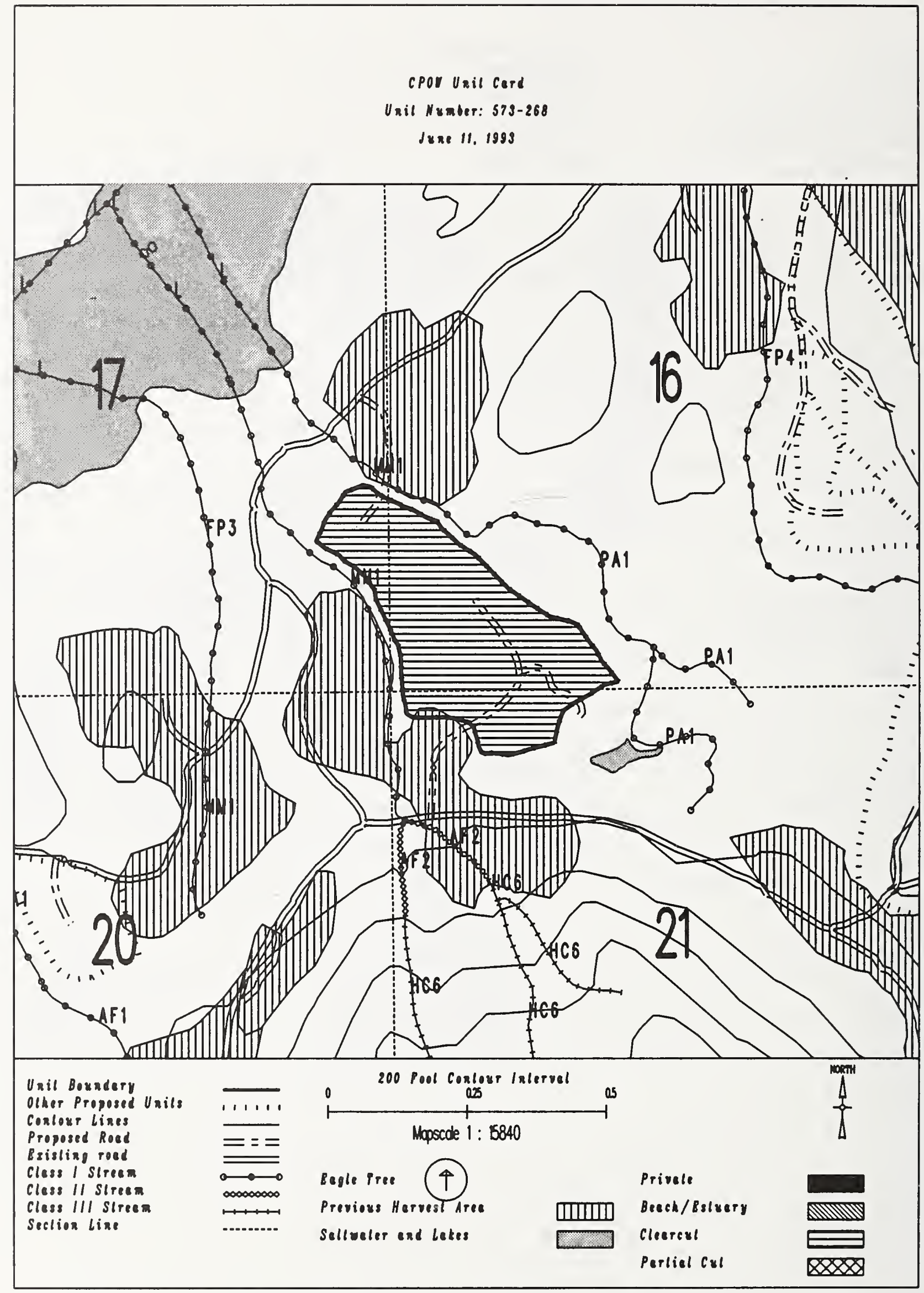


Unit 573-274

Planned acres 51

Est imated volume (mbf) 1655

Logging system skyline

silvicultural system clearcut

Forest type Cedar
Alternatives considered F2 F3 F4 F6

Quad CRGD3NWN

Mgmt Area $\mathrm{K} 08$

HAA 1421

Photo 990074

Aspect Hest

\section{PHYSICAL DESCRIPTION}

Volume class breakdown: VC4 $\quad 27$ acres VC5 $\quad 10$ acres VC6 $\quad 6$ acres VC7 $\quad 10$ acres

Elevation breakdown: $0-800 \mathrm{ft} . \underline{51}$ acres $800-1200 \mathrm{ft} . \underline{0}$ acres $1200-1500 \mathrm{ft}$. 0 acres over $1500 \mathrm{ft}$. 0 acres Mass movement index: Low 36 acres Medium 2 acres High 8 acres Very High 0

SOILS

This unit has high mass movement index soils. Partial log suspension required over these areas. (BMP13.9)

This unit contains 19 acres of forested wetlands. Site specific BMPs will be designed for selected approved

logging system and road construction practices. (BMPs 12.5, 13.9, 13.15).

TIMBER

There are no timber mitigation measures anticipated for this unit.

ENGINEER ING

High mass movement index soils. Road construction must minimize landslide potential (BMP14).

FISH/WATERSHED

Potential for additional Class I/II streams within unit. May be necessary to place additional buffers within unit in accordance with AHMU Handbook.

Potential impact on significant fishery habitat. May be necessary to expand planned buffer in accordance with AHMU Handbook.

\section{HILDLIFE}

Maintain diversity within unit by leaving 1-5 acre-sized islands of green trees at a rate of 1 acre of island for every 20 acres harvested. Leave islands must be compatible with logging system and safe working conditions.

\section{RECREATION / VISUALS}

The unit has a proposed voo of $M$ within the viewshed of Sweetwater Lake

as viewed from from centerline of lake.

\section{LANDS}

There are no lands mitigation measures anticipated for this unit.

\section{CULTURAL RESOURCES}

There are no cultural resource mitigation measures anticipated for this unit.

\section{GEOLOGY}

There are no karst mitigation measures anticipated for this unit. 


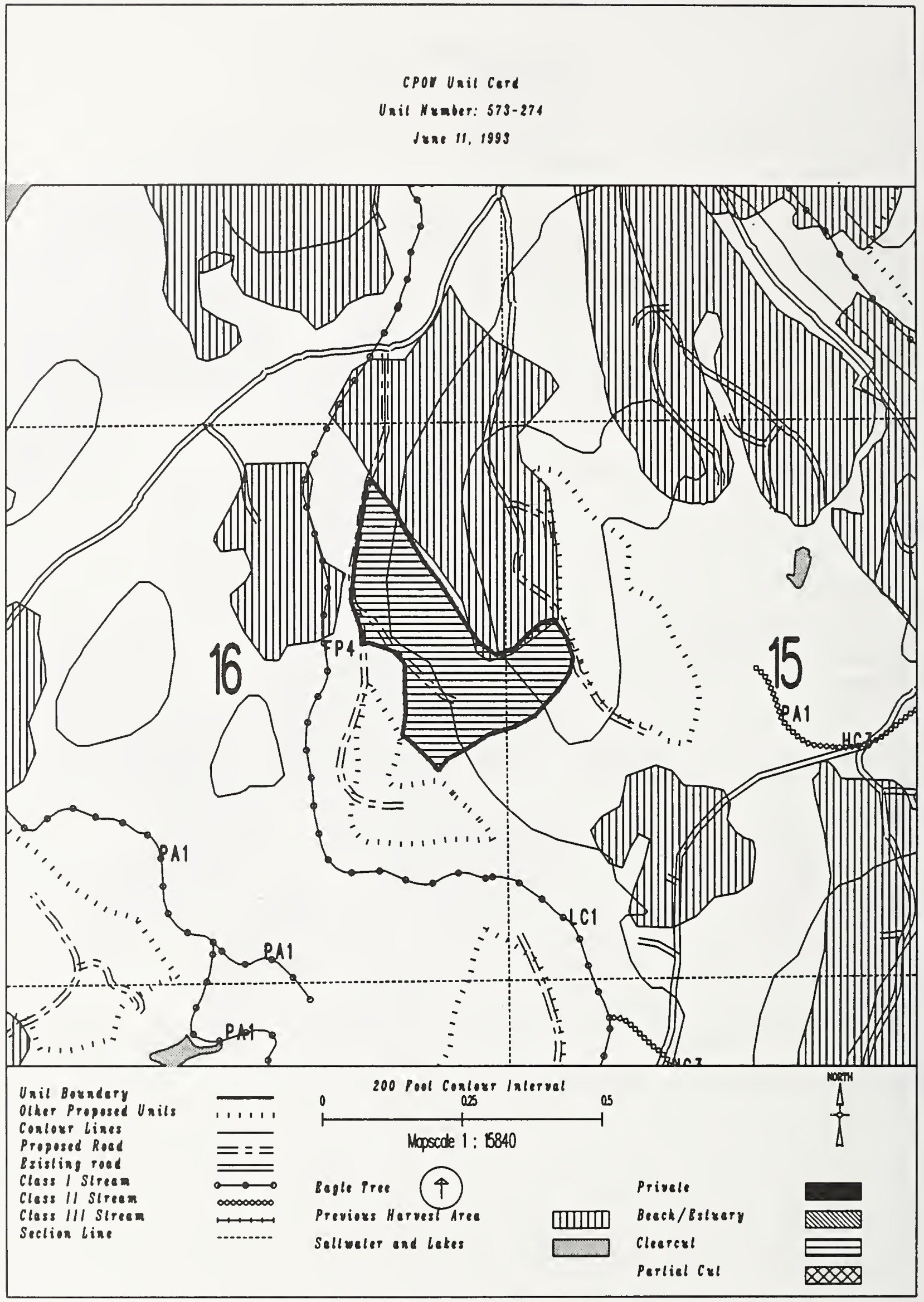


Unit $\quad \underline{573-275}$

Planned acres 19

Estimated volume (mbf) 412

Logging system Highlead

silvicultural system clearcut

Forest type Cedar
Alternatives considered F2 F3 F6

Quad CRGD3NWN

Mgmt Area K08

WAA 1421

Photo 990074

Aspect West

\section{PHYSICAL DESCRIPTION}

Volume class breakdown: VC4 15 acres VC5 1 acres VC6 $\quad 0$ acres vC7 1 acres

Elevation breakdown: $0-800 \mathrm{ft} .19$ acres $800-1200 \mathrm{ft} . \underline{0}$ acres 1200-1500 ft. 0 acres over $1500 \mathrm{ft}$. 0 acres Mass movement index: Low 1 acres Medium 0 acres High 10 acres Very High 0

SOILS

This unit has high mass movement index soils. Partial log suspension required over these areas. (BMP13.9)

This unit contains 18 acres of forested wetlands. Site specific BMPs will be designed for selected approved

logging system and road construction practices. (BMPs 12.5, 13.9, 13.15).

\section{TIMBER}

There are no timber mitigation measures anticipated for this unit.

\section{ENGINEER ING}

High mass movement index soils. Road construction must minimize landslide potential (BMP14).

\section{FISH/WATERSHED}

Potential for additional Class $1 / 11$ streams within unit. May be necessary to place additional buffers within unit in accordance with AHMU Handbook.

Potential impact on significant fishery habitat. May be necessary to expand planned buffer in accordance with AHMU Handbook.

\section{WILDLIFE}

Maintain diversity within unit by leaving 1-5 acre-sized islands of green trees at a rate of 1 acre of island for every 20 acres harvested. Leave islands must be compatible with logging system and safe working conditions.

RECREATION / VISUALS

This unit has a proposed voo of MM and is not seen from any viewpoint identified by this project.

LANDS

There are no lands mitigation measures anticipated for this unit.

CULTURAL RESOURCES

There are no cultural resource mitigation measures anticipated for this unit.

GEOLOGY

There are no karst mitigation measures anticipated for this unit. 


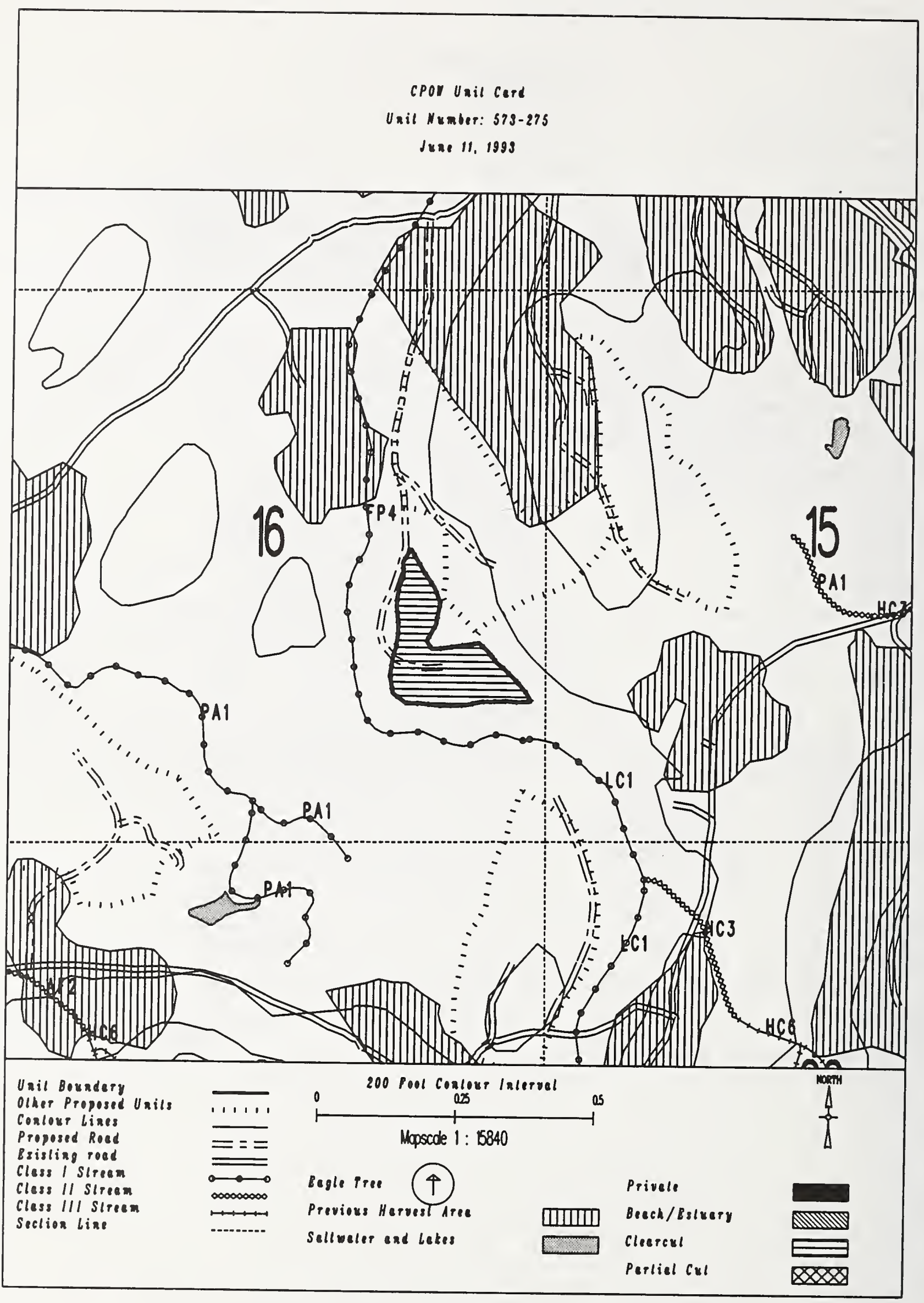




\section{Unit $\quad$ 573-289}

Planned acres 69

Estimated volume (mbf) 2482

Logging system skyline

silvicultural system clearcut

Forest type Mixed conifer
Al ternatives considered

Quad CRGD3NWS

Mgmt Area $\mathrm{KOB}$

WAA 1421

Photo 990057

Aspect North

\section{PHYSICAL DESCRIPTION}

Volume class breakdown: VC4 $\quad 0$ acres VC5 20 acres VC6 $\quad 48$ acres VC7 $\quad 0$ acres

Elevation breakdown: $0-800 \mathrm{ft} .68$ acres $800-1200 \mathrm{ft} . \underline{0}$ acres $1200-1500 \mathrm{ft} . \underline{0}$ acres over $1500 \mathrm{ft}$. 0 acres Mass movement index: Low 1 acres Medium 0 acres High 26 acres Very High 0

\section{SOILS}

This unit has high mass movement index soils. Partial log suspension required over these areas. (BMP13.9)

This unit contains 26 acres of forested wetlands. Site specific BMPs will be designed for selected approved

logging system and road construction practices. (BMPs 12.5, 13.9, 13.15).

\section{TIMBER}

There are no timber mitigation measures anticipated for this unit.

\section{ENGINEER ING}

High mass movement index soils. Road construction must minimize landslide potential (BMP14).

The road into this unit crosses a $\underline{B 2}$ channel. Meet stream and lake protection prescription requirements in TLMP Draft Revision (1991a) for this process group.

\section{FISH/WATERSHEO}

Potential for additional Class $1 / 11$ streams within unit. May be necessary to place additional buffers within unit in accordance with AHMU Handbook.

\section{WILDLIFE}

Harvest operations restricted to April 1 to October 31 to protect trumpeter swans on Barnes, Sweetwater Lakes.

\section{RECREATION / VISUALS}

This unit has a proposed VQO of MM and is not seen from any viewpoint identified by this project.

\section{LANDS}

There are no lands mitigation measures anticipated for this unit.

CULTURAL RESOURCES

There are no cultural resource mitigation measures anticipated for this unit.

GEOLOGY

There are no karst mitigation measures anticipated for this unit. 


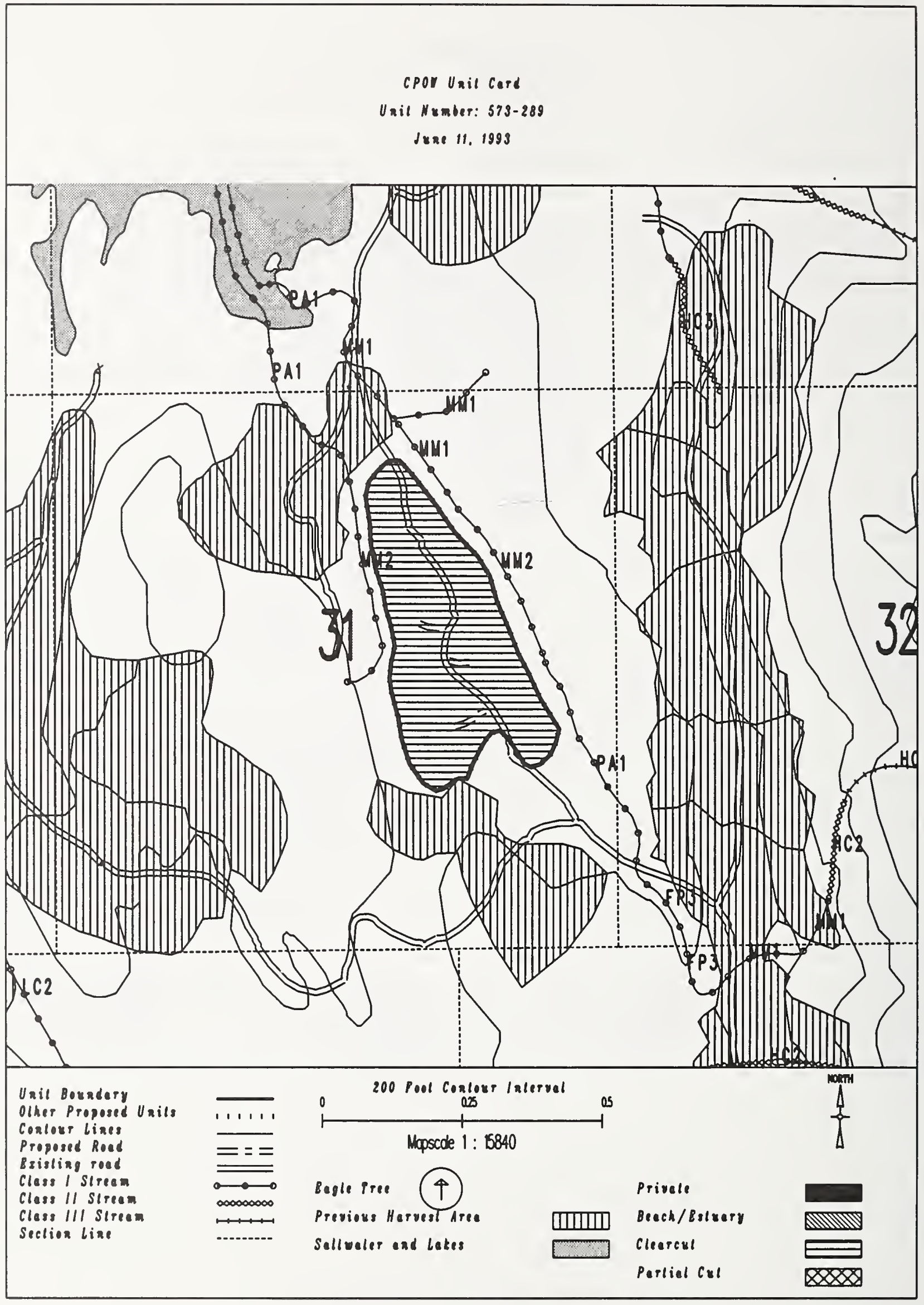


Unit 573-296

Planned acres 56

Estimated volume (mbf) 2002

Logging system Highlead

silvicultural system Clearcut

Forest type Mixed conifer
Alternatives considered

Quad CRGD3NWN

Mgmt Area K08

WAA 1421

Photo 890107

Aspect South

PHYSICAL DESCRIPTION

Volume class breakdown: VC4 $\quad 0$ acres VC5 15 acres VC6 $\quad 37$ acres VC7 $\quad 2$ acres

Elevation breakdown: $0-800 \mathrm{ft} .54$ acres $800-1200 \mathrm{ft} . \underline{0}$ acres $1200-1500 \mathrm{ft}$. 0 acres over $1500 \mathrm{ft}$. 0 Mass movement index: Low $\_$acres Medium $\_$acres High 33 acres Very High 0

\section{SOILS}

This unit has high mass movement index soils. Partial log suspension required over these areas. (BMP13.9)

This unit contains 31 acres of forested wetlands. Site specific BMPs will be designed for selected approved

logging system and road construction practices. (BMPs 12.5, 13.9, 13.15).

This unit contains 5 acres of slopes > $75 \%$.

\section{TIMBER}

Potential for shovel logging on 63 acres, if soil and water quality protected (BMP13.7)

\section{ENGI NEER ING}

High mass movement index soils. Road construction must minimize landslide potential (BMP14).

The road into this unit crosses a $\underline{C 2}$ channel. Meet stream and lake protection prescription requirements in TLMP Draft Revision (1991a) for this process group.

\section{FISH/WATERSHED}

Potential for additional Class I/II streams within unit. May be necessary to place additional buffers within unit

in accordance with AHMU Handbook.

This unit contains streams which have recently been classified/channel typed but require field verification.

\section{HILDLIFE}

There are no wildlife mitigation measures anticipated for this unit.

\section{RECREATION / VISUALS}

This unit has a proposed voo of MM and is not seen from any viewpoint identified by this project.

\section{LANDS}

There are no lands mitigation measures anticipated for this unit.

CULTURAL RESOURCES

There are no cultural resource mitigation measures anticipated for this unit.

GEOLOGY

There are no karst mitigation measures anticipated for this unit. 


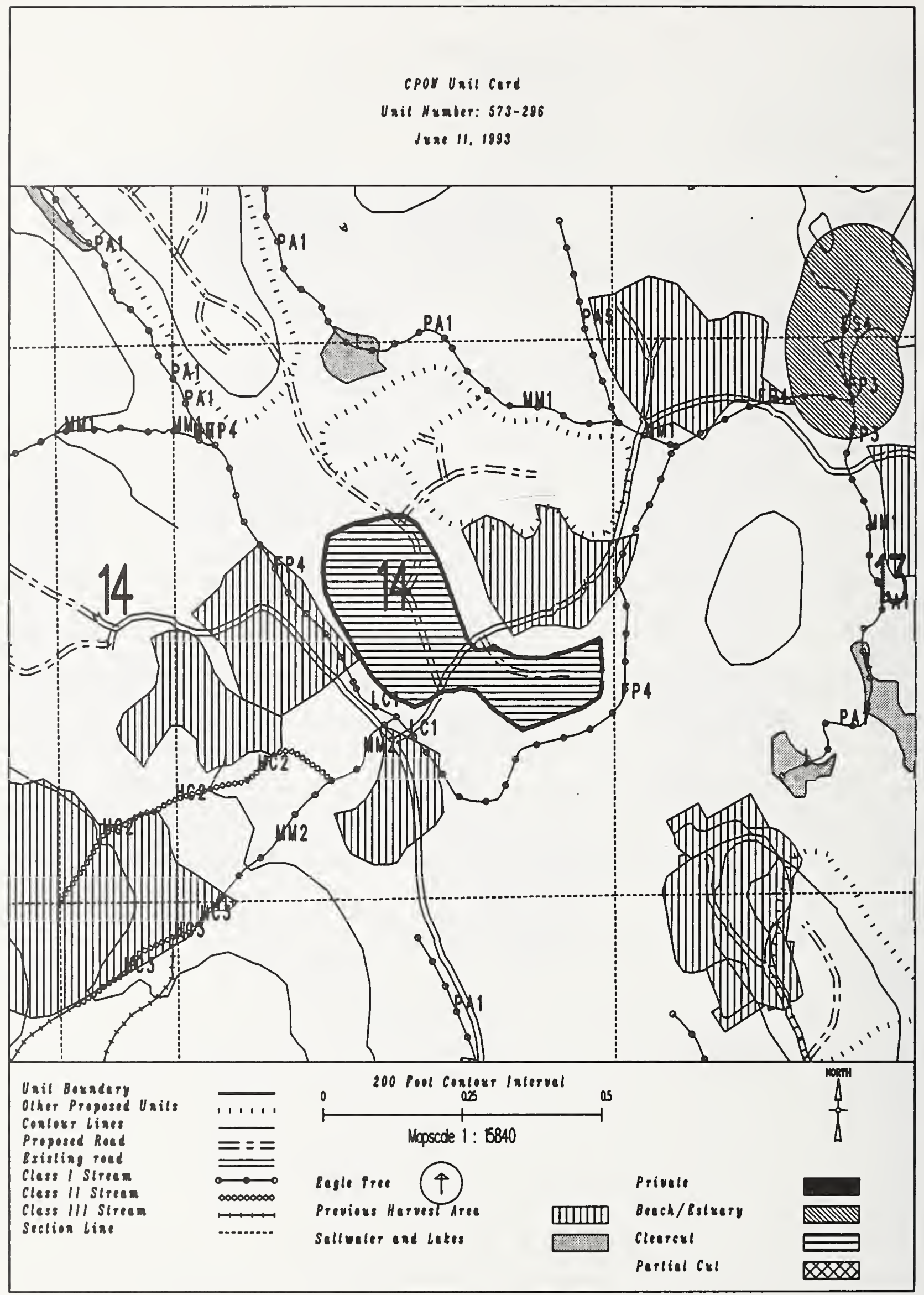


Unit $\quad 573-297$

Planned acres 60

Estimated volume (mbf) 1535

Logging system Highlead

silvicultural system Riparian

Forest type Mixed conifer
Alternatives considered

Quad CRGD3NWN

Mgmt Area K08

WAA 1421

Photo 890107

Aspect East

PHYSICAL DESCRIPTION

Volume class breakdown: VC4 $\quad 0$ acres VC5 3 acres vC6 46 acres vc7 0 acres

Elevation breakdown: $0-800 \mathrm{ft} . \underline{58}$ acres $800-1200 \mathrm{ft} . \underline{0}$ acres $1200-1500 \mathrm{ft} . \underline{0}$ acres over $1500 \mathrm{ft}$. 0 Mass movement index: Low 5 acres Medium 0 acres High 36 acres Very High 0

SOILS

This unit has high mass movement index soils. Partial log suspension required over these areas. (BMP13.9)

This unit contains 27 acres of forested wetlands. Site specific BMPs will be designed for selected approved

logging system and road construction practices. (BMPs 12.5, 13.9, 13.15).

\section{TIMBER}

Uneven-aged harvest for riparian management on an estimated 17 acres.

Potential for shovel logging on 17 acres, if soil and water quality protected (BMP13.7)

\section{ENGINEERING}

High mass movement index soils. Road construction must minimize landslide potential (BMP14).

The road into this unit crosses a B2 channel. Meet stream and lake protection prescription requirements in TLMP Draft Revision (1991a) for this process group.

\section{FISH/WATERSHED}

Potential for additional Class I/II streams within unit. May be necessary to place additional buffers within unit in accordance with AHMU Handbook.

\section{WI LDL IFE}

There are no wildlife mitigation measures anticipated for this unit.

RECREATION / VISUALS

This unit has a proposed VQO of MM and is not seen from any viewpoint identified by this project.

LANDS

There are no lands mitigation measures anticipated for this unit.

\section{CULTURAL RESOURCES}

The planned unit boundary and road location is immediately adjacent to significant cultural resources. Any changes must be coordinated with cultural resource personnel.

\section{GEOLOGY}

There are no karst mitigation measures anticipated for this unit. 
cpor Uail Cerd

Unil Number: 573-297

June 11, 1999

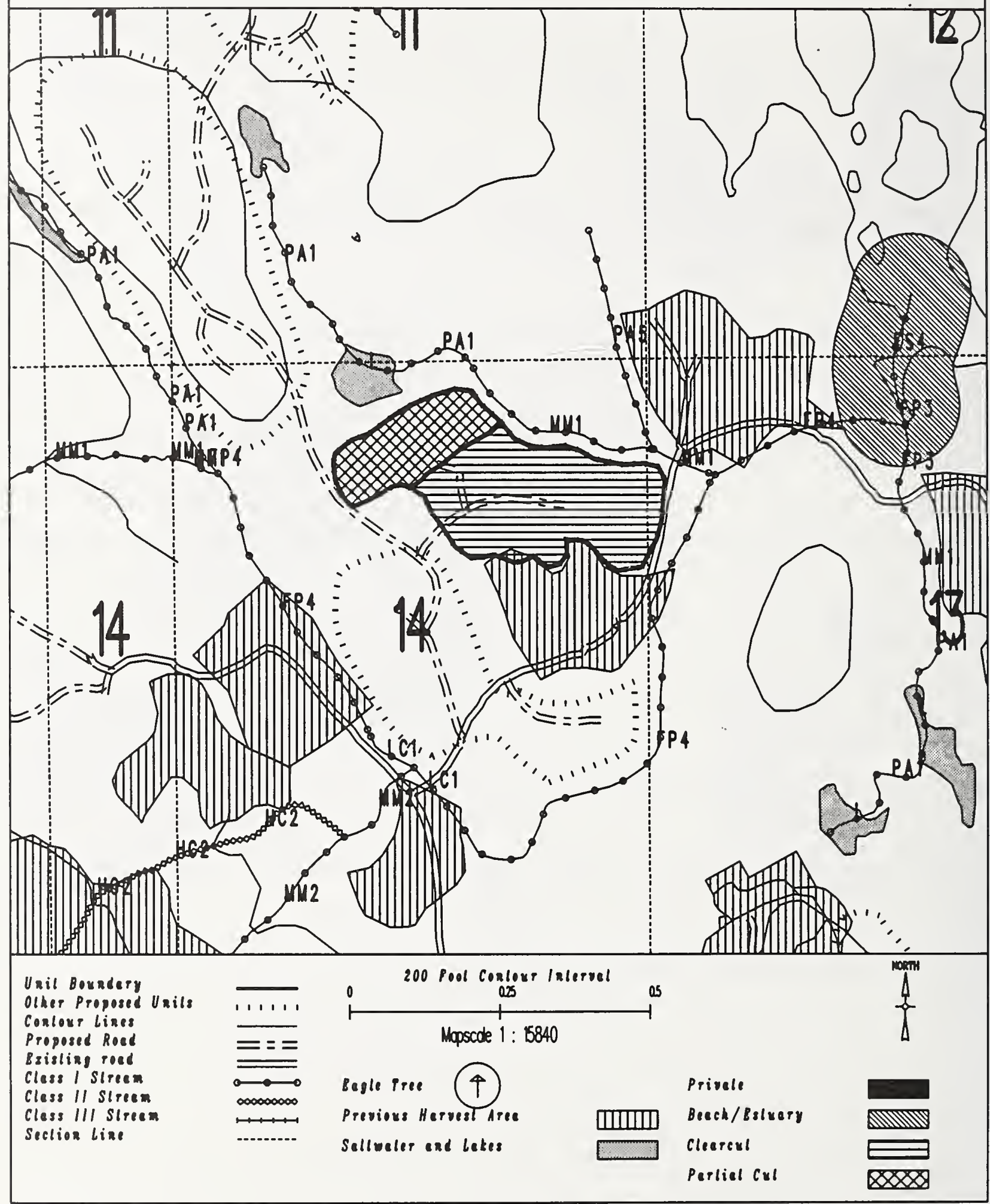


Unit $573-300$

Planned acres 18

Estimated volume (mbf) 416

Logging system Highlead

silvicultural system Clearcut

Forest type Hemlock
Alternatives considered

Quad CRGD3NWN

Mgmt Area $\mathrm{KO8}$

WAA 1421

Photo 990061

Aspect South

\section{PHYSICAL DESCRIPTION}

Volume class breakdown: VC4 16 acres VC5 2 acres VC6 $\quad 0$ acres VC7 $\quad 0$ acres

Elevation breakdown: $0-800 \mathrm{ft} .16$ acres $800-1200 \mathrm{ft} . \underline{0}$ acres $1200-1500 \mathrm{ft} . \underline{0}$ acres over $1500 \mathrm{ft}$. 0 acres Mass movement index: Low $\_$acres Medium 1 acres High 2 acres Very High 0 acres

SOILS

This unit has high mass movement index soils. Partial log suspension required over these areas.(BMP13.9)

This unit contains 16 acres of forested wetlands. Site specific BMPs will be designed for selected approved

logging system and road construction practices. (BMPs 12.5, 13.9, 13.15).

This unit contains 4 acres of slopes $>75 \%$.

\section{TIMBER}

There are no timber mitigation measures anticipated for this unit.

\section{ENGINEER ING}

There are no engineering mitigation measures anticipated for this unit.

\section{FISH/WATERSHED}

There are no fishery mitigation measures anticipated for this unit.

\section{WILDLIFE}

There are no wildlife mitigation measures anticipated for this unit.

RECREATION / VISUALS

This unit has a proposed voo of MM and is not seen from any viewpoint identified by this project.

LANDS

There are no lands mitigation measures anticipated for this unit.

\section{CULTURAL RESOURCES}

There are no cultural resource mitigation measures anticipated for this unit.

There are no karst mitigation measures anticipated for this unit. 


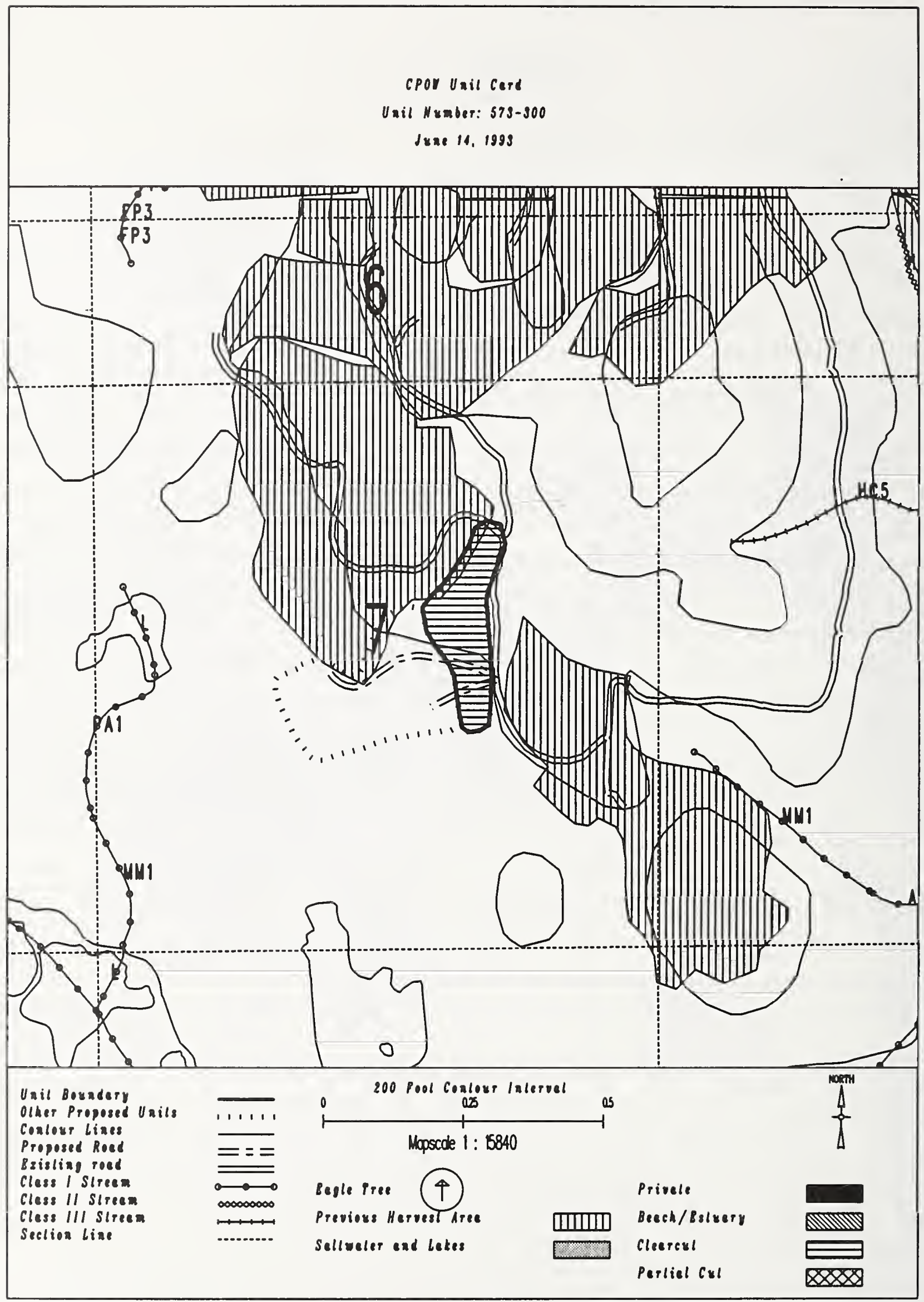


Unit $\quad 573-308$

Planned acres 57

Estimated volume (mbf) 1786

Logging system Helicopter

silvicultural system clearcut

Forest type Mixed conifer
Alternatives considered

Quad CRGD3NHN

Mgmt Area $\mathrm{KO8}$

WAA 1421

Photo 1190067

Aspect East

\section{PHYSICAL DESCRIPTION}

Volume class breakdown: VC4 10 acres VC5 42 acres vc6 5 acres vc7 0 acres

Elevation breakdown: $0-800 \mathrm{ft} . \underline{21}$ acres 800-1200 ft. ․ㅡ acres 1200-1500 ft. 0 acres over $1500 \mathrm{ft}$. 0 acres Mass movement index: Low $\underline{O}$ acres Medium 0 acres High 21 acres Very High 0

SOILS

This unit has high mass movement index soils. Partial log suspension required over these areas. (BMP13.9)

\section{TIMBER}

There are no timber mitigation measures anticipated for this unit.

\section{ENGINEERING}

There are no engineering mitigation measures anticipated for this unit.

\section{FISH/WATERSHED}

This unit contains a $\underline{A} 1$ class $\underline{3}$ stream. No specific buffer required, but full suspension, if yarding across. This unit contains streams which have recently been classified/channel typed but require field verification.

\section{WILDLIFE}

There are no wildlife mitigation measures anticipated for this unit.

RECREATION / VISUALS

The unit has a proposed VaO of PR within the viewshed of Sweetwater Lake as viewed from from centerline of lake.

LANDS

There are no lands mitigation measures anticipated for this unit.

CULTURAL RESOURCES

There are no cultural resource mitigation measures anticipated for this unit. 


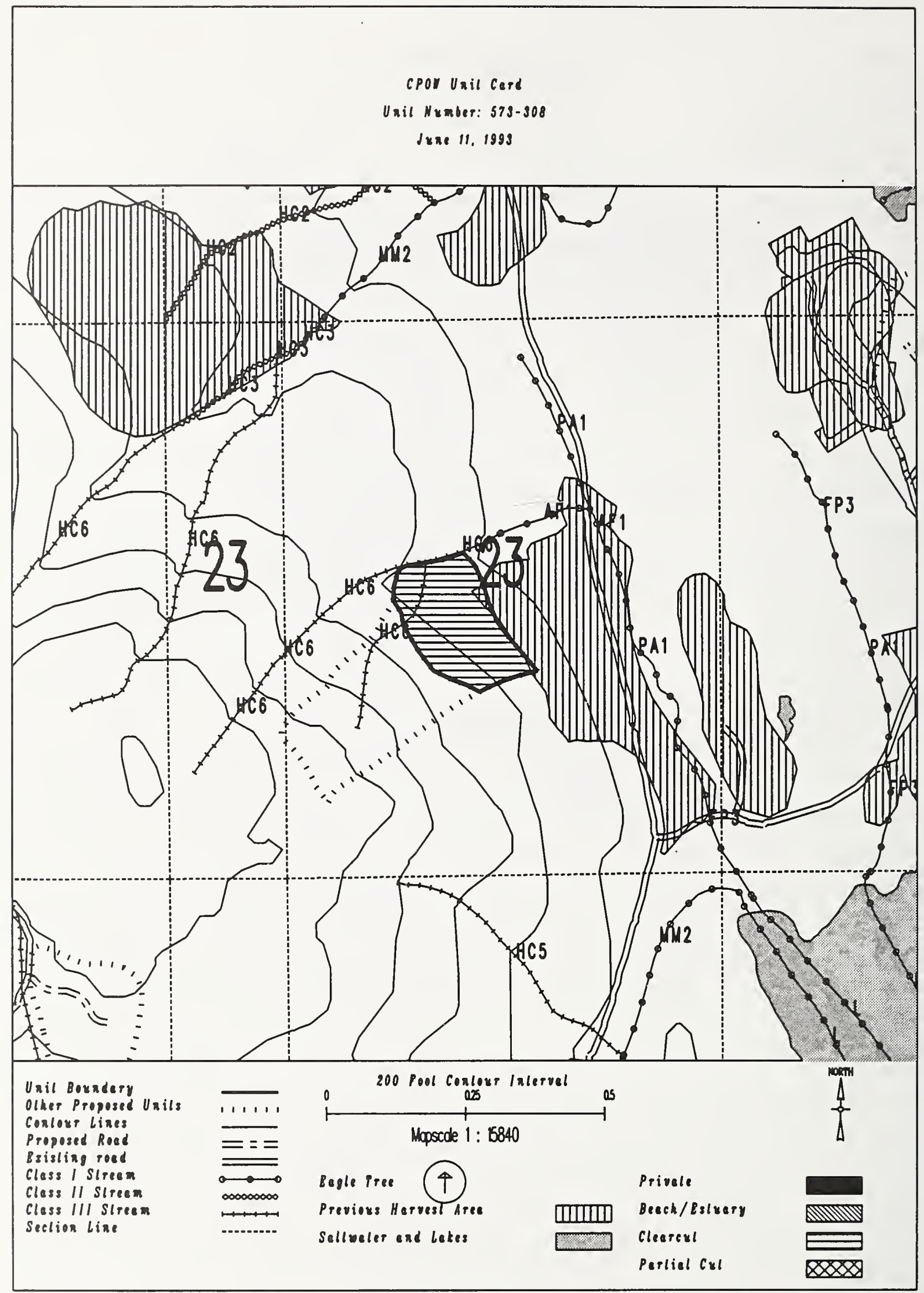


Unit $573-314$

Planned acres 97

Est imated volume (mbf) 1285

Logging system Highlead

silvicultural system Riparian

Forest type Hemlock
Alternatives considered

F3

Quad CRGD3NWN

Mgmt Area $\mathrm{KO8}$

WAA 1421

Photo 1190069

Aspect East

\section{PHYSICAL DESCRIPTION}

Volume class breakdown: VC4 12 acres VC5 90 acres VC6 $\quad 0$ acres VC7 $\quad 0$ acres

Elevation breakdown: $0-800 \mathrm{ft} . \underline{98}$ acres $800-1200 \mathrm{ft} . \underline{0}$ acres $1200-1500 \mathrm{ft} . \underline{0}$ acres over $1500 \mathrm{ft}$. Mass movement index: Low 34 acres Medium 31 acres High 33 acres Very High 0 acres

SOILS

This unit has high mass movement index soils. Partial log suspension required over these areas.(BMP13.9)

This unit contains 54 acres of forested wetlands. Site specific BMPs will be designed for selected approved

logging system and road construction practices. (BMPs 12.5, 13.9, 13.15).

\section{TIMBER}

Uneven-aged harvest for riparian management on an estimated 97 acres.

Potential for shovel logging on 13 acres, if soil and water quality protected (BMP13.7)

\section{ENGINEER ING}

High mass movement index soils. Road construction must minimize landslide potential (BMP14).

\section{FISH/WATERSHED}

Potential for additional Class I/II streams within unit. May be necessary to place additional buffers within unit in accordance with AHMU Handbook.

WILDLIFE

There are no wildlife mitigation measures anticipated for this unit.

RECREATION / VISUALS

This unit has a proposed Vao of MM and is not seen from any viewpoint identified by this project.

\section{LANDS}

There are no lands mitigation measures anticipated for this unit.

\section{CULTURAL RESOURCES}

The planned unit boundary and road location is immediately adjacent to significant cultural resources. Any changes must be coordinated with cultural resource personnel.

\section{GEOLOGY}

There are no karst mitigation measures anticipated for this unit. 


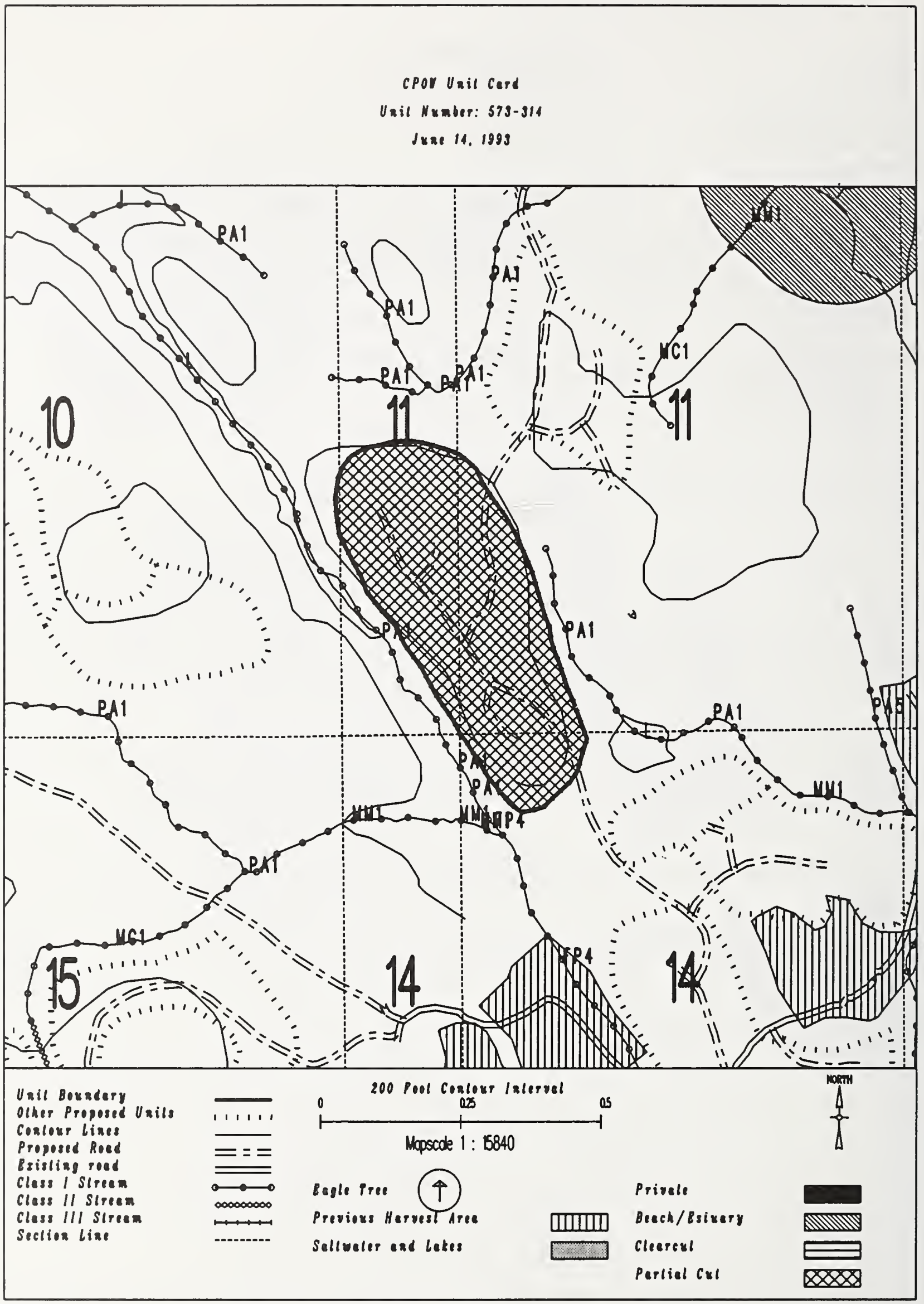




\section{Unit $\quad 574-210$}

Planned acres 40

Estimated volume (mbf) 886

Logging system slackline

silvicultural system clearcut

Forest type Hemlock
Alternatives considered F2 F3 F4 F5

Quad CRGD3SWN

Mgmt Area $\mathrm{K08}$

WAA 1421

Photo 990052

Aspect North

PHYSICAL DESCRIPTION

Volume class breakdown: VC4 24 acres VC5 11 acres vC6 $\quad 0$ acres vc7 $\quad 0$ acres

Elevation breakdown: $0-800 \mathrm{ft} . \underline{36}$ acres $800-1200 \mathrm{ft} . \underline{2}$ acres $1200-1500 \mathrm{ft} . \underline{0}$ acres over $1500 \mathrm{ft} . \underline{0}$ acres Mass movement index: Low 16 acres Medium 9 acres High 11 acres Very High 0 acres

SOILS

This unit has high mass movement index soils. Partial log suspension required over these areas. (BMP13.9)

This unit contains 24 acres of forested wetlands. Site specific BMPs will be designed for selected approved

logging system and road construction practices. (BMPs 12.5, 13.9, 13.15).

TIMBER

There are no timber mitigation measures anticipated for this unit.

ENGINEER ING

High mass movement index soils. Road construction must minimize landslide potential (BMP14).

\section{FISH/WATERSHED}

There are no fishery mitigation measures anticipated for this unit.

\section{WILDLIFE}

Maintain diversity within unit by leaving 1-5 acre-sized islands of green trees at a rate of 1 acre of island for every 20 acres harvested. Leave islands must be compatible with logging system and safe working conditions.

\section{RECREATION / VISUALS}

The unit has a proposed voo of PR within the viewshed of Hatchery Lake

as viewed from from centerline of lake.

\section{LANDS}

There are no lands mitigation measures anticipated for this unit.

CULTURAL RESOURCES

There are no cultural resource mitigation measures anticipated for this unit.

GEOLOGY

There are no karst mitigation measures anticipated for this unit. 


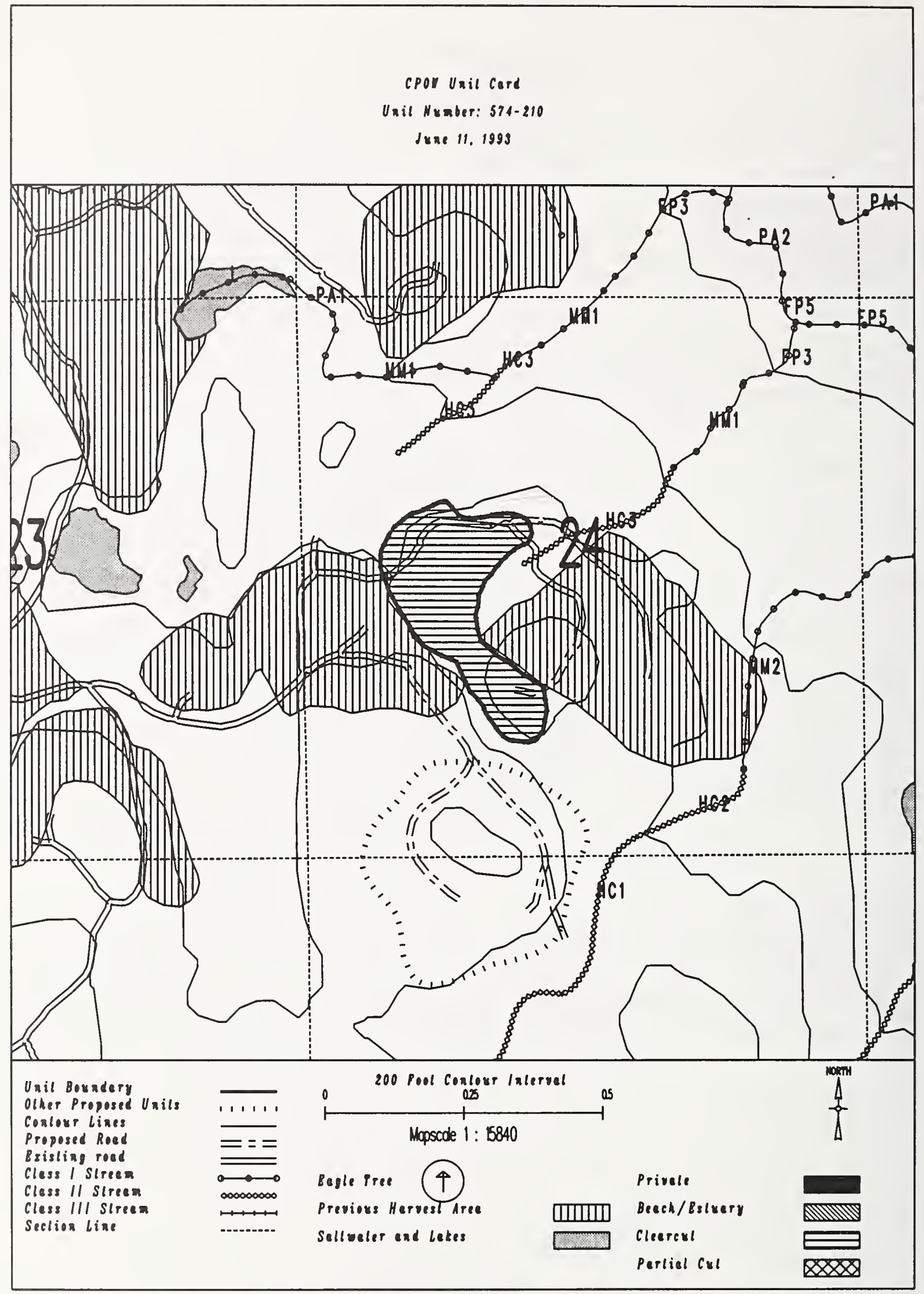


Unit $\quad 574-224$

Planned acres 65

Est imated volume (mbf) 1651.

Logging system skyline

silvicultural system clearcut

Forest type Hemlock
Alternatives considered F2 F3

Quad CRGD3SWN

Mgmt Area K08

WAA 1421

Photo 990-052

Aspect East

PHYSICAL DESCRIPTION

Volume class breakdown: VC4 32 acres VC5 29 acres VC6 $\quad 0$ acres vC7 $\quad 0$ acres

Elevation breakdown: $0-800 \mathrm{ft} . \underline{16}$ acres $800-1200 \mathrm{ft} . \underline{46}$ acres $1200-1500 \mathrm{ft} . \underline{0}$ acres over $1500 \mathrm{ft}$. 0 acres Mass movement index: Low 6 acres Medium 0 acres High 33 acres Very High 0 acres

SOILS

This unit has high mass movement index soils. Partial log suspension required over these areas. (BMP13.9)

This unit contains 28 acres of forested wetlands. Site specific BMPs will be designed for selected approved

logging system and road construction practices. (BMPs 12.5, 13.9, 13.15).

This unit contains 32 acres of slopes > $75 \%$.

TIMBER

There are no timber mitigation measures anticipated for this unit.

ENGINEER ING

High mass movement index soils. Road construction must minimize landslide potential (BMP14).

slopes greater than $75 \%$ may require full bench construction and endhaul of waste (BMP 14.7).

FISH/WATERSHED

Potential for additional Class I/II streams within unit. May be necessary to place additional buffers within unit in accordance with AHMU Handbook.

This unit contains streams which have recently been classified/channel typed but require field verification.

\section{WILDLIFE}

Maintain diversity within unit by leaving 1-5 acre-sized islands of green trees at a rate of 1 acre of island for every 20 acres harvested. Leave islands must be compatible with logging system and safe working conditions.

\section{RECREATION / VISUALS}

This unit has a proposed voo of $M M$ and is not seen from any viewpoint identified by this project.

\section{LANDS}

There are no lands mitigation measures anticipated for this unit.

\section{CULTURAL RESOURCES}

There are no cultural resource mitigation measures anticipated for this unit.

\section{GEOLOGY}

There are no karst mitigation measures anticipated for this unit. 


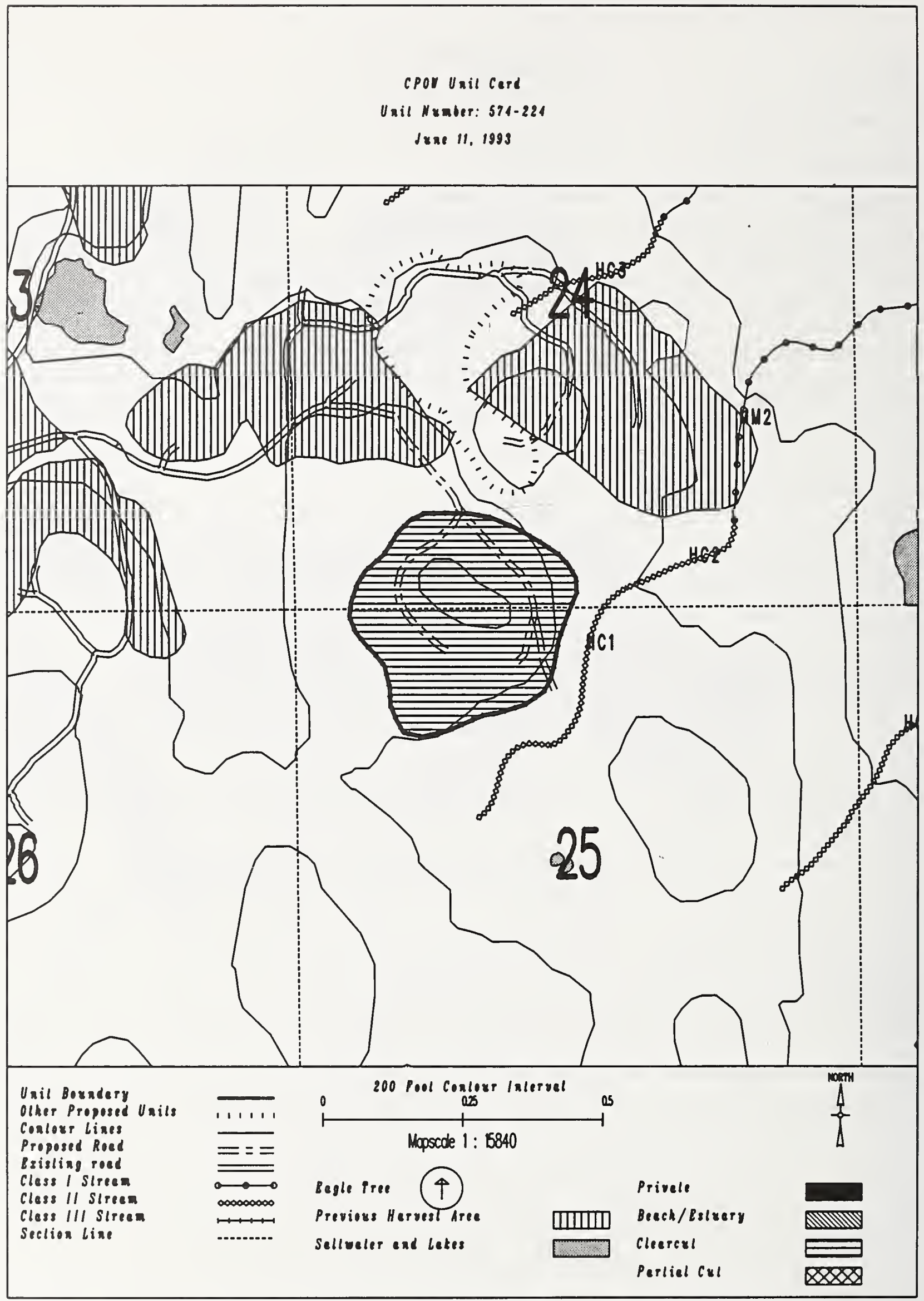


Unit $\quad$ 574-238

Planned acres 54

Estimated volume (mbf) 1509

Logging system skyline

silvicultural system Partial cut

Forest type Mixed conifer
Alternatives considered F3
Mgmt Area $\mathrm{KO8}$

WAA 1421

Photo 990079

Aspect West

\section{PHYSICAL DESCRIPTION}

Volume class breakdown: VC4 21 acres VC5 32 acres vc6 $\quad 0$ acres vc7 $\quad 0$ acres

Elevation breakdown: $0-800 \mathrm{ft} . \underline{52}$ acres $800-1200 \mathrm{ft} . \quad 0$ acres $1200-1500 \mathrm{ft} . \underline{0}$ acres over $1500 \mathrm{ft}$. 0 Mass movement index: Low 4 acres Medium 0 acres High 13 acres Very High 0 acres

\section{SOILS}

This unit has high mass movement index soils. Partial log suspension required over these areas. (BMP13.9)

This unit contains 29 acres of forested wetlands. Site specific BMPs will be designed for selected approved

logging system and road construction practices. (BMPs 12.5, 13.9, 13.15).

\section{TIMBER}

Partial cut harvest required to meet specified visual quality objectives.

Selective harvest required to meet direction of Honker Management Plan adopted by TLMP.

ENGINEER ING

High mass movement index soils. Road construction must minimize landslide potential (BMP14).

FISH/WATERSHED

Potential for additional Class I/II streams within unit. May be necessary to place additional buffers within unit in accordance with AHMU Handbook.

Potential impact on significant fishery habitat. May be necessary to expand planned buffer in accordance with AHMU Handbook.

\section{WILDLIFE}

There are no wildlife mitigation measures anticipated for this unit.

\section{RECREATION / VISUALS}

The unit has a proposed VQO of PR within the viewshed of Hatchery Lake

as viewed from from centerline of lake.

This unit lies within $1 / 2$ mile Thorne River boundary established by the Honker Managment Plan adopted by TLMP.

\section{LANDS}

There are no lands mitigation measures anticipated for this unit.

\section{CULTURAL RESOURCES}

There are no cultural resource mitigation measures anticipated for this unit. 


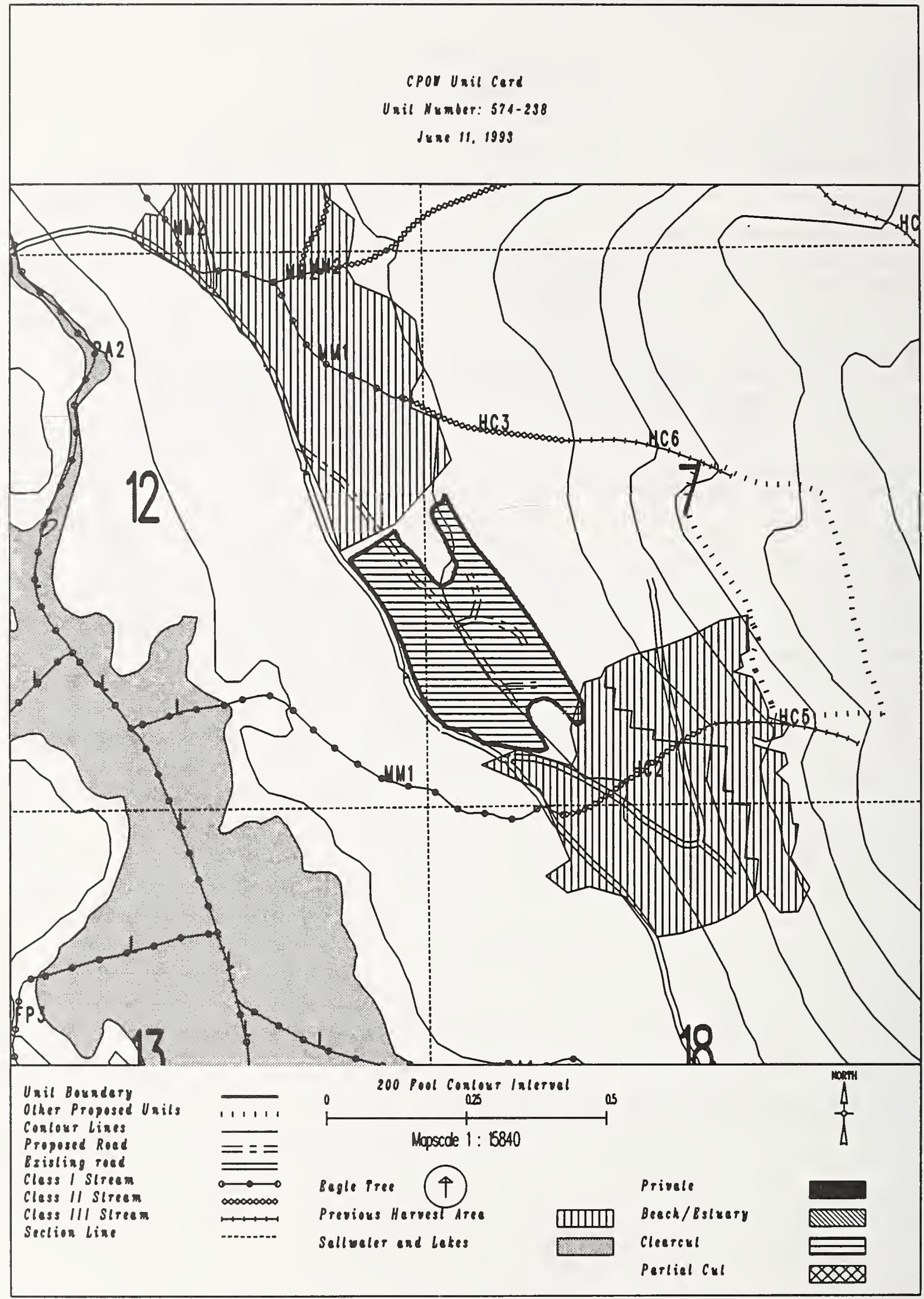


Unit $\quad 574-239$

Planned acres 58

Estimated volume (mbf) 1110

Logging system Helicopter

silvicultural system shelterwood

Forest type Hemlock
Alternatives considered

Quad CRGD3NWS

Mgmt Area K08

WAA 1421

Photo 990079

Aspect West

\section{PHYSICAL DESCRIPTION}

Volume class breakdown: VC4 20 acres vC5 35 acres vC6 $\quad 0$ acres vc7 $\quad 0$ acres

Elevation breakdown: $0-800 \mathrm{ft} . \underline{0}$ acres $800-1200 \mathrm{ft} . \underline{4}$ acres $1200-1500 \mathrm{ft} . \underline{13}$ acres over $1500 \mathrm{ft}$. 0

Mass movement index: Low $\underline{23}$ acres Medium $\underline{0}$ acres High $\underline{27}$ acres Very High $\underline{0}$ acres

SOILS

This unit has high mass movement index soils. Partial log suspension required over these areas. (BMP13.9)

This unit contains 15 acres of forested wetlands. Site specific BMPs will be designed for selected approved

logging system and road construction practices. (BMPs 12.5, 13.9, 13.15).

\section{TIMBER}

Shelterwood harvest. Cedar will not be harvested.

\section{ENG INEER ING}

There are no engineering mitigation measures anticipated for this unit.

\section{FISH/WATERSHED}

This unit contains a $\underline{A} 1$ class $\underline{3}$ stream. No specific buffer required, but full suspension, if yarding across.

\section{WILDLIFE}

There are no wildlife mitigation measures anticipated for this unit.

\section{RECREATION / VISUALS}

The unit has a proposed VoO of PR within the viewshed of Hatchery Lake

as viewed from from centerline of lake.

This unit is prescribed for shelterwood harvest for cedar regeneration and to meet vQO.

\section{LANDS}

There are no lands mitigation measures anticipated for this unit.

CULTURAL RESOURCES

There are no cultural resource mitigation measures anticipated for this unit.

GEOLOGY

There are no karst mitigation measures anticipated for this unit. 


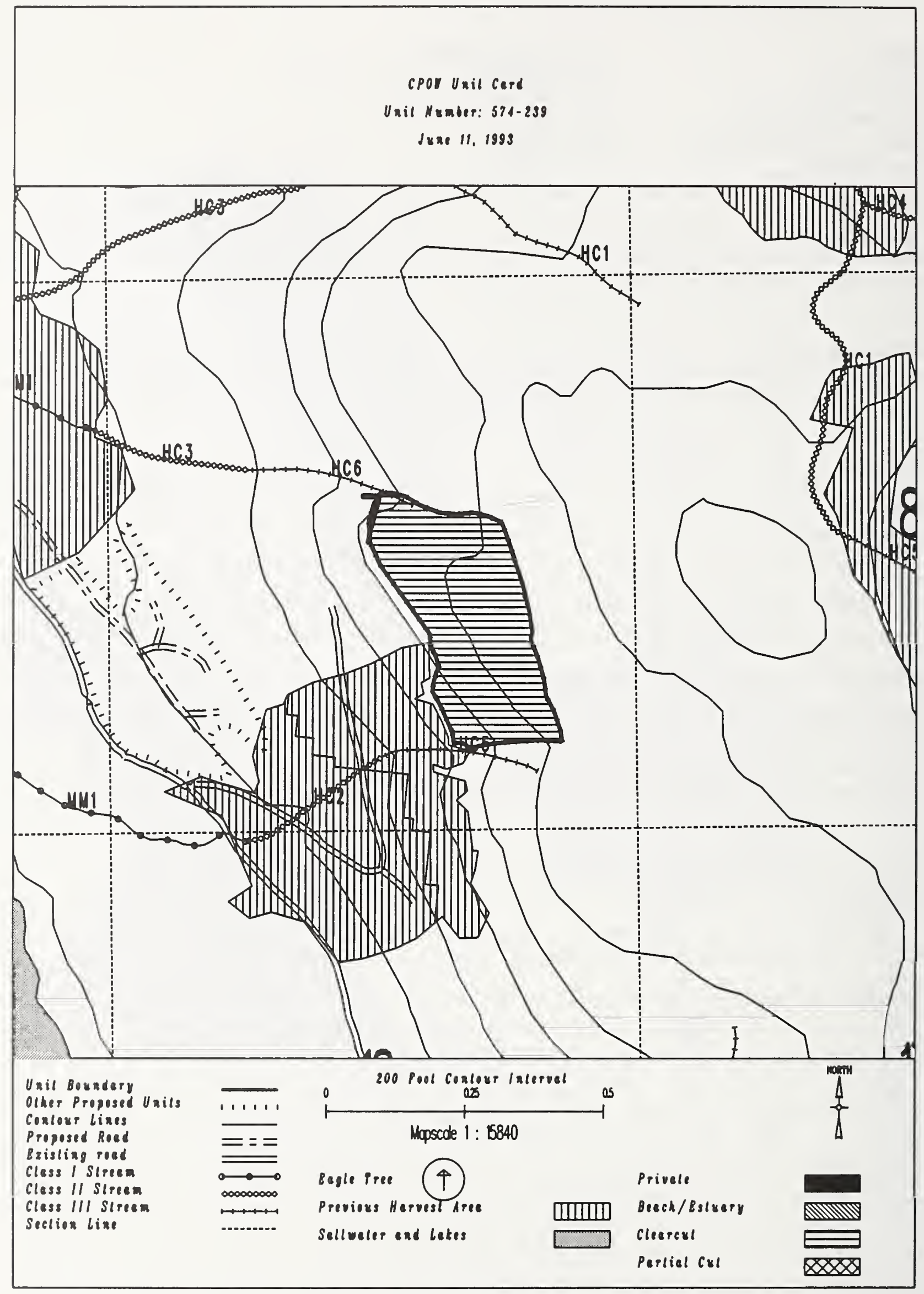




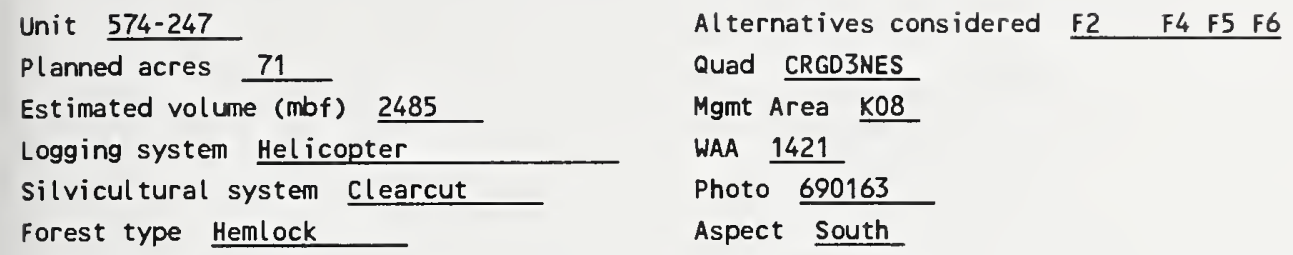

PHYSICAL DESCRIPTION

Volume class breakdown: vC4 $\quad 0$ acres vc5 70 acres vc6 $\quad 5$ acres vc7 $\quad 0$ acres

Elevation breakdown: $0-800 \mathrm{ft} . \underline{0}$ acres 800-1200 ft. 6 acres 1200-1500 ft. 5 acres over $1500 \mathrm{ft}$. 37 acres Mass movement index: Low 75 acres Medium 0 acres High 0 acres Very High 0 acres

SOILS

This unit will be monitored for effects of harvest/roading on steep slopes.

TIMBER

There are no timber mitigation measures anticipated for this unit.

ENGINEERING

There are no engineering mitigation measures anticipated for this unit.

FISH/WATERSHED

There are no fishery mitigation measures anticipated for this unit.

\section{WILDLIFE}

Maintain diversity within unit by leaving 1-5 acre-sized islands of green trees at a rate of 1 acre of island for every 20 acres harvested. Leave islands must be compatible with logging system and safe working conditions.

\section{RECREATION / VISUALS}

The unit has a proposed voo of $M$ within the viewshed of Hatchery Lake as viewed from from centerline of lake.

\section{LANDS}

There are no lands mitigation measures anticipated for this unit.

CULTURAL RESOURCES

There are no cultural resource mitigation measures anticipated for this unit.

GEOLOGY

There are no karst mitigation measures anticipated for this unit. 


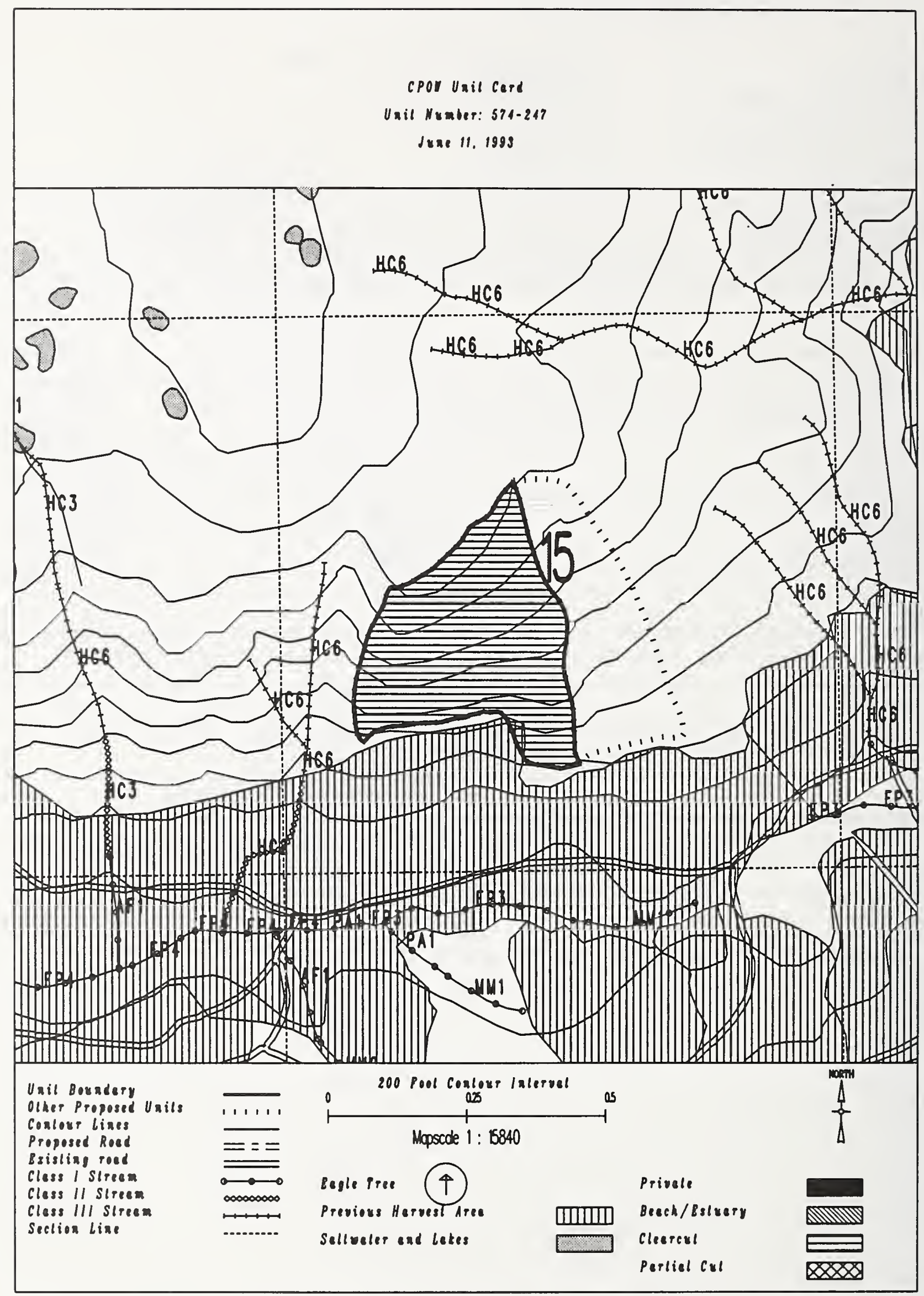


Unit $\quad 574-248$

Planned acres 45

Estimated volume (mbf) 1572

Logging system Helicopter

silvicultural system clearcut

Forest type Hemlock
Alternatives considered F2 F4 F5 F6

Quad CRGD3NES

Mgmt Area $\mathrm{KO8}$

WAA 1421

Photo 1090207

Aspect South

PHYSICAL DESCRIPTION

Volume class breakdown: VC4 $\quad 0$ acres vc5 41 acres vc6 $\quad 6$ acres vc7 0 acres

Elevation breakdown: $0-800 \mathrm{ft} . \underline{0}$ acres $800-1200 \mathrm{ft} . \underline{12}$ acres $1200-1500 \mathrm{ft} . \underline{4}$ acres over $1500 \mathrm{ft}$. 14 acres Mass movement index: Low 46 acres Medium 0 acres High 0 acres Very High 0 acres

SOILS

This unit will be monitored for effects of harvest/roading on steep slopes.

TIMBER

There are no timber mitigation measures anticipated for this unit.

\section{ENGINEER I NG}

There are no engineering mitigation measures anticipated for this unit.

\section{FI SH/WATERSHED}

There are no fishery mitigation measures anticipated for this unit.

\section{WILDLIFE}

Maintain diversity within unit by leaving 1-5 acre-sized islands of green trees at a rate of 1 acre of island for every 20 acres harvested. Leave islands must be compatible with logging system and safe working conditions.

RECREATION / VISUALS

This unit has a proposed VQO of MM and is not seen from any viewpoint identified by this project.

\section{LANDS}

There are no lands mitigation measures anticipated for this unit.

CULTURAL RESOURCES

There are no cultural resource mitigation measures anticipated for this unit.

There are no karst mitigation measures anticipated for this unit. 
cPor Unil cerd

Uail Number: 571-218

June 11, 1999

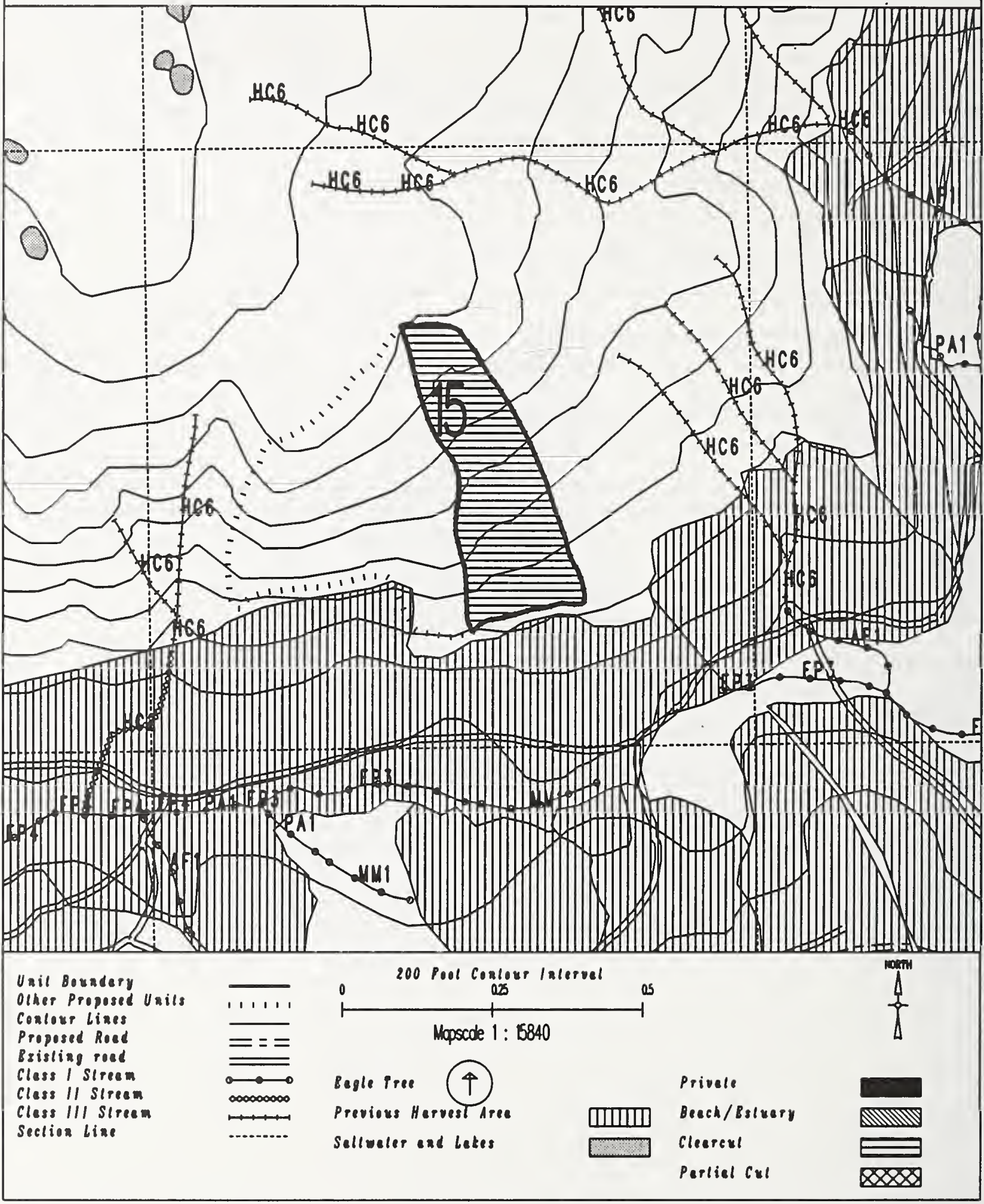


Unit $\quad 577-200$

Planned acres 36

Estimated volume (mbf) 1070

Logging system skyline

silvicultural system clearcut

Forest type Hemlock
Alternatives considered F2 F3 F4 F5 F6

Quad CRGD3NWS

Mgmt Area K08

WAA 1421

Photo 890113

Aspect West

PHYSICAL DESCRIPTION

Volume class breakdown: VC4 18 acres VC5 9 acres VC6 10 acres VC7 $\quad 0$ acres

Elevation breakdown: $0-800 \mathrm{ft} . \underline{30}$ acres $800-1200 \mathrm{ft} . \underline{1}$ acres $1200-1500 \mathrm{ft} . \underline{0}$ acres over $1500 \mathrm{ft}$. 0 Mass movement index: Low 0 acres Medium 0 acres High 9 acres Very High 0 acres

SOILS

This unit has high mass movement index soils. Partial log suspension required over these areas. (BMP13.9) This unit contains 26 acres of forested wetlands. Site specific BMPs will be designed for selected approved

logging system and road construction practices. (BMPs 12.5, 13.9, 13.15).

TIMBER

There are no timber mitigation measures anticipated for this unit.

ENGINEERING

High mass movement index soils. Road construction must minimize landslide potential (BMP14).

FISH/WATERSHED

This unit contains streams which have recently been classified/channel typed but require field verification.

WILDLIFE

There are no wildlife mitigation measures anticipated for this unit.

RECREATION / VISUALS

This unit has a proposed VQO of MM and is not seen from any viewpoint identified by this project.

LANDS

There are no lands mitigation measures anticipated for this unit.

CULTURAL RESOURCES

There are no cultural resource mitigation measures anticipated for this unit.

GEOLOGY

There are no karst mitigation measures anticipated for this unit. 


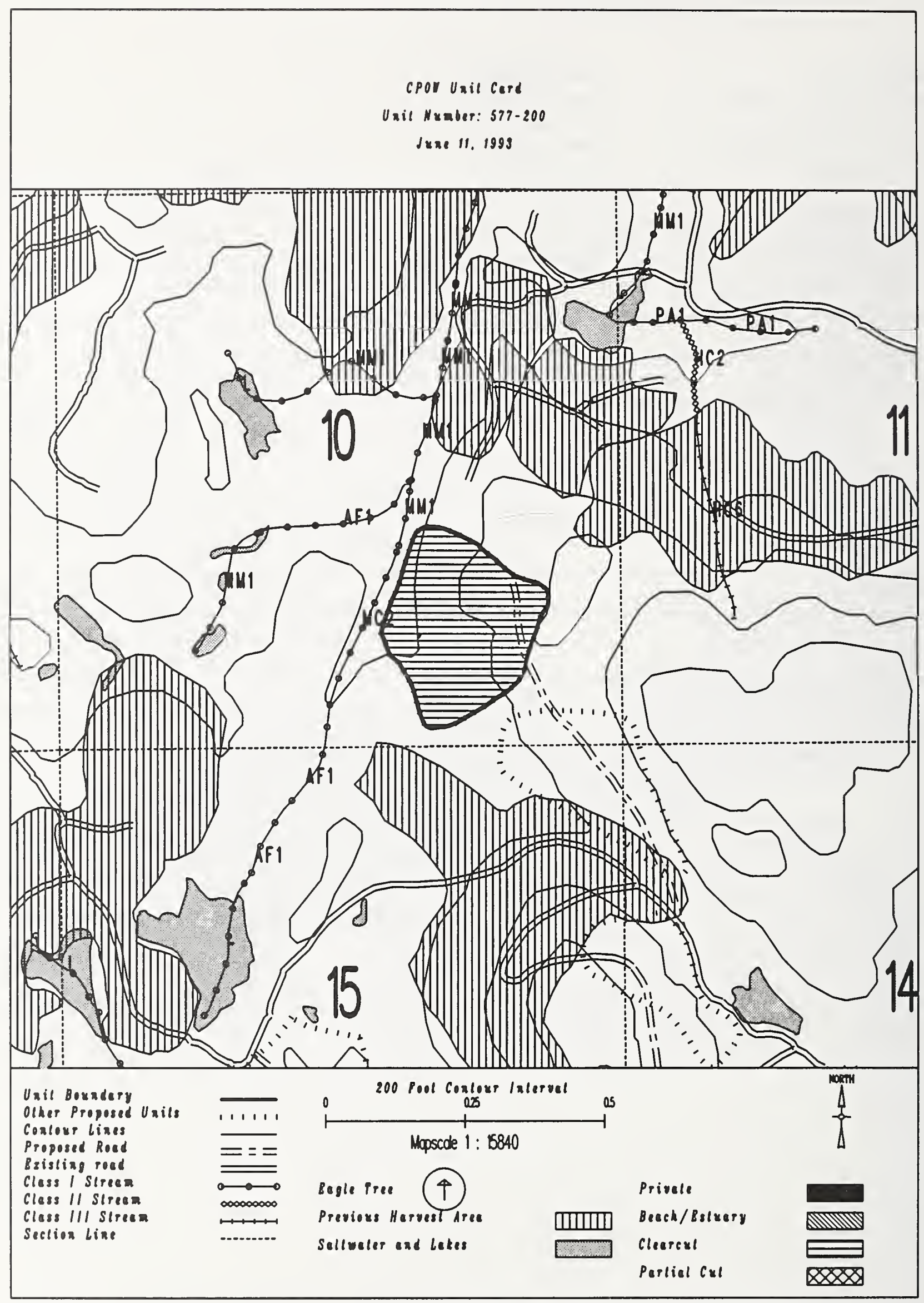


Unit $\quad 577-201$

Planned acres 31

Estimated volume (mbf) 657

Logging system Highlead

silvicultural system Clearcut

Forest type Hemlock

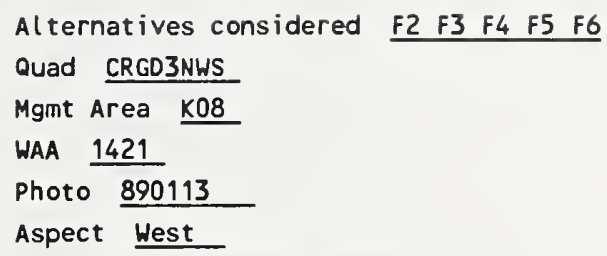

PHYSICAL DESCRIPTION

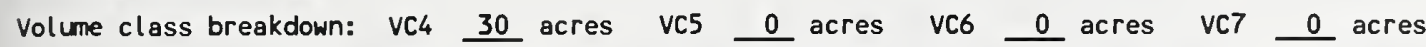

Elevation breakdown: $0-800 \mathrm{ft} . \underline{17}$ acres $800-1200 \mathrm{ft} . \underline{8}$ acres $1200-1500 \mathrm{ft} . \underline{0}$ acres over $1500 \mathrm{ft}$. 0 Mass movement index: Low 2 acres Medium 0 acres High 3 acres Very High 0

\section{SOILS}

This unit contains 22 acres of forested wetlands. Site specific BMPs will be designed for selected approved logging system and road construction practices. (BMPs 12.5, 13.9, 13.15).

This unit contains 7 acres of slopes $>75 \%$.

\section{TIMBER}

There are no timber mitigation measures anticipated for this unit.

\section{ENGINEER ING}

Slopes greater than $75 \%$ may require full bench construction and endhaul of waste (BMP14.7).

\section{FISH/WATERSHED}

This unit contains streams which have recently been classified/channel typed but require field verification.

\section{WILOLIFE}

There are no wildlife mitigation measures anticipated for this unit.

RECREATION / VISUALS

This unit has a proposed VQO of MM and is not seen from any viewpoint identified by this project.

\section{LANDS}

There are no lands mitigation measures anticipated for this unit.

CULTURAL RESOURCES

There are no cultural resource mitigation measures anticipated for this unit.

GEOLOGY

There are no karst mitigation measures anticipated for this unit. 


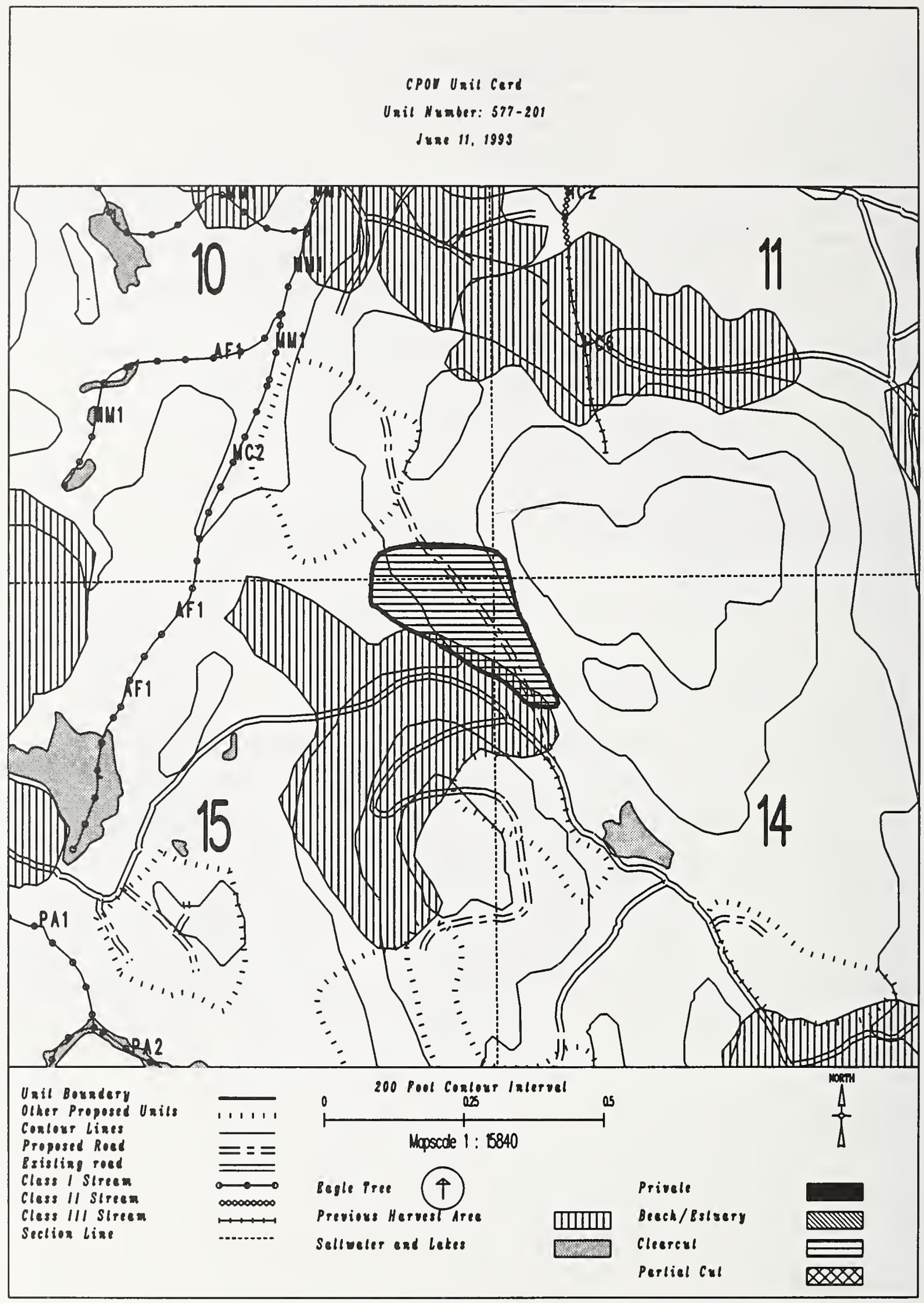


Unit 577-202

Planned acres 21

Estimated volume (mbf) 448

Logging system Highlead

silvicultural system clearcut

Forest type Hemlock
Al ternatives considered

Quad CRGD3NWS

Mgmt Area $\mathrm{KOB}$

WAA 1421

Photo

Aspect East

\section{PHYSICAL DESCRIPTION}

Volume class breakdown: VC4 13 acres VC5 5 acres VC6 0 acres VC7 0 acres

Elevation breakdown: $0-800 \mathrm{ft} .13$ acres $800-1200 \mathrm{ft} .6$ acres $1200-1500 \mathrm{ft} . \quad 0$ acres over $1500 \mathrm{ft}$. Mass movement index: Low 1 acres Medium 0 acres High 11 acres Very High 0 acres

SOILS

This unit has high mass movement index soils. Partial log suspension required over these areas.(BMP13.9)

This unit contains 12 acres of forested wetlands. Site specific BMPs will be designed for selected approved

logging system and road construction practices. (BMPs 12.5, 13.9, 13.15).

This unit contains 19 acres of slopes $>75 \%$.

\section{TIMBER}

There are no timber mitigation measures anticipated for this unit.

\section{ENGINEERING}

High mass movement index soils. Road construction must minimize landslide potential (BMP14).

slopes greater than $75 \%$ may require full bench construction and endhaul of waste (BMP14.7).

\section{FISH/WATERSHED}

There are no fishery mitigation measures anticipated for this unit.

WILDLIFE

There are no wildlife mitigation measures anticipated for this unit.

\section{RECREATION / VI SUALS}

This unit has a proposed VQO of MM and is not seen from any viewpoint identified by this project.

\section{LANDS}

There are no lands mitigation measures anticipated for this unit.

CULTURAL RESOURCES

There are no cultural resource mitigation measures anticipated for this unit. 


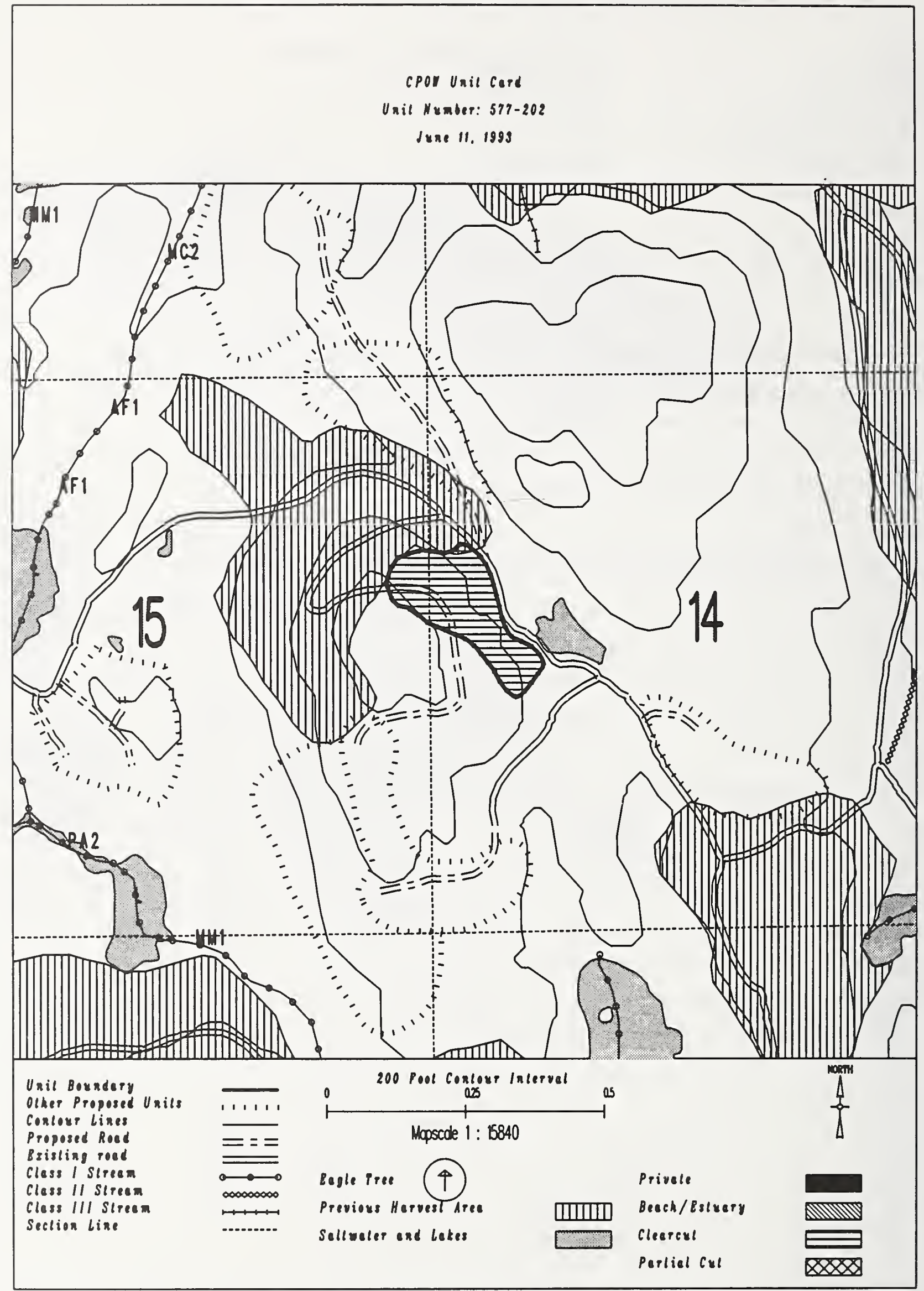




\section{Unit 577-204}

Planned acres 21

Estimated volume (mbf)

Logging system Highlead

silvicultural system Clearcut

Forest type Hemlock

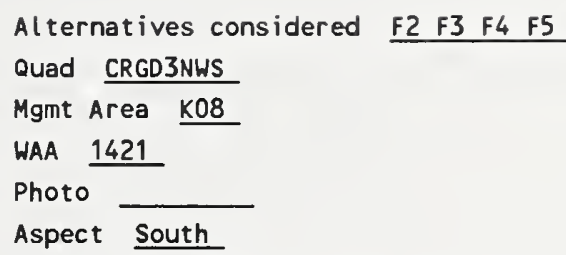

\section{PHYSICAL DESCRIPTION}

Volume class breakdown: VC4 $\quad 0$ acres VC5 22 acres VC6 $\quad 0$ acres vC7 $\quad 0$ acres

Elevation breakdown: $0-800 \mathrm{ft} . \underline{20}$ acres $800-1200 \mathrm{ft} . \underline{0}$ acres 1200-1500 ft. 0 acres over $1500 \mathrm{ft}$. 0 acres Mass movement index: Low 4 acres Medium 0 acres High 16 acres Very High 0 acres

\section{SOILS}

This unit has high mass movement index soils. Partial log suspension required over these areas. (BMP13.9)

This unit contains 16 acres of slopes $>75 \%$.

\section{TIMBER}

There are no timber mitigation measures anticipated for this unit.

\section{ENGINEER ING}

High mass movement index soils. Road construction must minimize landslide potential (BMP14).

Slopes greater than $75 \%$ may require full bench construction and endhaul of waste (8MP14.7).

\section{FISH/WATERSHED}

There are no fishery mitigation measures anticipated for this unit.

\section{WILDLIFE}

There are no wildlife mitigation measures anticipated for this unit.

\section{RECREATION / VISUALS}

This unit has a proposed Voo of MM and is not seen from any viewpoint identified by this project.

\section{LANDS}

There are no lands mitigation measures anticipated for this unit.

\section{CULTURAL RESOURCES}

There are no cultural resource mitigation measures anticipated for this unit.

\section{GEOLOGY}

There are no karst mitigation measures anticipated for this unit. 


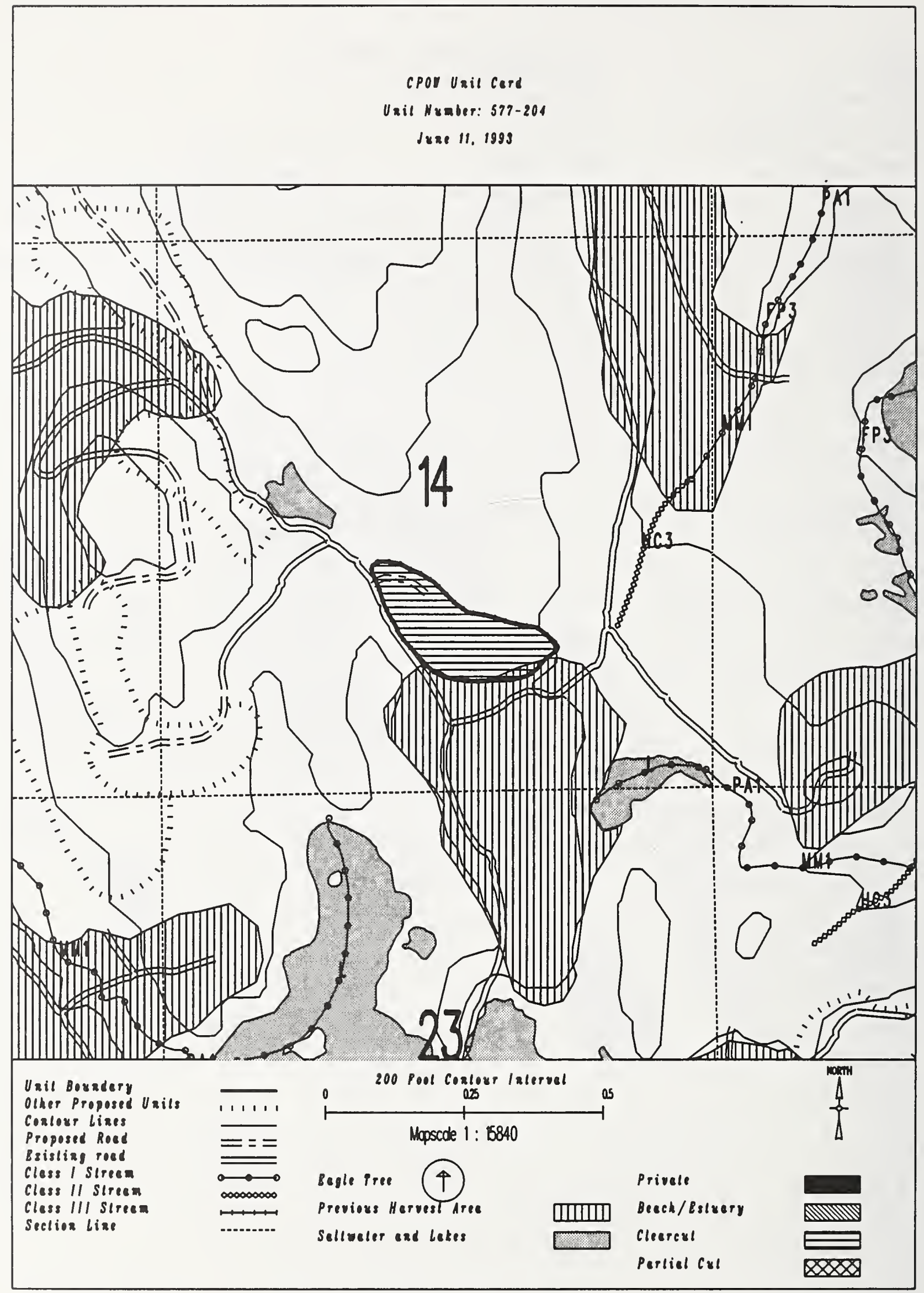


Unit $577-205$

Planned acres 30

Estimated volume (mbf)

Logging system skyline

silvicultural system clearcut

Forest type Hemlock
Alternatives considered

Quad CRGD3NWS

Mgmt Area $\mathrm{K} 08$

WAA 1421

Photo 890114

Aspect South

\section{PHYSICAL DESCRIPTION}

Volume class breakdown: VC4 $\quad 27$ acres VC5 $\quad 1$ acres VC6 $\quad 0$ acres vc7 $\quad 0$ acres

Elevation breakdown: $0-800 \mathrm{ft} .15$ acres $800-1200 \mathrm{ft} . \underline{Q}$ acres $1200-1500 \mathrm{ft} .00$ acres over $1500 \mathrm{ft}$. 0 acres Mass movement index: Low 4 acres Medium 0 acres High 1 acres Very High 0

\section{SOILS}

This unit contains 23 acres of forested wetlands. Site specific BMPs will be designed for selected approved logging system and road construction practices. (BMPs 12.5, 13.9, 13.15).

This unit contains 3 acres of slopes $>75 \%$.

\section{TIMBER}

Potential for shovel logging on 4 acres, if soil and water quality protected (BMP13.7)

\section{ENGINEER ING}

There are no engineering mitigation measures anticipated for this unit.

\section{FISH/WATERSHED}

This unit contains streams which have recently been classified/channel typed but require field verification.

\section{WILDLIFE}

There are no wildlife mitigation measures anticipated for this unit.

\section{RECREATION / VISUALS}

This unit has a proposed VQO of MM and is not seen from any viewpoint identified by this project.

\section{LANDS}

There are no lands mitigation measures anticipated for this unit.

\section{CULTURAL RESOURCES}

There are no cultural resource mitigation measures anticipated for this unit. 


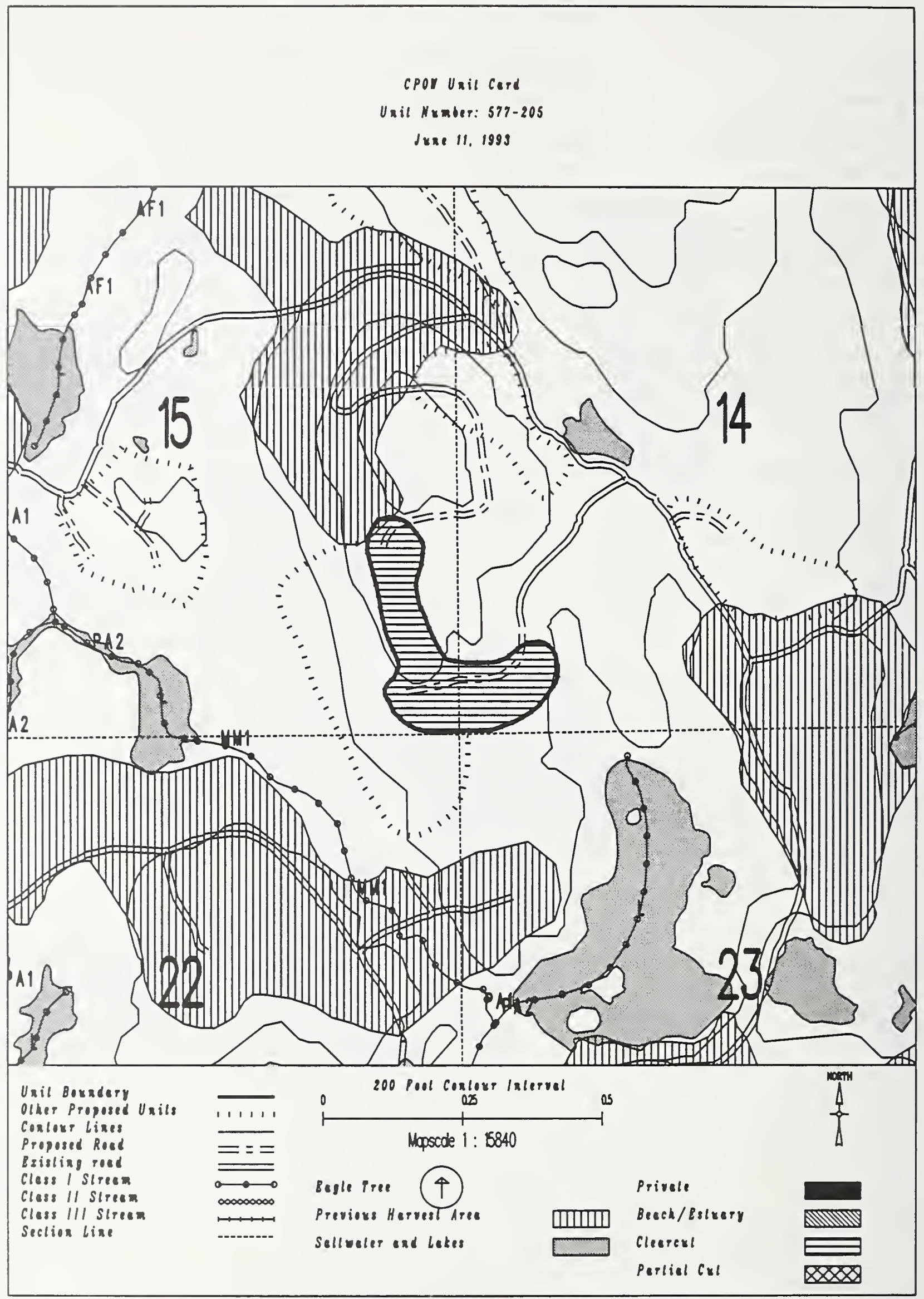


Unit $577-205^{3}$

Planned acres 46

Estinated volume (mbi) 1126

Logiing system skyline

silviculiural system clearcut

Forest iype Hemlock
Alternatives considered F3 F5 F6

Quad CRCO3his

Hgra: Area $\mathrm{KOS}$

What 1429

Fhoto

Aspes: Wes:

PHYSICAL DESCRIPTIOH

Volume class breakdown: VCh 26 acres vC5 17 asres vCS 0 asres vC7 0 acres

Elevation breakdown: $0.800 \mathrm{ft.} 33$ acres $800-1200 \mathrm{ft} .6$ acres $1200-1500 \mathrm{ft}$. 0 acres over 1500 tt. 0 acres Mass movement index: Low 18 acres Wediun 0 acres High 5 asres very tigh 0 asres

\section{SOILS}

inis unit has high mass movement index soils. Partial log suspension required over inese areas. (3wpi3.9)

This unit has a significant possibility to have areas reolassified as MW: $=4$.

inis unit contains 25 asres of forested wetlands. Site specific 3Mes will be designed for selested aporaved

logging system and road construction practices. (3wDs 12.5, 13.9, 13.15).

This unit contains 11 acres of slepes $>75 \%$.

This unit will be monilered for effects of harvest/roading on wosilvery soils.

\section{TIMEER}

There are no :inder mitigazion reasures anicicated for this unit.

\section{EMGIHEERIKG}

High mass movemen: index szils. Raad senstrustian mus: minimize landslide poren:ial (3wzi-).

Slopes greater than $75 \%$ nay reouire tull bench construction and end aul of waste (3wp14.7).

\section{FISHTHATERSHED}

There are no fishery witigation measures anticipated for this unit.

\section{W:LOLIFE}

There are no wildlite aitigation besures anticipared for this unit.

\section{RECREATION / VISUALS}

Ihis unit has a proposed veo of wh and is not seen fron any viewpoint identitied by this project.

\section{LALDS}

There are no lands mitigation reasures anticipated for this unit.

\section{CULTURAL RESOREES}

There are no cultural resource misigation teasures anticipated tor this unit.

There are no karsi mitigation seasures anticipates for this unit. 


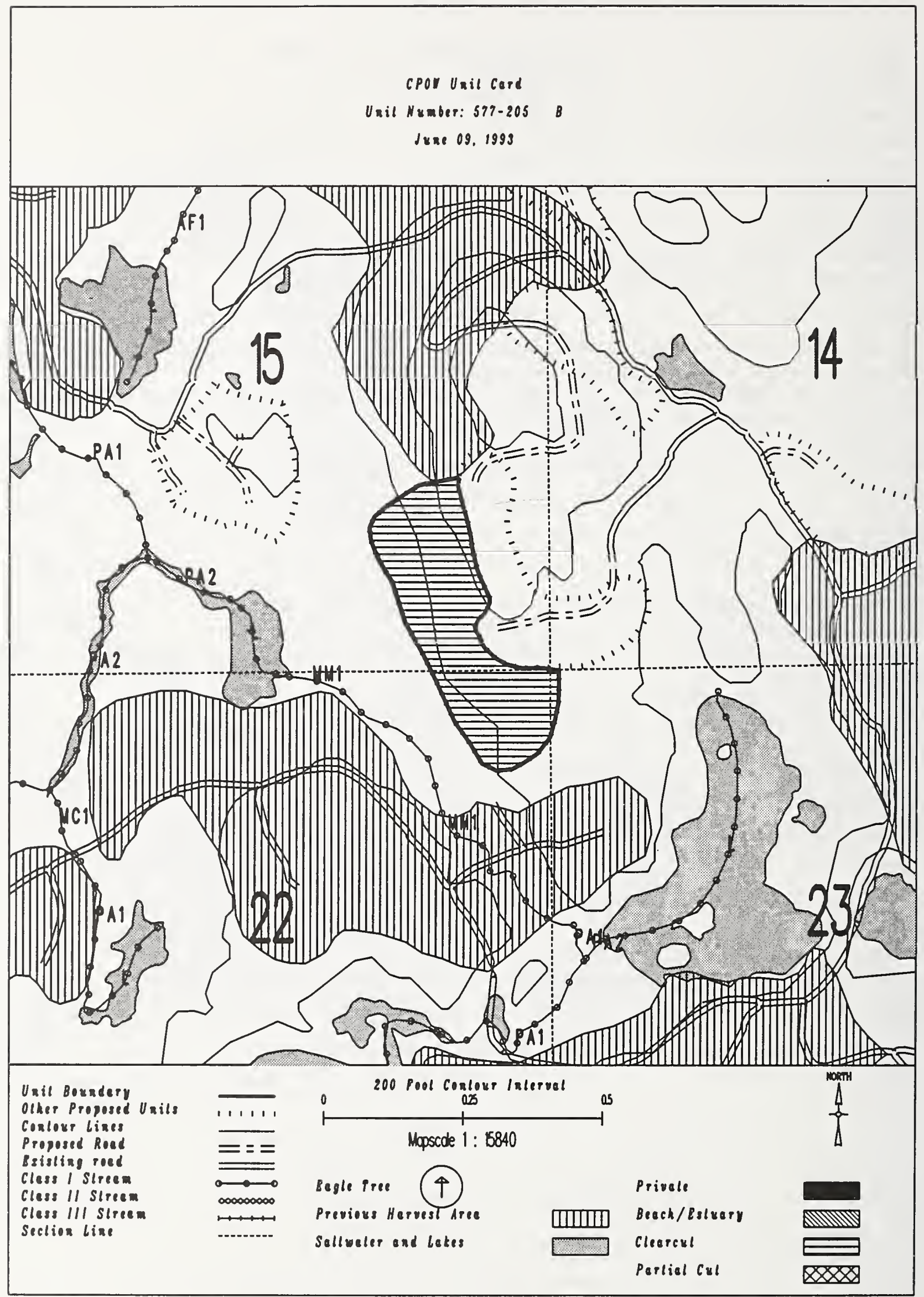


Unit $\quad 577-214$

Planned acres 37

Estimated volume (mbf) 1055

Logging system skyline

silvicultural system clearcut

Forest type Mixed conifer
Alternatives considered F2 F3 F4 F5

Quad CRGD4SEN

Mgmt Area K08

WAA 1421

Photo

Aspect South

PHYSICAL DESCRIPTION

Volume class breakdown: VC4 $\quad 0$ acres VC5 $\quad 2$ acres VC6 26 acres vc7 $\quad 0$ acres

Elevation breakdown: $0-800 \mathrm{ft} . \underline{34}$ acres $800-1200 \mathrm{ft} . \underline{0}$ acres $1200-1500 \mathrm{ft} . \underline{0}$ acres over $1500 \mathrm{ft}$. 0 Mass movement index: Low 0 acres Medium 0 acres High 35 acres Very High $\underline{0}$ acres

\section{SOILS}

This unit has high mass movement index soils. Partial log suspension required over these areas. (BMP13.9)

\section{TIMBER}

There are no timber mitigation measures anticipated for this unit.

\section{ENGINEER ING}

High mass movement index soils. Road construction must minimize landslide potential (BMP14).

\section{FISH/WATER SHED}

Potential for additional Class I/II streams within unit. May be necessary to place additional buffers within unit

in accordance with AHMU Handbook.

\section{WILDLIFE}

There are no wildlife mitigation measures anticipated for this unit.

\section{RECREATION / VISUALS}

This unit has a proposed voo of MM and is not seen from any viewpoint identified by this project.

\section{LANDS}

There are no lands mitigation measures anticipated for this unit.

CULTURAL RESOURCES

There are no cultural resource mitigation measures anticipated for this unit.

GEOLOGY

Planned unit boundary/road location/logging system are designed to avoid damage to significant karst features.

Mitigation measures may apply. Unit layout/changes must be coordinated with Cave Resource Specialists. 


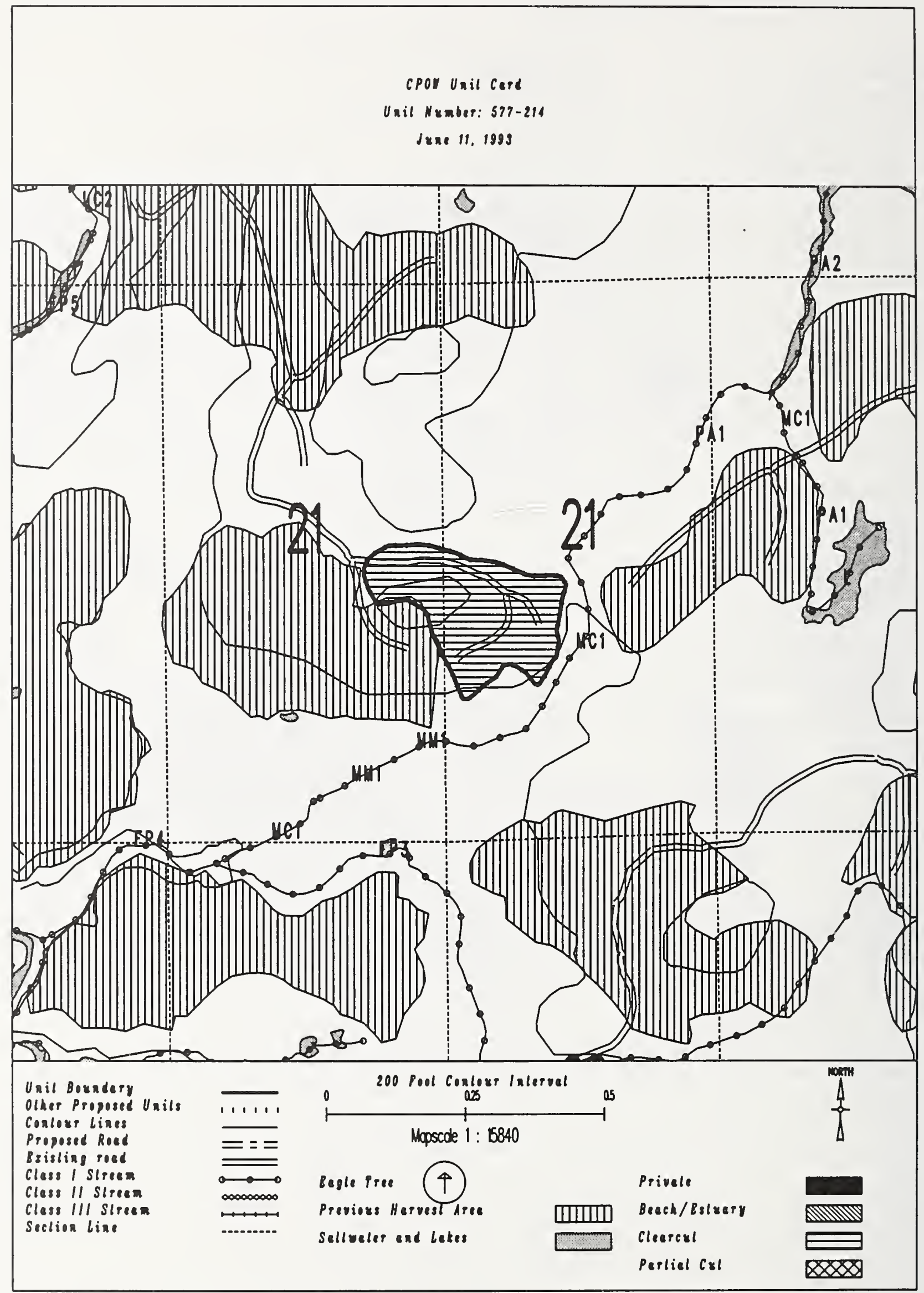


UNIT PLAN/LAYOUT/SALE ADMINISTRATION CARD FOR CPOW FEIS

Unit $\quad 577-276$

Planned acres 56

Estimated volume (mbf) 1694

Logging system skyline

silvicultural system Clearcut

Forest type Hemlock

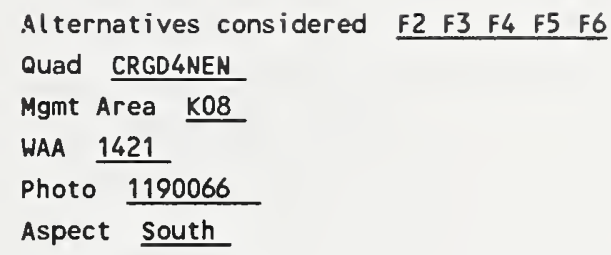

PHYSICAL DESCRIPTION

Volume class breakdown: VC4 13 acres VC5 43 acres VC6 $\quad 0$ acres VC7 $\quad 0$ acres

Elevation breakdown: $0-800 \mathrm{ft} .11$ acres $800-1200 \mathrm{ft} . \underline{31}$ acres $1200-1500 \mathrm{ft} . \underline{9}$ acres over $1500 \mathrm{ft} . \underline{0}$ acres Mass movement index: Low 49 acres Medium 0 acres High 0 acres Very High 0

SOILS

This unit contains 31 acres of forested wetlands. Site specific BMPs will be designed for selected approved logging system and road construction practices. (BMPs 12.5, 13.9, 13.15).

TIMBER

There are no timber mitigation measures anticipated for this unit.

\section{ENG INEER ING}

There are no engineering mitigation measures anticipated for this unit.

\section{FISH/WATERSHED}

There are no fishery mitigation measures anticipated for this unit.

\section{WILDLIFE}

There are no wildlife mitigation measures anticipated for this unit.

RECREATION / VISUALS

This unit has a proposed $V_{00}$ of MM and is not seen from any viewpoint identified by this project.

\section{LANDS}

There are no lands mitigation measures anticipated for this unit.

\section{CULTURAL RESOURCES}

There are no cultural resource mitigation measures anticipated for this unit.

\section{GEOLOGY}

There are no karst mitigation measures anticipated for this unit. 
CPOI Uail Cerd

Uail Number: 577-276

June 11, 1993

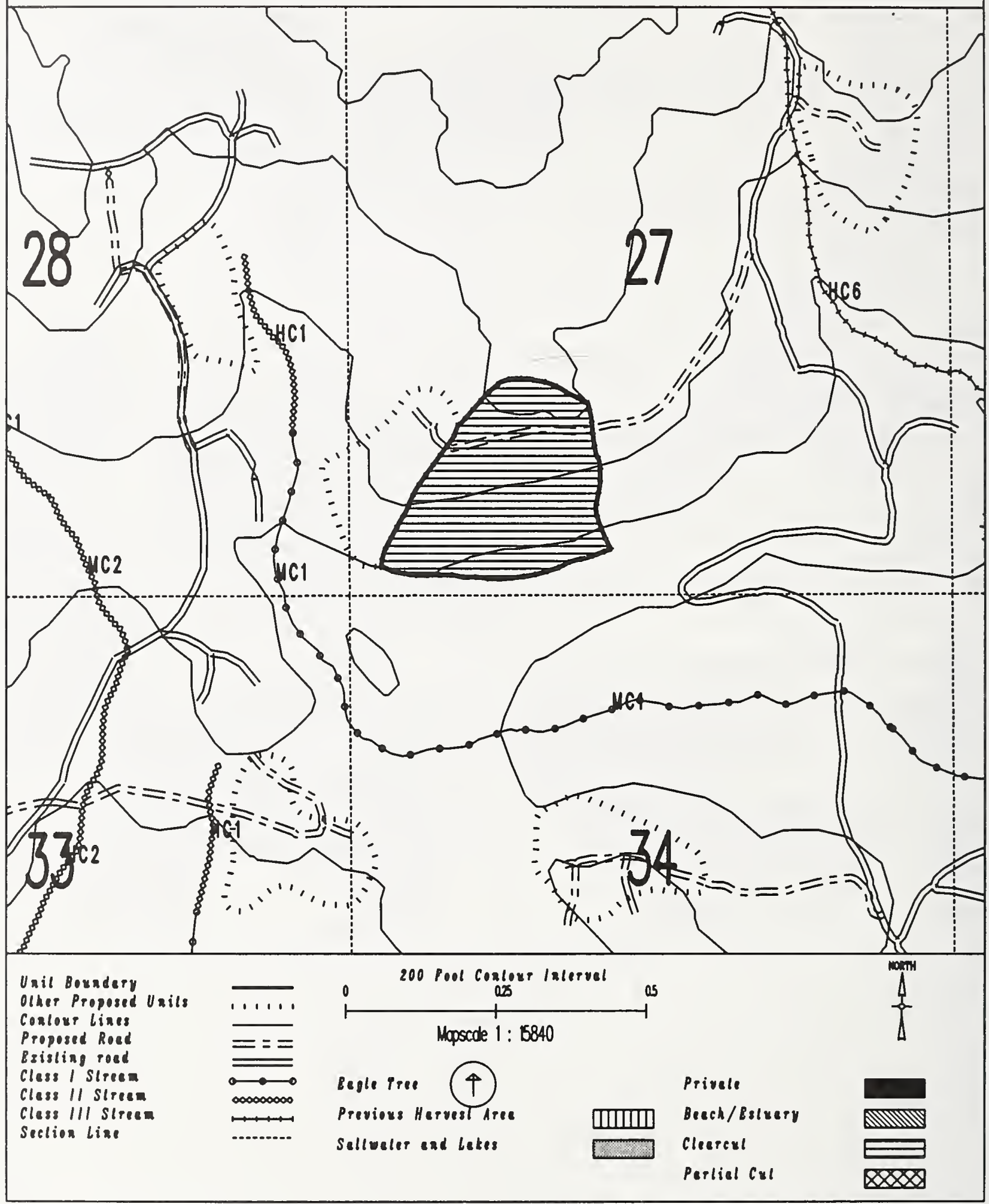


Unit $\quad 577-278$

Planned acres 23

Estimated volume (mbf)

Logging system Highlead

silvicultural system clearcut

Forest type Hemlock
Alternatives consid
Quad CRGD4NES
Mgmt Area K08
WAA 1421
Photo 1190065
Aspect North

PHYSICAL DESCRIPTION

Volume class breakdown: VC4 22 acres VC5 1 acres vc6 $\quad 0$ acres vc7 0 acres

Elevation breakdown: $0-800 \mathrm{ft} . \underline{14}$ acres $800-1200 \mathrm{ft} . \underline{7}$ acres $1200-1500 \mathrm{ft} . \underline{0}$ acres over $1500 \mathrm{ft}$. 0 acres Mass movement index: Low 23 acres Medium 0 acres High 0 acres Very High 0 acres

\section{SOILS}

This unit contains 11 acres of forested wetlands. Site specific BMPs will be designed for selected approved logging system and road construction practices. (BMPs 12.5, 13.9, 13.15).

\section{TIMBER}

There are no timber mitigation measures anticipated for this unit.

\section{ENGINEERING}

There are no engineering mitigation measures anticipated for this unit.

\section{FISH/WATERSHED}

There are no fishery mitigation measures anticipated for this unit.

\section{WILDLIFE}

There are no wildlife mitigation measures anticipated for this unit.

RECREATION / VISUALS

This unit has a proposed VQO of MM and is not seen from any viewpoint identified by this project.

\section{LANDS}

There are no lands mitigation measures anticipated for this unit.

\section{CULTURAL RESOURCES}

There are no cultural resource mitigation measures anticipated for this unit.

\section{GEOLOGY}

There are no karst mitigation measures anticipated for this unit. 


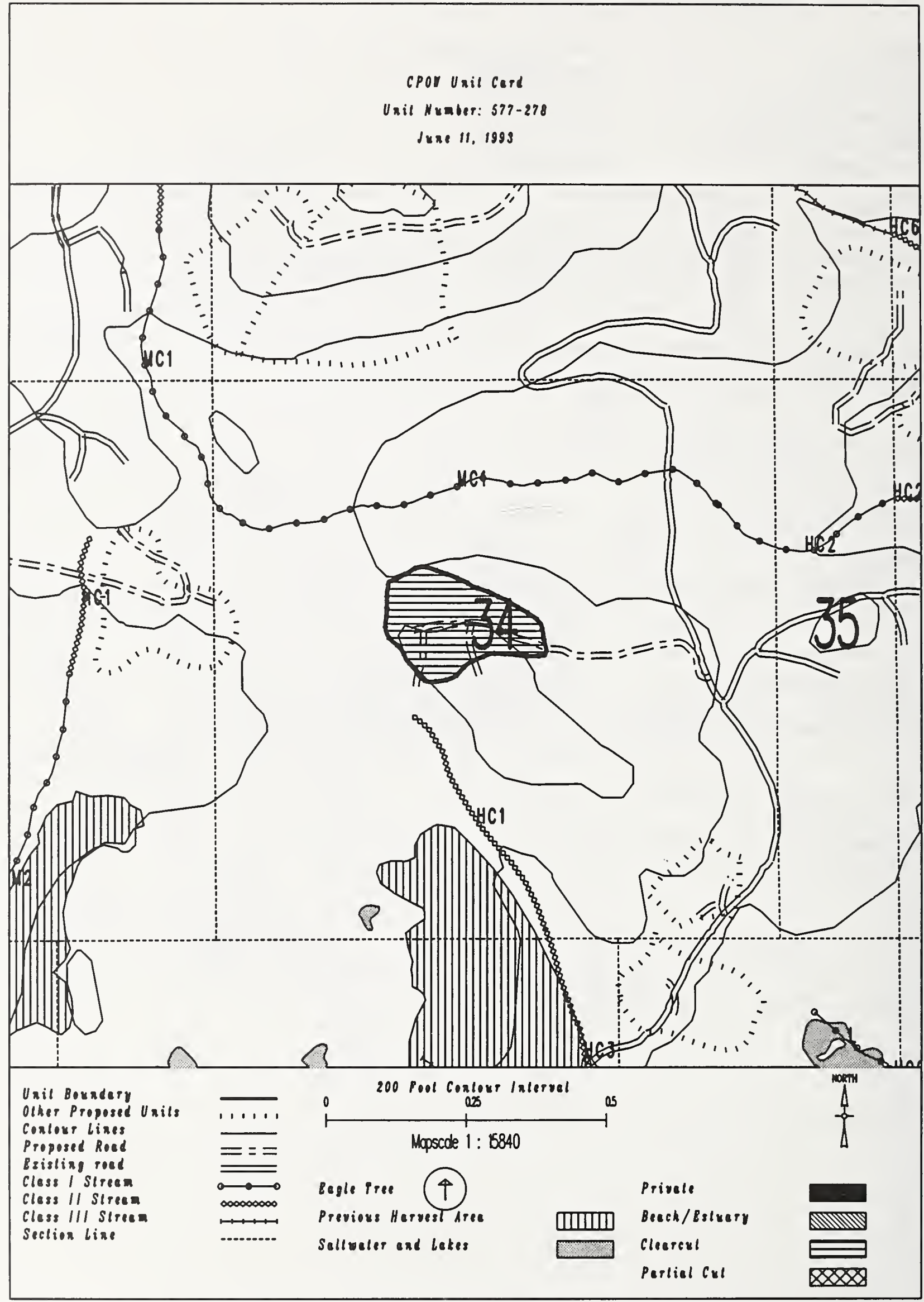


Unit $\quad 577-280$

Planned acres 10

Est imated volume (mbf) 230

Logging system skyline

Silvicultural system Clearcut

Forest type Hemlock
Alternatives considered $\underline{F 2}$ F3 $F 4$ F5 F6

Quad CRGD4NES

Mgmt Area K08

WAA 1421

Photo 1190065

Aspect South

\section{PHYSICAL DESCRIPTION}

Volume class breakdown: VC4 9 acres VC5 1 acres VC6 0 acres VC7 0 acres

Elevation breakdown: $0-800 \mathrm{ft}$. 9 acres $800-1200 \mathrm{ft} .0$ acres $1200-1500 \mathrm{ft} .0$ acres over $1500 \mathrm{ft}$. 0 acres Mass movement index: Low 0 acres Medium 0 acres High 9 acres Very High 0 acres

\section{SOILS}

This unit has high mass movement index soils. Partial log suspension required over these areas. (BMP13.9)

This unit contains 6 acres of forested wetlands. Site specific BMPs will be designed for selected approved

logging system and road construction practices. (BMPs 12.5, 13.9, 13.15).

This unit contains 3 acres of slopes $>75 \%$.

\section{TIMBER}

There are no timber mitigation measures anticipated for this unit.

\section{ENGI NEER I NG}

High mass movement index soils. Road construction must minimize landslide potential (BMP14).

\section{FISH/WATERSHED}

There are no fishery mitigation measures anticipated for this unit.

\section{WILDLIFE}

There are no wildlife mitigation measures anticipated for this unit.

\section{RECREATION / VISUALS}

This unit has a proposed Voo of MM and is not seen from any viewpoint identified by this project.

\section{LANDS}

There are no lands mitigation measures anticipated for this unit.

\section{CULTURAL RESOURCES}

There are no cultural resource mitigation measures anticipated for this unit.

\section{GEOLOGY}

There are no karst mitigation measures anticipated for this unit. 


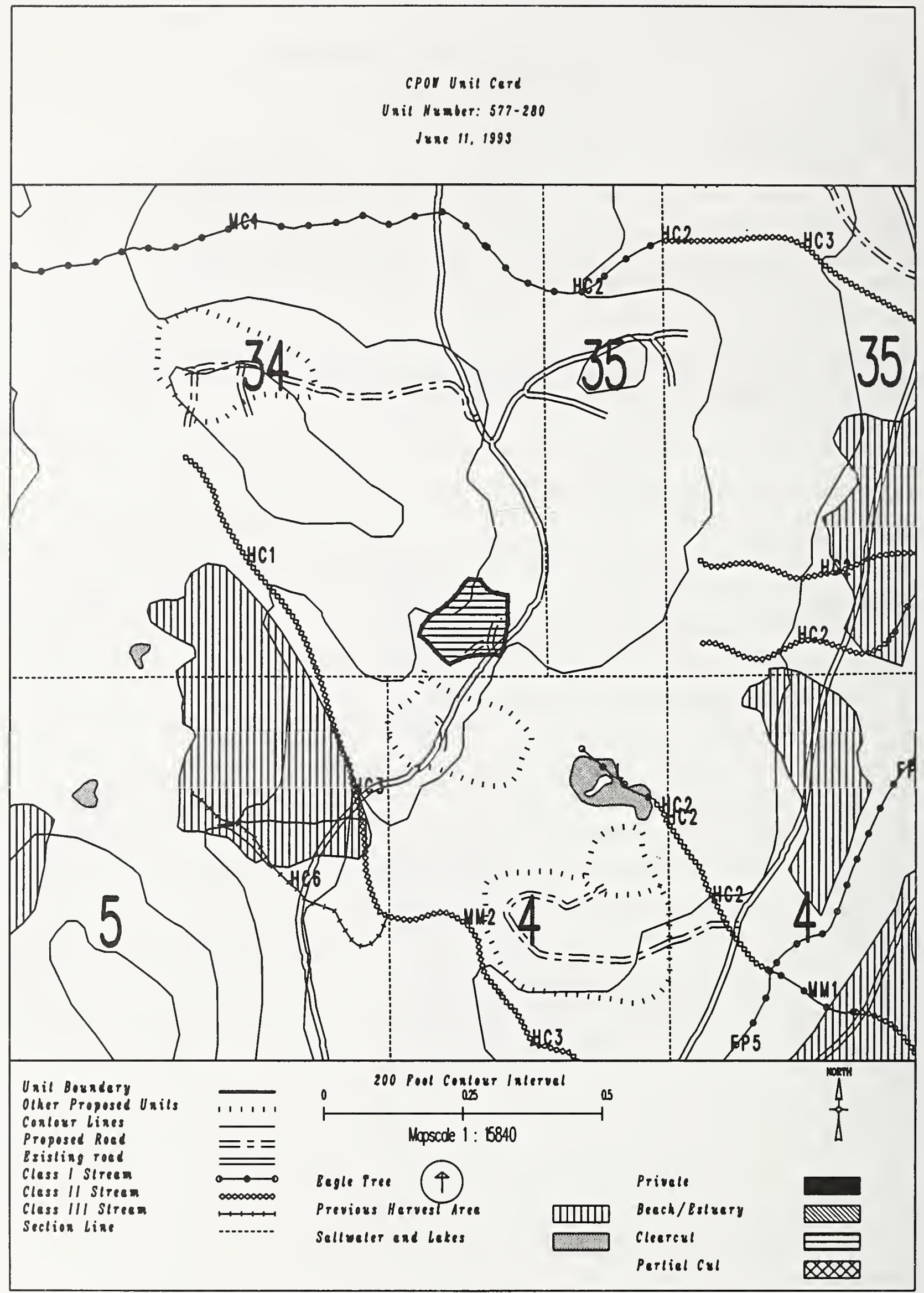


Unit $\quad 577-281$

Planned acres 20

Estimated volume (mbf) 623

Logging system skyline

silvicultural system clearcut

Forest type Mixed conifer
Alternatives considered $\begin{array}{llllll}\mathrm{F} 2 & \mathrm{~F} 3 & \mathrm{~F} 4 & \mathrm{~F} 5 & \mathrm{F6}\end{array}$

Quad CRGD4NES

Mgmt Area $\mathrm{K} 08$

WAA 1421

Photo 1190065

Aspect South

PHYSICAL DESCRIPIION

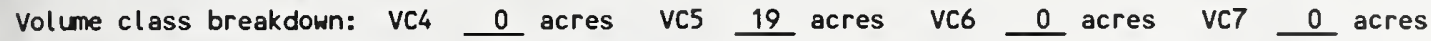

Elevation breakdown: $0-800 \mathrm{ft} . \underline{18}$ acres $800-1200 \mathrm{ft} . \quad 0$ acres $1200-1500 \mathrm{ft} . \quad 0$ acres over $1500 \mathrm{ft}$. 0 acres Mass movement index: Low 1 acres Medium 0 acres High 16 acres Very High 0 acres

SOILS

This unit has high mass movement index soils. Partial log suspension required over these areas. (BMP13.9)

This unit contains 7 acres of forested wetlands. Site specific BMPs will be designed for selected approved

logging system and road construction practices. (BMPs 12.5, 13.9, 13.15).

This unit contains 9 acres of slopes > $75 \%$.

TIMBER

There are no timber mitigation measures anticipated for this unit.

\section{ENGINEER ING}

High mass movement index soils. Road construction must minimize landslide potential (BMP14).

slopes greater than $75 \%$ may require full bench construction and endhaul of waste (BMP14.7).

\section{FISH/WATERSHED}

There are no fishery mitigation measures anticipated for this unit.

WILDLIFE

There are no wildlife mitigation measures anticipated for this unit.

RECREATION / VISUALS

This unit has a proposed VoO of MM and is not seen from any viewpoint identified by this project.

LANDS

There are no lands mitigation measures anticipated for this unit.

CULTURAL RESOURCES

There are no cultural resource mitigation measures anticipated for this unit.

There are no karst mitigation measures anticipated for this unit. 


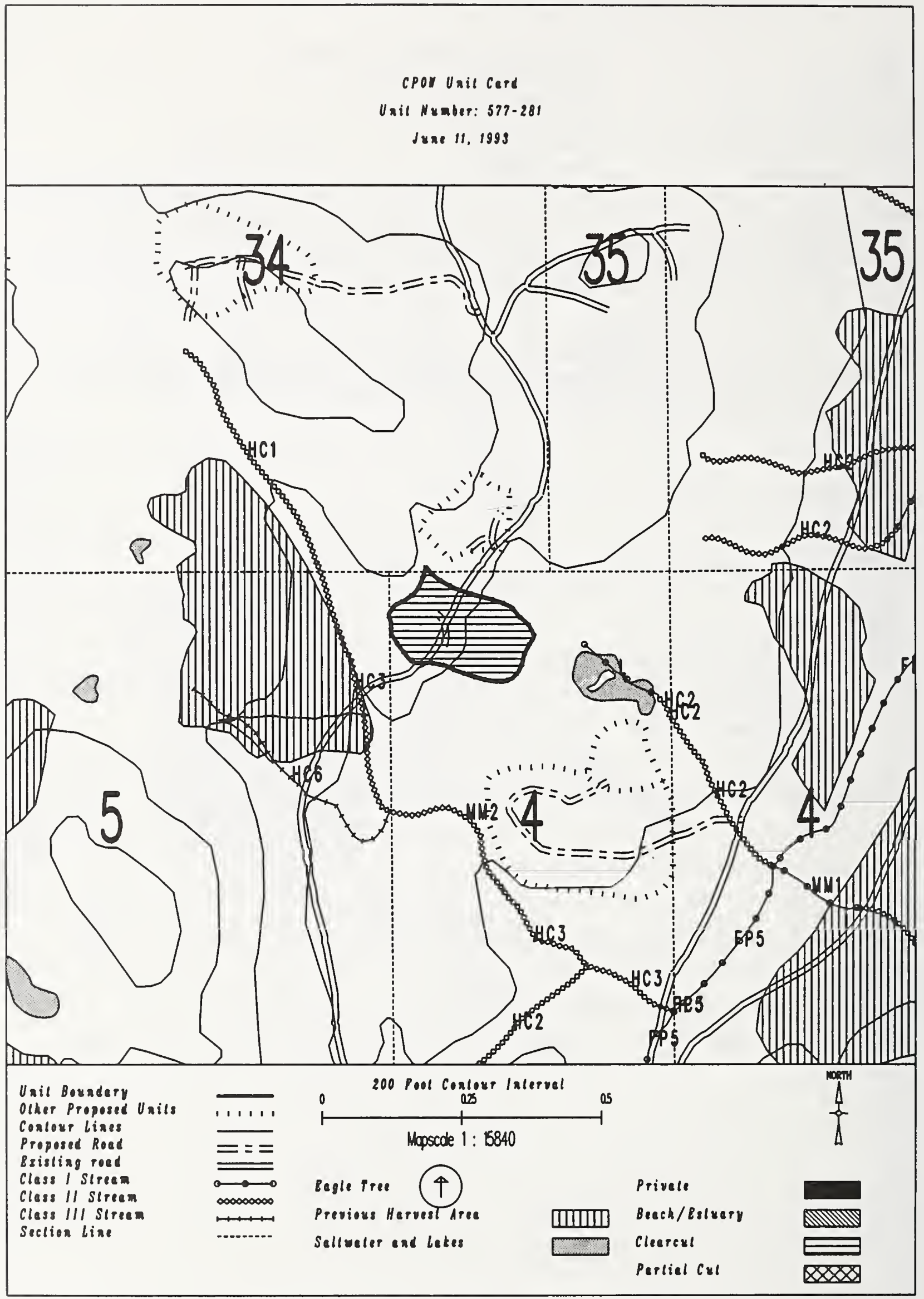


Unit $\quad 577-284$

Planned acres 45

Estimated volume (mbf) 1434

Logging system Highlead

Silvicultural system Riparian

Forest type Hemlock
Alternatives considered $\quad$ F2 F3 $F 4$ F5 F6

Quad CRGD4NES

Mgmt Area K08

WAA 1421

Photo 1190065

Aspect South

\section{PHYSICAL DESCRIPIION}

Volume class breakdown: VC4 $\quad 0$ acres vC5 46 acres vC6 $\quad 0$ acres vc7 $\quad 0$ acres

Elevation breakdown: $0-800 \mathrm{ft} . \underline{42}$ acres $800-1200 \mathrm{ft} . \underline{0}$ acres $1200-1500 \mathrm{ft}$. 0 acres over $1500 \mathrm{ft}$. 0 acres Mass movement index: Low 1 acres Medium 23 acres High 12 acres Very High 0

\section{SOILS}

This unit has high mass movement index soils. Partial log suspension required over these areas. (BMP13.9)

This unit contains 43 acres of forested wetlands. Site specific BMPs will be designed for selected approved

logging system and road construction practices. (BMPs 12.5, 13.9, 13.15).

\section{TIMBER}

Uneven-aged harvest for riparian management on an estimated 7 acres.

\section{ENGINEER ING}

High mass movement index soils. Road construction must minimize landslide potential (BMP14).

\section{FISH/WATERSHED}

There are no fishery mitigation measures anticipated for this unit.

\section{HILDLIFE}

There are no wildlife mitigation measures anticipated for this unit.

\section{RECREATION / VISUALS}

This unit has a proposed VQO of MM and is not seen from any viewpoint identified by this project.

\section{LANDS}

There are no lands mitigation measures anticipated for this unit.

CULTURAL RESOURCES

There are no cultural resource mitigation measures anticipated for this unit.

\section{GEOLOGY}

There are no karst mitigation measures anticipated for this unit. 


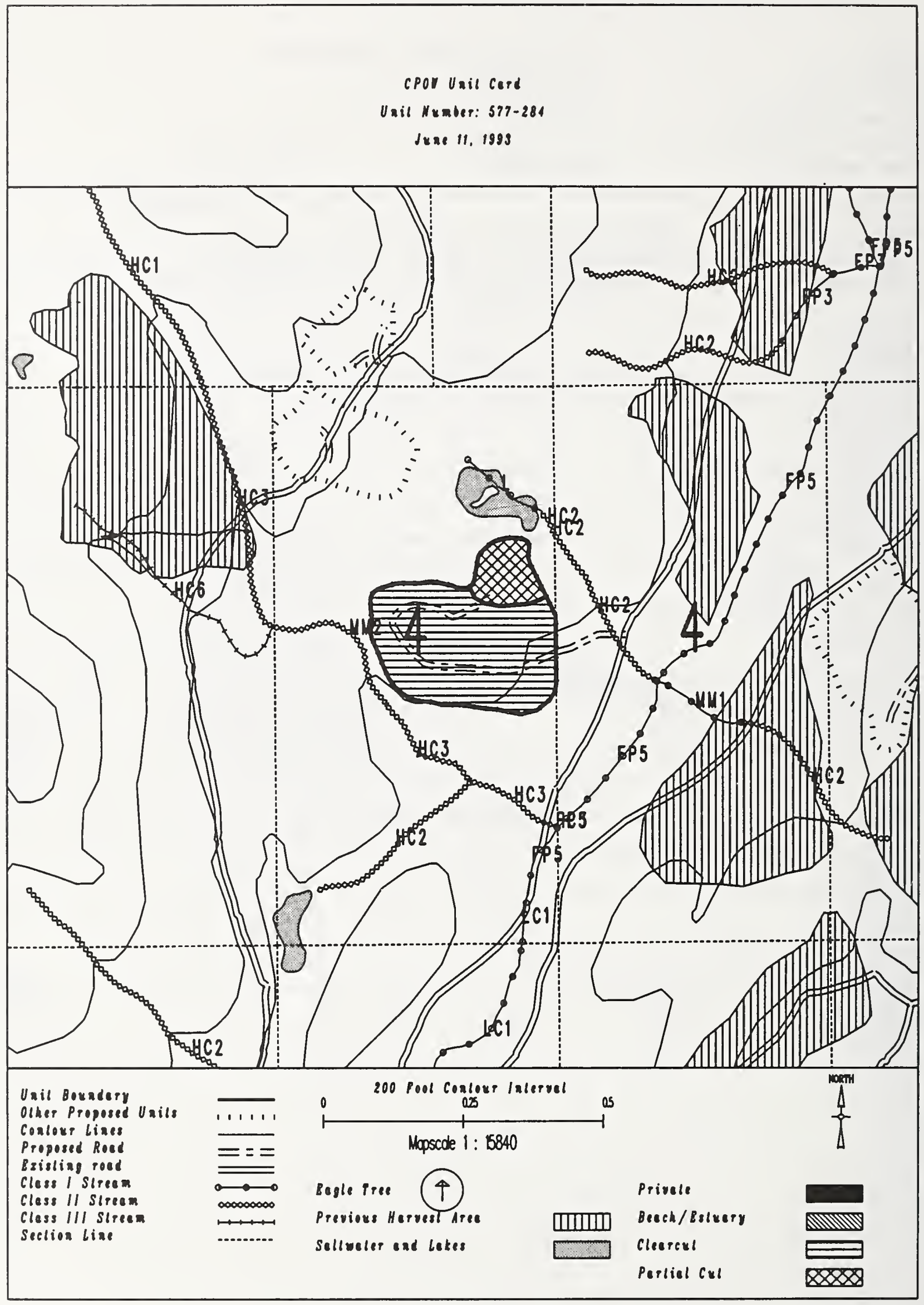


Unit $\quad 577-286$

Planned acres 46

Estimated volume (mbf) 1501

Logging system Highlead

silvicultural system clearcut

Forest type Mixed conifer
Al ternatives considered $\quad$ F2 $F 3$ F4 F5 $\quad$ F6

Quad CRGD4NES

Mgmt Area $\mathrm{KOB}$

WAA 1421.

Photo 1190063

Aspect West

\section{PHYSICAL DESCRIPTION}

Volume class breakdown: VC4 $\quad 0$ acres VC5 40 acres vC6 5 acres vc7 0 acres

Elevation breakdown: $0-800 \mathrm{ft} .42$ acres $800-1200 \mathrm{ft} . \quad 0$ acres 1200-1500 ft. 0 acres over $1500 \mathrm{ft}$. 0 acres Mass movement index: Low 0 acres Medium 0 acres High 39 acres Very High 0 acres

\section{SOILS}

This unit has high mass movement index soils. Partial log suspension required over these areas.(BMP13.9)

This unit contains 16 acres of forested wetlands. Site specific BMPs will be designed for selected approved

logging system and road construction practices. (BMPs 12.5, 13.9, 13.15).

\section{TIMBER}

There are no timber mitigation measures anticipated for this unit.

\section{ENGINEERING}

High mass movement index soils. Road construction must minimize landslide potential (BMP14).

\section{FISH/WATERSHED}

This unit contains streams which have recently been classified/channel typed but require field verification.

\section{WILDLIFE}

There are no wildlife mitigation measures anticipated for this unit.

\section{RECREATION / VISUALS}

This unit has a proposed VQO of MM and is not seen from any viewpoint identified by this project.

\section{LANDS}

There are no lands mitigation measures anticipated for this unit.

CULTURAL RESOURCES

There are no cultural resource mitigation measures anticipated for this unit.

\section{GEOLOGY}

There are no karst mitigation measures anticipated for this unit. 


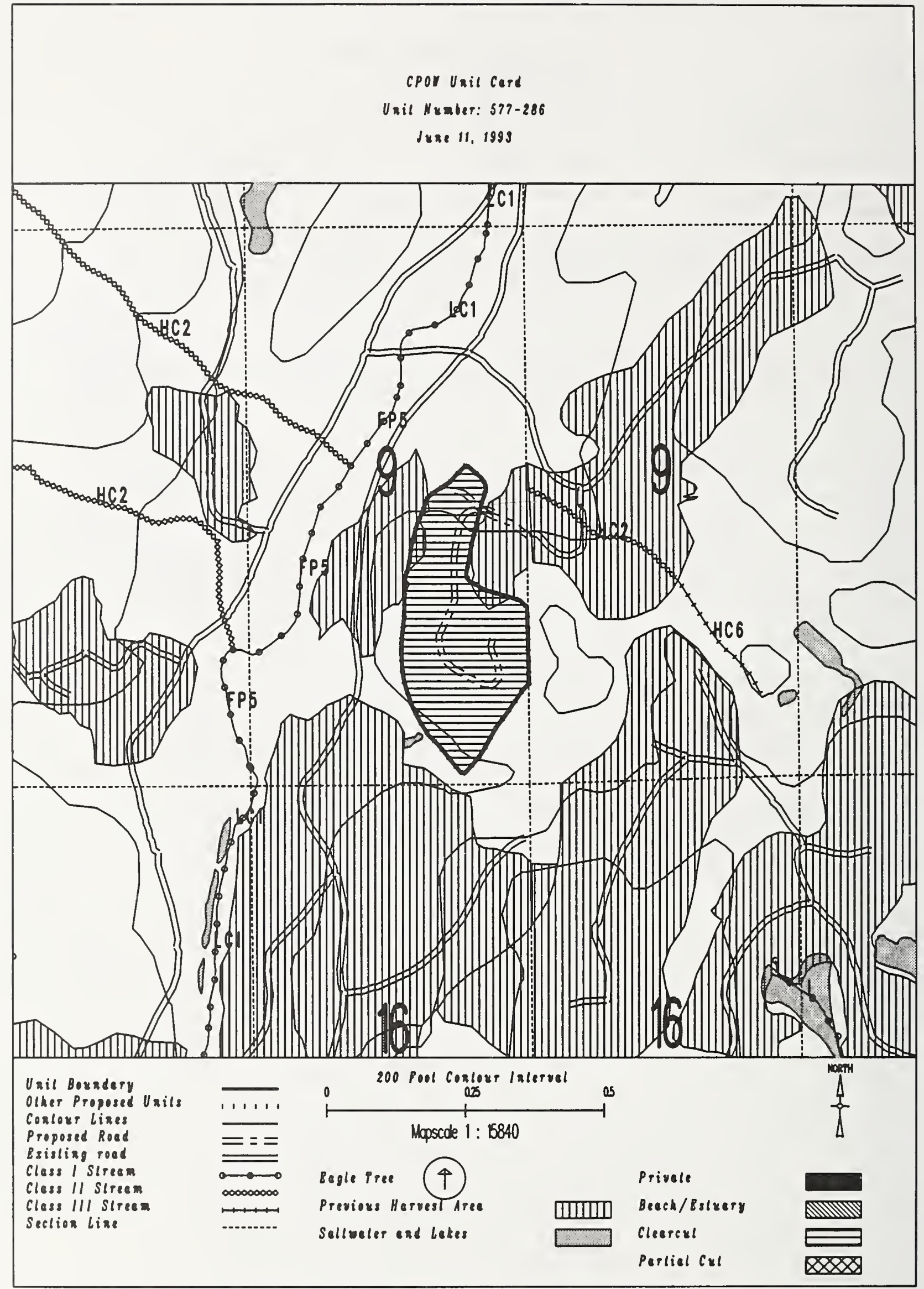


Unit $577-316$

Planned acres 21

Estimated volume (mbf) 773

Logging system skyline

silvicultural system clearcut

Forest type Mixed conifer
Alternatives considered $\mathrm{F2}$ F3 $\mathrm{F} 4$ F5 F6

Quad CRGD3NWS

Mgmt Area $\underline{\mathrm{K} 08}$

WAA 1421

Photo 890111

Aspect West

PHYSICAL DESCRIPTION

Volume class breakdown: VC4 $\quad 0$ acres VC5 $\quad 5$ acres $\quad$ VC6 $\quad 16$ acres vc7 $\quad 0$ acres

Elevation breakdown: $0-800 \mathrm{ft} .17$ acres $800-1200 \mathrm{ft} . \quad 0$ acres $1200-1500 \mathrm{ft}$. 0 acres over $1500 \mathrm{ft}$. 0 Mass movement index: Low 0 acres Medium 0 acres High 11 acres Very High 0

SOILS

This unit has high mass movement index soils. Partial log suspension required over these areas.(BMP13.9)

This unit contains 6 acres of forested wetlands. Site specific BMPs will be designed for selected approved

logging system and road construction practices. (BMPs 12.5, 13.9, 13.15).

TIMBER

There are no timber mitigation measures anticipated for this unit.

ENGINEER ING

High mass movement index soils. Road construction must minimize landslide potential (BMP14).

FISH/WATERSHED

Potential for additional Class I/II streams within unit. May be necessary to place additional buffers within unit

in accordance with AHMU Handbook.

This unit contains streams which have recently been classified/channel typed but require field verification.

WILDLIFE

There are no wildlife mitigation measures anticipated for this unit.

RECREATION / VISUALS

This unit has a proposed vao of MM and is not seen from any viewpoint identified by this project.

LANDS

There are no lands mitigation measures anticipated for this unit.

CULTURAL RESOURCES

There are no cultural resource mitigation measures anticipated for this unit.

GEOLOGY

There are no karst mitigation measures anticipated for this unit. 


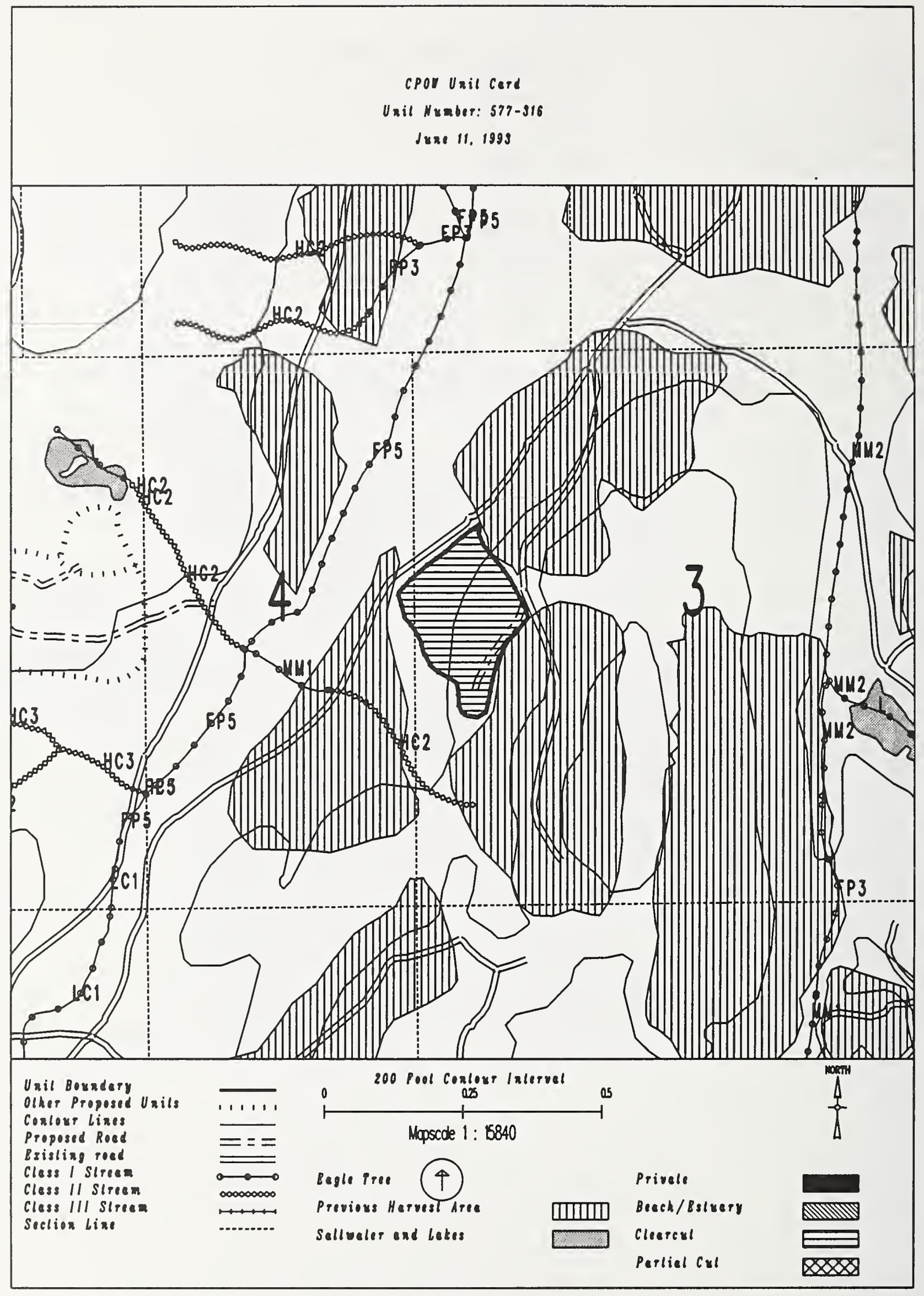


Unit $577-317$

Planned acres 47

Estimated volume (mbf) 1522

Logging system skyline

silvicultural system clearcut

Forest type Hemlock
Quad CRGD3NWN
Mgmt Area $\mathrm{KO8}$
WAA 1421
Photo 1190066
Aspect East

Al ternatives considered

F3 F4 F6

PHYSICAL DESCRIPTION

Volume class breakdown: VC4 $\quad 8$ acres VC5 $\quad 26$ acres $v C 6 \quad 13$ acres $\quad$ vC7 $\quad 0$ acres

Elevation breakdown: $0-800 \mathrm{ft} . \underline{44}$ acres $800-1200 \mathrm{ft} . \underline{0}$ acres $1200-1500 \mathrm{ft} . \underline{0}$ acres over $1500 \mathrm{ft}$. 0 Mass movement index: Low 2 acres Medium 3 acres High 7 acres Very High 0 acres

SOILS

This unit has high mass movement index soils. Partial log suspension required over these areas. (BMP13.9) This unit contains 42 acres of forested wetlands. Site specific BMPs will be designed for selected approved

logging system and road construction practices. (BMPS 12.5, 13.9, 13.15).

TIMBER

There are no timber mitigation measures anticipated for this unit.

ENGINEERING

High mass movement index soils. Road construction must minimize landslide potential (BMP14).

FISH/WATERSHED

Potential for additional Class I/II streams within unit. May be necessary to place additional buffers within unit in accordance with AHMU Handbook.

WILDLIFE

There are no wildlife mitigation measures anticipated for this unit.

RECREATION / VISUALS

The unit has a proposed voO of PR within the viewshed of Sweetwater Lake

as viewed from from centerline of lake.

LANDS

There are no lands mitigation measures anticipated for this unit.

CULTURAL RESOURCES

There are no cultural resource mitigation measures anticipated for this unit.

GEOLOGY

There are no karst mitigation measures anticipated for this unit. 


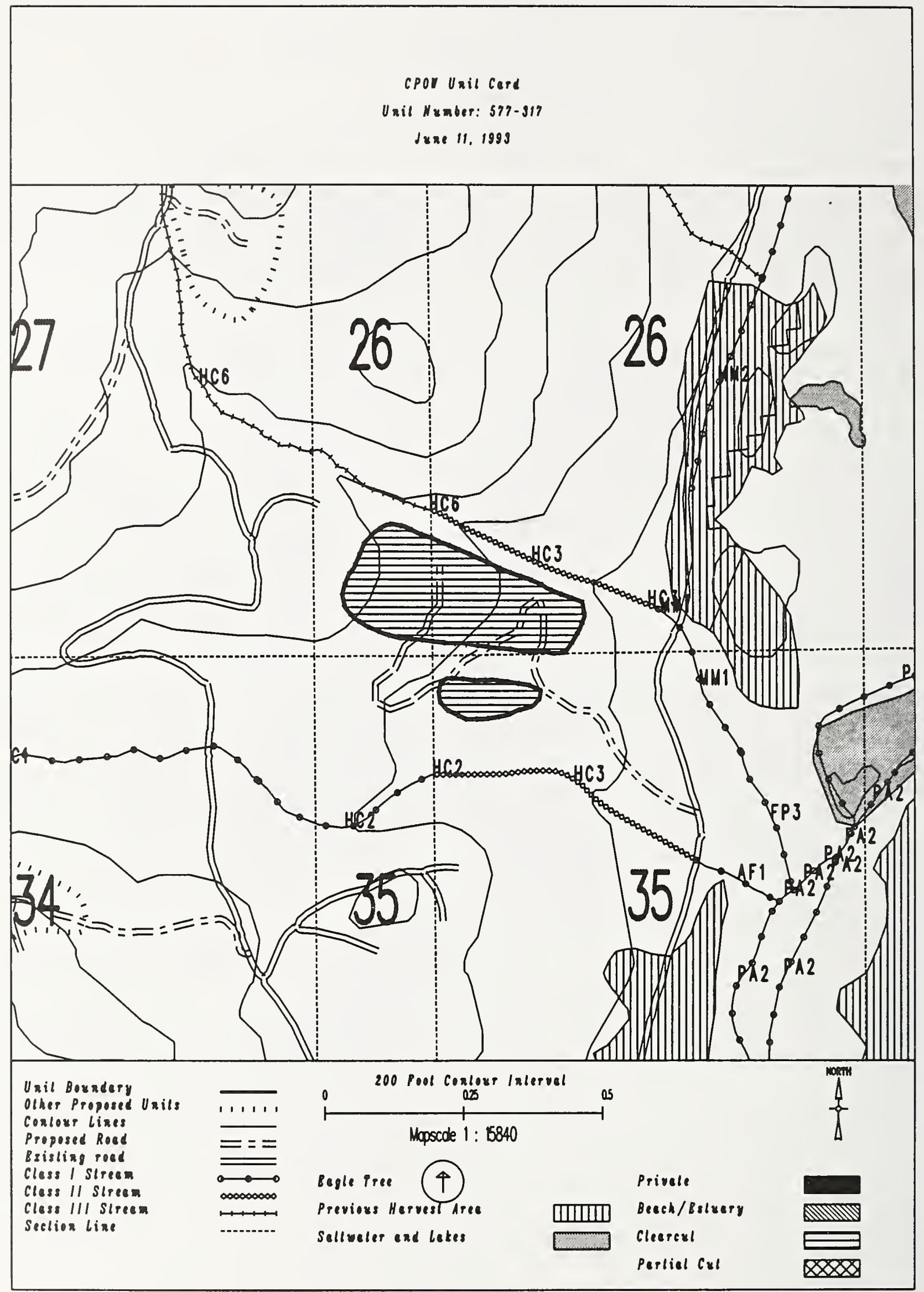


Unit $\quad 577-320$

Planned acres 31

Estimated volume (mbf) 918

Logging system skyline

Silvicultural system Clearcut

Forest type Mixed conifer
Alternatives considered

Quad CRGD3NWS

Mgmt Area $\mathrm{K08}$

WAA 1421

Photo 890113

Aspect South

PHYSICAL DESCRIPTION

Volume class breakdown: VC4 $\quad 0$ acres VC5 28 acres VC6 0 acres vC7 0 acres

Elevation breakdown: $0-800 \mathrm{ft} . \underline{30}$ acres $800-1200 \mathrm{ft} . \underline{0}$ acres $1200-1500 \mathrm{ft} . \underline{0}$ acres over $1500 \mathrm{ft}$. 0 acres Mass movement index: Low 18 acres Medium $\_$acres High 23 acres Very High 0 acres

\section{SOILS}

This unit has high mass movement index soils. Partial log suspension required over these areas.(BMP13.9)

This unit contains 23 acres of slopes > $75 \%$.

TIMBER

Potential for shovel logging on 17 acres, if soil and water quality protected (BMP13.7)

\section{ENG INEER ING}

High mass movement index soils. Road construction must minimize landslide potential (BMP14).

slopes greater than $75 \%$ may require full bench construction and endhaul of waste (BMP14.7).

\section{FISH/WATERSHED}

There are no fishery mitigation measures anticipated for this unit.

\section{WILDLIFE}

There are no wildlife mitigation measures anticipated for this unit.

RECREATION / VISUALS

This unit has a proposed VQO of MM and is not seen from any viewpoint identified by this project.

LANDS

There are no lands mitigation measures anticipated for this unit.

CULTURAL RESOURCES

There are no cultural resource mitigation measures anticipated for this unit. 


\section{CPOY Unil cerd \\ Unit Number: $577-320$}

dxae II 1993

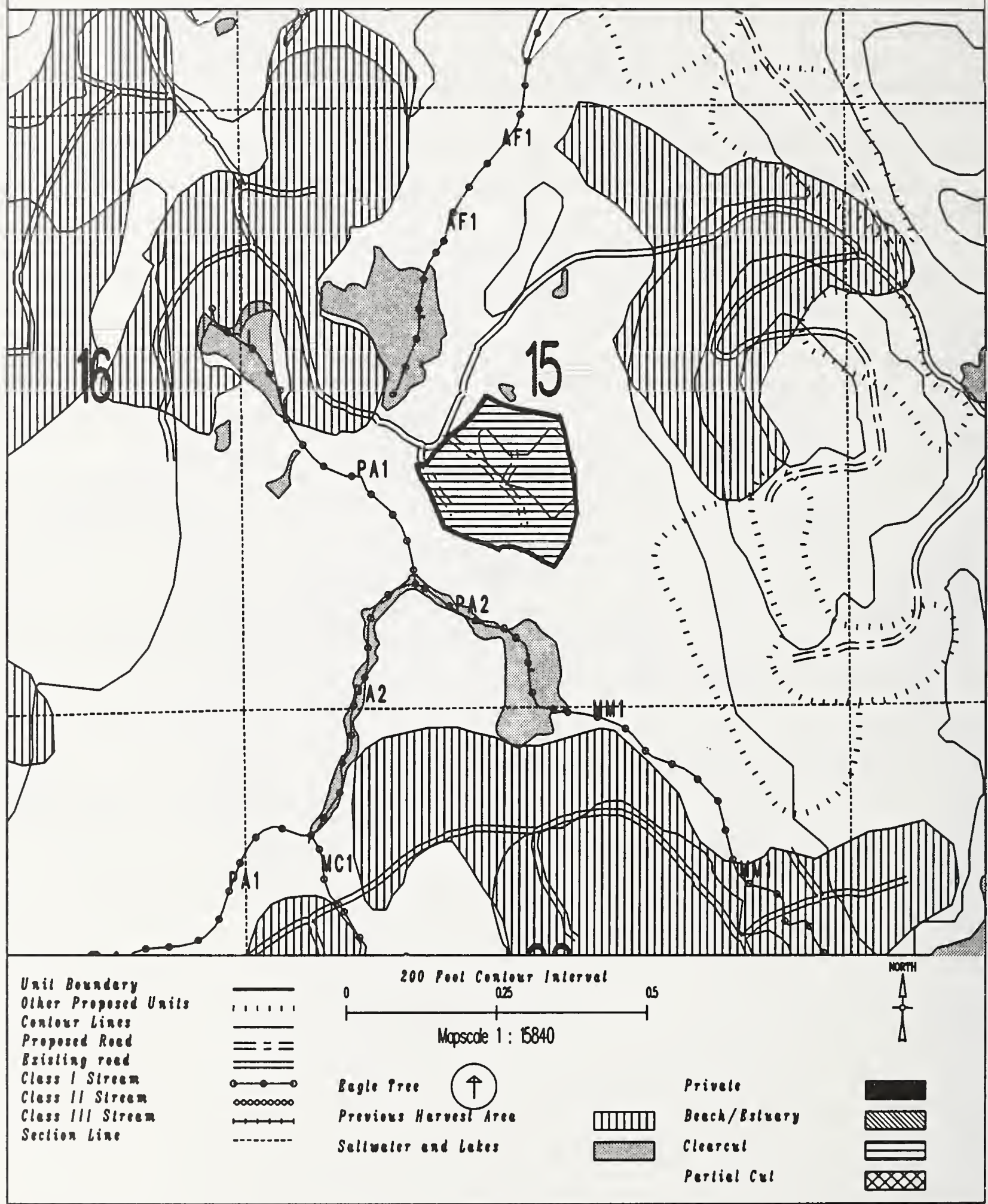


Unit 579-201

Planned acres 51

Estimated volume (mbf) 1073

Logging system Highlead

silvicultural system clearcut

Forest type Hemlock

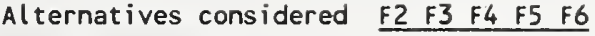

Quad CRGD2SWS

Mgmt Area K09

WAA 1319

Photo 1090086

Aspect West

PHYSICAL DESCRIPTION

Volume class breakdown: VC4 49 acres VC5 $\quad 0$ acres VC6 0 acres VC7 0 acres

Elevation breakdown: $0-800 \mathrm{ft} . \quad 0$ acres $800-1200 \mathrm{ft} . \underline{22}$ _ acres $1200-1500 \mathrm{ft}$. 18 acres over $1500 \mathrm{ft}$. 0 acres Mass movement index: Low 50 acres Medium 0 acres High 0 acres Very High 0 acres

SOILS

This unit contains 25 acres of forested wetlands. Site specific BMPs will be designed for selected approved logging system and road construction practices. (BMPs 12.5, 13.9, 13.15).

\section{TIMBER}

There are no timber mitigation measures anticipated for this unit.

\section{ENG INEER ING}

The road into this unit crosses a B6 channel. Meet stream and lake protection prescription requirements in TLMP Draft Revision (1991a) for this process group.

\section{FISH/WATERSHED}

There are no fishery mitigation measures anticipated for this unit.

\section{WILDLIFE}

There are no wildlife mitigation measures anticipated for this unit.

RECREATION / VISUALS

This unit has a proposed VQO of MM and is not seen from any viewpoint identified by this project.

\section{LANDS}

There are no lands mitigation measures anticipated for this unit.

CULTURAL RESOURCES

There are no cultural resource mitigation measures anticipated for this unit. 


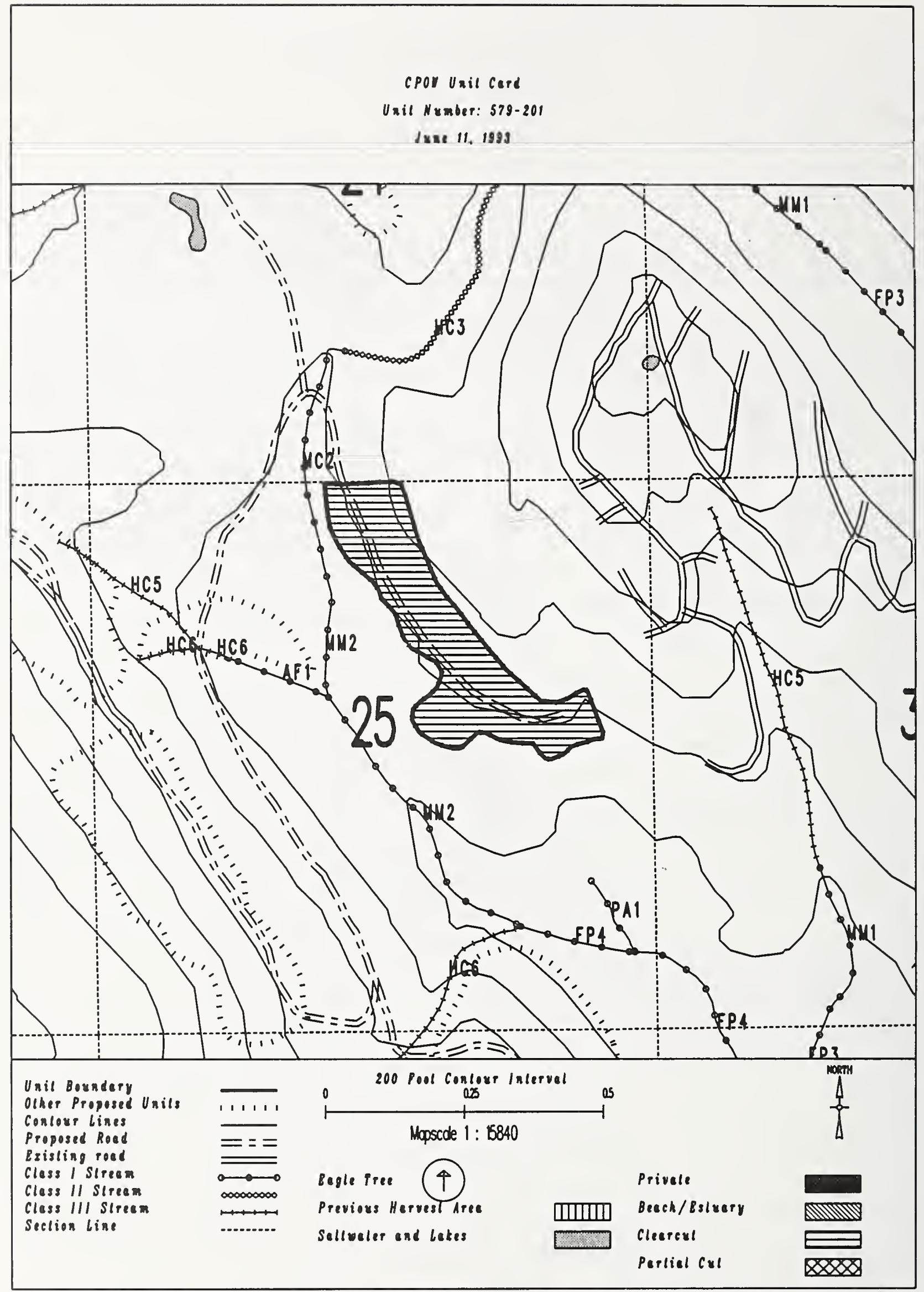


Unit $\quad 579-203$

Planned acres 56

Estimated volume (mbf) 1585

Logging system skyline

silvicultural system clearcut

Forest type Mixed conifer
Alternatives considered F2 $\quad$ F5 F6

Quad CRGD2SWS

Mgmt Area K09

WAA 1319

Photo 690041

Aspect North

PHYSICAL DESCRIPTION

Volume class breakdown: VC4 14 acres VC5 $\underline{39}$ acres VC6 $\quad 0$ acres vc7 0 acres

Elevation breakdown: $0-800 \mathrm{ft} . \quad 0$ acres 800-1200 ft. 느 acres 1200-1500 ft. 4 acres over $1500 \mathrm{ft}$. 1 acres Mass movement index: Low 5 acres Medium 14 acres High $\underline{35}$ acres Very High 0

SOILS

This unit has high mass movement index soils. Partial log suspension required over these areas. (BMP13.9)

This unit contains 31 acres of forested wetlands. Site specific BMPs will be designed for selected approved

logging system and road construction practices. (BMPs 12.5, 13.9, 13.15).

This unit contains 23 acres of slopes $>75 \%$.

This unit will be monitored for effects of harvest/roading on landslide-prone slopes.

\section{TIMBER}

There are no timber mitigation measures anticipated for this unit.

\section{ENGINEERING}

High mass movement index soils. Road construction must minimize landslide potential (BMP14).

slopes greater than $75 \%$ may require full bench construction and endhaul of waste (BMP14.7).

\section{FISH/WATERSHED}

This unit contains a $\underline{A 4}$ class $\underline{3}$ stream. No specific buffer required, but full suspension, if yarding across.

\section{WILDLIFE}

Maintain diversity within unit by leaving 1-5 acre-sized islands of green trees at a rate of 1 acre of island for every 20 acres harvested. Leave islands must be compatible with logging system and safe working conditions.

\section{RECREATION / VISUALS}

The unit has a proposed VQO of MM within the viewshed of Sal creek as viewed from ferry/cruise ship route (2-4 miles off shore).

\section{LANDS}

There are no lands mitigation measures anticipated for this unit.

\section{CULTURAL RESOURCES}

There are no cultural resource mitigation measures anticipated for this unit.

\section{GEOLOGY}

There are no karst mitigation measures anticipated for this unit. 


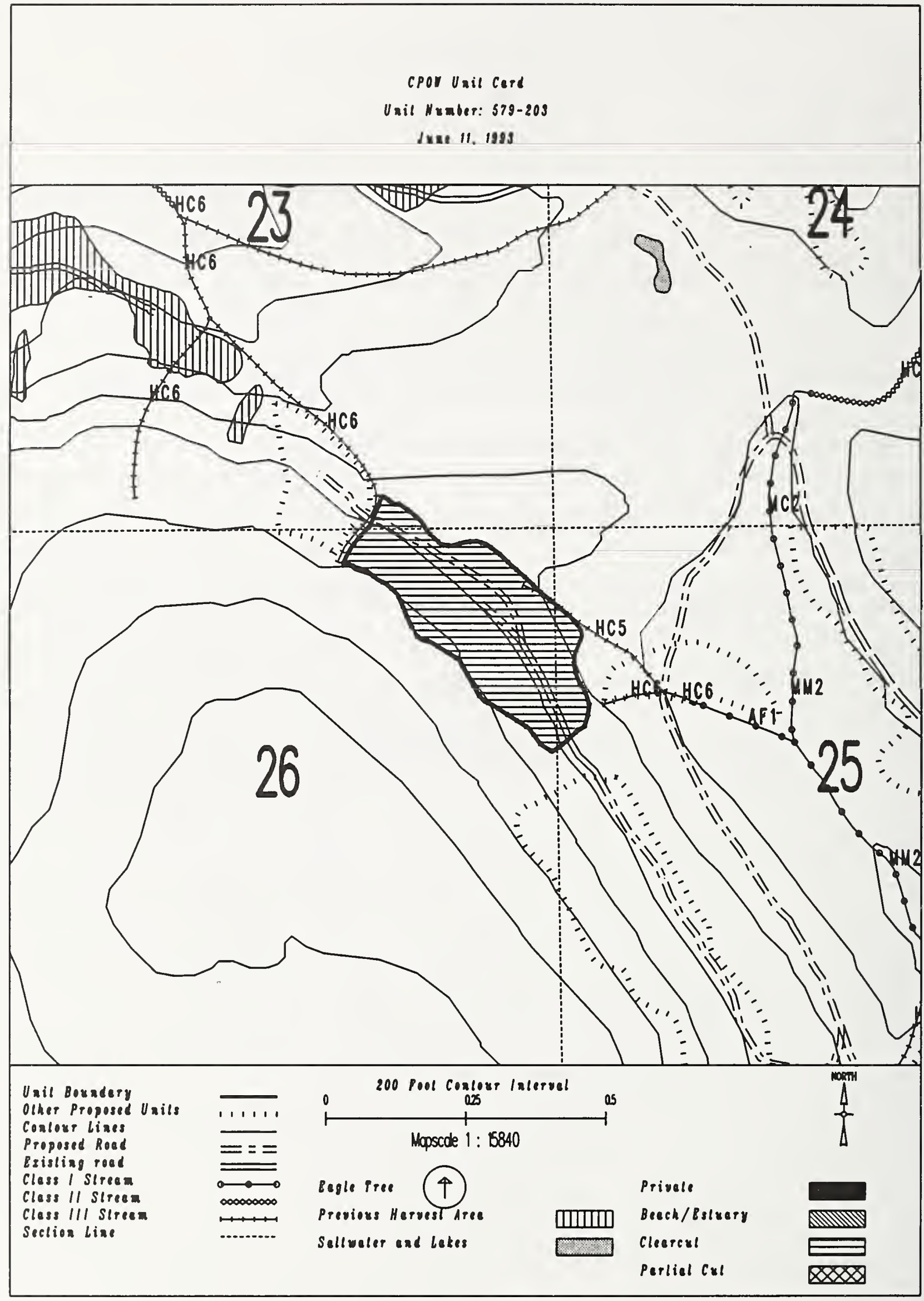




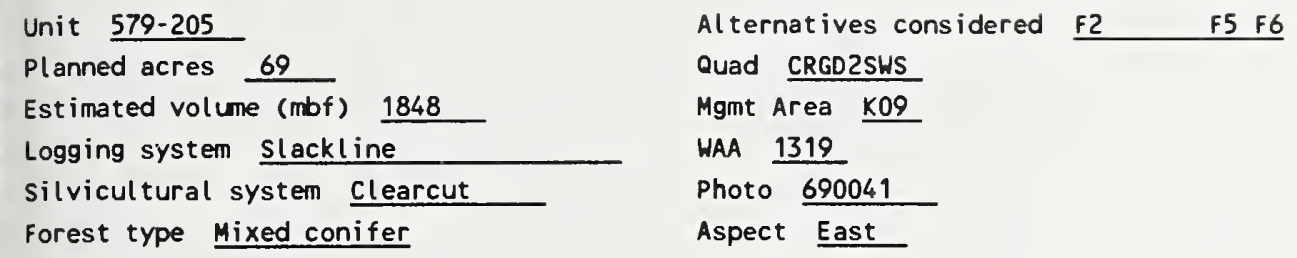




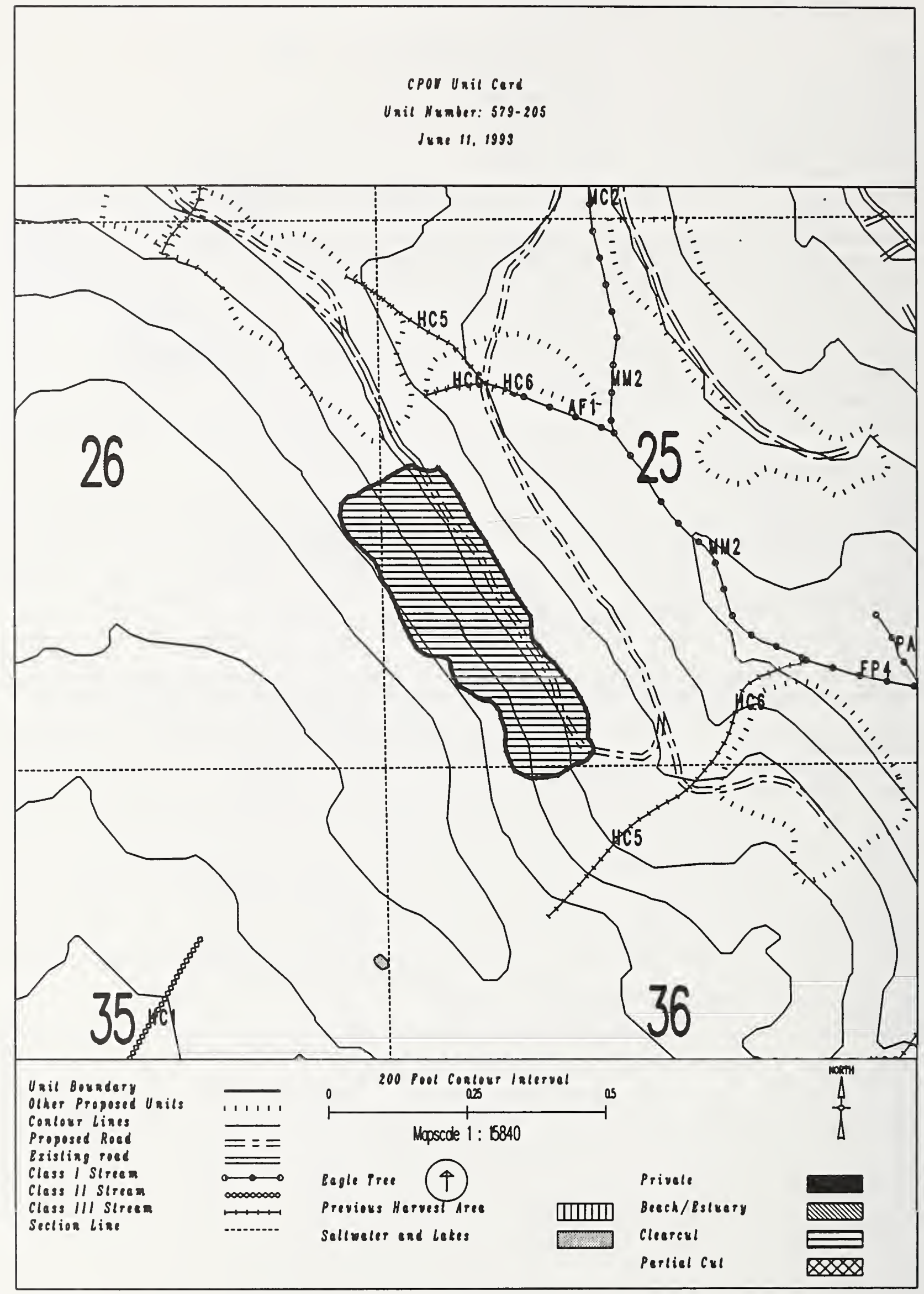




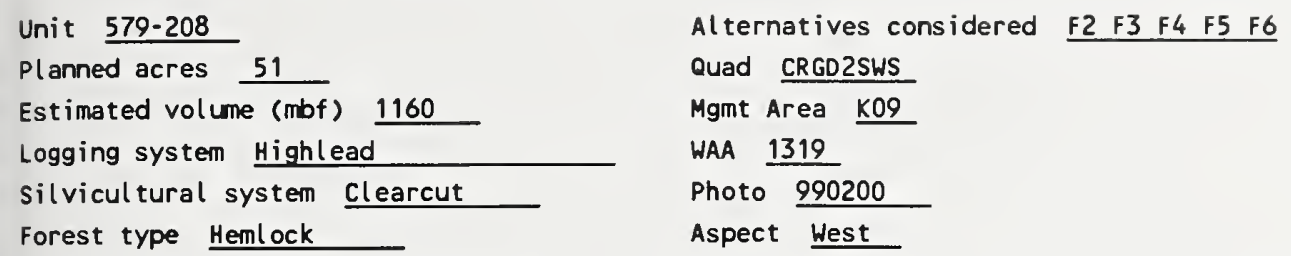

This unit contains streams which have recently been classified/channel typed but require field verification.

\section{WILDLIFE}

Maintain diversity within unit by leaving 1-5 acre-sized islands of green trees at a rate of 1 acre of island for every 20 acres harvested. Leave islands must be compatible with logging system and safe working conditions.

This unit has a proposed voo of MM and is not seen from any viewpoint identified by this project.

LANDS

There are no lands mitigation measures anticipated for this unit.

CULTURAL RESOURCES

There are no cultural resource mitigation measures anticipated for this unit. 


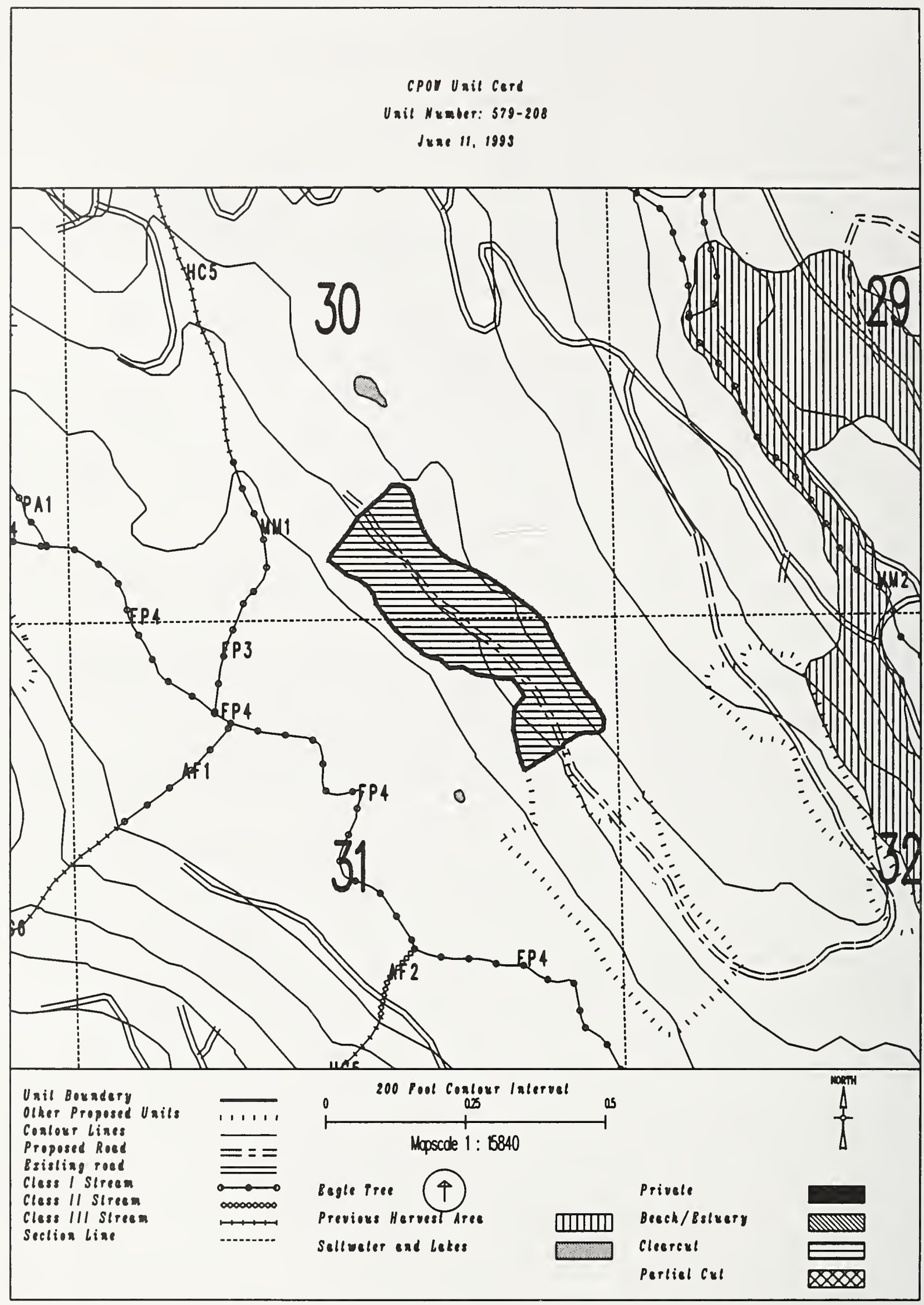


Unit 579-209

Planned acres 55

Estimated volume (mbf) 1226

Logging system skyline

silvicultural system clearcut

Forest type Hemlock

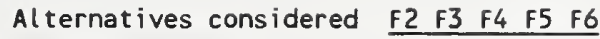

Quad CRGD2SWS

Mgmt Area K09

WAA 1319

Photo 990200

Aspect West

PHYSICAL DESCRIPIION

Volume class breakdown: VC4 56 acres VC5 $\quad 0$ acres VC6 $\quad 0$ acres VC7 0 acres

Elevation breakdown: $0-800 \mathrm{ft}$. $\quad 0$ acres $800-1200 \mathrm{ft} . \underline{37}$ acres 1200-1500 ft. 14 acres over $1500 \mathrm{ft}$. 0 acres

Mass movement index: Low 2 acres Medium 8 acres High 0 acres Very High 0

SOILS

This unit contains 56 acres of forested wetlands. Site specific BMPs will be designed for selected approved

logging system and road construction practices. (BMPs 12.5, 13.9, 13.15).

\section{TIMBER}

There are no timber mitigation measures anticipated for this unit.

\section{ENGINEER ING}

There are no engineering mitigation measures anticipated for this unit.

\section{FISH/WATERSHED}

This unit contains streams which have recently been classified/channel typed but require field verification.

\section{WILDLIFE}

Maintain diversity within unit by leaving 1-5 acre-sized islands of green trees at a rate of 1 acre of island for every 20 acres harvested. Leave islands must be compatible with logging system and safe working conditions.

RECREATION / VISUALS

This unit has a proposed Voo of MM and is not seen from any viewpoint identified by this project.

\section{LANDS}

There are no lands mitigation measures anticipated for this unit.

CULTURAL RESOURCES

There are no cultural resource mitigation measures anticipated for this unit.

GEOLOGY

There are no karst mitigation measures anticipated for this unit. 


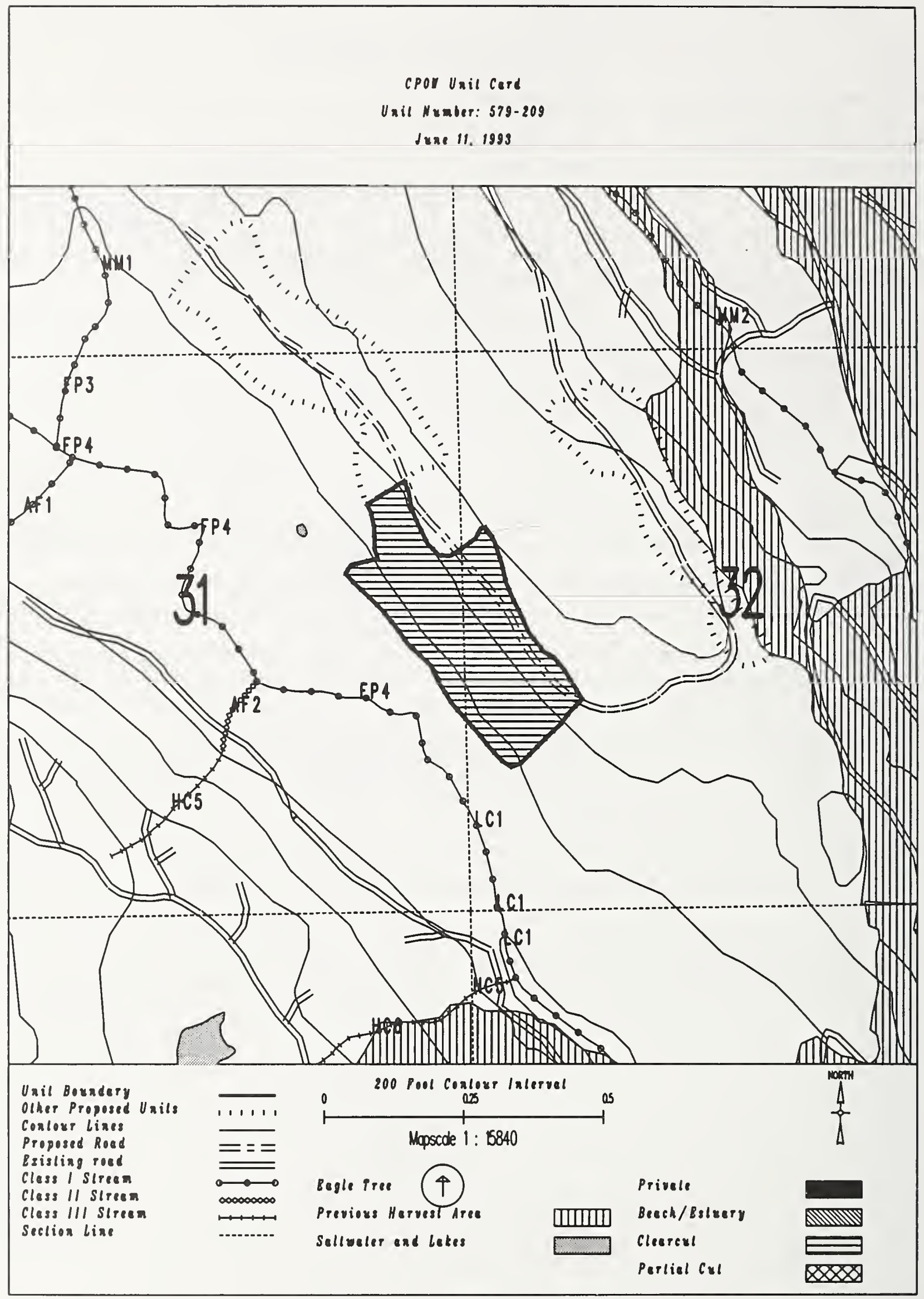


Unit $579-212$

Planned acres 33

Estimated volume (mbf) 1038

Logging system Highlead

silvicultural system clearcut

Forest type Mixed conifer
Alternatives considered $\mathrm{F} 2 \quad \mathrm{~F} 3 \quad \mathrm{~F} 4 \quad$ F5 $\quad$ F6

Quad CRGC2NWN

Mgmt Area K09

WAA 1319

Photo 690039

Aspect South

PHYSICAL DESCRIPTION

Volume class breakdown: VC4 4 acres VC5 29 acres vC6 $\quad 0$ acres vc7 $\quad 0$ acres

Elevation breakdown: $0-800 \mathrm{ft} . \underline{0}$ acres $800-1200 \mathrm{ft} . \underline{3}$ acres $1200-1500 \mathrm{ft} . \overline{10}$ acres over $1500 \mathrm{ft} . \underline{0}$ acres Mass movement index: Low 18 acres Medium 0 acres High 14 acres Very High 0 acres

SOILS

This unit has high mass movement index soils. Partial log suspension required over these areas.(BMP13.9)

TIMBER

There are no timber mitigation measures anticipated for this unit.

\section{ENG INEER ING}

High mass movement index soils. Road construction must minimize landslide potential (BMP14).

\section{FISH/WATERSHED}

There are no fishery mitigation measures anticipated for this unit.

\section{WILDL IFE}

Maintain adequate distribution of snags by leaving 0.1 acre-sized patches of green trees within the unit for every 10 acres harvested. Snag patches must be compatible with logging system and safe working conditions.

RECREATION / VISUALS

This unit has a proposed voo of MM and is not seen from any viewpoint identified by this project.

\section{LANDS}

There are no lands mitigation measures anticipated for this unit.

\section{CULTURAL RESOURCES}

There are no cultural resource mitigation measures anticipated for this unit. 


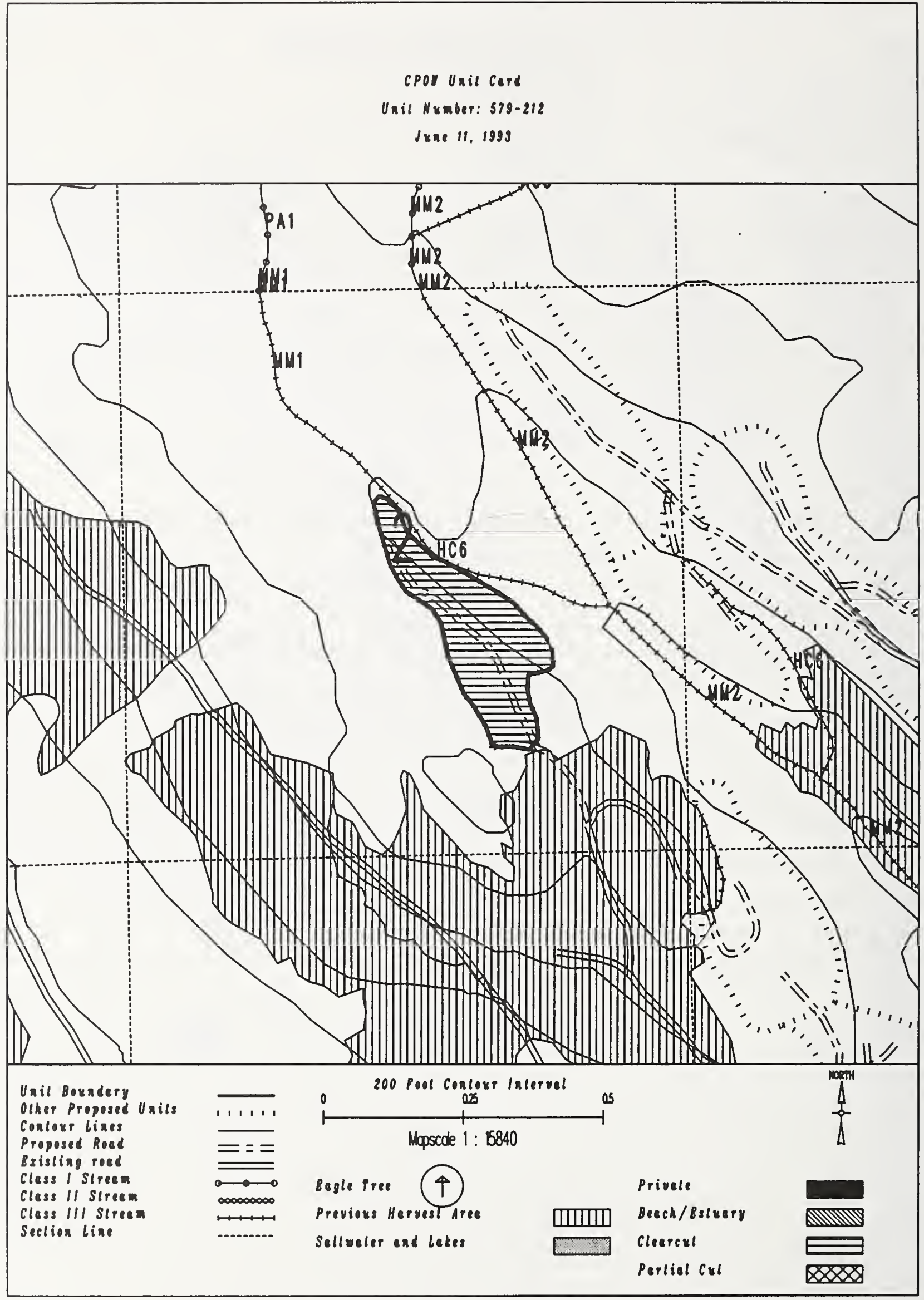


Unit $579-213$

Planned acres 41

Estimated volume (mbf) 819

Logging system Highlead

silvicultural system Clearcut

Forest type Hemlock
Al ternatives considered F2 F3 F4 F5 F6

Quad CRGC2NWN

Mgmt Area K09

WAA 1319

Photo 690038

Aspect East

PHYSICAL DESCRIPTION

Volume class breakdown: VC4 $\quad 0$ acres VC5 25 acres VC6 $\quad 0$ acres VC7 $\quad 0$ acres

Elevation breakdown: $0-800 \mathrm{ft} . \underline{0}$ acres $800-1200 \mathrm{ft} .29$ acres 1200-1500 ft. 9 acres over $1500 \mathrm{ft}$. 0 acres Mass movement index: Low 26 acres Medium $\underline{0}$ acres High 13 acres Very High 0 acres

\section{SOILS}

This unit has high mass movement index soils. Partial log suspension required over these areas. (BMP13.9)

This unit contains 26 acres of forested wetlands. Site specific BMPs will be designed for selected approved

logging system and road construction practices. (BMPs 12.5, 13.9, 13.15).

\section{TIMBER}

There are no timber mitigation measures anticipated for this unit.

ENGINEER ING

High mass movement index soils. Road construction must minimize landslide potential (BMP14).

\section{FISH/HATERSHED}

This unit contains streams which have recently been classified/channel typed but require field verification.

\section{WILDLIFE}

Maintain adequate distribution of snags by leaving 0.1 acre-sized patches of green trees within the unit for every 10 acres harvested. Snag patches must be compatible with logging system and safe working conditions.

RECREATION / VISUALS

This unit has a proposed Voo of MM and is not seen from any viewpoint identified by this project.

\section{LANDS}

There are no lands mitigation measures anticipated for this unit.

CULTURAL RESOURCES

There are no cultural resource mitigation measures anticipated for this unit.

GEOLOGY

There are no karst mitigation measures anticipated for this unit. 


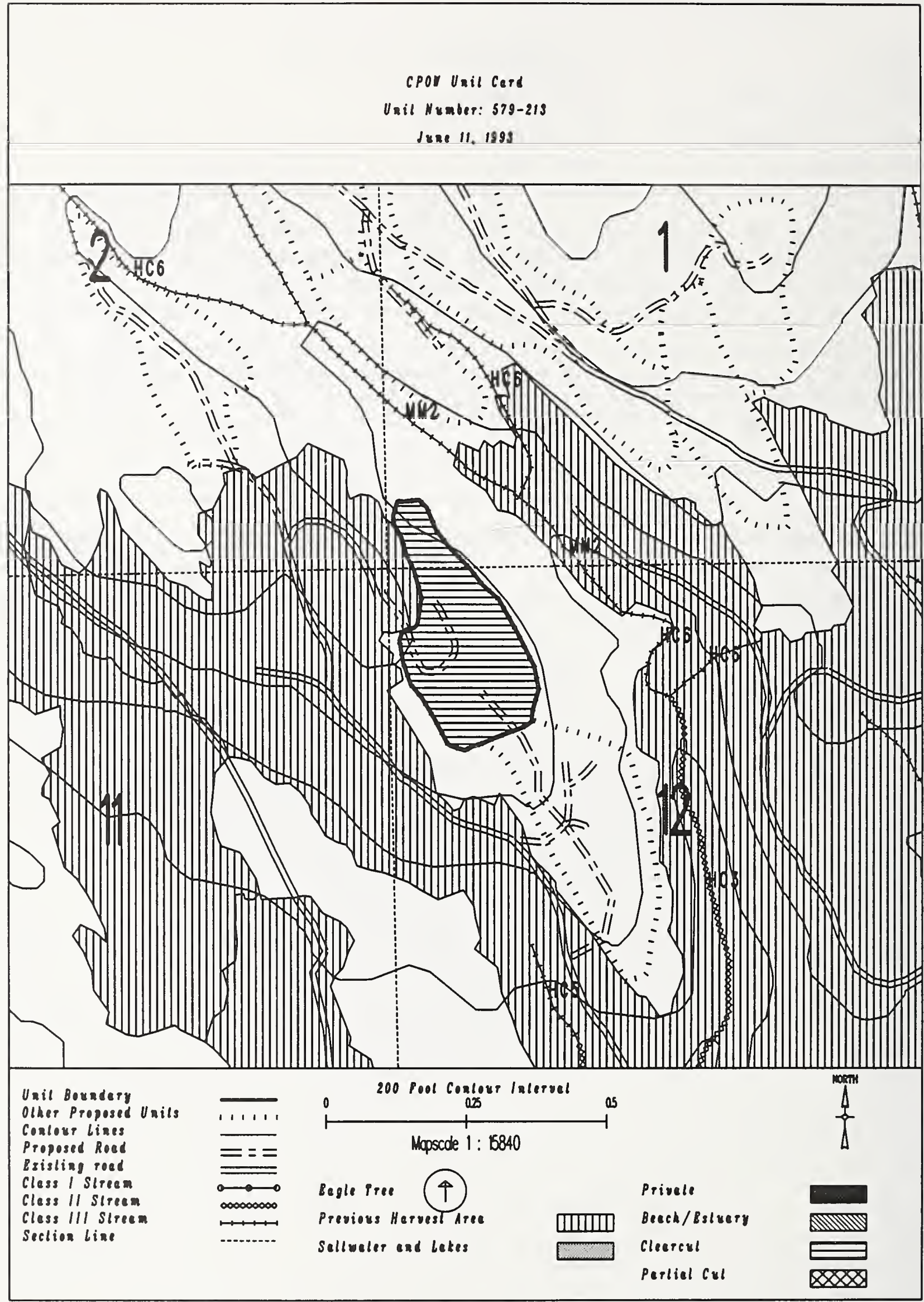


Unit $579-214$

Planned acres 45

Estimated volume (mbf) 766

Logging system skyline

Silvicultural system clearcut

Forest type Hemlock
Alternatives considered F2 F3 F4 F5 F6

Quad CRGC2NWN

Mgmt Area K09

WAA 1319

Photo 1090082

Aspect East

PHYSICAL DESCRIPTION

Volume class breakdown: VC4 35 acres VC5 $\quad 0$ acres vC6 $\quad 0$ acres vC7 $\quad 0$ acres

Elevation breakdown: $0-800 \mathrm{ft} . \underline{19}$ acres $800-1200 \mathrm{ft} . \underline{23}$ acres $1200-1500 \mathrm{ft} . \underline{0}$ acres over $1500 \mathrm{ft} . \underline{0}$ acres Mass movement index: Low 30 acres Medium 0 acres High 15 acres Very High 0 acres

SOILS

This unit has high mass movement index soils. Partial log suspension required over these areas.(BMP13.9) This unit contains 29 acres of forested wetlands. Site specific BMPs will be designed for selected approved

logging system and road construction practices. (BMPs 12.5, 13.9, 13.15).

TIMBER

There are no timber mitigation measures anticipated for this unit.

\section{ENGINEERING}

High mass movement index soils. Road construction must minimize landslide potential (BMP14).

\section{FISH/WATERSHED}

This unit contains streams which have recently been classified/channel typed but require field verification.

\section{HILDLIFE}

Maintain adequate distribution of snags by leaving 0.1 acre-sized patches of green trees within the unit for every 10 acres harvested. Snag patches must be compatible with logging system and safe working conditions.

RECREATION / VISUALS

This unit has a proposed voo of MM and is not seen from any viewpoint identified by this project.

LANDS

There are no lands mitigation measures anticipated for this unit.

CULTURAL RESOURCES

There are no cultural resource mitigation measures anticipated for this unit. 
CPOI Unil cerd

Unil Nember: 579-214

June 11, 1993

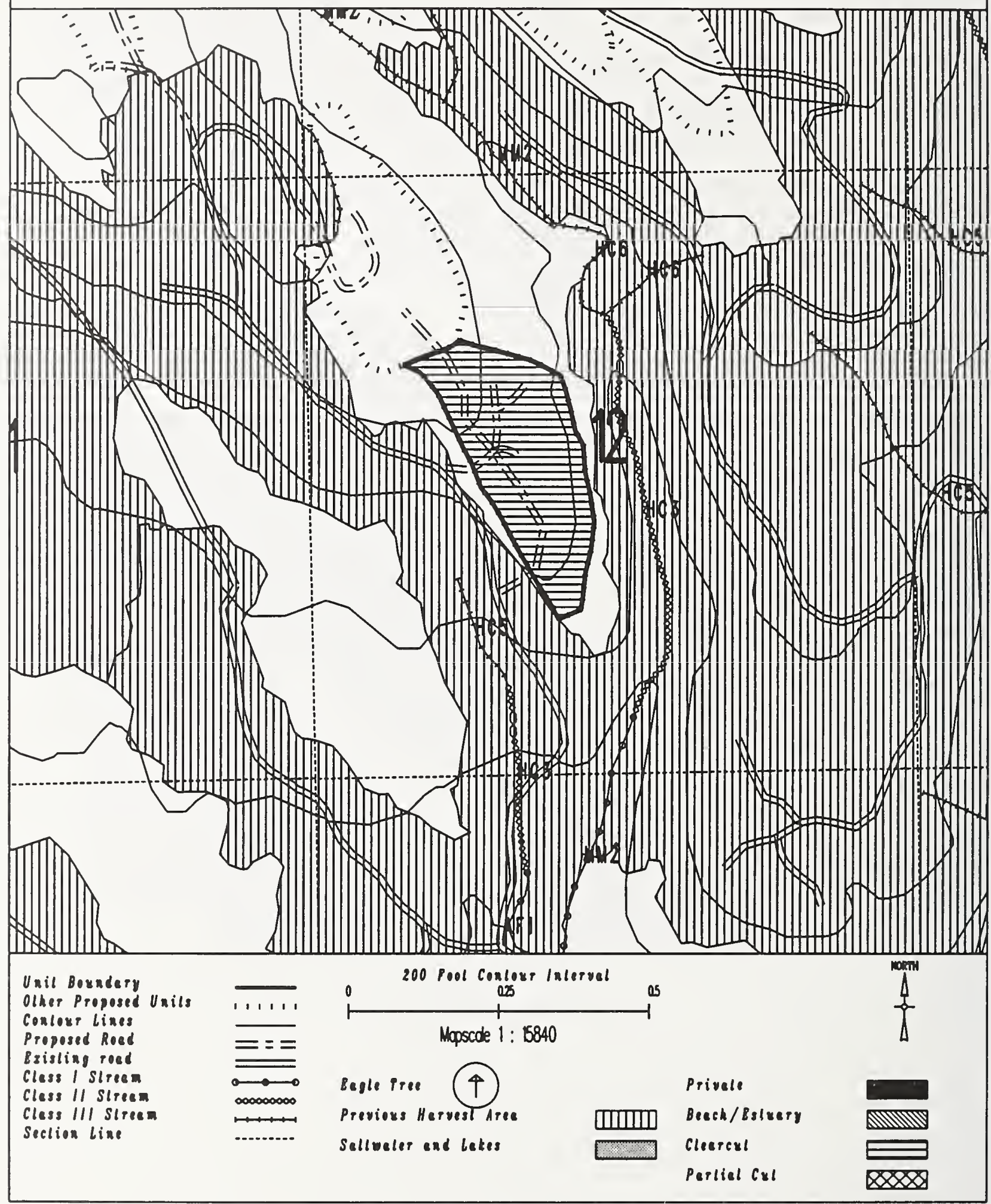


Unit $579-215$

Planned acres 30

Estimated volume (mbf) 875

Logging system Highlead

Silvicultural system Clearcut

Forest type Mixed conifer
Alternatives considered F2 F3 $F 4$ F5 F6

Quad CRGC2NWN

Mgmt Area K09

WAA 1319

Photo 1090082

Aspect South

\section{PHYSICAL DESCRIPTION}

Volume class breakdown: VC4 13 acres VC5 18 acres VC6 $\quad 0$ acres vC7 0 acres

Elevation breakdown: $0-800 \mathrm{ft} .\left[\begin{array}{l}0 \\ 0\end{array}\right.$ Mass movement index: Low $\underline{5}$ acres Medium 25 acres High 1 acres Very High $\underline{0}$ acres

\section{SOILS}

There are no soils mitigation measures anticipated for this unit.

\section{TIMBER}

There are no timber mitigation measures anticipated for this unit.

\section{ENGINEERING}

There are no engineering mitigation measures anticipated for this unit.

\section{FISH/WATERSHED}

There are no fishery mitigation measures anticipated for this unit.

\section{HILDLIFE}

Maintain diversity within unit by leaving 1-5 acre-sized islands of green trees at a rate of 1 acre of island for every 20 acres harvested. Leave islands must be compatible with logging system and safe working conditions.

RECREATION / VISUALS

This unit has a proposed VQO of MM and is not seen from any viewpoint identified by this project.

\section{LANDS}

There are no lands mitigation measures anticipated for this unit.

CULTURAL RESOURCES

There are no cultural resource mitigation measures anticipated for this unit.

\section{GEOLOGY}

There are no karst mitigation measures anticipated for this unit. 


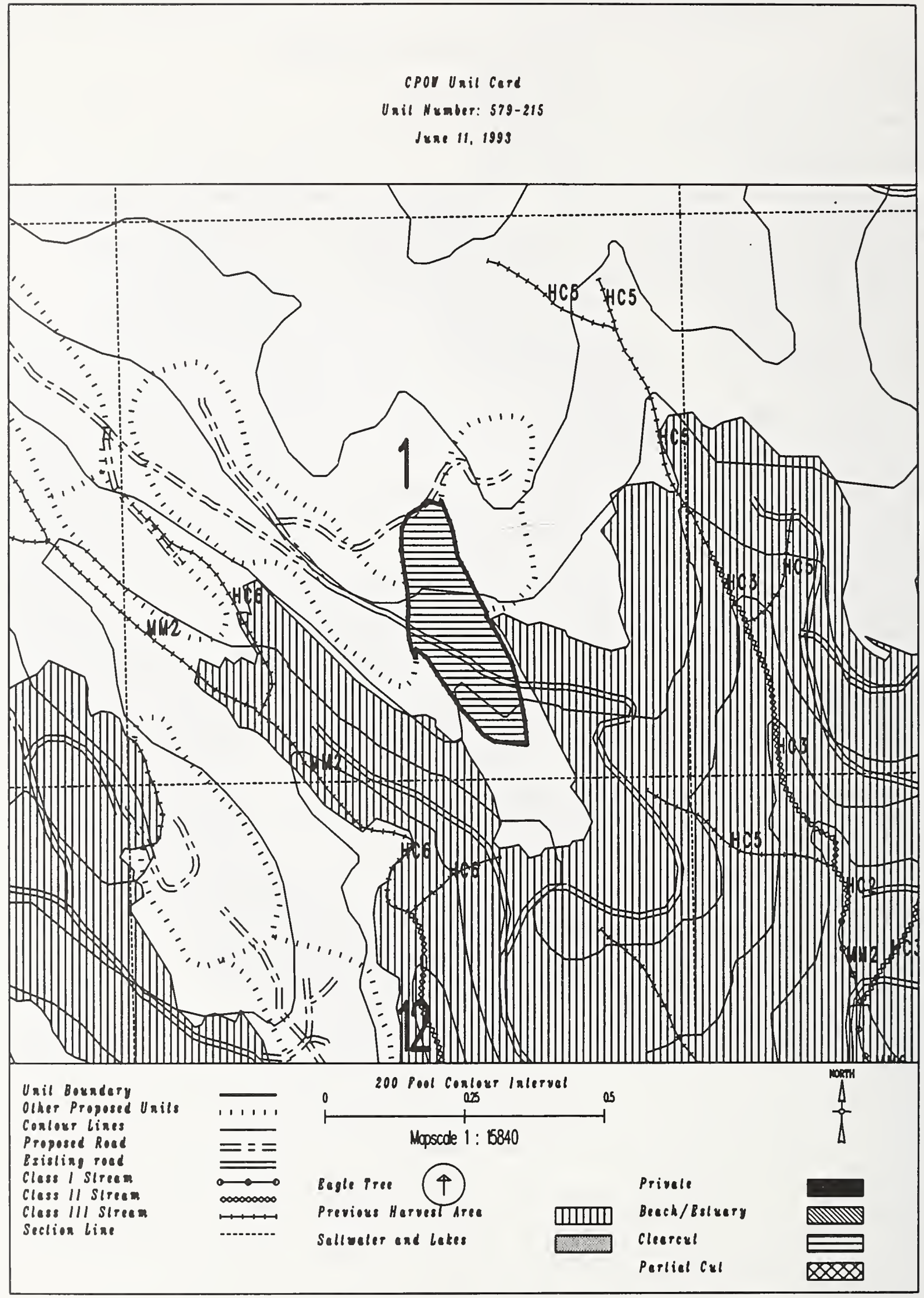


Unit $\quad \underline{579-216}$

Planned acres 62

Estimated volume (mbf) 1695

Logging system Highlead

silvicultural system Clearcut

Forest type Hemlock
Alternatives considered

Quad CRGC2NHN

Mgmt Area $\mathrm{KO9}$

WAA 1319

Photo 690039

Aspect South

\section{PHYSICAL DESCRIPTION}

Volume class breakdown: VC4 28 acres VC5 33 acres VC6 0 acres VC7 0 acres

Elevation breakdown: $0-800 \mathrm{ft} . \quad[\quad 0$ acres $800-1200 \mathrm{ft} . \underline{0}$ acres $1200-1500 \mathrm{ft} . \underline{0}$ acres over $1500 \mathrm{ft}$. 12 acres Mass movement index: Low 5 acres Medium 16 acres High 43 acres Very High 0

SOILS

This unit has high mass movement index soils. Partial log suspension required over these areas. (BMP13.9)

TIMBER

There are no timber mitigation measures anticipated for this unit.

ENGINEER ING

High mass movement index soils. Road construction must minimize landslide potential (BMP 14).

FISH/WATERSHED

This unit contains streams which have recently been classified/channel typed but require field verification.

WILDLIFE

Maintain diversity within unit by leaving 1-5 acre-sized islands of green trees at a rate of 1 acre of island for every 20 acres harvested. Leave islands must be compatible with logging system and safe working conditions.

RECREATION / VISUALS

This unit has a proposed VQO of MM and is not seen from any viewpoint identified by this project.

\section{LANDS}

There are no lands mitigation measures anticipated for this unit.

CULTURAL RESOURCES

There are no cultural resource mitigation measures anticipated for this unit.

GEOLOGY

There are no karst mitigation measures anticipated for this unit. 


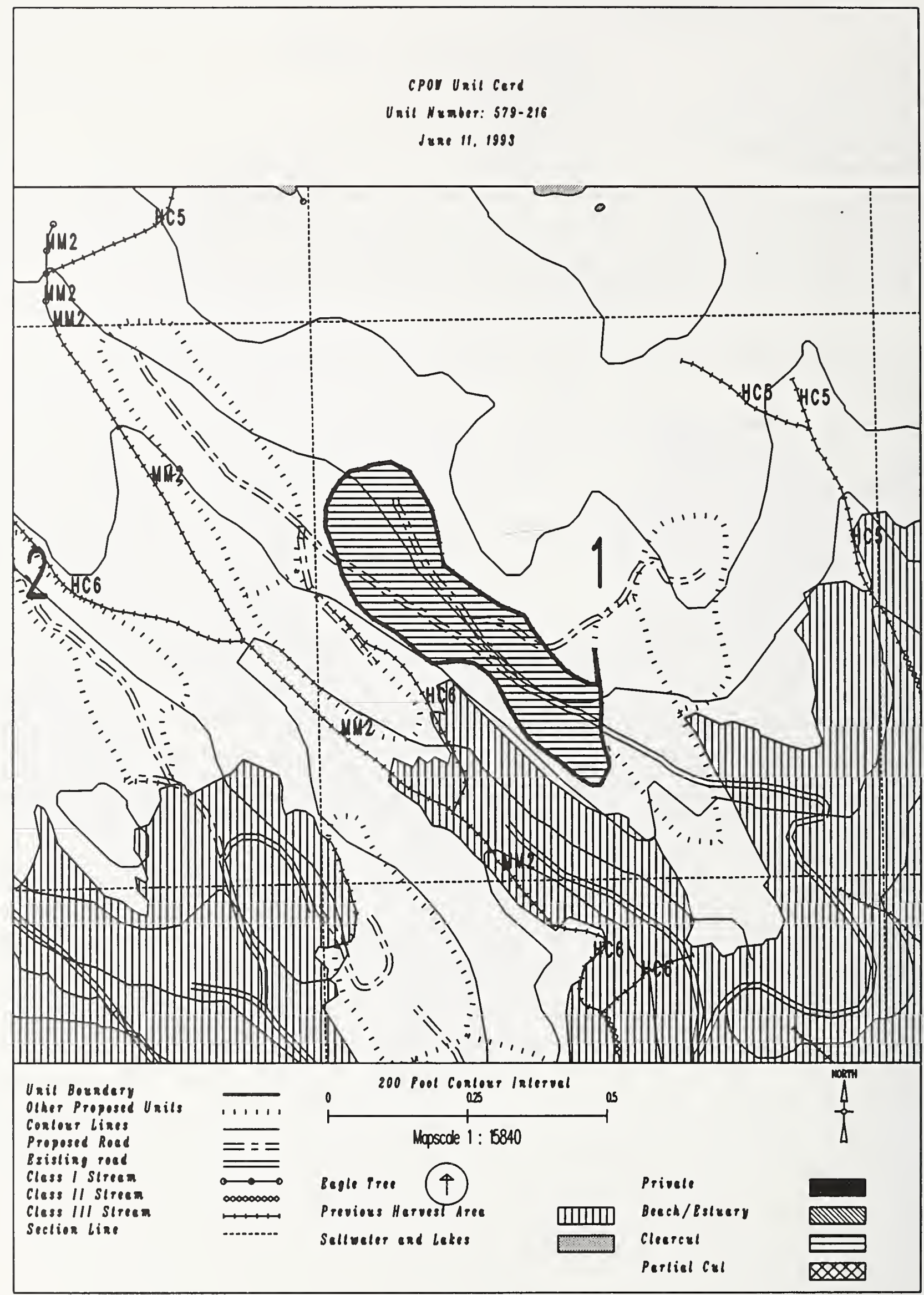


Unit $\quad 579-217$

Planned acres 24

Estimated volume (mbf)

Logging system Highlead

silvicultural system clearcut

Forest type Hemlock
Alternatives considered F2 F5 F6

Quad CRGC2NWN

Mgmt Area K09

WAA 1319

Photo 690039

Aspect Hest

PHYSICAL DESCRIPTION

Volume class breakdown: VC4 17 acres VC5 $\quad 7$ acres VC6 $\quad 0$ acres VC7 $\quad 0$ acres

Elevation breakdown: $0-800 \mathrm{ft} . \quad 0$ acres $800-1200 \mathrm{ft} . \underline{2}$ acres 1200-1500 ft. 19 acres over $1500 \mathrm{ft}$. 0 acres

Mass movement index: Low 0 acres Medium 14 acres High 9 acres Very High 0 acres

SOILS

This unit has high mass movement index soils. Partial log suspension required over these areas.(8MP13.9)

This unit contains 14 acres of forested wetlands. Site specific BMPs will be designed for selected approved

logging system and road construction practices. (BMPs 12.5, 13.9, 13.15).

\section{TIMBER}

There are no timber mitigation measures anticipated for this unit.

\section{ENGINEER ING}

High mass movement index soils. Road construction must minimize landslide potential (8MP14).

FISH/WATERSHED

There are no fishery mitigation measures anticipated for this unit.

HILOLIFE

There are no wildtife mitigation measures anticipated for this unit.

RECREATION / VISUALS

This unit has a proposed VQO of MM and is not seen from any viewpoint identified by this project.

LANDS

There are no lands mitigation measures anticipated for this unit.

CULTURAL RESOURCES

There are no cultural resource mitigation measures anticipated for this unit.

GEOLOGY

There are no karst mitigation measures anticipated for this unit. 


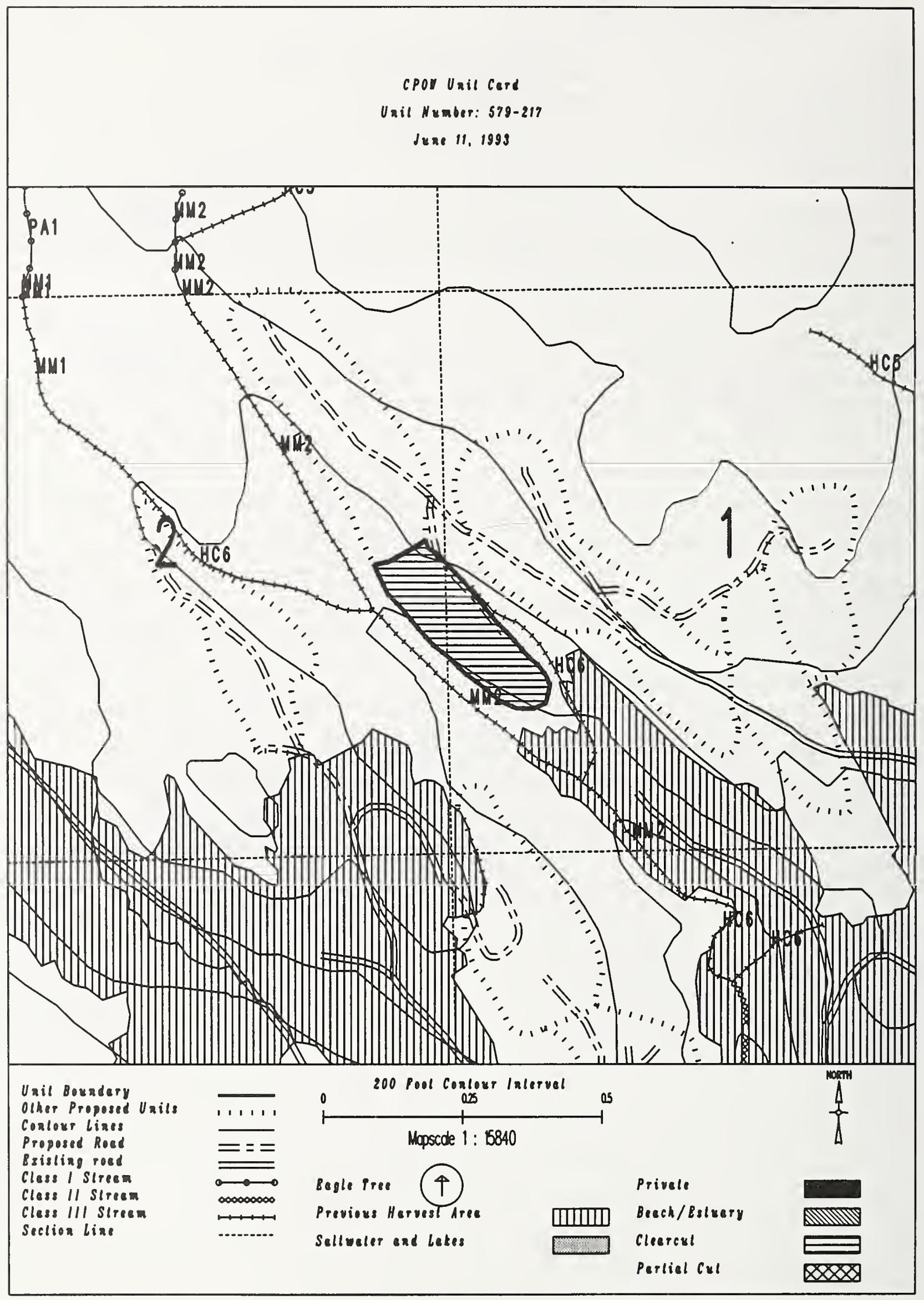


Unit $\mathbf{5 7 9 - 2 1 8}$

Planned acres 50

Estimated volume (mbf) 1410

Logging system Skyline

silvicultural system Clearcut

forest type Mixed conifer
Alternatives considered $\underline{F 2}$

Quad CRGD2SWS

Mgmt Area KO9

WAA 1319

Photo 690039

Aspect South

PHYSICAL DESCRIPTION

Volume class breakdown: vc4 15 acres vc5 33 acres vc6 $\quad 0$ acres vc7 0 acres

Elevation breakdown: $0-800 \mathrm{ft} . \angle 0$ acres $800-1200 \mathrm{ft} . \underline{0}$ acres 1200-1500 ft. 3 acres over $1500 \mathrm{ft} .11$ acres Mass movement index: Low 6 acres Medium 19 acres High 23 acres Very High 0 acres

SOILS

This unit has high mass movement index soils. Partial log suspension required over these areas. (BMP13.9)

This unit contains 19 acres of forested wetlands. Site specific BMPs will be designed for selected approved

logging system and road construction practices. (BMPs 12.5, 13.9, 13.15).

TIMBER

There are no timber mitigation measures anticipated for this unit.

ENGINEERING

High mass movement index soils. Road construction must minimize landslide potential (BMP14).

FISH/WATERSHED

There are no fishery mitigation measures anticipated for this unit.

WILDLIFE

There are no wildlife mitigation measures anticipated for this unit.

RECREATION / VISUALS

This unit has a proposed VQO of MM and is not seen from any viewpoint identified by this project.

\section{LANDS}

There are no lands mitigation measures anticipated for this unit.

\section{CULTURAL RESOURCES}

There are no cultural resource mitigation measures anticipated for this unit.

\section{GEOLOGY}

There are no karst mitigation measures anticipated for this unit. 
CPOU Unil cerd

Unil Number: 579-218

Juae 11, 1993

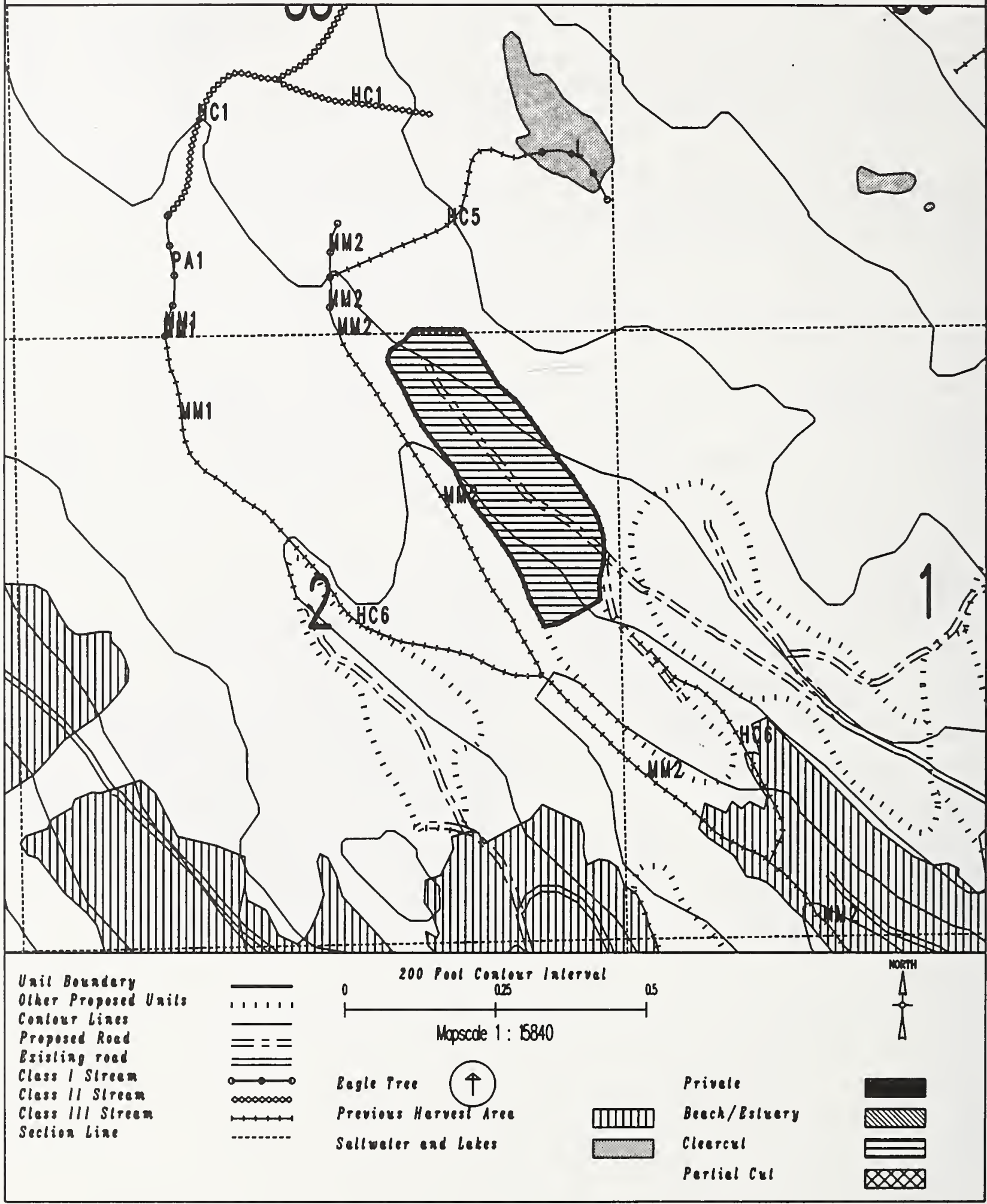




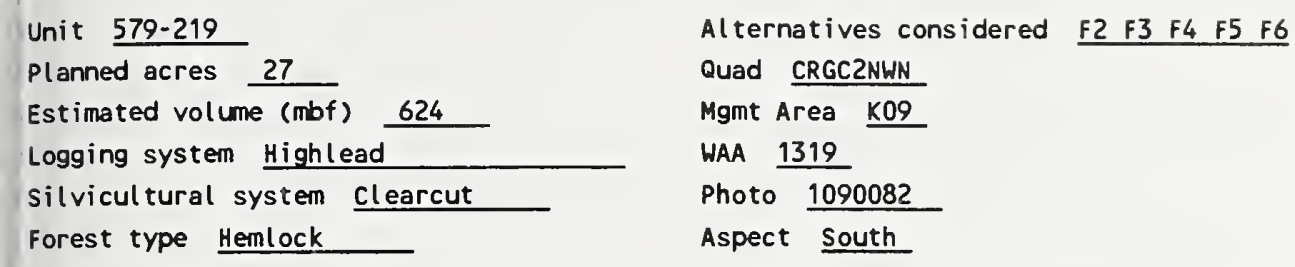

This unit contains streams which have recently been classified/channel typed but require field verification.

HILDLIFE

Maintain diversity within unit by leaving 1-5 acre-sized islands of green trees at a rate of 1 acre of island for every 20 acres harvested. Leave islands must be compatible with logging system and safe working conditions.

RECREATION / VISUALS

This unit has a proposed VQO of MM and is not seen from any viewpoint identified by this project.

LANDS

There are no lands mitigation measures anticipated for this unit.

CULTURAL RESOURCES

There are no cultural resource mitigation measures anticipated for this unit.

There are no karst mitigation measures anticipated for this unit. 


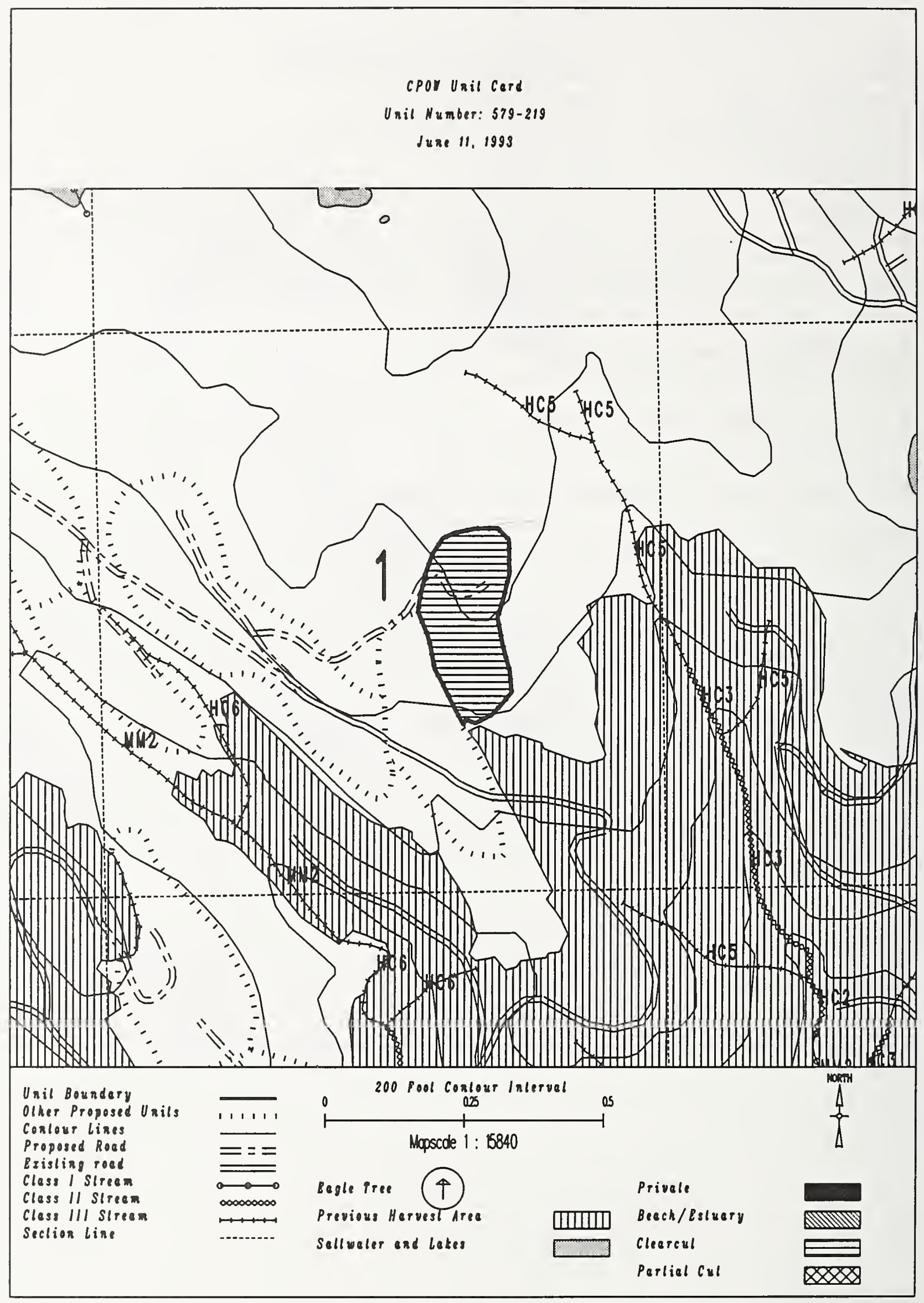


UNIT PLAN/LAYOUT/SALE ADMINISTRATION CARD FOR CPOW FEIS

Unit $\quad 579-220$

Planned acres 46

Estimated volume (mbf) 1442

Logging system Highlead

silvicultural system clearcut

Forest type Hemlock
Alternatives considered $\mathrm{F2} \quad \mathrm{F3} \quad \mathrm{F4} \quad$ F5 $\quad$ F6

Quad CRGC2NWN

Mgmt Area KO9

WAA 1319

Photo 1090082

Aspect South

PHYSICAL DESCRIPTION

Volume class breakdown: VC4 3 acres VC5 42 acres VC6 0 acres VC7 0 acres

Elevation breakdown: $0-800 \mathrm{ft} . \quad 0$ acres $800-1200 \mathrm{ft} . \quad 0$ acres $1200-1500 \mathrm{ft}$. 0 acres over $1500 \mathrm{ft}$. 0 acres Mass movement index: Low 2 acres Medium $\underline{32}$ acres High 10 acres Very High 0 acres

SOILS

This unit has high mass movement index soils. Partial log suspension required over these areas. (BMP13.9)

This unit contains 34 acres of forested wetlands. Site specific BMPs will be designed for selected approved

logging system and road construction practices. (BMPs 12.5, 13.9, 13.15).

TIMBER

There are no timber mitigation measures anticipated for this unit.

ENGINEER ING

High mass movement index soils. Road construction must minimize landslide potential (BMP14).

FISH/WATERSHED

This unit contains streams which have recently been classified/channel typed but require field verification.

WILDL IFE

There are no wildlife mitigation measures anticipated for this unit.

RECREATION / VISUALS

The unit has a proposed voo of $M$ within the viewshed of Sal Creek

as viewed from ferry/cruise ship route (2-4 miles off shore).

LANDS

There are no lands mitigation measures anticipated for this unit.

CULTURAL RESOURCES

There are no cultural resource mitigation measures anticipated for this unit.

GEOLOGY

There are no karst mitigation measures anticipated for this unit. 


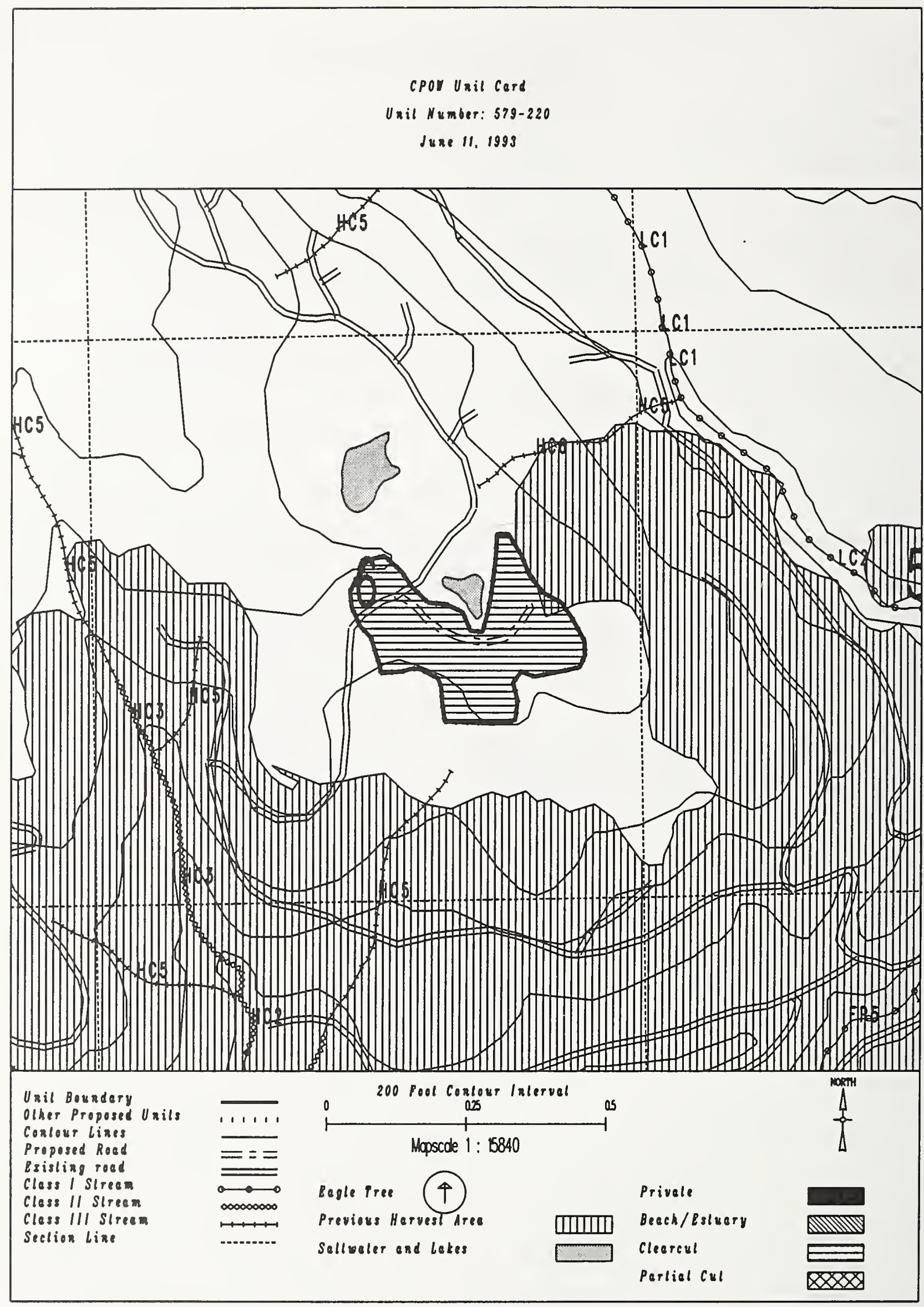


Unit $579-222$

Planned acres 37

Estimated volume (mbf)

Logging system Highlead

silvicultural system clearcut

Forest type Hemlock

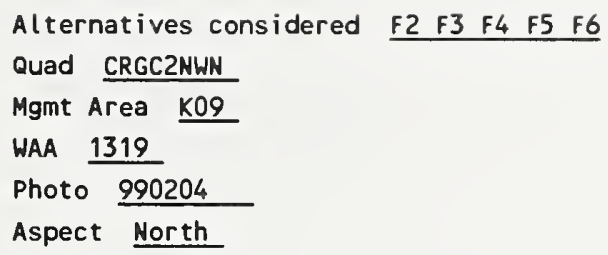

PHYSICAL DESCRIPTION

Volume class breakdown: VC4 23 acres vC5 10 acres vc6 $\quad 0$ acres vc7 0 acres

Elevation breakdown: $0-800 \mathrm{ft} . \underline{22}$ acres $800-1200 \mathrm{ft} . \underline{13}$ acres $1200-1500 \mathrm{ft} . \underline{0}$ acres over $1500 \mathrm{ft} . \underline{0}$ acres Mass movement index: Low $\underline{0}$ acres Medium $\underline{20}$ acres High 16 acres Very High 0 acres

SOILS

This unit has high mass movement index soils. Partial log suspension required over these areas.(BMP13.9)

TIMBER

There are no timber mitigation measures anticipated for this unit.

ENGINEER ING

High mass movement index soils. Road construction must minimize landslide potential (BMP14).

\section{FISH/WATERSHED}

There are no fishery mitigation measures anticipated for this unit.

\section{WILDLIFE}

Maintain adequate distribution of snags by leaving 0.1 acre-sized patches of green trees within the unit for every 10 acres harvested. Snag patches must be compatible with logging system and safe working conditions.

\section{RECREATION / VISUALS}

This unit has a proposed VQO of MM and is not seen from any viewpoint identified by this project.

\section{LANDS}

There are no lands mitigation measures anticipated for this unit.

CULTURAL RESOURCES

There are no cultural resource mitigation measures anticipated for this unit.

\section{GEOLOGY}

There are no karst mitigation measures anticipated for this unit. 


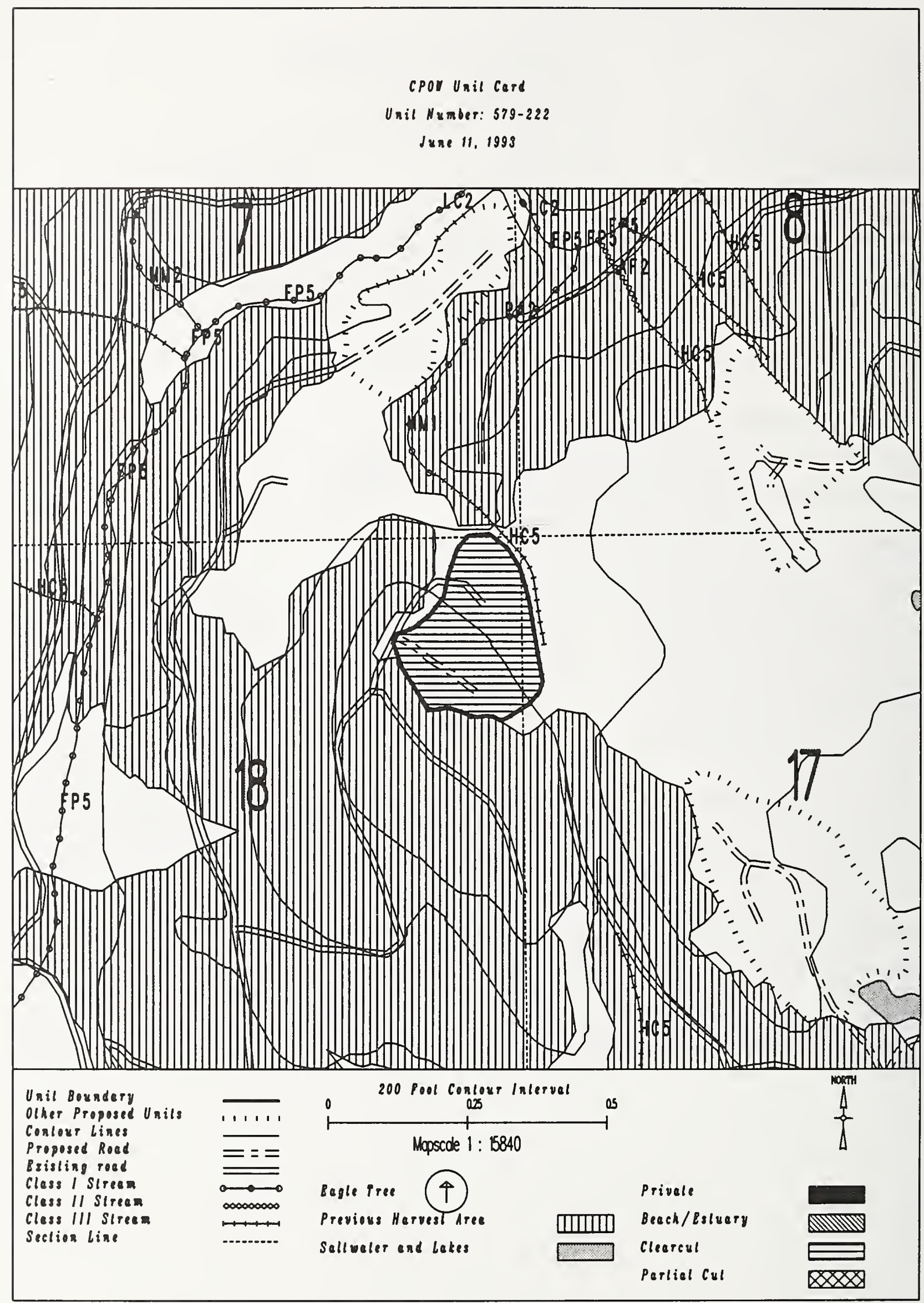


UNIT PLAN/LAYOUT/SALE ADMINISTRATION CARD FOR CPOW FEIS

Unit

Planned acres 32

Estimated volume (mbf) 711

Logging system Highlead

silvicultural system clearcut

Forest type Hemlock
Alternatives considered F2 F3 $F 4$ F5 F6

Quad CRGC2NWW

Mgmt Area $\mathrm{KO9}$

WAA 1319

Photo 990203

Aspect South

PHYSICAL DESCRIPTION

Volume class breakdown: VC4 13 acres VC5 13 acres VC6 $\quad 0$ acres vC7 $\quad 0$ acres

Elevation breakdown: $0-800 \mathrm{ft} . \underline{31}$ acres $800-1200 \mathrm{ft} . \quad 0$ acres $1200-1500 \mathrm{ft}$. 0 acres over $1500 \mathrm{ft}$. 0 acres Mass movement index: Low 5 acres Medium 18 acres High 8 acres Very High 0

\section{SOILS}

This unit has high mass movement index soils. Partial log suspension required over these areas. (BMP13.9)

This unit contains 21 acres of forested wetlands. Site specific BMPs will be designed for selected approved

logging system and road construction practices. (BMPs 12.5, 13.9, 13.15).

\section{TIMBER}

There are no timber mitigation measures anticipated for this unit.

\section{ENGINEERING}

High mass movement index soils. Road construction must minimize landslide potential (BMP14).

\section{FISH/WATER SHED}

Potential for additional Class I/II streams within unit. May be necessary to place additional buffers within unit in accordance with AHMU Handbook.

Proposed stream buffers may need to be modified to meet AHMU Handbook standards.

\section{WILDL IFE}

Maintain adequate distribution of snags by leaving 0.1 acre-sized patches of green trees within the unit for every 10 acres harvested. Snag patches must be compatible with logging system and safe working conditions.

\section{RECREATION / VISUALS}

This unit has a proposed VQO of MM and is not seen from any viewpoint identified by this project.

\section{LANDS}

There are no lands mitigation measures anticipated for this unit.

CULTURAL RESOURCES

There are no cultural resource mitigation measures anticipated for this unit. 


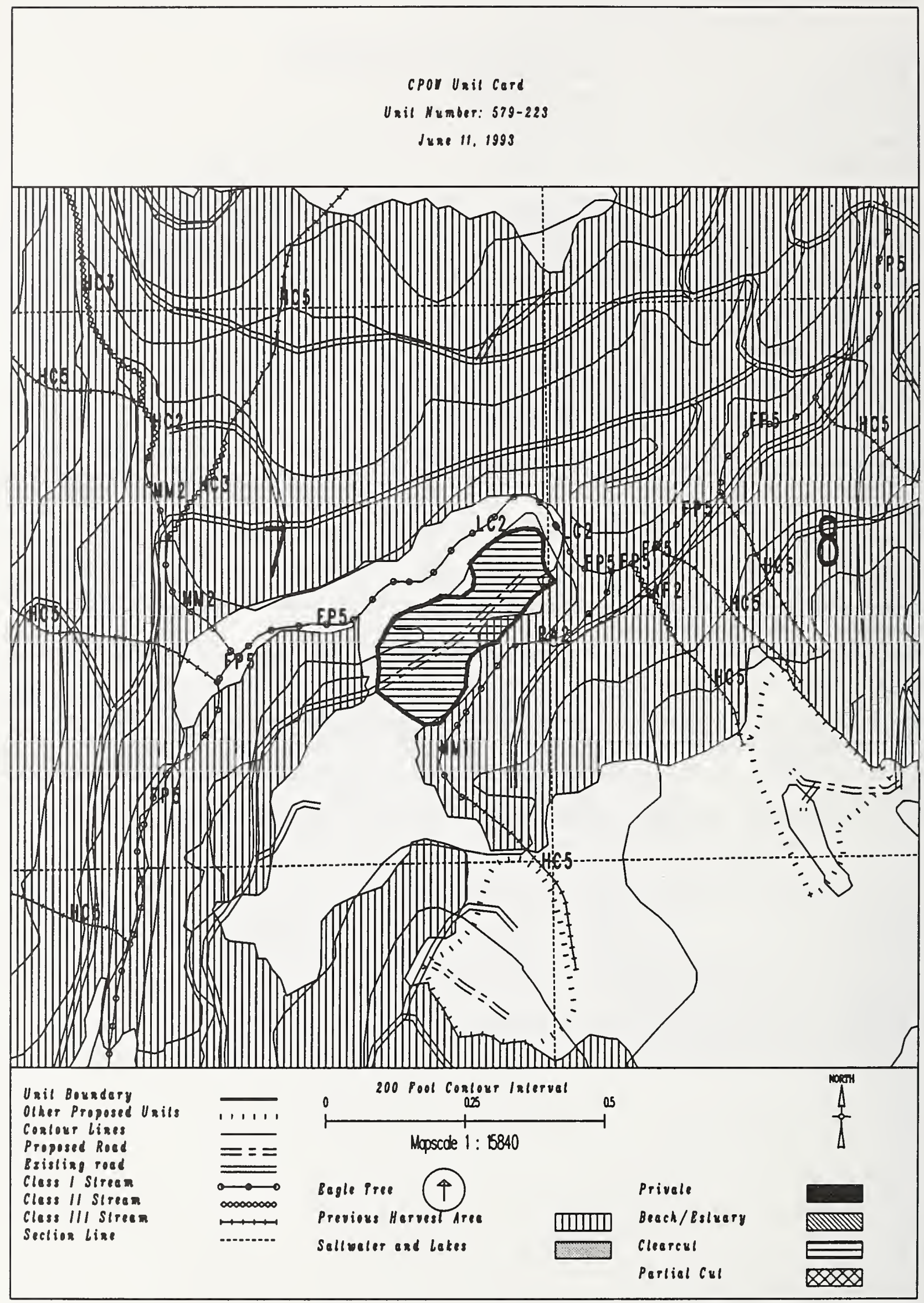




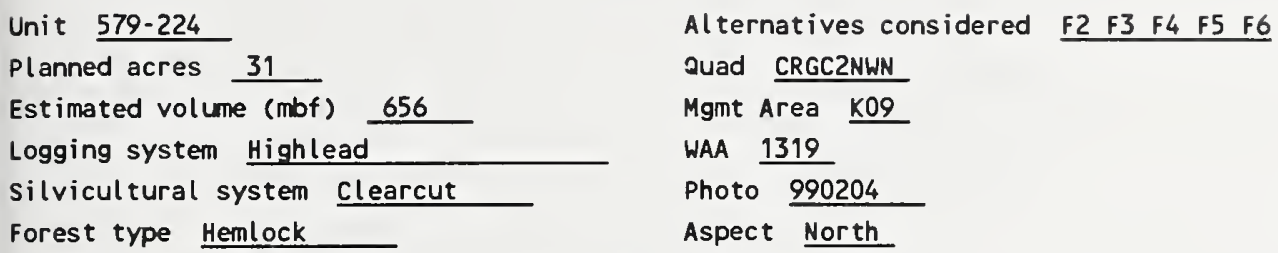

There are no cultural resource mitigation measures anticipated for this unit. 


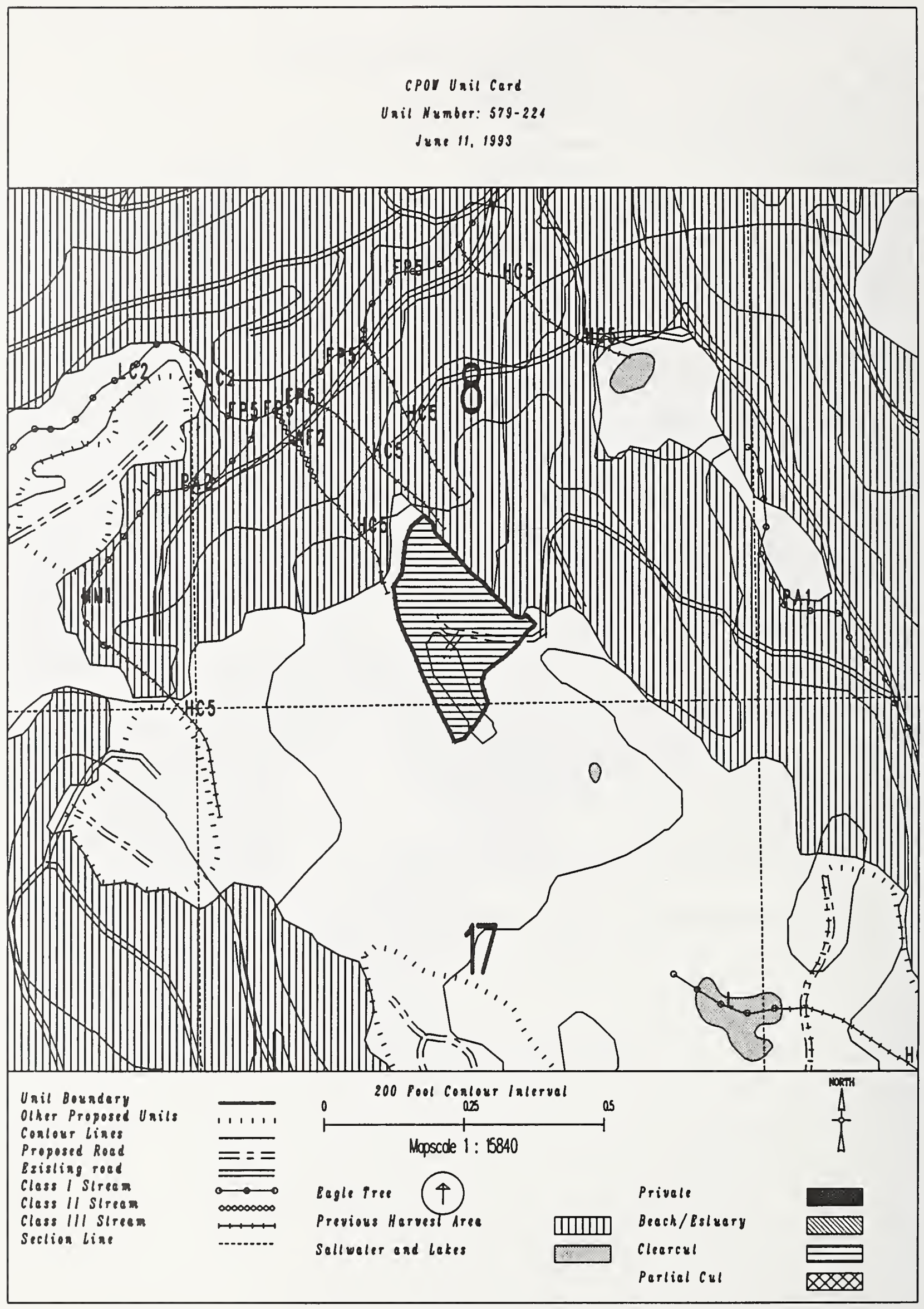


Unit $579-229$

Planned acres 45

Estimated volume (mbf) 1620

Logging system skyline

silvicultural system clearcut

Forest type Mixed conifer

\author{
Alternatives considered F2 F3 F4 F5 F6 \\ Quad CRGO2SUS \\ Mgmt Area K09 \\ WAA 1422 \\ Photo 1090084 \\ Aspect North
}

\section{PHYSICAL DESCRIPTION}

Volume class breakdown: VC4 1 acres VC5 $\quad 0$ acres vC6 42 acres vc7 $\quad 0$ acres

Elevation breakdown: $0-800 \mathrm{ft} . \underline{6}$ acres $800-1200 \mathrm{ft} . \underline{15}$ acres $1200-1500 \mathrm{ft} . \underline{6}$ acres over $1500 \mathrm{ft}$. 0 acres Mass movement index: Low 3 acres Medium 0 acres High 40 acres Very High 0 acres

\section{SOILS}

This unit has high mass movement index soils. Partial log suspension required over these areas.(BMP13.9)

This unit has a significant possibility to have areas reclassified as MMI $=4$.

This unit contains 15 acres of forested wetlands. Site specific BMPs will be designed for selected approved logging system and road construction practices. (BMPs 12.5, 13.9, 13.15).

This unit contains 7 acres of slopes $>75 \%$.

\section{TIMBER}

There are no timber mitigation measures anticipated for this unit.

\section{ENG INEER ING}

Very difficult road construction due to unstable, slope > $75 \%$ or extended steep grades.

May need to revise logging system to helicopter.

High mass movement index soils. Road construction must minimize landslide potential (BMP14).

Slopes greater than $75 \%$ may require full bench construction and endhaul of waste (BMP14.7).

\section{FISH/WATERSHED}

Potentiol impact on significant fishery habitat. May be necessary to expand planned buffer in accordance with AHMU Handbook.

HILOLIFE

There are no wildlife mitigation measures anticipated for this unit.

\section{RECREATION / VISUALS}

The unit has a proposed voo of $M$ within the viewshed of Sal Creek as viewed from ferry/cruise ship route (2-4 miles off shore).

\section{LANDS}

There are no lands mitigation measures anticipated for this unit.

\section{CULTURAL RESOURCES}

There are no cultural resource mitigation measures anticipated for this unit.

GEOLOGY

There are no karst mitigation measures anticipated for this unit. 


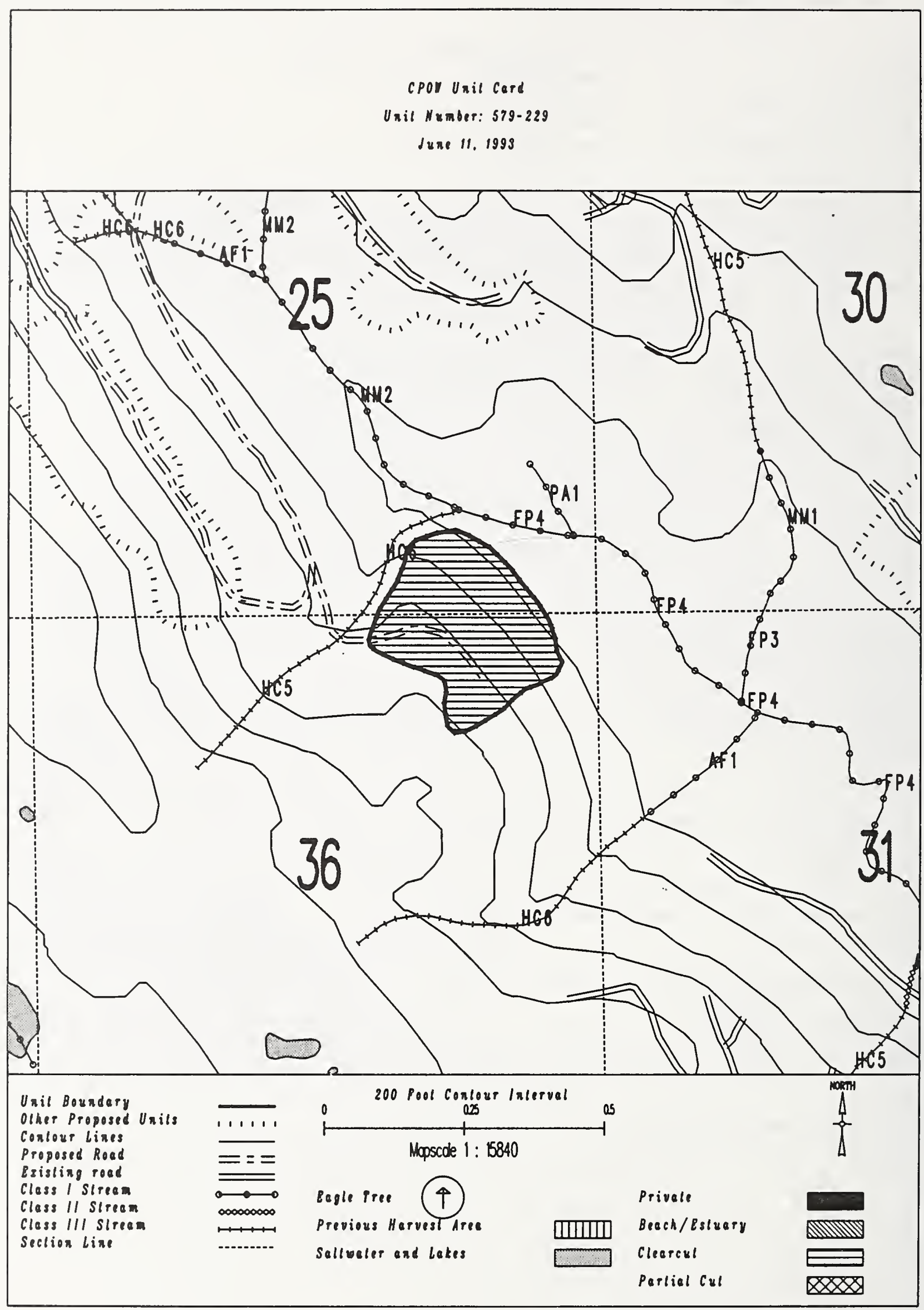


Unit $580-200$

Planned acres 20

Estimated volume (mbf) 420

Logging system Helicopter

silvicultural system Shelterwood

Forest type Mixed conifer
Alternatives considered $\mathrm{F2}$

Quad CRGD2SWS

Mgmt Area K09

WAA 1319

Photo 690044

Aspect Hest

PHYSICAL DESCRIPTION

Volume class breakdown: VC4 10 acres VC5 $\quad 0$ acres VC6 10 acres vC7 0 acres

Elevation breakdown: $0-800 \mathrm{ft} . \quad 0$ acres $800-1200 \mathrm{ft} . \underline{2}$ acres 1200-1500 ft. 1 acres over $1500 \mathrm{ft}$. 7 acres Mass movement index: Low $\_$acres Medium 2 acres High 14 acres Very High 0 acres

SOILS

This unit has high mass movement index soils. Partial log suspension required over these areas.(BMP13.9)

This unit has a significant possibility to have areas reclassified as MMI $=4$.

This unit contains 10 acres of slopes > $75 \%$.

\section{TIMBER}

Shelterwood harvest. Cedar will not be harvested.

ENGINEER ING

There are no engineering mitigation measures anticipated for this unit.

FISH/WATERSHED

There are no fishery mitigation measures anticipated for this unit.

HILDL I FE

There are no wildlife mitigation measures anticipated for this unit.

RECREATION / VISUALS

This unit has a proposed VQO of MM and is not seen from any viewpoint identified by this project.

LANDS

There are no lands mitigation measures anticipated for this unit.

CULTURAL RESOURCES

There are no cultural resource mitigation measures anticipated for this unit. 


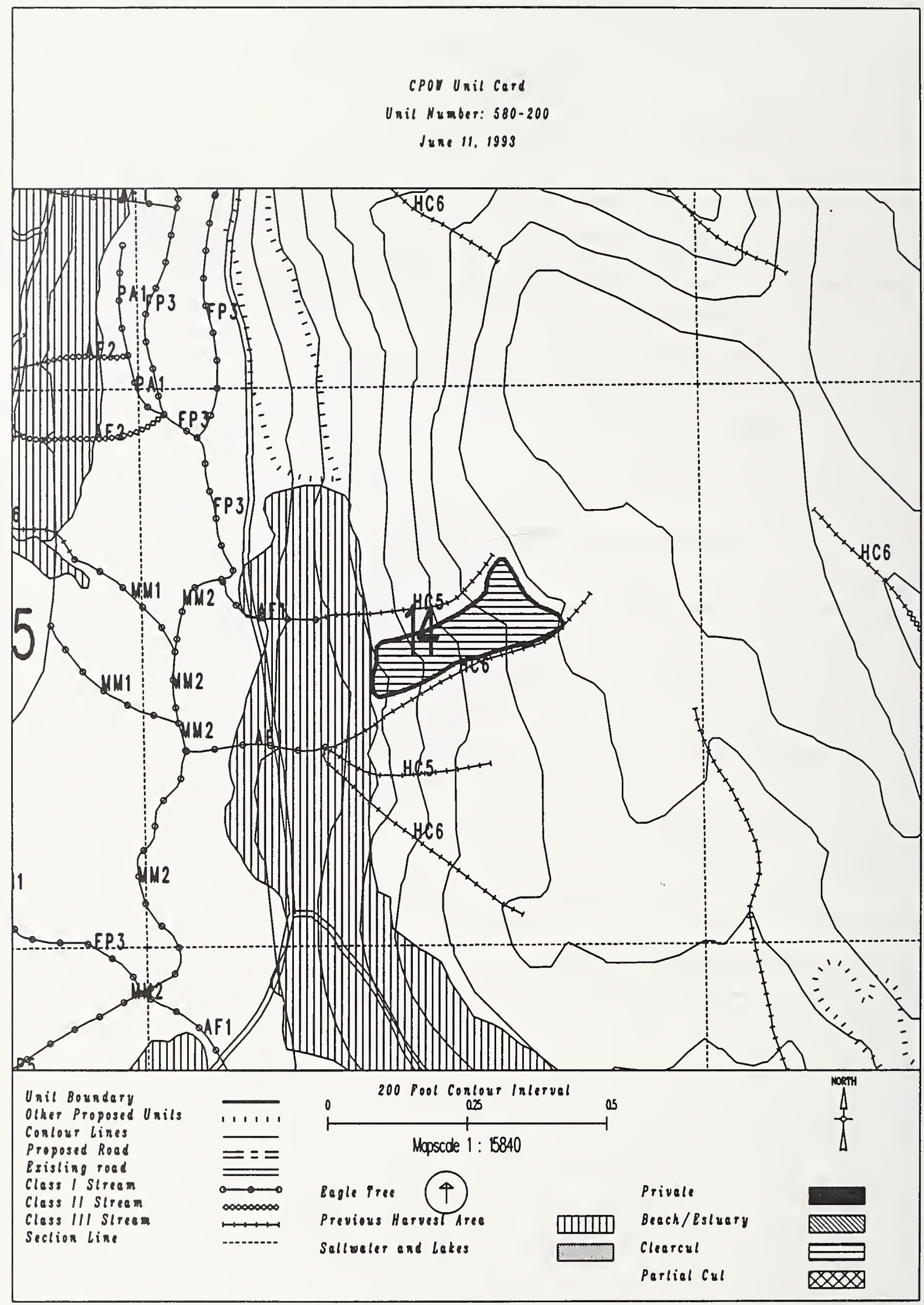


Unit 580-201

Planned acres 37

Estimated volume (mbf) 744

Logging system Hel icopter

silvicultural system clearcut

Forest type Hemlock
Alternatives considered

Quad CRGD2SWS

Mgmt Area $\mathrm{KO9}$

WAA 1319

Photo 1090087

Aspect West

PHYSICAL DESCRIPTION

Volume class breakdown: VC4 34 acres VC5 $\quad 0$ acres VC6 $\quad 0$ acres VC7 0 acres

Elevation breakdown: $0-800 \mathrm{ft}$. $\quad 0$ acres $800-1200 \mathrm{ft} . \ldots$ acres $1200-1500 \mathrm{ft}$. 0 acres over $1500 \mathrm{ft}$. 19 acres

Mass movement index: Low 31 acres Medium 0 acres High 4 acres Very High 0 acres

SOILS

This unit has high mass movement index soils. Partial log suspension required over these areas. (BMP13.9)

This unit contains 20 acres of forested wetlands. Site specific BMPs will be designed for selected approved

logging system and road construction practices. (BMPs 12.5, 13.9, 13.15).

TIMBER

There are no timber mitigation measures anticipated for this unit.

ENGINEER ING

There are no engineering mitigation measures anticipated for this unit.

FISH/WATERSHED

There are no fishery mitigation measures anticipated for this unit.

WILDL IFE

There are no wildlife mitigation measures anticipated for this unit.

RECREATION / VISUALS

This unit has a proposed VQO of MM and is not seen from any viewpoint identified by this project.

LANDS

There are no lands mitigation measures anticipated for this unit.

CULTURAL RESOURCES

There are no cultural resource mitigation measures anticipated for this unit.

GEOLOGY

There are no karst mitigation measures anticipated for this unit. 
CPOr Unil Cerd

Unil Number: $580-201$

June 11, 1993

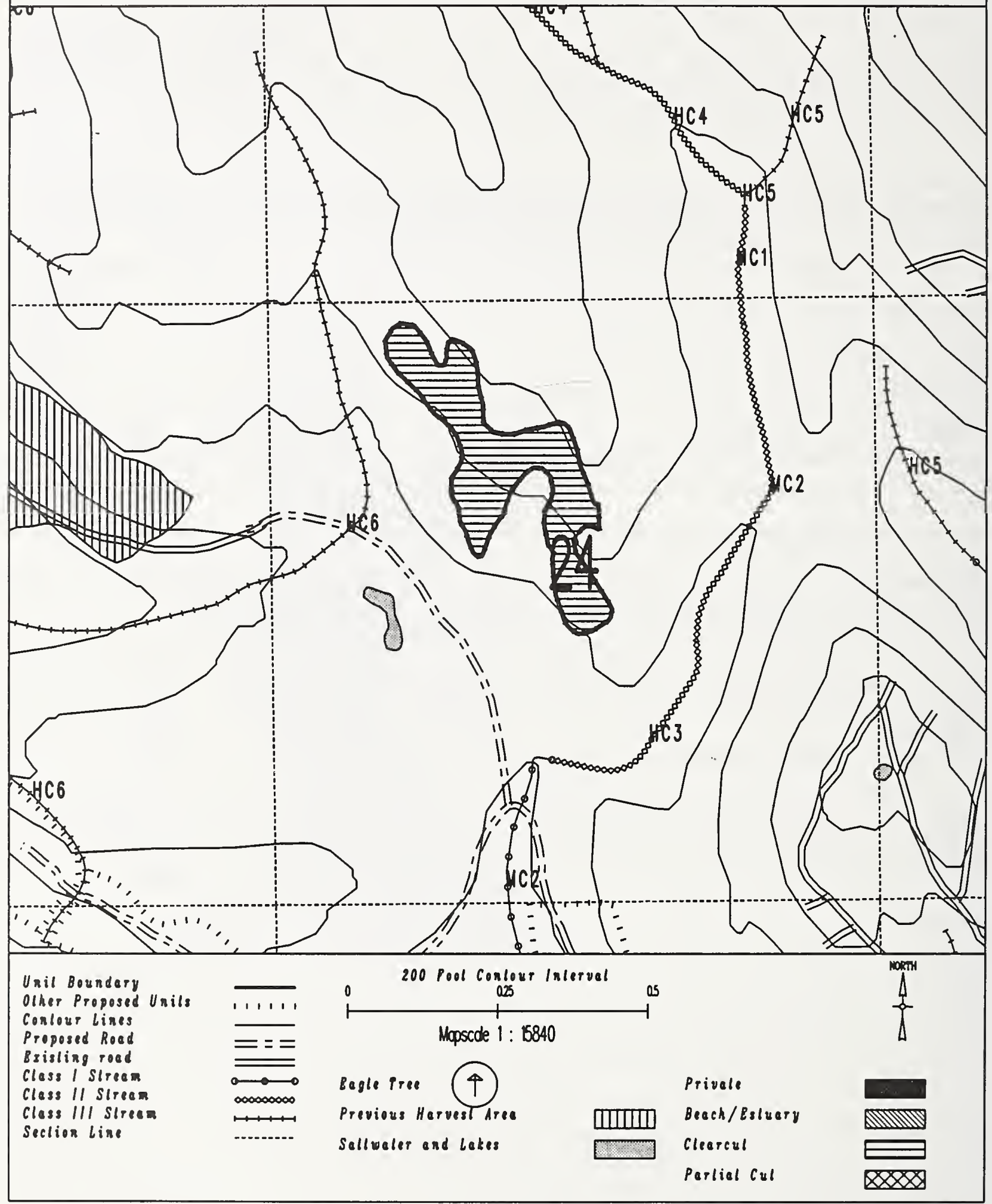


Unit 580-202

Planned acres 18

Estimated volume (mbf) 546

Logging system skyline

silvicultural system clearcut

Forest type Mixed conifer
Alternatives considered

Quad CRGD2SWS

Mgmt Area K09

WAA 1319

Photo 690041

Aspect North

PHYSICAL DESCRIPTION

Volume class breakdown: VC4 4 acres VC5 14 acres vC6 0 acres vc7 0 acres

Elevation breakdown: $0-800 \mathrm{ft}$. $\quad 0$ acres $800-1200 \mathrm{ft} . \quad 3$ acres $1200-1500 \mathrm{ft}$. 3 acres over $1500 \mathrm{ft}$. 0 acres Mass movement index: Low 0 acres Medium 0 acres High 17 acres Very High 0

SOILS

This unit has high mass movement index soils. Partial log suspension required over these areas. (BMP13.9)

This unit will be monitored for effects of harvest/roading on landslide-prone slopes.

TIMBER

There are no timber mitigation measures anticipated for this unit.

ENGINEER ING

Very difficult road construction due to unstable, slope $>75 \%$ or extended steep grades.

May need to revise logging system to helicopter.

High mass movement index soils. Road construction must minimize landslide potential (BMP14).

FISH/WATERSHED

There are no fishery mitigation measures anticipated for this unit.

WILDLIFE

Maintain diversity within unit by leaving 1-5 acre-sized islands of green trees at a rate of 1 acre of island for every 20 acres harvested. Leave islands must be compatible with logging system and safe working conditions.

RECREATION / VISUALS

This unit has a proposed VQO of MM and is not seen from any viewpoint identified by this project.

LANDS

There are no lands mitigation measures anticipated for this unit.

CULTURAL RESOURCES

There are no cultural resource mitigation measures anticipated for this unit.

GEOLOGY

There are no karst mitigation measures anticipated for this unit. 


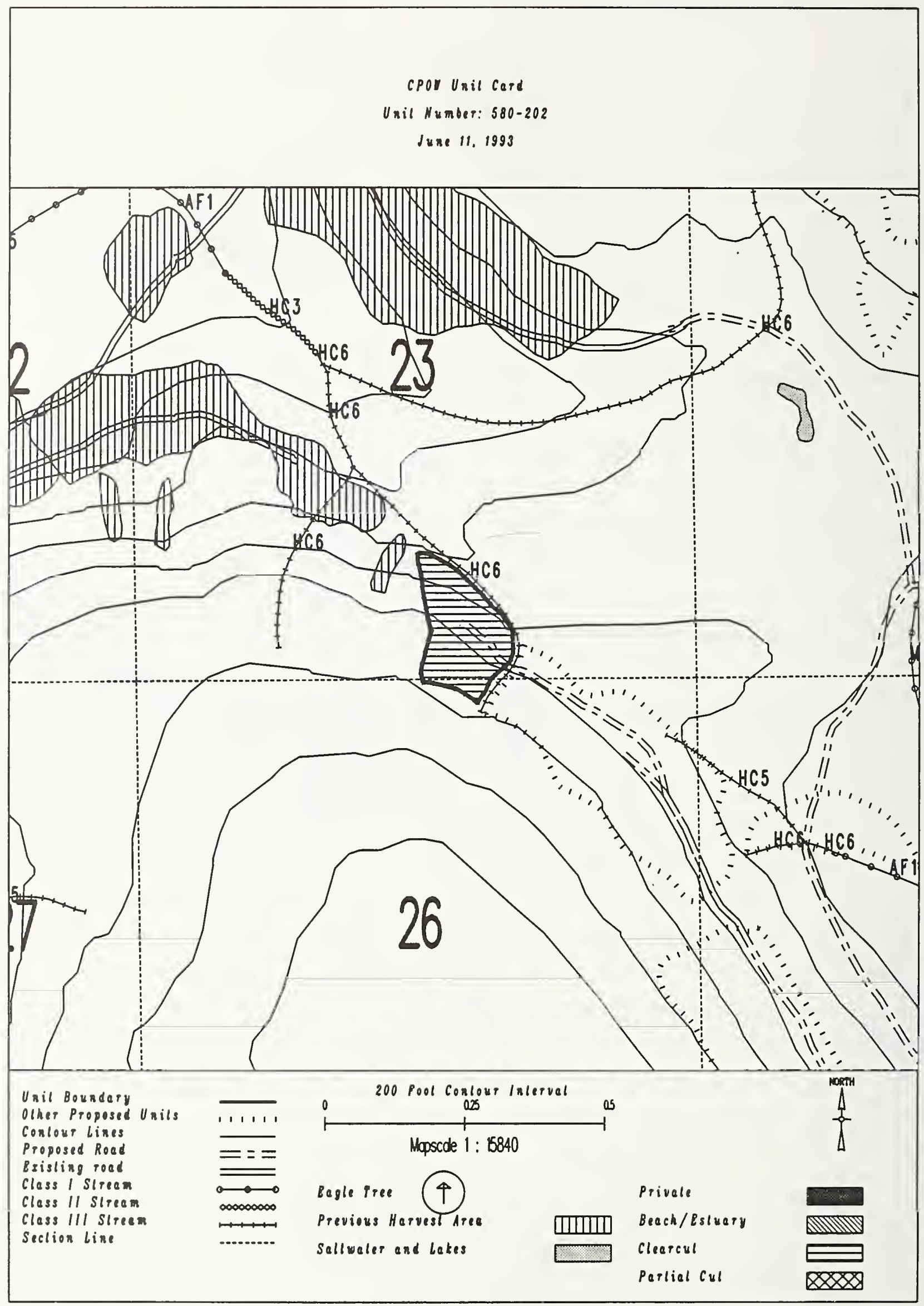


Unit $580-212$

Planned acres 47

Estimated volume (mbf) 1421

Logging system Helicopter

silvicultural system clearcut

Forest type Hemlock
Alternatives considered F2 F4 F5 F6

auad CRGD3SEN

Mgmt Area K09

WAA 1319

Photo 1090013

Aspect South

PHYSICAL DESCRIPTION

Volume class breakdown: VC4 17 acres VC5 32 acres vC6 0 acres vC7 $\quad 0$ acres

Elevation breakdown: $0-800 \mathrm{ft} . \quad 0$ acres $800-1200 \mathrm{ft} . \underline{0}$ acres $1200-1500 \mathrm{ft} . \underline{6}$ acres over $1500 \mathrm{ft}$. 17 acres Mass movement index: Low $\underline{0}$ acres Medium 0 acres High 48 acres Very High 0 acres

SOILS

This unit has high mass movement index soils. Partial log suspension required over these areas. (BMP13.9)

This unit contains $\underline{27}$ acres of forested wetlands. Site specific BMPs will be designed for selected approved

logging system and road construction practices. (BMPs 12.5, 13.9, 13.15).

This unit contains 48 acres of slopes $>75 \%$.

TIMBER

Potential regeneration problem. May need to consider other silvicultural prescriptions (or hand plant) to meet BMP13.19.

ENGINEER ING

There are no engineering mitigation measures anticipated for this unit.

\section{FISH/WATERSHED}

This unit contains streams which have recently been classified/channel typed but require field verification.

\section{WILDLIFE}

Maintain diversity within unit by leaving 1-5 acre-sized islands of green trees at a rate of 1 acre of island for every 20 acres harvested. Leave islands must be compatible with logging system and safe working conditions.

RECREATION / VISUALS

This unit has a proposed VQO of MM and is not seen from any viewpoint identified by this project.

\section{LANDS}

There are no lands mitigation measures anticipated for this unit.

CULTURAL RESOURCES

There are no cultural resource mitigation measures anticipated for this unit.

There are no karst mitigation measures anticipated for this unit. 


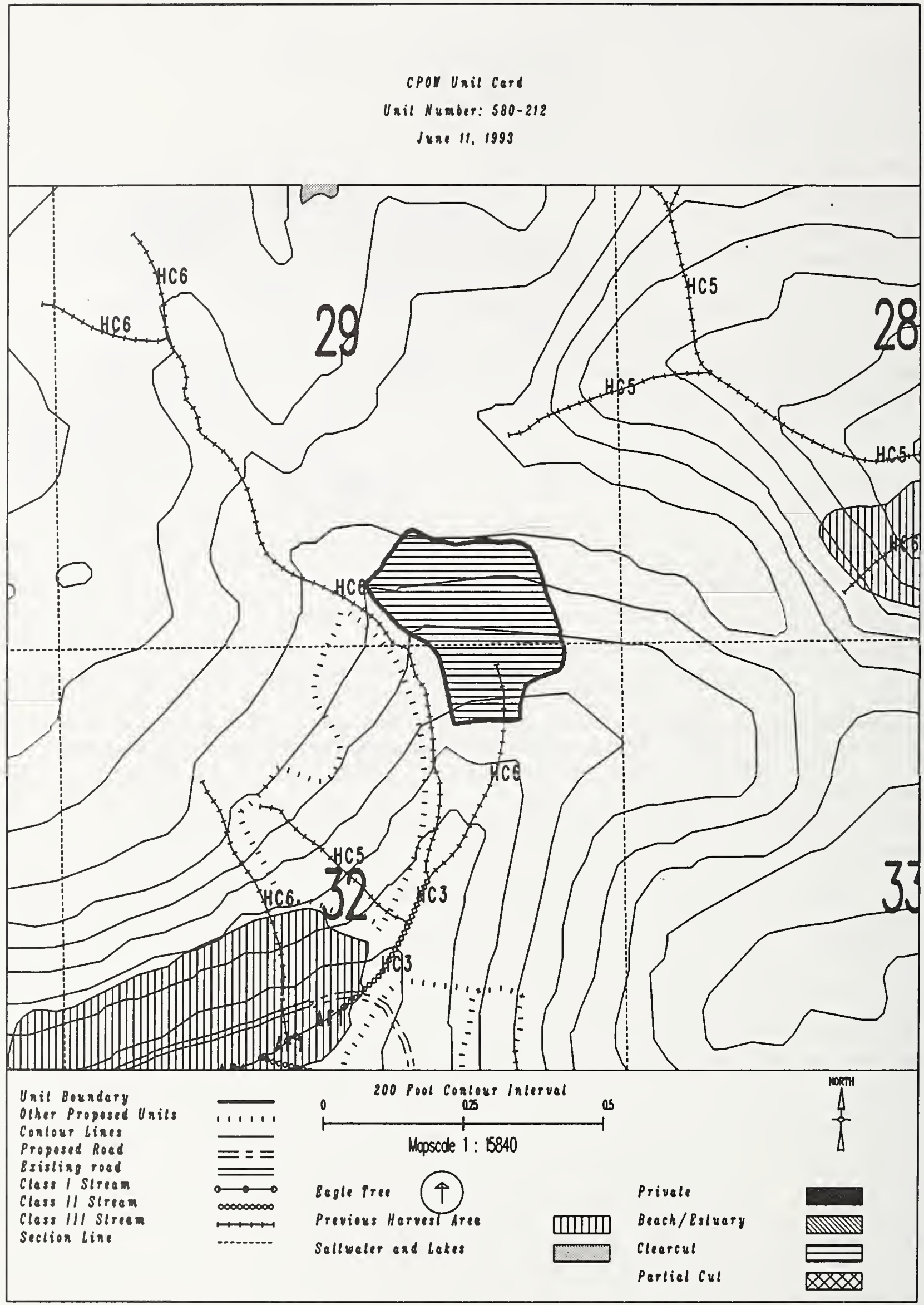


Unit $580-213$

Planned acres 63

Estimated volume (mbf) 2065

Logging system Helicopter

silvicultural system clearcut

Forest type Hemlock
Alternatives considered F2 $\quad$ F4 F5 $\quad$ F6

Quad CRGD3SEN

Mgmt Area K09

WAA 1319

Photo 1090013

Aspect East

\section{PHYSICAL DESCRIPTION}

Volume class breakdown: VC4 9 acres VC5 57 acres vC6 0 acres VC7 0 acres

Elevation breakdown: $0-800 \mathrm{ft} . \quad 7$ acres $800-1200 \mathrm{ft} .12$ acres $1200-1500 \mathrm{ft} .2 \frac{2}{2}$ acres over $1500 \mathrm{ft}$. 4 acres Mass movement index: Low 2 acres Medium 0 acres High 64 acres Very High 0

\section{SOILS}

This unit has high mass movement index soils. Partial log suspension required over these areas.(BMP13.9)

This unit contains 17 acres of forested wetlands. Site specific BMPs will be designed for selected approved

logging system and road construction practices. (BMPs 12.5, 13.9, 13.15).

This unit contains 32 acres of slopes > $75 \%$.

\section{TIMBER}

There are no timber mitigation measures anticipated for this unit.

\section{ENGINEER ING}

There are no engineering mitigation measures anticipated for this unit.

\section{FISH/WATERSHED}

This unit contains a $\underline{A} 4$ class $\underline{3}$ stream. No specific buffer required, but full suspension, if yarding across.

WILDLIFE

Maintain diversity within unit by leaving $1-5$ acre-sized islands of green trees at a rate of 1 acre of island for every 20 acres harvested. Leave islands must be compatible with logging system and safe working conditions.

\section{RECREATION / VISUALS}

This unit has a proposed VQO of MM and is not seen from any viewpoint identified by this project.

\section{LANDS}

There are no lands mitigation measures anticipated for this unit.

CULTURAL RESOURCES

There are no cultural resource mitigation measures anticipated for this unit. 


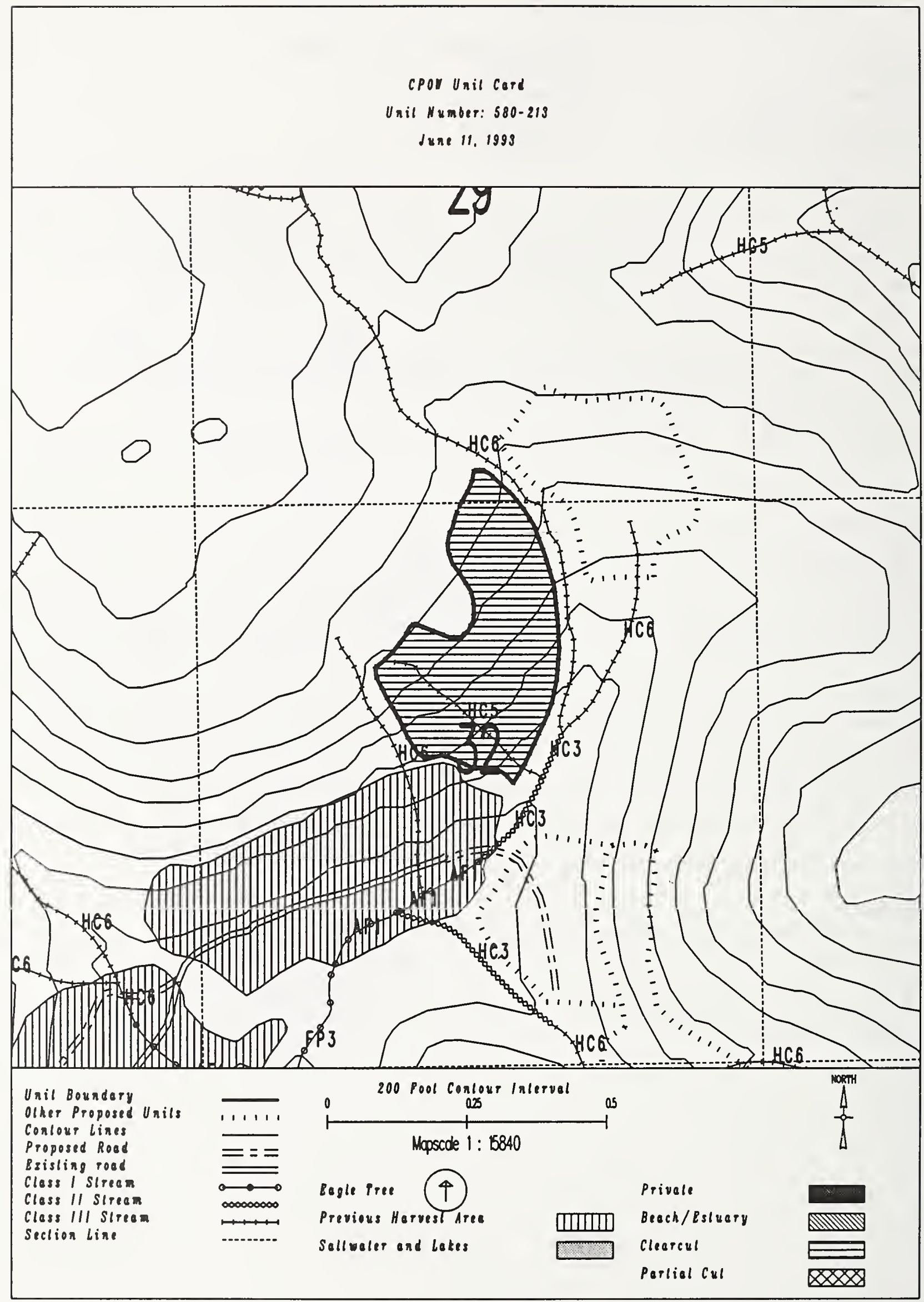


Unit

Planned acres 74

Estimated volume (mbf) 1586

Logging system Helicopter

silvicultural system clearcut

Forest type Hemlock
Alternatives considered F2 F4 F5

Quad CRGD3SEN

Mgmt Area $\mathrm{KO9}$

WAA 1319

Photo 1090114

Aspect South

\section{PHYSICAL DESCRIPTION}

Volume class breakdown: VC4 56 acres VC5 11 acres vC6 $\quad 0$ acres vC7 $\quad 0$ acres

Elevation breakdown: $0-800 \mathrm{ft} . \underline{0}$ acres $800-1200 \mathrm{ft} . \underline{17}$ acres 1200-1500 ft. 16 acres over $1500 \mathrm{ft}$. 1 acres Mass movement index: Low $\underline{22}$ acres Medium $\underline{3}$ acres High $\underline{42}$ acres Very High 0 acres

\section{SOILS}

This unit has high mass movement index soils. Partial log suspension required over these areas. (BMP13.9)

This unit contains 42 acres of forested wetlands. Site specific BMPs will be designed for selected approved

logging system and road construction practices. (BMPs 12.5, 13.9, 13.15).

This unit contains 28 acres of slopes > $75 \%$.

This unit will be monitored for effects of harvest/roading on landslide-prone slopes.

\section{TIMBER}

There are no timber mitigation measures anticipated for this unit.

\section{ENGINEERING}

There are no engineering mitigation measures anticipated for this unit.

\section{FISH/WATERSHED}

This unit contains a $\underline{A 2}$ class $\underline{2}$ stream. Allow no harvest within 100 feet and full suspension, if yarding across.

\section{WILDLIFE}

Maintain diversity within unit by leaving 1-5 acre-sized islands of green trees at a rate of 1 acre of island for every 20 acres harvested. Leave islands must be compatible with logging system and safe working conditions.

\section{RECREATION / VISUALS}

This unit has a proposed Voo of MM and is not seen from any viewpoint identified by this project.

\section{LANDS}

There are no lands mitigation measures anticipated for this unit.

There are no cultural resource mitigation measures anticipated for this unit. 
cPor Unil Cord

Unil Number: $580-218$

June 11, 1993

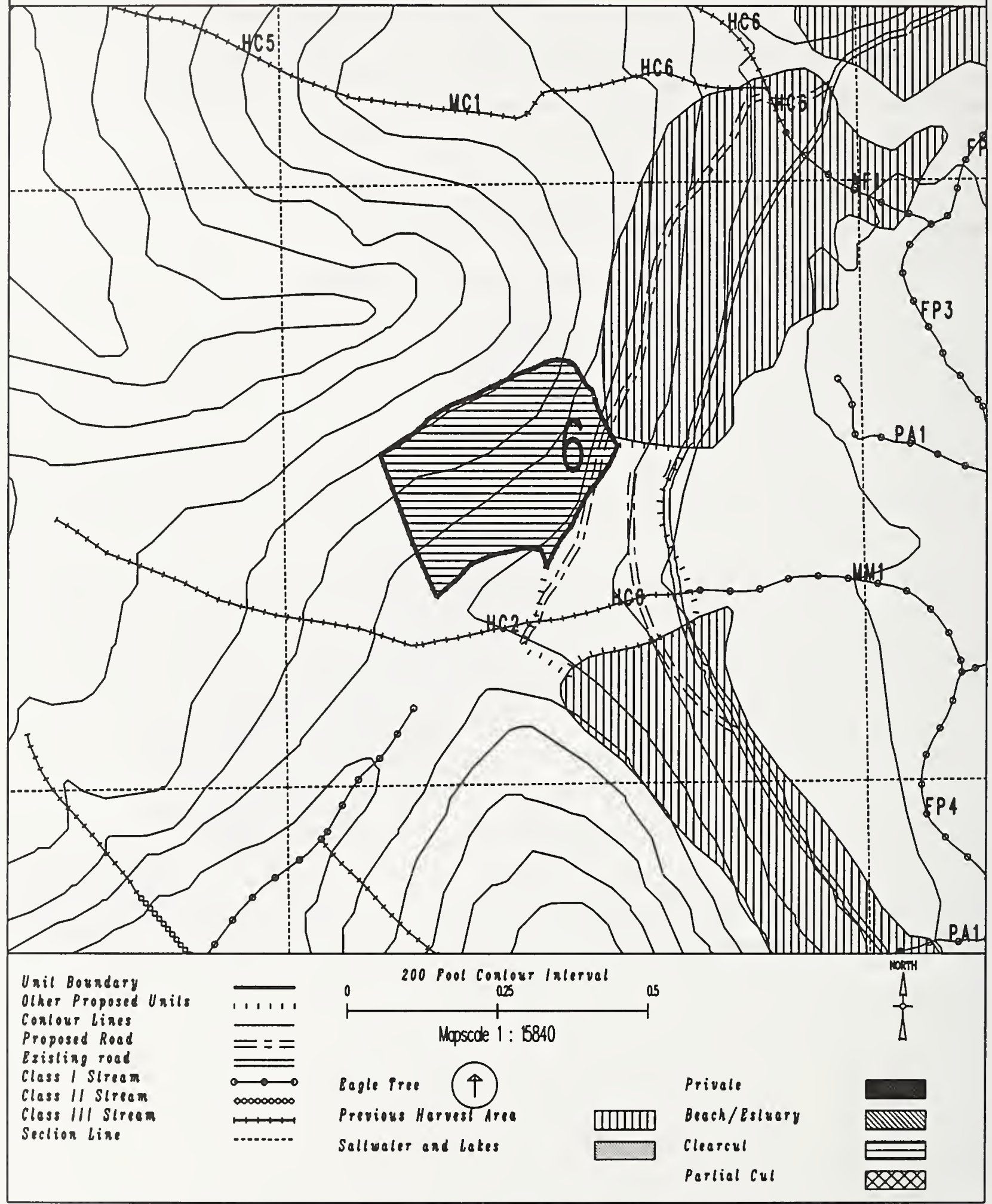


Unit 580-219

Planned acres 39

Estimated volume (mbf) 1137

Logging system skyline

silvicultural system clearcut

Forest type Hemlock
Alternatives considered F2 F3 F4 F5

Quad CRGD3SEN

Mgmt Area K09

WAA 1319

Photo 1090114

Aspect East

\section{PHYSICAL DESCRIPIION}

Volume class breakdown: vC4 19 acres vC5 22 acres vc6 $\quad 0$ acres vc7 $\quad 0$ acres

Elevation breakdown: $0-800 \mathrm{ft} .21$ acres $800-1200 \mathrm{ft} . \underline{15}$ acres $1200-1500 \mathrm{ft}$. 0 acres over $1500 \mathrm{ft}$. 0 acres Mass movement index: Low 0 acres Medium 26 acres High 6 acres Very High 0 acres

\section{SOILS}

This unit has high mass movement index soils. Partial log suspension required over these areas. (BMP13.9) This unit contains 34 acres of forested wetlands. Site specific BMPs will be designed for selected approved logging system and road construction practices. (BMPs 12.5, 13.9, 13.15).

\section{TIMBER}

There are no timber mitigation measures anticipated for this unit.

\section{ENGINEERING}

High mass movement index soils. Road construction must minimize landslide potential (BMP14).

\section{FISH/WATERSHED}

This unit contains a $\underline{A 1}$ class $\underline{3}$ stream. No specific buffer required, but full suspension, if yarding across.

\section{WI LDL I FE}

Maintain diversity within unit by leaving 1.5 acre-sized islands of green trees at a rate of 1 acre of island for every 20 acres harvested. Leave islands must be compatible with logging system and safe working conditions.

RECREATION / VISUALS

This unit has a proposed VQO of MM and is not seen from any viewpoint identified by this project.

\section{LANDS}

There are no lands mitigation measures anticipated for this unit.

CULTURAL RESOURCES

There are no cultural resource mitigation measures anticipated for this unit.

\section{GEOLOGY}

There are no karst mitigation measures anticipated for this unit. 


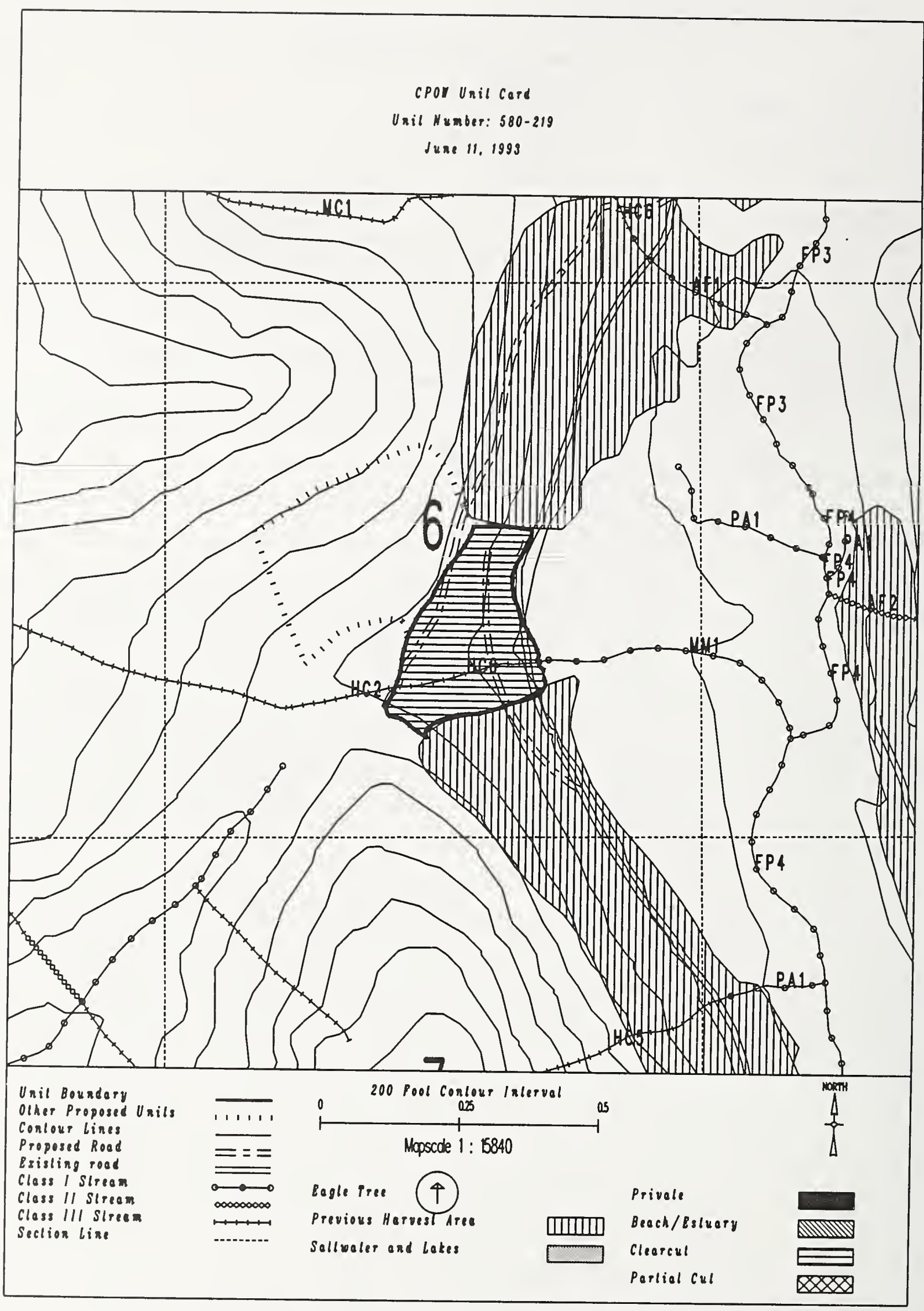




\section{Unit $\quad 580-221$}

Planned acres 61

Estimated volume (mbf) 2033

Logging system Helicopter

silvicultural system clearcut

Forest type Mixed conifer

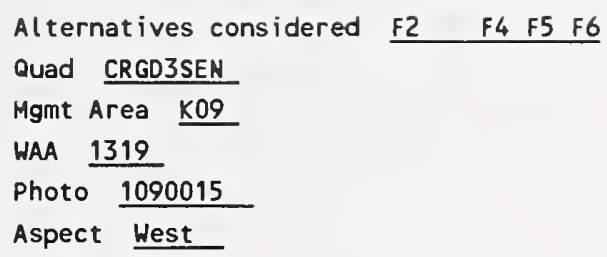

\section{PHYSICAL DESCRIPTION}

Volume class breakdown: VC4 $\quad 6$ acres VC5 58 acres VC6 $\quad 0$ acres VC7 $\quad 0$ acres

Elevation breakdown: $0-800 \mathrm{ft} . \underline{0}$ acres $800-1200 \mathrm{ft} . \underline{20}$ acres $1200-1500 \mathrm{ft} . \underline{7}$ acres over $1500 \mathrm{ft}$. 3 acres Mass movement index: Low $\_$acres Medium 0 acres High 64 acres Very High 0 acres

\section{SOILS}

This unit has high mass movement index soils. Partial log suspension required over these areas. (BMP13.9)

This unit contains 7 acres of slopes $>75 \%$.

\section{TIMBER}

There are no timber mitigation measures anticipated for this unit.

\section{ENGINEER ING}

There are no engineering mitigation measures anticipated for this unit.

\section{FISH/WATERSHED}

This unit contains a $\underline{A} 1$ class $\underline{3}$ stream. No specific buffer required, but full suspension, if yarding across.

\section{WILDL IFE}

There are no wildlife mitigation measures anticipated for this unit.

\section{RECREATION / VISUALS}

This unit has a proposed Vao of MM and is not seen from any viewpoint identified by this project.

\section{LANDS}

There are no lands mitigation measures anticipated for this unit.

\section{CULTURAL RESOURCES}

There are no cultural resource mitigation measures anticipated for this unit. 


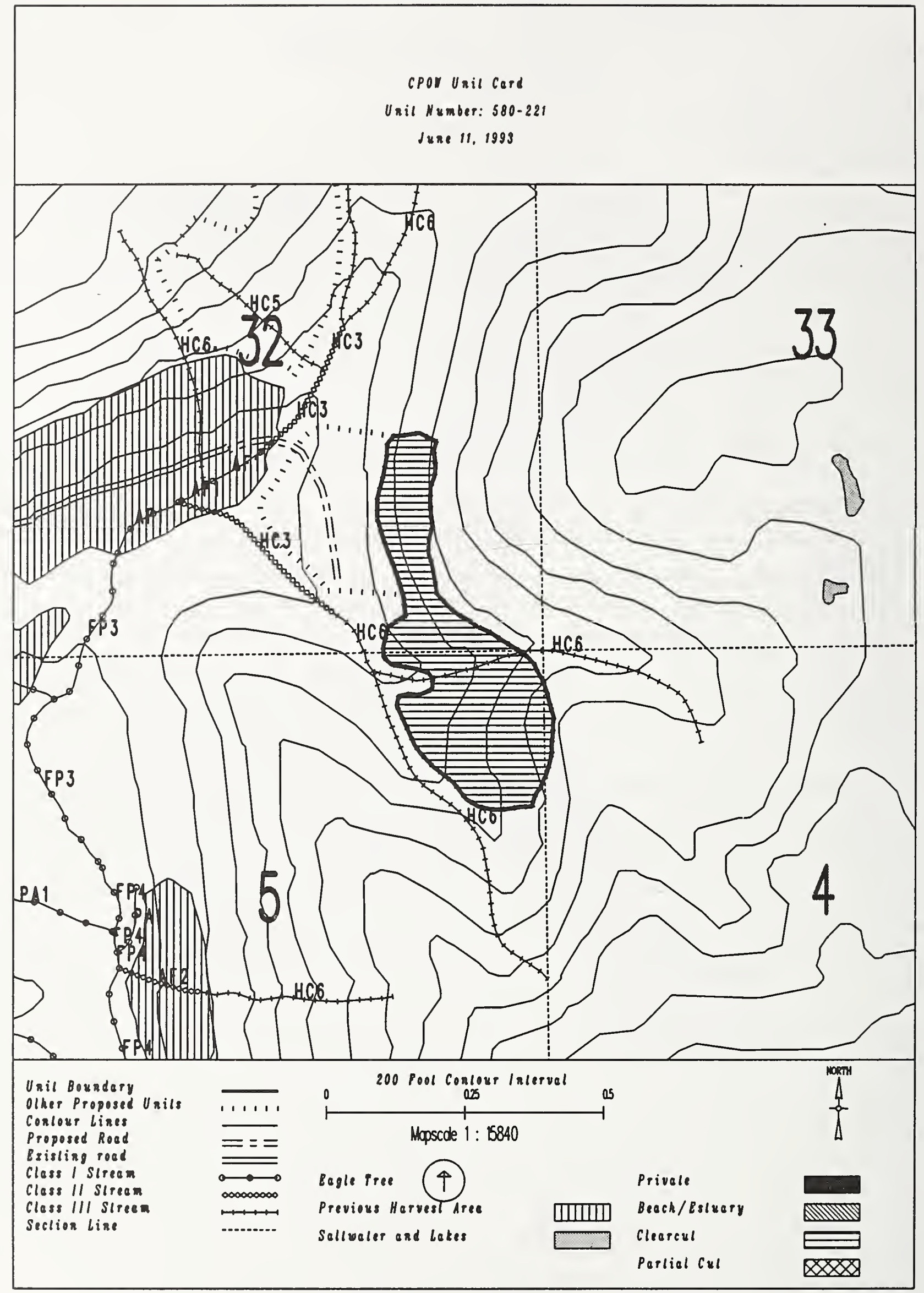


Unit 580-227

Planned acres 56

Estimated volume (mbf) 1908

Logging system skyline

silvicultural system Clearcut

Forest type Mixed conifer
Al ternatives considered

Quad CRGD3SES

Mgmt Area K09

WAA 1319

Photo 1090018

Aspect East

\section{PHYSICAL DESCRIPTION}

Volume class breakdown: VC4 $\quad 0$ acres VC5 $\underline{35}$ acres vC6 $\underline{20}$ acres vc7 $\quad 0$ acres

Elevation breakdown: $0-800 \mathrm{ft} . \underline{53}$ acres $800-1200 \mathrm{ft} . \quad 0$ acres $1200-1500 \mathrm{ft} . \underline{0}$ acres over $1500 \mathrm{ft}$. 0 Mass movement index: Low 0 acres Medium 34 acres High 17 acres Very High 0 acres

\section{SOILS}

This unit has high mass movement index soils. Partial log suspension required over these areas. (BMP13.9)

This unit has a significant possibility to have areas reclassified as MMI $=4$.

This unit contains $\underline{42}$ acres of forested wetlands. Site specific BMPs will be designed for selected approved

logging system and road construction practices. (BMPs 12.5, 13.9, 13.15).

This unit contains 14 acres of slopes $>75 \%$.

\section{TIMBER}

Potential for shovel logging on 15 acres, if soil and water quality protected (BMP13.7)

\section{ENG INEER ING}

High mass movement index soils. Road construction must minimize landslide potential (BMP14).

Slopes greater than $75 \%$ may require full bench construction and endhaul of waste (BMP14.7).

\section{FISH/WATERSHED}

Potential for additional Class I/II streams within unit. May be necessary to place additional buffers within unit in accordance with AHMU Handbook.

This unit contains a $\underline{A} 4$ class $\underline{3}$ stream. No specific buffer required, but full suspension, if yarding across.

\section{WILDLIFE}

Maintain diversity within unit by leaving 1-5 acre-sized islands of green trees at a rate of 1 acre of island for every 20 acres harvested. Leave islands must be compatible with logging system and safe working conditions.

\section{RECREATION / VISUALS}

This unit has a proposed VQO of MM and is not seen from any viewpoint identified by this project.

\section{LANDS}

There are no lands mitigation measures anticipated for this unit.

CULTURAL RESOURCES

There are no cultural resource mitigation measures anticipated for this unit.

GEOLOGY

There are no karst mitigation measures anticipated for this unit. 


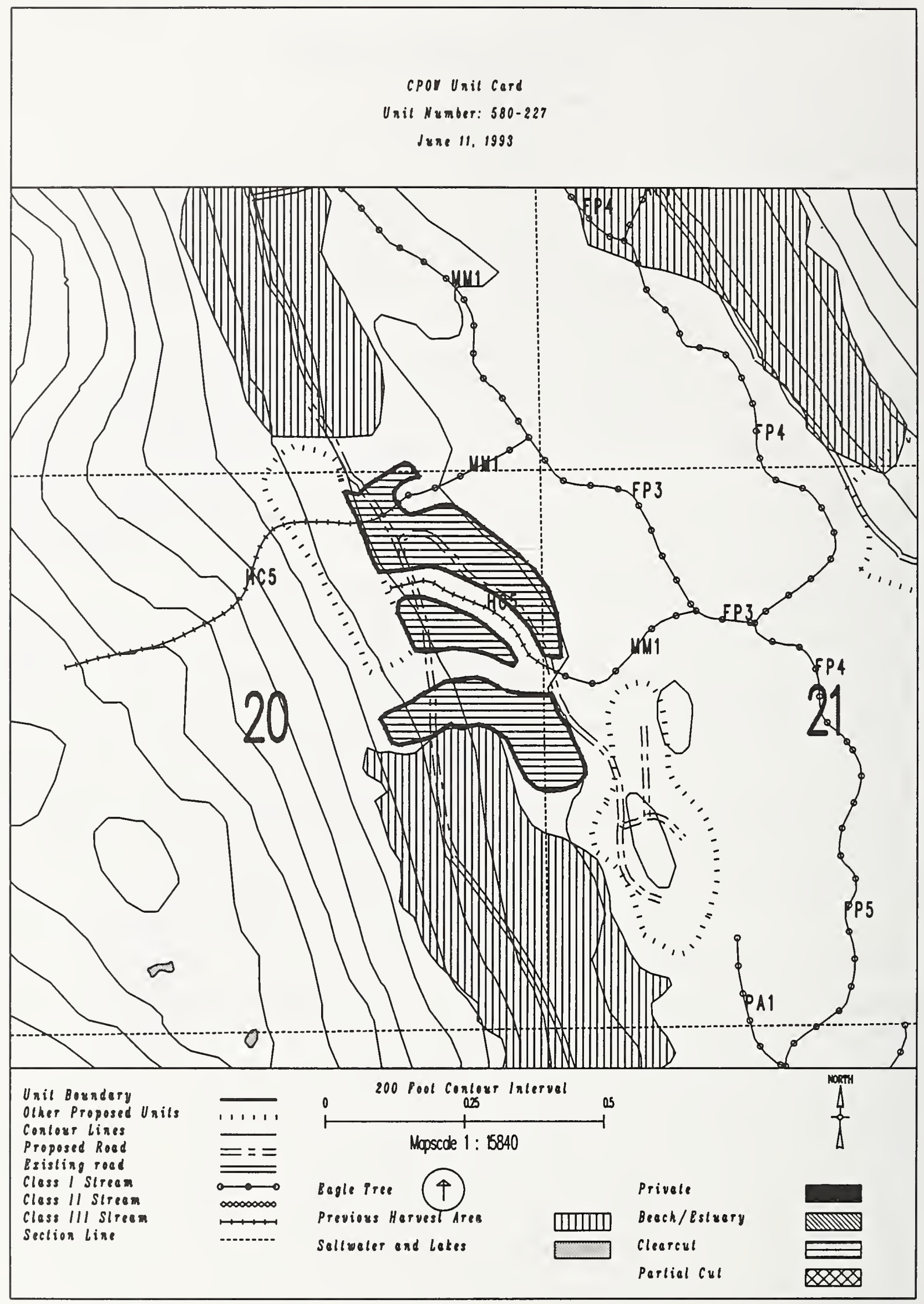


Unit $580-227 \quad B$

Planned acres 27

Estimated volume (mbf) 1066

Logging system skyline

silvicultural system clearcut

Forest type Mixed conifer
Alternatives considered

Quad CRGD3SES

Mgmt Area K09

WAA 1422

Photo

Aspect East

PHYSICAL DESCRIPTION

Volume class breakdown: VC4 $\quad 0$ acres VC5 $\quad 0$ acres VC6 28 acres vC7 $\quad 0$ acres

Elevation breakdown: $0-800 \mathrm{ft} . \underline{22}$ acres $800-1200 \mathrm{ft} . \underline{1}$ acres $1200-1500 \mathrm{ft} . \underline{0}$ acres over $1500 \mathrm{ft}$. 0 acres Mass movement index: Low 0 acres Medium $\underline{0}$ acres High 27 acres Very High 0

SOILS

This unit has high mass movement index soils. Partial log suspension required over these areas. (BMP13.9)

This unit contains 26 acres of slopes > $75 \%$.

TIMBER

There are no timber mitigation measures anticipated for this unit.

ENGINEERING

High mass movement index soils. Road construction must minimize landslide potential (BMP14).

Slopes greater than $75 \%$ may require full bench construction and endhaul of waste (BMP14.7).

FISH/HATERSHED

This unit contains a $\underline{A} 4$ class $\underline{3}$ stream. No specific buffer required, but full suspension, if yarding across.

This unit contains streams which have recently been classified/channel typed but require field verification.

\section{WILDLIFE}

Maintain diversity within unit by leaving 1-5 acre-sized islands of green trees at a rate of 1 acre of island for every 20 acres harvested. Leave islands must be compatible with logging system and safe working conditions.

\section{RECREATION / VISUALS}

This unit has a proposed VQO of MM and is not seen from any viewpoint identified by this project.

\section{LANDS}

There are no lands mitigation measures anticipated for this unit.

\section{CULTURAL RESOURCES}

There are no cultural resource mitigation measures anticipated for this unit.

\section{GEOLOGY}

There are no karst mitigation measures anticipated for this unit. 


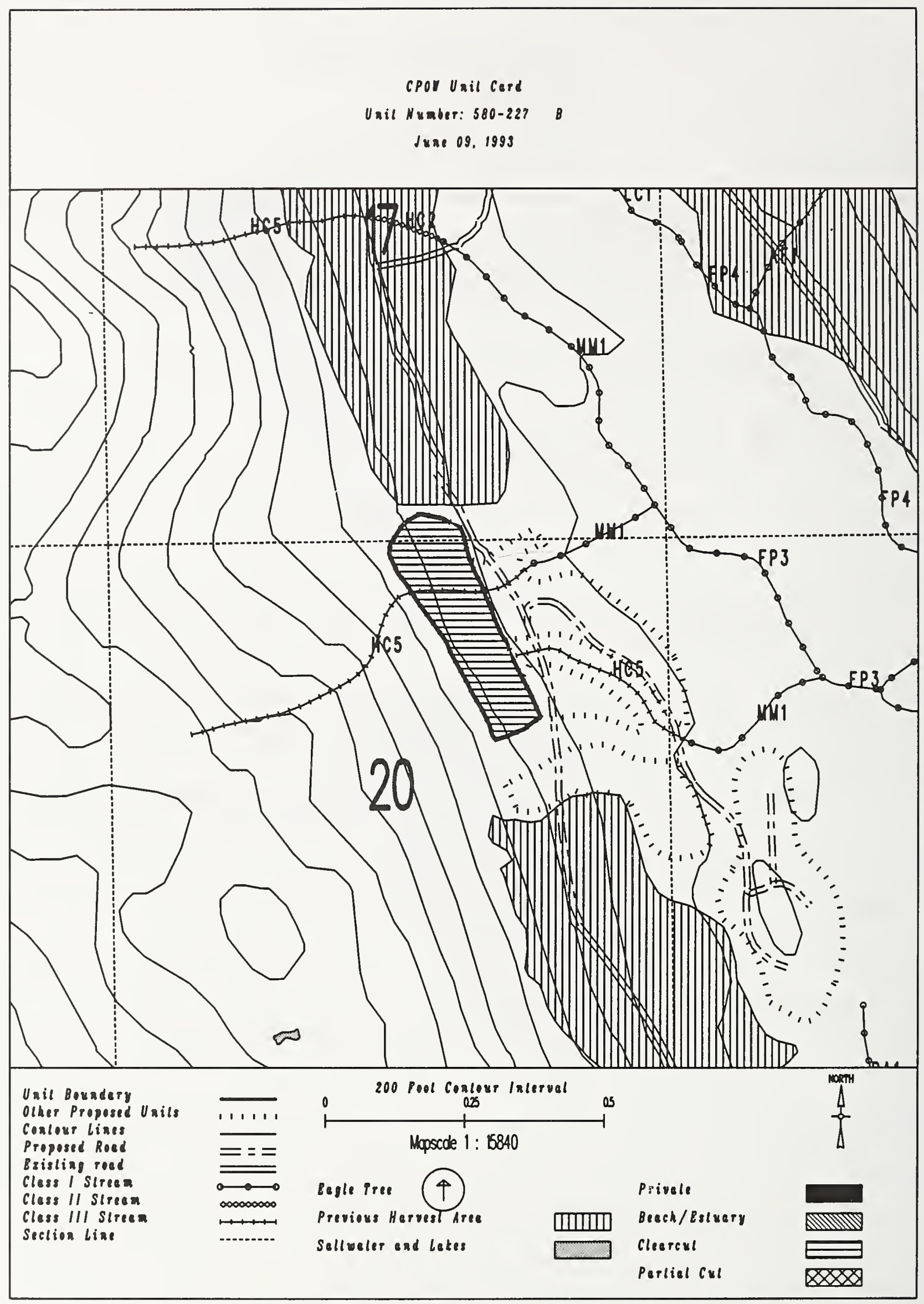


Unit $580-230$

Planned acres 40

Estimated volume (mbf)

Logging system skyline

silvicultural system clearcut

Forest type Mixed conifer
Alternatives considered

Quad CRGD3SES

Mgmt Area $\mathrm{KO9}$

WAA 1319

Photo 990172

Aspect South

PHYSICAL DESCRIPTION

Volume class breakdown: VC4 16 acres VC5 15 acres VC6 $\quad 0$ acres vC7 $\quad 0$ acres

Elevation breakdown: $0-800 \mathrm{ft} . \underline{39}$ acres $800-1200 \mathrm{ft} . \underline{0}$ acres $1200-1500 \mathrm{ft} . \underline{0}$ acres over $1500 \mathrm{ft}$. 0 Mass movement index: Low 0 acres Medium 26 acres High 0 acres Very High 0

\section{SOILS}

This unit contains 40 acres of forested wetlands. Site specific BMPs will be designed for selected approved logging system and road construction practices. (BMPs 12.5, 13.9, 13.15).

TIMBER

There are no timber mitigation measures anticipated for this unit.

\section{ENGINEER ING}

There are no engineering mitigation measures anticipated for this unit.

\section{FISH/WATERSHED}

There are no fishery mitigation measures anticipated for this unit.

\section{HILDLIFE}

Maintain diversity within unit by leaving 1-5 acre-sized islands of green trees at a rate of 1 acre of island for every 20 acres harvested. Leave islands must be compatible with logging system and safe working conditions.

\section{RECREATION / VISUALS}

This unit has a proposed VQo of $M M$ and is not seen from any viewpoint identified by this project.

\section{LANDS}

There are no lands mitigation measures anticipated for this unit.

\section{CULTURAL RESOURCES}

There are no cultural resource mitigation measures anticipated for this unit.

\section{GEOLOGY}

There are no karst mitigation measures anticipated for this unit. 


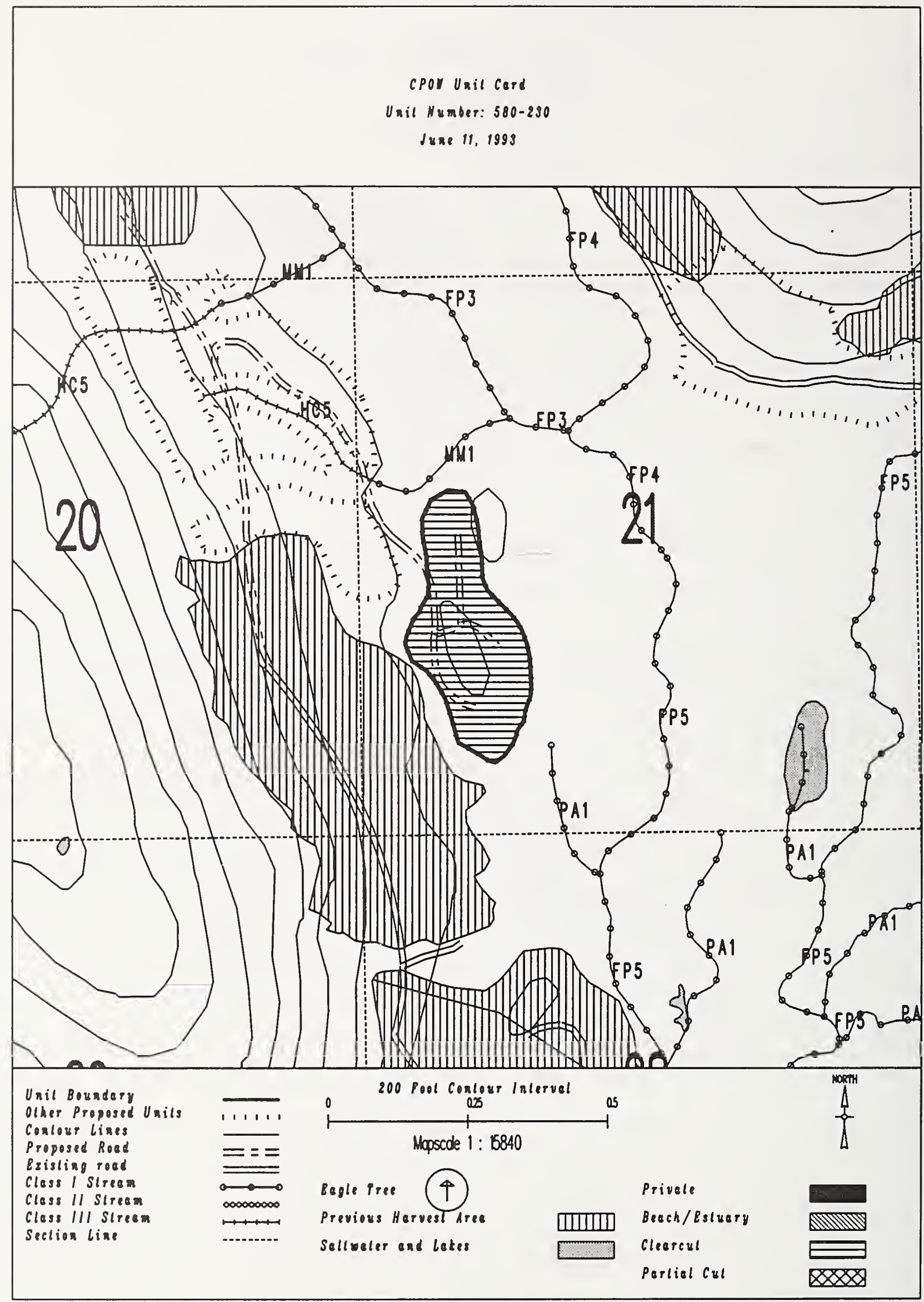


Unit 580-235

Planned acres 53

Estimated volume (mbf) 1571

Logging system skyline

silvicultural system Clearcut

forest type Hemlock
Alternatives considered F2 F3 F4

Quad CRGO3SES

Mgmt Area K09

WAA 1422

Photo 990173

Aspect South

\section{PHYSICAL DESCRIPTION}

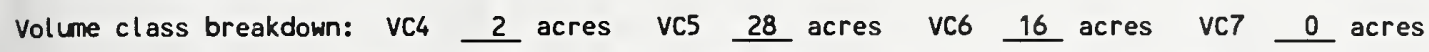

Elevation breakdown: $0-800 \mathrm{ft} . \underline{51}$ acres $800-1200 \mathrm{ft} . \underline{0}$ acres $1200-1500 \mathrm{ft}$. 0 acres over $1500 \mathrm{ft}$. 0 acres Mass movement index: Low 10 acres Medium 32 acres High 7 acres Very High 0 acres

\section{SOILS}

This unit has high mass movement index soils. Partial log suspension required over these areas.(BMP13.9)

This unit has a slight possibility to be reclassified as MMI $=4$.

This unit contains 41 acres of forested wetlands. Site specific BMPs will be designed for selected approved logging system and road construction practices. (BMPs 12.5, 13.9, 13.15).

\section{TIMBER}

There are no timber mitigation measures anticipated for this unit.

\section{ENGINEER ING}

High mass movement index soils. Road construction must minimize landslide potential (BMP14).

\section{FISH/HATERSHED}

There are no fishery mitigation measures anticipated for this unit.

\section{WILOLIFE}

There are no wildlife mitigation measures anticipated for this unit.

\section{RECREATION / VISUALS}

This unit has a proposed Voo of MM and is not seen from any viewpoint identified by this project.

\section{LANDS}

There are no lands mitigation measures anticipated for this unit.

CULTURAL RESOURCES

There are no cultural resource mitigation measures anticipated for this unit. 


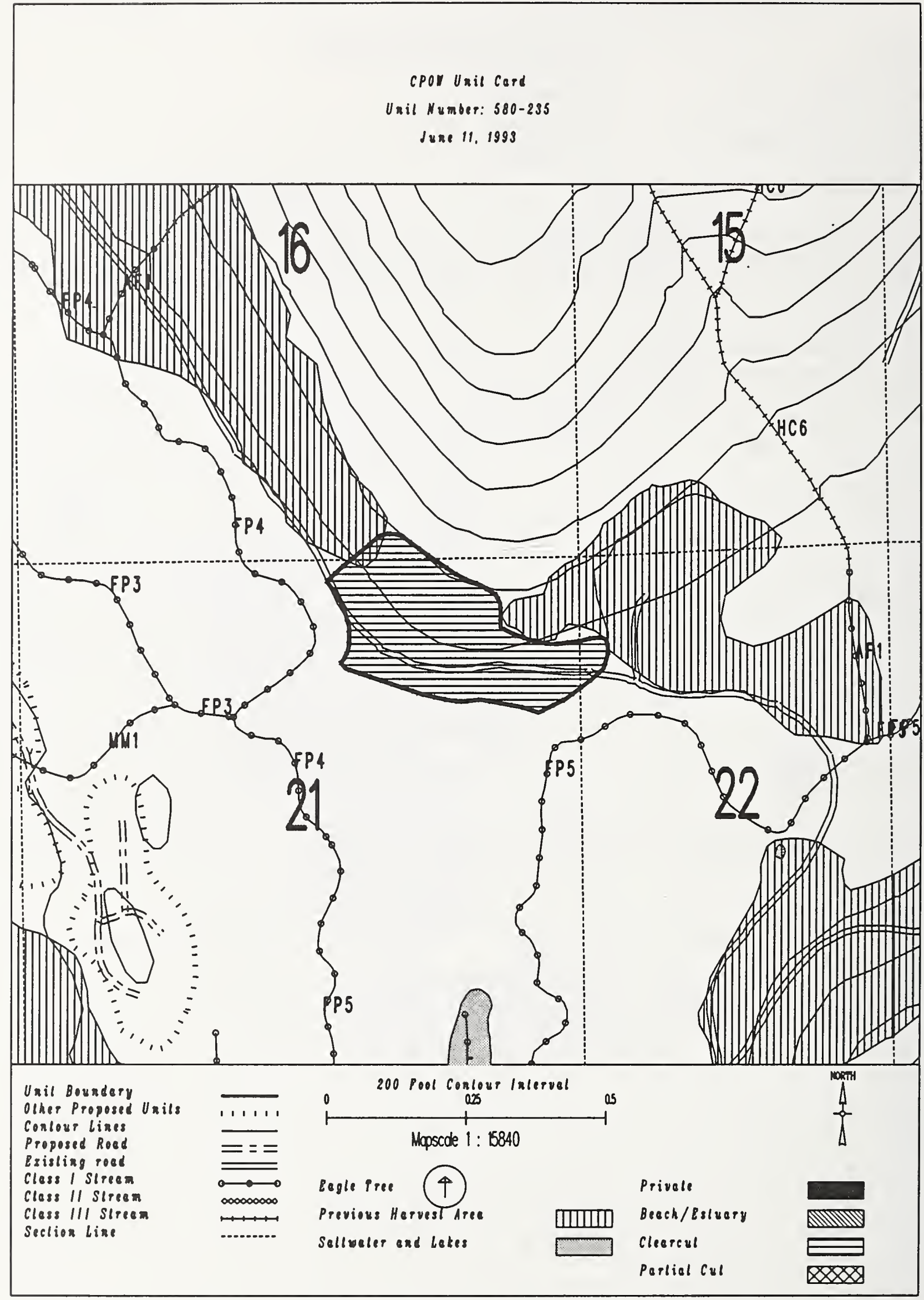


Unit $580-239$

Planned acres 31

Estimated volume (mbf) 1082

Logging system slackline

silvicultural system Clearcut

Forest type Hemlock

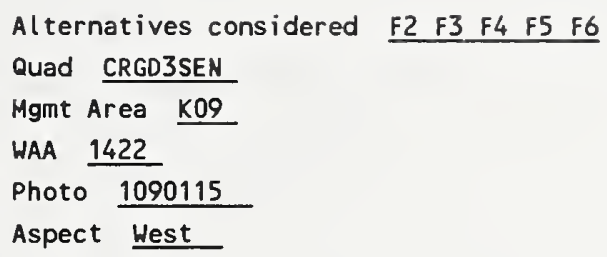

PHYSICAL DESCRIPTION

Volume class breakdown: VC4 $\quad 0$ acres VC5 $\quad 33$ acres VC6 $\quad 0$ acres $\quad$ VC7 $\quad 0$ acres

Elevation breakdown: $0-800 \mathrm{ft} .19$ acres $800-1200 \mathrm{ft} .10$ acres $1200-1500 \mathrm{ft} . \underline{0}$ acres over $1500 \mathrm{ft}$. 0 acres Mass movement index: Low 0 acres Medium 0 acres High $\underline{30}$ acres Very High 0

\section{SOILS}

This unit has high mass movement index soils. Partial log suspension required over these areas.(BMP13.9)

\section{TIMBER}

There are no timber mitigation measures anticipated for this unit.

\section{ENGINEERING}

High mass movement index soils. Road construction must minimize landslide potential (BMP14).

\section{FISH/WATERSHED}

There are no fishery mitigation measures anticipated for this unit.

\section{HILDLIFE}

There are no wildlife mitigation measures anticipated for this unit.

\section{RECREATION / VISUALS}

This unit has a proposed VQO of MM and is not seen from any viewpoint identified by this project.

\section{LANDS}

There are no lands mitigation measures anticipated for this unit.

CULTURAL RESOURCES

There are no cultural resource mitigation measures anticipated for this unit. 


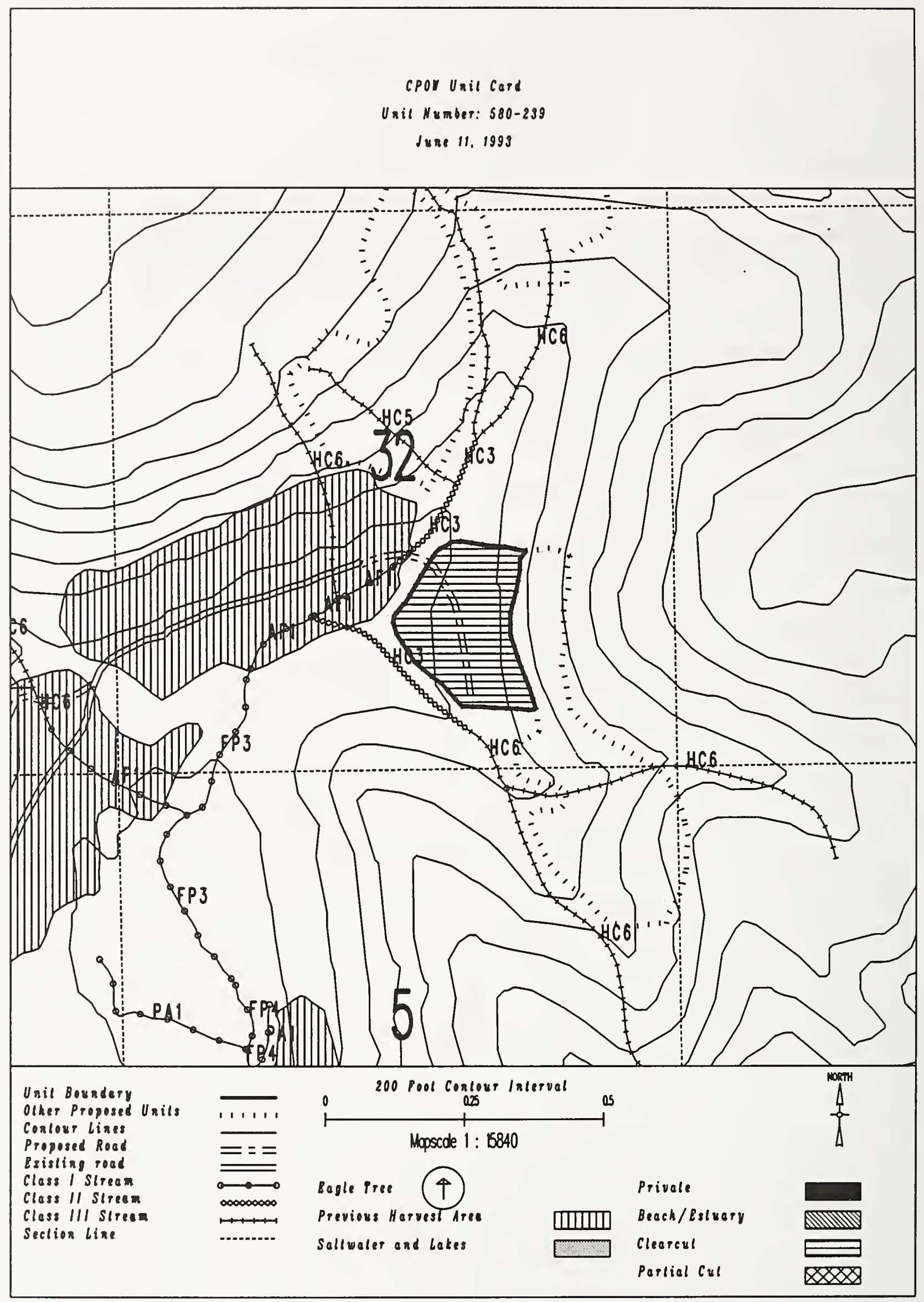


Unit $581-200$

Planned acres 78

Estimated volume (mbf) 1607

Logging system slackline

silvicultural system clearcut

Forest type Hemlock

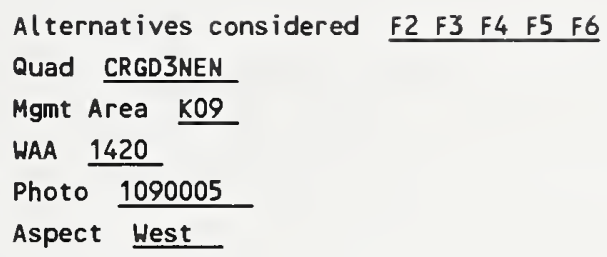

\section{PHYSICAL DESCRIPTION}

Volume class breakdown: VC4 12 acres VC5 41 acres VC6 $\quad 0$ acres VC7 $\quad 0$ acres

Elevation breakdown: $0-800 \mathrm{ft} . \underline{20}$ acres $800-1200 \mathrm{ft} . \underline{52}$ acres $1200-1500 \mathrm{ft} . \underline{0}$ acres over $1500 \mathrm{ft}$. 0 acres Mass movement index: Low 40 acres Medium 0 acres High 37 acres Very High 0

\section{SOILS}

This unit has high mass movement index soils. Partial log suspension required over these areas. (BMP13.9)

This unit contains $\mathbf{5 7}$ acres of forested wetlands. Site specific BMPs will be designed for selected approved

logging system and road construction practices. (BMPs 12.5, 13.9, 13.15).

\section{TIMBER}

There are no timber mitigation measures anticipated for this unit.

\section{ENGINEER ING}

High mass movement index soils. Road construction must minimize landslide potential (BMP14).

\section{FISH/WATERSHED}

There are no fishery mitigation measures anticipated for this unit.

\section{WILDLIFE}

There are no wildlife mitigation measures anticipated for this unit.

\section{RECREATION / VISUALS}

The unit has a proposed voo of $M$ within the viewshed of Baird Peak

as viewed from ferry/cruise ship route $(2-4 \mathrm{miles}$ off shore).

\section{LANDS}

There are no lands mitigation measures anticipated for this unit.

\section{CULTURAL RESOURCES}

There are no cultural resource mitigation measures anticipated for this unit.

\section{GEOLOGY}

There are no karst mitigation measures anticipated for this unit. 


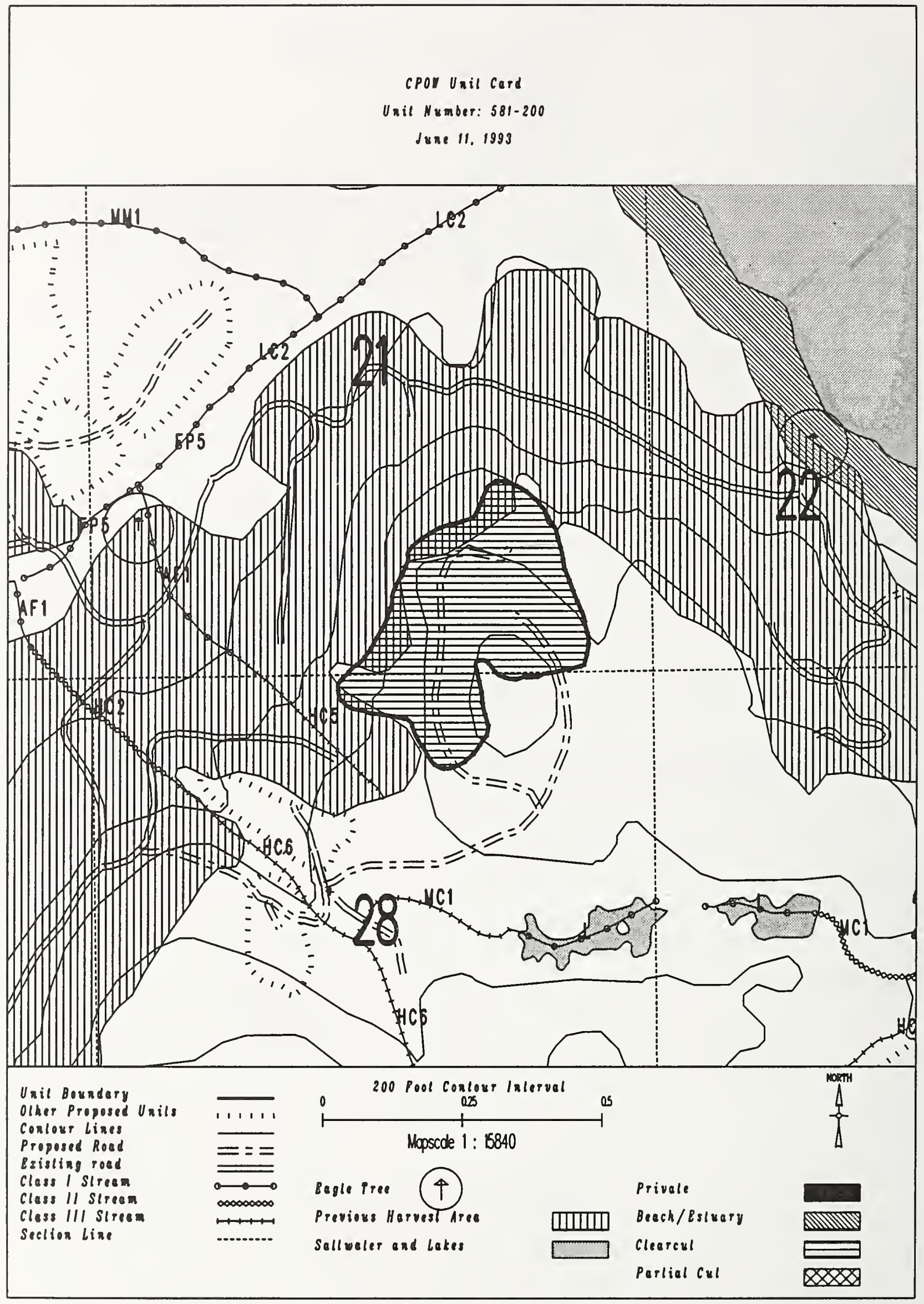


Unit $581-201$

Planned acres 13

Estimated volume (mbf) 426

Logging system skyline

silvicultural system clearcut

Forest type Hemlock

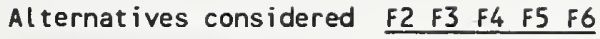

Quad CRGD3NEN

Mgmt Area $\mathrm{KO9}$

WAA 1420

Photo 1090005

Aspect West

\section{PHYSICAL DESCRIPIION}

Volume class breakdown: VC4 $\quad \begin{array}{llllllllll}0 & \text { acres VC5 } 13 \text { acres VC6 } \quad 0 \text { acres } & \text { VC7 } & 0 & \text { acres }\end{array}$

Elevation breakdown: $0-800 \mathrm{ft}$. 11 acres $800-1200 \mathrm{ft} . \underline{0}$ acres 1200-1500 ft. 0 acres over $1500 \mathrm{ft}$. 0 Mass movement index: Low 4 acres Medium 0 acres High 7 acres Very High 0

\section{SOILS}

This unit has high mass movement index soils. Partial log suspension required over these areas. (BMP13.9)

This unit contains 10 acres of forested wetlands. Site specific BMPs will be designed for selected approved

logging system and road construction practices. (BMPs 12.5, 13.9, 13.15).

\section{TIMBER}

There are no timber mitigation measures anticipated for this unit.

\section{ENGINEER ING}

High mass movement index soils. Road construction must minimize landslide potential (BMP14).

\section{FISH/WATERSHED}

There are no fishery mitigation measures anticipated for this unit.

\section{WILDLIFE}

There are no wildlife mitigation measures anticipated for this unit.

\section{RECREATION / VISUALS}

The unit has a proposed VoO of $M$ within the viewshed of Baird Peak as viewed from ferry/cruise ship route (2-4 miles off shore).

\section{LANDS}

There are no lands mitigation measures anticipated for this unit.

CULTURAL RESOURCES

There are no cultural resource mitigation measures anticipated for this unit. 
cPOI Unil Cord

Unil Number: 581-201

dune 11, 1993

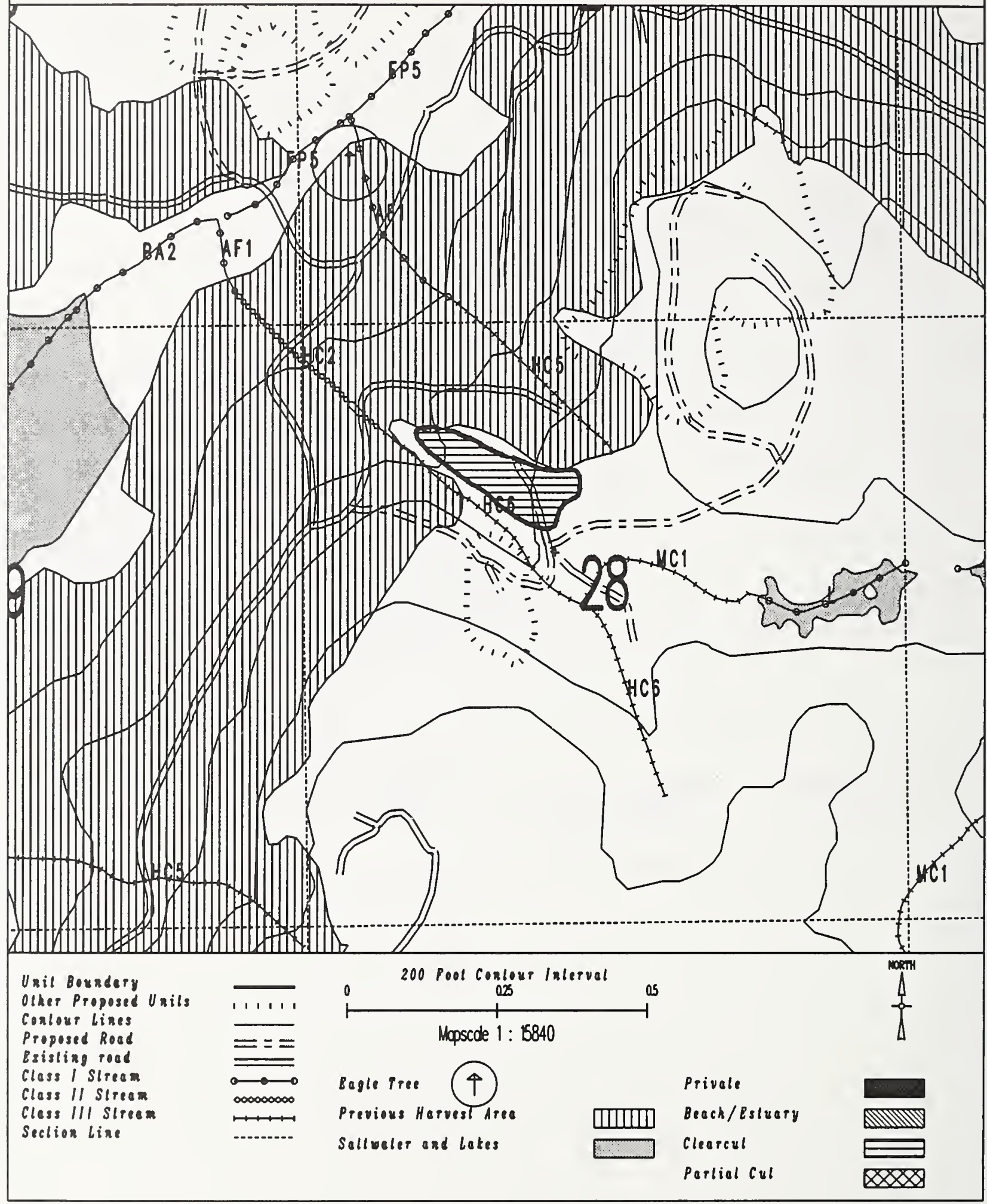


Unit $\quad \underline{51-202}$

Planned acres 12

Estimated volume (mbf) 295

Logging system skyline

silvicultural system clearcut

Forest type Hemlock
Alternatives considered $\quad$ F2 $F 3 \quad F 4 \quad F 5 \quad F 6$

Quad CRGD3NEN

Mgmt Area KO9

WAA 1420

Photo 1090005

Aspect North

PHYSICAL DESCRIPTION

Volume class breakdown: VC4 6 acres vc5 5 acres vc6 $\quad 0$ acres vc7 0 acres

Elevation breakdown: $0-800 \mathrm{ft} .10$ acres $800-1200 \mathrm{ft} . \quad 0$ acres $1200-1500 \mathrm{ft}$. 0 acres over $1500 \mathrm{ft}$. 0 acres Mass movement index: Low 9 acres Medium 0 acres High 2 acres Very High 0 acres

\section{SOILS}

This unit has high mass movement index soils. Partial log suspension required over these areas.(BMP13.9)

This unit contains 1 acres of slopes > $75 \%$.

\section{TIMBER}

There are no timber mitigation measures anticipated for this unit.

ENGINEERING

There are no engineering mitigation measures anticipated for this unit.

\section{FISH/WATERSHED}

There are no fishery mitigation measures anticipated for this unit.

\section{WILDLIFE}

There are no wildlife mitigation measures anticipated for this unit.

\section{RECREATION / VISUALS}

The unit has a proposed VQO of $M$ within the viewshed of Baird Peak

as viewed from ferry/cruise ship route (2-4 miles off shore).

\section{LANDS}

There are no lands mitigation measures anticipated for this unit.

CULTURAL RESOURCES

There are no cultural resource mitigation measures anticipated for this unit.

\section{GEOLOGY}

There are no karst mitigation measures anticipated for this unit. 
cpor Unil cerd

Unil Number: $581-202$

June 11, 1993

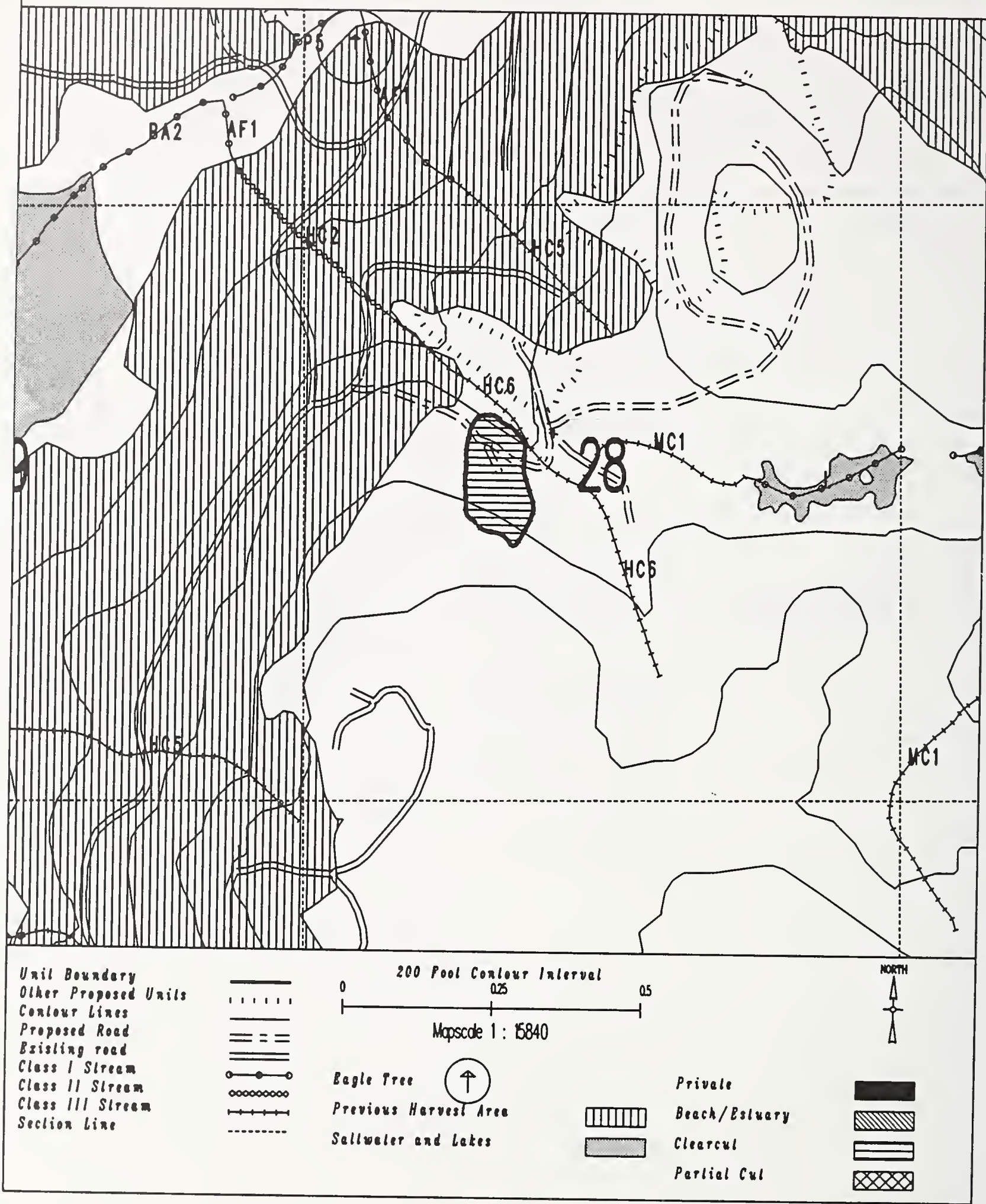


Unit $\quad 581-204$

Planned acres 27

Estimated volume (mbf)

Logging system Highlead

silvicultural system clearcut

Forest type Hemlock
Alternatives considered $F 2$ F3 F4 F5

Quad CRGD3NEN

Mgmt Area KO9

WAA 1420

Photo 1090103

Aspect South

PHYSICAL DESCRIPTION

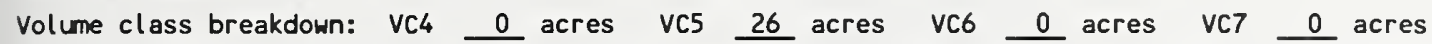

Elevation breakdown: $0-800 \mathrm{ft} . \underline{27}$ acres $800-1200 \mathrm{ft} . \underline{0}$ acres $1200-1500 \mathrm{ft} . \underline{0}$ acres over $1500 \mathrm{ft}$. 0 acres Mass movement index: Low 8 acres Medium 0 acres High 7 acres Very High 0 acres

\section{SOILS}

This unit has high mass movement index soils. Partial log suspension required over these areas. (BMP13.9)

This unit contains 11 acres of forested wetlands. Site specific BMPs will be designed for selected approved logging system and road construction practices. (BMPs 12.5, 13.9, 13.15).

\section{TIMBER}

Potential for shovel logging on 30 acres, if soil and water quality protected (BMP13.7)

\section{ENG INEER ING}

High mass movement index soils. Road construction must minimize landslide potential (BMP14).

\section{FISH/WATERSHED}

Potential for additional Class I/II streams within unit. May be necessary to place additional buffers within unit in accordance with AHMU Handbook.

\section{WILDL IFE}

There are no wildlife mitigation measures anticipated for this unit.

\section{RECREATION / VISUALS}

This unit has a proposed veo of MM and is not seen from any viewpoint identified by this project.

\section{LANDS}

There are no lands mitigation measures anticipated for this unit.

\section{CULTURAL RESOURCES}

There are no cultural resource mitigation measures anticipated for this unit. 
cPor Unil Cerd

Unil Number: 581-204

Juke 11, 1993

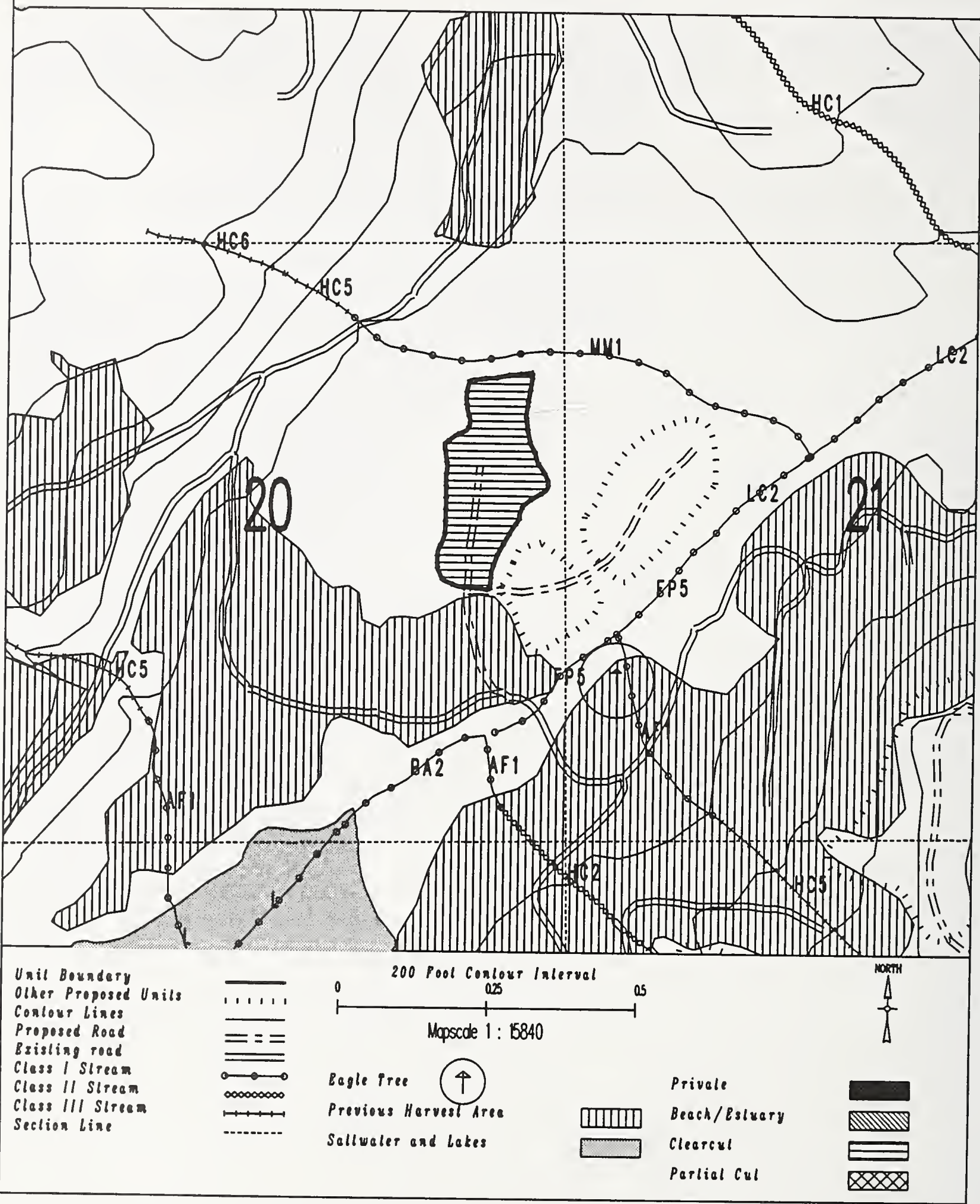


Unit 581-204 B

Planned acres 35

Estimated volume (mbf) 1202

Logging system skyline

silvicultural system Partial cut

Forest type Hemlock
Alternatives considered F2 F3 F4 F5

Quad CRGD3NEN

Mgmt Area $\mathrm{KO9}$

WAA 1420

Photo

Aspect South

PHYSICAL DESCRIPTION

Volume class breakdown: VC4 $\quad 0$ acres VC5 20 acres VC6 $\quad 1$ acres VC7 10 acres

Elevation breakdown: $0-800 \mathrm{ft} . \underline{33}$ acres $800-1200 \mathrm{ft} . \underline{0}$ acres 1200-1500 ft. 0 acres over $1500 \mathrm{ft}$. 0 Mass movement index: Low $\_$acres Medium $\_$acres High 10 acres Very High 0

SOILS

This unit has high mass movement index soils. Partial log suspension required over these areas. (BMP13.9)

This unit contains 14 acres of forested wetlands. Site specific BMPs will be designed for selected approved

logging system and road construction practices. (BMPs 12.5, 13.9, 13.15).

\section{TIMBER}

Partial cut harvest required to meet specified visual quality objectives.

Potential for shovel logging on 30

acres, if soil and water quality protected (BMP13.7)

ENGINEER ING

High mass movenent index soils. Road construction must minimize landslide potential (BMP14).

FISH/WATERSHED

Potential for additional Class I/II streams within unit. May be necessary to place additional buffers within unit in accordance with AHMU Handbook.

\section{WILDLIFE}

There are no wildlife mitigation measures anticipated for this unit.

RECREATION / VISUALS

The unit has a proposed VQO of $M$ within the viewshed of Baird Peak

as viewed from ferry/cruise ship route (2-4 miles off shore).

Maintain old-growth character of fishing access trail. No-cut $300^{\prime}$ buffer above trail and partial cut below road.

\section{LANDS}

There are no lands mitigation measures anticipated for this unit.

\section{CULTURAL RESOURCES}

The planned unit boundary and road location is immediately adjacent to significant cultural resources. Any changes must be coordinated with cultural resource personnel.

GEOLOGY

There are no karst mitigation measures anticipated for this unit. 


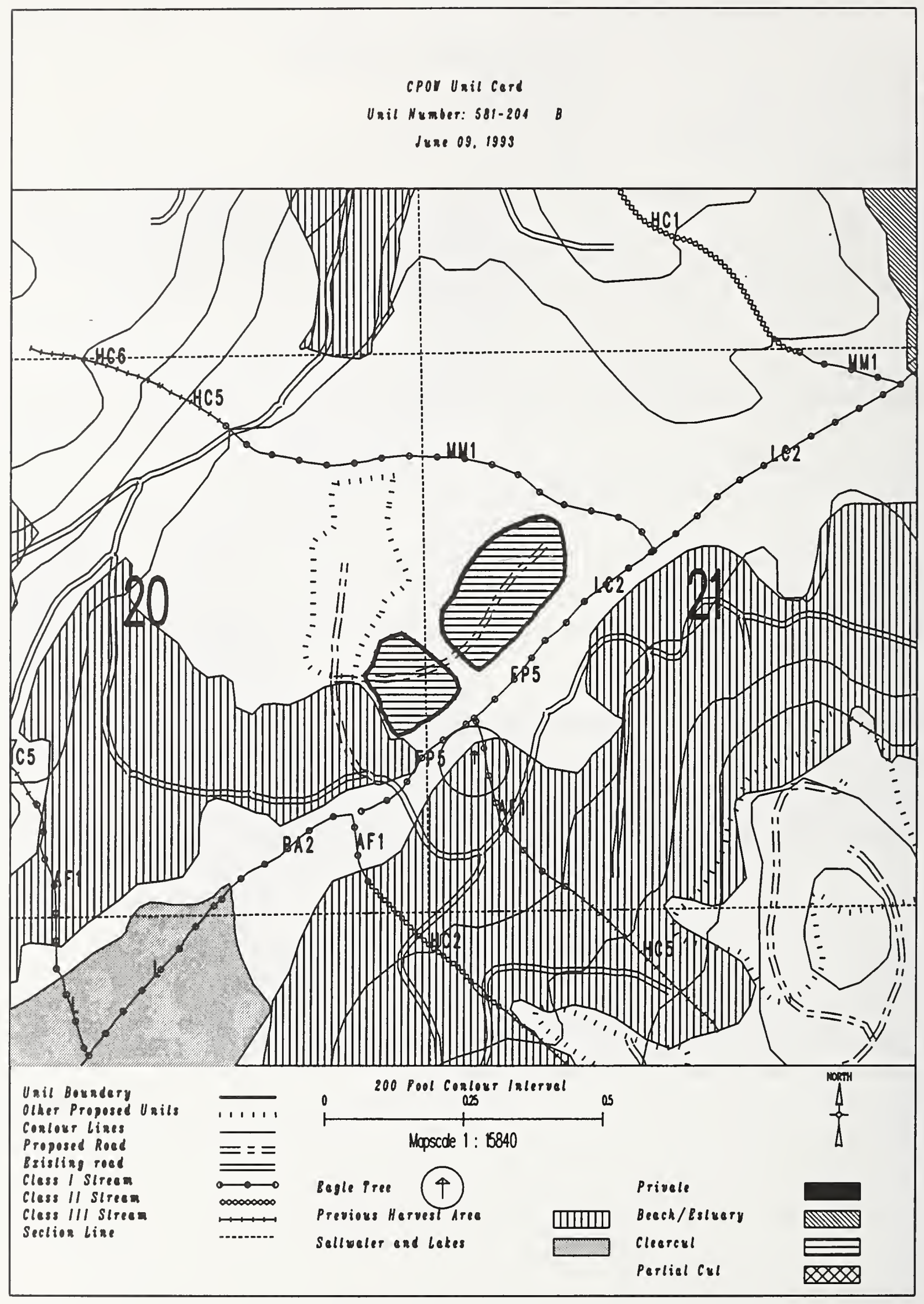


Unit $581-218$

Planned acres 23

Estimated volume (mbf) 747

Logging system slackline

silvicultural system clearcut

forest type Hemlock
Alternatives considered F2 F3 F4 F5 F6

Quad CRGD3NES

Mgmt Area K09

WAA 1420

Photo

Aspect West

PHYSICAL DESCRIPTION

Volume class breakdown: VC4 6 acres VC5 $\quad 6$ acres vC6 11 acres vC7 $\quad 0$ acres

Elevation breakdown: $0-800 \mathrm{ft} . \quad 0$ acres $800-1200 \mathrm{ft} . \underline{0}$ acres $1200-1500 \mathrm{ft}$. 0 acres over $1500 \mathrm{ft}$. 22 acres

Mass movement index: Low $\underline{0}$ acres Medium $\underline{0}$ acres High 21 acres Very High $\underline{0}$ acres

\section{SOILS}

This unit has high mass movement index soils. Partial log suspension required over these areas.(BMP13.9)

This unit has a significant possibility to have areas reclassified as MMI $=4$.

This unit contains 10 acres of forested wetlands. Site specific BMPs will be designed for selected approved

logging system and road construction practices. (BMPs 12.5, 13.9, 13.15).

This unit contains 5 acres of slopes $>75 \%$.

\section{TIMBER}

There are no timber mitigation measures anticipated for this unit.

\section{ENGINEER ING}

High mass movement index soils. Road construction must minimize landslide potential (BMP14).

\section{FISH/WATERSHED}

There are no fishery mitigation measures anticipated for this unit.

\section{HILDL IFE}

There are no wildlife mitigation measures anticipated for this unit.

\section{RECREATION / VISUALS}

This unit has a proposed voo of MM and is not seen from any viewpoint identified by this project.

\section{LANDS}

There are no lands mitigation measures anticipated for this unit.

\section{CULTURAL RESOURCES}

There are no cultural resource mitigation measures anticipated for this unit. 


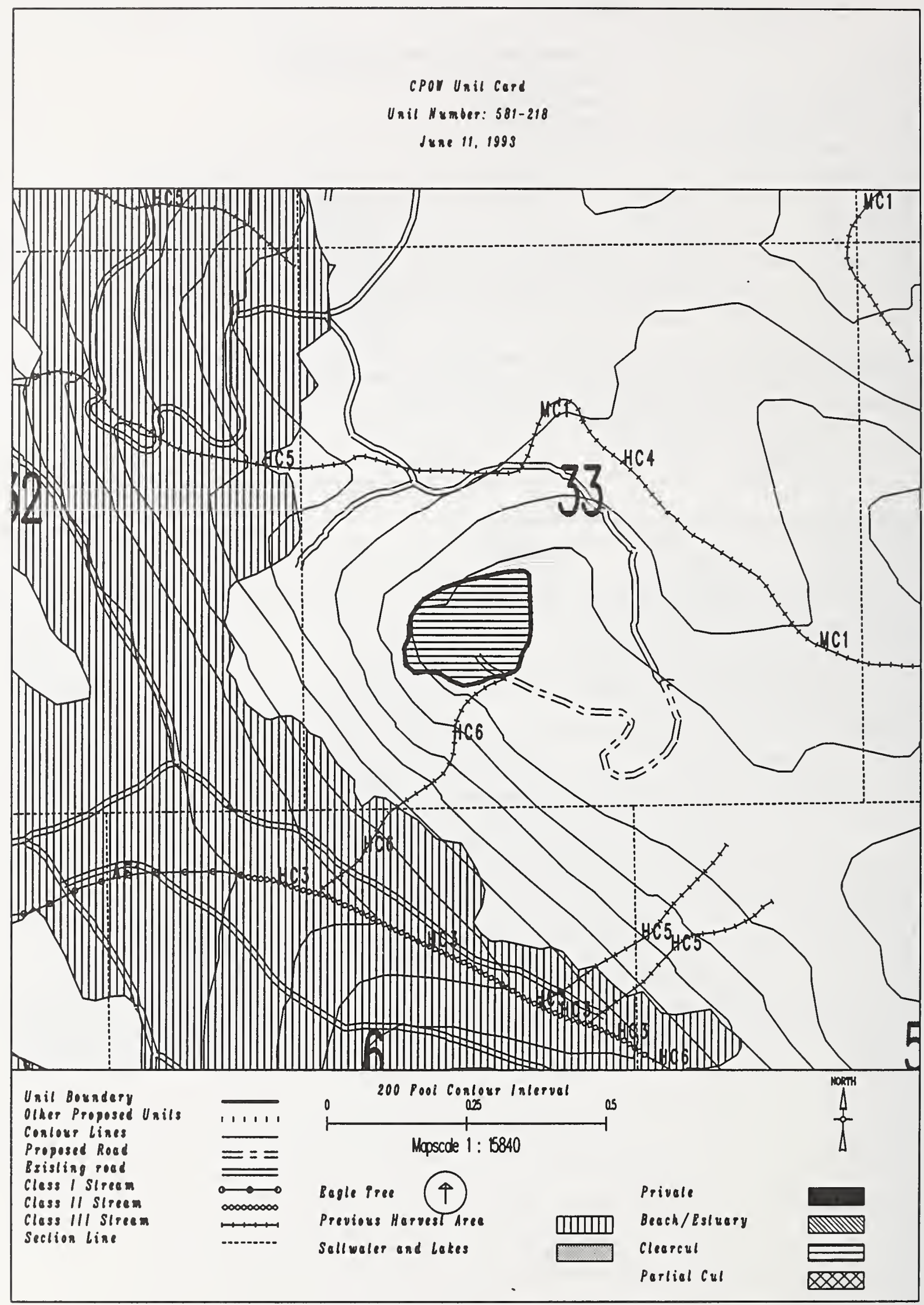


Unit 581-219

Planned acres 21

Estimated volume (mbf) 656

Logging system Helicopter

silvicultural system clearcut

Forest type Hemlock
Alternatives considered $\mathrm{F} 2$

Quad CRGD3NES

Ngmt Area $\underline{\mathrm{KO9}}$

WAA 1420

Photo 1090007

Aspect North

\section{PHYSICAL DESCRIPTION}

Volume class breakdown: vC4 $\quad 0$ acres vc5 $\underline{20}$ acres vc6 $\quad 0$ acres vc7 $\quad 0$ acres

Elevation breakdown: $0-800 \mathrm{ft} . \quad 0$ acres $800-1200 \mathrm{ft} . \ldots$ Mass movement index: Low $\_$acres Medium $\_$acres High 21 acres Very High 0

\section{SOILS}

This unit has high mass movement index soils. Partial log suspension required over these areas.(BMP13.9)

This unit has a slight possibility to be reclassified as MMI $=4$.

\section{TIMBER}

There are no timber mitigation measures anticipated for this unit.

\section{ENGINEER ING}

There are no engineering mitigation measures anticipated for this unit.

\section{FISH/WATERSHED}

There are no fishery mitigation measures anticipated for this unit.

\section{WI LDL I FE}

There are no wildlife mitigation measures anticipated for this unit.

\section{RECREATION / VISUALS}

This unit has a proposed VQO of MM and is not seen from any viewpoint identified by this project.

\section{LANDS}

There are no lands mitigation measures anticipated for this unit.

There are no cultural resource mitigation measures anticipated for this unit.

There are no karst mitigation measures anticipated for this unit. 


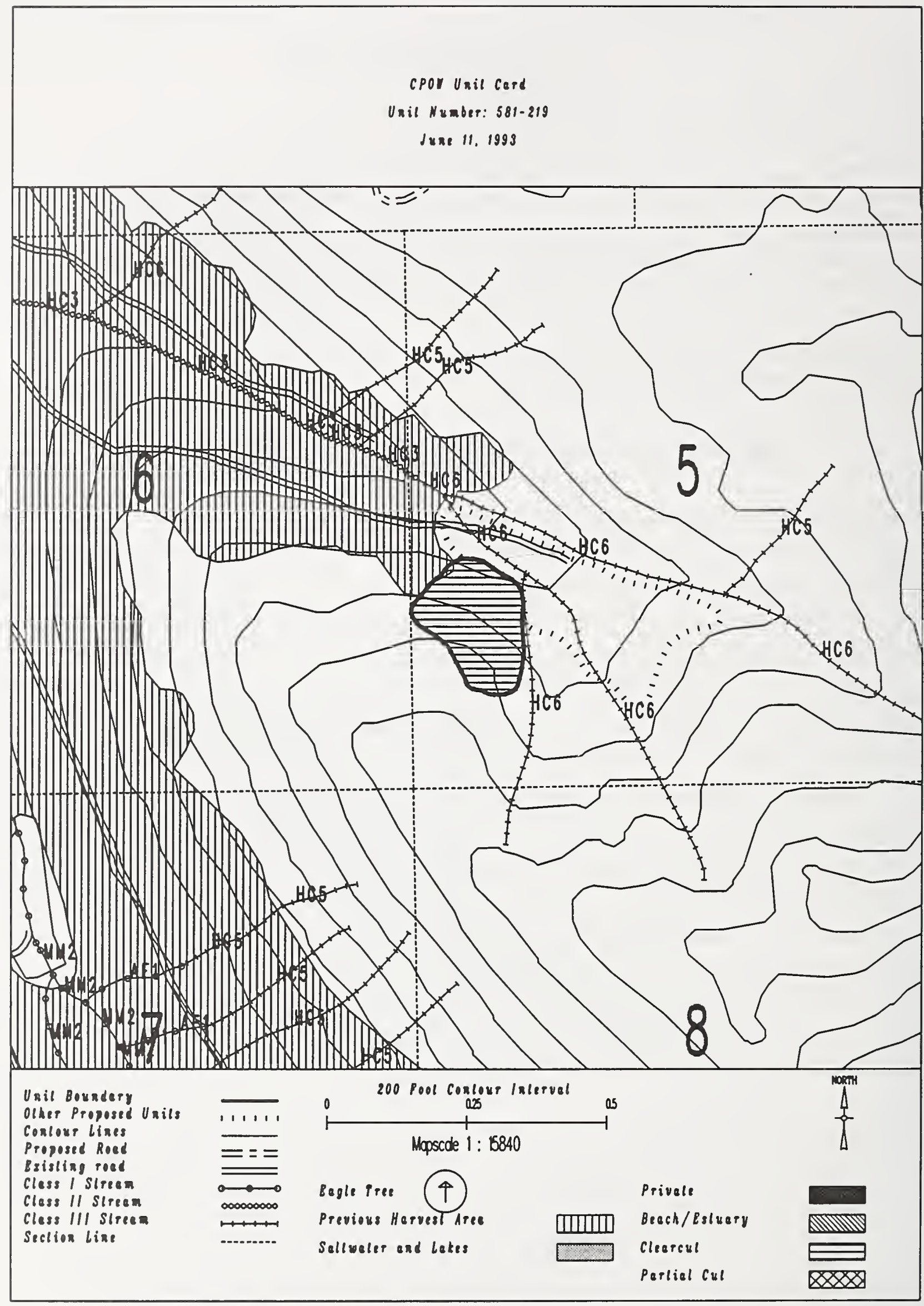


Unit $581-219 \quad B$

Planned acres 40

Est imated volume (mbf) 1268

Logging system Helicopter

silvicultural system Clearcut

Forest type Hemlock
Alternatives considered F2

Quad CRGD3NES

Mgmt Area $\mathrm{KO9}$

WAA 1420

Photo

Aspect North

PHYSICAL DESCRIPTION

Volume class breakdown: VC4 4 acres VC5 36 acres VC6 $\quad 0$ acres VC7 0 acres

Elevation breakdown: $0-800 \mathrm{ft} . \quad 0$ acres $800-1200 \mathrm{ft} . \angle 4$ acres $1200-1500 \mathrm{ft} . \quad 4$ acres over $1500 \mathrm{ft} . \quad 7$ acres Mass movement index: Low 0 acres Medium 0 acres High 40 acres Very High 0

SOILS

This unit has high mass movement index soils. Partial log suspension required over these areas.(BMP13.9)

This unit has a significant possibility to have areas reclassified as MMI $=4$.

This unit contains 15 acres of forested wetlands. Site specific BMPs will be designed for selected approved

logging system and road construction practices. (BMPs 12.5, 13.9, 13.15).

This unit contains 36 acres of slopes > $75 \%$.

TIMBER

There are no timber mitigation measures anticipated for this unit.

\section{ENGINEER ING}

There are no engineering mitigation measures anticipated for this unit.

\section{FISH/WATERSHED}

This unit contains a $\underline{A} 1$ class $\underline{3}$ stream. No specific buffer required, but full suspension, if yarding across.

\section{WILDLIFE}

There are no wildlife mitigation measures anticipated for this unit.

\section{RECREATION / VISUALS}

This unit has a proposed VQO of MM and is not seen from any viewpoint identified by this project.

\section{LANDS}

There are no lands mitigation measures anticipated for this unit.

\section{CULTURAL RESOURCES}

There are no cultural resource mitigation measures anticipated for this unit.

There are no karst mitigation measures anticipated for this unit. 


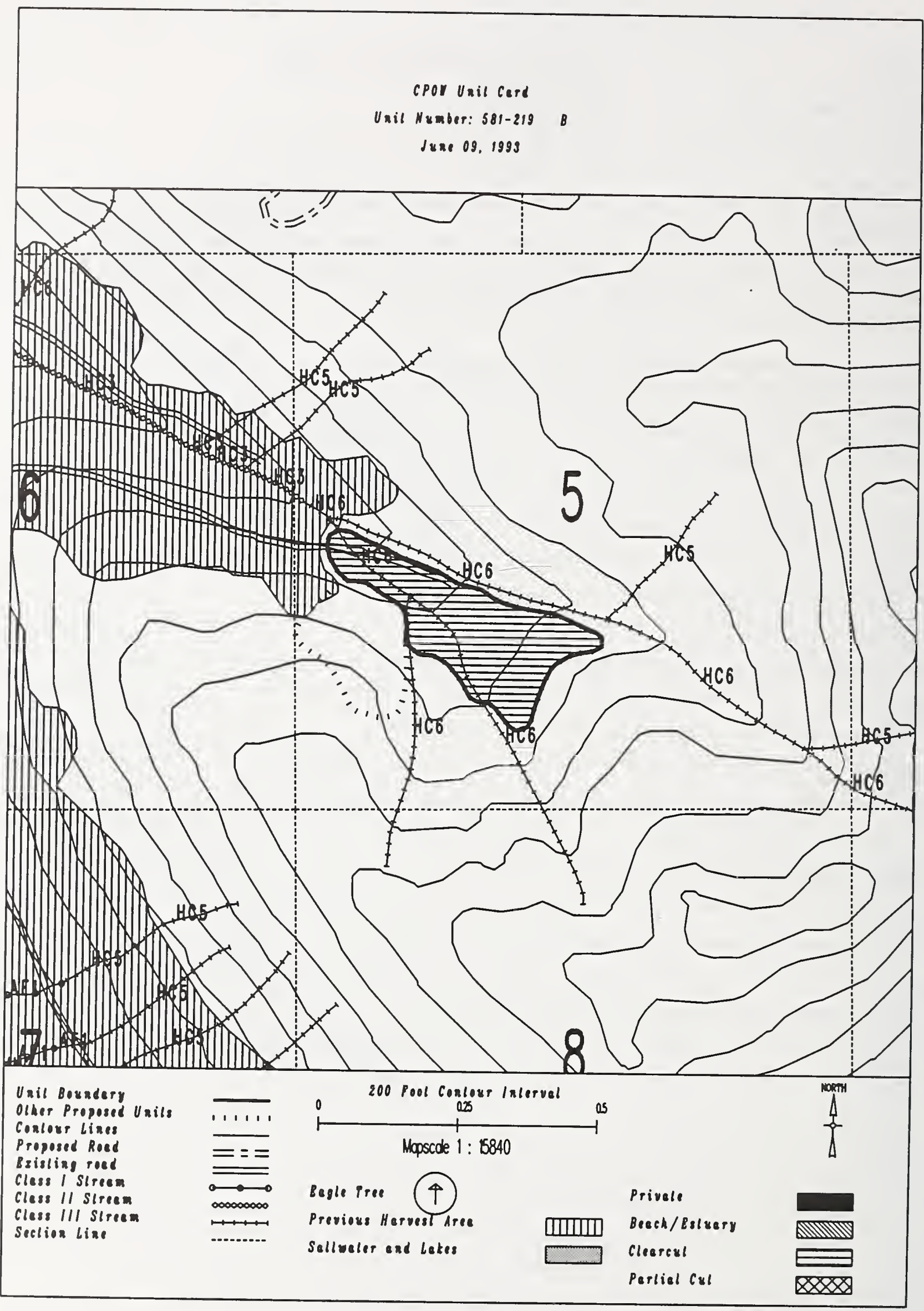


Unit $\quad 581-231$

Planned acres 35

Estimated volume (mbf) 1049

Logging system Helicopter

silvicultural system clearcut

Forest type Hemlock

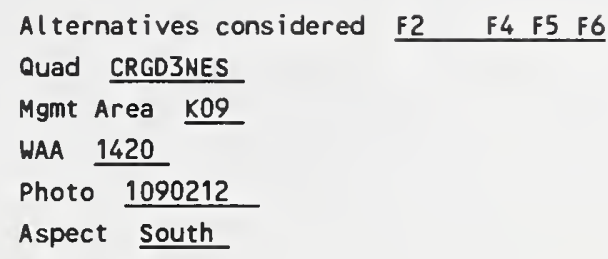

\section{PHYSICAL DESCRIPTION}

Volume class breakdown: VC4 2 acres VC5 26 acres VC6 0 acres vC7 0 acres

Elevation breakdown: $0-800 \mathrm{ft} . \underline{0}$ acres $800-1200 \mathrm{ft} . \underline{0}$ acres $1200-1500 \mathrm{ft}$. 0 acres over $1500 \mathrm{ft}$. 25 acres Mass movement index: Low 35 acres Medium 0 acres High 0 acres Very High 0

\section{SOILS}

There are no soils mitigation measures anticipated for this unit.

There are no timber mitigation measures anticipated for this unit.

ENGINEERING

There are no engineering mitigation measures anticipated for this unit.

\section{FISH/WATERSHED}

There are no fishery mitigation measures anticipated for this unit.

WILDLIFE

There are no wildlife mitigation measures anticipated for this unit.

RECREATION / VISUALS

This unit has a proposed voo of MM and is not seen from any viewpoint identified by this project.

There are no lands mitigation measures anticipated for this unit.

There are no cultural resource mitigation measures anticipated for this unit. 


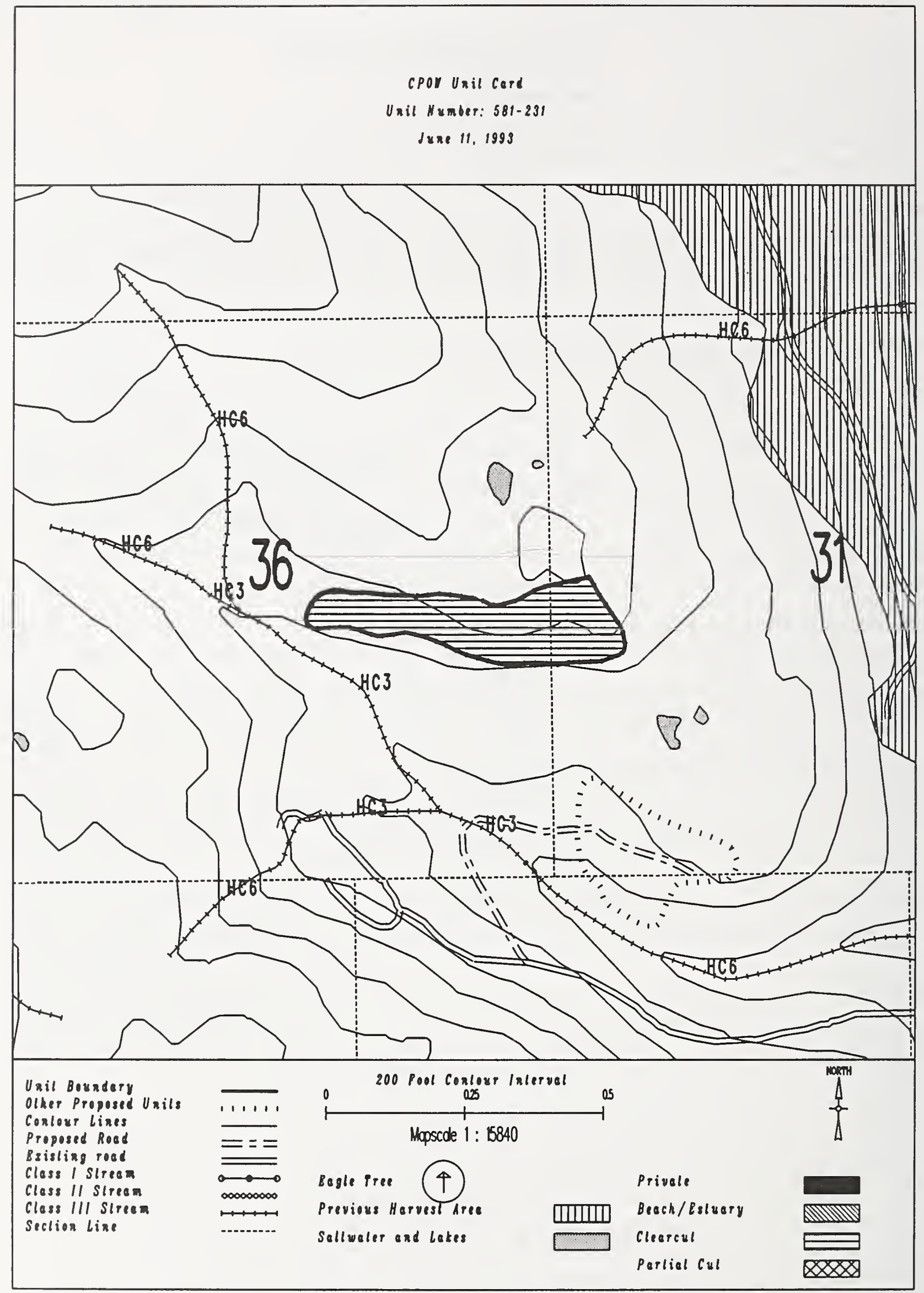


Unit 581-232

Planned acres 26

Estimated volume (mbf)

Logging system Skyline

silvicultural system clearcut

Forest type Hemlock

\author{
Quad CRGD3NES \\ Mgmt Area KO9 \\ WAA 1420 \\ Photo \\ Aspect South
}

Alternatives considered

PHYSICAL DESCRIPTION

Volume class breakdown: VC4 11 acres vC5 14 acres vC6 0 acres vc7 $\quad 0$ acres

Elevation breakdown: $0-800 \mathrm{ft} . \underline{0}$ acres $800-1200 \mathrm{ft} . \underline{8}$ acres $1200-1500 \mathrm{ft} . \underline{7}$ acres over $1500 \mathrm{ft} . \underline{0}$ acres Mass movement index: Low 17 acres Medium 0 acres High 9 acres Very High 0 acres

\section{SOILS}

This unit has high mass movement index soils. Partial log suspension required over these areas.(BMP13.9)

This unit contains 11 acres of forested wetlands. Site specific BMPs will be designed for selected approved

logging system and road construction practices. (BMPS 12.5, 13.9, 13.15).

This unit contains 8 acres of slopes $>75 \%$.

\section{TIMBER}

There are no timber mitigation measures anticipated for this unit.

\section{ENGINEERING}

High mass movement index soils. Road construction must minimize landslide potential (BMP14).

slopes greater than $75 \%$ may require full bench construction and endhaul of waste (BMP 14.7).

\section{FISH/WATERSHED}

There are no fishery mitigation measures anticipated for this unit.

\section{WILDL I FE}

There are no wildlife mitigation measures anticipated for this unit.

RECREATION / VISUALS

This unit has a proposed voo of MM and is not seen from any viewpoint identified by this project.

\section{LANDS}

There are no lands mitigation measures anticipated for this unit.

CULTURAL RESOURCES

There are no cultural resource mitigation measures anticipated for this unit.

There are no karst mitigation measures anticipated for this unit. 
CPOy Uail card

Unil Number: $581-232$

June 11, 1993

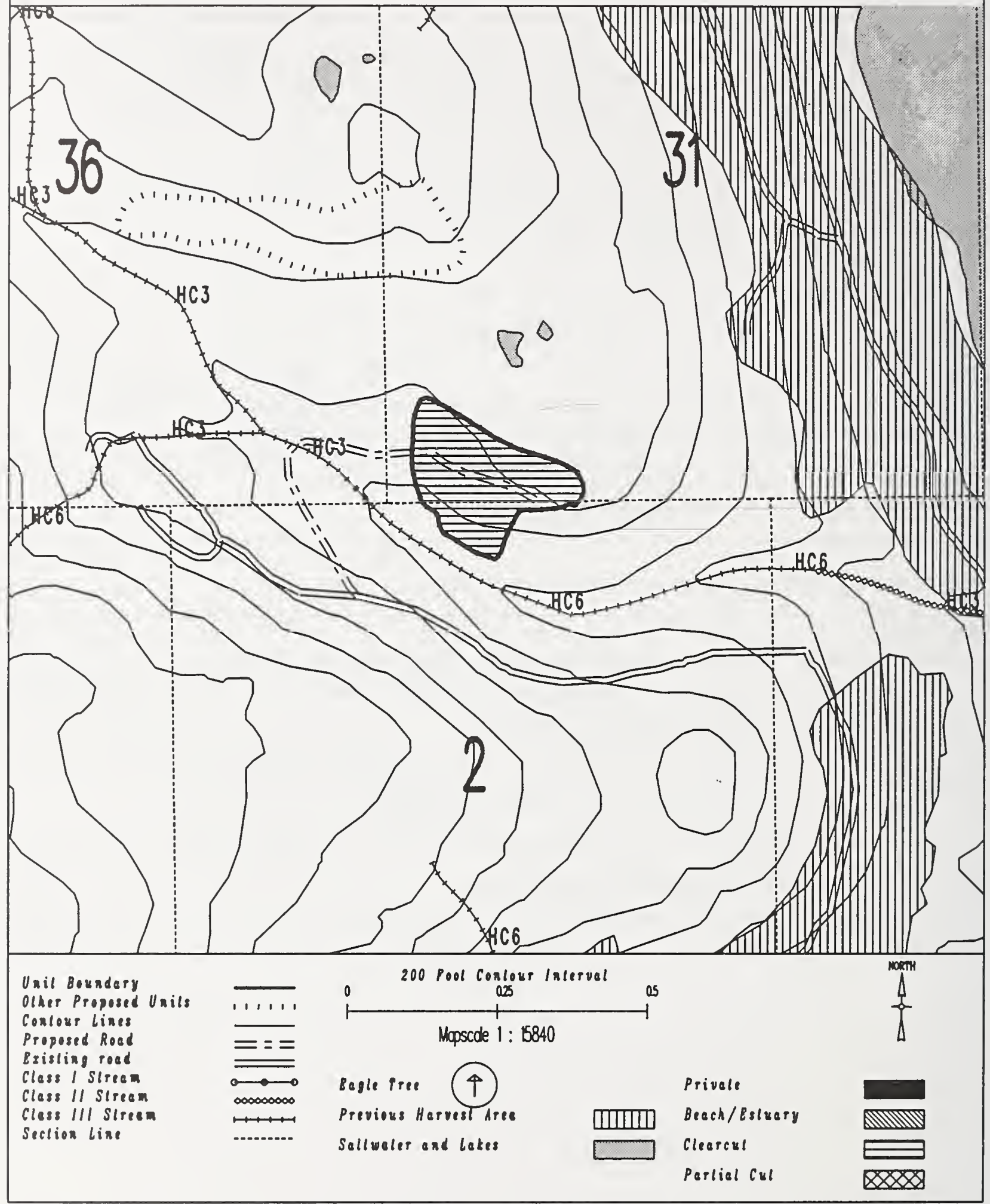




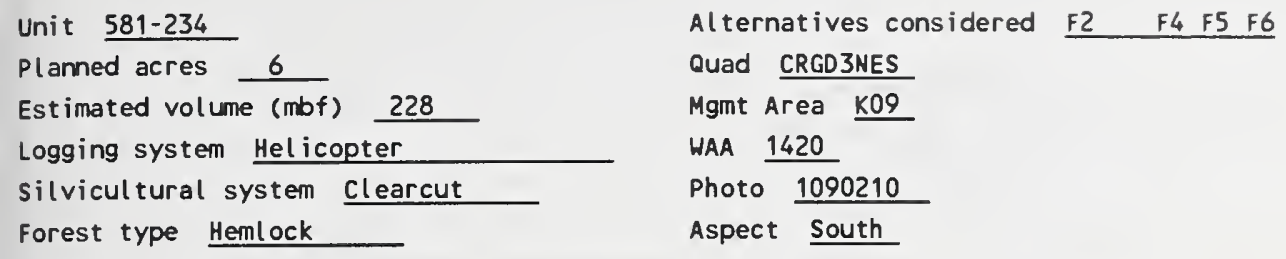




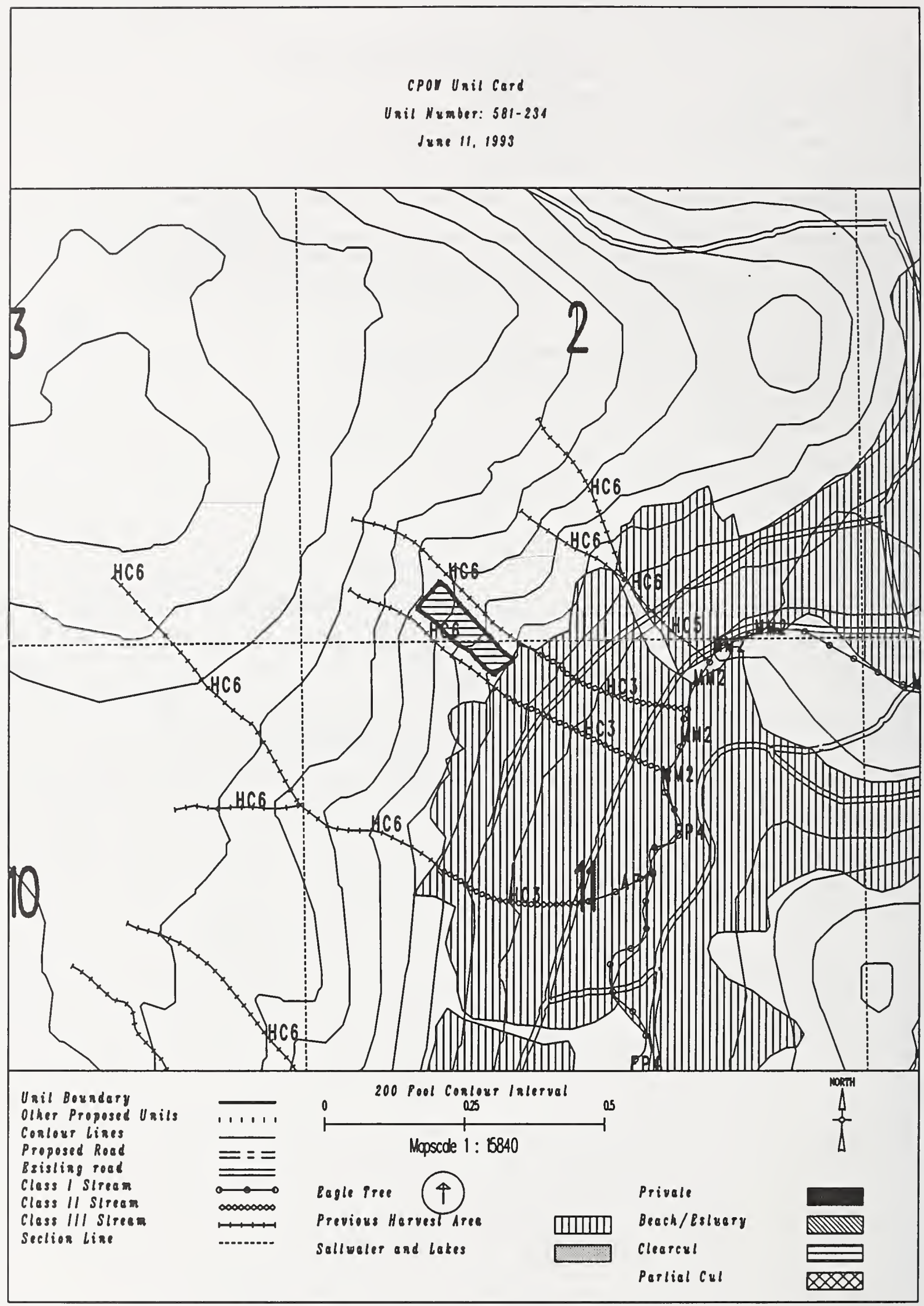


Unit $581-241$

Planned acres 34

Estimated volume (mbf) 1157

Logging system Helicopter

silvicultural system Clearcut

Forest type Mixed conifer
Alternatives considered

Quad CRGD3SEN

Mgmt Area $\mathrm{KO9}$

WAA 1420

Photo 1090111

Aspect West

\section{PHYSICAL DESCRIPTION}

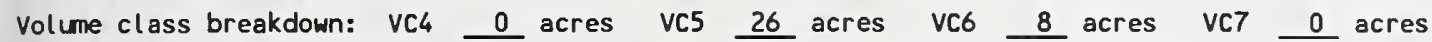

Elevation breakdown: $0-800 \mathrm{ft} .{ }_{0}^{0}$ acres $800-1200 \mathrm{ft} . \quad 0$ acres $1200-1500 \mathrm{ft} . \underline{2}$ acres over $1500 \mathrm{ft}$. 8 acres Mass movement index: Low 0 acres Medium 0 acres High 33 acres Very High 0 acres

\section{SOILS}

This unit has high mass movement index soils. Partial log suspension required over these areas.(BMP13.9) This unit contains 18 acres of forested wetlands. Site specific BMPs will be designed for selected approved logging system and road construction practices. (BMPs 12.5, 13.9, 13.15).

This unit contains 29 acres of slopes $>75 \%$.

\section{TIMBER}

Potential regeneration problem. May need to consider other silvicultural prescriptions (or hand plant) to meet BMP13.19.

\section{ENGINEER ING}

There are no engineering mitigation measures anticipated for this unit.

\section{FISH/WATERSHED}

This unit contains streams which have recently been classified/channel typed but require field verification.

\section{WILDLIFE}

There are no wildlife mitigation measures anticipated for this unit.

\section{RECREATION / VISUALS}

This unit has a proposed vao of MM and is not seen from any viewpoint identified by this project.

\section{LAMDS}

There are no lands mitigation measures anticipated for this unit.

\section{CULTURAL RESOURCES}

There are no cultural resource mitigation measures anticipated for this unit. 


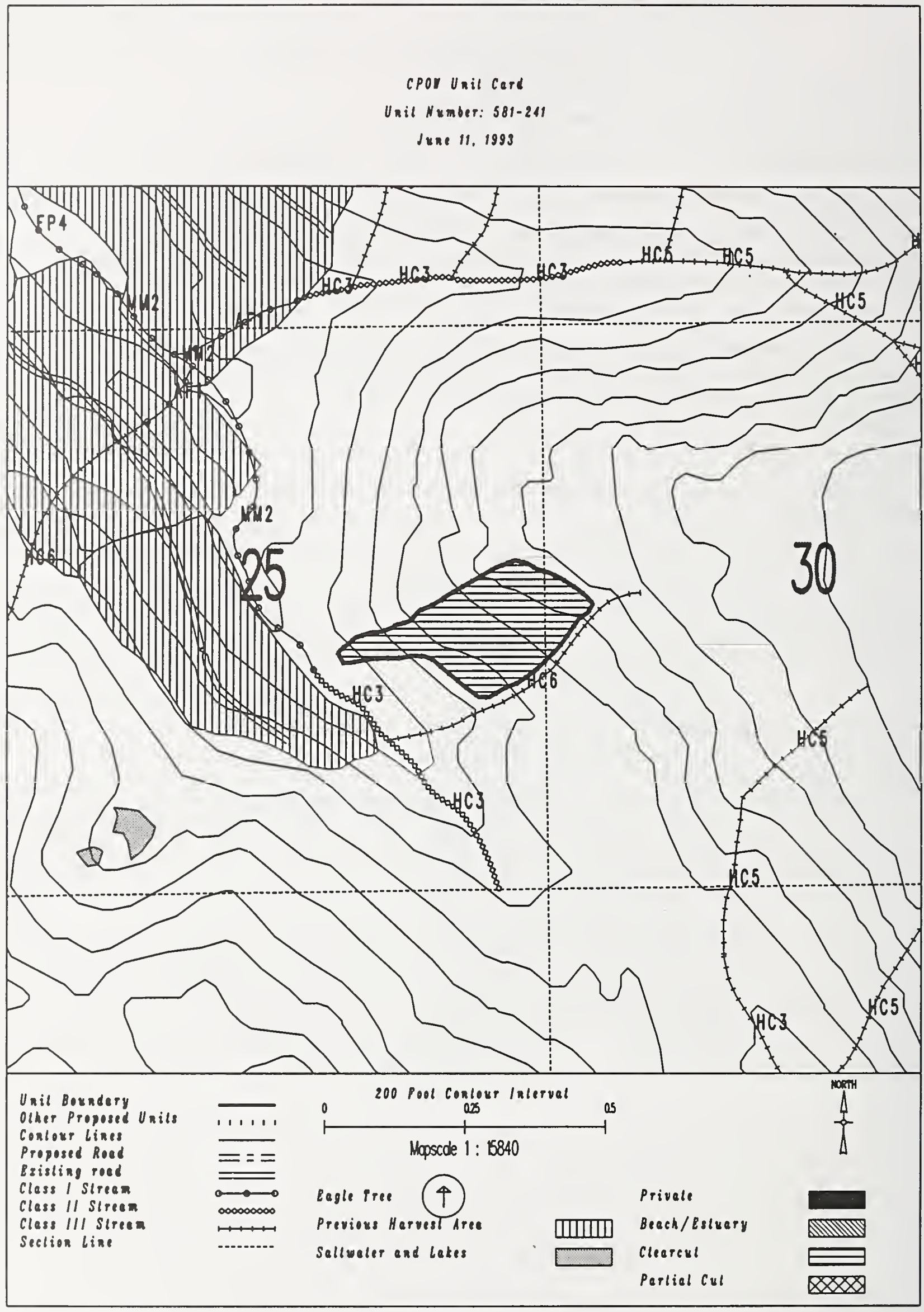


Unit $582-211$

Planned acres 32

Estimated volume (mbf) 1081

Logging system skyl ine

silvicultural system clearcut

Forest type Hemlock
Alternatives considered F2 F3 $\quad$ F5 F6

Quad CRGD2NWS

Mgmt Area KO9

WAA 1420

Photo 690055

Aspect East

\section{PHYSICAL DESCRIPTION}

Volume class breakdown: VC4 0 acres vC5 26 acres vC6 6 acres vc7 0 acres

Elevation breakdown: $0-800 \mathrm{ft} . \underline{27}$ acres $800-1200 \mathrm{ft}$. 0 acres $1200-1500 \mathrm{ft}$. 0 acres over $1500 \mathrm{ft}$. 0 acres Mass movement index: Low 1 acres Medium 10 acres High 20 acres Very High 0 acres

\section{SOILS}

This unit has high mass movement index soils. Partial log suspension required over these areas.(BMP13.9)

This unit contains 10 acres of forested wetlands. Site specific BMPs will be designed for selected approved

logging system and road construction practices. (BMPs 12.5, 13.9, 13.15).

\section{TIMBER}

There are no timber mitigation measures anticipated for this unit.

\section{ENGINEER ING}

High mass movement index soils. Road construction must minimize landslide potential (BMP14).

\section{FISH/WATERSHED}

This unit contains streams which have recently been classified/channel typed but require field verification.

\section{WILDLIFE}

There are no wildtife mitigation measures anticipated for this unit.

\section{RECREATION / VISUALS}

The unit has a proposed voo of $M$ within the viewshed of Baird Peak

as viewed from ferry/cruise ship route (2-4 miles off shore).

There are no lands mitigation measures anticipated for this unit.

CULTURAL RESOURCES

There are no cultural resource mitigation measures anticipated for this unit.

There are no karst mitigation measures anticipated for this unit. 


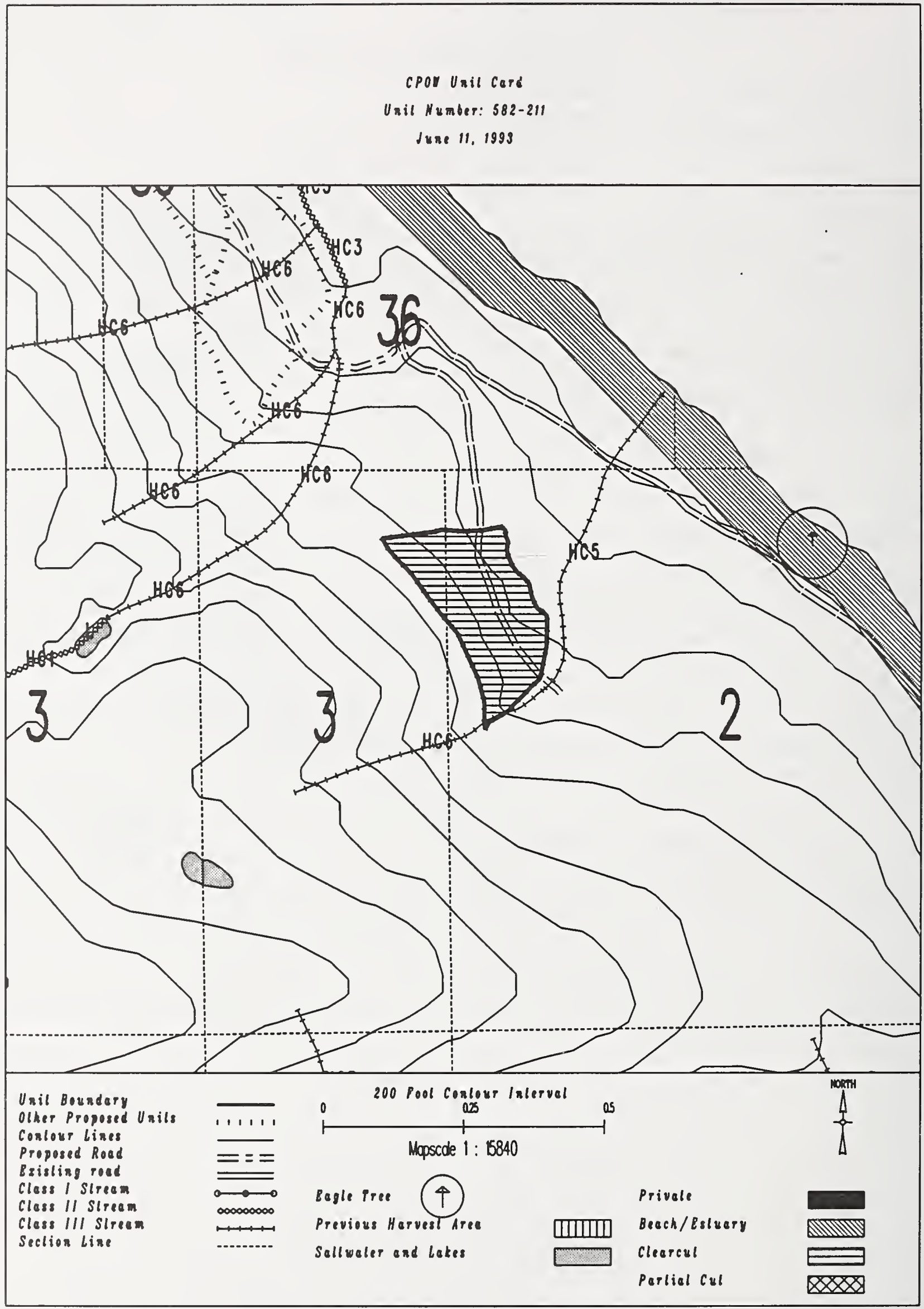


Unit $\quad 582-214$

Planned acres 40

Estimated volume (mbf) 1988

Logging system skyline

silvicultural system Clearcut

Forest type Mixed conifer
Alternatives considered F2 F3 F5 F6

Quad CRGD2NWS

Mgmt Area $\mathrm{K} 09$

WAA 1420

Photo 690056

Aspect North

PHYSICAL DESCRIPTION

Volume class breakdown: VC4 $\quad 0$ acres VC5 6 acres VC6 3 acres VC7 33 acres

Elevation breakdown: $0-800 \mathrm{ft} . \underline{36}$ acres $800-1200 \mathrm{ft} . \quad \ldots$ acres $1200-1500 \mathrm{ft} . \underline{0}$ acres over $1500 \mathrm{ft}$. 0 Mass movement index: Low $\underline{0}$ acres Medium 33 acres High 6 acies Very High 0 acres

SOILS

This unit has high mass movement index soils. Partial log suspension required over these areas.(BMP13.9)

This unit contains 35 acres of forested wetlands. Site specific BMPs will be designed for selected approved logging system and road construction practices. (BMPs 12.5, 13.9, 13.15).

TIMBER

There are no timber mitigation measures anticipated for this unit.

\section{ENGINEER ING}

Very difficult road construction due to unstable, slope $>75 \%$ or extended steep grades.

May need to revise logging system to helicopter.

High mass movement index soils. Road construction must minimize landslide potential (BMP14).

\section{FISH/WATERSHED}

Potential for additional Class I/II streams within unit. May be necessary to place additional buffers within unit in accordance with AHMU Handbook.

This unit contains a $\underline{A} 1$ class $\underline{3}$ stream. No specific buffer required, but full suspension, if yarding across.

\section{WILDL IFE}

There are no wildlife mitigation measures anticipated for this unit.

\section{RECREATION / VISUALS}

The unit has a proposed voo of $M$ within the viewshed of Baird Peak

as viewed from ferry/cruise ship route (2-4 miles off shore).

Design of leave strip necessary to reduce opening size < 100 acres shall be coordinated with a Landscape Architect.

\section{LANDS}

There are no lands mitigation measures anticipated for this unit.

\section{CULTURAL RESOURCES}

There are no cultural resource mitigation measures anticipated for this unit. 


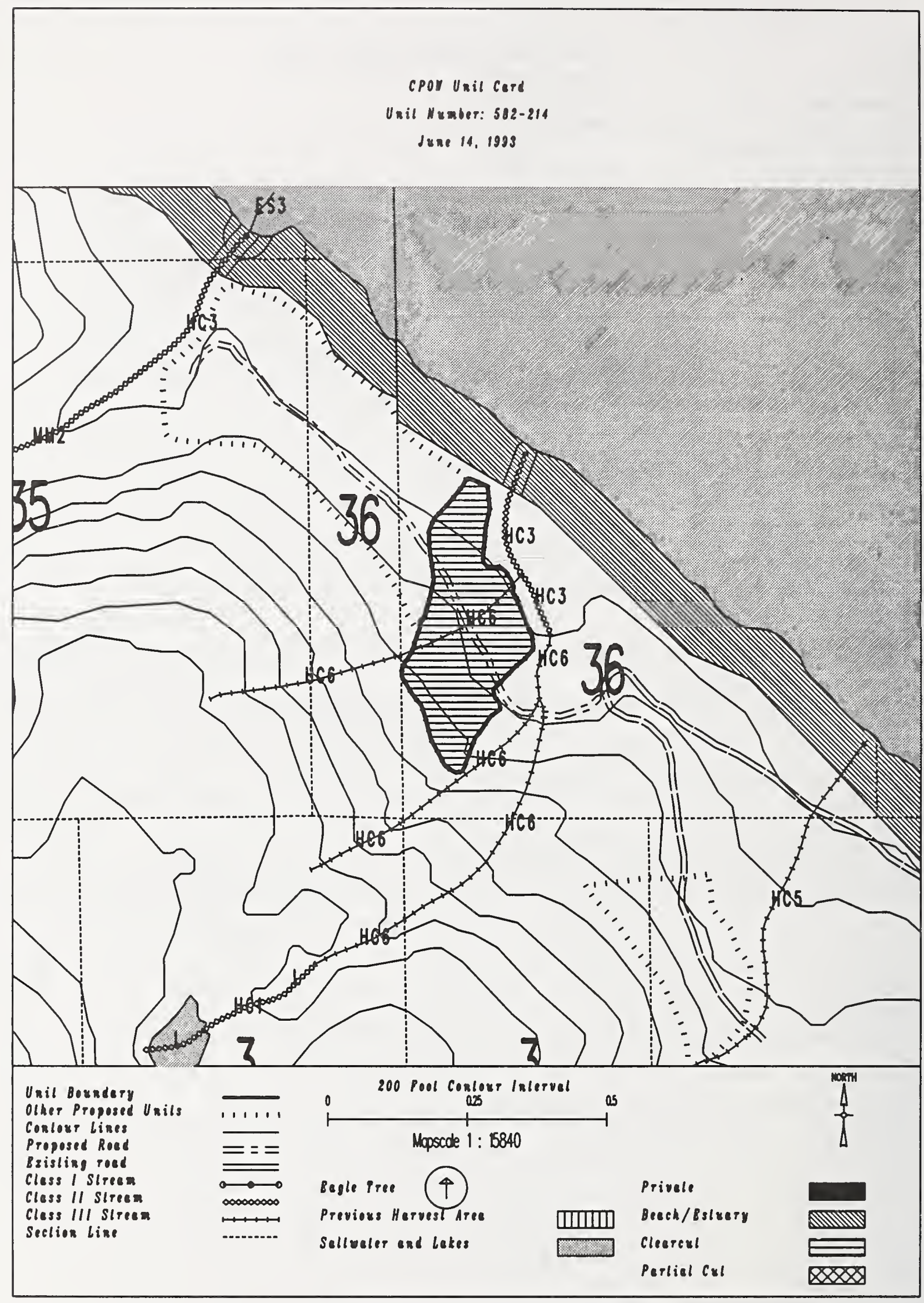


Unit 582-215

Planned acres 77

Est imated volume (mbf) 3417

Logging system skyline

silvicultural system clearcut

Forest type Mixed conifer

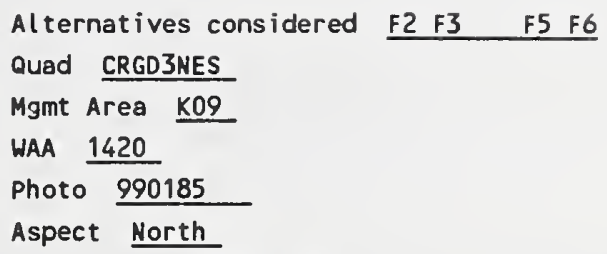

\section{PHYSICAL DESCRIPTION}

Volume class breakdown: vC4 16 acres VC5 6 acres vC6 14 acres vC7 46 acres

Elevation breakdown: $0-800 \mathrm{ft} . \underline{72}$ acres $800-1200 \mathrm{ft} . \underline{0}$ acres $1200-1500 \mathrm{ft} . \underline{0}$ acres over $1500 \mathrm{ft}$. 0 Mass movement index: Low 0 acres Medium 17 acres High 48 acres Very High 0 acres

\section{SOILS}

This unit has high mass movement index soils. Partial log suspension required over these areas.(BMP13.9) This unit contains 30 acres of forested wetlands. Site specific BMPs will be designed for selected approved logging system and road construction practices. (BMPs 12.5, 13.9, 13.15).

\section{TIMBER}

There are no timber mitigation measures anticipated for this unit.

\section{ENGINEERING}

Very difficult road construction due to unstable, slope $>75 \%$ or extended steep grades.

May need to revise logging system to helicopter.

High mass movement index soils. Road construction must minimize landslide potential (BMP14).

\section{FISH/WATERSHED}

There are no fishery mitigation measures anticipated for this unit.

\section{HILDLIFE}

There are no wildlife mitigation measures anticipated for this unit.

\section{RECREATION / VISUALS}

The unit has a proposed voo of $M$ within the viewshed of Baird Peak

as viewed from ferry/cruise ship route (2-4 miles off shore).

Design of leave strip necessary to reduce opening size < 100 acres shall be coordinated with a Landscape Architect.

\section{LANDS}

There are no lands mitigation measures anticipated for this unit.

CULTURAL RESOURCES

There are no cultural resource mitigation measures anticipated for this unit.

There are no karst mitigation measures anticipated for this unit. 
CPOI Unil Cerd

Unil Number: 582-215

Juxe 14, 1999

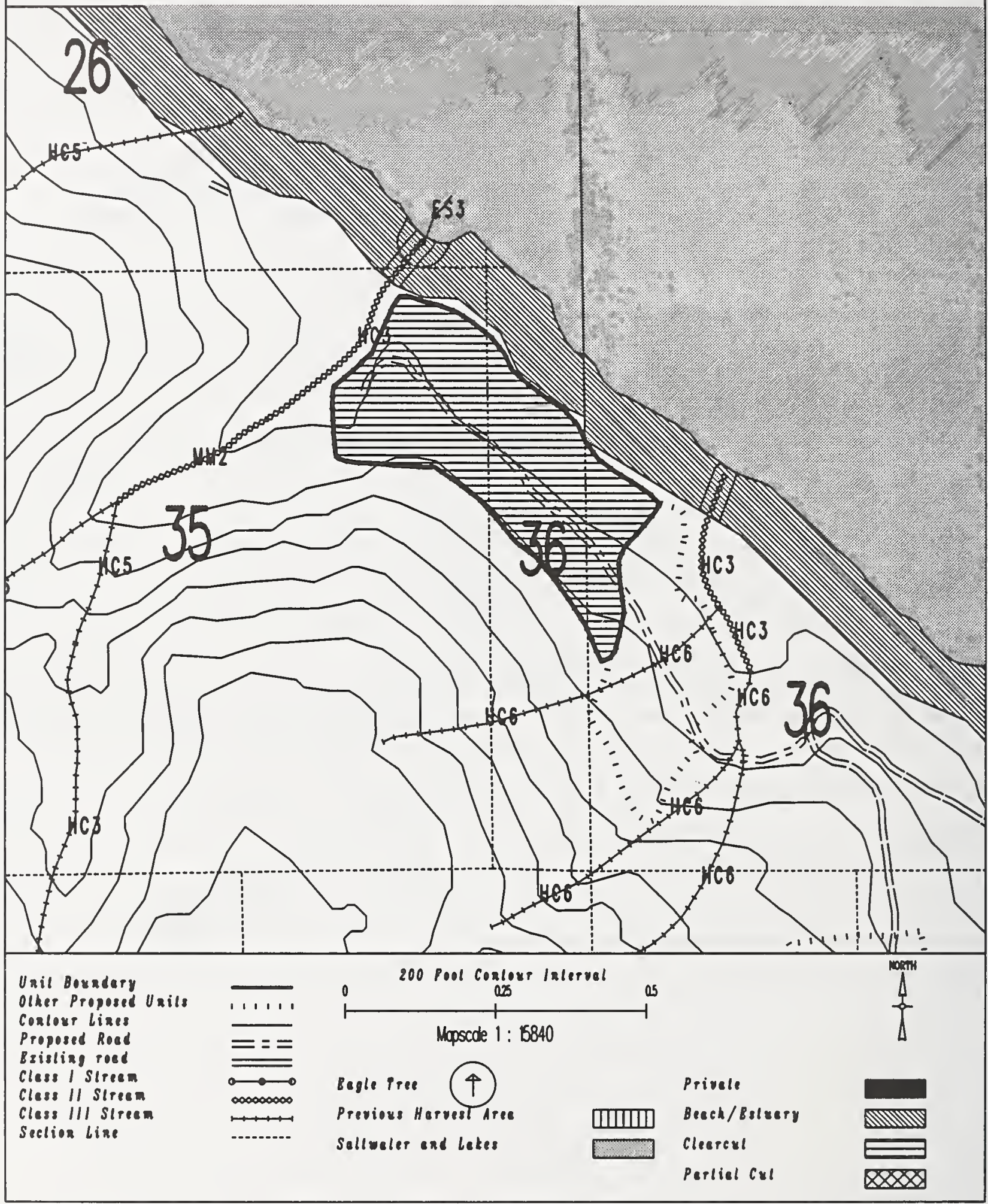




\section{Unit}

Planned acres 46

Estimated volume (mbf) $\underline{2210}$

Logging system Helicopter

silvicultural system clearcut

Forest type spruce
Alternatives considered F2 F 4 F5 F6

Quad CRGD3NEN

Mgmt Area KO9

WAA 1420

Photo 990186

Aspect North

PHYSICAL DESCRIPTION

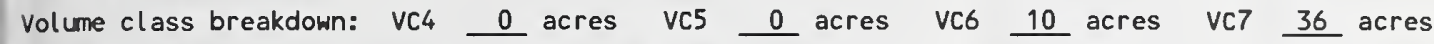

Elevation breakdown: $0-800 \mathrm{ft} .14$ acres $800-1200 \mathrm{ft} .17$ acres $1200-1500 \mathrm{ft} .11$ acres over $1500 \mathrm{ft}$. 0 acres Mass movement index: Low 0 acres Medium 0 acres High 41 acres Very High 0

\section{SOILS}

This unit has high mass movement index soils. Partial log suspension required over these areas.(BMP13.9)

This unit has a significant possibility to have areas reclassified as MMI $=4$.

\section{TIMBER}

There are no timber mitigation measures anticipated for this unit.

\section{ENGINEER ING}

There are no engineering mitigation measures anticipated for this unit.

\section{FISH/WATERSHED}

This unit contains a $\underline{A} 1$ class $\underline{3}$ stream. No specific buffer required, but full suspension, if yarding across.

\section{WILDLIFE}

There are no wildlife mitigation measures anticipated for this unit.

\section{RECREATION / VISUALS}

The unit has a proposed VQo of $M$ within the viewshed of Baird Peak as viewed from ferry/cruise ship route (2-4 miles off shore).

\section{LANDS}

There are no lands mitigation measures anticipated for this unit.

CULTURAL RESOURCES

There are no cultural resource mitigation measures anticipated for this unit. 


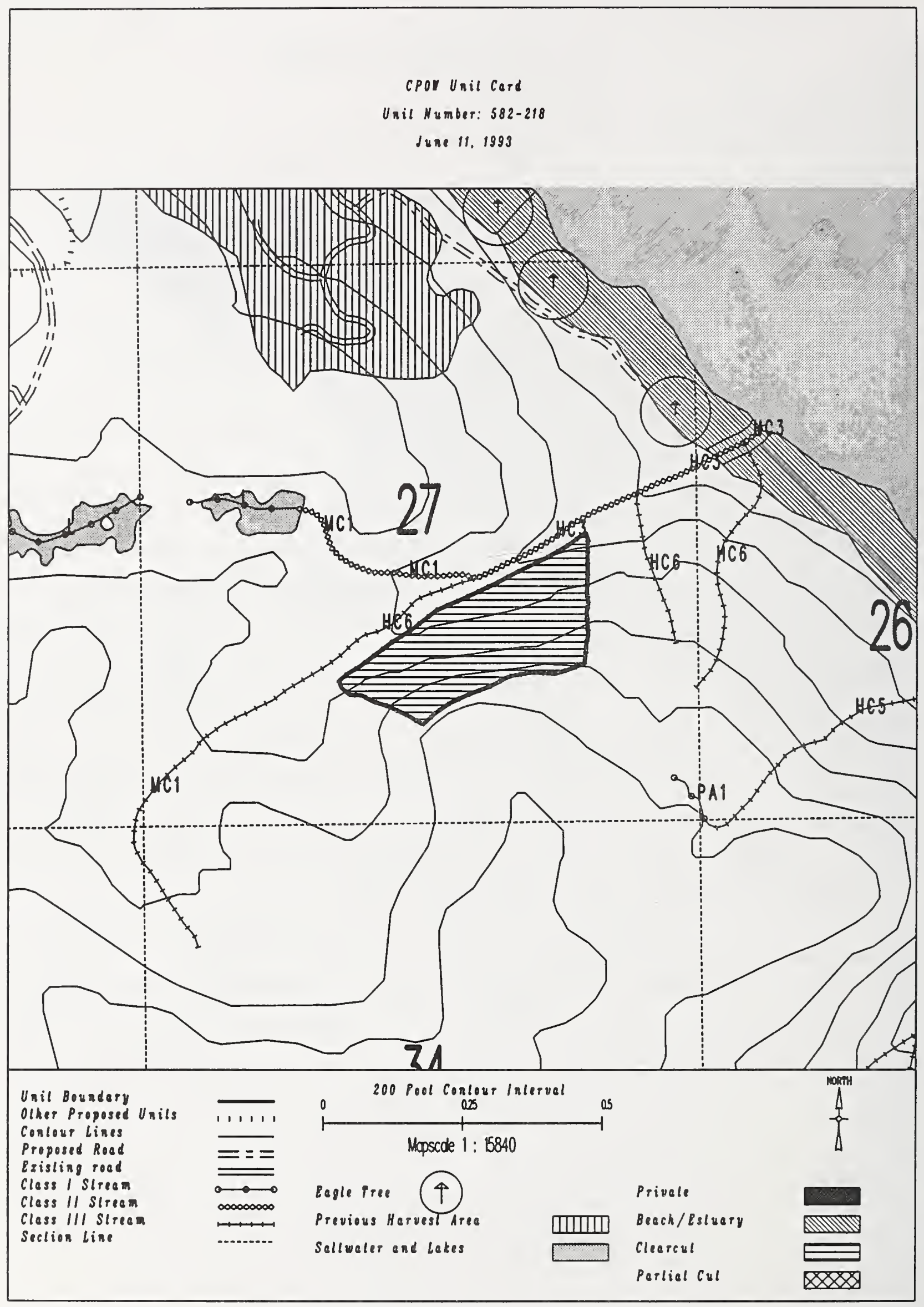


Unit $\quad 583-214$

Planned acres 10

Estimated volume (mbf) 248

Logging system skyline

silvicultural system clearcut

Forest type Hemlock

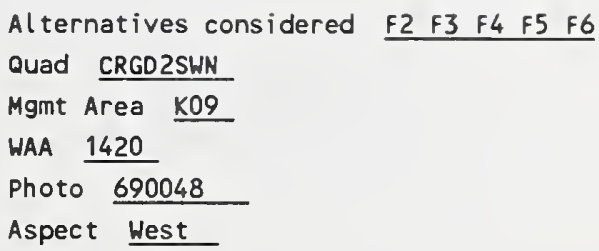

PHYSICAL DESCRIPTION

Volume class breakdown: VC4 $\quad 9$ acres VC5 $\quad 0$ acres vc6 $\quad 0$ acres vc7 1

Elevation breakdown: $0-800 \mathrm{ft} . \quad \frac{7}{7}$ acres $800-1200 \mathrm{ft} . \quad 0$ acres $1200-1500 \mathrm{ft} . \underline{0}$ acres over $1500 \mathrm{ft}$. 0 acres Mass movement index: Low 0 acres Medium 0 acres High 5 acres Very High 0 acres

SOILS

This unit has high mass movement index soils. Partial log suspension required over these areas. (BMP13.9)

TIMBER

There are no timber mitigation measures anticipated for this unit.

ENGINEERING

There are no engineering mitigation measures anticipated for this unit.

FISH/WATERSHED

There are no fishery mitigation measures anticipated for this unit.

WILDLIFE

There are no wildlife mitigation measures anticipated for this unit.

RECREATION / VISUALS

This unit has a proposed voo of MM and is not seen from any viewpoint identified by this project.

\section{LANDS}

There are no lands mitigation measures anticipated for this unit.

CULTURAL RESOURCES

There are no cultural resource mitigation measures anticipated for this unit.

GEOLOGY

There are no karst mitigation measures anticipated for this unit. 
cpor Unil cerd

Unil Number: 589-214

June 11, 1993

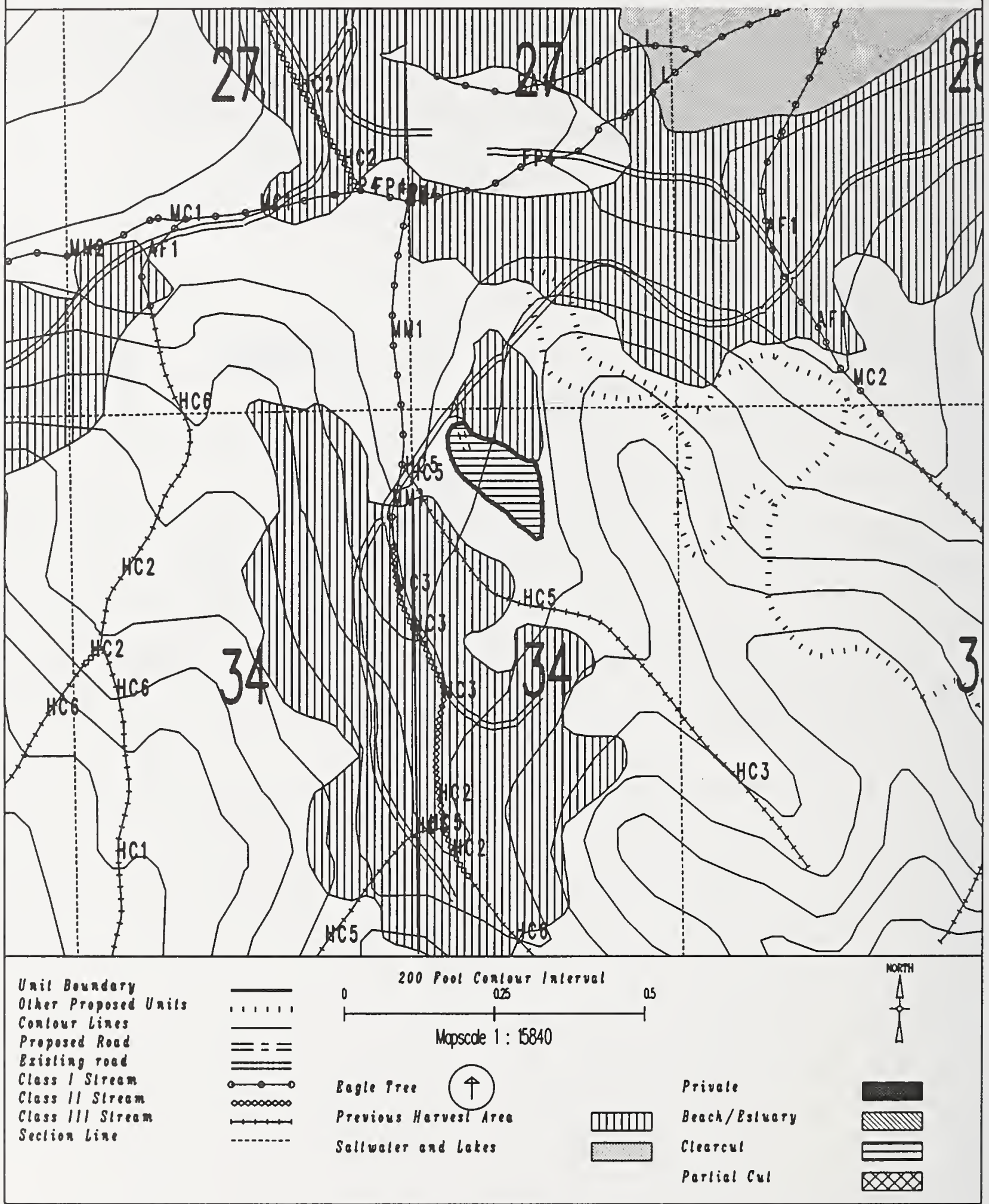


Unit $583-215$

Planned acres 45

Estimated volume (mbf) 1056

Logging system Helicopter

silvicultural system clearcut

Forest type Hemlock
Alternatives considered F2 F4 F5 F6

Quad CRGD2SWN

Hgmt Area KO9

WAA 1420

Photo 690048

Aspect South

\section{PHYSICAL DESCRIPTION}

Volume class breakdown: VC4 39 acres VC5 5 acres VC6 1 acres VC7 $\quad 0$ acres

Elevation breakdown: $0-800 \mathrm{ft} . \underline{26}$ acres $800-1200 \mathrm{ft} . \underline{7}$ acres $1200-1500 \mathrm{ft} . \underline{0}$ acres over $1500 \mathrm{ft}$. Mass movement index: Low 2 acres Medium 27 acres High 6 acres Very High 0 acres

SOILS

This unit has high mass movement index soils. Partial log suspension required over these areas. (BMP13.9)

This unit contains 9 acres of forested wetlands. Site specific BMPs will be designed for selected approved

logging system and road construction practices. (BMPS 12.5, 13.9, 13.15).

\section{TIMBER}

There are no timber mitigation measures anticipated for this unit.

\section{ENGINEER ING}

There are no engineering mitigation measures anticipated for this unit.

\section{FISH/WATERSHED}

This unit contains streams which have recently been classified/channel typed but require field verification.

WILDLIFE

Maintain diversity within unit by leaving 1-5 acre-sized islands of green trees at a rate of 1 acre of island for every 20 acres harvested. Leave islands must be compatible with logging system and safe working conditions.

\section{RECREATION / VISUALS}

This unit has a proposed voo of MM and is not seen from any viewpoint identified by this project.

\section{LANDS}

There are no lands mitigation measures anticipated for this unit.

CULTURAL RESOURCES

There are no cultural resource mitigation measures anticipated for this unit.

\section{GEOLOGY}

There are no karst mitigation measures anticipated for this unit. 


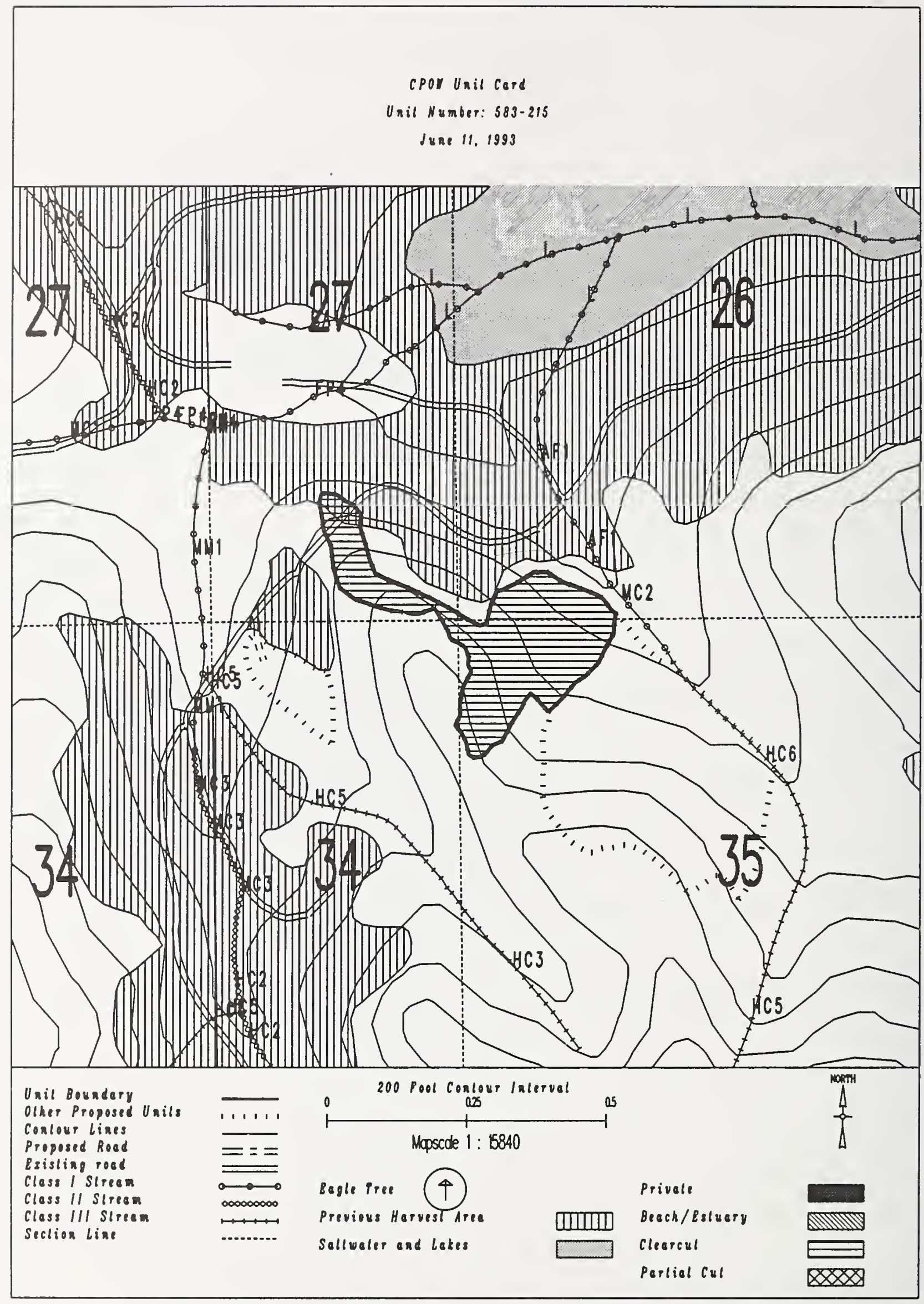


Unit $583-216$

Planned acres 77

Estimated volume (mbf) 2379

Logging system Helicopter

silvicultural system clearcut

Forest type Hemlock

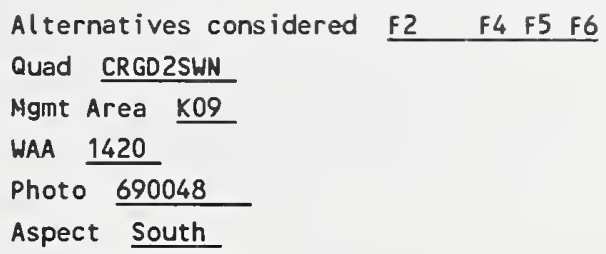

PHYSICAL DESCRIPTION

Volume class breakdown: VC4 $\quad \underline{36}$ acres VC5 $\quad 23$ acres vC6 $\quad 22$ acres vc7 $\quad 0$ acres

Elevation breakdown: $0-800 \mathrm{ft} . \underline{28}$ acres $800-1200 \mathrm{ft} . \underline{33}$ acres $1200-1500 \mathrm{ft} . \underline{4}$ acres over $1500 \mathrm{ft}$. 0 Mass movement index: Low 16 acres Medium 32 acres High 1 acres Very High 0

SOILS

This unit contains 34 acres of forested wetlands. Site specific BMPs will be designed for selected approved logging system and road construction practices. (BMPs 12.5, 13.9, 13.15).

This unit contains 1 acres of slopes $>75 \%$.

TIMBER

There are no timber mitigation measures anticipated for this unit.

ENGINEER ING

There are no engineering mitigation measures anticipated for this unit.

FISH/WATERSHED

This unit contains streams which have recently been classified/channel typed but require field verification.

\section{WILDLI FE}

Maintain diversity within unit by leaving 1-5 acre-sized islands of green trees at a rate of 1 acre of island for every 20 acres harvested. Leave islands must be compatible with logging system and safe working conditions.

RECREATION / VISUALS

This unit has a proposed VQO of MM and is not seen from any viewpoint identified by this project.

\section{LANDS}

There are no lands mitigation measures anticipated for this unit.

CULTURAL RESOURCES

There are no cultural resource mitigation measures anticipated for this unit.

GEOLOGY

There are no karst mitigation measures anticipated for this unit. 


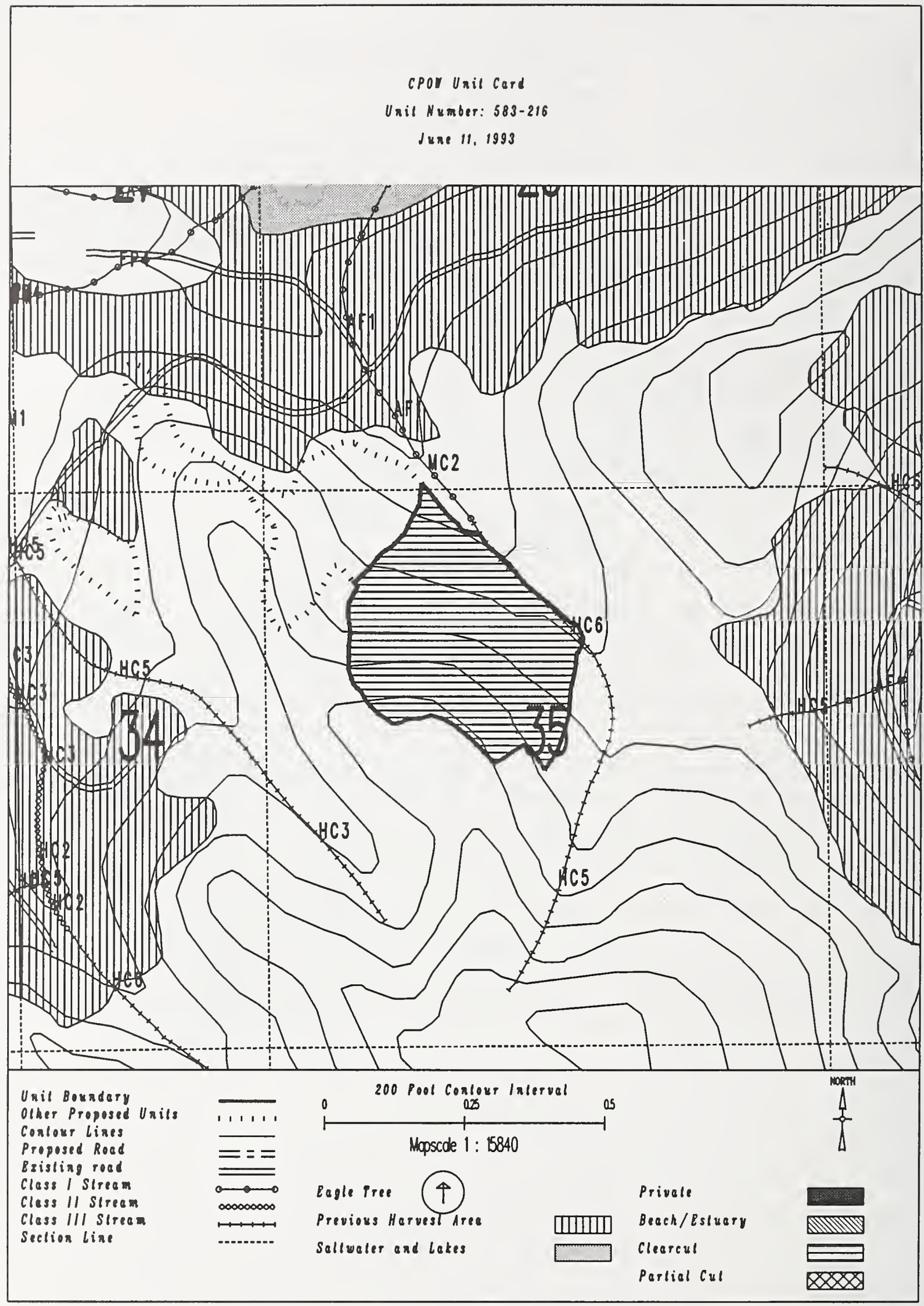


Unit 583-225 B

Planned acres 42

Estimated volume (mbf) 1529

Logging system Helicopter

Silvicultural system clearcut

forest type Mixed conifer
Alternatives considered $\mathrm{F2}$

Quad CRGD2SWN

Mgmt Area K09

WAA 1420

Photo 690050

Aspect West

PHYSICAL DESCRIPTION

Volume class breakdown: VC4 3 acres VC5 4 acres VC6 35 acres vC7 $\quad 0$ acres

Elevation breakdown: $0-800 \mathrm{ft} . \underline{11}$ acres $800-1200 \mathrm{ft} . \underline{4}$ acres $1200-1500 \mathrm{ft} . \underline{2}$ acres over $1500 \mathrm{ft}$. 0 acres Mass movement index: Low 0 acres Medium 0 acres High 41 acres Very High 0 acres

SOILS

This unit has high mass movement index soils. Partial log suspension required over these areas. (BMP13.9)

This unit has a significant possibility to have areas reclassified as MMI $=4$.

This unit contains 16 acres of forested wetlands. Site specific BMPs will be designed for selected approved

logging system and road construction practices. (BMPs 12.5, 13.9, 13.15).

This unit contains 27 acres of slopes $>75 \%$.

TIMBER

There are no timber mitigation measures anticipated for this unit.

ENGINEER ING

There are no engineering mitigation measures anticipated for this unit.

FISH/WATERSHED

There are no fishery mitigation measures anticipated for this unit.

WILDLIFE

There are no wildlife mitigation measures anticipated for this unit.

RECREATION / VISUALS

The unit has a proposed voo of $M$ within the viewshed of Ratz Harbors

as viewed from ferry/cruise ship route (2-4 miles off shore).

\section{LANDS}

There are no lands mitigation measures anticipated for this unit.

CULTURAL RESOURCES

There are no cultural resource mitigation measures anticipated for this unit.

There are no karst mitigation measures anticipated for this unit. 


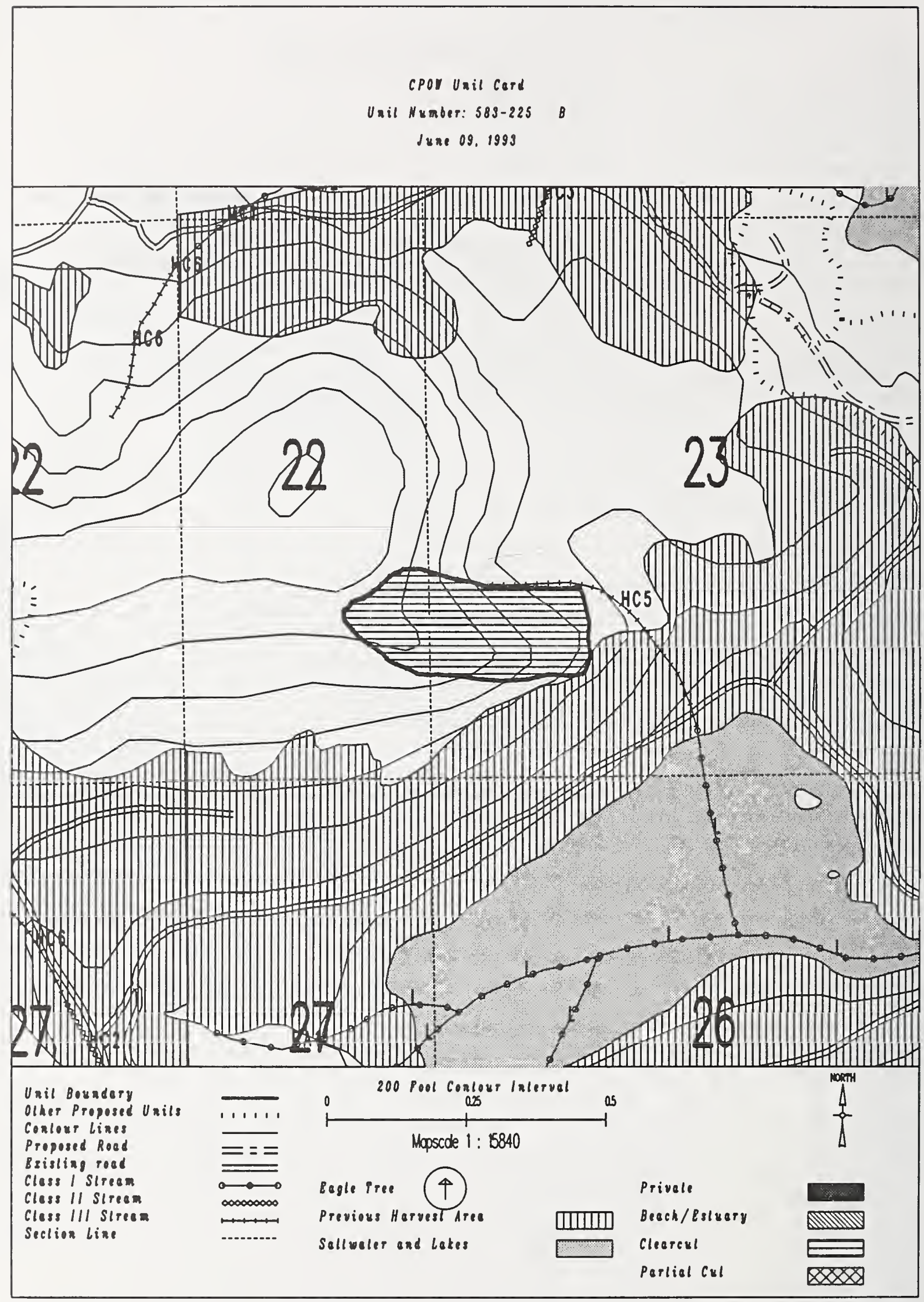


Unit $583-227$

Planned acres 29

Estimated volume (mbf) 635

Logging system Highlead

silvicultural system clearcut

Forest type Hemlock

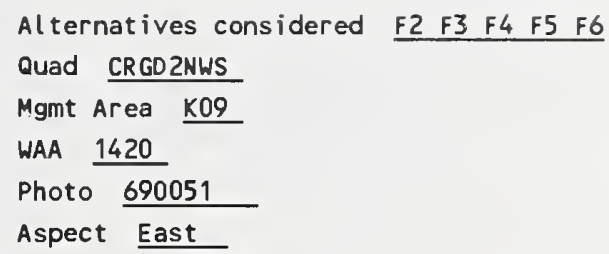

PHYSICAL DESCRIPTION

Volume class breakdown: VC4 29 acres VC5 $\quad 0$ acres VC6 $\quad 0$ acres vc7 $\quad 0$ acres

Elevation breakdown: $0-800 \mathrm{ft} .28$ acres $800-1200 \mathrm{ft} . \quad 0$ acres $1200-1500 \mathrm{ft} . \quad 0$ acres over $1500 \mathrm{ft}$. 0 acres Mass movement index: Low 6 acres Medium 9 acres High 5 acres Very High 0 acres

SOILS

This unit has high mass movement index soils. Partial log suspension required over these areas.(BMP13.9)

This unit contains 17 acres of forested wetlands. Site specific BMPs will be designed for selected approved

logging system and road construction practices. (BMPs 12.5, 13.9, 13.15).

TIMBER

There are no timber mitigation measures anticipated for this unit.

ENGINEERING

There are no engineering mitigation measures anticipated for this unit.

FISH/WATER SHED

Potential for additional Class I/II streams within unit. May be necessary to place additional buffers within unit in accordance with AHMU Handbook.

\section{WILDLIFE}

Maintain adequate distribution of snags by leaving 0.1 acre-sized patches of green trees within the unit for every 10 acres harvested. Snag patches must be compatible with logging system and safe working conditions. Unit is adjacent to estuary or beach fringe; maintain appropriate buffer.

\section{RECREATION / VISUALS}

This unit has a proposed voo of MM and is not seen from any viewpoint identified by this project.

\section{LANDS}

There are no lands mitigation measures anticipated for this unit.

\section{CULTURAL RESOURCES}

There are no cultural resource mitigation measures anticipated for this unit.

There are no karst mitigation measures anticipated for this unit. 


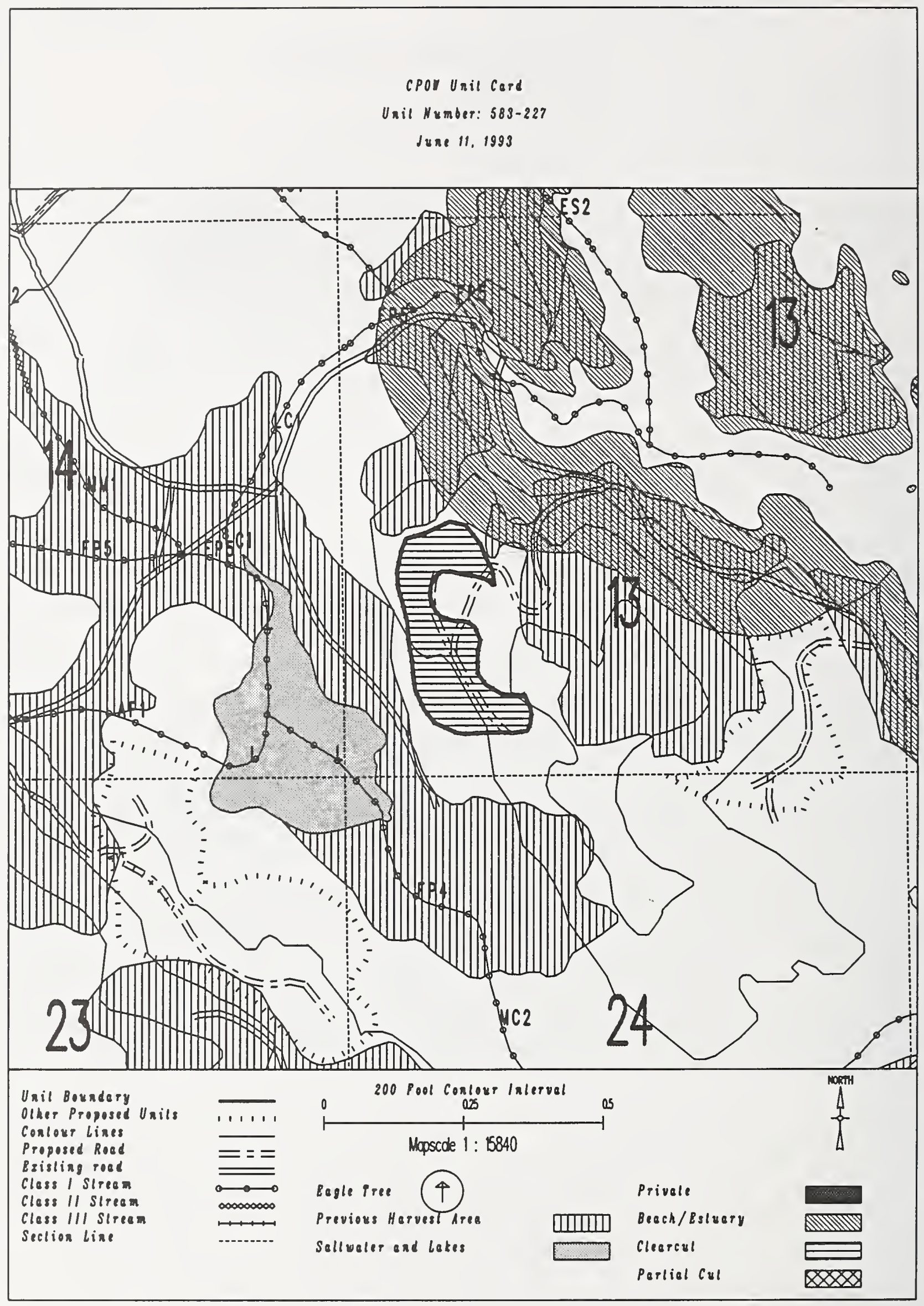




\section{Unit 583-229}

Planned acres 53

Estimated volume (mbf)

logging system skyline

silvicultural system Clearcut

Forest type Mixed conifer

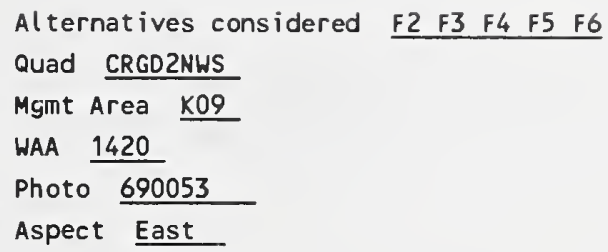

PHYSICAL DESCRIPTION

Volume class breakdown: VC4 48 acres VC5 $\quad 4$ acres VC6 $\quad 0$ acres VC7 $\quad 0$ acres

Elevation breakdown: $0-800 \mathrm{ft} .44$ acres $800-1200 \mathrm{ft} . \underline{0}$ acres $1200-1500 \mathrm{ft} . \underline{0}$ acres over $1500 \mathrm{ft}$. 0 acres Mass movement index: Low 0 acres Medium 0 acres High 43 acres Very High 0 acres

\section{SOILS}

This unit has high mass movement index soils. Partial log suspension required over these areas. (BMP13.9) This unit contains 22 acres of forested wetlands. Site specific BMPs will be designed for selected approved logging system and road construction practices. (BMPS 12.5, 13.9, 13.15).

\section{TIMBER}

There are no timber mitigation measures anticipated for this unit.

\section{ENGINEER ING}

High mass movement index soils. Road construction must minimize landslide potential (BMP14).

\section{FISH/WATERSHED}

This unit contains streams which have recently been classified/channel typed but require field verification.

\section{WILDLIFE}

There are no wildlife mitigation measures anticipated for this unit.

\section{RECREATION / VISUALS}

The unit has a proposed VQO of $M$ within the viewshed of Baird Peak

as viewed from ferry/cruise ship route (2-4 miles off shore).

\section{LANDS}

There are no lands mitigation measures anticipated for this unit.

CULTURAL RESOURCES

There are no cultural resource mitigation measures anticipated for this unit. 
cPor Unil card

Unil Number: 583-229

June 11, 1993

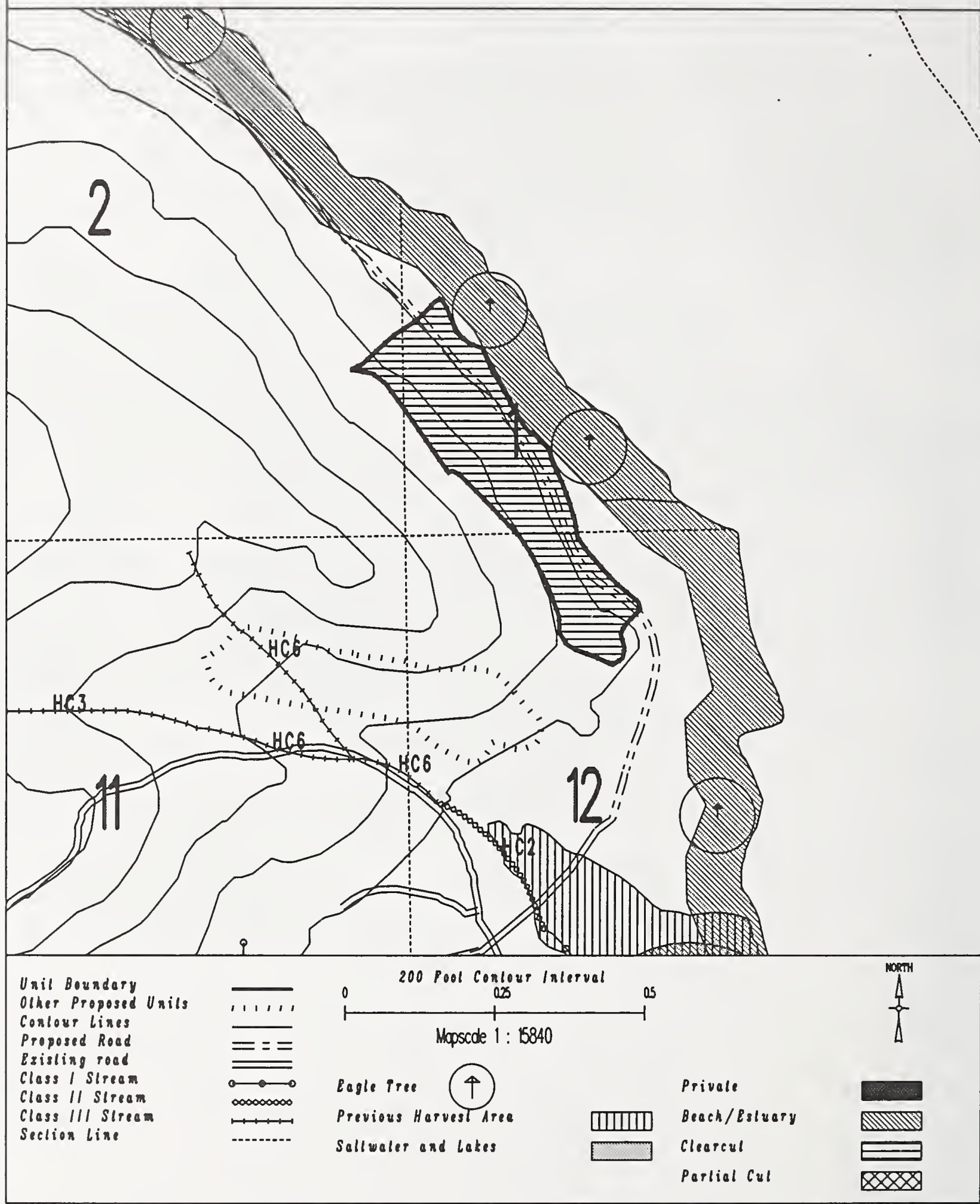




\section{Unit $583-233$}

Planned acres 36

Estimated volume (mbf) 1044

Logging system Helicopter

silvicultural system Partial cut

Forest type Mixed conifer
Al ternatives considered $\quad \mathrm{F} 2 \quad \mathrm{~F} 4 \quad \mathrm{F6}$

Quad CRGD2NWS

Mgmt Area $\mathrm{K} 09$

WAA 1420

Photo 690053

Aspect South

PHYSICAL DESCRIPTION

Volume class breakdown: VC4 13 acres VC5 22 acres VC6 $\quad 1$ acres VC7 $\quad 0$ acres

Elevation breakdown: $0-800 \mathrm{ft} . \underline{32}$ acres $800-1200 \mathrm{ft} . \underline{0}$ acres $1200-1500 \mathrm{ft}$. 0 acres over $1500 \mathrm{ft}$. 0 acres Mass movement index: Low 0 acres Medium 0 acres High. 34 acres Very High 0 acres

\section{SOILS}

This unit has high mass movement index soils. Partial log suspension required over these areas. (BMP13.9)

This unit contains 36 acres of forested wetlands. Site specific BMPs will be designed for selected approved

logging system and road construction practices. (BMPs 12.5, 13.9, 13.15).

This unit contains 31 acres of slopes > $75 \%$.

\section{TIMBER}

Partial cut harvest required to meet specified visual quality objectives.

Water quality streams may be present, where it is impractical to split yard. Full suspension required over all streancourses (BMPs13.9, 13.16).

\section{ENG INEER ING}

There are no engineering mitigation measures anticipated for this unit.

\section{FISH/WATERSHED}

Leave all deciduous and conifer trees (< 12" dbh) in $35 \mathrm{ft}$ buffer adjacent to Class III streams to provide shade. This unit contains a $\underline{A} 1$ class $\underline{3}$ stream. No specific buffer required, but full suspension, if yarding across.

\section{WILDLIFE}

There are no wildlife mitigation measures anticipated for this unit.

\section{RECREATION / VISUALS}

The unit has a proposed voo of $M$ within the viewshed of Ratz Harbors

as viewed from ferry/cruise ship route (2-4 miles off shore).

This unit is prescribed for selective harvest to meet voo proposed for this project.

\section{LANDS}

There are no lands mitigation measures anticipated for this unit.

\section{CULTURAL RESOURCES}

There are no cultural resource mitigation measures anticipated for this unit.

\section{GEOLOGY}

There are no karst mitigation measures anticipated for this unit. 


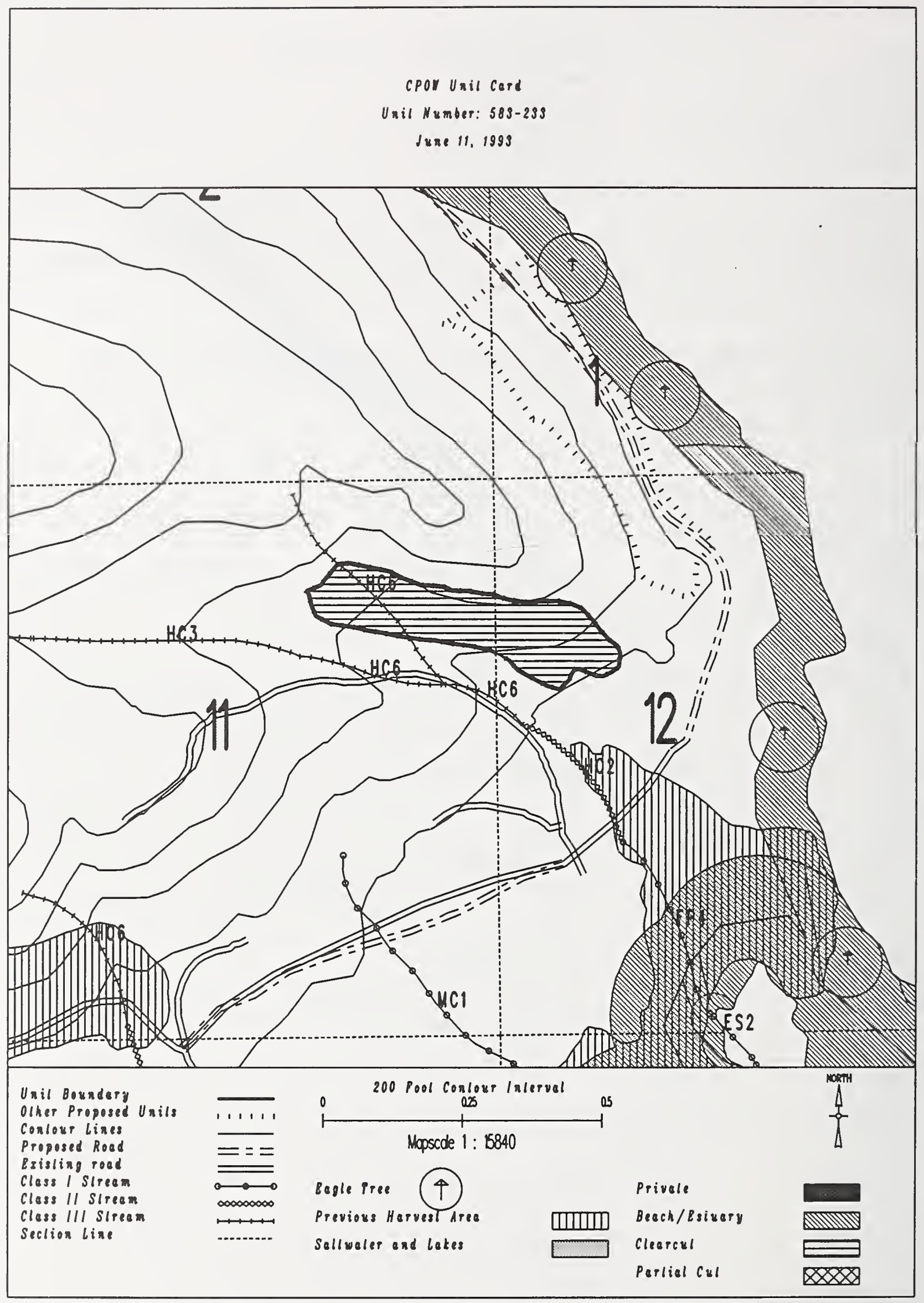


UNIT PLAN/LAYOUT/SALE ADMINISTRATION CARD FOR CPOW FEIS

Unit 583-242

Planned acres 62

Estimated volume (mbf) 2065

Logging system Helicopter

silvicultural system clearcut

Forest type Mixed conifer
Alternatives considered F2 F4 F5 F6

Quad CRGD3SEN

Migmt Area K09

WAA 1420

Photo 990179

Aspect South

\section{PHYSICAL DESCRIPTION}

Volume class breakdown: VC4 0 acres VC5 63 acres VC6 0 acres vc7 0 acres

Elevation breakdown: $0-800 \mathrm{ft} . \underline{0}$ acres $800-1200 \mathrm{ft} . \underline{1}$ acres $1200-1500 \mathrm{ft} . \underline{4}$ acres over $1500 \mathrm{ft}$. 27 acres Mass movement index: Low 3 acres Medium 0 acres High 61 acres Very High 0

\section{SOILS}

This unit has high mass movement index soils. Partial log suspension required over these areas. (BMP13.9)

This unit has > 40\% MCGilvery soils. Partial suspension required (BMP13.9)

to ensure reforestation (BMP13.19).

This unit contains $\underline{25}$ acres of forested wetlands. Site specific BMPs will be designed for selected approved

logging system and road construction practices. (BMPs 12.5, 13.9, 13.15).

This unit contains 45 acres of slopes $>75 \%$.

\section{TIMBER}

There are no timber mitigation measures anticipated for this unit.

\section{ENGINEERING}

There are no engineering mitigation measures anticipated for this unit.

\section{FISH/WATERSHED}

There are no fishery mitigation measures anticipated for this unit.

\section{WILDLIFE}

Maintain diversity within unit by leaving 1-5 acre-sized islands of green trees at a rate of 1 acre of island for every 20 acres harvested. Leave islands must be compatible with logging system and safe working conditions.

RECREATION / VISUALS

This unit has a proposed VQO of MM and is not seen from any viewpoint identified by this project.

\section{LANDS}

There are no lands mitigation measures anticipated for this unit.

\section{CULTURAL RESOURCES}

There are no cultural resource mitigation measures anticipated for this unit.

GEOLOGY

There are no karst mitigation measures anticipated for this unit. 
cPor Unil Cerd

Unit Number: 583-212

dune 11, 1993

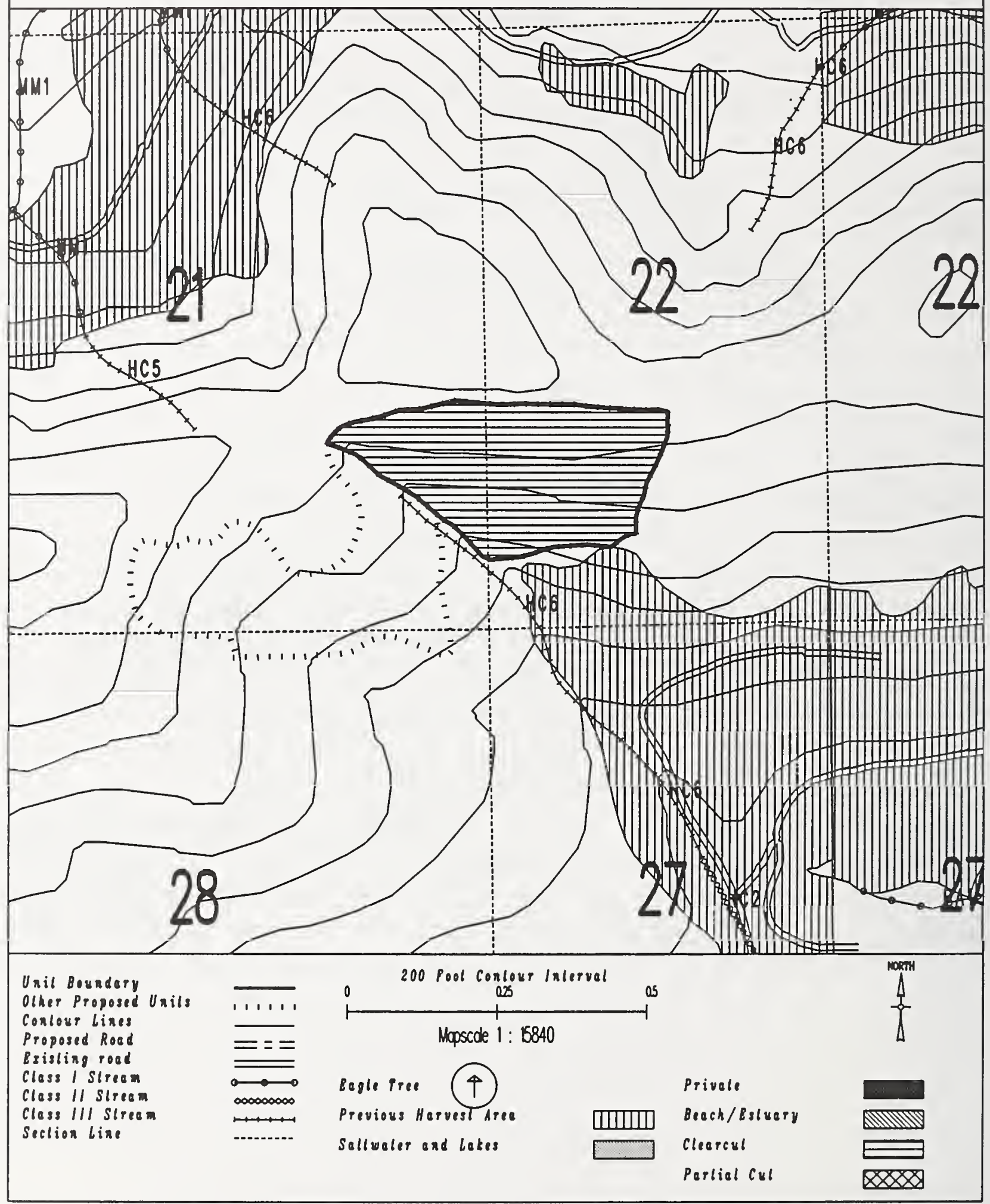


Unit 583-243

Planned acres 61

Estimated volume (mbf) 1695

Logging system Helicopter

silvicultural system clearcut

Forest type Mixed conifer
Alternatives considered

Quad CRGD3SEN

Migmt Area K09

WAA 1420

Photo 990179

Aspect South

PHYSICAL DESCRIPTION

Volume class breakdown: VC4 31 acres VC5 31 acres VC6 $\quad 0$ acres VC7 0 acres

Elevation breakdown: $0-800 \mathrm{ft} . \quad 0$ acres $800-1200 \mathrm{ft} . \underline{5}$ acres 1200-1500 ft. 7 acres over $1500 \mathrm{ft}$. 12 acres Mass movement index: Low 19 acres Medium 0 acres High $\underline{44}$ acres Very High 0

SOILS

This unit has high mass movement index soils. Partial log suspension required over these areas. (BMP13.9)

This unit contains 35 acres of forested wetlands. Site specific BMPs will be designed for selected approved

logging system and road construction practices. (BMPs 12.5, 13.9, 13.15).

This unit contains 25 acres of slopes $>75 \%$.

\section{TIMBER}

There are no timber mitigation measures anticipated for this unit.

ENGI NEERING

There are no engineering mitigation measures anticipated for this unit.

\section{FISH/WATERSHED}

This unit contains a $\underline{A} \mathbf{1}$ class $\underline{3}$ stream. No specific buffer required, but full suspension, if yarding across. This unit contains streams which have recently been classified/channel typed but require field verification.

\section{WILDLIFE}

Maintain diversity within unit by leaving 1-5 acre-sized islands of green trees at a rate of 1 acre of island for every 20 acres harvested. Leave islands must be compatible with logging system and safe working conditions.

RECREATION / VISUALS

This unit has a proposed VQO of MM and is not seen from any viewpoint identified by this project.

\section{LANDS}

There are no lands mitigation measures anticipated for this unit.

CULTURAL RESOURCES

There are no cultural resource mitigation measures anticipated for this unit. 


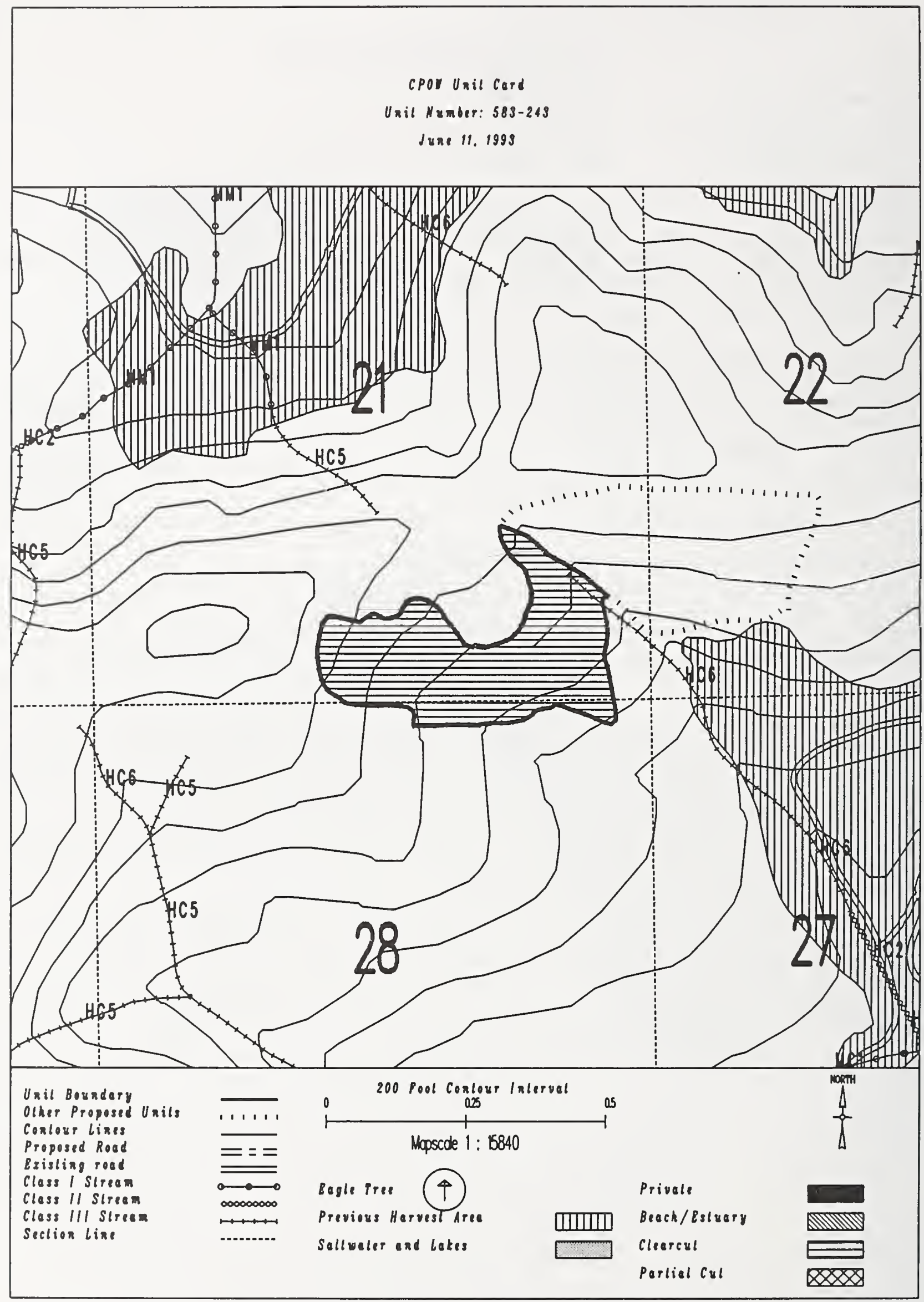


Unit $\quad$ 583-256

Planned acres 31

Estimated volume (mbf)

Logging system skyline

silvicultural system clearcut

Forest type Hemlock

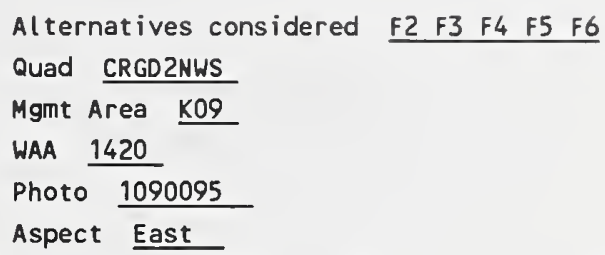

PHYSICAL DESCRIPTION

Volume class breakdown: VC4 30 acres VC5 $\quad 0$ acres VC6 $\quad 0$ acres vc7 $\quad 0$ acres

Elevation breakdown: $0-800 \mathrm{ft} . \underline{30}$ acres $800-1200 \mathrm{ft} . \quad 0$ acres $1200-1500 \mathrm{ft} . \overline{0}$ acres over $1500 \mathrm{ft} . \quad 0$ Mass movement index: Low 7 acres Medium 7 acres High 2 acres Very High 0 acres

SOILS

This unit contains $\underline{24}$ acres of forested wetlands. Site specific BMPs will be designed for selected approved

logging system and road construction practices. (BMPs 12.5, 13.9, 13.15).

TIMBER

Potential for shovel logging on 19 acres, if soil and water quality protected (BMP13.7)

ENGINEERING

There are no engineering mitigation measures anticipated for this unit.

FISH/WATERSHED

There are no fishery mitigation measures anticipated for this unit.

WILDLIFE

Unit is adjacent to estuary or beach fringe; maintain appropriate buffer.

RECREATION / VISUALS

The unit has a proposed VQO of $M$ within the viewshed of Ratz Harbors

as viewed from ferry/cruise ship route (2-4 miles off shore).

LANDS

There are no lands mitigation measures anticipated for this unit.

CULTURAL RESOURCES

There are no cultural resource mitigation measures anticipated for this unit.

GEOLOGY

There are no karst mitigation measures anticipated for this unit. 


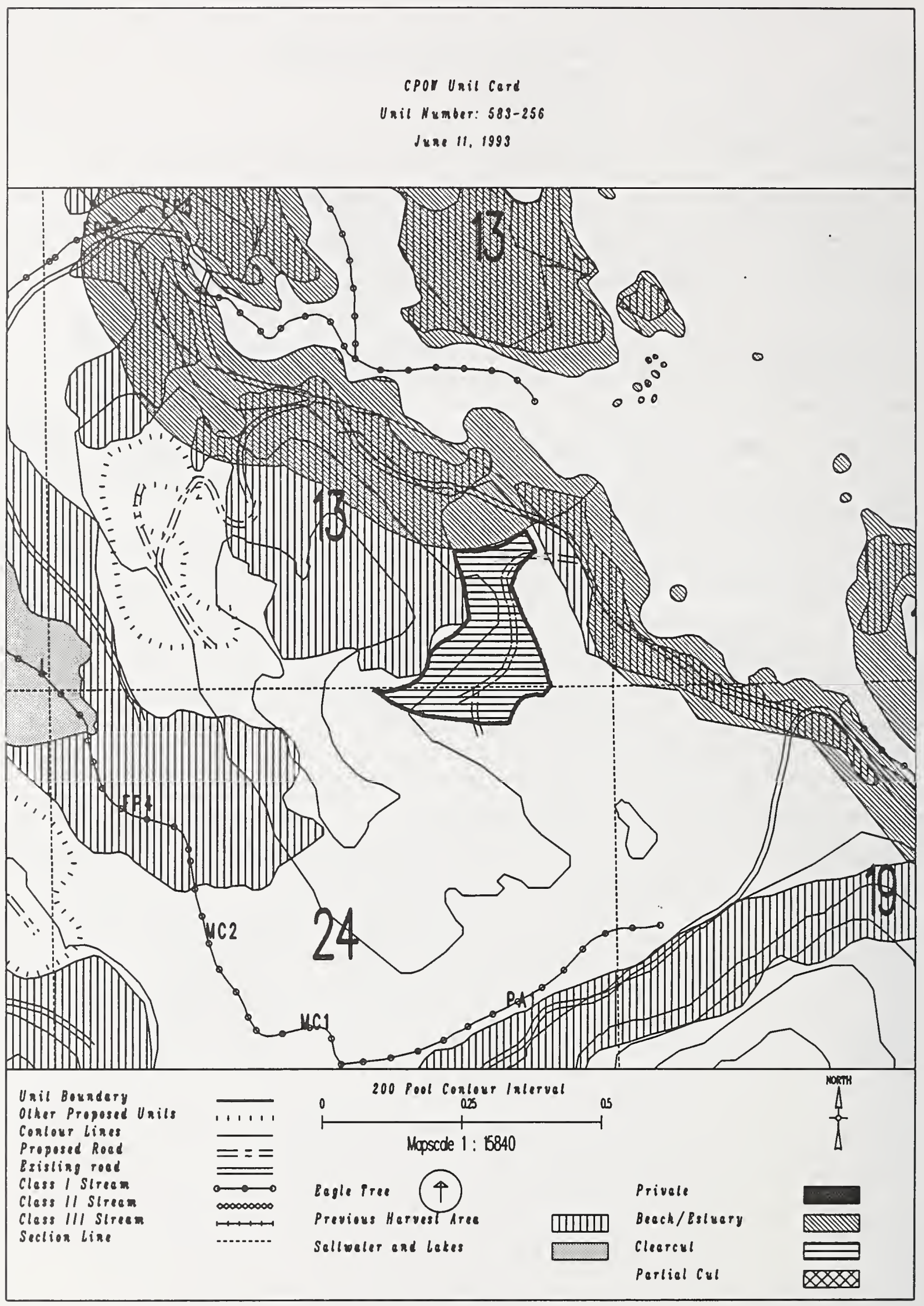


Unit 583-258

Planned acres 80

Estimated volume (mbf) 1596

Logging system skyline

Silvicultural system Riparian

Forest type Hemlock
Alternatives consic
Quad CRGD2SWN
Mgmt Area K09
WAA 1420
Photo 690050
Aspect South

PHYSICAL DESCRIPTION

Volume class breakdown: VC4 23 acres VC5 44 acres vc6 $\quad 0$ acres vC7 $\quad 0$ acres

Elevation breakdown: $0-800 \mathrm{ft} . \underline{78}$ acres $800-1200 \mathrm{ft} .{ }_{0}$ acres $1200-1500 \mathrm{ft} . \underline{0}$ acres over $1500 \mathrm{ft} . \underline{0}$ acres Mass movement index: Low 69 acres Medium 11 acres High 0 acres Very High 0 acres

SOILS

This unit has a slight possibility to be reclassified as MMI $=4$.

This unit contains 45 acres of forested wetlands. Site specific BMPs will be designed for selected approved logging system and road construction practices. (BMPs 12.5, 13.9, 13.15).

\section{TIMBER}

Uneven-aged harvest for riparian management on an estimated 24 acres.

Potential for shovel logging on 34 acres, if soil and water quality protected (BMP13.7)

\section{ENGINEERING}

High mass movenent index soils. Road construction must minimize landslide potential (BMP14).

\section{FISH/WATERSHED}

There are no fishery mitigation measures anticipated for this unit.

\section{WILDLIFE}

Road construction/harvest operations is not permitted from January 1 to June 30 to protect wolf denning area.

\section{RECREATION / VISUALS}

The unit has a proposed VQO of $M$ within the viewshed of Ratz Harbors

as viewed from ferry/cruise ship route $(2-4 \mathrm{miles}$ off shore).

\section{LANDS}

There are no lands mitigation measures anticipated for this unit.

\section{CULTURAL RESOURCES}

There are no cultural resource mitigation measures anticipated for this unit.

\section{GEOLOGY}

There are no karst mitigation measures anticipated for this unit. 


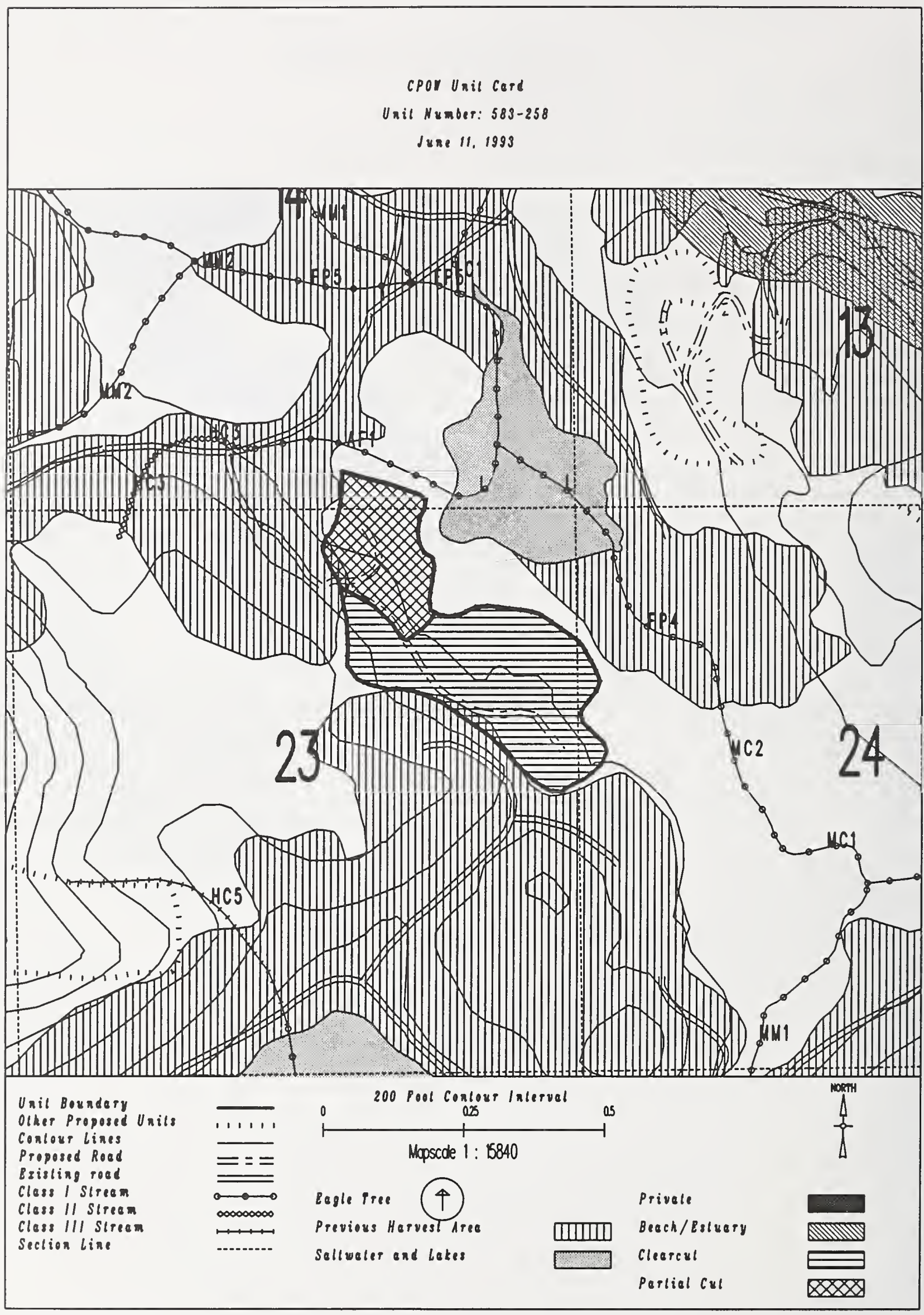


Unit 584-218

Planned acres 57

Estimated volume (mbf) 1629

Logging system skyline

silvicultural system clearcut

Forest type Mixed conifer
Alternatives considered F2 $F 3 \quad F 4 \quad F 5$ F6

Quad CRGD2SWS

Mgmt Area KO9

WAA 1315

Photo 990196

Aspect South

\section{PHYSICAL DESCRIPTION}

Volume class breakdown: VC4 22 acres VC5 35 acres VC6 $\quad 0$ acres VC7 0 acres

Elevation breakdown: $0-800 \mathrm{ft}$. 9 acres $800-1200 \mathrm{ft} .34$ acres $1200-1500 \mathrm{ft}$. 4 acres over $1500 \mathrm{ft}$. 0 acres Mass movement index: Low 23 acres Medium $\_$acres High 11 acres Very High 0

\section{SOILS}

This unit has high mass movement index soils. Partial log suspension required over these areas. (BMP13.9)

This unit has a significant possibility to have areas reclassified as MMI $=4$.

This unit contains 24 acres of forested wetlands. Site specific BMPs will be designed for selected approved

logging system and road construction practices. (BMPs 12.5, 13.9, 13.15).

This unit contains 19 acres of slopes $>75 \%$.

\section{TIMBER}

There are no timber mitigation measures anticipated for this unit.

\section{ENGINEER ING}

Very difficult road construction due to unstable, slope $>75 \%$ or extended steep grades.

May need to revise logging system to helicopter.

High mass movement index soils. Road construction must minimize landslide potential (BMP14).

slopes greater than $75 \%$ may require full bench construction and endhaul of waste (BMP14.7).

\section{FISH/WATERSHED}

There are no fishery mitigation measures anticipated for this unit.

\section{WILDLIFE}

There are no wildlife mitigation measures anticipated for this unit.

\section{RECREATION / VISUALS}

The unit has a proposed VoO of $M$ within the viewshed of Sal Creek

as viewed from ferry/cruise ship route (2-4 miles off shore).

\section{LANDS}

There are no lands mitigation measures anticipated for this unit.

CULTURAL RESOURCES

There are no cultural resource mitigation measures anticipated for this unit.

GEOLOGY

There are no karst mitigation measures anticipated for this unit. 


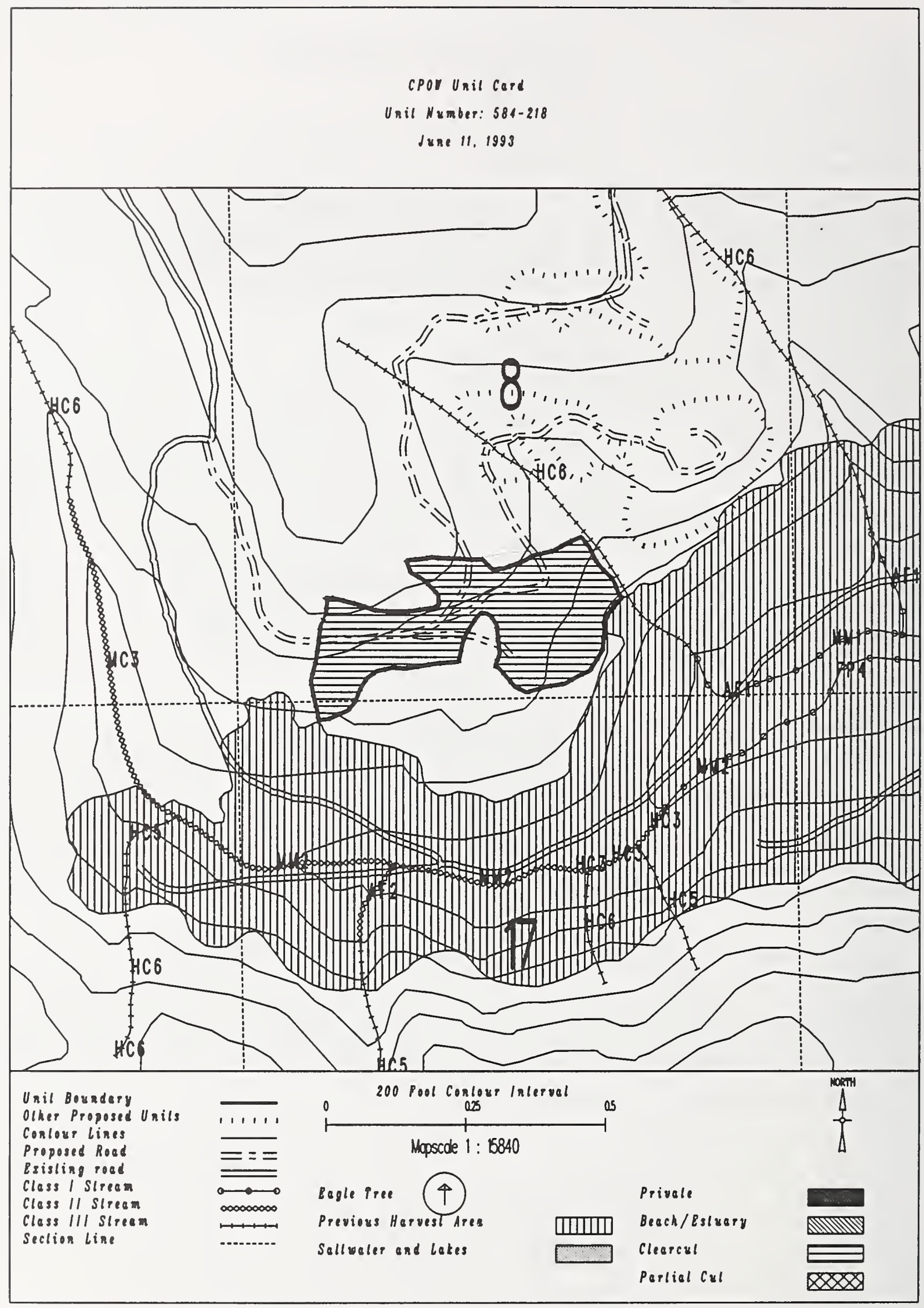


Unit $584-220$

Planned acres 17

Estimated volume (mbf)

Logging system skyline

silvicultural system clearcut

Forest type Hemlock
Alternatives considered $\mathrm{F2} \quad \mathrm{F} 3 \quad \mathrm{~F} 4 \quad \mathrm{F5}$

Quad CRGD2SWS

Mgmt Area K09

WAA 1315

Photo 290003

Aspect East

\section{PHYSICAL DESCRIPTION}

Volume class breakdown: VC4 16 acres VC5 1 acres VC6 $\quad 0$ acres vC7 0 acres

Elevation breakdown: $0-800 \mathrm{ft} . \underline{15}$ acres $800-1200 \mathrm{ft} . \underline{0}$ acres $1200-1500 \mathrm{ft} . \underline{0}$ acres over $1500 \mathrm{ft}$. 0 acres Mass movement index: Low 1 acres Medium 16 acres High 0 acres Very High 0 acres

\section{SOILS}

This unit contains 12 acres of forested wetlands. Site specific BMPs will be designed for selected approved logging system and road construction practices. (BMPs 12.5, 13.9, 13.15).

\section{TIMBER}

Potential for shovel logging on 5 acres, if soil and water quality protected (BMP13.7)

\section{ENGINEER ING}

There are no engineering mitigation measures anticipated for this unit.

\section{FISH/WATERSHED}

This unit contains streams which have recently been classified/channel typed but require field verification.

\section{HILDLIFE}

There are no wildlife mitigation measures anticipated for this unit.

\section{RECREATION / VISUALS}

The unit has a proposed VQO of $M$ within the viewshed of Sal Creek as viewed from ferry/cruise ship route (2-4 miles off shore).

\section{LANDS}

There are no lands mitigation measures anticipated for this unit.

\section{CULTURAL RESOURCES}

There are no cultural resource mitigation measures anticipated for this unit.

\section{GEOLOGY}

There are no karst mitigation measures anticipated for this unit. 


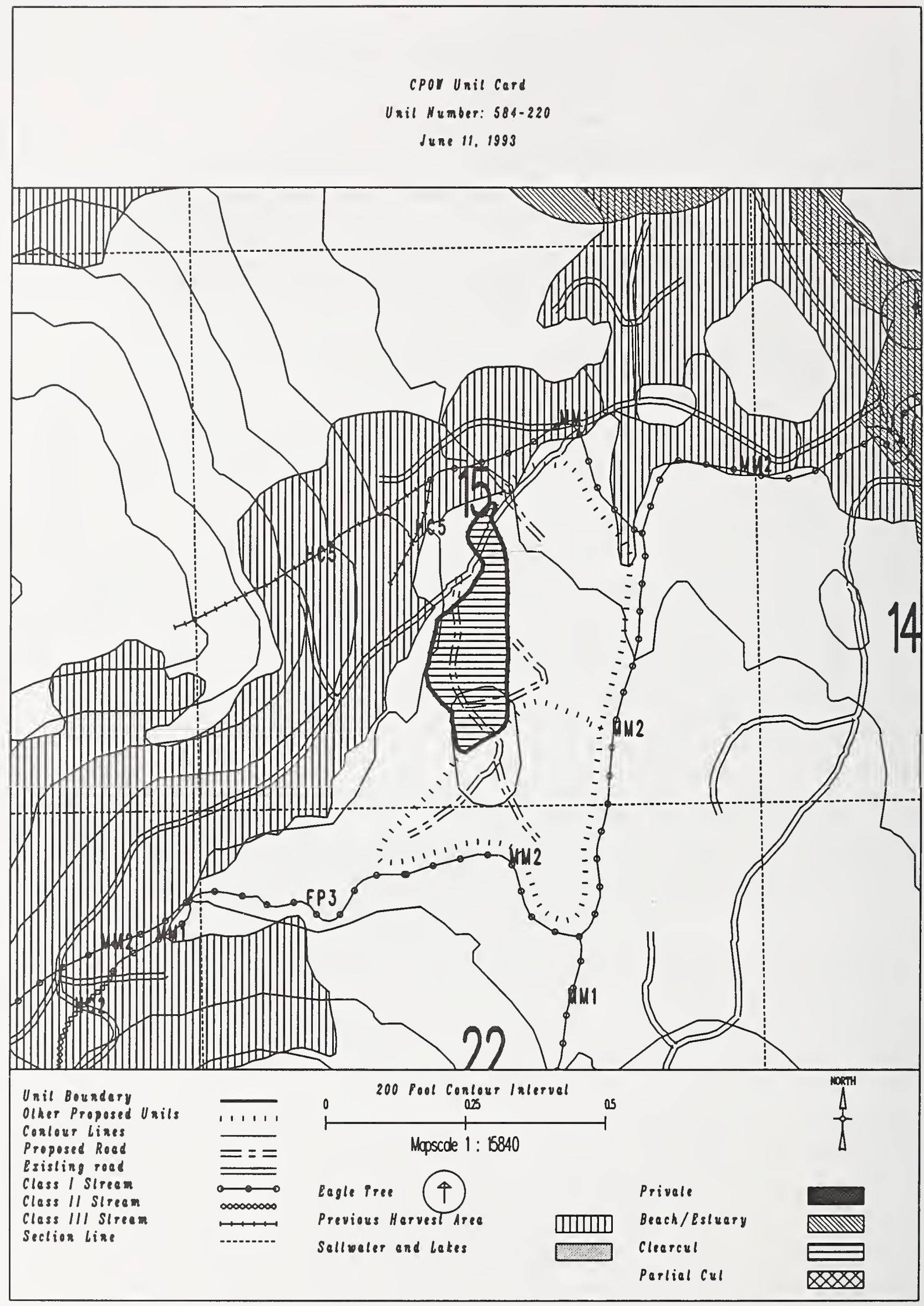


Unit $584-220 \quad B$

Planned acres 35

Estimated volume (mbf) 1006

Logging system skyline

silvicultural system clearcut

Forest type Hemlock

\section{Alternatives considered F2 F3}

Quad CRGD2SWS

Mgmt Area $\underline{K 09}$

WAA 1315

Photo

Aspect East

\section{PHYSICAL DESCRIPTION}

Volume class breakdown: VC4 25 acres vC5 $\quad 14$ acres vC6 $\quad 0$ acres vC7 $\quad 0$ acres

Elevation breakdown: $0.800 \mathrm{ft} . \underline{35}$ acres $800-1200 \mathrm{ft} . \quad 0$ acres $1200-1500 \mathrm{ft} . \underline{0}$ acres over $1500 \mathrm{ft}$. 0 acres Mass movement index: Low 0 acres Medium 32 acres High 6 acres Very High 0 acres

SOILS

This unit has high mass movement index soils. Partial log suspension required over these areas. (BMP13.9)

This unit contains $\underline{24}$ acres of forested wetlands. Site specific BMPs will be designed for selected approved logging system and road construction practices. (BMPs $12.5,13.9,13.15$ ).

\section{TIMBER}

Potential for shovel logging on 33 acres, if soil and water quality protected (BMP13.7)

\section{ENGINEERING}

High mass movement index soils. Road construction must minimize landslide potential (BMP14).

\section{FISH/WATERSHED}

This unit contains streams which have recently been classified/channel typed but require field verification.

\section{WILDLIFE}

There are no wildtife mitigation measures anticipated for this unit.

\section{RECREATION / VISUALS}

The unit has a proposed vQO of $M$ within the viewshed of Sal Creek as viewed from ferry/cruise ship route (2-4 miles off shore).

\section{LANDS}

There are no lands mitigation measures anticipated for this unit.

CULTURAL RESOURCES

There are no cultural resource mitigation measures anticipated for this unit. 


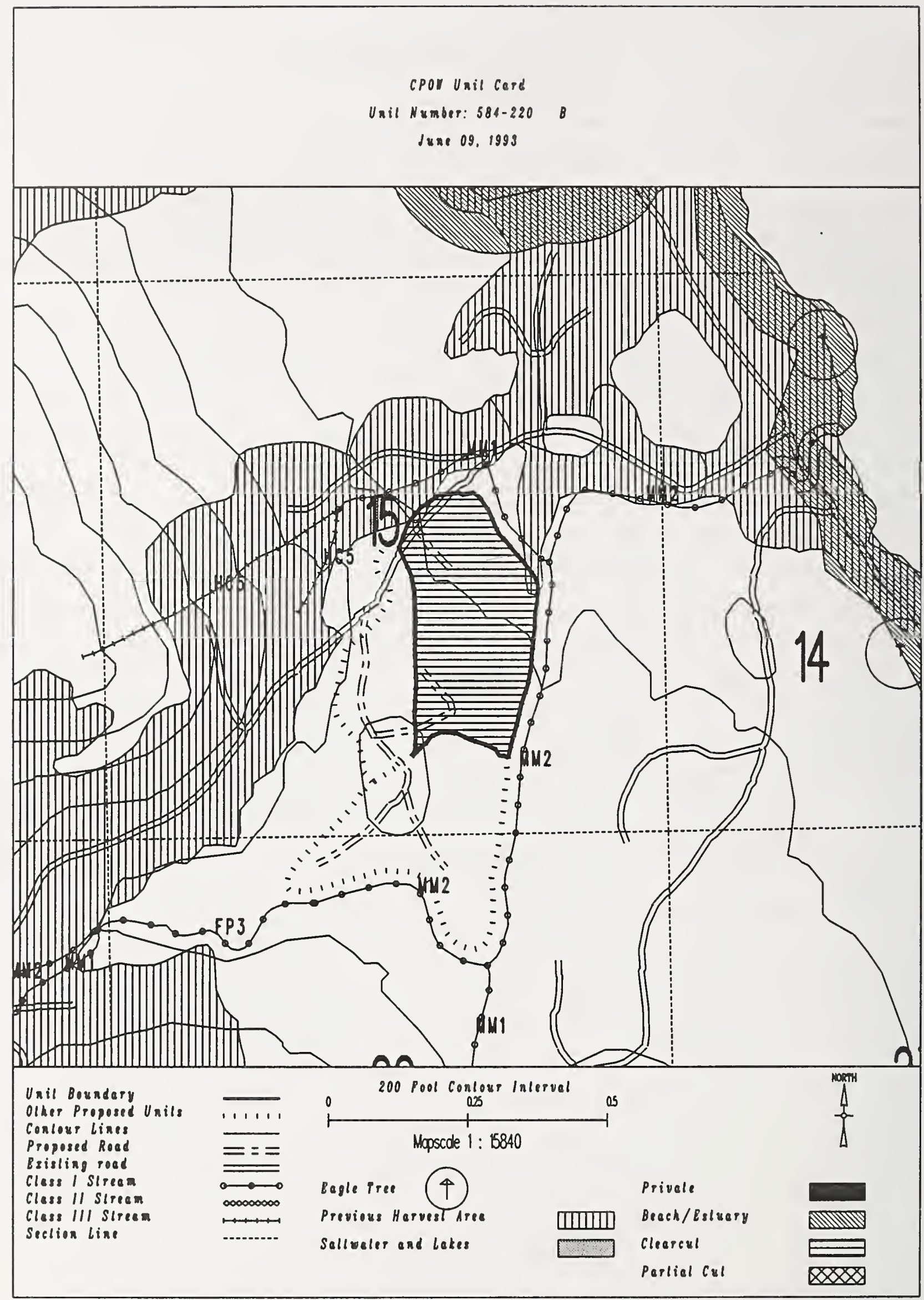




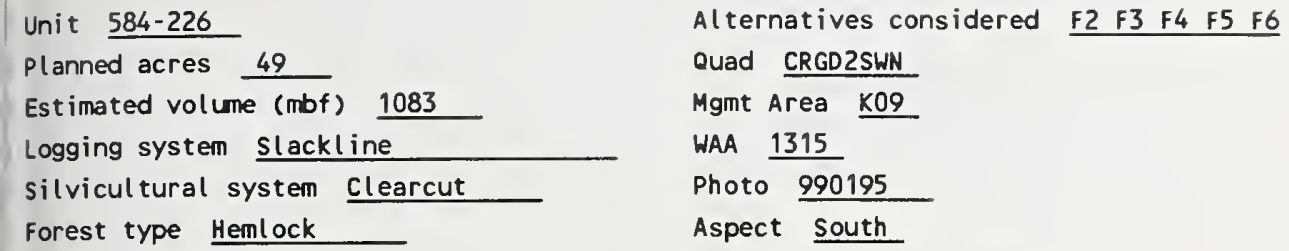

\section{FISH/WATERSHED}

This unit contains a $\underline{A} 1$ class $\underline{3}$ stream. No specific buffer required, but full suspension, if yarding across. This unit contains streams which have recently been classified/channel typed but require field verification.

\section{WILDLIFE}

There are no wildlife mitigation measures anticipated for this unit.

\section{RECREATION / VISUALS}

The unit has a proposed voo of $M$ with in the viewshed of Sal Creek

as viewed from ferry/cruise ship route $(2-4 \mathrm{miles}$ off shore).

\section{LANDS}

There are no lands mitigation measures anticipated for this unit.

\section{CULTURAL RESOURCES}

There are no cultural resource mitigation measures anticipated for this unit.

\section{GEOLOGY}

There are no karst mitigation measures anticipated for this unit. 


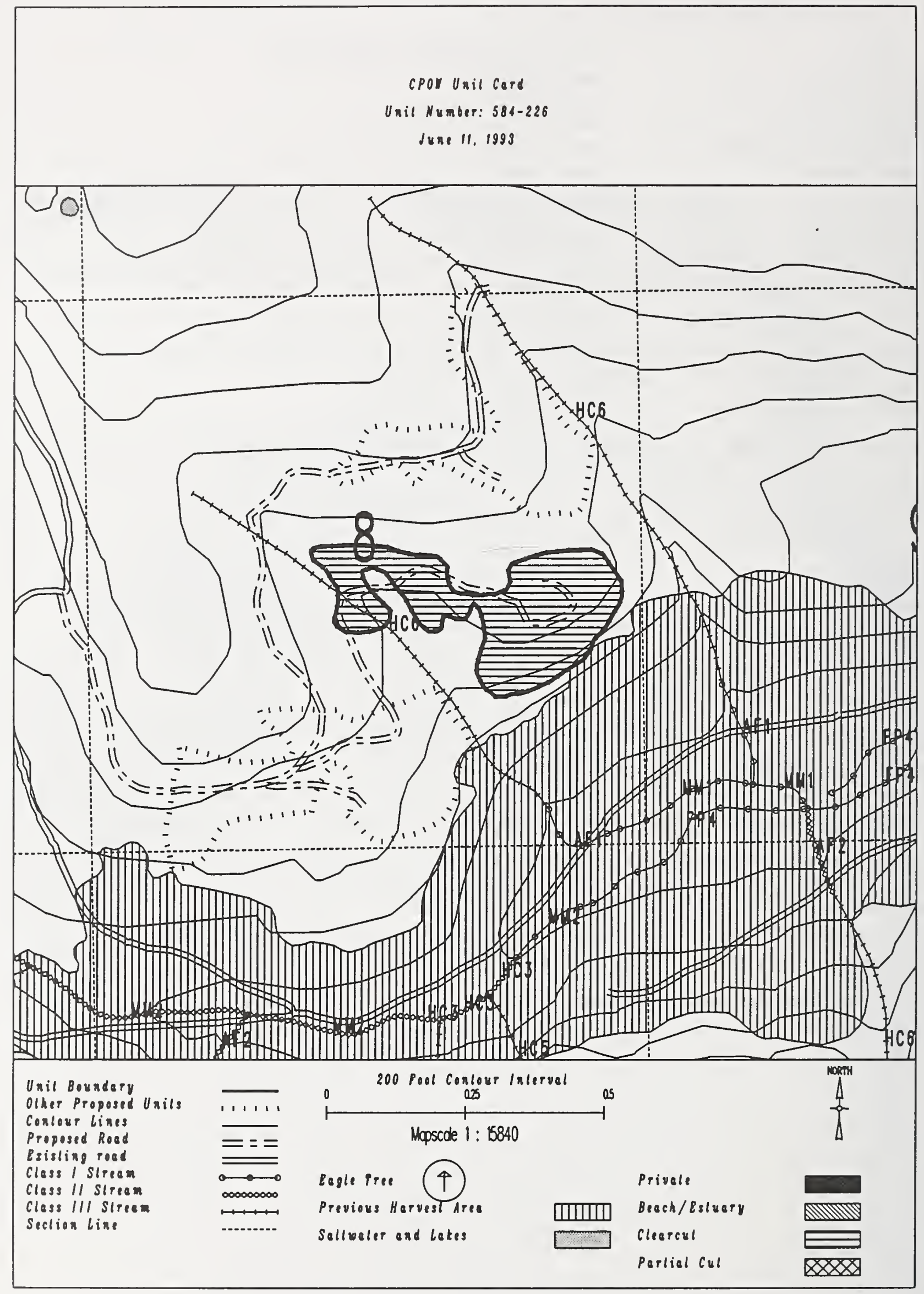


Unit $584-227$

Planned acres 46

Estimated volume (mbf) 941

Logging system slackline

silvicultural system clearcut

Forest type Hemlock
Alternatives considered F2 $\quad$ F4 $\quad$ F5 $\quad$ F6

Quad CRGD2SWN

Mgmt Area KO9

WAA 1315

Photo 990195

Aspect East

\section{PHYSICAL DESCRIPTION}

Volume class breakdown: VC4 43 acres VC5 $\quad 0$ acres VC6 $\quad 0$ acres VC7 $\quad 0$ acres

Elevation breakdown: $0-800 \mathrm{ft}$. $\quad 0$ acres $800-1200 \mathrm{ft} . \quad \ldots$ acres 1200-1500 ft. 6 acres over $1500 \mathrm{ft}$. 0 Mass movement index: Low 22 acres Medium 4 acres High 0 acres Very High 0 acres

SOILS

This unit contains 27 acres of forested wetlands. Site specific BMPs will be designed for selected approved

logging system and road construction practices. (BMPs 12.5, 13.9, 13.15).

\section{TIMBER}

Potential regeneration problem. Monitor regeneration to determine if hand planting is required to meet BMP13.19.

\section{ENGINEER ING}

Very difficult road construction due to unstable, slope $>75 \%$ or extended steep grades.

May need to revise logging system to helicopter.

\section{FISH/WATERSHED}

There are no fishery mitigation measures anticipated for this unit.

\section{WILDLIFE}

There are no wildlife mitigation measures anticipated for this unit.

\section{RECREATION / VISUALS}

The unit has a proposed VQO of $M$ within the viewshed of Sal Creek as viewed from ferry/cruise ship route (2-4 miles off shore).

\section{LANDS}

There are no lands mitigation measures anticipated for this unit.

CULTURAL RESOURCES

There are no cultural resource mitigation measures anticipated for this unit. 


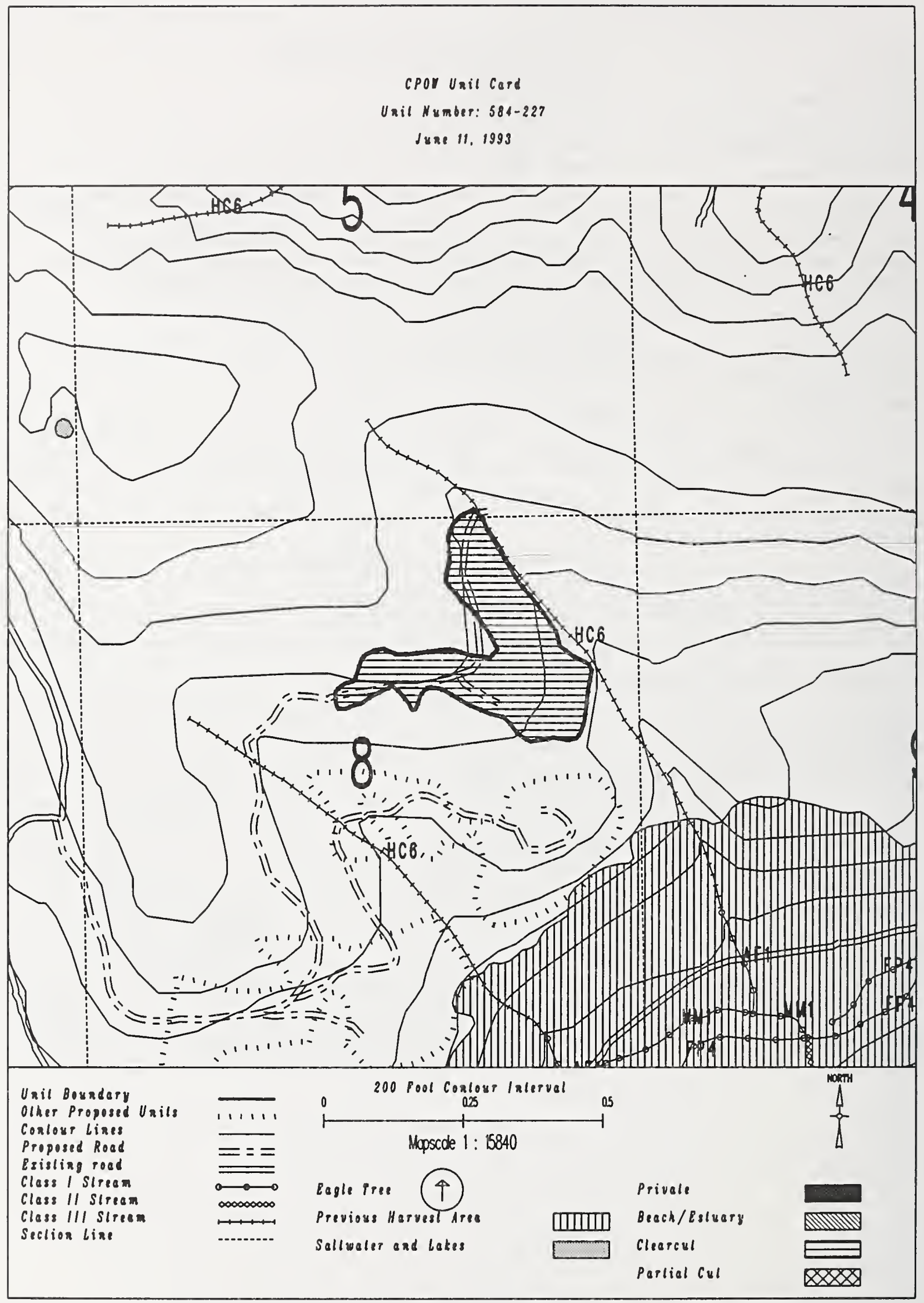


Unit 584-245

Planned acres 35

Est imated volume (mbf) 1082

Logging system Helicopter

silvicultural system clearcut

Forest type Hemlock
Alternatives considered

Quad CRGD2SWN

Mgmt Area KO9

WAA 1315

Photo 1090091

Aspect West

\section{PHYSICAL DESCRIPTION}

Volume class breakdown: VC4 0 acres VC5 33 acres VC6 $\quad 0$ acres VC7 0

Elevation breakdown: $0-800 \mathrm{ft} . \underline{2}$ acres $800-1200 \mathrm{ft} .13$ acres 1200-1500 ft. 16 acres over $1500 \mathrm{ft}$. 0 Mass movement index: Low 14 acres Medium 5 acres High 15 acres Very High 0

\section{SOILS}

This unit has high mass movement index soils. Partial log suspension required over these areas.(BMP13.9)

This unit contains 14 acres of forested wetlands. Site specific BMPs will be designed for selected approved logging system and road construction practices. (BMPs 12.5, 13.9, 13.15).

\section{TIMBER}

There are no timber mitigation measures anticipated for this unit.

\section{ENGINEER ING}

There are no engineering mitigation measures anticipated for this unit.

\section{FISH/WATERSHED}

There are no fishery mitigation measures anticipated for this unit.

\section{WILOLIFE}

There are no wildlife mitigation measures anticipated for this unit.

RECREATION / VISUALS

This unit has a proposed VQO of MM and is not seen from any viewpoint identified by this project.

\section{LANDS}

There are no lands mitigation measures anticipated for this unit.

There are no cultural resource mitigation measures anticipated for this unit. 


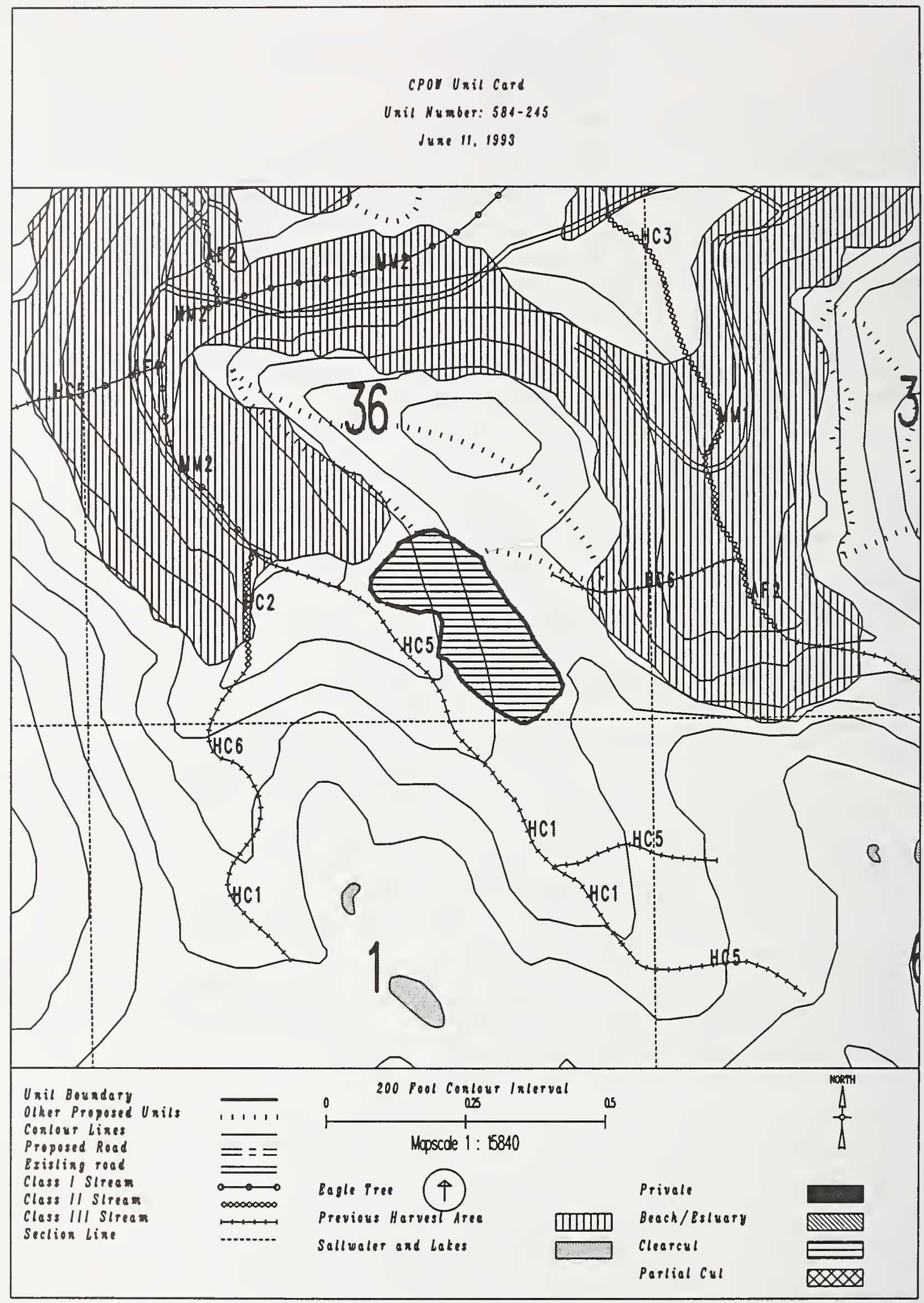


Unit $\quad 584-250$

Planned acres 48

Estimated volume (mbf) 1585

Logging system skyline

silvicultural system clearcut

Forest type Mixed conifer
Alternatives considered F2 $F 3$ F4 F5 F6

Quad CRGO2SWN

Ngmt Area K09

WAA 1315

Photo 990192

Aspect East

PHYSICAL DESCRIPIION

Volume class breakdown: VC4 4 acres VC5 45 acres vC6 $\quad 0$ acres vc7 $\quad 0$ acres

Elevation breakdown: $0-800 \mathrm{ft} . \underline{48}$ acres $800-1200 \mathrm{ft} . \quad 0$ acres $1200-1500 \mathrm{ft} . \underline{0}$ acres over $1500 \mathrm{ft} . \quad 0$ Mass movement index: Low $\underline{21}$ acres Medium 10 acres High 17 acres Very High $\underline{0}$ acres

\section{SOILS}

This unit has high mass movement index soils. Partial log suspension required over these areas. (BMP13.9) This unit contains 33 acres of forested wetlands. Site specific BMPs will be designed for selected approved

logging system and road construction practices. (BMPs 12.5, 13.9, 13.15).

\section{TIMBER}

There are no timber mitigation measures anticipated for this unit.

ENGINEER ING

High mass movement index soils. Road construction must minimize landslide potential (BMP14).

FISH/WATERSHED

There are no fishery mitigation measures anticipated for this unit.

WILDLIFE

Maintain diversity within unit by leaving 1-5 acre-sized islands of green trees at a rate of 1 acre of island for every 20 acres harvested. Leave islands must be compatible with logging system and safe working conditions.

RECREATION / VISUALS

This unit has a proposed VQO of MM and is not seen from any viewpoint identified by this project.

\section{LANDS}

There are no lands mitigation measures anticipated for this unit.

\section{CULTURAL RESOURCES}

There are no cultural resource mitigation measures anticipated for this unit.

GEOLOGY

There are no karst mitigation measures anticipated for this unit. 


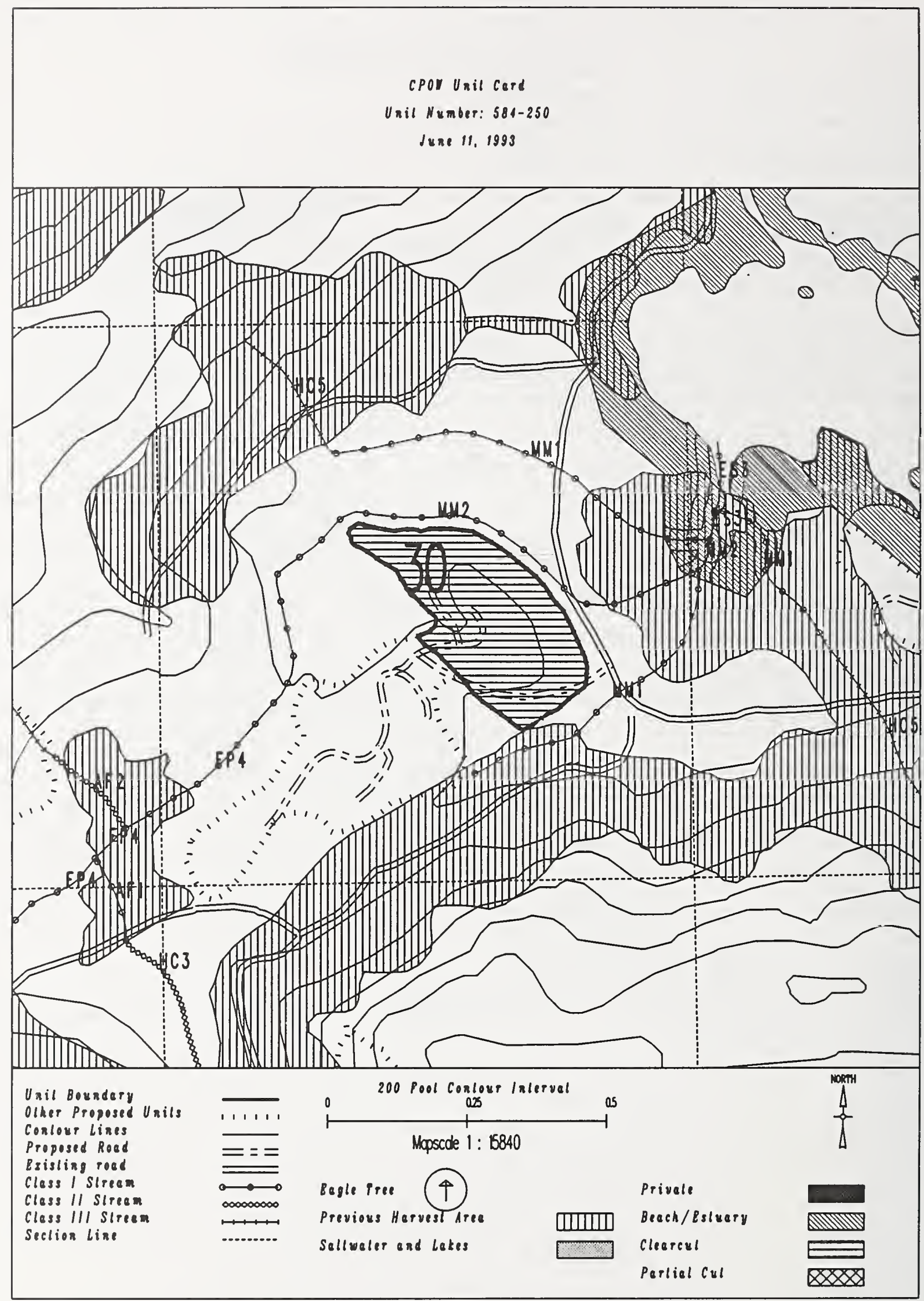




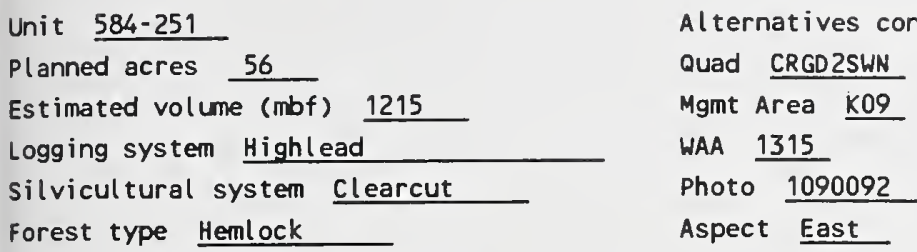

This unit has a proposed VQO of MM and is not seen from any viewpoint identified by this project.

\section{LANDS}

There are no lands mitigation measures anticipated for this unit.

\section{CULTURAL RESOURCES}

There are no cultural resource mitigation measures anticipated for this unit.

\section{GEOLOGY}

There are no karst mitigation measures anticipated for this unit. 


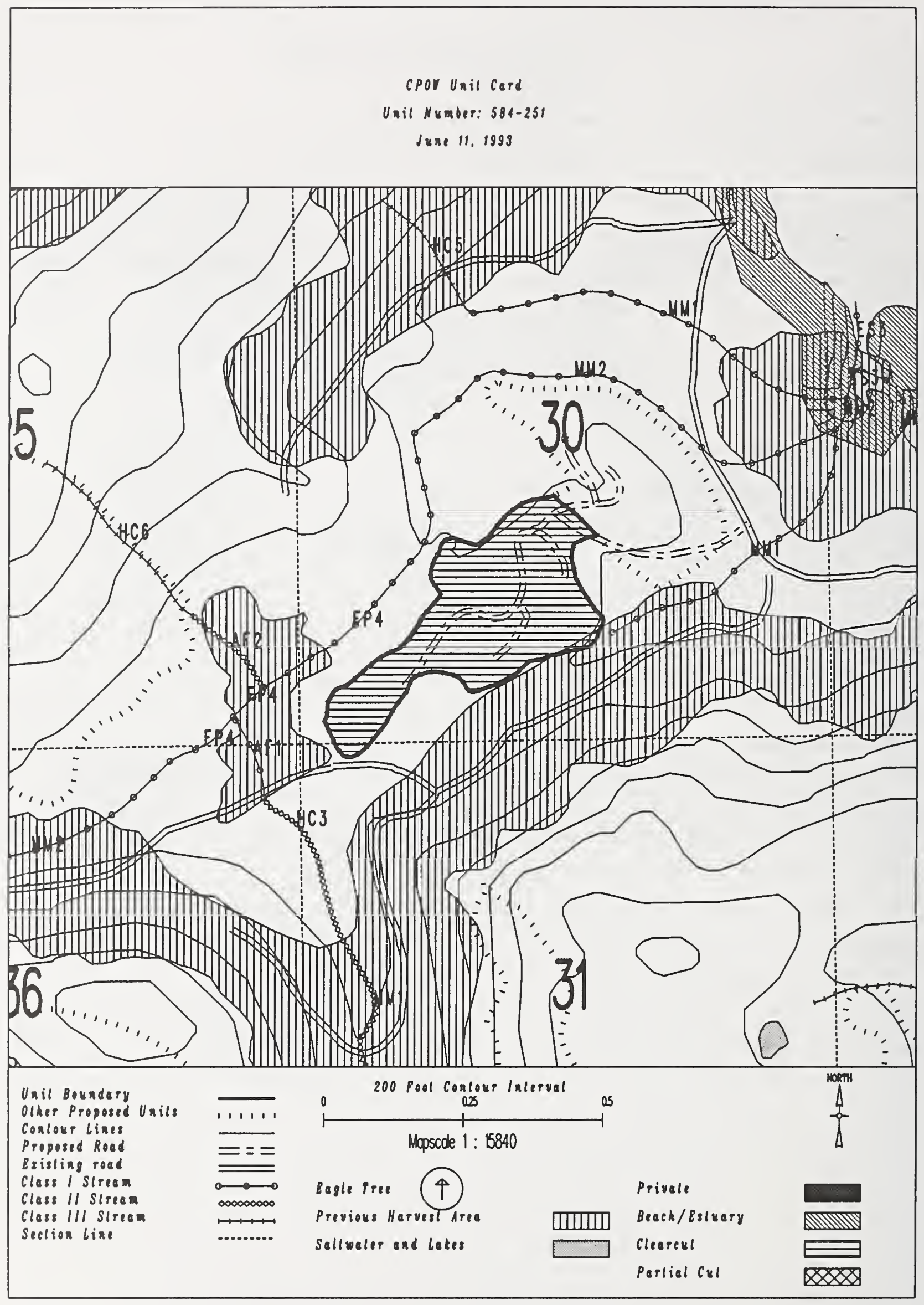


Unit 584-252

Planned acres 25

Estimated volume (mbf)

Logging system Highlead

silvicultural system clearcut

Forest type Hemlock
Al ternatives considered $\quad$ F2 $\quad$ F3 $\quad$ F4 $\quad$ F5 $\quad$ F6

Quad CRGD2SWN

Mgmt Area $\mathrm{K} 09$

WAA 1315

Photo 990192

Aspect North

\section{PHYSICAL DESCRIPTION}

Volume class breakdown: VC4 $\quad 0$ acres VC5 24 acres vc6 $\quad 0$ acres VC7 $\quad 0$ acres

Elevation breakdown: $0-800 \mathrm{ft} . \underline{24}$ acres $800-1200 \mathrm{ft} . \underline{0}$ acres $1200-1500 \mathrm{ft} . \underline{0}$ acres over $1500 \mathrm{ft}$. 0 acres Mass movement index: Low 0 acres Medium 2 acres High 0 acres Very High 0

\section{SOILS}

This unit contains 24 acres of forested wetlands. Site specific BMPs will be designed for selected approved

logging system and road construction practices. (BMPs 12.5, 13.9, 13.15).

\section{TIMBER}

Potential regeneration problem. Monitor regeneration to determine if hand planting is required to meet BMP13.19.

\section{ENGINEER ING}

There are no engineering mitigation measures anticipated for this unit.

\section{FISH/WATERSHED}

There are no fishery mitigation measures anticipated for this unit.

\section{WILDL I FE}

There are no wildlife mitigation measures anticipated for this unit.

\section{RECREATION / VISUALS}

The unit has a proposed VQO of $M$ within the viewshed of Ratz Harbors

as viewed from ferry/cruise ship route (2-4 miles off shore).

\section{LANDS}

There are no lands mitigation measures anticipated for this unit.

\section{CULTURAL RESOURCES}

There are no cultural resource mitigation measures anticipated for this unit. 
CPOY Unil cerd

Unil Number: 581-252

June II, 1993

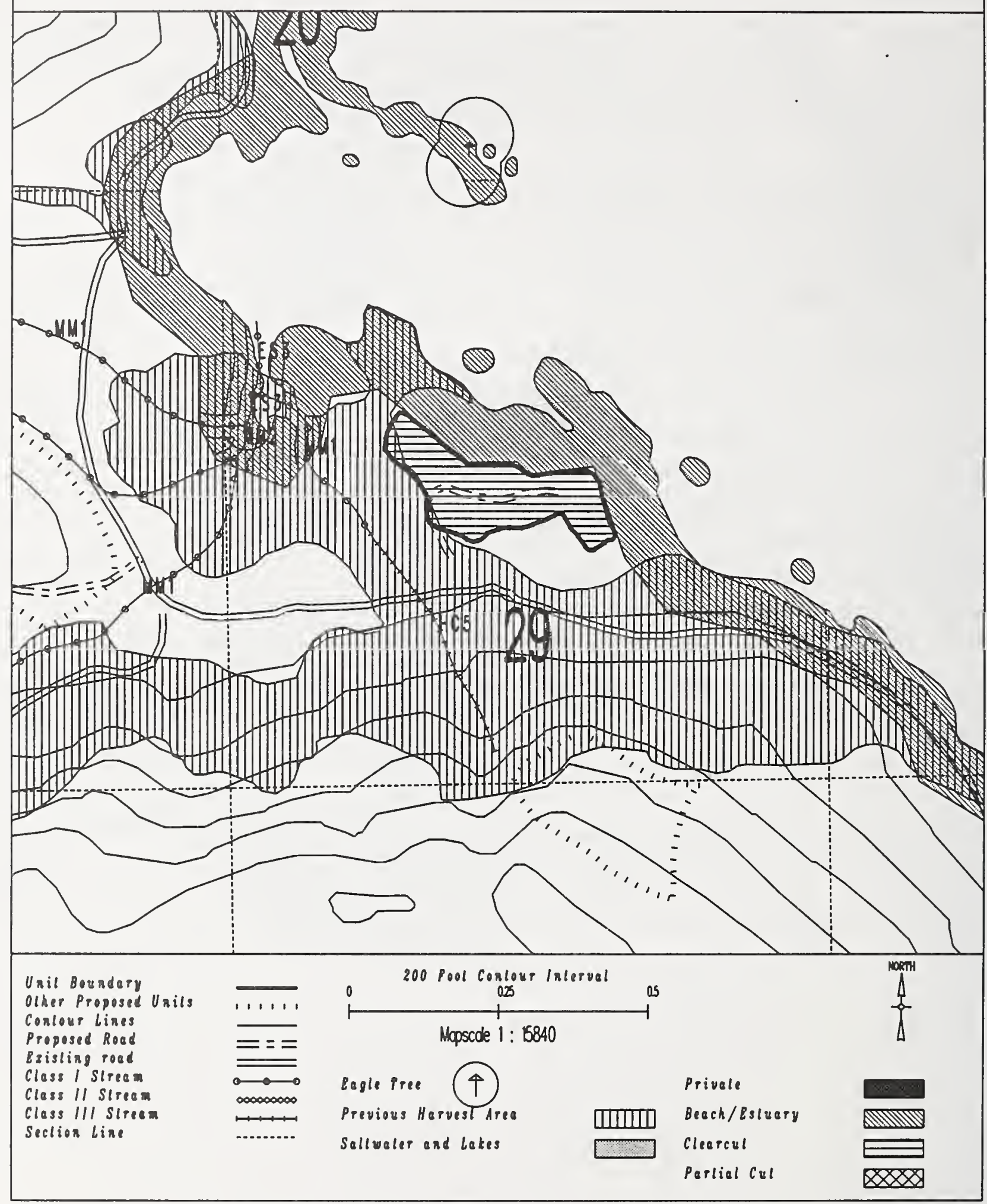


Unit $584-254$

Planned acres 47

Estimated volume (mbf) 1290

Logging system Helicopter

silvicultural system clearcut

Forest type Hemlock
Alternatives considered F2 $\quad$ F4 F5 F6

Quad CRGD2SWN

Mgmt Area $\mathrm{K} 09$

WAA 1315

Photo 1090091

Aspect South

PHYSICAL DESCRIPTION

Volume class breakdown: VC4 $\underline{23}$ acres VC5 $\quad 24$ acres vC6 $\quad 0$ acres vc7 $\quad 0$ acres

Elevation breakdown: $0-800 \mathrm{ft} . \underline{0}$ acres $800-1200 \mathrm{ft} . \underline{12}$ acres $1200-1500 \mathrm{ft}$. 16 acres over $1500 \mathrm{ft}$. 0 acres Mass movement index: Low 5 acres Medium 0 acres High 41 acres Very High 0 acres

SOILS

This unit has high mass movement index soils. Partial log suspension required over these areas.(BMP13.9)

This unit contains 31 acres of forested wetlands. Site specific BMPs will be designed for selected approved

logging system and road construction practices. (BMPs 12.5, 13.9, 13.15).

TIMBER

There are no timber mitigation measures anticipated for this unit.

ENGINEER ING

There are no engineering mitigation measures anticipated for this unit.

FISH/HATERSHED

There are no fishery mitigation measures anticipated for this unit.

WILDLIFE

There are no wildlife mitigation measures anticipated for this unit.

RECREATION / VISUALS

The unit has a proposed veO of $M$ within the viewshed of Ratz Harbors

as viewed from ferry/cruise ship route (2-4 miles off shore).

LANDS

There are no lands mitigation measures anticipated for this unit.

CULTURAL RESOURCES

There are no cultural resource mitigation measures anticipated for this unit.

GEOLOGY

There are no karst mitigation measures anticipated for this unit. 
cpor Unil Card

Unil Number: 584-254

June 11, 1999

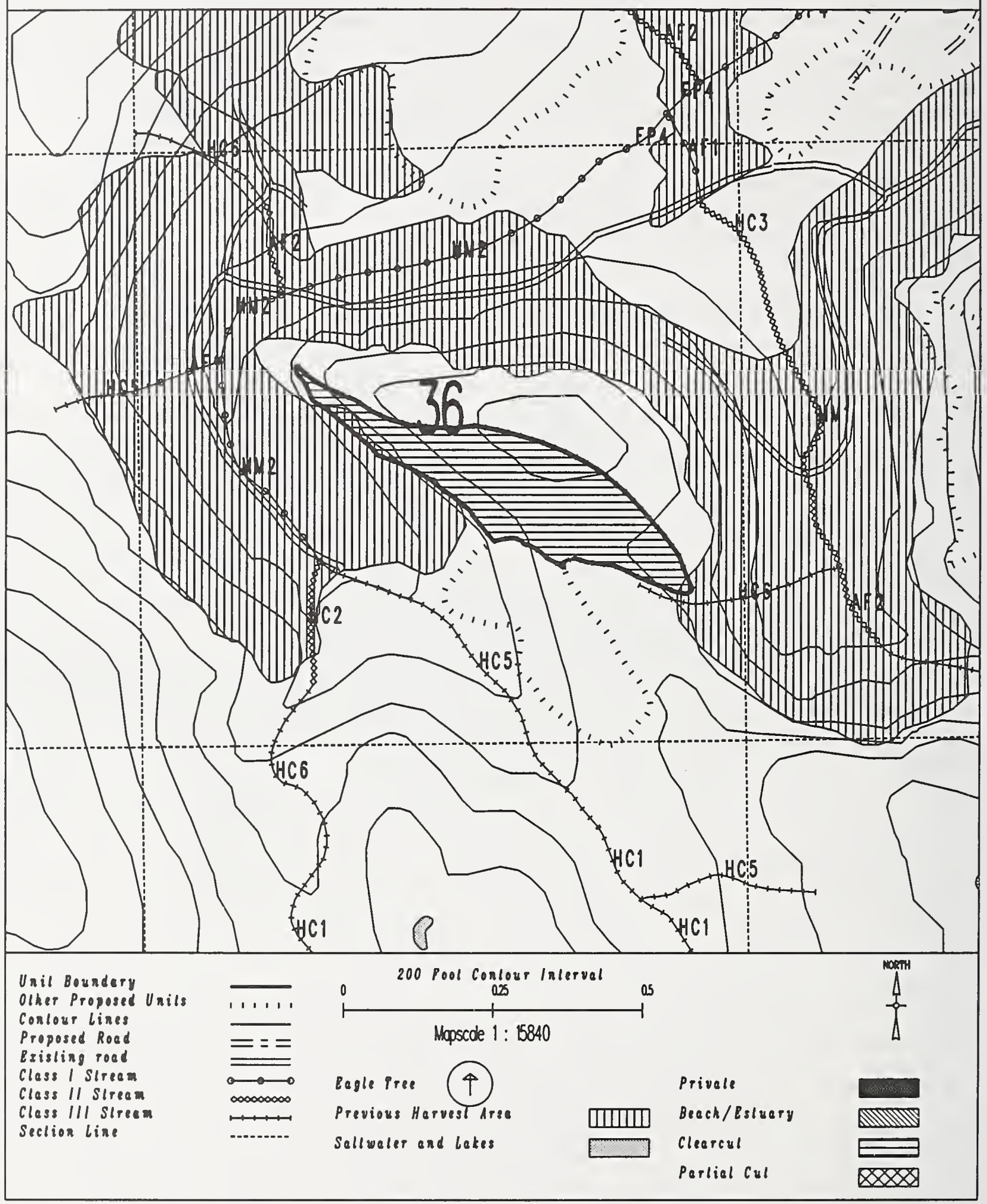


Unit 584-263

Planned acres 48

Est imated volume (mbf) 1236

Logging system skyline

silvicultural system clearcut

Forest type Hemlock

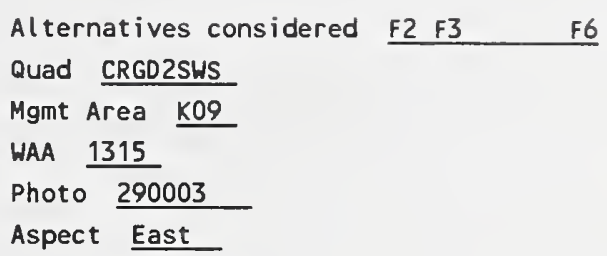

\section{PHYSICAL DESCRIPTION}

Volume class breakdown: VC4 31 acres VC5 17 acres VC6 0 acres VC7 $\quad 0$ acres

Elevation breakdown: $0-800 \mathrm{ft} .49$ acres $800-1200 \mathrm{ft} . \underline{0}$ acres $1200-1500 \mathrm{ft}$. 0 acres over $1500 \mathrm{ft}$. 0 acres Mass movement index: Low 24 acres Medium 22 acres High 2 acres Very High 0 acres

SOILS

This unit contains 14 acres of forested wetlands. Site specific BMPs will be designed for selected approved logging system and road construction practices. (BMPs 12.5, 13.9, 13.15).

TIMBER

Potential for shovel logging on 17 acres, if soil and water quality protected (BMP13.7)

ENGINEERING

There are no engineering mitigation measures anticipated for this unit.

FISH/WATERSHED

There are no fishery mitigation measures anticipated for this unit.

WILDLIFE

There are no wildlife mitigation measures anticipated for this unit.

RECREATION / VISUALS

The unit has a proposed VQO of $M$ within the viewshed of Sal Creek

as viewed from ferry/cruise ship route (2-4 miles off shore).

LANDS

There are no lands mitigation measures anticipated for this unit.

CULTURAL RESOURCES

There are no cultural resource mitigation measures anticipated for this unit.

GEOLOGY

There are no karst mitigation measures anticipated for this unit. 


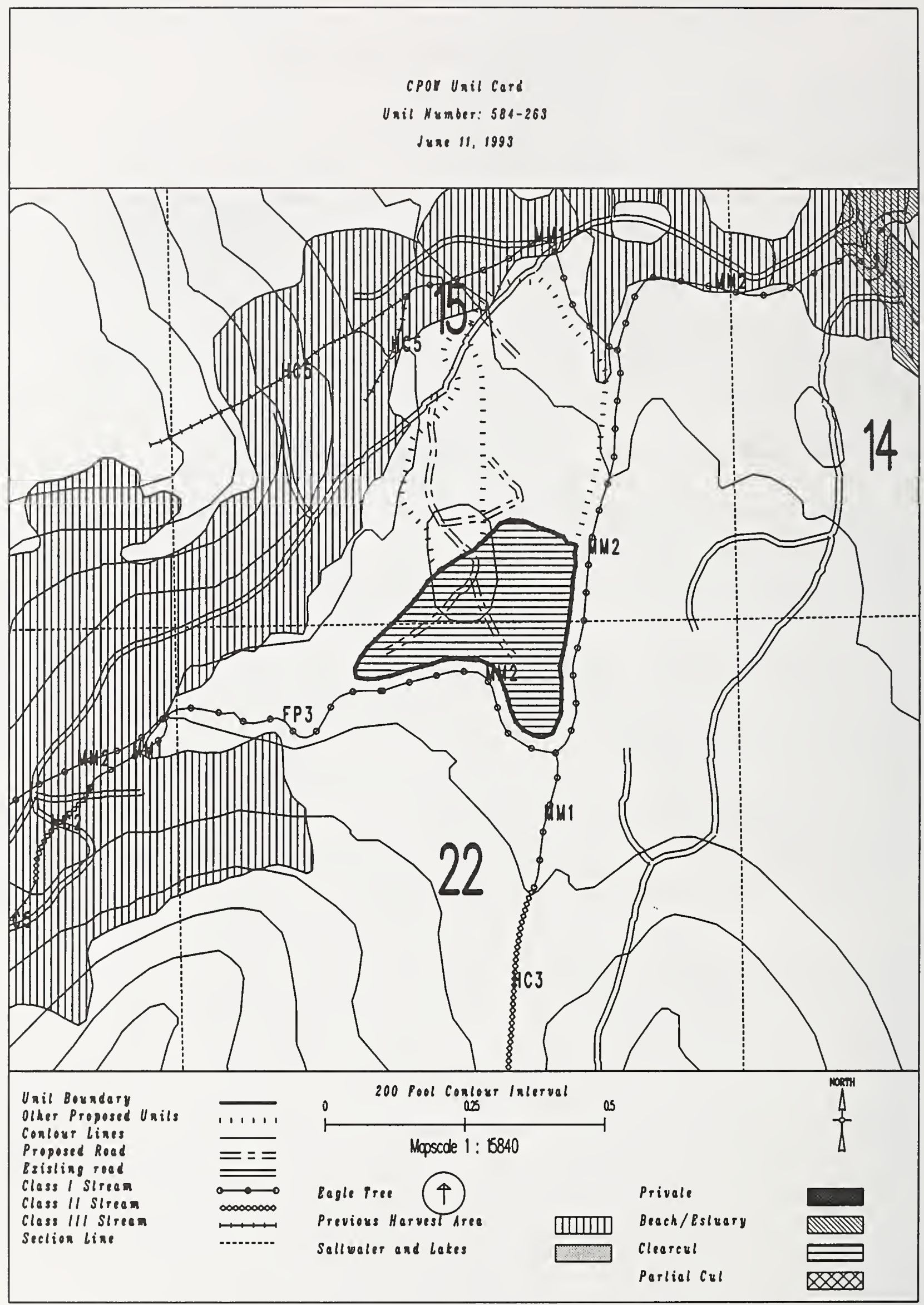


Unit $\quad 584-267$

Planned acres 29

Estimated volume (mbf) 765

Logging system Helicopter

silvicultural system clearcut

Forest type Mixed conifer
Alternatives considered $\mathrm{F2} \quad \mathrm{F} 4 \quad \mathrm{F6}$

Quad CRGD2SWN

Mgmt Area $\mathrm{KO9}$

WAA 1315

Photo 990193

Aspect North

PHYSICAL DESCRIPTION

Volume class breakdown: VC4 14 acres vC5 14 acres vC6 $\quad 0$ acres vC7 $\quad 0$ acres

Elevation breakdown: $0-800 \mathrm{ft} .11$ acres $800-1200 \mathrm{ft} .16$ acres 1200-1500 ft. 5 acres over $1500 \mathrm{ft}$. 0 acres Mass movement index: Low 0 acres Medium 0 acres High 8 acres Very High 0 acres

\section{SOILS}

This unit has high mass movement index soils. Partial log suspension required over these areas.(BMP13.9)

This unit has a significant possibility to have areas reclassified as MMI $=4$.

This unit contains 20 acres of forested wetlands. Site specific BMPs will be designed for selected approved

logging system and road construction practices. (BMPs 12.5, 13.9, 13.15).

\section{TIMBER}

There are no timber mitigation measures anticipated for this unit.

\section{ENG INEER ING}

There are no engineering mitigation measures anticipated for this unit.

\section{FISH/WATERSHED}

This unit contains streams which have recently been classified/channel typed but require field verification.

\section{WILDLIFE}

There are no wildlife mitigation measures anticipated for this unit.

\section{RECREATION / VISUALS}

The unit has a proposed voo of $M$ within the viewshed of Ratz Harbors as viewed from ferry/cruise ship route (2-4 miles off shore).

\section{LANDS}

There are no lands mitigation measures anticipated for this unit.

\section{CULTURAL RESOURCES}

There are no cultural resource mitigation measures anticipated for this unit.

\section{GEOLOGY}

There are no karst mitigation measures anticipated for this unit. 


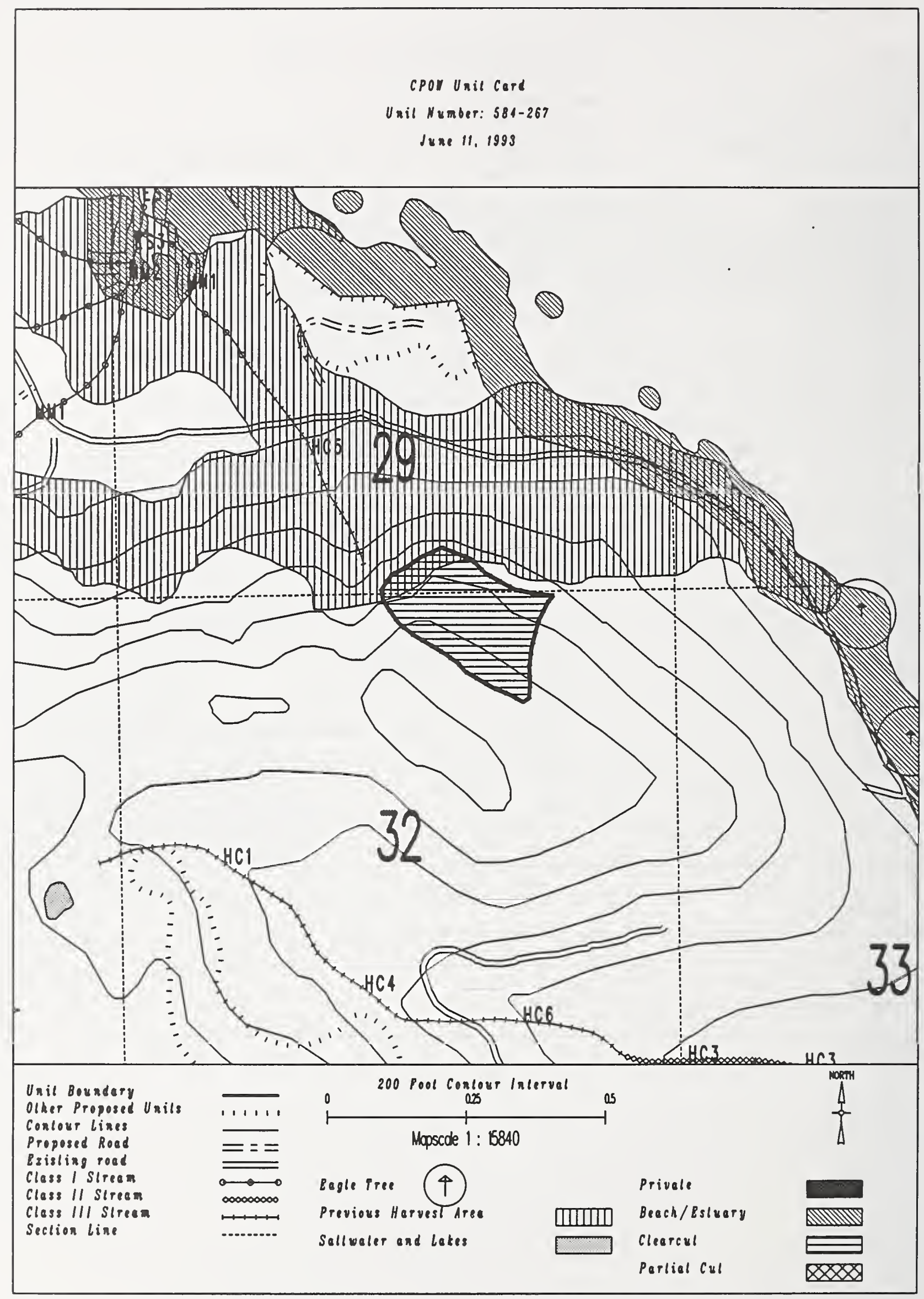


Unit $\quad 584-272$

Plamed acres 132

Estimated volume (mbf) 2922

Logging system Helicopter

silvicultural system Shelterwood

Forest type Hemlock
Alternatives considered F2 $\quad$ F4 F5 $\quad$ F6

Quad CRGO2SWN

Mgmt Area K09

WAA 1315

Photo 1090092

Aspect East

\section{PHYSICAL DESCRIPTION}

Volume class breakdown: VC4 26 acres VC5 $\underline{110}$ acres VC6 $\quad 0$ acres VC7 $\quad 0$ acres

Elevation breakdown: $0-800 \mathrm{ft} . \underline{71}$ acres $800-1200 \mathrm{ft} . \underline{31}$ acres 1200-1500 ft. 14 acres over $1500 \mathrm{ft}$. 0 acres Mass movement index: Low $\underline{12}$ acres Medium $\underline{21}$ acres High $\underline{64}$ acres Very High $\underline{0}$ acres

\section{SOILS}

This unit has high mass movement index soils. Partial log suspension required over these areas. (BMP13.9)

This unit contains 75 acres of forested wetlands. Site specific BMPs will be designed for selected approved logging system and road construction practices. (BMPs 12.5, 13.9, 13.15).

This unit contains 26 acres of slopes $>75 \%$.

\section{TIMBER}

Shelterwood harvest. Cedar will not be harvested.

\section{ENGINEER ING}

There are no engineering mitigation measures anticipated for this unit.

\section{FISH/WATERSHED}

This unit contains streams which have recently been classified/channel typed but require field verification.

WILDLIFE

Maintain diversity within unit by leaving 1-5 acre-sized islands of green trees at a rate of 1 acre of island for every 20 acres harvested. Leave islands must be compatible with logging system and safe working conditions.

RECREATION / VISUALS

The unit has a proposed voo of $M$ within the viewshed of Ratz harbors as viewed from

\section{LANDS}

There are no lands mitigation measures anticipated for this unit.

CULTURAL RESOURCES

There are no cultural resource mitigation measures anticipated for this unit. 


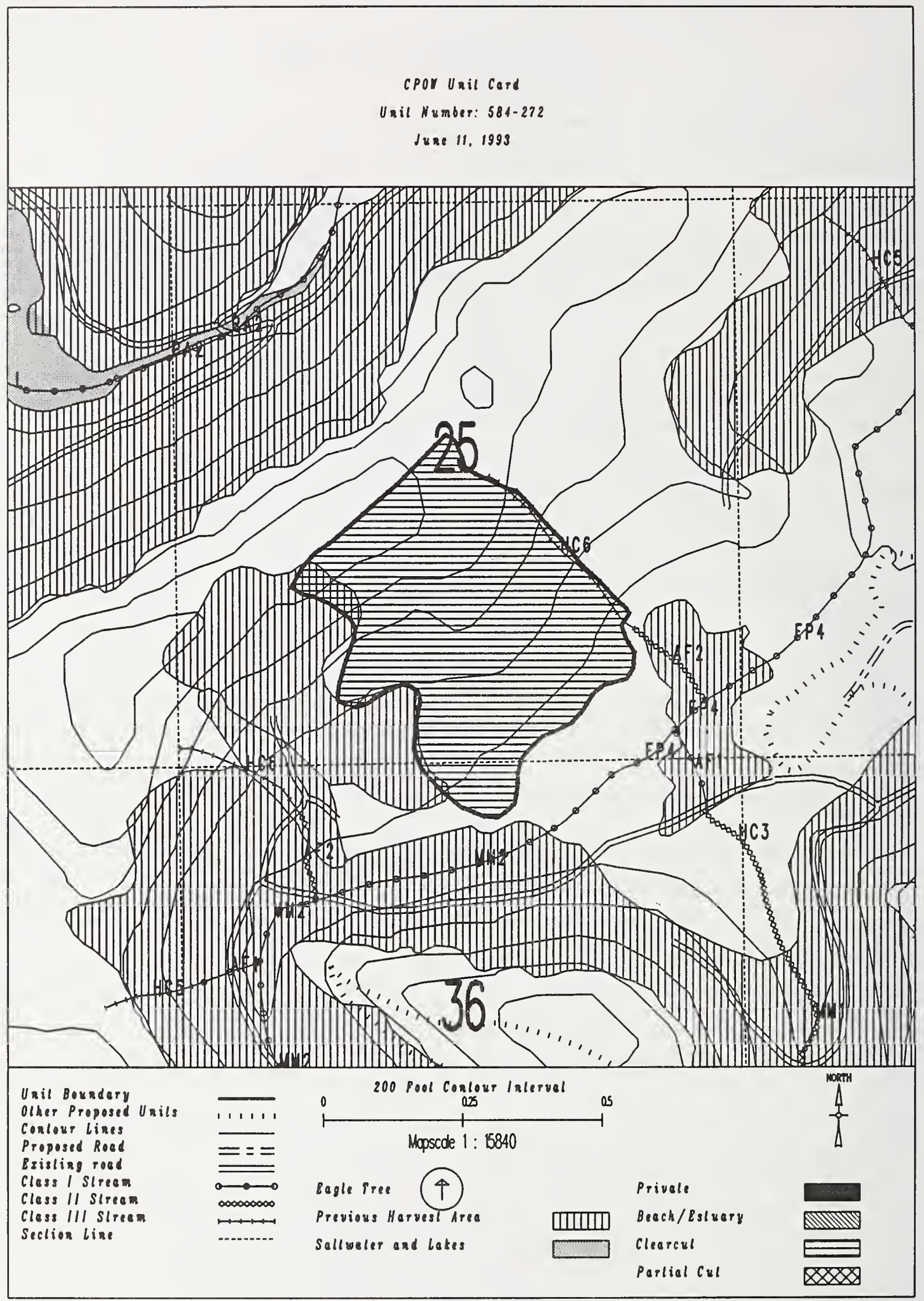


Unit 585-201

Planned acres 50

Estimated volume (mbf) 1031

Logging system skyline

silvicultural system Riparian

Forest type Hemlock

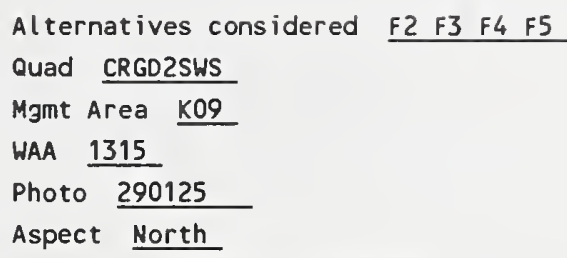

\section{PHYSICAL DESCRIPTION}

Volume class breakdown: VC4 11 acres VC5 31 acres VC6 0 acres VC7 0 acres

Elevation breakdown: $0-800 \mathrm{ft}$. 46 acres $800-1200 \mathrm{ft} . \underline{1}$ acres 1200-1500 ft. 0 acres over $1500 \mathrm{ft}$. 0 acres Mass movement index: Low 26 acres Medium 15 acres High 1 acres Very High 0 acres

\section{SOILS}

This unit contains 17 acres of forested wetlands. Site specific BMPs will be designed for selected approved logging system and road construction practices. (BMPs 12.5, 13.9, 13.15).

\section{TIMBER}

Uneven-aged harvest for riparian management on an estimated 15 acres.

Potential for shovel logging on 17 acres, if soil and water quality protected (BMP13.7)

\section{ENGINEER ING}

There are no engineering mitigation measures anticipated for this unit.

\section{FISH/WATERSHED}

There are no fishery mitigation measures anticipated for this unit.

\section{WILDLIFE}

Maintain diversity within unit by leaving 1-5 acre-sized islands of green trees at a rate of 1 acre of island for every 20 acres harvested. Leave islands must be compatible with logging system and safe working conditions.

\section{RECREATION / VISUALS}

This unit has a proposed VoO of MM and is not seen from any viewpoint identified by this project.

\section{LANDS}

There are no lands mitigation measures anticipated for this unit.

\section{CULTURAL RESOURCES}

There are no cultural resource mitigation measures anticipated for this unit.

\section{GEOLOGY}

There are no karst mitigation measures anticipated for this unit. 


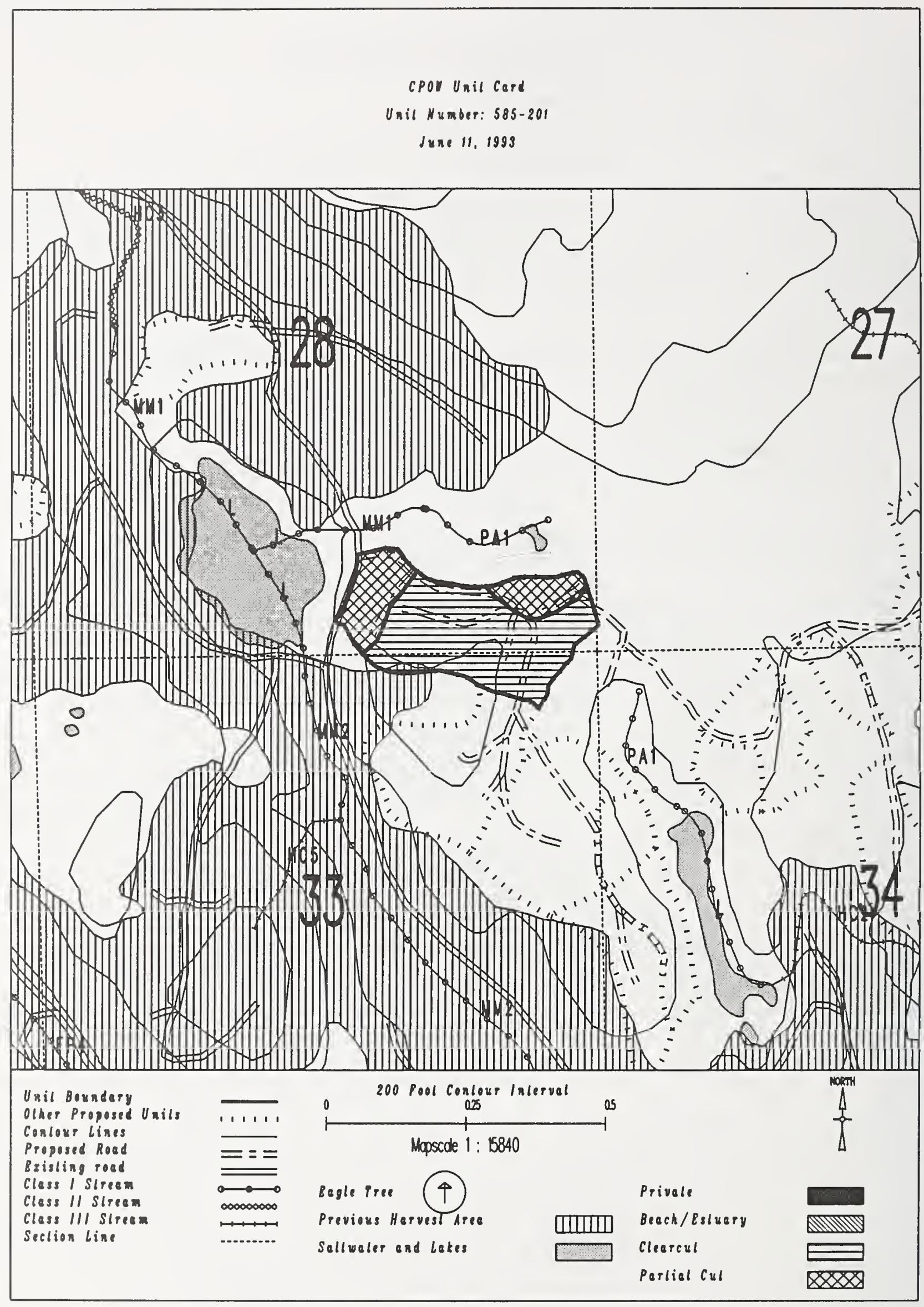


Unit 585-202

Planned acres 31

Est imated volume (mbf) 733

Logging system skyline

silvicultural system clearcut

Forest type Hemlock
Alternatives considered F2 F3 F4 F5

Quad CRGO2SWS

Mgmt Area $\mathrm{KO9}$

WAA 1315

Photo

Aspect South

PHYSICAL DESCRIPTION

Volume class breakdown: VC4 23 acres VC5 $\quad 7$ acres VC6 $\quad 0$ acres VC7 0 acres

Elevation breakdown: $0-800 \mathrm{ft} . \underline{22}$ acres $800-1200 \mathrm{ft} . \underline{8}$ acres 1200-1500 ft. 0 acres over $1500 \mathrm{ft}$. 0 acres Mass movement index: Low 5 acres Medium 19 acres High 0 acres Very High 0 acres

SOILS

This unit contains 29 acres of forested wetlands. Site specific BMPs will be designed for selected approved

logging system and road construction practices. (BMPs 12.5, 13.9, 13.15).

\section{TIMBER}

There are no timber mitigation measures anticipated for this unit.

ENGINEERING

There are no engineering mitigation measures anticipated for this unit.

\section{FISH/WATERSHED}

There are no fishery mitigation measures anticipated for this unit.

WILDLIFE

Maintain diversity within unit by leaving 1-5 acre-sized islands of green trees at a rate of 1 acre of island for every 20 acres harvested. Leave islands must be compatible with logging system and safe working conditions.

RECREATION / VISUALS

This unit has a proposed VQO of MM and is not seen from any viewpoint identified by this project.

\section{LANDS}

There are no lands mitigation measures anticipated for this unit.

CULTURAL RESOURCES

There are no cultural resource mitigation measures anticipated for this unit.

GEOLOGY

There are no karst mitigation measures anticipated for this unit. 
CPOY Unit Card

Unil Nymber: 585-202

June 11, 1993

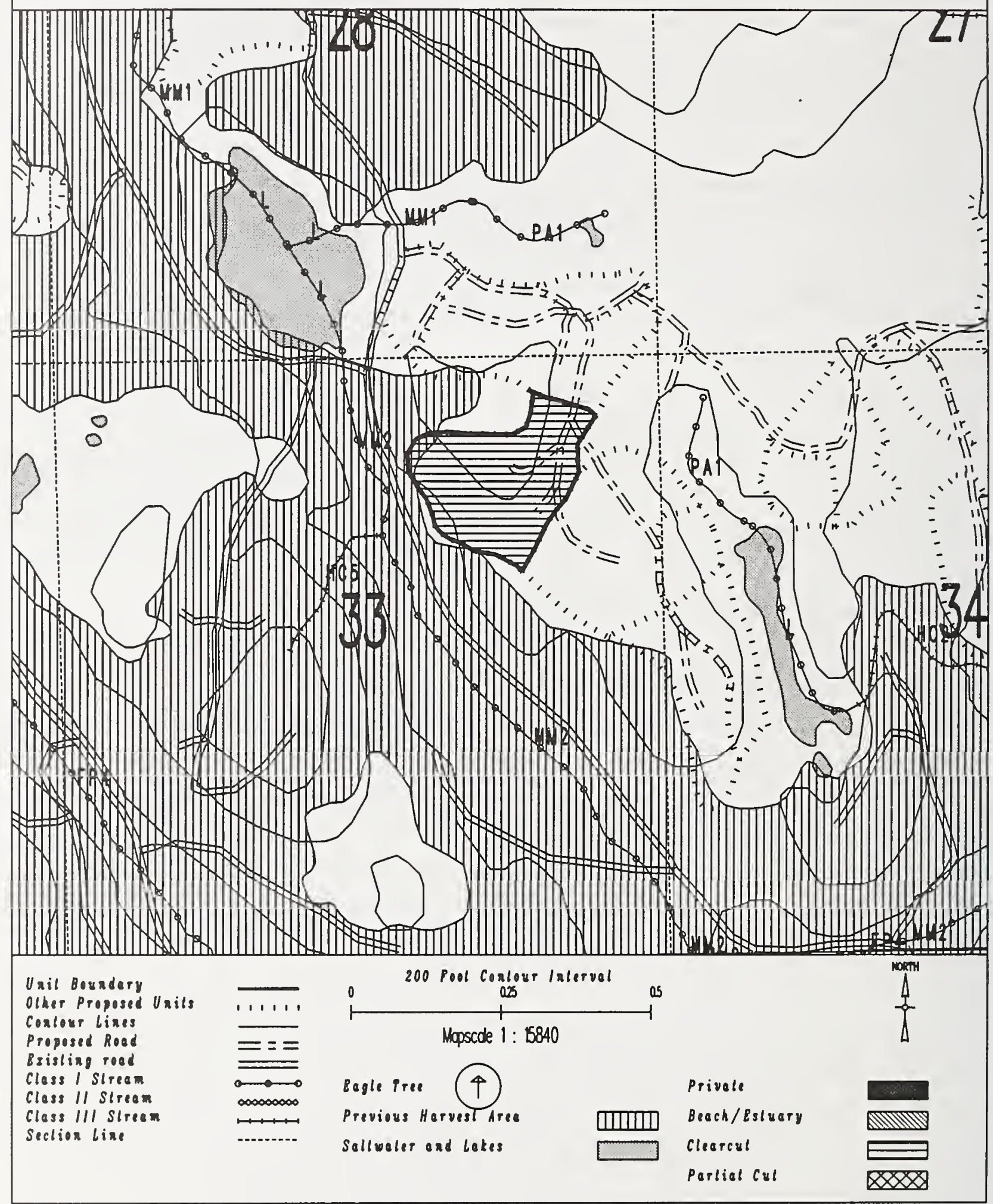


UNIT PLAN/LAYOUT/SALE ADMINISTRATION CARD FOR CPOW FEIS

Unit $\quad 585-203$

Planned acres 42

Estimated volume (mbf)

Logging system skyline

Silvicultural system Riparian

Forest type Hemlock

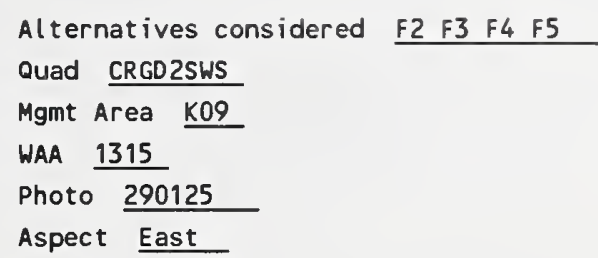

\section{PHYSICAL DESCR IPTION}

Volume class breakdown: VC4 29 acres VC5 11 acres vc6 $\quad 0$ acres vc7 $\quad 0$ acres

Elevation breakdown: $0-800 \mathrm{ft} .41$ acres $800-1200 \mathrm{ft} . \quad 0$ acres $1200-1500 \mathrm{ft} . \quad 0$ acres over $1500 \mathrm{ft}$. 0 acres Mass movement index: Low 11 acres Medium 11 acres High 0 acres Very High 0

\section{SOILS}

This unit contains $\underline{25}$ acres of forested wetlands. Site specific BMPs will be designed for selected approved logging system and road construction practices. (BMPs 12.5, 13.9, 13.15).

\section{TIMBER}

Uneven-aged harvest for riparian management on an estimated 8 acres.

\section{ENGINEERING}

There are no engineering mitigation measures anticipated for this unit.

\section{FISH/WATERSHED}

There are no fishery mitigation measures anticipated for this unit.

\section{WILOLIFE}

Maintain diversity within unit by leaving 1-5 acre-sized islands of green trees at a rate of 1 acre of island for every 20 acres harvested. Leave islands must be compatible with logging system and safe working conditions.

\section{RECREATION / VISUALS}

This unit has a proposed VQO of MM and is not seen from any viewpoint identified by this project.

\section{LANDS}

There are no lands mitigation measures anticipated for this unit.

\section{CULTURAL RESOURCES}

There are no cultural resource mitigation measures anticipated for this unit.

\section{GEOLOGY}

There are no karst mitigation measures anticipated for this unit. 
cPol Unil Cerd

Unil Number: 585-203

June 11, 1993

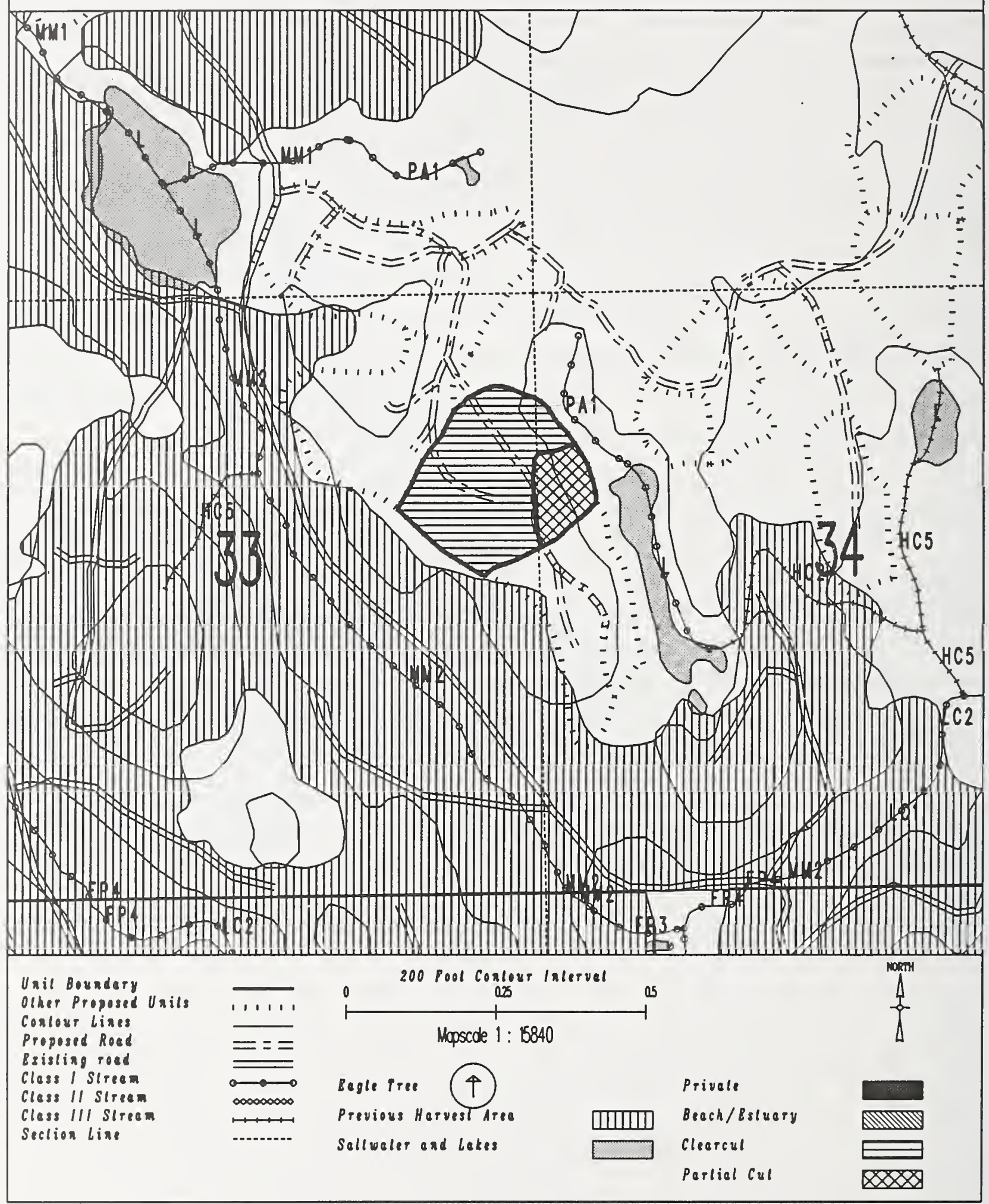


UNIT PLAN/LAYOUT/SALE ADMINISTRATION CARD FOR CPOW FEIS

Unit 585-204

Planned acres 29

Estimated volume (mbf) 552

Logging system Highlead

Silvicultural system Riparian

Forest type Hemlock
Alternatives considered

Quad CRGD2SWS

Mgmt Area $\mathrm{KO9}$

WAA 1315

Photo 290125

Aspect East

PHYSICAL DESCRIPTION

Volume class breakdown: VC4 19 acres VC5 10 acres VC6 $\quad 0$ acres VC7 $\quad 0$ acres

Elevation breakdown: $0-800 \mathrm{ft} . \underline{28}$ acres $800-1200 \mathrm{ft} . \quad 0$ acres $1200-1500 \mathrm{ft}$. 0 acres over $1500 \mathrm{ft}$. 0 acres Mass movement index: Low 15 acres Medium 5 acres High 1 acres Very High 0 acres

SOILS

This unit contains 13 acres of forested wetlands. Site specific BMPs will be designed for selected approved

logging system and road construction practices. (BMPs 12.5, 13.9, 13.15).

\section{TIMBER}

Uneven-aged harvest for riparian management on an estimated 12 acres.

ENGINEER ING

There are no engineering mitigation measures anticipated for this unit.

FISH/WATERSHED

Leave all deciduous and conifer trees (< $12^{\prime \prime} \mathrm{dbh}$ ) in $35 \mathrm{ft}$ buffer adjacent to Class 111 streams to provide shade.

WILOLIFE

There are no wildlife mitigation measures anticipated for this unit.

RECREATION / VISUALS

This unit has a proposed VQO of MM and is not seen from any viewpoint identified by this project.

\section{LANDS}

There are no lands mitigation measures anticipated for this unit.

CULTURAL RESOURCES

There are no cultural resource mitigation measures anticipated for this unit.

GEOLOGY

There are no karst mitigation measures anticipated for this unit. 


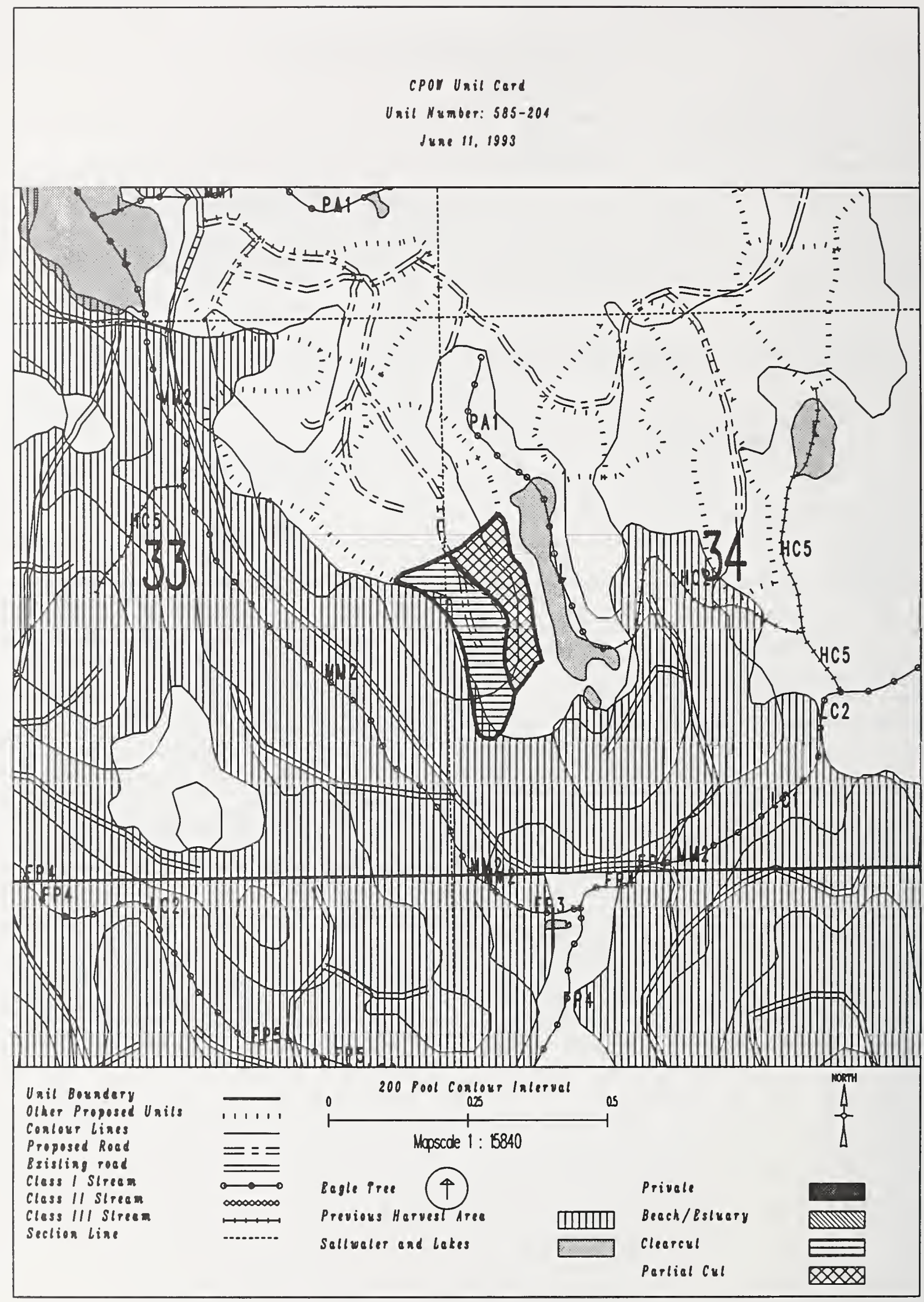


Unit 585-206

Planned acres 25

Est imated volume (mbf) 636

Logging system skyline

silvicultural system Riparian

Forest type Hemlock
Al ternatives considered $\quad$ F2 $F 3 \quad F 4 \quad F 5$

Quad CRGD2SWS

Mgmt Area KO9

WAA 1315

Photo 290125

Aspect East

PHYSICAL DESCRIPTION

Volume class breakdown: VC4 0 acres VC5 24 acres VC6 $\quad 0$ acres VC7 0 acres

Elevation breakdown: $0-800 \mathrm{ft} . \underline{24}$ acres 800-1200 ft. 0 acres 1200-1500 ft. 0 acres over $1500 \mathrm{ft}$. 0 acres Mass movement index: Low 1 acres Medium 24 acres High 0 acres Very High 0

SOILS

There are no soils mitigation measures anticipated for this unit.

TIMBER

Uneven-aged harvest for riparian management on an estimated 8 acres.

\section{ENGINEER ING}

There are no engineering mitigation measures anticipated for this unit.

\section{FISH/WATERSHED}

Potential for additional Class I/II streams within unit. May be necessary to place additional buffers within unit in accordance with AHMU Handbook.

Leave all deciduous and conifer trees ( $<12^{\prime \prime} \mathrm{dbh}$ ) in $35 \mathrm{ft}$ buffer adjacent to Class III streams to provide shade.

WILDL IFE

There are no wildtife mitigation measures anticipated for this unit.

RECREATION / VISUALS

This unit has a proposed voo of MM and is not seen from any viewpoint identified by this project.

\section{LANDS}

There are no lands mitigation measures anticipated for this unit.

CULTURAL RESOURCES

There are no cultural resource mitigation measures anticipated for this unit.

GEOLOGY

There are no karst mitigation measures anticipated for this unit. 


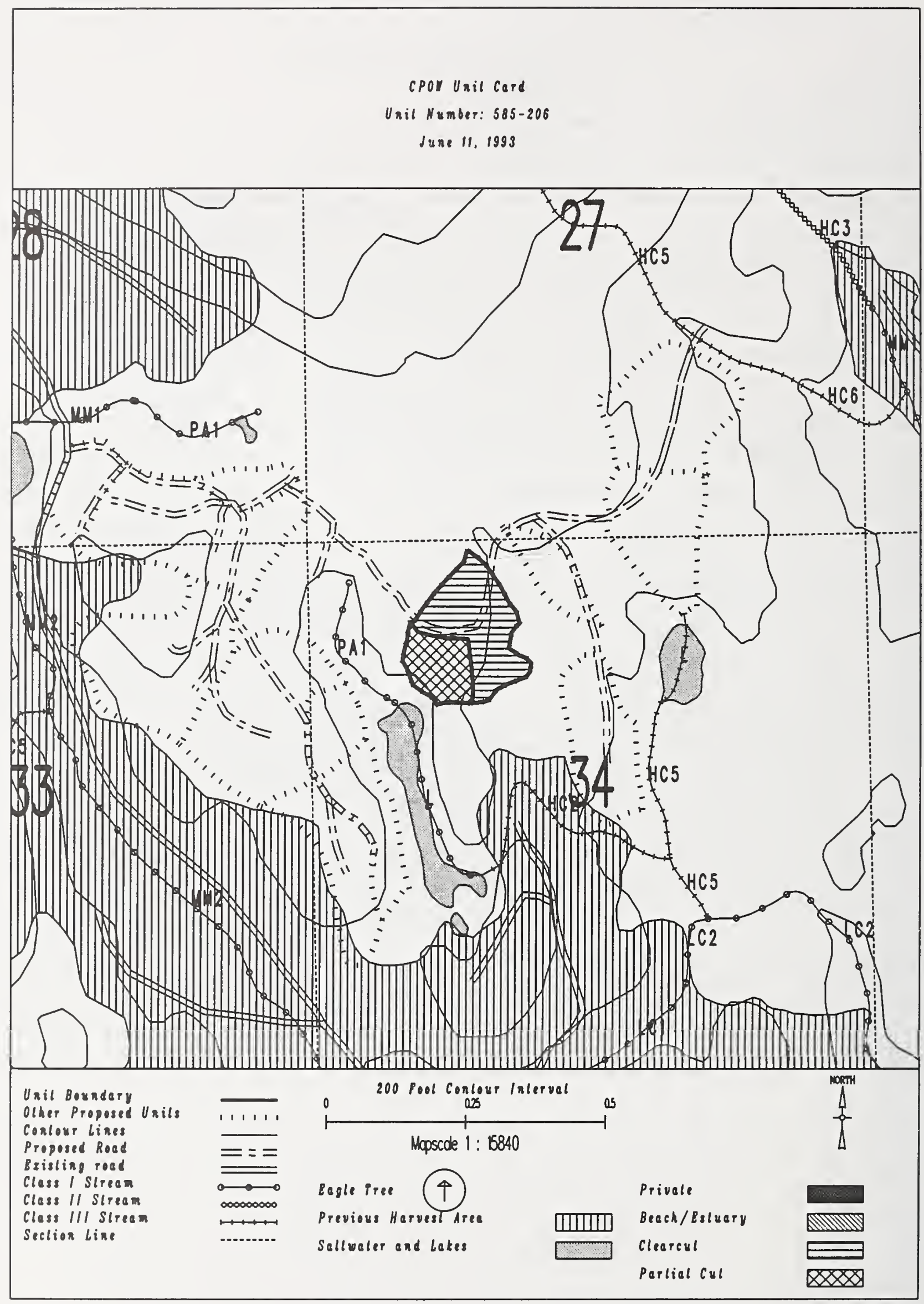


Unit 585-208

Planned acres 23

Estimated volume (mbf)

Logging system Highlead

silvicultural system clearcut

Forest type Hemlock

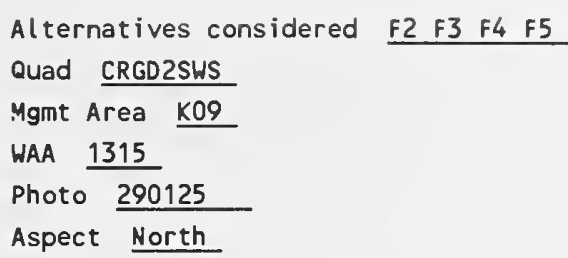

PHYSICAL DESCRIPTION

Volume class breakdown: VC4 21 acres vC5 $\quad 3$ acres vC6 $\quad 0$ acres vc7 $\quad 0$ acres

Elevation breakdown: $0-800 \mathrm{ft} . \underline{21}$ acres $800-1200 \mathrm{ft} . \underline{0}$ acres 1200-1500 ft. 0 acres over $1500 \mathrm{ft}$. 0 Mass movement index: Low $\underline{9}$ acres Medium 14 acres High 0 acres Very High 0 acres

SOILS

This unit contains 17 acres of forested wetlands. Site specific BMPs will be designed for selected approved logging system and road construction practices. (BMPs 12.5, 13.9, 13.15).

\section{TIMBER}

There are no timber mitigation measures anticipated for this unit.

\section{ENGINEERING}

There are no engineering mitigation measures anticipated for this unit.

\section{FISH/WATERSHED}

Proposed stream buffers may need to be modified to meet AHMU Handbook standards.

Leave all deciduous and conifer trees (< $12^{\prime \prime} \mathrm{dbh}$ ) in $35 \mathrm{ft}$ buffer adjacent to Class III streams to provide shade.

\section{HILDLIFE}

There are no wildlife mitigation measures anticipated for this unit.

\section{RECREATION / VISUALS}

This unit has a proposed voo of MM and is not seen from any viewpoint identified by this project.

\section{LANDS}

There are no lands mitigation measures anticipated for this unit.

CULTURAL RESOURCES

There are no cultural resource mitigation measures anticipated for this unit.

There are no karst mitigation measures anticipated for this unit. 


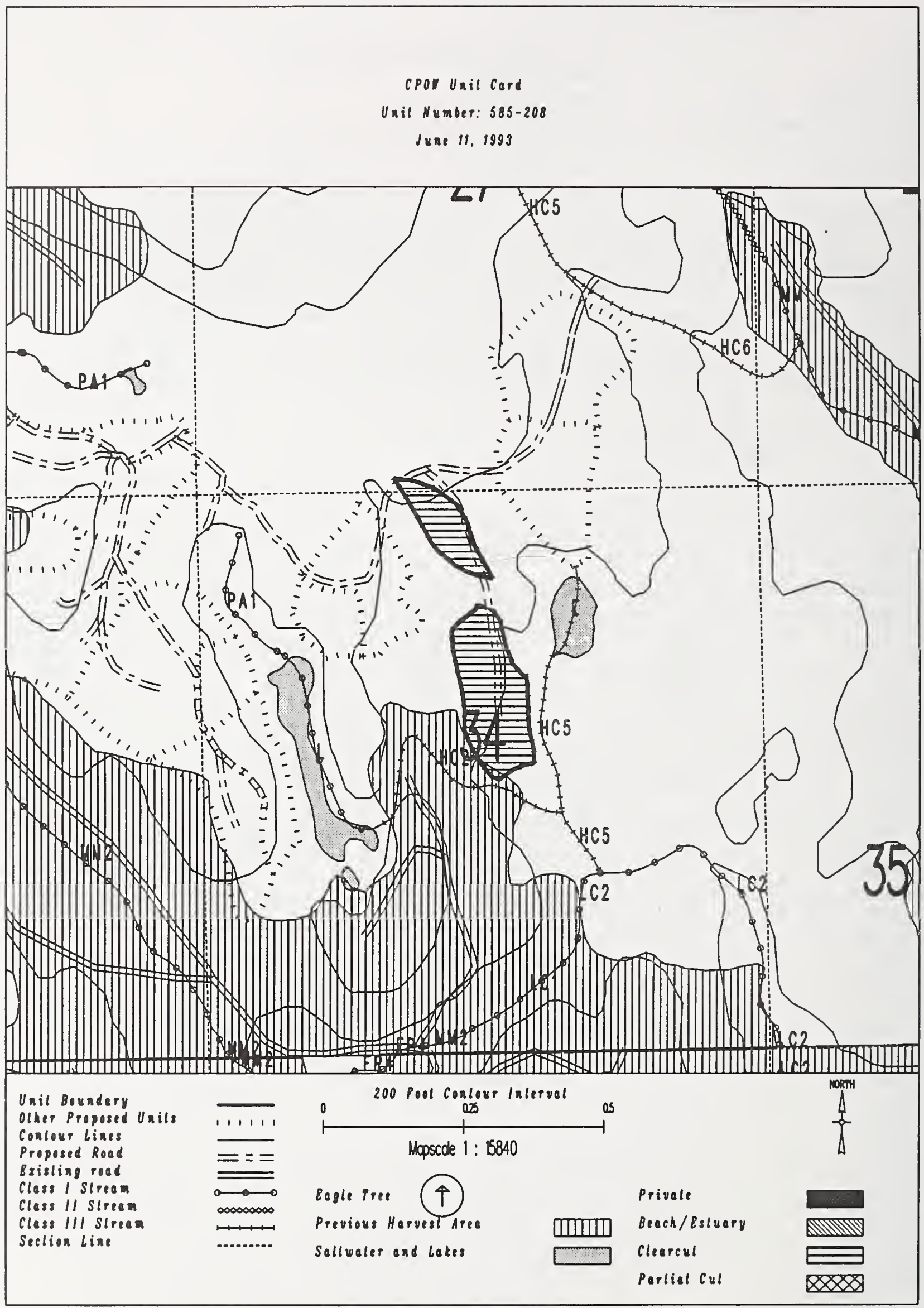


Unit $585-210$

Planned acres 19

Estimated volume (mbf) 416

Logging system Highlead

silvicultural system Clearcut

Forest type Hemlock
Alternatives considered $\mathrm{F} 2_{2} \quad \mathrm{~F} 3 \mathrm{~F} 4 \mathrm{F5}$

Quad CRGD2SWS

Mgmt Area K09

WAA 1315

Photo 290125

Aspect North

\section{PHYSICAL DESCRIPTION}

Volume class breakdown: VC4 19 acres vC5 $\quad 0$ acres $v C 6 \quad 0$ acres $\quad$ VC7 $\quad 0$ acres

Elevation breakdown: $0-800 \mathrm{ft} .17$ acres $800-1200 \mathrm{ft} . \underline{0}$ acres 1200-1500 ft. 0 acres over $1500 \mathrm{ft}$. 0 acres Mass movement index: Low 19 acres Medium 0 acres High 0 acres Very High 0

SOILS

This unit contains 9 acres of forested wetlands. Site specific BMPs will be designed for selected approved

logging system and road construction practices. (BMPS 12.5, 13.9, 13.15).

\section{TIMBER}

There are no timber mitigation measures anticipated for this unit.

\section{ENGINEER ING}

There are no engineering mitigation measures anticipated for this unit.

\section{FISH/WATERSHED}

Leave all deciduous and conifer trees ( $<12^{\prime \prime} \mathrm{dbh}$ ) in $35 \mathrm{ft}$ buffer adjacent to Class III streams to provide shade.

WILDLIFE

There are no wildlife mitigation measures anticipated for this unit.

RECREATION / VISUALS

The unit has a proposed vao of MM within the viewshed of Sal Creek

as viewed from ferry/cruise ship route (2-4 miles off shore).

\section{LANDS}

There are no lands mitigation measures anticipated for this unit.

CULTURAL RESOURCES

There are no cultural resource mitigation measures anticipated for this unit.

There are no karst mitigation measures anticipated for this unit. 
cPor Unil card

Unil Number: $585-210$

June 11, 1993

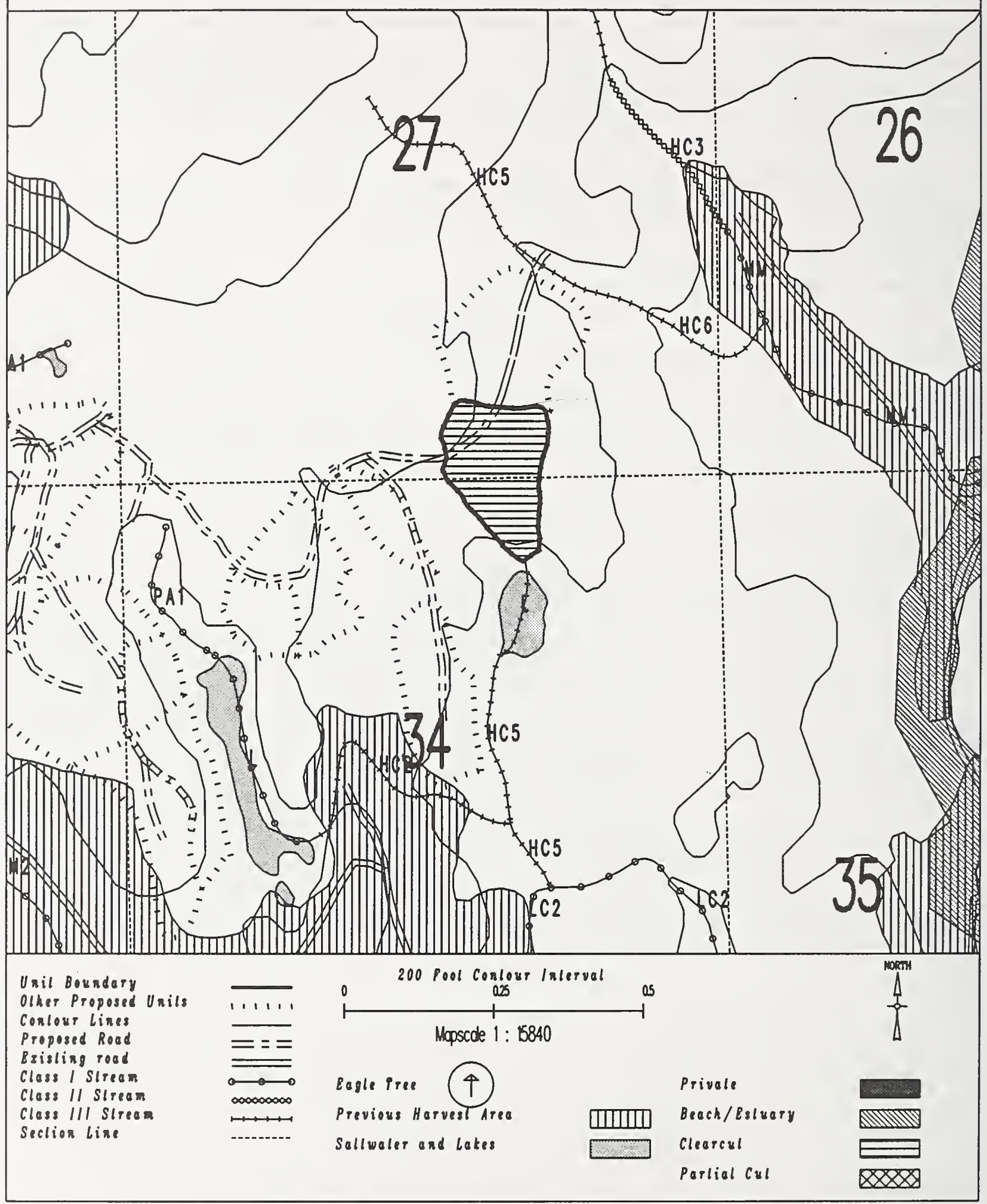


UNIT PLAN/LAYOUT/SALE ADMINISTRATION CARD FOR CPOW FEIS

Unit 585-210 B

Planned acres 26

Estimated volume (mbf) 525

logging system skyline

silvicultural system clearcut

Forest type Hemlock
Alternatives considered F2 F3 F4 F5

Quad CRGD2SWS

Mgmt Area K09

WAA 1315

Photo

Aspect East

PHYSICAL DESCRIPTION

Volume class breakdown: VC4 24 acres vc5 $\quad 0$ acres vC6 $\quad 0$ acres vc7 $\quad 0$ acres

Elevation breakdown: $0-800 \mathrm{ft} . \underline{24}$ acres $800-1200 \mathrm{ft} . \underline{0}$ acres $1200-1500 \mathrm{ft}$. 0 acres over $1500 \mathrm{ft}$. 0 Mass movement index: Low 25 acres Medium 0 acres High $\underline{0}$ acres Very High $\underline{0}$ acres

SOILS

This unit contains 13 acres of forested wetlands. Site specific BMPs will be designed for selected approved

logging system and road construction practices. (BMPs 12.5, 13.9, 13.15).

\section{TIMBER}

Potential regeneration problem. Monitor regeneration to determine if hand planting is required to meet BMP13.19.

\section{ENGI NEER I NG}

There are no engineering mitigation measures anticipated for this unit.

\section{FISH/WATERSHED}

Potential for additional Class I/II streams within unit. May be necessary to place additional buffers within unit in accordance with AHMU Handbook.

\section{WILDLIFE}

There are no wildlife mitigation measures anticipated for this unit.

RECREATION / VISUALS

The unit has a proposed VQo of MM within the viewshed of Sal Creek

as viewed from ferry/cruise ship route (2-4 miles off shore).

\section{LANDS}

There are no lands mitigation measures anticipated for this unit.

CULTURAL RESOURCES

There are no cultural resource mitigation measures anticipated for this unit. 


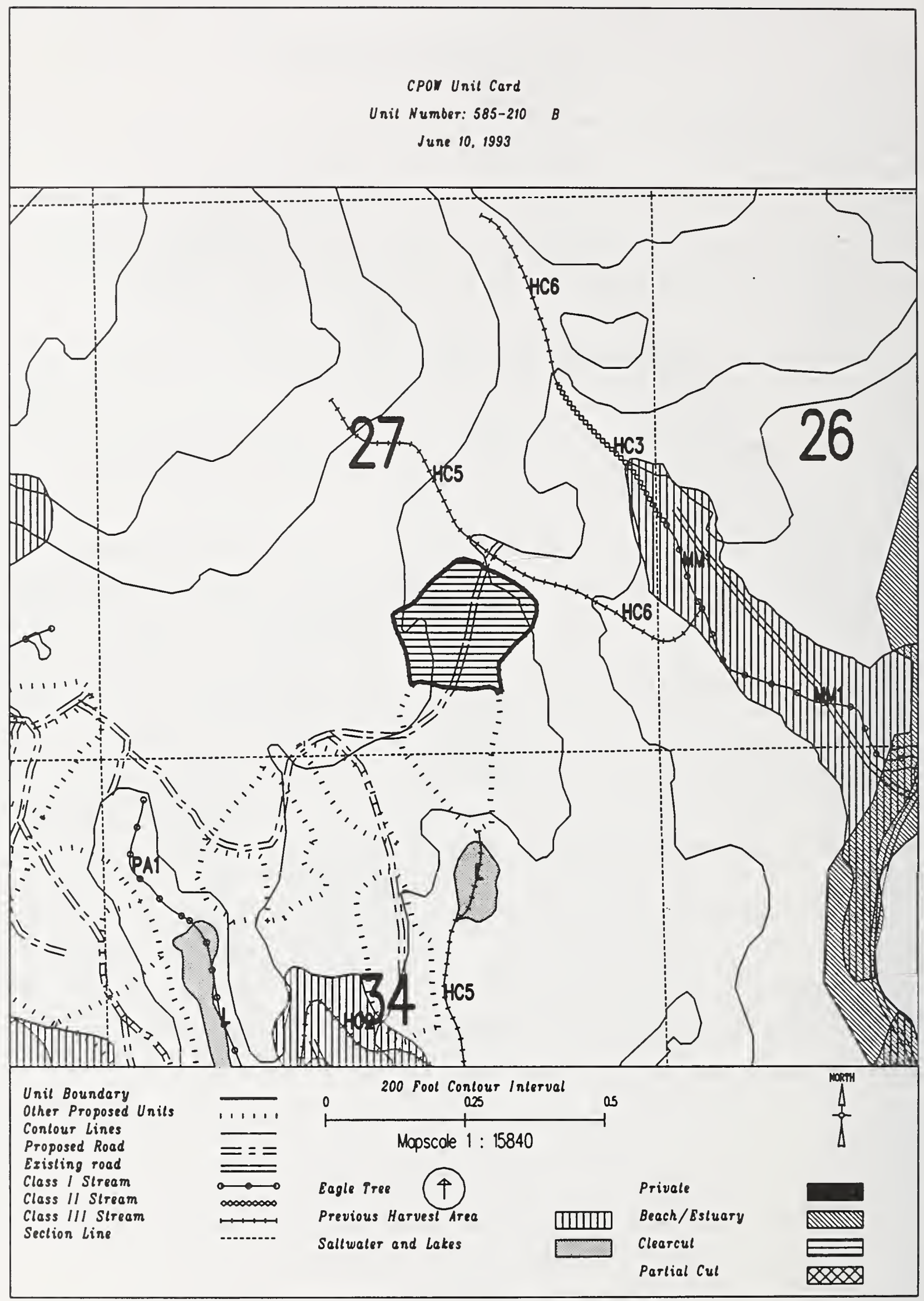




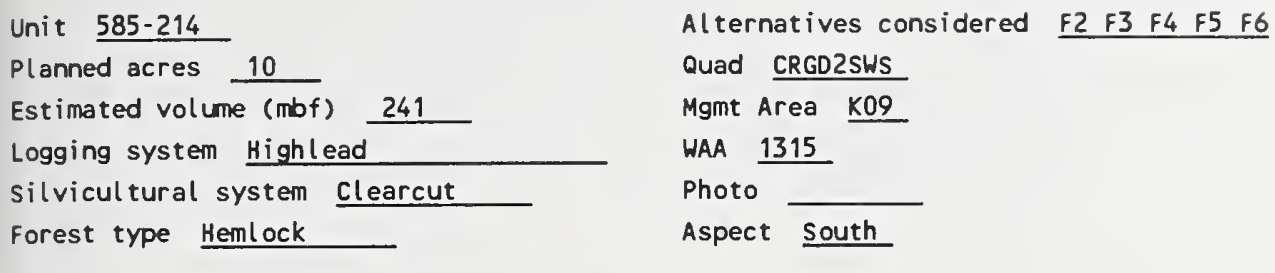




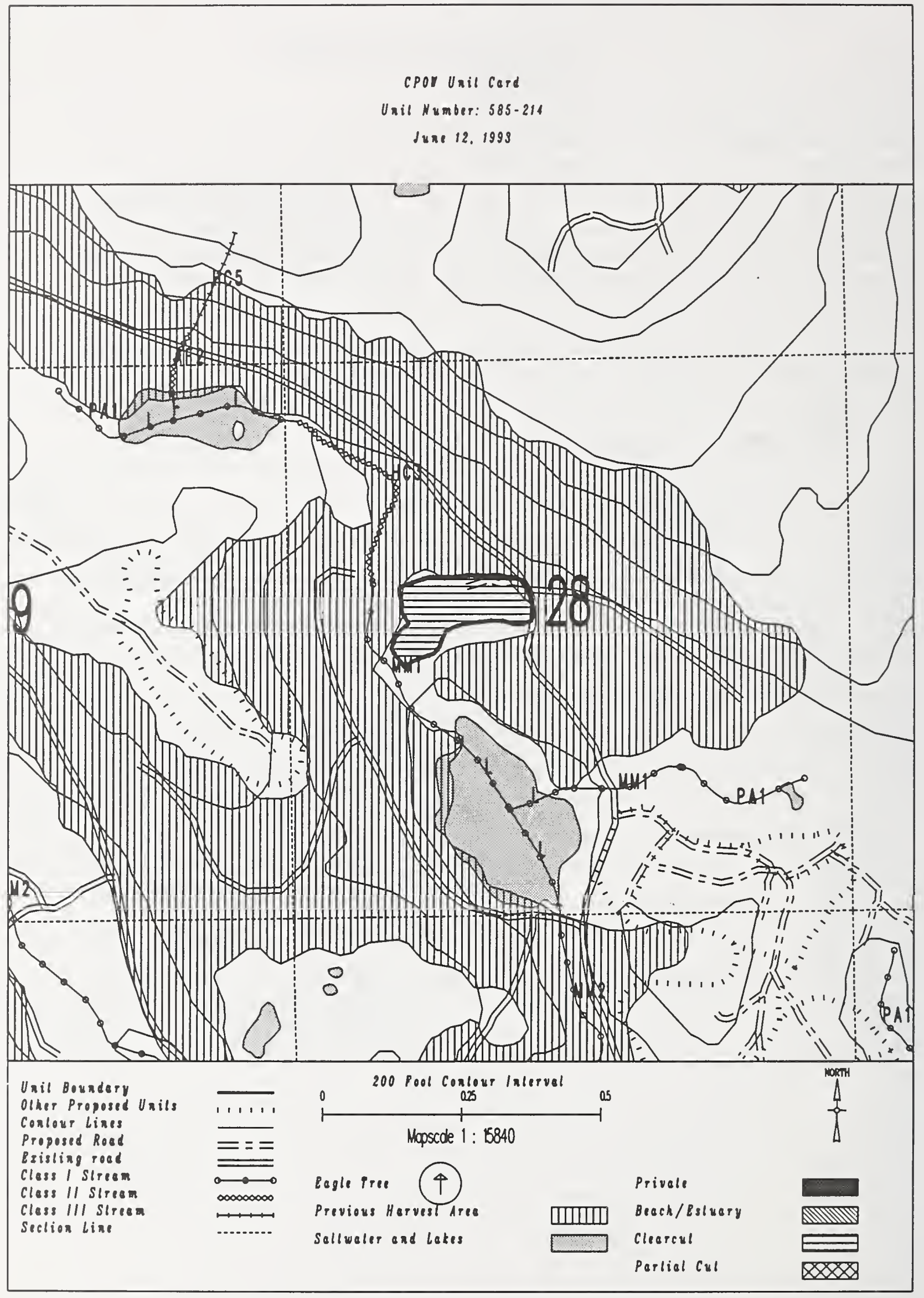




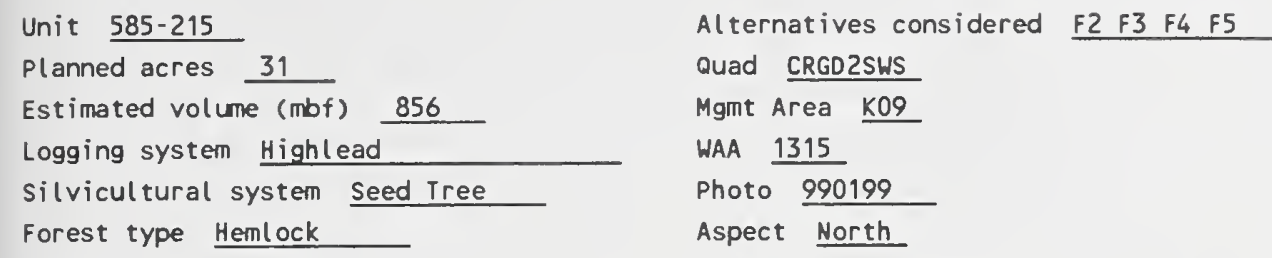




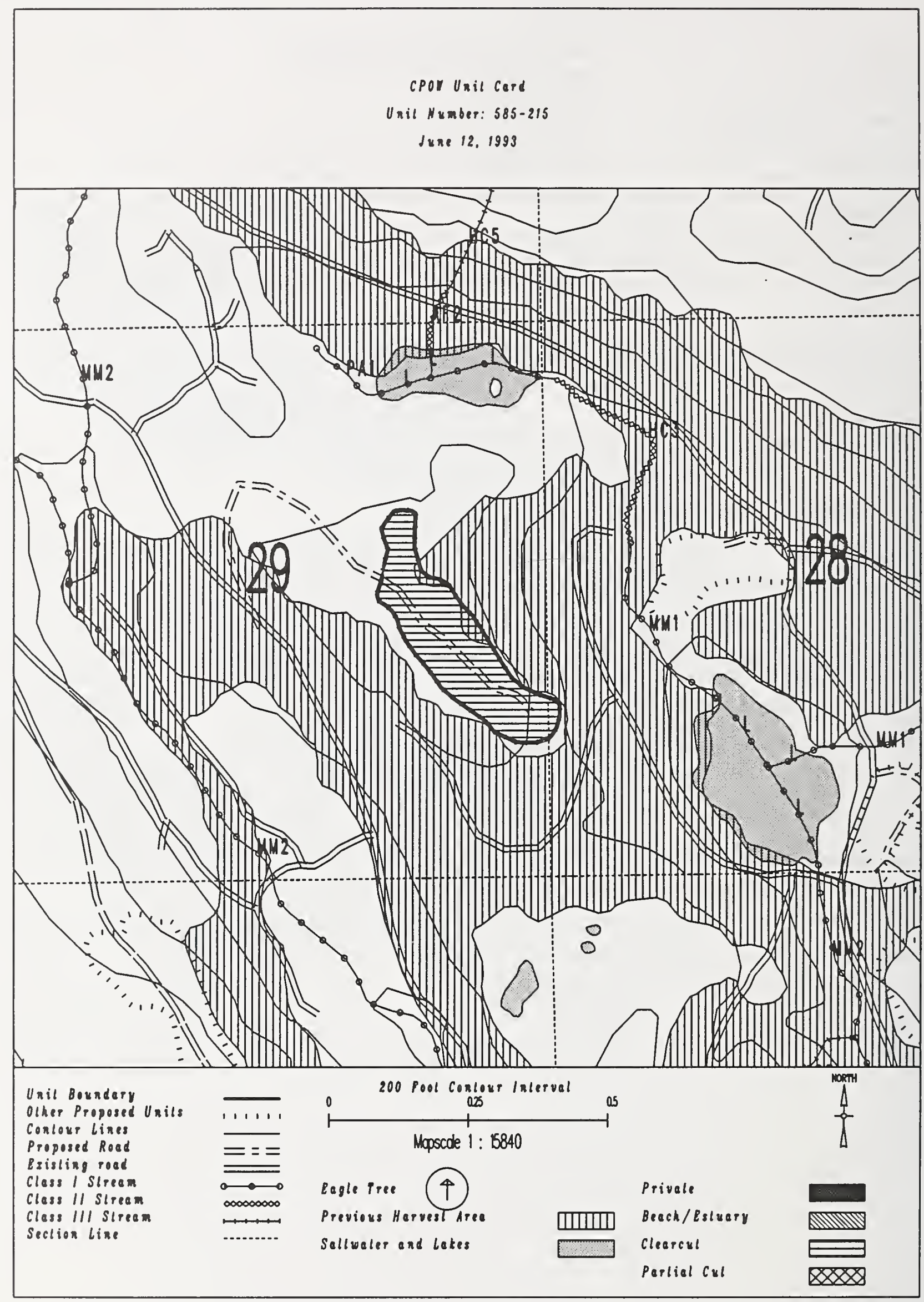




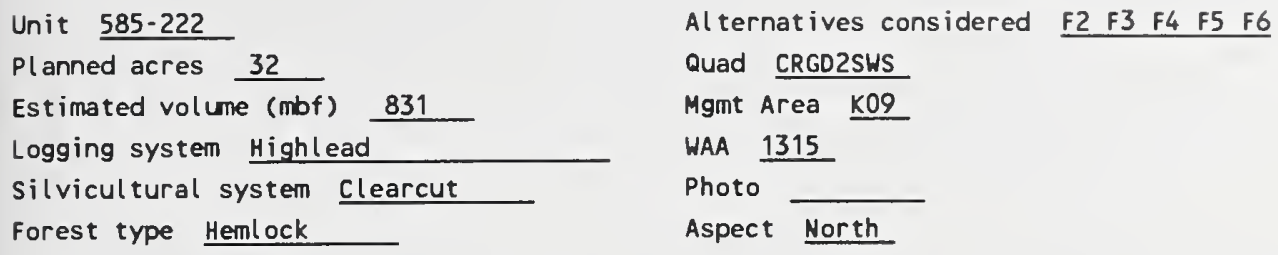




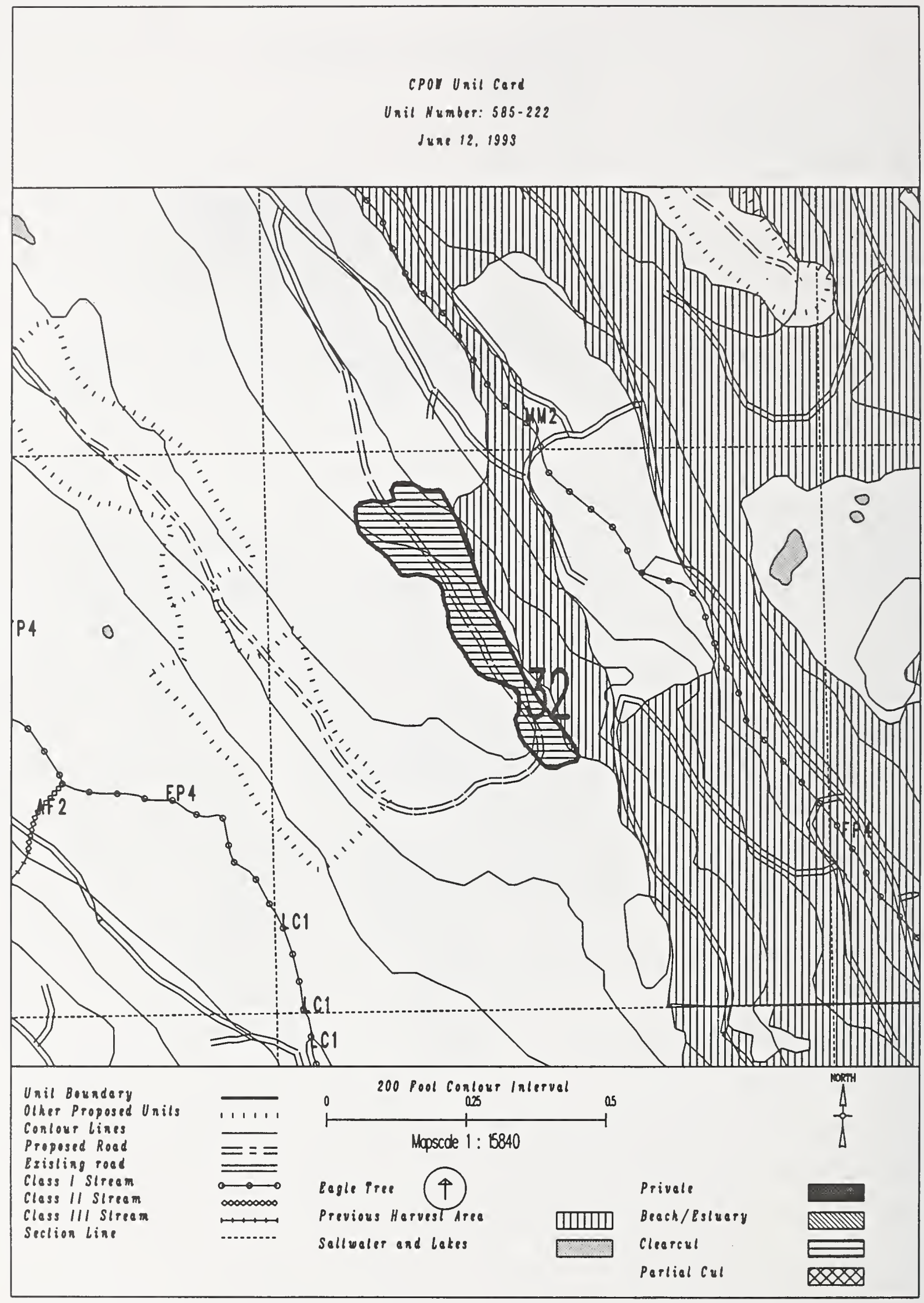


Unit 586-201

Planned acres 61

Estimated volume (mbf) 1487

Logging system Highlead

silvicultural system clearcut

Forest type Hemlock
Alternatives considered F2 F3 F4 F5 F6

Quad CRGC2NWN

Mgmt Area $\mathrm{K} 10$

WAA 1315

Photo 990204

Aspect East

PHYSICAL DESCRIPTION

Volume class breakdown: VC4 29 acres vC5 26 acres vc6 $\quad 0$ acres vc7 0 acres

Elevation breakdown: $0-800 \mathrm{ft} . \underline{36}$ acres 800-1200 ft. 24 acres 1200-1500 ft. 0 acres over $1500 \mathrm{ft}$. 0 acres Mass movement index: Low 2 acres Medium 0 acres High 58 acres Very High 0 acres

SOILS

This unit has high mass movement index soils. Partial log suspension required over these areas. (BMP13.9)

\section{TIMBER}

There are no timber mitigation measures anticipated for this unit.

\section{ENG INEER ING}

High mass movement index soils. Road construction must minimize landslide potential (BMP14).

\section{FISH/WATERSHED}

There are no fishery mitigation measures anticipated for this unit.

\section{WILDLIFE}

There are no wildlife mitigation measures anticipated for this unit.

RECREATION / VISUALS

This unit has a proposed voO of MM and is not seen from any viewpoint identified by this project.

LANDS

There are no lands mitigation measures anticipated for this unit.

CULTURAL RESOURCES

There are no cultural resource mitigation measures anticipated for this unit.

\section{GEOLOGY}

There are no karst mitigation measures anticipated for this unit. 


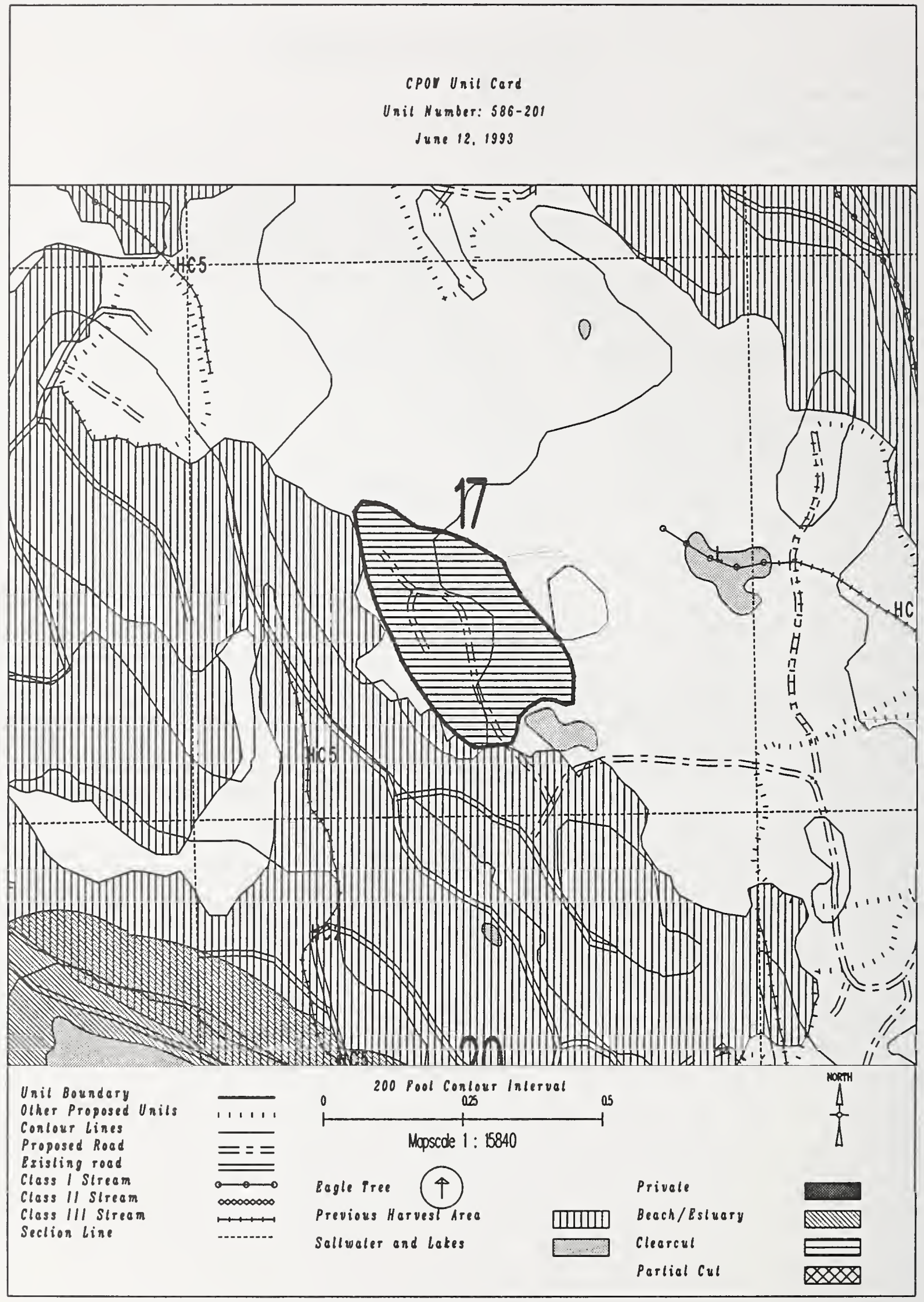




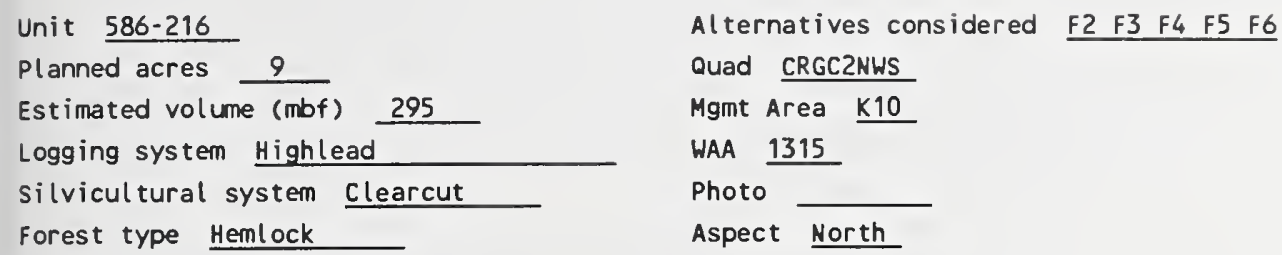




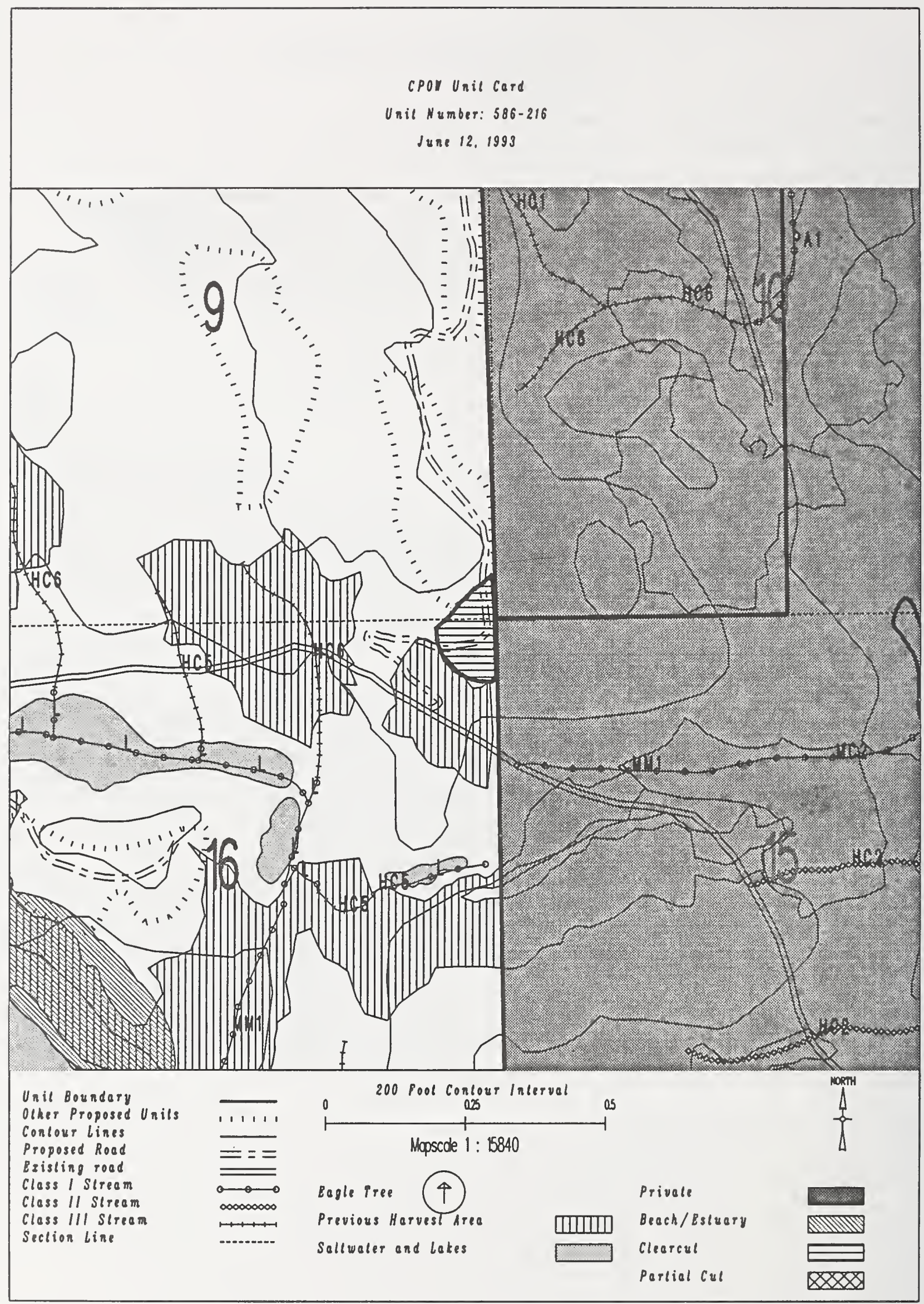


Unit $586-217$

Planned acres 32

Estimated volume (mbf) 645

Logging system Highlead

silvicultural system clearcut

Forest type Hemlock
Alternatives considered $\mathrm{F2} \quad \mathrm{F3} \quad \mathrm{F} 4$ F5 $\quad$ F6

Quad CRGC2NWS

Mgmt Area $\underline{\mathrm{K} 10}$

WAA 1315

Photo 290115

Aspect East

PHYSICAL DESCRIPTION

Volume class breakdown: VC4 13 acres VC5 11 acres VC6 $\quad 0$ acres VC7 $\quad 0$ acres

Elevation breakdown: $0.800 \mathrm{ft}$. 30 acres $800-1200 \mathrm{ft} . \quad 0$ acres $1200-1500 \mathrm{ft} . \underline{0}$ acres over $1500 \mathrm{ft}$. 0 acres Mass movement index: Low 32 acres Medium 0 acres High 0 acres Very High 0 acres

SOILS

This unit has > 40\% MCGilvery soils. Partial suspension required (BMP13.9)

to ensure reforestation (BMP13.19).

\section{TIMBER}

There are no timber mitigation measures anticipated for this unit.

ENGINEERING

There are no engineering mitigation measures anticipated for this unit.

\section{FISH/WATERSHED}

This unit contains streams which have recently been classified/channel typed but require field verification.

WILDLIFE

There are no wildlife mitigation measures anticipated for this unit.

RECREATION / VISUALS

This unit has a proposed VQO of MM and is not seen from any viewpoint identified by this project.

\section{LANDS}

This unit adjacent to other ownership. Boundary establishment required prior to layout.

CULTURAL RESOURCES

There are no cultural resource mitigation measures anticipated for this unit.

GEOLOGY

There are no karst mitigation measures anticipated for this unit. 


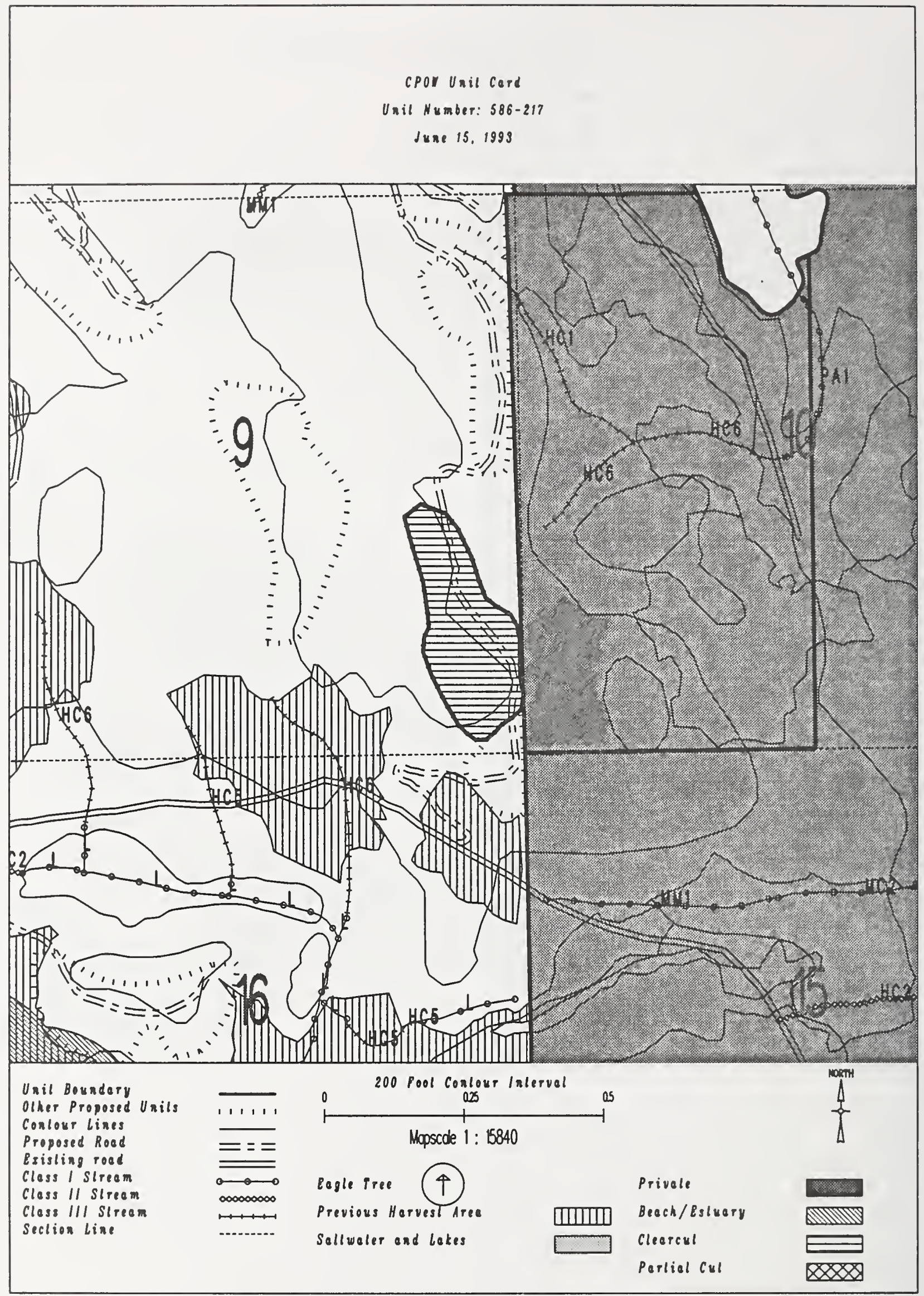


Unit $586-218$

Planned acres 20

Estimated volume (mbf)

Logging system Highlead

silvicultural system clearcut

Forest type Hemlock

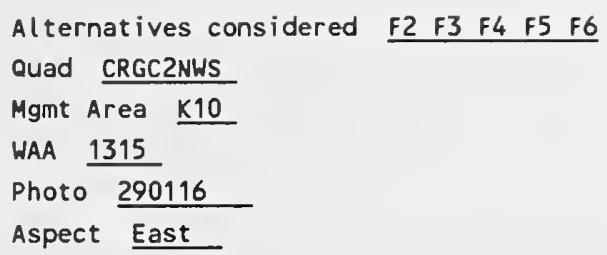

\section{PHYSICAL OESCRIPTION}

Volume class breakdown: VC4 $\quad 7$ acres VC5 11 acres vC6 $\quad 0$ acres VC7 $\quad 0$ acres

Elevation breakdown: $0-800 \mathrm{ft} . \underline{18}$ acres $800-1200 \mathrm{ft} . \underline{0}$ acres $1200-1500 \mathrm{ft}$. 0 acres over $1500 \mathrm{ft}$. 0 acres Mass movement index: Low 14 acres Medium 0 acres High 4 acres Very High 0 acres

\section{SOILS}

This unit has high mass movement index soils. Partial log suspension required over these areas.(BMP13.9)

This unit has > 40\% McGilvery soils. Partial suspension required (BMP13.9)

to ensure reforestation (BMP13.19).

\section{TIMBER}

There are no timber mitigation measures anticipated for this unit.

\section{ENGINEER ING}

There are no engineering mitigation measures anticipated for this unit.

\section{FISH/WATERSHED}

This unit contains streams which have recently been classified/channel typed but require field verification.

\section{WILDLIFE}

There are no wildlife mitigation measures anticipated for this unit.

\section{RECREATION / VISUALS}

This unit has a proposed Voo of MM and is not seen from any viewpoint identified by this project.

\section{LANDS}

This unit adjacent to other ownership. Boundary establishment required prior to layout.

CULTURAL RESOURCES

There are no cultural resource mitigation measures anticipated for this unit.

There are no karst mitigation measures anticipated for this unit. 


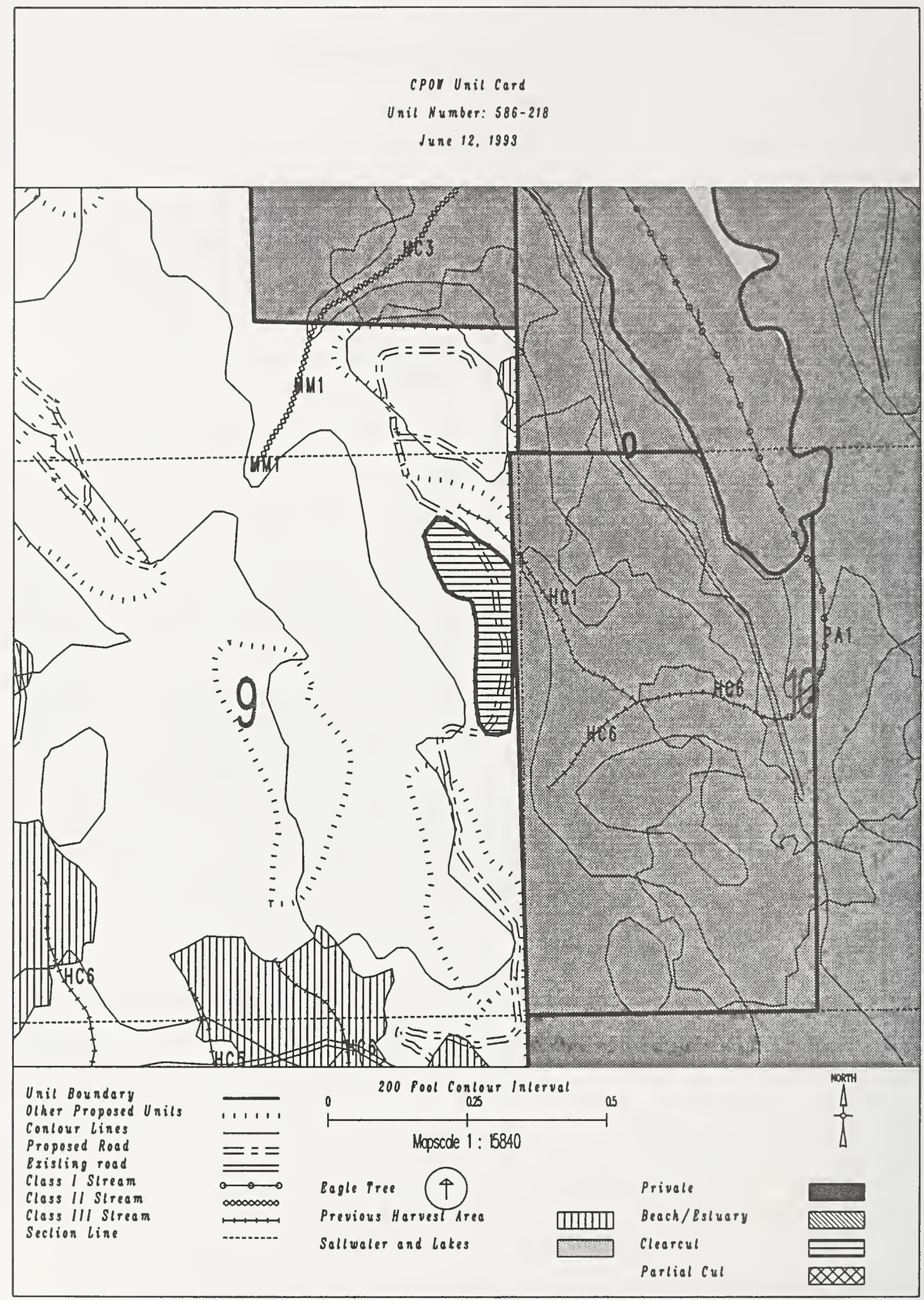




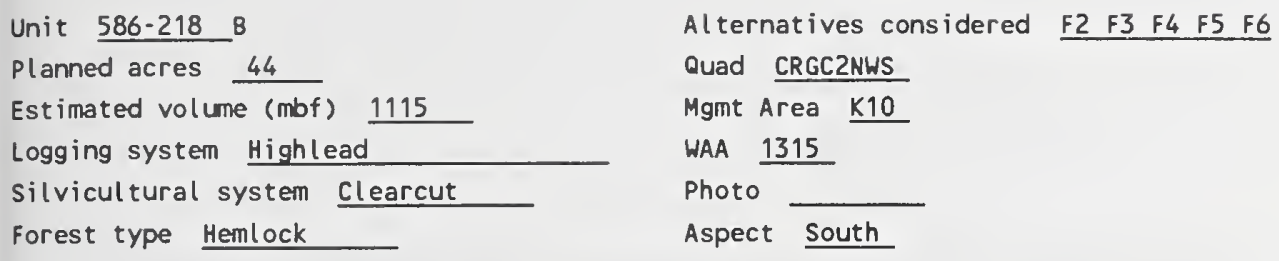




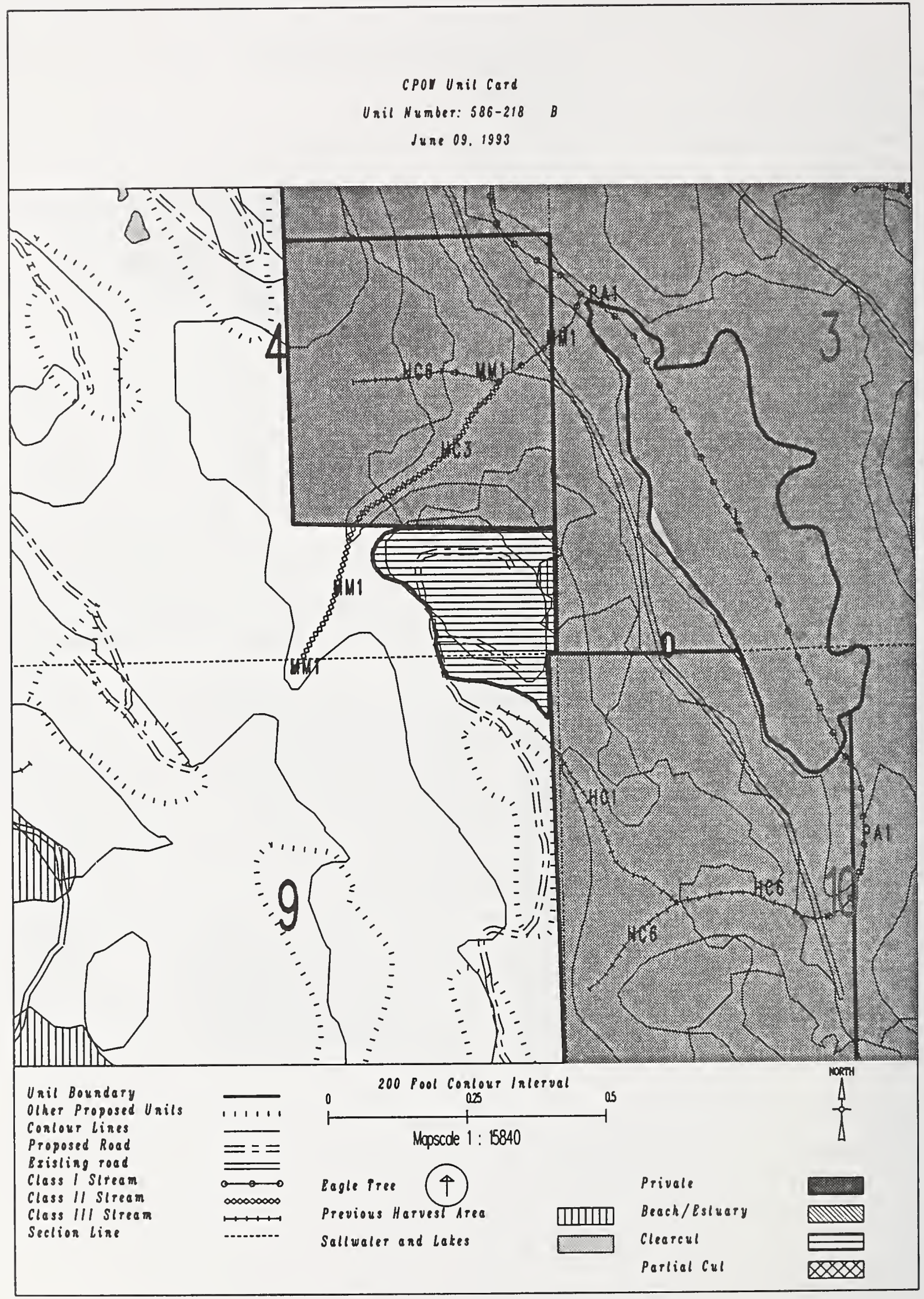


Unit 586-219

Planned acres 26

Estimated volume (mbf) 819

Logging system Highlead

silvicultural system clearcut

Forest type Hemlock
Alternatives considered $\mathrm{F2} \quad$ F4 F5 F6

Quad CRGC2NWS

Mgmt Area $\mathrm{K} 10$

WAA 1315

Photo 690139

Aspect East

PHYSICAL OESCRIPTION

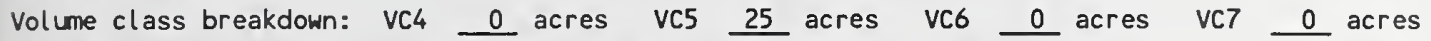

Elevation breakdown: $0-800 \mathrm{ft} .15$ acres $800-1200 \mathrm{ft} . \underline{9}$ acres $1200-1500 \mathrm{ft}$. 0 acres over $1500 \mathrm{ft}$. 0 acres Mass movement index: Low 26 acres Medium $\_$acres High 0 acres Very High 0

SOILS

This unit has < 40\% McGilvery soils. Partial suspension required (BMP13.9) to ensure reforestation (BMP13.19).

TIMBER

There are no timber mitigation measures anticipated for this unit.

\section{ENGINEERING}

There are no engineering mitigation measures anticipated for this unit.

\section{FISH/WATERSHEO}

There are no fishery mitigation measures anticipated for this unit.

HILOLIFE

There are no wildlife mitigation measures anticipated for this unit.

RECREATION / VISUALS

This unit has a proposed VQO of MM and is not seen from any viewpoint identified by this project.

LANDS

There are no lands mitigation measures anticipated for this unit.

CULTURAL RESOURCES

There are no cultural resource mitigation measures anticipated for this unit.

\section{GEOLOGY}

There are no karst mitigation measures anticipated for this unit. 


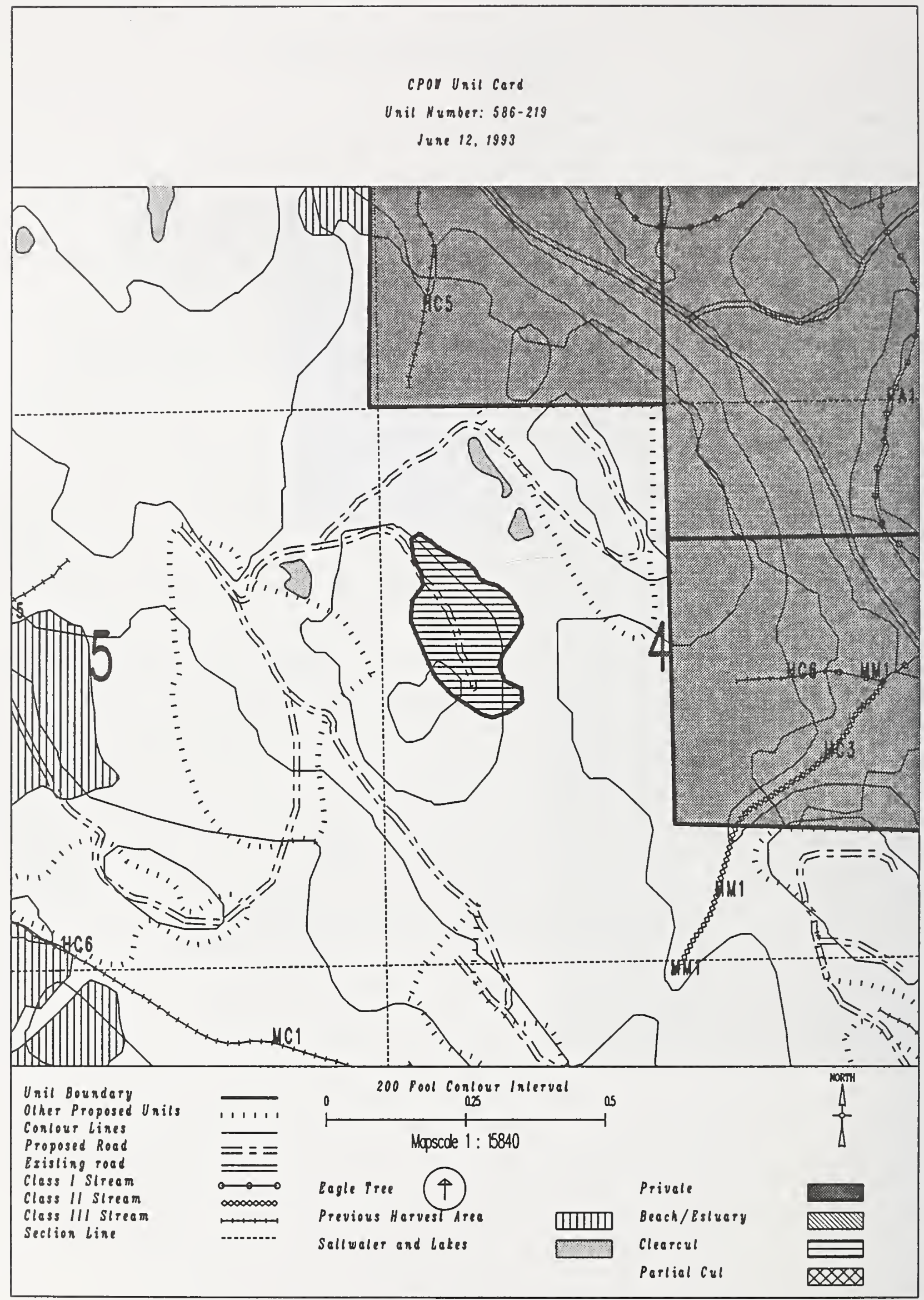




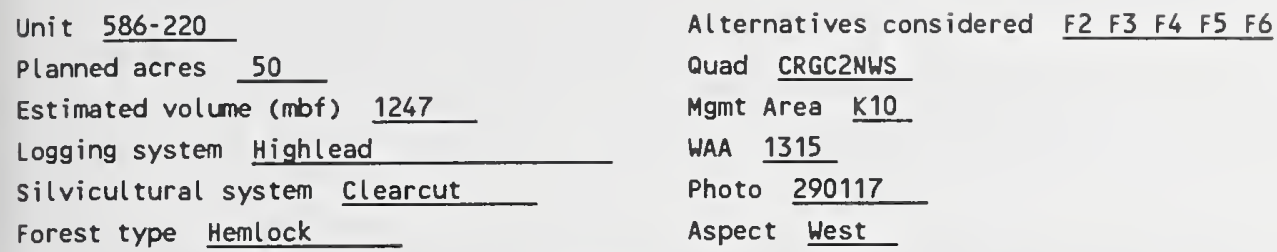




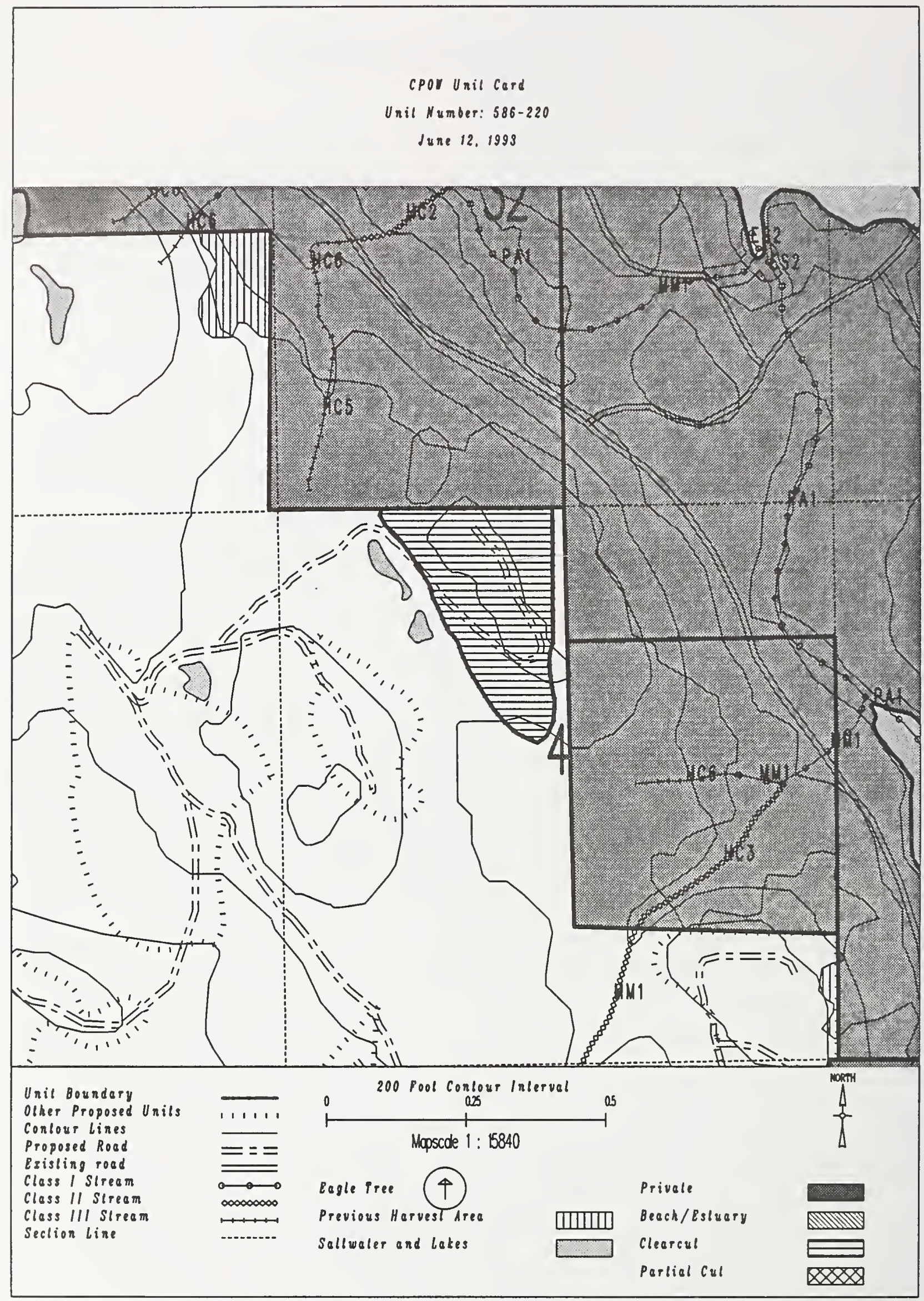




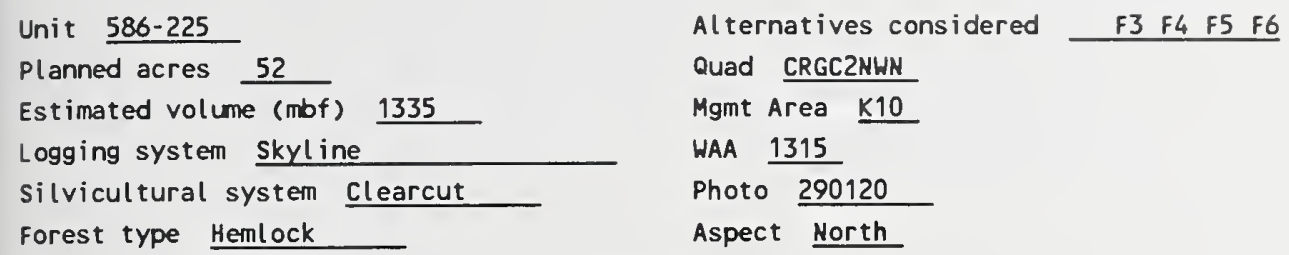




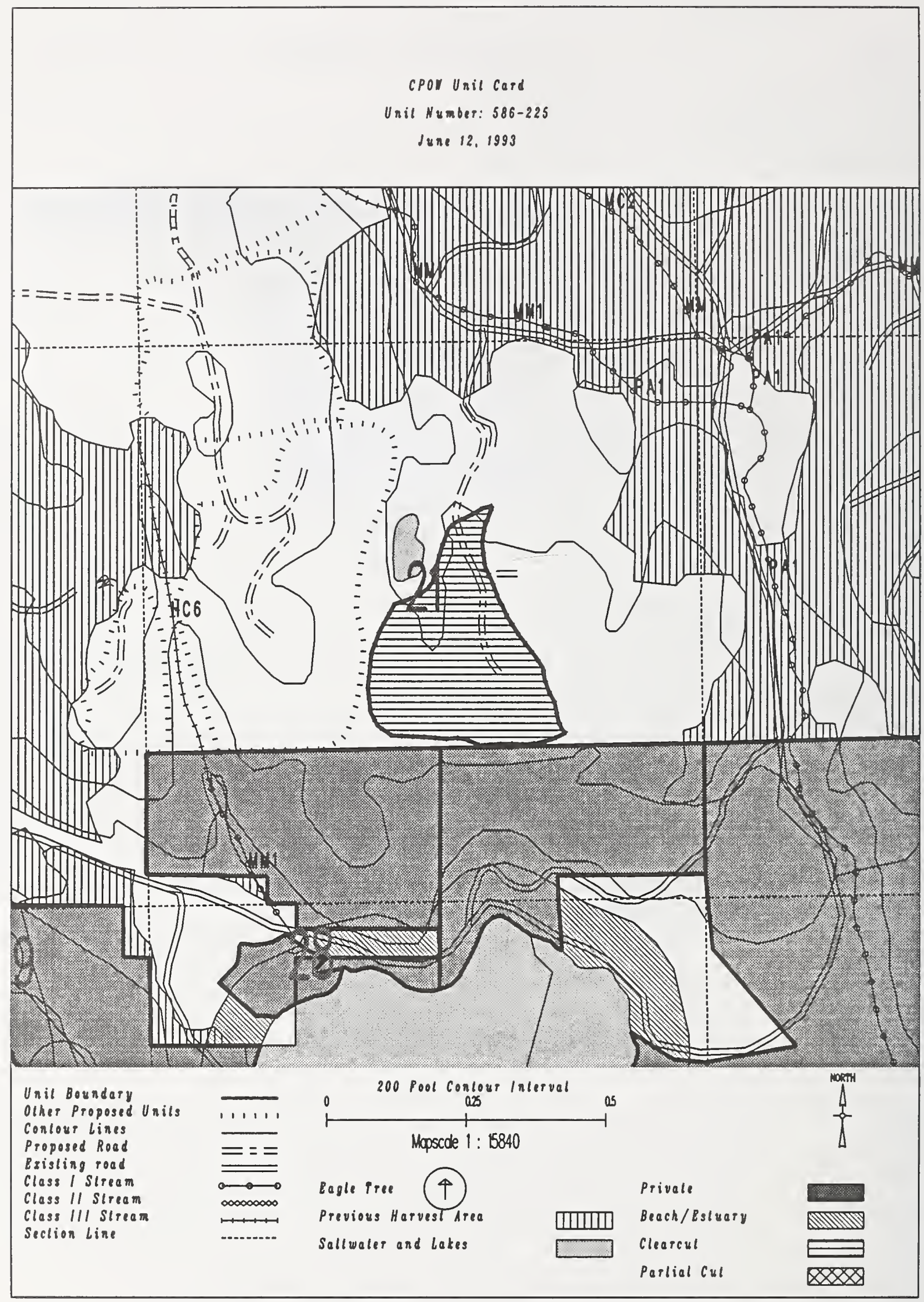




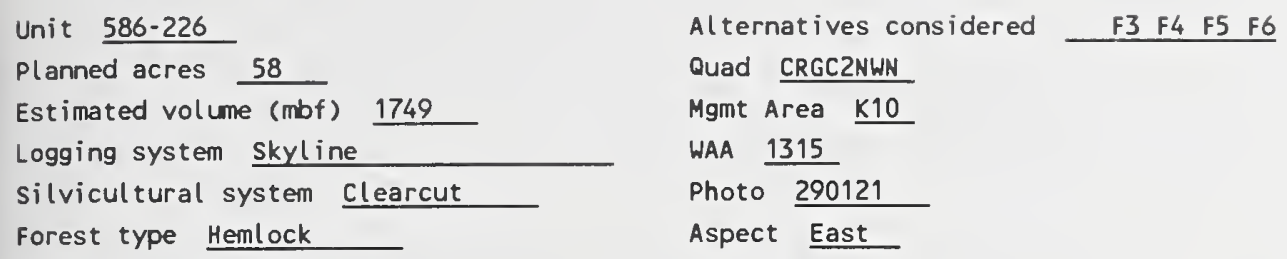




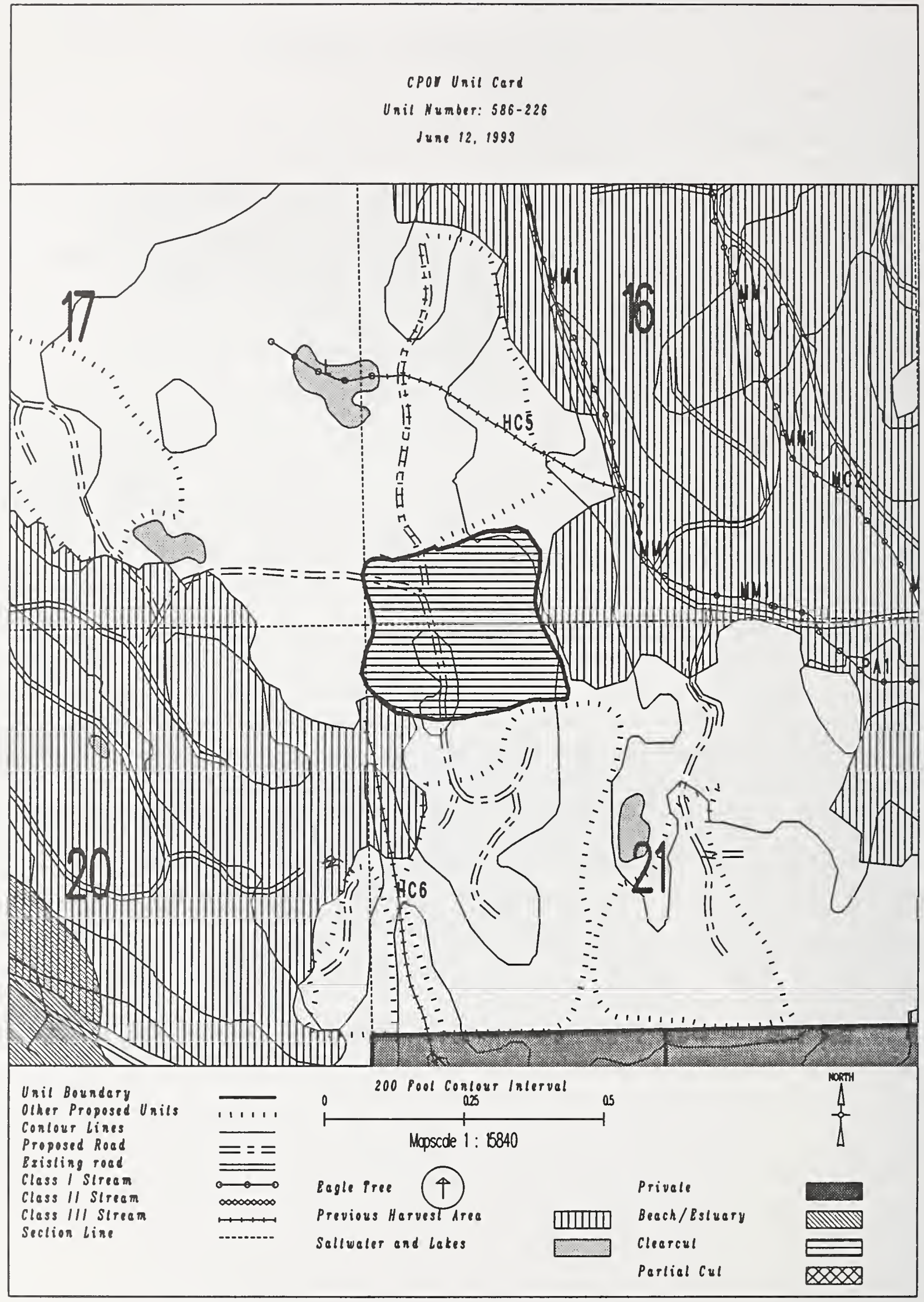


Unit $586-227$

Planned acres 63

Estimated volume (mbf) 2065

Logging system skyline

silvicultural system clearcut

Forest type Hemlock

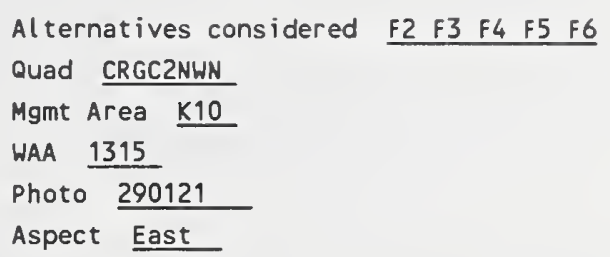

PHYSICAL DESCRIPTION

Volume class breakdown: vC4 0 acres VC5 63 acres vc6 0 acres vc7 0 acres

Elevation breakdown: $0-800 \mathrm{ft} . \underline{60}$ acres $800-1200 \mathrm{ft} . \underline{0}$ acres $1200-1500 \mathrm{ft} . \overline{0}$ acres over $1500 \mathrm{ft} . \underline{0}$ acres Mass movement index: Low 0 acres Medium 56 acres $\mathrm{High} 7$ acres Very High 0 acres

SOILS

This unit has high mass movement index soils. Partial log suspension required over these areas. (BMP13.9)

This unit has a slight possibility to be reclassified as MMI $=4$.

This unit contains 46 acres of forested wetlands. Site specific BMPs will be designed for selected approved

logging system and road construction practices. (BMPs 12.5, 13.9, 13.15).

TIMBER

There are no timber mitigation measures anticipated for this unit.

ENGINEER ING

High mass movement index soils. Road construction must minimize landslide potential (BMP14).

FISH/WATERSHED

This unit contains a $\underline{A} 4$ class $\underline{3}$ stream. No specific buffer required, but full suspension, if yarding across.

\section{HILDLIFE}

Maintain diversity within unit by leaving 1-5 acre-sized islands of green trees at a rate of 1 acre of island for every 20 acres harvested. Leave islands must be compatible with logging system and safe working conditions.

\section{RECREATION / VISUALS}

This unit has a proposed VQO of MM and is not seen from any viewpoint identified by this project.

\section{LANDS}

There are no lands mitigation measures anticipated for this unit.

CULTURAL RESOURCES

There are no cultural resource mitigation measures anticipated for this unit.

\section{GEOLOGY}

There are no karst mitigation measures anticipated for this unit. 


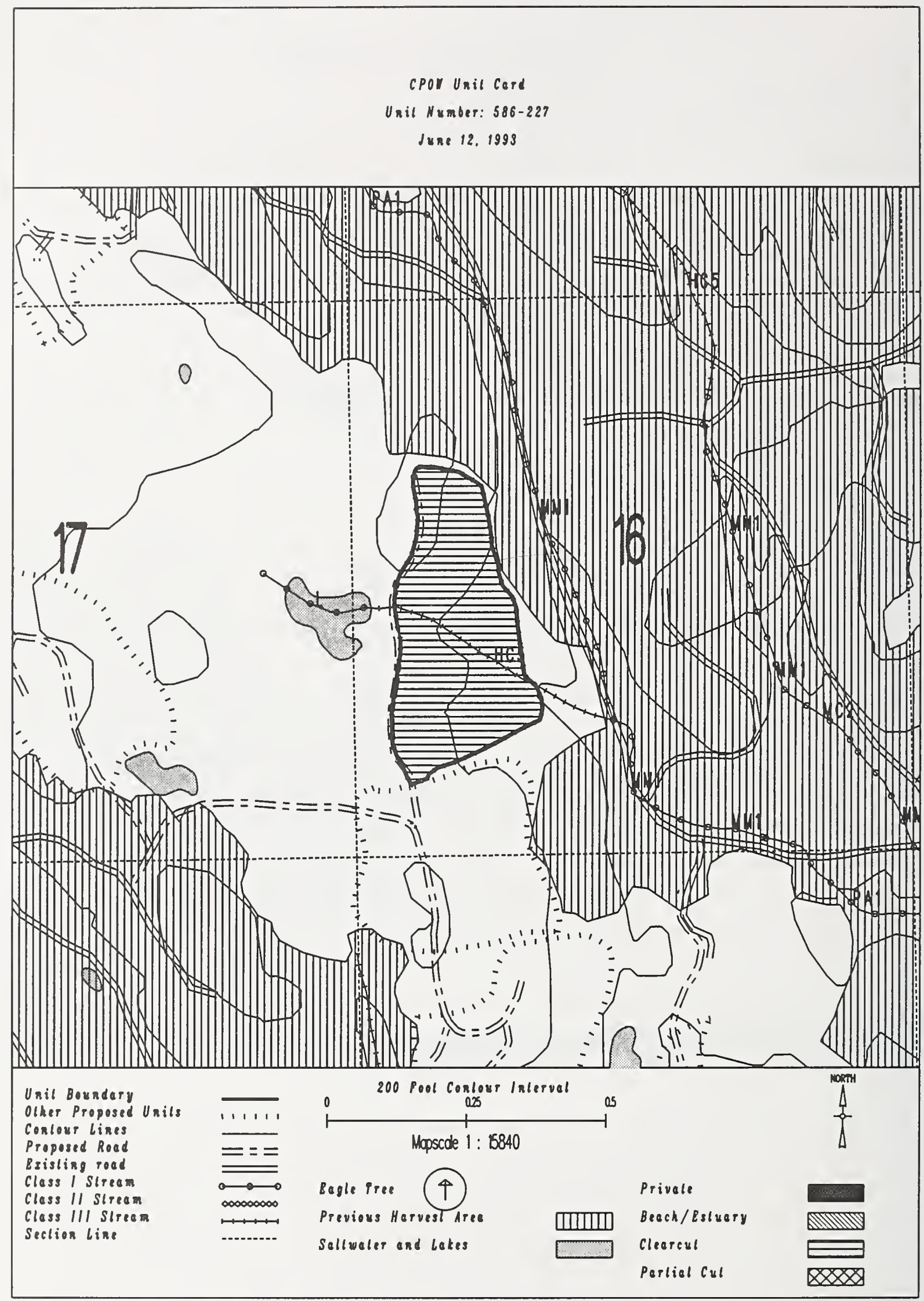


Unit 586-228

Planned acres 97

Estimated volume (mbf) 2777

logging system Skyline

Silvicultural system clearcut

Forest type Hemlock
Alternat ives considered $\mathrm{F2}$

Quad CRGC2NWN

Mgmt Area $\underline{\mathrm{K} 10}$

WAA 1315

Photo 290120

Aspect East

\section{PHYSICAL DESCRIPTION}

Volume class breakdown: VC4 52 acres vC5 50 acres vC6 0 acres vc7 0 acres

Elevation breakdown: $0-800 \mathrm{ft}$. 99 acres $800-1200 \mathrm{ft} . \quad 0$ acres $1200-1500 \mathrm{ft}$. 0 acres over $1500 \mathrm{ft}$. 0 acres Mass movement index: Low $\underline{3}$ acres Medium $\underline{29}$ acres. High $\underline{69}$ acres Very High $\underline{0}$ acres

\section{SOILS}

This unit has high mass movement index soils. Partial log suspension required over these areas.(BMP13.9)

This unit contains 12 acres of forested wetlands. Site specific BMPs will be designed for selected approved

logging system and road construction practices. (BMPs 12.5, 13.9, 13.15).

TIMBER

There are no timber mitigation measures anticipated for this unit.

\section{ENGINEERING}

High mass movement index soils. Road construction must minimize landslide potential (BMP14).

\section{FISH/WATERSHED}

There are no fishery mitigation measures anticipated for this unit.

\section{WILDLIFE}

Maintain diversity within unit by leaving 1-5 acre-sized islands of green trees at a rate of 1 acre of island for every 20 acres harvested. Leave islands must be compatible with logging system and safe working conditions.

\section{RECREATION / VISUALS}

This unit has a proposed VQO of MM and is not seen from any viewpoint identified by this project.

\section{LANDS}

This unit adjacent to other ownership. Boundary establishment required prior to layout.

\section{CULTURAL RESOURCES}

There are no cultural resource mitigation measures anticipated for this unit.

\section{GEOLOGY}

There are no karst mitigation measures anticipated for this unit. 
cpor Unil cerd

Unil Number: 586-228

June 12, 1999

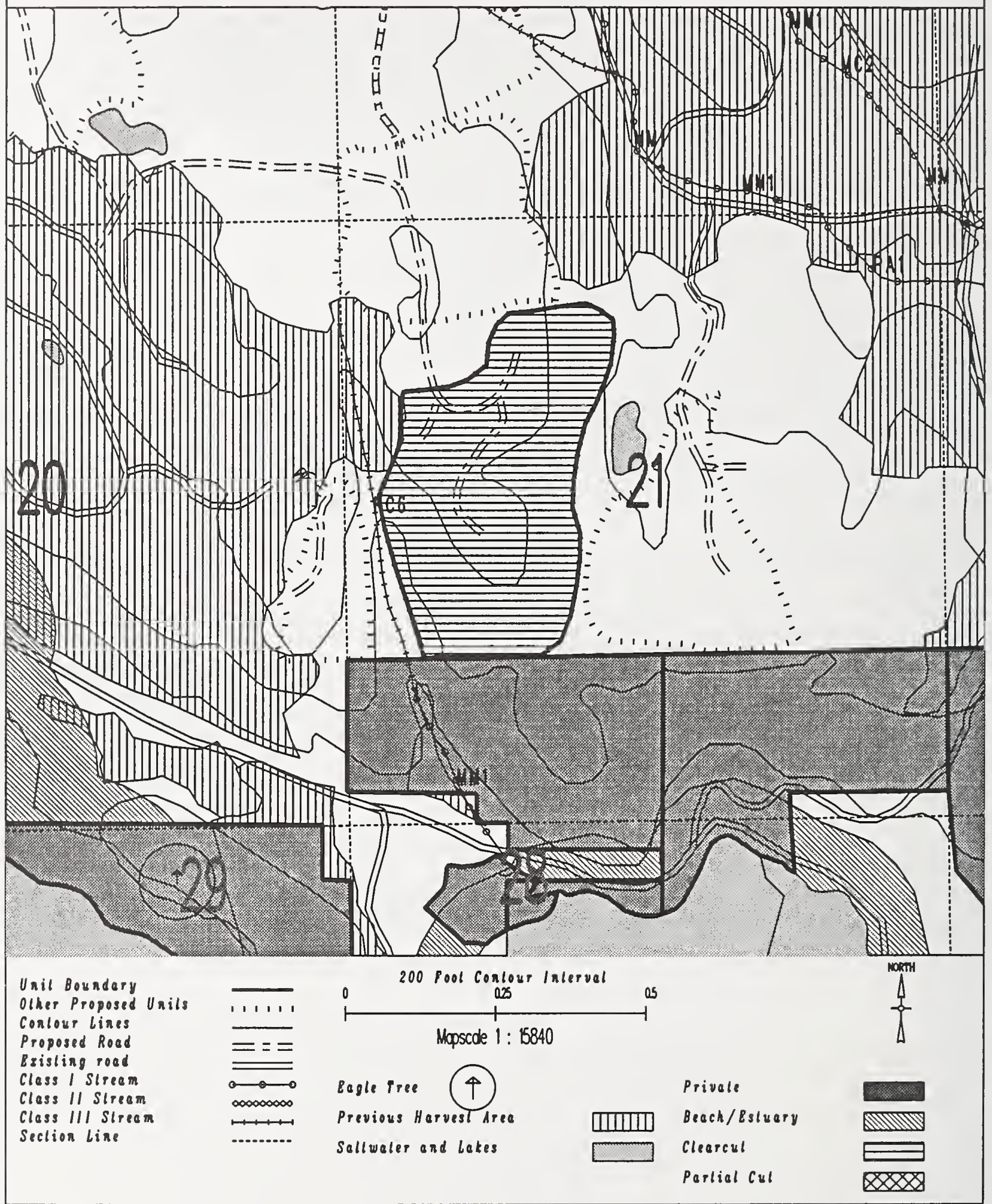


Unit $586-229$

Planned acres 22

Estimated volume (mbf)

Logging system skyline

silvicultural system Clearcut

Forest type Hemlock

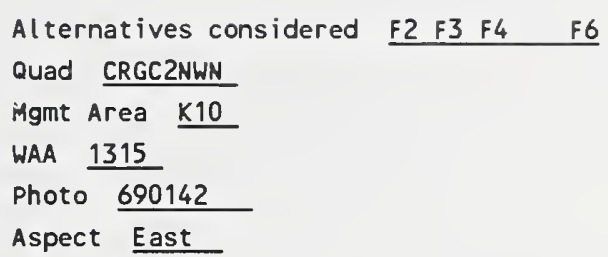

PHYSICAL DESCRIPTION

Volume class breakdown: vC4 9 acres vc5 13 acres vc6 0 acres vc7 0 acres

Elevation breakdown: $0-800 \mathrm{ft} .19$ acres $800-1200 \mathrm{ft} . \quad 0$ acres $1200-1500 \mathrm{ft} . \underline{0}$ acres over $1500 \mathrm{ft} . \quad 0$ Mass movement index: Low 0 acres Medium 15 acres High 6 acres Very High 0 acres

SOILS

This unit has high mass movement index soils. Partial log suspension required over these areas.(BMP13.9)

TIMBER

There are no timber mitigation measures anticipated for this unit.

ENGINEERING

High mass movement index soils. Road construction must minimize landslide potential (BMP14).

FISH/WATERSHED

There are no fishery mitigation measures anticipated for this unit.

WILDLIFE

Maintain diversity within unit by leaving 1-5 acre-sized islands of green trees at a rate of 1 acre of island for every 20 acres harvested. Leave islands must be compatible with logging system and safe working conditions.

RECREATION / VISUALS

This unit has a proposed VoO of MM and is not seen from any viewpoint identified by this project.

LANDS

This unit adjacent to other ownership. Boundary establishment required prior to layout.

CULTURAL RESOURCES

There are no cultural resource mitigation measures anticipated for this unit.

GEOLOGY

There are no karst mitigation measures anticipated for this unit. 
cpor Unil cerd

Unit Number: 586-229

June 14, 1999

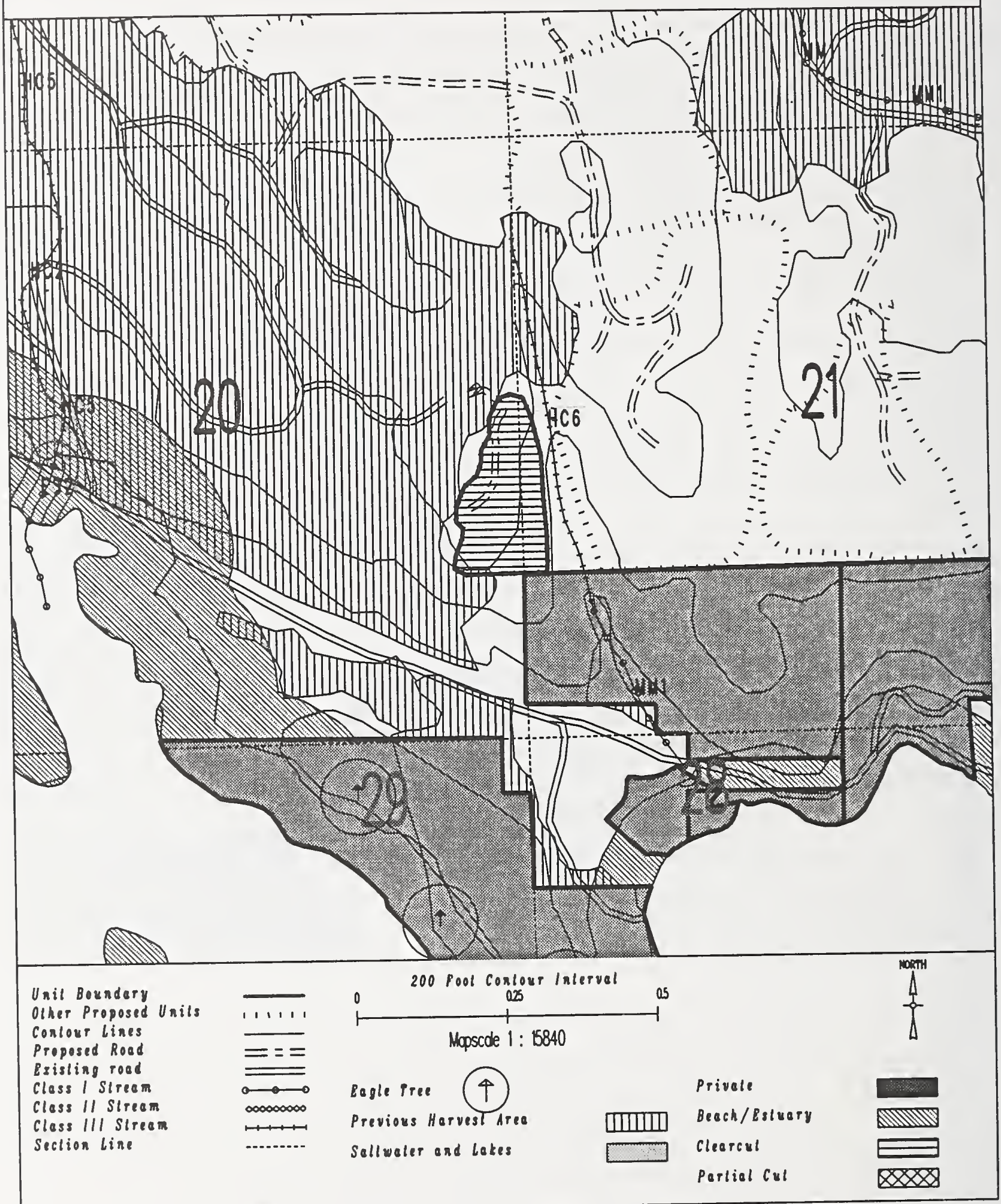


Unit 586-232

Planned acres 55

Estimated volume (mbf) 1506

Logging system skyline

silvicultural system clearcut

Forest type Hemlock
Alternatives considered F2 $\quad$ F4 F5 F6

Quad CRGC2NWS

Mgmt Area K10

WAA 1315

Photo 690141

Aspect North

PHYSICAL DESCRIPTION

Volume class breakdown: VC4 9 acres VC5 26 acres VC6 12 acres vc7 0 acres

Elevation breakdown: $0-800 \mathrm{ft} . \underline{18}$ acres $800-1200 \mathrm{ft} . \underline{28}$ acres $1200-1500 \mathrm{ft} . \underline{0}$ acres over $1500 \mathrm{ft} .0$

Mass movement index: Low 29 acres Medium 24 acres High 0 acres Very High 0 acres

\section{SOILS}

There are no soils mitigation measures anticipated for this unit.

\section{TIMBER}

There are no timber mitigation measures anticipated for this unit.

\section{ENG INEERING}

There are no engineering mitigation measures anticipated for this unit.

\section{FISH/WATERSHED}

There are no fishery mitigation measures anticipated for this unit.

\section{WILDLIFE}

Maintain diversity within unit by leaving 1-5 acre-sized islands of green trees at a rate of 1 acre of island for every 20 acres harvested. Leave islands must be compatible with logging system and safe working conditions.

RECREATION / VISUALS

This unit has a proposed voo of MM and is not seen from any viewpoint identified by this project.

\section{LANDS}

This unit adjacent to other ownership. Boundary establishment required prior to layout.

CULTURAL RESOURCES

There are no cultural resource mitigation measures anticipated for this unit.

GEOLOGY

There are no karst mitigation measures anticipated for this unit. 


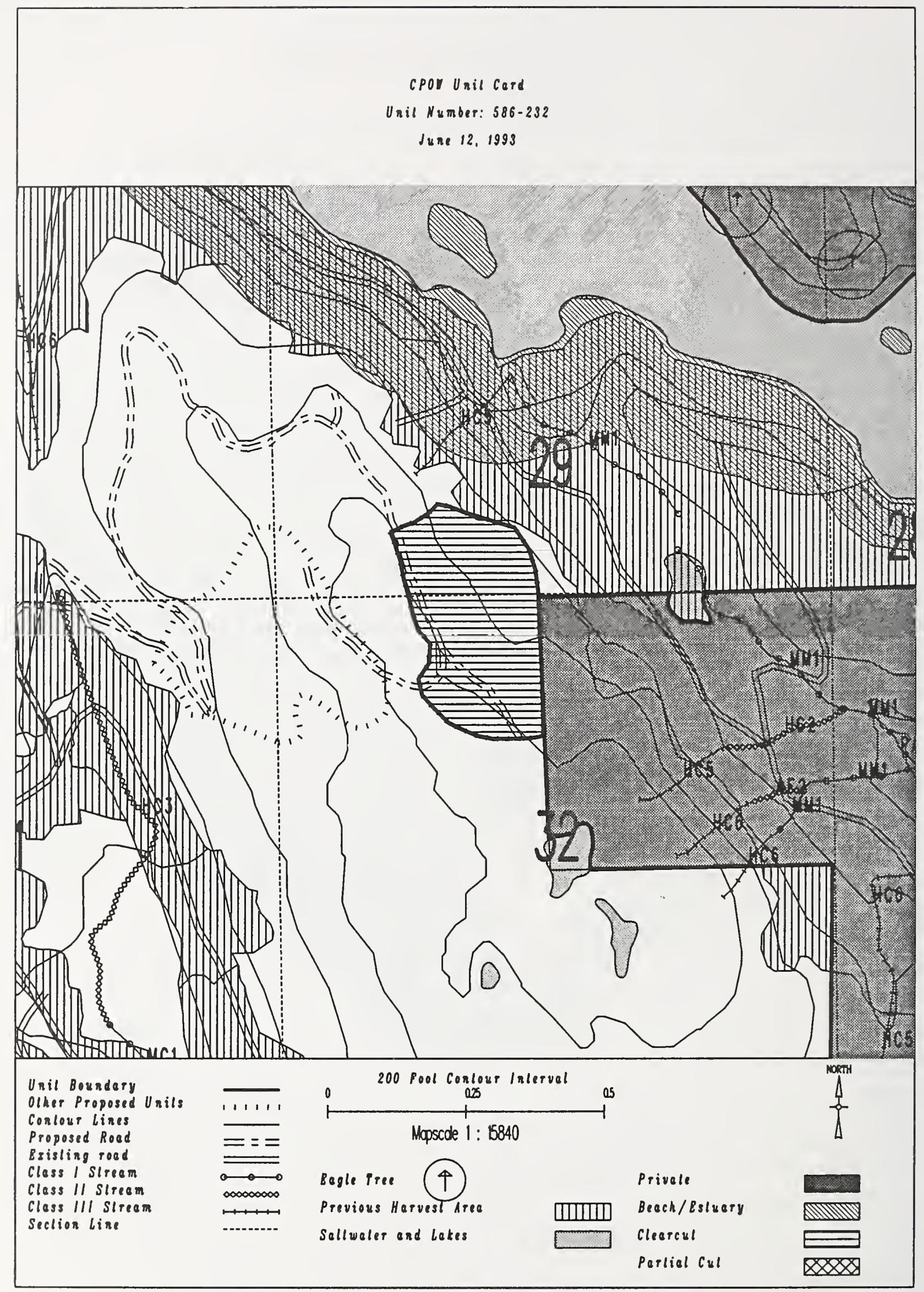


Unit $587.1-206$

Planned acres 40

Estimated volume (mbf) 1083

Logging system Highlead

silvicultural system clearcut

forest type Hemlock
Alternatives considered F2 $\quad$ F3 F4 F5 F6

Quad CRGD4SEN

Mgmt Area $\mathrm{K} 07$

WAA 1422

Photo 1290032

Aspect West

\section{PHYSICAL DESCRIPTION}

Volume class breakdown: VC4 21 acres VC5 19 acres VC6 $\quad 0$ acres vC7 $\quad 0$ acres

Elevation breakdown: $0-800 \mathrm{ft} . \underline{38}$ acres $800-1200 \mathrm{ft} . \underline{0}$ acres $1200-1500 \mathrm{ft}$. 0 acres over $1500 \mathrm{ft}$. 0 acres Mass movement index: Low 10 acres Medium 21 acres High 3 acres Very High $\underline{0}$ acres

\section{SOILS}

This unit contains $\_$acres of forested wetlands. Site specific BMPs will be designed for selected approved

logging system and road construction practices. (BMPs 12.5, 13.9, 13.15).

\section{TIMBER}

There are no timber mitigation measures anticipated for this unit.

\section{ENGINEERING}

There are no engineering mitigation measures anticipated for this unit.

\section{FISH/WATERSHED}

There are no fishery mitigation measures anticipated for this unit.

\section{WILDLIFE}

There are no wildlife mitigation measures anticipated for this unit.

\section{RECREATION / VISUALS}

The unit has a proposed VQO of MM within the viewshed of Kussan Point

as viewed from 1 mile from west coast of Prince of Wales.

\section{LANDS}

There are no lands mitigation measures anticipated for this unit.

\section{CULTURAL RESOURCES}

There are no cultural resource mitigation measures anticipated for this unit.

\section{GEOLOGY}

There are no karst mitigation measures anticipated for this unit. 


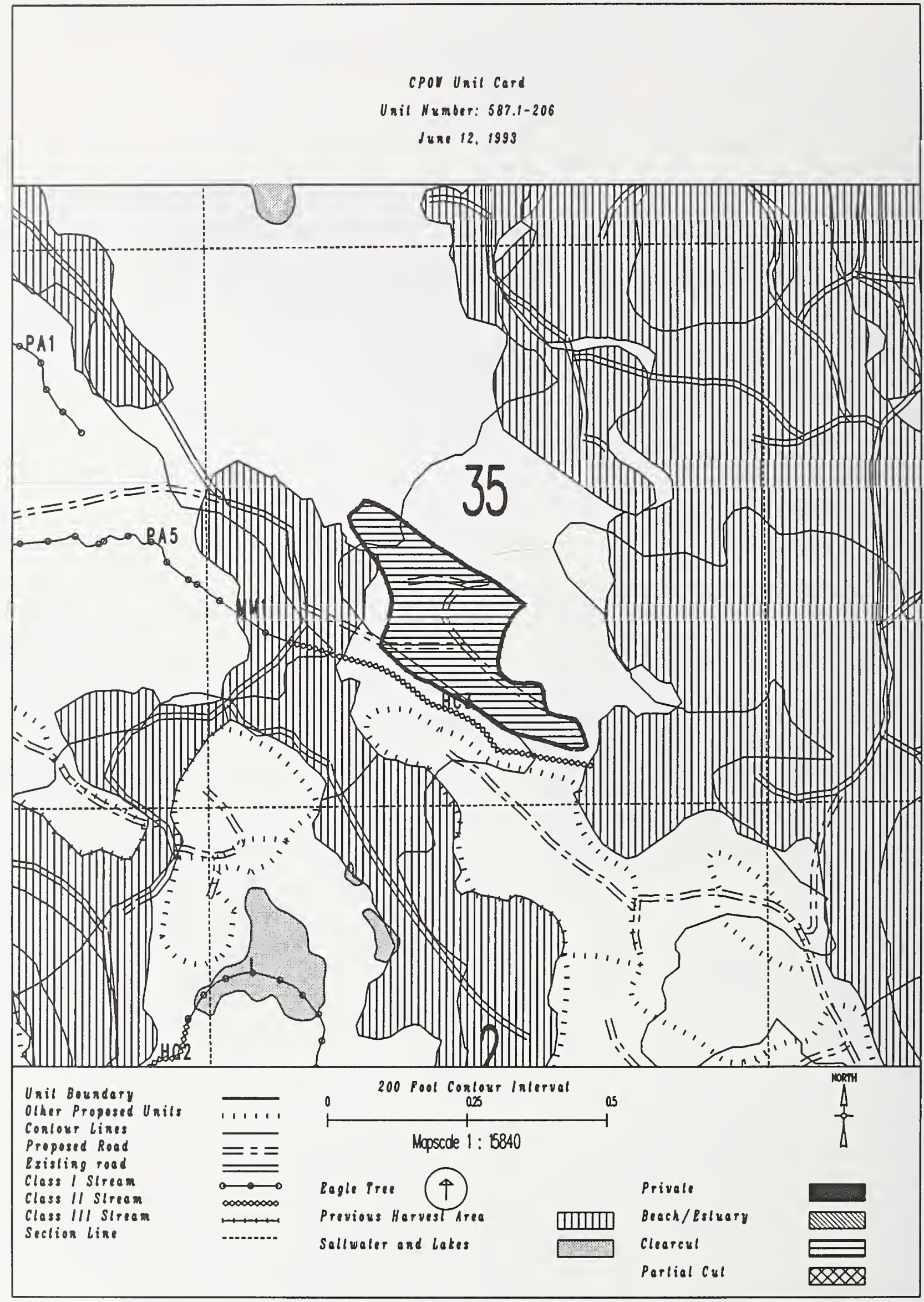


Unit 587.1-207

Planned acres 12

Estimated volume (mbf) 414

Logging system Highlead

silvicultural system clearcut

Forest type Spruce
Alternatives considered F2 $\quad$ F3 $\quad$ F4 $\quad$ F5 $\quad$ F6

Quad CRGD4SEN

Mgmt Area $\mathrm{KO7}$

WAA 1422

Photo 1190118

Aspect South

PHYSICAL DESCRIPIION

Volume class breakdown: VC4 2 acres VC5 2 acres VC6 8 acres VC7 0 acres

Elevation breakdown: $0-800 \mathrm{ft} .10$ acres $800-1200 \mathrm{ft} . \quad 0$ acres 1200-1500 ft. 0 acres over $1500 \mathrm{ft}$. 0 acres Mass movement index: Low $\_$acres Medium 0 acres High 1 acres Very High 0

\section{SOILS}

There are no soils mitigation measures anticipated for this unit.

\section{TIMBER}

There are no timber mitigation measures anticipated for this unit.

\section{ENGINEER ING}

There are no engineering mitigation measures anticipated for this unit.

FISH/WATERSHED

This unit contains streams which have recently been classified/channel typed but require field verification.

WILDLIFE

There are no wildlife mitigation measures anticipated for this unit.

RECREATION / VISUALS

This unit has a proposed VoO of MM and is not seen from any viewpoint identified by this project.

\section{LANDS}

There are no lands mitigation measures anticipated for this unit.

CULTURAL RESOURCES

There are no cultural resource mitigation measures anticipated for this unit.

GEOLOGY

This unit is underlain with karst, although no significant features have yet been identified. 


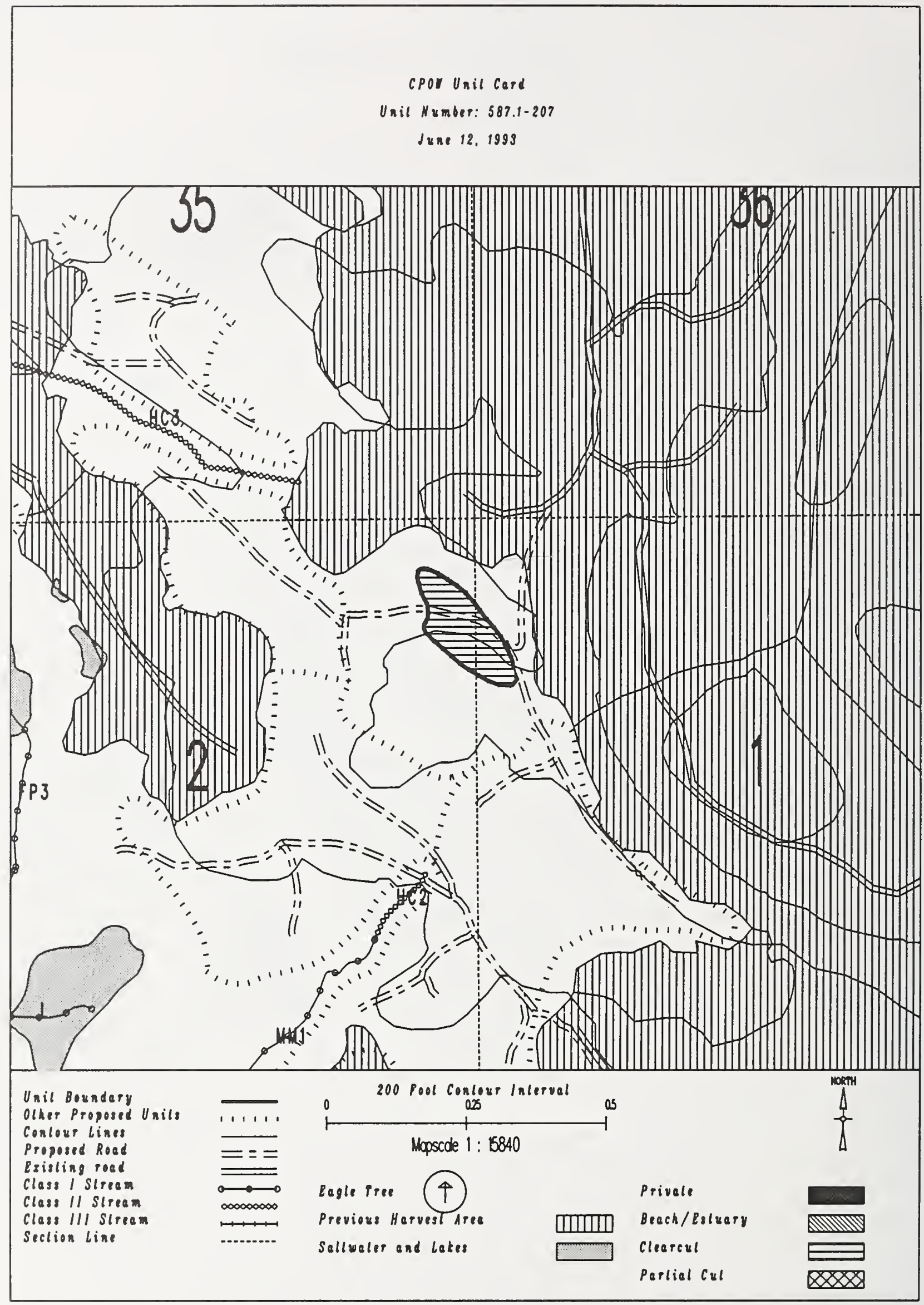


Unit 587.1-208

Planned acres 51

Estimated volume (mbf) 952

Logging system slackl ine

silvicultural system clearcut

forest type Hemlock
Alternatives considered F2 F3 F4 F5 F6

Quad CRGD4SEN

Mgmt Area $\mathrm{KO7}$

WAA 1422

Photo 1290031

Aspect North

\section{PHYSICAL DESCRIPTION}

Volume class breakdown: VC4 27 acres VC5 11 acres vC6 0 acres vc7 0 acres

Elevation breakdown: $0-800 \mathrm{ft} .53$ acres $800-1200 \mathrm{ft} . \quad 0$ acres $1200-1500 \mathrm{ft}$. 0 acres over $1500 \mathrm{ft}$. 0 Mass movement index: Low $\underline{27}$ acres Medium $\underline{0}$ acres High $\underline{21}$ acres Very High $\underline{0}$ acres

SOILS

This unit has high mass movement index soils. Partial log suspension required over these areas.(BMP13.9)

This unit contains 26 acres of forested wetlands. Site specific BMPs will be designed for selected approved

logging system and road construction practices. (BMPs 12.5, 13.9, 13.15).

This unit contains 13 acres of slopes $>75 \%$.

TIMBER

There are no timber mitigation measures anticipated for this unit.

ENGINEERING

High mass movement index soils. Road construction must minimize landslide potential (BMP14).

slopes greater than $75 \%$ may require full bench construction and endhaul of waste (BMP14.7).

\section{FISH/WATERSHED}

There are no fishery mitigation measures anticipated for this unit.

\section{WILDLIFE}

Maintain adequate distribution of snags by leaving 0.1 acre-sized patches of green trees within the unit for every 10 acres harvested. Snag patches must be compatible with logging system and safe working conditions.

RECREATION / VISUALS

This unit has a proposed VQO of MM and is not seen from any viewpoint identified by this project.

LANDS

There are no lands mitigation measures anticipated for this unit.

CULTURAL RESOURCES

There are no cultural resource mitigation measures anticipated for this unit.

GEOLOGY

There are no karst mitigation measures anticipated for this unit. 


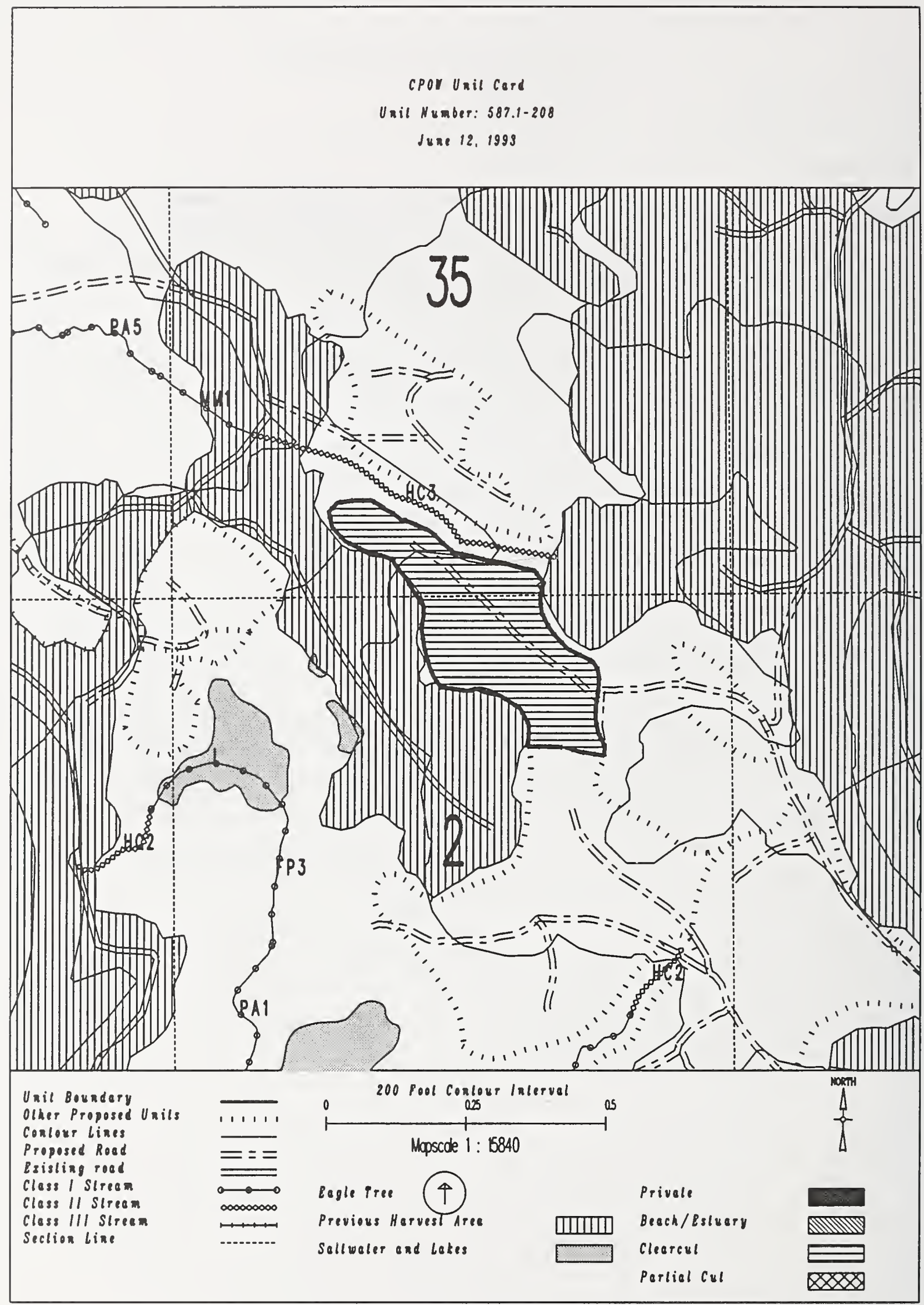


Unit 587.1-209

Planned acres 40

Est imated volume (mbf) 1024

logging system Highlead

Silvicultural system Riparian

Forest type Hemlock
Alternatives considered $\mathrm{F2} \quad \mathrm{F} 3 \quad \mathrm{~F} 4 \quad \mathrm{F5} \quad \mathrm{F6}$

Quad CRGD4SEN

Mgmt Area $\mathrm{KO7}$

WAA 1422

Photo 1290031

Aspect North

PHYSICAL DESCRIPTION

Volume class breakdown: VC4 4 acres VC5 17 acres VC6 12 acres VC7 4 acres

Elevation breakdown: $0-800 \mathrm{ft} . \quad 37$ acres $800-1200 \mathrm{ft} . \quad 0$ acres $1200-1500 \mathrm{ft}$. 0 acres over $1500 \mathrm{ft}$. 0 acres Mass movement index: Low 10 acres Medium 6 acres High 18 acres Very High 0 acres

\section{SOILS}

This unit has high mass movement index soils. Partial log suspension required over these areas. (BMP13.9)

This unit contains 16 acres of forested wetlands. Site specific BMPs will be designed for selected approved

logging system and road construction practices. (BMPs 12.5, 13.9, 13.15).

This unit contains 12 acres of slopes $>75 \%$.

\section{TIMBER}

Uneven-aged harvest for riparian management on an estimated 14 acres.

\section{ENGINEER ING}

High mass movement index soils. Road construction must minimize landslide potential (BMP14).

Slopes greater than $75 \%$ may require full bench construction and endhaul of waste (BMP14.7).

\section{FISH/WATERSHED}

Potential for additional Class I/II streams within unit. May be necessary to place additional buffers within unit

in accordance with AHMU Handbook.

\section{WILDLIFE}

There are no wildlife mitigation measures anticipated for this unit.

\section{RECREATION / VISUALS}

The unit has a proposed VQO of MM within the viewshed of Kussan Point

as viewed from 1 mile from west coast of Prince of Wales.

\section{LANDS}

There are no lands mitigation measures anticipated for this unit.

\section{CULTURAL RESOURCES}

There are no cultural resource mitigation measures anticipated for this unit.

\section{GEOLOGY}

There are no karst mitigation measures anticipated for this unit. 
cpol Unil card

Uxil Number: 587.1-209

June 12, 1999

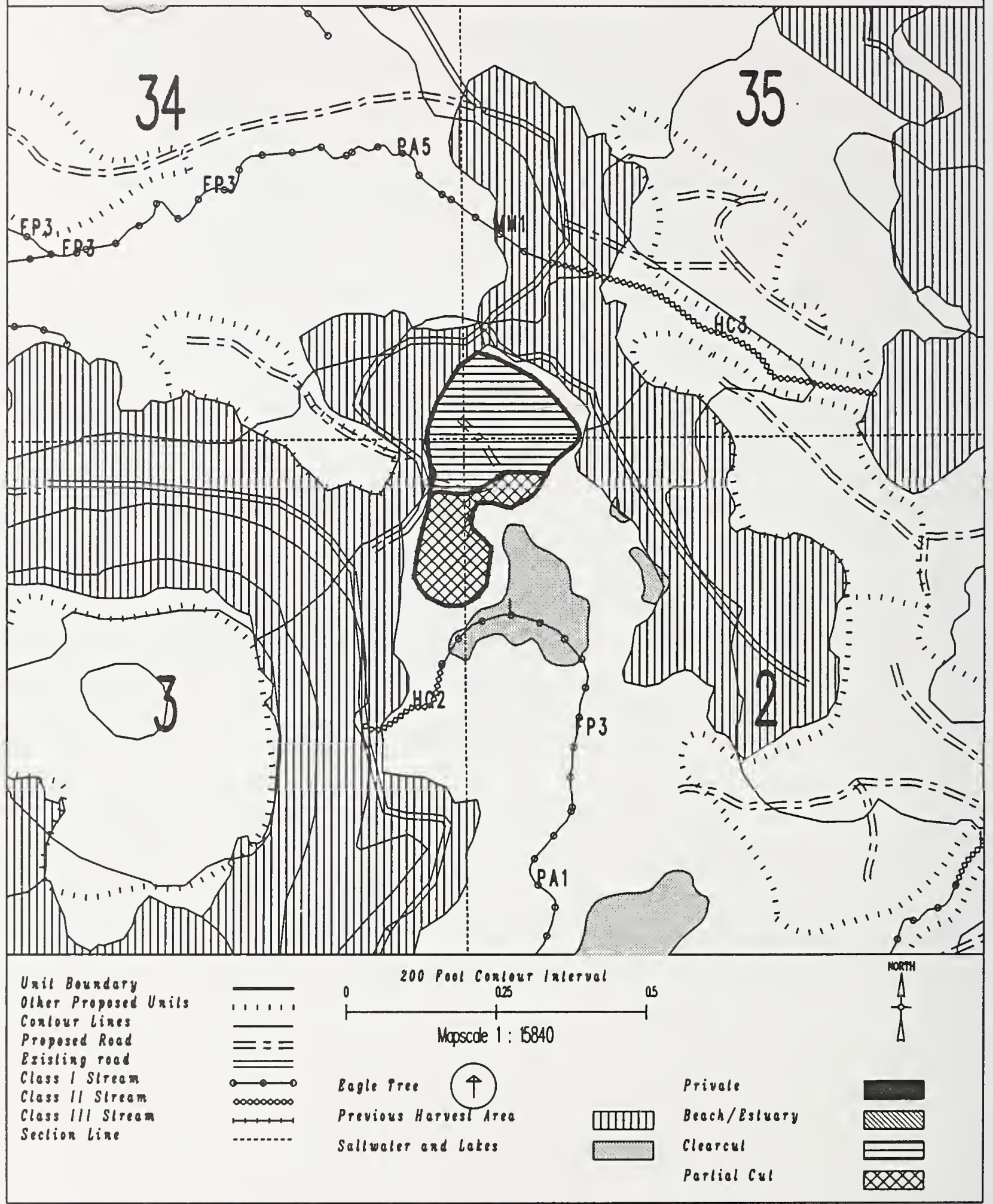


Unit $\underline{587.1-210}$

Planned acres 23

Est imated volume (mbf) 482

Logging system Highlead

silvicultural system clearcut

Forest type Hemlock
Alternatives considered $\mathrm{F2} \quad \mathrm{F3} \quad$ F4 $\quad$ F5 $\quad$ F6

Quad CRGD4SEN

Mgmt Area K07

WAA 1422

Photo

Aspect North

PHYSICAL DESCRIPTION

Volume class breakdown: VC4 22 acres VC5 $\quad 0$ acres VC6 $\quad 0$ acres vc7 $\quad 0$ acres

Elevation breakdown: $0-800 \mathrm{ft} . \underline{21}$ acres $800-1200 \mathrm{ft} . \underline{0}$ acres $1200-1500 \mathrm{ft} . \underline{0}$ acres over $1500 \mathrm{ft}$. 0

Mass movement index: Low 22 acres Medium 0 acres High 1 acres Very High 0 acres

SOILS

This unit contains 11 acres of forested wetlands. Site specific BMPs will be designed for selected approved

logging system and road construction practices. (BMPs 12.5, 13.9, 13.15).

This unit contains 1 acres of slopes > $75 \%$.

\section{TIMBER}

There are no timber mitigation measures anticipated for this unit.

\section{ENGINEER ING}

There are no engineering mitigation measures anticipated for this unit.

\section{FISH/WATERSHED}

Potential for additional Class I/II streams within unit. May be necessary to place additional buffers within unit

in accordance with AHMU Handbook.

WILDLIFE

There are no wildlife mitigation measures anticipated for this unit.

RECREATION / VISUALS

The unit has a proposed Voo of MM within the viewshed of Kussan Point

as viewed from $1 \mathrm{mile}$ from west coast of Prince of Wales.

LANDS

There are no lands mitigation measures anticipated for this unit.

CULTURAL RESOURCES

There are no cultural resource mitigation measures anticipated for this unit.

GEOLOGY

There are no karst mitigation measures anticipated for this unit. 


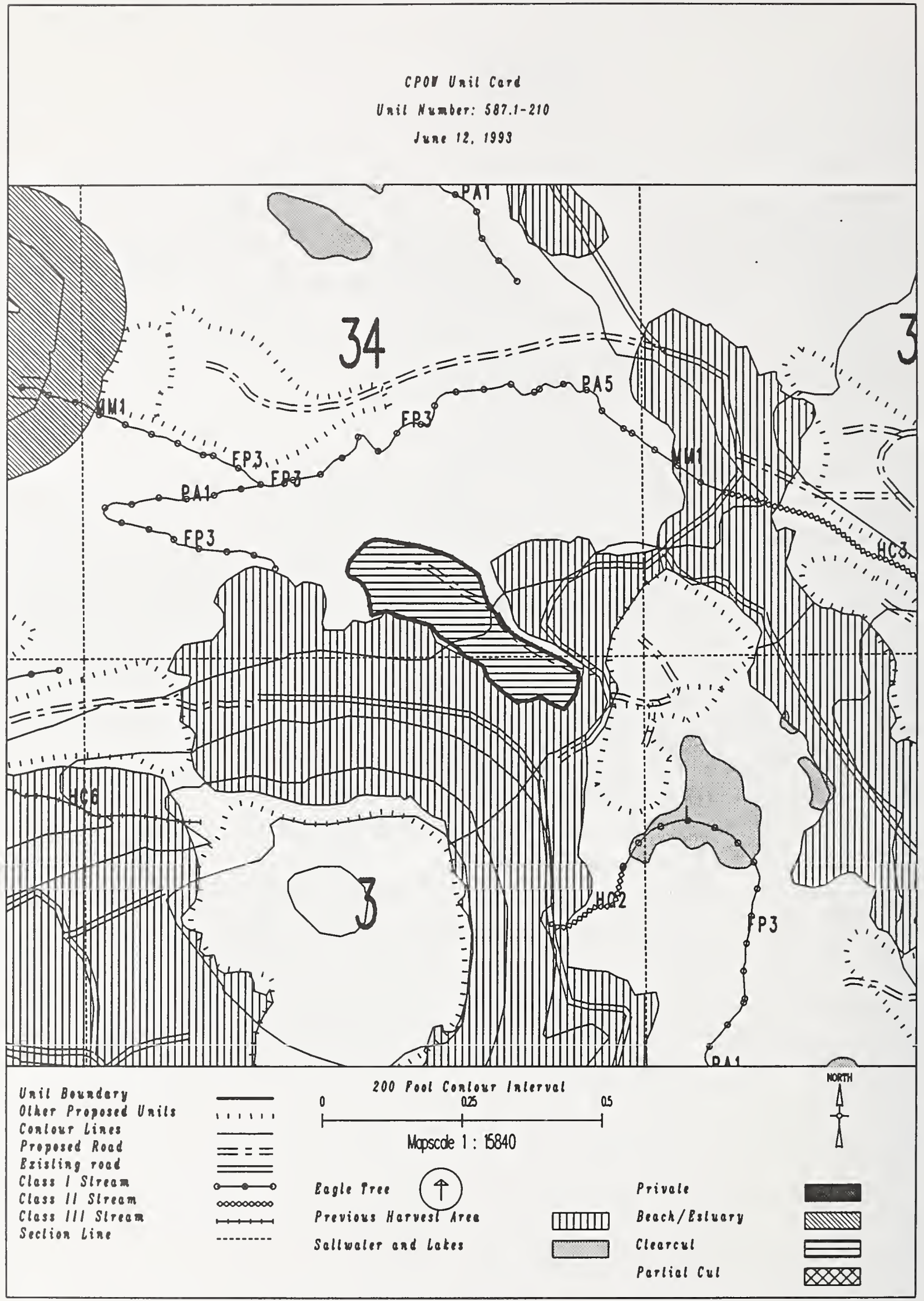


Unit $587.1-212$

Planned acres 36

Estimated volume (mbf) 777

Logging system skyline

Silvicultural system clearcut

Forest type Hemlock
Alternatives considered F2 F3 F4 F5 $\quad$ F6

Quad CRGD4SEN

Mgmt Area $\mathrm{KOT}$

WAA 1422

Photo 1290033

Aspect South

PHYSICAL DESCRIPTION

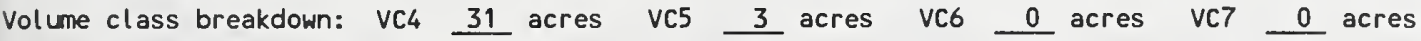

Elevation breakdown: $0-800 \mathrm{ft} .34$ acres $800-1200 \mathrm{ft} . \quad 0$ acres $1200-1500 \mathrm{ft} . \underline{0}$ acres over $1500 \mathrm{ft}$. 0 acres Mass movement index: Low 36 acres Medium 0 acres High 0 acres Very High 0 acres

SOILS

This unit contains 17 acres of forested wetlands. Site specific BMPs will be designed for selected approved

logging system and road construction practices. (BMPs 12.5, 13.9, 13.15).

TIMBER

There are no timber mitigation measures anticipated for this unit.

ENGINEERING

Very difficult road construction due to unstable, slope > $75 \%$ or extended steep grades.

May need to revise logging system to helicopter.

FISH/WATERSHED

Potential for additional Class I/II streams within unit. May be necessary to place additional buffers within unit

in accordance with AHMU Handbook.

Proposed stream buffers may need to be modified to meet AHMU Handbook standards.

WILDL IFE

There are no wildlife mitigation measures anticipated for this unit.

RECREATION / VISUALS

This unit has a proposed VQO of MM and is not seen from any viewpoint identified by this project.

LANDS

There are no lands mitigation measures anticipated for this unit.

CULTURAL RESOURCES

There are no cultural resource mitigation measures anticipated for this unit.

GEOLOGY

There are no karst mitigation measures anticipated for this unit. 


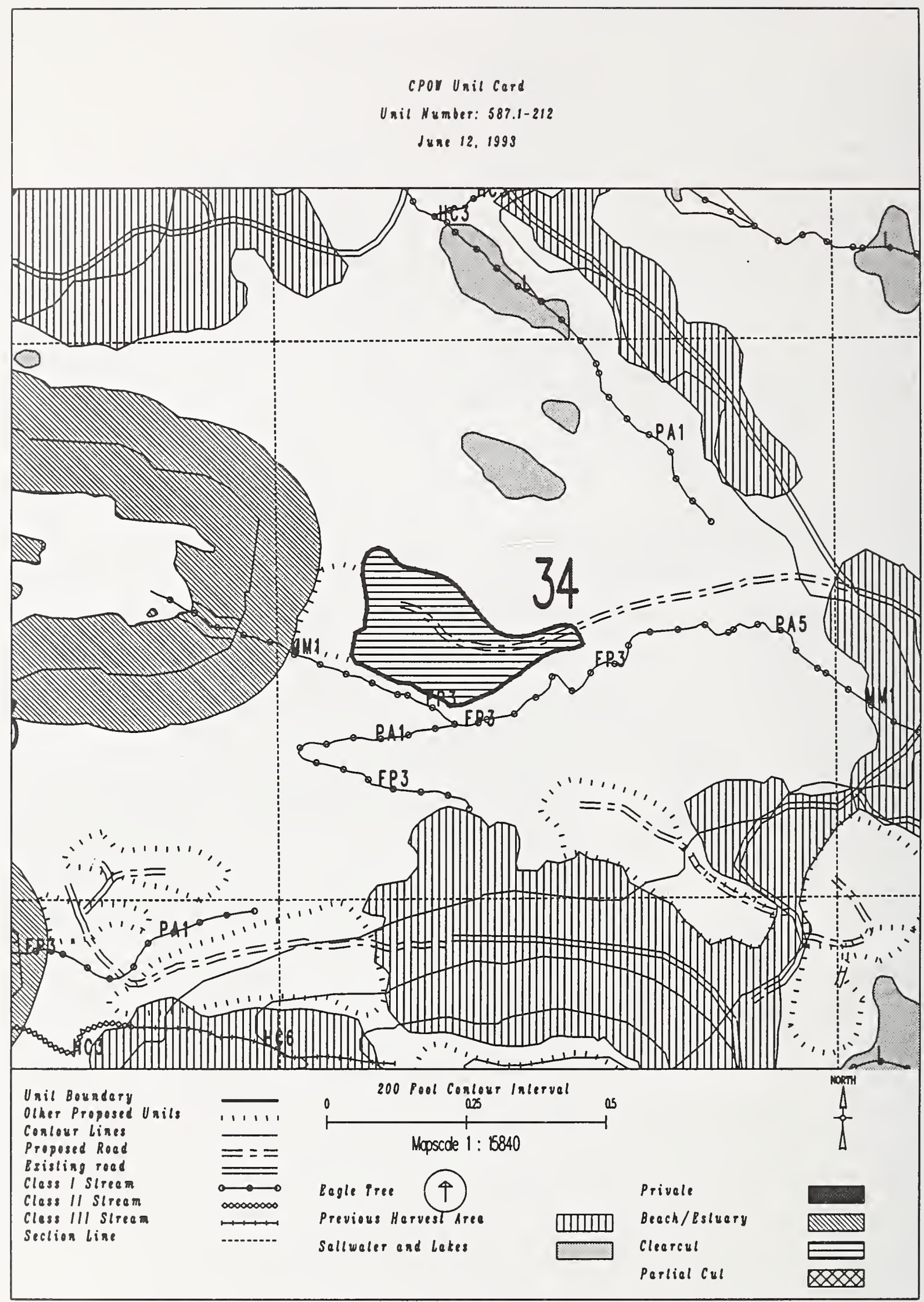


UNIT PLAN/LAYOUT/SALE ADMINISTRATION CARD FOR CPOW FEIS

Unit 587.1-212B

Planned acres 10

Estimated volume (mbf)

Logging system skyline

silvicultural system Clearcut

Forest type Mixed conifer
Al ternatives considered F2 $\quad$ F3 $\quad$ F4 4 F5 $\quad$ F6

Quad CRGD4SEN

Mgmt Area $\underline{\mathrm{KOT}}$

WAA 1422

Photo

Aspect West

PHYSICAL DESCRIPTION

Volume class breakdown: VC4 7 acres VC5 $\quad 0$ acres VC6 $\quad 0$ acres VC7 $\quad 3$ acres

Elevation breakdown: $0-800 \mathrm{ft}$. $\quad$ g acres $800-1200 \mathrm{ft}$. _ 0 acres $1200-1500 \mathrm{ft}$. 0 acres over $1500 \mathrm{ft}$. 0 acres Mass movement index: Low 7 acres Medium 2 acres High 0 acres Very High 0

SOILS

There are no soils mitigation measures anticipated for this unit.

TIMBER

There are no timber mitigation measures anticipated for this unit.

ENGINEER ING

There are no engineering mitigation measures anticipated for this unit.

\section{FISH/WATERSHED}

Potential for additional Class I/II streams within unit. May be necessary to place additional buffers within unit in accordance with AHMU Handbook.

WILDLIFE

Unit is adjacent to estuary or beach fringe; maintain appropriate buffer.

RECREATION / VISUALS

This unit has a proposed VQO of MM and is not seen from any viewpoint identified by this project.

\section{LANDS}

There are no lands mitigation measures anticipated for this unit.

CULTURAL RESOURCES

There are no cultural resource mitigation measures anticipated for this unit.

GEOLOGY

There are no karst mitigation measures anticipated for this unit. 


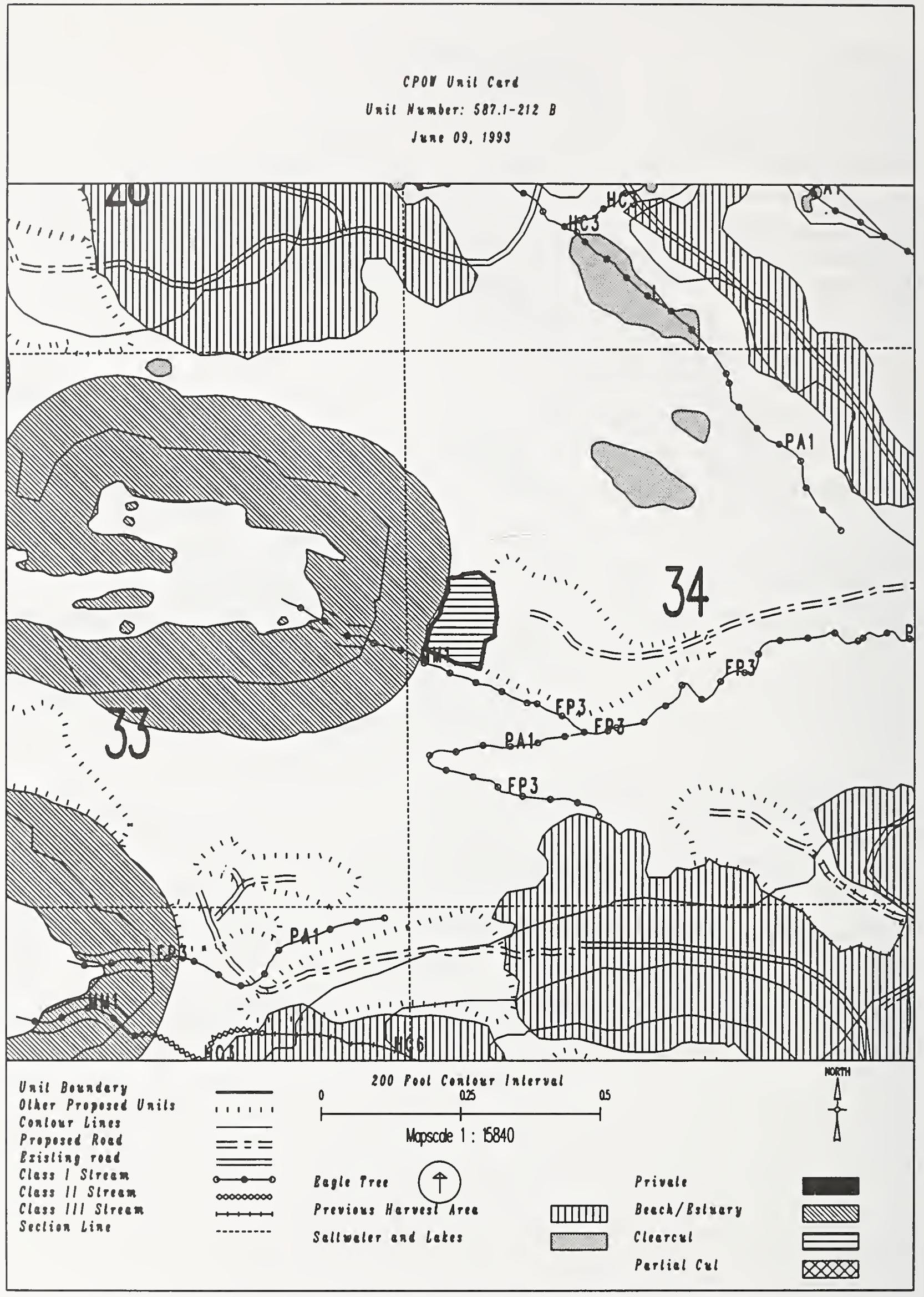


Unit 587.1-215

Planned acres 27

Estimated volume (mbf) 1372

Logging system Highlead

silvicultural system clearcut

Forest type Spruce
Alternatives considered F2 $\quad$ F3 $F 4$ F5 $\quad$ F6

Quad CRGD4SEN

Mgmt Area K07

WAA 1422

Photo 1290171

Aspect South

PHYSICAL DESCRIPTION

Volume class breakdown: vC4 $\quad 0$ acres vc5 $\quad 0$ acres vc6 $\quad 0$ acres vc7 27 acres

Elevation breakdown: $0-800 \mathrm{ft} . \underline{27}$ acres $800-1200 \mathrm{ft} . \underline{0}$ acres $1200-1500 \mathrm{ft} . \underline{0}$ acres over $1500 \mathrm{ft} . \underline{0}$ acres Mass movement index: Low $\underline{0}$ acres Medium 27 acres $H i g h \quad 0$ acres Very High 0 acres

SOILS

There are no soils mitigation measures anticipated for this unit.

TIMBER

There are no timber mitigation measures anticipated for this unit.

\section{ENGINEER ING}

There are no engineering mitigation measures anticipated for this unit.

\section{FISH/WATERSHED}

There are no fishery mitigation measures anticipated for this unit.

\section{WILDLIFE}

Unit is adjacent to estuary or beach fringe; maintain appropriate buffer.

RECREATION / VISUALS

The unit has a proposed VQO of MM within the viewshed of Kussan Point as viewed from 1 mile from west coast of Prince of Wales.

\section{LANDS}

There are no lands mitigation measures anticipated for this unit.

CULTURAL RESOURCES

There are no cultural resource mitigation measures anticipated for this unit. 


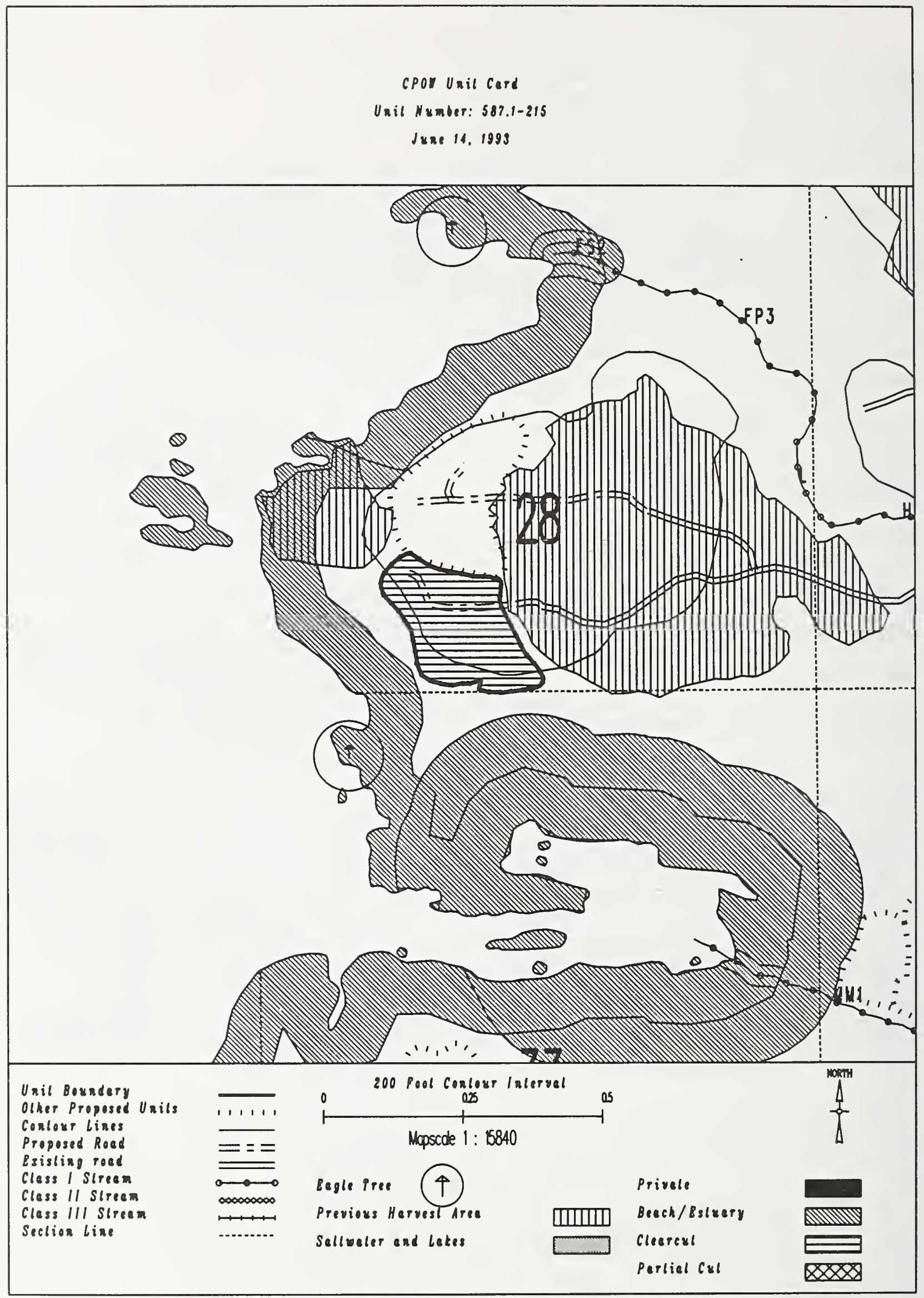


Unit $587.1-220$

Planned acres 17

Estimated volume (mbf) 372

Logging system highlead

silvicultural system clearcut

Forest type Hemlock
Alternatives considered F2 F3 F4 F5

Quad CRGD4SEN

Mgmt Area $\mathrm{KO7}$

WAA 1422

Photo 1290173

Aspect North

PHYSICAL DESCRIPTION

Volume class breakdown: VC4 17 acres VC5 0 acres VC6 $\quad 0$ acres vc7 0

Elevation breakdown: $0-800 \mathrm{ft} .16$ acres $800-1200 \mathrm{ft}$. $\ldots$ acres $1200-1500 \mathrm{ft}$. 0 acres over $1500 \mathrm{ft}$. 0 acres Mass movement index: Low $\quad 8$ acres Medium $\quad 0$ acres High 0 acres Very High 0

SOILS

This unit contains 13 acres of forested wetlands. Site specific BMPs will be designed for selected approved

logging system and road construction practices. (BMPs 12.5, 13.9, 13.15).

TIMBER

There are no timber mitigation measures anticipated for this unit.

ENGINEERING

The road into this unit crosses a B1 channel. Meet stream and lake protection prescription requirements in TLMP Draft Revision (1991a) for this process group.

FISH/WATERSHED

Potential for additional Class $1 / 11$ streams within unit. May be necessary to place additional buffers within unit in accordance with AHMU Handbook.

WILDLIFE

Unit is adjacent to estuary or beach fringe; maintain appropriate buffer.

RECREATION / VISUALS

This unit has a proposed VQO of MM and is not seen from any viewpoint identified by this project.

LANDS

There are no lands mitigation measures anticipated for this unit.

CULTURAL RESOURCES

The planned unit boundary and road location is immediately adjacent to significant cultural resources. Any changes must be coordinated with cultural resource personnel. 
CPOI Unil Cerd

Unil Humber: 587.1-220

June 12, 1999

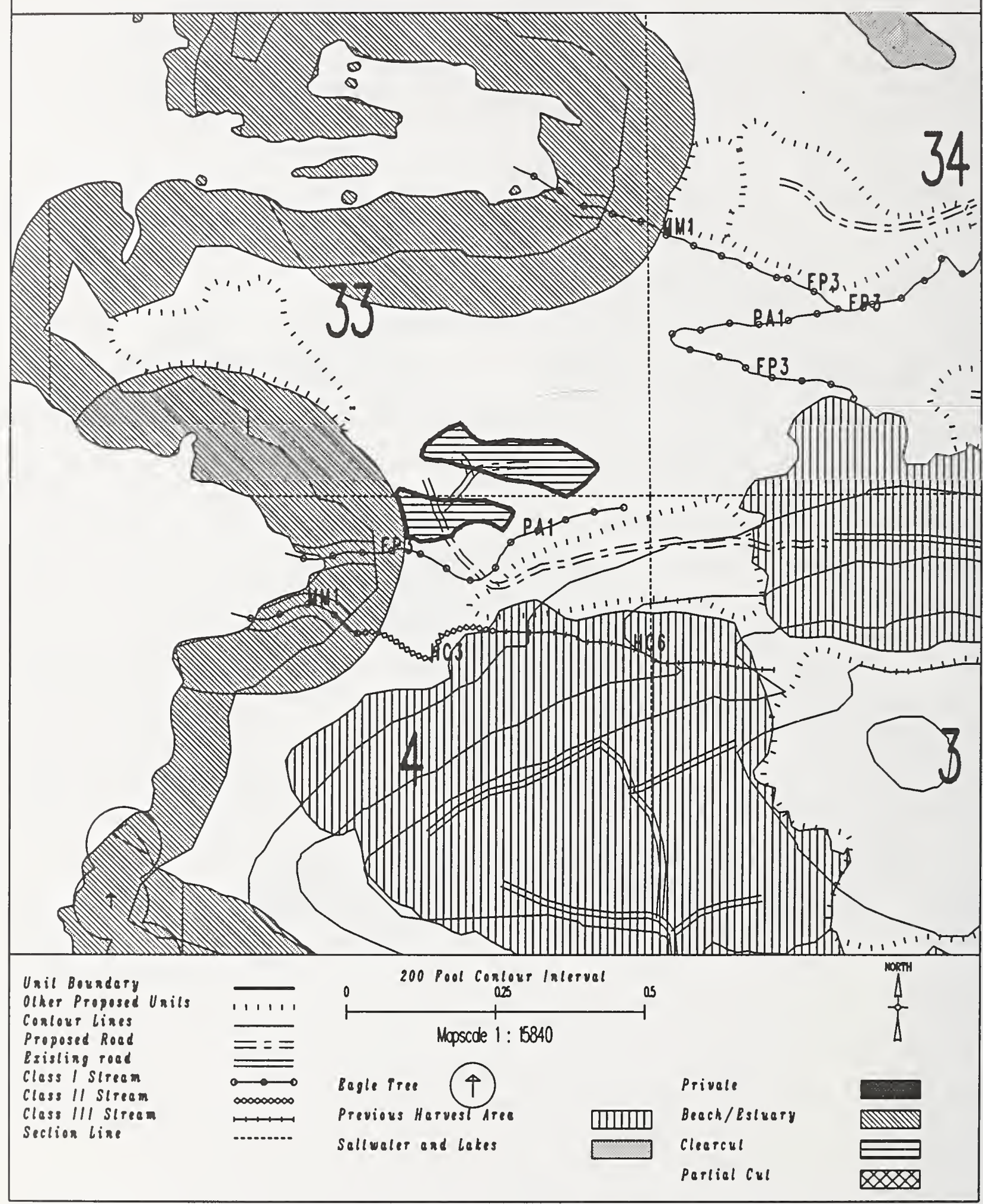


Unit 587.1-221

Planned acres 36

Estimated volume (mbf) 1327

Logging system skyline

silvicultural system clearcut

Forest type Mixed conifer
Alternatives considered F2 F3 F4 F5

Quad CRGD4SEN

Mgmt Area $\mathrm{KO7}$

WAA 1422

Photo 1290032

Aspect North

PHYSICAL DESCRIPTION

Volume class breakdown: VC4 0 acres VC5 1 acres VC6 34 acres VC7 0 acres

Elevation breakdown: $0-800 \mathrm{ft} . \quad 34$ acres $800-1200 \mathrm{ft} . \underline{0}$ acres $1200-1500 \mathrm{ft}$. 0 acres over $1500 \mathrm{ft}$. 0 acres Mass movement index: Low 1 acres Medium 18 acres High 26 acres Very High 0 acres

SOILS

This unit has high mass movement index soils. Partial log suspension required over these areas. (BMP13.9)

This unit has a slight possibility to be reclassified as MMI $=4$.

This unit contains 26 acres of slopes > $75 \%$.

\section{TIMBER}

There are no timber mitigation measures anticipated for this unit.

\section{ENGINEER ING}

High mass movement index soils. Road construction must minimize landslide potential (BMP14).

Slopes greater than $75 \%$ may require full bench construction and endhaul of waste (BMP14.7).

\section{FISH/WATERSHED}

There are no fishery mitigation measures anticipated for this unit.

WI LDL IFE

There are no wildlife mitigation measures anticipated for this unit.

\section{RECREATION / VI SUALS}

The unit has a proposed Voo of MM within the viewshed of Kussan Point

as viewed from $1 \mathrm{mile}$ from west coast of Prince of Wales.

\section{LANDS}

There are no lands mitigation measures anticipated for this unit.

\section{CULTURAL RESOURCES}

The planned unit boundary and road location is immediately adjacent to significant cultural resources. Any changes must be coordinated with cultural resource personnel. 


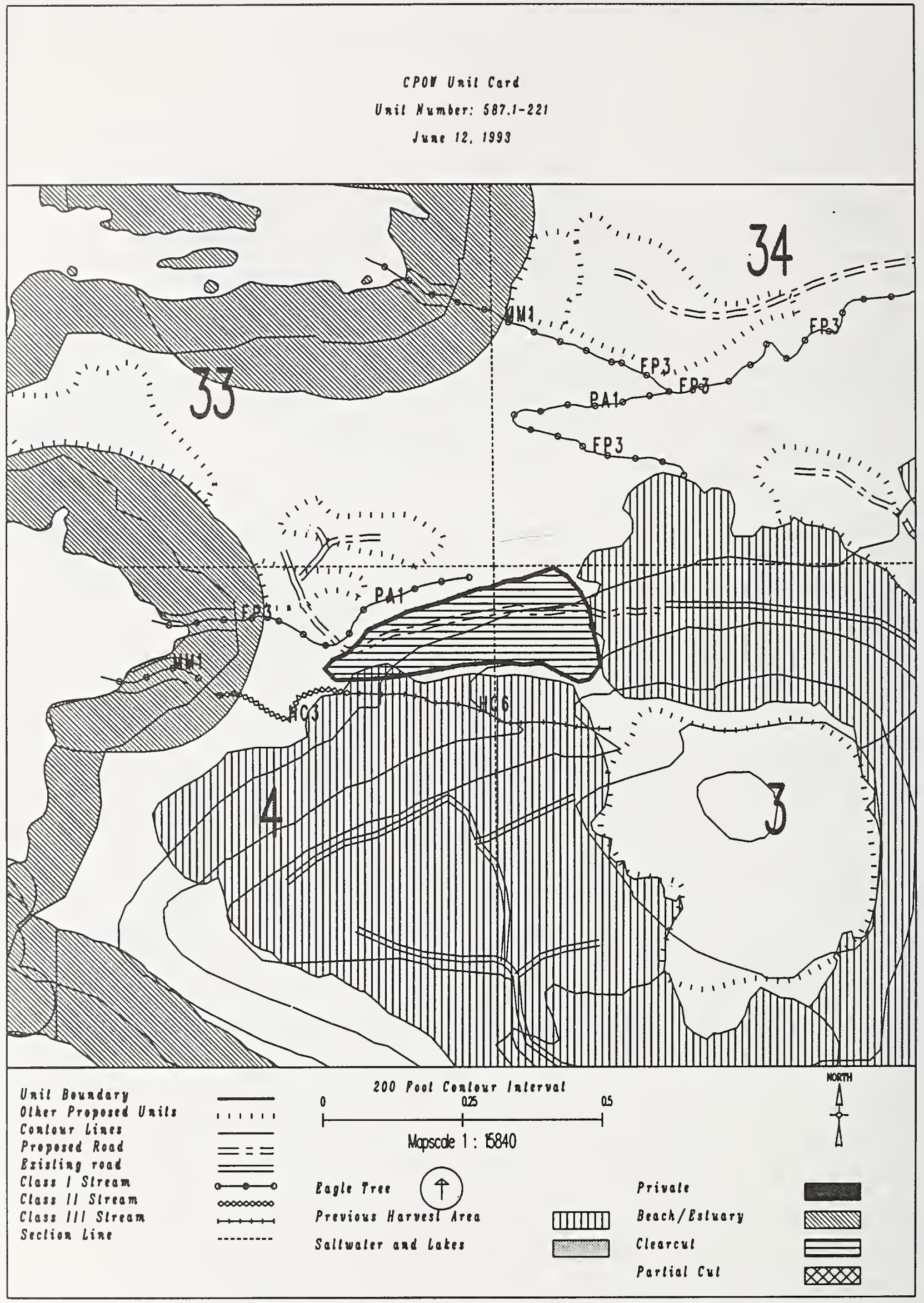




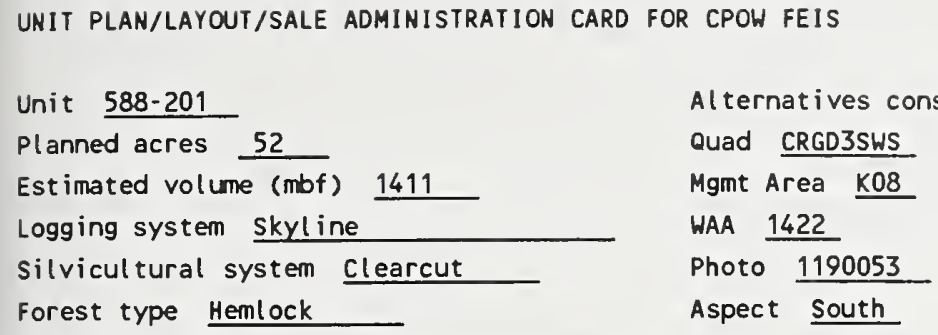




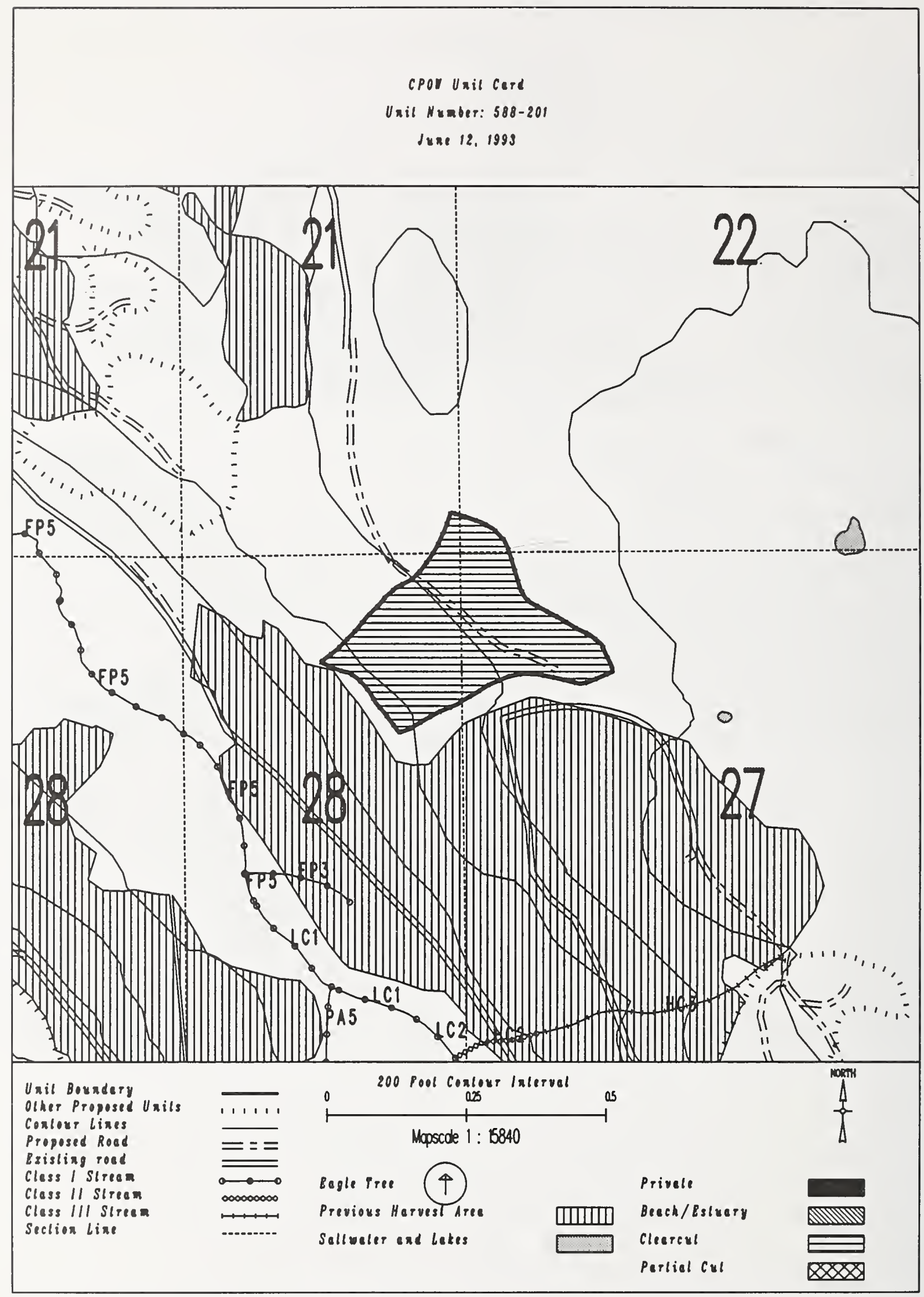


Unit 588-203

Planned acres 62

Estimated volume (mbf) 1716

Logging system skyline

silvicultural system Clearcut

Forest type Mixed conifer
Alternatives considered F2 $\quad$ F3 $F 4$ F5

Quad CRGD3SWS

Mgmt Area $\mathrm{K08}$

WAA 1422

Photo 890123

Aspect West

PHYSICAL DESCRIPTION

Volume class breakdown: VC4 20 acres vc5 $\quad 39$ acres vC6 $\quad 0$ acres vc7 $\quad 0$ acres

Elevation breakdown: $0-800 \mathrm{ft} . \underline{0}$ acres $800-1200 \mathrm{ft} . \underline{5}$ acres $1200-1500 \mathrm{ft} . \underline{25}$ acres over $1500 \mathrm{ft}$. 0 acres Mass movement index: Low 10 acres Medium 0 acres High 50 acres Very High 0 acres

SOILS

This unit has high mass movement index soils. Partial log suspension required over these areas.(BMP13.9)

This unit contains 50 acres of forested wetlands. Site specific BMPs will be designed for selected approved

logging system and road construction practices. (BMPs 12.5, 13.9, 13.15).

TIMBER

There are no timber mitigation measures anticipated for this unit.

ENGINEERING

High mass movement index soils. Road construction must minimize landslide potential (BMP14).

FISH/WATERSHED

This unit contains a $\underline{A} 4$ class $\underline{3}$ stream. No specific buffer required, but full suspension, if yarding across.

This unit contains streams which have recently been classified/channel typed but require field verification.

WILDL IFE

There are no wildlife mitigation measures anticipated for this unit.

RECREATION / VISUALS

This unit has a proposed VQO of MM and is not seen from any viewpoint identified by this project.

LANDS

There are no lands mitigation measures anticipated for this unit.

CULTURAL RESOURCES

There are no cultural resource mitigation measures anticipated for this unit.

GEOLOGY

This unit is underlain with karst, although no significant features have yet been identified. 


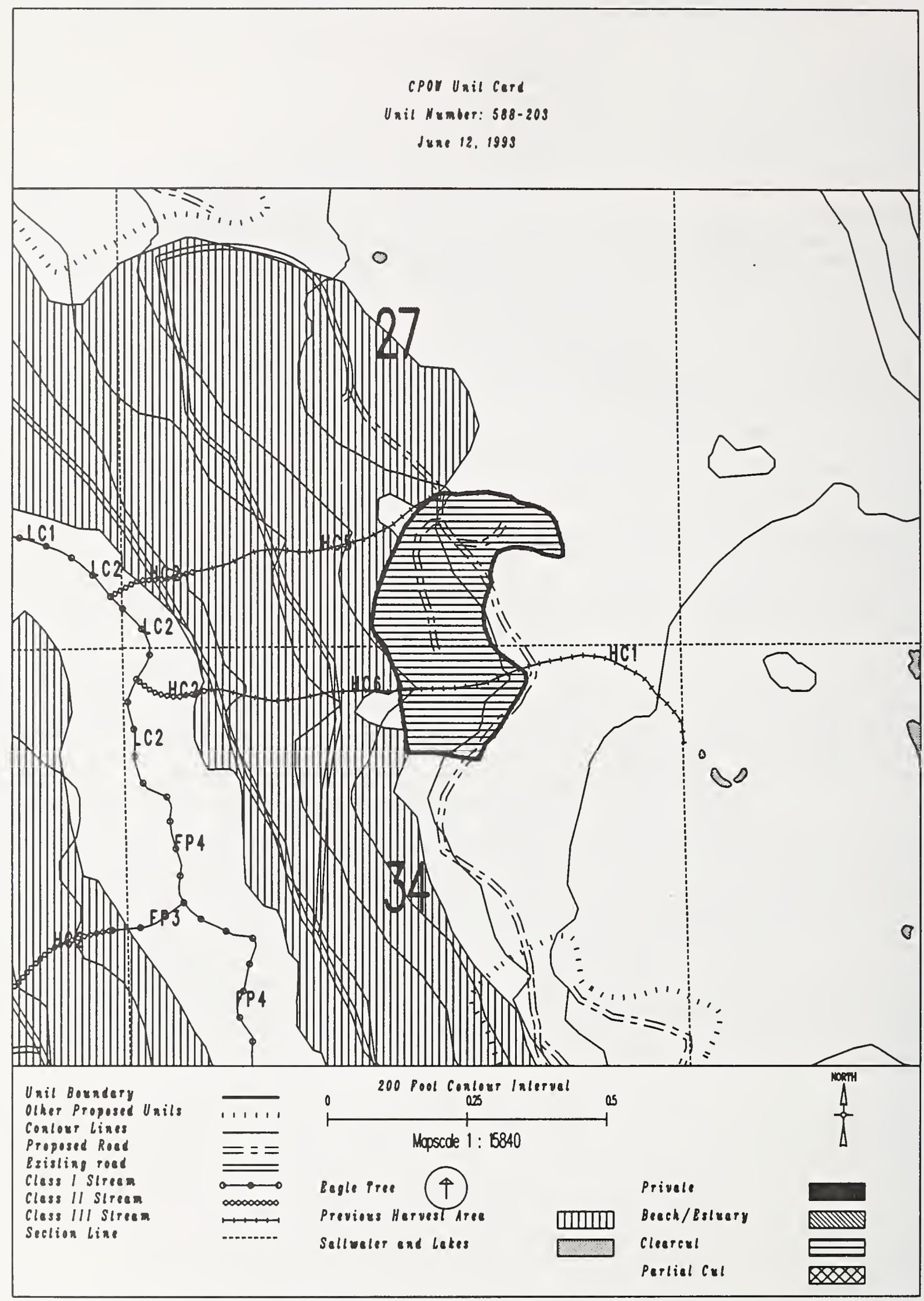


Unit 588-204

Planned acres 94

Estimated volume (mbf) 2393

Logging system slackline

silvicultural system clearcut

forest type Hemlock
Alternatives considered F2 F3 F4 F5 F6

Quad CRGD3SWS

Mgmt Area K08

WAA 1422

Photo 890124

Aspect South

PHYSICAL DESCRIPTION

Volume class breakdown: VC4 15 acres VC5 63 acres VC6 $\quad 0$ acres VC7 0 acres

Elevation breakdown: $0-800 \mathrm{ft} . \underline{2}$ acres $800-1200 \mathrm{ft} . \underline{9}$ acres $1200-1500 \mathrm{ft}$. 9 acres over $1500 \mathrm{ft}$. 11 acres Mass movement index: Low 2 acres Medium $\_$acres High $\underline{8}$ acres Very High 0

SOILS

This unit has high mass movement index soils. Partial log suspension required over these areas. (BMP13.9)

This unit contains 27 acres of forested wetlands. Site specific BMPs will be designed for selected approved

logging system and road construction practices. (BMPS 12.5, 13.9, 13.15).

This unit contains 51 acres of slopes > $75 \%$.

\section{TIMBER}

There are no timber mitigation measures anticipated for this unit.

\section{ENGINEER ING}

High mass movement index soils. Road construction must minimize landslide potential (BMP14).

Slopes greater than $75 \%$ may require full bench construction and endhaul of waste (BMP14.7).

\section{FISH/WATERSHED}

There are no fishery mitigation measures anticipated for this unit.

\section{WILDLIFE}

There are no wildlife mitigation measures anticipated for this unit.

RECREATION / VISUALS

This unit has a proposed VQO of MM and is not seen from any viewpoint identified by this project.

\section{LANDS}

There are no lands mitigation measures anticipated for this unit.

\section{CULTURAL RESOURCES}

There are no cultural resource mitigation measures anticipated for this unit. 


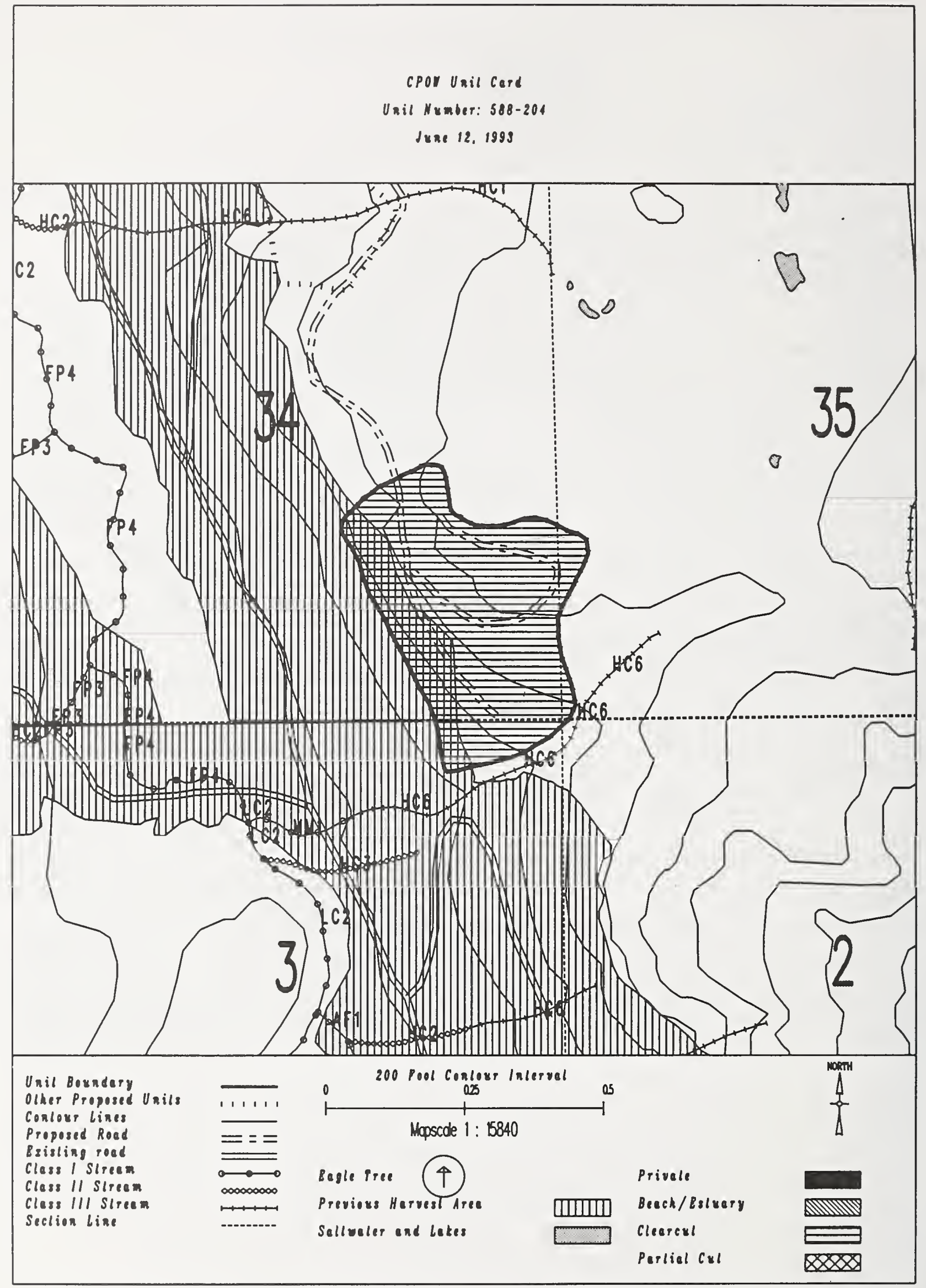


Unit $\quad 588-212$

Planned acres 10

Estimated volume (mbf) 349

Logging system Highlead

silvicultural system clearcut

forest type Hemlock
Alternatives considered F2 F3 F4 F5 F6

Quad CRGD4SES

Mgmt Area $\mathrm{KOT}$

WAA 1422

Photo 1190120

Aspect West

\section{PHYSICAL DESCRIPTION}

Volume class breakdown: VC4 $\quad 0$ acres VC5 $\quad 6$ acres VC6 $\quad 4$ acres VC7 $\quad 0$ acres

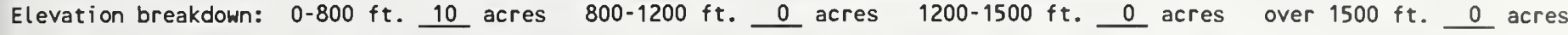
Mass movement index: Low 2 acres Medium 20 acres High 4 acres Very High 0

\section{SOILS}

This unit has high mass movement index soils. Partial log suspension required over these areas.(BMP13.9)

This unit contains 9 acres of forested wetlands. Site specific BMPs will be designed for selected approved logging system and road construction practices. (BMPs 12.5, 13.9, 13.15).

\section{TIMBER}

There are no timber mitigation measures anticipated for this unit.

\section{ENGINEER ING}

The road into this unit crosses a B1 channel. Meet stream and lake protection prescription requirements in TLMP Draft Revision (1991a) for this process group.

\section{FISH/WATERSHED}

Potential for additional Class I/II streams within unit. May be necessary to place additional buffers within unit in accordance with AHMU Handbook.

Potential impact on significant fishery habitat. May be necessary to expand planned buffer in accordance with AHMU Handbook.

\section{WILDLIFE}

Maintain diversity within unit by leaving 1-5 acre-sized islands of green trees at a rate of 1 acre of island for every 20 acres harvested. Leave islands must be compatible with logging system and safe working conditions.

RECREATION / VISUALS

This unit has a proposed VQo of MM and is not seen from any viewpoint identified by this project.

\section{LANDS}

There are no lands mitigation measures anticipated for this unit.

\section{CULTURAL RESOURCES}

There are no cultural resource mitigation measures anticipated for this unit.

\section{GEOLOGY}

There are no karst mitigation measures anticipated for this unit. 
cpor Unil Cerd

Unil Number: 588-212

June 12, 1993

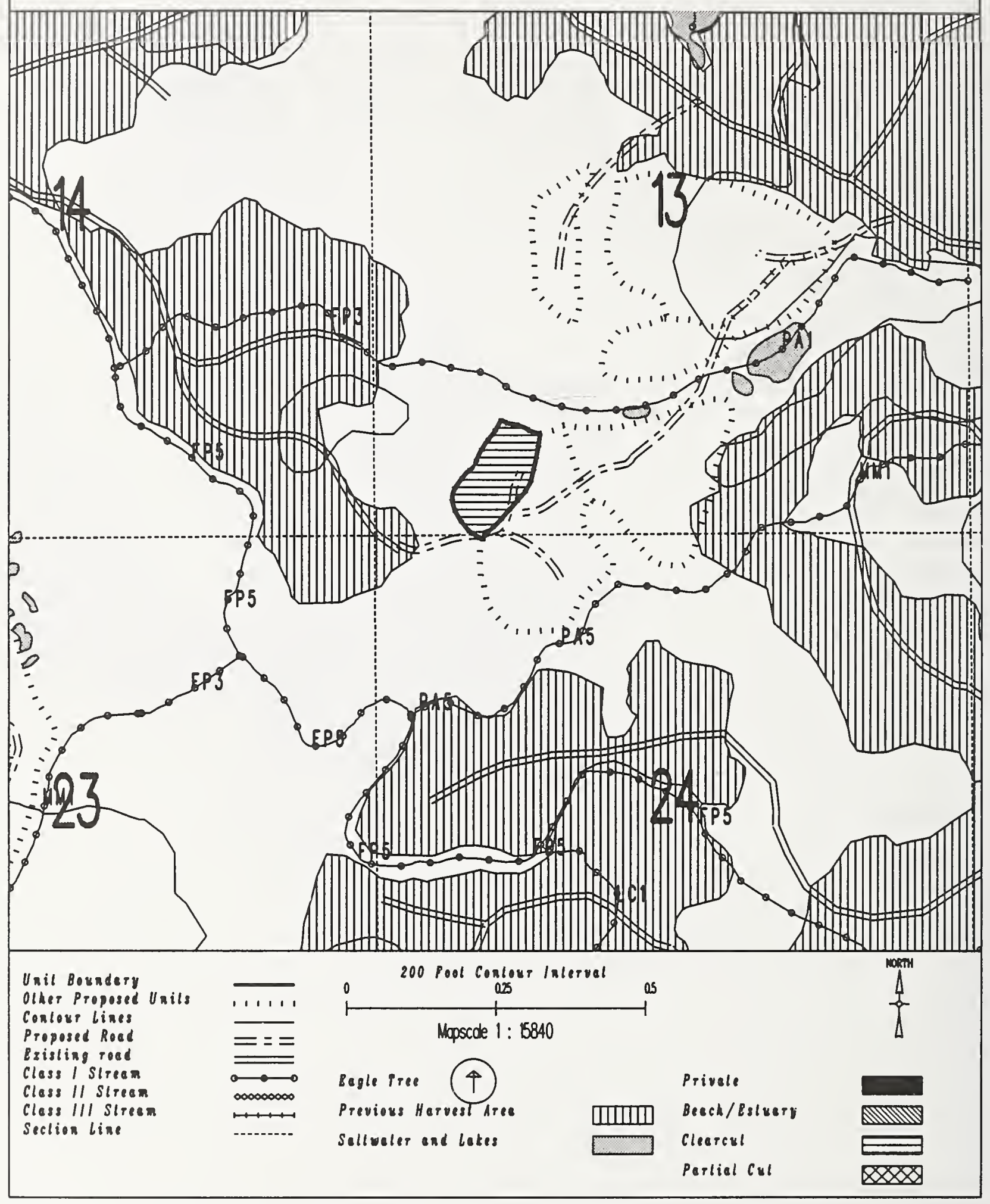


Unit $588-212 \quad B$

Planned acres 58

Estimated volume (mbf) 1262

Logging system Highlead

silvicultural system Riparian

Forest type Hemlock
Alternatives considered F2 $F 3$ F4

Quad CRGD4SES

Mgmt Area $\mathrm{K} 07$

WAA 1422

Photo

Aspect West

\section{PHYSICAL DESCRIPTION}

Volume class breakdown: VC4 $\quad 6$ acres VC5 34 acres VC6 15 acres VC7 $\quad 0$ acres

Elevation breakdown: $0-800 \mathrm{ft} . \underline{57}$ acres $800-1200 \mathrm{ft} . \underline{0}$ acres 1200-1500 ft. 0 acres over $1500 \mathrm{ft}$. 0 acres Mass movement index: Low 11 acres Medium $\_$acres High 28 acres Very High 0 acres

\section{SOILS}

This unit has high mass movement index soils. Partial log suspension required over these areas. (BMP13.9)

This unit contains $\underline{38}$ acres of forested wetlands. Site specific BMPs will be designed for selected approved

logging system and road construction practices. (BMPs 12.5, 13.9, 13.15).

This unit contains 7 acres of slopes $>75 \%$.

\section{TIMBER}

Uneven-aged harvest for riparian management on an estimated 29 acres.

\section{ENGINEER ING}

High mass movement index soils. Road construction must minimize landslide potential (BMP14).

The road into this unit crosses a B1 channel. Meet stream and lake protection prescription requirements in TLMP Draft Revision (1991a) for this process group.

Slopes greater than $75 \%$ may require full bench construction and endhaul of waste (BMP14.7).

\section{FISH/WATERSHED}

Potential for additional Class $1 / 11$ streams within unit. May be necessary to place additional buffers within unit in accordance with AHMU Handbook.

Potential impact on significant fishery habitat. May be necessary to expand planned buffer in accordance with AHMU Handbook.

Leave all deciduous and conifer trees $\left(<12^{\prime \prime} \mathrm{dbh}\right.$ ) in $35 \mathrm{ft}$ buffer adjacent to Class III streams to provide shade.

\section{WILDLIFE}

Maintain diversity within unit by leaving 1-5 acre-sized islands of green trees at a rate of 1 acre of island for every 20 acres harvested. Leave islands must be compatible with logging system and safe working conditions.

\section{RECREATION / VISUALS}

This unit has a proposed VQO of MM and is not seen from any viewpoint identified by this project.

\section{LANDS}

There are no lands mitigation measures anticipated for this unit.

\section{CULTURAL RESOURCES}

There are no cultural resource mitigation measures anticipated for this unit.

GEOLOGY

There are no karst mitigation measures anticipated for this unit. 


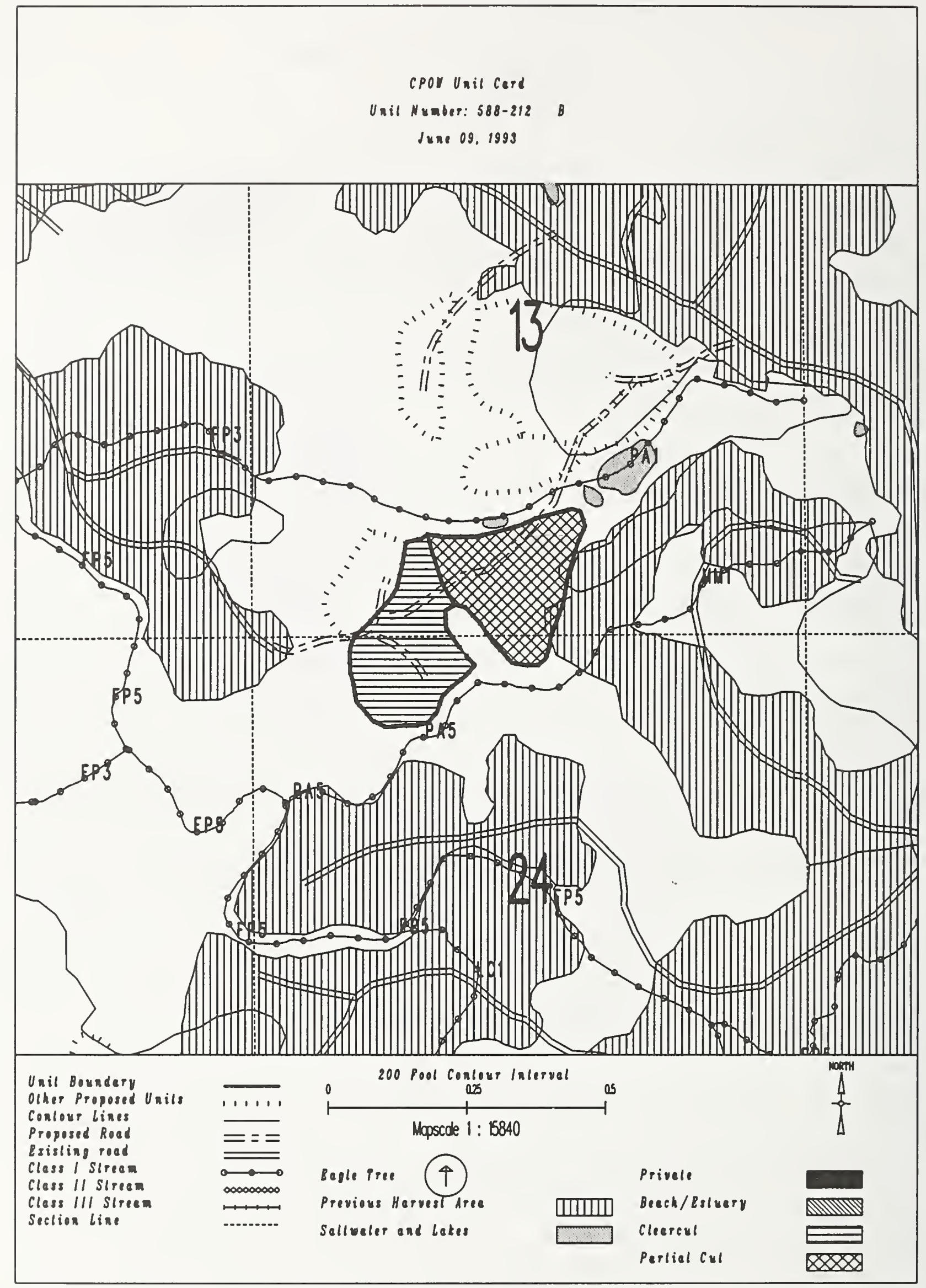


Unit $588-213$

Planned acres 10

Estimated volume (mbf)

Logging system Highlead

silvicultural system clearcut

Forest type Hemlock
Alternatives considered F2 F3 F4 F5 F6

Quad CRGO4SES

Mgmt Area $\mathrm{KO7}$

WAA 1422

Photo 1190120

Aspect West

PHYSICAL DESCRIPTION

Volume class breakdown: VC4 $\quad 0$ acres VC5 0 acres vc6 10 acres vc7 0 acres

Elevation breakdown: $0-800 \mathrm{ft} . \underline{10}$ acres $800-1200 \mathrm{ft} . \underline{0}$ acres 1200-1500 ft. 0 acres over $1500 \mathrm{ft}$. 0 acres Mass movement index: Low 0 acres Medium 0 acres High 4 acres Very High 0 acres

SOILS

This unit has high mass movement index soils. Partial log suspension required over these areas.(BMP13.9)

TIMBER

There are no timber mitigation measures anticipated for this unit.

ENGINEER ING

There are no engineering mitigation measures anticipated for this unit.

FISH/WATERSHED

Potential for additional Class $1 / 11$ streams within unit. May be necessary to place additional buffers within unit in accordance with AHMU Handbook.

Potential impact on significant fishery habitat. May be necessary to expand planned buffer in accordance with AHMU Handbook.

WILDLIFE

Maintain diversity within unit by leaving 1-5 acre-sized islands of green trees at a rate of 1 acre of island for every 20 acres harvested. Leave islands must be compatible with logging system and safe working conditions.

RECREATION / VISUALS

This unit has a proposed VQO of MM and is not seen from any viewpoint identified by this project.

LANDS

There are no lands mitigation measures anticipated for this unit.

CULTURAL RESOURCES

There are no cultural resource mitigation measures anticipated for this unit.

GEOLOGY

There are no karst mitigation measures anticipated for this unit. 


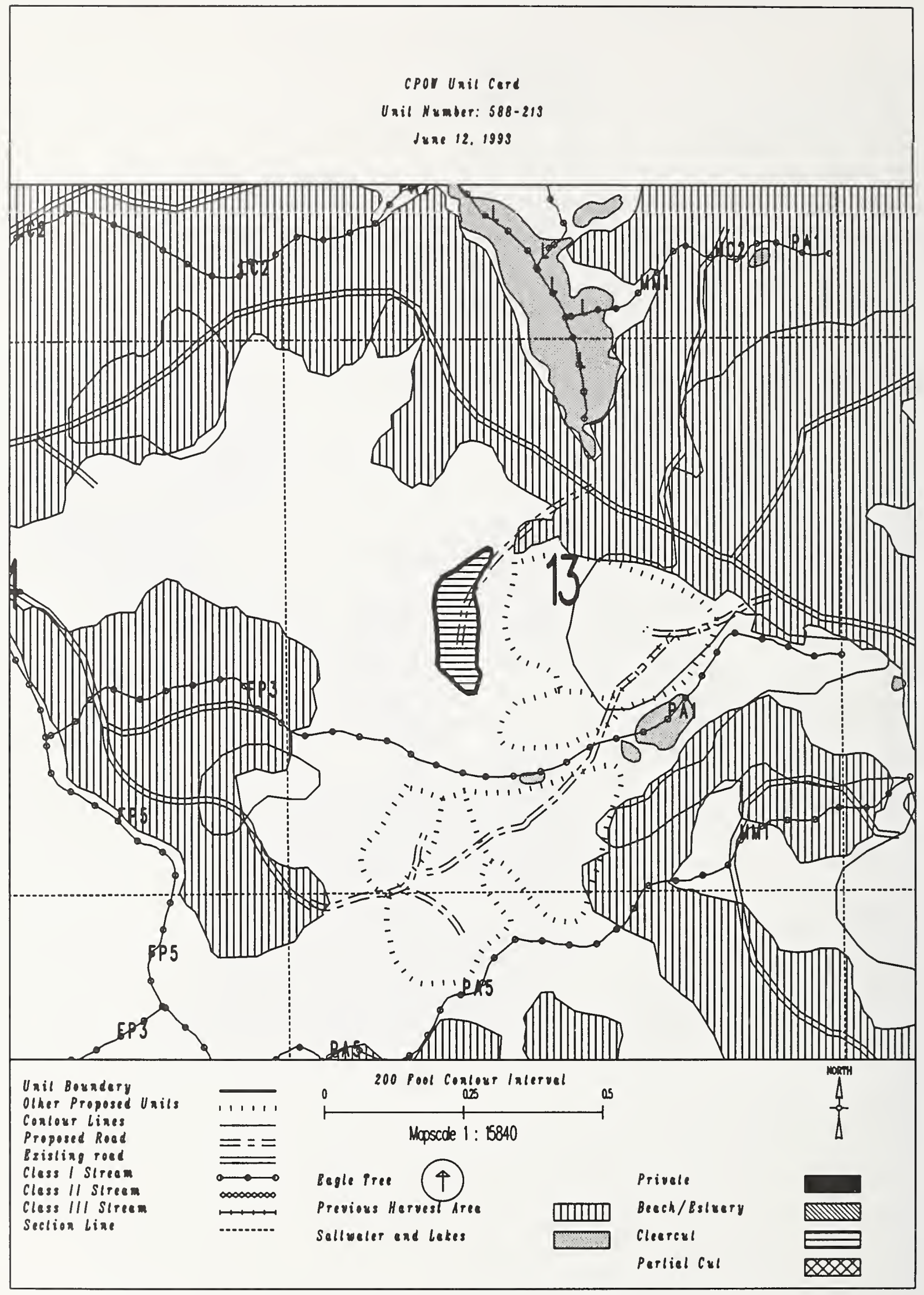




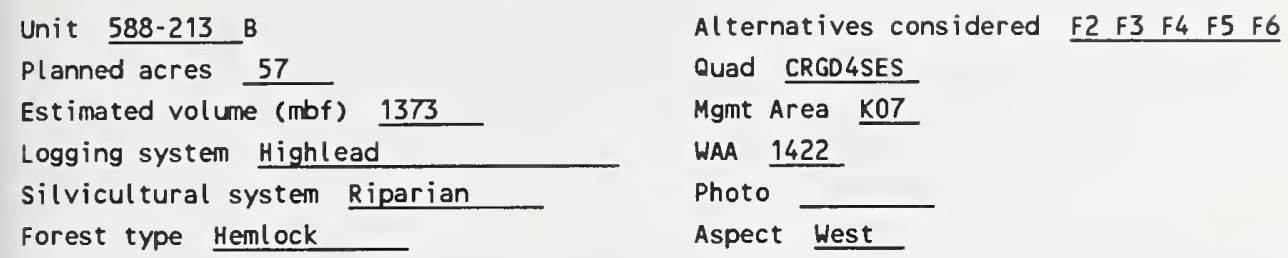

This unit contains 45 acres of forested wetlands. Site specific BMPs will be designed for selected approved logging system and road construction practices. (BMPs 12.5, 13.9, 13.15).

TIMBER

Uneven-aged harvest for riparian management on an estimated 17 acres.

\section{ENGINEER ING}

There are no engineering mitigation measures anticipated for this unit.

\section{FISH/WATERSHED}

Potential for additional Class $1 / 11$ streams within unit. May be necessary to place additional buffers within unit

in accordance with AHMU Handbook.

Potential impact on significant fishery habitat. May be necessary to expand planned buffer in accordance with AHMU Handbook.

Leave all deciduous and conifer trees (< 12" dbh) in $35 \mathrm{ft}$ buffer adjacent to class 111 streams to provide shade.

\section{WILDLIFE}

Maintain diversity within unit by leaving 1-5 acre-sized islands of green trees at a rate of 1 acre of island for every 20 acres harvested. Leave islands must be compatible with logging system and safe working conditions.

RECREATION / VISUALS

This unit has a proposed Voo of MM and is not seen from any viewpoint identified by this project.

LANDS

There are no lands mitigation measures anticipated for this unit.

CULTURAL RESOURCES

There are no cultural resource mitigation measures anticipated for this unit.

GEOLOGY

There are no karst mitigation measures anticipated for this unit. 


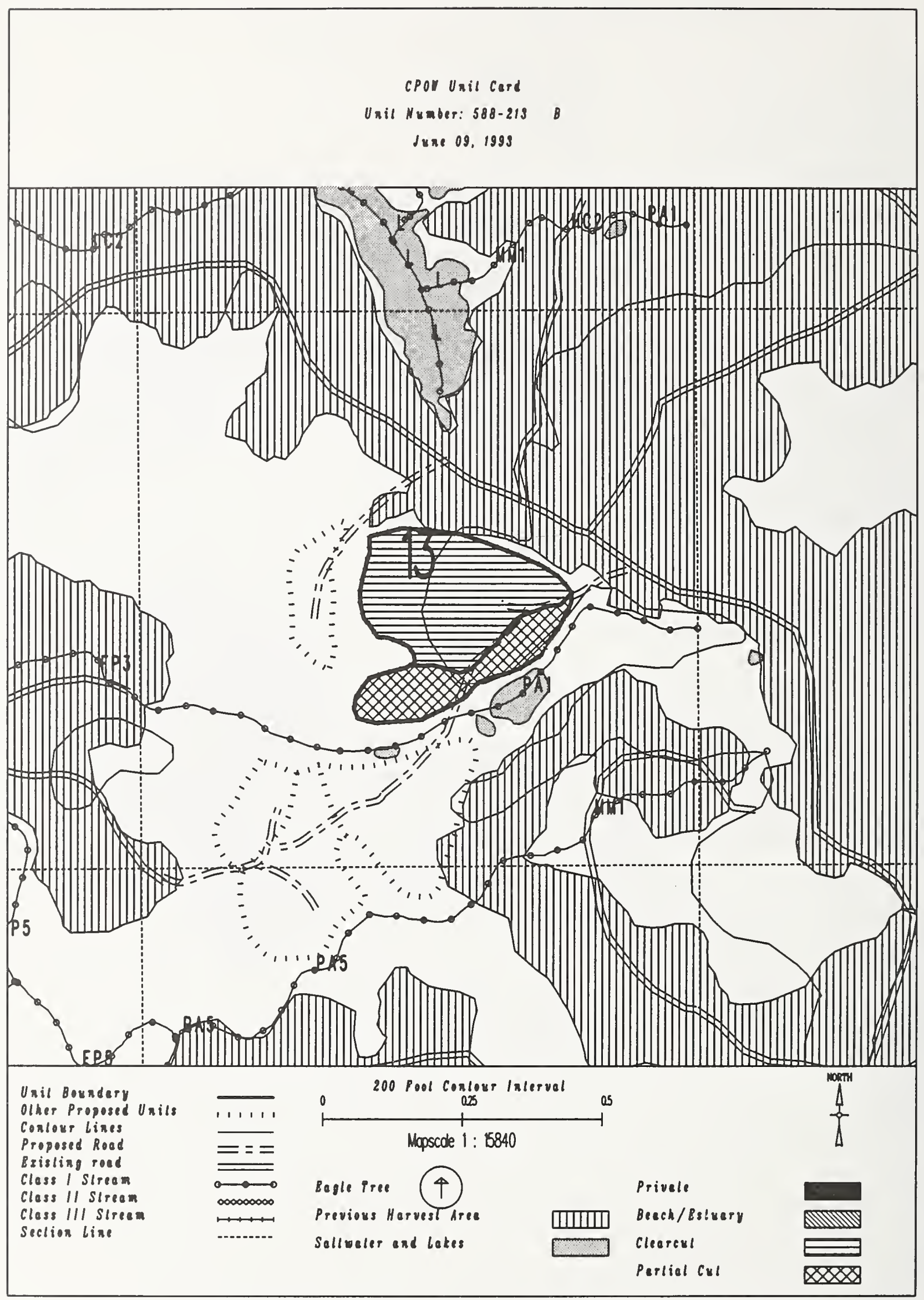


Unit $588-214$

Planned acres 19

Estimated volume (mbf) 940

Logging system Highlead

silvicultural system Clearcut

Forest type Hemlock
Alternatives considered $\mathrm{F} 2 \quad \mathrm{~F} 3 \quad \mathrm{~F} 4$ F5

Quad CRGD4SES

Mgmt Area $\mathrm{K} 07$

WAA 1422

Photo 1290028

Aspect North

\section{PHYSICAL DESCRIPTION}

Volume class breakdown: VC4 $\quad 0$ acres VC5 $\quad 0$ acres VC6 2 acres vC7 17 acres

Elevation breakdown: $0-800 \mathrm{ft} .18$ acres $800-1200 \mathrm{ft} . \underline{0}$ acres $1200-1500 \mathrm{ft} . \underline{0}$ acres over $1500 \mathrm{ft}$. 0 acres Mass movement index: Low 0 acres Medium 2 acres High 14 acres Very High 0

\section{SOILS}

This unit has high mass movement index soils. Partial log suspension required over these areas. (BMP13.9)

This unit contains 6 acres of forested wetlands. Site specific BMPs will be designed for selected approved

logging system and road construction practices. (BMPs 12.5, 13.9, 13.15).

This unit contains 12 acres of slopes $>75 \%$.

\section{TIMBER}

There are no timber mitigation measures anticipated for this unit.

\section{ENGINEERING}

High mass movement index soils. Road construction must minimize landslide potential (BMP14).

slopes greater than $75 \%$ may require full bench construction and endhaul of waste (BMP14.7).

\section{FISH/WATERSHED}

There are no fishery mitigation measures anticipated for this unit.

\section{WILDLIFE}

There are no wildlife mitigation measures anticipated for this unit.

\section{RECREATION / VISUALS}

The unit has a proposed VQO of $M$ within the viewshed of Staney Creek

as viewed from 1 mile from west coast of Prince of Wales.

\section{LANDS}

There are no lands mitigation measures anticipated for this unit.

\section{CULTURAL RESOURCES}

There are no cultural resource mitigation measures anticipated for this unit.

\section{GEOLOGY}

This unit is underlain with karst, although no significant features have yet been identified. 


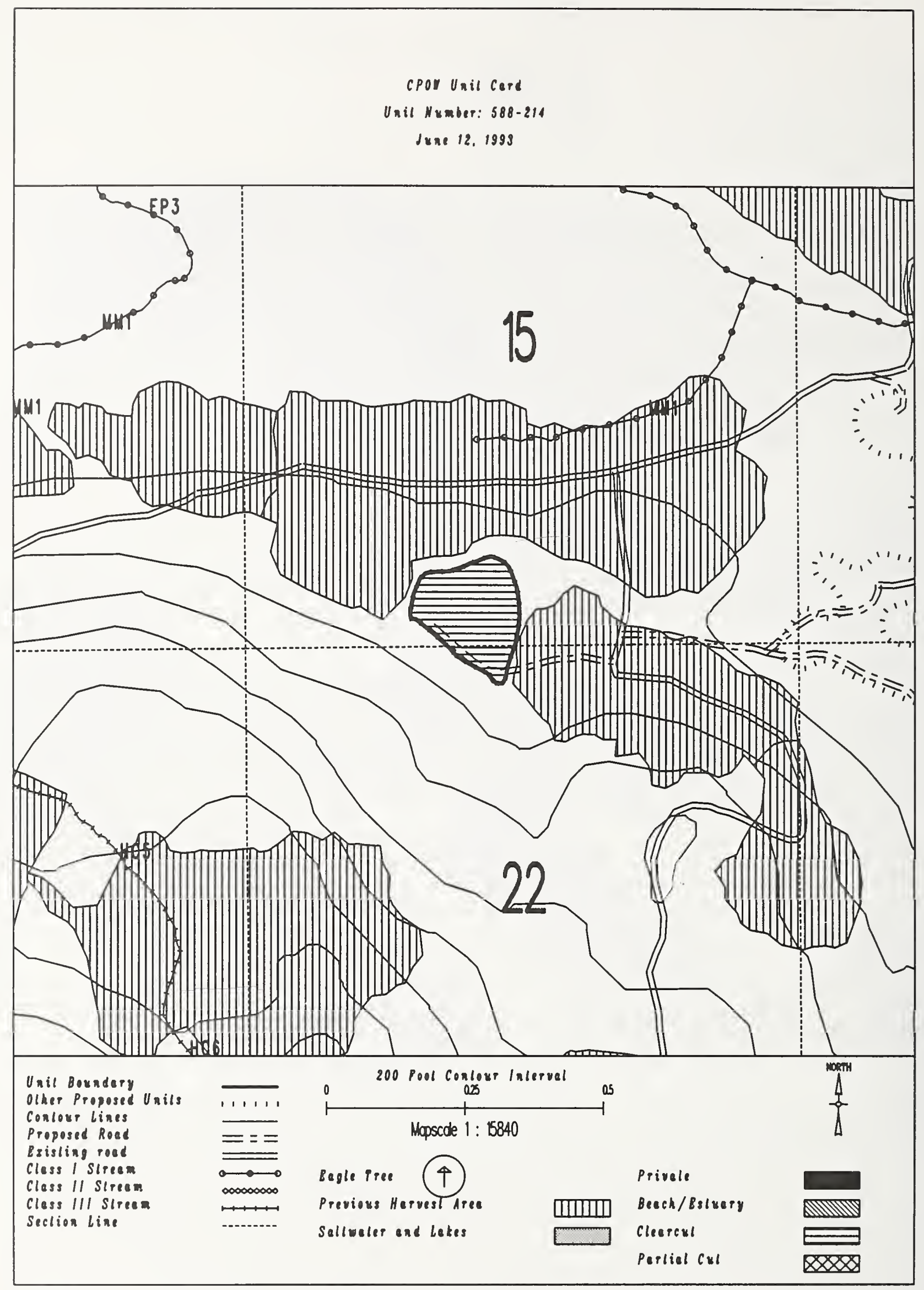


Unit 588-215

Planned acres 28

Est imated volume (mbf) 631

Logging system Highlead

Silvicultural system clearcut

Forest type Hemlock
Alternatives considered $\mathrm{F2} \quad \mathrm{F3} \quad \mathrm{F} 4 \quad$ F5

Quad CRGD4SES

Mgmt Area K07

WAA 1422

Photo 1190120

Aspect North

\section{PHYSICAL DESCRIPTION}

Volume class breakdown: VC4 22 acres VC5 3 acres VC6 $\quad 0$ acres vc7 1 acres

Elevation breakdown: $0-800 \mathrm{ft} . \underline{30}$ acres $800-1200 \mathrm{ft} . \quad 0$ acres $1200-1500 \mathrm{ft}$. 0 acres over $1500 \mathrm{ft}$. 0 Mass movement index: Low 20 acres Mediun 0 acres High 5 acres Very High 0 acres

\section{SOILS}

This unit has high mass movement index soils. Partial log suspension required over these areas.(BMP13.9)

This unit contains 19 acres of forested wetlands. Site specific BMPs will be designed for selected approved

logging system and road construction practices. (BMPS 12.5, 13.9, 13.15).

\section{TIMBER}

There are no timber mitigation measures anticipated for this unit.

\section{ENGINEERING}

There are no engineering mitigation measures anticipated for this unit.

\section{FISH/WATERSHED}

Potential for additional Class I/II streams within unit. May be necessary to place additional buffers within unit in accordance with AHMU Handbook.

Potentia! impact on significant fishery habitat. May be necessary to expand planned buffer in accordance with AHMU Handbook.

\section{WILDLIFE}

There are no wildlife mitigation measures anticipated for this unit.

RECREATION / VISUALS

This unit has a proposed VQO of MM and is not seen from any viewpoint identified by this project.

\section{LANDS}

There are no lands mitigation measures anticipated for this unit.

CULTURAL RESOURCES

There are no cultural resource mitigation measures anticipated for this unit.

GEOLOGY

This unit is underlain with karst, although no significant features have yet been identified. 


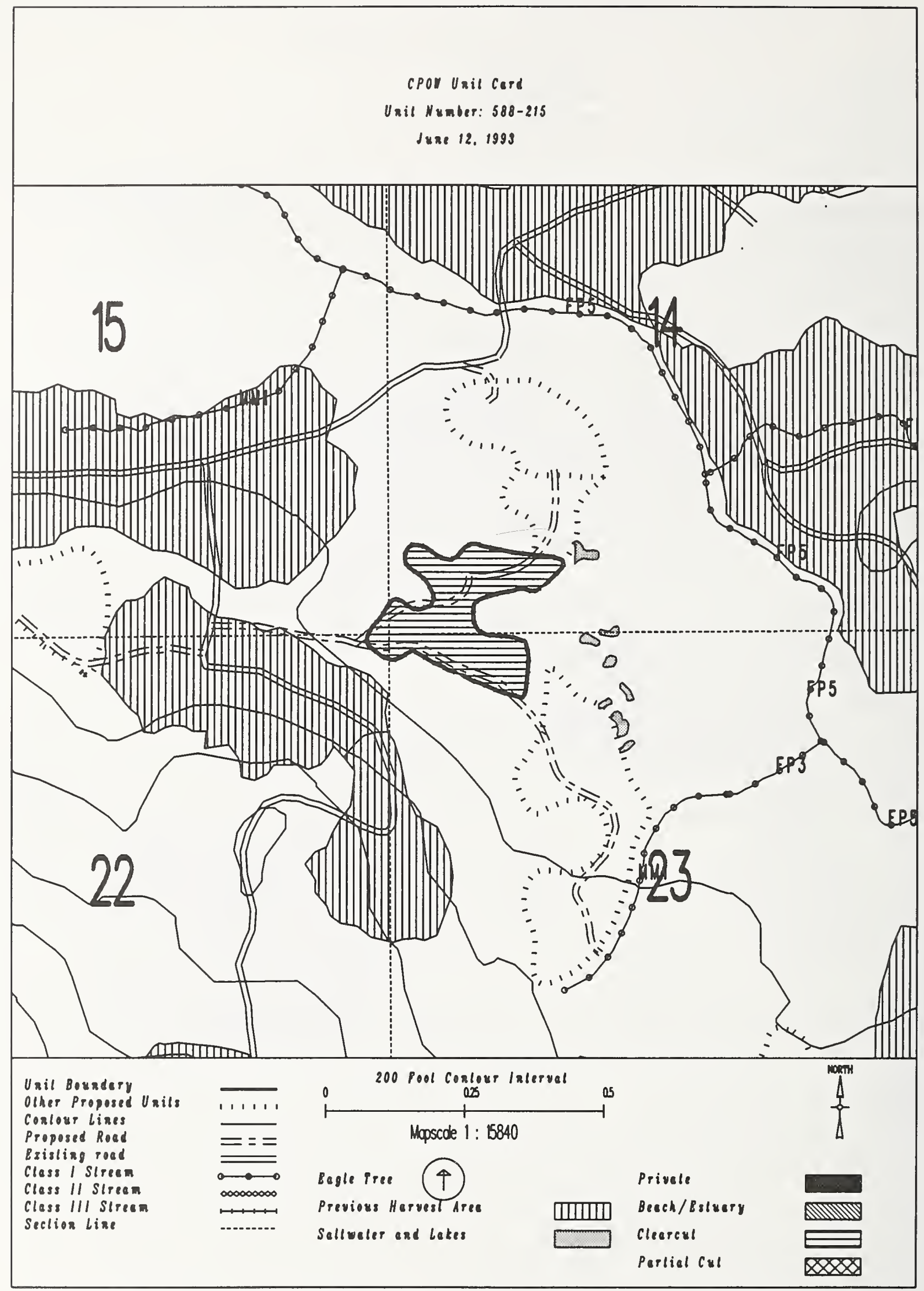


Unit

Planned acres 32

Estimated volume (mbf) 926

Logging system Highlead

Silvicultural system Riparian

Forest type Hemlock
Alternatives considered

Quad CRGD4SES

Mgmt Area $\mathrm{K07}$

WAA 1422

Photo

Aspect North

\section{PHYSICAL DESCRIPTION}

Volume class breakdown: VC4 0 acres vc5 $\quad 0$ acres vC6 $\quad 0$ acres vc7 31 acres

Elevation breakdown: $0-800 \mathrm{ft} . \underline{29}$ acres $800-1200 \mathrm{ft} . \underline{0}$ acres $1200-1500 \mathrm{ft} . \underline{0}$ acres over $1500 \mathrm{ft} . \underline{0}$ acres Mass movement index: Low 6 acres Medium $\_$acres High 24 acres Very High 0

\section{SOILS}

This unit has high mass movement index soils. Partial log suspension required over these areas. (BMP13.9)

This unit contains 23 acres of slopes $>75 \%$.

This unit contains $\frac{5}{5}$ acres of riparian soils. Maintain water quality and fish habitat (BMPs12.6, 13.9).

\section{TIMBER}

Uneven-aged harvest for riparian management on an estimated 22 acres.

Potential for shovel logging on 27 acres, if soil and water quality protected (BMP13.7)

\section{ENGINEER ING}

High mass movement index soils. Road construction must minimize landslide potential (BMP14).

This unit contains riparian soils. Use site specific BMPs to maintain water quality and fish habitat/passage

during road construbtion (BMP14.13).

slopes greater than $75 \%$ may require full bench construction and endhaul of waste (BMP14.7).

\section{FISH/WATERSHED}

Potential impact on significant fishery habitat. May be necessary to expand planned buffer in accordance with AHMU Handbook.

\section{WILDLIFE}

There are no wildlife mitigation measures anticipated for this unit.

\section{RECREATION / VISUALS}

This unit has a proposed VQO of MM and is not seen from any viewpoint identified by this project.

\section{LANDS}

There are no lands mitigation measures anticipated for this unit.

CULTURAL RESOURCES

There are no cultural resource mitigation measures anticipated for this unit. 


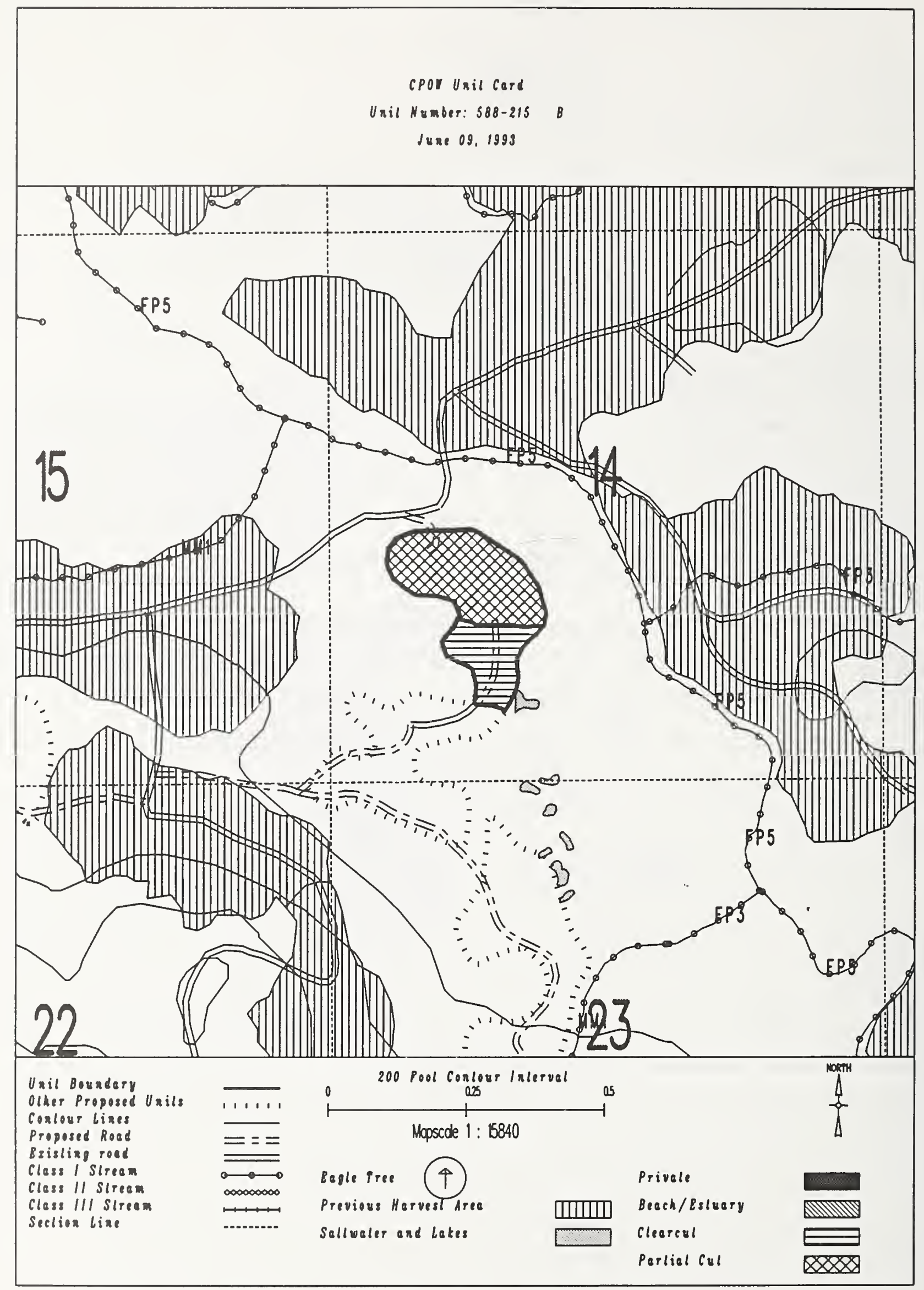


Unit 588-216

Planned acres 42

Est imated volume (mbf) 1278

Logging system Highlead

silvicultural system clearcut

Forest type Hemlock

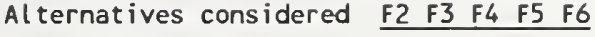

Quad CRGD4SES

Mgmt Area $\mathrm{KO7}$

WAA 1422

Photo 1190121

Aspect East

PHYSICAL DESCRIPTION

Volume class breakdown: VC4 0 acres VC5 39 acres vc6 $\quad 0$ acres vC7 0 acres

Elevation breakdown: $0-800 \mathrm{ft} . \underline{42}$ acres $800-1200 \mathrm{ft} . \underline{0}$ acres 1200-1500 ft. 0 acres over $1500 \mathrm{ft}$. 0 Mass movement index: Low 13 acres Medium 0 acres High 17 acres Very High 0 acres

SOILS

This unit has high mass movement index soils. Partial log suspension required over these areas.(BMP13.9)

This unit contains 36 acres of forested wetlands. Site specific BMPs will be designed for selected approved

logging system and road construction practices. (BMPs 12.5, 13.9, 13.15).

\section{TIMBER}

There are no timber mitigation measures anticipated for this unit.

ENGINEERING

High mass movement index soils. Road construction must minimize landslide potential (BMP14).

\section{FISH/WATERSHED}

Potential for additional Class l/II streams within unit. May be necessary to place additional buffers within unit in accordance with AHMU Handbook.

Potential impact on significant fishery habitat. May be necessary to expand planned buffer in accordance with AHMU Handbook.

\section{WILDLIFE}

There are no wildlife mitigation measures anticipated for this unit.

RECREATION / VISUALS

The unit has a proposed VoO of $M$ within the viewshed of Staney Creek

as viewed from $1 \mathrm{mile}$ from west coast of Prince of Wales.

\section{LANDS}

There are no lands mitigation measures anticipated for this unit.

CULTURAL RESOURCES

There are no cultural resource mitigation measures anticipated for this unit.

GEOLOGY

There are no karst mitigation measures anticipated for this unit. 


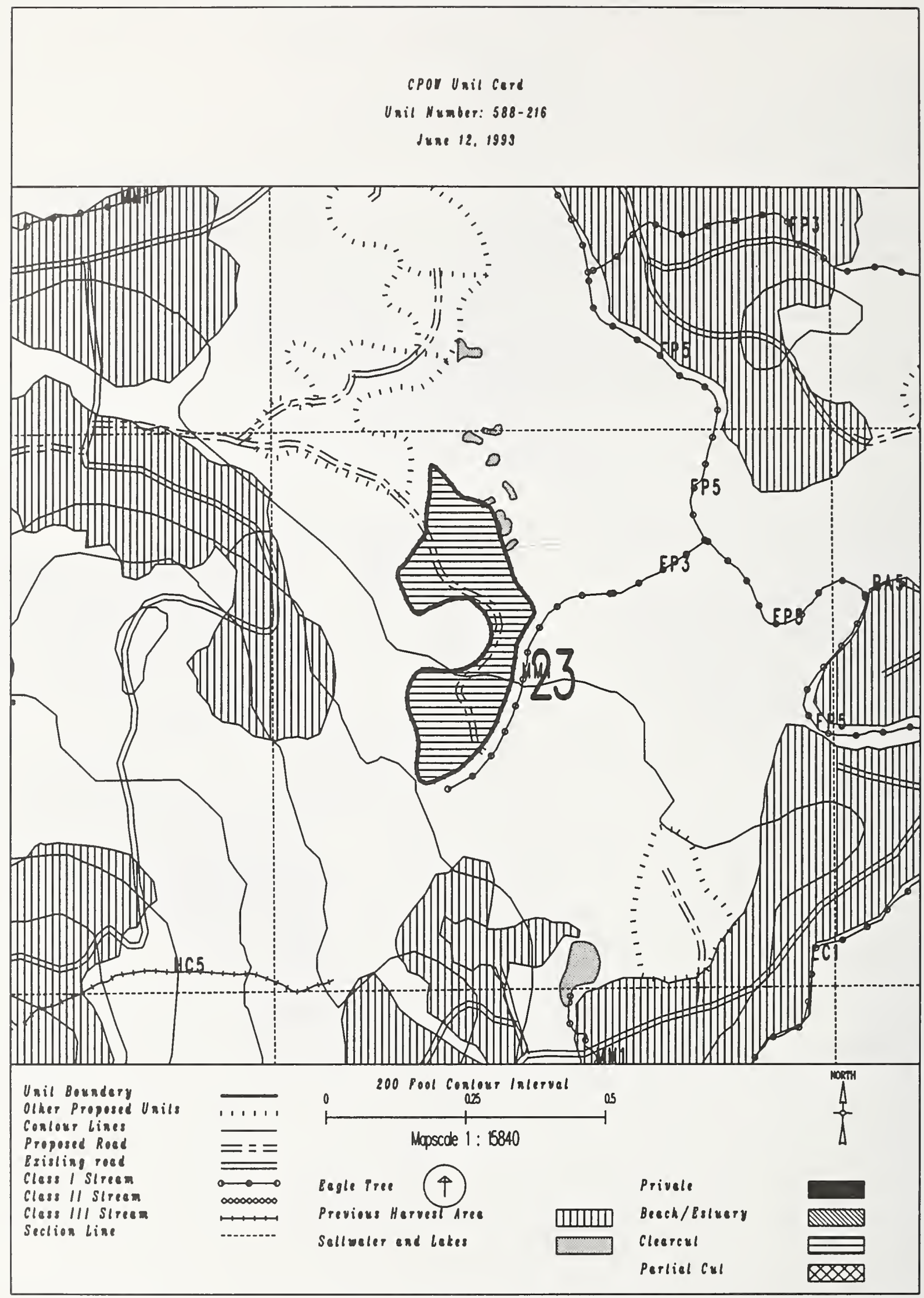


Unit $\quad 588-219$

Planned acres 21

Estimated volume (mbf) 682

Logging system Highlead

silvicultural system Clearcut

Forest type Hemlock
Alternatives considered

Quad CRGD4SES

Mgmt Area $\mathrm{KOT}$

WAA 1422

Photo

Aspect East

PHYSICAL DESCRIPTION

Volume class breakdown: VC4 0 acres VC5 15 acres VC6 5 acres vc7 0 acres

Elevation breakdown: $0-800 \mathrm{ft} . \underline{20}$ acres $800-1200 \mathrm{ft} . \underline{0}$ acres $1200-1500 \mathrm{ft}$. 0 Mass movement index: Low 15 acres Medium 20 acres High 2 acres Very High 0 acres

SOILS

This unit contains 9 acres of forested wetlands. Site specific BMPs will be designed for selected approved logging system and road construction practices. (BMPs 12.5, 13.9, 13.15).

\section{TIMBER}

There are no timber mitigation measures anticipated for this unit.

\section{ENGINEER ING}

There are no engineering mitigation measures anticipated for this unit.

\section{FISH/WATERSHED}

Potential for additional Class I/II streams within unit. May be necessary to place additional buffers within unit in accordance with AHMU Handbook.

\section{WILDLIFE}

There are no wildlife mitigation measures anticipated for this unit.

\section{RECREATION / VISUALS}

This unit has a proposed Voo of MM and is not seen from any viewpoint identified by this project.

\section{LANDS}

There are no lands mitigation measures anticipated for this unit.

CULTURAL RESOURCES

There are no cultural resource mitigation measures anticipated for this unit. 


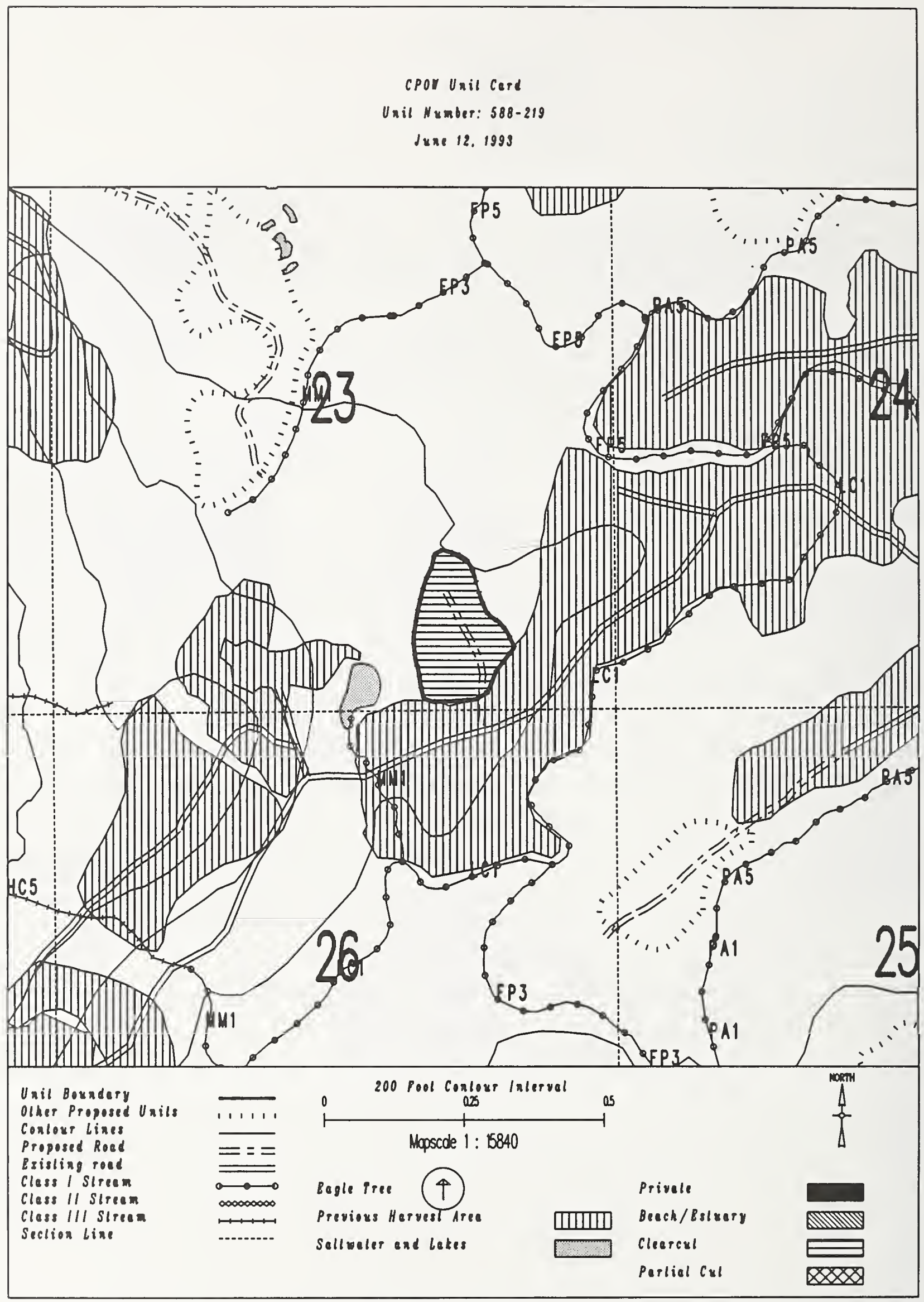


Unit 588-231

Planned acres 20

Estimated volume (mbf) 632

Logging system Highlead

silvicultural system Clearcut

Forest type Hemlock
Alternatives considered F2 F3 F4 F5 F6

Quad CRGD4SES

Mgmt Area $\mathrm{KO7}$

WAA 1422

Photo 1190121

Aspect North

PHYSICAL DESCRIPTION

Volume class breakdown: VC4 $\quad 8$ acres VC5 $\quad 0$ acres VC6 12 acres VC7 $\quad 0$ acres

Elevation breakdown: $0-800 \mathrm{ft} . \underline{19}$ acres $800-1200 \mathrm{ft} . \underline{0}$ acres 1200-1500 ft. 0 acres over $1500 \mathrm{ft}$. 0 acres Mass movement index: Low 1 acres Medium 0 acres High 10 acres Very High 0 acres

SOILS

This unit has high mass movement index soils. Partial log suspension required over these areas.(BMP13.9)

This unit contains 18 acres of forested wetlands. Site specific BMPs will be designed for selected approved

logging system and road construction practices. (BMPS 12.5, 13.9, 13.15).

\section{TIMBER}

There are no timber mitigation measures anticipated for this unit.

ENGINEER ING

High mass movement index soils. Road construction must minimize landslide potential (BMP14).

FISH/WATERSHED

Potential for additional Class I/II streams within unit. May be necessary to place additional buffers within unit in accordance with AHMU Handbook.

Potential impact on significant fishery habitat. May be necessary to expand planned buffer in accordance with AHMU Handbook.

HILDL IFE

There are no wildlife mitigation measures anticipated for this unit.

RECREATION / VISUALS

This unit has a proposed VQO of MM and is not seen from any viewpoint identified by this project.

LANDS

There are no lands mitigation measures anticipated for this unit.

CULTURAL RESOURCES

There are no cultural resource mitigation measures anticipated for this unit.

GEOLOGY

There are no karst mitigation measures anticipated for this unit. 


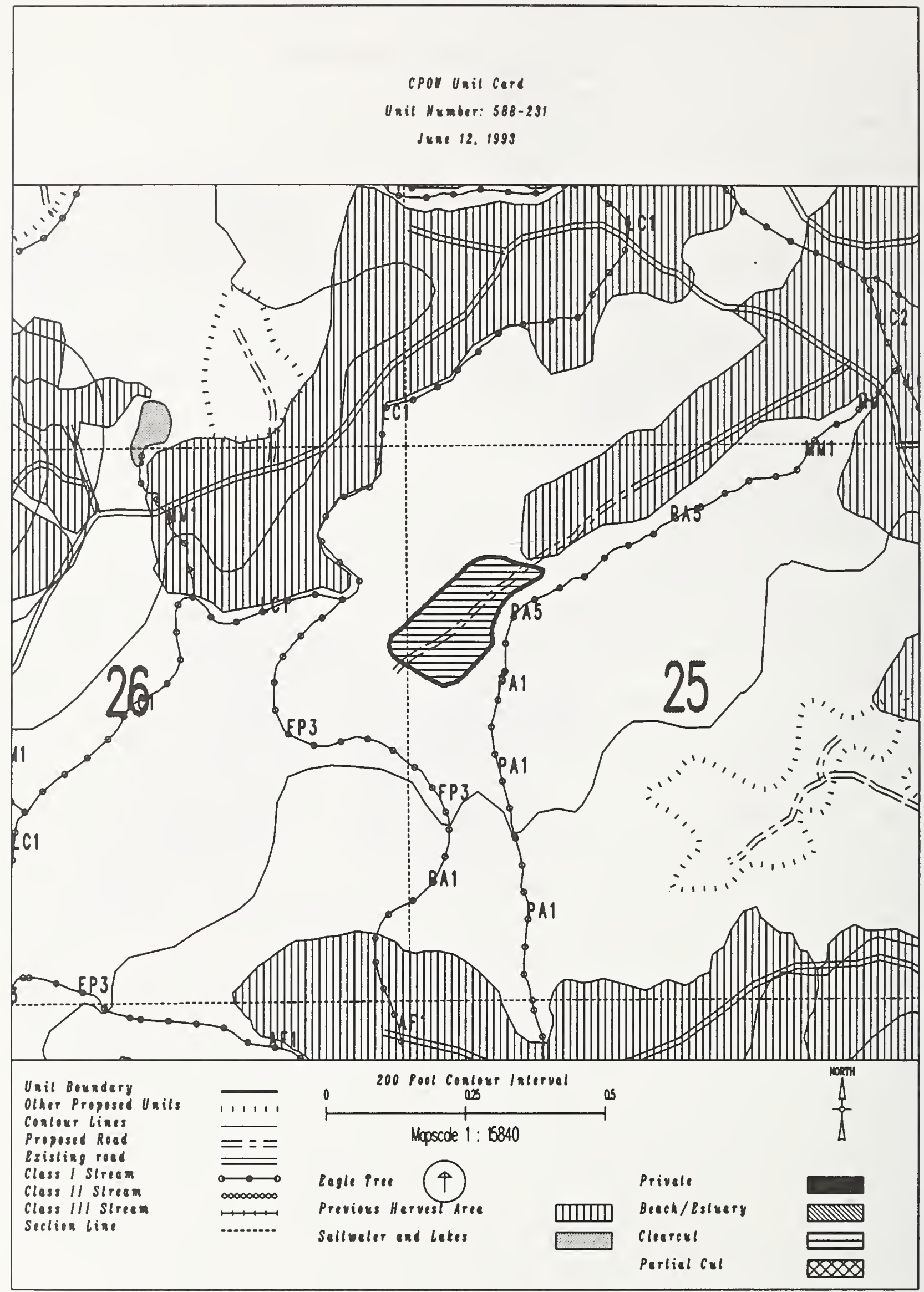


Unit $588-240$

Planned acres 11

Estimated volume (mbf) 241

Logging system Highlead

silvicultural system Clearcut

Forest type Hemlock

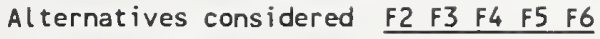

Quad CRGD4SES

Mgmt Area $\mathrm{KO7}$

HAA 1422

Photo 1190041

Aspect North

PHYSICAL DESCRIPTION

Volume class breakdown: VC4 11 acres VC5 0 acres VC6 0 acres VC7 0 acres

Elevation breakdown: $0-800 \mathrm{ft}$. 10 acres $800-1200 \mathrm{ft} . \quad 0$ acres $1200-1500 \mathrm{ft}$. 0 acres over $1500 \mathrm{ft}$. 0 acres Mass movement index: Low 10 acres Medium 0 acres High 0 acres Very High 0 acres

\section{SOILS}

There are no soils mitigation measures anticipated for this unit.

\section{TIMBER}

There are no timber mitigation measures anticipated for this unit.

\section{ENGI NEER ING}

There are no engineering mitigation measures anticipated for this unit.

\section{FISH/WATERSHED}

There are no fishery mitigation measures anticipated for this unit.

\section{WI LDL I FE}

There are no wildlife mitigation measures anticipated for this unit.

RECREATION / VISUALS

This unit has a proposed VQO of MM and is not seen from any viewpoint identified by this project.

\section{LANDS}

There are no lands mitigation measures anticipated for this unit.

CULTURAL RESOURCES

There are no cultural resource mitigation measures anticipated for this unit. 


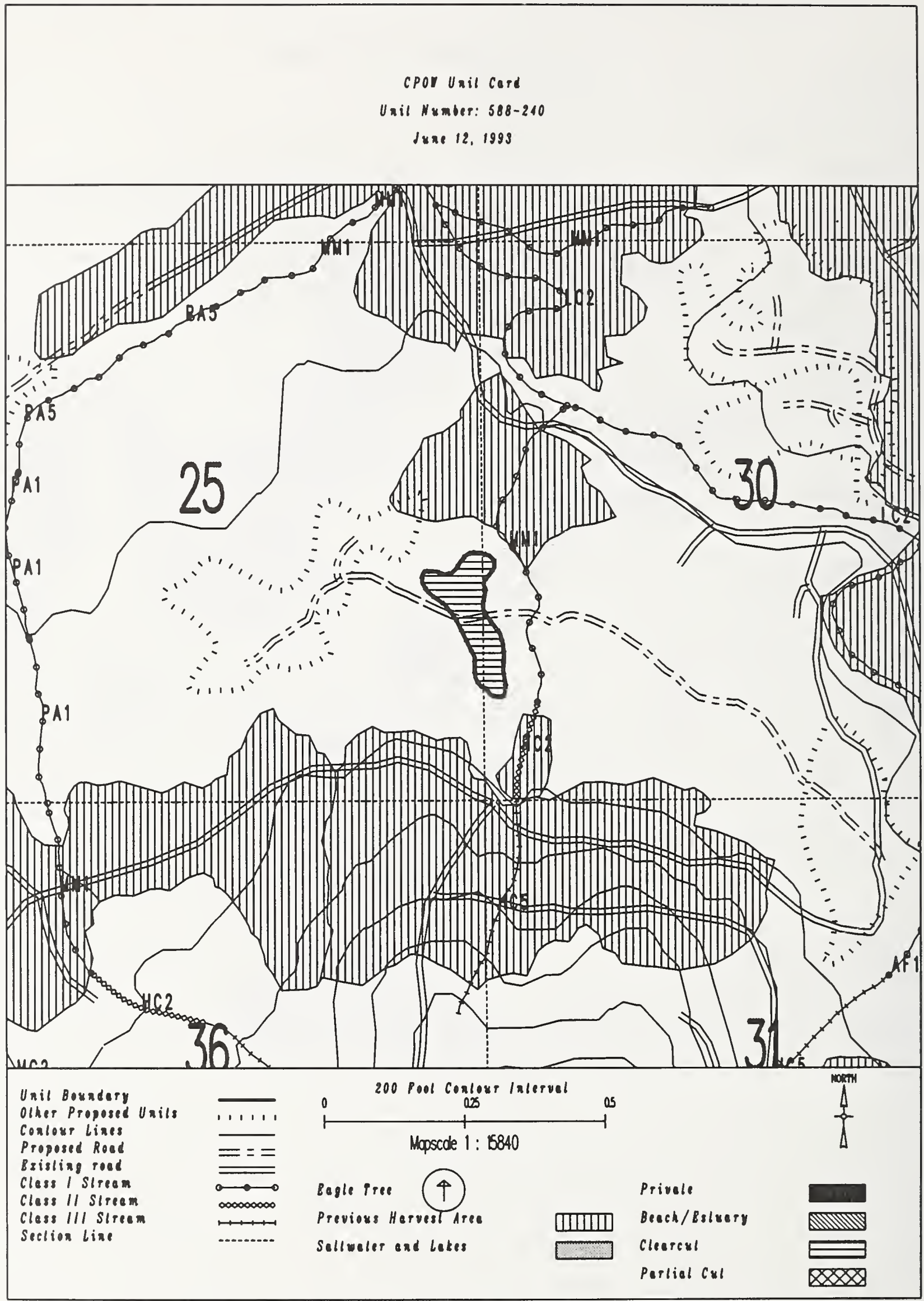


Unit 588-241

Planned acres 33

Estimated volume (mbf)

Logging system Highlead

Silvicultural system Clearcut

Forest type Hemlock

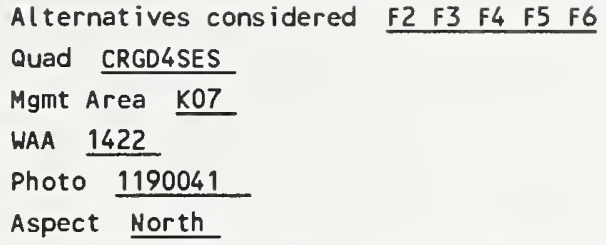

PHYSICAL DESCRIPTION

Volume class breakdown: VC4 32 acres VC5 $\quad 0$ acres vC6 $\quad 0$ acres VC7 0 acres

Elevation breakdown: $0-800 \mathrm{ft} .33$ acres $800-1200 \mathrm{ft} . \quad 0$ acres $1200-1500 \mathrm{ft}$. 0 acres over $1500 \mathrm{ft}$. 0 acres Mass movement index: Low 32 acres Medium 0 acres High 0 acres Very High 0 acres

SOILS

This unit contains 15 acres of forested wetlands. Site specific BMPs will be designed for selected approved

logging system and road construction practices. (BMPS 12.5, 13.9, 13.15).

TIMBER

There are no timber mitigation measures anticipated for this unit.

ENGINEERING

There are no engineering mitigation measures anticipated for this unit.

FISH/WATERSHED

This unit contains streams which have recently been classified/channel typed but require field verification.

WILOLIFE

There are no wildlife mitigation measures anticipated for this unit.

RECREATION / VISUALS

This unit has a proposed Voo of MM and is not seen from any viewpoint identified by this project.

LANDS

There are no lands mitigation measures anticipated for this unit.

CULTURAL RESOURCES

There are no cultural resource mitigation measures anticipated for this unit.

GEOLOGY

There are no karst mitigation measures anticipated for this unit. 


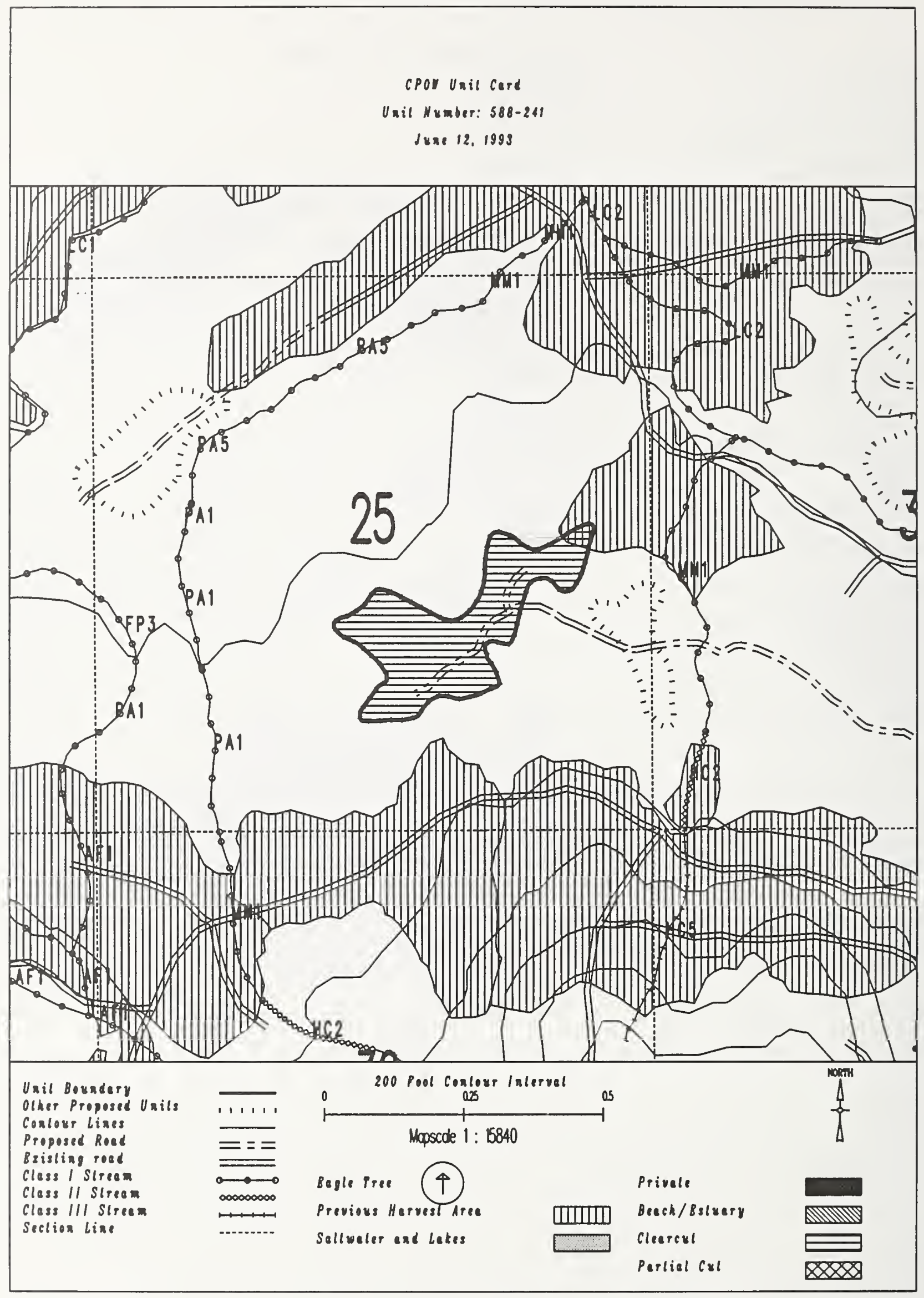




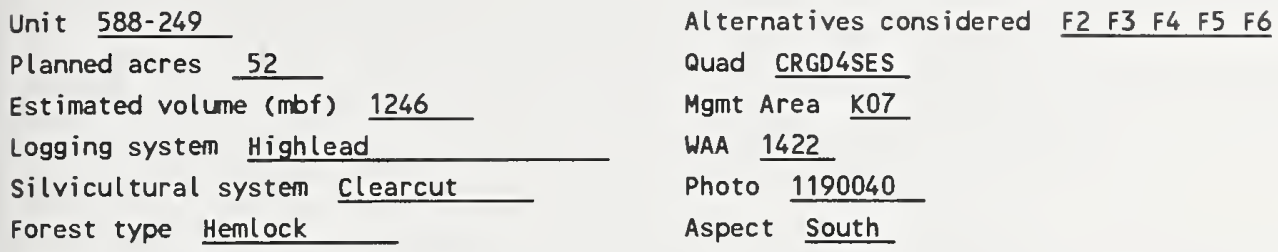




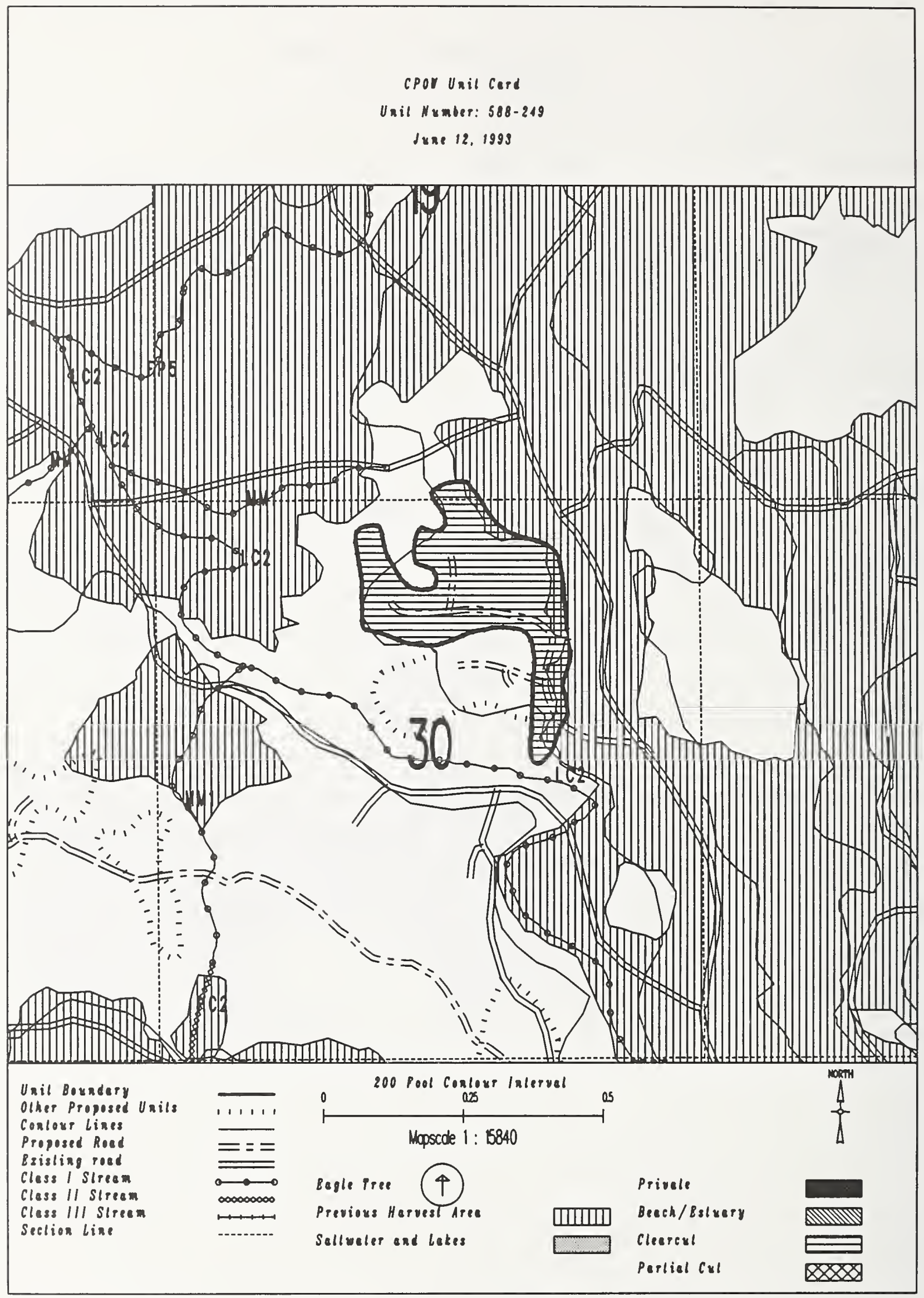




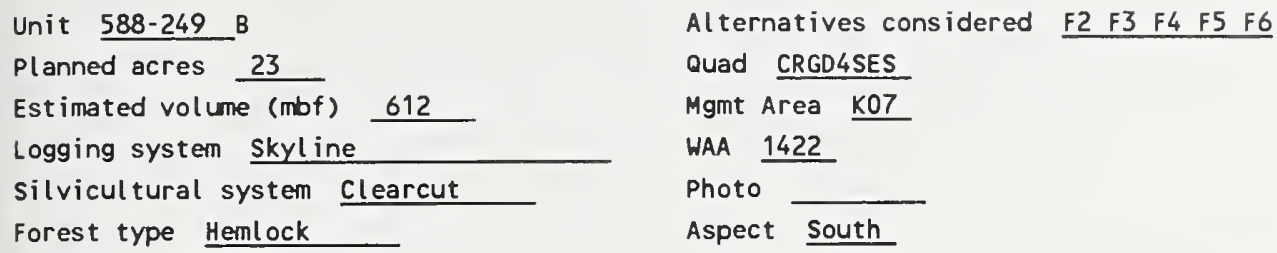




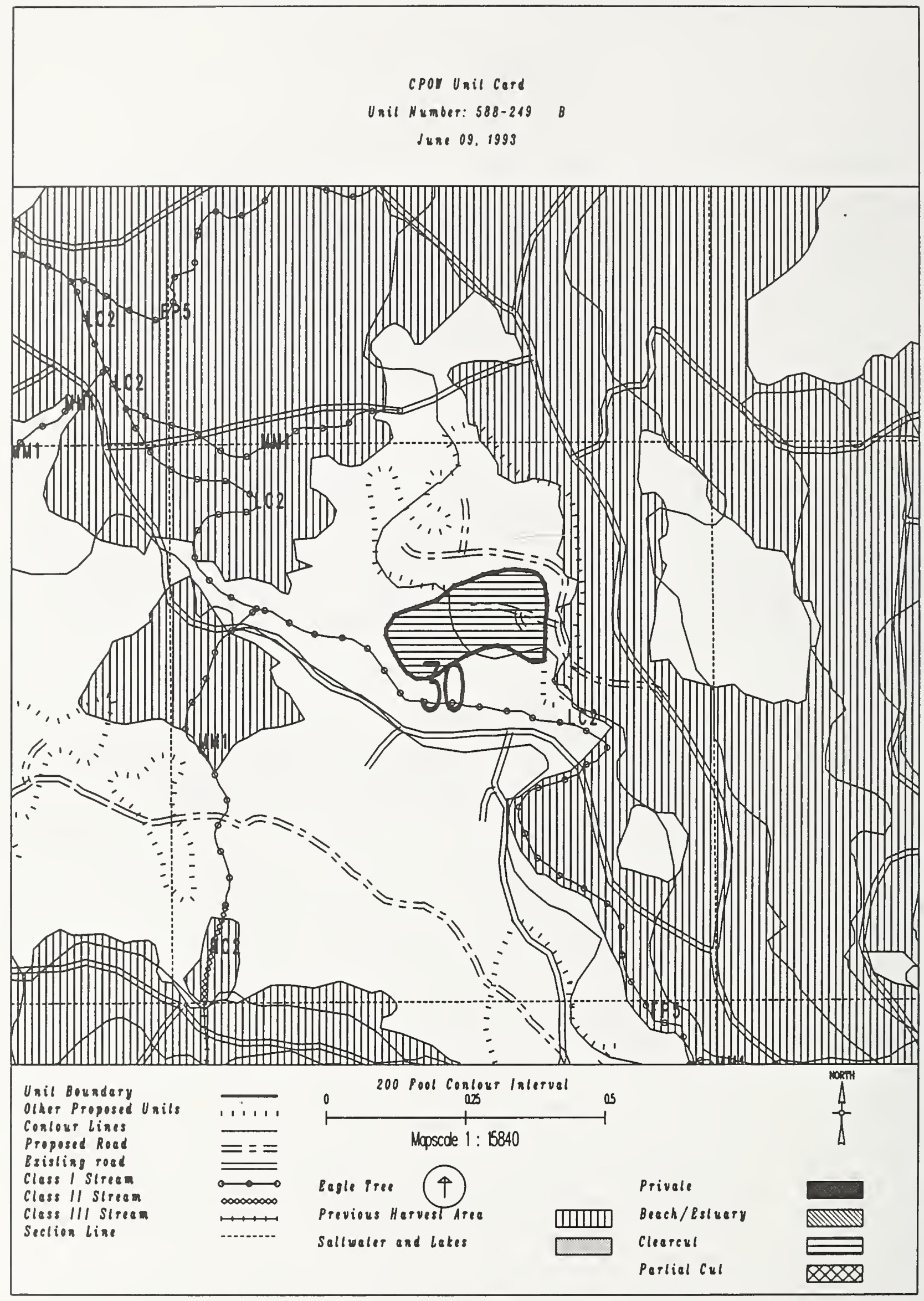


Unit 588-257

Planned acres 34

Estimated volume (mbf) 918

Logging system Highlead

silvicultural system clearcut

Forest type Hemlock

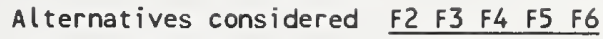

Quad CRGD4SES

Mgmt Area $\mathrm{K} 07$

WAA 1422

Photo

Aspect West

PHYSICAL DESCRIPTION

Volume class breakdown: VC4 14 acres VC5 14 acres $\quad$ VC6 $\quad 4$ acres VC7 $\quad 0$ acres

Elevation breakdown: $0-800 \mathrm{ft} . \underline{32}$ acres $800-1200 \mathrm{ft} . \quad 0$ acres $1200-1500 \mathrm{ft}$. 0 acres over $1500 \mathrm{ft}$. 0 acres Mass movement index: Low $\_$acres Medium 0 acres High 19 acres Very High 0

SOILS

This unit has high mass movement index soils. Partial log suspension required over these areas. (BMP13.9)

This unit contains 32 acres of forested wetlands. Site specific BMPs will be designed for selected approved

logging system and road construction practices. (BMPs 12.5, 13.9, 13.15).

\section{TIMBER}

There are no timber mitigation measures anticipated for this unit.

ENGINEER ING

High mass movement index soils. Road construction must minimize landslide potential (BMP14).

FISH/HATERSHED

Potential for additional Class I/II streams within unit. May be necessary to place additional buffers within unit in accordance with AHMU Handbook.

\section{HILDLIFE}

There are no wildlife mitigation measures anticipated for this unit.

RECREATION / VISUALS

This unit has a proposed VQO of MM and is not seen from any viewpoint identified by this project.

LANDS

This unit adjacent to Sarkar Management Area. Boundary establishment required prior to layout.

CULTURAL RESOURCES

There are no cultural resource mitigation measures anticipated for this unit.

GEOLOGY

There are no karst mitigation measures anticipated for this unit. 


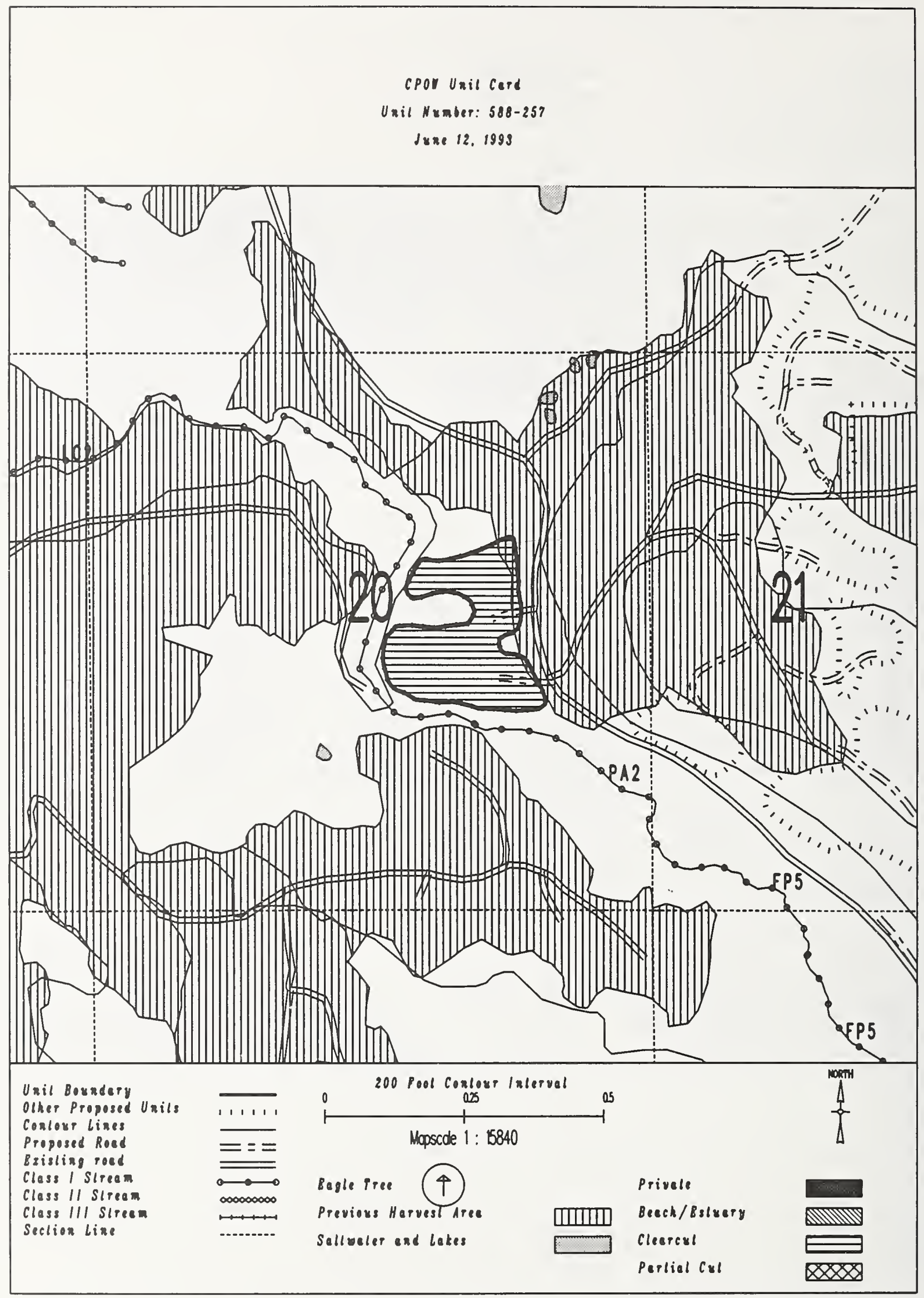


Unit 588-259

Planned acres 47

Estimated volume (mbf) 1147

Logging system skyline

silvicultural system clearcut

Forest type Hemlock
Alternatives considered $\quad$ F2 $\quad F 3 \quad F 4 \quad F 5$

Quad CRGD4SES

Mgmt Area $\mathrm{K08}$

WAA 1422

Photo 1190054

Aspect West

PHYSICAL DESCRIPTION

Volume class breakdown: VC4 $\quad 0$ acres VC5 35 acres VC6 $\quad 0$ acres VC7 0

Elevation breakdown: $0-800 \mathrm{ft} . \underline{44}$ acres $800-1200 \mathrm{ft} . \ldots$ Mass movement index: Low 16 acres Medium 0 acres High 12 acres Very High 0

SOILS

This unit has high mass movement index soils. Partial log suspension required over these areas.(BMP13.9)

This unit contains 18 acres of forested wetlands. Site specific BMPs will be designed for selected approved

logging system and road construction practices. (BMPs 12.5, 13.9, 13.15).

\section{TIMBER}

There are no timber mitigation measures anticipated for this unit.

\section{ENG I NEER I NG}

High mass movement index soils. Road construction must minimize landslide potential (BMP14).

\section{FISH/WATERSHED}

There are no fishery mitigation measures anticipated for this unit.

\section{HI LDL I FE}

Maintain diversity within unit by leaving 1-5 acre-sized islands of green trees at a rate of 1 acre of island for every 20 acres harvested. Leave islands must be compatible with logging system and safe working conditions.

RECREATION / VISUALS

This unit has a proposed VQO of MM and is not seen from any viewpoint identified by this project.

\section{LANDS}

There are no lands mitigation measures anticipated for this unit.

CULTURAL RESOURCES

There are no cultural resource mitigation measures anticipated for this unit.

GEOLOGY

Planned unit boundary/road location/logging system are designed to avoid damage to significant karst features. Mitigation measures may apply. Unit layout/changes must be coordinated with Cave Resource Specialists. 


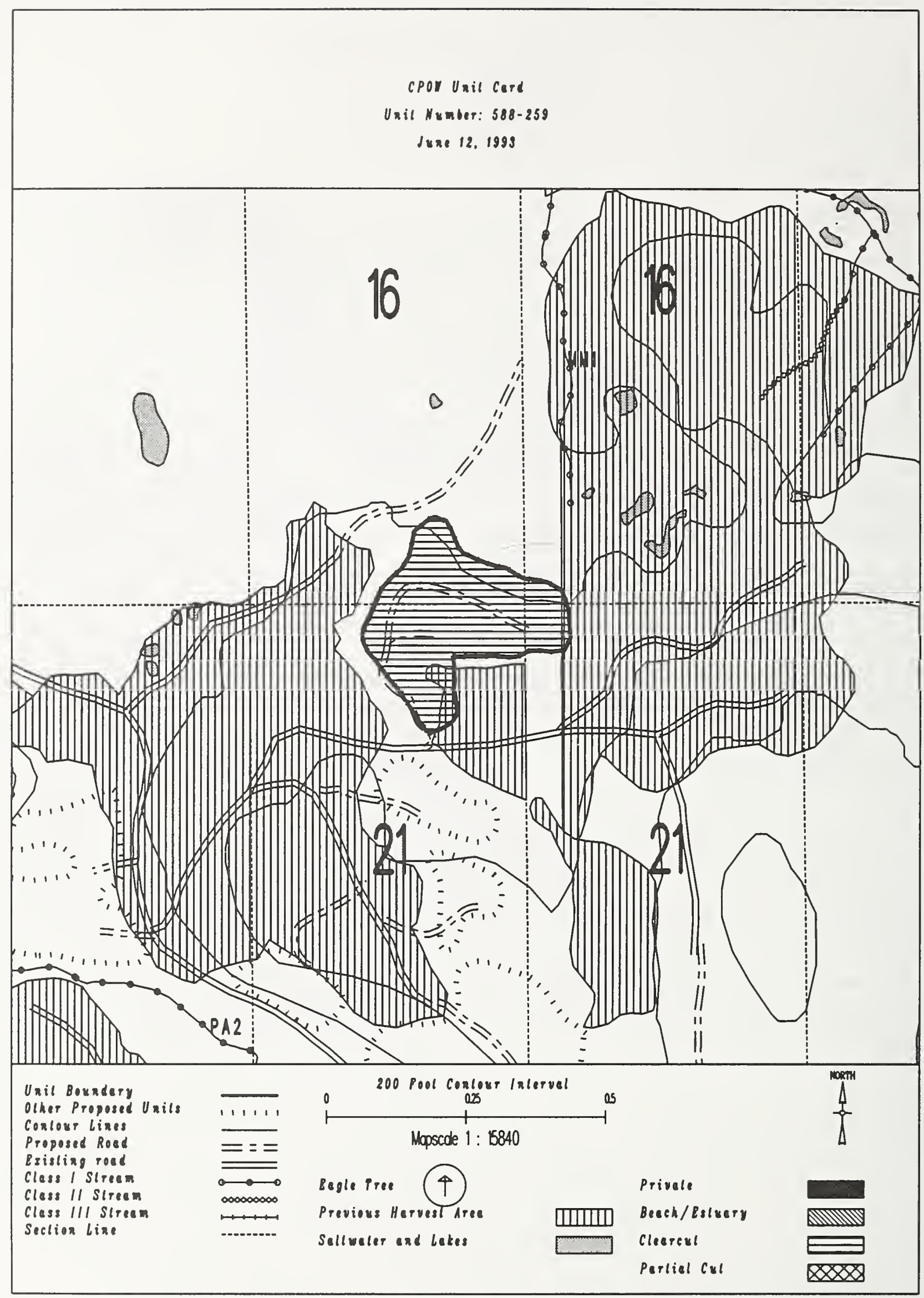


Unit $\quad 588-260$

Planned acres 9

Estimated volume (mbf) 361

Logging system Highlead

silvicultural system Clearcut

Forest type Hemlock
Alternatives considered F2 F3 F4 F5

Quad CRGD4SES

Mgmt Area $\mathrm{KO7}$

WAA 1422

Photo 1190054

Aspect North

PHYSICAL DESCRIPIION

Volume class breakdown: VC4 0 acres VC5 11 acres vc6 0 acres vc7 0 acres

Elevation breakdown: $0-800 \mathrm{ft}$. 9 acres $800-1200 \mathrm{ft} . \quad 0$ acres $1200-1500 \mathrm{ft}$. 0 acres over $1500 \mathrm{ft}$. 0 acres Mass movement index: Low 4 acres Medium 0 acres High 1 acres Very High 0 acres

\section{SOILS}

This unit has high mass movement index soils. Partial log suspension required over these areas. (BMP13.9)

\section{TIMBER}

There are no timber mitigation measures anticipated for this unit.

\section{ENGINEER ING}

There are no engineering mitigation measures anticipated for this unit.

\section{FISH/WATERSHED}

Potential for additional Class I/II streams within unit. May be necessary to place additional buffers within unit in accordance with AHMU Handbook.

\section{WILDLIFE}

Maintain diversity within unit by leaving 1-5 acre-sized islands of green trees at a rate of 1 acre of island for every 20 acres harvested. Leave islands must be compatible with logging system and safe working conditions.

\section{RECREATION / VISUALS}

This unit has a proposed Vao of MM and is not seen from any viewpoint identified by this project.

\section{LANDS}

There are no lands mitigation measures anticipated for this unit.

\section{CULTURAL RESOURCES}

There are no cultural resource mitigation measures anticipated for this unit.

\section{GEOLOGY}

This unit is underlain with karst, al though no significant features have yet been identified. 


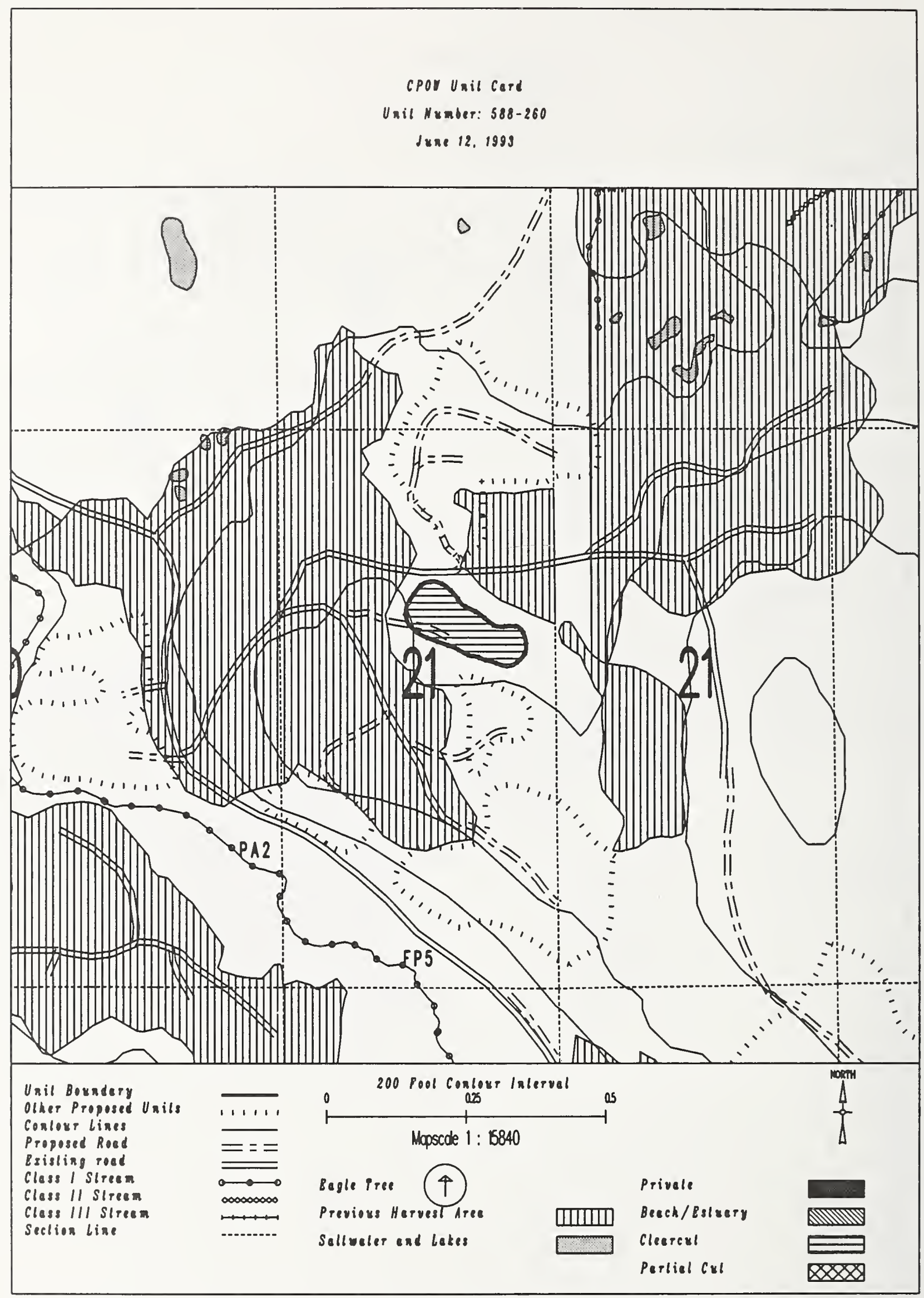


Unit $588-261$

Planned acres 8

Estimated volume (mbf)

Logging system Highlead

silvicultural system clearcut

Forest type Hemlock
Alternatives considered F2 F3 F4 F5

Quad CRGD4SES

Mgmt Area K07

WAA 1422

Photo 1190054

Aspect West

\section{PHYSICAL DESCRIPTION}

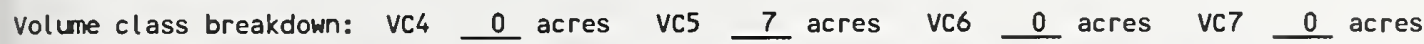

Elevation breakdown: $0-800 \mathrm{ft} . \underline{0}$ acres $800-1200 \mathrm{ft} . \underline{7}$ acres $1200-1500 \mathrm{ft} . \underline{0}$ acres over $1500 \mathrm{ft}$. 0 Mass movement index: Low 5 acres Medium 0 acres High 1 acres Very High 0

\section{SOILS}

This unit has high mass movement index soils. Partial log suspension required over these areas. (BMP13.9)

\section{TIMBER}

There are no timber mitigation measures anticipated for this unit.

\section{ENGINEER ING}

There are no engineering mitigation measures anticipated for this unit.

\section{FISH/WATERSHED}

Potential for additional class $1 / 11$ streams within unit. May be necessary to place additional buffers within unit

in accordance with AHMU Handbook.

\section{WILDLIFE}

Maintain diversity within unit by leaving 1-5 acre-sized islands of green trees at a rate of 1 acre of island for every 20 acres harvested. Leave islands must be compatible with logging system and safe working conditions.

RECREATION / VISUALS

This unit has a proposed veo of MM and is not seen from any viewpoint identified by this project.

\section{LANDS}

There are no lands mitigation measures anticipated for this unit.

CULTURAL RESOURCES

There are no cultural resource mitigation measures anticipated for this unit.

GEOLOGY

Planned unit boundary/road location/logging system are designed to avoid damage to significant karst features. Mitigation measures may apply. Unit layout/changes must be coordinated with Cave Resource Specialists. 


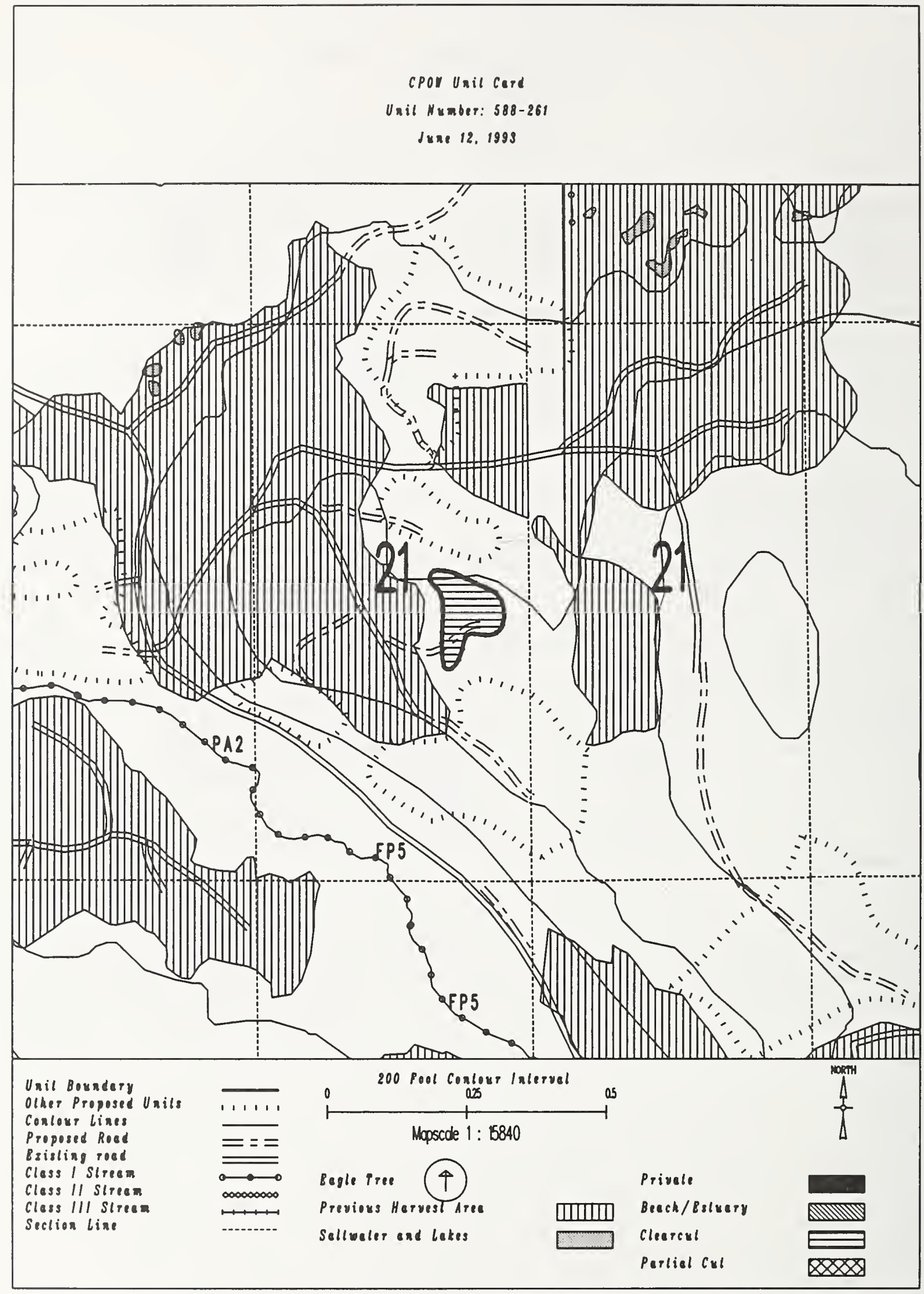


Unit $588-262$

Planned acres 10

Est imated volume (mbf) 328

Logging system Highlead

silvicultural system clearcut

Forest type Hemlock
Alternatives considered F2 F3 F4 F5

Quad CRGD4SES

Mgmt Area $\mathrm{KOT}$

WAA 1422

Photo 1190054

Aspect South

PHYSICAL DESCRIPTION

Volume class breakdown: VC4 0 acres VC5 10 acres VC6 $\quad 0$ acres VC7 0 acres

Elevation breakdown: $0-800 \mathrm{ft} . \quad 7$ acres $800-1200 \mathrm{ft} . \underline{0}$ acres 1200-1500 ft. 0 acres over $1500 \mathrm{ft}$. 0 acres Mass movement index: Low $\_$acres Medium $\_$acres High 4 acres Very High 0

SOILS

This unit has high mass movement index soils. Partial log suspension required over these areas. (BMP13.9)

\section{TIMBER}

There are no timber mitigation measures anticipated for this unit.

\section{ENGINEER ING}

There are no engineering mitigation measures anticipated for this unit.

\section{FISH/WATERSHED}

There are no fishery mitigation measures anticipated for this unit.

\section{WILDLIFE}

Maintain diversity within unit by leaving 1-5 acre-sized islands of green trees at a rate of 1 acre of island for every 20 acres harvested. Leave islands must be compatible with logging system and safe working conditions.

RECREATION / VISUALS

This unit has a proposed VQo of MM and is not seen from any viewpoint identified by this project.

\section{LANDS}

There are no lands mitigation measures anticipated for this unit.

CULTURAL RESOURCES

There are no cultural resource mitigation measures anticipated for this unit.

\section{GEOLOGY}

This unit is underlain with karst, although no significant features have yet been identified. 


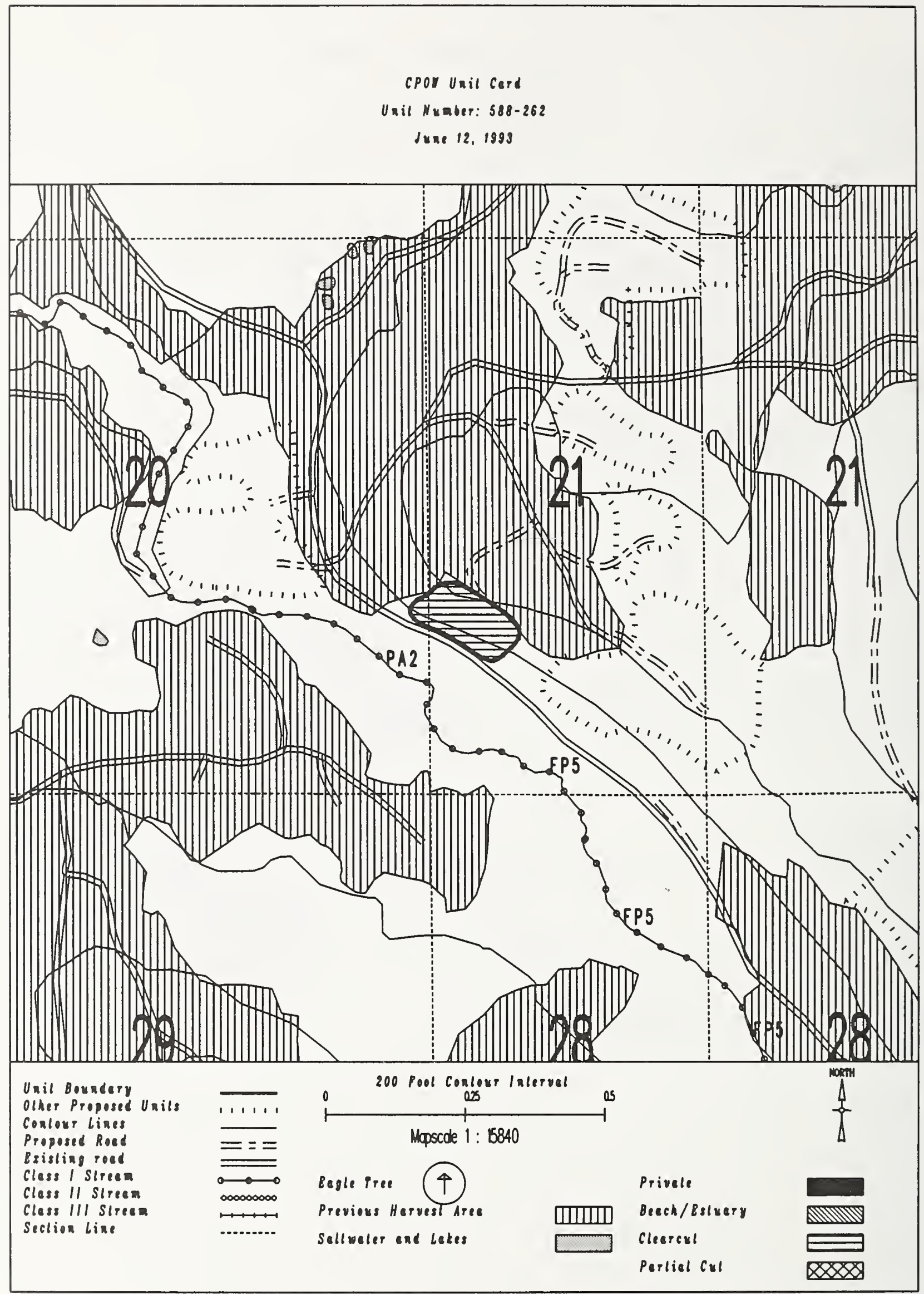


Unit 588-263

Planned acres 47

Estimated volume (mbf) 1338

Logging system Highlead

silvicultural system clearcut

Forest type Hemlock

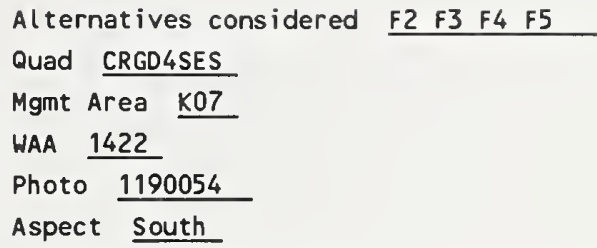

\section{PHYSICAL DESCRIPTION}

Volume class breakdown: VC4 9 acres VC5 29 acres VC6 5 acres VC7 $\quad 0$ acres

Elevation breakdown: $0-800 \mathrm{ft} . \underline{16}$ acres $800-1200 \mathrm{ft} . \underline{25}$ acres $1200-1500 \mathrm{ft} . \underline{0}$ acres over $1500 \mathrm{ft}$. 0 acres Mass movement index: Low 18 acres Medium 0 acres High 9 acres Very High 0 acres

\section{SOILS}

This unit has high mass movement index soils. Partial log suspension required over these areas.(BMP13.9)

This unit contains 15 acres of forested wetlands. Site specific BMPs will be designed for selected approved

logging system and road construction practices. (BMPs 12.5, 13.9, 13.15).

\section{TIMBER}

There are no timber mitigation measures anticipated for this unit.

\section{ENGINEERING}

High mass movement index soils. Road construction must minimize landslide potential (BMP14).

\section{FISH/WATERSHED}

There are no fishery mitigation measures anticipated for this unit.

\section{WILDLIFE}

Maintain diversity within unit by leaving 1-5 acre-sized islands of green trees at a rate of 1 acre of island for every 20 acres harvested. Leave islands must be compatible with logging system and safe working conditions.

\section{RECREATION / VISUALS}

The unit has a proposed VoO of MM within the viewshed of Staney Creek as viewed from $1 \mathrm{mile}$ from west coast of Prince of Wales.

\section{LANDS}

There are no lands mitigation measures anticipated for this unit.

\section{CULTURAL RESOURCES}

There are no cultural resource mitigation measures anticipated for this unit.

\section{GEOLOGY}

This unit is underlain with karst, although no significant features have yet been identified. 


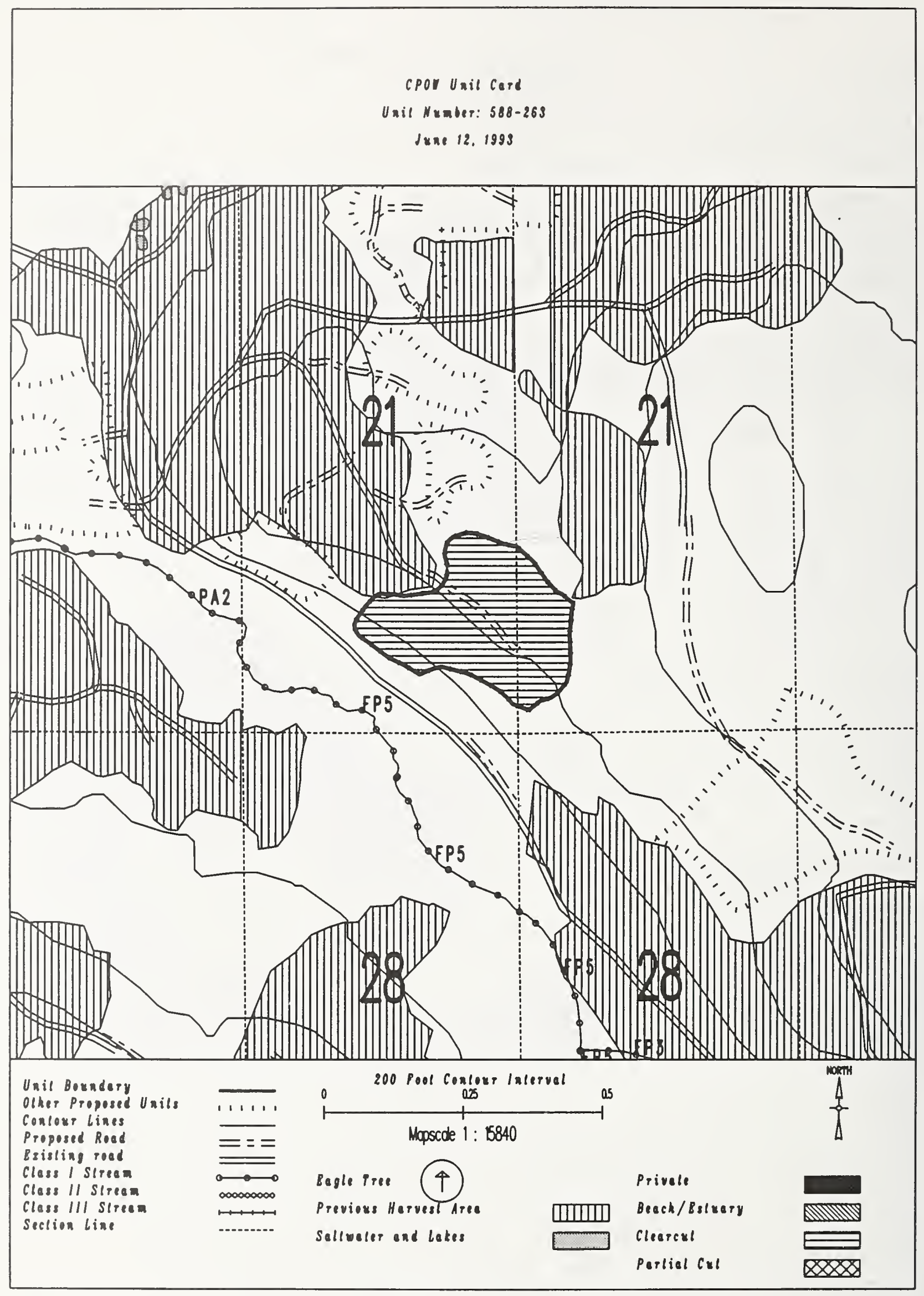


Unit $\quad 588-268$

Planned acres 42

Estimated volume (mbf) 1552

Logging system slackline

silvicultural system clearcut

Forest type Mixed conifer
Alternatives considered

Quad CRGD4SES

Mgmt Area $\mathrm{K07}$

WAA 1422

Photo 1190052

Aspect North

PHYSICAL DESCRIPTION

Volume class breakdown: VC4 $\quad$ O acres VC5 $\quad 16$ acres VC6 27 acres vC7 $\quad 0$ acres

Elevation breakdown: $0-800 \mathrm{ft}$. 0 acres $800-1200 \mathrm{ft} . \quad 0$ acres $1200-1500 \mathrm{ft}$. 11 acres over $1500 \mathrm{ft}$. 8 acres Mass movement index: Low 22 acres Medium $\underline{0}$ acres High 21 acres Very High $\underline{0}$ acres

SOILS

This unit has high mass movement index soils. Partial log suspension required over these areas. (BMP13.9)

This unit has > 40\% McGilvery soils. Partial suspension required (BMP13.9)

to ensure reforestation (BMP13.19).

This unit contains 14 acres of forested wetlands. Site specific BMPs will be designed for selected approved

logging system and road construction practices. (BMPs 12.5, 13.9, 13.15).

This unit contains 21 acres of slopes > $75 \%$.

TIMBER

There are no timber mitigation measures anticipated for this unit.

ENGINEERING

High mass movement index soils. Road construction must minimize landslide potential (BMP14).

Slopes greater than $75 \%$ may require full bench construction and endhaul of waste (BMP14.7).

FISH/WATERSHED

There are no fishery mitigation measures anticipated for this unit.

WILDLIFE

There are no wildlife mitigation measures anticipated for this unit.

RECREATION / VISUALS

This unit has a proposed Voo of MM and is not seen from any viewpoint identified by this project.

LANDS

There are no lands mitigation measures anticipated for this unit.

CULTURAL RESOURCES

There are no cultural resource mitigation measures anticipated for this unit.

GEOLOGY

There are no karst mitigation measures anticipated for this unit. 


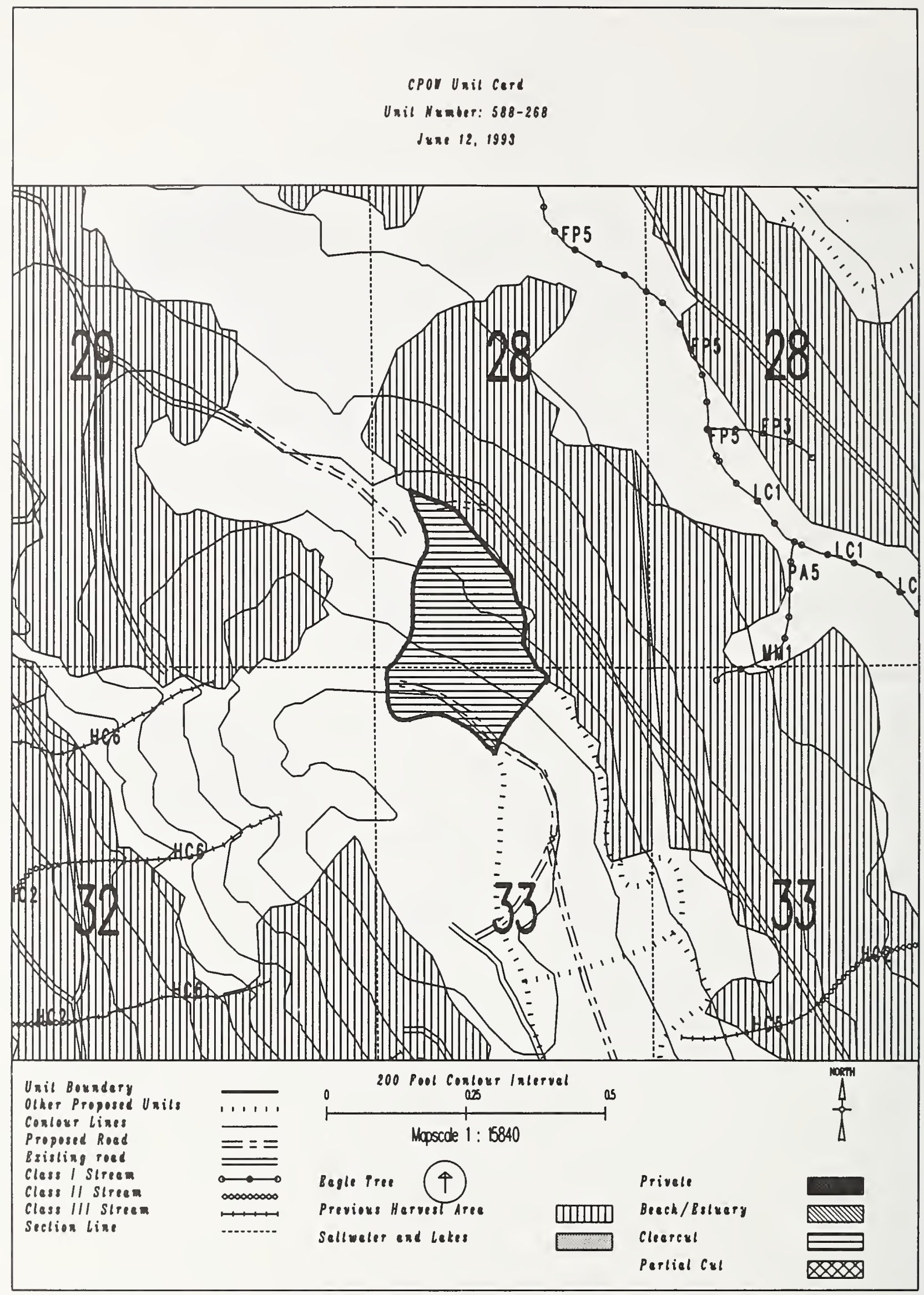


Unit 588-269

Planned acres 64

Estimated volume (mbf) 2247

logging system slackline

silvicultural system clearcut

Forest type Hemlock
Alternatives considered $\quad$ F2 $F 3$ F4 F5 F6

Quad CRGD4SES

Mgmt Area $\mathrm{KO7}$

WAA 1422

Photo 1190052

Aspect East

\section{PHYSICAL DESCRIPTION}

Volume class breakdown: VC4 $\quad 7$ acres VC5 $\quad 0$ acres vC6 55 acres vc7 0 acres

Elevation breakdown: $0-800 \mathrm{ft} . \underline{2}$ acres $800-1200 \mathrm{ft} . \underline{1}$ acres $1200-1500 \mathrm{ft} . \underline{3}$ acres over $1500 \mathrm{ft}$. 26 acres Mass movement index: Low 13 acres Medium 0 acres High 53 acres Very High 0 acres

\section{SOILS}

This unit has high mass movement index soils. Partial log suspension required over these areas.(BMP13.9)

This unit contains 48 acres of forested wetlands. Site specific BMPs will be designed for selected approved

logging system and road construction practices. (BMPs 12.5, 13.9, 13.15).

This unit contains 26 acres of slopes $>75 \%$.

\section{TIMBER}

There are no timber mitigation measures anticipated for this unit.

\section{ENGINEER ING}

High mass movement index soils. Road construction must minimize landslide potential (BMP14).

slopes greater than $75 \%$ may require full bench construction and endhaul of waste (BMP14.7).

\section{FISH/WATERSHED}

This unit contains streams which have recently been classified/channel typed but require field verification.

\section{WILDLIFE}

Maintain diversity within unit by leaving 1-5 acre-sized islands of green trees at a rate of 1 acre of island for every 20 acres harvested. Leave islands must be compatible with logging system and safe working conditions.

\section{RECREATION / VISUALS}

This unit has a proposed VQO of MM and is not seen from any viewpoint identified by this project.

\section{LANDS}

There are no lands mitigation measures anticipated for this unit.

\section{CULTURAL RESOURCES}

There are no cultural resource mitigation measures anticipated for this unit.

GEOLOGY

There are no karst mitigation measures anticipated for this unit. 


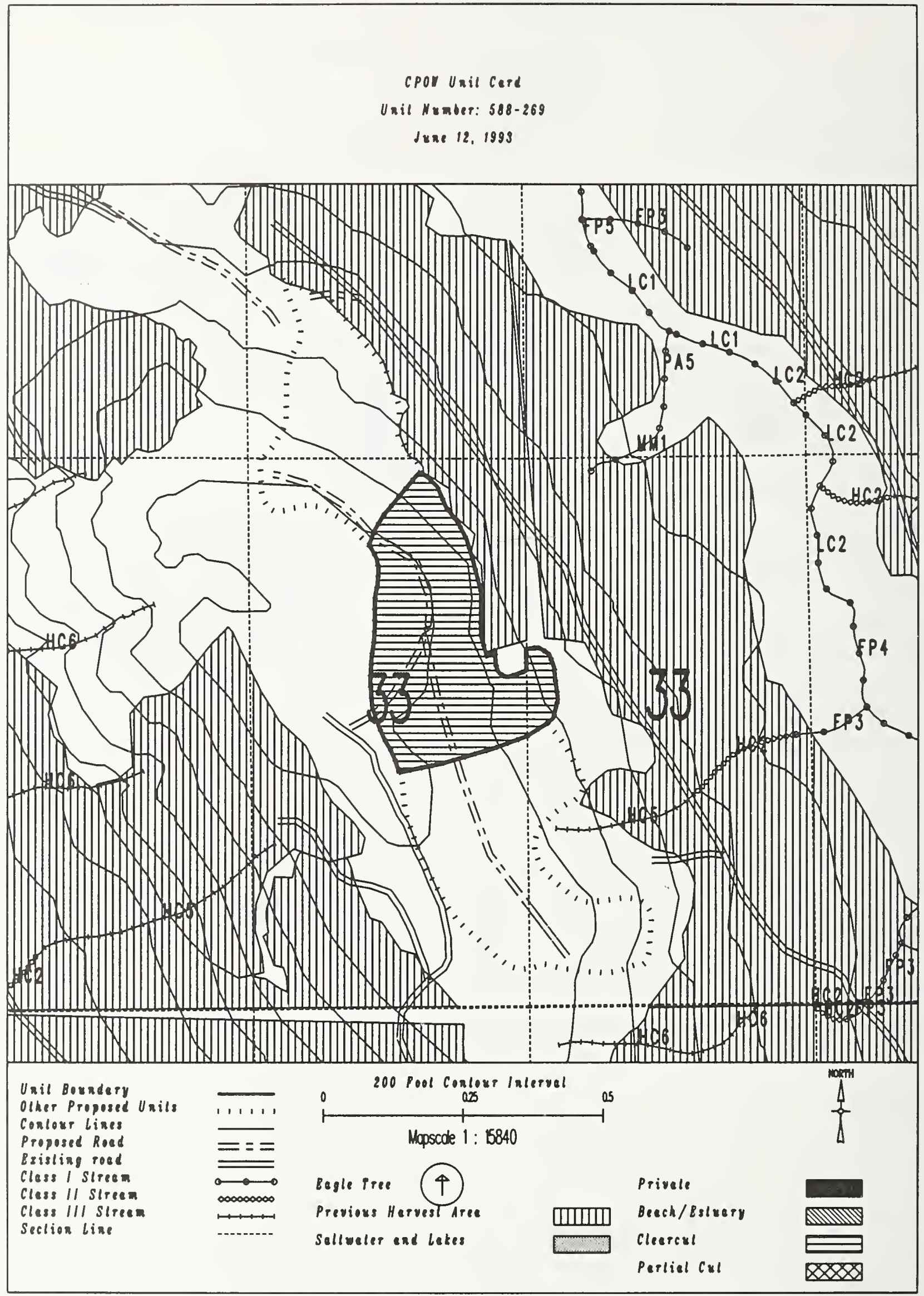


Unit $\quad 588-270$

Planned acres 66

Estimated volume (mbf) 2201

Logging system slackline

silvicultural system clearcut

Forest type Hemlock
Alternatives considered $\quad$ F2 $\quad$ F3 $\quad$ F4 $\quad$ F5 $\quad$ F6

Quad CRGD3SWS

Mgmt Area $\mathrm{KO7}$

WAA 1422

Photo 1190052

Aspect South

\section{PHYSICAL DESCRIPTION}

Volume class breakdown: VC4 0 acres VC5 30 acres VC6 32 acres VC7 $\quad 0$ acres

Elevation breakdown: $0-800 \mathrm{ft}$. 6 acres $800-1200 \mathrm{ft} . \underline{1}$ acres 1200-1500 ft. 6 acres over $1500 \mathrm{ft}$. 21 acres Mass movement index: Low 24 acres Medium $\_$acres High $\underline{44}$ acres Very High $\underline{0}$ acres

\section{SOILS}

This unit has high mass movement index soils. Partial log suspension required over these areas. (BMP13.9)

This unit contains 56 acres of forested wetlands. Site specific BMPs will be designed for selected approved

logging system and road construction practices. (BMPs 12.5, 13.9, 13.15).

This unit contains 13 acres of slopes > $75 \%$.

\section{TIMBER}

There are no timber mitigation measures anticipated for this unit.

\section{ENGINEER ING}

High mass movement index soils. Road construction must minimize landslide potential (BMP14).

Slopes greater than $75 \%$ may require full bench construction and endhaul of waste (BMP14.7).

\section{FISH/WATERSHED}

This unit contains streams which have recently been classified/channel typed but require field verification.

\section{WILDLIFE}

Maintain diversity with in unit by leaving 1-5 acre-sized islands of green trees at a rate of 1 acre of island for every 20 acres harvested. Leave islands must be compatible with logging system and safe working conditions.

RECREATION / VISUALS

This unit has a proposed VQO of MM and is not seen from any viewpoint identified by this project.

\section{LANDS}

There are no lands mitigation measures anticipated for this unit.

CULTURAL RESOURCES

There are no cultural resource mitigation measures anticipated for this unit. 


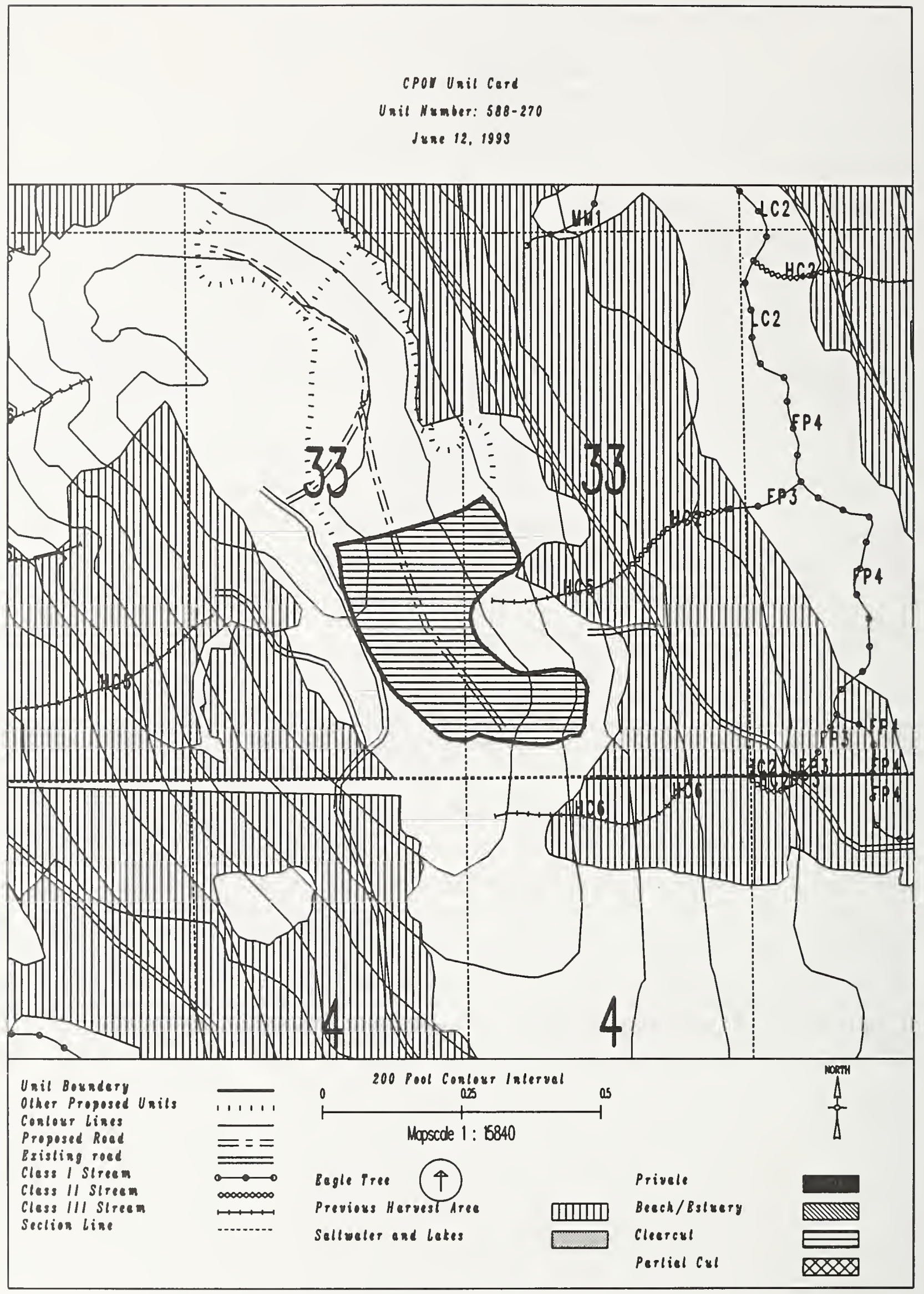


Unit 588-276

Planned acres 48

Estimated volume (mbf) 1610

Logging system Skyline

silvicultural system Clearcut

Forest type Hemlock
Alternatives considered \begin{tabular}{lllll} 
F2 & $F 3$ & F4 & F5 & F6 \\
\hline
\end{tabular}

Quad CRGD4SES

Mgmt Area $\mathrm{KO7}$

WAA 1422

Photo 1190123

Aspect West

\section{PHYSICAL DESCRIPTION}

Volume class breakdown: VC4 $\quad 0$ acres VC5 41 acres VC6 $\quad 7$ acres VC7 $\quad 0$ acres

Elevation breakdown: $0-800 \mathrm{ft} .11$ acres $800-1200 \mathrm{ft} .11$ acres $1200-1500 \mathrm{ft} .4$ acres over $1500 \mathrm{ft}$. 9 acres Mass movement index: Low 3 acres Medium 0 acres High $\underline{34}$ acres Very High 0

\section{SOILS}

This unit has high mass movement index soils. Partial log suspension required over these areas. (BMP13.9)

This unit contains 15 acres of slopes $>75 \%$.

\section{TIMBER}

There are no timber mitigation measures anticipated for this unit.

\section{ENG INEER ING}

High mass movement index soils. Road construction must minimize landslide potential (BMP14).

slopes greater than $75 \%$ may require full bench construction and endhaul of waste (BMP14.7).

\section{FISH/WATERSHED}

This unit contains a $\underline{A} 1$ class $\underline{3}$ stream. No specific buffer required, but full suspension, if yarding across.

\section{HILDLIFE}

There are no wildlife mitigation measures anticipated for this unit.

\section{RECREATION / VISUALS}

The unit has a proposed Voo of MM within the viewshed of Staney Creek

as viewed from 1 mile from west coast of Prince of Wales.

\section{LANDS}

There are no lands mitigation measures anticipated for this unit.

CULTURAL RESOURCES

There are no cultural resource mitigation measures anticipated for this unit. 


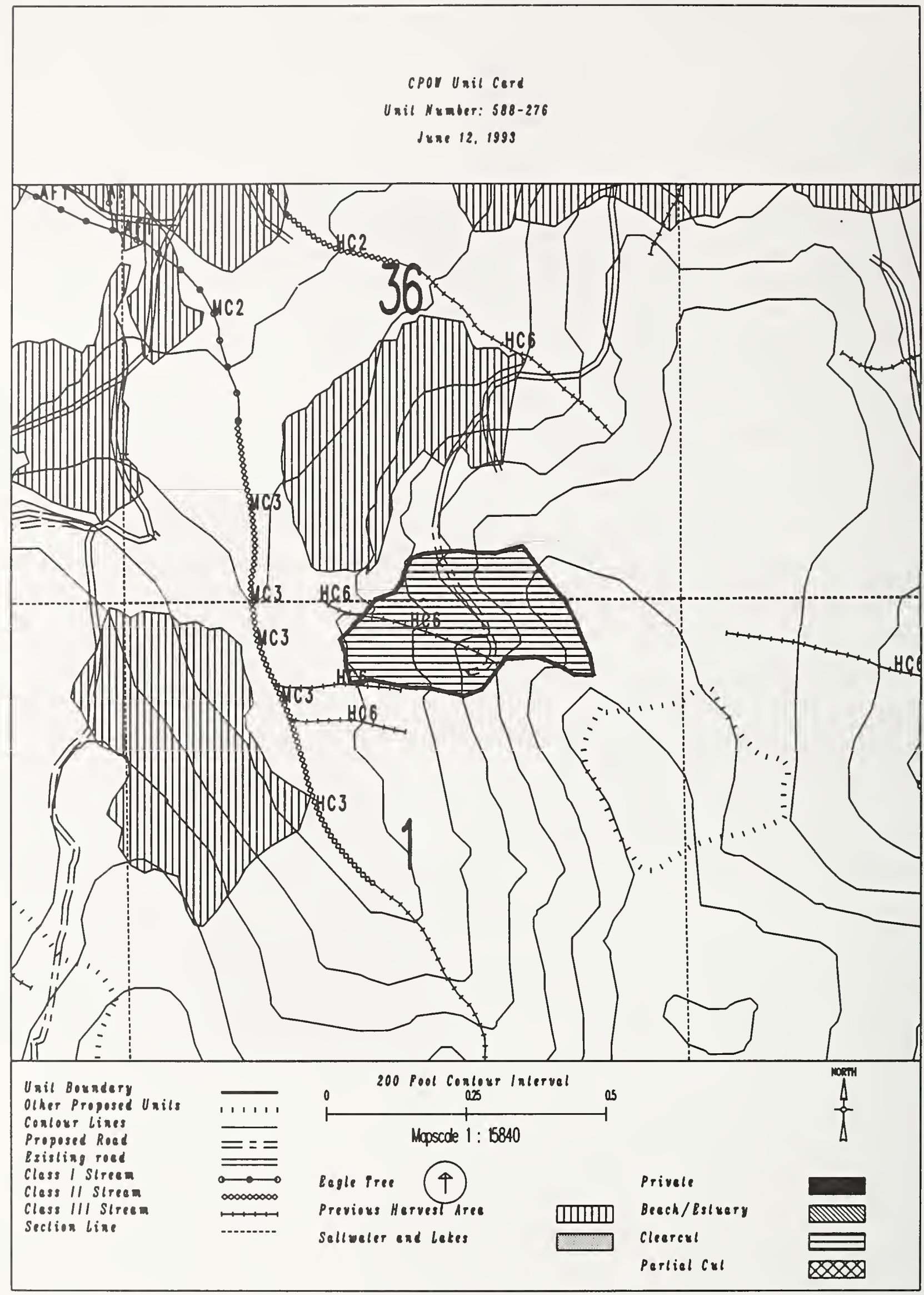


Unit $\underline{588-277}$

Planned acres 44

Est imated volume (mbf) 1530

Logging system Helicopter

silvicultural system Clearcut

Forest type Mixed conifer
Al ternatives considered

Quad CRGC4NEN

Mgmt Area $\mathrm{KO7}$

WAA 1422

Photo 1290024

Aspect East

\section{PHYSICAL DESCRIPTION}

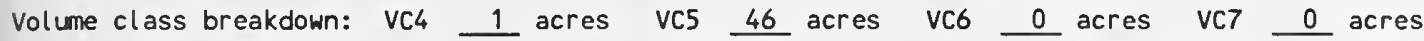

Elevation breakdown: $0-800 \mathrm{ft} . \quad 0$ acres $800-1200 \mathrm{ft} . \underline{3}$ acres $1200-1500 \mathrm{ft} . \underline{5}$ acres over $1500 \mathrm{ft} . \underline{21}$ acres

Mass movement index: Low $\underline{0}$ acres Medium 0 acres High 26 acres Very High 0 acres

SOILS

This unit has high mass movement index soils. Partial log suspension required over these areas. (BMP13.9)

This unit contains 40 acres of slopes $>75 \%$.

\section{TIMBER}

Implement $50 \mathrm{ft}$ selective harvest buffers on Class III streams.

\section{ENG I NEER I NG}

There are no engineering mitigation measures anticipated for this unit.

\section{FISH/WATERSHED}

This unit contains a $\underline{A} 4$ class $\underline{3}$ stream. No specific buffer required, but full suspension, if yarding across.

This unit contains streams which have recently been classified/channel typed but require field verification.

\section{WI LDLIFE}

There are no wildlife mitigation measures anticipated for this unit.

RECREATION / VISUALS

This unit has a proposed Voo of MM and is not seen from any viewpoint identified by this project.

\section{LANDS}

There are no lands mitigation measures anticipated for this unit.

CULTURAL RESOURCES

There are no cultural resource mitigation measures anticipated for this unit.

GEOLOGY

There are no karst mitigation measures anticipated for this unit. 
CPOU Uail Cerd

Unil Nember: 588-277

Juse 12, 1993

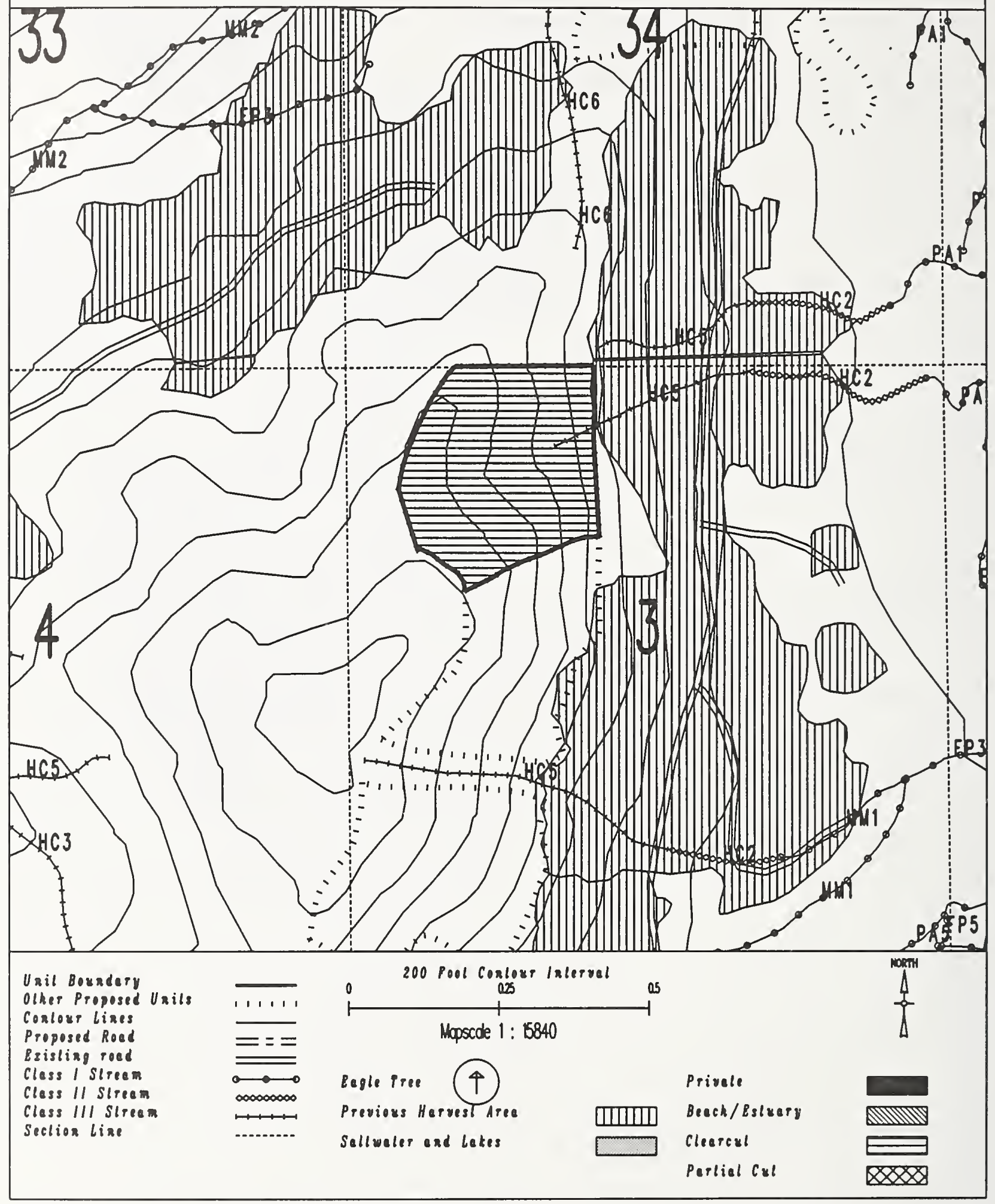


Unit $\underline{588-278}$

Planned acres 35

Estimated volume (mbf) 1213

Logging system Helicopter

silvicultural system clearcut

Forest type Hemlock
Alternatives considered F2 F4 F5 F6

Quad CRGC4NEN

Mgmt Area $\mathrm{KOT}$

WAA 1422

Photo 1290024

Aspect East

PHYSICAL DESCRIPTION

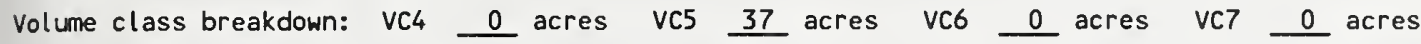

Elevation breakdown: $0-800 \mathrm{ft} . \ldots$ acres $800-1200 \mathrm{ft} . \underline{1}$ acres 1200-1500 ft. 3 acres over $1500 \mathrm{ft}$. 18 acres Mass movement index: Low $\_$acres Medium $\_$acres High $\underline{24}$ acres Very High 0

SOILS

This unit has high mass movement index soils. Partial log suspension required over these areas.(BMP13.9)

This unit has a significant possibility to have areas reclassified as MMI $=4$.

This unit contains 25 acres of slopes $>75 \%$.

This unit will be monitored for effects of harvest/roading on steep slopes.

\section{TIMBER}

Implement $50 \mathrm{ft}$ selective harvest buffers on Class III streams.

ENGINEERING

There are no engineering mitigation measures anticipated for this unit.

FISH/WATERSHED

This unit contains streams which have recently been classified/channel typed but require field verification.

\section{WI LDL I FE}

There are no wildlife mitigation measures anticipated for this unit.

RECREATION / VISUALS

This unit has a proposed VQO of MM and is not seen from any viewpoint identified by this project.

\section{LANDS}

There are no lands mitigation measures anticipated for this unit.

CULTURAL RESOURCES

There are no cultural resource mitigation measures anticipated for this unit. 


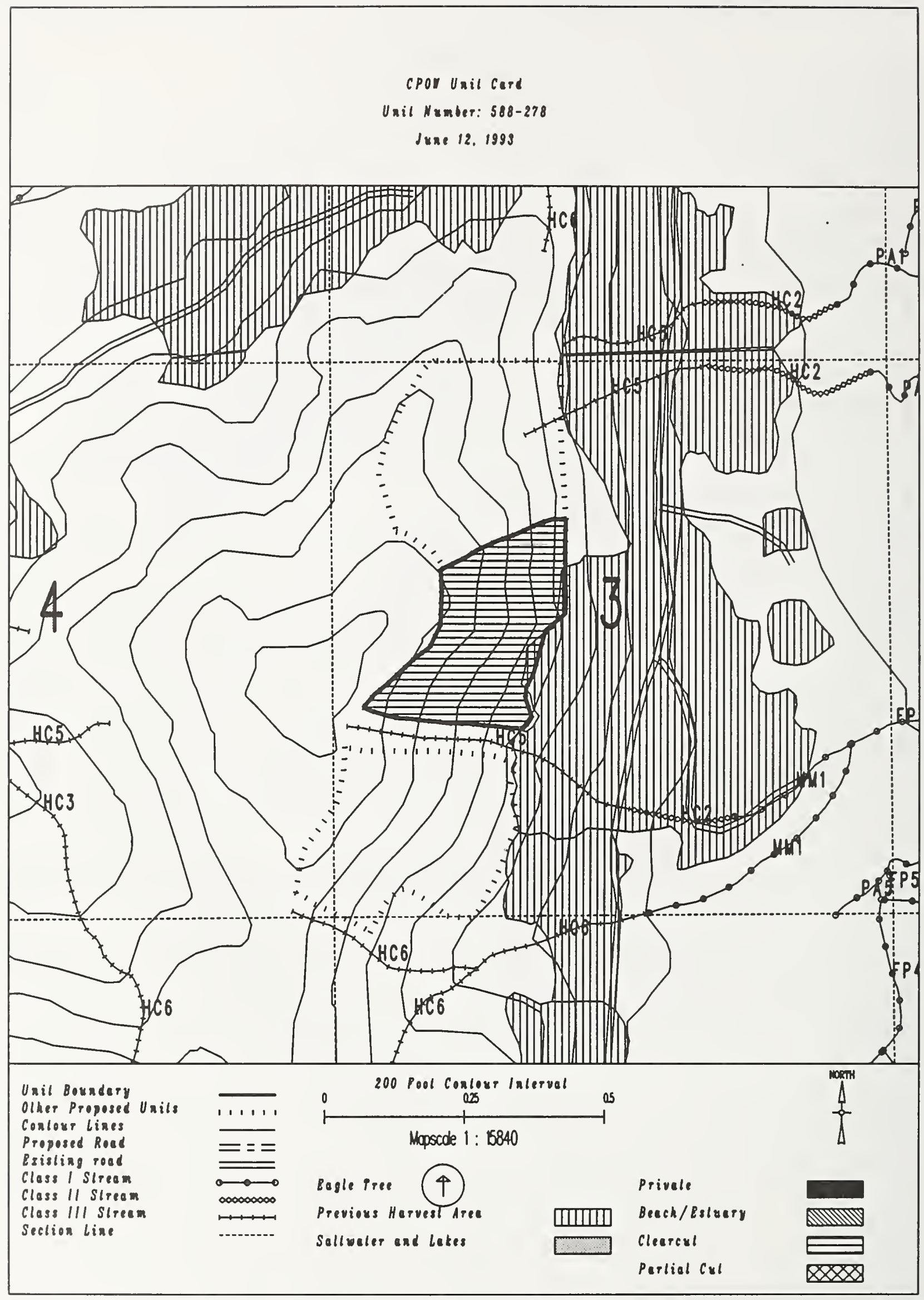


Unit

Planned acres 76

Estimated volume (mbf) 1713

Logging system Helicopter

silvicultural system Shelterwood

Forest type Mixed conifer
Alternatives considered F2 F4 F5 F6

ouad CRGC4NEN

Mgmt Area $\mathrm{KO7}$

WAA 1422

Photo 1290022

Aspect East

PHYSICAL DESCRIPTION

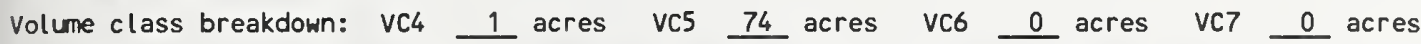

Elevation breakdown: $0-800 \mathrm{ft} . \ldots 0$ acres $800-1200 \mathrm{ft} . \underline{1}$ acres 1200-1500 ft. 2 acres over $1500 \mathrm{ft}$. 25 acres Mass movement index: Low $\_$acres Medium 0 acres High 52 acres Very High 0

SOILS

This unit has high mass movement index soils. Partial log suspension required over these areas. (BMP13.9)

This unit contains 47 acres of slopes $>75 \%$.

TIMBER

Shelterwood harvest. Cedar will not be harvested.

\section{ENGINEERING}

There are no engineering mitigation measures anticipated for this unit.

\section{FISH/WATERSHED}

This unit contains streams which have recently been classified/channel typed but require field verification.

\section{WILDLIFE}

Maintain diversity within unit by leaving 1-5 acre-sized islands of green trees at a rate of 1 acre of island for every 20 acres harvested. Leave islands must be compatible with logging system and safe working conditions.

RECREATION / VISUALS

This unit has a proposed VQO of MM and is not seen from any viewpoint identified by this project.

\section{LANDS}

There are no lands mitigation measures anticipated for this unit.

CULTURAL RESOURCES

There are no cultural resource mitigation measures anticipated for this unit.

There are no karst mitigation measures anticipated for this unit. 


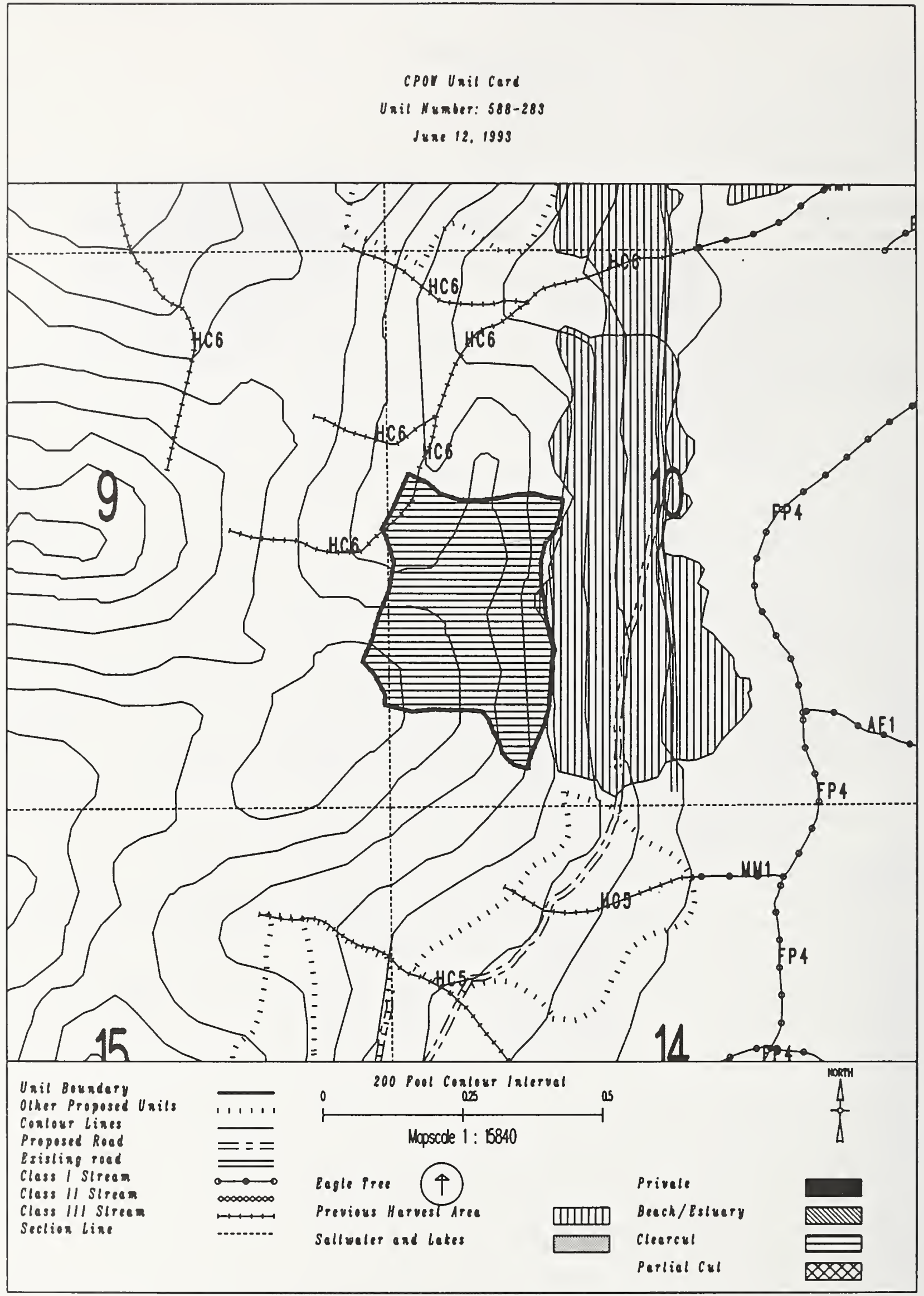


Unit $588-285$

Planned acres 49

Estimated volume (mbf) 1410

Logging system slackline

silvicultural system clearcut

Forest type Hemlock

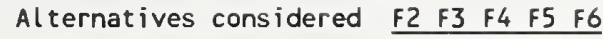

Quad CRGC4NEN

Mgmt Area $\mathrm{KO7}$

WAA 1422

Photo 1290022

Aspect South

PHYSICAL DESCR IPTION

Volume class breakdown: VC4 18 acres VC5 31 acres VC6 $\quad 0$ acres VC7 $\quad 0$ acres

Elevation breakdown: $0-800 \mathrm{ft} . \underline{27}$ acres $800-1200 \mathrm{ft} . \underline{12}$ acres 1200-1500 ft. 0 acres over $1500 \mathrm{ft}$. 0 acres Mass movement index: Low 1 acres Medium 38 acres High 9 acres Very High 0

SOILS

This unit has high mass movement index soils. Partial log suspension required over these areas. (BMP13.9)

This unit contains 24 acres of forested wetlands. Site specific BMPs will be designed for selected approved

logging system and road construction practices. (BMPs 12.5, 13.9, 13.15).

TIMBER

There are no timber mitigation measures anticipated for this unit.

ENGINEERING

High mass movement index soils. Road construction must minimize landslide potential (BMP14).

\section{FISH/WATERSHED}

This unit contains a $\underline{A} 4$ class $\underline{3}$ stream. No specific buffer required, but full suspension, if yarding across. This unit contains streams which have recently been classified/channel typed but require field verification.

\section{HILDLIFE}

Maintain diversity within unit by leaving 1-5 acre-sized islands of green trees at a rate of 1 acre of island for every 20 acres harvested. Leave islands must be compatible with logging system and safe working conditions.

RECREATION / VISUALS

This unit has a proposed VQO of MM and is not seen from any viewpoint identified by this project.

\section{LANDS}

There are no lands mitigation measures anticipated for this unit.

CULTURAL RESOURCES

There are no cultural resource mitigation measures anticipated for this unit.

GEOLOGY

There are no karst mitigation measures anticipated for this unit. 


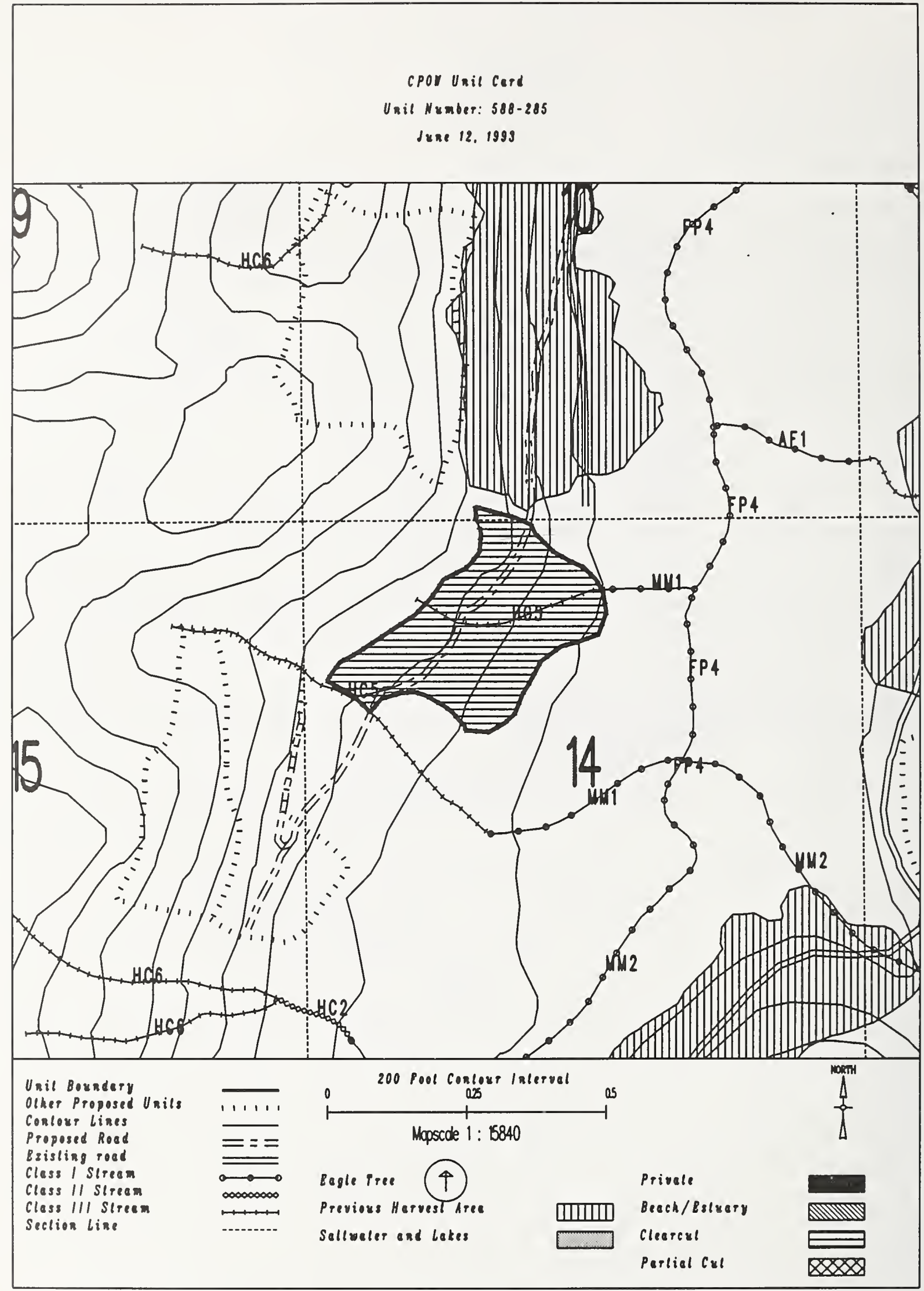


Unit $588-286$

Planned acres 35

Estimated volume (mbf)

Logging system skyline

silvicultural system clearcut

Forest type Hemlock
Alternatives considered

Quad CRGC4NEN

Mgmt Area $\mathrm{KO7}$

WAA 1422

Photo 1290021

Aspect East

PHYSICAL DESCRIPTION

Volume class breakdown: VC4 22 acres VC5 13 acres vC6 $\quad 0$ acres vc7 $\quad 0$ acres

Elevation breakdown: $0-800 \mathrm{ft} . \ldots 1$ acres $800-1200 \mathrm{ft} . \underline{5}$ acres 1200-1500 ft. 6 acres over $1500 \mathrm{ft}$. 0 acres Mass movement index: Low $\_$acres Medium 9 acres High 22 acres Very High 0

SOILS

This unit has high mass movement index soils. Partial log suspension required over these areas. (BMP13.9)

This unit contains 9 acres of forested wetlands. Site specific BMPs will be designed for selected approved

logging system and road construction practices. (BMPs 12.5, 13.9, 13.15).

This unit contains 5 acres of slopes $>75 \%$.

TIMBER

There are no timber mitigation measures anticipated for this unit.

ENGINEERING

Very difficult road construction due to unstable, slope $>75 \%$ or extended steep grades.

May need to revise logging system to helicopter.

High mass movement index soils. Road construction must minimize landslide potential (BMP14).

FISH/HATERSHED

There are no fishery mitigation measures anticipated for this unit.

WILDLIFE

There are no wildlife mitigation measures anticipated for this unit.

RECREATION / VISUALS

This unit has a proposed VQO of MM and is not seen from any viewpoint identified by this project.

LANDS

There are no lands mitigation measures anticipated for this unit.

CULTURAL RESOURCES

There are no cultural resource mitigation measures anticipated for this unit.

GEOLOGY

There are no karst mitigation measures anticipated for this unit. 


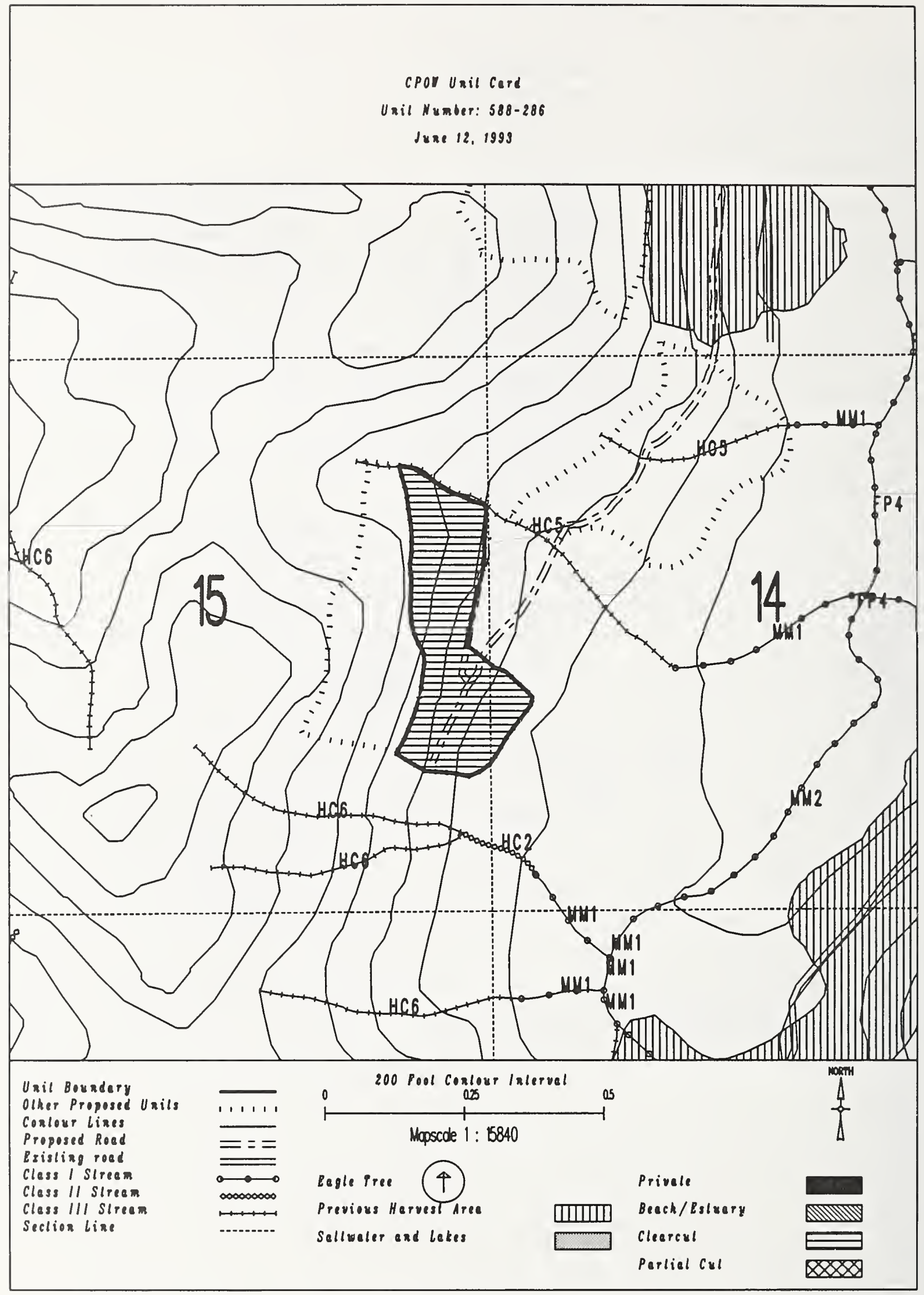


Unit 588-287

Planned acres 39

Estimated volume (mbf) 1137

Logging system Helicopter

silvicultural system Clearcut

Forest type Mixed conifer
Alternatives considered

Quad CRGC4NEN

Mgmt Area $\mathrm{KOT}$

WAA 1422

Photo 1290021

Aspect East

PHYSICAL DESCRIPTION

Volume class breakdown: VC4 16 acres VC5 $\quad 24$ acres VC6 $\quad 0$ acres VC7 $\quad 0$ acres

Elevation breakdown: $0-800 \mathrm{ft} . \quad 0$ acres $800-1200 \mathrm{ft} . \underline{0}$ acres 1200-1500 ft. 0 acres over $1500 \mathrm{ft}$. 18 acres Mass movement index: Low 1 acres Medium $\underline{0}$ acres High 25 acres Very High 0

SOILS

This unit has high mass movement index soils. Partial log suspension required over these areas.(BMP13.9)

This unit contains 26 acres of slopes $>75 \%$.

TIMBER

There are no timber mitigation measures anticipated for this unit.

ENGINEERING

There are no engineering mitigation measures anticipated for this unit.

FISH/WATERSHED

This unit contains streams which have recently been classified/channel typed but require field verification.

WILDLIFE

There are no wildlife mitigation measures anticipated for this unit.

RECREATION / VISUALS

This unit has a proposed voo of MM and is not seen from any viewpoint identified by this project.

LANDS

There are no lands mitigation measures anticipated for this unit.

CULTURAL RESOURCES

There are no cultural resource mitigation measures anticipated for this unit.

GEOLOGY

There are no karst mitigation measures anticipated for this unit. 


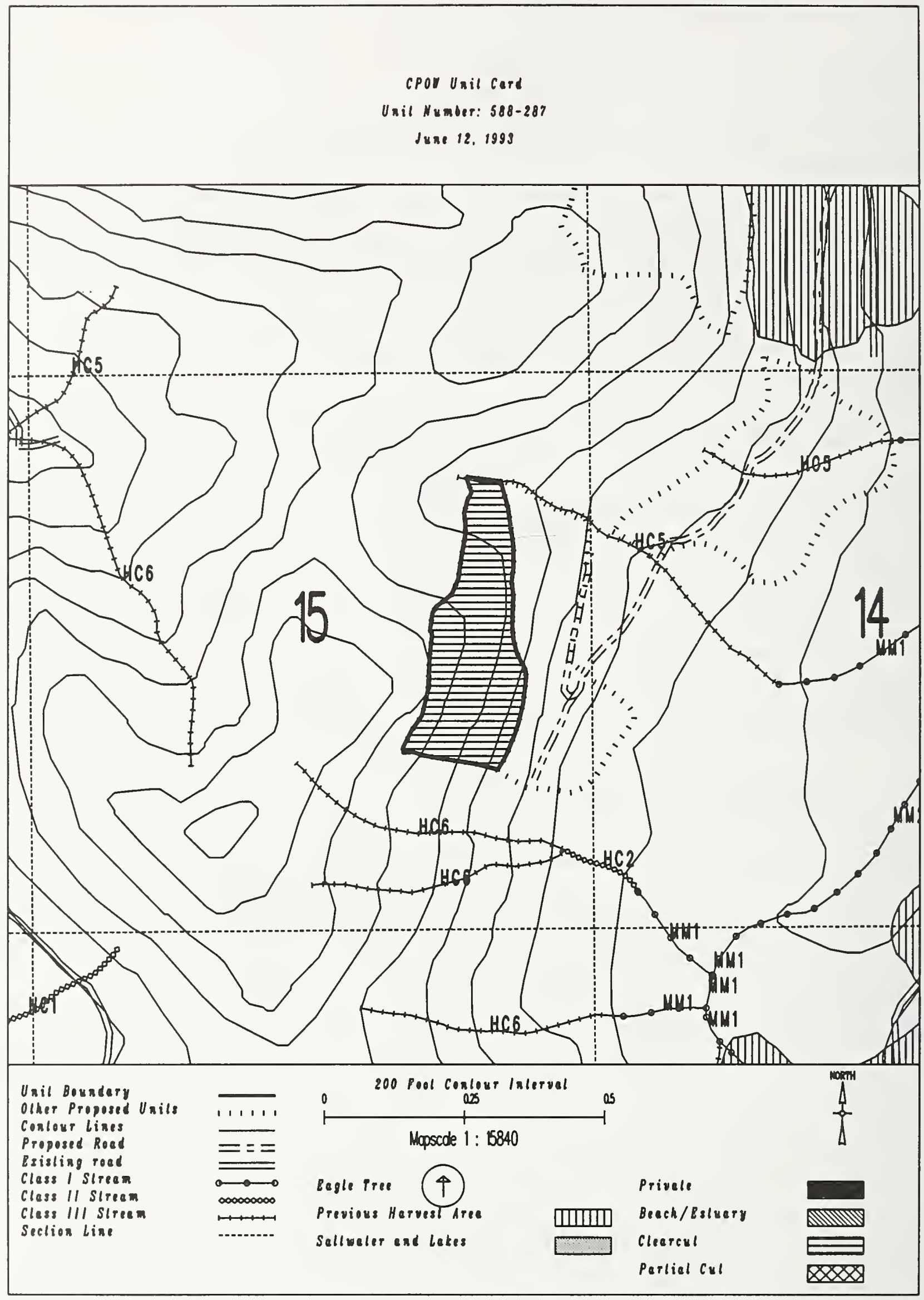


Unit 588-295

Planned acres 24

Estimated volume (mbf) 839

Logging system Helicopter

silvicultural system clearcut

Forest type Mixed conifer
Alternatives considered $\mathrm{F2}$

Quad CRGC4NEN

Mgmt Area $\mathrm{KOT}$

WAA 1422

Photo 1290020

Aspect North

PHYSICAL DESCRIPTION

Volume class breakdown: VC4 2 2 acres VC5 $\quad 8$ acres vC6 14 acres vC7 $\quad 0$ acres

Elevation breakdown: $0-800 \mathrm{ft} . \ldots 1$ acres $800-1200 \mathrm{ft} . \quad 6$ acres $1200-1500 \mathrm{ft} . \underline{3}$ acres over $1500 \mathrm{ft}$. 0 acres Mass movement index: Low 0 acres Medium 0 acres High 14 acres Very High 0

SOILS

This unit has high mass movement index soils. Partial log suspension required over these areas.(BMP13.9)

This unit has a significant possibility to have areas reclassified as MMI $=4$.

This unit contains 17 acres of slopes > $75 \%$.

TIMBER

There are no timber mitigation measures anticipated for this unit.

ENGINEERING

There are no engineering mitigation measures anticipated for this unit.

FISH/WATERSHED

This unit contains streams which have recently been classified/channel typed but require field verification.

WILDLIFE

There are no wildlife mitigation measures anticipated for this unit.

RECREATION / VISUALS

This unit has a proposed VQO of MM and is not seen from any viewpoint identified by this project.

LANDS

There are no lands mitigation measures anticipated for this unit.

CULTURAL RESOURCES

There are no cultural resource mitigation measures anticipated for this unit.

There are no karst mitigation measures anticipated for this unit. 


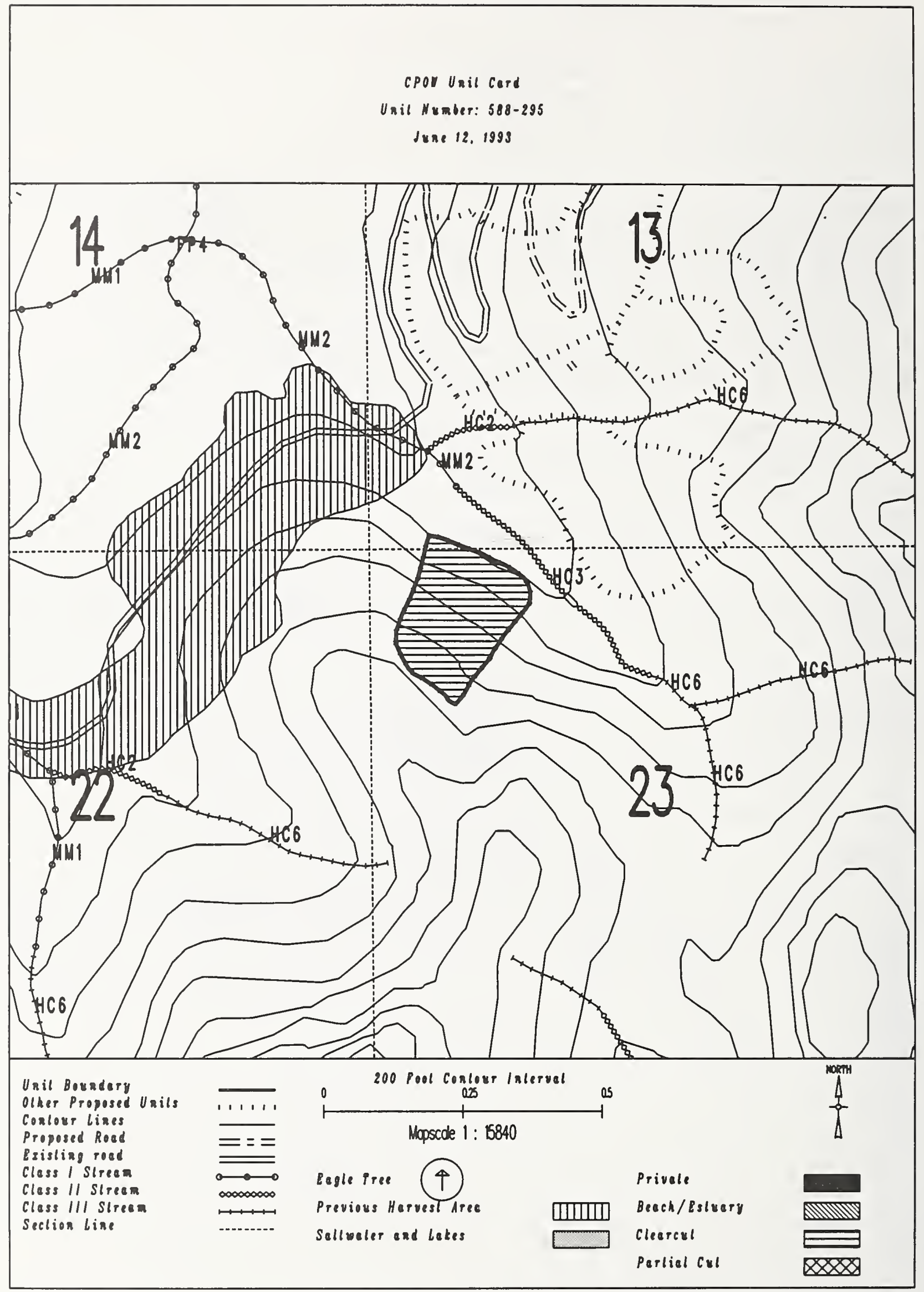


UNIT PLAN/LAYOUT/SALE ADMINISTRATION CARD FOR CPOW FEIS

Unit $\quad 588-300$

Planned acres 48

Estimated volume (mbf) 1969

Logging system Helicopter

silvicultural system Clearcut

Forest type Hemlock
Alternatives considered

Quad CRGC4NEN

Mgmt Area $\mathrm{KO7}$

WAA 1422

Photo 1290020

Aspect West

PHYSICAL DESCRIPIION

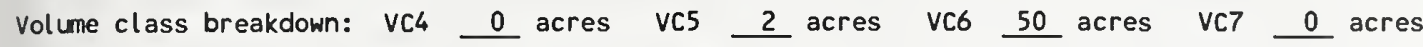

Elevation breakdown: $0-800 \mathrm{ft} .21$ acres $800-1200 \mathrm{ft} .11$ acres $1200-1500 \mathrm{ft} .4$ acres over $1500 \mathrm{ft}$. 0 acres Mass movement index: Low 0 acres Medium 10 acres High 32 acres Very High 0 acres

SOILS

This unit has high mass movement index soils. Partial log suspension required over these areas. (BMP13.9)

This unit contains 10 acres of forested wetlands. Site specific BMPs will be designed for selected approved

logging system and road construction practices. (BMPs 12.5, 13.9, 13.15).

This unit contains 18 acres of slopes > $75 \%$.

TIMBER

Potential regeneration problem. May need to consider other silvicultural prescriptions (or hand plant) to meet BMP13.19.

ENGINEERING

There are no engineering mitigation measures anticipated for this unit.

FISH/WATERSHED

This unit contains streams which have recently been classified/channel typed but require field verification.

WILDLIFE

There are no wildlife mitigation measures anticipated for this unit.

RECREATION / VISUALS

This unit has a proposed VQO of MM and is not seen from any viewpoint identified by this project.

LANDS

There are no lands mitigation measures anticipated for this unit.

CULTURAL RESOURCES

There are no cultural resource mitigation measures anticipated for this unit.

GEOLOGY

There are no karst mitigation measures anticipated for this unit. 


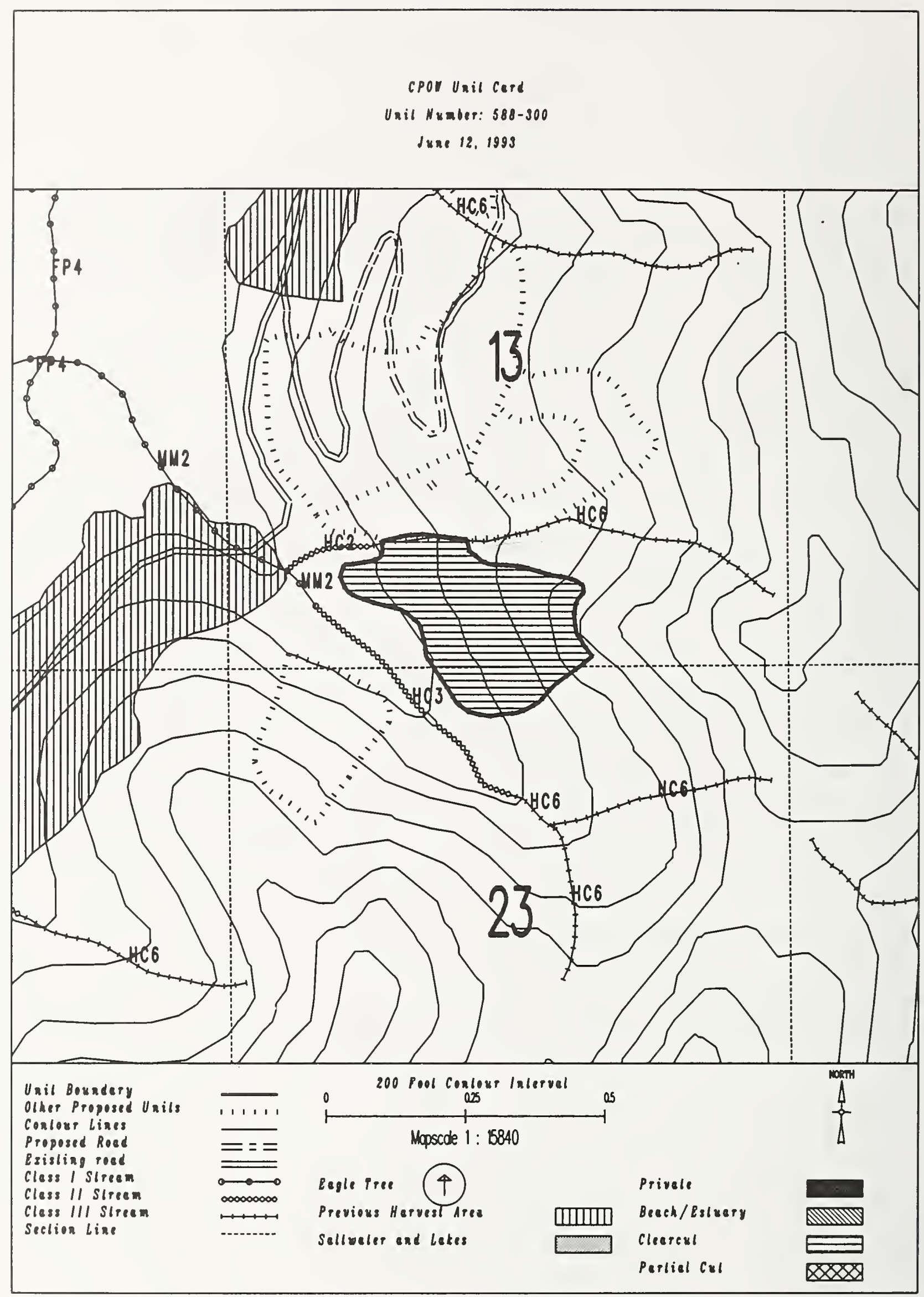


Unit 588-301

Planned acres 37

Est imated volume (mbf) 1172

Logging system Helicopter

silvicultural system Clearcut

Forest type Hemlock
Alternatives considered

Quad CRGC4NEN

Mgmt Area $\mathrm{KO7}$

WAA 1422

Photo 1290021

Aspect West

PHYSICAL DESCRIPTION

Volume class breakdown: VC4 15 acres VC5 $\quad 6$ acres VC6 17 acres VC7 $\quad 0$ acres

Elevation breakdown: $0-800 \mathrm{ft} . \quad 5$ acres $800-1200 \mathrm{ft} .11$ acres $1200-1500 \mathrm{ft} . \underline{3}$ acres over $1500 \mathrm{ft}$. 0 acres Mass movement index: Low 4 acres Medium 3 acres High 17 acres Very High 0

\section{SOILS}

This unit has high mass movement index soils. Partial log suspension required over these areas. (BMP13.9)

This unit has > 40\% MCGilvery soils. Partial suspension required (BMP13.9)

to ensure reforestation (BMP13.19).

This unit contains $\underline{7}$ acres of forested wetlands. Site specific BMPs will be designed for selected approved logging system and road construction practices. (BMPs 12.5, 13.9, 13.15).

This unit contains 25 acres of slopes $>75 \%$.

\section{TIMBER}

Potential regeneration problem. May need to consider other silvicultural prescriptions (or hand plant) to meet BMP13.19.

\section{ENGINEERING}

There are no engineering mitigation measures anticipated for this unit.

\section{FISH/WATERSHED}

This unit contains streams which have recently been classified/channel typed but require field verification.

\section{WILDLIFE}

Maintain diversity within unit by leaving 1-5 acre-sized islands of green trees at a rate of 1 acre of island for every 20 acres harvested. Leave islands must be compatible with logging system and safe working conditions.

\section{RECREATION / VISUALS}

This unit has a proposed Voo of MM and is not seen from any viewpoint identified by this project.

\section{LANDS}

There are no lands mitigation measures anticipated for this unit.

\section{CULTURAL RESOURCES}

There are no cultural resource mitigation measures anticipated for this unit.

There are no karst mitigation measures anticipated for this unit. 


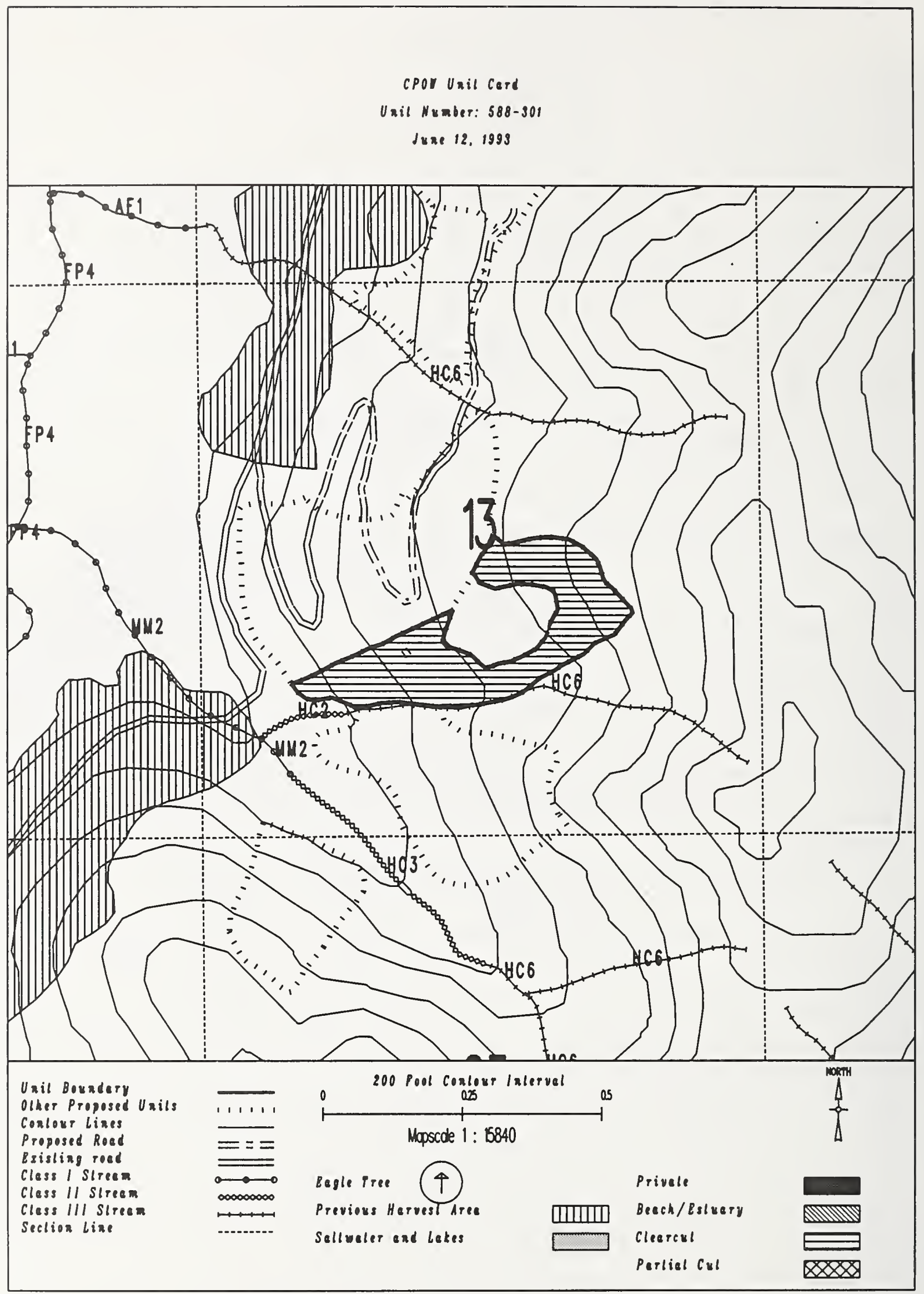




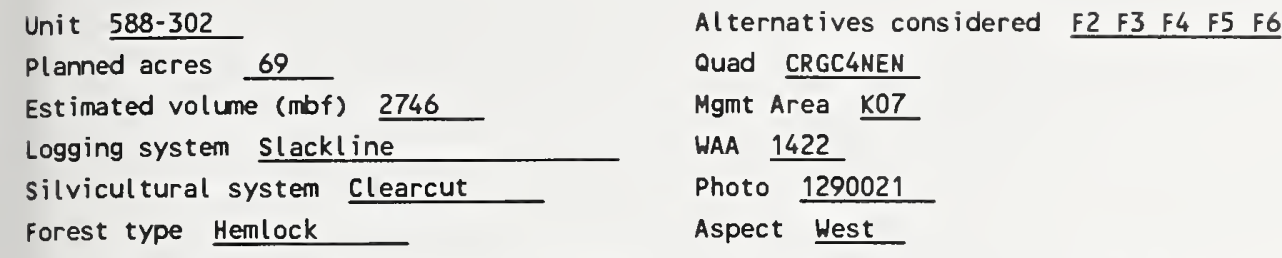




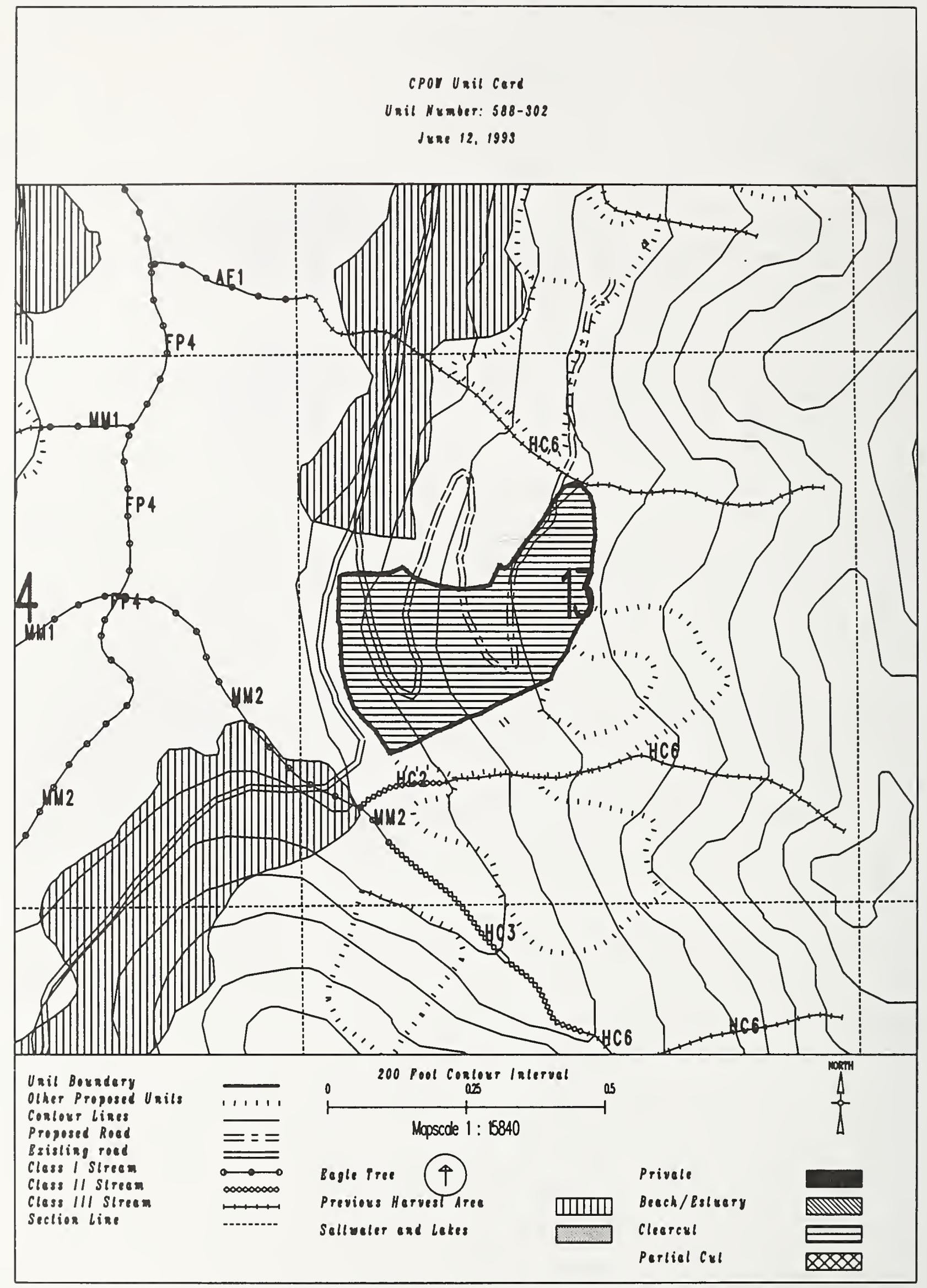


Unit $\quad 588-304$

Planned acres 25

Estimated volume (mbf) 887

Logging system slackline

silvicultural system clearcut

Forest type Hemlock
Alternatives considered F2 $F 3$ F4 $\quad$ F5 $\quad$ F6

Quad CRGC4NEN

Mgmt Area $\mathrm{KO7}$

HAA 1422

Photo 1290022

Aspect Hest

PHYSICAL DESCRIPTION

Volume class breakdown: VC4 4 acres VC5 $\quad 0$ acres VC6 21 acres vc7 $\quad 0$ acres

Elevation breakdown: $0-800 \mathrm{ft} . \underline{7}$ acres $800-1200 \mathrm{ft} . \underline{13}$ acres $1200-1500 \mathrm{ft}$. 0 acres over $1500 \mathrm{ft}$. 0 acres Mass movement index: Low 0 acres Medium 0 acres High 17 acres Very High 0

SOILS

This unit has high mass movement index soils. Partial log suspension required over these areas. (BMP13.9)

This unit contains 14 acres of slopes $>75 \%$.

\section{TIMBER}

There are no timber mitigation measures anticipated for this unit.

\section{ENGINEER ING}

High mass movement index soils. Road construction must minimize landslide potential (BMP14).

Slopes greater than $75 \%$ may require full bench construction and endhaul of waste (BMP 14.7).

\section{FISH/WATERSHED}

This unit contains streams which have recently been classified/channel typed but require field verification.

WILDLIFE

Maintain diversity within unit by leaving 1-5 acre-sized islands of green trees at a rate of 1 acre of island for every 20 acres harvested. Leave islands must be compatible with logging system and safe working conditions.

RECREATION / VISUALS

This unit has a proposed VQO of MM and is not seen from any viewpoint identified by this project.

LANDS

There are no lands mitigation measures anticipated for this unit.

CULTURAL RESOURCES

There are no cultural resource mitigation measures anticipated for this unit.

GEOLOGY

There are no karst mitigation measures anticipated for this unit. 


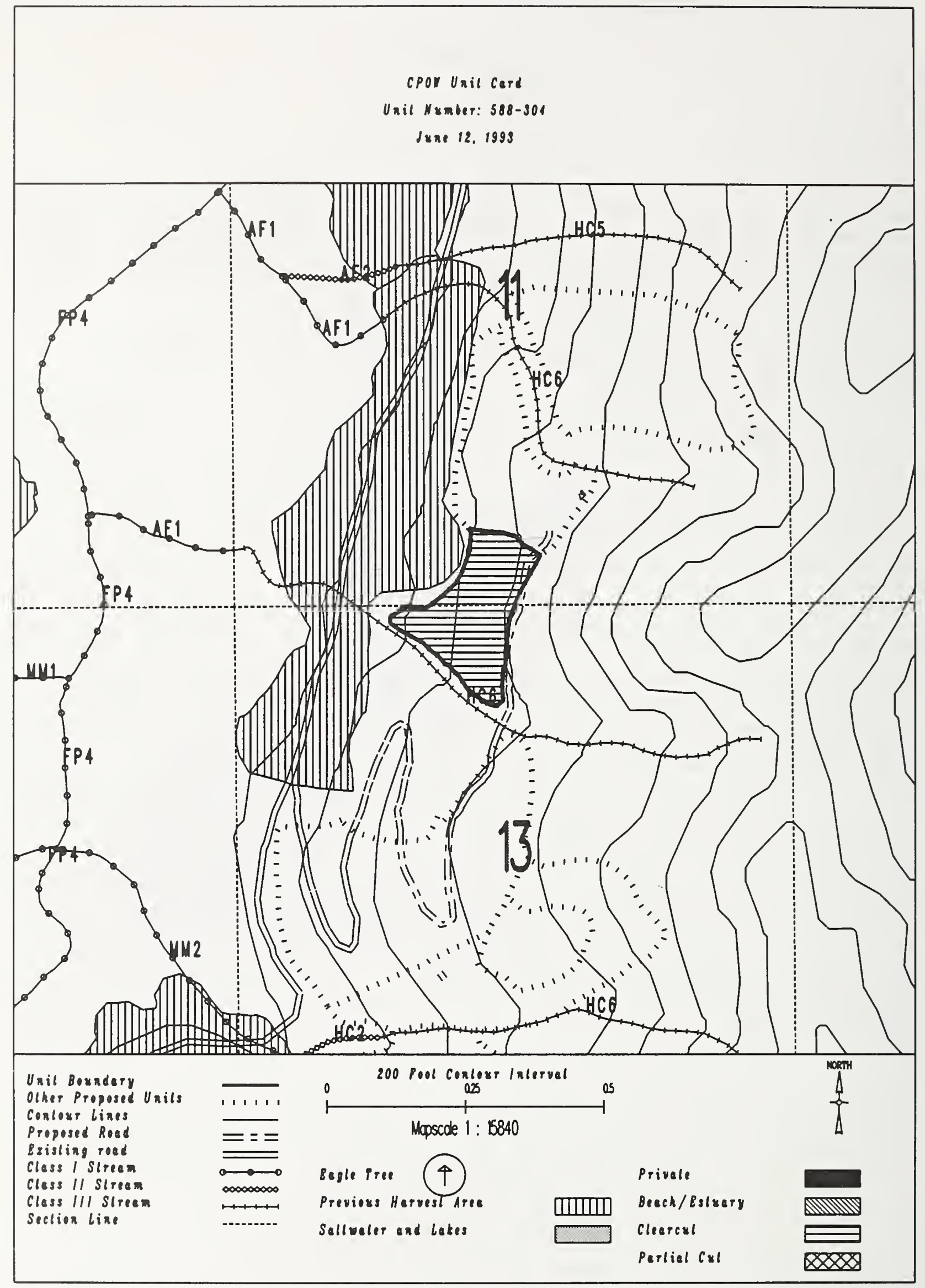


Unit 588-305

Planned acres 33

Est imated volume (mbf) 1408

Logging system Helicopter

silvicultural system clearcut

Forest type Hemlock
Alternatives considered $\mathrm{F2}$

Quad CRGC4NEN

Mgmt Area $\mathrm{KOT}$

WAA 1422

Photo 1290022

Aspect North

\section{PHYSICAL DESCRIPTION}

Volume class breakdown: VC4 $\quad 0$ acres VC5 10 acres VC6 3 acres VC7 19 acres

Elevation breakdown: $0-800 \mathrm{ft} . \underline{7}$ acres $800-1200 \mathrm{ft} .18$ acres $1200-1500 \mathrm{ft} . \underline{2}$ acres over $1500 \mathrm{ft}$. 0 acres Mass movement index: Low 0 acres Medium 0 acres High 17 acres Very High 0 acres

SOILS

This unit has high mass movement index soils. Partial log suspension required over these areas.(BMP13.9)

This unit contains 30 acres of slopes $>75 \%$.

TIMBER

Potential regeneration problem. May need to consider other silvicultural prescriptions (or hand plant) to meet BMP13.19.

\section{ENG INEER ING}

There are no engineering mitigation measures anticipated for this unit.

\section{FISH/WATERSHED}

This unit contains streams which have recently been classified/channel typed but require field verification.

\section{WILDLIFE}

Maintain diversity within unit by leaving 1-5 acre-sized islands of green trees at a rate of 1 acre of island for every 20 acres harvested. Leave islands must be compatible with logging system and safe working conditions.

\section{RECREATION / VISUALS}

This unit has a proposed VQO of MM and is not seen from any viewpoint identified by this project.

\section{LANDS}

There are no lands mitigation measures anticipated for this unit.

\section{CULTURAL RESOURCES}

There are no cultural resource mitigation measures anticipated for this unit. 


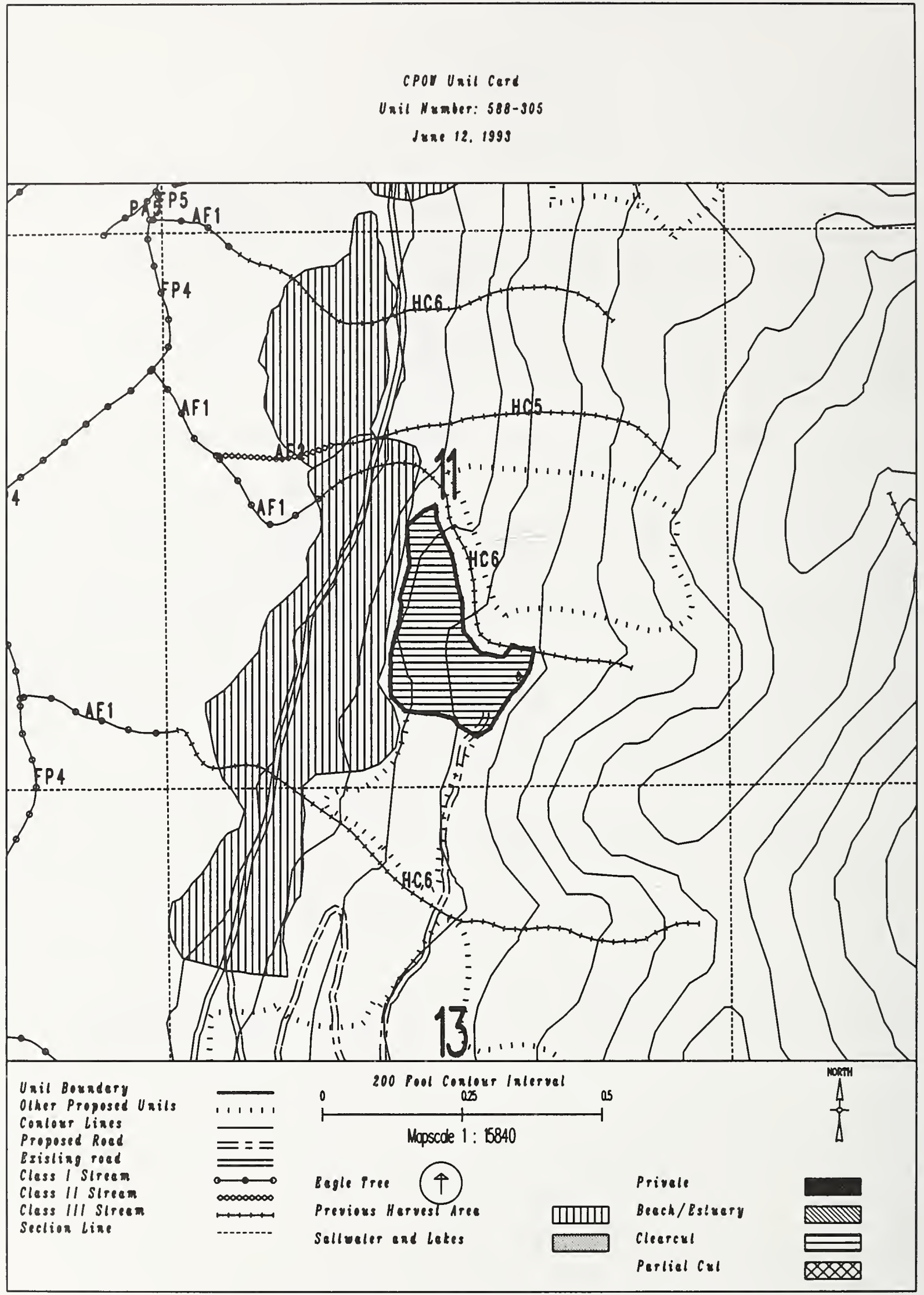


Unit $588-306$

Planned acres 58

Estimated volume (mbf) 2065

Logging system Helicopter

silvicultural system clearcut

Forest type Hemlock

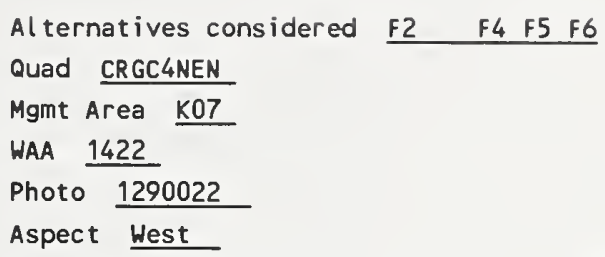

PHYSICAL DESCRIPTION

Volume class breakdown: VC4 $\quad 0$ acres VC5 27 acres vc6 31 acres vc7 $\quad 0$ acres

Elevation breakdown: $0-800 \mathrm{ft} . \ldots 1$ acres $800-1200 \mathrm{ft} .11$ acres $1200-1500 \mathrm{ft}$. 6 acres over $1500 \mathrm{ft}$. 12 acres Mass movement index: Low 3 acres Medium $\_$acres High 28 acres Very High 0 acres

\section{SOILS}

This unit has high mass movement index soils. Partial log suspension required over these areas. (BMP13.9)

This unit contains 51 acres of slopes $>75 \%$.

TIMBER

There are no timber mitigation measures anticipated for this unit.

ENGINEERING

There are no engineering mitigation measures anticipated for this unit.

\section{FISH/HATERSHED}

This unit contains streams which have recently been classified/channel typed but require field verification.

\section{WILDLIFE}

Maintain diversity within unit by leaving 1-5 acre-sized islands of green trees at a rate of 1 acre of island for every 20 acres harvested. Leave islands must be compatible with logging system and safe working conditions.

RECREATION / VISUALS

This unit has a proposed VQO of MM and is not seen from any viewpoint identified by this project.

\section{LANDS}

There are no lands mitigation measures anticipated for this unit.

CULTURAL RESOURCES

There are no cultural resource mitigation measures anticipated for this unit.

GEOLOGY

There are no karst mitigation measures anticipated for this unit. 


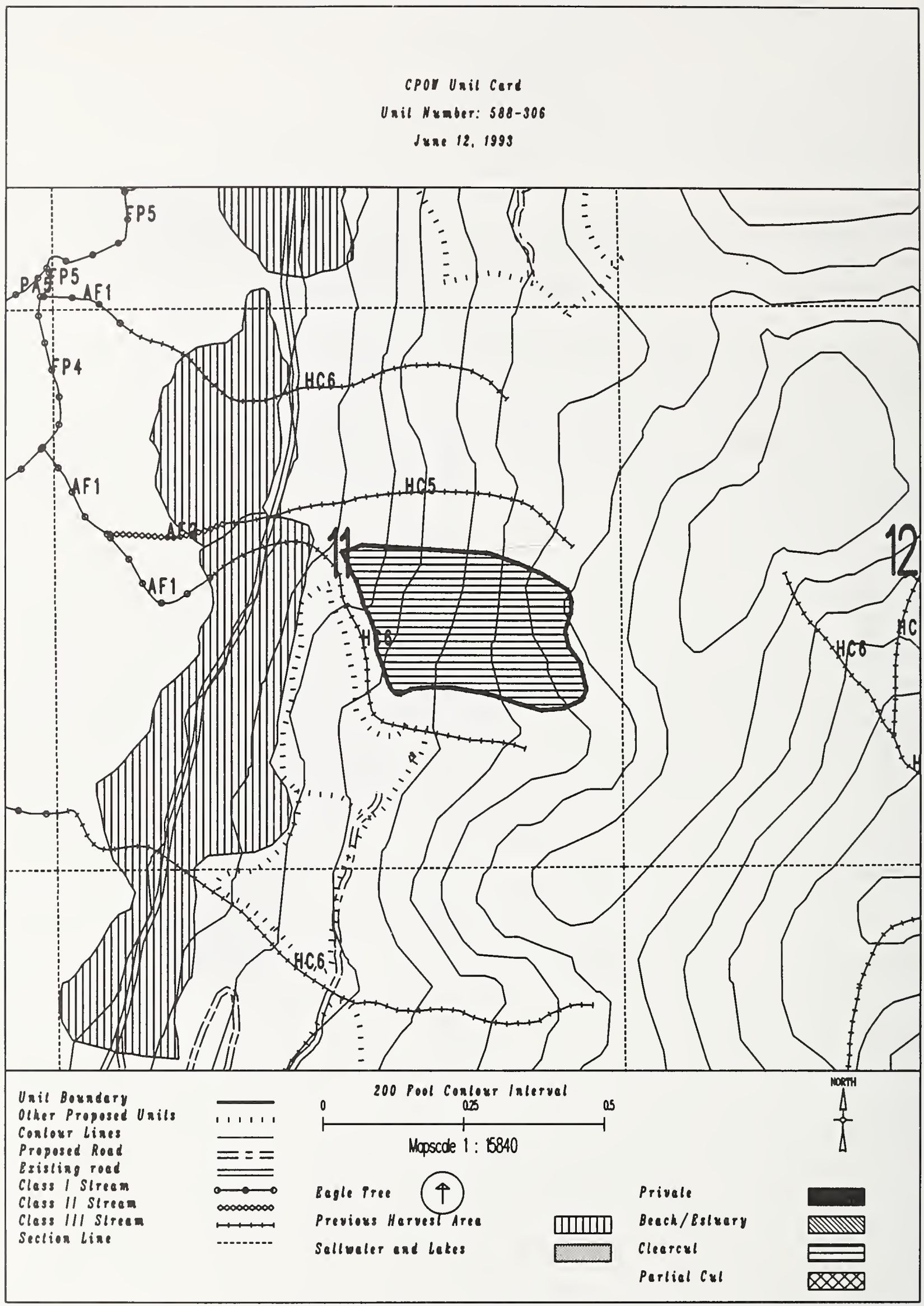


Unit $\underline{588-310}$

Planned acres 59

Estimated volume (mbf) 2242

Logging system slackline

silvicultural system clearcut

Forest type Hemlock
Alternatives considered F2 $\quad F 3 \quad F 4 \quad F 5 \quad$ F6

Quad CRGC4NEN

Mgmt Area $\mathrm{K} 07$

WAA 1422

Photo 1290023

Aspect West

\section{PHYSICAL DESCRIPTION}

Volume class breakdown: VC4 $\quad 0$ acres VC5 $\underline{44}$ acres vC6 $\underline{21}$ acres VC7 $\quad 0$ acres

Elevation breakdown: $0-800 \mathrm{ft} .11$ acres $800-1200 \mathrm{ft} .17$ acres $1200-1500 \mathrm{ft} . \underline{6}$ acres over $1500 \mathrm{ft}$. 9 acres Mass movement index: Low 3 acres Medium $\_$acres High 30 acres Very High 0

SOILS

This unit has high mass movement index soils. Partial log suspension required over these areas.(BMP13.9)

This unit has > 40\% McGilvery soils. Partial suspension required (BMP13.9)

to ensure reforestation (BMP13.19).

This unit contains 59 acres of slopes $>75 \%$.

\section{TIMBER}

There are no timber mitigation measures anticipated for this unit.

\section{ENG INEER ING}

High mass movement index soils. Road construction must minimize landslide potential (BMP14).

Slopes greater than $75 \%$ may require full bench construction and endhaul of waste (BMP14.7).

\section{FISH/WATERSHED}

This unit contains a $\underline{A} 4$ class $\underline{3}$ stream. No specific buffer required, but full suspension, if yarding across.

This unit contains streams which have recently been classified/channel typed but require field verification.

\section{WILDLIFE}

Maintain diversity within unit by leaving 1-5 acre-sized islands of green trees at a rate of 1 acre of island for every 20 acres harvested. Leave islands must be compatible with logging system and safe working conditions.

\section{RECREATION / VISUALS}

This unit has a proposed VQO of MM and is not seen from any viewpoint identified by this project.

\section{LANDS}

There are no lands mitigation measures anticipated for this unit.

CULTURAL RESOURCES

There are no cultural resource mitigation measures anticipated for this unit.

GEOLOGY

There are no karst mitigation measures anticipated for this unit. 


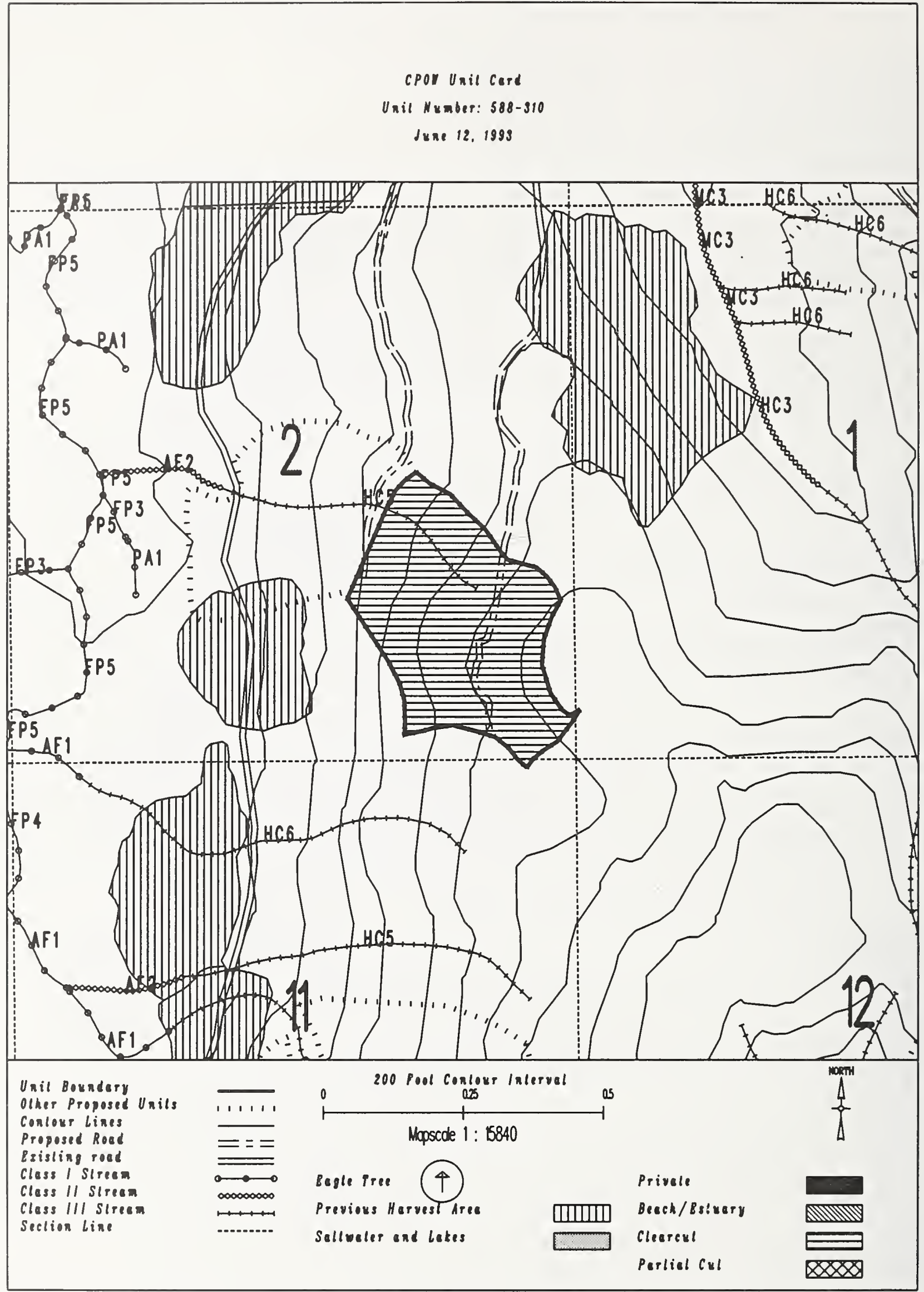


Unit 588-312

Planned acres 52

Estimated volume (mbf) 2034

Logging system Skyline

silvicultural system clearcut

Forest type Hemlock
Alternatives considered F2 $F 3$ F4 $\quad F 5 \quad$ F6

Quad CRGC4NEN

Mgmt Area $\mathrm{KO7}$

WAA 1422

Photo 1290023

Aspect West

\section{PHYSICAL DESCRIPTION}

Volume class breakdown: VC4 $\quad 6$ acres VC5 $\quad 0$ acres VC6 50 acres vc7 $\quad 0$ acres

Elevation breakdown: $0-800 \mathrm{ft} . \underline{47}$ acres $800-1200 \mathrm{ft} . \underline{2}$ acres $1200-1500 \mathrm{ft} . \underline{0}$ acres over $1500 \mathrm{ft}$. 0 acres Mass movement index: Low 0 acres Medium 0 acres High 51 acres Very High 0 acres

\section{SOILS}

This unit has high mass movement index soils. Partial log suspension required over these areas. (BMP13.9)

This unit contains 6 acres of slopes $>75 \%$.

This unit will be monitored for effects of harvest/roading on steep slopes.

\section{TIMBER}

There are no timber mitigation measures anticipated for this unit.

\section{ENGINEER ING}

High mass movement index soils. Road construction must minimize landslide potential (BMP14).

Slopes greater than $75 \%$ may require full bench construction and endhaul of waste (BMP14.7).

\section{FISH/WATERSHED}

This unit contains a $\underline{A} 4$ class $\underline{3}$ stream. No specific buffer required, but full suspension, if yarding across.

This unit contains streams which have recently been classified/channel typed but require field verification.

\section{WILDLIFE}

Maintain diversity within unit by leaving 1-5 acre-sized islands of green trees at a rate of 1 acre of island for every 20 acres harvested. Leave islands must be compatible with logging system and safe working conditions.

\section{RECREATION / VISUALS}

This unit has a proposed Voo of MM and is not seen from any viewpoint identified by this project.

\section{LANDS}

There are no lands mitigation measures anticipated for this unit.

\section{CULTURAL RESOURCES}

There are no cultural resource mitigation measures anticipated for this unit.

\section{GEOLOGY}

There are no karst mitigation measures anticipated for this unit. 


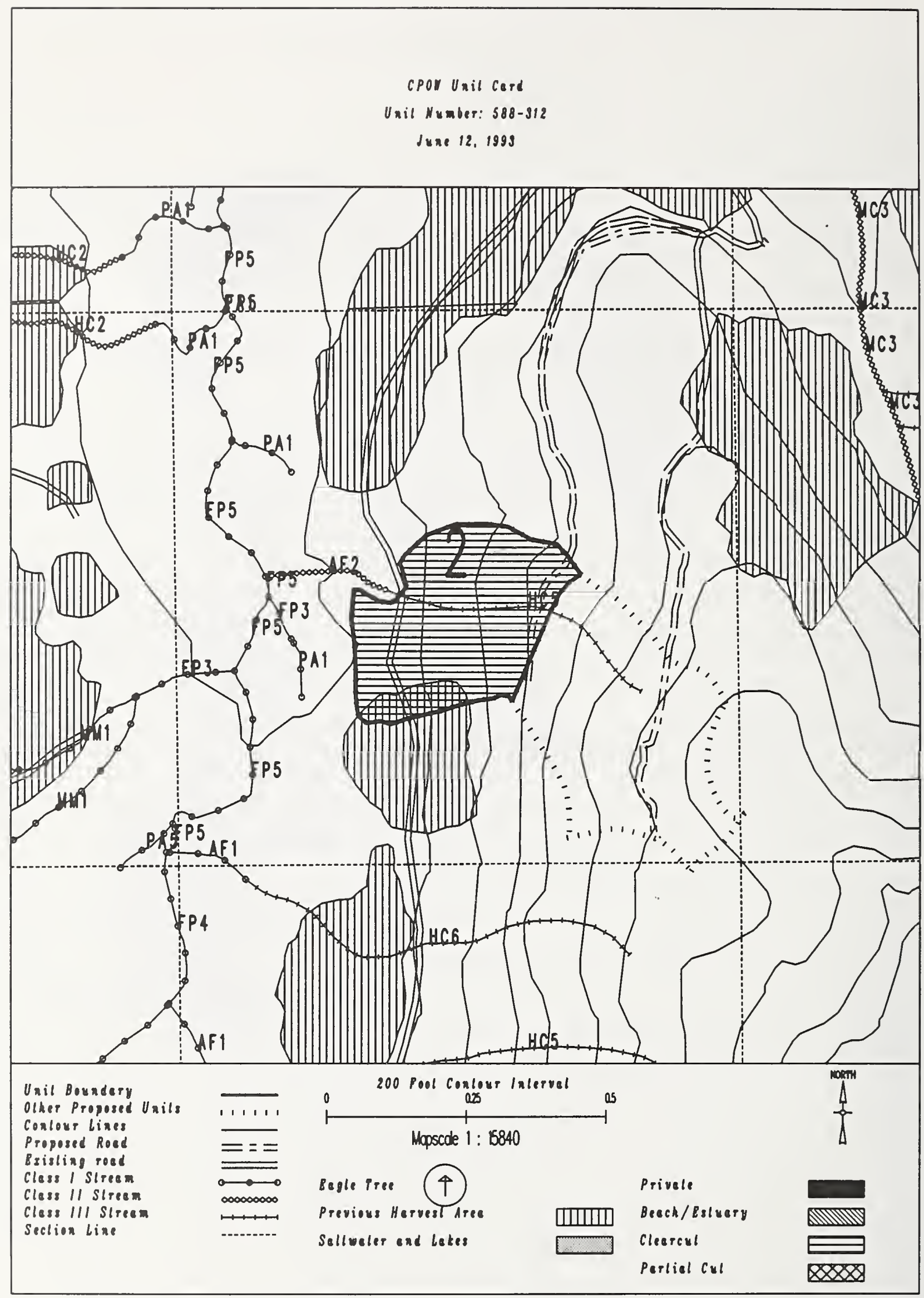


Unit $\quad 588-322$

Planned acres 140

Estimated volume (mbf) 4240

Logging system Highlead

silvicultural system clearcut

Forest type Hemlock

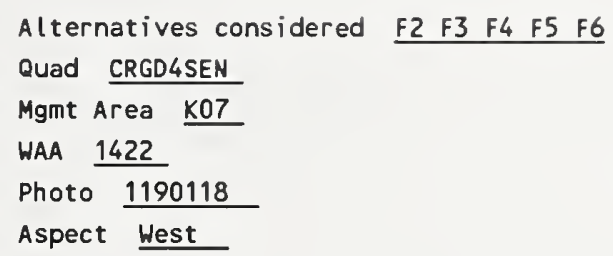

PHYSICAL DESCRIPTION

Volume class breakdown: VC4 23 acres VC5 114 acres VC6 $\quad 0$ acres VC7 $\quad 0$ acres

Elevation breakdown: $0-800 \mathrm{ft} . \underline{137}$ acres $800-1200 \mathrm{ft} . \underline{0}$ acres $1200-1500 \mathrm{ft} . \underline{0}$ acres over $1500 \mathrm{ft}$. 0 Mass movement index: Low 75 acres Medium 50 acres High 6 acres Very High 0 acres

SOILS

This unit contains 93 acres of forested wetlands. Site specific BMPs will be designed for selected approved logging system and road construction practices. (BMPs 12.5, 13.9, 13.15).

This unit contains 1 acres of slopes $>75 \%$.

TIMBER

There are no timber mitigation measures anticipated for this unit.

ENGINEER I NG

High mass movement index soils. Road construction must minimize landslide potential (BMP14).

\section{FI SH/WATERSHED}

This unit contains streams which have recently been classified/channel typed but require field verification.

\section{WILDLIFE}

Maintain diversity within unit by leaving 1-5 acre-sized islands of green trees at a rate of 1 acre of island for every 20 acres harvested. Leave islands must be compatible with logging system and safe working conditions.

RECREATION / VISUALS

The unit has a proposed VQO of MM within the viewshed of Staney Creek as viewed from 1 mile from west coast of Prince of Wales.

\section{LANDS}

There are no lands mitigation measures anticipated for this unit.

\section{CULTURAL RESOURCES}

There are no cultural resource mitigation measures anticipated for this unit.

GEOLOGY

This unit is underlain with karst, although no significant features have yet been identified. 


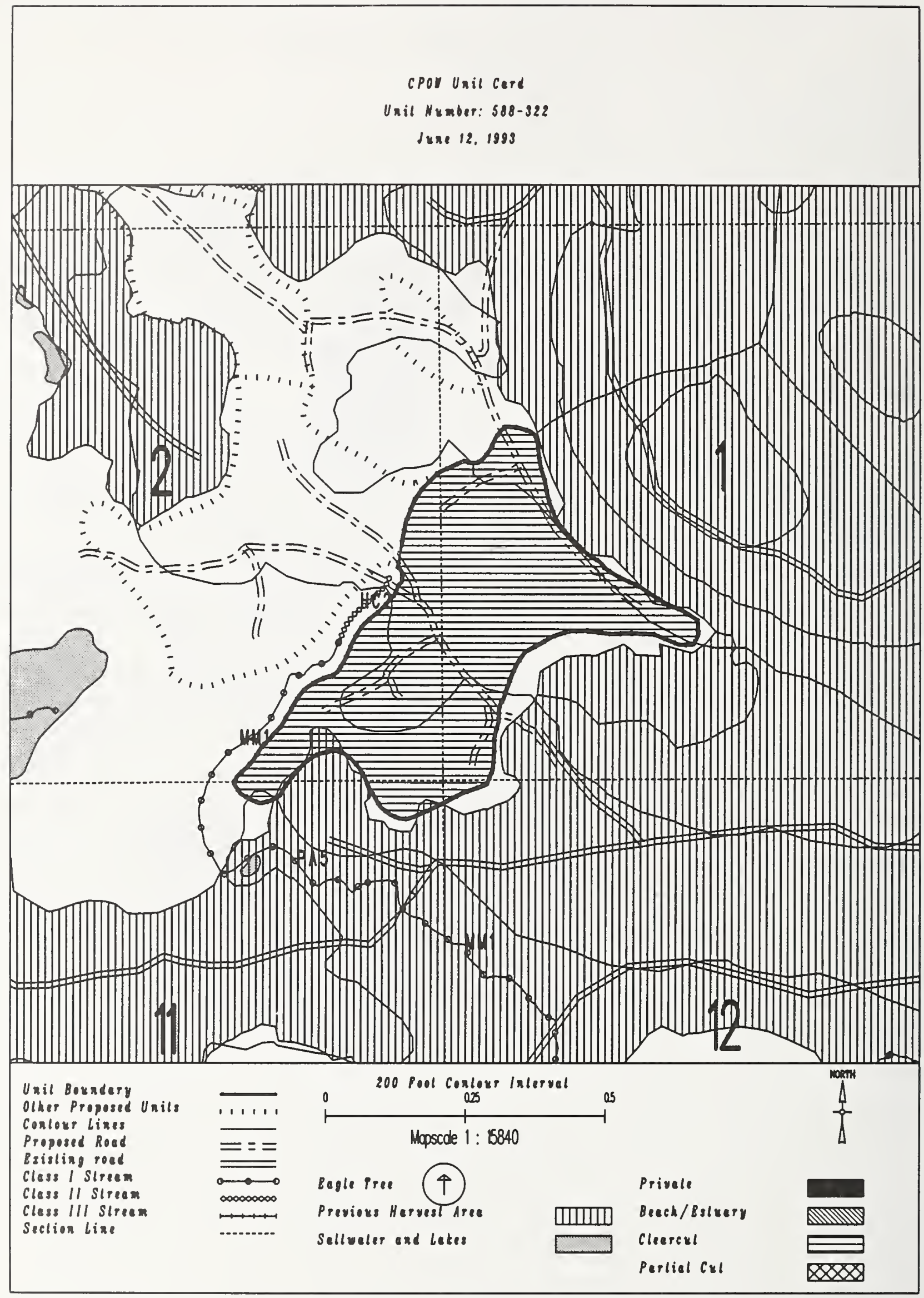


Unit $588-324$

Planned acres 92

Estimated volume (mbf)

Logging system skyline

silvicultural system clearcut

Forest type Hemlock
Alternatives considered

Quad CRGD4SEN

Mgmt Area $\mathrm{KOT}$

WAA 1422

Photo 1190118

Aspect South

\section{PHYSICAL DESCRIPTION}

Volume class breakdown: VC4 65 acres VC5 23 acres vC6 $\quad 0$ acres vc7 $\quad 0$ acres

Elevation breakdown: $0-800 \mathrm{ft} . \underline{88}$ acres $800-1200 \mathrm{ft} . \underline{0}$ acres $1200-1500 \mathrm{ft} . \underline{0}$ acres over $1500 \mathrm{ft}$. 0 acres Mass movement index: Low 19 acres Medium 51 acres High 11 acres Very High 0 acres

\section{SOILS}

This unit has high mass movement index soils. Partial log suspension required over these areas. (BMP13.9)

This unit contains 77 acres of forested wetlands. Site specific BMPs will be designed for selected approved

logging system and road construction practices. (BMPs 12.5, 13.9, 13.15).

\section{TIMBER}

There are no timber mitigation measures anticipated for this unit.

\section{ENGINEER ING}

High mass movement index soils. Road construction must minimize landslide potential (BMP14).

\section{FISH/WATERSHED}

Leave all deciduous and conifer trees (< $12^{\prime \prime} \mathrm{dbh}$ ) in $35 \mathrm{ft}$ buffer adjacent to class III streams to provide shade. This unit contains streams which have recently been classified/channel typed but require field verification.

\section{WILDL IFE}

There are no wildlife mitigation measures anticipated for this unit.

\section{RECREATION / VISUALS}

The unit has a proposed VQO of MM within the viewshed of Staney Creek

as viewed from 1 mile from west coast of Prince of Wales.

\section{LANDS}

There are no lands mitigation measures anticipated for this unit.

\section{CULTURAL RESOURCES}

The planned unit boundary and road location is immediately adjacent to significant cultural resources. Any changes must be coordinated with cultural resource personnel.

\section{GEOLOGY}

There are no karst mitigation measures anticipated for this unit. 


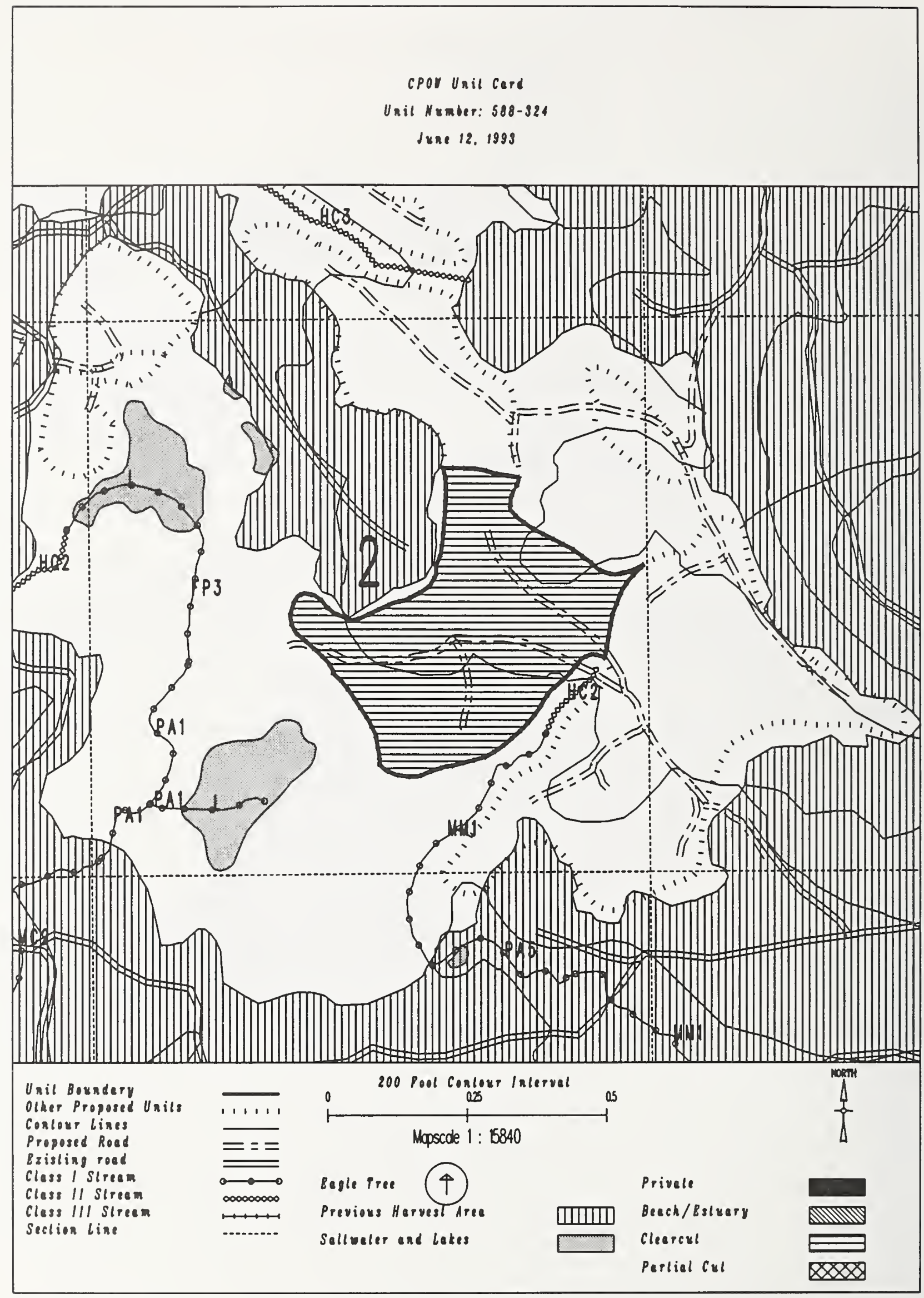


Unit $\quad 588-327$

Planned acres 111

Estimated volume (mbf) 4824

Logging system Helicopter

silvicultural system clearcut

Forest type Mixed conifer
Alternatives considered

Quad CRGD4SEN

Mgmt Area $\mathrm{KO7}$

WAA 1422

Photo

Aspect South

PHYSICAL DESCRIPTION

Volume class breakdown: VC4 0 acres VC5 0 acres VC6 72 acres VC7 41 acres

Elevation breakdown: $0-800 \mathrm{ft} .20$ acres $800-1200 \mathrm{ft} . \underline{94}$ acres $1200-1500 \mathrm{ft} . \underline{0}$ acres over $1500 \mathrm{ft}$. 0 Mass movement index: Low 0 acres Medium 117 acres High 0 acres Very High 0

SOILS

There are no soils mitigation measures anticipated for this unit.

TIMBER

There are no timber mitigation measures anticipated for this unit.

ENGINEERING

There are no engineering mitigation measures anticipated for this unit.

FISH/WATERSHED

This unit contains streams which have recently been classified/channel typed but require field verification.

\section{HILDLIFE}

Maintain adequate distribution of snags by leaving 0.1 acre-sized patches of green trees within the unit for every 10 acres harvested. Snag patches must be compatible with logging system and safe working conditions. Maintain diversity within unit by leaving 1-5 acre-sized islands of green trees at a rate of 1 acre of island for every 20 acres harvested. Leave islands must be compatible with logging system and safe working conditions.

\section{RECREATION / VISUALS}

The unit has a proposed VQO of MM within the viewshed of Kussan Point as viewed from 1 mile from west coast of Prince of Wales.

\section{LANDS}

There are no lands mitigation measures anticipated for this unit.

CULTURAL RESOURCES

There are no cultural resource mitigation measures anticipated for this unit.

GEOLOGY

Planned unit boundary/road location/logging system are designed to avoid damage to significant karst features. Mitigation measures may apply. Unit layout/changes must be coordinated with Cave Resource Specialists. 


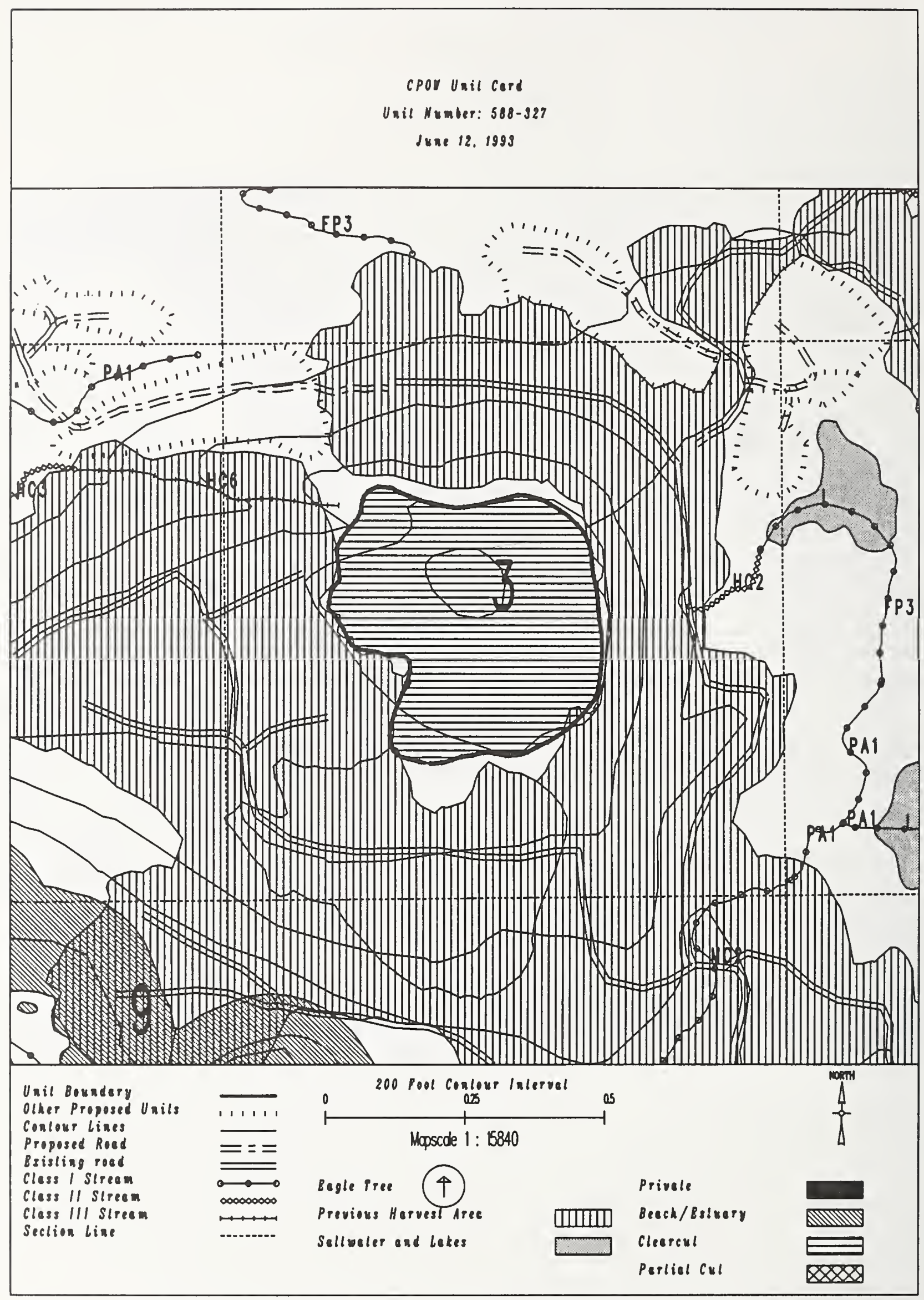


Unit $589-203$

Planned acres 45

Est imated volume (mbf) 1388

Logging system Helicopter

silvicultural system Clearcut

forest type Hemlock
Alternatives considered

Quad CRGD4SES

Mgmt Area K07

WAA 1422

Photo

Aspect South

\section{PHYSICAL DESCRIPTION}

Volume class breakdown: VC4 14 acres vC5 33 acres vC6 $\quad 0$ acres vc7 $\quad 0$ acres

Elevation breakdown: $0-800 \mathrm{ft} .{ }_{0}^{0}$ acres $800-1200 \mathrm{ft} . \underline{0}$ acres 1200-1500 ft. 0 acres over $1500 \mathrm{ft}$. 39 acres Mass movement index: Low 4 acres Medium $\_$acres High 42 acres Very High 0 acres

\section{SOILS}

This unit has high mass movement index soils. Partial log suspension required over these areas. (BMP13.9)

This unit contains 45 acres of forested wetlands. Site specific BMPs will be designed for selected approved

logging system and road construction practices. (BMPs 12.5, 13.9, 13.15).

\section{TIMBER}

There are no timber mitigation measures anticipated for this unit.

\section{ENGINEER ING}

There are no engineering mitigation measures anticipated for this unit.

\section{FISH/WATERSHED}

There are no fishery mitigation measures anticipated for this unit.

\section{WILDL IFE}

Maintain diversity within unit by leaving 1-5 acre-sized islands of green trees at a rate of 1 acre of island for every 20 acres harvested. Leave islands must be compatible with logging system and safe working conditions.

\section{RECREATION / VISUALS}

This unit has a proposed vQO of MM and is not seen from any viewpoint identified by this project.

\section{LANDS}

There are no lands mitigation measures anticipated for this unit.

\section{CULTURAL RESOURCES}

There are no cultural resource mitigation measures anticipated for this unit.

\section{GEOLOGY}

There are no karst mitigation measures anticipated for this unit. 
CPOI Uail Cerd

Unil Number: 589-203

dune 12, 1999

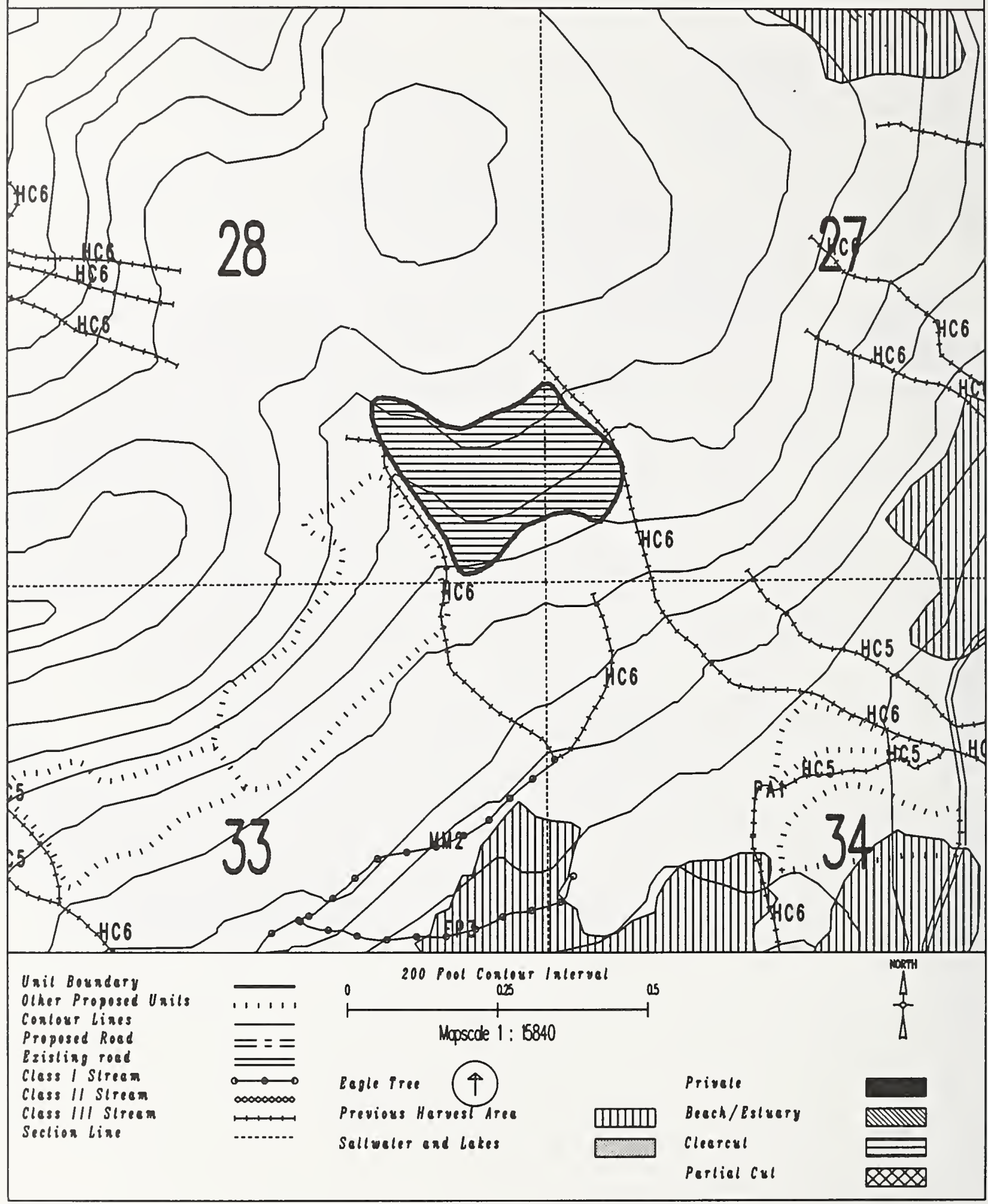


Unit 589-204

Planned acres 55

Estimated volume (mbf) 1596

Logging system Helicopter

silvicultural system Clearcut

forest type Hemlock
Alternatives considered

Quad CRGD4SES

Mgmt Area $\mathrm{K07}$

WAA 1422

Photo 1490115

Aspect South

PHYSICAL DESCRIPTION

Volume class breakdown: VC4 16 acres VC5 38 acres VC6 $\quad 0$ acres VC7 $\quad 0$ acres

Elevation breakdown: $0-800 \mathrm{ft} . \underline{0}$ acres $800-1200 \mathrm{ft} . \underline{0}$ acres $1200-1500 \mathrm{ft} . \underline{0}$ acres over $1500 \mathrm{ft} . \underline{20}$ acres Mass movement index: Low 21 acres Medium 0 acres High 36 acres Very High 0

SOILS

This unit has high mass movement index soils. Partial log suspension required over these areas. (BMP13.9)

This unit contains 37 acres of forested wetlands. Site specific BMPs will be designed for selected approved

logging system and road construction practices. (BMPS 12.5, 13.9, 13.15).

This unit contains 24 acres of slopes $>75 \%$.

TIMBER

There are no timber mitigation measures anticipated for this unit.

ENGINEERING

There are no engineering mitigation measures anticipated for this unit.

FISH/WATERSHED

There are no fishery mitigation measures anticipated for this unit.

WILDLIFE

Maintain diversity within unit by leaving 1-5 acre-sized islands of green trees at a rate of 1 acre of island for every 20 acres harvested. Leave islands must be compatible with logging system and safe working conditions.

RECREATION / VISUALS

This unit has a proposed VQO of MM and is not seen from any viewpoint identified by this project.

LANDS

There are no lands mitigation measures anticipated for this unit.

CULTURAL RESOURCES

There are no cultural resource mitigation measures anticipated for this unit.

GEOLOGY

There are no karst mitigation measures anticipated for this unit. 
cpor Unil cerd

Unil Number: 589-204

Juae 12, 1993

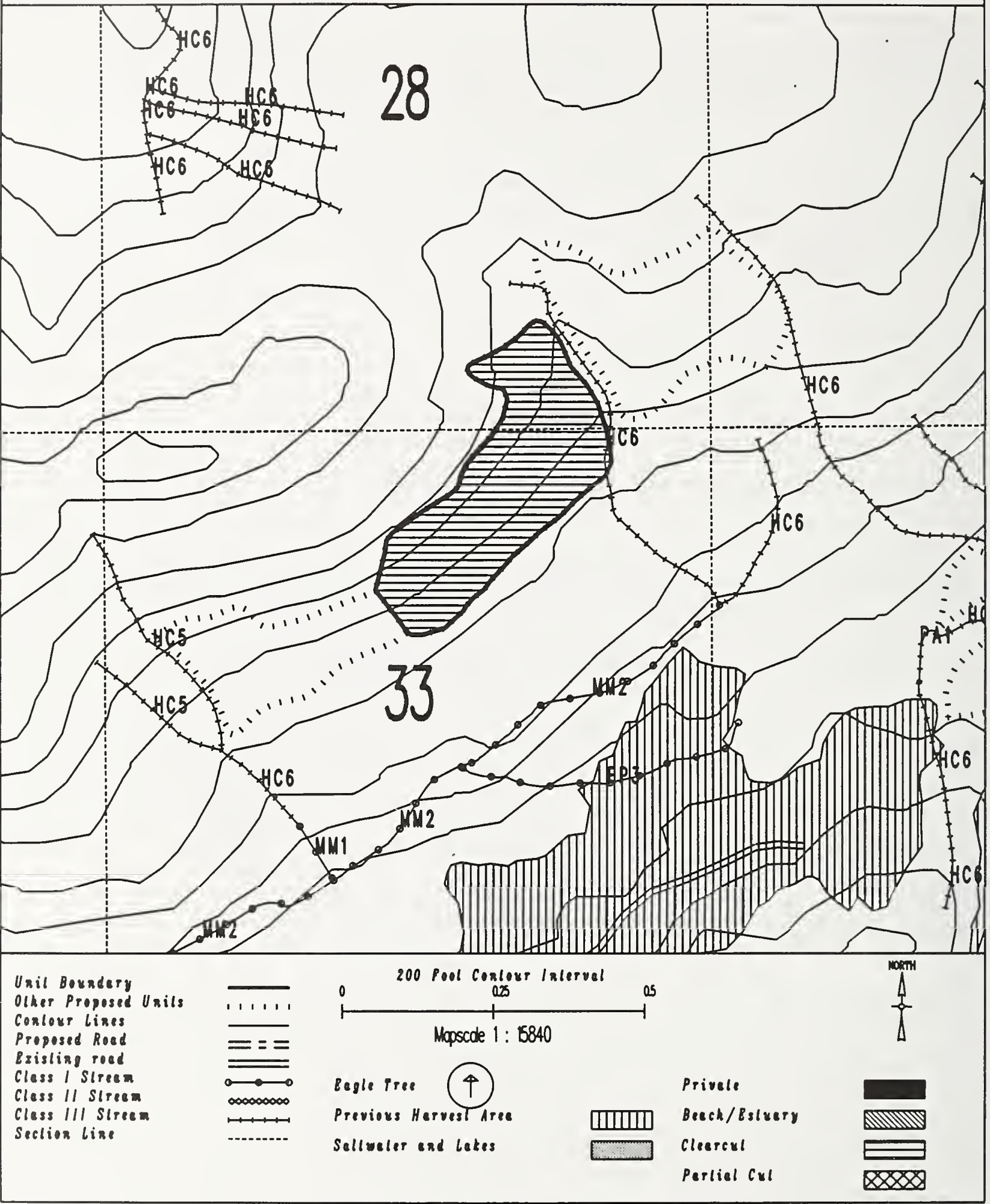


Unit 589-205

Planned acres 28

Estimated volume (mbf) 842

Logging system Helicopter

silvicultural system Clearcut

forest type Hemlock
Alternatives considered

Quad CRGD4SES

Mgmt Area $\mathrm{KO7}$

WAA 1422

Photo 1490115

Aspect South

\section{PHYSICAL DESCRIPTION}

Volume class breakdown: VC4 7 acres VC5 21 acres vC6 $\quad 0$ acres VC7 0 acres

Elevation breakdown: $0.800 \mathrm{ft}$. $\ldots$ acres $800-1200 \mathrm{ft} . \underline{0}$ acres $1200-1500 \mathrm{ft}$. 0 acres over $1500 \mathrm{ft}$. 4 acres Mass movement index: Low 12 acres Medium 0 acres High 15 acres Very High 0

\section{SOILS}

This unit has high mass movement index soils. Partial log suspension required over these areas.(BMP13.9)

This unit contains 15 acres of forested wetlands. Site specific BMPs will be designed for selected approved

logging system and road construction practices. (BMPs 12.5, 13.9, 13.15).

This unit contains 15 acres of slopes > $75 \%$.

\section{TIMBER}

There are no timber mitigation measures anticipated for this unit.

\section{ENGINEER ING}

There are no engineering mitigation measures anticipated for this unit.

\section{FISH/WATERSHED}

There are no fishery mitigation measures anticipated for this unit.

\section{WILDLIFE}

Maintain diversity within unit by leaving 1-5 acre-sized islands of green trees at a rate of 1 acre of island for every 20 acres harvested. Leave islands must be compatible with logging system and safe working conditions.

\section{RECREATION / VISUALS}

This unit has a proposed VQO of MM and is not seen from any viewpoint identified by this project.

\section{LANDS}

There are no lands mitigation measures anticipated for this unit.

\section{CULTURAL RESOURCES}

There are no cultural resource mitigation measures anticipated for this unit. 


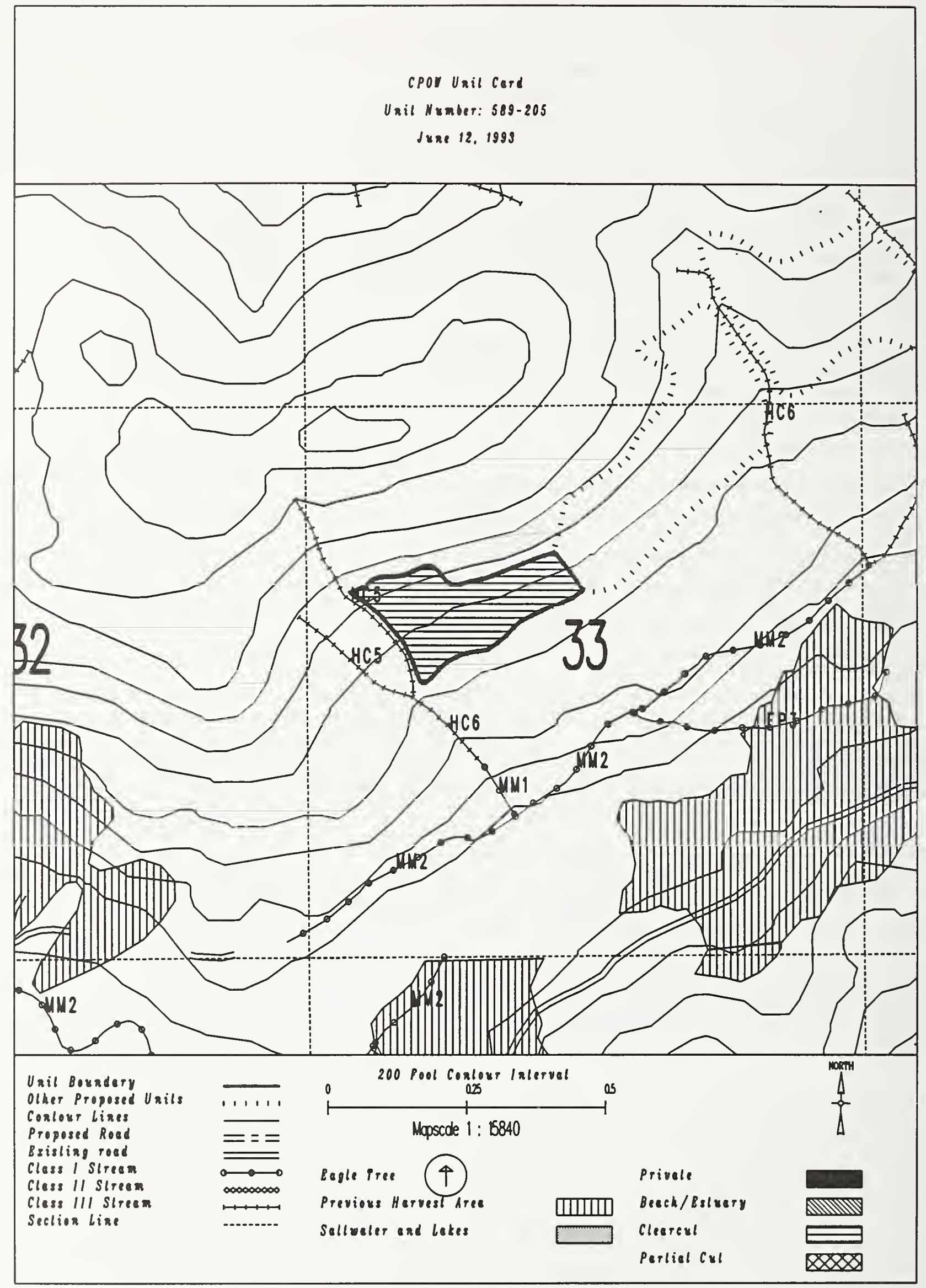


Unit 589-214

Planned acres 24

Estimated volume (mbf)

Logging system Highlead

silvicultural system clearcut

Forest type Cedar
Alternatives considered

Quad CRGC4NWN

Mgmt Area K07

WAA 1422

Photo 1990083

Aspect West

\section{PHYSICAL DESCRIPTION}

Volume class breakdown: VC4 12 acres VC5 12 acres VC6 $\quad 0$ acres vc7 $\quad 0$ acres

Elevation breakdown: $0-800 \mathrm{ft} .18$ acres $800-1200 \mathrm{ft} . \underline{0}$ acres $1200-1500 \mathrm{ft} . \underline{0}$ acres over $1500 \mathrm{ft}$. 0 acres Mass movement index: Low 5 acres Medium 18 acres High 0 acres Very High 0

SOILS

This unit contains 21 acres of forested wetlands. Site specific BMPs will be designed for selected approved logging system and road construction practices. (BMPs 12.5, 13.9, 13.15).

\section{TIMBER}

Potential regeneration problem. Monitor regeneration to determine if hand planting is required to meet BMP13.19.

\section{ENGINEERING}

There are no engineering mitigation measures anticipated for this unit.

\section{FISH/WATERSHED}

Potential impact on significant fishery habitat. May be necessary to expand planned buffer in accordance with AHMU Handbook.

This unit contains streams which have recently been classified/channel typed but require field verification.

\section{WILDLIFE}

There are no wildlife mitigation measures anticipated for this unit.

\section{RECREATION / VISUALS}

The unit has a proposed VQO of MM within the viewshed of Shaheen Creek as viewed from 2 mile from west coast of Prince of Wales.

\section{LANDS}

There are no lands mitigation measures anticipated for this unit.

\section{CULTURAL RESOURCES}

There are no cultural resource mitigation measures anticipated for this unit.

\section{GEOLOGY}

There are no karst mitigation measures anticipated for this unit. 


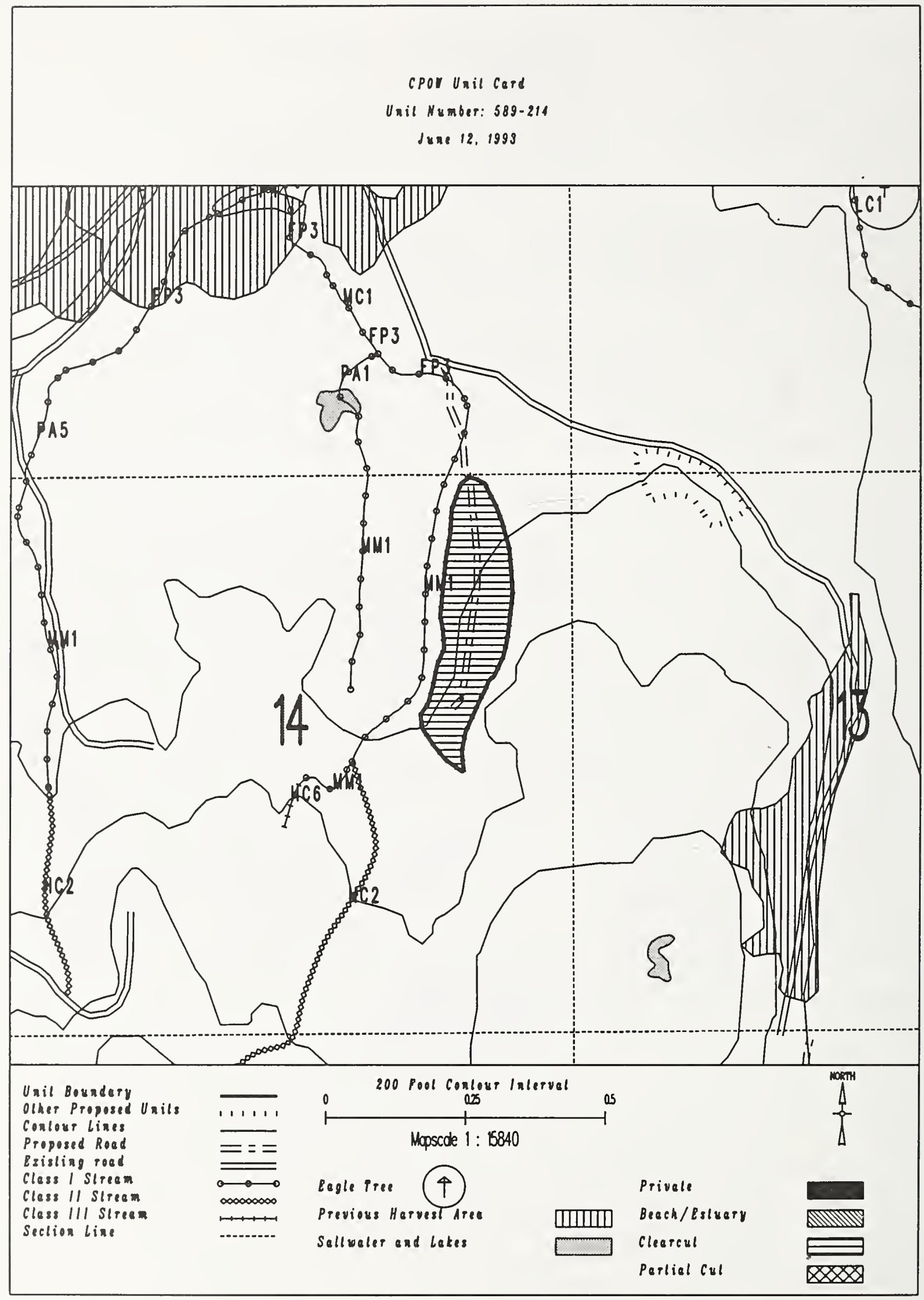


Unit $\quad 589-218$

Planned acres 31

Est imated volume (mbf)

Logging system Highlead

silvicultural system clearcut

Forest type Cedar
Alternatives considered

Quad CRGC4NWN

Mgmt Area $\mathrm{KO7}$

WAA 1422

Photo 1990050

Aspect South

PHYSICAL DESCRIPTION

Volume class breakdown: VC4 30 acres VC5 $\quad 1$ acres VC6 $\quad 0$ acres VC7 $\quad 0$ acres

Elevation breakdown: $0-800 \mathrm{ft} . \underline{29}$ acres $800-1200 \mathrm{ft} . \underline{0}$ acres $1200-1500 \mathrm{ft} . \underline{0}$ acres over $1500 \mathrm{ft} . \underline{0}$ acres Mass movement index: Low 2 acres Medium 21 acres High 6 acres Very High 0 acres

SOILS

This unit has high mass movement index soils. Partial log suspension required over these areas. (BMP13.9)

This unit contains 31 acres of forested wetlands. Site specific BMPs will be designed for selected approved

logging system and road construction practices. (BMPs 12.5, 13.9, 13.15).

TIMBER

There are no timber mitigation measures anticipated for this unit.

ENGINEER ING

High mass movement index soils. Road construction must minimize landslide potential (BMP14).

FISH/WATERSHED

This unit contains streams which have recently been classified/channel typed but require field verification.

WILDLIFE

There are no wildlife mitigation measures anticipated for this unit.

RECREATION / VISUALS

This unit has a proposed VQO of MM and is not seen from any viewpoint identified by this project.

\section{LANDS}

There are no lands mitigation measures anticipated for this unit.

CULTURAL RESOURCES

There are no cultural resource mitigation measures anticipated for this unit.

There are no karst mitigation measures anticipated for this unit. 


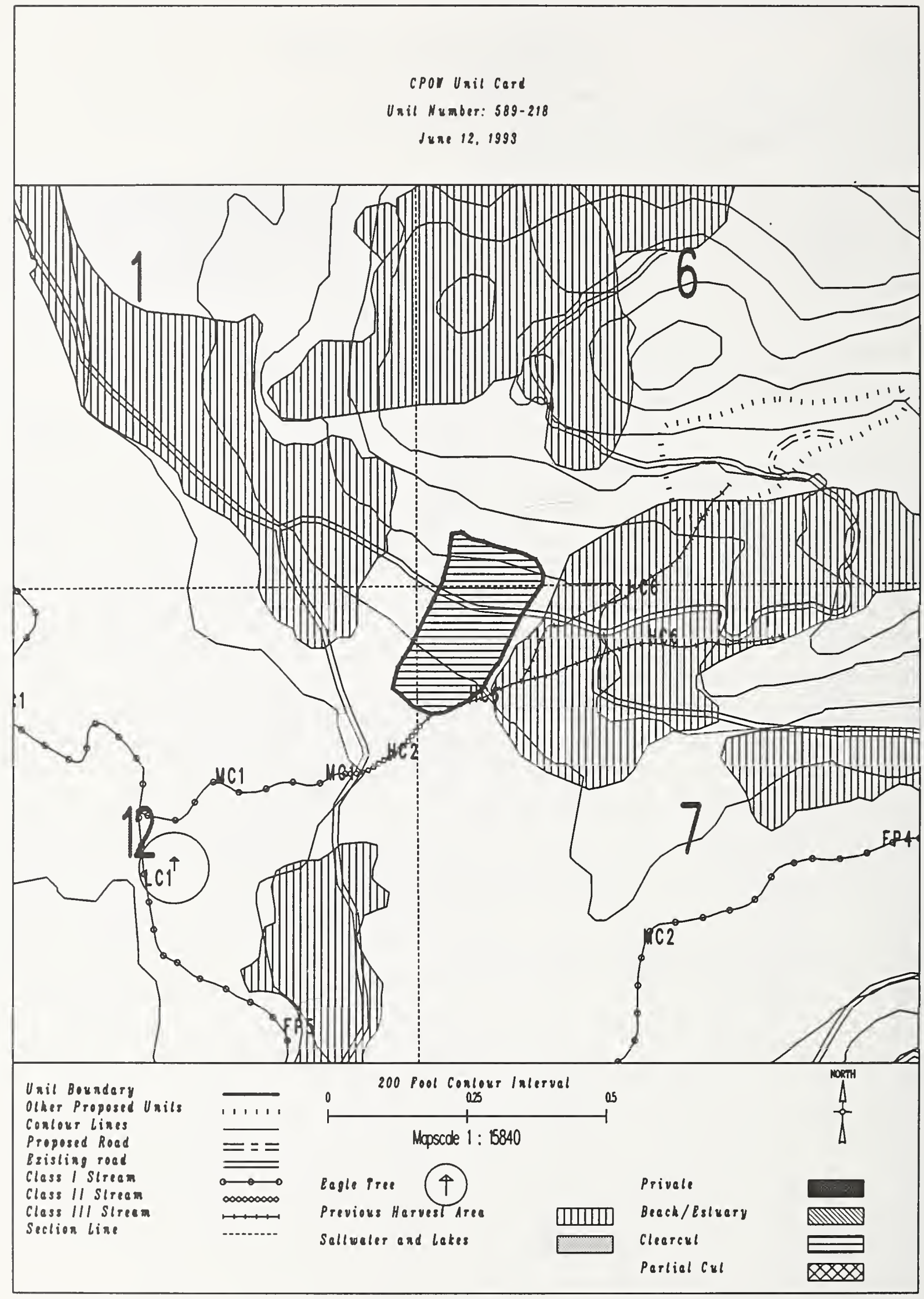


Unit $\quad 589-220$

Planned acres 34

Estimated volume (mbf) 700

Logging system skyline

silvicultural system clearcut

Forest type Cedar
Alternatives considered

Quad CRGC4NWN

Mgmt Area $\mathrm{KOT}$

WAA 1422

Photo 1990050

Aspect South

PHYSICAL DESCRIPTION

Volume class breakdown: VC4 $\quad 32$ acres VC5 $\quad 0$ acres vC6 $\quad 0$ acres VC7 $\quad 0$ acres

Elevation breakdown: $0-800 \mathrm{ft} . \underline{0}$ acres $800-1200 \mathrm{ft} . \underline{13}$ acres $1200-1500 \mathrm{ft} . \underline{7}$ acres over $1500 \mathrm{ft} . \underline{0}$ acres Mass movement index: Low $\_$acres Medium $\_$acres High 33 acres Very High 0 acres

SOILS

This unit has high mass movement index soils: Partial log suspension required over these areas.(8MP13.9)

This unit contains 33 acres of forested wetlands. Site specific BMPs will be designed for selected approved

logging system and road construction practices. (BMPs 12.5, 13.9, 13.15).

This unit contains 7 acres of slopes $>75 \%$.

TIMBER

There are no timber mitigation measures anticipated for this unit.

\section{ENGINEER ING}

High mass movement index soils. Road construction must minimize landslide potential (BMP14).

slopes greater than $75 \%$ may require full bench construction and endhaul of waste (BMP14.7).

\section{FISH/WATERSHED}

There are no fishery mitigation measures anticipated for this unit.

WILDLIFE

There are no wildlife mitigation measures anticipated for this unit.

RECREATION / VISUALS

This unit has a proposed VQO of MM and is not seen from any viewpoint identified by this project.

\section{LANDS}

There are no lands mitigation measures anticipated for this unit.

CULTURAL RESOURCES

There are no cultural resource mitigation measures anticipated for this unit.

GEOLOGY

There are no karst mitigation measures anticipated for this unit. 


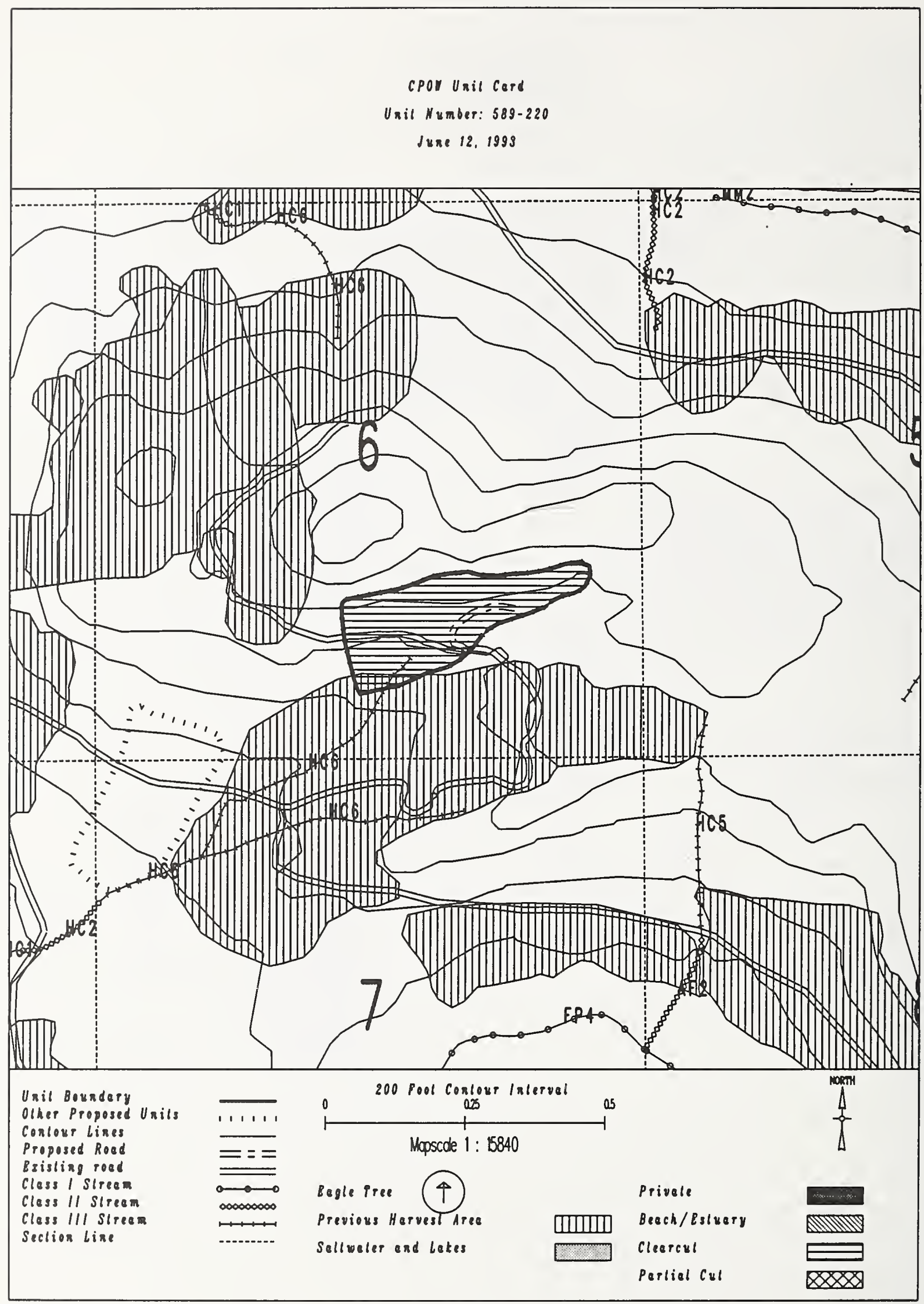


Unit $\quad 589-229$

Planned acres 40

Est imated volume (mbf) $\quad 854$

Logging system Skyline

silvicultural system clearcut

Forest type Hemlock
Al ternatives considered

Quad CRGC4NWN

Mgmt Area $\mathrm{KO7}$

WAA 1422

Photo

Aspect East

PHYSICAL DESCRIPTION

Volume class breakdown: VC4 39 acres vC5 $\quad 0$ acres vc6 $\quad 0$ acres vc7 $\quad 0$ acres

Elevation breakdown: $0-800 \mathrm{ft} . \underline{27}$ acres $800-1200 \mathrm{ft} . \underline{3}$ acres $1200-1500 \mathrm{ft} . \underline{0}$ acres over $1500 \mathrm{ft} . \quad 0$ Mass movement index: Low 4 acres Medium $\underline{6}$ acres High 28 acres Very High 0

SOILS

This unit has high mass movement index soils. Partial log suspension required over these areas. (BMP13.9)

This unit has > 40\% McGilvery soils. Partial suspension required (BMP13.9)

to ensure reforestation (BMP13.19).

This unit contains 36 acres of forested wetlands. Site specific BMPs will be designed for selected approved

logging system and road construction practices. (BMPs 12.5, 13.9, 13.15).

TIMBER

There are no timber mitigation measures anticipated for this unit.

ENGINEERING

High mass movement index soils. Road construction must minimize landslide potential (BMP14).

FISH/WATERSHED

This unit contains streams which have recently been classified/channel typed but require field verification.

HILDLIFE

There are no wildlife mitigation measures anticipated for this unit.

RECREATION / VISUALS

This unit has a proposed voo of MM and is not seen from any viewpoint identified by this project.

LANDS

There are no lands mitigation measures anticipated for this unit.

CULTURAL RESOURCES

There are no cultural resource mitigation measures anticipated for this unit.

GEOLOGY

There are no karst mitigation measures anticipated for this unit. 


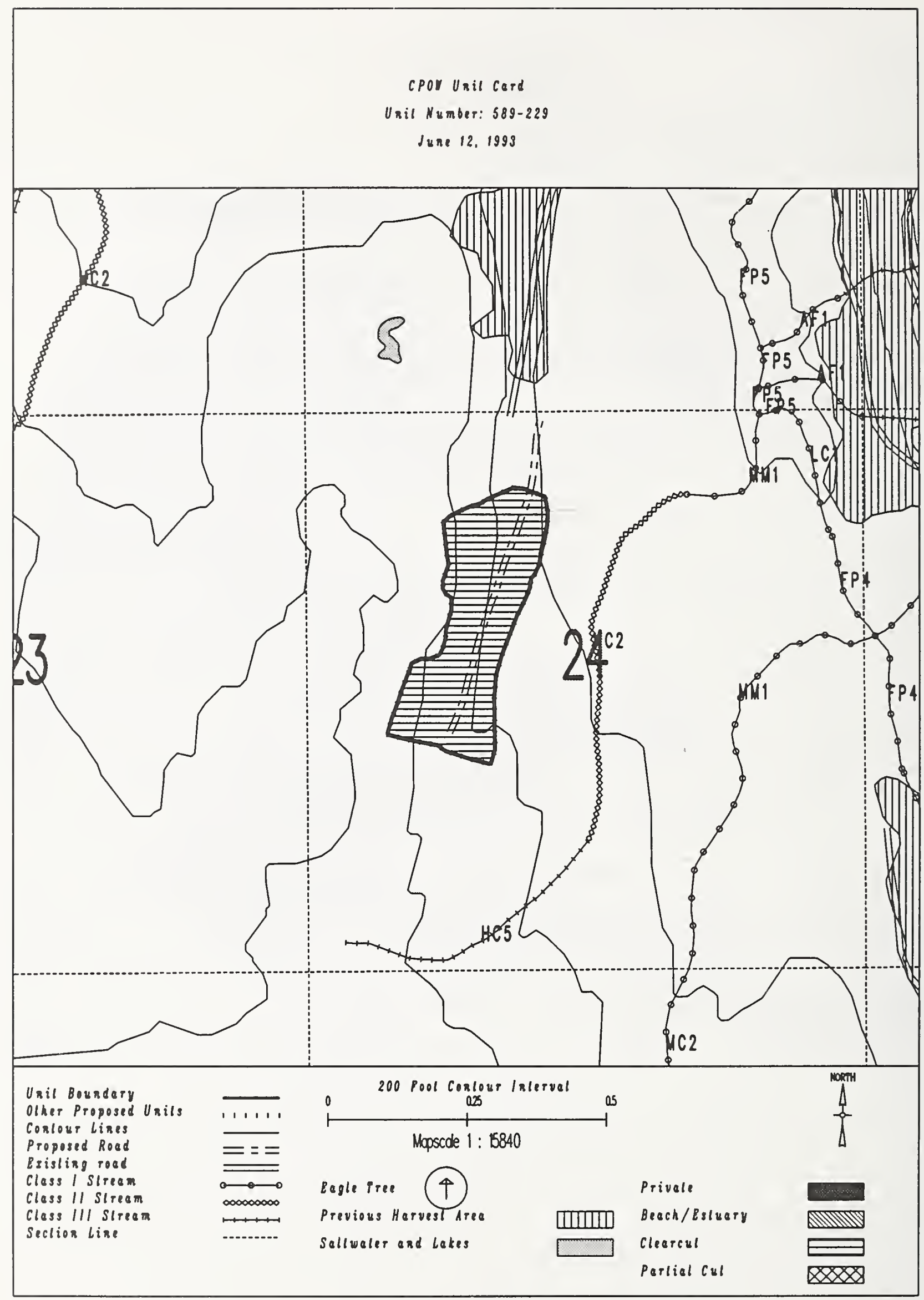


Unit 589-230

Planned acres 54

Estimated volume (mbf) 1138

Logging system Highlead

silvicultural system clearcut

Forest type Hemlock
Alternatives considered

Quad CRGC4NHS

Mgmt Area $\mathrm{KO7}$

WAA 1422

Photo 1990055

Aspect East

\section{PHYSICAL DESCRIPTION}

Volume class breakdown: VC4 52 acres VC5 $\quad 0$ acres vc6 $\quad 0$ acres vc7 $\quad 0$ acres

Elevation breakdown: $0-800 \mathrm{ft} . \underline{49}$ acres $800-1200 \mathrm{ft} . \underline{2}$ acres $1200-1500 \mathrm{ft} . \underline{0}$ acres over $1500 \mathrm{ft}$. 0 acres Mass movement index: Low 5 acres Medium 0 acres High 48 acres Very High 0 acres

\section{SOILS}

This unit has high mass movement index soils. Partial log suspension required over these areas. (BMP13.9)

This unit has a slight possibility to be reclassified as MMI $=4$.

\section{TIMBER}

There are no timber mitigation measures anticipated for this unit.

\section{ENG INEER ING}

Very difficult road construction due to unstable, slope > $75 \%$ or extended steep grades.

May need to revise logging system to helicopter.

High mass movement index soils. Road construction must minimize landslide potential (BMP14).

\section{FISH/WATERSHED}

This unit contains streams which have recently been classified/channel typed but require field verification.

\section{HILDLIFE}

There are no wildlife mitigation measures anticipated for this unit.

\section{RECREATION / VISUALS}

This unit has a proposed Voo of MM and is not seen from any viewpoint identified by this project.

\section{LANDS}

There are no lands mitigation measures anticipated for this unit.

CULTURAL RESOURCES

There are no cultural resource mitigation measures anticipated for this unit.

GEOLOGY

There are no karst mitigation measures anticipated for this unit. 


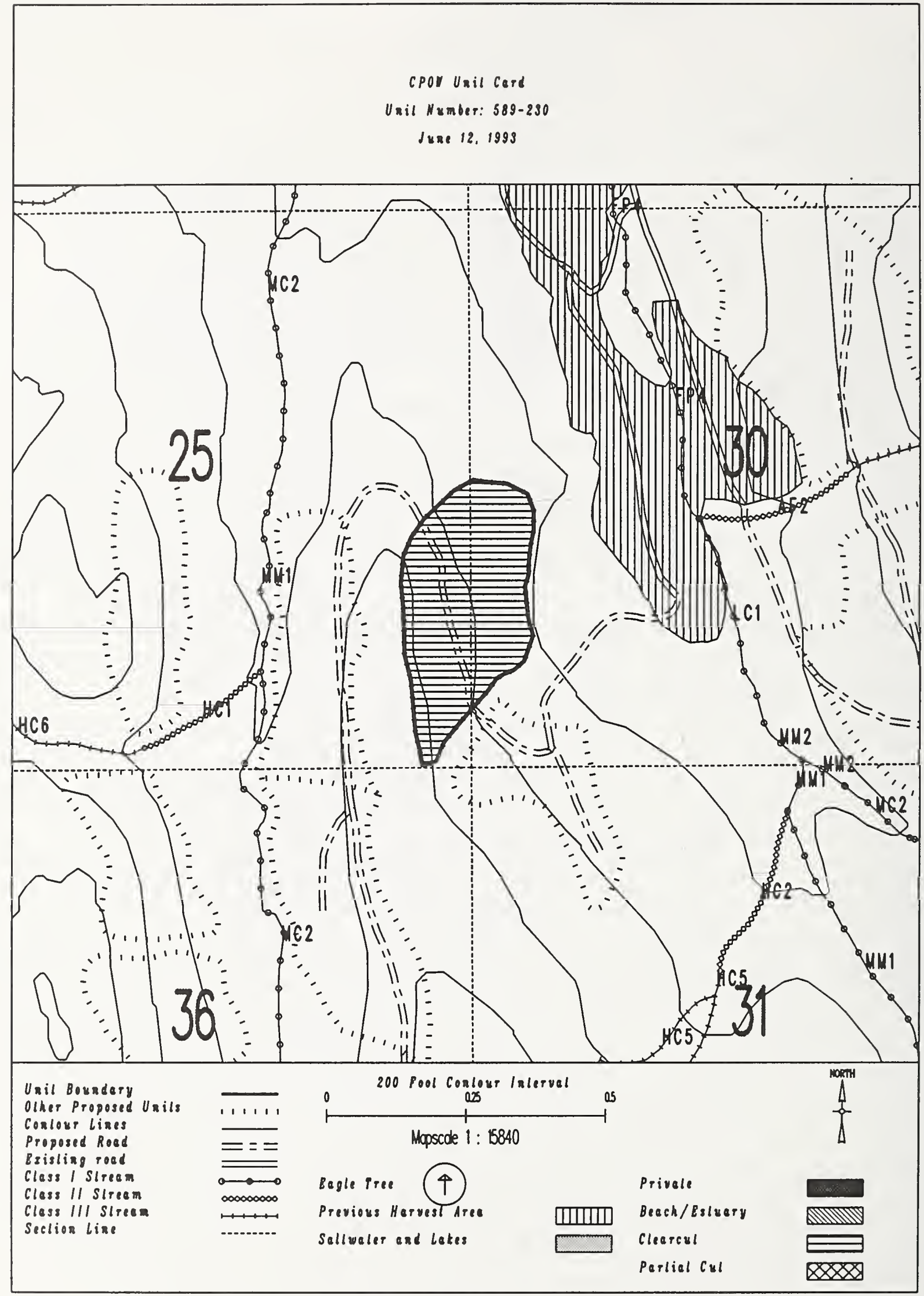




\section{Unit 589-231}

Planned acres 30

Estimated volume (mbf)

Logging system Highlead

silvicultural system clearcut

forest type Hemlock
Al ternatives considered

Quad CRGC4NWS

Mgmt Area $\mathrm{K} 07$

WAA 1422

Photo 1990055

Aspect East

\section{PHYSICAL DESCRIPTION}

Volume class breakdown: VC4 29 acres VC5 $\quad 0$ acres vC6 $\quad 0$ acres vC7 $\quad 0$ acres

Elevation breakdown: $0-800 \mathrm{ft} . \underline{26}$ acres $800-1200 \mathrm{ft} . \underline{0}$ acres $1200-1500 \mathrm{ft} . \underline{0}$ acres over $1500 \mathrm{ft}$. 0 acres Mass movement index: Low 6 acres Medium $\underline{0}$ acres High 23 acres Very High $\underline{0}$ acres

\section{SOILS}

This unit has high mass movement index soils. Partial log suspension required over these areas. (BMP13.9)

This unit contains 6 acres of forested wetlands. Site specific BMPs will be designed for selected approved

logging system and road construction practices. (BMPs 12.5, 13.9, 13.15).

\section{TIMBER}

There are no timber mitigation measures anticipated for this unit.

\section{ENGINEERING}

High mass movement index soils. Road construction must minimize landslide potential (BMP14).

\section{FISH/WATERSHED}

There are no fishery mitigation measures anticipated for this unit.

\section{WILDL IFE}

There are no wildlife mitigation measures anticipated for this unit.

\section{RECREATION / VISUALS}

This unit has a proposed VQO of MM and is not seen from any viewpoint identified by this project.

\section{LANDS}

There are no lands mitigation measures anticipated for this unit.

\section{CULTURAL RESOURCES}

There are no cultural resource mitigation measures anticipated for this unit.

\section{GEOLOGY}

There are no karst mitigation measures anticipated for this unit. 


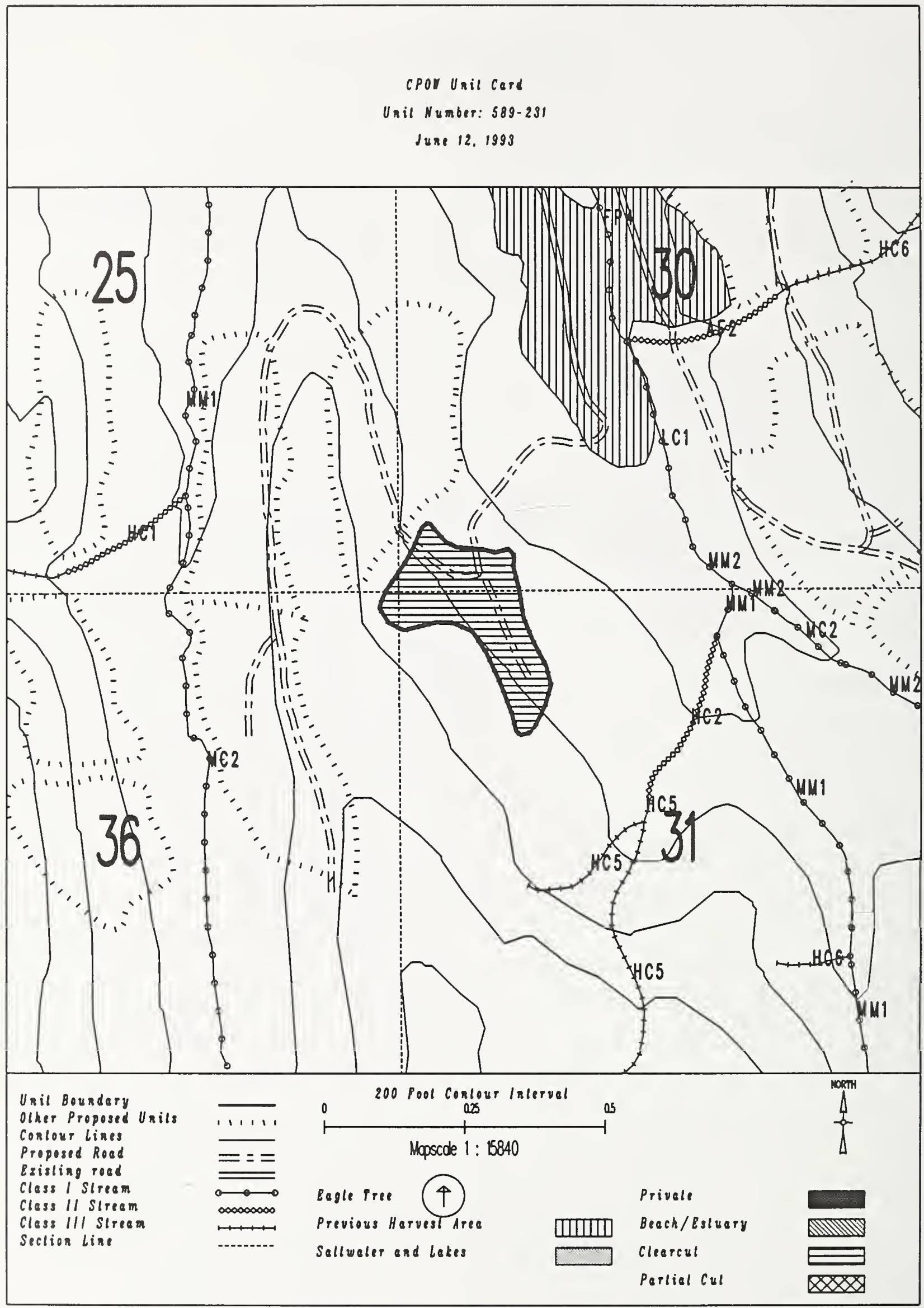


Unit $589-232$

Planned acres 37

Est imated volume (mbf) 1028

Logging system Highlead

silvicultural system clearcut

Forest type Hemlock
Alternatives considered

Quad CRGC4NWS

Mgmt Area $\mathrm{KOT}$

WAA 1422

Photo 1990055

Aspect West

\section{PHYSICAL DESCRIPTION}

Volume class breakdown: VC4 11 acres VC5 24 acres vC6 $\quad 0$ acres vc7 $\quad 0$ acres

Elevation breakdown: $0-800 \mathrm{ft} . \underline{35}$ acres $800-1200 \mathrm{ft} . \underline{1}$ acres $1200-1500 \mathrm{ft}$. 0 acres over $1500 \mathrm{ft}$. 0 acres Mass movement index: Low 14 acres Medium $\_$acres High 24 acres Very High 0

SOILS

This unit has high mass movement index soils. Partial log suspension required over these areas. (BMP13.9)

\section{TIMBER}

There are no timber mitigation measures anticipated for this unit.

\section{ENGINEER ING}

High mass movement index soils. Road construction must minimize landslide potential (BMP14).

\section{FISH/WATERSHED}

This unit contains streams which have recently been classified/channel typed but require field verification.

\section{WILDLIFE}

There are no wildlife mitigation measures anticipated for this unit.

\section{RECREATION / VISUALS}

This unit has a proposed VQo of MM and is not seen from any viewpoint identified by this project.

\section{LANDS}

There are no lands mitigation measures anticipated for this unit.

CULTURAL RESOURCES

There are no cultural resource mitigation measures anticipated for this unit.

There are no karst mitigation measures anticipated for this unit. 


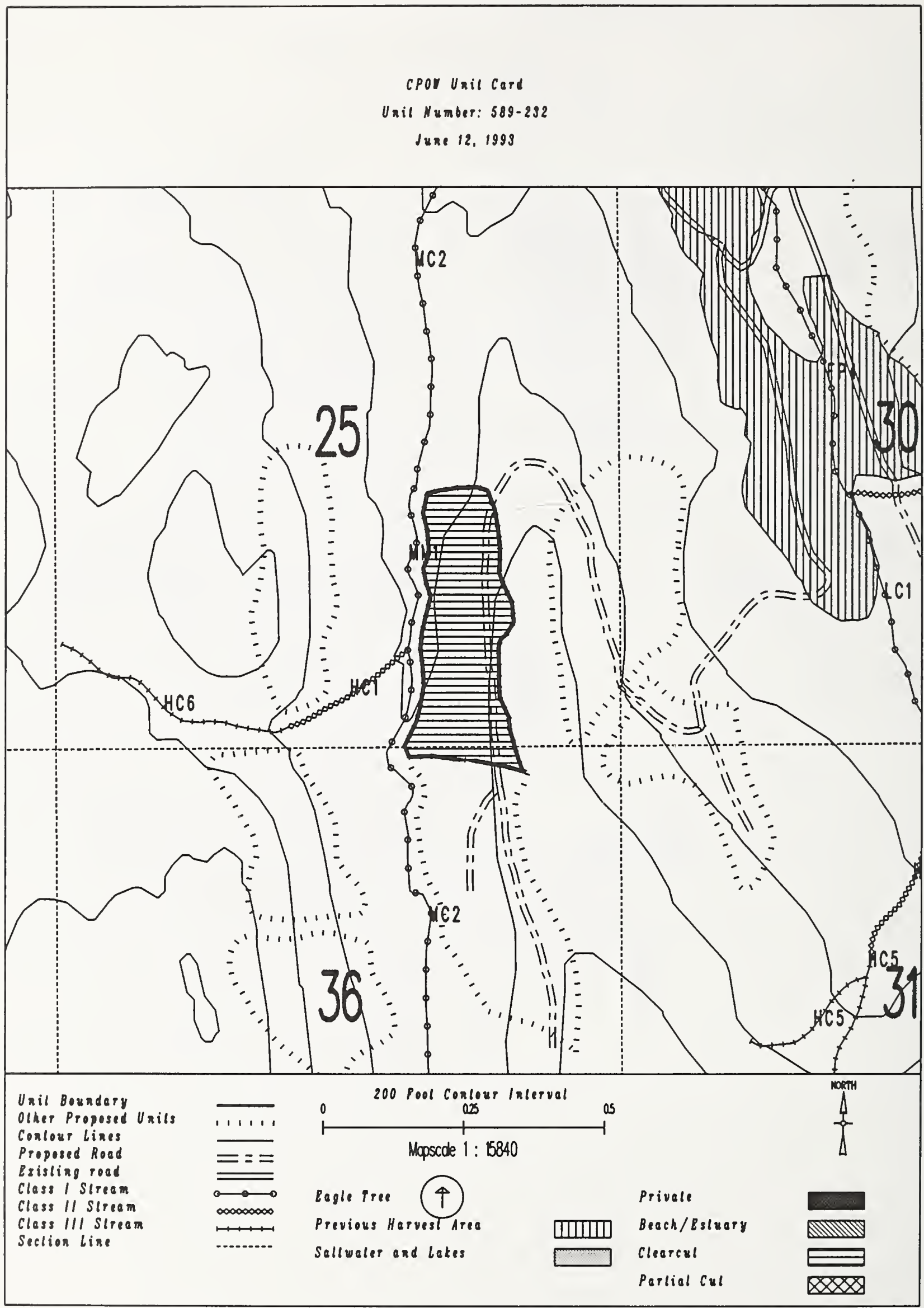


Unit $\quad 589-233$

Planned acres 52

Est imated volume (mbf) 1400

Logging system skyline

silvicultural system clearcut

Forest type Hemlock
Alternatives considered

Quad CRGC4NWS

Mgmt Area $\mathrm{KO7}$

WAA 1422

Photo 1990055

Aspect West

PHYSICAL DESCRIPTION

Volume class breakdown: VC4 34 acres VC5 20 acres vc6 $\quad 0$ acres vc7 $\quad 0$ acres

Elevation breakdown: $0-800 \mathrm{ft} . \underline{30}$ acres $800-1200 \mathrm{ft} . \underline{22}$ acres 1200-1500 ft. 0 acres over $1500 \mathrm{ft}$. 0 Mass movement index: Low $\underline{2}$ acres Medium $\underline{25}$ acres High 26 acres Very High $\underline{0}$ acres

SOILS

This unit has high mass movement index soils. Partial log suspension required over these areas. (BMP13.9)

This unit has < 40\% MCGilvery soils. Partial suspension required (BMP13.9) to ensure reforestation (BMP13.19).

This unit contains 25 acres of forested wetlands. Site specific BMPs will be designed for selected approved

logging system and road construction practices. (BMPs 12.5, 13.9, 13.15).

TIMBER

There are no timber mitigation measures anticipated for this unit.

ENGINEER ING

High mass movement index soils. Road construction must minimize landslide potential (BMP14).

FISH/WATERSHED

This unit contains streams which have recently been classified/channel typed but require field verification.

WILDLIFE

There are no wildlife mitigation measures anticipated for this unit.

RECREATION / VISUALS

This unit has a proposed voo of MM and is not seen from any viewpoint identified by this project.

\section{LANDS}

There are no lands mitigation measures anticipated for this unit.

CULTURAL RESOURCES

There are no cultural resource mitigation measures anticipated for this unit.

There are no karst mitigation measures anticipated for this unit. 


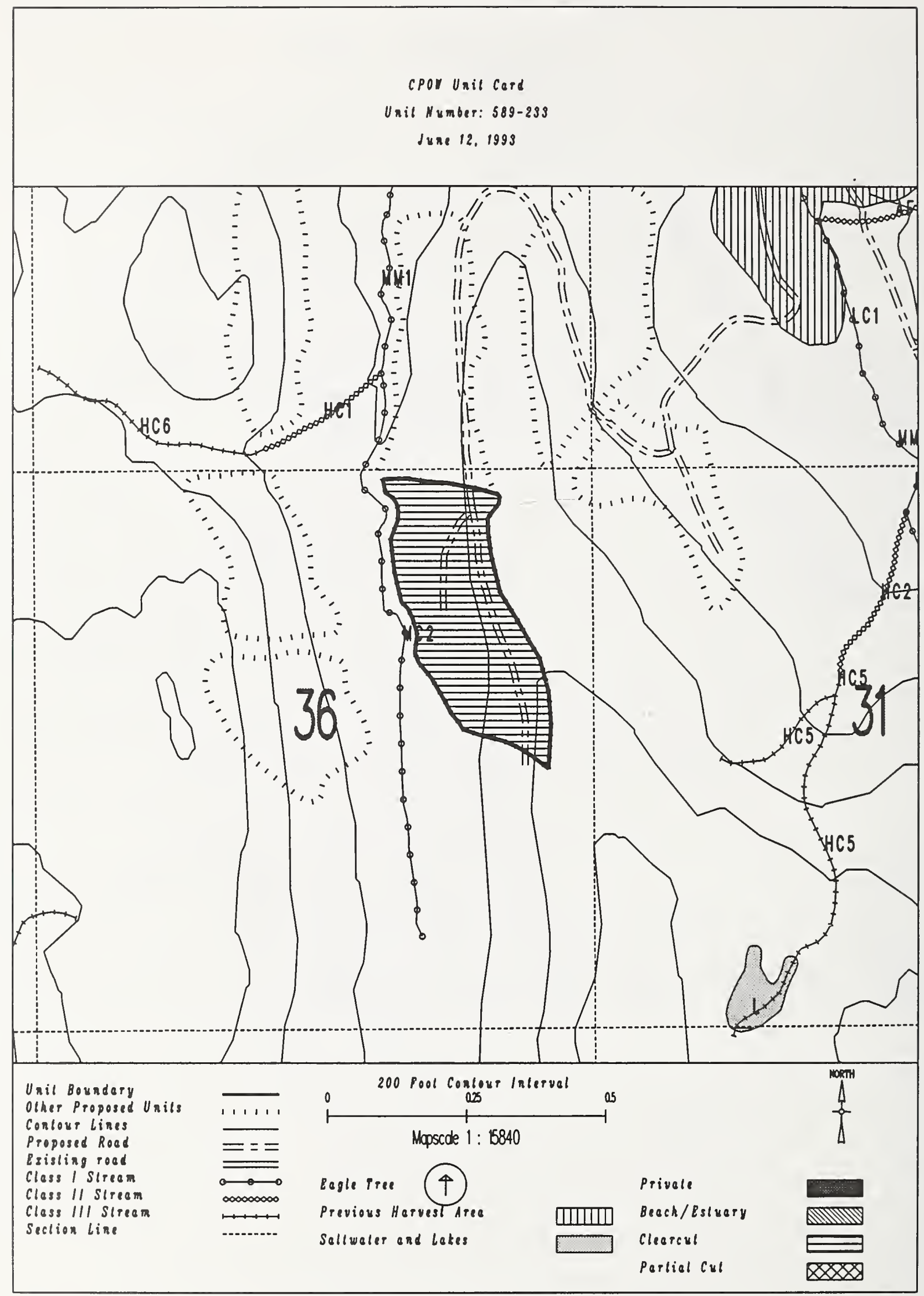


Unit $\quad$ 589-236

Planned acres 33

Est imated volume (mbf)

Logging system Helicopter

silvicultural system clearcut

Forest type Hemlock
Al ternatives considered

Quad CRGC4NHS

Mgmt Area $\mathrm{KO7}$

WAA 1422

Photo 1990055

Aspect East

\section{PHYSICAL DESCRIPTION}

Volume class breakdown: VC4 14 acres VC5 19 acres vC6 $\quad 0$ acres VC7 $\quad 0$ acres

Elevation breakdown: $0-800 \mathrm{ft} . \underline{10}$ acres $800-1200 \mathrm{ft} . \underline{20}$ acres $1200-1500 \mathrm{ft} . \underline{0}$ acres over $1500 \mathrm{ft} . \underline{0}$ acres Mass movement index: LoH 17 acres Medium 0 acres High 25 acres Very High 0

\section{SOILS}

This unit has high mass movement index soils. Partial log suspension required over these areas.(BMP13.9)

\section{TIMBER}

There are no timber mitigation measures anticipated for this unit.

\section{ENGINEER ING}

There are no engineering mitigation measures anticipated for this unit.

\section{FISH/WATERSHED}

There are no fishery mitigation measures anticipated for this unit.

\section{WILOLIFE}

There are no wildlife mitigation measures anticipated for this unit.

\section{RECREATION / VISUALS}

This unit has a proposed voo of MM and is not seen from any viewpoint identified by this project.

\section{LANDS}

There are no lands mitigation measures anticipated for this unit.

\section{CULTURAL RESOURCES}

There are no cultural resource mitigation measures anticipated for this unit.

\section{GEOLOGY}

There are no karst mitigation measures anticipated for this unit. 


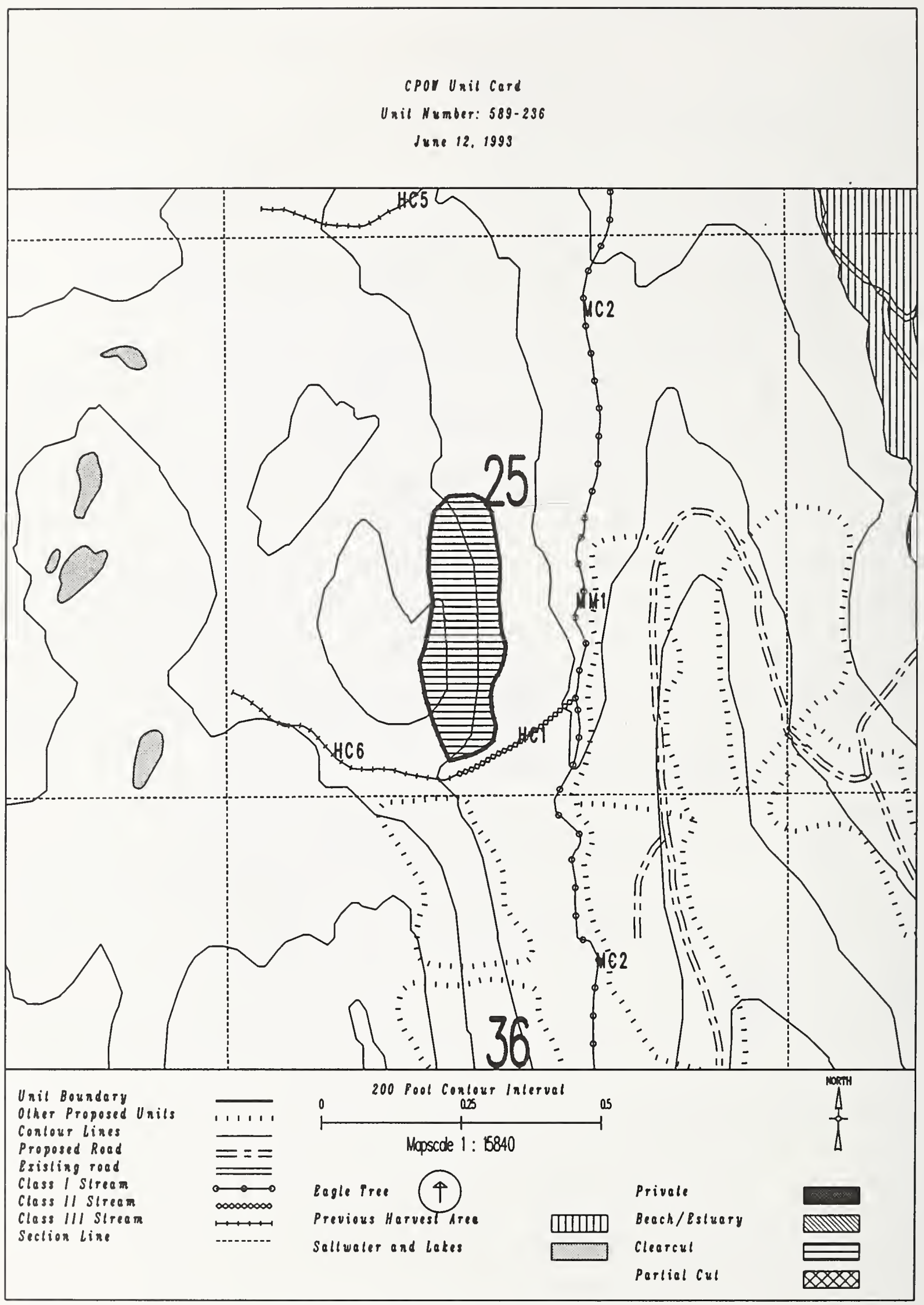


Unit $\quad 589-237$

Planned acres 31

Estimated volume (mbf) 907

Logging system Helicopter

silvicultural system Clearcut

Forest type Hemlock
Alternatives considered

Quad CRGC4NWS

Mgmt Area $\mathrm{KOT}$

WAA 1422

Photo 1990055

Aspect East

\section{PHYSICAL DESCRIPTION}

Volume class breakdown: VC4 10 acres VC5 21 acres vc6 $\quad 0$ acres vc7 $\quad 0$ acres

Elevation breakdown: $0-800 \mathrm{ft} .6 \frac{6}{6}$ acres $800-1200 \mathrm{ft} . \underline{19}$ acres $1200-1500 \mathrm{ft} . \underline{1}$ acres over $1500 \mathrm{ft}$. 0 acres Mass movement index: Low 2 acres Medium 1 acres High 27 acres Very High 0

\section{SOILS}

This unit has high mass movement index soils. Partial log suspension required over these areas. (BMP13.9)

\section{TIMBER}

There are no timber mitigation measures anticipated for this unit.

\section{ENGINEER ING}

There are no engineering mitigation measures anticipated for this unit.

\section{FISH/WATERSHED}

There are no fishery mitigation measures anticipated for this unit.

\section{WILDLIFE}

There are no wildlife mitigation measures anticipated for this unit.

\section{RECREATION / VISUALS}

This unit has a proposed VQO of MM and is not seen from any viewpoint identified by this project.

\section{LANDS}

There are no lands mitigation measures anticipated for this unit.

\section{CULTURAL RESOURCES}

There are no cultural resource mitigation measures anticipated for this unit.

There are no karst mitigation measures anticipated for this unit. 
cpor Unil cerd

Unil Number: 589-237

June 12, 1993

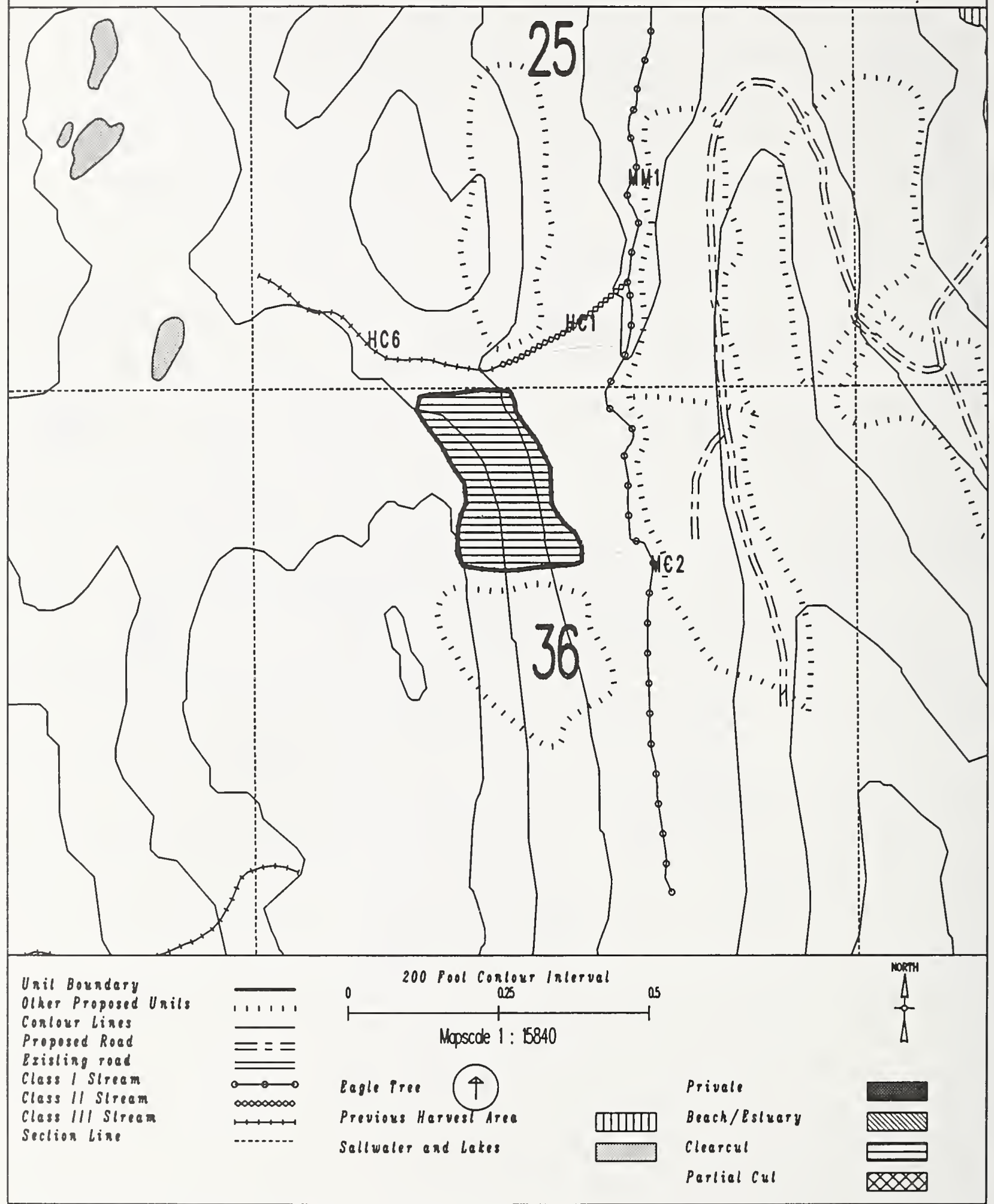


Unit $\quad 589-238$

Planned acres 31

Estimated volume (mbf) $\quad \mathbf{8 8 5}$

Logging system Helicopter

silvicultural system clearcut

Forest type Hemlock
Alternatives considered F5 F6

Quad CRGC4NWS

Mgmt Area $\mathrm{KO7}$

WAA 1422

Photo 1990055

Aspect East

\section{PHYSICAL DESCRIPTION}

Volume class breakdown: VC4 12 acres vC5 19 acres vC6 $\quad 0$ acres VC7 0 acres

Elevation breakdown: $0-800 \mathrm{ft} .4_{4}$ acres $800-1200 \mathrm{ft} .15$ acres $1200-1500 \mathrm{ft}$. 4 acres over $1500 \mathrm{ft}$. 0 acres Mass movement index: Low 1 acres Medium 23 acres High 4 acres Very High 0

\section{SOILS}

This unit has high mass movement index soils. Partial log suspension required over these areas.(BMP13.9)

This unit contains 24 acres of forested wetlands. Site specific BMPs will be designed for selected approved logging system and road construction practices. (BMPs 12.5, 13.9, 13.15).

\section{TIMBER}

There are no timber mitigation measures anticipated for this unit.

ENGINEER ING

There are no engineering mitigation measures anticipated for this unit.

\section{FISH/WATERSHED}

This unit contains streams which have recently been classified/channel typed but require field verification.

WILDLIFE

There are no wildlife mitigation measures anticipated for this unit.

RECREATION / VISUALS

This unit has a proposed VQO of MM and is not seen from any viewpoint identified by this project.

\section{LANDS}

There are no lands mitigation measures anticipated for this unit.

\section{CULTURAL RESOURCES}

There are no cultural resource mitigation measures anticipated for this unit.

There are no karst mitigation measures anticipated for this unit. 


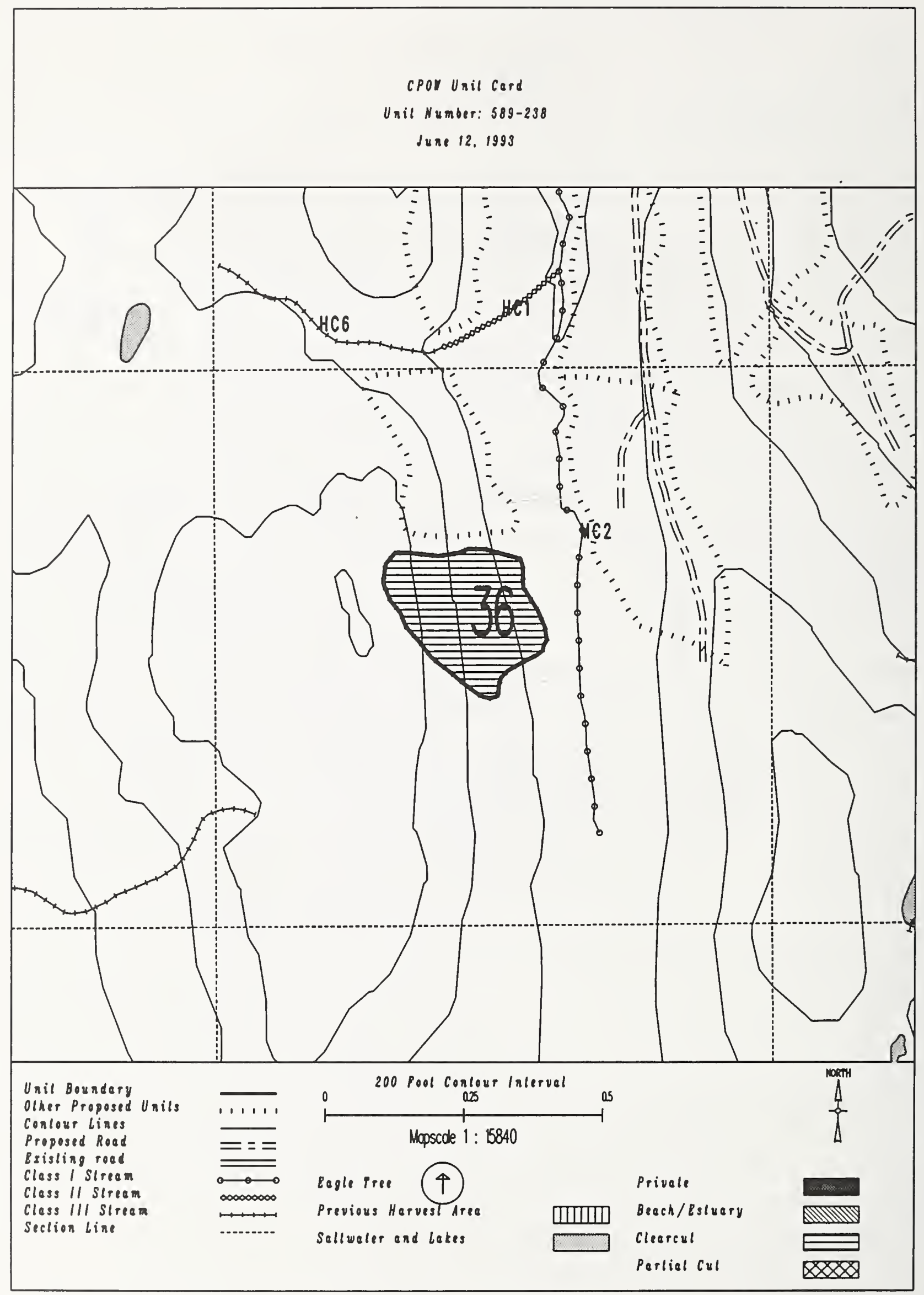


Unit 589-262

Planned acres 40

Estimated volume (mbf) 1278

Logging system skyline

silvicultural system clearcut

Forest type Hemlock
Alternatives considered \begin{tabular}{lllll} 
F2 & F3 & F4 & F6 \\
\hline
\end{tabular}

Quad CRGC4NWN

Mgmt Area $\mathrm{KO7}$

HAA 1422

Photo 790004

Aspect North

\section{PHYSICAL DESCRIPIION}

Volume class breakdown: VC4 17 acres VC5 16 acres vC6 $\quad 2$ acres vC7 6 acres

Elevation breakdown: $0-800 \mathrm{ft} . \underline{36}$ acres $800-1200 \mathrm{ft} . \quad 0$ acres $1200-1500 \mathrm{ft}$. 0 acres over $1500 \mathrm{ft}$. 0 Mass movement index: Low 13 acres Medium 0 acres High 13 acres Very High 0 acres

\section{SOILS}

This unit has high mass movement index soils. Partial log suspension required over these areas. (BMP13.9)

This unit contains 10 acres of forested wetlands. Site specific BMPs will be designed for selected approved

logging system and road construction practices. (BMPs 12.5, 13.9, 13.15).

This unit contains 26 acres of slopes $>75 \%$.

\section{TIMBER}

There are no timber mitigation measures anticipated for this unit.

\section{ENGINEER ING}

High mass movement index soils. Road construction must minimize landslide potential (BMP14). Slopes greater than $75 \%$ may require full bench construction and endhaul of waste (BMP14.7).

\section{FISH/WATERSHED}

This unit contains streams which have recently been classified/channel typed but require field verification.

\section{WILDLIFE}

There are no wildlife mitigation measures anticipated for this unit.

RECREATION / VISUALS

The unit has a proposed voO of MM within the viewshed of Shaheen Creek as viewed from 2 mile from west coast of Prince of Wales.

\section{LANDS}

There are no lands mitigation measures anticipated for this unit.

CULTURAL RESOURCES

There are no cultural resource mitigation measures anticipated for this unit. 


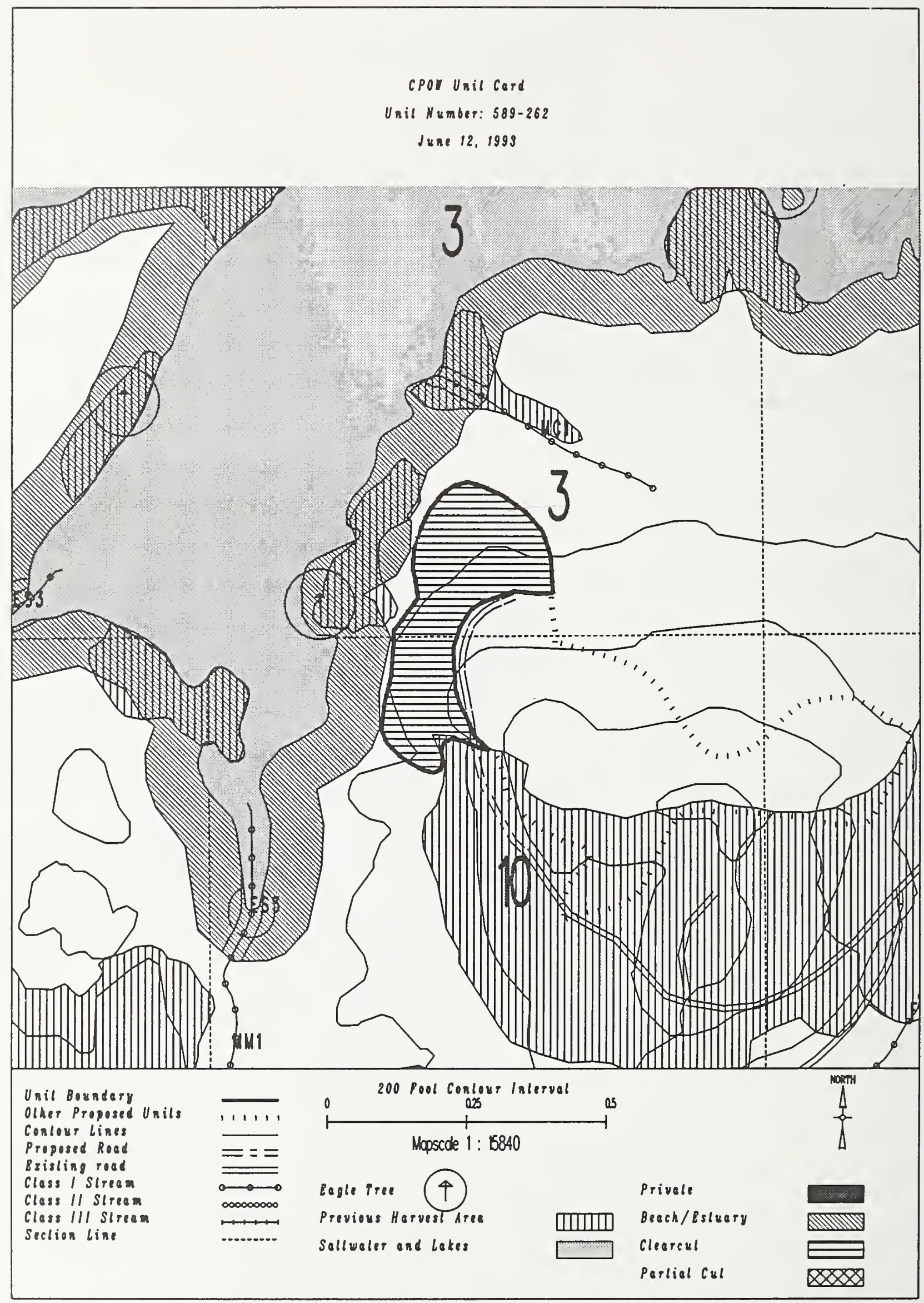


Unit $589-263$

Planned acres 9

Estimated volume (mbf)

Logging system Highlead

silvicultural system clearcut

Forest type Hemlock
Alternatives considered

Quad CRGC4NWN

Mgmt Area $\mathrm{KOT}$

WAA 1422

Photo 1990083

Aspect North

PHYSICAL DESCRIPTION

Volume class breakdown: VC4 $\quad 9$ acres VC5 $\quad 0$ acres vC6 $\quad 0$ acres vC7 $\quad 0$ acres

Elevation breakdown: $0-800 \mathrm{ft} . \quad 8$ acres $800-1200 \mathrm{ft} . \underline{0}$ acres $1200-1500 \mathrm{ft} . \underline{0}$ acres over $1500 \mathrm{ft}$. 0 acres Mass movement index: Low 0 acres Medium 0 acres High 8 acres Very High 0

SOILS

This unit has high mass movement index soils. Partial log suspension required over these areas. (BMP13.9)

This unit contains $\_$acres of forested wetlands. Site specific BMPs will be designed for selected approved

logging system and road construction practices. (BMPs 12.5, 13.9, 13.15).

\section{TIMBER}

There are no timber mitigation measures anticipated for this unit.

\section{ENGINEER ING}

High mass movement index soils. Road construction must minimize landslide potential (BMP14).

\section{FISH/WATERSHED}

There are no fishery mitigation measures anticipated for this unit.

\section{WILDLIFE}

There are no wildlife mitigation measures anticipated for this unit.

\section{RECREATION / VISUALS}

The unit has a proposed VQO of MM within the viewshed of Shaheen Creek

as viewed from 2 mile from west coast of Prince of Wales.

\section{LANDS}

There are no lands mitigation measures anticipated for this unit.

CULTURAL RESOURCES

There are no cultural resource mitigation measures anticipated for this unit.

There are no karst mitigation measures anticipated for this unit. 
CPOr Unil Cerd

Unil Number: 589-263

June 12, 1993

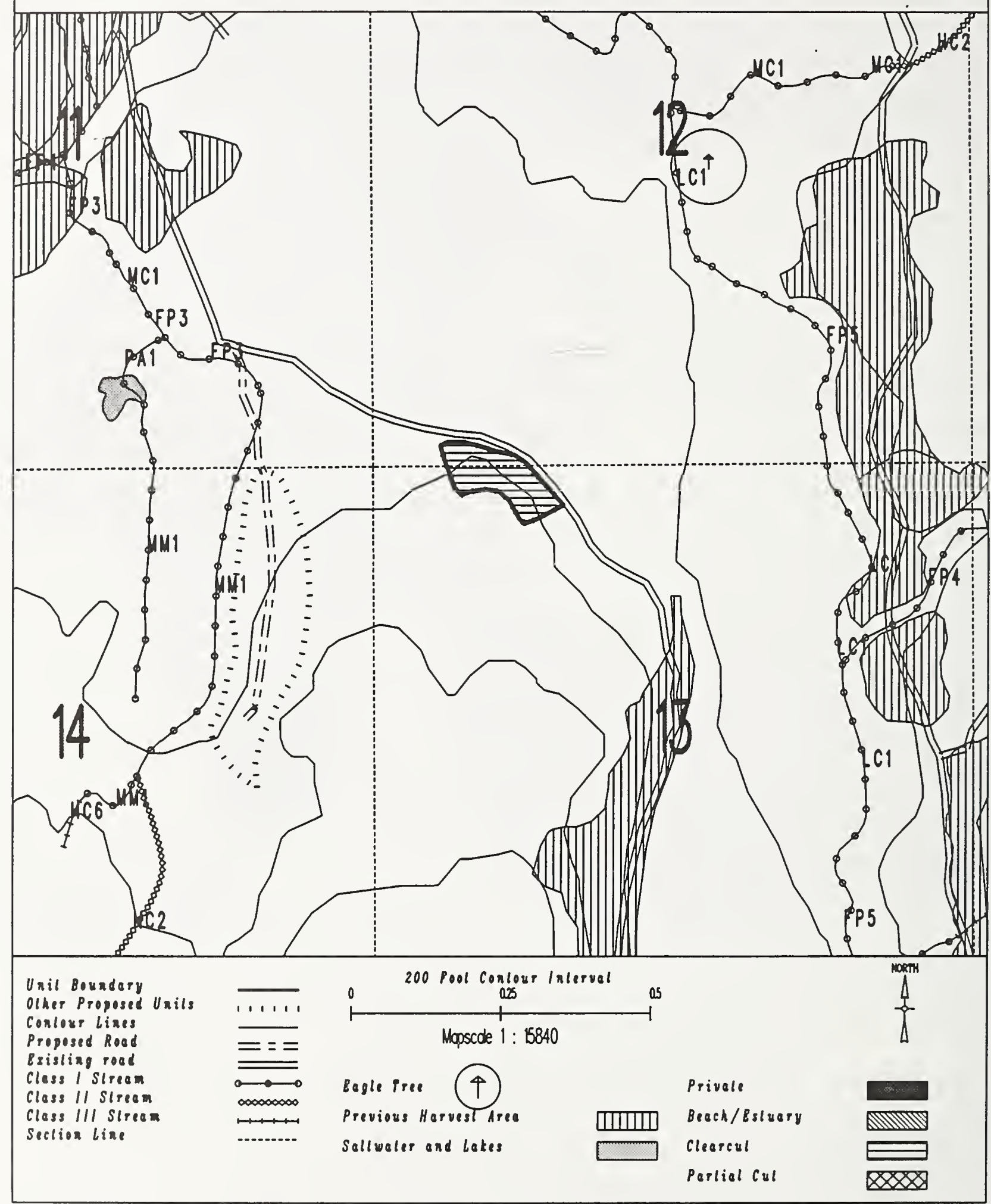


Unit $\quad 589-271$

Planned acres 32

Estimated volume (mbf)

Logging system Helicopter

silvicultural system Clearcut

Forest type Hemlock
Alternatives considered

Quad CRGC4NWN

Mgmt Area $\mathrm{KOT}$

WAA 1422

Photo 1990053

Aspect West

PHYSICAL DESCRIPTION

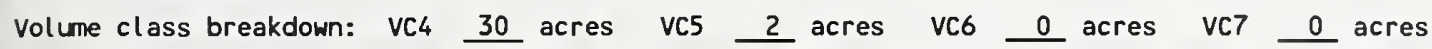

Elevation breakdown: $0-800 \mathrm{ft} . \underline{16}$ acres $800-1200 \mathrm{ft} . \underline{12}$ acres $1200-1500 \mathrm{ft} . \underline{0}$ acres over $1500 \mathrm{ft} . \underline{0}$ acres Mass movement index: Low $\underline{0}$ acres Medium 1 acres High $\underline{29}$ acres Very High 0

SOILS

This unit has high mass movement index soils. Partial log suspension required over these areas. (BMP13.9)

This unit contains 28 acres of forested wetlands. Site specific BMPs will be designed for selected approved

logging system and road construction practices. (BMPs 12.5, 13.9, 13.15).

TIMBER

There are no timber mitigation measures anticipated for this unit.

ENGINEERING

There are no engineering mitigation measures anticipated for this unit.

FISH/WATERSHED

This unit contains streams which have recently been classified/channel typed but require field verification.

WILDLIFE

There are no wildlife mitigation measures anticipated for this unit.

RECREATION / VISUALS

This unit has a proposed voo of MM and is not seen from any viewpoint identified by this project.

\section{LANDS}

There are no lands mitigation measures anticipated for this unit.

CULTURAL RESOURCES

There are no cultural resource mitigation measures anticipated for this unit

There are no karst mitigation measures anticipated for this unit. 
cPor Unil cerd

Unil Number: 589-271

June 12, 1993

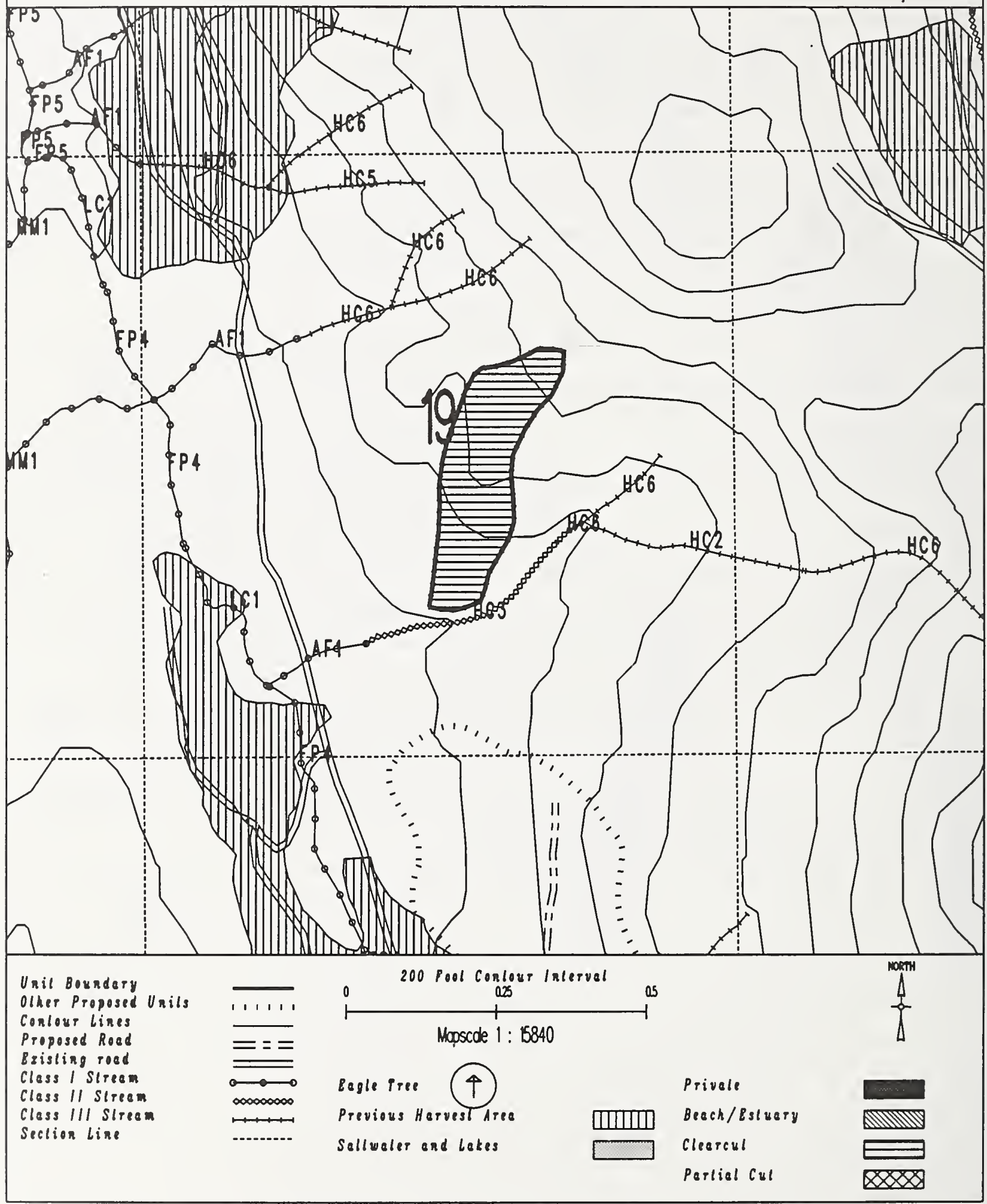


Unit 589-273

Planned acres 77

Estimated volume (mbf) 1749

Logging system slackline

Silvicultural system Clearcut

forest type Mixed conifer
Alternatives considered

Quad CRGC4NWN

Mgmt Area $\underline{\mathrm{KOT}}$

WAA 1422

Photo 1990054

Aspect West

\section{PHYSICAL DESCRIPTION}

Volume class breakdown: VC4 $\quad 8$ acres vC5 48 acres vC6 $\quad 0$ acres vc7 $\quad 0$ acres

Elevation breakdown: $0-800 \mathrm{ft} .60$ acres $800-1200 \mathrm{ft} . \underline{8}$ acres $1200-1500 \mathrm{ft}$. 0 acres over $1500 \mathrm{ft}$. 0 acres Mass movement index: Low 14 acres Medium 10 acres High 52 acres Very High 0 acres

\section{SOILS}

This unit has high mass movement index soils. Partial log suspension required over these areas.(BMP13.9)

This unit contains 24 acres of forested wetlands. Site specific BMPs will be designed for selected approved

logging system and road construction practices. (BMPs 12.5, 13.9, 13.15).

\section{TIMBER}

There are no timber mitigation measures anticipated for this unit.

\section{ENGINEER ING}

High mass movement index soils. Road construction must minimize landslide potential (BMP14).

\section{FISH/WATER SHED}

This unit contains streams which have recently been classified/channel typed but require field verification.

\section{HILDLIFE}

There are no wildlife mitigation measures anticipated for this unit.

\section{RECREATION / VISUALS}

The unit has a proposed Voo of MM within the viewshed of Shaheen Creek

as viewed from 2 mile from west coast of Prince of Wales.

\section{LANDS}

There are no lands mitigation measures anticipated for this unit.

\section{CULTURAL RESOURCES}

There are no cultural resource mitigation measures anticipated for this unit.

\section{GEOLOGY}

There are no karst mitigation measures anticipated for this unit. 


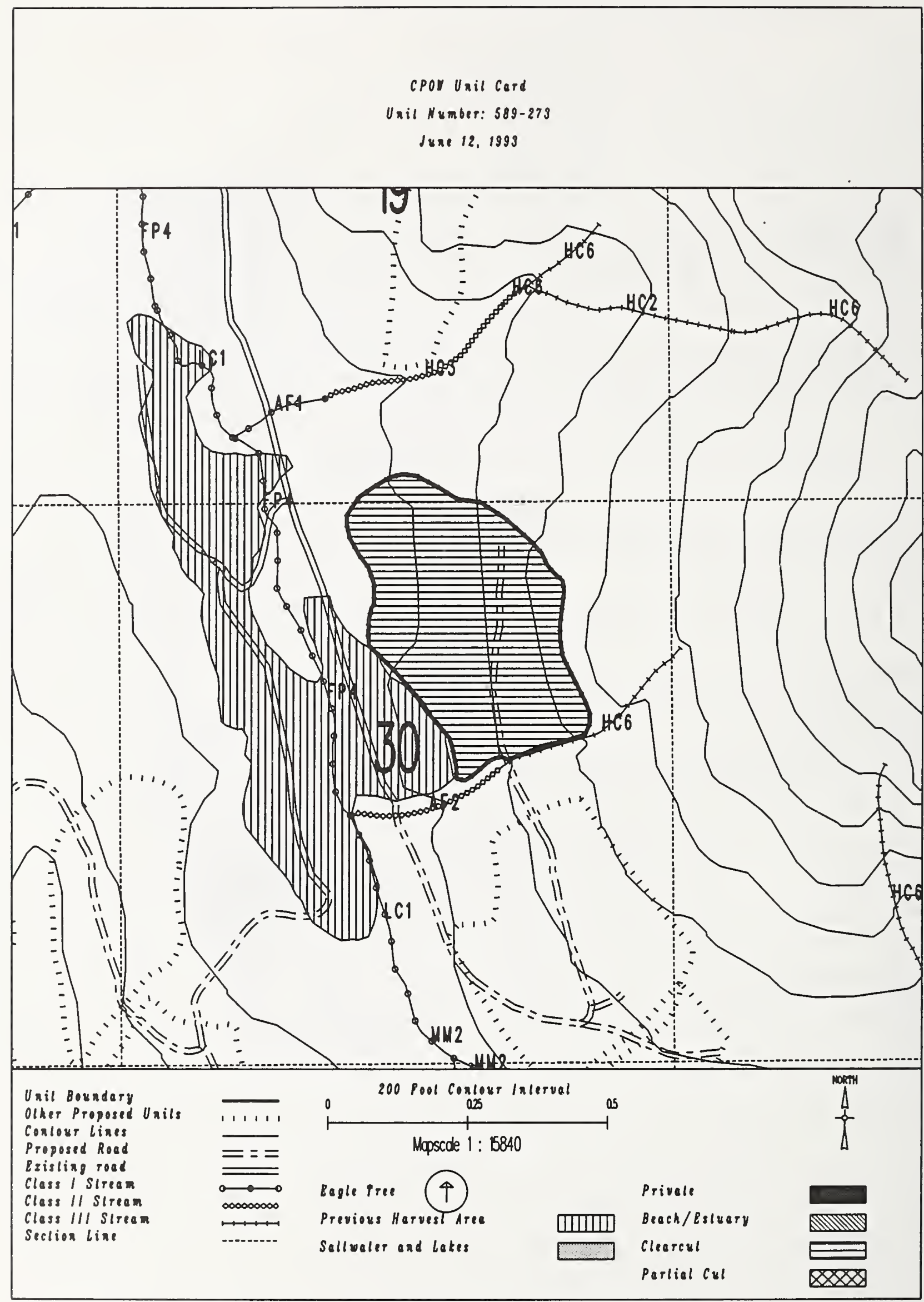


Unit 589-274

Planned acres 73

Estimated volume (mbf) 2219

Logging system slackline

silvicultural system clearcut

Forest type Hemlock

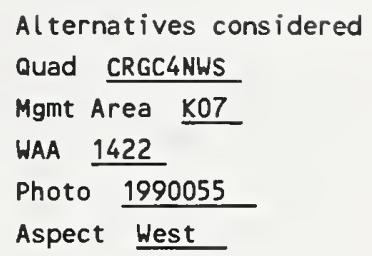

This unit has high mass movement index soils. Partial log suspension required over these areas. (BMP13.9) This unit contains 26 acres of forested wetlands. Site specific BMPs will be designed for selected approved logging system and road construction practices. (BMPs 12.5, 13.9, 13.15).

TIMBER

There are no timber mitigation measures anticipated for this unit.

\section{ENG INEER ING}

High mass movement index soils. Road construction must minimize landslide potential (BMP14).

The road into this unit crosses a $\underline{C 2}$ channel. Meet stream and lake protection prescription requirements in TLMP Draft Revision (1991a) for this process group.

\section{FISH/HATERSHED}

Potential for additional Class I/II streams within unit. May be necessary to place additional buffers within unit in accordance with AHMU Handbook.

This unit contains streams which have recently been classified/channel typed but require field verification.

\section{WILDLIFE}

There are no wildlife mitigation measures anticipated for this unit.

\section{RECREATION / VISUALS}

This unit has a proposed Voo of MM and is not seen from any viewpoint identified by this project.

\section{LANDS}

There are no lands mitigation measures anticipated for this unit.

\section{CULTURAL RESOURCES}

There are no cultural resource mitigation measures anticipated for this unit.

\section{GEOLOGY}

There are no karst mitigation measures anticipated for this unit. 


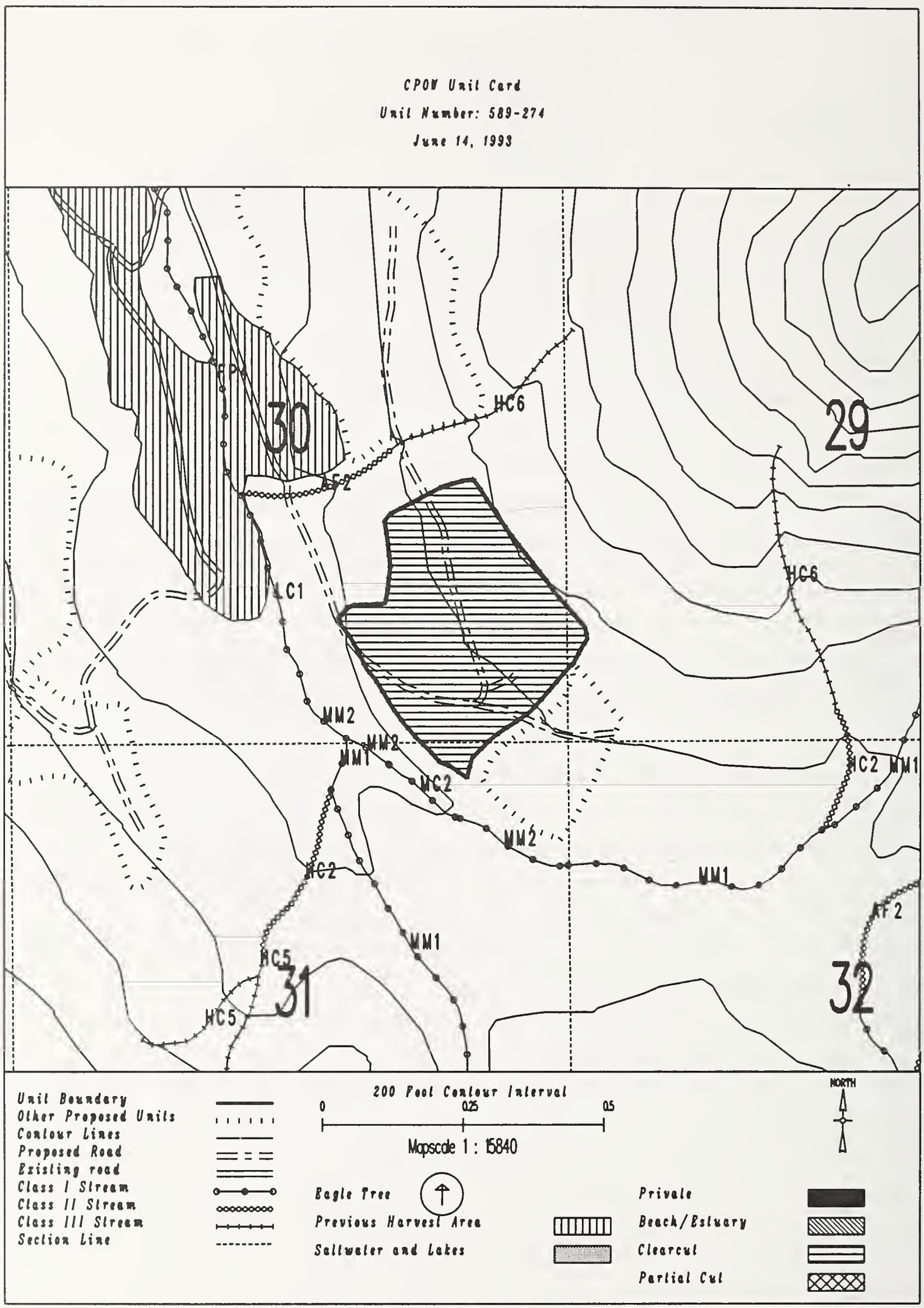


Unit $\quad 589-275$

Planned acres 20

Estimated volume (mbf) $\quad 524$

Logging system Highlead

silvicultural system clearcut

Forest type Hemlock
Alternatives considered

Quad CRGC4NWS

Mgmt Area $\mathrm{KOT}$

WAA 1422

Photo 1990055

Aspect South

PHYSICAL DESCRIPTION

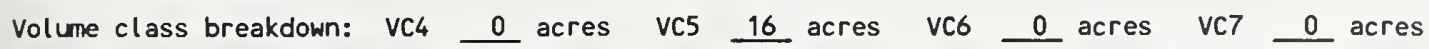

Elevation breakdown: $0-800 \mathrm{ft} . \underline{20}$ acres $800-1200 \mathrm{ft} . \underline{0}$ acres $1200-1500 \mathrm{ft} . \underline{0}$ acres over $1500 \mathrm{ft} . \quad 0$ acres Mass movement index: Low 3 acres Medium 0 acres High 17 acres Very High 0 acres

SOILS

This unit has high mass movement index soils. Partial log suspension required over these areas. (BMP13.9)

This unit contains 13 acres of forested wetlands. Site specific BMPs will be designed for selected approved

logging system and road construction practices. (BMPs 12.5, 13.9, 13.15).

\section{TIMBER}

There are no timber mitigation measures anticipated for this unit.

\section{ENGINEER ING}

High mass movement index soils. Road construction must minimize landslide potential (BMP14).

The road into this unit crosses a $\underline{C 2}$ channel. Meet stream and lake protection prescription requirements in TLMP Draft Revision (1991a) for this process group.

\section{FISH/WATERSHED}

Potential for additional Class I/II streams within unit. May be necessary to place additional buffers within unit in accordance with AHMU Handbook.

\section{WILDLIFE}

There are no wildlife mitigation measures anticipated for this unit.

\section{RECREATION / VISUALS}

This unit has a proposed Voo of MM and is not seen from any viewpoint identified by this project.

\section{LANDS}

There are no lands mitigation measures anticipated for this unit.

CULTURAL RESOURCES

There are no cultural resource mitigation measures anticipated for this unit.

There are no karst mitigation measures anticipated for this unit. 
cpor Unil cerd

Unil Number: 589-275

June 12. 199:

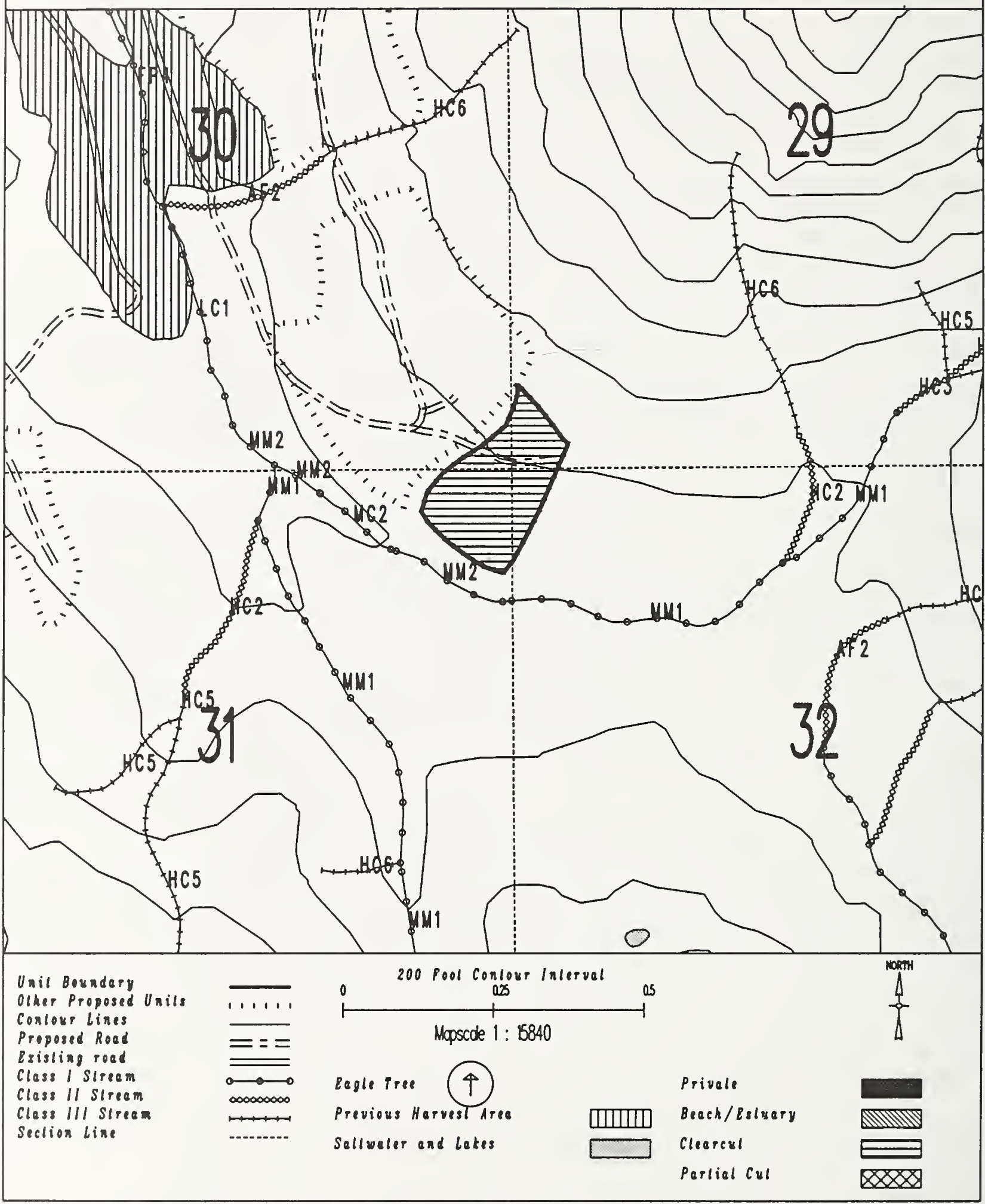


Unit $590-201$

Planned acres 49

Estimated volume (mbf) 1617

Logging system Helicopter

silvicultural system Clearcut

Forest type Mixed conifer
Alternatives considered F2 F4 F5 F6

Quad CRGC4NEN

Mgmt Area $\mathrm{KO7}$

WAA 1422

Photo 1190042

Aspect East

PHYSICAL DESCRIPTION

Volume class breakdown: VC4 $\quad 0$ acres VC5 $\quad \begin{aligned} & 47 \\ & \text { acres }\end{aligned}$ VC6 $\quad 2$ acres vC7 $\quad 0$ acres

Elevation breakdown: $0-800 \mathrm{ft} .{ }_{0}^{0}$ acres $800-1200 \mathrm{ft} . \underline{0}$ acres $1200-1500 \mathrm{ft} . \underline{0}$ acres over $1500 \mathrm{ft}$. 47 acres

Mass movement index: Low 1 acres Medium $\underline{0}$ acres High 23 acres Very High 0

SOILS

This unit has high mass movement index soils. Partial log suspension required over these areas.(BMP13.9)

This unit contains 47 acres of slopes $>75 \%$.

TIMBER

There are no timber mitigation measures anticipated for this unit.

ENG I NEER ING

There are no engineering mitigation measures anticipated for this unit.

\section{FI SH/WATER SHED}

There are no fishery mitigation measures anticipated for this unit.

\section{WI LDLI FE}

There are no wildlife mitigation measures anticipated for this unit.

RECREATION / VISUALS

This unit has a proposed VQO of MM and is not seen from any viewpoint identified by this project.

\section{LANDS}

There are no lands mitigation measures anticipated for this unit.

CULTURAL RESOURCES

There are no cultural resource mitigation measures anticipated for this unit.

There are no karst mitigation measures anticipated for this unit. 


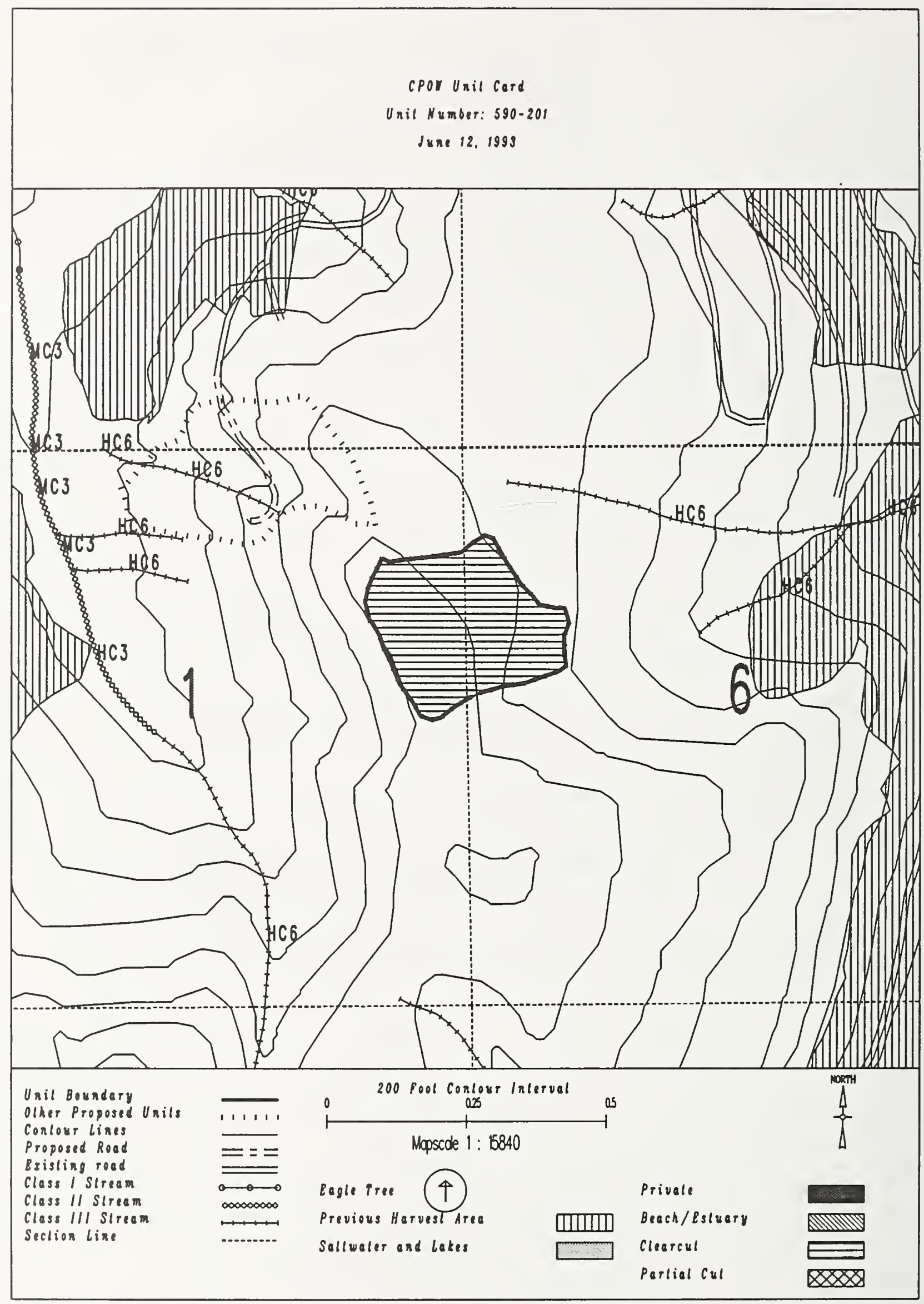




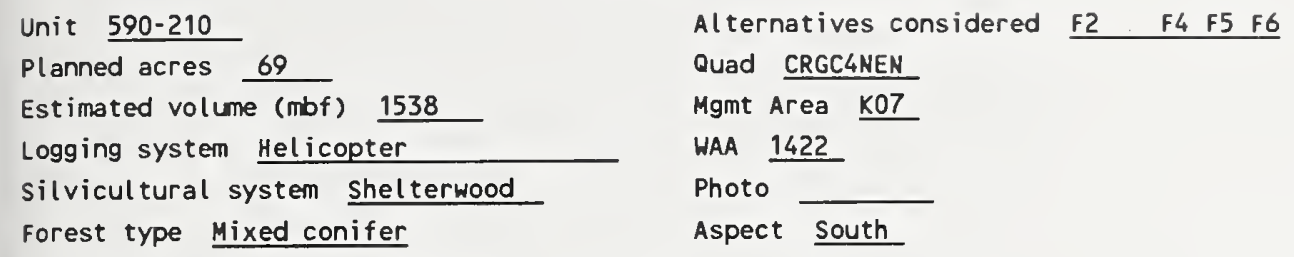

This unit has a proposed voo of MM and is not seen from any viewpoint identified by this project.

LANDS

There are no lands mitigation measures anticipated for this unit.

CULTURAL RESOURCES

There are no cultural resource mitigation measures anticipated for this unit. 


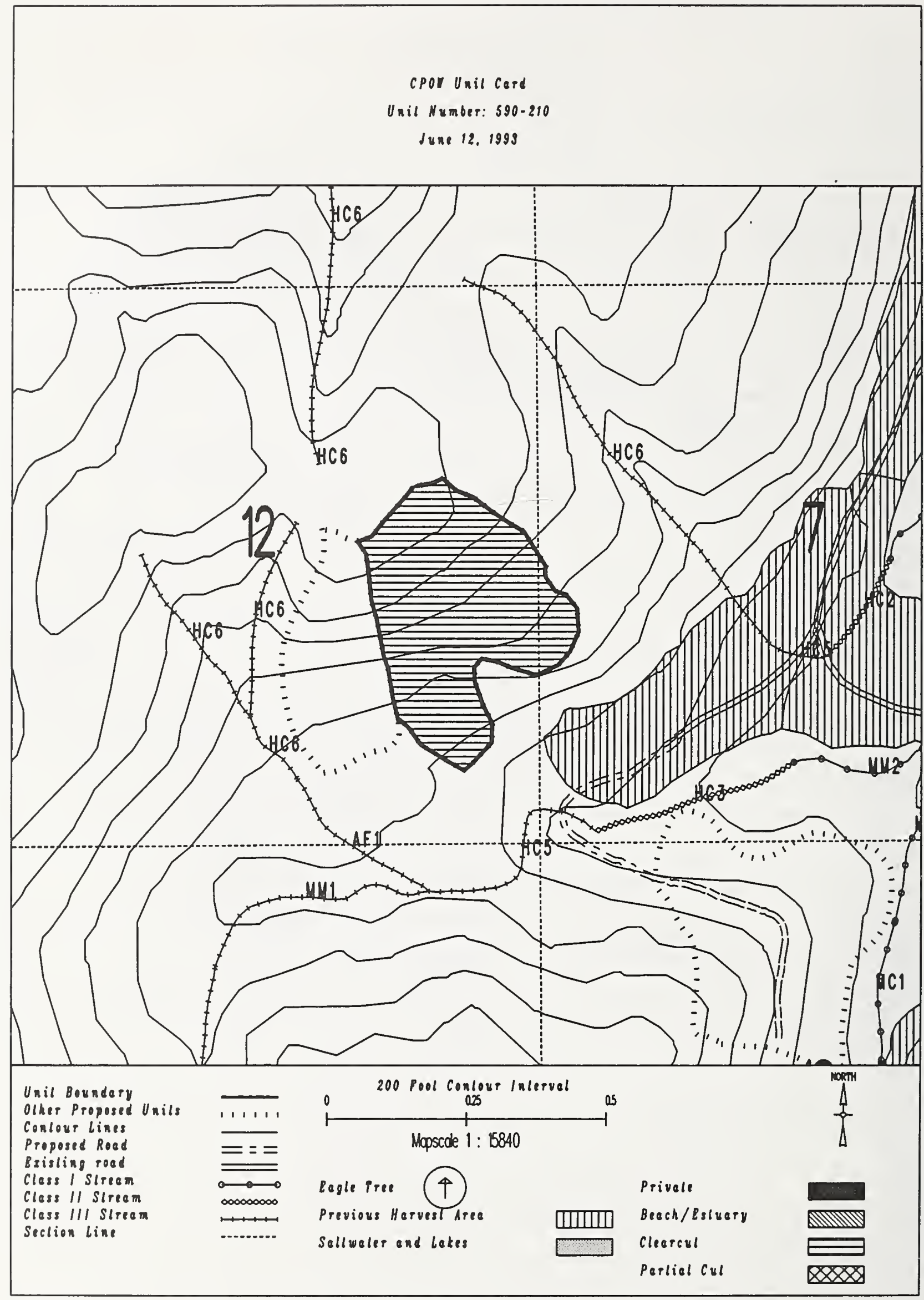




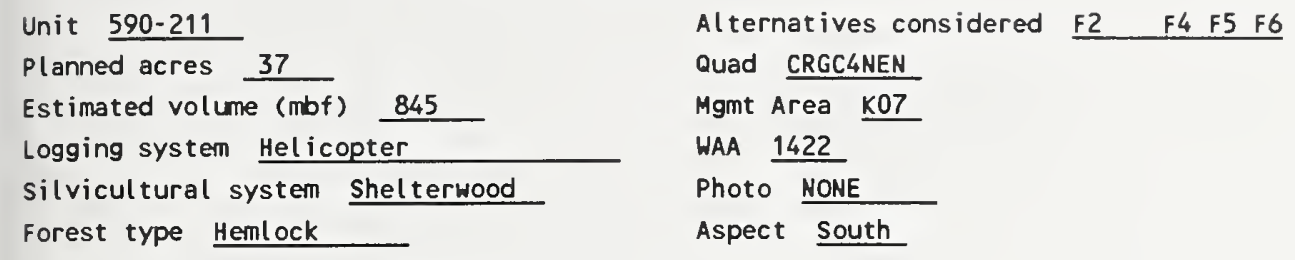

This unit contains streams which have recently been classified/channel typed but require field verification.

HILDLIFE

Maintain diversity within unit by leaving 1-5 acre-sized islands of green trees at a rate of 1 acre of island for every 20 acres harvested. Leave islands must be compatible with logging system and safe working conditions.

RECREATION / VISUALS

This unit has a proposed VQO of MM and is not seen from any viewpoint identified by this project.

\section{LANDS}

There are no lands mitigation measures anticipated for this unit.

\section{CULTURAL RESOURCES}

There are no cultural resource mitigation measures anticipated for this unit.

\section{GEOLOGY}

There are no karst mitigation measures anticipated for this unit. 


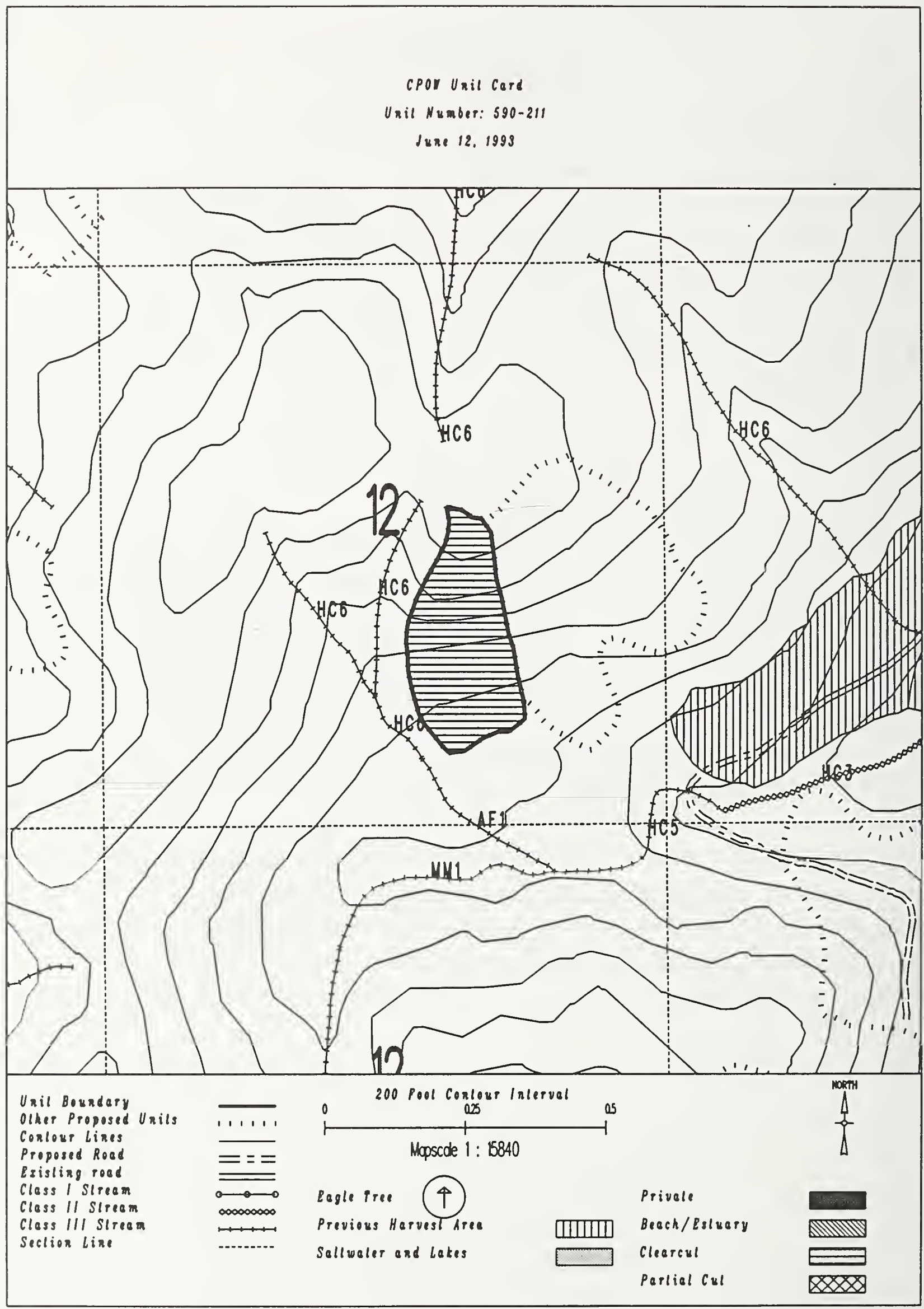


Unit $\quad 590-217$

Planned acres 81

Estimated volume (mbf) 2760

Logging system slackline

silvicultural system clearcut

Forest type Mixed conifer

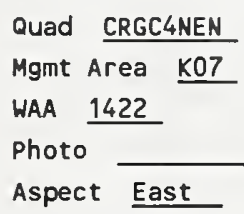

PHYSICAL DESCRIPTION

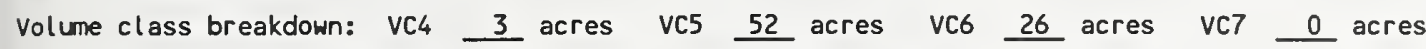

Elevation breakdown: $0-800 \mathrm{ft} . \underline{56}$ acres $800-1200 \mathrm{ft} . \underline{9}$ acres $1200-1500 \mathrm{ft} . \overline{3}$ acres over $1500 \mathrm{ft} . \underline{0}$ acres Mass movement index: Low 0 acres Medium 0 acres High 63 acres Very High 0 acres

SOILS

This unit has high mass movement index soils. Partial log suspension required over these areas.(BMP13.9)

This unit has a significant possibility to have areas reclassified as MMI $=4$.

This unit has > 40\% MCGilvery soils. Partial suspension required (BMP13.9)

to ensure reforestation (BMP13.19).

This unit contains 32 acres of slopes $>75 \%$.

TIMBER

There are no timber mitigation measures anticipated for this unit.

ENG INEER ING

High mass movement index soils. Road construction must minimize landslide potential (BMP14).

Slopes greater than $75 \%$ may require full bench construction and endhaul of waste (BMP 14.7).

FISH/WATERSHED

This unit contains streams which have recently been classified/channel typed but require field verification.

WILDLIFE

There are no wildlife mitigation measures anticipated for this unit.

RECREATION / VISUALS

This unit has a proposed VQO of MM and is not seen from any viewpoint identified by this project.

LANDS

There are no lands mitigation measures anticipated for this unit.

CULTURAL RESOURCES

There are no cultural resource mitigation measures anticipated for this unit.

GEOLOGY

There are no karst mitigation measures anticipated for this unit. 


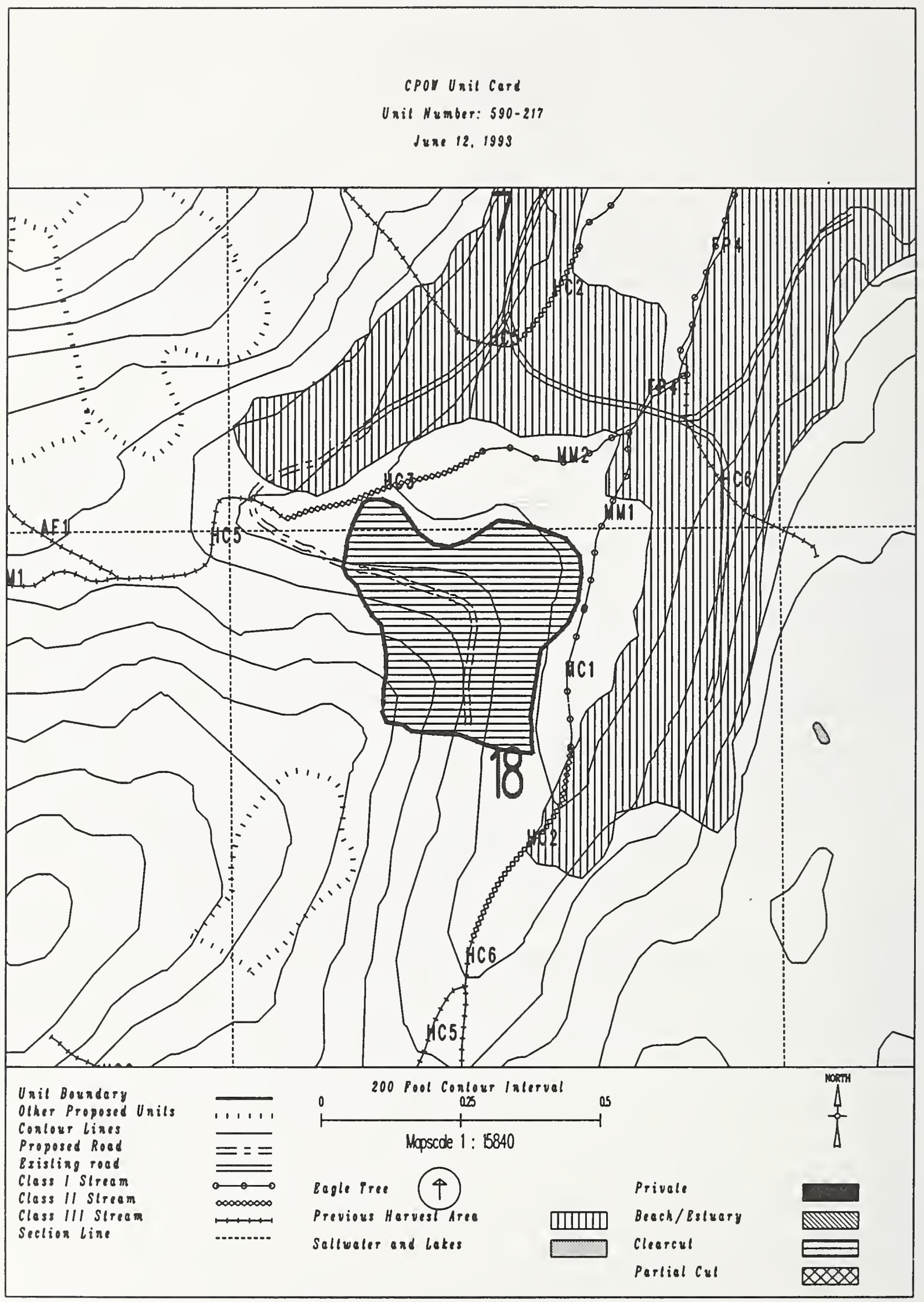


Unit 590-219

Planned acres 36

Estimated volume (mbf) 769

Logging system Helicopter

silvicultural system Shelterwood

Forest type Mixed conifer

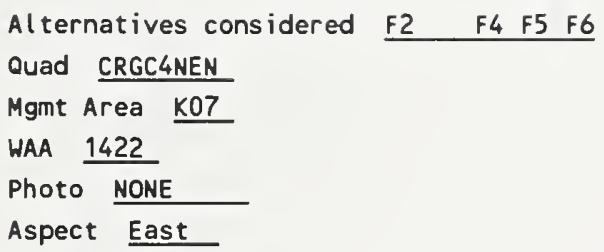

PHYSICAL DESCRIPTION

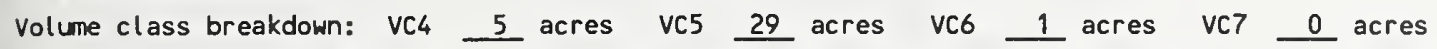

Elevation breakdown: $0-800 \mathrm{ft} . \underline{0}$ acres $800-1200 \mathrm{ft} . \underline{0}$ acres $1200-1500 \mathrm{ft} . \underline{0}$ acres over $1500 \mathrm{ft} . \underline{30}$ acres Mass movement index: Low 0 acres Medium 0 acres High 17 acres Very High 0 acres

SOILS

This unit has high mass movement index soils. Partial log suspension required over these areas.(BMP13.9)

This unit contains 34 acres of slopes $>75 \%$.

TIMBER

Shelterwood harvest. Cedar will not be harvested.

ENGINEERING

There are no engineering mitigation measures anticipated for this unit.

FISH/WATERSHED

This unit contains streams which have recently been classified/channel typed but require field verification.

WILDLIFE

There are no wildlife mitigation measures anticipated for this unit.

RECREATION / VISUALS

This unit has a proposed voo of MM and is not seen from any viewpoint identified by this project.

\section{LANDS}

There are no lands mitigation measures anticipated for this unit.

CULTURAL RESOURCES

There are no cultural resource mitigation measures anticipated for this unit.

GEOLOGY

There are no karst mitigation measures anticipated for this unit. 


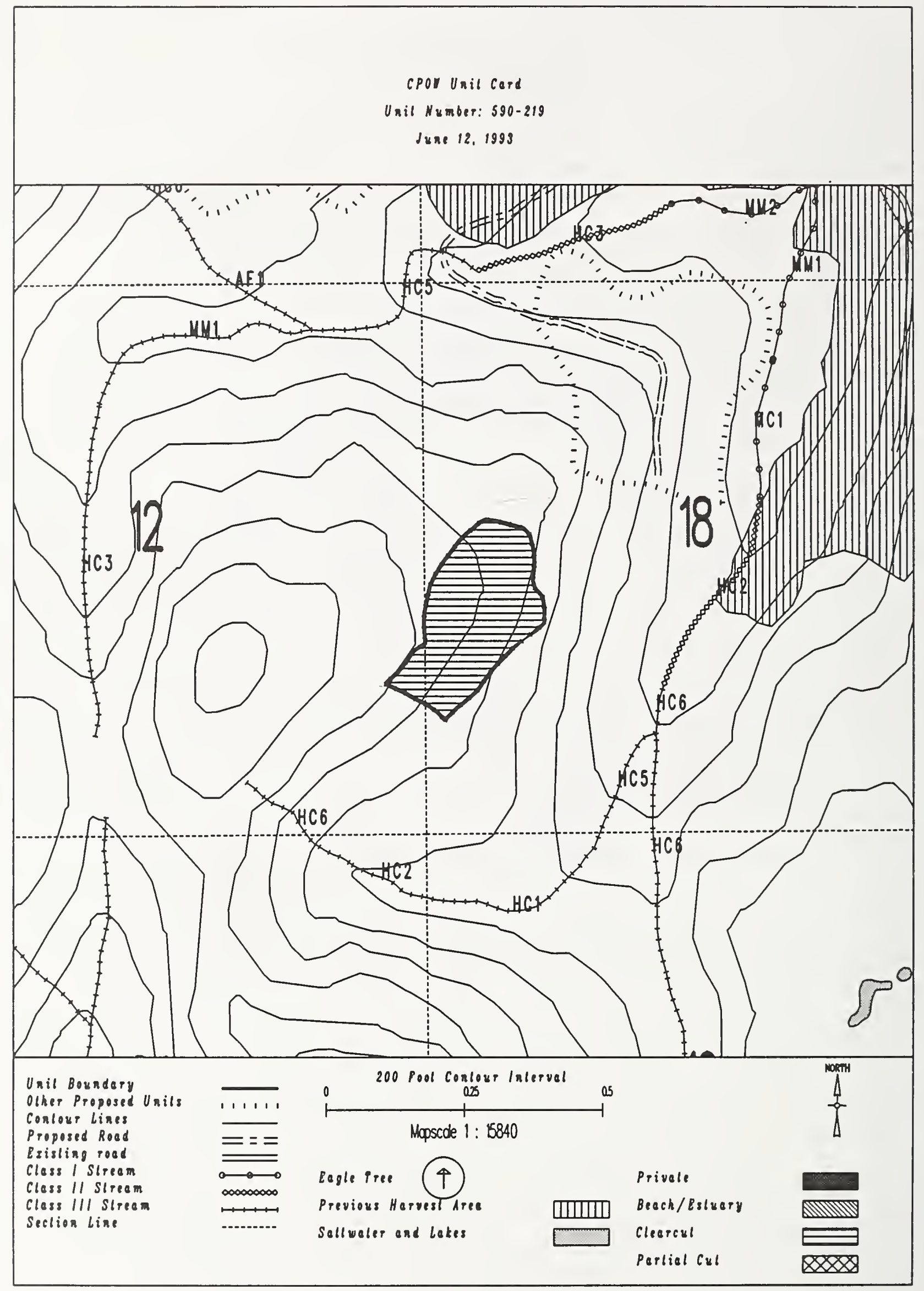


Unit 590-229

Planned acres 62

Estimated volume (mbf) 1776

Logging system Helicopter

silvicultural system clearcut

Forest type Hemlock

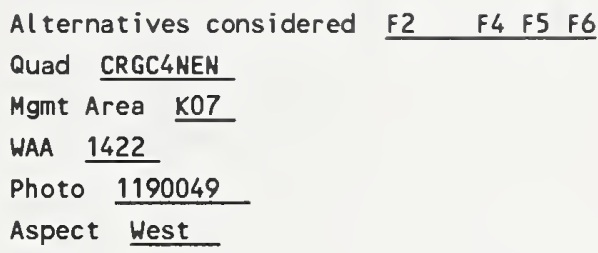

PHYSICAL DESCRIPTION

Volume class breakdown: VC4 $\quad 0$ acres vC5 $\underline{24}$ acres $V C 6 \quad \underline{26}$ acres $v C 7 \quad \underline{0}$ acres

Elevation breakdown: $0-800 \mathrm{ft} . \underline{17}$ acres $800-1200 \mathrm{ft} . \quad 39$ acres $1200-1500 \mathrm{ft} . \overline{3}$ acres over $1500 \mathrm{ft}$. 0 acres Mass movement index: Low 0 acres Medium 0 acres High 52 acres Very High 0 acres

SOILS

This unit has high mass movement index soils. Partial log suspension required over these areas.(BMP13.9)

This unit contains 25 acres of slopes $>75 \%$.

TIMBER

There are no timber mitigation measures anticipated for this unit.

ENGINEER ING

There are no engineering mitigation measures anticipated for this unit.

FISH/WATERSHED

This unit contains streams which have recently been classified/channel typed but require field verification.

WILDLIFE

Maintain diversity within unit by leaving 1-5 acre-sized islands of green trees at a rate of 1 acre of island for every 20 acres harvested. Leave islands must be compatible with logging system and safe working conditions.

RECREATION / VISUALS

This unit has a proposed VQo of MM and is not seen from any viewpoint identified by this project.

\section{LANDS}

There are no lands mitigation measures anticipated for this unit.

CULTURAL RESOURCES

There are no cultural resource mitigation measures anticipated for this unit.

GEOLOGY

There are no karst mitigation measures anticipated for this unit. 


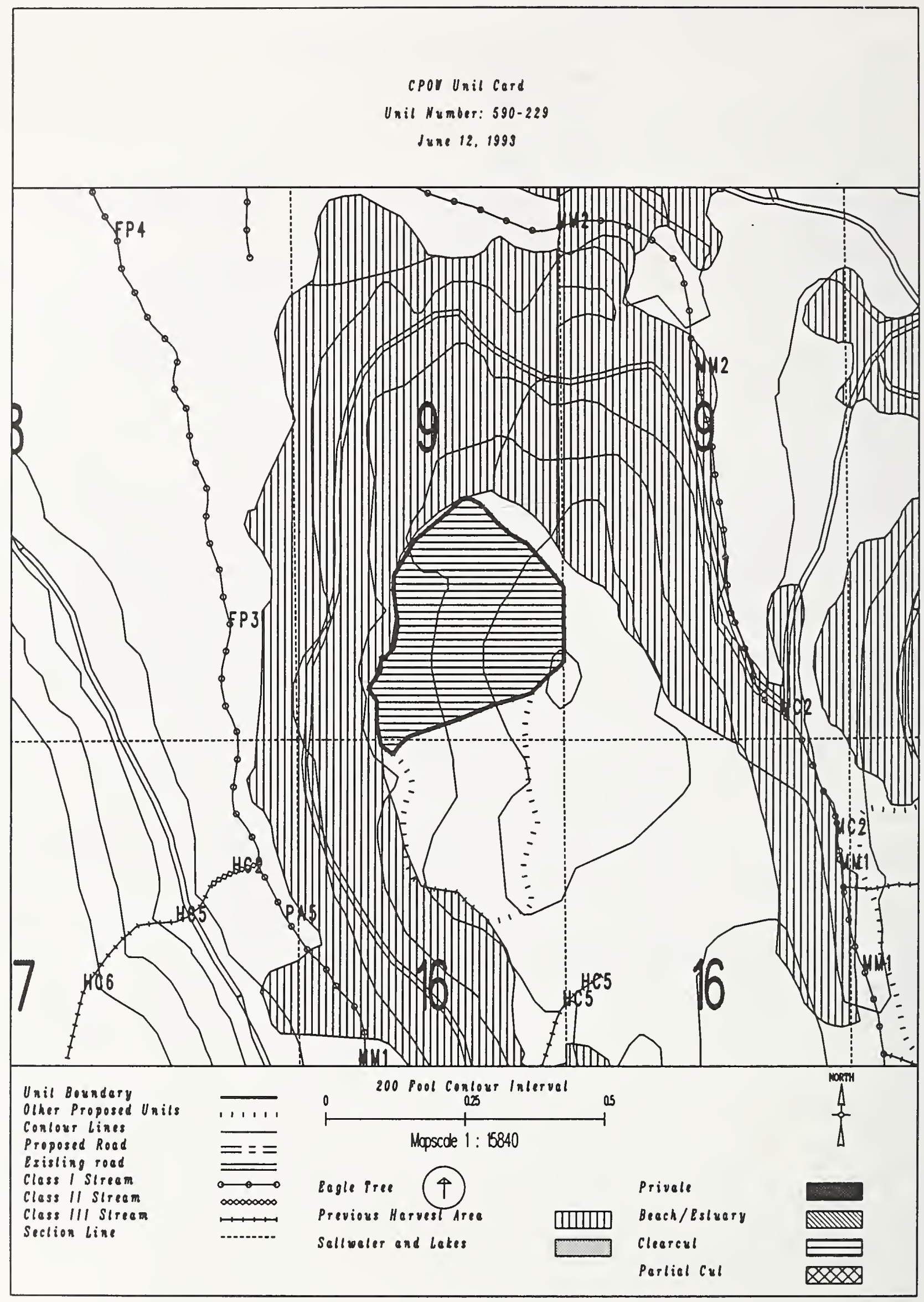




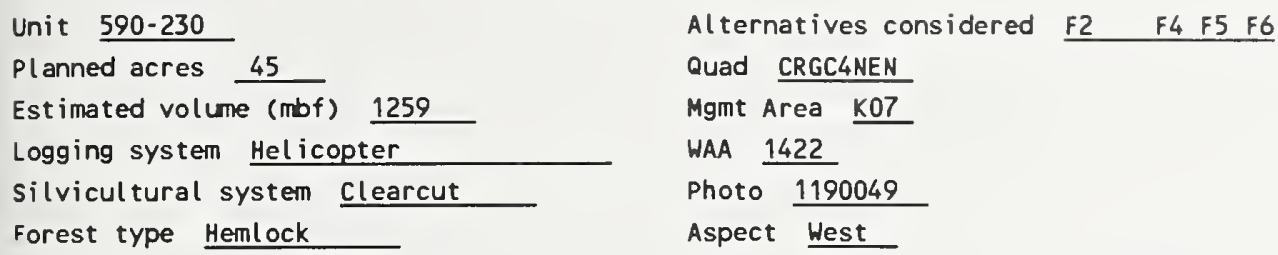




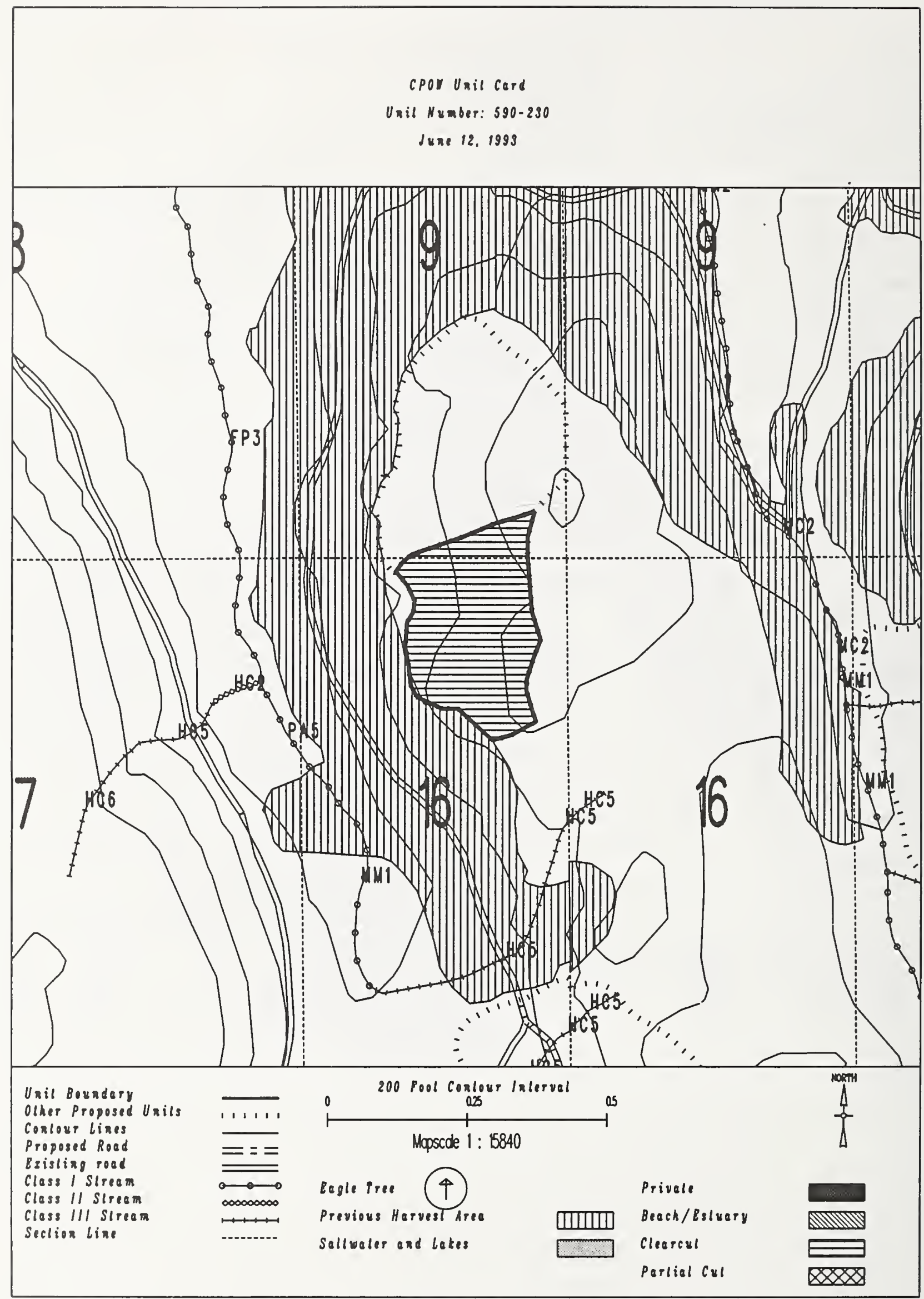


Unit $\quad 590-231$

Planned acres 82

Estimated volume (mbf) 2333

Logging system Helicopter

Silvicultural system Riparian

Forest type Mixed conifer
Alternatives considered F2 F4 F5 F6

Quad CRGC3NWN

Mgmt Area $\mathrm{KO7}$

WAA 1422

Photo 1190047

Aspect West

PHYSICAL DESCRIPTION

Volume class breakdown: VC4 3 acres VC5 $\quad 46$ acres vC6 33 acres vC7 $\quad 0$ acres

Elevation breakdown: $0-800 \mathrm{ft} . \underline{33}$ acres $800-1200 \mathrm{ft} . \underline{29}$ acres $1200-1500 \mathrm{ft} . \underline{6}$ acres over $1500 \mathrm{ft} . \underline{0}$ acres Mass movement index: Low 18 acres Medium 0 acres High 48 acres Very High $\underline{0}$ acres

SOILS

This unit has high mass movement index soils. Partial log suspension required over these areas.(BMP13.9)

This unit contains 29 acres of slopes $>75 \%$.

This unit contains 18 acres of riparian soils. Maintain water quality and fish habitat (BMPs12.6, 13.9).

TIMBER

Uneven-aged harvest for riparian management on an estimated 27 acres.

ENGINEERING

There are no engineering mitigation measures anticipated for this unit.

FISH/WATERSHED

This unit contains streams which have recently been classified/channel typed but require field verification.

\section{WILDLIFE}

There are no wildlife mitigation measures anticipated for this unit.

RECREATION / VISUALS

This unit has a proposed VQO of MM and is not seen from any viewpoint identified by this project.

\section{LANDS}

There are no lands mitigation measures anticipated for this unit.

CULTURAL RESOURCES

There are no cultural resource mitigation measures anticipated for this unit.

There are no karst mitigation measures anticipated for this unit. 


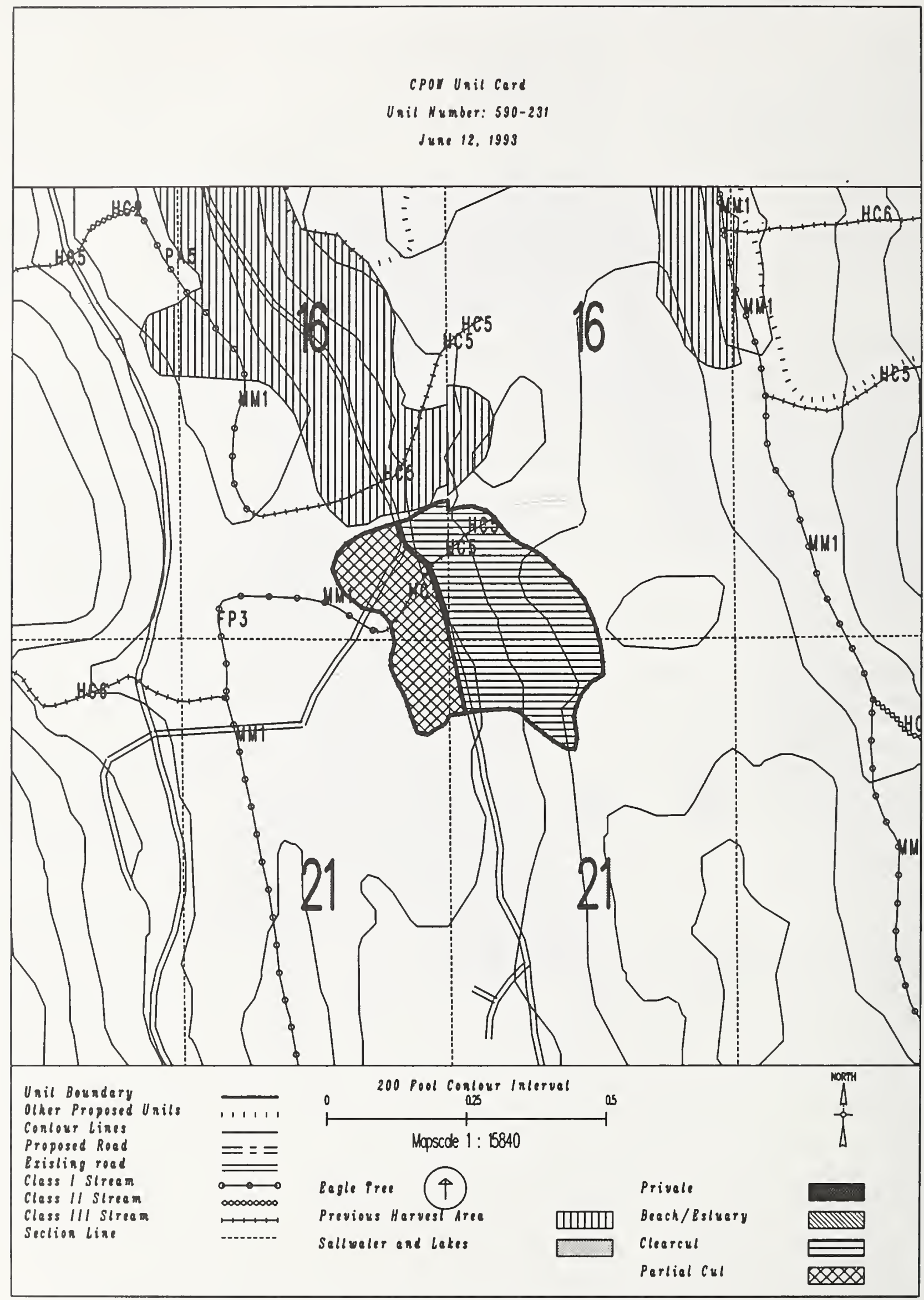


Unit $590-243$

Planned acres 98

Estimated volume (mbf) 3206

Logging system Helicopter

silvicultural system clearcut

Forest type Hemlock
Alternatives considered F2 F4 F5 F6

Quad CRGC3NWN

Mgmt Area K07

WAA 1422

Photo 890128

Aspect West

PHYSICAL DESCRIPTION

Volume class breakdown: VC4 14 acres VC5 78 acres vc6 9 acres vc7 0 acres

Elevation breakdown: $0-800 \mathrm{ft} . \underline{0}$ acres $800-1200 \mathrm{ft} .43$ acres $1200-1500 \mathrm{ft} . \overline{14}$ acres over $1500 \mathrm{ft} . \underline{1}$ acres Mass movement index: Low $\_$acres Medium 68 acres High 14 acres Very High 0 acres

SOILS

This unit has high mass movement index soils. Partial log suspension required over these areas. (BMP13.9)

This unit contains 10 acres of forested wetlands. Site specific BMPs will be designed for selected approved

logging system and road construction practices. (BMPS 12.5, 13.9, 13.15).

This unit contains 8 acres of slopes $>75 \%$.

TIMBER

There are no timber mitigation measures anticipated for this unit.

\section{ENGI NEER I NG}

There are no engineering mitigation measures anticipated for this unit.

\section{FISH/WATERSHED}

Potential for additional Class I/II streams within unit. May be necessary to place additional buffers within unit in accordance with AHMU Handbook.

Potential impact on significant fishery habitat. May be necessary to expand planned buffer in accordance with AHMU Handbook.

This unit contains a $\underline{A} 1$ class $\underline{3}$ stream. No specific buffer required, but full suspension, if yarding across.

\section{WILDLIFE}

There are no wildlife mitigation measures anticipated for this unit.

RECREATION / VISUALS

This unit has a proposed voo of MM and is not seen from any viewpoint identified by this project.

\section{LANDS}

There are no lands mitigation measures anticipated for this unit.

CULTURAL RESOURCES

There are no cultural resource mitigation measures anticipated for this unit.

There are no karst mitigation measures anticipated for this unit. 


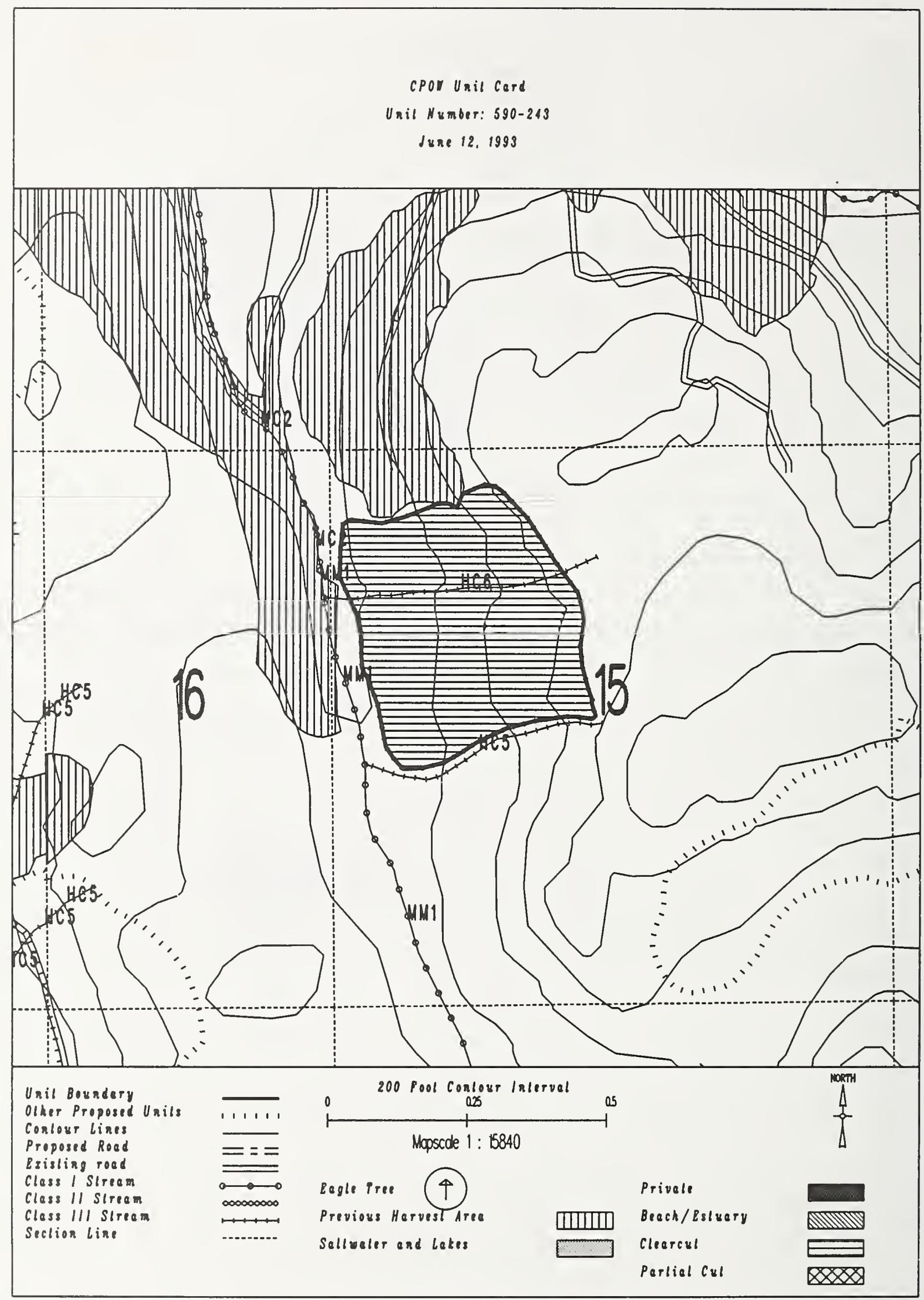




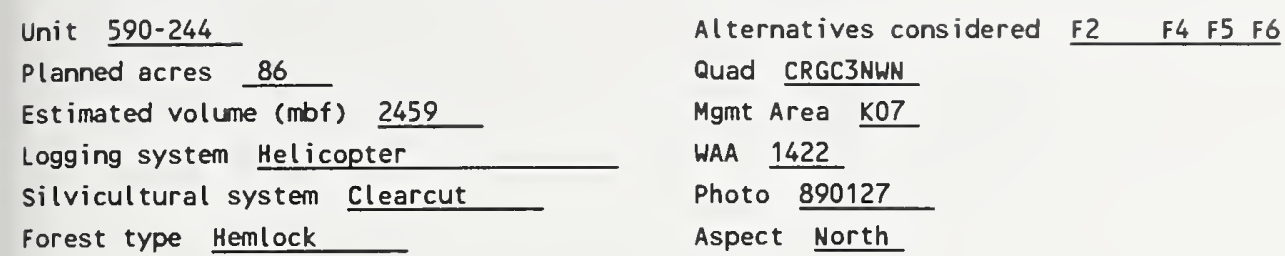




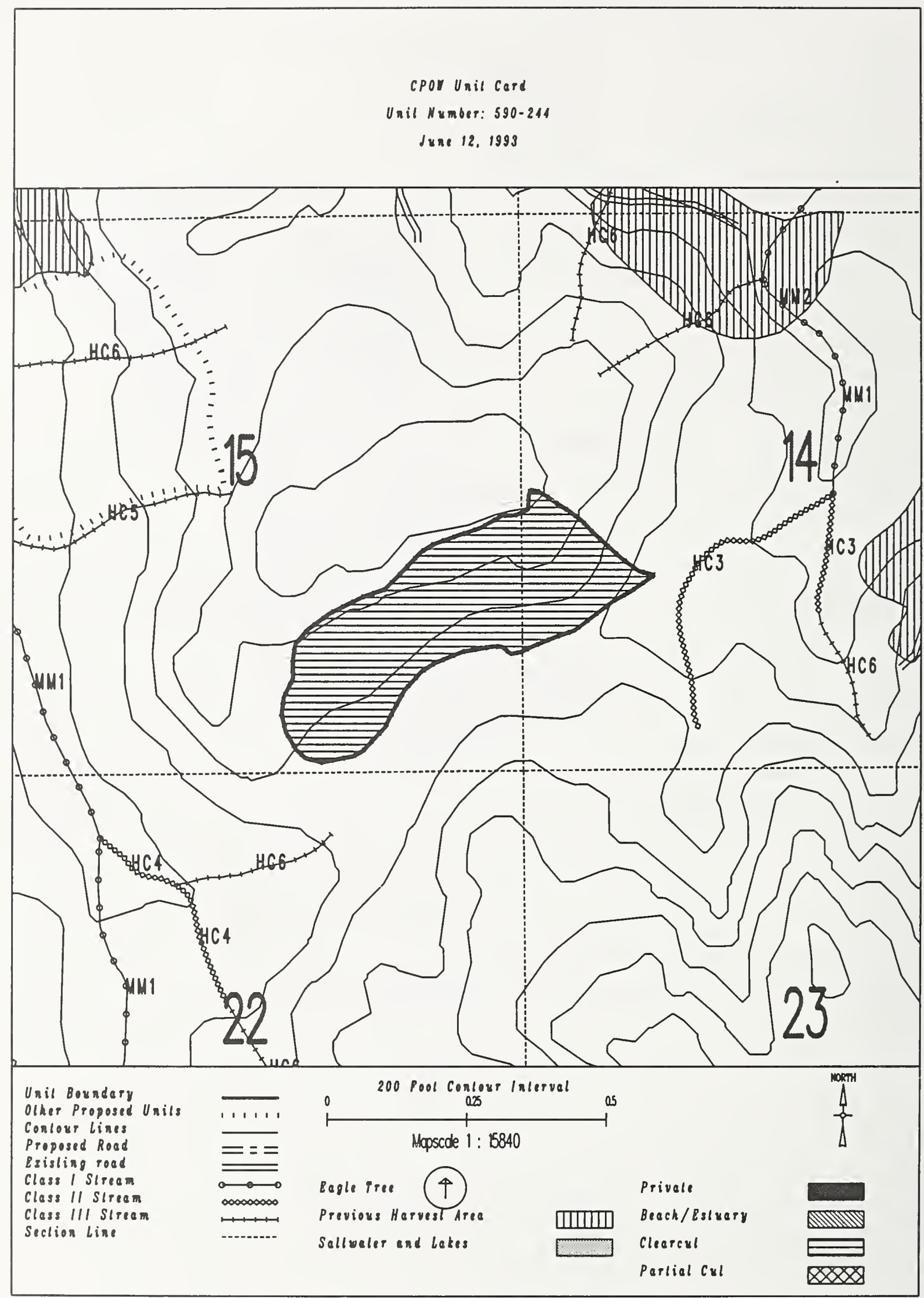


Unit 590-246

Planned acres 56

Estimated volume (mbf) 1430

Logging system skyline

silvicultural system Clearcut

Forest type Hemlock

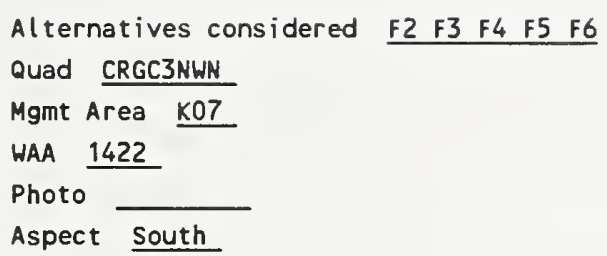

This unit has high mass movement index soils. Partial log suspension required over these areas.(BMP13.9) This unit contains 17 acres of forested wetlands. Site specific BMPs will be designed for selected approved logging system and road construction practices. (BMPs 12.5, 13.9, 13.15).

\section{TIMBER}

There are no timber mitigation measures anticipated for this unit.

\section{ENGINEER ING}

High mass movement index soils. Road construction must minimize landslide potential (BMP14).

\section{FISH/WATERSHED}

Potential for additional Class I/II streams within unit. May be necessary to place additional buffers within unit in accordance with AHMU Handbook.

\section{WILDL IFE}

There are no wildlife mitigation measures anticipated for this unit.

RECREATION / VISUALS

This unit has a proposed VQO of MM and is not seen from any viewpoint identified by this project.

\section{LANDS}

There are no lands mitigation measures anticipated for this unit.

CULTURAL RESOURCES

There are no cultural resource mitigation measures anticipated for this unit. 


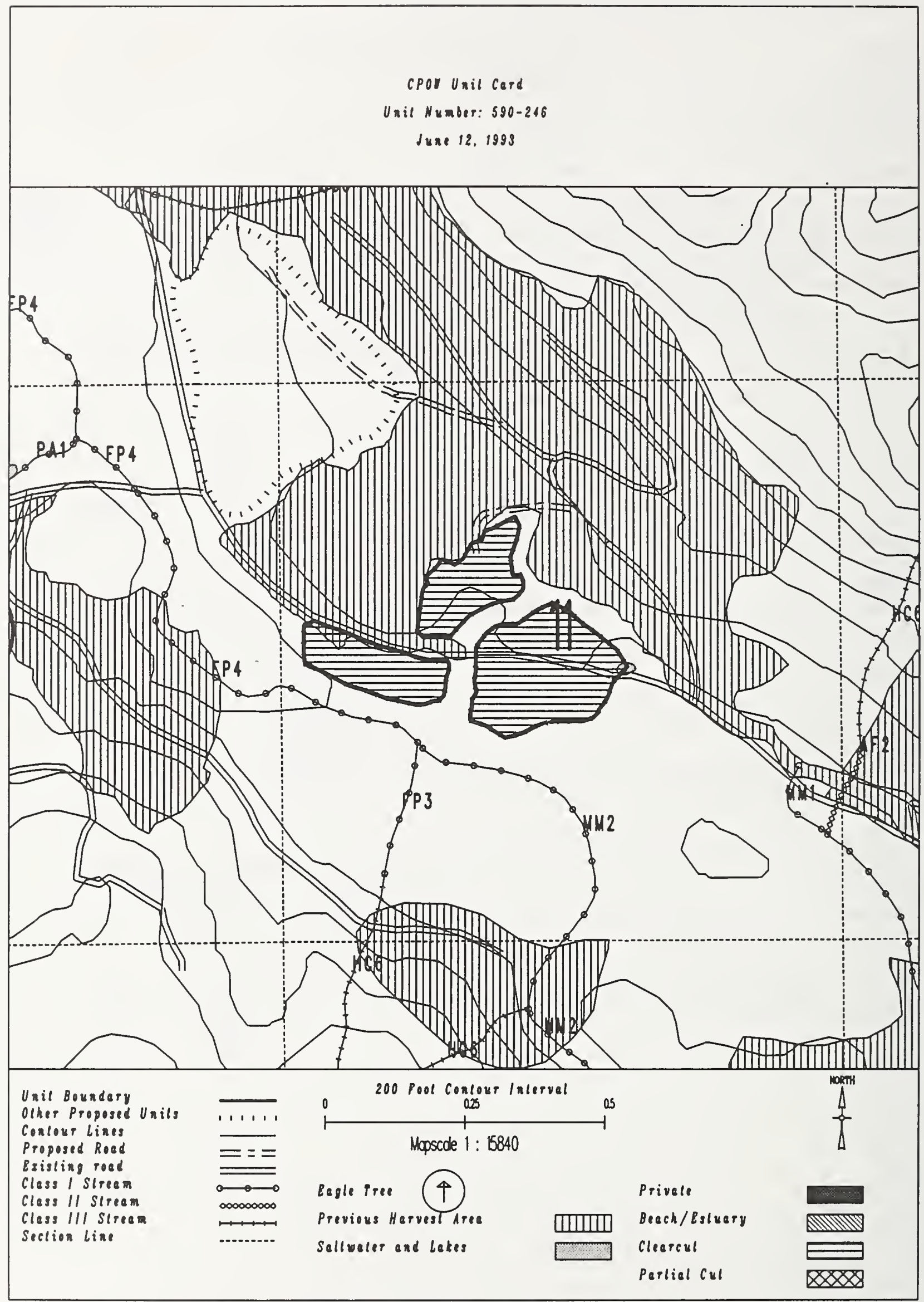


Unit $590-276$

Planned acres 72

Estimated volume (mbf) 1989

Logging system skyline

silvicultural system clearcut

forest type Hemlock

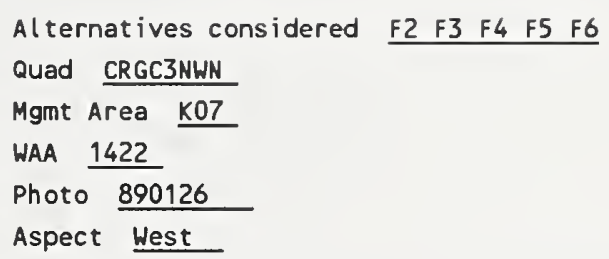

PHYSICAL DESCRIPTION

Volume class breakdown: VC4 22 acres vC5 46 acres vC6 $\quad 0$ acres vC7 $\quad 0$ acres

Elevation breakdown: $0.800 \mathrm{ft} . \underline{37}$ acres $800-1200 \mathrm{ft} . \underline{32}$ acres $1200-1500 \mathrm{ft} . \underline{0}$ acres over $1500 \mathrm{ft}$. 0 Mass movement index: Low 19 acres Medium 0 acres High 21 acres Very High 0 acres

\section{SOILS}

This unit has high mass movement index soils. Partial log suspension required over these areas. (BMP13.9) This unit contains 39 acres of forested wetlands. Site specific BMPs will be designed for selected approved logging system and road construction practices. (BMPS 12.5, 13.9, 13.15).

\section{TIMBER}

There are no timber mitigation measures anticipated for this unit.

\section{ENGINEERING}

High mass movement index soils. Road construction must minimize landslide potential (BMP14).

\section{FISH/WATERSHED}

This unit contains streams which have recently been classified/channel typed but require field verification.

\section{WILDLIFE}

There are no wildlife mitigation measures anticipated for this unit.

RECREATION / VISUALS

This unit has a proposed vaO of MM and is not seen from any viewpoint identified by this project.

\section{LANDS}

There are no lands mitigation measures anticipated for this unit.

CULTURAL RESOURCES

There are no cultural resource mitigation measures anticipated for this unit. 


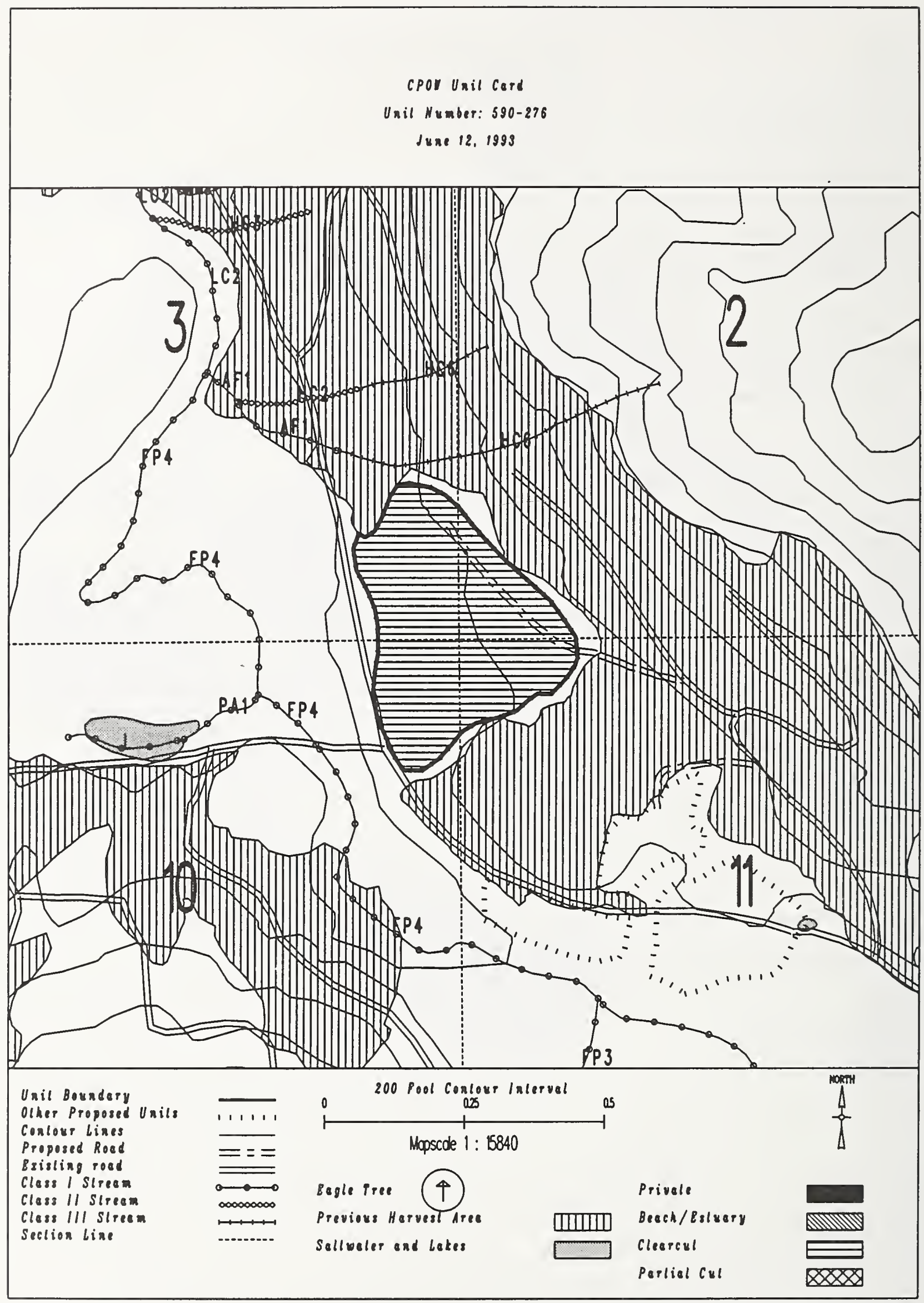


Unit 598-203

Planned acres 27

Estimated volume (mbf) 779

Logging system skyline

silvicultural system clearcut

Forest type Mixed conifer
Alternatives considered

F3 F4

Mgmt Area $\mathrm{K} 10$

WAA 1315

Photo 690137

Aspect South

PHYSICAL DESCRIPTION

Volume class breakdown: VC4 13 acres vC5 $\quad 0$ acres vc6 13 acres vc7 $\quad 0$ acres

Elevation breakdown: $0-800 \mathrm{ft} . \underline{25}$ acres $800-1200 \mathrm{ft} . \underline{0}$ acres $1200-1500 \mathrm{ft} . \underline{0}$ acres over $1500 \mathrm{ft} . \underline{0}$ acres Mass movement index: Low 5 acres Medium 0 acres High 20 acres Very High 0 acres

SOILS

This unit has high mass movement index soils. Partial log suspension required over these areas.(BMP13.9)

\section{TIMBER}

There are no timber mitigation measures anticipated for this unit.

\section{ENGINEER ING}

High mass movement index soils. Road construction must minimize landslide potential (BMP14).

\section{FISH/WATERSHED}

This unit contains a $\underline{A} 4$ class $\underline{3}$ stream. No specific buffer required, but full suspension, if yarding across.

\section{WILDL I FE}

There are no wildlife mitigation measures anticipated for this unit.

RECREATION / VISUALS

This unit has a proposed VQO of MM and is not seen from any viewpoint identified by this project.

\section{LANDS}

There are no lands mitigation measures anticipated for this unit.

\section{CULTURAL RESOURCES}

The planned unit boundary and road location is immediately adjacent to significant cultural resources. Any changes must be coordinated with cultural resource personnel. 
cpor Unil Cord

Unit Number: 598-203

June 12, 1993

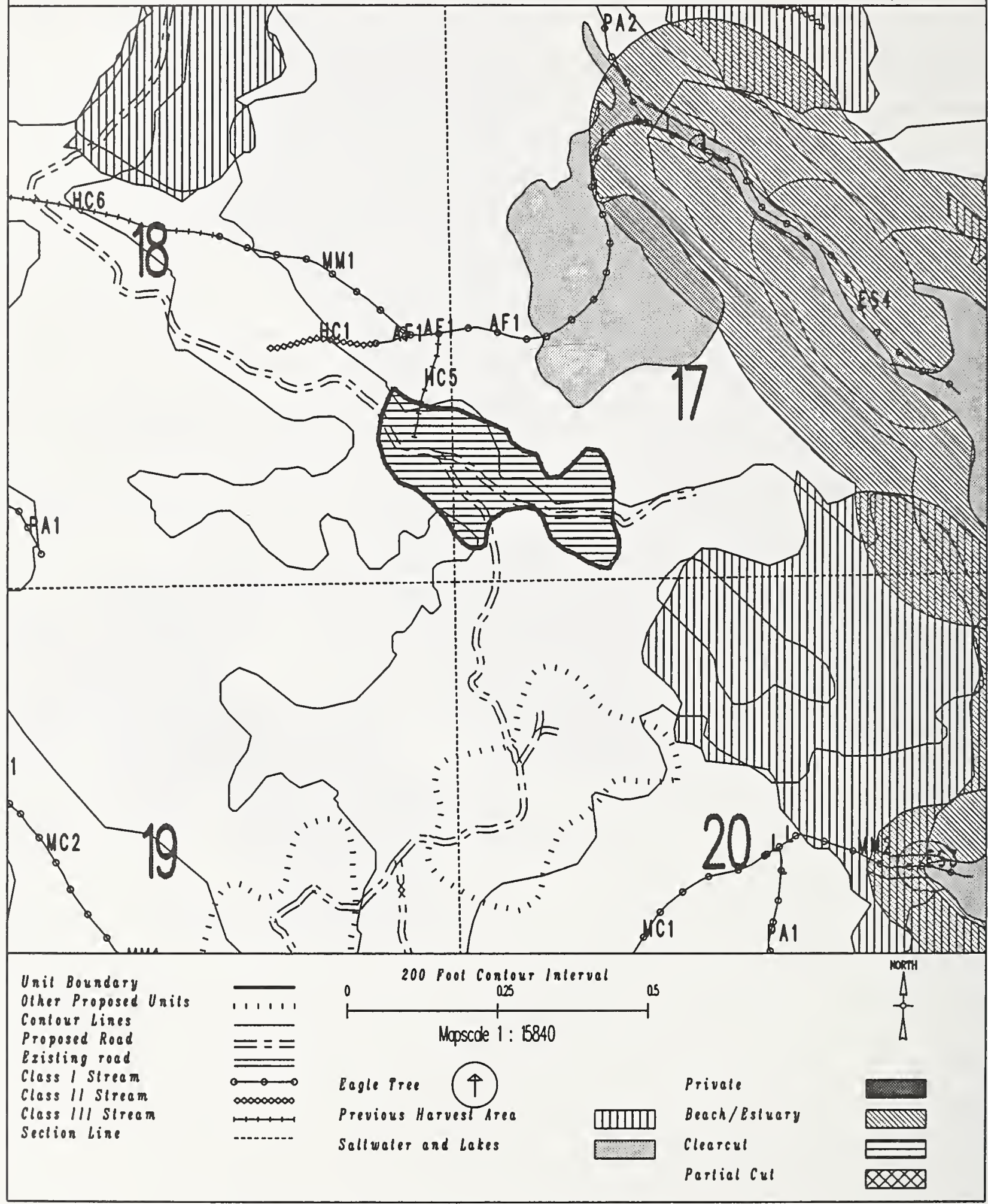


Unit 598-205

Planned acres 46

Estimated volume (mbf) 1007

Logging system skyline

silvicultural system clearcut

Forest type Hemlock

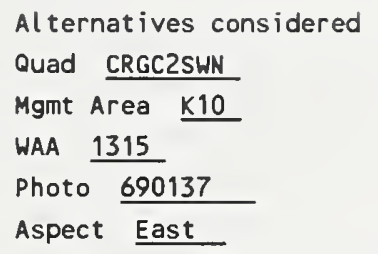

PHYSICAL DESCRIPTION

Volume class breakdown: VC4 46 acres VC5 $\quad 0$ acres VC6 $\quad 0$ acres VC7 $\quad 0$ acres

Elevation breakdown: $0-800 \mathrm{ft} . \underline{43}$ acres $800-1200 \mathrm{ft} . \underline{0}$ acres $1200-1500 \mathrm{ft} . \underline{0}$ acres over $1500 \mathrm{ft} . \underline{0}$ acres Mass movement index: Low 44 acres Medium 0 acres High 0 acres Very High 0 acres

\section{SOILS}

There are no soils mitigation measures anticipated for this unit.

\section{TIMBER}

There are no timber mitigation measures anticipated for this unit.

\section{ENGINEER ING}

There are no engineering mitigation measures anticipated for this unit.

\section{FISH/WATERSHED}

This unit contains streams which have recently been classified/channel typed but require field verification.

\section{HILDLIFE}

There are no wildlife mitigation measures anticipated for this unit.

RECREATION / VISUALS

This unit has a proposed Voo of $M M$ and is not seen from any viewpoint identified by this project.

\section{LANDS}

There are no lands mitigation measures anticipated for this unit.

CULTURAL RESOURCES

There are no cultural resource mitigation measures anticipated for this unit. 


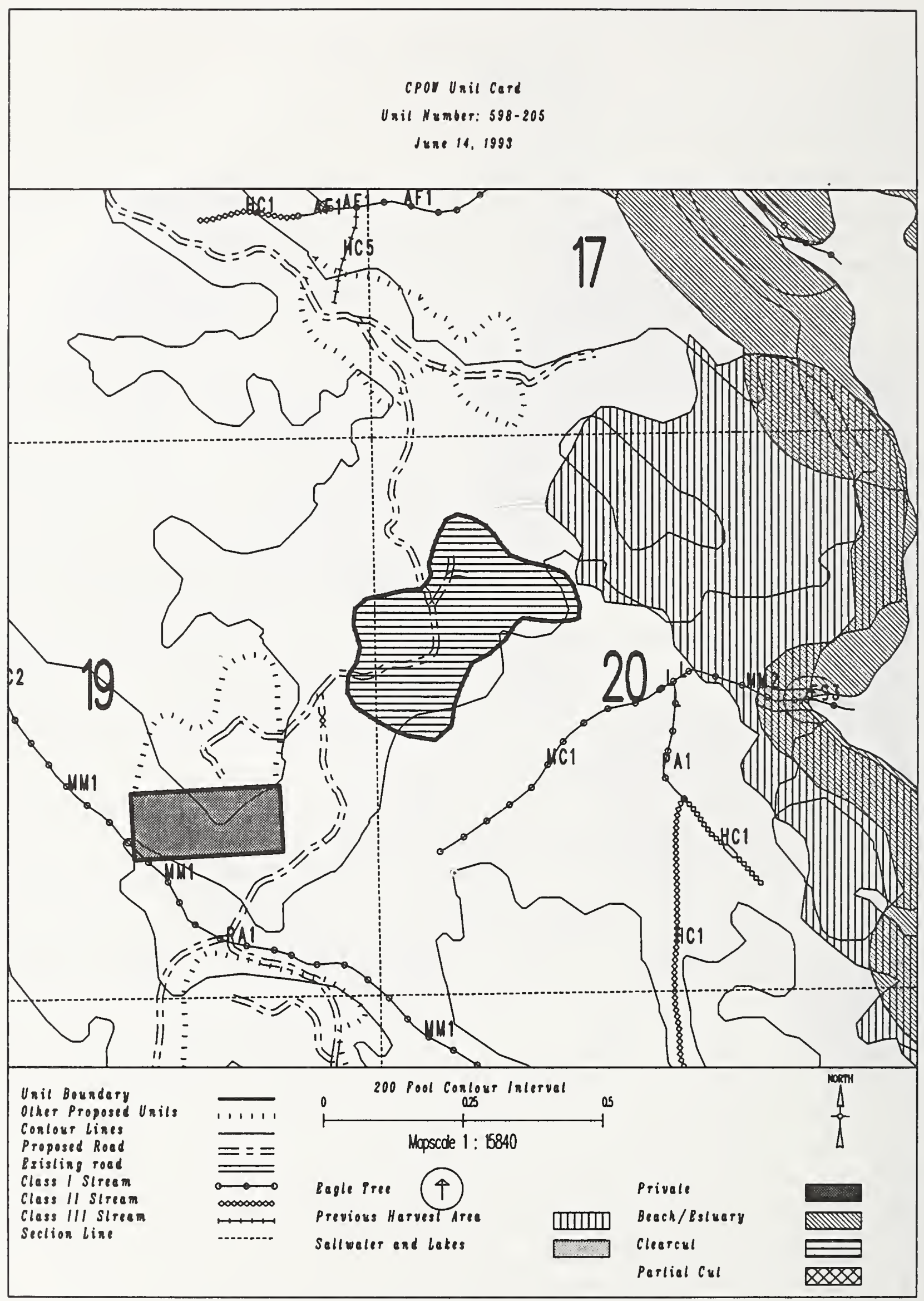


Unit 598-206

Planned acres 18

Estimated volume (mbf)

Logging system skyline

silvicultural system clearcut

Forest type Hemlock
Alternatives considered

F3 F4

Mgmt Area $\mathrm{K} 10$

WAA 1315

Photo 690136

Aspect South

PHYSICAL DESCRIPTION

Volume class breakdown: VC4 19 acres VC5 $\quad 0$ acres vc6 $\quad 0$ acres vc7 $\quad 0$ acres

Elevation breakdown: $0-800 \mathrm{ft} . \underline{16}$ acres $800-1200 \mathrm{ft} . \underline{0}_{2}$ acres $1200-1500 \mathrm{ft} . \underline{0}$ acres over $1500 \mathrm{ft}$. 0 Mass movement index: Low 16 acres Medium 0 acres $\mathrm{High} 2$ acres Very High 0 acres

\section{SOILS}

This unit has high mass movement index soils. Partial log suspension required over these areas. (BMP13.9)

\section{TIMBER}

There are no timber mitigation measures anticipated for this unit.

\section{ENGINEERING}

There are no engineering mitigation measures anticipated for this unit.

\section{FISH/WATERSHED}

There are no fishery mitigation measures anticipated for this unit.

\section{WILDLIFE}

There are no wildlife mitigation measures anticipated for this unit.

RECREATION / VISUALS

This unit has a proposed VQO of MM and is not seen from any viewpoint identified by this project.

\section{LANDS}

This unit adjacent to other ownership. Boundary establishment required prior to layout.

CULTURAL RESOURCES

There are no cultural resource mitigation measures anticipated for this unit.

There are no karst mitigation measures anticipated for this unit. 
cPor Unit cord

Unit Number: $598-206$

June 12, 1993

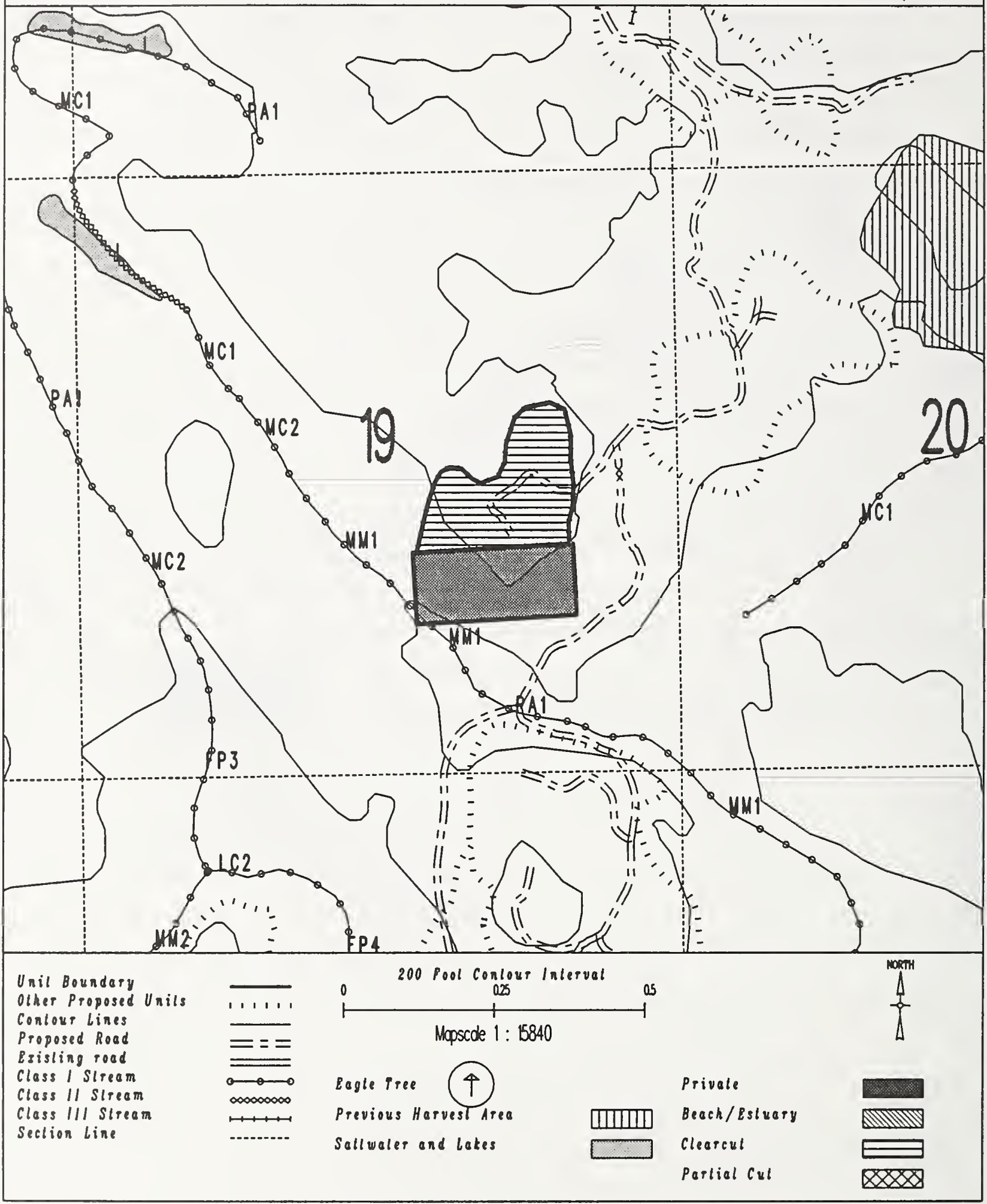


Unit $598-207$

Planned acres 89

Estimated volume (mbf) 2852

Logging system Highlead

silvicultural system clearcut

Forest type Hemlock

\author{
Quad CRGC2SWN \\ Mgmt Area $\mathrm{K} 10$ \\ WAA 1315 \\ Photo 690135 \\ Aspect North
}

Alternatives considered

\section{PHYSICAL DESCRIPTION}

Volume class breakdown: VC4 $\quad 22$ acres VC5 $\quad 70$ acres $\quad$ VC6 $\quad 2$ acres $\quad$ VC7 $\quad 0$ acres

Elevation breakdown: $0-800 \mathrm{ft} . \underline{91}$ acres $800-1200 \mathrm{ft} . \underline{0}$ acres $1200-1500 \mathrm{ft} . \underline{0}$ acres over $1500 \mathrm{ft}$. 0 Mass movement index: - Low 64 acres Medium $\_$acres High 29 acres Very High 0

\section{SOILS}

This unit has high mass movement index soils. Partial log suspension required over these areas. (BMP13.9)

This unit contains 64 acres of forested wetlands. Site specific BMPs will be designed for selected approved

logging system and road construction practices. (BMPS 12.5, 13.9, 13.15).

\section{TIMBER}

There are no timber mitigation measures anticipated for this unit.

\section{ENGINEERING}

High mass movement index soils. Road construction must minimize landslide potential (BMP14).

The road into this unit crosses a L1 channel. Meet stream and lake protection prescription requirements in TLMP Draft Revision (1991a) for this process group.

\section{FISH/WATERSHED}

There are no fishery mitigation measures anticipated for this unit.

\section{WILDLIFE}

Maintain diversity within unit by leaving 1-5 acre-sized islands of green trees at a rate of 1 acre of island for every 20 acres harvested. Leave islands must be compatible with logging system and safe working conditions.

RECREATION / VISUALS

This unit has a proposed vao of MM and is not seen from any viewpoint identified by this project.

\section{LANDS}

There are no lands mitigation measures anticipated for this unit.

CULTURAL RESOURCES

There are no cultural resource mitigation measures anticipated for this unit.

GEOLOGY

There are no karst mitigation measures anticipated for this unit. 


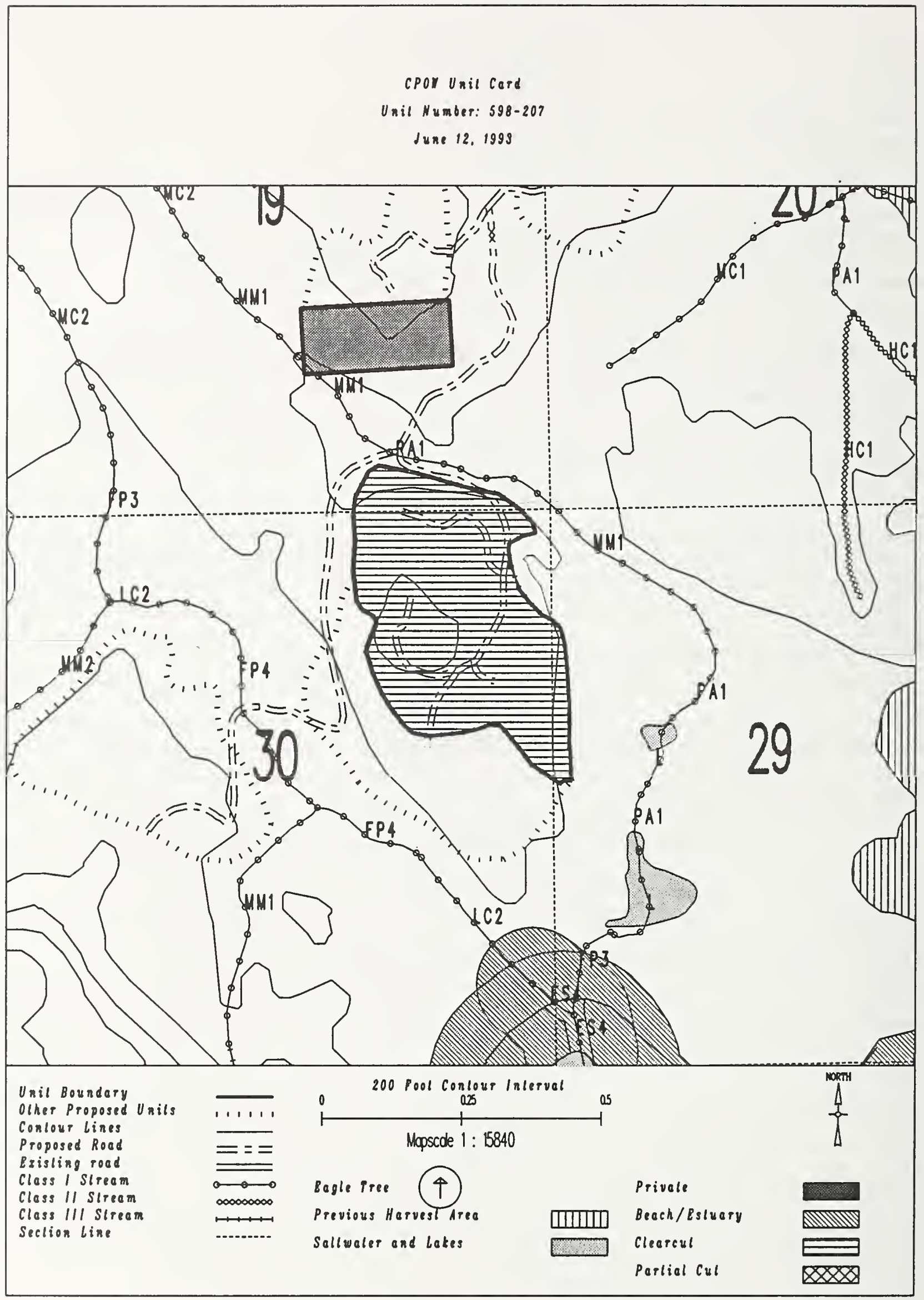


Unit 598-207

Planned acres 55

Estimated volume (mbf) 1780

Logging system slackline

silvicultural system clearcut

Forest type Hemlock
Alternatives considered

Quad CRGC2SWN

Mgmt Area $\mathrm{K} 10$

WAA 1315

Photo

Aspect South

\section{PHYSICAL DESCRIPTION}

Volume class breakdown: VC4 2 acres vC5 34 acres vc6 15 acres vc7 1 acres

Elevation breakdown: $0-800 \mathrm{ft} . \underline{54}$ acres $800-1200 \mathrm{ft} . \quad 0$ acres $1200-1500 \mathrm{ft}$. 0 acres over $1500 \mathrm{ft}$. 0 acres Mass movement index: Low 19 acres Medium 0 acres High 36 acres Very High 0 acres

SOILS

This unit has high mass movement index soils. Partial log suspension required over these areas. (BMP13.9) This unit contains 19 acres of forested wetlands. Site specific BMPs will be designed for selected approved logging system and road construction practices. (BMPs 12.5, 13.9, 13.15).

\section{TIMBER}

There are no timber mitigation measures anticipated for this unit.

\section{ENGINEERING}

Very difficult road construction due to unstable, slope $>75 \%$ or extended steep grades.

May need to revise logging system to helicopter.

High mass movement index soils. Road construction must minimize landslide potential (BMP14).

The road into this unit crosses a L1 channel. Meet stream and lake protection prescription requirements in TLMP Draft Revision (1991a) for this process group.

\section{FISH/WATERSHED}

Potential for additional Class I/II streams within unit. May be necessary to place additional buffers within unit in accordance with AHMU Handbook.

\section{WILDLIFE}

Maintain diversity within unit by leaving 1-5 acre-sized islands of green trees at a rate of 1 acre of island for every 20 acres harvested. Leave islands must be compatible with logging system and safe working conditions.

\section{RECREATION / VISUALS}

This unit has a proposed voo of MM and is not seen from any viewpoint identified by this project.

\section{LANDS}

There are no lands mitigation measures anticipated for this unit.

\section{CULTURAL RESOURCES}

There are no cultural resource mitigation measures anticipated for this unit.

\section{GEOLOGY}

There are no karst mitigation measures anticipated for this unit. 


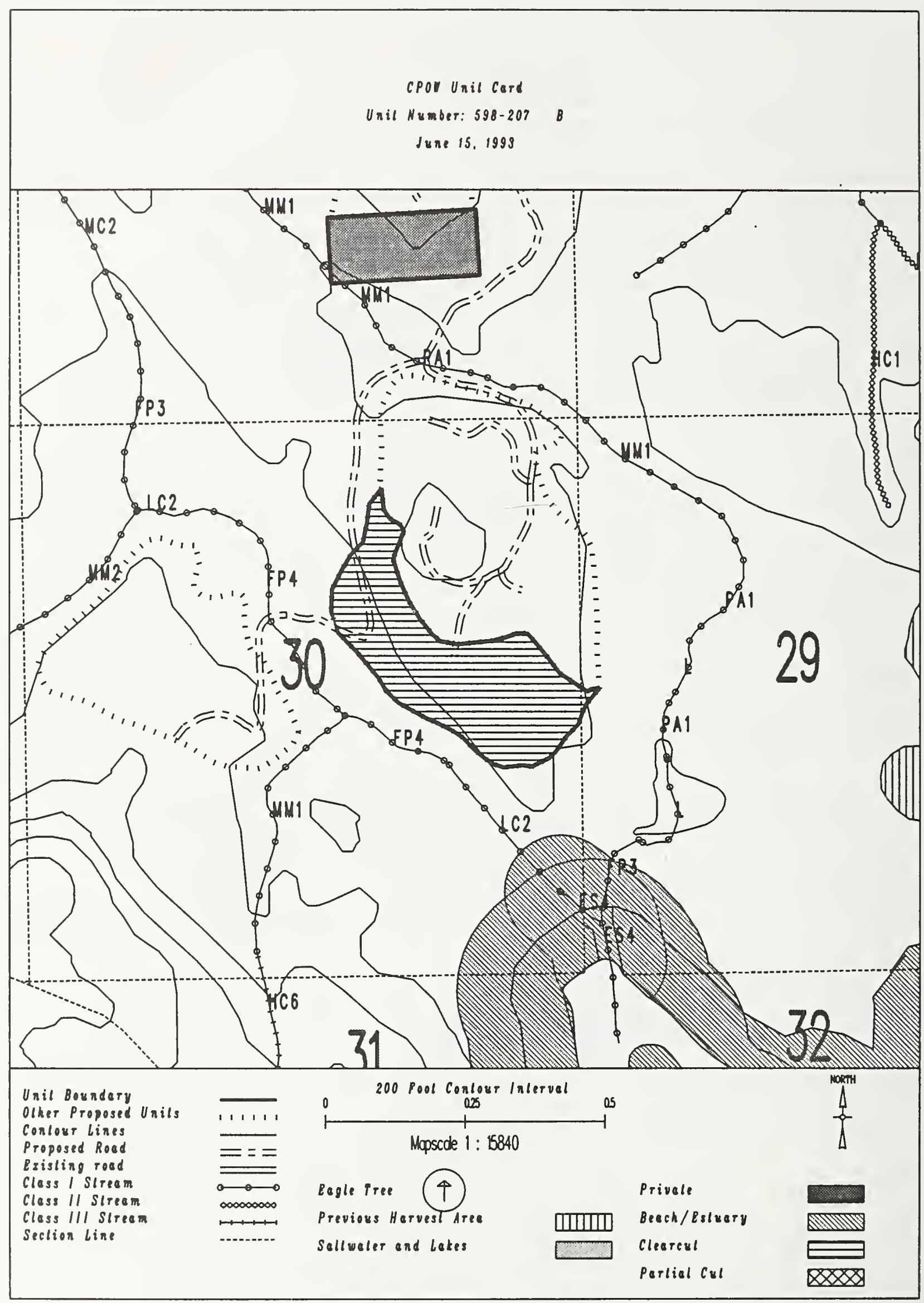


Unit $\quad 598-218$

Planned acres 41

Estimated volume (mbf) 897

Logging system Highlead

silvicultural system clearcut

Forest type Hemlock

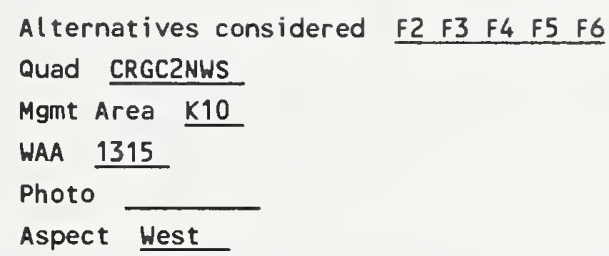

PHYSICAL DESCRIPTION

Volume class breakdown: VC4 26 acres VC5 10 acres VC6 $\quad 0$ acres VC7 $\quad 0$ acres

Elevation breakdown: $0-800 \mathrm{ft} . \underline{39}$ acres $800-1200 \mathrm{ft} . \underline{0}$ acres $1200-1500 \mathrm{ft} . \underline{0}$ acres over $1500 \mathrm{ft}$. 0 Mass movement index: Low 28 acres Medium 12 acres High 0 acres Very High 0 acres

\section{SOILS}

This unit contains 21 acres of forested wetlands. Site specific BMPs will be designed for selected approved logging system and road construction practices. (BMPS 12.5, 13.9, 13.15).

\section{TIMBER}

There are no timber mitigation measures anticipated for this unit.

\section{ENGI NEER I NG}

The road into this unit crosses a $\underline{B 2}$ channel. Meet stream and lake protection prescription requirements in TLMP Draft Revision (1991a) for this process group.

\section{FISH/WATERSHED}

There are no fishery mitigation measures anticipated for this unit.

\section{WILDL I FE}

There are no wildlife mitigation measures anticipated for this unit.

\section{RECREATION / VISUALS}

This unit has a proposed VQO of MM and is not seen from any viewpoint identified by this project.

\section{LANOS}

This unit adjacent to other ownership. Boundary establishment required prior to layout.

CULTURAL RESOURCES

There are no cultural resource mitigation measures anticipated for this unit.

GEOLOGY

There are no karst mitigation measures anticipated for this unit. 


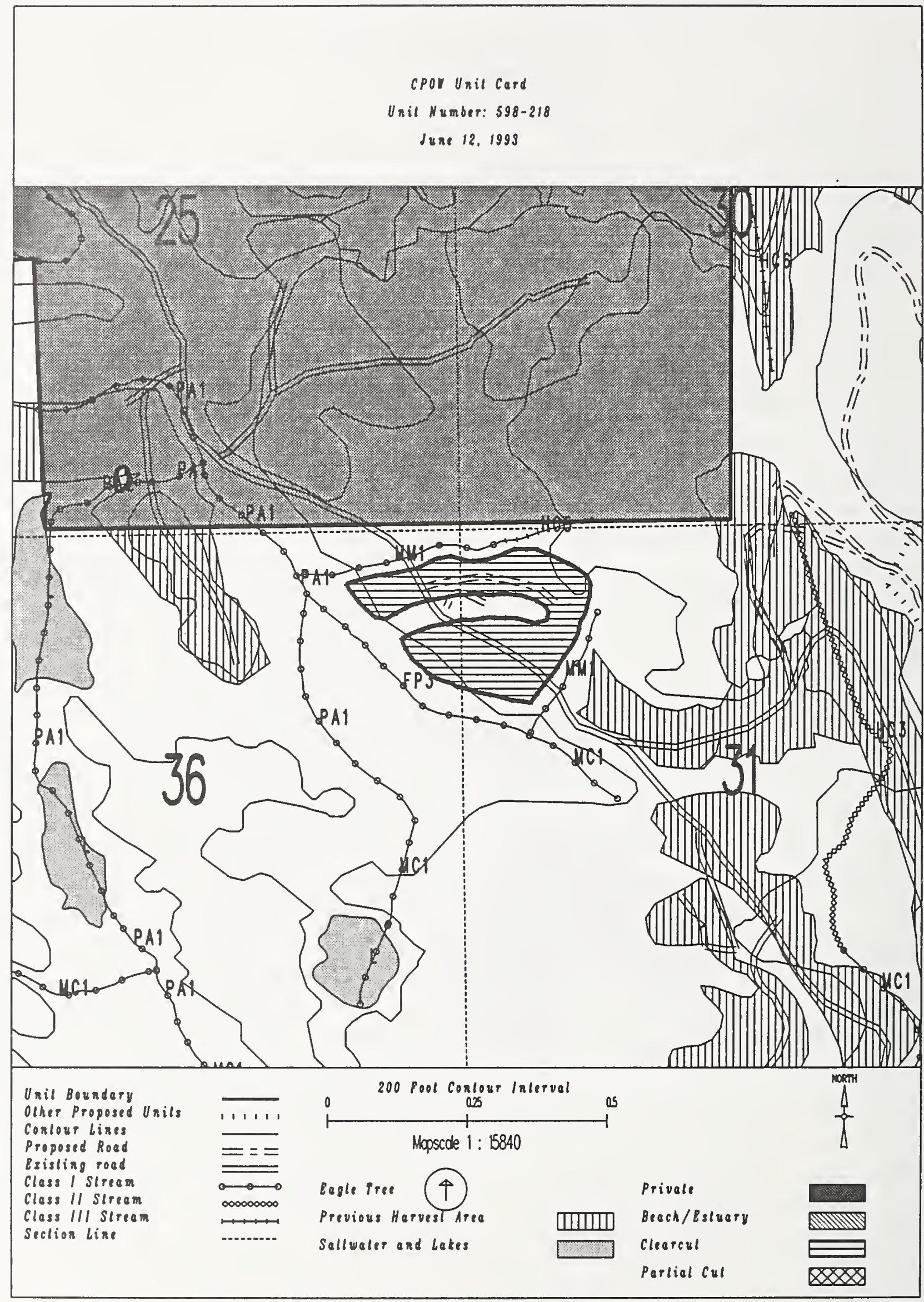


Unit $\quad 598-220$

Planned acres 89

Estimated volume (mbf) 1955

Logging system Highlead

silvicultural system clearcut

Forest type Hemlock
Alternatives considered F2 F3 F4 F5 F6

Quad CRGC2NHS

Mgmt Area $\mathrm{K} 10$

WAA 1315

Photo 1090076

Aspect North

PHYSICAL DESCRIPTION

Volume class breakdown: VC4 58 acres vC5 $\quad 0$ acres vc6 18 acres vc7 $\quad 0$ acres

Elevation breakdown: $0-800 \mathrm{ft} . \underline{88}$ acres $800-1200 \mathrm{ft} . \underline{0}$ acres $1200-1500 \mathrm{ft}$. 0 acres over $1500 \mathrm{ft}$. 0 acres

Mass movement index: Low 17 acres Medium 16 acres High 55 acres Very High 0 acres

\section{SOILS}

This unit has high mass movement index soils. Partial log suspension required over these areas. (BMP13.9)

This unit contains 13 acres of forested wetlands. Site specific BMPs will be designed for selected approved

logging system and road construction practices. (BMPs 12.5, 13.9, 13.15).

\section{TIMBER}

There are no timber mitigation measures anticipated for this unit.

\section{ENGINEERING}

High mass movement index soils. Road construction must minimize landslide potential (BMP14).

\section{FISH/WATERSHED}

This unit contains streams which have recently been classified/channel typed but require field verification.

\section{HILOLIFE}

There are no wildlife mitigation measures anticipated for this unit.

RECREATION / VISUALS

This unit has a proposed Voo of MM and is not seen from any viewpoint identified by this project.

\section{LANDS}

There are no lands mitigation measures anticipated for this unit.

\section{CULTURAL RESOURCES}

There are no cultural resource mitigation measures anticipated for this unit.

There are no karst mitigation measures anticipated for this unit. 


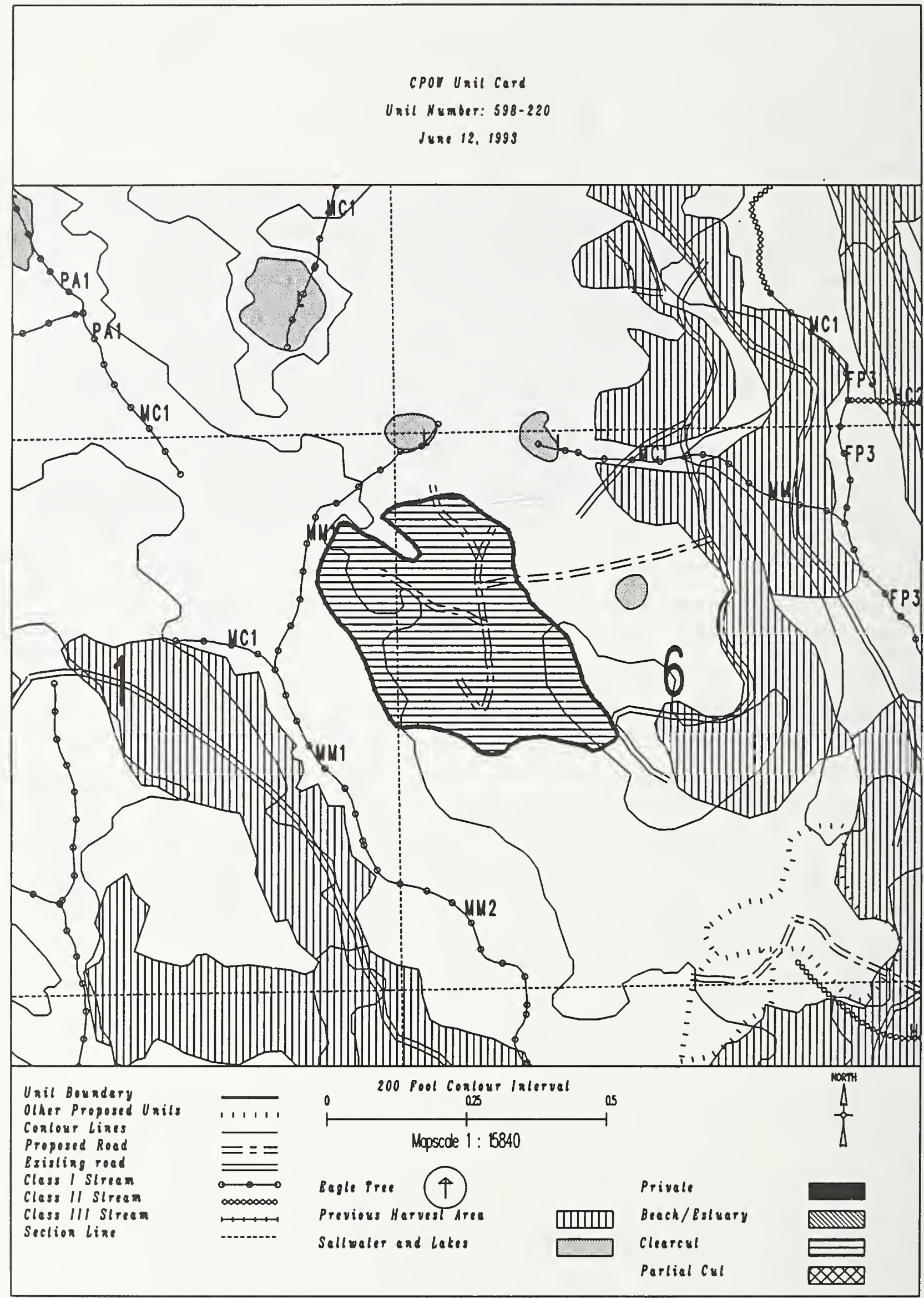


Unit $598-222$

Planned acres 31

Estimated volume (mbf) 950

Logging system Highlead

silvicultural system clearcut

forest type Hemlock

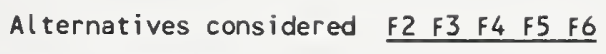

Quad CRGC2NHS

Mgmt Area $\underline{\mathrm{K} 10}$

HAA 1315

Photo 1090075

Aspect North

\section{PHYSICAL DESCRIPTION}

volume class breakdown: VC4 $\quad 0$ acres VC5 22 acres VC6 $\quad 6$ acres vC7 $\quad 0$ acres

Elevation breakdown: $0-800 \mathrm{ft} . \underline{30}$ acres $800-1200 \mathrm{ft} . \underline{0}$ acres $1200-1500 \mathrm{ft} . \underline{0}$ acres over $1500 \mathrm{ft} . \underline{0}$ acres Mass movement index: Low 11 acres Medium $\underline{0}$ acres High 20 acres Very High 0

SOILS

This unit has high mass movement index soils. Partial log suspension required over these areas. (BMP13.9)

TIMBER

Potential for shovel logging on 16 acres, if soil and water quality protected (BMP13.7)

\section{ENGINEER ING}

High mass movement index soils. Road construction must minimize landslide potential (BMP14).

\section{FISH/HATERSHED}

There are no fishery mitigation measures anticipated for this unit.

\section{WILDLIFE}

There are no wildlife mitigation measures anticipated for this unit.

\section{RECREATION / VISUALS}

This unit has a proposed voo of MM and is not seen from any viewpoint identified by this project.

\section{LANDS}

There are no lands mitigation measures anticipated for this unit.

\section{CULTURAL RESOURCES}

There are no cultural resource mitigation measures anticipated for this unit. 


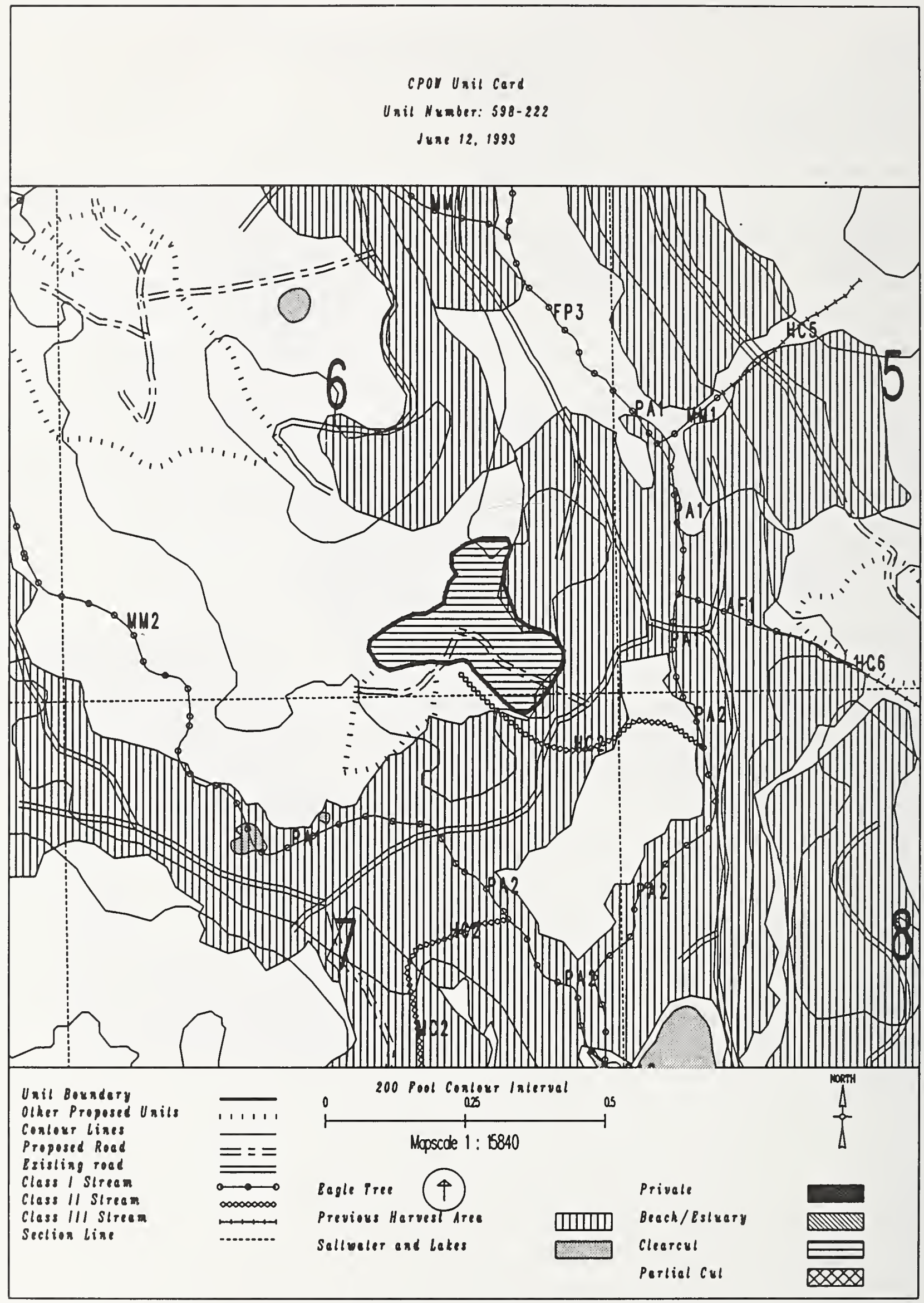




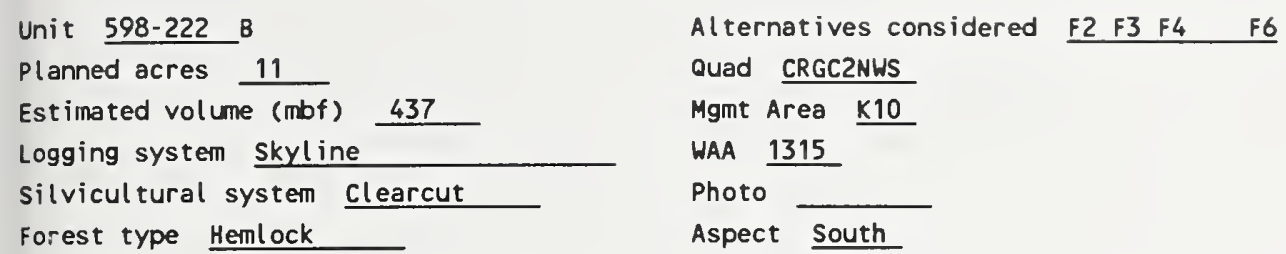




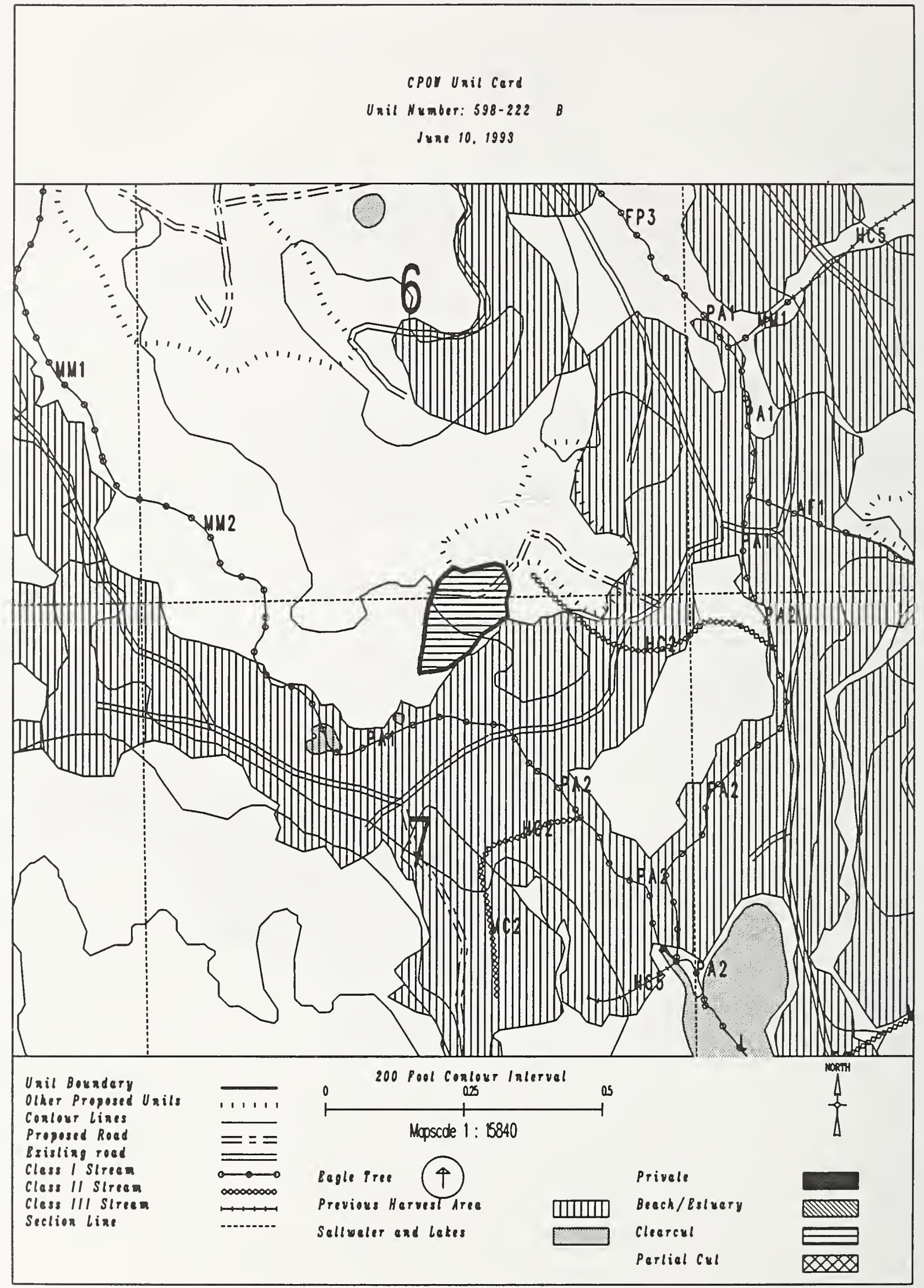


Unit 598-235

Planned acres 26

Estimated volume (mbf) 569

Logging system Highlead

silvicultural system Clearcut

Forest type Hemlock
Alternatives considered F2

Quad CRGC2NWS

Mgmt Area $\mathrm{K} 10$

WAA 1315

Photo 690139

Aspect South

\section{PHYSICAL DESCRIPTION}

Volume class breakdown: VC4 26 acres VC5 $\quad 0$ acres VC6 $\quad 0$ acres VC7 $\quad 0$ acres

Elevation breakdown: $0-800 \mathrm{ft} .24$ acres $800-1200 \mathrm{ft} . \underline{0}$ acres 1200-1500 ft. 0 acres over $1500 \mathrm{ft}$. 0 acres Mass movement index: Low 18 acres Medium 0 acres High 7 acres Very High 0 acres

\section{SOILS}

This unit has high mass movement index soils. Partial log suspension required over these areas.(BMP13.9)

\section{TIMBER}

There are no timber mitigation measures anticipated for this unit.

\section{ENG I NEER ING}

High mass movement index soils. Road construction must minimize landslide potential (BMP14).

\section{FISH/WATERSHED}

There are no fishery mitigation measures anticipated for this unit.

\section{WILDLIFE}

There are no wildlife mitigation measures anticipated for this unit.

RECREATION / VISUALS

This unit has a proposed VQO of MM and is not seen from any viewpoint identified by this project.

\section{LANDS}

There are no lands mitigation measures anticipated for this unit.

\section{CULTURAL RESOURCES}

There are no cultural resource mitigation measures anticipated for this unit.

There are no karst mitigation measures anticipated for this unit. 


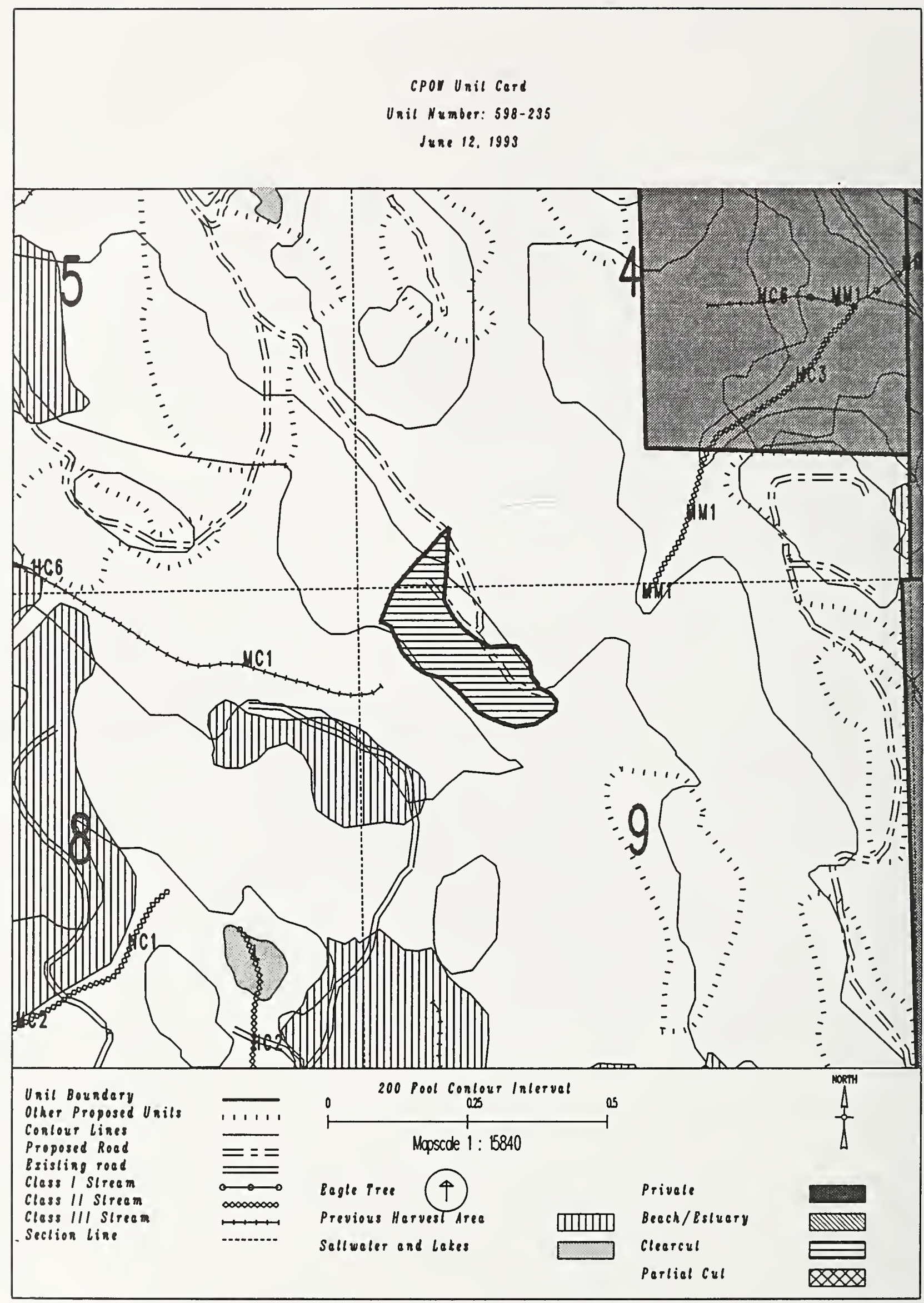


Unit $\quad 598-237$

Planned acres 8

Estimated volume (mbf) 1357

Logging system skyline

silvicultural system clearcut

Forest type Hemlock
Alternatives considered F2 F3 F4 F5 F6

Quad CRGC2NWS

Mgmt Area $\mathrm{K} 10$

WAA 1315

Photo 690139

Aspect South

PHYSICAL DESCRIPTION

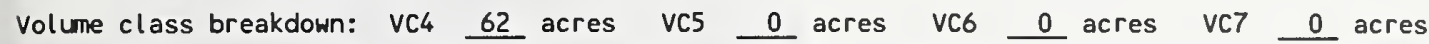

Elevation breakdown: $0-800 \mathrm{ft} . \underline{63}$ acres $800-1200 \mathrm{ft} . \underline{15}$ acres $1200-1500 \mathrm{ft} . \underline{0}$ acres over $1500 \mathrm{ft}$. 0 acres Mass movement index: Low $\underline{60}$ acres Medium $\_$acres High 23 acres Very High 0

\section{SOILS}

This unit has high mass movement index soils. Partial log suspension required over these areas. (BMP13.9)

This unit contains 11 acres of forested wetlands. Site specific BMPs will be designed for selected approved

logging system and road construction practices. (BMPs 12.5, 13.9, 13.15).

\section{TIMBER}

There are no timber mitigation measures anticipated for this unit.

ENGINEERING

High mass movement index soils. Road construction must minimize landslide potential (BMP14).

\section{FISH/WATERSHED}

This unit contains streams which have recently been classified/channel typed but require field verification.

\section{WILDLIFE}

There are no wildlife mitigation measures anticipated for this unit.

\section{RECREATION / VISUALS}

This unit has a proposed Voo of MM and is not seen from any viewpoint identified by this project.

\section{LANDS}

There are no lands mitigation measures anticipated for this unit.

\section{CULTURAL RESOURCES}

There are no cultural resource mitigation measures anticipated for this unit.

\section{GEOLOGY}

There are no karst mitigation measures anticipated for this unit. 


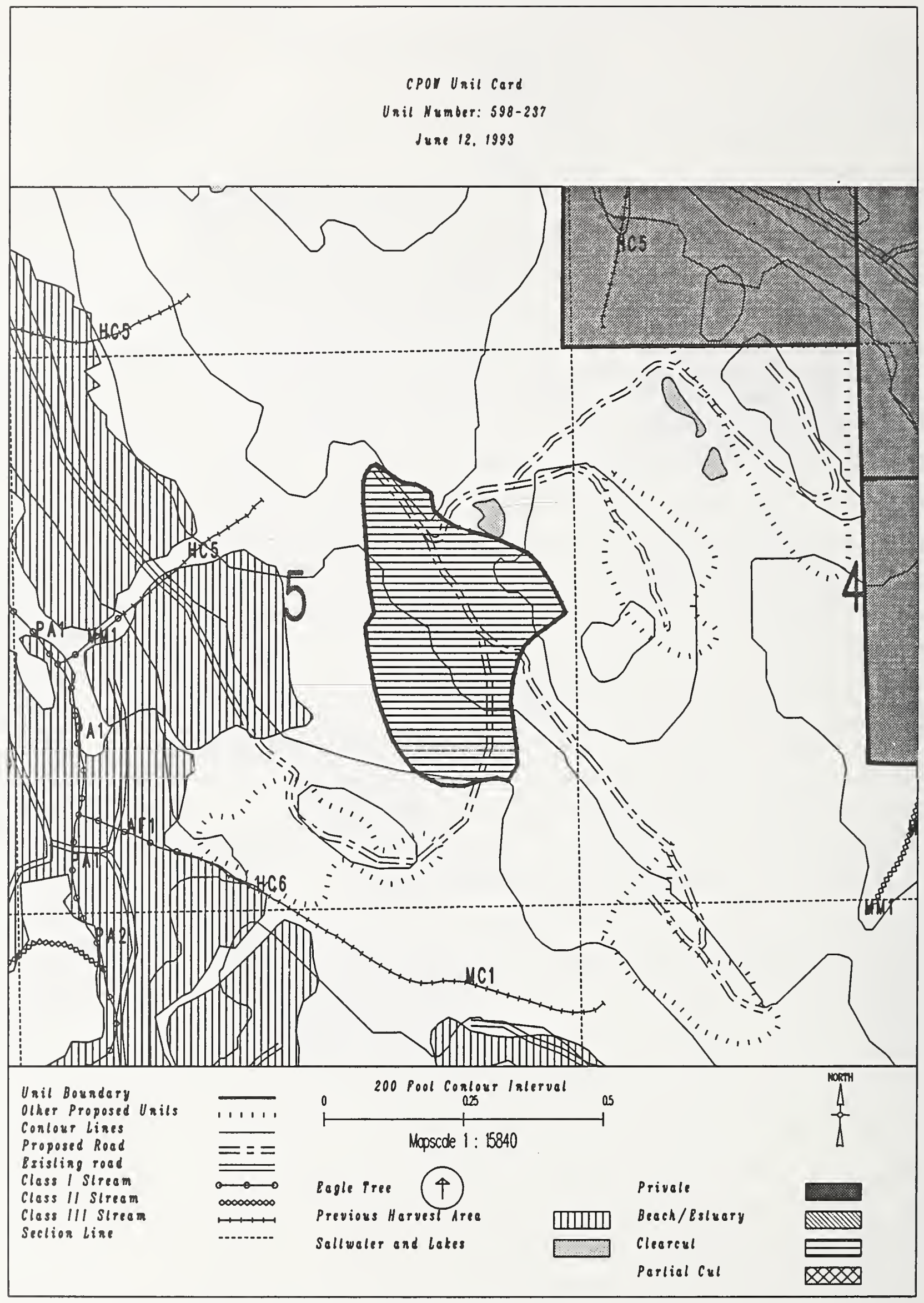


Unit $\quad 598-238$

Planned acres 31

Est imated volume (mbf) 657

Logging system Highlead

silvicultural system clearcut

Forest type Hemlock

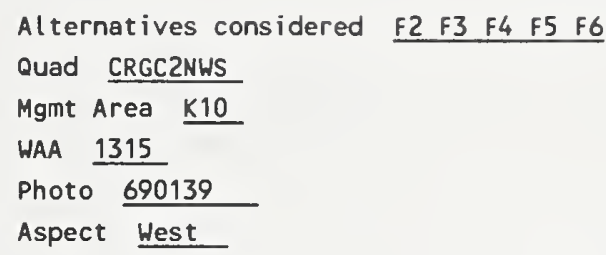

PHYSICAL DESCRIPTION

Volume class breakdown: VC4 30 acres VC5 $\quad \begin{array}{lllllllllll}0 & \text { acres } & \text { VC6 } & 0 & 0 & \text { acres } & \text { VC7 } & 0 & \text { acres }\end{array}$

Elevation breakdown: $0-800 \mathrm{ft} . \underline{29}$ acres $800-1200 \mathrm{ft} . \underline{0}$ acres $1200-1500 \mathrm{ft} . \underline{0}$ acres over $1500 \mathrm{ft}$. 0 acres Mass movement index: Low 25 acres Medium $\_$acres High 5 acres Very High 0

\section{SOILS}

This unit has high mass movement index soils. Partial log suspension required over these areas.(BMP13.9)

This unit contains 7 acres of forested wetlands. Site specific BMPs will be designed for selected approved

logging system and road construction practices. (BMPs 12.5, 13.9, 13.15).

\section{TIMBER}

There are no timber mitigation measures anticipated for this unit.

\section{ENG INEER ING}

There are no engineering mitigation measures anticipated for this unit.

\section{FISH/WATERSHED}

There are no fishery mitigation measures anticipated for this unit.

\section{WILDLIFE}

There are no wildlife mitigation measures anticipated for this unit.

\section{RECREATION / VISUALS}

This unit has a proposed VQO of MM and is not seen from any viewpoint identified by this project.

\section{LANDS}

There are no lands mitigation measures anticipated for this unit.

\section{CULTURAL RESOURCES}

There are no cultural resource mitigation measures anticipated for this unit.

\section{GEOLOGY}

There are no karst mitigation measures anticipated for this unit. 


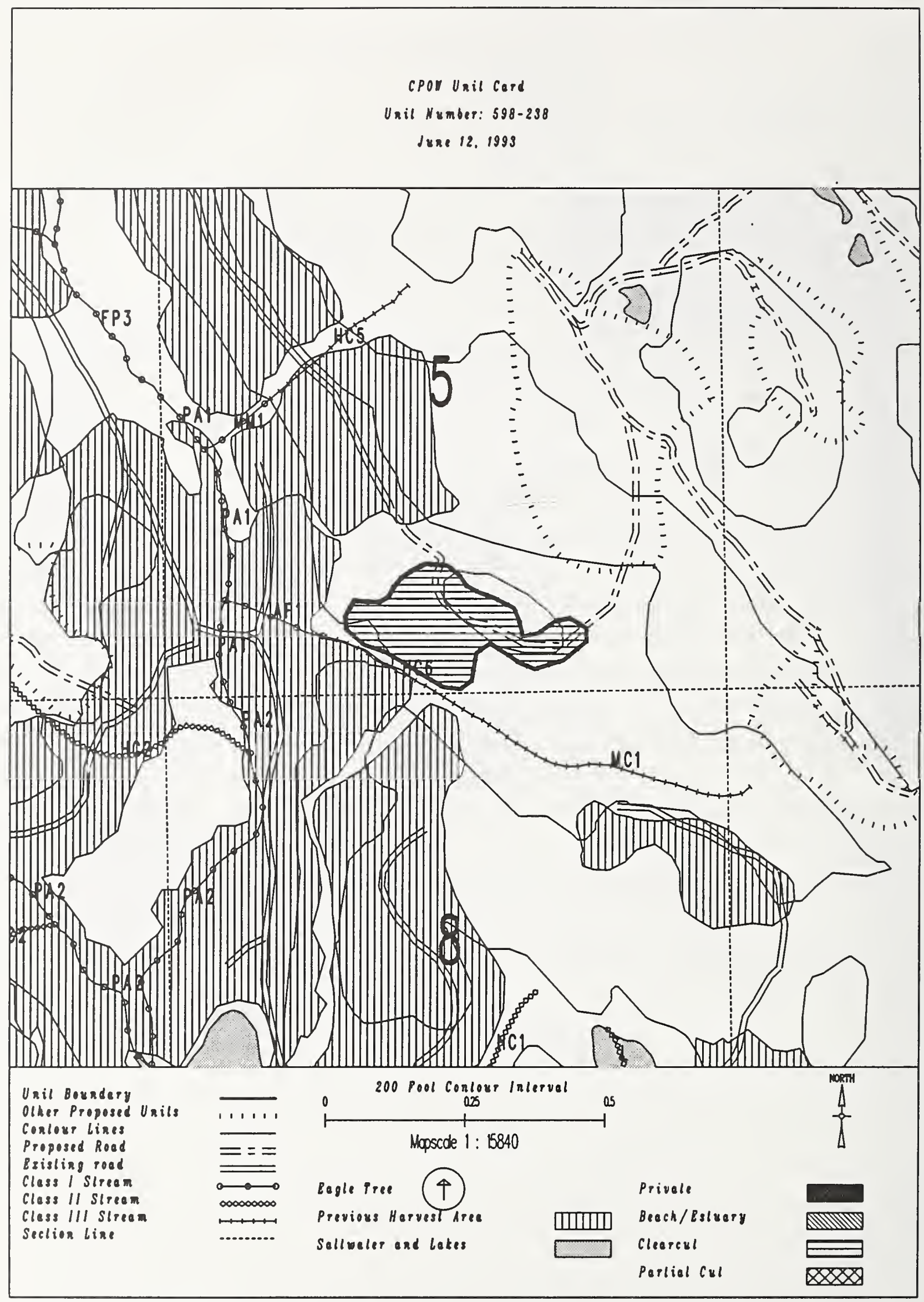


Unit $598-242$

Planned acres 62

Estimated volume (mbf) 1389

Logging system Highlead

silvicultural system clearcut

Forest type Hemlock

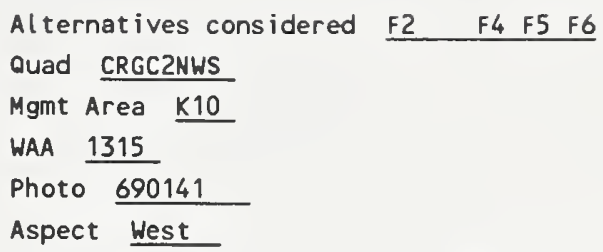

PHYSICAL DESCRIPTION

Volume class breakdown: VC4 29 acres VC5 23 acres VC6 $\quad 0$ acres VC7 $\quad 0$ acres

Elevation breakdown: $0-800 \mathrm{ft} . \underline{27}$ acres $800-1200 \mathrm{ft} . \underline{32}$ acres $1200-1500 \mathrm{ft} . \underline{0}$ acres over $1500 \mathrm{ft}$. 0 acres Mass movement index: Low $\underline{32}$ acres Medium $\underline{29}$ acres High $\underline{0}$ acres Very High 0 acres

SOILS

There are no soils mitigation measures anticipated for this unit.

TIMBER

There are no timber mitigation measures anticipated for this unit.

\section{ENGINEER ING}

There are no engineering mitigation measures anticipated for this unit.

\section{FISH/WATERSHED}

This unit contains streams which have recently been classified/channel typed but require field verification.

\section{WILDL IFE}

Maintain diversity within unit by leaving 1-5 acre-sized islands of green trees at a rate of 1 acre of island for every 20 acres harvested. Leave islands must be compatible with logging system and safe working conditions.

RECREATIOH / VISUALS

This unit has a proposed $V Q O$ of $M M$ and is not seen from any viewpoint identified by this project.

\section{LANDS}

There are no lands mitigation measures anticipated for this unit.

CULTURAL RESOURCES

There are no cultural resource mitigation measures anticipated for this unit.

GEOLOGY

There are no karst mitigation measures anticipated for this unit. 
cPol Unil cord

Unit Number: $598-212$

June 12, 1999

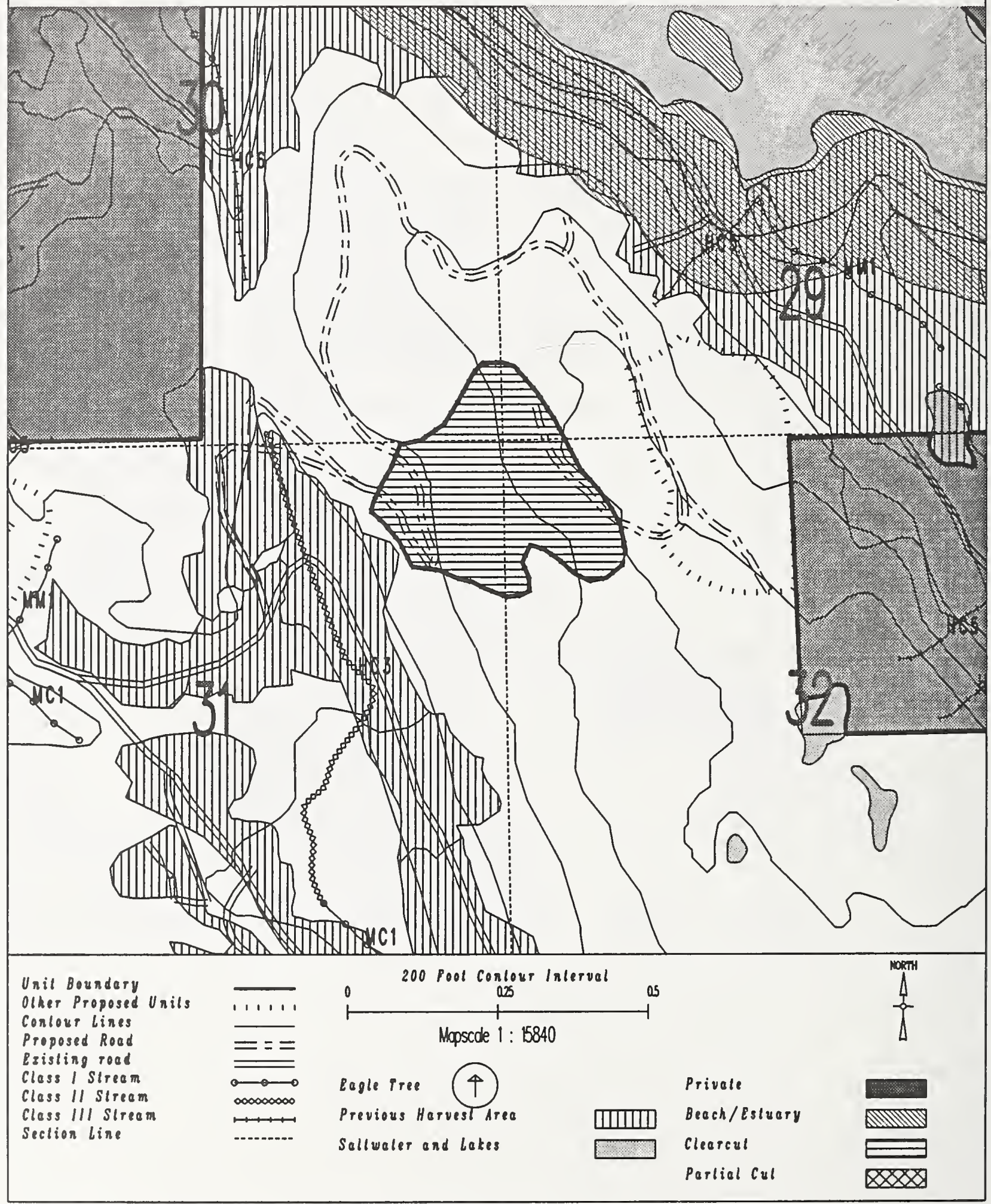


Unit 598-245

Planned acres 29

Estimated volume (mbf)

Logging system Highlead

silvicultural system clearcut

Forest type Hemlock
Al ternatives considered

Quad CRGC2NUS

Mgmt Area $\mathrm{K} 10$

HAA 1315

Photo 290115

Aspect South

PHYSICAL DESCRIPTION

Volume class breakdown: VC4 $\quad 27$ acres VCS $\quad 0$ acres vC6 $\quad 0$ acres vc7 $\quad 0$ acres

Elevation breakdown: $0-800 \mathrm{ft} . \underline{28}$ acres $800-1200 \mathrm{ft} . \underline{0}$ acres $1200-1500 \mathrm{ft} . \underline{0}$ acres over $1500 \mathrm{ft}$. 0 Mass movement index: Low 25 acres Medium 0 acres High 4 acres Very High 0 acres

SOILS

This unit has high mass movement index soils. Partial log suspension required over these areas.(BMP13.9)

This unit has a slight possibility to be reclassified as MMI $=4$.

\section{TIMBER}

There are no timber mitigation measures anticipated for this unit.

\section{ENGINEER ING}

High mass movement index soils. Road construction must minimize landslide potential (8MP14).

\section{FISH/WATERSHED}

There are no fishery mitigation measures anticipated for this unit.

\section{HILDLIFE}

Maintain adequate distribution of snags by leaving 0.1 acre-sized patches of green trees within the unit for every 10 acres harvested. Snag patches must be compatible with logging system and safe working conditions.

RECREATION / VISUALS

This unit has a proposed vQO of MM and is not seen from any viewpoint identified by this project.

\section{LANDS}

There are no lands mitigation measures anticipated for this unit.

CULTURAL RESOURCES

The planned unit boundary and road location is immediately adjacent to significant cultural resources. Any changes must be coordinated with cultural resource personnel. 
CPOY Unil Card

Unil Number: 598-215

June 12, 1999

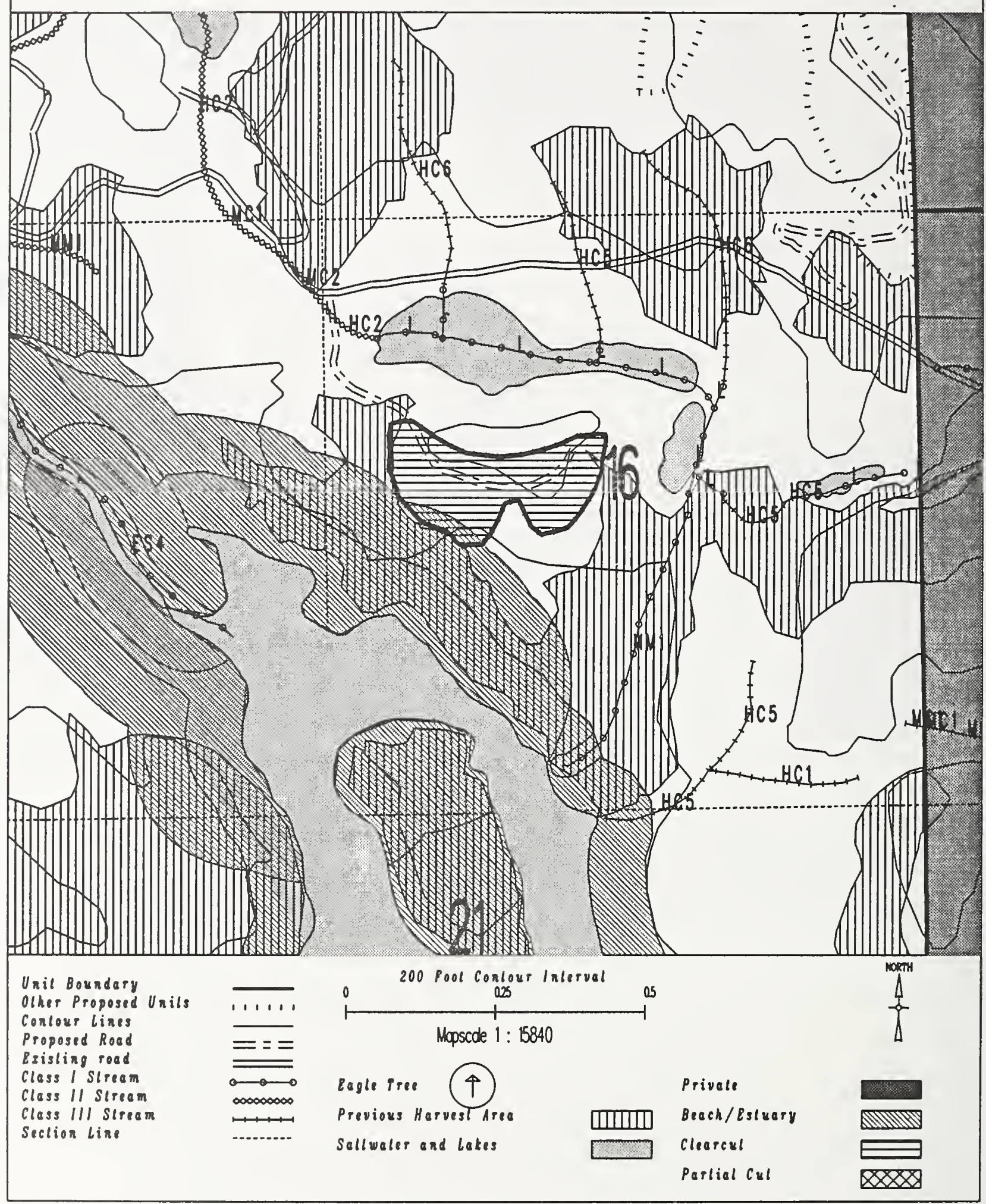


Unit $598-249$

Planned acres 63

Estimated volume (mbf) 2261

Logging system skyline

silvicultural system clearcut

Forest type Mixed conifer
Alternatives considered

F3 F4

CRGC2SWN

Mgmt Area $\mathrm{K} 10$

WAA 1315

Photo 690078

Aspect East

PHYSICAL DESCRIPTION

Volume class breakdown: VC4 $\quad 0$ acres VC5 14 acres VC6 42 acres vC7 4 acres

Elevation breakdown: $0-800 \mathrm{ft} .56$ acres $800-1200 \mathrm{ft} . \quad 0$ acres $1200-1500 \mathrm{ft}$. 0 acres over $1500 \mathrm{ft}$. 0 acres Mass movement index: Low 22 acres Medium $\underline{O}$ acres High $\underline{39}$ acres Very High $\underline{0}$ acres

SOILS

This unit has high mass movement index soils. Partial log suspension required over these areas. (BMP13.9)

TIMBER

There are no timber mitigation measures anticipated for this unit.

ENGINEERING

High mass movement index soils. Road construction must minimize landslide potential (BMP14).

The road into this unit crosses a $\underline{C 1}$ channel. Meet stream and lake protection prescription requirements in TLMP Draft Revision (1991a) for this process group.

\section{FISH/HATERSHED}

Potential for additional Class I/II streams within unit. May be necessary to place additional buffers within unit

in accordance with AHMU Handbook.

This unit contains streams which have recently been classified/channel typed but require field verification.

WILDLIFE

There are no wildlife mitigation measures anticipated for this unit.

RECREATION / VISUALS

This unit has a proposed vQo of MM and is not seen from any viewpoint identified by this project.

\section{LANDS}

There are no lands mitigation measures anticipated for this unit.

\section{CULTURAL RESOURCES}

There are no cultural resource mitigation measures anticipated for this unit.

\section{GEOLOGY}

There are no karst mitigation measures anticipated for this unit. 
cPor Unil Cerd

Unil Nember: $598-219$

Juxe 12, 1999

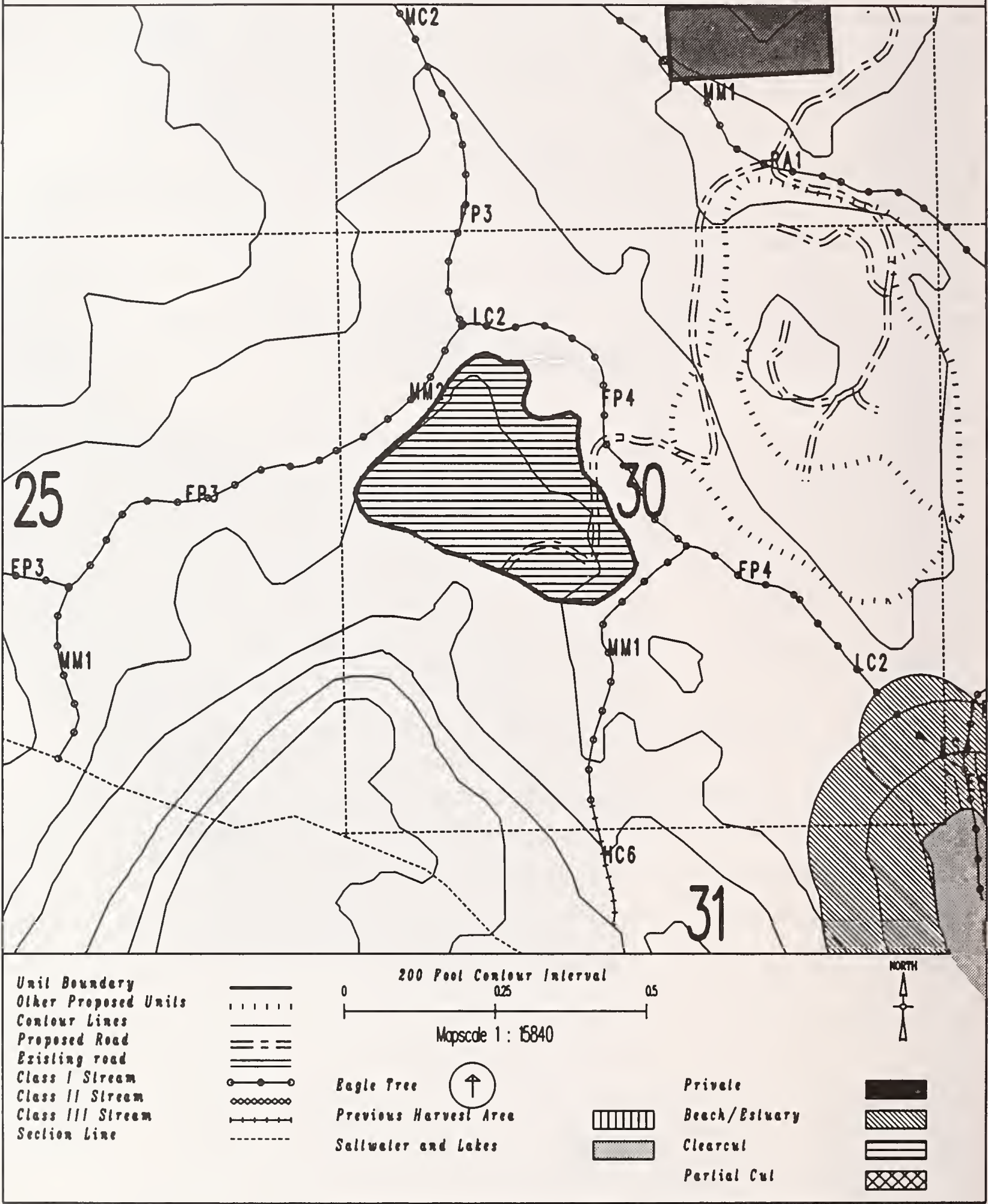




\section{Road Cards}

Road cards have been developed for each new specified road proposed for construction for the Central Prince of Wales (CPOW) Environmental Impact Statement (EIS). These cards are intended to display information, enabling the public to more fully understand road construction implications. They also serve as a mechanism to consolidate information gathered during office/field reconnaissance of the proposed road location to Forest service field personnel, and were used by the Interdisciplinary Team (IDT) for consideration in preparation of the Final EIS.

The road cards consist of two parts: (1) a schematic map, and (2) a summary of road management objectives and resource concerns. The map displays the existing transportation network, streams by AHMU class, and the proposed new specified road location, including road number.

The reverse side of the card provides a road number, access management classification/objective, types of streams crossed, resource concerns, and mitigation measures. Resource considerations are identifed for recreation, karst, wildife, fisheries, cultural resources, soils, and lands. 



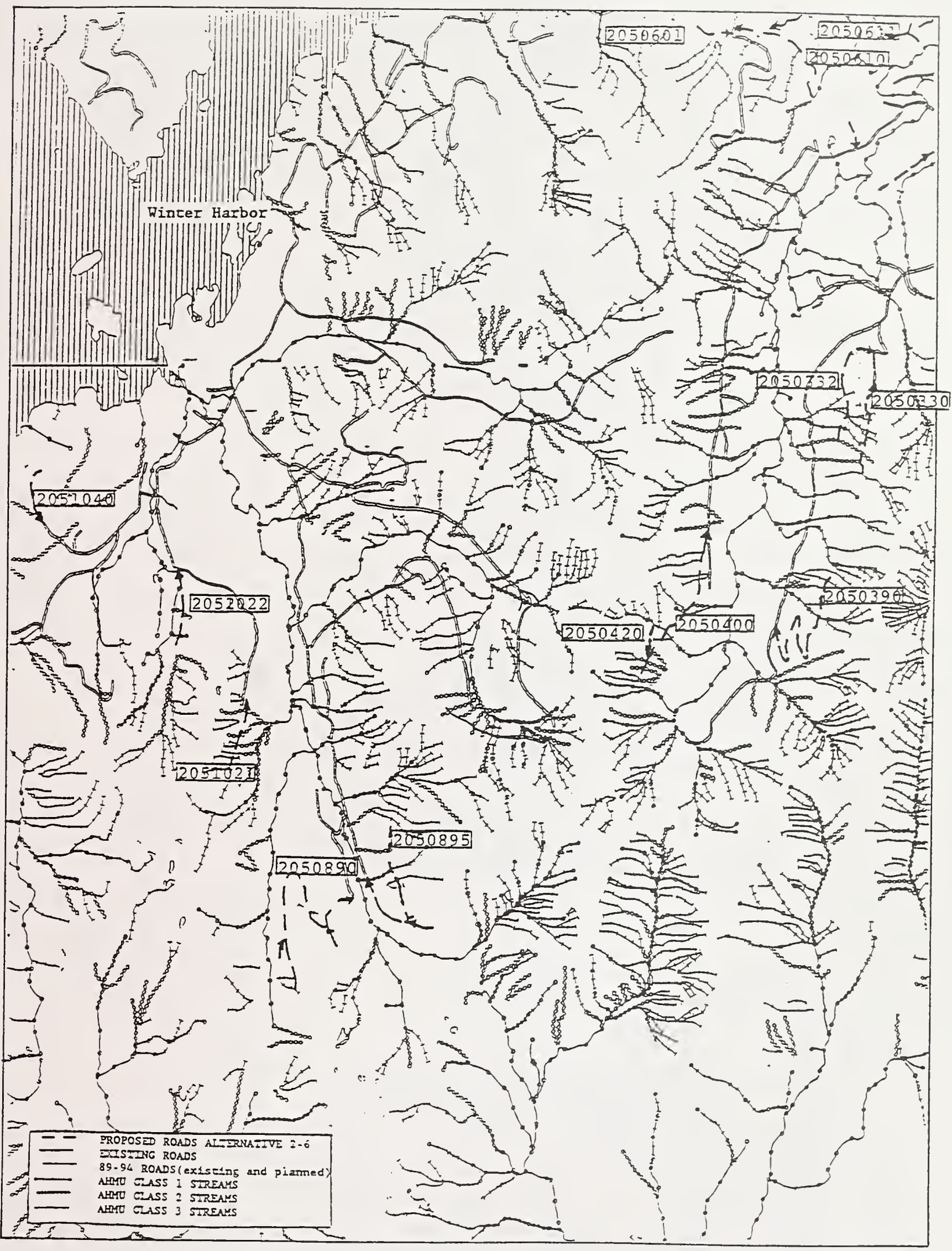




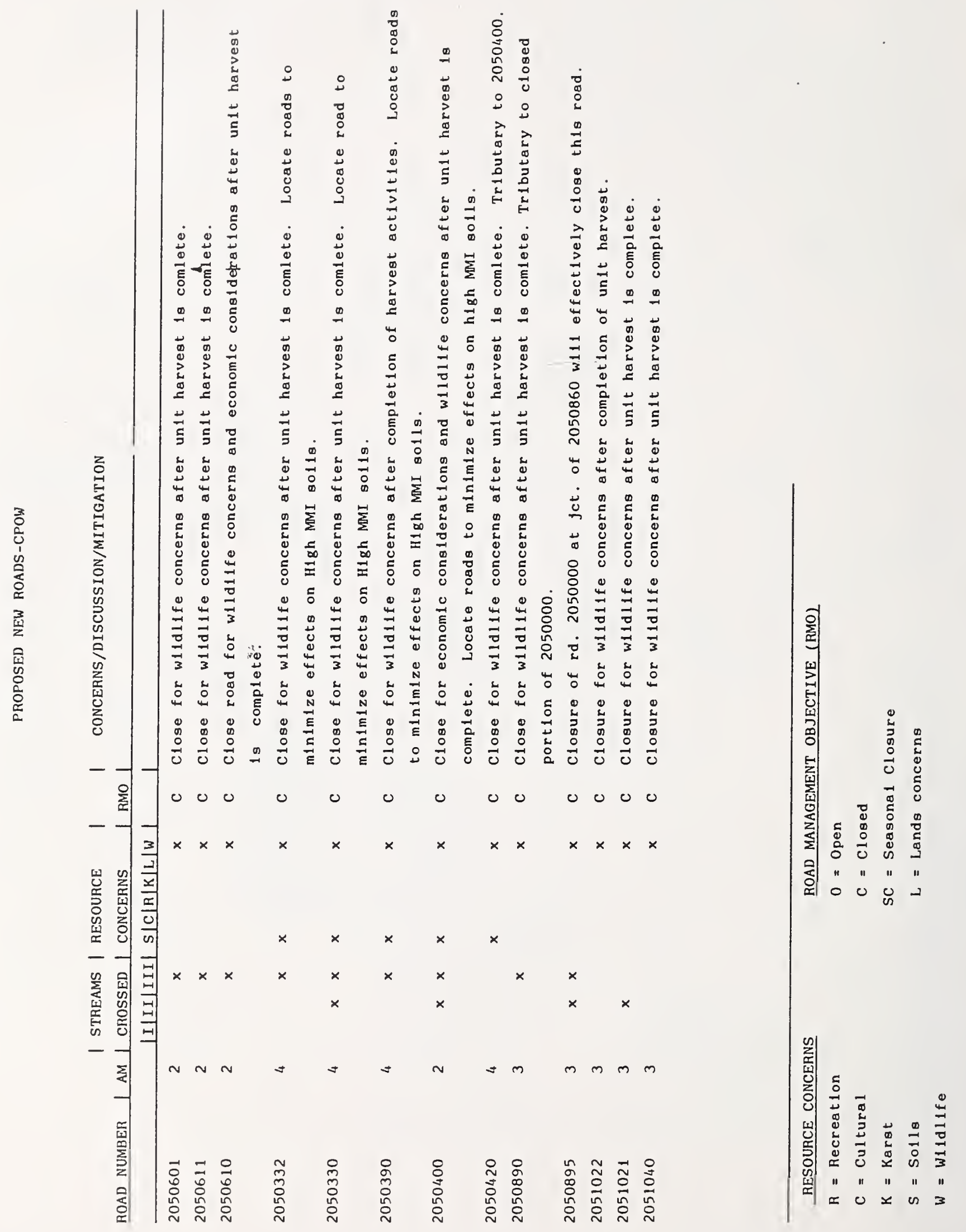




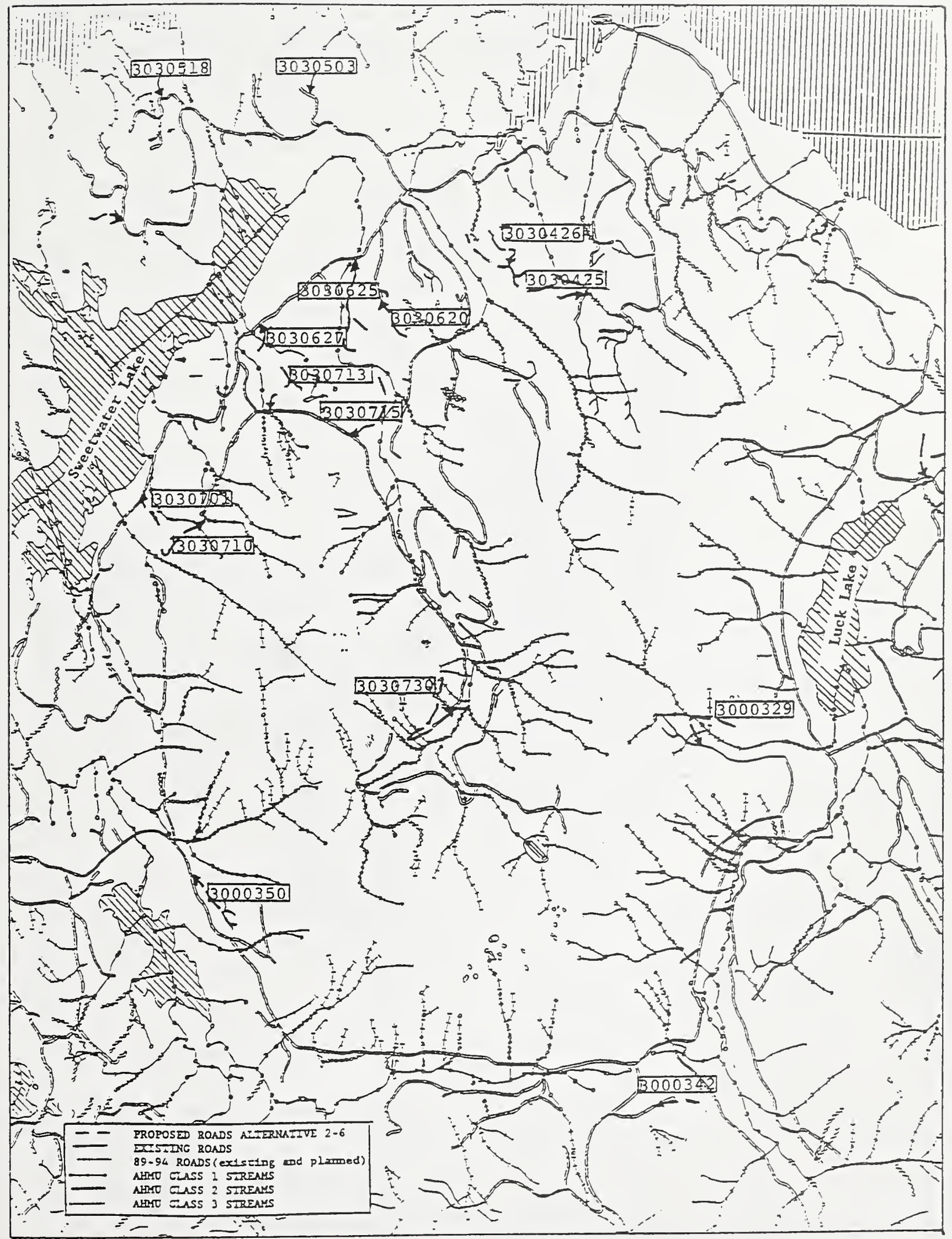




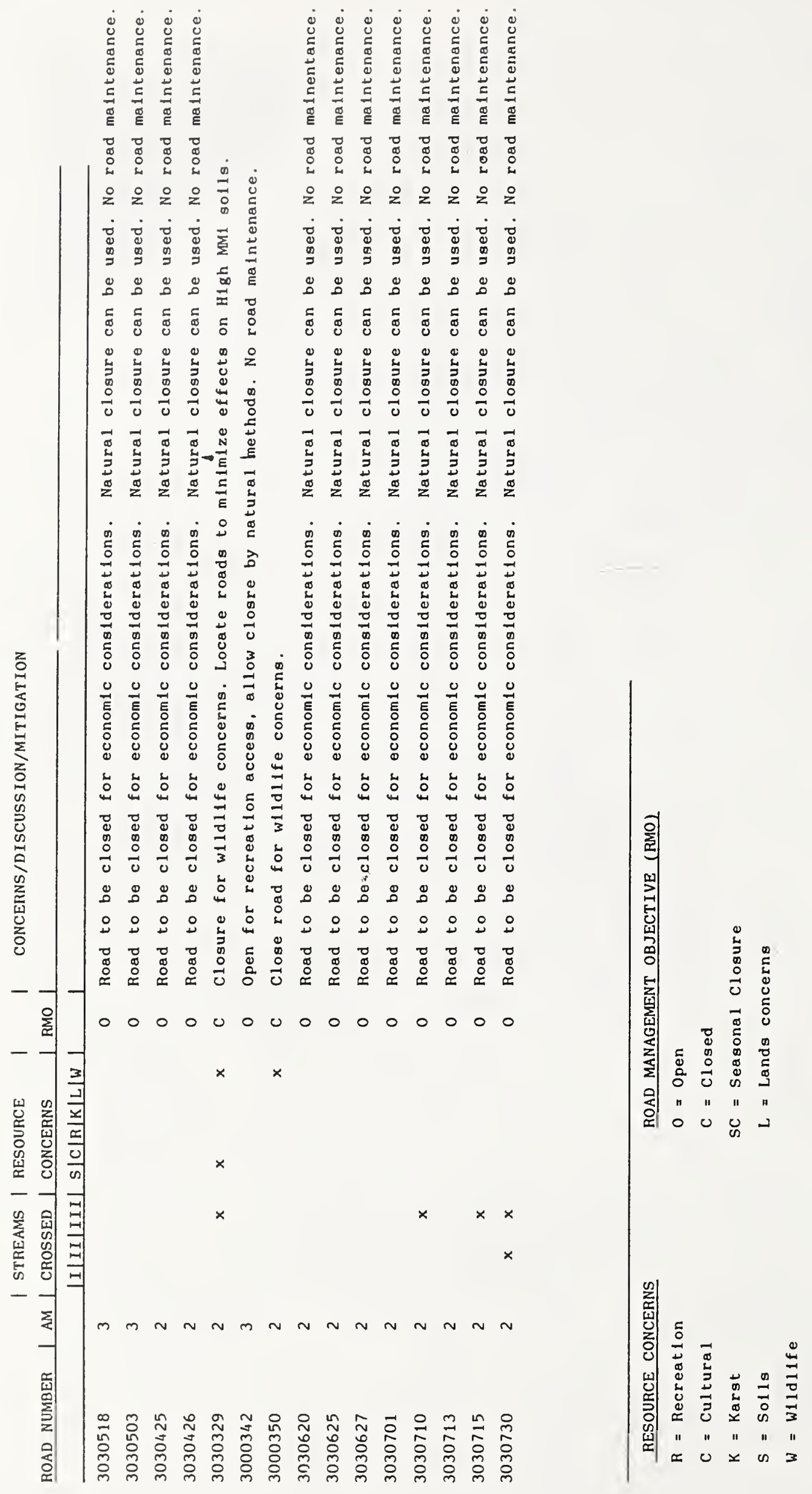




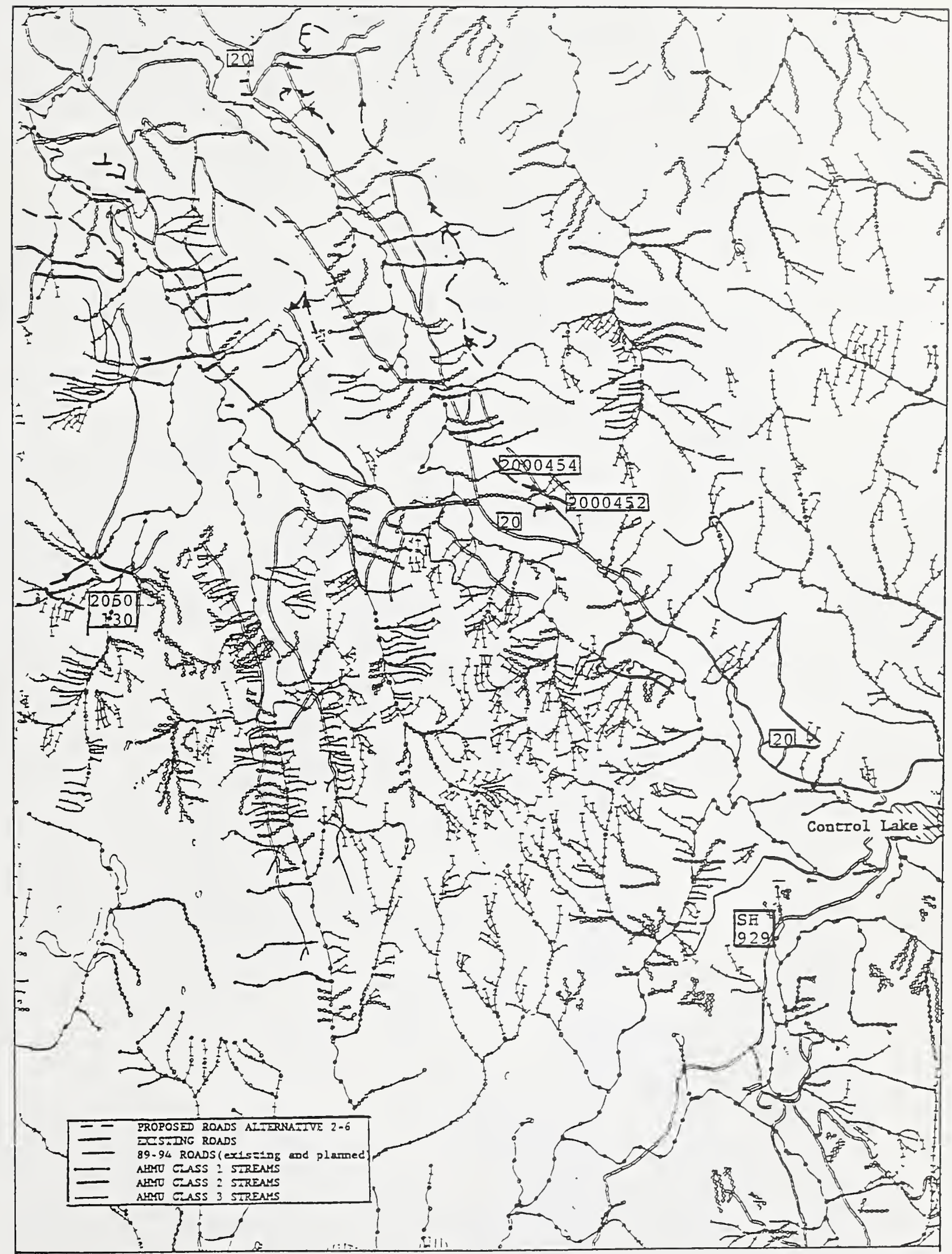




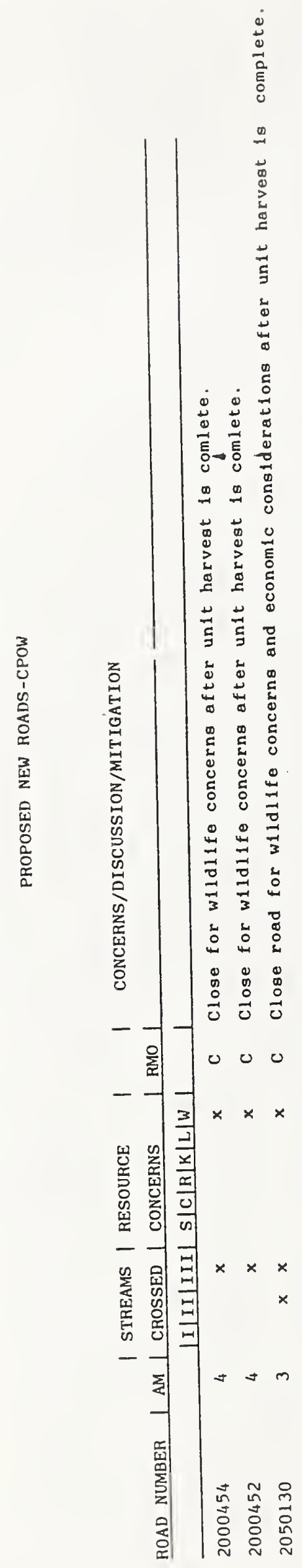

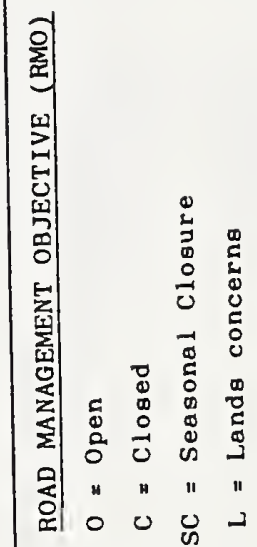

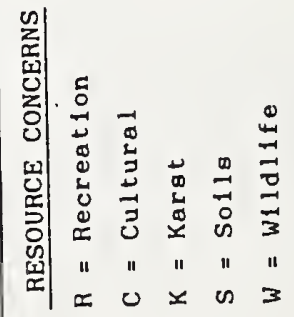




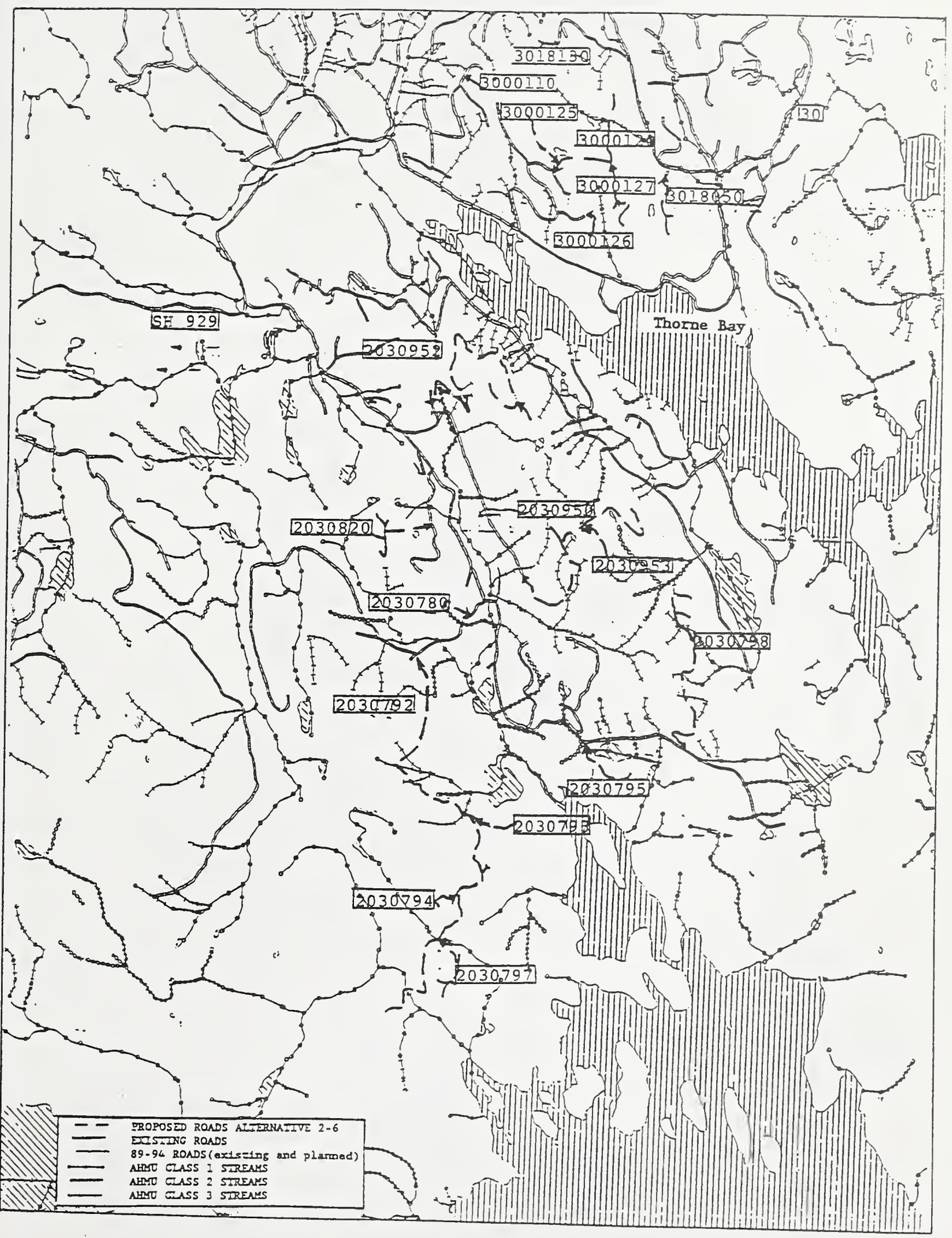




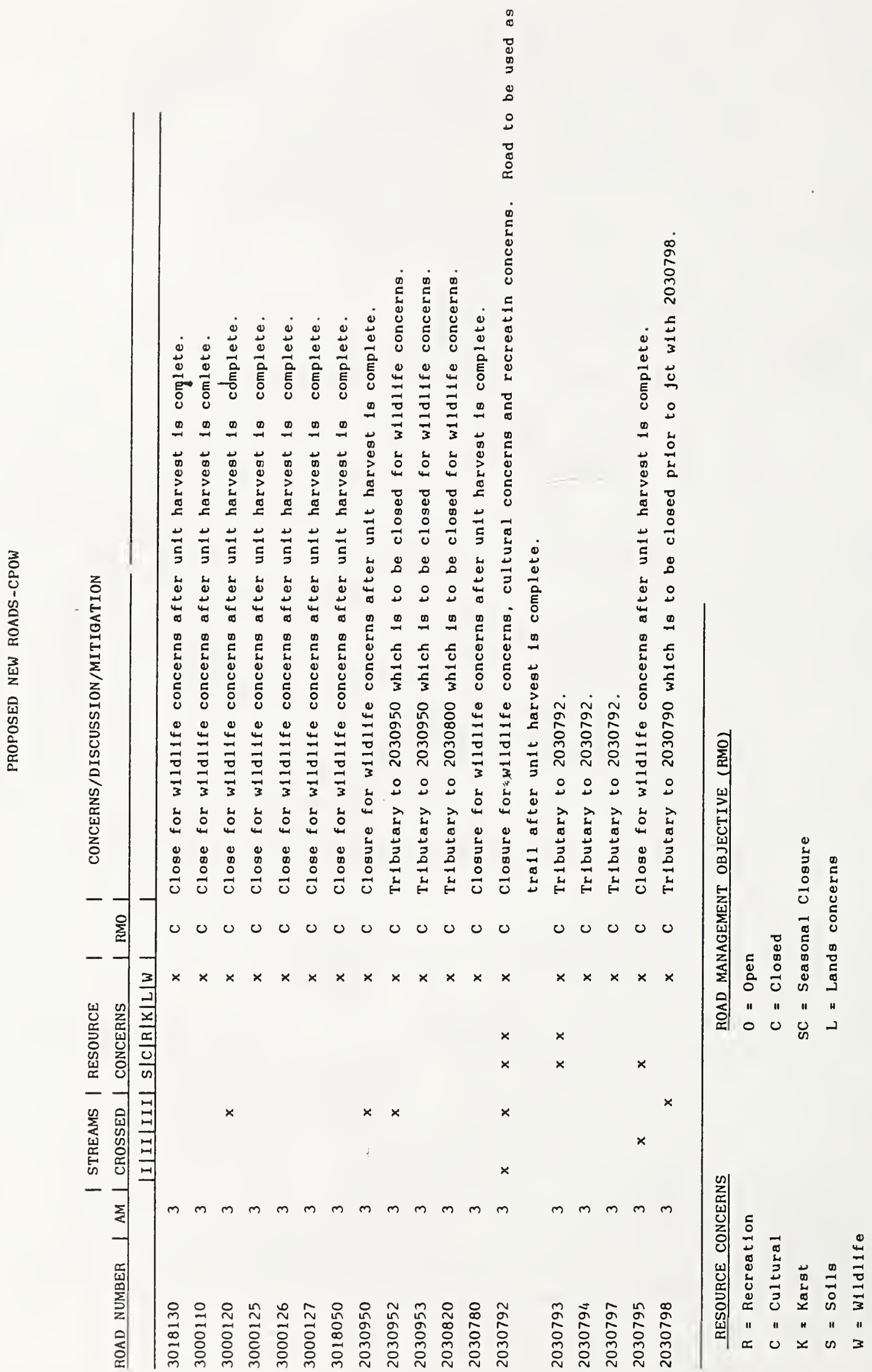




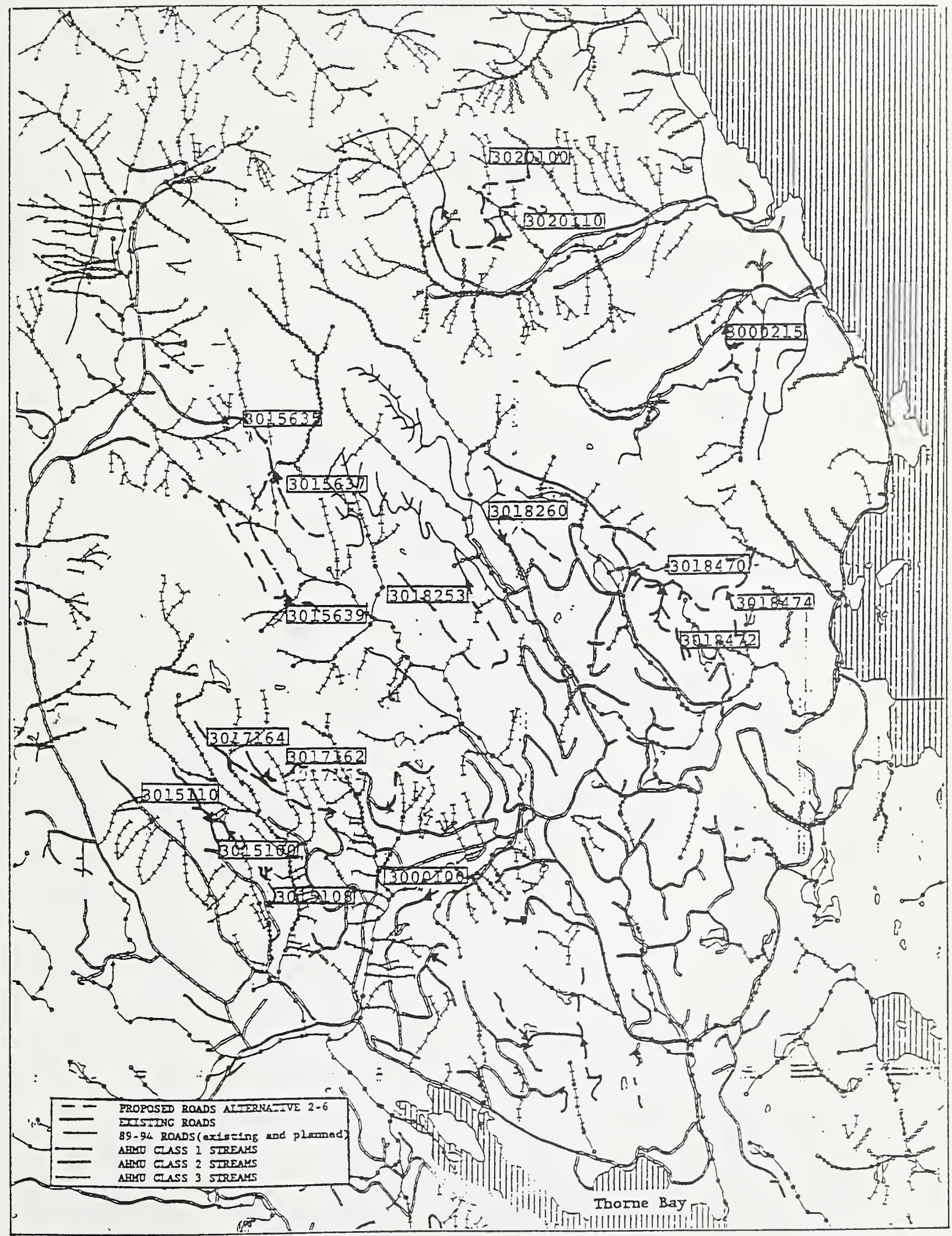




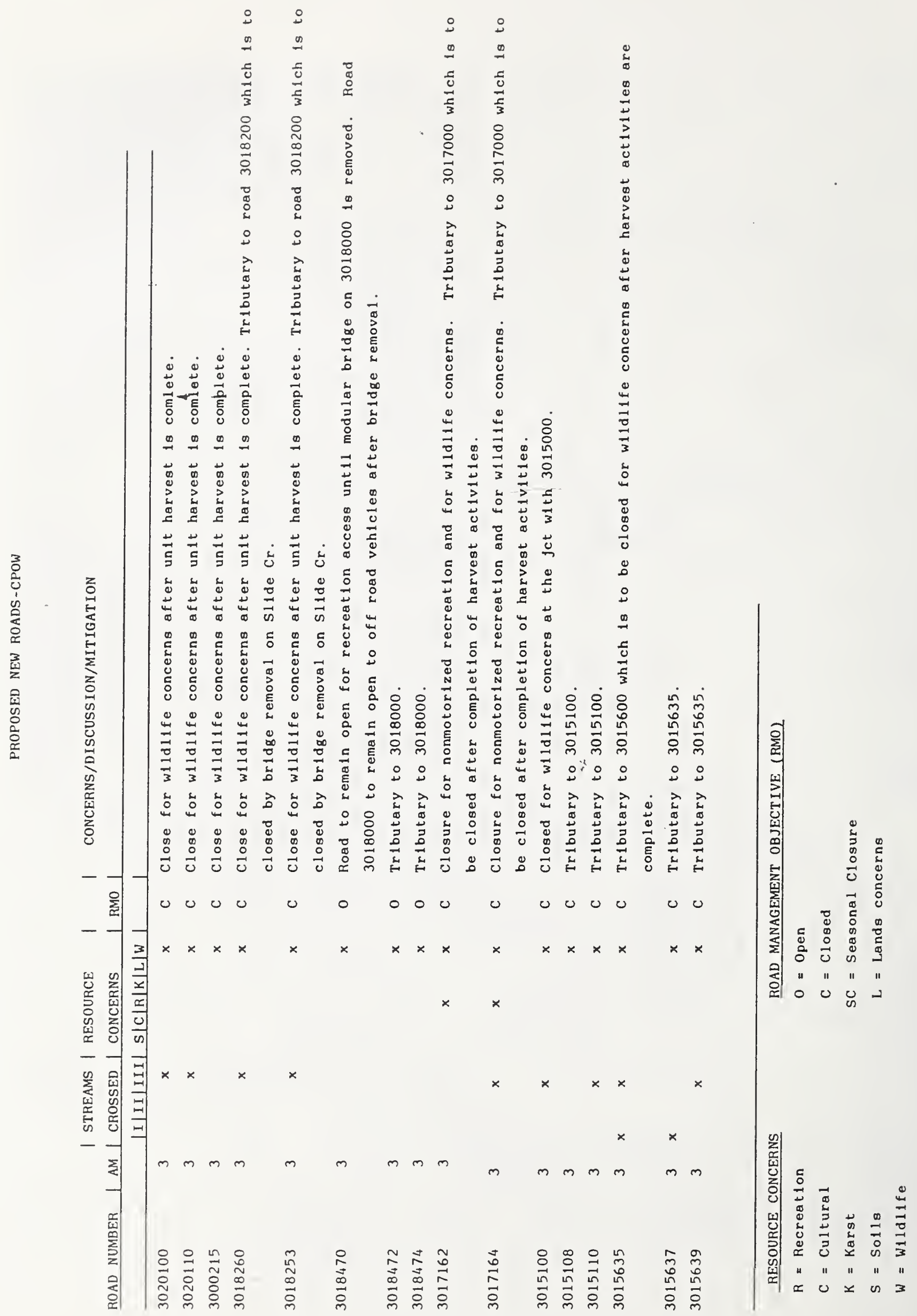




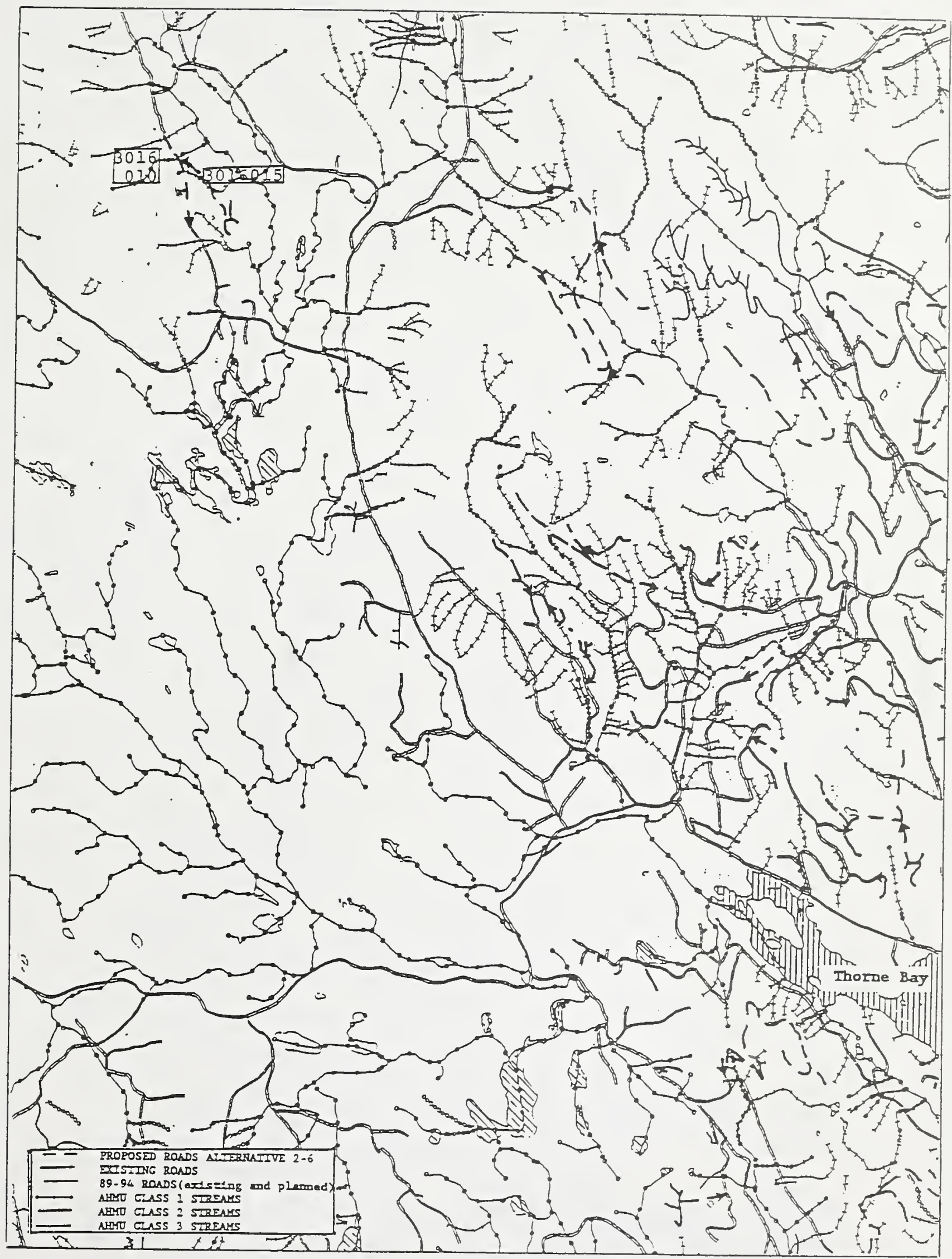




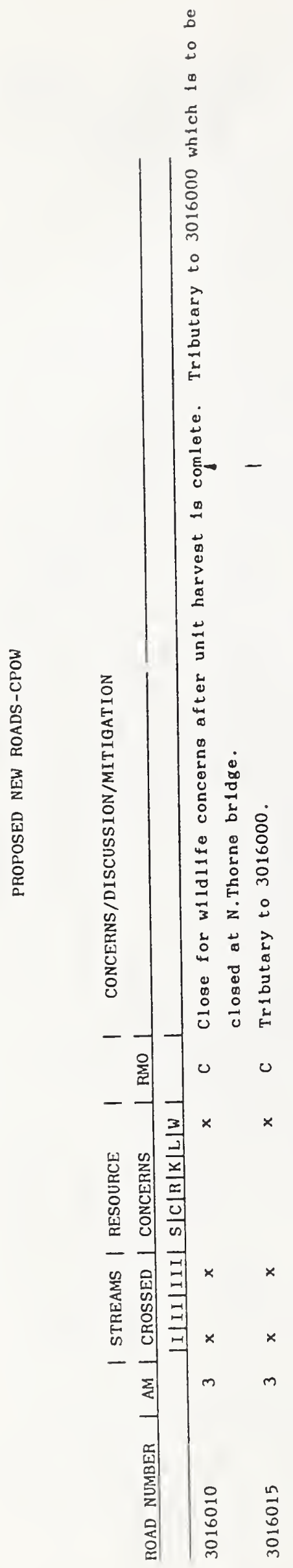

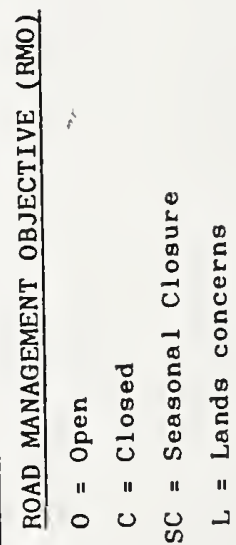

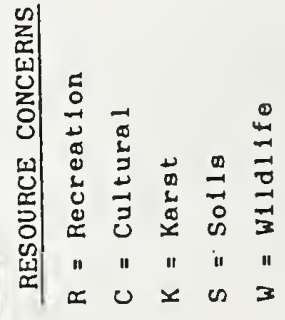




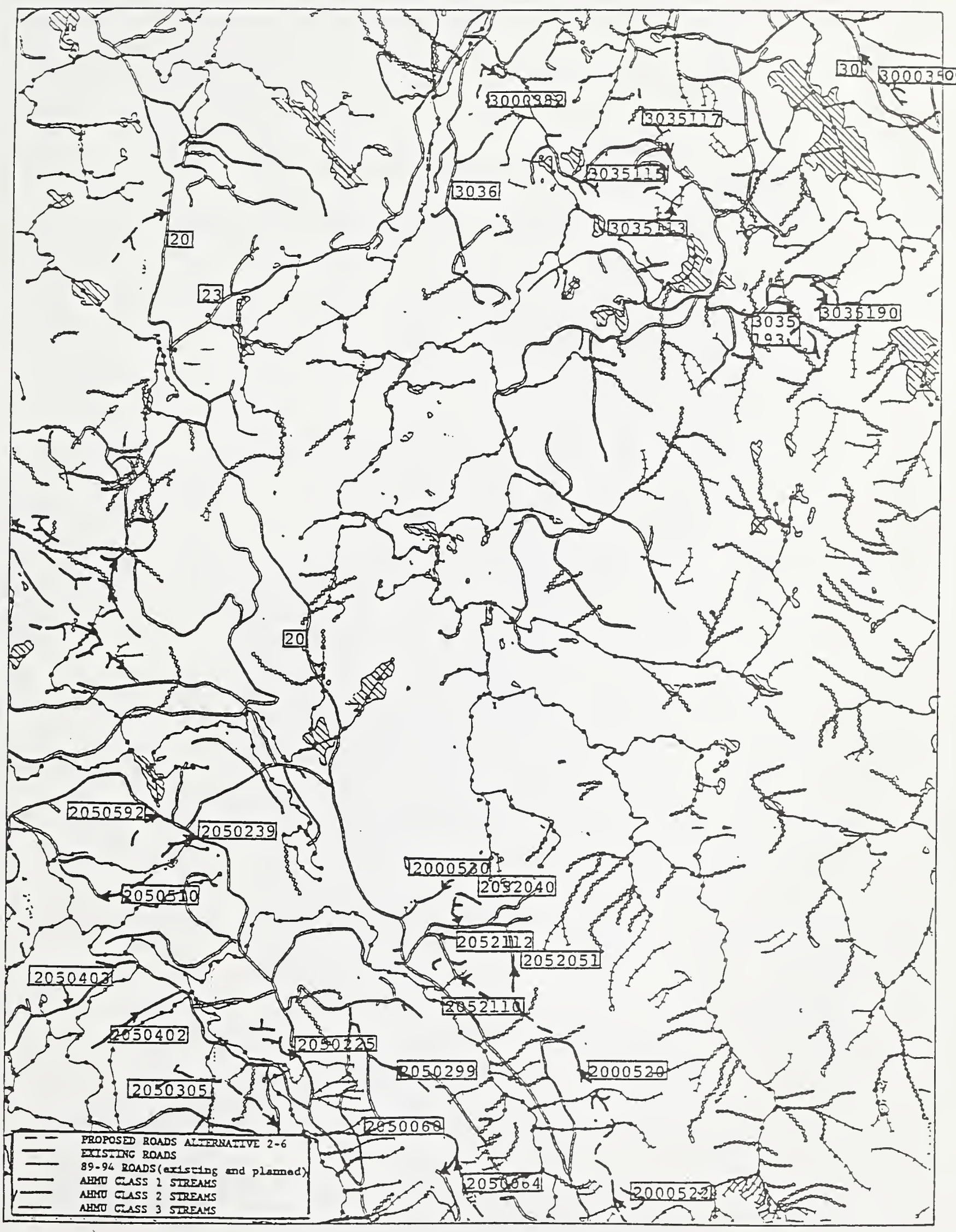




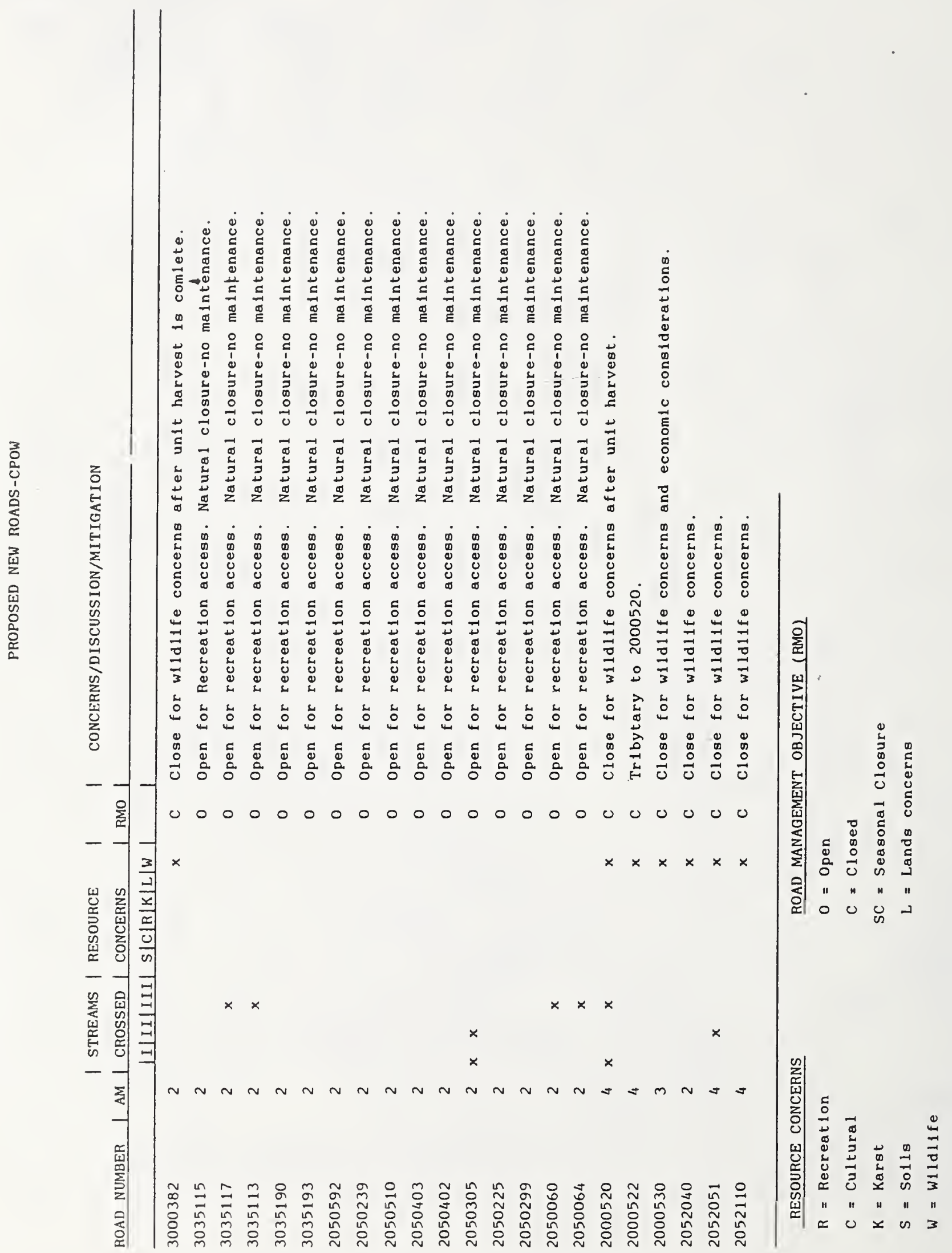




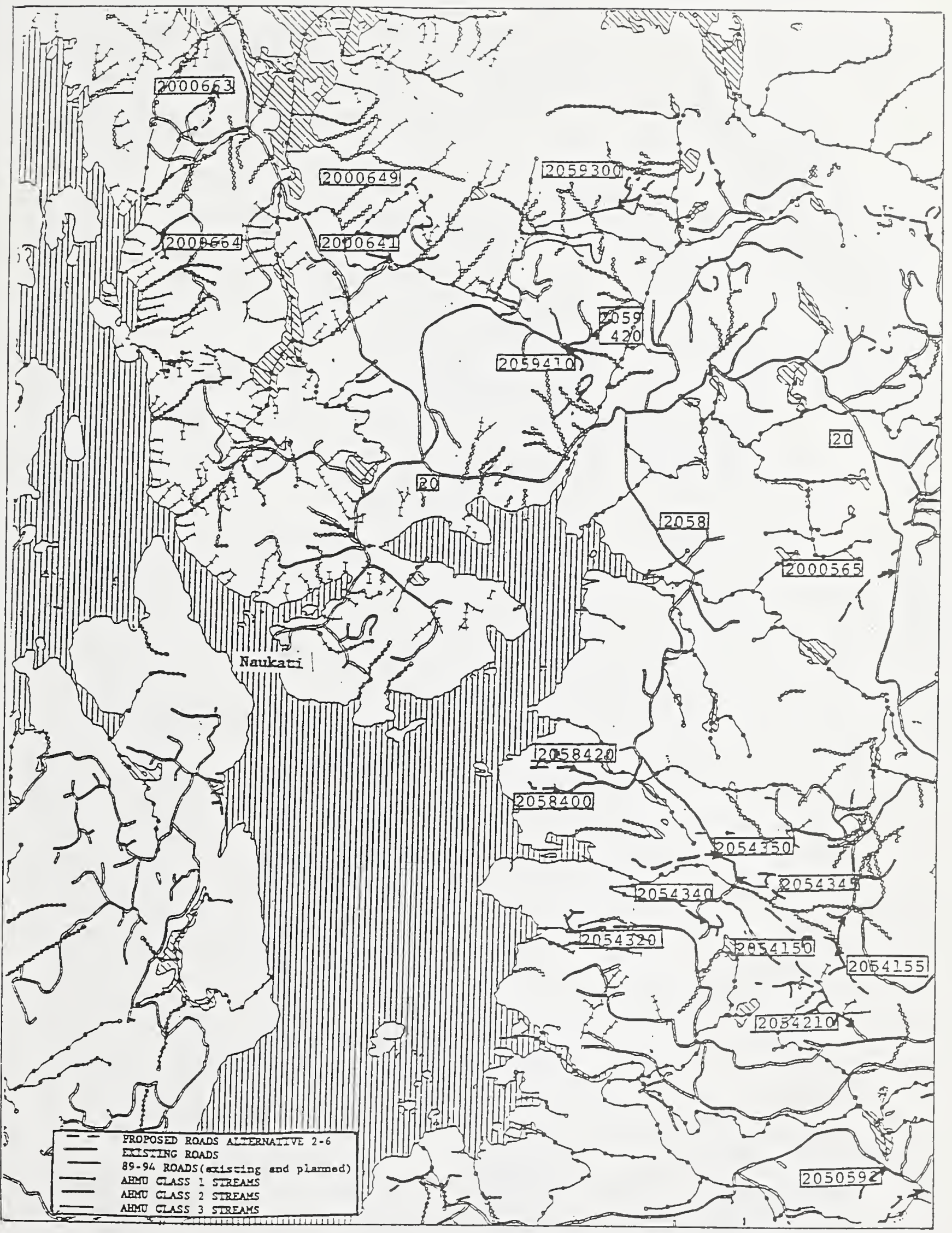



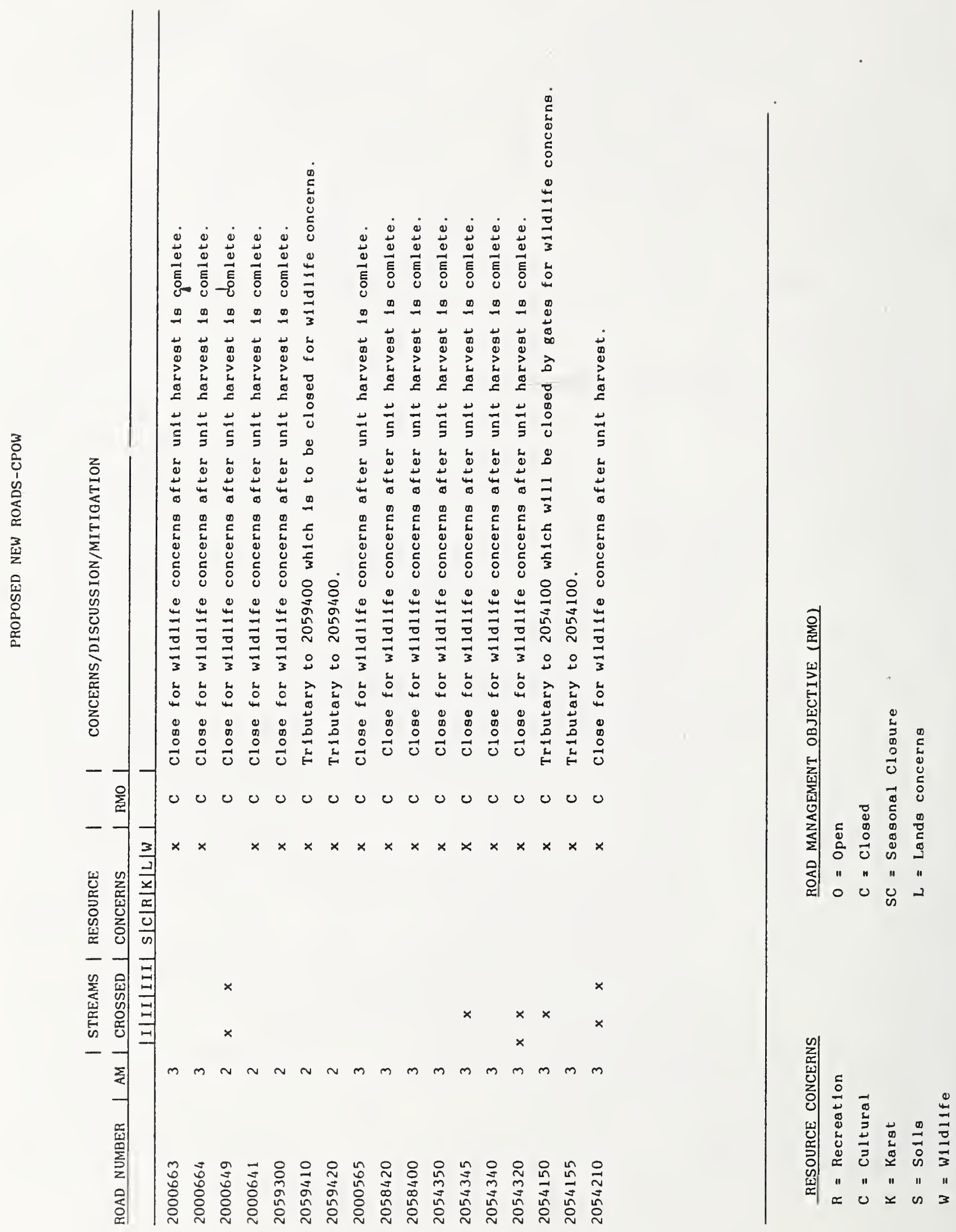


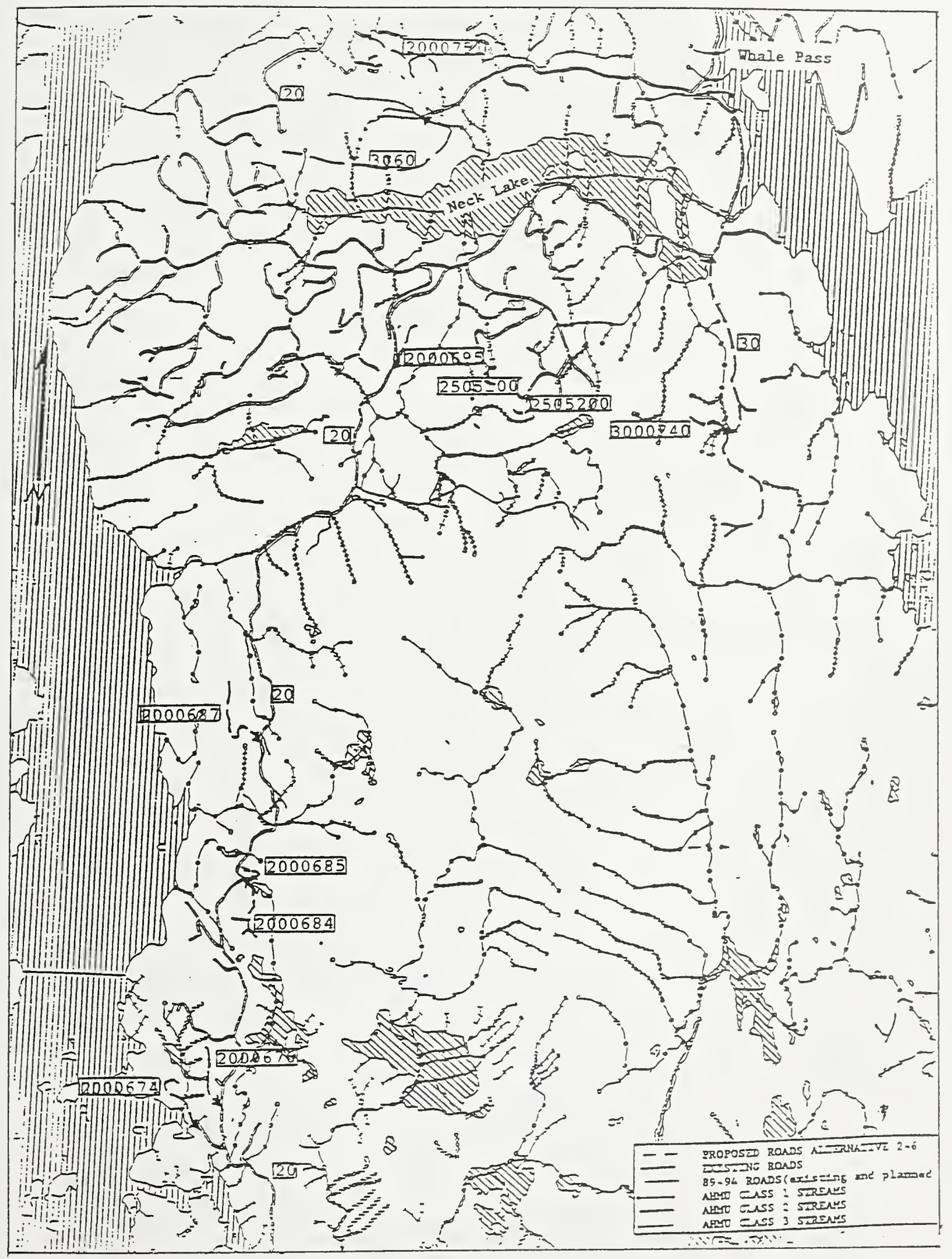



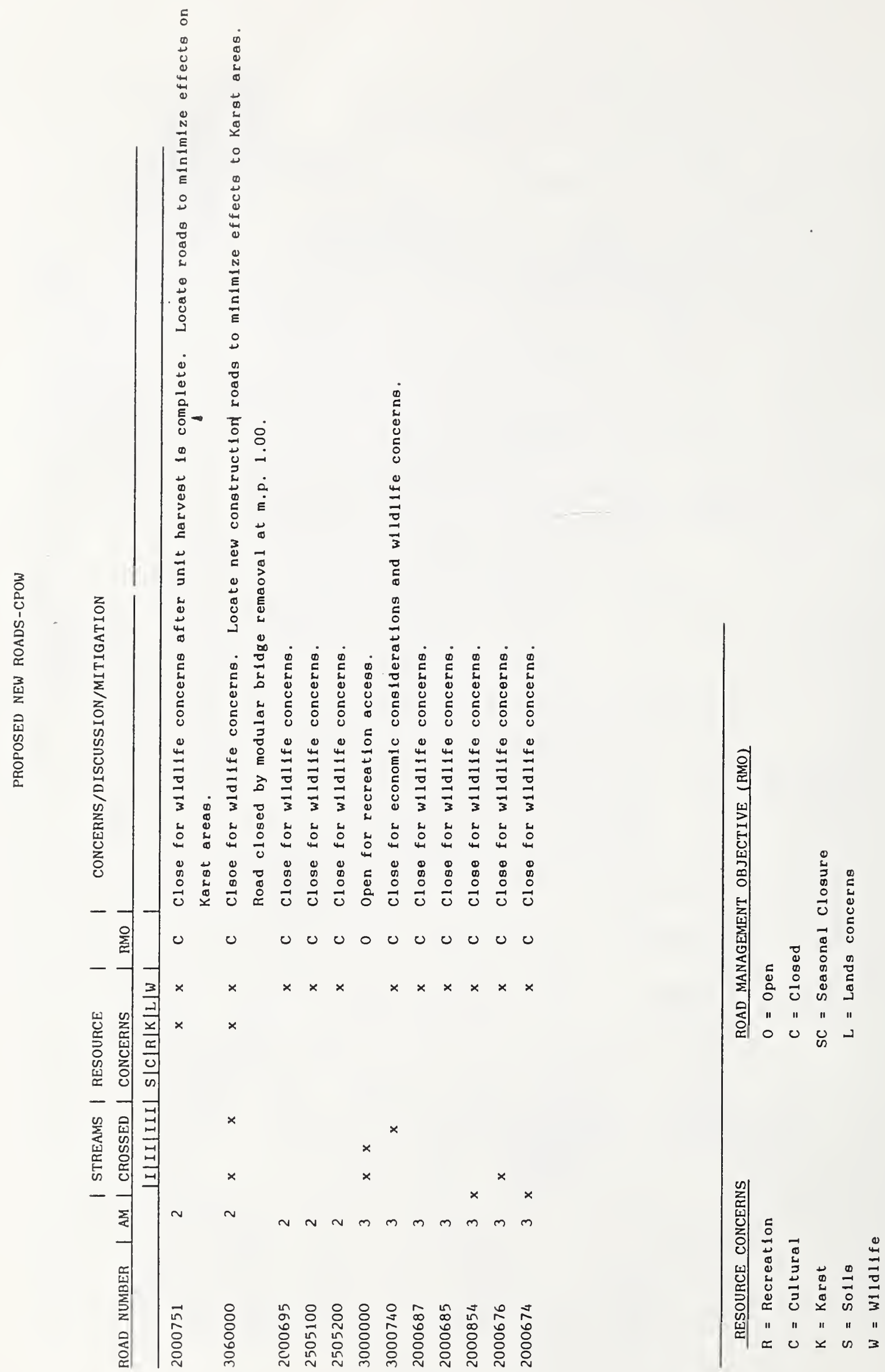


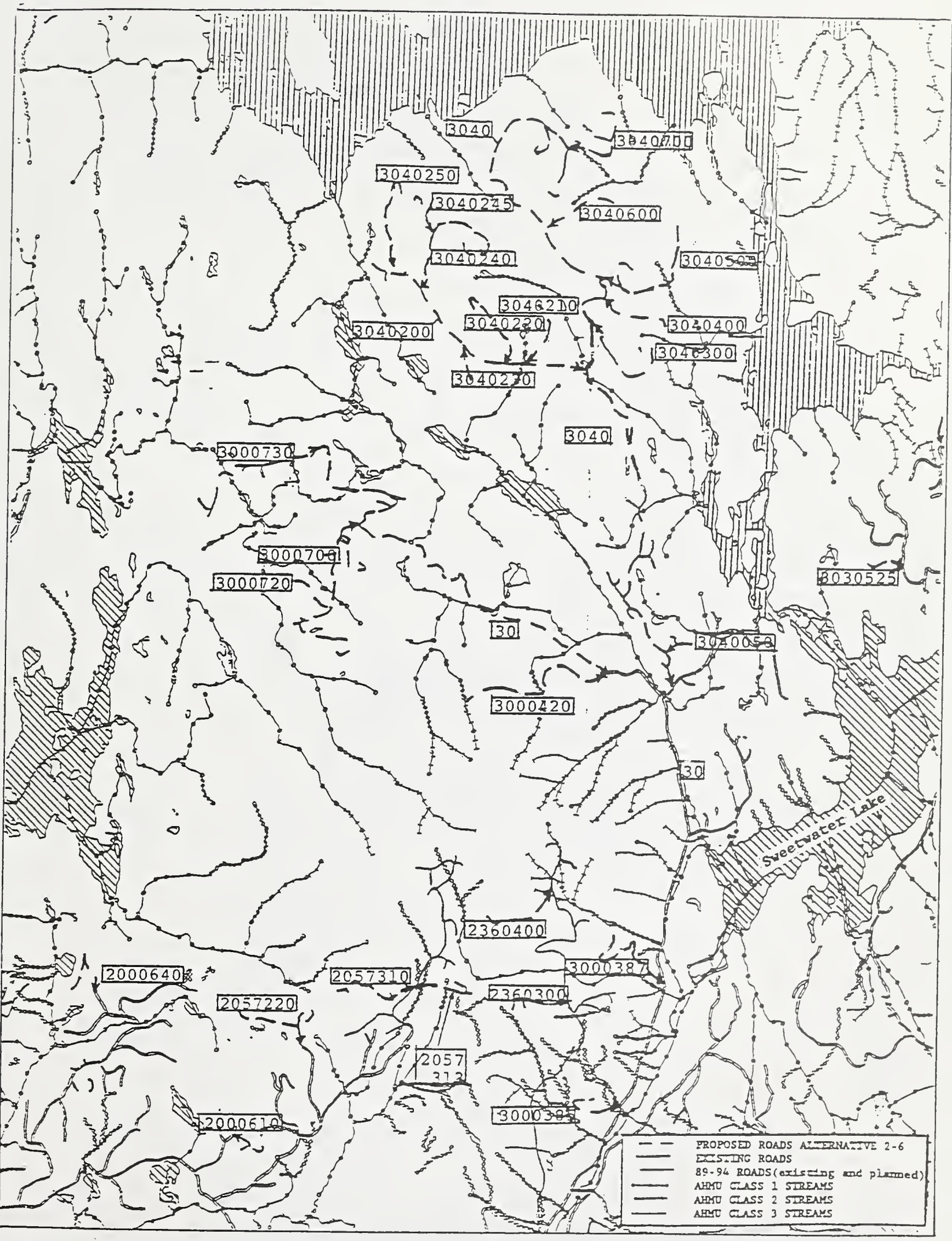




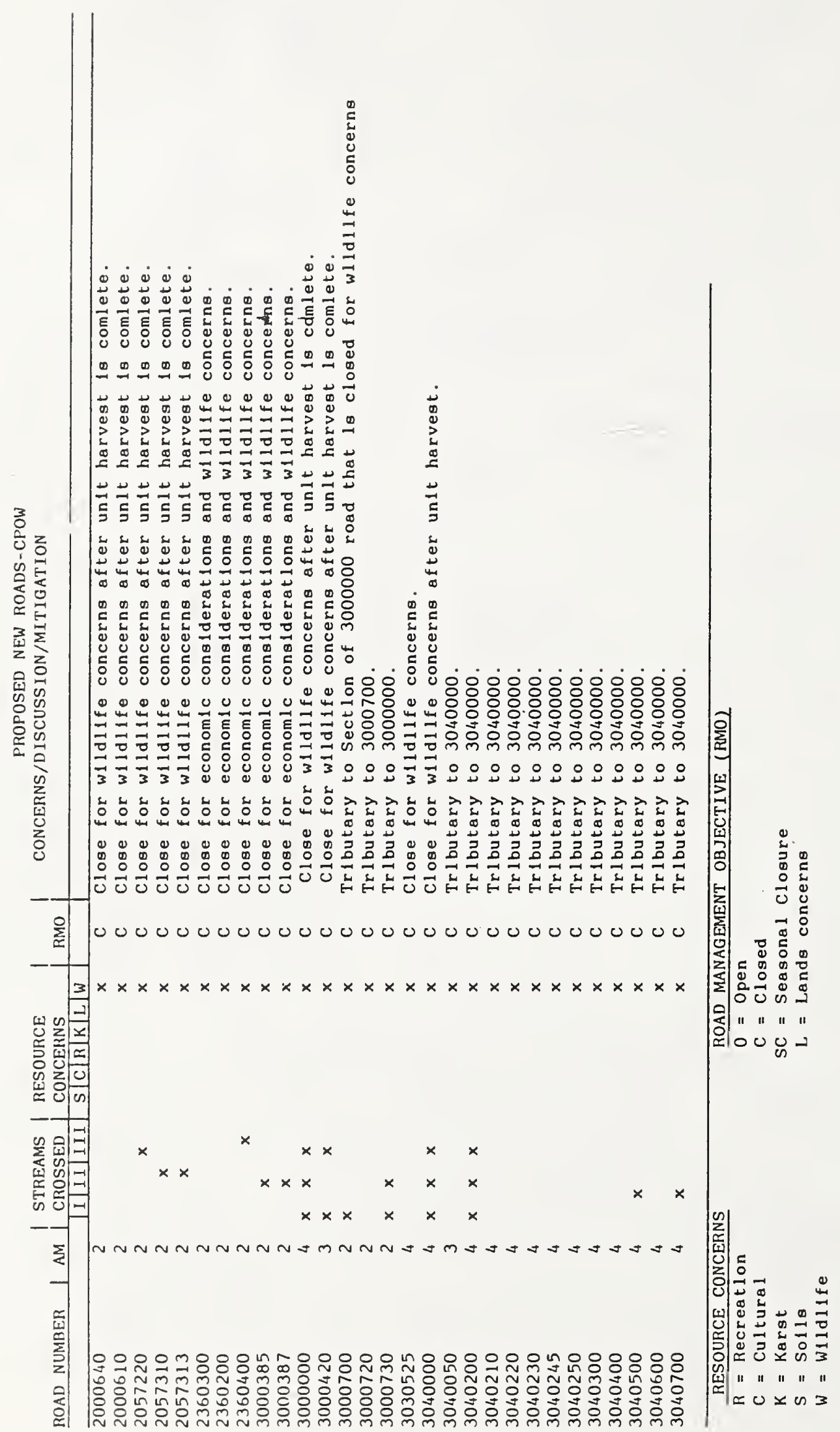




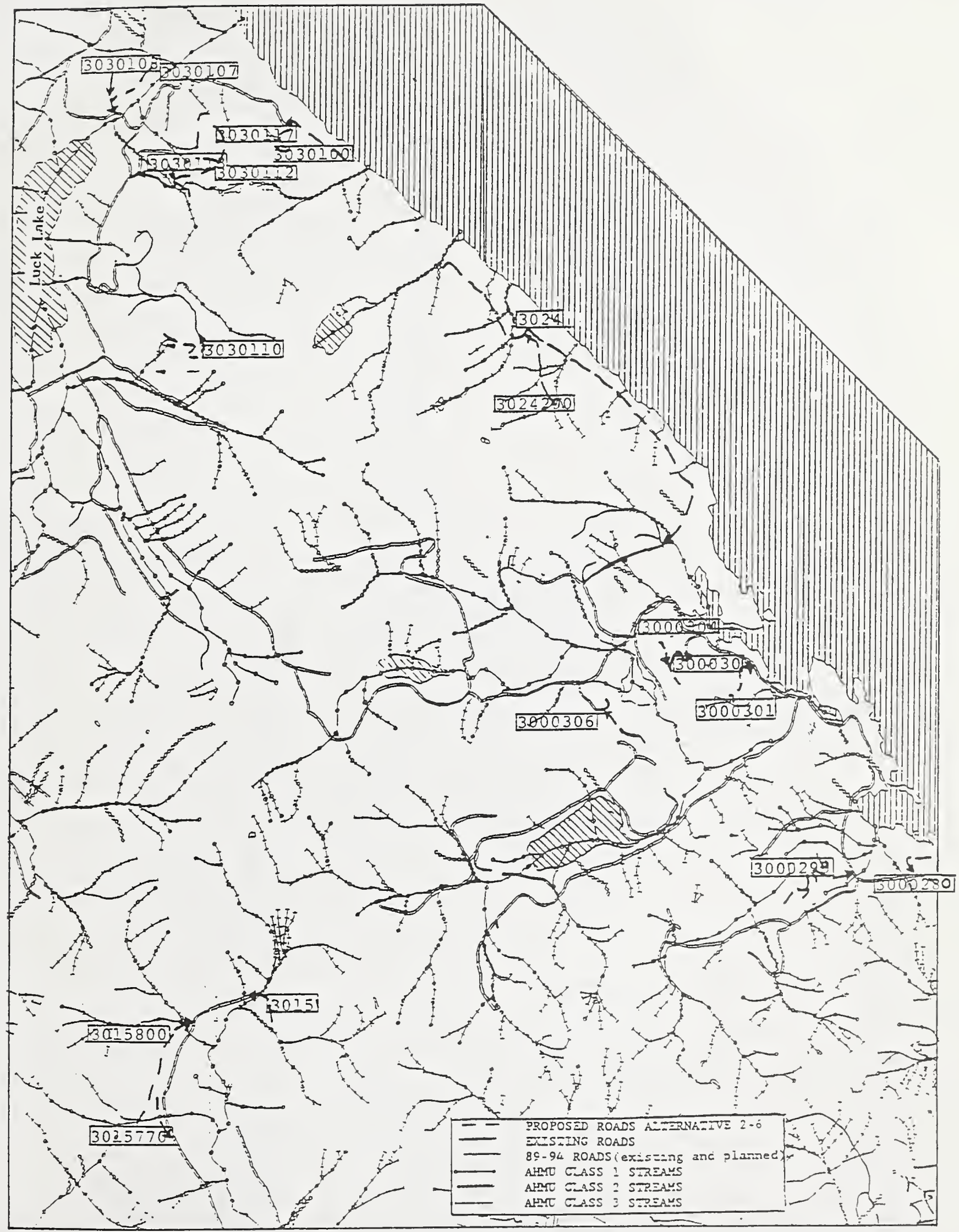




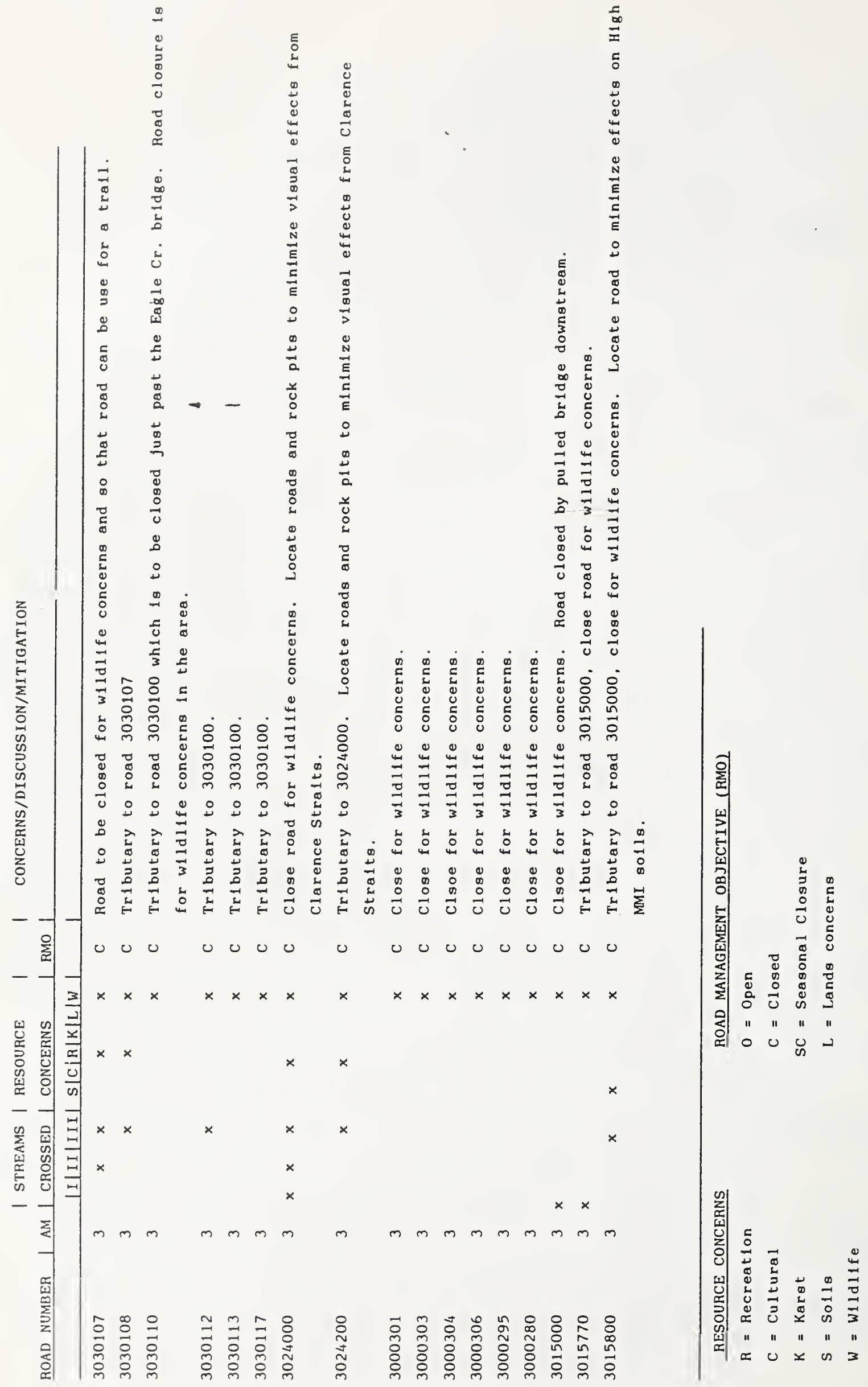






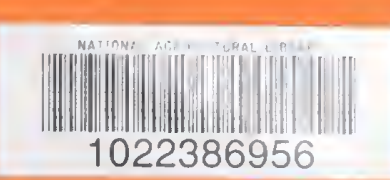


